\title{
De ontwikkeling van de arbeidsinspectie in een veranderende wetgeving
}

Citation for published version (APA):

van Drongelen, J. (1991). De ontwikkeling van de arbeidsinspectie in een veranderende wetgeving.

[Doctoral Thesis, Maastricht University]. Rijksuniversiteit Limburg. https://doi.org/10.26481/dis.19910307jd

Document status and date:

Published: 01/01/1991

DOI:

10.26481/dis.19910307jd

Document Version:

Publisher's PDF, also known as Version of record

\section{Please check the document version of this publication:}

- A submitted manuscript is the version of the article upon submission and before peer-review. There can be important differences between the submitted version and the official published version of record.

People interested in the research are advised to contact the author for the final version of the publication, or visit the DOI to the publisher's website.

- The final author version and the galley proof are versions of the publication after peer review.

- The final published version features the final layout of the paper including the volume, issue and page numbers.

Link to publication

\footnotetext{
General rights rights.

- You may freely distribute the URL identifying the publication in the public portal. please follow below link for the End User Agreement:

www.umlib.nl/taverne-license

Take down policy

If you believe that this document breaches copyright please contact us at:

repository@maastrichtuniversity.nl

providing details and we will investigate your claim.
}

Copyright and moral rights for the publications made accessible in the public portal are retained by the authors and/or other copyright owners and it is a condition of accessing publications that users recognise and abide by the legal requirements associated with these

- Users may download and print one copy of any publication from the public portal for the purpose of private study or research.

- You may not further distribute the material or use it for any profit-making activity or commercial gain

If the publication is distributed under the terms of Article $25 \mathrm{fa}$ of the Dutch Copyright Act, indicated by the "Taverne" license above, 
mr.drs. J. van Drongelen

\section{De ontwikkeling van de arbeidsinspectie in een veranderende wetgeving}

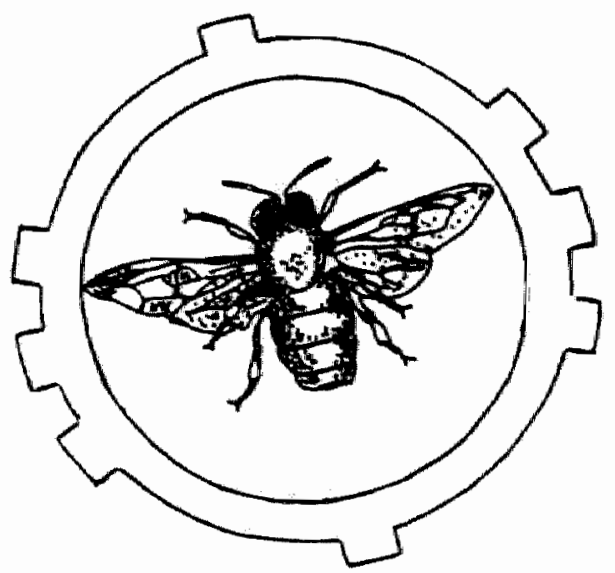




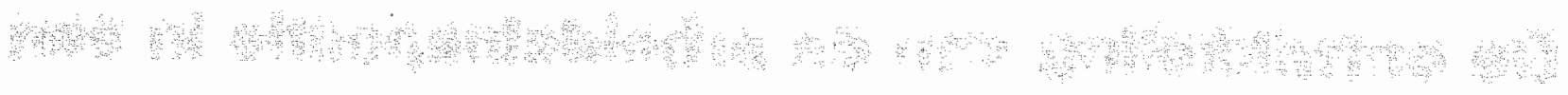

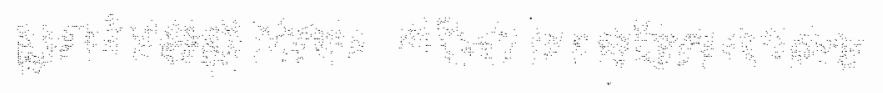


De ontwikkeling van de arbeidsinspectie in een veranderende wetgeving 


\section{De ontwikkeling van de arbeidsinspectie in een veranderende wetgeving}

\section{Proefschrift}

ter verkrijging van de graad van doctor aan de Rijksuniversiteit Limburg te Maastricht, op gezag van de Rector Magnificus, prof. mr. M.J. Cohen volgens het besluit van het College van Dekanen, in het openbaar te verdedigen op donderdag, 7 maart 1991 om 16.00 uur

door

Johannes van Drongelen

geboren te 's-Gravenhage 
अ०

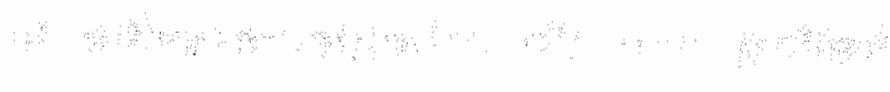

-

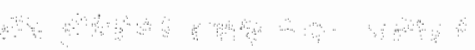

W(1. 
promotor:

prof.mr. A.J.C.M. Geers

Beoordelingscommissie: prof.mr. F.A.M. Stroink (voorzitter)

prof.mr. W.J.P.M. Fase

dr. J.J.H. Dekker

dr. J.A.M. Cornelissens

Hoewel bij deze uitgave de uiterste zorg is nagestreefd kan voor de afwezigheid van eventuele (druk-)fouten en onvolledigheden niet worden ingestaan en wordt deswege door de rechthebbende op het auteursrecht geen aansprakelijkheid aanvaard.

CIP-gegevens Koninklijke Bibliotheek, den Haag

DRONGELEN, JOHANNES VAN

DE ONTWIKKELING VAN DE ARBEIDSINSPECTIE IN EEN VERANDERENDE WETGEVING/JOHANNES VAN DRONGELEN

Proefschrift Maastricht - Met lit.opg. - Met samenvatting in het Engels

ISBN 90-5307-126-1

SISO 329.1 UDC 351.83.072.6(492)(091)(043.3)

Trefw:: arbeidsinspectic; Nederiand; geschiedenis/arbeidsomstandighedenrecht.

ISBN 90-5307-126-1

Druk: Reproductie-onderneming D. Elkerbout, Scheveningen

Ontwerp omslag: J. van Drongelen

Copyright (c) 1990 J. van Drongelen, Zoetermeer

Behoudens uitzonderingen door de wet gesteld mag zonder schriftelijke toestemming van de rechtshebbende op het auteursrecht niets uit deze uitgave worden veelvoudigd en/of openbaar gemaakt door middel van druk, fotocopie, microfilm of op welke andere wijze dan ook.

All rights reserved. No part of this publication may be reproduced, stored in a retrieval system, or transmitted in any form by any means, electronic, mechanical, photocopying, recording of otherwise, without the written of the author. 
Gebruikte afkortingen

\section{Hoofdstuk 1 Inleiding}

1. Inleiding

2. Het rechtsgebied arbeidsomstandighedenrecht

2.1. Nationale rechtsbronnen

2.2. Internationale rechtsbronnen

2.2.1. Raad van Europa; het Europees Sociaal Handvest

2.2.2. De Europese Economische Gemeenschap

2.2.3. De Internationale Arbeidsorganisatie

3. De arbeidsinspectie

4. Werkwijze

5. De opbouw van het boek noten

Hoofdstuk 2 Een lange weg ofwel het ontstaan van de arbeidsinspectie in de negentiende eeuw

1. Inleiding

1.1. Economische ontwikkeling en industrialisatie

1.2. "Armen" en "arbeiders"

1.3. Arbeidsomstandigheden

1.4. De rol van de overheid

2. De eerste voorstellen

3. Een eerste ministeriële enquête in $1841 \quad 17$

4. Het rapport-De Vries Robbe 18

5. Een ministeriële enquête uit 1860

6. Het initiatief-wetsvoorstel van Van Houten 19

7. De Kinderwet-Van Houten 20

8. Het voorontwerp-Van Lynden van Sandenburgh

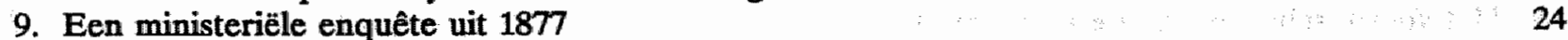

10. De wijziging van de Wet op het lager onderwijs en het toezicht op het verbod van kinderarbeid

11. Het ontwerp-Modderman

12. Het eerste ontwerp-Du Tour van Bellinchave

13. De parlementaire enquête van 1886

14. Het tweede ontwerp-Du Tour van Bellinchave

15. De Arbeidswet 1889

16. De redenen die ten grondslag lagen aan het instellen van een afzonderlijke arbeidsinspectie 
1. Inleiding

1.1. De industrialisatie en het ontstaan van de moderne arbeidsverhoudingen

1.2. Motieven voor overheidsingrijpen

1.3. De toenemende overheidszorg

2. In den beginne waren er slechts drie

3. Roep om uitbreiding

4. Maatregelen in het belang van de veiligheid en gezondheid

5. De Veiligheidswet en een wrijziging van de Arbeidswet 1889; de organisatie van de arbeidsinspectie ter discussie in het parlement

5.1. Ontwerp-Veiligheidswet

5.2. Wetsvoorstel tot wijziging van de Arbeidswet 1889

5.3. Verslag van het mondeling overleg

5.4. Vervolg van de behandeling van het wetswoorstel tot wijziging van de Arbeidswet 1889

86

5.5. Terug naar het ontwerp-Veiligheidswet en de afloop van de parlementaire discussie

6. Uitbreiding van de arbeidsinspectie

7. De Veiligheidswet en de Hinderwet

8. Verdere uitbreiding van de arbeidsinspectie 90

9. Voorstellen om de arbeiders te betrekken bij de handhaving van de arbeidswetgeving $\quad 92$

10. De Ongevallenwet 1901 en de Phosphorluciferwet $1901 \quad 95$

10.1. De Ongevallenwet 1901

10.2. De Phosphorluciferwet 1901

11. Opnieuw uitbreiding van de arbeidsinspectie met onder andere "specialiteiten"

12. De Caissonwet 1905

13. De adviezen inzake de wettelijke beperking van de arbeidsduur voor alle volwassen arbeiders

14. De inspecteur van de arbeid op bezoek

Hoofdstuk 4 De reorganisatie van de arbeidsinspectie

1. Inleiding

2. Het ontwerp-Kuyper

3. Het vooruitschuiven van de reorganisatie

4. De eerste stap van de reorganisatie; de benoeming van de directeur-generaal van de Arbeid

5. Vertraging

6. De goedkeuring van de reorganisatieplannen

7. De reorganisatie van de arbeidsinspectie en de reactie buiten het parlement

8. De wijziging van de Arbeidswet 1889 en de Veiligheidswet:

9. De uitwerking van de reorganisatie van de arbeidsinspectie

Hoofdstuk 5 De perlode vanaf de reorganisatie tot aan de Eerste Wereldoorlog

1. Opnieuw uitbreiding; de geneeskundige en de scheikundig-ingenieur bij de arbeidsinspectie 
2. De Arbeidswet 1911

3. Het ontwerp-Schaper 144

4. De Steenhouwerswet $1911 \quad 144$

5. Andere organen dan de arbeidsinspectie op het terrein van de arbeidsbeschermende wetgeving?

6. Bijzondere opdrachten 150

7. Rapporten en verslagen

noten

\section{Hoofdstuk 6 De Eerste Wereldoorlog}

1. Inleiding

2. De arbeidsbeschermende wetgeving en het verleggen van de prioriteiten $\quad 161$

3. Arbeidsbemiddeling

4. Het Koninklijk Nationaal Steuncomité

5. Verlof-aanvragen voor dienstplichtigen

6. Certificaten van oorsprong

7. Tewerkstelling van geïnterneerden

8. Kolendistributie

9. Turfdistributie

10. Andere activiteiten

11. Arbeidsinspectie en het overheidsingrijpen in de economie

12. Op de valreep: uitbreiding van het aantal districten

13. Bijzondere opdrachten

14. Rapporten en verslagen

Hoofdstuk 7 Het interbellum: de periode tot de wereldcrisis

1. Inleiding

2. De Hooge Raad van Arbeid 188

3. De Arbeidswet $1919 \quad 188$

4. De Arbeidswet 1919 en de regeling van de arbeidsinspectie ; 190

5. Uitbreiding van de arbeidsinspectie 191

6. De uitwerking van de regeling van de arbeidsinspectie 192

7. De invoerings-perikelen van de Arbeidswet $1919 \quad 194$

8. Opnieuw uitbreiding van het aantal districten 194

9. Wijziging van de Arbeidswet 1919

10. De districtshoofden en de machtigingsprocedure 199

11. De uitvoering van de Arbeidswet 1919

12. De kacheltjes van Jamin; de uitvoering van de Arbeidswet 1919 onder 's rechters hamer

13. Vertraging van de verdere invoering van de Arbeidswet 1919

14. De Steenhouwerswet 1921

15. De Veiligheidswet $\quad 207$

16. Werkzaamheden in verband met andere wetten waarvan de handhaving van en de medewerking aan de uitvoering geheel of gedeeltelijk aan de arbeidsinspectie was opgedragen 
$\begin{array}{lr}\text { 16.3. Overige } & 209\end{array}$

$\begin{array}{lr}\text { 17. Bijzondere opdrachten } & 209\end{array}$

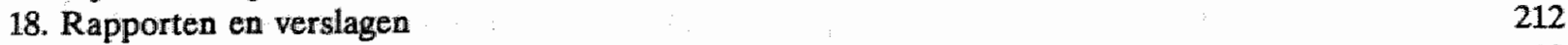

noten

Hoofdstuk 8 Het interbellum: de periode van de werelderisis

1. Inleiding

2. Bezuinigingen bij de arbeidsinspectie

3. Bezünigingen en de verdere invoering van de Arbeidswet 1919

4. Werkzaamheden in verband met andere wetten waarvan de handhaving van en de medewerking aan de uitwoering geheel of gedeeltelijk aan de arbeidsinspectie was opgedragen

4.1. De Arbeidswet 1919, de Veiligheidswet 1934, de Steenhouwerswet 1921

4.2. De Ongevallenwet 1921

4.3. De Hinderwet

4.4. De Phosphorluciferwet, de Caissonwet 1905

5. De Röntgenstralenwet

6. De Huisarbeidswet 1933

7. De Veiligheidswet 1934

8. De Rijtijdenwet 1936

9. De Wet houdende tijdelijke maatregelen betreffende de mechanisatie in de sigarenindustrie

10. De Wet tot regeling van het verrichten van arbeid door vreemdelingen 243

11. De Wet inzake verdeling van de beschikbare arbeid $1937 \quad 244$

12. Wet op het algemeen verbindend en onverbindend verklaren van bepalingen van collectieve arbeidsovereenkomsten 1937

13. De Bedrijfsvergunningenwet 1938

14. Andere organen dan de arbeidsinspectie op het terrein van de arbeidsbeschermende wetgeving?

15. Bijzondere opdrachten

16. Werkzaamheden ten behoeve van defensie-doeleinden $\quad 257$ noten

\section{Hoofdstuk 9 De Tweede Wereldoorlog}

1. Inleiding

2. Werkzaamheden in verband met de belangrijkste wetten waarvan de handhaving en de medewerking aan de uitvoering geheel of gedeeltelijk aan de arbeidsinspectie was opgedragen

2.1. De Arbeidswet 1919

2, 2, De Veiligheidswet 1934

23. De Rijtijdenwet 1936

3. Maatregelen betreffende het beperken van werk

4. Maatregelen omtrent lonen, salarissen en andere arbeidswoorwaarden

5. Het Bedrijfsvergunningenbesluit 1941 en het Kartelbesluit 
5.1. Het Bedrijfsvergunningenbesluit 1941

5.2. Het Kartelbesluit 286

6. Distributie

7. Andere activiteiten 287

8. De Stichting van de Arbeid $\quad 288$

9. Het Buitengewoon Besluit Arbeidsverhoudingen $\quad 291$

10. Middel tot wering van ambtenaren?

noten

Hoofdstuk 10 De wederopbouw: de periode 1945 tot 1962

1. Inleiding 303

2. De Arbeidswet $1919 \quad 304$

2.1. Overwerk en ploegendienst

2.2. Het streven naar een vijfdaagse werkweek 305

2.3. Contacten met de ondernemingsraden omtrent vergunningverlening; verdergaande medezeggenschap in sommige bedrijfstakken ( slagersbedrijf ) $\quad 306$

2.4. Bakkersarbeid $\quad 307$

2.5. Vrouwelijke arbeidskrachten

3. De Veiligheidswet $1934 \quad 309$

3.1. De bedrijfsgeneeskundige diensten $\quad 309$

3.2. Groeiend veiligheidsbesef $\quad 312$

4. Een bijzondere bevoegdheid van het districtshoofd van de arbeidsinspectie in het kader van de Arbeidswet 1919 en de Veiligheidswet 1934

5. De Steenhouwerswet 1921

6. De Silicosewet en de Wet op de gevaarlijke werktuigen $\quad 316$

6.1. De Silicosewet 316

6.2. De Wet op de gevaarlijke werktuigen $\quad 317$

6.3. Gevolgen van deze wettelijke regelingen $\quad 318$

7. De Huisarbeidswet $1933 \quad 319$

8. De Rijtijdenwet $1936 \quad 320$

9. Het Buitengewoon Besluit Arbeidsverhoudingen 1945

9.1. Inleiding $\quad 321$

9.2. De ontslagvergunningverlening: arbeidsinspectie of gewestelijk arbeidsbureau?

9.3. Betrokkenheid arbeidsinspectie $\quad 325$

9.4. Het ontslagverbod $\quad 326$

9.5. Het verbod van werktijdverkorting $\quad 327$

9.6. De wachtgeldregelingen $\quad 329$

9.7. Lonen en andere arbeidswoorwaarden $\quad 330$

10. De Wet plaatsing minder-valide arbeidskrachten 332

11. Werkzaamheden in verband met de overige wetten waarvan de handhaving van en de medewerking aan de uitvoering geheel of gedeeltelijk aan de arbeidsinspectie was opgedragen

11.1. De Ongevallenwet 1921

11.2. De Hinderwet $\quad 334$

11.3. De Wet wekelijkse rustdag toonkunstenaars

11.4. Overige

12. Bedrijfsmaatschappelijk werk en sociaal welzijn in de onderneming $\quad 336$

13. Bijzondere opdrachten $\quad 342$ 
Hoofdstuk 11 Stilte voor de storm; de periode 1962 tot 1975

1. Inleiding

2. De arbeidsinspectie en de afdeling Arbeid/Arbeidersbescherming; het ontstaan van het directoraat-generaal van de Arbeid

2.1. Inleiding

2.2. De verhouding tussen de arbeidsinspectie en de afdeling Arbeid/Arbeidersbescherming, met andere woorden de technici versus de juristen

2.3. Via de directie van de Arbeid naar het directoraat-generaal van de Arbeid

3. Veranderingen in de organisatie van de arbeidsinspectie

4. De Arbeidswet 1919

4.1. Overwerk

4.2. Bakkersarbeid

4.3. Ploegenarbeid

4.4. Variabelle werktijden

4.5. Het Jongerenstatuut

5. De Veilligheidswet 1934

6. De Bestrijdingsmiddelenwet $1962 \quad 377$

7. De Kernenergiewet

8. De Wet Gevaarlijke Stoffen

9. De Wet op het werken onder overdruk 381

10. De Wet inzake de luchtverontreiniging $\quad \cdots 382$

11. De Wet op de ondernemingsraden

12. Het Buitengewoon Besluit Arbeidsverhoudingen 1945

12.1. Het ontslagverbod

12.2. Het verbod van werktijdverkorting

12.3. "Andere" arbeidsvoorwaarden

13. Werkzaamheden in verband met andere wetten waarvan de handhaving van en de medewerking aan de uitvoering geheel of gedeeltelijk aan de arbeidsinspectie was opgedragen

13.1. De Rijtijdenwet $1936 \quad 386$

13.2. De Huisarbeidswet 1933

13.3. De Ongevallenwet 1921

13.4. De Hinderwet $\quad 387$

13.5. Overige

14. Bedrijfsmaatschappelijkwerk en sociaal welzijn in de onderneming 388

15. Bijzondere opdrachten $\quad 389$

15.1. Vrijstelling militaire dienst $\quad 389$

15.2. Civiele verdediging $\quad 390$ noten

Hoofdstuk 12 De toenemende belangstelling voor de arbeidsomstandigheden en kritiek op de arbeidsinspectie: de periode 1975 tot 1 maart 1990

1. Inleiding
1.1. Toenemende belangstelling voor de arbeidsomstandigheden 
2. De Arbeidswet $1919 \quad 410$

2.1. Bakkersarbeid $\quad: \quad: \quad 410$

2.2. Winkels/Winkelsluitingswet 1976

2.3. Nachtarbeid vrouwen in de industrie $\quad 412$

2.4. Jongerenstatuut 415

2.5. Arbeidstijdverkorting, flexibele werktijden, het beperken van overwerk en het te voeren vergunningenbeleid $\quad 419$

2.6. Een nieuwe Arbeidswet $\quad 424$

3. De Veiligheidswet 1934 en de Arbeidsomstandighedenwet 427

$\begin{array}{ll}\text { 3.1. Inleiding } & 427\end{array}$

3.2. De Arbeidsomstandighedenwet $\quad: \quad 428$

$\begin{array}{lr}3.2 .1 \text {. Inleiding } & 428\end{array}$

3.2.2. Het uitgangspunt en de hoofdlijnen 428

3.2.3. Het begrip "welzijn" 429

3.2.4. Algemeen geformuleerde verplichtingen van de werkgever 431

3.2.5. Instrumenten ter beschikking van de arbeidsinspectie 431

3.2.6. Meer omschreven verplichtingen van de werkgever $\quad 434$

3.2.7. Verplichtingen van de werknemer $\quad 435$

3.2.8. Het recht van werkonderbreking $\quad 436$

3.2.9. Overleg/medezeggenschap $\quad 436$

3.2.10. Deskundige diensten $\quad 437$

$\begin{array}{ll}\text { 3.2.11. Arbo-instituut } & 437\end{array}$

$\begin{array}{ll}\text { 3.2.12. Gefaseerde invoering } & 437\end{array}$

3.2.13. Deregulering $\quad 437$

3.2.14. Samenloop Wet op de ondernemingsraden en de Arbeidsomstandighedenwet 439

$\begin{array}{ll}\text { 3.2.15. Slot } & 439\end{array}$

4. Kritiek op de arbeidsinspectie; van het Project Ontwikkeling Arbeidsinspectie naar Arbo'91

4.1. Kritiek op de arbeidsinspectie

4.2. Het Project Ontwikkeling Arbeidsinspectie

4.3. Arbo'91

5. Veranderingen in de wettelijke regeling van de organisatie van de arbeidsinspectie

6. Over de ministeriële verantwoordelijkheid en de bevoegdheden van het districtshoofd en de directeur-generaal van de Arbeid

7. Tripartisering. Een discussie over een nieuw bestuursmodel voor het directoraat-generaal van de Arbeid

8. De Wet op de ondernemingsraden

9. De Wet arbeid gehandcapte werknemers

10. De Wet chemische afvalstoffen en de Afvalstoffenwet

11. De Binnenschepenwet

12. De Diergeneesmiddelenwet

13. De Wet milieugevaarlijke stoffen

14. Het Buitengewoon besluit Arbeidsverhoudingen 1945

14.1. Het ontslagverbod

14.2. Het verbod van werktijdverkorting

460

465

465

466

467

468

469

473

473

475

15. Werkzaamheden in verband met andere wetten waarvan de handhaving en de medewerking aan de uitvoering geheel of gedeeltelijk aan de arbeidsinspectie is opgedragen 
15.2. De Hinderwet

15.3. De Wet inzake de luchtverontreiniging 481

15.4. De Huisarbeidswet $1933 \quad 482$

15.5. Overige 482

16. Bijzondere opdrachten 483

16.1. Vrijstelling militaire dienst/koninklijke onderscheidingen 483

16.2. Civiele verdediging 483

16.3. Het Nederlands Instituut voor Arbeidsomstandigheden 484

16.4. De Subsidieregelingen arbeidsplaatsverbetering 484

16.5. De interdepartementale werkgroep selectieprocedure $\quad 486$

$\begin{array}{ll}\text { 17. Tot besluit } & 487\end{array}$

$\begin{array}{ll}\text { 17.1. Inleiding } & 487\end{array}$

17.2. De aan de arbeidsinspectie toebedeelde taken

17.3. Naar aanleiding van de kritiek op de arbeidsinspectie 494 noten

Hoofdstuk 13 Een aantal juridische aangelegenheden afzonderlijk beschouwd

1. Inleiding 535

2. De begrippen "onderneming", "bedrijf" en "inrichting"

2.1. De begrippen "onderneming" en "bedrijf"

2.1.1. Inleiding $\quad 535$

2.1.2. Levenbach versus De Gaay Fortman $\quad 536$

2.1.3. Een nieuw begrip "onderneming" $\quad 538$

\begin{tabular}{l} 
2.1.4. Van Dodeweerd versus Van Zwam \\
\hline
\end{tabular}

2.1.5. Het begrip "onderneming" in het kader van de Arbeidsomstandighedenwet. $\quad 540$

2.2. Het begrip "inrichting" $\quad 541$

2.2.1. Inleiding $\quad 541$

2.2.2. Het begrip "inrichting" in de Hinderwet $\quad 541$

2.2.3. Het begrip "inrichting" in het arbeidsomstandighedenrecht 543

2.3. Conclusies $\quad 546$

3. De regeling van de aansprakelijkheid in het arbeidsomstandighedenrecht 547

3.1. Arbeids- en rusttijden $\quad 547$

3.2. De voorgeschiedenis $\quad 547$

3.2.1. De Kinderwet-Van Houten $\quad 547$

3.2.2. De parlementaire enquête van $1886 \quad-\quad 547$

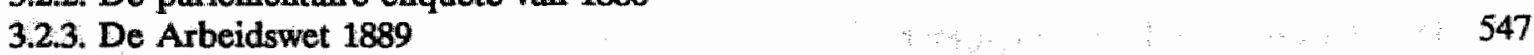

3.2.4. De Arbeidswet $1911 \quad 548$

3.3. De Arbeidswet $1919 \quad 548$

3.3.1. De Arbeidswet 1919 en de aansprakelijkheid ten aanzien van de arbeids-
en rusttijden van arbeiders van in het buitenland gevestigde ondernemingen

3.3.2. De Arbeidswet 1919 en een bijzondere aansprakelijkheid in verband met
kinderarbeid

3.4. Veiligheid en gezondheid $\quad 550$

3.4.1. De Veiligheidswet $1934 \quad 550$

3.4.2. De Veiligheidswet 1934 en een bijzondere aansprakelijkheid voor het hoofd
of de bestuurder

3.4.3. De Veiligheidswet 1934 en de aansprakelijkheid van de arbeider $\quad 551$

3.5. Vernieuwing; de aansprakelijkheidsregeling in de Arbeidsomstandighedenwet 552 
3.6.2. De Veiligheidswet $1934 \quad 558$

3.7. Strafuitsluitingsgronden $\quad 559$

3.7.1. Inleiding 559

3.7.2. De rechtvaardigingsgrond overmacht in de Arbeidswet $1919 \quad 559$

3.7.2.1. Het ontstaan en de strekking van de rechtvaardigingsgrond overmacht 559

3.7.2.2. De relatie tussen de bijzondere overmachtsbepaling van artikel 83, vierde lid, van de Arbeidswet 1919 en de algemene overmachtsbepaling van artikel 40 van het Wetboek van Strafrecht

3.7.2.3. De verhouding tussen disculpatie en overmacht 563

$\begin{array}{ll}\text { 3.7.3. Afwezigheid van alle schuld } & 564\end{array}$

3.8. Samenvatting

3.8.1. Aansprakelijkheidsregeling

3.8.2. Disculpatie

3.8.3. Strafuitsluitingsgronden

4. Bevoegdheden in het kader van het toezicht en de opsporing

4.1. Inleiding

4.2. De plicht tot spreken en het recht om te zwijgen $\quad 566$

4.2.1. Inleiding 566

4.2.2. De verplichting tot het verschaffen van inlichtingen $\quad 567$

4.2.3. Juiste inlichtingen verschaffen of niet? $\quad 569$

4.3. Het betreden van plaatsen $\quad 570$

4.3.1. Inleiding $\quad 570$

4.3.2. Arbeidswet 1919 en Veiligheidswet 1934

4.3.2.1. Beperking voor ambtenaren, niet zijnde ambtenaren van de arbeidsinspectie $\quad 570$

4.3.2.2. Bijzondere voorschriften voor ambtenaren, niet zijnde ambtenaren van de arbeidsinspectie

$\begin{array}{ll}\text { 4.3.2.3. Hulp van de sterke arm } & 571\end{array}$

4.3.2.4. Het betreden van een woning 571

4.3.3. De Arbeidsomstandighedenwet 572

4.3.3.1. Het betreden van plaatsen in het kader van het toezicht 572

4.3.3.2. De toezichthoudende taak en het betreden van woningen 573

4.3.3.3. Het betreden van plaatsen in het kader van de opsporing 575

4.3.4. De gehanteerde begrippen 575

4.3.4.1. "Toegang hebben tot", "binnentreden" en "betreden"" 575

$\begin{array}{lr}\text { 4.3.4.2. Het begrip "woning" } & 575\end{array}$

4.4. Samenvatting en conclusies 576

5. De geheimhoudingsverplichting 577

5.1. Inleiding 577

5.2. De geheimhoudingsverplichting in de Arbeidswet 1889 en de Veiligheidswet 577

5.3. Uitbreiding van de geheimhoudingsverplichting in de Arbeidswet 1911

5.4. De geheimhoudingsverplichting in de Arbeidswet 1919 en de Veiligheidswet 1934

5.5. Beperking van de geheimhoudingsverplichting 579

5.6. De geheimhoudingsverplichting in de Arbeidsomstandighedenwet $\quad 580$

5.7. Opnieuw een wijziging van de geheimhoudingsbepalingen 583

5.8. Samenvatting $\quad 584$ noten 
Hoofdstuk 14 De arbeidsinspectie en de regelingen van de Internationale Arbeidsorganisatie

1. Inleiding

2. De Aanbeveling betreffende de algemene beginselen voor de inrichting en de bevoegdheden van de arbeidsinspectie

2.1. Hoofddoelstelling

605

2.2. Bevoegdheden

606

2.3. Samenstelling van het personeel

607

2.4. Waarborging onafhankelijkheid

608

2.5. Werkwijze

2.6. Klachtrecht en samenwerking tussen werkgevers en arbeiders

608

2.7. Verslagen

609

2.8. Slotbeschouwing

609

609

3. Het Verdrag betreffende de arbeidsinspectie in industrie en handel 609

3.1. De verplichting tot het hebben van een arbeidsiuspectie $\quad 610$

3.2. De taak van de arbeidsinspectie

3.2.1. Wettelijke bepalingen betreffende de arbeidsvoorwaarden en de bescherming van werknemers

3.2.2. Inlichtingen en adviezen aan werkgevers en werknemers 612

3.2.3. Het onder de aandacht brengen van tekortkomingen van de wettelijke bepalingen 613

3.2.4. Preventieve taken 3.2.4.1. Bedrijfsongevallen en beroepsziekten

3.2.4.2. Nieuwe inrichtingen, nieuwe installaties of nieuwe produktieprocessen

3.2.5. Andere taken

3.3. De organisatie van de arbeidsinspectie 617

3.3.1. Overheidsorgaan

3.3.2. Samenwerking

3.4. Personele aangelegenheden betreffende de arbeidsinspectie

3.4.1. Status

3.4.2. Arbeidsvoorwaarden

3.4.2.1. Aanstelling(-speriode)

3.4.2.2. Beloning en carriere-vooruitzichten

3.4.3. Werving

3.4.4. Opleiding

3.5. Middelen ter beschikking van de arbeidsinspectie

3.5.1. Omvang van de arbeidsinspectie

3.5.2. Personeels-samenstelling

3.5.3.1. Kantoren, uitrusting en documentatie $\quad 630$

3.5.3.2. Vervoersfaciliteiten

3.5.4. Inspectiebezoeken

3.6.1. Toezichthoudende bevoegdheden

3.6.2. Corrigerende bevoegdheden $\quad 636$

3.7. Verplichtingen

3.7.1. Geen direct of indirect belang in ondernemingen onder hun toezicht geplaatst

3.7.2. Geheimhoudingsverplichting 
4. Het Verdrag betreffende de arbeidsinspectie in de landbouw

4.1. De verplichting tot het hebben van een arbeidsinspectie in de landbouw

4.2. Een afzonderlijke arbeidsinspectie in de landbouw?

4.3. Verschillen met betrekking tot het Verdrag betreffende de arbeidsinspectie in industrie en handel

noten

Hoofdstuk 15 Samenvatting en slotbeschouwingen

1. Inleiding

2. Slotbeschouwing

3. Samenvatting

661

noten

672

Summary

673

Geraadpleegde Literatuur

Rechtspraak-overzicht

709 


\section{GEBRUIKTE AFKORTINGEN}
$\mathrm{AAe}$
$\mathrm{AB}$
$A G$
AI
ANWV
AR
Arbowet
ARP
BBA
blz.
BW
din.
$\mathrm{CAO} / \mathrm{cao}$
- Ars Aequi
- Administratiefrechtelijke Beslissingen
- Advocaat-Generaal
- Arbeidsinspectie
- Algemeen Nederlandsch Werklieden Verbond
- Afdeling rechtspraak van de Raad van State
- Arbeidsomstandighedenwet
- Anti-revolutionaire Partij
- Buitengewoon Besluit Arbeidsverhoudingen
- bladzijde
- Burgerlijk Wetboek
- delen
$\mathrm{CCOZ}$
CDA
CHU
CNV
COB
C.P.N.
CRvB
D'66
DIA
D.U.W.
- Collectieve arbeidsovereenkomst
- Stichting Coördinatie van Communicatie met betrekking tot gegevens voor Onderzoek inzake Ziekteverzuim
DCA
- Christen Democratisch Appèl
- Christelijk Historische Unie
- Christelijk Nationaal Vakverbond
- Commissie Organisatie Bedrijven
- Communistische Partij Nederland
- Centrale Raad van Beroep
- Democraten '66
- Deregulering inkomensvorming en arbeidsmarkt
- Dienst Uitvoering Werken
DGA(rbeid)
$\mathrm{DD}$
- Dienst Collectieve Arbeidsvoorwaarden
EEG
- Directoraat-generaal van de Arbeid
E.G.(EG)
- Delikt en Delinkwent
- Europese Economische Gemeenschap
E.S.B.
- Europese Gemeenschappen
FNV
- Economische Statistische Berichten
GAB(gab)
Hfdst.
HR
- Federatie Nederlandse Vakbeweging
- Gewestelijk arbeidsbureau
- hoofdstuk
I.A.O.
- Hoge Raad der Nederlanden
I.L.O.
IVA
i.v.m.
K.b.
K.N.S.
KNVTO
K.S.W.
Ktg.
KVP
- Internationale Arbeidsorganisatie
- International Labour Organisation
- Instituut voor Sociaal-Wetenschappelijk Onderzoek
- in verband met
- Koninklijk besluit
- Koninklijk Nationaal Steuncomite
- Koninklijke Nederlandse Vereniging van Transportondernemingen
- Katholiek Sociaal Weekblad
- Kantongerecht
- Katholieke Volkspartij 


\begin{tabular}{ll} 
m.b.t. & - met betrekking tot \\
MD & - Management developement \\
M.v.A. & - Maandblad voor Arbeidsomstandigheden \\
NIA & - Nederlands Instituut voor Arbeidsomstandigheden \\
N.J. & - Nederlandse Jurisprudentie \\
N.J.B. & - Nederlands Juristenblad \\
NJV & - Nederlandse Juristenvereniging \\
NVV & - Nederlands Verbond van Vakverenigingen \\
no. & - nummer \\
nt. & - noot \\
p. & - page \\
par. & - paragraaf \\
Pb. & - Publikatieblad \\
PPR & - Politieke Partij Radicalen \\
PvdA & - Partij van de Arbeid \\
Rb & - Rechtbank \\
R.B.A. & - Rechterlijke Beslissingen inzake de Wet op de arbeidsovereenkomst \\
RCO & - Raad van Centrale Ondernemingsorganisaties \\
R.M. & - Rechtsgeleerd Magazijn \\
S & - Seite \\
SDAP & - Sociaal Democratische Arbeiderspartij \\
SER & - Sociaal-Economische Raad \\
SGP & - Staatkundig Gereformeerde Partij \\
S.M. & - Sociaal Maandblad \\
S.M.A. & - Sociaal Maandblad Arbeid \\
SR & - Tijdschrift voor Sociaal Recht \\
Stcrt. & - Staatscourant \\
Stb. & - Staatsblad \\
S.W. & - Sociaal Weekblad \\
SZW & - Ministerie van Sociale Zaken en Werkgelegenheid \\
t.a.p. & - ter aangehaalde plaatse \\
T.N.O. & - Instituut voor Toegepast Natuurwetenschappelijk Onderzoek \\
T.N.V.W. & - Tijdschrift der Nationale Vereeniging tegen de Werkloosheid \\
Trb. & - Tractatenblad \\
T.v.A. & - Tijdschrift voor Arbeidsvraagstukken \\
T.v.S. & - Tijdschrift voor Strafrecht \\
TVVS & - Maandblad voor ondernemingsrecht en rechtspersonen \\
utincl & - up to and included \\
Var & - Voorlopige Arbeidsraad \\
VN & - Vrij Nederland \\
VNO & - Vereniging van Nederlandse Ondernemingen \\
VVD & - Volkspartij voor Vrijheid en Democratie \\
WAGW & - Wet arbeid gehandicapte werknemers \\
WOR & - Wet op de ondernemingsraden \\
W.v.Sr. & - Wetboek van Strafrecht \\
W.v.Sv. & - Wetboek van Strafvordering \\
z.j. & - zonder jaar \\
z.p. & - zonder plaats \\
& \\
\hline
\end{tabular}


Dit boek bevat een onderzoek naar de ontwikkeling van de arbeidsinspectie in een veranderende wetgeving. De afsluitende datum is gesteld op 1 maart 1990, de datum waarop de arbeidsinspectie in ons land honderd jaar bestond; belangrijke wetenswaardigheden, die zich na deze datum hebben voorgedaan, zijn in de noten verwerkt. Voorts is geen trefwoorden- of zakenregister opgenomen, omdat uit de uitgebreide inhoudsopgave voldoende blijkt waar een bepaald onderwerp wordt behandeld.

Er liggen vele redenen ten grondslag aan het schrijven van een proefschrift. De belangrijkste reden voor mij om aan een dergelijke taak te beginnen was eenvoudig nieuwsgierigheid naar het wel en wee van de arbeidsinspectie, de overheidsorganisatie waarin ik zelf werkzaam ben.

In de vele jaren, die bij de totstandkoming van dit boek, voorbij zijn gegleden, heb ik van veel mensen hulp en steun gekregen waarvoor ik hen bijzonder dankbaar ben. In het bijzonder wil ik noemen prof. mr. B.S. Frenkel, die bereid was om als promotor te willen optreden, maar dit niet heeft kunnen afronden door het verlies van het promotierecht na enige jaren emeritaat, en prof. mr. A.J.C.M. Geers, die daarop bereid was als promotor te willen optreden. Beiden wil ik danken, niet alleen voor de gewaardeerde kritische kanttekeningen en suggesties, maar ook voor het geduld, dat zij bij de begeleiding van dit boek opbrachten.

Iedereen is geneigd om het bestaan van vele instanties als een vanzelfsprekendheid te aanvaarden. Er wordt gebruik gemaakt van de daar aanwezige faciliteiten en middellen. Er wordt op en tegen de medewerkers van die instanties gemopperd als het niet allemaal even gladjes verloopt, om hen, na het optrekken van de kruitdampen, vervolgens weer uit onze gedachten te bannen. Dit laatste is zeker niet mijn bedoeling. Ik wil dan ook de medewerkers van het Rijksarchief, het Centraal Historisch Archief van het ministerie van Sociale Zaken en Werkgelegenheid en het archief en de bibliotheek van het Ministerie van Justitie, en het archief en de bibliotheek van het directoraat-generaal van de Arbeid bedanken. Van mijn collega's wil ik in het bijzonder noemen de, inmiddels gepensioneerde heer A. Buyteweg en mevrouw Helmi Veenman.

Daarnaast wil ik mijn erkentelijkheid betuigen aan de heer H.M.J. Baan, die zo bereidwillig is geweest om de Nederlandse samenvatting in het Engels te vertalen.

Verder wil ik mijn beide zoons Vincent en Laurence bedanken voor de nodige afleiding waar zij regelmatig en met groot enthousiasme voor zorgden.

Mijn grootste dank gaat echter uit naar mijn vrouw voor haar geduld, haar ondersteuning en haar begrip. Zonder haar was het voor mij onmogelijk geweest om dit boek te voltooien.

Tot slot zou ik dit boek wil opdragen aan mijn zwager Jeronimo de Vries, van wie wij op veel te jeugdige leeftijd afscheid hebben moeten nemen. 
$\begin{array}{lll}3 & 4\end{array}$ 


\section{Hoofdstuk 1 INLEIDING}

\section{Inleiding}

De geschiedenis van de arbeidsinspectie is onlosmakelijk verbonden met die van de arbeidersbeschermende wetgeving. De term "arbeidersbescherming", die bijwoorbeeld door Molenaar' wordt gebezigd, heeft, aldus Geers en Gevers ${ }^{2}$, het nadeel, dat wordt gesuggereerd, dat het alleen maar gaat om het beschermen yan de arbeider tegen schadelijke invloeden, zonder dat het nodig zou zijn de gevaren en de bedreigingen waaraan hij bloot staat bij de bron aan te pakken. Daarom werd ook wel de term "arbeidsbeschermingsrecht" gebruikt ${ }^{3}$. Tegenwoordig wordt echter de voorkeur gegeven aan de term "arbeidsomstandighedenrecht" Het arbeidsomstandighedenrecht kan omschreven worden als het geheel van normen, dat gericht is op de bescherming van het lichamellijke en geestelijke welbevinden van de werkmemer tegen de met het verrichten van arbeid samenhangende invloeden die dit welbevinden kunnen bedreigen. De beschermende norm kan betrekking hebben op de regeling van de arbeids- en rusttijden van de werknemer, maar kan ook een regeling bevatten tegen de gevaren die aan het verrichten van arbeid verbonden zijn door 6 fe oorzaken weg te nemen of aan hem bijzondere bescherming te bieden. Gedacht kan worden aan bijwoorbeeld het stellen van eisen aan de inrichting van de arbeidsplaats en de tijd waaraan de werknemer aan een bepaalde werksituatie wordt blootgesteld ${ }^{5}$. Van deze ruime omschrijving zal in deze studie worden uitgegaan.

\section{Het rechtsgebied arbeidsomstandighedenrecht}

Het rechtsgebied arbeidsomstandighedenrecht kent een aantal rechtsbronnen. Hierbij kan allereerst een onderscheid worden gemaakt tussen nationale en internationale rechtsbronnen.

\subsection{Nationale rechtsbronnen}

De belangrijkste nationale rechtsbronnen zijn: de wet, de jurisprudentie en de collectieve arbeidsovereenkomst.

Voor wat betreft de eerstgenoemde nationale rechtsbron - de wet - wordt vaak aangenomen, dat het arbeidsomstandighedenrecht betrekking heeft op publiekrechtelijke normen, hetgeen tot gevolg kan hebben, dat niet-naleving ervan een strafbaar feit oplevert; het betreft dan zogenaamde bijzondere strafwetten, zoals bijvoorbeeld de Arbeidswet 1919, de Veiligheidswet 1934 en de Arbeidsomstandighedenwet ${ }^{6}$. Maar het rechtsgebied omvat meer dan alleen publiekrechtelijke normen. Zo bevat het Burgerlijk Wetboek terzake van de arbeidsovereenkomst een aantal bepalingen die van belang zijn. Allereerst kent artikel 1638 w een aantal verplichtingen woor de werkgever omtrent de arbeids- en rusttijden: zo mag in beginsel op zondag en op die dagen, die daarmee gelijk gesteld worden volgens plaatselijk gebruik, niet gewerkt worden en moet een minderjarige in de gelegenheid zijn om scholing te volgen. Tot slot geeft deze bepaling een rusttijdenregeling voor het in particuliere huishoudens werkzame personeel ${ }^{8}$. Daarnaast legt artikel $1638 \mathrm{x}$ een bijzondere zorgverplichting op de werkgever met betrekking tot de veiligheid en de gezondheid van zijn arbeiders, met daaraan gekoppeld een bijzondere schadevergoedingsverplichting". Tot slot kent de wettelijke regeling van de arbeidsovereenkomst een aantal algemene verplichtingen waaruit de werkgever en de arbeiders jegens elkaar regels omtrent het verrichten van arbeid kunnen afleiden ${ }^{10}$, zowel wat betreft bijvoorbeeld het onderwerp veilig werken, als omtrent bijvoorbeeld de vraag naar het verrichten van overwerk ${ }^{11}$ of ploegenarbeid $^{12}$. Daarbij moet vooral worden gedacht aan de artikelen $1638 \mathrm{z}$ en $1639 \mathrm{~d}$, waarin de werkgever onderscheidenlijk de arbeider de verplichting krijgt opgelegd om al datgene te doen of na te laten wat een goed 
werkgever of arbeider in gelijke omstandigheden behoort te doen en na te laten ${ }^{13}$.

Naast de wet geldt de jurisprudentie als rechtsbron. Op het terrein van het arbeidsomstandighedenrecht moet bij deze rechtsbron een onderscheid gemaakt worden tussen civielrechtelijke, administratiefrechtelijke en strafrechtelijke jurisprudentie. Terzake van de werkgever opgelegde civielrechtelijke zorgplicht op het terrein van het arbeidsomstandighedenrecht bestat een witgebreide en gepubliceerde jurisprudentie, hetgeen inherent is aan deze aldus opgelegde zorgverplichting. Het bepaalde in artikel 1638x van het Burgerlijk Wetboek kan gezien worden als een nadere uitwerking van artikel $1638 \mathrm{z}$, dat op zijn beurt de algemene norm herhaalt, dat overeenkomsten te goeder trouw ten uittwoer moeten worden gelegd en dat zij mede binden tot hetgeen de billijkheid vordert ${ }^{14}$. Wat redelijk en billijk is, zal telkens afhangen van de omstandigheden in een concrete situatie, hetgeen ter beoordeling is aan de rechter. Dit is, blijkens de toelichting ${ }^{15}$, ook uitdrukkelijk de bedoeling geweest. Met behulp van artikel $1638 \mathrm{z}$ van het Burgerlijk Wetboek worden, aldus de toenmalige bewindsman door

"eene gezonde rechtspraak"

uitkomsten verkregen ${ }^{10}$.

Voor zover het arbeidsomstandighedenrecht normen bevat, die in publiekrechtelijke wetgeving zijn neergelegd, heeft de jurisprudentie als rechtsbron slechts betrekkelijke waarde. Het overgrote deel van de uitspraken van de administratieve rechter en van met name lagere strafrechters is (nog) niet gepubliceerd of wordt niet gepubliceerd ${ }^{17}$.

Een andere rechtsbron is de collectieve arbeidsovereenkomst. Hierin komen in toenemende mate bepalingen voor omtrent de arbeidsomstandigheden. De praktische betekenis van deze bepalingen is in vergelijking met de bestaande wetgeving - vooralsmog - niet groot $^{18}$.

\subsection{Internationale rechtsbroninen}

Een steeds meer in belang toenemende rechtsbron vormen internationale verdragen en diverse andere internationale regelingen en aanbevelingen, van onder meer de Raad van Europa, de Europese Gemeenschappen en de Internationale Arbeidsorganisatie.

\subsubsection{Raad van Europa; het Europees Sociaal Handvest}

In Straatsburg werd van 1 tot en met 13 december 1958 door de Raad van Europa een conferentie gehouden ter bespreking van een ontwerp voor een Europees Sociaal Handvest ${ }^{19}$. Het Europees Sociaal Handvest is op 18 oktober 1961 tot stand gekomen ${ }^{20}$; ons land zou eerst in 1978 toetreden $^{21}$. Dit verdrag bevat een aantal bepalingen op het terrein van het arbeidsomstandighedenrecht. Zo heeft artikel 3 van dit verdrag betrekking op de arbeidssituatie voor wat betreft veilige en hygiënische arbeidsomstandigheden, geeft artikel 7 kinderen en jeugdige personen recht op bescherming en doet artikel 8 hetzelfde ten aanzien van vrouwelijke arbeiders.

Ieder land dat het Handvest heeft geratificeerd moet om de twee jaar aan de secretaris-generaal van de Raad van Europa over de uitvoering van de betreffende bepalingen rapporteren. Dit verslag moet vergezeld gaan van eventuele commentaren van de nationale werkgevers- en werknemersorganisaties. Het verslag en de commentaren worden beoordeeld door een comité van (onafhankelijke) deskundigen. De conclusies van de deskundigen worden doorgezonden naar het subcomité voor sociale zaken van het comité van ministers van de Raad van Europa. Dit subcomite beziet de bevindingen van de deskundigen en is verplicht hierover vertegenwoordigers van internationale werkgevers- en werknemersorganisaties te horen. Het rapport van het subcomité wordt daarna doorgestuurd naar het comité van ministers, dat zonodig op-en aanmerkingen, de zogenaamde recommendations, aan de betreffende nationale staat doet toekomen. De directe sanctie ont- 
breekt; controle vindt plaats door middel van informatie en confrontatie ${ }^{22}$.

De verdragsbepalingen terzake van de arbeidsomstandigheden zijn echter zo algemeen gesteld, dat toetsing hiervan aan nationale regelgeving niet of nauwelijks tot problemen kan leiden; zeker als voldaan wordt aan de verplichtingen die zijn aangegaan bij de verdragen en aanbevelingen van de Internationale Arbeidsorganisatie, die op dit terrein gedetailleerder zijn.

\subsubsection{De Europese Economische Gemeenschap}

Ook door de Europese Gemeenschappen wordt in toenemende mate aandacht geschonken aan de arbeidsomstandigheden.

In artikel 117 van het Verdrag van Rome, dat op 1 januari 1958 in werking is getreden ${ }^{23}$, wordt ter zake van de sociale politiek gesproken over de noodzaak van de

"verbetering van de levensstandaard en van de arbeidsvoorwaarden van de werknemers",

hetgeen onder meer bereikt moet worden via het

"nader tot elkaar brengen van wettelijke en bestuursrechtelijke bepalingen".

Artikel 118 van het verdrag draagt de Commissie ${ }^{24}$ op om een nauwe samenwerking op sociaal gebied tussen de lid-staten te bevorderen. Hierbij worden met name genoemd de bescherming van werknemers tegen bedrijfsongevallen en beroepsziekten en de arbeidshygine. De in het kader hiervan door de commissie uitgevaardigde aanbevelingen zijn niet bindend, maar worden over het algemeen wel opgevolgd, omdat zij totstandkomen na uitvoerige raadpleging van de lid-staten ${ }^{25}$. Het daarop volgende artikel $118 \mathrm{~A}^{26}$ draagt de lid-staten op zich te beijveren om de verbetering van met name het arbeidsmilieu te bevorderen, ten einde de veiligheid en de gezondheid van de werknemers te beschermen. Daarbij stellen zij zich de harmonisatie ten doel bij de verbetering van de op dit gebied bestaande omstandigheden. Ten einde tot de verwezenlijking van deze beoogde doelstelling bij te dragen, stelt de Raad van ministers ${ }^{27}$ op voordracht van de Commissie richtlijnen vast waarin de minimumvoorschriften worden vastgelegd, die geleidelijk zullen worden toegepast. Deze richtlijnen worden niet eerder uitgevaardigd, dan na raadpleging van het Economisch en Sociaal Comi$t^{28}$ en in samenwerking met het Europese Parlement ${ }^{28}$. De rechtskracht van een richtlijn wordt in artikel 189 van het verdrag als volgt omschreven:

"Een richtlijn is verbindend ten aanzien van het te bereiken resultaat voor elke lid-staat waarvoor zij bestemd is, doch aan de nationale instanties wordt de bevoegdheid gelaten, vorm en middelen te kiezen".

ledere lid-staat heeft weliswaar de vrijheid de bevoegdheden intern naar eigen goeddunken te verdelen en richtlijnen via maatregelen van regionale of plaatselijke overheden ten uitvoer te leggen, maar dit ontslaat hem niet van de verplichting om de richtlijn om te zetten in dwingende bepalingen van intern recht. Eenvoudige administratieve praktijken, die naar hun aard naar goeddunken van de administratie kunnen worden gewijzigd, kunnen niet worden beschouwd als een juiste uitvoering van de uit een richtlijn voortvloeiende verplichting ${ }^{3 n}$. Elke lid-staat is verplicht richtlijnen zodanig uit te voeren, dat volledig wordt voldaan aan de eis van rechtszekerheid en moeten dienovereenkomstig de bewoordingen van de richtlijn omgezet worden in interne bepalingen met een dwingend karakter; niet volstaan kan worden met circulaires, ambtelijke instructies of administratieve praktijken, die naar hun aard door de administratie kunnen worden gewijzigd en een passende openbaarmaking ontberen ${ }^{31}$.

Naast de aanbevelingen en richtlijnen kent artikel 189 van het verdrag nog een besluitvorm, namelijk de verordening, die wezenlijk verschilt van de richtlijn. Een verordening heeft een algemene strekking. Zij is verbindend in al haar onderdelen en is rechtstreeks toepasselijk in elke lid-staat.

Op grond van artikel 122 van het verdrag moet de Commissie jaarlijks verslag uitbrengen van de ontwikkeling van de sociale toestand in de Europese Gemeenschap, waarin een beeld wordt gegeven van wetgevende en andere activiteiten, die de lid-staten en de Gemeenschap zelf, onder meer op het terrein van het arbeidsomstandighedenrecht, ondernemen. 
In het kader van de Europese Economische Gemeenschap kunnen ten aanzien van het arbeidsomstandighedenrecht als voorbeelden van verordeningen uitgevaardigd door de Raad genoemd worden: verordening no. $3820 / 85$ tot harmonisatie van bepaalde voorschriften van sociale aard voor het wegvervoer ${ }^{32}$ en verordening no. $3821 / 85$ betreffende het controle-apparaat in het wegvervoer ${ }^{33}$. Voorbeelden van richtlijnen zijn: de richtlijn betreffende de vaststelling van basisnormen van de gezondheidsbescherming van bevolking en werknemers tegen de gevaren van ioniserende stralen $^{34}$; de richtlijn betreffende de onderlinge aanpassing van de wettelijke en bestuursrechtelijke bepalingen inzake de bescherming van werknemers die aan vinylchloridemonomeer zijn blootgestell ${ }^{35}$; de richtlijn inzake gemotoriseerde transportwerktuigen ${ }^{36}$ en de richtlijn betreffende de tenuitvoerlegging van maatregelen ter bevordering van de verbetering van de veiligheid en de gezondheid van werknemers op het werk ${ }^{37}$. Aanbevelingen op het terrein van het arbeidsomstandighedenrecht zijn bijvoorbeeld: de aanbeveling betreffende de bedrijfsgeneeskundige dienste ${ }^{38}$, de aanbeveling betreffende de medische controle van werknemers, die aan bijzondere risico's blootstaan ${ }^{39}$, en de aanbeveling betreffende de arbeidsbescherming van jeugdige personen ${ }^{40}$.

Voorts moet er nog op worden gewezen, dat in EG-verband de inspanningen op het terrein van de arbeidsomstandigheden hebben geleid tot het instellen van een Raadgevend Comité voor de veiligheid, hygiëne en gezondheidsbescherming op de arbeidsplaats ${ }^{41}$ en tot het oprichten van een Europese Stichting tot verbetering van de levens- en arbeidsomstandigheden ${ }^{42}$. Deze stichting heeft tot taak:

"studies over de verbetering van het leefklimaat en de arbeidsomstandigheden op middellange en lange termijn te ontwikkelen en uit te diepen, en de factoren die verandering kunnen bewerkstelligen op te sporen. Bij de uitvoering van haar taken houdt de Stichting rekening met het communautaire beleid op deze gebieden en licht zij de instellingen van de Gemeenschap voor over de in aanmerking komende doelstellingen en beleidslijnen, met name door hun de wetenschappelijke kennis en de technische gegevens te doen toekomen ${ }^{43 *}$.

In het kader van deze taakstelling heeft de Stichting al vele publicaties en aanbevelingen het licht doen zien, zoals bijwoorbeeld ten aanzien van het verschijnsel ploegenarbeid ${ }^{44}$. Andere publikaties zijn bijvoorbeeld New Forms of Work ${ }^{45}$, Legal and Contractual Limitations to Working-Time in the European Community Member States ${ }^{48}$ en De melding van bedrijfsongevallen en beroepsziekten in de Europese Gemeen$\operatorname{schap}^{47}$.

\subsubsection{De Internationale Arbeidsorganisatie}

Als laatste dient te worden genoemd de in 1919 opgerichte Internationale Arbeidsorganisatie ${ }^{48}$. De grondgedachte, die aan de basis van deze na de Eerste Wereldoorlog opgerichte organisatie ligt, is, dat vrede niet alleen het resultaat kan zijn van politieke overeenkomsten en ontwapeningsverdragen tussen landen. De vrede moet ook gebaseerd zijn op sociale rechtvaardigheid, dat wil zeggen op het economisch en sociaal welzijn van de volkeren in de wereld, op bevredigende loon-en arbeidsvoorwaarden, op een behoorlijk peil van de werkgelegenheid en op een redelijke levensstandaard. Deze doelstelling tracht de Internationale Arbeidsorganisatie te verwezenlijken door míddel van samenwerking, niet alleen tussen de regeringen van de lid-staten, maar ook met de medewerking van vertegenwoordigers van werknemers en van werkgevers ${ }^{49}$.

Deze internationale organisatie heeft gedurende haar bestaan een reeks verdragen en aanbevelingen ${ }^{60}$ het licht doen zien op het terrein van de arbeidsomstandigheden. Een geratificeerd verdrag verplicht de lidstaat om de nationale wetgeving in overeenstemming te brengen met de in het verdrag neergelegde beginselen. In een aanbeveling worden alleen normen vastgesteld die dienen als stimulans en oriëntatie voor maatregelen op nationaal niveau. De aanbeveling wordt aan alle lid-staten van de organisatie bekend gemaakt, die dan vervolgens de aanbeveling moeten voorleggen aan de bevoegde autoriteit, wat in de meeste gevallen het nationale parlement is,

"opdat er wetgevende of andere maatregelen ter zake worden genomen ${ }^{51 "}$ ". Het eerste verdrag dat in het kader van de Internationalle Arbeidsorganisatie tot stand kwam, was het Ver- 
drag strekkende tot beperking van de arbeidsduur in nijverheidsondernemingen tot acht uren per dag en achtenveertig uren per week ${ }^{52}$. Daarna zouden er nog vele volgen, zoals het Verdrag betreffendie de minimumleeftijd ${ }^{63}$, het Verdrag betreffende het geneeskundige onderzoek van jeugdige personen (industrie) ${ }^{54}$, Verdrag betreffende de bescherming van het moederschap ${ }^{55}$, Verdrag betreffende het gebruik van loodwit in verfstoffen ${ }^{56}$ en tot slot het Verdrag betreffende beroepsveiligheid en gezondheid en het arbeidsmi$\mathrm{lieu}^{57}$. Als voorbeelden van aanbevelingen kunnen worden genoemd de Aanbeveling betreffende het voorkomen van arbeidsongevallen ${ }^{53}$, de Aanbeveling betreffende bedrijfsgeneeskundige diensten ${ }^{5 *}$, de Aanbeveling betreffende de verkorte arbeidsduur ${ }^{60}$ en tot slot de Aanbeveling betreffende de bescherming van vrouwen en jeugdige personen tegen loodvergiftiging ${ }^{8 /:}$ :

Controle op de uitwoering van de verdragsverplichtingen geschiedt, evenals bij het Europees Sociaal Handvest, door middel van informatie en confrontatie.

\section{De arbeidsinspectie}

In het kader van het arbeidsomstandighedenrecht, neergelegd in publiekrechtelijke regelgeving, wordt men geconfronteerd met bepalingen, die erop gericht zijn de naleving van andere bepalingen te waarborgen. Deze zogenaamde controlebepalingen hebben enerzijds betrekking op de middelen, die controle mogelijk moeten maken, en anderzijds op personen die de controle tot taak hebben. Geen of onvoldoende controle bergt het risico in zich, dat dit deel van het arbeidsomstandighedenrecht verwordt tot een dode letter. Met andere woorden: een goede controle op de naleving kan van belang zijn voor de uitwerking van deze wetgeving. De belangrijkste overheidsinstantie die zich bezig houdt met de controle op de naleving van de arbeidsomstandighedenwetgeving is de arbeidsinspectie.

Opvallend is, dat het bestaan van de arbeidsinspectie als een gegeven werd en wordt beschouwd. Wellicht is dit de reden waarom de geschiedschrijving over de arbeidsinspectie zelf verbrokkeld en onvolledig blijkt te zijn en lacunes vertoont. Deze studie beoogt allereerst in deze lacune te voorzien. Daar de lotgevallen van de arbeidsinspectie zeer nauw verbonden zijn met de publiekrechtelijke wetgeving op het terrein van het arbeidsomstandighedenrecht, komt in deze studie, onvermijdelijk, de ontwikkeling van deze wetgeving aan de orde. De historie leert tevens, dat de arbeidsinspectie gedurende haar bestaan op vele andere terreinen bemoeienissen heeft gehad en thans nog heeft. Uit het vorenstaande vloeien een aantal nauw met elkaar samenhangende vragen voort, die in elk geval beantwoord zullen worden:

- welke redenen lagen er aan de instelling van een afzonderlijke arbeidsinspectie ten grondslag?

- welke taken waren haar toebedeeld?

- waarom heeft zij zich gedurende haar bestaan met andere (beleids-)terreinen beziggehouden dan die van de arbeidsomstandigheden?

Een andere vraag is in hoeverre kennis uit het verleden kan worden benut in het kader van toekomstige ontwikkelingen bij de arbeidsinspectie en haar beieidsterreinen?

\section{Werkwijze}

Zoals in het voorgaande reeds is vermeld, wordt een historisch beeld geschetst van de ontwikkeling van de arbeidsinspectie als organisatie en van haar werkterrein, niet alleen terzake van de wettelijke voorschriften op het terrein van de arbeidsomstandigheden, maar ook andere wetgeving waar de dienst bemoeienis mee heeft (gehad) en wat genoemd is de bijzondere opdrachten. Hierbij is gekozen voor een systeem waarbij de chronologie het voornaamste richtsnoer is. Waar in het geschetste historische beeld zonder problemen, dat wil zeggen zonder de kans, dat versnippering en verwarring optreedit, aandacht kan worden besteed aan typisch juridische aangelegenheden (zoals (sub)delegatie en de kacheltjes van Jamin ), of bijzondere bevoegdheden van de arbeidsinspectie ( zoals het bevel tot stillegging van werk), is dit ook gebeurd. De gekozen 
systematiek houdt echter een nadeel in. In de diverse hoofdstukken worden in relatie tot de wetgeving bepaalde begrippen gehanteerd, wordt de aansprakelijkheidsregeling aangenomen en de arbeidsinspectie bepaalde bewoegdheden toebedeeld zonder dat daarop om de reeds genoemde reden inhoudelijk kan worden ingegaan. Vandaar dat een afzonderlijk hoofdstuk is opgenomen, waarin een aantal juridische aangelegenheden behandeld wordt. Eveneens in een afzonderlijk hoofdstulk worden de taak, organisatie en bevoegdheden van de arbeidsinspectie getoetst aan internationale regelingen terzake.

Bij de indeling in hoofdstukken is gebruik gemaakt van een bepaalde indeling in tijdvakken. Bij iedere periodisering doet zich telkens hetzelfde probleem voor. Aan de hand van welke criteria moet de indeling worden gemaakt? In deze studie is gebruik gemaakt van twee soorten criteria, namelijk interne en externe criteria. Gezien het onderwerp van deze studie - de ontwikkeling van de arbeidsinspectie in een veranderende wetgeving - is in eerste instantie gekozen voor daaraan gerelateerde, interne criteria, zoals het ontstaan van de arbeidsinspectie, haar reorganisatie in 1909, het jaar 1962 waarin het directoraat-generaal van de Arbeid werd ingesteld en jaar 1975, het jaar waarin de arbeidsinspectie niet alleen opnieuw een reorganisatie te wachten stond, maar waarin ook de basis werd gelegd voor de Arbeidsomstandighedenwet, waarvan in het parlement is gezegd, dat het de belangrijkste na-oorlogse wet op het terrein van het arbeidsomstandighedenrecht is. Maar ook van externe criteria, zoals de beide wereldoorlogen en het interbellum, met als cesuur de crisis van 1929, is gebruik gemaakt. Deze gebeurtenissen zijn ook voor de arbeidsinspectie niet zonder gevolgen gebleven. Zowel de aard van de activiteiten, die zij in deze perioden moest verrichten, als de onder haar regarderende regelgeving ondergingen een verandering en verbreding.

Bij deze studie is gebruik gemaakt van bestaande literatuur. Daarnaast is gebruik gemaakt van parlementaire stukken, rapporten en verslagen, stukken afkomstig uit diverse archieven, zoals bijvoorbeeld het Rijksarchief en het Centraal Historische Archief. Een grote bron van informatie over de arbeidsinspectie en haar werkterrein vormen de verslagen van de inspecteurs van de arbeid en de latere jaarverslagen van de arbeidsinspectie en het directoraat-generaal van de Arbeid.

\section{De opbouw van het boek}

De opbouw van het boek is als volgt:

In hoofdstuk 2 wordt de ontstaansgeschiedenis van de arbeidsinspectie in de negentiende eeuw behandeld. Na een inleidende paragraaf warin onder meer de economische ontwikkeling en industrialisatie, de arbeidsomstandigheden en de rol van de overheid worden geschetst, wordt aandacht besteed aan die voorstellen waarin gepleit wordt voor overheidsoptreden, al dan niet door een afzonderlijk in te stellen controle-apparaat om aan mett name de misstanden terzake van aanvankelijk alleen de kinderarbeid een einde te maken. Voorts wordt aandacht besteed aan de Kinderwet-Van Houten en de diverse pogingen om dit wetje te verbeteren om ten slotte uit te komen bij de Arbeidswet 1889, waarbij de arbeidsinspectie werd ingesteld.

In hoofdstuk 3 wordt na een inleidendle paragraaf waarin de industrialisatie en het ontstaan van de moderne arbeidsverhoudingen, en een terugblik naar het vorige hoofdstuk terzake van de motieven voor overheidsingrijpen en vervolgens de toenemende overheidszorg geschetst worden, de periode beschreven tot de reorganisatie van de arbeidsinspectie in 1909. In deze periode komt een aantal wetten, zoals bijvoorbeeld de Veiligheidswet van 1895 tot stand, waarbij de arbeidsinspectie een rol heeft gespeeld. Maar deze periode wordt ook gekenmerkt door diverse aangelegenheden die de orgamisatie van de arbeidsinspectie betreffem, zoals de uitbreiding, en het al dan niet samengaan met de dienst voor het stoomwezen.

In hoofdstuk 4 wordt de reorganisatie van de arbeidsinspectie beschreven en de opvattingen en meningen daaromtrent zowel vanuit als van buiten het parlement.

In hoofdstuk 5 wordt de periode na de reorganisatie tot de Eerste Wereldoorlog beschreven. In deze periode zal de arbeidsinspectie de bevoegdheid overnemen van gemeentelijke en provinciale overheden tot het verlenen van vergunningen terzake van de arbeids- en rusttijden. Voorts komt in deze periode onder meer de 
Steenhouwerswet 1911 tot stand waarbij in het parlement uitgebreid de problematiek rond de (sub)delegatie aan de orde komt, maar ook de voorstellen van de toenmalige minister Talma om het georganiseerde bedrijfsleven bij de uitvoering van de arbeidersbeschermende wetgeving te betrekken.

Hoofdstuk 6 beschrijft de periode van de Eerste Wereldoorlog, die voor de arbeidsinspectie wordt gekenmerkt door een herschikking van prioriteiten, van arbeidsbeschermende wetgeving naar activiteiten, die erop gericht waren om het verstoorde economische leven behoeden voor nog meer dan de al bestaande nadelen en het lenigen van de ontstane economische nood.

In de hoofdstukken 7 en 8 wordt het interbellum behandeld, waarbij de krach van 1929 als cesuur dient. Deze periode(n) geven een enorme uitbreiding te zien van het takenpakket van de arbeidsinspectie, dat zich uitbreidt over de gehele sociaal-economische problematiek.

In hoofdstuk 9 worden de activiteiten van de arbeidsinspectie gedurende de Tweede Wereldoorlog besproken, en tevens de rol die deze dienst heeft gespeeld bij het totstandkomen van de Stichting van de Arbeid. Hoofdstuk 10 behandelt de periode van de wederopbouw, die zich uitstrekt tot 1962.

In hoofdstuk 11, dat de periode van 1962 tot 1975 testrijkt, gebeurt er, althans terzake van de wetgeving op het terrein van de arbeidsomstandigheden niet veel, vandaar de benaming: stilte voor de storm.

Het daarop volgende hoofdstuk behandelt de periode vanaf 1975 en geeft te zien, welke enorme veranderingen er plaatsvinden op het terrein van het arbeidsomstandigenhedenrecht, zoals bijvoorbeeld het totstandkomen van het Jongerenstatuut, de voorstellen omtrent een nieuwe Arbeidstijdenwet, en de totstandkoming van de Arbeidsomstandighedenwet; een periode die beheerst wordt door de deregulering, privatisering, bezuinigingen en dergelijke, hetgeen niet ongemerkt aan de arbeidsinspectie voorbij zal gaan, en ook veranderingen in de organisatie van de arbeidsinspectie.

In hoofdstuk 13 worden een aantal juridische problemen op het gebied van het arbeidsomstandighedenrecht, zij het beperkt tot de Arbeidswet 1919, de Veiligheidswet 1934 en de Arbeidsomstandighedenwet, afzonderlijk belicht.

In hoofdstuk 14 vindt de toetsing plaats aan internationaal overeengekomen normen van de Internationale Arbeidsorganisatie ten aanzien van de taak, organisatie en bevoegdheden van de arbeidsinspectie.

Hoofdstuk 15 bevat tot besluit een slotbeschouwing en een samenvatting. 
1. A.N. Molenaar, Arbeidsrecht deel IIA Bijzonder deel Het geldende recht, Zwolle 1957, blz 1175.

2. Zie A.J.C.M. Geers/J.K.M. Gevers, Arbeidsomstandighedenrecht, Deventer 1979, blz. 12.

3. Zie bijvoorbeeld H.L. Bakels/L. Opheikens, Schets van het Nederlands arbeidsrecht, Deventer 6e druk 1982 , blz. 34 .

4. A.J.C.M. Geers, Recht en humanisering van de arbeid, Deventer 1988, blz. 13; A.J.C.M. Geers/J.K.M. Gevers, t.a.p., blz. 11. Opgemerkt zij, dat ook H.L. Bakels/L. Opheikens in de 7e druk (Deventer 1986, blz. 35) en H.L. Bakels in de 8 e druk (Deventer 1987, blz. 41 ) deze term gebruiken ( zie nt. 3 ).

5. Zie A.J.C.M. Geers, t.a.p., blz. 13; A.J.C.M. Geers/ J.K.M. Gevers, t.a.p., blz. 11.

6. Resp. de Wet van 1 november 1919 , Stb. 624, de Wet van 2 juli 1934, Stb. 352 en de Wet van 8 november 1980 , Stb. 664 .

7. Zie hierover E.W. Catz, Quasi-zondagen, in De Gids 1967 blz. 112 - 113.

8. Zie hierover M.B. Vos, Wijziging van artikel 1638w BW, in S.M.A. 1960 blz. 566 - 567.

9. Zie A.J.C.M. Geers/J.K.M. Gevers, t.a.p., blz. $135 \mathrm{t} / \mathrm{m}$ 155; Th.H.J. Dorrestein, Hernieuwde belangstelling voor art. 1638x, in N.J.B. 1972 blz. $1141 \mathrm{t} / \mathrm{m}$ 1151; A.J.C.M. Geers/J.K.M. Gevers, Schadeloosstelling van slachtoffers van bedrijfsongevallen en beroepsziekten, in N.J.B. $1977 \mathrm{blz} .951 \mathrm{t} / \mathrm{m}$ 959; H. van Oostrum, Arbeidsrechtelijke en strafrechtelijke aspecten van bedrijfsongevallen, in AAe $1974 \mathrm{blz} .131 \mathrm{t} / \mathrm{m}$ 144; A.J.C.M. Geers, t.a.p., blz.. 148 t/m 169; L. Bier, Aansprakelijkheid voor bedrijfsongevallen en beroepsziekten, Deventer 1988 .

10. Zie artikel $1639 \mathrm{~b}$ van het Burgerlijk Wetboek, dat luidt:

"De arbeider is verplicht zich te houden aan de voorschriften omtrent het verrichten van den arbeid alsmede aan die, welke strekken ter bevordering van de goede orde in de onderneming des werkgevers, hem door of namens de werkgever binmen de perken van wet of verordening, van overeenkomst of reglement gegeven".

De tegenhanger voor de werkgever is neergelegd in artikel $1638 \mathrm{z}$ van het Burgerlijk Wetboek, dat luidt:

"De werkgever is in het algemeen verplicht al datgene te doen en na te laten, wat een goed werkgever in gelijke omstandigheden behoort te doen en na te laten".

11. Zie J. van Drongelen, De verplichting tot het verrichten van overwerk, in S.M.A. 1983 blz. $78 \mathrm{t} / \mathrm{m} 83$; M.G. Levenbach, Overwerk, in R.B.A. XXe serie blz. $49 \mathrm{t} / \mathrm{m}$ 52; R.C. Gisolf, Ander werk, Arnhem 1985, blz. $34-35$.

12. Zie R.C. Gisolf, ta.p., blz. 34 .

13. Zie over deze artikelen onder meer W.C.L. van der Grinten, De goede werkgever en de goede arbeider, in Hedendaags arbeidsrecht, Alphen a/d Rijn 1966, blz. 134 t/m 145; M.G. Rood, Over de goede werkgever en de goede werknemer, in S.M.A. 1982 blz. $498 \mathrm{t} / \mathrm{m} \mathrm{507;} \mathrm{R.C.} \mathrm{Gisolf,} \mathrm{De} \mathrm{goede} \mathrm{werkgever,} \mathrm{in} \mathrm{Arbeid} \mathrm{en}$ kort geding, Deventer 1983, blz 33 t/m 52; R.C. Gisolf, Ander werk, Arnhem 1985. 
14. Zie de artikelen 1374 en 1375 van het B.W..

15. Bijlagen Hand. Tweede Kamer, zitting 1903 - 1904, 137.3 (memorie van toelichting) blz. 33. Zie A.E. Bles, Wet op de arbeidsovereenkomst. Deel II, "s-Gravenhage 1908, blz. $374-375$.

16. Zie voor de jurisprudentie de in de nt. $8 \mathrm{t} / \mathrm{m} 13$ genoemde literatuur.

17. Zie voor een overzicht onder meer J.J. Dodeweerd/J. Struik, Uitspraken Veiligheidswetgeving, Deventer 1979.

18. Zie A.J.C.M. Geers/J.K.M. Gevers, t.a.p., blz. $106 \mathrm{t} / \mathrm{m}$ 108; H. de Burlet, Gezondheid en veiligheid op de werkplek, Leiden 1978, blz. 15 - 16; A.J.C.M. Geers, t.a.p., blz. 256 t/m 266. Zie Hfdst. 12 par. 1 (Inleiding).

19. Het handvest is een aanvulling op de in 1950 tot stand gekomen Europese conventie van de rechten van de mens. Zijn in deze conventie de zogenaamde vrijheidsrechten, zoals de vrijheid van godsdienst, drukpers en vereniging en vergadering neergelegd, het handvest bevat zogenaamde sociale rechten. Zijn de vrijheidsrechten gebaseerd op het idec, dat de burger bescherming behoeft tegen het misbruik, dat de staat van zijn macht kan maken, de sociale rechten zijn vooral gebaseerd op de gedachte, dat de staat zo nodig in het maatschappelijk leven moet ingrijpen of er voor moet te zorgen, dat bepaalde sociale rechten van de burger inderdaad worden verwezenlijkt. Zie H.L. Bakels, Het Europees Sociaal Handvest, in NJB 1959 blz. 85 - 86.

20. Zie Trb. 19623.

21. Zie Rijkswet van 2 november 1978, Stb. 639. Zie Trb. 198065.

22. Zie H.L. Bakels, in NJB 1959 blz. 90.

23. Trb. 195791.

24. Zie de artikelen $155 \mathrm{t} / \mathrm{m} 163$ van het Verdrag van Rome.

25. Zie A.J.C.M. Geers/J.K.M. Gevers, t.a.p., blz. 20.

26. Zie artikel 21 van de Europese Akte van 17 en 28 februari 1986, Trb. 198663 (in werking getreden op 1 juli 1987; zie Trb. 1987118 ), waarbij deze bepaling aan het Verdrag van Rome is toegevoegd.

27. Zie de artikelen $145 \mathrm{t} / \mathrm{m} 153$ van het Verdrag van Rome.

28. Zie de artikellen $193 \mathrm{t} / \mathrm{m} 198$ van het Verdrag van Rome

29. De uit hoofde van dit artikel vastgestelde bepalingen beletten niet, dat een lid-staat maatregelen voor een hogere graad van bescherming van de arbeidsomstandigheden handhaaft en treft die met het verdrag verenigbaar zijn ( zie artikel 118A, derde lid, van het Verdrag van Rome).

30. Zie L.J. Brinkhorst/R. Barents, Grondlijnen van Europees recht, Alphen a/d Rijn/Brussel 1989, blz, 189 190. 
31. Zie P.J.G. Kapteyn/P. Verloren van Themaat, Inleiding tot het recht van de Europese Gemeenschappen, Deventer 4e druk 1987, blz. $141-142$.

32. Deze verordening is gepubliceerd in $\mathrm{Pb} \mathrm{EG} \mathrm{L} \mathrm{370/1.} \mathrm{Deze} \mathrm{verordening} \mathrm{is} \mathrm{met} \mathrm{name} \mathrm{gebaseerd} \mathrm{op} \mathrm{artikel}$ 75 van het Verdrag van Rome, dat valt onder titel $\Gamma$, en dat handelt over vervoer.

33. Deze verordening is gepubliceerd in $\mathrm{Pb}$ EG L $370 / 8$.

34. Richtlijn van 2 februari 1959, Pb EG $1959 \mathrm{blz}$. 221.

35. Richtlijn van 29 juni 1978, Pb EG L 197 blz, 12 t/m 18.

36. Richtlijn van 24 december 1986 , Pb EG L 384/12.

37. Richtlijn van 12 juni 1989, Pb. EG 1989 L 183.

38. Gepubliceerd in $\mathrm{Pb}$. EG van 31 augustus 1962 no. 80.

39. Deze aanbeveling is gepubliceerd in Pb. EG van 1966 blz. 2753 .

40. Deze aanbeveling is gepubliceerd in $\mathrm{Pb}$. EG van 15 februari 1972 no. 25 .

41. Zie Publ.blad van 9 juli 1974 L. 185 blz. 15. Het oprichtingsbesluit is overwegend gebaseerd op artikel 145 van het Verdrag van Rome.

42. Verordening van 26 mei 1975, no. 1365/75. Zie ook A.J.C.M. Geers/J.K.M. Gevers, t.a.p., blz. 19 t/m 21; zie ook M. van Bleiswijk/H. van Doorneveld-Luuring, EG-nieuwe stijl moet ook leiden tot verbetering van arbeidsomstandigheden, in M.v.A. $1988 \mathrm{blz} .539 \mathrm{t} / \mathrm{m} 542$.

43. Zie artikel 2 van de Verordening van 26 mei 1975, no. 1365/75.

44. Zie onder meer Europese Stichting tot verbetering van de levens- en arbeidsomstandigheden ( hierna Europese Stichting/European Foundation), Overzicht van de research van de Europese Stichting over ploegenarbeid 1977 - 1980, Dublin 1982, waarin een overzicht wordt gegeven van 66 afzonderlijke rapporten die zijn uitgebracht.

45. Europese Stichting, New Forms of Work. Labour Law and Social Security Aspects in the European Community, Dublin 1987.

46. European Foundation, Legal and Contractual Limitations to Working-Time in the European Community Member States, Deventer 1988.

47. Europese Stichting, De melding van bedrijfsongevallen en beroepsziekten in de Europese Gemeenschap, Dublin 1989.

48. Zie over de ontstaangeschiedenis van deze internationale organisatie onder meer: B.W. Schaper, Oorsprong, achtergrond en historie van de I.A.O., in ILO 1919 - 1969. Vijftig jaar Internationale Arbeidsorganisatic, Alphen a/d Rijn 1969, blz. $35 \mathrm{t} / \mathrm{m} 45$. 
49. Zie B. Roolvink, de toenmalige minister van Sociale Zaken en Volksgezondheid, in een ten geleide in het speciale nummer van S.M.A. dat werd gewijd aan het 50-jarige bestaan van de I.A.O., Alphen a/d Rijn 1969 blz. 7 .

50. Zie voor eef overzicht: De invloed van internationale arbeidsverdragen en -aanbevelingen van de Internationale Arbeidsorganisatie, Deventer 1979, blz. $111 \mathrm{t} / \mathrm{m} 124$.

51. Zie: De invloed van internationale arbeidsverdragen en -aanbevelingen van de Internationale Arbeidsorganisatie, blz. 7 nt. 1 .

52. Verdrag no. 1; zie Tweede Kamer, zitting 1920 - 1921, 553.1 en 2 (bijlage ).

53. Verdrag no. 138, Trb. 197471.

54. Zie Tweede Kamer, zitting 1947 - 1948, 787.1 ( bijlage ).

55. Verdrag no. 103, Trb. 1953 129. Zie hierover J. van Drongelen/T. Kappelhof, Verdrag no. 103 van de Internationale Arbeidsorganisatie en artikel 11 van de Arbeidswet 1919, in S.M.A. 1984 blz. 167 t/m 173; M.P. Timmers-de Vin/W.C. Monster, Het zoogrecht gespeend van een goede wettelijke regeling, in NJB 1987 blz. 931 t/m 935; W.C. Monster/M.P. Timmers-de. Vin, Positierecht. Rechtspositie van zwangere en pas bevallen werkneemsters, Alphen a/d Rijn 1989, blz. 148 t/m 154.

56. Verdrag no. 13. Zie Trb. 1957 150; Trb. 1965100.

57. Verdrag no. 155. Zie: Trb. 1981243 en Trb. 1982100.

58. Aanbeveling no. 31 ( 1929 ).

59. Aanbeveling no. 112 ( 1959 ).

60. Aanbeveling no. 116 ( 1962 ).

61. Aanbeveling no. 4 ( 1921 ). 


\section{of het ontstaan van de arbeidsinspectie in de negentiende eeuw}

\section{Inleiding}

\subsection{Economische ontwikkeling en industrialisatie}

De roep om overheidsbemoeiing en het ontstaan van de arbeidersbeschermende wetgeving vinden voor een belangrijk deel hun oorsprong in de industrialisatie. Tot het midden van de negentiende eeuw was er sprake van berusting en stagnatie niet alleen op het terrein van de economische ontwikkeling en de industrialisatie maar ook ten aanzien van de rol van de factor arbeid en de arbeiders daarbij. In 1846 zou de Maatschappij van Nijverheid omtrent de tijdgeest het volgende naar voren brengen"

"De heillooze stelling, dat er tot het opzetten eener industriele onderneming meer behoefd wordt dan een klein beginkapitaal, een geringe arbeidzaamheid en een oudere meesterknecht, deze beillooze stelling is het, die onze Nijverheid heeft in den grond geboord".

Dat er tot circa 1850 nauwelijks sprake was van industrialisatie blijkt vit de conclusie van De Jonge ${ }^{2}$, dat ten minste de helft van de beroepsbevolking in ons land rechtstreeks afhankelijk was van de werkgelegenheid in de agrarische sector of daarbij nauw betrokken. Echte industriesteden met een grote hoeveelheid fabrieksarbeiders bestonden nog niet met uitzondering van de stad Maastricht. Het was de enige stad in Nederland met een grotendeels van de aldaar gevestigde industrieën afhankelijke beroepsbevolking ${ }^{3}$. In de meeste andere steden waren voornamelijk kleine ambachtelijke bedrijven gevestigd met de traditionele meester-knecht verhoudingen. Wel bestonden er in sommige grotere steden een of meer grote of middelgrote bedrijven, die op een modern aandoende wijze werden geleid, zoals de fabriek van stoom- en andere werktuigen van Van Vhissingen en Dudok van Heel in Amsterdam, begonnen in 1827 met 26 arbeiders; in 183080 a 100 ; in 1848 ruim 800 en in 18561600 arbeiders, en de in 1825 opgerichte Rotterdamse scheepswerf Fijenoord met ongeveer 650 arbeiders in $1852^{4}$.

In deze periode trad een zekere kentering op en werd er een verschuiving merkbaar van de agrarische naar de industriële sector ${ }^{5}$; niet alleen het aantal personen, dat in de industrie werkzaam was, nam toe, maar ook het aantal grote bedrijven groeide. De stoommachine begon de gebruikeijke beweegkracht te vormen. Waren er in 1855 nog slechts 800 stoomketels in gebruik, in 1871 waren dat er al 3000 , tien jaar later was dit aantal verdubbeld ${ }^{\oplus}$. Bestaande fabrieken gingen langzamerhand over op nieuwe produktiemethoden en moderne technologieën en er werden in verschillende delen van het land nieuwe bedrijfstakken gevestigd die zich van meet af aan richtten op massaproduktie. Maar de echte doorbraak begon eerst rond 1870. Als bewijs daar voor kan dienen het groeiende aantal naamloze vennootschappen ${ }^{7}$. Waren er in 1850 nog slechts 137 naamloze vennootschappen, twintig jaar later was dit aantal reeds opgelopen tot $456^{8}$. Deze juridische constructie maakt het mogelijk een meer rationele bedrijfsvoering te voeren doordat een scheiding wordt aangebracht tussen prive-vermogen en (bedrijfs)kapitaal; een scheiding die in de eerste helft van de negentiende eeuw ongebruikelijk was.

De industrialisatie van ons land kwam niet alleen later tot stand in vergelijking met de ons omringende landen, maar verliep ook trager. Als verklaring voor deze late start van de industrialisatie kan onder meer de al genóemde tijdgeest, zoals die tot uiting kwam in de houding van de fabrikanten, worden genoemd. Maar dit niet alleen. Ook andere factoren speelden een rol, zoals het ontbreken van belangrijke grondstoffen en energiebronnen als ijzer en kolen die voor de industrialisatie van groot belang zijn, de gebrekkige transportmiddelen en de ontoereikende infrastructuur en communicatiemogelijkheden ${ }^{\theta}$. Daarnaast konden de ons omringende landen door het bezit van grondstoffen en een toereikende comsumptieve vraag een eigen handelspolitiek voeren. Hierdoor konden de buitenlandse ondernemingen well op de Nederlandse markt concur- 
reren, maar ondervond de afzet van Nederlandse produkten in het buitenland in het algemeen grote moeilijkheden. Bovendien nodigde het ruime aanbod van arbeidskrachten, dat als gevolg van de economische malaise aanwezig was, niet uit tot mechanisatie. De slechte infrastructuur maakte, dat de kosten verbonden aan de invoer van grond-en hulpstoffen, hoog waren. Bovendien leidde de bodemgesteldheid van ons land ertoe, dat verbetering van de infrastructuur zowel financieel als technisch moeilijk te verwezenlijken was.

\section{2. "Armen" en "arbeiders"}

Slechte oogsten, aardappelziekte, hongersnood, cholera en de buitengewoon slechte economische situatie leidden ertoe, dat omstreeks het midden van de worige eeuw door de burgerij steeds meer werd gesproken en geschreven over de miserabele omstandigheden waarin de lagere standen leefden. Armoede werd steeds meer als een nijpend probleem gezien waarvoor een oplossing gezocht diende te worden. Eén van de vele initiatieven door de burgerij in verband met dit armoedeprobleem genomen, was het oprichten van de Algemeene Vereeniging tegen het pauperisme bij de arbeidende klasse, die het op zich nam landelijke congressen over het armwezen te organiseren. Uit het verslag van het eurste Nederlandsche Congres over het armwezen, dat in 1854 werd gehouden, blijkt, dat volgens de officiële statistieken ongeveer een zevende van de "Nederlandse Natie" woor kortere of langere tijd bedeeld werd, terwijl naar schatting ongeveer een vierde deel van de totale bevolking in zorgwekkende toestand verkeerde ${ }^{10}$. Van der Ploeg en Zinkstok concluderen hieruit, dat, in de ogen van hun beter gesitueerde tijdgenoten, "armen" en "arbeiders" niet van elkaar te onderscheiden waren" $"$. Van de denkbeelden over het arbeidersvraagstuk vór $1850 \mathrm{kan}$, aldus Brugmans ${ }^{12}$, slechts gezegd worden, dat zij .... niet bestonden. De gegoede burgerij zag tegenover zich slechts de "armen" zonder op te merken welke grote verscheidenheid daaronder schuil ging. De "arbeider" werd eveneens tot de "armen" gerekend. Hieronder werd namelijk verstaan: zij, die in kommervolle, "armoedige" omstandigheden verkeerden. Met andere woorden: men kende slechts het vraagstuk van de armoede, van het pauperisme.

Vanwaar die groeiende belangstelling van het armoedeprobleem ${ }^{13}$ ? De Bosch Kemper ${ }^{14}$ schrijft dit, althans voor een deel, toe aan de

"de meerdere zachtheid en gevoeligheid der menschen".

Ongetwijfeld zal zeker een rol gespeeld hebben, dat in de publieke opinie in die dagen voortdurend door alarmerende berichten van medici en van dominees gewaarschuwd werd voor het morele en fysieke verval van de volkskracht. Als tweede reden noemde De Bosch Kemper de invloed van de staathuishoudkunde. Als gevolg van deze nieuwe wetenschap werd steeds meer statistische informatie geproduceerd en een grote hoeveellheid cijfermateriaal over aantallen behoeftigen, bedeelden en arbeiders, alsook over lonen en prijzen. Het toenemende aantal statistische gegevens over het aantal en de omvang van fabrieken en ondernemingen, de daarin werkzame personen en hun produktie, naast verslagen over de ontwikkelingen in de landbouw, misten hun invloed niet; een beginnend besef van de waarde van de arbeidskracht zou ontluiken. Langzaam drong door, dat de "lagere bezigheden" van de lagere volksklasse een wezenlijk economisch belang vertegenwoordigden; de arbeider werd niet meer alleen gezien als consument, maar ook als producent, die een welvarende natie mogelijk maakte. De Bosch Kemper verwoordt de waarde van de factor arbeid als volgt:

"alleen door arbeid wordt de grondstof der natuur geschikt om aan 's menschen behoefte te voldoen".

Zo werd geleidelijk aan een onderscheid gemaakt tussen de "armen", die nutteloos hun handen ophielden bij de armbesturen, en de "arbeiders", die hun karig loon verdienden met werken. Deze nieuwe inzichten leidden ertoe, dat een strenger toezicht werd uitgeoefend op de "armen", hetgeen zijn weerslag vond in de Armenwet van $1870^{15}$, maar evengoed tot het oprichten van het Comite ter bespreking der Sociale Quaestie ${ }^{10}$, waar men zich zou gaan bezighouden met de problemen van de arbeidende klasse. Hiermee werd in hetzelfde jaar een cesuur aangebracht tussen "armen" en "arbeiders". De Witt Hamer schreef in $1866^{17}$ :

"De tijden zijn voorbij, dat eene aristocratie, waarop de balsem is afgedropen van het gezalfde hoofd van den vorst bij Gods genadle, zijne hooge bescherming moet leenen aan de 
arbeidende klasse; - de arbeiders gaan meer en meer begrijpen, dat zij het verdienstelijke deel der maatschappij uitmaken, dat het hume roeping niet langer is, evenals de honden te leven van de tafels der grooten".

In 1872 werd de eerste vakbond, dat wil zeggen een organisatie waarvan alleen arbeiders in loondienst lid konden worden, in Nederland opgericht - het Algemeen Nederlands Werklieden Verbond ${ }^{18}$.

\subsection{Arbeidsomstandigheden}

Wij zien dus, dat vanaf het midden van de vorige eeuw de arbeidende klasse zich als afzonderlijke klasse begon te openbaren. Vanaf dat moment kwamen er ook meer gegevens beschikbaar over de arbeidsomstandigheden in de langzaam op gang komende industrie en de mensen die daarin werkzaam waren. De arbeidstijden waren buitengewoon lang; zelfs werkdagen van 16 en meer uren behoorden niet tot de zeldzaamheden. Een record in dit opzicht werd behaald door de klei-industrie. Er werden werktijden vermeld die bijna ongeloofwaardig aandoen. In de Franeker "tichelwerken" werd in 1841 gewerkt van "s morgens 2 uur tot 's avonds 10 uur, wat dus neerkomt op een werkdag, met inbegrip van de schaftijd(en), van 20 uren. In pannenfabrieken daarentegen werd slechts 15 uren gewerkt ${ }^{10}$. De enquête van 1860 geeft voor de Franeker steenfabrieken een arbeidsdag van 18 uren, niet alleen voor volwassen mannen, maar ook voor jongens tussen 14 en 18 jaar; de vrouwen werkten daarentegen "slechts" 12 uren ${ }^{20}$. In andere provincies waren de arbeidsdagen niet zo exorbitant, maar toch. In de provincie Utrecht waren in 1860 werktijden van 14 en 15 uren niet ongebruikelijk; in de Gelderse steenbakkerijen was een 12-urige werkdag niet ongewoon ${ }^{21}$. Het euvel van deze zeer langdurige werkdagen was algemeen verbreid en niet tot losse gevallen beperkt. Tot slot daarom nog de diamantindustrie waar omstreeks het midden van de vorige eeuw 12 a 15 uren per dag gewerkt werd; in de huisindustrie was dit nog langer ${ }^{22}$. Eén onderwerp, dat volop in de belangstelling stond, en dat op sprekende wijze is beschreven, was de kinderarbeid. De motieven, die aan het laten werken van kinderen verbonden waren, lagen voor de hand; de lonen van veel volwassen mannelijke arbeiders waren zo laag, dat vaak via kinderarbeid het inkomen van het gezin aangevuld moest worden. Dit hoefde niet altijd het geval te zijn. Soms werd het werken door kinderen gepresenteerd in het kader van een zogenaamde "leerling"-verhouding, waarbij kinderen naar de fabriek werden gezonden om een vak te leren en zij voor het werken geen loon ontvingen. Maar Brugmans ${ }^{23}$ constateert hierover - uitzonderingen daargelaten natuurlijk -, dat

"ten onzent onder het mom van opleiding kinderexploitatie is voorgekomen".

Vrouwenarbeid werd in hoofdzaak op jonge leeftijd uitgeoefend; de arbeidster die trouwde, zei de fabriek vaarwel. De arbeid die door vrouwen werd verricht was in de regel ongeschoolde arbeid. Vandaar dat vrou-wen dan ook arbeid verrichten in dezelfde soort bedrijven, waar kinderarbeid voorkwam, in vooral de grote bedrijven dus, waar nu eenmaal veel ongeschoolde arbeid te verrichten was ${ }^{24}$.

Maar wat waren de omstandigheden waaronder in de fabrieken door mannen, vrouwen en kinderen gewerkt moest worden? Daarbij moet dan wel een onderscheid worden gemaakt tussen het werken in grote(re) of in kleine(re) fabrieken en de werschillende soorten van arbeid die werden verricht. Een volledig overzicht is onmogelijk, zodat volstaan wordt met een kijkje. Ten aanzien van de diamantindustrie vermeldde Coronel ${ }^{25}$, dat de werkplaatsen op de zolders, waar deze industrie in het begin van de vorige eeuw uitsluitend werd uitgeoefend,

"broeinesten van onzedelijkheid, onreinheid en ziekte"

waren. Behoorlijk afvoer van (kolen)damp van de vuurpotten en olielampen ontbrak; de zolders waren tochtig en bouwvallig. Door de enge ruimte en het slechte onderhoud van de machimes vonden er veel ongelukken plaats. Toen het fabriekssysteem in zwang kwam, verbeterde de situatie aanmerkelijk, maar er werd toch geklaagd over de bedorven atmosfeer en de snikhete temperatuur. In 1861 waren er in Enschede drie soorten spinnerijen, waaronder de handspinmerijen, waarvan het volgende gezegd werd ${ }^{2 \theta}$ :

"De localen dezer zonder stoom werkende fabrieken zijn oud, slecht en beknopt".

Daarnaast bestonden de zogenaamde oude fabrieken, waarin de zuiveringsmachines door stoom, de andere 
door handkracht werden bewogen, waardoor katoenstof in de atmosfeer woorkwam dat voor de gezondheid nadelig was. In de nieuwe stoomfabrieken, waar alles door stoomkracht in beweging werd gebracht, was de atmosfeer gezonder. Ook het oordeel over de Zeeuwse calicotfabrieken ${ }^{27}$ was niet gunstig. In de gebouwen kwamen in het algemeen onvoldoende hygienische toestanden voor. De meeste waren wegens de spleten in deuren, vensters en ramen zeer tochtig; de zolderwerkplaatsen waren in de zomer ondraaglijk heet, in de winter koud. De verwarming was onvoldoende en ondoeltreffend; de verlichting hoogst gebrekkig, soms zelfs gevaarlijk en schadelijk. De luchtverversing liet, vooral als de lampen brandden, te wensen over. De privaten waren ondraaglijk vuil en gaven aanleiding tot onzedelijkheid. Zorg voor hygiëne ontbrak; de mannen brachten met hun klompen veel vuil naar binnen, en verontreinigden de grond door te pruimen en te spuwen ${ }^{28}$. En dan moet ook nog in aanmerking genomen worden, dat deze fabrieken onder commissies van toezicht stonden, waarvan aanzienlijke ingezetenen lid waren en dat hier nog niet eens sprake was wan zuiver speculatieve ondermemingen. Deze weverijen mag men dan ook niet, aldus Brugmans ${ }^{20}$, als ongunstige uitzonderingen beschouwen, eerder het tegendeel.

Aan matregelen, om de arbeiders in de fabrieken tegen gevaarlijke machines te beschermen, werd niet gedacht. In de oude Leidse wolfabrieken waren de machines soms zo dicht op elkaar geplaatst, dat de arbeiders over de grijpraderen heen moesten springen om van het ene looppad in het andere te komen ${ }^{30}$.

Van de arbeiders zelf kon weinig of niets verwacht worden ten aanzien van een verbetering van de arbeidsomstandigheden. Dit was eerst mogelijk nadat zij zich organiseerden. Veranderingen, die doorgevoerd werden, waren hoogstens te danken aan het medelijden dat hun situatie opwekte, of aan het feit, dat op de langere termijn, de erbarmelijke situatie waarin zij verkeerden negatieve gevolgen zouden hebben voor de economische ontwikkeling ${ }^{31}$.

\subsection{De rol van de overheid}

Na de revolutieperiode had de overheid, zowel als reactie op het overspannen en veelal ook verouderde reglementeringssysteem van de prerevolutionaire periode als uit hoofde van het in de revolutietijd gekoesterde vrijheids- en gelijkheidsideaal, zich van het gebied van de arbeidersbescherming aanvankelijk teruggetrokken. Deze houding werd nog eens versterkt door de liberale economie met haar laisser-faire-beginsel. Toen echter de praktijk uitwees, dat de vrijheid tot ongebondenheird en dus tot de ernstige misbruiken leidde, groeide het inzicht, dat de overheid de taak had, de zwakkere, onderdrukte individuen door nieuwe verbodsbepalingen en reglementen te ondersteunen ${ }^{32}$. Althans zo verliep in de meeste Westeuropese landen, en dan met name in Engeland. Maar in ons land verliep het proces anders. Van een zich terugtrekkende overheid was onder koning Willem I geen sprake, in tegendeel voor straffe reglementering deinsde deze vorst niet terug. Brugmans $^{\text {as }}$ wijst er op, dat het ontbreken van overheidsbemoeienis dan ook niet toegeschreven kan worden aan de overheersing van het onthoudingsbeginsel.

Vanaf het midden van de vorige eeuw werd het anders. De overheid trok zich terug en de liberale economische beginselen kregen meer ruimte. Maar tegelijkertijd ontstond de belangstelling voor de arbeidende klasse en gingen er steeds meer stemmen op om het kind te beschermen door middel van overheidsingrijpen. Het opmerkelijke feit deed zich dus voor, dat de gedachte aan arbeidersbescherming in de periode van vaderlijke staatszorg ontbrak en dat zij opkwam in de periode van staatsonthouding, aldus Brugmans ${ }^{34}$. De verklaring hiervoor is hierboven al te lezen. De roep om overheidsingrijpen vond zijn basis in de kinderarbeid ${ }^{35}$, niet zozeer om de arbeid zelf als wel omdat het leidde tot schoolverzuim en als gevolg daarvan als ongewenst werd ervaren. Na 1850 zou het in de eerste helft van de vorige eeuw voorzichtig geplante zaadje uitwassen tot een enorme boom. Onze aandacht richt zich vooral op die voorstellen, waarbij (overheids-) toezicht op de naleving van eventuele wettelijke bepalingen aan de orde werd gesteld ${ }^{30}$.

\section{De eerste roorstellen}

Ackersdijk bepleitte in de Algemeene Konst- en Letterbode van $1839^{37}$ de wettelijke vaststelling van een 
minimumleeftijd voor kinderen in verschillende soorten fabrieken en van hun arbeidstijd, alsmede toezicht van overheidswege op de naleving van deze wettelijke bepalingen. Wettelijke voorschriften waren, aldus de auteur, noodzakelijk om concurrentievervalsing tegen te gaan. Het overheidstoezicht diende om de kinderen te beschermen tegen de wil van hun ouders waarvan niet verwacht kon worden, dat zij de nadelen van het werken door kinderen konden onderkennen.

In het provinciaal verslag van de provincie Overijssel over het jaar $1835 \mathrm{kwam}$ een passage voor waarin met zoveel woorden werd vermeld, dat het fabriekswezen het schoolverzuim bevorderde en dat het moeilijk was daartegen doeltreffende maatregelen te nemen ${ }^{36}$. Dit verslag kwam onder ogen van de toenmalige minister van Binmenlandse Zaken De Kock, die daarop de gouverneur van Overijssel Graaf van Rechteren van Apeltern om nadere informatie vroeg ${ }^{39}$. De nodige correspondentie over en weer tussen beiden ${ }^{40}$ resulteerde uiteindelijk in 1840 in een door de gouverneur opgesteld wetsvoorstel ${ }^{44}$ : een verbod van arbeid door kinderen jonger dan tien jaar en voor oudere kinderen als zij geen drie jaar onderwijs of onvoldoende onderwijs hadden genoten. De gouverneur sprak vervolgens de wenselijkheid uit, dat het aantal werkuren van deze al wat oudere kinderen werd beperkt, opdat zij na afloop van de werkzaamheden onderwijs zouden kunnen volgen. De plaatselijke besturen zouden hebben toe te zien op de naleving van de bepalingen, de overtreding - een strafbaar feit - hebben te constateren en deze ter kennis van de bevoegde rechter hebben te brengen $^{42}$. Om controle mogelijk te maken zouden er nauwkeurig lijsten bijgehouden moeten worden waarop alle in de fabriek werkzame arbeiders stonden vermeld, en die naast de namen tevens de leeftijd en de datum van indiensttreding dienden te bevatten. Deze lijsten zouden "in het bureau der fabrijk" opgehangen moeten worden en op verzoek van de plaatselijke besturen moeten worden getoond ${ }^{43}$.

\section{Een eerste ministeriële enquête in 1841}

Nog geen jaar later, in 1841, richtte de toenmalige bewindsman van Binnenlandse Zaken Schimmelpenninck van Oye zich met de circulaire ${ }^{44}$ tot de gouverneurs van de provincies met de opdracht in hun ambtsgebied via de gemeentebesturen een enquête in te stellen naar de omstandigheden waaronder arbeid werd verricht en dan met name kinderarbeid ${ }^{45}$. Tegelijkertijd maakte de toenmalige minister kenbaar, dat de regering voornemens was tegen

"het aangeduide kwaad ..... voorzieningen ..... daar te stellen".

Uit de ingezonden antwoorden blijkt, dat geen van de gouverneurs zich tegen dit voornemen van de regering om voorzieningen te treffen verzette. Op die van Noord-Brabant na, waren alle gouverneurs voor een wettelijke regeling van de arbeid van kinderen in fabrieken, hetzij door het vaststellen van een minimumleeftijd waarop de kinderen zouden mogen worden toegelaten, hetzij door een regeling van de arbeidsduur. De gouverneur van Noord-Brabant gaf de voorkeur aan een plaatselijke verordening. Omtrent de inhoud van de te treffen maatregelen liepen de meningen echter sterk uiteen ${ }^{46}$. Uit de antwoorden van een aantal gouverneurs blijkt tevens, dat zij, naast verlangens op het terrein van de materiële inhoud van de te treffen wettelijke regeling, de nodige voorzieningen wilden ten aanzien van het toezicht op de naleving ervan.

Zo wilde de gouverneur van Drenthe ${ }^{47}$ het toezicht opdragen aan een commissie van vertrouwde personen, die door het bestuur van de plaats waar de fabriek is gevestigd, benoemd diende te worden. Deze commissie was verplicht om overtreding van de te treffen wettelijke bepalingen alsmede iedere onregelmatigheid, zedeloosheid of ieder wangedrag aan dat bestuur te rapporteren, opdat deze laatste handelend kon optreden al naar gelang de omstandigheden. Niet-naleving van de bepalingen door de werkgever - "eigenaren, houders of directievoerders" - zou gesanctioneerd moeten worden met "gepaste geldboeten en gevangenisstraffen". Om controle mogelijk te maken zou de werkgever verplicht moeten worden nauwkeurig en volledig registers aan te leggen en steeds regelmatig bij te houden, bevattende de namen, het geslacht, de tijd en plaats van geboorte, de woonplaats, de ouders of voogden, het tijdstip van indiensttreding van kinderen in de fabriek en hun gedrag aldaar. Bovendien bepleitte de gouverneur een voor het gehele, in de fabriek werkzame per- 
soneel geldend en

"steeds doeltreffend toe te passen reglement van orde en tucht, gegrond op beginselen van godsdienstigheid en zedelijkheid en huishoudelijk bestuur, $\epsilon e n$ en ander onder goedkeuring van hel bestuur van de plaats waar de fabriek gevestigd is".

De gouverneur van Zeeland ${ }^{46}$ stelde een aanhoudend toezicht op de fabrieken, trafieken en werkwinkels en de zorg voor een behoorlijke naleving van de vastgestelde bepalingen door het plaatselijk bestuur voor. Overtreding van de bepalingen zou gestraft moeten worden overeenkomstig het bepaalde bij de Wet van $1818^{49}$. Ook hij bepleitte een door de werkgever op te maken doelmatige naamlijst van alle fabrieksarbeiders, die in de fabriek aanwezig moet zijn om door het openbaar gezag geraadpleegd te kunnen worden. Deze lijst moest de nodige aanwijzigingen bevatten omtrent naam, ouderdom, geboortetijd, ouders, tijd van indiensttreding, letterkundige kennis, zedelijk gedrag en een geneeskundig getuigschrift ${ }^{50}$. Tevens wilde hij een arbeidsboekje voor iedere fabrieksarbeider voorschrijven.

Ook de gouverneur van Limburg Gericke van Herwijnen wilde een toezicht door het plaatselijk bestuur ${ }^{51}$. Dit bestuur zou zich moeten verzekeren van een stipte naleving van de gegeven voorschriften door middel van

" 2 of vier lokale Inspectiën ...... te houden op onbepaalde tijdstippen".

Hiervan zou telkens het resultaat meegedeeld moeten worden aan het provinciale bestuur. Om controle mogelijk te maken zou in ledere fabriek (een) lijst(en) te allen tijde aanwezig moeten zijn, met de vermelding wan de namen en voornamen van de kinderen en jongelieden beneden de achttien jaar, hun leeftijd en de werkzaamheden die zij verrichten alsmede of door hen al dan niet lager onderwijs was genoten. Overigens bepleitte hij niet-naleving van de bepalingen met aanzienlijke boetes - bij iedere herhaalde overtreding opklimmend te verhogen - te bestraffen.

Hoewel de gouverneurs kenbaar hadden gemaakt zich niet te verzetten tegen een overheidsingrijpen in deze zou de enquête toch zonder enig gevolg blijven.

\section{Het rapport-De Vries Robbé}

In 1859 riep de toenmalige minister van Binnenlandse Zaken Tets van Goudriaan de hulp in van het ministerie van Buitenlandse Zaken om te weten te komen welke bepalingen met betrekking tot de arbeid van kinderen in het buitenland bestonden. De op deze aanvraag ontvangen stukken werden vanaf 21 september van dat jaar ${ }^{62}$ voor advies ter hand gesteld aan De Vries Robbe, ingenieur voor het stoomwezen ${ }^{53}$.

Het rapport van De Vries Robbe dateert van 7 oktober $1860^{54}$ en was gericht aan de toenmalige bewindsman van Binnenlandse Zaken Van Heemstra. Het rapport is wel eens de stichtingsbrief van onze sociale wetgeving uit de nieuwere tijd genoemd ${ }^{55}$; in overeenstemming hiermee kan gesproken worden van de stichtingsbrief van de arbeidsinspectie. Het toezicht diende te gebeuren door een inspecteur bijgestaan door een secretaris en éen of meer assistenten, al naar gelang de behoefte. Deze inspecteur zou vooral bevoegd moeten zijn alle mogelijke inlichtingen en hulp te verkrijgen van het plaatselijke bestuur. De inspecteur of assistenten zouden minstens eén maal per jaar de fabrieken moeten bezoeken en daarover per kwartaal verslag moeten doen aan de minister van Binnenlandse Zaken. Zij zouden de bevoegdheid moeten hebben om de fabriek op ieder moment te betreden. $\mathrm{Zij}$ zouden tot taak moeten hebben het toezien op de nalleving van de wettelijke bepalingen alsmede op de zindelijkheid in de werkplaatsen en de veiligheid in het algemeen. $\mathrm{Zij}$ moesten die veranderingen kumnen aanbevelen die in het belang van de arbeiders noodzakelijk waren. Ook besteedde De Vries Robbé aandacht aan de controlemiddelen. Elke fabrikant zou een legger moeten houden van alle arbeiders met naam, voornaam, woonplaats, met opgave van de leeftijd en het geslacht. Bovendien zou vam elk kind beneden de zestien jaar een boekje aanwezig moeten zijn, waarin door het plaatselijk bestuur vermeld moest zijn de naam, de voornaam, de leeftijd en het geslacht; tevens een door een plaat- 
selijke geneesheer afgegeven bewijs van geschiktheid. In dit boekje moest door de schoolmeester maandelijks aangetekend worden, dat de kinderen van negen tot twaalf jaar geregeld drie uur per dag of als zij om de andere dag werkten op die tussenliggende dagen vijf uur naar school gingen.

Niet-nalewing van de wettelijke bepalingen zou moeten worden bestraft met een boete van wijf tot tien gulden. Bij herhaling van de overtreding diende de boete te worden verdubbeld tot een maximum van tweehonderd gulden; én en ander te bepalen door de inspecteur, behoudens een beroep op de rechtbank of de kantonrechter. De Vries Robbé stelde derhalve het stelsel van de zogenaamde "administratieve boete" voor, waarover heden ten dage als sanctiemaatregel ook nog wel eens wordt gedacht.

\section{Een ministerièle enquête uit 1860}

Het rapport van De Vries Robbe was yoor de toenmalige bewindsman aanleiding zich bij brief van 17 december $1860^{56}$ tot de commissarissen van de Koning te wenden. In deze brief verklaarde de bewindsman, dat hij, hoewel doordrongen van de wenselijkheid $\mathrm{cm}$ in zaken van nijverheid slechts dan in te grijpen wanneer verzuim of nalatigheid van de kant van particulieren dit vorderde, een voorziening nodig achtte om de voortgang van het kwaad, waarmee hij doelde op de ondervinding, dat kinderarbeid niet zelden een noodlottige invloed uitoefende op de lichamelijke, geestelijke en zedelijke ontwikkeling van de kinderen, zoveel mogelijk te stuiten. Daarop volgde de motivering van het sturen van de brief:

"Alvorens intusschen te kunnen bepalen, welke voorschriften die voorziening behooren uit te maken, wensch ik in het bezit gesteld te worden van zoodanige opgaven, als cen algemeen overzigt omtrent het aantal en den aard der hier te lande bestaande fabrieksinrigtingen en het daarin werkzaam zijnde personeel kunnen verschaffen".

Uit de ingezonden antwoorden van de commissarissen van de Koning blijkt niet van enig verzet tegen de plannen van de regering om maatregelen te treffen. Als zij expliciet hun oordeel gaven, was het instemmend $^{57}$.

Van deze enquête kan, aldus Coronel ${ }^{5 \theta}$, worden gezegd, dat zij hoofdzakelijk een cijferresultaat opleverde. Desalniettemin trekt het bericht van de commissaris van de provincie Limburg ${ }^{59}$ de aandacht. Deze meldde, dat in de gemeente Maastricht de heer P. Regout ${ }^{60}$, blijkens het door het gemeentebestuur ontvangen bericht van de hoofdcommissaris van politie ${ }^{\text {at }}$ in de meest stellige bewoordingen had geweigerd om de verzochte opgaven te verstrekken

"als daartoe door geene wettelijke bepalingen gehouden".

De brief van de bedoelde hoofdcommissaris van politie is ook in een ander opzicht interessant. Op grond van zijn ervaringen bepleitte hij namelijk

"met de meeste voortvarendheid, al ware zulks ook slechts bij voorraad, tot later te nemen maatregelen eenige voorschriften voor ..... toezigt zouden worden vastgesteld".

Dit toezicht zou door schoolopzieners onder leiding van de inspecteur voor het schoolwezen en wel ieder in zijn ressort dienen te gebeuren. Dit had namelijk als voordeel, zo vervolgde hij, dat het toezicht op scholen gekoppeld werd aan het toezicht op de fabrieken en dat de schoolopzieners van de bij het onderwijs betrokkenen inlichtingen zouden kunnen verkrijgen omtrent het schoolbezoek van de arbeidende klasse.

\section{Het initiatief-wetsvoorstel van Van Houten}

Nog voordat Van Houten zijn initiatief-wetsvoorstel indiende, zou op 2 juni 1871, tijdens de eerste algemene vergadering van het Nederlandsch Schoolverbond een commissie worden ingestelld ${ }^{\text {be }}$, die ter bevordering van het onderwijs een aantal voorstellen ontwierp voor een wettelijke regeling van de kinderarbeid ${ }^{63}$.

Een van deze voorstellen had, zij het summier, betrekking op het toezicht. De commissie stelde voor aan de eén of andere autoriteit op te dragen voor de handhaving en uitvoering van de bepalingen te waken. De toelichting schept echter meer duidelijkheid. 
${ }^{\prime}$ Uwe commissie, die omtrent dit punt in woerige discussie had, is van oorded, dat, al-

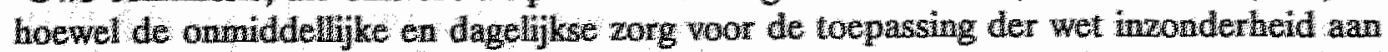
de gemeentebesturen en het schoolioezich diende we worden overgelaten, de zekerheid voor eene richtige handhaviuglleen kan worden vertegen, indien $k E$ of meer mspecteurs met de byzondere controle züu belast.

De werkgever zou woorts verplicht moeten worden by de indienstkeding van de kinderen een werklariwg te

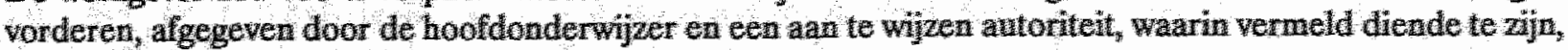
dat voldoende lager onderwys was genoten. Deze wetklaringen zouden bewaard moeten worden en steeds ter inzage woor de antoriteiten dienen te $\mathrm{z}^{\mathrm{a}}$.

Toen Van Houten op 27 februar 1873 zjy mitialief-wetswoorstel bul de Twede Kamer der Staten-Generaat indiende $^{\text {ts }}$, weverde Corone ${ }^{\text {Be }}$ onder meer kritek op het feit, dat enige bepaling ontrent het hoezcht ontbrat.

"Wel stelt hel ontwerp owertreding met geldboeten en gevangents strabaar. Maar indien eene wet geen bepaalden persoon aanwist, die de overtreding moet constateren, blj t cene zodanige bepaling een bedreiging op pupier, waararn niemand zich zal storen. Men zal toch niet verwachten, dat de burgemeesters zelven dat naauwgezet toezigt zwhen houden? En wanneer het aan policie-agenten of marechausses wordt opgedragen, dan lan men er zeker van zijn, dat de overtreding algemeen zal worden, zonder dat er cout een proces-verbad tegen de schuldigen zal opgemaakt worden. Het is zeer opmerkely, dat de heer Van Houten van dit alles afdoend toezigt net geen woord in zyn ontwerp heeft gerept Deinsde

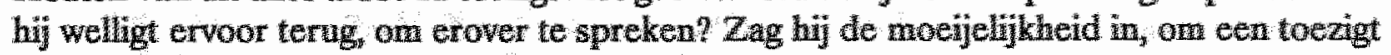
aan die autoriteiten op te dragen en was hy hwiverig daarvoor speciale ambtenaren aan te wijzen? " Is mogelik. Maar zonder die aanduidung hangt z:y geheele voorstel in de ucht en valt aan de toepassing datrvan niet te denken, zal he zin $^{\text {no }}$ doel ten eenemale missen".

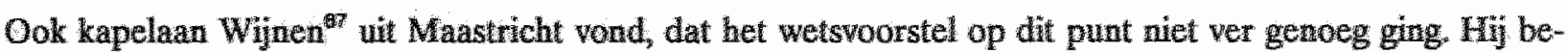
pleutte een toezicht op en uitwoering van de wet door de burgemeester en de provinciale inspecteur, $Z$ ij dienden de bevoegdheid te hebben de werkplatsen te betreden en de registers en de boekjes van de werknemers beneden de zestien jaar in te zien.

Zo werd op een vergadering op 30 november 1873 van thet Comite ter bespreking der Sociale Ouaestie besloten een speciale vergadering te beleggen ter ondersteuning van het woorstel. Door een commissie ${ }^{\text {as }}$ werd een motie ontworpen, waarin de wenseliyk heid werd neergelegd, dat als $6 \epsilon n$ van de hoofdbeginselen in een wettelijke regeling zou moeten gelden, dat men het toezicht op de nakoming hiervan speciale, door de regering te benoemen, inspecteurs zouden worden belast ${ }^{* 0}$. Deze motie werd op de vergadering van 15 februari 1874 te Rotterdam behandeld en unaniem aangenomen ${ }^{70}$ en zou op 19 april van dat jaar tijdens Het Paaschcongres" van het Algemeen Nederlandsch Werklieden Verbond in Diligentia te "s-Gravenhage centraal staan tijdens de tot dan toe in ons land grootste arbeidersdemonstratie ter onderstewning van Van Houtens initiatief ${ }^{\prime \prime}$.

\section{De Kinderwet-Van Houten}

Ondanks al de aandrang van verschillende zijden vindt men in de Kinderwet - Van Houten ${ }^{72}$ niets terug met betrekking tot het toezicht op de naleving ervan. Dat wil echter niet zeggen, dat daaraan tijdens de parlementaire behandeling geen aandacht is besteed. In het verslag van de commissie van rapporteurs ${ }^{73}$ werd vermeld, dat

"naar veler oordeel het al verder eene zeer wezenlijke leemte in het wetswoorstel ( door generlei bepaling de uitvoering daarvan verzekerd is. ..... Hier schijnt alles te zullen 
afhangen van den ijver der politieambtenaren. Maar men kan daarop genoegzaam rekenen en zal ook om deze redenen de wet geen gevaar loopen onuitgevoerd te blijven" ${ }^{174}$.

Van Houten antwoordde daarop, dat

"de vraag, of al dan niet speciale ambtenaren voor de handhaving dezer wet noodig zijn, ......... opzettelijk ter zijde (is ) gelaten. De beoordeling daarvan laat hij over aan de Regering, die eventueel voor de uitvoering ervan zorg zal hebben te dragen. Heeft deze voor dit doel beambten noodig, de Staten-Generaal zullen ongetwijfeld de middelen niet weigeren om de handhaving van door hen noodig geachte beperking te verzekeren ${ }^{475}$.

Ook bij de mondelinge beraadslaging ontbraken de opmerkingen over het gemis aan controle niet. Zo wees Verheijen op het in het wetsontwerp geheel ontbreken van controle waardoor het onvoldoende waarborg opleverde voor een goede uitvoering van de verbodsbepalingen ${ }^{78}$. Mees betoogde, dat door het ontbreken van de aanwijzing van de autoriteiten die met de controle belast zouden worden, een zeer essentiele bepaling in het wetsontwerp werd gemist ${ }^{77}$. Heijdenrijck verklaarde zich bereid mee te werken aan het treffen van maatregelen omtrent onder meer het "politietoezigt ${ }^{178}$. Bredius noemde het

"niet raadzaam, het toezigt over te laten aan de gemeentebesturen, omdat deze soms voor een deel kunnen zijn zamengesteld uit personen, die als industrieel belang hebben bij het behoud van kinderarbeid en die dus alligt geneigd zouden zijn om het verkeerde, dat in hunnen gemeente gebeurt, oogluikend toe te laten. Wordt dus het beginsel dezer wet aangenomen, dan schijnt het mij noodig toe het toezigt over den kinderarbeid op te dragen aan Rijksinspecteurs, van wie men een stelselmatiger, naauwkeuriger en onpartijdig toezigt kan verwachten ${ }^{\text {"77 }}$.

De Bruyn Kops meende,

"dat de handhaving der wetsbepalingen en het toezien op mogelijke uitzonderingen beter zouden zijn toevertrouwd aan fabrieksinspecteurs, dan aan de uiteenloopende inzigten van burgemeesters en wethouders in de verschillende gemeenten: die zijn, ...., te zeer aan locale invloeden onderworpen .... Bij een gecentraliseerd toezigt zou men ook dit groote voordeel hebben dat zij die in de verschillende deelen des lands de omstandigheden kunnen vergelijken en de gevolgen van gelijke maatregelen nagaan, een schat van ondervinding zullen opdoen, waarmede de Regering haar nut kan doen als grondslag voor verdere regeling en die onmogelijk te bekomen ware door de gemeentebesturen ${ }^{\sharp 80}$.

Desondanks bleef Van Houten van mening,

"... dat alle gewone beambten van politie de overtredingen zullen opsporen, evenals alle andere waarop het toezicht niet aan speciale ambtenaren is opgedragen ${ }^{\text {"18" }}$.

Met het door de Staten-Generaal annemen van het voorstel van Van Houten was het beginsel aangenomen, dat de staat onmondigen behoorde te beschermen tegen overmatige arbeid en verwaarlozing ${ }^{\text {az }}$. Het feit, dat het hier de eerste positieve arbeidersbeschermende regeling hier te lande betreft, rechtvaardigt naar mijn mening een nadere beschouwing omtrent de materiële inhoud.

Het wetje gaf in artikel 1 een verbod om kinderen beneden de 12 jaar in dienst te nemen of te hebben; verklaarde in artikel 2 dat het verbod niet toepasselijk was op huiselijke en persoonlijke diensten en op veldarbeid; stelde in artikel 3 de hoofden of bestuurders van de desbetreffende ondernemingen aansprakelijk en bepaalde in artikel 4 de straf op overtreding, terwijl artikel 5 een overgangsbepaling bevatte.

De praktische betekenis van het wetje was beperkt. Allereerst omdat niet duidelijk was wat nu precies onder het verbod viel. Zo gaf de rechterlijke macht in een aantal gevallen een strikt juridische uitleg aan de termen "in dienst nemen" of "in dienst hebben". Een voorbeeld daarvan is het vonnis van de Rb. te Rotterdam van 15 mei $1875^{83}$. In casu werd een achtjarige jongen buiten medeweten van de ondernemer door zijn vader als wieldraaier in een touwslagerij gebruikt. De vader werd door de rechtbank ontslagen van rechtsvervolging, daar

"in casu de arbeid, door den achtjarigen Nicollaas verrigt, geschied is ingevolge het bevel 
van zïn vader, krachtens de vaderlijke magt en er daardoor geen dienstbetrekking tusschen dat kind en wien dan ook is ontstaan, zoodat er van in dienst stellen en in dienst hebben in den zin der wet ten deze geen sprake kan zijn ${ }^{n 34}$.

Andere uitspraken bestaan echter ook, zoals bijwoorbeeld de uitspraak van de rechtbank te Groningen van 29 juni $1882^{\text {ts }}$. Het betrof hier een koopman, die een elfjarige jongen gebruikte om zakjes dicht te maken, boodschappen te doen of op het paard te passen. Hij werd door de rechtbank veroordeeld op grond van de overweging

"dat de door de wet strafbaar gestelde toestand daar is wanneer het kind beneden een bepaalde leeftijd feitelijk voortdurend werkzaamheden verrigt ten behoeve eener onderneming zonder dat daarvoor noodig is, dat vooraf de dienstpraestatie bij contract zij geregeld" ${ }^{n 8 s}$ De enge, strikt juridische, interpretatie van artikel 1 van bet Kinderwetje leidde tot onacceptabele situaties. Zo merkte Veegens ${ }^{87}$ op, dat als gevolg van de genoemde uitspraak van de rechtbank te Rotterdam

"tal van jonge kinderen in het ressort der rechtbank de school verlieten, om in de lijnbanen

te gaan werken"8.

Vervolgens was niet duidelijk hoever de uitzonderingen op het verbod, namelijk huiselijke en persoonlijke diensten en veldarbeid reikten, omdat de wetgever deze begrippen niet gedefinieerd had.

Het begrip "persoonlijke diensten" zou al snel ruim uitgelegd worden. De rechtbank te Zwolle overwoog in de eerder aangehaalde uitspraak, dat onder deze uitdrukking moest worden verstaan:

"die kleine dienstverrigtingen welke meer ten behoeve van den persoon voor wien zij ge-

schieden dan ten behove van diens bedrijf gepraestreerd worden".

De rechtbank te Rotterdam gaf in de uitspraak van 13 april $1876^{89}$ aan:

"dat het woord "persoonlijk" dan ook vanzelfs aanwijst de hoedanigheid van den dienst en

waarin die moet bestaan, namelijk in een dienst eigen aan den persoon, door wien die wordt gevorderd".

Veegens $^{90}$ komt bij een nadere beschouwing van deze ruime interpretatie tot het volgende: onder het begrip "huiselijke diensten" zouden kunnen vallen alle diensten, die aan huis verricht worden, dus bijvoorbeeld ook geregeide huisarbeid voor een fabriek, terwijl onder het begrip "persoonlijke diensten" begrepen zouden worden, alle diensten aan de ouders verleend, ook in de fabriek of werkplaats waar zij werken. Zijn conclusie:

"Op deze wijze zou de deur voor ontduiking wijd geopend worden en zou de wet bijna alle kracht verliezen"

Met de term "veldabeid" is het niet anders. Ook dit werd ruim uitgelegd. De HR overwoog in het arrest van 20 oktober $1879^{\text {th }}$ het volgende:

"dat onder veldarbeid in rumen zin worden verstaan alle verrigtingen op het veld, welke tot landbouw of veeteelt in betrekking staan, en dat, blikens de gewisselde stukken en gevoerde beraadslagingen, de wetgever dit woord in dien rümeren zin heeft gebezigd, en daar onder met name ook het hoeden van vee heeft willen begrijpen" ${ }^{\text {"83 }}$.

Tot slot vormden het gemis van een afzonderlik toezichthoudend orgaan ${ }^{84}$ alsmede het ontbreken van de bevoegdheid on tegen de wil van de ondernemer de fabrieken of werkplatsen binnen te treden eveneens een wakke schakel in het geheel. Vandaar dat al snel pogingen in het werk werden gesteld om het Kinderwetje van Van Houten te verbeteren.

\section{Het voorontwerp-Van Lynden van Sandenburgh}

De toenmalige minister van Justitie Van Lynden van Sandenburgh nam de Kinderwet onder zijn hoede en zond al op 30 september 1874 een circulaire aan de procureurs-generaal, fungerende directeuren van politie in de provincie, warin hij

"het niet geheel overbodig (achtte) op deze wet meer bijzonder hun aandacht te vestigen en daarbij ( hun ) gewaardeerde medewerking in te roepen ten einde aan haar nauwkeurige 
uitvoering de hand te houden".

Daartoe leek

"het noodig, al dadelijk te onderzoeken of en in hoeverre de feitelijke toestand op (dat)

oogenblik in overeenstemming was met de wet, terwijl het hem aangenaam ( zou ) zijn, de

uitkomsten met de beschouwingen dienaangaande zoo spoedig mogelijk te vernemen ${ }^{n 95}$.

Een uiterst voortvarend begin, waardoor de kritiek van onder meer van Coronel ${ }^{96}$ ondergraven lijkt te worden. Maar wat was het vervolg? Tijdens de behandeling van de begroting van Justitie voor het jaar 1876 zei dezelfde bewindsman:

"Ik heb inderdaad een onderzoek ingesteld naar de werking van de wet; maar de verkregen resultaten zijn ongeschikt om - gelijk ik gewenst had - aan de publiciteit overgegeven te worden, omdat zij niet volledig genoeg zijn om tot bepaalde conclusiën te leiden ${ }^{\text {"197 }}$.

Inmiddels was op het ministerie van Justitie op 5 maart 1875 een nota opgesteld ${ }^{98}$, waarin de resultaten van het ingestelde onderzoek waren samengevat. In de nota wordt onder meer opgemerkt, dat de commissarissen van de koning bij circulaire in het provinciar l blad de burgemeesters kunnen wijzen op het

"hooge gewigt van de stipte naleving der wet door het houden van een streng toezigt".

Voorts zou het aan te bevelen zijn de gewone politie de bevoegdheid te verlenen om binnen te treden in de lokaliteiten, waar het onderzoek naar verboden kinderarbeid noodzakelijk is ${ }^{9 \theta}$.

Uit het commentaar op de nota ${ }^{100}$ blijkt, dat het raadzaam geacht werd de ontwikkelingen in de praktijk af te wachten. Om daarvan op de hoogte te blijven, zou aan het openbaar ministerie bekend gemaakt kunnen worden,

"dat de Minister vertrouwt, dat daar, waar de feitelijke toestand nog niet in overeenstem-

ming is met de wet, daaraan van de zijde van het O.M. door waakzame zorg, door verma-

ning en desnoods door vervolging een einde zal worden gemaakt"tor.

In een nota van 11 oktober van datzelfde jaar ${ }^{102}$ werd een verdergaand standpunt ingenomen. $\mathrm{Nu}$ werd gesteld, dat een

"nieuwe en meer omvattende regeling van het onderwerp noodzakelijk is";

de te ontwerpen wet zou onder meer een regeling hebben te bevatten omtrent de controle op de naleving door rijksinspecteurs. Daarbij werd aangegeven, dat het toezicht uitgeoefend zou kunnen worden door de inspecteurs van het geneeskundig staatstoezicht ${ }^{103}$.

In dezelfde maand nog werd een voorontwerp van wet opgesteld. Hierdoor was het voor de toenmalige minister mogelijk op de vraag of hij de bedoeling had om een aanvulling en verduidelijking van de Wet van 19 september 1874 voor te dragen, te antwoorden, dat

"hij weldra eene meer afdoende regeling van dit onderwerp aan de overweging der Verte-

genwoordiging hoopte aan te bieden"104.

Het voorontwerp van wet ${ }^{105}$ bepaalde in artikel 9 onder meer, dat het toezicht op de arbeid van kinderen, jongelieden en vrouwen, waarover het voorontwerp zich uitstrekte, is opgedragen aan inspecteurs, wier aantal en onderlinge verhouding door de Kroon bepaald; benoeming en ontslag geschiedt eveneens door de Kroon. Daarnaast bepaalde artikel 16, dat bij algemene maatregel van bestuur nadere bepalingen omtrent het door hen uit te oefenen toezicht vastgesteld worden. De toelichting op het voorontwerp leerde, dat de instelling van inspecteurs onmisbaar geacht werd. Daarvoor werden als voornaamste argumenten aangevoerd, dat ervaringen in Engeland en Frankrijk uitwezen, dat zonder inspecteurs de wet onvoldoende werd nageleefd en dat de rapporten van de inspecteurs de regering - naar men mag vertrouwen - belangrijke aanwijzingen konden geven over verdere aanvullingen en verbeteringen die de wetgeving zal blijken te behoeven ${ }^{100}$. Hoewel het voorontwerp van wet een afzonderlijke inspectie instelde, die belast was met het toezicht op de naleving van de wet, werd in het midden gelaten of de inspecteurs uitsluitend belast zouden zijn met het toezicht op de arbeid. Of dit de bedoeling was, kan twijfelachtig genoend worden, met name omdat de nota van 11 oktober 1875 - de basis van het voorontwerp van wet - de gedachte ventileerde, dat bet toezicht uitgeoefend kon worden door inspecteurs van het geneeskundig staatstoezicht. Tevens regelde het voorontwerp 
een aantal bevoegdheden van de inspecteurs. Zo bepaalde artikel 10 , dat zij bevoegd waren alle door hen nodig geachte inlichtingen en opgaven te vragen betreffende de arbeid van kinderen, jongelieden en vrouwen. Verder hadden zij - binnen de kring waarvoor zij waren aangesteld - te allen tijde toegang tot de lokalen in de fabrieken, de werkplaatsen en tot het veld. Bij weigering van toegang konden zij zich die verschaffen, eventueel met behulp van de "openbare magt", de sterke arm van de politie dus. Hetzelfde artikel bepaalde voorts, dat, indien de toegang tot de lokalen van de fabrieken, de werkplaatsen en tot het veld alleen mogelijk was via een woning, de inspecteurs deze ook tegen de will van de bewoner konden betreden, zij het dan vergezeld doot of de kantonrechter, de burgemeester of een wethouder, of door de commissaris van politie. Van de laatstgenoemden moet degene, die bij dit binnentreden aanwezig was geweest, hiervan alsmede van de redenen, waarom dit gebeurde, binnen achtenveertig uur proces-verbaal opgemaakt hebben. Dit procesverbaal moest in afschrift worden medegedeeld aan degene wiens woning betreden was. De toelichting op het voorontwerp van wet wees erop, dat het bewaste artikel geen nieuwe bevoegdheden creëerde; gewezen werd op bijvoorbeeld de artikelen 14 en 15 van de Wet van 28 mei 1869 , regelende het toezicht op het gebruik van stoomtoestellen ${ }^{107}$. Artikel 11 tenslotte regelde een laatste bevoegdheid van de inspecteurs; zij waren bevoegd tot het opsporen van overtredingen van zowel de wet als de algemene maatregelen van bestuur. Opgemerkt dient te worden, dat het weigeren van toegang aan de inspecteur alsmede het hem onthouden van de verlangde inlichtingen en opgaven dan wel het in enig ander opzicht belemmeren of verijdelen van zijn, overeenkomstig de wet verrichte, handelingen - gelet op artikel 14 - de zwaarst bestrafte overtreding opleverde, namelijk gevangenisstraf van én tot dertig dagen of een boete van drie tot honderd gulden. Herhaling van een dergelijke overtreding binnen een jaar na veroordeling werd bestraft met een gevangenisstraf van drie dagen tot drie maanden of een boete van tien tot vijthonderd gulden. Daarnaast voorzag het wetsvoorstel in een aantal controlemiddelen. Voorgeschreven werd, dat een werkgever, voordat hij kinderen in dienst nam, een aantal verklaringen, afhankelijk van de leeftijd van het kind moest hebben, namelijk: een geboorteakte, een geneeskundige verklaring betreffende de geschiktheid om arbeid te verrichten en verklaringen waaruit bleek, dat voldoende onderwijs was genoten ${ }^{108}$.

Verder moest de werkgever de burgemeester halfjaarlijks een opgave verstrekken over de bij hem in dienst zijnde kinderen, jongelieden en vrouwen.

Ook moest hij een livret houden waarin geregeld werd vermeld de naam, de woonplaats en de leeftijd van het kind of de jeugdige, de woonplaats en de namen van ouders of voogden, de tijd waarop zij in dienst kwamen of deze verlieten en andere gegevens in de daarvoor te bepalen vorm. Maar ook arbeidsregisters werden voorgeschreven. Naast de verplichting tot het voeren van een "doorlopend register" van kinderen en jongelieden, opgemaakt overeenkomstig de verplichte livetten, moest de werkgever verplicht een "doorlopend register" aanhouden van de vrouwen die hij in dienst nam ${ }^{100}$. Het niet-naleven van deze voorschriften leverde eveneens een strafbaar feit op.

\section{Een ministerièle enquête uit 1877}

Over het voorontwerp van wet van Van Lynden van Sandenburgh werd advies gevraagd aan de minister van Binnenlandse Zaken ${ }^{10}$. Bij de advisering is vooral belangrijk de nota van het hoofd van de twaalfde afdeling ( nationale nijuerheid) van 23 oktober $1876^{11}$. Deze stelde voor de mening van de Kamers van Koophandel en Fabrieken te vragen, omdat sommige bepalingen van het voorontwerp nogal ingrijpend waren. Van Lynden van Sandenburgh nam dit advies ter harte. Bij circulaire van 2 januari $1877^{112}$ vroeg hij, daarbij verwijzend naar het in bewerking zijn van een wetswoorstel tot uitbreiding van de Kinderwet-Van Houten, de mening van de Kamers van Koophandel en Fabrieken, de Maatschappijen van Landbouw, de Nederlandsche Maatschappij ter bevordering van Nijverheid en de Vereeniging ter bevordering van Fabrieks- en Handwerksnijuerheid in Nederland over een elftal vraagpunten betreffende de vaststelling van wettelijke bepalingen omtrent de arbeid van kinderen, jongelieden en vrouwen.

Eén van de vraagpunten trekt onze bijzondere aandacht, namelijk vraagpunt elf:

"Worden er afzonderlijke inspecteurs vereischt, om te waken voor de nakoming der nieuwe 
wet?".

De binnengekomen antwoorden ${ }^{13}$ lopen op dit punt nogal uiteen. Tot de tegenstanders van de instelling van afzonderlijke inspecteurs behoren de Kamers van Koophandel en Fabrieken van Schiedam, Amsterdam en Zwolle. De beide eerstgenoemde gaven geen nadere motivering, terwijl de laatstgenoemde vreesde, dat door haar, bij beantwoording van dit vraagpunt, een terrein werd betreden, dat niet tot het hare behoorde, namelijk dat van de wetskritiek, omdat zij van mening was, dat het land al ruim voorzien was van inspecteurs "van alle wapens". Tegenstanders waren ook de Kamers van Koophandel en Fabrieken van Deventer, Dordrecht, Schoonhoven en Delft, die het toezicht door de politie uitgeoefend wilden zien. De Kamer van Koophandel van Venlo wenste noch toezicht door de politie noch door aparte inspecteurs uitgeoefend te zien; het beste zouden andere rijksambtenaren met het toezicht belast kunnen worden, bijvoorbeeld

"de ambtenaren of Controleurs bij de Rijksbelastingen, die toch wegens de patent en accijnswetten meer aanhoudend in aanraking zijn met vele fabrikanten en ook gestadig beter kunnen beoordelen of de voorschriften der wet behoorlijk worden nagekomen, dan de Inspecteurs, die dikwijls van sommige fabrieken verwijderd zijn".

Ook bij de voorstanders van afzonderlijke inspecteurs liepen de motieven uiteen. De Kamer van Koophandel en Fabrieken van Heerenveen en de Hollandsche Maatschappij van Landbouw gaven geen enkele motivering. De Kamer van Koophandel en Fabrieken van Tilburg en de Friesche Maatschappij van Landbouw waren voor afzonderlijke inspecteurs, omdat

"voortdurend toezicht, wil de wet hare goede werking verkrijgen, voorzeker is aan te raden" respectievelijk omdat

"de zorg voor de naleving van de wet in kwestie onmogelijk kan worden overgellaten aan de Rijks en gemeentepolitie, die ..... niet dan noode acht geeft op de naleving van de wet, van welke uitbreiding thans de rede is".

De Kamer van Koophandel en Fabrieken van 's-Hertogenbosch schreef, dat de wet alleen dan vruchten kon dragen

"wanneer zij streng uitgevoerd wordt. Veelvuldige ontduiking zoude ook zeker het noodwendige nevenresultaat der wet, stijging der loonen verminderen en daarmede de gevolgen der wet even rampzalig kunmen maken als zij zegenrijk kunnen zijn. Het toezicht der gewone politie kan althans in de eerste jaren niet voldoende geacht worden en het in ' $t$ leven roepen van een bijzonder toezicht wordt alleszins wenschelijk geacht, totdat de bepalingen der wet in de volkszeden zijn doorgedrongen".

De Nederlandsche Maatschappij ter bevordering van Nijverheid achtte

"het noodzakelijk dat op geregelde tijden de werkplaatsen door bijzondere, daartoe bij wet aangestelde inspecteurs, worden bezocht, die echter met een groote mate van tact, bij de uitoefening hunner betrekking aan den dag zullen moeten leggen, daar wij niet ontkennen dat anders die inspectie nadeelig kan worden voor het prestige en het gezag der werkgevers, dat in onzen tijd reeds zoo moeijelijk is te handhaven".

De Vereeniging ter bevordering van Fabrieks- en Handwerksnijverheid in Nederland stelde, dat "het grootendeels van den takt der inspecteurs zal afhangen, of het toezicht de nijverheid bereid zal vinden tot medewerking, dan of de industrieelen integendeel alle krachten zullen inspannen om zich daarvan te ontslaan en het des mogelijk illusoir te maken".

Bij de voorstanders van afzonderlijke inspecteurs was een categorie, die de inspecteurs niet uitsluitend een controlerende taak willen toebedelen. Zo bepleitte de Kamer van Koophandel en Fabrieken van Groningen een verruiming van hun taak, namelijk dat zij nagingen of de noodzakelijkheid bestond om de KinderwetVan Houten uit te breiden conform de gestelde vragen in de circulaire van de minister. De Kamer van Koophandel en Fabrieken van Amersfoort achtte de aanstelling van afzonderlijke inspecteurs zeer gewenst: dit kon leiden

"tot eene meer eenvormige toepassing der wet en hunnen rapporten kunnen uitnemende 
diensten bewijzen, om de werking der wet na te gaan en aan te toonen welke gebreken zij in de praktijk zal toonen te bezitten, en alzoo tot leidraad verstrekken, voor latere verbeteringen, zoo die blijken noodig te zijn".

Een zelfde argument gaf de Kamer van Koophandel en Fabrieken van Leeuwarden.

Als we de binnengekomen antwoorden op de vraag of er afzonderlijke inspecteurs vereist zijn, overzien, dan blijkt het strijdpuntt te zijn wie controle moet uitoefenen: de politie of afzonderlijke inspecteurs. Wordt de vraag ten gunste van de laatste beantwoord, dan rijst de vraag of zij naast een controlerende taak nog éen of meer andere taken dienen te vervullen.

Als we nu nagaan wat het resultaat van deze enquête is geweest, dan moet het antwoord luiden: niets. Van Lynden van Sandenburghs opvolger Smidt antwoordde tijdens de begrotingsbehandeling van Justitie over het dienstjaar 1879 naar aanleiding van aandrang op niet alleen de stipte handhaving van de Kinderwetvan Houten, maar ook op uitbreiding van deze wet, mits op rationele wijze ${ }^{114}$, dat omtrent de noodzaak van uitbreiding van deze wet reeds overleg was gepleegd $\mathbf{m}$ t de minister van het nieuw ingestelde ministerie van Verkeer en Waterstaat, Handel en Nijverheid ${ }^{115}$ Tak van Poortvliet. Wat de door Van Lynden van Sandenburgh verzamelde bouwstoffen betreft, antwoordde hij, dat deze "in geenen deele voldoende" waren om daarop een nieuwe, deugdelijke en volledige regeling te kunnen bouwen. Dit onderwerp zou, zo vervolgde hij, intussen niet door de regering uit het oog verloren worden ${ }^{16}$. Kortom: de op de circulaire van Van Lynden van Sandenburgh binnengekomen antwoorden werden in de departementale archieven gedeponeerd, zonder dat er enige publiciteit aan gegeven werd.

Het zal geen verbazing wekken, dat de vraagpunten ook van anderen reacties uitlokten. Bosch ${ }^{117}$ achtte $^{10}$ buiten en behalve het gewone toezicht van de politie een bijzondere inspectie wenselijk,

"althans tot dat de wet met hare gevolgen door de bevolking op prijs gesteld worde en in de volkszeden doorgedrongen is".

Hij gaat, zich beroepend op de aanleiding tot de hele wet, namelijk de bescherming van de zwakken en afhankelijken, daarbij zelfs zover, dat hij toezicht in de woningen nodig acht. De hierdoor ontstane werkzaamheden vereisen een

"sterken onvermoeiden arm, die nooit door andere bezigheden verhinderd wordt, en althans in de eerste tijden van het bestaan der wet, met argus ogen overal rondziet. Dit is van de gewone politie moeijelijk te vragen. Groote gestrengheid moet toegepast worden, want is men daartoe niet geneigd, dan ware het beter de gehele wet achterwege te laten".

Volgens Coronel ${ }^{118}$ zal zonder een speciaal toezicht noch de bestaande, noch een uitgebreide wet voldoende aan haar doel beantwoorden. De praktijkervaringen hebben uitgewezen, dat het toezicht door de politie weinig effectief is gebleken. Maar, zo vervolgde hij, het politietoezicht behoort echter behouden te blijven, wil men niet vervallen in een stelsel van plaatselijke inspecteurs, dat zeer kostbaar zou worden. De plaatselijke politie zou ondergeschikt gemaakt moeten worden an provinciale of districtsinspecteurs.

Ook het Algemeen Nederlandsch Werklieden Verbond in een adres van 5 januari 1878 aan de minister van Justitie was voor het aanstellen van afzonderlijke inspecteurs, die een ruime volmacht moeten hebben, terwijl aan hun beslissing veel moet worden overgelaten. Gewaarschuwd werd de taak van het inspecteren niet op te dragen aan politieagenten, noch aan ambteloze burgers, gepensioneerde militairen enzovoort, maar aan mannen die wegens hun karakter en door goede bezoldiging onafhankelijk zijn; die een juist oordeel bezitten en met de mijverheid bekend, in staat zijn bij voorkomende gevallen onmiddellijk te beslissen. Deze inspecteurs konden de werkplaatsen op onbepaalde tijden bezoeken en er zich van owertuigen, dat door iedere patroon of fabrikant een register werd bijgehouden, waarin de namen, de voornamen, de ouderdom en de woonplaats van alle, zowel meerder - als minderjarige arbeiders, voorkomt. Verder konden zij de arbeiders ondervragen en die bewijzen omtrent éen en ander vorderen die zij nodig oordeelden ${ }^{110}$. 
In datzelfde jaar 1878 werd tijdens de algemene vergadering van 7 en 8 augustus van de Vereeniging tot bevordering van Fabrieks - en Handwerksnijverheid in Nederland besloten een commissie te benoemen ter beantwoording van de vraag

"in hoeverre de witwoering eener wet op den arbeid in Nederland wenschelijk is"?

Tevens nodigde mon afgevaardigden uit om deel te nemen aan werkzaamheden van deze commissie van de Maatschappij tot Nut van 't Algemeen, de Maatschappij ter bevordering van Nijverheid en het Algemeen Nederlandsch Werklieden Verbond. Uit het op 26 februari 1880 verschenen rapport $^{120}$, blijkt niet alleen, dat deze gemengde commissie zichzelf beperkingen had opgelegd ten opzichte van het haar verleende mandaat, maar tevens, dat zij aandacht had geschonken aan de uitvoering van de wet. Verwijzend naar het hierna te behandelen onderzoek van Kerdijk, bepleitte zij de instelling van speciale rijksambtenaren die zowel voor aanhoudende verbetering als voor de witvoering van de wet onmisbaar waren; hun bevoegdheden moesten met het oog op dit tweeledige doel wettelijk geregeld worden ${ }^{121}$.

Het hierbedoelde onderzoek van Kerdijk was een gevolg van de circulaire van 2 januari 1877 van de minister van Justitie Van Lynden van Sandenburgh. Uit de bewoordingen van deze circulaire leidde Kerdijk af, dat de daarin bedoelde voorbereidende wetgeving al tamelijk ver gevorderd was. Hij vroeg zich af of het nier nodig werd om te weten hoe het gesteld was en waarom dit zo was met een wet waarmee al drie jaar geleefd werd. Eén en ander was voor hem aanleiding om eigenmachtig een onderzoek in te stellen. In het daaruit voortgevloeide artikel in Vragen des Tijds ${ }^{122}$ valt te lezen, dat de wet ontdoken werd en zij haar doel in vele opzichten niet bereikte. Hij bepleitte dan ook onder meer haar uitvoering op te dragen aan afzonderlijke inspecteurs.

\section{De wijziging van de Wet op het lager onderwijs en het toezicht op het verbod van kinderarbeld}

Toen de Kinderwet-Van Houten niet aan haar doel bleek te beantwoorden, werd in 1878 een mogelijkheid tot werbetering van de situatie geschapen en wel in de Wet op het lager onderwijs ${ }^{123}$. Artikel 82 , onder 1e, van die wet bepaalde namelijk, dat de gemeenteraad, voor zover dit niet bij wet was gebeurd, verbodsbepalingen omtrent het arbeiden van kinderen beneden de twaalf jaar kon vaststellen. De minister van Binnenlandse Zaken Kappeyne van de Coppello lichtte dit artikel als volgt toe:

"Uitbreiding van het verbod van kinderarbeid is een der krachtigste middelen tot het tegengaan van het verderfelijke schoolverzuim. Het is echter bij het groote verschil wan plaatselijke omstandigheden gewaagd te veel te bepalen bij de algemeene wet. Plaatselijke verordeningen moeten in die onderwerpen voorzien, waarin het huishoudelijk belang der gemeente. voorzieningen wenschelijk maakt"124.

Tegen deze bepaling werd desondanks bezwaar aangetekend, omdat een bepaling in de Wet op het lager onderwijs werd opgenomen, die in een wet op de kinderarbeid thuishoorde ${ }^{125}$. De bewindsman antwoordde daarop met een vraag:

"Waarom zou in afwachting eener wet op den kinderarbeid een goed voorschrift hier misplaatst zijn"126.

Tijdens de mondelinge beraadslaging diende Van den Berch van Heemstede een amendement ${ }^{127}$ in om het gewraakte artikelonderdeel te laten vervallen. Als argument voerde hij aan, dat het de taak van de wetgevende macht is om wijziging te brengen in bestaande wetten en dat dit niet tot de taak van gemeentebesturen behoort ${ }^{128}$. De bewindsman bestreed daarop niet alleen de juistheid van dit standpunt, maar wees tevens op de mogelijkheid, dat het gelegenheid geven aan gemeenteraden dit onderwerp te behartigen, misschien langzamerhand zou kunnen leiden tot een regeling die later tot grondslag zou strekken voor de "algemeene wetgever", terwijl op dit moment deze gevaar liep mis te tasten. Het was veel beter de zaak aan de gemeenteraden over te laten, aldus de minister ${ }^{129}$.

$\mathrm{Bij}$ brief van 10 augustus $1881^{130}$ werd vanüit het ministerie van Binnenlandse Zaken bij de gedeputeerde staten van de provincies nagegaan in hoeverre door gemeentebesturen van deze bevoegdheid gebruik was gemaakt. Het resultaat was niet overweldigend te noemen. Uit de binnengekomen antwoorden ${ }^{131}$ blijkt 
dit slechts in 41 gemeenten te zijn geweest. Kerdij|k ${ }^{132}$ geeft als resultaat van een door hem ingesteld onderzoek een aantall van 49 gemeenten ${ }^{133}$. Hoe is het gesteld met de handhaving van deze verordeningen? Ondanks de beperkt opgedane ervaringen geeft het door Kerdijk ingestelde onderzoek een aardige indicatie op dit punt. Door hemzelf wordt het resultaat bestempeld als

"nog, geenszins een onvoorwaardelijk verblijdende".

Zo schreef een burgemeester:

de naleving der voorschriften is in deze moeielijk te verzekeren, met het oog op het weinig talrijke politiepersoneel".

Andere mededelingen luidden als volgt:

"de bepalingen zijn tot nu toe een dode letter gebleven, terwijl toch uit de absentie-lijsten der schoolhoofden blijkt, dat er overtredingen - en niet zelden - gepleegd worden";

"de genoemde verordening wordt hier niet gehandhaafd, dewijl zoowel de rijks- alls de gemeentepolitie wienig acht slaat op den veldarbeid";

"ofschoon er volgens de loopende geruchten wel overtredingen plaats hebben, moet het eerste proces-verbaal nog worden opgemaakt".

Een onderwijzer berichtte:

"er wordt volstrekt geen uitvoering aan gegeven. Bij de eerste overtreding heb ik geïnformeerd, of er niet zulk een verordening bestond () en de overtreder opgegeven, maar zonder eenig gevolg".

Een andere onderwijzer schreef:

"uit een nieuwsblad vernam ik, dat er een verordening was ingevoerd, maar gemerkt heb ik er niets van".

Aan negatieve getuigenissen dus geen gebrek. Maar daar tegenover stonden ook positieve berichten. Zo mellde een onderwijzer het volgende:

"Bij een aanvrage van twee leerlingen om eenigen tijd van school te mogen wegblijven, ten einde te werken op het land, rustte mijn weigering, die het gewenste gevollg had, op genoemd besluit".

Een ander:

"een jongen, die verlof vroeg, voor het doel een poosje te verzuimen, wees ik op de verordening, en toen is bij geregeld ter school gekomen".

Kerdijk wijst erop, dat het regelen van de kinderarbeid - met name veldarbeiid - afgestemd op plaatselijke behoeften, te begrijpen is, maar dat dientengevolge een grote verscheidenheid aan regelingen ontstaat. Zijn conclusie luidt dan ook, dat de bevoegdheid door de Wet op het lager onderwijs aan de gemeenten verleend, als tijdelijke maatregel acceptabel was, maar

"stellig zodra doenlijk overbodig behoort te worden gemaakt door een wettelijke regeling voor het geheele rijk".

\section{Het ontwerp-Modderman}

Na deze opmerking van Kerdijk wordt het tijd eens na te gaan of er van regeringszijde activiteiten werden ontplooid, die gericht waren op uitbreiding en herziening van de Kinderwet-Van Houten. Een soortgelijke vraag werd ook gesteld tijdens de begrotingsbehandeling van Justitie voor het dienstjaar $1882^{134}$. Hierop antwoordde de toenmalige minister van Justitie Modderman dat hij

"een, door bekwame hand opgestelde en in overleg met een bevoegde specialiteit verbeterd, wetsontwerp tot vervanging van de wet van september 1874 ...... reeds tijdens de vorige zitting in gereedheid (had). In 't belang der zaak zelve, heeft hij echter deze zaak tot deze zitting laten rusten; trouwens de tijd voor behandeling van het ontwerp zou hebben ontbroken ${ }^{\text {mis }}$.

Toen tijdens de mondelinge beraadslaging de toenmalige bewindsman een aantal vragen werd gesteld, waar- 
onder de vraag of hij bereid was het toegezegde wetsvoorstel in te dienen ${ }^{136}$, gaf hij te kennen, dat dit voorstel in mei 1882 als wet in werking kon treden ${ }^{137}$. Het betreffende wetsvoorstel en de daarbij behorende toelichting waren bij schrijven wan 13 december $1881^{138}$ voor advies naar de Raad van State gezonden.

Dat voorstel voorzag in een toezicht op de kinderarbeid ${ }^{139}$. Artikel 10 bepaalde, dat dit toezicht in het gehele rijk was opgedragen aan de met de uitvoering van de wet belaste minister. Dit toezicht werd onder zijn bevelen uitgeoefend door inspecteurs en adjunct-inspecteurs. Het ambtsgebied van iedere inspecteur omvatte én of meer provincies, terwijl dat van een adjunct-inspecteur én of meer districten omvatte waarin het ambtsgebied van iedere inspecteur door de Kroon werd verdeeld, aldus artikel 11. Ditzelfde artikel bepaalde voorts onder meer; dat de inspecteurs en adjunct-inspecteurs door de Kroon benoemd, geschorst en ontslagen werden en dat in geval van ziekte, afwezigheid, ontstentenis of schorsing een inspecteur door een adjunct-inspecteur, een adjunct-inspecteur door een van zijn ambtsgenoten werd vervangen. De plaatsvervanger werd door de minister aangewezen. Tot slot gaf het woorstel cen regeling omtrent de verhouding tussen de personen, die belast waren met het toezicht op de kinderarbeid; de adjunct-inspecteurs waren, blijkens artikel 13, ondergeschikt aan de inspecteurs.

In een zeer uitgebreide toelichting verdedigde de toenmalige bewindsman de instelling van afzonderlijke inspecteurs, die onder zijn verantwoordelijkheid, het toezicht uitoefenden als volgt:

"Zal eene wet als de thans voorgestelde eenige uitwerking hebben, dan behoeft het geen betoog, dat er eene uitgebreide contrôle, een zeer streng toezicht nodig is. Tot nog toe is deze taak aan de politie opgedragen, en zij vervult haar taak zoo goed mogelijk. Door de voorgestelde regeling wordt de taak echter zoo omvangrijk, raakt zij woor een groot deel zoo ver buiten het kader van de politie, dat van een dergelijke toezicht alleen geen sprake kan zijn. De politie blijft werken tegen de overtredingen dezer wet, zooals zij dat doet tegen die van alle andere wetten, maar zij heeft daarbij hullp noodig. $\mathrm{Zij}$ is niet bij machte alle fabrieken, werkplaatsen, alle gelegenheden waar geregeld gearbeid wordt, voortdurend te inspecteren, te onderzoeken op de scholen of de kinderen het anderwijs bijwonen. En er is meer te doen. De regering moet ook steeds voorgelicht worden om de taak, haar in artikel 5 opgelegd, goed te kunnen vervullen. Onder het oppertoezicht van de verantwoordelijke Minister wordt het Rijkstoezicht uitgeoefend door speciale ambtenaren, namelijk inspecteurs en adjunctinspecteurs"140.

Voorts besteedde de toenmalige minister in zijn toelichting aandacht aan het denkbeeld het toezicht op te dragen aan schoolopzieners. Hoewel hij toegaf, dat ex een nauw werband bestond tussen een regeling van de arbeid en van het schoolbezoek, werd met deze gedachte afgerekend. Daarvoor werd als argument aangevoerd de onverenigbaarheid van functies. Ook de mogelijkheid om naast de inspecteurs en adjunt-inspecteurs toezicht wit te laten oefenen door in te stellen plaatselijke commissies van toezicht werd in ogenschouw geno$\operatorname{men}^{141}$. Ook dit werd afgewezen, op grond van het argument, dat analogie met het schooltoezicht hier niet was toegelaten:

"is het onderwijs ook gemeentezaak, de beperking van den kinderarbeid is uitsluitend rijkszaak" $^{\mathrm{n}}$.

Bovendien zou de medewerking van de gemeentelijke autoriteiten de zo nodige eenheid allerminst bevorderen.

Blijkens het voorstel hadden de inspecteurs tot taak in hun ambtsgebied, naast de regeling van de werkzaamheden die verband houden met het toezicht op de kinderarbeid, bekend te blijven met de toestand van jeugdige arbeiders en deze zoveel mogelijk te verbeteren. Een en ander konden zij doen door het bezoeken van fabrieken, werkplaatsen, landerijen en zo nodig ook van scholen, en door overleg met de adjunct-inspecteurs en het schooltoezicht. Voorts hadden zij in hun ambtsgebied te waken over een stipte naleving van de wettelijke voorschriften op de kinderarbeid en moesten zij de verantwoordelijke bewindisman inlichtingen verstrekken over alle onderwerpen, waarower hun bevinding of oordeel werd gevraagd. Bovendien hebben zij wit de verslagen van de adjunct-inspecteurs en uit hun eigen bevindingen jaarlijks een uitvoerig rapport op te stellen 
- dat gepubliceerd wordt - over de toestand van de jeugdige arbeiders in hun ambtsgebied en dit v66r 1 juli aan de verantwoordelijke minister toe te sturen. Tot slot hadden zij tot taak gedeputeerde staten te adviseren omtrent een verzoek van een gemeenteraad om schorsing van het verbod van veldarbeid voor kinderen van negen tot dertien jaar - onder voorwaarde, dat zij geregeld onderwijs genoten gedurende de rest van het jaar en hun gestel de arbeid aankon - voor een periode van zes weken.

De taken van de adjunct-inspecteurs kwamen overeen met die van de inspecteurs. Ook zij zorgden voor het bezoeken van fabrieken, werkplaatsen, landerijen en zo nodig ook van scholen en van woningen, moesten zij bekend blijven met de toestand van de jeugdige arbeiders binnen hun district en die zoveel mogelijk verbeteren. Ook zij waakten voor een stipte nalleving van de wettelijke voorschriften op de kinderarbeid. Voorts dienden zij de inspecteur inlichtingen te verstrekken over alle onderwerpen waarover hun bevinding of oordeel gevraagd wordt en dienden zij jaarlijks een uitvoerig rapport op te maken over hun ervaringen over de toestand van de jeugdige arbeiders in hun district en sturen dit vór 15 april aan de inspecteur onder wie zij gesteld waren.

De ambtenaren, belast met het toezicht op de kinderarbeid dienden, aldus artikel 18, proces-verbaal op te maken van de door hen geconstateerde overtredingen vat. de wettelijke voorschriften op de kinderarbeid. Uit het hierboven gestelde blijkt, dat de personen die belast zouden worden met het toezicht op de kinderarbeid een tweeledige taak zouden hebben, namelijk een controlerende en een voorlichtende. De toelichting leert, dat de inspecteurs meer belast zouden zijn met, wat aldaar genoemd wordt, het technische gedeelte van het toezicht: zij moesten de regering en de gedeputeerde staten voorlichten bij de regelingen die aan hen werden overgelaten, terwijl bovendien hun rapporten bronnem zouden zijn voor latere wetgeving betreffende de arbeid. Daarnaast oefenden zij ook het administratieve gedeelte uit door voor een gelijkmatige toepassing van de wet in alle delen van het land te zorgen. De handhaving van de wet berustte, blijkens de toelichting, vooral bij de adjunct-inspecteurs: zij zouden onder leiding en toezicht van de inspecteurs grotendeels de controle uitoefenen en door middel van hun rapporten de inspecteurs voorlichten.

Ten einde deze taken te kunnen uitoefenen voorzag het wetsvoorstel in een aantal bevoegdheden voor de inspecteurs en de adjunct-inspecteurs. Zo hadden zij ter vervulling van hun taak op grond van artikel 16 toegang tot alle fabrieken, werkplaatsen, scholen, woningen en landerijen. Als een fabriek, werkplaats of een stuk land alléen toegankelijk was via een woning, dan konden zij deze niet tegen de wil van de bewoner zonder een schriftelijke vergunning van de burgemeester betreden. Zouden zij een woning willen onderzoeken, dan gold niet alleen deze voorwaarde, maar moesten zij tevens vergezeld zijn van een door de burgemeester aangewezen politie-ambtenaar.

Zou, ondanks het inachtnemen van deze formaliteiten, toegang toch geweigerd worden, dan konden zij zich die verschaffen, desnoods met behulp van de sterke arm. Zou tegen de wil van de bewoner een woning betreden worden, nadat was voldaan aan alle formaliteiten, dan diende daarvan proces-verbaal opgemaakt te worden, waarvan binnen achtenveertig uur een afschrift aan deze bewoner moest worden gezonden. Het verlenen van dergelijke bevoegdheden werd in de toelichting verdedigd met het argument, dat voorgekomen was en voortaan herhaaldelijk zal gebeuren, dat toegang geweigerd was en de politie op grond van artikel 153 van de Grondwet ${ }^{142}$ dan machteloos was. Een onvoorwaardelijke bevoegdheid enerzijds leverde strijd op met de geest van dit genoemde artikel, terwijl anderzijds vele formaliteiten verwijdering van de bewijzen van overtreding met zich zou kunnen brengen. De voorgestelde regeling bood, aldus de toelichting, voldoende waarborgen tegen misbruik. Het betreden van een woning werd verdedigd met de opmerking, dat anders het kwaad zich van de fabriek naar de woning zou verplaatsen. Als men het kwaad wilde bestrijden, dan moest men ook de middelen daartegen willen, aldus Modderman. De inspecteurs en adjunct-inspecteurs kregen vervolgens een bijzondere bevoegdheid, die was neergelegd in artikel 8 van het wetsvoorstel: indien zij van mening waren, dat aan een kind beneden de zestien jaar arbeid was opgedragen, die, hoewel toegestaan ingevolge de wet, klaarblijkelijk zijn krachten te boven ging of voor hem gevaarlijk was, konden zij de voortzetting van deze arbeid verbieden. Dit verbod en de redenen waarop zij berustte, moest bij exploit ter kennis worden gebracht aan zowell degene die de ouderlijke macht of de voogdij over het betreffende kind uitoefen- 
de als aan de werkgever. Na de betekening was de overtreding van het verbod een strafbaar feit, tenzij de rechter zou beslissen, dat het verbod ten onrechte was opgelegd. Overigens zij erop gewezen, dat de bevoegdheid om de eerder genoemde plaatsen te betreden, evenals de verplichting van de werkgever en het schoolhoofd om de gevraagde inlichtingen te verschaffen, gekoppeld is aan een verplichting tot geheimhouding van hetgeen het bedrijf betreft, voor zover het niet strijdt met de wettelijke voorschriften op de kinderarbeid. Opzettelijke schending van deze geheimhoudingsplicht door een ambtenaar, belast met het toezicht op de kinderarbeid, werd gestraft met een geldboete van maximaal zeshonderd gulden of gevangenisstraf van ten hoogste zes maanden. Vervolging had op grond van artikel 24 alleen plaats na een klacht van de bestuurder van de fabriek of werkplaats.

Het wetswoorstel bevatte tevens een aantal controlemiddelen. Ook hier schriftelijke verklaringen, waaruit moest blijken, dat voldoende (huis)onderwijs gemoten werd. Daarnaast moest op grond van artikel 7 van kinderen beneden de zestien jaar de werkgever in het bezit zjn van een door de burgemeester van de gemeente waarbinnen het kind arbeid zal verrichten afgegeven kaart waarop vermeld stonden: de naam, de voornaam, de geboortedag en -plaats van het kind, de naam en woonplaats van degene die over het kind de ouderlijke macht of de voogdij uitoefende, alsmede de vermelding dat eerdergenoemde verklaringen aan de burgemeester getoond waren. De werkgever was verplicht de kaart te bewaren en op verzoek aan de met het toezicht belaste personen te laten zien. Niet-naleving van deze voorschriften was een strafbaar feit. Volgens de toelichting was het voorgestelde controlemiddel woldoende; de werkgever te verplichten registers bij te houden van de arbeiders werd door de toenmalige minister onnodig bezwarend geacht.

Paste Modderman zijn wetsvoorstel ten aanzien van een aantal voorstellen, neergelegd in het advies van de

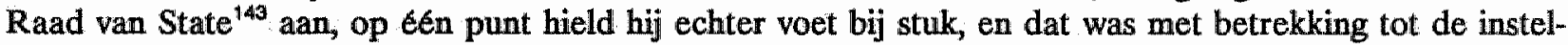
ling van afzonderlijke inspecteurs. De bezwaren van de Raad van State tegen een dergelijke instelling waren tweeledig. In de eerste plaats zou een nauwgezet toezicht wrevel op kunnen wekken bij de bevolking, terwijl in de tweede plaats de financiën te zwaar belast zouden worden. Beide bezwaren legde Modderman naast zich neer ${ }^{144}$.

De suggestie van de Raad van State om het toezicht aan de politie op te dragen, werd door de toenmalige bewindsman verworpen. Hiervoor voerde hij een drietal argumenten aan. Ten eerste was voor de vervulling van de taak van de inspecteurs zeer speciale kennis vereist, een kennis

"die men van politieambtenaren niet mag vorderen".

Ten tweede was de taak van de gewone politie al veelomvattend, en ten derde was uit ervaringen in het buitenland gebleken, dat de inspectie een weinig kostbare en uitstekende instelling was. In plaats van de in artikel 7 van het voorstel bedoelde kaart stelde de Raad van State voor om de burgemeester een register te laten bijhouden van de kinderen beneden de zestien jaar, die op welke manier dan ook in de gemeente arbeid verrichtten, met de vermelding van de werkgever bij wie zij werkzaam waren. Een uittreksel van dit register zou dan aan elke werkgever en misschien ook aan de vader en voogd uitgereikt kunnen worden. Ook dit voorstel werd door Modderman van de hand gewezen. Op 23 april 1882 werd het ontwerp-Modderman, houdende wettelijke bepalingen tot het tegengaan van overmatigen arbeid en verwaarloozing van kinderen, aan de Tweede Kamer ter overweging aangeboden ${ }^{145}$.

Het wetswoorstel had ten aanzien van de eerdere versie een aantal wijzigingen ondergaan ten einde aan een aantal verlangens van de Raad van State tegemoet te komen. Eén en ander had tot gevolg, dat de artikelen opnieuw waren gerangschikt en genummerd.

Hoewel het wetswoorstel geen verandering laat zien ten aanzien van het toezicht als zodanig, was wel de in het eerdere voorstel neergelegde bijzondere bevoegdheid van hen die belast waren met het toezicht op de kinderarbeid gewijzigd. De voortzetting van de arbeid, die, hoewel geoorloofd voor een kind beneden zestien jaar, zijn kracht te boven ging, kon verboden worden totdat door een praktiserend geneesheer - na onderzoek - op de werkkaart werd geschreven, dat het gestel van het kind dergelijke arbeid (weer) toeliet. Op vertoon van het exploit, waarbij het verbod was opgelegd, zou het onderzoek door de geneeskundige kosteloos 
verrieht worden. Niet-naleving van het werbod leverde een strafbaar feit op voor degene aan wie het exploit was betekend.

Had het oorspronkelijke voorstel slechts de verplichting tot het hebben van een kaart; het bij de Tweede Kàmer ingediende wetsvoorstel wet bepaalde in artikel 7 bovendien, dat in alle fabrieken en werkplaatsen een lijst moest zijn aangeplakt of zijn opgehangen, met een opgave van de uren waarop de kinderen werkten. Deze verplichting was overigens niet direct strafbaar gesteld. Als een werkgever echter niet aan de verplichting na een bevel of een vordering daartoe door een bevoegde ambtenaar gegeven voldeed, dan leverde dit een strafbaar feit op ${ }^{148}$.

Vermeldenswaard is tenslotte artikel 19 van het wetsvoorstel. Daarin werd uitdrukkelijk bepaald, dat, indien diegenen, die met het toezicht op de kinclerarbeid belast waren, een school bezochten, zij zich niet mochten inlaten met aangelegenheden die de school en het onderwijs betroffen.

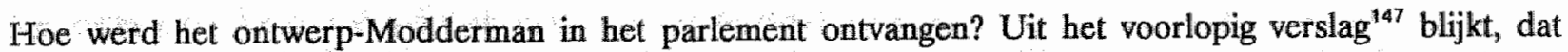
de instelling van inspecteurs en adjunct-inspecteurs door de meerderheid van de Tweede Kamer onvoorwaardelijk werd afgekeurd.

"Een leger van ambtenaren met de daaraan verbonden groote kosten zou daarvan het gevolg zijn, en de eentheid, welke de Regering door het scheppen van dit toezicht hoopt te verkrijgen, werd door velen niet gewenscht, die oordeelden dat het hier juist aankomt op verschil van toepassing, naar gelang der onderscheidene plaatselijke omstandigheden........ Eene goede plaatselijke politie, een commissie van toezicht uit de gemeente, voorgelicht en gesteund door het geneeskundig Staatstoezicht, ofwel toezicht van dit laatste alleen, achtten velen ook oneindig doelmatiger".

De voorstanders van de in het wetsontwerp voorgelegde regeling waren van mening, dat het korps ambtenaren niet zonder grote noodzaak moest worden uitgebreid, maar vonden tevens; dat in de memorie van toelichting de noodzakelijkheid van de aanstelling van enkele inspecteurs op goede gronden was aangetoond. Zij stelden, dat iedere verbetering van de Kinderwet-Van Houten zeer weinig zou baten, als de wet er niet tevens in voorzag, dat er in het vervolg voldoende controle zou zijn. Deze voorstanders benadrukten echter met name de voorlichtende rol van de inspecteurs, die als adviseurs van de regering bouwstoffen verzamelden, zowel om een goede uitvoering van de bestaande wetgeving te bevorderen als om tot bronnen te dienen voor latere regelingen aangaande het onderhavige onderwerp.

Wat betreft het betreden van een woning tegen de wil van de bewoner door de ambtenaren die belast waren met het toezicht op de kinderarbeid, met onder meer een schriftelijke last van de burgemeester ontlokte in het voorlopig verslag de opmerking, dat een dergelijke last wel nooit geweigerd zou worden. Om deze last voldoende te laten zijn voor het betreden van een woning werd niet wenselijk geacht. In andere gevallen werd een dergelijke bevoegdheid alleen gegeven tot de opsporing van misdrijven of wetsovertredingen en nooit, zoals hier in verband met het volgende artikel ${ }^{14}$ blijkt, ook voor het verkrijgen van inlichtingen. Bovendien bleek uit het voorlopig versllag, dat sommigen zich niet konden voorstellen, hoe een inspecteur het gewenste toezicht zou kunnen uitoefenen. Vandaar dat werd gesteld, dat toezicht op de kinderarbeid in woningen en op landerijen alleen zou kunnen gebeuren door plaatselijke commissies.

Ook de verplichting van het schoolhoofd tot het geven van inlichtingen vond bij velen geen genade en wel, omdat deze

"om verschillende redenen reeds met werkzaamheden van dien aard overladen (zijn)".

Daarnaast werd door sommigen de aan de inspecteurs opgelegde geheimhoudingsplicht een onvoldoende waarborg voor de industrie genoemd, alleen al vanwege het feit, dat deze ambtenaren uit de aard van hun betrekking bekend werden met geheimen. Bij de strafbepalingen zou bepaald moeten worden, dat een ambtenaar die zich schuldig maakte aan schending van de geheimhoudingsplicht en die daarvoor veroordeeld werd, ontzet zou kunnen worden van het recht om ambten in het algemeen of het ambt van inspecteur of adjunct-inspecteur op het kinderarbeid te bekleden. 
Afrondend kan gesteld worden, dat het wetsvoorstel met gemengde gevoelens is ontvangen, zelfs door de voorstanders van een verbeterde wettelijke regeling. Dit ondanks het feit, dat toch al hun wensen in het wetsvoorstel neergelegd waren. Hun bedenkingen richtten zich dan ook tegen de wijze waarop éen en ander geregeld was. In eén opzicht is het voorlopig verslag ook nog van belang. Het recht en de plicht van de staat om het kind te beschermen werd niet meer betwist.

Men accepteerde wat in de aanhef van de memorie van toelichting was aangevoerd:

"dat het recht en de plicht van den staat tot bescherming van het kind tegen het gevaar, waaraan het door te vroegtijdigen of overmatigen arbeid wordt blootgesteld, niet meer behoeven betoogd te worden en blijkens de wet van 1874 door onze wetgevende macht zijn erkend"149.

Principiële bezwaren werden dan ook niet geopperd; hoewel uitdrukkelijk nog wel werd verklaard, dat "de uitbreiding van de staatszorg niet te rechtvaardigen is"

\section{Het eerste ontwerp-Du Tour Van Bellinchave}

Modderman heeft zijn wetsontwerp nooit kunnen verdedigen. Het voorlopig verslag verscheen pas, nadat het kabinet, waarvan hij deel uitmaakte ${ }^{151}$, was afgetreden. $\mathrm{Zijn}_{\mathrm{j}}$ opvolger Du Tour van Bellinchave zag af van verdediging van het wetsvoorstel. Bij brief van 5 juli $1883^{152}$ aan de voorzitter van de Tweede Kamer trok hij dan ook het bewuste wetsvoorstel in. De redenen daarvoor gaf hij aan in een latere brief ${ }^{153}$ aan de commissarissen van de Koning, waarin hij hun oordeel over een aantal vraagpunten ${ }^{154}$ wilde weten. Eén van de redenen, dat hij zich niet kon verenigen met het wetsvoorstel was

"de wijze waarop volgens dat ontwerp het toezicht op den arbeid van kinderen was geregeld".

Uit het yoorlopig verslag van de commissie van rapporteurs uit de Tweede $\mathrm{Kamer}^{155}$ naar aanleiding van de begrotingsbehandeling van Justitie voor het dienstjaar $1884^{158}$ valt af te leiden, dat de intrekking van het ontwerp-Modderman met gemengde gevoelens werd ontvangen; sommigen stemden ermee in, terwijl anderen het juist afkeurden. Ook over de wenselijkheid van een nieuw wetsvoorstel werd verschillend gedacht. Zij die daar niet onwelwillend tegenover stonden, stelden echter wel, dat dit alleen dan kon gebeuren

"na onderzoek van de behoeften meer bijzonder in ons eigen land". Anderen wilden geen druk op de regering uitoefenen, maar vroegen zich af

"of de zaak een onderwerp van overweging bij haar blijft uitmaken en of zij wellicht bouw-

stoffen tot de samenstelling eener nieuwe wetsvoordracht tracht te verzamelen".

Het hierop door de toenmalige minister gegeven antwoord getuigde van een grote terughoudendheid:

"De vraag of uitbreiding van de bestaande wetgeving op den kinderarbeid wenschelijk is, maakt bij den ondergetekende een punt van overweging uit. Hij durft echter op dit oogenblik geen toezegging doen, dat door hem een nieuw ontwerp zal worden ingediend"157.

Toen tijdens de mondelinge beraadslaging door Goeman Borgesius aan de bewindsman onder meer werd gevraagd, of de ontduiking van de Kinderwet-Van Houten geen reden was om een nieuwe wet voor te stellen en of het toezicht op deze wet voldoende was ${ }^{459}$, antwoordde Du Tour van Bellinchave, dat hij de zaak wilde laten rusten. Hij wees Goeman Borgesius op het bestaan van artikel 253 van het Wetboek van Strafrecht en van artikel 82 van de Wet op het lager onderwijs ${ }^{150}$.

In het voorlopig verslag van de commissie van rapporteurs ${ }^{100}$ van de daarop volgende begroting werd aan de minister gevraagd of hij tot een beslissing was gekomen over de wenselijkheid om de Kinderwet-Van Houten uit te breiden ${ }^{161}$. Du Tour van Bellinchave antwoordde daarop, dat

"een ontwerp van wet tot regeling van den arbeid van kinderen bij den Raad van State in overweging (is) ${ }^{\text {n192 }}$.

Het wetsvoorstel waar de bewindsman op doelde, was bij schrijven van 20 december $1884^{163}$ voor advies naar de Raad van State gezonden. 
Artikel 9 van het voorstel voorzag in het toezicht op de naleving van de wettelijke bepalingen. Bepaald was namelijk, dat met het opsporen van overtredingen van deze wet, naast de bij artikel 11 van het Wetboek van Strafvordering ${ }^{104}$ aangewezenen, belast waren de marechaussee en alle ambtenaren van rijks- en gemeentepolitie. Het principe van afzonderlijke inspecteurs werd dus losgelaten. De enige taak van de in dit artikel bedoelde ambtenaren was het opsporen van strafbare feiten. Daartoe hadden zij in het er op volgende artikel te allen tijde toegang tot alle fabrieken, werkplaatsen, landerijen, schepen en woningen. $\mathrm{B}_{1 j}$ weigering van toegang konden zij zich die desnoods verschaffen met behulp van "den sterken arm". Woningen benevens fabrieken en werkplaatsen of schepen tevens woningen en fabrieken, werkplaatsen of landerijen die alleen door een woning te bereiken waren, konden niet tegen de wil van de bewoner worden betreden zonder schriftelijke last van de burgemeester of de kantonrechter. Van het binnentreden moest proces-verbaal opgemaakt worden en binnen twee maal vierentwintig uur aan de bewoner, wiens woning was betredlen, in afschrift medegedeeld worden.

Ook dit wetsvoorstel bevatte een geheimhoudingsbepaling. De in artikel 10 bedoelde ambtenaren waren op grond van artikel 11 verplicht tot geheimhouding van hetgeen hum door het binnentreden van fabrieken, werkplaatsen, landerijen, schepen en woningen omtrent het daar witgeoefende bedrijf bekend werd, voor zover dit niet in strijd was met de bepalingen van deze wet. Het opzettelijk schenden van de aan de bedoelde ambtenaren opgelegde geheimhoudingsplicht werd gestraft met gevangenisstraf van minimaal eén dag en maximaal zes maanden of een geldboete van tenminste vijftig cent en ten hoogste zeshonderd gulden; én en ander al dan niet met ontheffing van het recht om ambten te bekleden. Vervolging vond plaats op klacht van het hoofd of de bestuurder van het bedrijf of de onderneming. Het wetsontwerp bevat slechts een soort controlemiddel, namelijk door een onderwijzer verplicht af te geven verklaringen ten behoeve van zijn leerlingen omtrent het onderwijs dat zij genoten dan wel genoten hadden.

De Raad van State ${ }^{165}$ had onder meer bezwaar tegen het opnemen van "woningen" en "schepen" in artikel 10. In het advies stond aangaande artikel 10 het volgende:

"De Raad van State zou meenen dat de vermelding van woningen en schepen in het eerste lid van dit artikel behoort te vervallen, en zou de bevoegdheid om woningen tegen den will der bewoners binnen te treden aan de ambtenaren bij artikel 9 bedoeld, alleen dan willen toekennen, wanneer het noodzakelijk is om zich toegang te verschaffen tot een fabriek of een werkplaats. Niet alleen mag de waarborg door artikel 153 van de Grondwet aan alle ingezetenen verzekerd, niet worden verkort, maar er ligt ook in het ten allen tijde binnentreden bij dit voorgesteld, iets krenkends voor de arbeidende klasse, wijl het hier uit den aard der zaak voornamelijk hare woningen moet gelden. Ook hare woningen wil artikel 153 der Grondwet geëerbiedigd zien".

Uit het nader rapport van 7 april $1884^{168}$ blijkt, dat de minister aan deze wens van de Raad van State tegemoet kwam en de betreffende bepalingen in het wetsvoorstel dienovereenkomstig wijzigde.

Daarnaast had de Raad van State bezwaar tegen het in het ontwerp opnemen van onderwijsbepalingen.

"Zoolang velen in den lande gemoedsbewaren koesteren tegen het openbaar onderwijs, en toch alleen dat onderwijs op vele plaatsen voor de kinderen openstaat, zou het voorgestelde moeten geacht worden inbreuk te maken op het recht der ouders om voor hunne kinderen het onderwijs te kiezen, dat zij verlangen. Het komt eigenlijk ook neder op eene zijdelingsche invoering van den leerplicht, ter gelegenheid van een wetsontwerp tot het tegengaan van overmatigen arbeid van kinderen; en dit nog wel alleen voor de zoogenaamde arbeidende klasse, daar de kinderen der meer gegoeden niet vallen onder het bereik dezer wet". Ook aan dit bezwaar kwam Du Tour van Bellinchave tegemoet: alle voorwaarden van en bepalingen betreffende het onderwijs werden door hem uit het wetsvoorstel verwijderd. Hierdoor vervielen de in het oorspronkelijke ontwerp opgenomen bepalingen omtrent de verklaring met betrekking tot het onderwijs ${ }^{167}$.

Nadat in het wetswoorstel onder meer de bovenvermelde wijzigingen aangebracht waren, werd het aan de 
Tweede Kamer toegezonden ${ }^{188}$. Hoe reageerde de Tweede Kamer op dit ingediende wetsvoorstel? De commissie van rapporteurs ${ }^{160}$ merkte in het voorlopig verslag ${ }^{170} \mathrm{op}_{\text {, dat }}$

"de indruk, door de indiening van dit wetsontwerp nagenoeg algemeen teweeggebracht; dan ook verre van gunstig (was)".

Verder valt in hel verslag de veelvuldige verwijzing op naar de door de Kamer geleverde kritiek op het ontwerp-Modderman. Voor ons onderwerp is van belang, dat vele leden bezwaar opperden tegen het ontwerp, namelijk dat

"het, tot wet verheven, wanneer men niet ten minste tot een verdubbelling van het politietoezicht wilde overgaan, onmogelijk voor handhaving vatbaar zou zijn, ...........".

Men was er dam ook van overtuigd,

"dat, ofschoon de Regeering thans uit het vorig ontwerp de inspecteurs heeft weggelaten, daaraan niet teveel gewicht moet worden toegekend, en men ten gevolge van niet-handhaving der nieuwe bepalingen al spoedig zal komen met het voorstel tot aanstelling van dergelijke ambtenaren. Voor dit geval gaven summigen in overweging de aanstelling van een tweetal inspecteurs, bekend met het fabriekswezen, onder toevoeging van een derden, met den landbouw vertrouwd, tot wier bemoeiing zou moeten behooren de aanraking en correspondentie met gemeentebesturen, fabrikanten enz, en die, het land bereizende, kennis zouden verkrijgen waar al dan niet regeling of beperking zou behooren plaats te vinden".

Door anderen werd hiertegen aangevoerd, dat dergelijke ambtenaren meer adviseurs van het departement zouden zijn met het oog op het ontwerpen van wettelijke bepalingen, dan controleurs van de uitvoering van de wet en wakers tegen ongeoorloofde kinderarbeid. Zij waren overigens tegen alle inspecties, mede op grond van het feit, dat zij niet wilden, dat er een nieuwe categorie van ambtenaren in het leven geroepen zou worden ${ }^{171}$.

Het zal geen verwondering wekken, dat dit voorlopig verslag voor de betrokken bewindsman geen aanmoediging was om op de ingeslagen weg voort te gaan. Het bleef dan ook onbeantwoord. Dit had weer tot gevolg, dat het wetsvoorstel bij de ontbinding van de Tweede Kamer van de lijst van werkzaamheden van de Kamer werd afgevoerd ${ }^{172}$. Uit het feit, dat onder de wetsontwerpen, die na de Kamerontbinding opnieuw aanhangig werden gemaakt, dat op de kinderarbeid niet voorkwam, leidde een aantal Kamerleden af, dat het niet in de bedoeling van de regering lag om alsnog over haar wetsontwerp een Kamerbeslissing uit te lokken.

\section{De parlementaire enquête van 1886}

De hoofdreden, die tot het ongunstige onthaal van de ontwerpen-Modderman en -Du Tour Bellinchave had geleid, was dat er voorstellen met ingrijpende maatregelen waren gedaan zonder dat de regering de wenselijkheid ervan en het nauwe verband tussen de voorgestelde bepalingen en de bestaande toestanden met feitelijke gegevens kon aantonen. Om dit argument voorgoed de pas af te snijden, werd door Goeman Borgesius en tien andere Kamerleden op 12 augustus 1886 een voorstel ingediend om tot het houden van een parle-

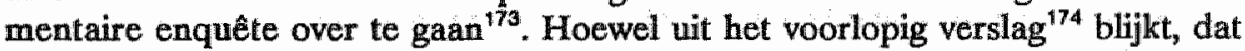

"sommige leden in beginsel gekant (waren), omdat daardoor naar zij vreesden, bij de arbei-

ders overdreven verwachtingen zouden worden opgewekt",

werd op 13 oktober 1886 het enquête-voorstel door de Tweede Kamer aangenomen ${ }^{17 t}$ en werd de enquête-commissie ingesteld ${ }^{176}$. De enquête-commissie diende zich bezig te houden met de volgende vragen:

"a. Wellke is de werking van de wet van 19 September 1874 (Staatsblad no. 130), ook in verband met art. 82 van de wet van 17 augustus 1878 ( Staatsblad no. 127)? In hoever geven de bestaande toestanden aanleiding eene aanvulling en uitbreiding der eerstgenoemde wet in overweging te nemen?

b. Welke is de toestand in fabrieken en werkplaatsen hier te lande, met het oog op de veiligheid, de gezondheid en het welzijn der werklieden? In hoeverre worden tot verbetering 
van dien toestand maatregelen van overheidswege vereischt" ${ }^{117}$.

De enquête-commissie begon onmiddellijk met haar werkzaamheden en bracht op 27 juli 1887 verslag uit $^{778}$. In haar verslag besteedde zij aandacht aan het toezicht op de naleving van wettelijke bepalingen ${ }^{178}$. In navolging van het door de meeste beschaafde staten gegeven voorbeeld, zou men, aldus de commissie, ook hier te lande tot een geregeld toezicht op de toestand van fabrieken en werkplaatsen met het oog op de veiligheid, de gezondheid en het welzijn van de werknemers door middel van fabrieksinspecteurs dienen te komen. Aan dit staatstoezicht werd, zo vervolgde de commissie, door allen die zich met het onderwerp ernstig bezig gehouden hebben veel waarde gehecht ${ }^{100}$.

De enquête-commissie was echter van oordeel, dat "een leger van ambtenaren" uitsluitend belast met het toezicht op de kinderarbeid, daarbij tot hulp dienend van de politie en met het oog op deze taak gekozen,

"geen voldoende waarborgen opleveren voor een zoodanig welberaden, maar tevens be-

scheiden gebruik van wettelijke bevoegdheden, waardoor zonder gedurige botsingen met

de ingezetenen de naleving der wet verzekerd werd ${ }^{\text {m181 }}$.

De weinig talrijke fabrieksinspecteurs, die de commissie zich voorstelde, zouden echter een geheel ander karakter dragen. $\mathrm{Zij}$ zouden in de eerste plaats met het toezicht op de werklokalen en werktuigen uit het oogpunt van veiligheid en gezondheid moeten worden belast. Technische en praktische ervaring zouden bij hun benoeming op de voorgrond moeten $\operatorname{staan}^{162}$. De enquête-commissie maakte echter geen keuze voor afzonderlijke inspecteurs, zoals zal blijken.

"Het zou de vraag kunnen zijn, of het Staatstoezicht op de fabrieken en werkplaatsen wellicht op doelmatige wijze ware te organiseren door uitbreiding van den werkkring en vermeerdering van het getal der ingenieurs voor het stoomwezen".

Dit zou, aldus de commissie, het voordeel hebben, dat de industriëlen niet voortdurend met een groot aantal categorieën van ambtenaren geconfronteerd zouden worden.

"Doch ook al mocht het verkieslijk geacht worden, voor het Staatstoezicht afzonderlijk ambtenaren aan te stellen, dan nog zou de Commissie meenen dat de fabrieksinspecteurs, om aan de eischen hunner betrekking in allen dele te voldoen, noch politie-beambten, noch geneeskundigen, maar bij voorkeur ervaren ingenieurs zouden behoren te zijn.

... Voor zoover hunne werkzaamheden het gebied der hygiëne mochten raken, zouden zij de medewerking der ambtenaren van het geneeskundig Staatstoezicht kunnen inroepen

De taak van de fabrieksinspecteurs zou, volgens de commissie een driedelige zijn. In de eerste plaats zouden zij zich op de hoogte hebben te houden van de toestand van de werklokalen en de verbeteringen hebben aan te wijzen, die daarin met het oog op de veiligheid, de gezondheid en het welzijn van de werknemers aan te brengen zijn. In de tweede plaats zouden zij de regering hebben voor te lichten over bestaande toestanden op het gebied van de nijverheid en haar te adviseren bij de toepassing van geldende voorschriften en over de verbeteringen in de wetgeving, die zij wenselijk en praktisch uityoerbaar achten. In de derde plaats zouden zij hebben toe te zien op de behoorlijke naleving van de wettelijke bepalingen op het terrein van de industriële arbeid. Hoewel de enquête-commissie geen keuze maakte voor afzonderlijke inspecteurs, kan wel opgemerkt worden, dat haar sterke voorkeur uitging naar technische ambtenaren.

Veegens, die als rapporteur deel uitmaakte van de enquête-commissie was tegen de instelling van aparte inspecteurs ${ }^{184}$. Daarvoor gaf hij een tweetal argumenten. In de eerste plaats waren inspecteurs, hoewel zij in andere landen uitstekende diensten hebben bewezen, over het algemeen hier te lande niet populair. Het ambt als zodanig boezemde de Nederlander weinig ontzag in; het was een trek van ons volkskarakter, aldus Veegens, dat wij de inmenging van openbare ambtenaren in onze zaken niet gemakkelijk verdroegen. In de tweede plaats waren deze ambtenaren belast met het opsporen van strafbare feiten wat voor rechterlijke ambtenaren betekende, dat in enigerlei mate in de kring van bevoegdheden werd ingegrepen. Hij bepleitte dan ook uitbreiding van een al bestaande tak van staatstoezicht, de dienst van het stoomwezen, met dezelfde argumentatie dié in het verslag van de enquêtecommissie te vinden is. Kortom: Veegens koos voor het toe- 
zicht op maatregelen ter bevordering van de velligheid en de gezondheid van de werknemers uitsluittend voor technische ambtenaren, de ingenieurs van het stoomwezen. Met name tegen deze eenzijdige benadering keerde Coronel ${ }^{185}$ zich. Hij achtte het verkeerd om al het gewicht op de technische kant van het toezicht te leggen. Een fabrieksinspecteur moest, om volkomen berekend te zijn op zijn taak, een goed inzicht in de sociale en industriële toestanden hebben. Hij moest, aldus Coronel, zowel met de eisen van de werkgevers als met de behoeften van de werknemers bekend zijn. Hij bepleitte dan ook een toericht door speciaal daarvoor opgeleide of op andere wijze bekwame en verantwoordelijke ambtenaren. Bij de keuze van de ambtenaren diende niet op eenzijdige, maar op veelzijdige bekwaamheden gelet te worden. Men moest zich niet, zo vervolgde hij, uitsluitend bepalen tot een enge kring van personen, die krachtens hun staatsambt met een onderdeel van de fabriek in aanraking kwamen, omdat zij slechts daarvoor opgeleid zijn. Voor zijn pleidooi voor afzonderlijke inspecteurs vond hij onder andere steun bij Mouton ${ }^{\text {186. }}$.

\section{Het tweede ontwerp-Du Tour van Bellinchave}

Het verslag van de enquête-commissie is van grote invloed geweest op de tweede poging van Du Tour van Bellinchave om de Kinderwet-Van Houten te vervangen ${ }^{187}$,

Het nieuwe wetsvoorstel werd op 3 oktober $1887^{188}$ naar de ministerraad gezonden. Daarna is het met enkele kleine wijzigingen op 25 oktober van dat jaar ${ }^{189}$ door Du Tour van Bellinchave naar zijn ambtgenoot van Binnenlandse Zaken Heemskerk gestuurd. Deze laatste was mede-ondertekenaar van het wetsontwerp geworden, omdat niet alleen in het wetsvoorstel het toezicht op de naleving van de bepalingen onder meer was opgedragen aan ambtenaren van het geneeskundig staatstoezicht, maar ook, omdat artikel 82 van de Wet op het lager onderwijs werd ingetrokken.

Nadat de Raad van State advies had uitgebracht ${ }^{100}$, zonden de beide bewindslieden een gemeenschappelijk nader rapport aan de Koning ${ }^{191}$. Van belang is een nota van het hoofd van de Medische Politie Ruysch van 9 december 1887 aan minister Heemskerk. In deze nota verwees Ruysch naar de door hem bijgevoegde brochure. Deze brochure "Hygiëne en Fabrieksarbeid" is ook afgedrukt in Vragen des Tijds ${ }^{192}$.

Ruysch stelde onder meer voor om de ambtenaren van het geneeskundig staatstoezicht in het betreffende artikel als eerste te vermelden. Daarnaast meende hij, dat ook de leden van de geneesikundige raden ${ }^{193}$ met de opsporing van overtredingen zouden moeten worden belast. Verder wilde hij de geheimhoudingsverplichting van de opsporingsambtenaren wit het wetsontwerp geschrapt hebben. Alleen dit laatste van deze voorstellen werd door de bewindsman onderschreven ${ }^{104}$. Du Tour van Bellinchave nam het voorstel echter niet over ${ }^{405}$.

Op 18 december 1887 werd het tweede ontwerp-Du Tour van Bellinchave de Tweede Kamer toegezon$\operatorname{den}^{198}$. Artikel 11 van het wetsvoorstel ${ }^{197}$ voorzag in het toezicht op de naleving van de wettelijke bepalingen. Naast de in artikel 8 van het Wetboek van Strafvordering ${ }^{188}$ aangewezen personen, waren behalve de marechaussée alle ambtenaren van rijks- en gemeentepolitie en de ambtenaren van het geneeskundig staatstoezicht, met de opsporing van overtredingen van de wet belast. De keuze woor ambtenaren van het geneeskundig staatstoezicht werd in de toelichting ${ }^{199}$ verdedigd met een verwijzing naar een eventuele algemene maatregel van bestuur op grond van artikel $4^{200}$. Deze keus is wel opmerkelijk, gezien de sterke voorkeur van de enquête-commissie voor technische ambtenaren. De bij artikel 11 genoemde ambtenaren hebben, ingevolge het daaropvolgende artikel, te allen tijde toegang tot fabrieken, trafieken, werkplaatsen, vaartuigen en landerijen. Bij weigering van toegang konden zij zich die verschaffen, desnoods met behulp van de sterke arm. Fabrieken, trafieken, werkplaatsen of vaartuigen, tevens woningen zijnde, en fabrieken, trafieken, werkplaatsen of landerijen, die alleen door een woning toegankelijk waren, konden door deze ambtenaren niet tegen de wil van de bewoner betreden worden, tenzij in het bezitvan een schriftelijke last van de burgemeester of de kantonrechter. Van dit binnentreden moest door hen proces-verbaal opgemaakt worden en binnen twee maal vierentwintig uur in afschrift aan degene wiens woning is binnengetreden medegedeeld 
worden.

Corresponderend met deze bevoegdheid werd aan de betreffende ambtenaren een geheimhoudingsplicht opgelegd omtrent hetgeen hun door het binnentreden van fabrieken, trafieken, werkplaatsen, vaartuigen, landerijen en woningen over het daar uitgeoefende bedrijf bekend was geworden. Een en ander voor zover dit niet strijdig was met de bepalingen van deze wet.

Opzettelijke schending van deze geheimhoudingsplicht werd bestraft met een gevangenisstraf van maximaal zes maanden of een geldboete van ten hoogste zeshonderd gulden, met of zonder ontzetting van het recht om ambten te bekleden. Vervolging vond alleen plaats op klacht van het hoofd of de bestuurder van het bedrijf of de onderneming. De toelichting verwees naar de corresponderende artikelen van het vorige wetsvoorstel en de toelichting daarop. Wel werd nu opgemerkt, dat, naar aanleiding van het voorlopige verslag van hetzelfde eerdere wetsvoorstel, tevens het woord "trafieken" was opgenomen. Het begrip "vaartuigen" was ingevoerd, aldus de toelichting, om alle twijfel weg te nemen of vaartuigen onder het begrip "werkplaatsen" vielen $^{20 \%}$. Het wetsvoorstel bevatte geen controlemiddelen meer.

Afrondend kan geconcludeerd worden, dat wat betreft het toezicht en de daarmee samenhangende bepalingen tussen dit wetsvoorstel en het eerste ontwerp-Du Tour van Bellinchave, op het aanwijzen van de ambtenaren van het geneeskundig staatstoezicht na, nauwelijks een verschil te zien geeft.

Dit tweede ontwerp van Du Tour van Bellinchave is door de Tweede Kamer niet meer in behandeling genomen, als gevolg van het ontbinden van de Kamer in maart 1888 naar aanleiding van de grondwetsherzie$\operatorname{ning}^{202}$.

\section{De Arbeidswet 1889}

\section{Opvolger van Du Tour van Bellinchave werd, volgens Goeman Borgesius ${ }^{20 s}$}

"een der meest ijverige leden der Enquêtecommissie",

Ruys van Beerenbroek. Na de drie mishukte pogingen van zijn voorgangers tot verbetering van de KinderwetVan Houten achtte hij het zijn plicht

"deze zaak zoo mogelijk spoedig tot een goed einde te brengen"

en de conclusies van de enquête-commissie in wetsbepalingen om te zetten ${ }^{204}$. De nieuwe minister van Justitie ging voortvarend te werk. Al op 5 september $1888^{200}$ werd een

"ontwerp van wet, houdende bepalingen tot het tegengaan van overmatigen arbeid van jeug-

dige personen en vrouwen"

bij de Raad van State aanhangig gemaakt. Op 25 september van dat jaar bracht de Raad van State advies uit ${ }^{206}$. Uit het advies wordt duidelijk, dat het toezicht op de naleving van de wettelijke bepalingen onder meer was opgedragen aan ambtenaren van het geneeskundig staatstoezicht. De eerste opmerking van de Raad van State in zijn advies betrof het gemis van de medewerking van de bewindsman van Binnenlandse Zaken tot de wetswoordracht, terwijl toch de ambtenaren van het geneeskundig staatstoezicht genoemd werden onder de opsporingsambtenaren. Ruys van Beerenbroek vond dit echter onvoldoende aanleiding om medewerking van zijn ambtgenoot in te roepen ${ }^{207}$. De minister vervolgde met op te merken, dat de genoemde ambtenaren op grond van artikel 5 van de Wet van 1 juni 1865 , waarin het geneeskundig staatstoezicht was geregeld, al de bevoegdheid hadden om alle fabrieken en werkplaatsen binnen te treden ${ }^{208}$ en dat dit voorstel hen dus niet een nieuwe verplichting oplegde, maar uitdrukkelijk alleen een recht toekende om overtredingen te constateren, die zij bij de vervulling van hun gewone ambtstaak mochten ontdekken. Niet zonder grond zou zelfs kunnen worden beweerd, aldus Ruys van Beerenbroek, dat zij ook zonder de bepaling van artikel 13 van deze wetswoorstel die bevoegdheid bezaten ingevolge artikel 6 van de eerder genoemde wet $^{200}$; tenminste als een wet tegen overmatige arbeid van jeugdige personen en van vrouwen geacht kan worden te zijn vastgesteld ter bevordering van de volksgezondheid.

Op 29 oktober 1888 werd het wetswoorstel bij de Tweede Kamer aanhangig gemaakt ${ }^{210}$. 
Artikel 13 van het wetsvoorstel ${ }^{211}$ bepaalde, dat met het opsporen van de overtredingen wan de wet en de op grond hiervan uitgevaardigde algemene maatregelen van bestuur, behalve de bij artikel 8 van het Wetboek van Strafvordering aangewezen personen, belast zijn, de marechaussee, alle ambtenaren van rijks-en gemeentepolitie en de ambtenaren van het geneeskundig saatstoezicht. Ook Ruys van Beerenbroek maakte niet de principiele keuze voor een toezicht door afzonderlijke inspecteurs; zijn keuze kwam overeen met die van Du Tour van Bellinchave in diens tweede wetsvoorstel ${ }^{212}$. Het opnemen van ambtenaren van het geneeskundig staatstoezicht verdedigde deze bewindsman met hetzelfde argument als zijn voorganger.

"Zolang geen speciaal toezicht op den arbeid van jeugdige lieden en vrouwen of op den arbeid in het algemeen bestaat - tot het in het leven roepen waarvan de ondergetekende het oogenblik nog niet gekomen acht - kan het nuttig zijn ook de hygiënisten met het toezicht op de handhaving van de wet te belasten, vooral met het oog op de voorwaarden, te stellen bij de algemeene maatregelen van bestuur, bedoeld in de artikelen 3 en 4 . De ambtenaren wan het geneeskundig Staatstoezicht schijnen daartoe als vanzelf aangewezen", aldus de toelichting ${ }^{213}$.

Ook dit wetsvoorstel gaf aan de bedoelde ambtenaren te allen tijde toegang tot alle fabrieken, werkplaatsen en vaartuigen. Bij weigering hiervan konden zij zich die desnoods met het inroepen van de sterke arm verschaffen. In fabrieken, werkplaatsen of vaartuigen, tevens woningen zijnde, en in fabrieken of werkplaatsen, alleen door een woning toegankelijk, konden zij, blijkens artikel 14, tegen de wil van de bewoner niet binnenkomen dan met een schriftelijke last van de burgemeester of van de kantonrechter. Van dit binnentreden moest door hen proces-verbaal worden opgemaakt en binnen twee maal vierentwintig uur aan degene, wiens woning was binnengetreden, in afschrift worden medegedeeld. Ook dit wetsartikel was nagenoeg een copie van het betreffende artikel in het tweede ontwerp-Du Tour van Bellinchave. Hetzelfde kan gezegd worden van het artikel, dat verplicht tot geheimhouding. De bedoelde ambtenaren waren op grond van artikel 15 verplicht tot geheimhouding van hetgeen hun in fabrieken, werkplaatsen, vaartuigen en woningen omtrent het aldaar uitgeoefend bedrijf bekend was geworden voor zover dit niet in strijd was met de bepalingen van deze wet. Opzettelijke schending, waarvan vervolging alleen plaats kon vinden op klacht van het hoofd of de bestuurder van het betreffende bedrijf of de betreffende onderneming, werd gestraft met een gevangenisstraf van maximaal zes maanden of een geldboete van ten hoogste zeshonderd gulden, all dan niet gepaard gaand met ontzegging van het recht om ambten te bekleden.

Wel nieuw ten opzichte van haar voorgangster waren de in dit wetsvoorstel neergelegde controlemiddelen. Zo was hij, die een persoon beneden de achttien jaar arbeid deed verrichten, ingevolge artikel 10 , verplicht een, door de burgemeester van de gemeente, waarin de jeugdige persoon arbeid verrichtte, afgegeven kaart te hebben, waarin de naam, de voornamen, de geboortedag en -plaats van deze persoon, de naam en woonplaats van het hoofd van het gezin waarbij of van het gesticht waarin deze persoon woonde en van hem, die de arbeid deed verrichten; vermeld moesten zijn. De werkgever was verplicht deze kaart op verzoek aan de opsporingsambtenaren te laten zien. Deze "arbeidskaart"14 beoogde, blijkens de toelichtimg, een tweeledlig doel. Ten eerste, dat de opsporingsambtenaren op de plaats zelf konden nagaan of een kind dat daar werkend werd aangetroffen de gevorderde leeftijd had bereikt en wie in geval van overtreding strafrechtelijk aansprakelijk was. In de tweede plaats werd het toezicht op de naleving sterk vergemakkelijkt als de opsporingsambtenaren vooraf konden weten of, en zo ja, waar een zeker kind werkte ${ }^{215}$. Overigens wäs de werkgever verplicht deze kaart bij ontslag van de betreffende jeugdige persoon terug te brengen bij de burgemeester die de kaart had afgegeven. Naast de "arbeidskaart" is degene die én of meer personen beneden de achttien jaar of vrouwen in fabrieken of werkplaatsen arbeid deed verrichten, op grond van artikel 11 , verplicht er voor te zorgen, dat op de plaats waar arbeid werd verricht, steeds op zichtbare wijze, een door hem ondertekende lijst met de namen en voornamen van die personen of vrouwen en het begin en het einde van de in de wet voorgeschreven rusttijden, woor elk afzonderlijk vermeld, is opgehangen. Met andere woorden: een "arbeidslijst"1218. De bedoeling was, blijkens de toelichting ${ }^{217}$, om de opsporingsambtenaren de mogelijkheid te geven "met een oogopslag" na te gaan of op een zeker tijdstip een schaftuur was aangevangen en of de jongelieden en vrouwen wel de hun bij wet toegekende rusttijd genoten. 
Uit het voorlopig verslag blijkt $\mathrm{kt}^{218}$, dat men zich in de Tweede kamer, evenals het geval was geweest bij de Raad van State, afvroeg waarom dit wetsvoorstel alleen was uitgegaan van het ministerie van Justitie.

"Was er wegens de taak daarbij: aan ambtenaren van het geneeskundig Staatstoezicht opge-

legd reeds aanleiding om te verwachten, dat de medewerking van de Minister van Binnenlandsche Zaken zou zijn gevraagd, die van den Minister van Waterstaat, Handel en Nijverheid kan in elk geval hier moeilijk gemist worden. Immers deze Minister heeft krachtens zijn ambt te waken, dat de belangen der industrie bij deze wettelijke regeling behoorlijk worden in het oog gehouden."

Sommige Kamerleden gingen zover, dat zij meenden, dat de voordracht in de eerste plaats van het ministerie van Waterstaat, Handel en Nijverheid had behoren uit te gaan. Dit, omdat het hier geenszins een strafrechtelijke regeling betrof, maar veeleer een met betrekking tot de uitoefening wan bedrijven, waarbij het ministerie van Justitie alleen maar vanwege de daaraan gekoppelde strafbepalingen betrokken was. De bewindsman antwoordde ten aanzien van de medewerking van zijn ambtgenoot van Binnenlandse Zaken overeenkomstig hetgeen geschreven was in het nader rapport naar aanleiding van het advies van de Raad van State. Ten aanzien van zijn ambtgenoot van Waterstaat, Handel en Nijverheid antwoordde hij, dat deze ook bij de drie aan dit wetsvoorstel voorafgaande voorstellen geen medewerking had verleend en er voor de regeling geen aanleiding bestond om het nu aanhangig wetsontwerp in de eerste plaats bij diens ministerie onder te brengen. Hij beriep zich daarbij op het feit, dat verschillende andere delen van de "zogenaamde sociale wetgeving" juist tot de werkkring van zijn ministerie worden gerekend en daar waren of werden voorbereid. Bovendien verwees hij naar hetgeen de Kamer zelf in het voorlopig verslag ${ }^{218}$ stelde,

"dat andere wettelijke maatregelen betreffende de arbeid van den Minister van Justitie te verwachten zijin"

en men in plaats van te verklaren, dat deze niet tot zijn werkkring behoorden juist vroeg om een uiteenzetting van de beginselen waarvan hij dacht uit te gaan ${ }^{220}$.

Bleek uit het voorlopig verslag naar aanleiding van het ontwerp-Modderman mog, dat de Kamer zich niet verzette tegen het beschermen van kinderen tegen vroegtijdige en overmatige arbeid, maar dat een uitbreiding van de staatszorg niet te rechtvaardigen was ${ }^{221}$, het voorlopig verslag van het onderhavige wetsvoorstel laat een kentering in de opvattingen zien. Men achtte de vraag gewettigd of, nu dit wetswoorstel bepalingen tegen misbruik van de arbeidskracht van vrouwen bevatte, niet ook bepalingen gemaakt zouden moeten worden omtrent het gebruik van de arbeidskracht van volwassen mannem. Daar gaf men zelf het volgende antwoord op:

"Overigens werd betwist, dat de arbeid van vrouwen met den arbeid van volwassen mannen gelijk is te stellen. De rechtstoestand van beiden is niet dezelfde, en uit de omstandigheid, dat de wetgever termen vindt om de vrouw tegen exploitatie te beschermen, volgt nog geenszins dat het evenzeer nodig of nuttig zou zijn bepalingen te maken omtrent het gebruik der arbeidskracht van volwassen mannen."

Dientengevolge had de bewindsman zich beperkt tot maatregelen, waarvan de wenselijkheid thans reeds vaststond, en die inderdaad zouden blijken over het algemeen voor de nijverheid weinig bezwaar op te leveren. Sommige Kamerleden hadden liever gehad, dat de minister "onomwonden had verklaard, dat de bepalingen omtrent den arbeid van vrouwen ten doel hebben het familieleven en de huiselijke belangen te bevorderen" ${ }^{\text {"zaza }}$.

De minister van Justitie kwam aan dit verlangen tegemoet en maakte deze zinsnede in zijn antwoord tot de zijune $^{223}$.

Het standpunt over de rol van de staat in deze, dat door de Kamer werd ingenomen, komt erop neer, dat de staat niet met wettelijke bepalingen moest komen, zodra, zich op maatschappelijk gebied "verkeerdheden" vertoonden. In elk bijzonder geval moest onderzocht worden of staatsinmenging wel nodig en wenselijk is. Daartoe zou alleen dan overgegaan moeten worden, indien niet alleen bewezen was, dat er misbruiken bestonden, die door particuliere krachten alleen miet gekeerd konden worden, maar tevens, dat door het staatsingrijpen het bestaande kwaad kon worden weggenomen of verminderd, en dat dit ingrijpen geen ander, mis- 
schien groter kwaad teweeg zou brengen ${ }^{224}$.

Terugkerend naar de inhoud van het wetsvoorstel zelf gaan we nu na wat men in de Tweede Kamer vond van het door de minister voorgestelde toezicht. In het voorlopig verslag werd opgemerkt, dat de minister in zijn toelichting schreef, dat hij het moment nog niet gekomen achtte om een speciaal toezicht op de arbeid van jongelieden en vrouwen of op de arbeid in het algemeen in het leven te roepen,

"maar hij verzwijgt, op welke grond deze mening berust".

Vele leden zouden daaromtrent graag nader geïnformeerd worden en verklaarden zich voorshands met

"s Ministers gevoelen niet te kunnen verenigen".

Wel verklaarde men zich te keren tegen het aanstellen van een zo vitgebreid korps ambtenaren als in het ontwerp-Modderman was voorgesteld, maar de bezwaren die daar tegen in het voorlopig verslag waren geuit, konden niet gelden voor het voorstel, dat in het verslag van de enquête-commissie was neergelegd. De daar bedoelde inspecteurs zouden zich op de hoogte hebben te houden van de bestaande toestanden op het gebied van de njjverheid. Zij zouden belast moeten worden met het uitbrengen van advies aan de regering omtrent de toepassing en ook omtrent de verbetering van de wettelijke bepalingen betreffende de industriële arbeid. Er werd op gewezen, dat het advies van dergelijke ambtenaren woor de regering nuttig kon zijn voor de vaststelling van de in het voorstel bedoelde algemene maatregelen van bestuur. Daarnaast vroeg men zich af tot wie de regering bij het ontbreken van inspecteurs zou wenden om de hiervoor benodigde informatie te krijgen.

"Zou zij zich daartoe wenden tot de ingenieurs, die thans met eene opneming van fabrieken en werkplaatsen zijn belast?".

Naast deze taak zouden de inspecteurs het oppertoezicht hebben te houden op de uitvoering van de wettelijke bepalingen op de industriële arbeid. Het constateren van overtredingen moest echter opgedragen blijven an de politie;

"de inspecteurs zouden alleen hebben te zorgen voor werkdadige en gelijkmatige toepassing en voor het verkrijgen van rechterlijke uitspraken in hoogste ressort omtrent de uitlegging der wettelijke bepalingen".

Om deze werkzaamheden te kunnen vervallen zou het aanstellen van twee of drie inspecteurs voldoende zijn, waardoor de maatregel ook niet al te grote kosten met zich zou brengen. Bij de keuze van de inspecteurs wenste men, dat vooral op praktische aanleg en bekendheid met de industrie gellet werd. Er moest voor gezorgd worden, dat de inspecteurs niet door de industriëlen gewantrouwd werden. Dat dit mogelijk was, blijkt uit de ervaringen ten aanzien van de al eerder genoemde ingenieurs, die door hun taktwol optreden door de fabrikanten overal met de "meeste bereidwilligheid" worden voorgelicht. Bij sommige Kamerleden bestond geen bezwaar om onder de drie inspecteurs én inspecteur op te nemen, die als geneeskundige meer bijzonder de hygiëne op de fabrieken tot zijn werkterrein zou nemen. Vrij algemeen werd de mening verkondigd, dat de betrokken bewindsman een belangrijke verbetering in het wetswoorstel zou aanbrengen als hij de aanstelling van drie inspecteurs mogelijk maakte. Zonder een dergelijke voorziening kon de toepassing van de wet immers niet anders dan gebrekkig zijn. De minister antwoordde daarop, dat

"voor de instelling ..... van een blijvend toezicht thans geen bezwaar meer (schijnt) te bestaan, te minder omdat de nijverheid zelve algemeen daarop prijs lijkt te stellen, getuige de vele adressen in dien geest bij de Kamer en de Regeering ingekomen ...."225 "

Met het oog hierop diende Ruys van Beerenbroek bij zijn memorie van antwoord een nota van wijzigingen in. Hierin werd het betreffende artikel aangevuld met de zinsnede:

", alsmede ten hoogste drie door Ons te benoemen inspecteurs wier werkkring en verdere

bevoegdheden door Ons van Onzentwege worden geregeld"2e日.

Hij gaf te kennen, dat door het opnemen van speciale inspecteurs er minder bezwaren waren om ook de ambtenaren van het geneeskundig staatstoezicht te vermelden,

"wier werkkring inderdaad niet onnut is te achten ook maast de werkzaamheid der bijzondere inspecteurs" 
Gezien het feit, dat deze ambtenaren toch al toegang hadden tot alle fabrieken en werkplaatsen achtte hij het verkeerd, indien de wetgever daarmee niet zijn voordeel zou doen door hen, voor zover nog nodig, de bevoegdheid te geven overtredingen te kunnen constateren. Door de aanstelling van speciale inspecteurs meende Ruys van Beerenbroek, dat het opnemen van de ingenieurs van het stoomwezen in het artikel niet nodig was $^{227}$. Deze handreiking was voor de commissie van rapporteurs aanleiding on bij haar eindverslag $^{20}$ bij] amendement voor te stellen het toezicht van de inspecteurs in een afzonderlijk artikel te regelen. Zo stelde zij voor een nieuw artikel $12 \mathrm{a}$ in te voegen, waarbij het toezicht op de uitvoering en de naleving van de wet werd uitgeoefend door ten hoogste drie door de Kroon te benoemen inspecteurs waarvan de werkkring en de bevoegdheden bij algemene maatregel van bestuur werden geregeld. In artikel 14 diende de door de bewindsman aangebrachte aanvulling te worden geschrapt, omdat de commissie van rapporteurs van mening was, dat de inspecteurs onder de werking van artikel 8 , onder $7 \mathrm{e}$, van het Wetboek van Strafvordering vielen ${ }^{22 a}$.

Tijdens de mondelinge beraadslaging werd op 21 maart door Fabius, Kolkman, Farncombe Sanders en Veegens bij amendement voorgesteld om een nienwe paragraaf onder de kop "Toezicht" in het wetsontwerp op te nemen, waarin een nieuw artikel $12 \mathrm{a}$ bepaalt, dat onder de bevelen van de minister, die belast was met de uitvoering van de wet, het toezicht op de uitwoering van die wet werd opgedragen aan door de Kroon te benoemen inspecteurs waarvan de werkkring en de bevoegdheden bij algemene maatregel van bestuur werden geregeld ${ }^{230}$. Dit amendement werd door Ruys van Beerenbroek bij nota van wijziging op 8 april 1889 overgenomen ${ }^{231}$. Op 10 april stelde Schaepman tijdens de beraadslaging voor om de woorden "ten hoogste drie", zoals voorgesteld door de commissie van rapporteurs weer in het betreffende artikel op te nemen $^{232}$. Zowel Farncombe Sanders als Ruys van Beerenbroek verzetten zich hiertegen. De laatstgenoemde voerde aan, dat het in de toekomst wel eens nodig zou kunnen zijn om meer dan drie inspecteurs aan te stellen, omdat hun werkkring te uitgebreid, te omvangrijk zou blijken. Maar door hun aantal wettelijk vast te leggen was daarvoor een wetswijziging noodzakelijk $\mathrm{k}^{233}$. Het verzet en de daarbij aangewoerde argumenten mochten echter niet baten. De door Schaepman voorgestelde wijziging werd aangenomen ${ }^{234}$.

Daarnaast stelden Fabius en zijn mede-indieners van het amendement voor in deze nieuwe paragraaf op te nemen de verplichting voor de hoofden of bestuurders van fabrieken en werkplaatsen en de daarin werkzame personen aan de bevoegde inspecteur, die met het toezicht op de uitvoering van de wet belast was, de door hem verlangde inlichtingen te geven over zaken en feiten die de naleving van de wet betroffen. Ook dit voorstel werd door de minister overgenomen, zij het onder schrapping van de tussenzin

"met bet toezicht op de uitwoering der wet belast".

Dit, omdat onder bevoegde inspecteurs in deze paragraaf alleen maar begrepen konden worden de op grond van de wet in te stellen inspecteurs. Bevoegd was die inspecteur in wiens ressort het bedrijf of de onderneming lag $^{\text {ats }}$.

Verder hadden Fabius en de mede-indieners in hun amendement opgenomen het verbod van de inspecteurs om middellijk of onmiddellijk deel te nemen aan bedrijven of ondernemingen van fabrieks- of ambachtsnijverheid: Ook dit voorstel maakte de minister tot het zijne. Over de omvang van het verbod stelde Van Alphen tijdens de mondelinge beraadslaging de vraag of het artikel beoogde de fabrieksinspecteurs ook uit te sluiten van het recht om aandeelhouder te zijn in naamloze vennootschappen, die de uitoefening van bedrijven of ondernemingen van fabrieks- of ambachtsnijverheid ten doel hebben. De minister antwoordde daar bevestigend $\mathrm{op}^{23 \mathrm{a}}$.

In het woorlopig verslag werd er overigens door de Eerste Kamer op gewezen dat het verbod zo ruim gesteld was, dat ook de deelneming aan buitenlandse nijverheidsondernemingen ongeoorlloofd was ${ }^{237}$. Het verbod was zo algemeen gesteld, aldus het antwoord van de minister, omdat buitenlandse ondernemingen soms ten nauwste verwant zijn met binnenlandse, bijvoorbeeld door de levering van grondstoffen en dergelijke betrekkingen $^{230}$.

Bovendien legde het voorstell van Fabius en zijn mede-indieners aan het hoofd of de bestuurder van een bedrijf of een onderneming, die in een fabriek of werkplaats arbeid deed verrichten, de verplichting op elk aan een in dat bedrijf of die onderneming werkzame personen overkomen ongeluk binnen vierentwintig uur ter 
kennis te brengen van de burgemeester van de gemeente waar het ongeluk had plaatsgevonden. De burgemeester deelde deze kennisgeving weer binnen vierentwintig uur mee aan de bevoegde inspecteur. De burgemeester stelde een onderzoek in naar de oorzaken en de gevolgen van het ongeval en deelde de uitslag daarvan mee aan de bevoegde inspecteur. Deze laatste kon, als hem dat nodig leek, een nader onderzoek instellen. Ook met dit voorstel had de minister geen problemen; het werd bij de al eerder genoemde nota van wijzigingen overgenomen. Tijdens de mondelinge beraadslaging werd het artikel uitwoerig behandeld en werden diverse wijzigingsvoorstellen ingediend; echter zonder gevolgen ${ }^{239}$.

Het laatste artikel in de paragraaf "Toezicht" verplichte de inspecteurs om jaarlijks een

"beredeneerd verslag over hunnen ambtsbezigheden"

op te stellen en deze vó́r 1 mei aan de betrokken minister te zenden. Deze verslagen dienden hetzij geheel, hetzij gedeeltelijk aan de Staten-Generaal overgelegd te worden. Deze bepaling was ingevoegd naar aanleiding van een amendement van Bahlmann ${ }^{240}$. De minister verzette zich niet tegen het amendement, maar vond, dat een dergelijke bepaling in de instructie van de inspecteurs thuis hoorde en niet in de wet ${ }^{34}$. De kracht van de bepaling was, aldus de indiener van het amendement, gelegen in het feit, dat de verslagen geheel of gedeeltelijk juist aan de Staten-Generaal moesten worden overgelegd en dat deze verslagen de bouwstoffen zouden leveren voor de latere uitbreiding van de sociale wetgeving ${ }^{242}$.

Nu het toezicht op de uitwoering van de wet in een afzonderlijke paragraaf aan fabrieksinspecteurs was opgedragen, rest nog de vraag hoe nu de opsporingsbevoegdheid geregeld was. In het betreffende artikel werden naast de fabrieksinspecteurs nog steeds de ambtenaren van het geneeskundig staatstoezicht vermeld. Teneinde de laatsten alsnog te schrappen, dienden Van Kempen, Bahlman en Secret een amendement in $^{243}$, dat ondanks de opmerkingen van de minister werd aangenomen ${ }^{244}$. Het betreffende artikel zou echter nog een wijziging ondergaan. Reuther en Rooseboom stelden voor aan het artikel twee nieuwe leden toe te voegen ${ }^{245}$. Met het opsporen van overtredingen van de wet ten aanzien van inrichtingen, als bedoeld in artikel 24 van de Wet van 2 juni 1875 tot regeling van het toezicht bij het oprichten van inrichtingen die gevaar, schade of hinder kunnen veroorzaken ${ }^{246}$, waren uitsluitend de door de Kroon benoemde inspecteurs en de door de minister van Oorlog, op grond van het tweede lid van genoemd artikel 24, aangewezen ambtenaren en officieren belast. Dit voorstel richtte zich voornamelijk op de buskruitfabriek "De Krijgsman" te Muiden. De indieners van het amendement meenden, dat het aan alle genoemde opsporingsambtenaren verlenen van de bevoegdheid, zij het met een schriftelijke bijzondere last van de burgemeester of van de kantonrechter, om de fabriek binmen te treden, ongewenst was. Door de aard van het bedrijf en de inrichting van de verschillende lokaliteiten waar gewerkt wordt, is het van groot belang voor de veiligheid en het voorkomen van ongelukken, dat geen personen werden toegelaten die niet dringend nodig zijn en dat het toezicht werd uitgeoefend door deskundigen. Voorts werd op de werkzaamheden in de fabriek toezicht gehouden door ambtenaren die daartoe door de minister van Oorlog waren aangewezen. Het voorgestelde amendement zorgde op voldoende wijze voor een strenge naleving van de wet. Wat betreft het opsporen van overtredingen van de wettelijke bepalingen in rijkswerkplaatsen en -fabrieken werd voorgesteld de regeling van het toezicht over te laten aan de ministers van de betrokken ministeries. Het bestuur van dergelijke inrichtingen was opgedragen aan hoofden, in de regel hooggeplaatste officieren, die verantwoording verschuldigd waren aan de minister. Men kon bijvoorbeeld, aldus de indieners van het amendement, aan marechaussées niet opdragen na te gaan of deze officieren in hun plicht te kort schoten. Bovendien was er geen reden om aan te nemen, dat aldaar in strijd met deze wet zou worden gehandeld, omdat deze hoofden en andere besturende ambtenaren hoegenaamd geen belang hadden bij het in strijd met de wet toelaten van hetzij vrouwen, hetzij jeugdige personen. Tijdens de mondelinge beraadslaging stelde Ruys van Beerenbroek, dat, nadat hem sommige bezwaren medegedeeld waren, hij al bezig was met een wijzigingsvoorstel om aan deze bezwaren tegemoet te komen. De indieners van het amendement waren hem echter voor geweest, zodat een voorstel van regeringszijde overbodig was geworden. Hij verklaarde het amendement onveranderd over te nemen ${ }^{247}$.

Omtrent de aan de opsporingsambtenaren verleende bevoegdheid tot het te allen tijde toegang hebben tot 
alle fabrieken, werkplaatsen en vaartuigen kan opgemerkt worden, dat de betreffende bepaling tijdens de parlementaire behandeling ingrijpend gewijzigd werd.

Een van deze wijzigingen had betrekking op het gegeven dat toegang nu mogelijk was tot alle plaatsen waar arbeid werd verricht of pleegde te worden verricht. Dit hing onder meer samen met de omschrijving van het begrip "fabrieken of werkplaatsen" in het nieuwe artikel 2. Een andere wijziging betrof het aantal personen dat van deze bevoegdheid gebruik kon maken ${ }^{248}$, lagere opsporingsambtenaren ${ }^{249}$ konden dit nog slechts als zij in het bezit waren van een bijzondere schriftelijke last van de burgemeester of van de kantonrechter. Dezelfde voorwaarde werd bij wijziging vereist voor alle opsporingsambtenaren voor het betreden van plaatsen waar arbeid wordt verricht of pleegt te worden verricht die tevens woningen zijn of alleen via een woning toegankelijk zijn. Ongewijzigd bleef het voorschrift dat van dit laatste een proces-verbaal moest worden opgemaakt en binnen twee maal vierentwintig uren aan degene wiens woning was betreden in afschrift medegedeeld diende te worden.

Naar aanleiding van de aan de opsporingsambtenaren opgelegde verplichting tot geheimhouding werd in het voorlopig verslag ${ }^{250}$ door sommige Kamerleden onder meer de vraag opgeworpen of het gehele artikel of althans de laatste twee artikelleden niet behoorden te vervallen. Dit, omdat het Wetboek van Strafrecht al een strafbepaling tegen de schending van ambtsgeheimen bevat ${ }^{251}$. Handhaving van de geheimhoudingsplicht in dit artikel kon dan ook alleen maar nuttig zijn om buiten twijfel te stellen, dat de hier bedoelde ambtenaren krachtens hun ambt geheimhouding verplicht waren. De minister reageerde ${ }^{252}$ daarop met de oprnerking, dat de betreffende bepaling van het Wetboek van Strafrecht niet van toepassing kan zijn, omdat in dit geval geen sprake was van een geheim, dat men uit hoofde van zijn ambt verplicht was te bewaren. Toch zou tijdens de parlementaire behandeling nog een wijziging in het artikel aangebracht worden; niet alleen bet opzettelijk schending, maar ook het door onvoorzichtigheid of achteloosheid schenden van de geheimhoudingsplicht leverde een strafbaar feit op ${ }^{253}$.

Ook de artikelen die de controlemiddelen regelen, zouden niet ongeschonden uit de parlementaire behandeling te voorschijn komen en de nodige, meer ondergeschikte, wijzigingen ondergaan ${ }^{254}$.

Op 12 april 1889 werd thet wetsontwerp in de Tweede Kamer aangenomen ${ }^{255}$, met als enige tegenstemmer Ferdinand Domela Nieuwenhuis, het eerste socialistische Kamerlid, die zijn rede op 19 maart 1889 aldus afsloot ${ }^{28 s}$;

"dat voor ons de aanneming of de verwerping van dit ontwerp mij wel onverschillig is, want als het wordt verworpen hebben wij niets, en als het wordt aangenomen hebben wij eigenlijk precies evenveel... en daarom kan het ontwerp moeilijk juister en billijker worden gekarakteriseerd dan door de woorden van een mijner vrienden op de laatst gehouden meeting alhier: "Het is eene buiteling der kapitalisten ten gevolge van een schop, hun door de socialisten toegediend"."

Op 3 mei van dat jaar zou het ontwerp met algemene stemmen worden aangenomen ${ }^{207}$. Twee dagen later was de Arbeidswet 1889 een feit ${ }^{259}$ en had Nederland zijn drie fabrieksinspecteurs, zijn arbeidsinspectie.

\section{De redenen die ten grondslag lagen aan het instellen van een afzonderlijke arbeidsinspectie}

Op grond van de bevindingen wil ik dit hoofdstuk afsluiten met een beschouwing waarbij antwoord wordt gegeven op de in het inleidende hoofdstuk geformuleerde vraag naar de redenen die ten grondslag lagen aan het instellen van een afzonderlijke arbeidsinspectie.

Ondanks veelvuldig aandringen op speciaal te benoemen ambtenaren door onder andere De Vries-Robbé in zijn uit 1860 daterende rapport, het Comite ter bespreking der Sociale Quaestie, het Algemeen Nederlandsch Werklieden Verbond, beide in 1874, en diverse auteurs, waaronder Coronel, kwamen in het in 1874 
op initiatief van het Tweede Kamerlid Van Houten tot stand gekomen Kinderwetje hieromtrent geen bepalingen voor, alhoewel vanuit de parlement op het gemis hiervan was gewezen. De problematiek rond de controle had Van Houten opzettelijk ter beoordeling aan de regering overgelaten. Het wetje bevatte louter verbodsbepalingen; de opsporing van overtreding was opgedragen aan

"alle gewone beambten van politie".

De praktische betekenis van het wetje was gering, onder meer door het ontbreken van een afzonderlijke inspectie en van bevoegdheden, als onder meer het betreden van bepaalde plaatsen tegen de wil van de betrokkene.

In de daarop volgende jaren bleef de discussie omtrent de vraag door wie er nu gecontroleerd moest worden onverkort doorgaan. Bij deze discussie zijn in grote lijnen de volgende mogelijkheden te onderscheiden:

- controle door de gewone politieambtenaren,

- controle door ambtenaren, die reeds belast waren met het toezicht op de naleving wan én of meer andere wetten, zoals bijvoorbeeld de ingenieurs van het stoomwezen en de inspecteurs van het geneeskundig staatstoezicht;

- controle door speciaal daartoe te benoemen ambtenaren, een afzonderlijke arbeidsinspectie.

Voor de beantwoording van de vraag, waarom in ons land een afzonderlijke arbeidsinspectie is ingesteld, richten wij ons voornamelijk op de redenen, die door de voorstanders gegeven werden.

Nog tijdens de parlementaire behandeling van de Kinderwet-Van Houten stelde het Tweede Kamerlid Bredius, dat het niet raadzaam zou zijn, het toezicht te laten uitoefenen door gemeentebesturen, waarvan soms personen deel uitmaakten, die een (industrieel) belang hadden bij het voortduren van de kinderarbeid. Van een afzonderlijke inspectie kon stelselmatiger, nauwkeuriger en onpartijdig toezicht verwacht worden. Het Tweede Kamerlid De Bruyn Kops voerde bij dezelfde gelegenheid aan, dat een gecentraliseerd toezicht het grote voordeel had van het kunnen maken van vergelijking omtrent de omstandigheden en de gevolgen van de uit te vaardigen wettelijke regeling(en) in de verschillende delen van het land. Op deze wijze werd informatie verkregen, die de basis zou kunnen vormen van nieuwe door de regering uit te vaardigen regelingen. Uit de antwoorden naar aanleiding van de door de toenmalige bewindsman Van Lynden van Sandenburgh gehouden enquête in 1877 werden door de voorstanders van een afzonderlijke arbeidsinspectie de volgende argumenten gegeven: door andere organen werd de controle-taak niet goed uitgevoerd of kon deze niet goed worden uitgevoerd (Kamer van Koophandel en Fabrieken van Tilburg en de Friesche Maatschappij van Landbouw); het bevorderen van een meer uniforme toepassing van de wet (Kamer van Koophandel en Fabrieken van Amersfoort en van Leeuwarden); de rapporten van de ambtenaren van de arbeidsinspectie konden dienen om de werking van de wet na te gaan en wat de gebreken daarvan in de praktijk waren en kon den voorts als basis fungeren van noodzakelijk gebleken verbeteringen (Kamer van Koophandel en Fabrieken van Amersfoort en van Leeuwarden).

Het Algemeen Nederlandsch Werklieden Verbond stelde in 1878 in een adres aan de bewindsman van Justitie het inspecteren niet over te laten aan politieagenten, ambteloze burgers en gepensioneerde militairen en dergelijke, maar aan onafhankelijke personen, die niet alleen een juist oordeel bezitten, maar ook met de nijverheid bekend zijn, om in voorkomende gevallen onmiddellijk te kunnen beslissen.

De toenmalige minister van Justitie Modderman verdedigde het opnemen van een afzonderlijke arbeidsinspectie in zijn in 1882 in het parlement ingediende wetsvoorstel met de volgende argumenten: voor de vervulling van de taak van de inspecteurs was een zeer speciale kennis vereist, een kennis die men van gewone politie-ambtenaren niet mocht vorderen; de taak van de gewone politie, was al veel omvattend; uit ervaringen in het buitenland was gebleken, dat de arbeidsinspectie een weinig kostbare en uitstekende instelling was. Hoewel het wetswoorstel in het parlement slecht werd ontvangen, vond deze stellingname steun bij een aantal Tweede Kamerleden. Zij voegden daar nog aan toe, dat iedere verbetering van de Kinderwet-van Houten weinig zin zou hebben als niet tevens werd voorzien in voldoende controle. Zij benadrukten tevens de voorlichtende rol van de afzonderlijke inspecteurs, die als adviseurs van de regering bouwstoffen verzamelden, zowel om een goede uitvoering van de bestaande wetgeving te bevorderen als om tot bronnen te dienen voor 
eventueel nog uit te vaardigen regelingen.

De reactie van het parlement op het in 1885 ingediende eerste ontwerp-Du Tour van Bellinchave is opmerkelijk. Hoewel het toezicht was opgedragen aan de gewone politie merkte men op, dat handhaving van dit tot wet verheven wetsvoorstel zou leiden tot ten minste een verdubbeling van het aantal politieagenten. Bovendien had men zich klaarblijkelijk toch al neergelegd bij het feit, dat, hoewel in het wetsvoorstel niet in de regeling van een afzonderlijke arbeidsinspectie voorzag, dit spoedig zou volgen, omdat de uitgevaardigde bepalingen onvoldoende gehandhaafd zouden kunnen worden. Met andere woorden: de regering zou noodgedwongen een afzonderlijke inspectie moeten instellen. Deze zou dan moeten bestaan uit een tweetal inspecteurs bekend met het fabriekswezen en een derde die met de landbouw vertrouwd is.

De parlementaire enquête-commissie liet in haar eindverslag in het midden, of er een afzonderlijke arbeidsinspectie moest komen. Mocht dit toch gebeuren, dan behoorden de inspecteurs bij voorkeur ervaren ingenieurs te zijn. De taakstelling behoorde als volgt te zijn: het zich op de hoogte houden van de toestand van de werklokalen, het aangeven van de verbeteringen, die daarin met het oog op de veiligheid, de gezondheid en het welzijn van de arbeiders aan te brengen zijn, het voorlichten van de regering over bestaande toestanden op het gebied van de nijverheid, het adviseren bij de loepassing van de geldende voorschriften en met betrekking tot verbeteringen in de wetgeving en het toezien op een behoorlijke naleving van de wettelijke bepalingen op het terrein van de industriële arbeid.

De opvolger van $\mathrm{Du}$ Tour van Bellinchave als minister van Justitie was Ruys van Beerenbroek, éen van de leden van de parlementaire enquête-commissie. Zijn wetswoorstel, dat uiteindelijk zou uitmonden in de Arbeidswet 1889 , bevatte, evenals zijn voorganger niet de principiële keuze voor een afzonderlijke inspectie. Het daarvoor gegeven argument, dat de tijd daarvoor nog niet rijp was; werd terecht door de Tweede Kamer onvoldoende onderbouwd geacht. Bovendien maakte men kenbaar dit standpunt op voorhand niet te delen. Vrij algemeen werd naar voren gebracht, dat de bewindsman het wetsvoorstel belangrijk zou verbeteren door de aanstelling van afzonderlijke inspecteurs mogelijk te maken. De taken, die men deze afzonderlijke inspecteurs wilde toebedelen, kwamen overeen met de voorstellen van de parlementaire enquête-commissie. De bewindsman kwam tegemoet aan de druk van de Tweede Kamer en zo werd een afzonderlijke arbeidsinspectie in ons land een feit.

Uit het vorenstaande blijkt, dat er niet én specifieke reden aan te geven is, die zou kunnen gelden als dè reden voor het instellen van een afzonderlijke arbeidsinspectie. Een aantal redenen werd regelmatig aangevoerd. Allereerst een behoorlijk toezicht op de naleving van de regelgeving en het bewerkstelligen van uniformiteit in de toepassing van de regelgeving. Daarnaast de onpartijdigheid van de betreffende te benoemen ambtenaren. Daar voegde de toenmalige minister Modderman nog éen niet onbelangrijke reden aan toe: voor de vervulling van de taak van inspecteur was een zeer speciale kennis vereist, een kennis die men van gewone politie-ambtenaren niet mocht vorderen.

Voorts mag niet onvermeld blijven hetgeen destijds door dezelfde bewindsman Modderman naar voren was gebracht: uit ervaringen in het buitenland was gebleken, dat de arbeidsinspectie een weinig kostbare en uitstekende instelling was. Het feit, dat het een "weinig kostbare" instelling was; is niet onbelangrijk in een periode van een grote wereldwijde economische depressie, die omstreeks 1873 begon en eerst circa 1895 zou eindigen $^{269}$. Maar tevens blijkt, dat men de ogen niet sloot voor ontwikkelingen terzake in het buitenland, zoals overigens al eerder was gebleken. De instelling van een afzonderlijke arbeidsinspectie hier te lande paste in de ontwikkelingen, die zich in Europa in ruwweg de laatste vijfentwintig jaren van de negentiende eeuw voordeden. Dit blijkt uit het volgende overzicht ${ }^{200}$ :

$$
\begin{aligned}
& \text { - } 1871 \text { Basel ( stad ); } \\
& \text { - } 1872 \text { Saksen; } \\
& \text { - } 1873 \text { Denemarken; } \\
& \text { - } 1874 \text { Frankrijk; } \\
& \text { - } 1877 \text { Zwitserland; } \\
& \text { - } 1878 \text { Duitsland; }
\end{aligned}
$$


- 1882 Rusland;

- 1883 Oostenrijk;

- 1889 Belgiê, Finland en Zweden;

- 1892 Noorwegen;

- 1893 Hongarije en Portugal.

De eer voor het leggen van de eerste grondslagen vam een afzonderlijke arbeidsinspectie komt overigens toe aan Groot-Brittannië, waar al vanaf 1833 een dergelijke inspectie functioneerde ${ }^{261}$.

Ook mag in dit verband niet onvermeld blijven de volgende uitlating van minister Ruys van Beerenbroek. Blijkens de vele adressen, die bij de Kamer en de regering waren binnengekomen, onder meer van de zijde van de nijverheid, bleek er geen bezwaar meer te bestaan tegen een blijvend toezicht door een afzonderlijke arbeidsinspectie. Hieraan zullen ongetwijfeld de activiteiten van de ingenieur van het stoomwezen Struve en van de ingenieur van de waterstaat Bekaar, terzake van een algemene fabrieksinspectie tot voorbereiding van een nijverheidsstatistiek, waarmee zij in februari 1888 begonnen, niet vreemd zijn. Het ambtelijk bezoek in de fabrieken deed bij de ondernemers de tegenstand tegen fabrieksinspecteurs belangrijk verminderen ${ }^{202}$. Tenslotte wil ik nog wijzen op de Grondwetsherziening van 1887, die haar maatschappelijke betekenis voor een groot deel ontleende aan de verruiming van het kiesrecht. Het nu meer dan verdubbelde aantal kiezers had belangstelling voor sociaal politieke vraagstukken. Vraagstukken van sociale politiek vroegen om een oplossing, omdat de belanghebbende maatschappelijke groeperingen geen genoegen meer namen met uitstel; de wetgever diende eindelijk de economisch-zwakkeren te beschermen door uitbreiding van de KinderwetVan Houten zoals door de parlementaire enquête-commissie was voorgesteld. Zie hier de toenemende druk om sociale wetgeving. En wat is het belang hiervan? Sociale wetgeving is een vorm van wetgeving, waarbij het groepsbelang van de arbeiders, waarvan de industriële arbeider de vertegenwoordiger bij uitstek was; werd erkend als een algemeen en daarmee maatschappelijk belang. De Arbeidswet 1889 was een eerste stap, zij het ingegeven door praktische politiek, geënt op het principe van geleidelijke uitbreiding van de sociale wetgeving. Voor een verder gaande vitbreiding van de sociale wetgeving beschikte de regering echter over onvoldoende kennis. Vandaar de instelling van de staatscommissie-Rochussen, die tot taak had gegevens te verzamelen en voorstellen te doen om de wetgeving op maatschappelijk gebied uit te breiden ${ }^{26 a}$. En naar mijn mening liggen ook hier verbanden met de instelling van een afzonderlijke arbeidsinspectie; de regering zou daardoor namelijk dè beschikking krijgen over een orgaan, dat haar op de hoogte kon houden omtrent de bestaande toestanden op het gebied van de nijverheid en dat haar kon adviseren omtrent de toepassing en ook verbetering van wettelijke bepalingen betreffende de arbeid. 
1. Zie I.J. Brugmans, De arbeidende klasse in Nederland in de 19e eeuw (1813-1870), Utrecht/Antwerpen 8 e druk $\left(z_{. j}.\right)$, blz. 69 .

2. J.A. de Jonge, De industrialisatie in Nederland tussen 1850 en 1914, Nijmegen 1976 ( reprint), blz. 21.

3. Hiervoor zijn verschillende verklaringen mogelijk, waarbij echter waarschijnlijk de geografische ligging een grote rol heeft gespeeld. Zie R, van der Ploeg/R. Zinkstok, Wij zijn allen werklieden. De opkomst van de moderne arbeidsmoraal in Nederland in de negentiende eeuw, Baarn 1986, blz. 16.

4. Zie R. van der Ploeg/R. Zinkstok, l.a.p., blz. $16-17$, I.J. Brugmans, t.a.p, blz. 33.

5. J.A. de Jonge, t.a.p, blz. $228-229$.

6. J. en A. Romein, De lage landen bij de zee. Een geschiedenis van het Nederlandse volk, Amsterdam 1977, blz. 475 .

7. J. Valkhoff, Een eeuw rechtsontwikkeling. De vermaatschappelijking van het Nederlandse privaatrecht sinds de codificatie ( 1838 ), Amsterdam 2e druk 1949, blz. $121-122$.

8. J.A. de Jonge, t.a.p., blz. 235 .

9. Zie EJ. Fischer, Fabriqueurs en fabrikanten. Twente, Borne en de katoennijverheid $1800-1930$, Utrecht 1983, blz. 13 - 14, A.J.C.M. Geers, t.a.p., blz. 20 -21; R. van der Ploeg/R. Zinkstok, t.a.p., blz. 30 - 31.

10. L. Ali Cohen, Verslag van het eerste Nederlandsche Congres over het Armwezen, Groningen 1854 , blz. 8 - aangehaald door R. van der Ploeg/R. Zinkstok, t.a.p., blz. 18.

11. Zelfs Multatuli maakte geen onderscheid tussen "armen" en "arbeiders". In Ideeën II, Amsterdam 1865, schrijft hij:

"Hoe zal de mishandelle arme zich doen hooren. Men schijnt te menen dat de arbeider geboren is tot onthouding, verdriet, geloof, vermoeienis, zweet, hongerlijden en berusten".

Geciteerd door R, van der Ploeg/R. Zinkstok, t.a.p., blz. 18.

12. I.J. Brugmans, t.a.p., blz. 194.

13. Uit 1852 dateert de opmerking van S. Vissering, in De Gids $1852 \mathrm{II} \mathrm{blz.} 318$, dat de armoede een rijke materie was; aangehaald door I.J. Brugmans, t.a.p., blz. 194.

14. J. de Bosch Kemper, Geschiedkundig onderzoek naar de armoede in ons vaderland, hare oorzaken en de middelen die tot hare vermindering zouden kunnen worden aangewend, Haarlem 1851, blz. 140.

15. Wet van 1 juni 1870 , Stb. 85 , houdende wijziging van de Wet van 28 juni 1854 , Stb. 100 ( in werking getreden op 1 juli 1870 ; zie Stb. 93 ).

16. Opgericht op 30 oktober 1870 te Utrecht; zie B. Bymholt, Geschiedenis der arbeidersbeweging in Nederland ( 1894 ) deel 1, Amsterdam 1975 t.a.p., blz. 70. 
17. M.J. de Witt Hamer, De arbeidersvereenigingen, Leiden 1866, blz. 9.

18. G. Harmsen/B. Reinalda, Voor de bevrijding van de arbeid. Beknopte geschiedenis van de Nederlandse vakbeweging, Nijmegen 1975, blz. 45. Zie over het ontstaan onder meer B.H. Heldt, Algemeen Nederlandsch Werklieden Verbond 1871-1896, Leeuwarden 1896, blz. I t/m VIII; J.J. Giele, De eerste Internationale in Nederland - een onderzoek naar het ontstaan van de Nederlandse arbeidersbeweging van 1868 tot 1876 -, Nijmegen 1973; H. Smits, De Nederlandsche Arbeidersbeweging in de negentiende eeuw, Rotterdam 1902, blz. $23 \mathrm{t} / \mathrm{m}$ 36; B. Bymholt, t.a.p. I, blz. $44 \mathrm{t} / \mathrm{m} 60$ en blz. $68 \mathrm{t} / \mathrm{m} 94$.

De belangrijkste doelstellingen van bet ANWV, waarvan de statuten bij K.b. van 6 juni 1873 werden goedgekeurd, waren:

- langs ordelijke en wettige wegen alles aan te wenden wat strekken kan tot verheffing van de werkmansstand in zedelijke waarde, zijne stoffelijke welvaart, staatsburgerlijke rechten en gelijkheid en maatschappelijke vrijheid;

- de middelen op te sporen om den arbeid, als een der hoofdbronnen van 's menschen bestaan, te beschermen en te verheffen, opdat zijne beoefenaren hun wettige plaats in de maatschappij kunnen erlangen.

Zie B. Bymholt, t.a.p. deel I, blz. 138.

19. C.W. de Vries/R.A. Gorter, Gegevens omtrent den kinderarbeid in Nederland volgens de enquêtes van 1841 en 1860, in Econ.-Hist. Jaarboek 1922 ( overdruk ) blz. 75.

20. C.W. de Vries/R.A. Gorter, in Econ.-Hist. Jaarboek 1922 blz. 201. Zie ook I.J. Brugmans, t.a.p., blz. 110.

21. C.W. de Vries/R.A. Gorter, in Econ.-Hist. Jaarboek 1922 blz. 249 en blz. 224 - 225. Zie ook I.J. Brugmans, t.a.p., blz. 110 .

22. I.J. Brugmans, t.a.p., blz. 111.

23. I.J. Brugmans, t.a.p., blz. 107 - 108.

24. I.J. Brugmans, t.a.p., blz. 108 - 109. Zie over dit onderwerp: W.N. Schilstra, Vrouwenarbeid in landbouw en industrie in Nederland in de tweede helft der negentiende eeuw, Nijmegen 1976 ( reprint), blz. $32 \mathrm{t} / \mathrm{m}$ 46.

25. S.Sr. Coronel, De diamantwerkers te Amsterdam. Eene hygienische studie, in Ned. Tijdschfrit voor Geneeskunde 1864 blz. 633. Zie ook I.J. Brugmans, t.a.p., blz. 150 - 151.

26. C.W. de Vries/R.A. Gorter, in Econ.Hist. Jaarboek 1922 blz. 220 - 221. Zie ook I.J. Brugmans, t.a.p., blz. 151 .

27. Calicot is fijn bedrukt katoen.

28. S.Sr. Coronel, De gezondheidsleer toegepast op de fabrieksnijverheid, Haarlem 1861, 371 - 372 en blz. 305. Zie ook L.J. Brugmans, t.a.p., blz. 152.

29. I.J. Brugmans, t.a.p., blz. 152.

30. S.Sr. Coronel, De Leidsche wolfabrieken en haar invloed op de gezondheid der arbeiders, in Ned. Tijdschr, voor Geneeskunde 1864 blz. 226. 
31. Zie AJ.C.M. Geers, ta.p., blz. 26.

32. 1]. Brugmans, t.a.p., blz. 193.

33. 1J. Brugmans, t.a.p., blz. 193.

34. IJ. Brugmans, t.a.p., blz. 193 .

35. Het betrof voornamelijk de beperking en afschaffing van kinderarbeid in fabrieken en werkplaatsen. Literatuur over de kinderarbeid onder meer: E. Boekman, De eerste periode der Nederlandsche arbeidswetgeving, in De Socialistische Gids $1919 \mathrm{blz} 580 \mathrm{t} / \mathrm{m} 587$, blz. $732 \mathrm{t} / \mathrm{m} 746 \mathrm{en} \mathrm{blz} 855 \mathrm{t} / \mathrm{m} 866$; Joh. Kerkvliet Asz., Het Kinderwetje Van Houten, een gouden jubileum, in K.S.W. 1924 blz. 513 t/m 518 , blz. 529 t/m 532 , blz. $541 \mathrm{t} / \mathrm{m} 543$ en blz. $553 \mathrm{t} / \mathrm{m} 555$; B. Bymholt, Kinderarbeid voor 1874 (een historische schets), in De Socialistische Gids $1926 \mathrm{blz} .251 \mathrm{t} / \mathrm{m} 267$, blz. $448 \mathrm{t} / \mathrm{m} 457$ en blz. 726 t/m 779; P.A. Diepenhorst, De Nederlandsche arbeidswetgeving deel I, Utrecht 1921 (hfdst. 4 par. 2. ); J.C. Vleggeert, De kinderarbeid ( de geschiedenis van haar beperking door de kinderwet van mr. Samuel van Houten ), Amsterdam 1951; J.C. Vleggeert, Kinderarbeid in Nederland 1500-1874 ( van berusting tot beperking), Assen 1964; J.C. Vleggeert, Kinderarbeid in de negentiende eeuw, Haarlem $2 \mathrm{e}$ druk ( z.j. ) I.J. Brugmans, t.a.p., blz. 223 t/m 245 ; M.G. Levenbach, Arbeid, in Nederlands bestuursrecht (uitgave 1962) II, Alphen a/d Rijn 1964, bfdst I (historisch overzicht).

36. Dat het overheidstoezicht op de naleving van arbeidsbeschermende wetgeving in hoofdzaak ontsproten is aan de maatschappelijke denkbeelden die in de loop van de negentiende eeuw zijn ontstaan, wil echter niet zeggen dat er niet eerder een dergelijk toezicht zou hebben bestaan. Het meest markante voorbeeld daarvan is te vinden in de stad Leiden, waar in de 17 e eeuw een instelling bestond, waarvan de taak

"op tal van punten overeenstemming vertoont met de taak der tegenwoordige Arbeidsinspectie",

aldus Geudeker. Zie Th.C. Geudeker, Arbeidswetgeving, in Maatschappelijke Encyclopaedie, Enschede 1930, blz. 351.

Zie over deze "voorloopster" in de 17e eeuw: Th.C. Geudeker, Arbeidsinspectie in de 17e eeuw, in Sociale Voorzorg $1924 \mathrm{I}$, blz. $99 \mathrm{t} / \mathrm{m}$ 114; N.W. Posthumus, Kinderarbeid in de zeventiende eeuw in Delft, in Econ. Hist. Jaarboek $1943 \mathrm{blz} .43 \mathrm{t} / \mathrm{m}$ 50; N.W. Posthumus, De geschiedenis van de Leidse lakenindustrie III, 'sGravenhage 1939; N.W. Posthumus, Bronnen tot de geschiedenis van de Leidse Textielnijverheid IV ( 1611 1650 ), (z.p./z.j. ); N.W. Posthumus, Bronnen tot de geschiedenis van de Leidse Textielnijverheid V ( 1651 $1672),(\mathrm{z} . \mathrm{p} . / \mathrm{z} . \mathrm{j}$.$) .$

37. J. Ackersdijck, Over het werken van kinderen in fabrycken, in de Algemeene Konst- en Letterbode 1839 I blz. $82 \mathrm{t} / \mathrm{m} \mathrm{85;} \mathrm{zie} \mathrm{ook} \mathrm{J.H.} \mathrm{Opdorp,} \mathrm{Over} \mathrm{kinderarbeid,} \mathrm{in} \mathrm{de} \mathrm{Algemeene} \mathrm{Konst-} \mathrm{en} \mathrm{Letterbode} 1839 \mathrm{I}$ blz. $114 \mathrm{t} / \mathrm{m} 116$, die ernstige bezwaren tegen de voorstellen van Ackersdijck uitte.

38. Zie voor de voorgeschiedenis R.A. Gorter, De eerste stap op het terrein der arbeidswetgeving in Nederland ( $1835-1840$ ), in De Economist $1920 \mathrm{blz} .257 \mathrm{tm} 290$; voor samenvattingen zij verwezen naar I.J. Brugmans, t.a.p., blz. 223 - 224; J.C. Vleggeert, Kinderarbeid in Nederland 1500-1874, blz. 35 t/m 37 .

39. Brief van 22 april 1837, no. 188 e Afdeeling, weergegeven door R.A. Gorter, in De Economist 1920 , blz. 283. 
40. Brieven van 25 april 1837, no. $1897 / 13151$ e Afdeeling (gouverneur), 21 maart 1839, no. 130 (minister); 31 mei 1839, no. 1504/2055 1e Afdeeling (gouverneur); 13 juli 1839, no. 158 e Afdeeling (minister). De brieven zijn weergegeven door R.A. Gorter, in De Economist $1920 \mathrm{blz}, 283 \mathrm{t} / \mathrm{m} 287$.

41. Brief met nota van 3 oktober 1840 , no. 3301 van 1839/3026 1e Afdeeling, omtrent onderwijs aan fabriekskinderen; weergegeven door R.A. Gorter, in De Economist 1920, blz. $287 \mathrm{t/m} 290$.

Het wetsvoorstel van de gouverneur is gebaseerd op een Pruisische Wet van 8 maart 1839 - "Regulativ uber die Beschäftigung zu jugendlicher Kinder in Fabriken" -; zie voor een samenvatting van de wettekst de Arnhemse Courant van 12 mei 1839, no. 75 weergegeven door R.A. Gorter, in De Economist 1920 blz. $285-286$; zie voor de Nederlandse weergave van de wettekst C.W. de Vries/R.A. Gorter, Sociaal-economische toestanden in Nederland, volgens officiële documenten uit het midden der vorige eeuw, in Sociale Voorzorg 1919 blz. $787 \mathrm{t} / \mathrm{m}$ 789; zie voor de Duitse wettekst C.W. de Vries/J. de Vries, Early Labour Legislation deel I (1791 - 1848), Leiden 1949, blz. 30 - 31.

42. Punt 6 van de onder nt. 6 bedoelde nota van 3 oktober 1840 .

43. Punt 5 van de onder nt. 6 bedoelde nota van 3 oktober 1840 .

44. Circulaire van 6 juni 1841, no. 168 6e Afdeeling weergegeven door N.W. Posthumus, Uit de voorgeschiedenis van de wetgeving tegen den kinderarbeid, in Econ.-Hist. Jaarboek $1918 \mathrm{blz} .9 \mathrm{t} / \mathrm{m} \mathrm{12;} \mathrm{P.J.M.} \mathrm{Aalberse,}$ Een onbekende enquête naar de arbeidstoestanden in Nederland, gehouden in het jaar 1841, in K.S.W. 1918 blz. $242-243$ en door C.W. de Vries/R.A. Gorter, Gegevens omtrent den kinderarbeid in Nederland volgens de enquêtes van 1841 en 1860 , in Econ.-Hist. Jaarboek $1922 \mathrm{blz} .67 \mathrm{t} / \mathrm{m} 70$.

45. Zie over deze eerste enquête van overheidswege onder meer P.J.M. Aalberse, in K.S.W. 1918 blz. 241 $\mathrm{t} / \mathrm{m} \mathrm{243}$, blz. $253 \mathrm{t} / \mathrm{m} 257$, blz. $261 \mathrm{t} / \mathrm{m} \mathrm{263}$, blz. $283 \mathrm{t} / \mathrm{m} \mathrm{286,} \mathrm{blz.} 293 \mathrm{t} / \mathrm{m} 296 \mathrm{en} \mathrm{blz.} 313 \mathrm{t} / \mathrm{m} 315$; N.W. Posthumus, in Econ.-Hist. Jaarboek $1918 \mathrm{blz} .13 \mathrm{t} / \mathrm{m} 20$ en blz. $67 \mathrm{t} / \mathrm{m} 181$; C.W. de Vries/R.A. Gorter, in Sociale Voorzorg $1919 \mathrm{blz} .251 \mathrm{t} / \mathrm{m} \mathrm{274}$, blz. $505 \mathrm{t} / \mathrm{m} 523$ en blz. $786 \mathrm{t} / \mathrm{m} 811$.

46. Zie voor een overzicht van de verlangens van de gouverneurs C.W. de Vries/R.A. Gorter in Sociale Voorzorg $1919 \mathrm{blz} .805 \mathrm{t} / \mathrm{m} 807$.

47. Brief van 26 november 1841; weergegeven door C.W. de Vries/R.A. Gorter, in Econ.-Hist. Jaarboek 1922 blz. $90 \mathrm{t} / \mathrm{m} 94$.

48. Brief van 29 januari 1842 weergegeven door C.W. de Vries/R.A. Gorter, in Econ.-Hist. Jaarboek 1922 blz. $153 \mathrm{t} / \mathrm{m} 158$.

49. Wet omtrent de straffen tegen de overtreders van algemeene verordeningen uit te spreken of bij provinciale of plaatselijke reglement vast te stellen, van 6 maart 1818, Stb. 12.

50. De gouverneur stelde voor, dat niemand beneden de leeftijd van 16 jaar - hij bepleitte een verbod van kinderarbeid beneden de 10 jaar - zou mogen werken in fabrieken of werkwinkels zonder een geldend getuigschirift van een geneesheer waaruit blijkt, dat de bewuste arbeider gezond, sterk en bekwaam is om de vermoeienissen van de arbeid te kunnen verdragen. Dit getuigschrift moet worden bewaard om te allen tijde het openbaar gezag te kunnen tonen.

51. Brief van 17 september 1841; weergegeven door C.W. de Vries/R.A. Gorter, in Econ.-Hist. Jaarboek 1922 blz. $122 \mathrm{t} / \mathrm{m} 125$. 
52. Missives van 21 september 1859 , no. $144 ; 17$ oktober 1859 , no. $228 ; 3$ december 1859 , no. $182 ; 16$ januari 1860, no. 155. Zie N.W. Posthumus, in Econ.-Hist. Jaarboek 1918 blz. 27.

53. Zie voor een overzicht van de geschiedenis van de dienst voor het stoomwezen onder meer: A.M. Piepers, Bijdrage tot de geschiedenis van het toezicht op het stoomwezen in Nederland, 's-Gravenhage 1914; "Stoombedrijf en veiligheid", uitgegeven ter gelegenheid van het honderdjarig bestaan van de Dienst voor het Stoomwezen; 's-Gravenhage 1955; G. Wilhelm, Dienst voor het Stoomwezen 125 jaar, in Noodzaak 1980 blz. $36 \mathrm{t} / \mathrm{m}$ 39; G. Wilhelm, 125 jaar Stoomwezen, in Lastechniek 1980 ble. $210 \mathrm{t} / \mathrm{m}$ 213; P. van Rossen, Historische achtergronden van de Dienst voor het Stoomwezen, in De Veiligheid $1982 \mathrm{blz}$.11 t/m 14; zie ook de Stcrt. 1980 , no. 197 blz. $4-5$ en 13 .

54. Rapport van 7 oktober 1860 van de ingenieur voor het stoomwezen aan Van Heemstra; weergegeven door N.W. Posthumus, in Econ.-Hist. Jaarboek $1918 \mathrm{blz} .27 \mathrm{t} / \mathrm{m} \mathrm{36}$; zie ook B. Bymholt, in De Socialistische Gids $1926 \mathrm{blz} 454 \mathrm{t} / \mathrm{m}$ 457. Een afschrift van het rapport is te vinden in het archief van het directoraat-generaal van de Arbeid.

55. C.W. de Vries/R.A. Gorter, Bijdrage tot de geschiedenis der Nederlandse sociale wetgeving (1840 1874), in De Economist 1919 blz. 311.

56. Brief van 17 december 1860 , no. 215 Afd. 6 Nijverheid; weergegeven door C.W. de Vries/R.A. Gorter, in Econ.-Hist Jaarboek $1922 \mathrm{blz} 196 \mathrm{t} / \mathrm{m} 198$. Zie ook J.C Vleggeert, Kinderarbeid in Nederland 1500 1874 , blz 64 - 65 en De Economist 1861 blz 94.

57. Zie over de enquête onder meer C.W. de Vries/R.A. Gorter, in Econ.-Hist. Jaarboek 1922 blz. $196 \mathrm{t} / \mathrm{m}$ 253; C.W. de Vries/R.A. Gorter, in De Economist 1919 blz, $311 \mathrm{t} / \mathrm{m} \mathrm{313;} \mathrm{S.Sr.} \mathrm{Coronel,} \mathrm{Gezondheidsleer,}$ blz. $254 \mathrm{t} / \mathrm{m} 260 ;$ S.Sr. Coronel, De arbeid van kinderen tegenover de wetgeving, in De Economist $1873 \mathrm{blz}$. $488 \mathrm{t} / \mathrm{m} 504 \mathrm{en} \mathrm{blz.} 615 \mathrm{t} / \mathrm{m} 655$.

Zie voor het verschil tussen de enquête van 1841 en deze enquête onder meer C.W. de Vries/R.A.Gorter, in Econ.-Hist. Jaarboek 1922 blz. 196.

Zie voor kritiek op de enquête onder meer S.Sr. Coronel, Gezondheidsleer, blz 256 t/m 258 en J.Th. Mouton, op het Congres voor Nijverheidshygiëne en Reddingwezen 1890 deel I, Amsterdam 1891, blz. 52.

58. S.Sr. Coronel, in De Economist 1873 blz. 490, daarin gesteund door A. Kerdijk, De Wet op de kinderarbeid, in Vragen des Tijds $1878 \mathrm{I}$ blz. $95-96$.

59. Brief van 2 meil 1861; weergegeven door C.W. de Vries/R.A. Gorter, in Econ.-Hist. Jaarboek 1922 blz. $237 \mathrm{t} / \mathrm{m} 241$.

60. Zie over de Regouts onder meer M. Ubachs, Een eeuw modern kapitalisme, De Regouts/leed en strijd van Maastrichts proletariaat, Nijmegen ( z.j. ); A.J.Fr. Maenem, Petrus Regout 1801 - 1873. Een bijdrage tot de sociaal-economische geschiedenis van Maastricht, Nijmegen 1959.

61. Brief van 15 april 1861; weergegeven door C.W. de Vries/R.A. Gorter, in Econ.-Hist. Jaarboek 1922 blz. $232 \mathrm{t} / \mathrm{m} 235$.

62. De commissie bestond uit de leden L. Mulder ( secretaris ), G.B. Lalleman ( auteur van onder meer Slavernij in Nederland, in De Economist $1855 \mathrm{blz} 33 \mathrm{t} / \mathrm{m} 43$ ) en A. Sassen ( secretaris ). 
63. Deze voorstellen zijn te vinden in het Rapport over het onderwijs der kinderen, die in of voor fabrieken arbeiden, Hand. en Verslagen van het Nederlandsch Schoolverbond 1872 no. 4 ( hierna Rapport Schoolverbond ).

64. Rapport Schoolverbond, blz 48 - 49 (zie voor de conclusies van de commissie blz 22 - 23); zie J.C. Vleggeert, Kinderarbeid in Nederland $1500-1874$, blz. 116 t/m 118.

65. Zie Bijlagen Tweede Kamer, Bijblad Stcrt. $1872-1873,113.1 \mathrm{t} / \mathrm{m} 3$.

66. S.Sr. Coronel, in De Economist $1873 \mathrm{blz} .660-661$.

67. J.H. Wijnen, De arbeid der kinderen in fabrieken, onder godsdienstig, zedelijk en stoffelijk oogpunt beschouwd, (z.p.) 1873, blz. $73-74$.

68. De commissie bestond uit de leden H. Goeman Borgesius, A. Sassen en M.J. de Witt Hamer.

69. De motie is weergegeven door J.C. Vleggeert, Kinderarbeid in Nederland $1500-1874$, blz. 157.

70. Overigens werd de motie verdedigd door B.H. Heldt, de voorzitter van het. ANWV.

71. Zie over "Het Paaschcongres" en haar voorgeschiedenis onder meer J.C. Vleggeert, Kinderarbeid in Nederland $1500-1874$, blz. $158 \mathrm{t} / \mathrm{m}$ 166. Onder de toehoorders bevonden zich naast leden van het Comite ter bespreking der Sociale Quaestie eveneens veertien volksvertegenwoordigers waaronder Van Houten: G.J. Royaards, Geschiedkundige schets van pogingen welke er in Nederland zijn aangewend ter verbetering van den toestand der arbeidende klasse, aangehaald door B. Bymholt, t.a.p. deel I, blz. 170, merkt op, dat

"de redevoeringen op deze bijeenkomst gehouden waren, volgens het getuigenis van leden der Staten-Generaal zelven, niet zonder invloed op het lot van het wetsontwerp".

72. Wet van 19 september 1874 , houdende maatregelen tot het tegengaan van den overmatigen arbeid en verwaarloozing van kinderen, Stb. 130; gewijzigd bij Wet van 15 april 1886, houdende bepalingen, regelende het in werking treden van het bij Wet van 3 maart 1886 ( Stb. 35) vastgestelde Wetboek van Strafrecht en den overgang van de oude tot de nieuwe strafwetgeving, alsmede om overeenstemming te brengen tusschen de bestaande wetten en het nieuwe wetboek, Stb. 64 (in werking getreden met het Wetboek van Strafrecht op 1 september 1886 ).

73. Deze commissie bestond uit de leden Bredius, Janckbloet, Jolles en De Brauw.

74. Bijlagen Tweede Kamer, Bijblad Stcrt. 1873 - 1874, 34.1. ( par. 3 ) blz. 3.

75. Bijlagen Tweede Kamer, Bijblad Stcrt. 1873 - 1874, 34.2. ( par.6) blz. 9.

76. Hand. Tweede Kamer, Bijblad Stcrt. 1873 - 1874 II, blz. 1340.

77. Hand. Tweede Kamer, Bijblad Stcrt. 1873 - 1874 II, blz. 1345.

78. Hand. Tweede Kamer, Bijblad Stcrt. 1873 - 1874 II, blz. 1346.

79. Hand. Tweede Kamer, Bijblad Stcrt. 1873 - 1874 II, blz. 1357. 
80. Hand. Tweede Kamer, Bijblad Stcrt. 1873 - 1874 II, blz. 1364. Overigens zij er op gewezen, dat geen van de ingediende amandementen (Bijlagen Tweede Kamer, Bijblad Stcrt. $1873-1874,34.5$ t/m 7 en 9 ) betrekking had op het toezicht; dit dus ondanks de klachten over het gemis ervan.

81. Hand. Tweede Kamer, Bijblad Stcrt. $1873-1874$ II, blz. 1378.

82. Het initiatief-wetsvoorstel van Van Houten werd door de Tweede Kamer met een ruime meerderheid van stemmen, namelijk 64 voor en 6 tegen aangenomen ( Hand. Tweede Kamer, Bijblad Stcrt. 1873 - 1874 II, blz. 1438 ); door de Eerste Kamer met 29 tegen 7 stemmen ( Hand. Eerste Kamer, Bijblad Stort. I 1873 1874 I; blz. 291 ).

Zie hierover onder andere S.Sr. Coronel, Geschiedkundig overzicht van het vraagstuk van den kinderarbeid in Nederland, in De Tijdspiegel $1888 \mathrm{~N} \mathrm{blz.} 33$.

83. Rb. Rotterdam 15 mei 1875, W.3855. Zie ook Jac. van Waning, Wet op den Kinderarbeid, Alpen a/d Rijn 1888, blz. 16; J.D. Veegens, Wettelijke maatregelen omtrent kinderarbeid en werklokalen, in Vragen des Tijds 1887 II blz. 69 .

84. In dezelfde lijn: Rb. 's-Gravenhage 18 oktober 1875 , W.3904; Ktg. Vollenhove 6 september 1876 , W.4048. Zie Jac. van Waning, t.a.p., blz. $20-21$.

85. Rb. Groningen 29 juni 1882 , W.4810.

86. Zie voor een gelijksoortige uitspraak Rb. Zwolle 26 oktober 1876, W.4058. Zie ook J.D. Veegens, in Vragen des Tijds 1887 II blz. 65 .

87. J.D. Veegens, in Vragen des Tijds 1887 II blz. 69.

88. Zie over de termen "in dienst nemen" en "in dienst hebben" A. Postma, De mislukte pogingen tussen 1874 en 1889 tot verbetering en uitbreiding van de Kinderwet-Van Houten, Deventer ( z.j. ), blz. $87 \mathrm{t} / \mathrm{m} 89$.

89. Rb. Rotterdam 13 juli 1876, W.4230; zie Jac. van Waning, t.a.p., blz. $25-26$.

90. J.D. Veegens, in Vragen des Tijds $1887 \mathrm{II} \mathrm{blz.66.} \mathrm{Zie} \mathrm{ook} \mathrm{A.} \mathrm{Kerdijk,} \mathrm{in} \mathrm{Vragen} \mathrm{des} \mathrm{Tijds} 1878$ I blz. 139.

91. Zie over de begrippen "huiselijke en persoonlijke diensten" A. Postma, t.a.p., blz. 89 t/m 91.

92. HR 20 oktober 1879, W.4444. Zie Jac. van Waning, t.a.p., blz, 26. Een ruime uitleg is tevens te vinden in Rb. Groningen 6 maart 1879, W.4412. Een enge uitleg gaf Rb. Rotterdam 15 maart 1879, W.4347. Zie Jac. van Waning, t.a.p., blz. $26-27$.

93. Zie over dit begrip "veldarbeid" A. Postma, t.a.p., blz. 92 - 93.

94. M.G. Levenbach, Arbeid, in Nederlands betuusrecht, blz. 439 - 440, merkt op, dat de politie, vooral op het platteland, als opsporingsorgaan ongeschikt was wegens zijn nederige positie tegenover de fabrikanten.

95. A. Kerdijk, in Vragen des Tijds $1878 \mathrm{I}$ blz. 118 - 119. Zie ook S.Sr. Coronel, in De Tijdspiegel 1888 II blz. 34 en W.3767. 
96. S.Sr. Coronel, in De Tijdspiegel $1888 \mathrm{II}$ blz. 33.

97. Hand. Tweede Kamer, Bijblad Stcrt. 1875 - 1876 II, blz. 568 ( Hfdst. IV begroting Justitie).

98. De nota was gericht aan raadadviseur A.A. de Pinto en is van de hand van commies G.J.Th. Beelaerts van Blokland. Deze laatste achtte de gegevens "te onvolledig en te weinig betrouwbaar" voor publikatie in de Stcrt. Hij werd daarin gesteund door De Pinto. De nota is te vinden in wetten 114 van het archief van het ministerie van Justitie; zie ook A. Postma, t.a.p., blz. 21 - 22.

99. Beelaerts van Blokland raadde af deze bevoegdheid aan inspecteurs van het lager onderwijs te verlenen, omdat de Tweede Kamer juist alles wat op onderwijs betrekking had uit het wetsontwerp van Van Houten (artikel 5, Afdeeling II Van den leerpligt) had geschrapt.

100. Van de raad-adviseur De Pinto.

101. Voorgesteld werd tevens een halfjaarlijks verslag omtrent de stand van zaken, met opgave van de gevallen waarin vervolging heeft plaatsgevonden en van het resultaat daarvan.

102. Weer van Beelaerts van Blokland aan De Pinto. Ook deze nota is te vinden in wetten $114 ;$ zie ook A. Postma, t.a.p., blz. 22 - 23 .

103. Ingesteld bij de Wet van 1 juni 1865, regelend het geneeskundig Staatstoezigt, Stb. 58 (in werking getreden op 1 november 1865 - K.b. van 3 juni 1865, Stb. 64). Zie over deze dienst onder meer: S.Sr. Coronel, Het geneeskundig staatstoezicht in Nederland, in Vragen des Tijds $1879 \mathrm{I} \mathrm{blz.} 339 \mathrm{t} / \mathrm{m} 372 ;$ G.W. Bruinsma, De geneeskundige wetgeving in Nederland en de ontwerpen tot herziening, in De Gids $1886 \mathrm{blz} .75 \mathrm{t} / \mathrm{m} 110$. Artikel 5 van de genoemde Wet van 1 juni 1865 geeft de ambtenaren van deze dienst de bevoegdheid onder andere

"fabrieken of andere werkplaatsen binnen te treden ten einde zich zooveel mogelijk bekend

te maken met den toestand en de inrichting dier gebouwen in het belang der gezondheid".

De wetgever heeft echter verzuimd mogelijk te maken, dat de kennis aan de veiligheid en gezondheid van de arbeiders ten goede komt, terwijl te beoordelen aan het verslag van de hierna nog te bespreken parlementaire enquete-commissie deze ambtenaren zich niet allen op het verwerven van deze kennis al te veel gelegen laten liggen; zie de Enquête betreffende de werking en uitbreiding der wet van 19 september 1874 ( Staatsblad no. 130) en naar den toestand van fabrieken en werkplaatsen, Tweede Kamer, zitting 1886-1887, 105.1 (getuigenverhoren) blz. $1 \mathrm{t} / \mathrm{m} 6$ en J. Giele, Een kwaad leven - de arbeidsenquête van 1887, Nijmegen 1981, Deel I blz $5 \mathrm{t} / \mathrm{m} 13$ (verhoor van J.P. Dozy, inspecteur van het geneeskundig Staatstoezigt voor de provincie Noord-Holland te Amsterdam); Enquête, Tweede Kamer, zitting 1886-1887, 105.2 ( getuigenverhoren) blz. $1 \mathrm{t} / \mathrm{m} 17$ en J. Giele, Een kwaad leven, deel II blz. $3 \mathrm{t} / \mathrm{m} 23$ (verhoor van E. Wintgens, adj,-inspecteur van het geneeskundig Staatstoezigt voor de provincies Noord-Brabant en Limburg te Maastricht ); zie ook J. Gie-le, Een kwaad leven, deel III blz. $295 \mathrm{t} / \mathrm{m}$ 298. A.J.C.M. Geers, t.a.p., blz. $30-31$, stelt, dat het geneeskundig staatstoezicht wellicht als een voorloopster van de arbeidsinspectie beschouwd zou kunnen worden. Dit gaat mij echter net iets te ver. Hoewel deze overheidsinstelling de omstandigheden van de arbeidende bevolking in de gaten diende te houden, was dit echter in het belang van de volksgezondheid en niet zozeer in het belang ván de arbeiders zelf. De onmiddellijke dreiging van een cholera epidemie was de rechtvaardiging voor het instellen van deze overheidsdienst; zie J. Giele, La.p., deel III, blz. 296.

104. Resp. Bijlagen Tweede Kamer ( Bijlage A), Bijblad Stcrt. 1876 - 1877, no. 11 blz. 1 ( Hfdst. IV begroting Justitie ) en no. 12 blz. 1 ( Hfdst. IV begroting Justitie). 
105. Te vinden in wetten 114. Het vocrontwerp is wan de hand van de meer genoemde Beelaerts van Blokland; zie ook A. Postma, La.p, blz. $26 \mathrm{~V} / \mathrm{m} 33$.

106. De toelichting gaf aas, dat een dergelifke regeling niet nieuw is; een vergelijking wordt gemaakt met de regeling van artikel 47 van de Wet wan 2 mei 1863, houdende regeling van het middelbaar onderwijs, Stb. 50.

107. Wet van 28 mei 1869 , regelende het toezicht op het gebraik van stoomtoestellen, Stb. 97 ( in werking getreden op 1 oktober 1869 ).

108. Zie de artikelen 3 en 5 van het woorortwerp van wet.

109. Zie artikel 8 van bet woorontwerp wan wet. Gewezen moet worden op artikel 16 van het voorontwerp. Daarin werd bepaald, dat met betrekking tot de bedoelde verklaringen, livretten en registers bij algemene mantregel van bestuur nadere bepalingen zouden worden vastgesteld.

110. Na op 28 oktober 1876 bij schrijwen van de 1e Afd. van Justitie onder no. 126 naar de Raad van Ministers te zijn gestuurd; zie wetten 114 .

111. De nota is van de hand wan W.T. Koster. Voorts was er een nota verschenen op 20 oktober 1876 van het hoofd van de negende afdeling (medische politie) $H$. van Cappelle; zie wetten 114 en A. Postma, t.a.p. ble. $33-34$.

112. 1 e Afd, no. $158 \mathrm{~A}$; wetten 114. De circulaire is onder andere weergegeven door A. Sassen, Nadeelige vrijheid en noodzakelijke dwang, in Vragen des Tijds 1878 I blz $404-405$; A. Postma, Eed onbekende enquete uit 1877, in Econ. Soc. Hist. Jaarboek 1973 blz. $217-218$. Ze ook G. Bosch, Kinderarbeid, in De Economist 18771 blz $200 \mathrm{Vm} 210 \mathrm{en}$ S.Sr. Coronel, In hoever is uitbreiding van de Wet op den kinderarbeid wenschelijk en witwoerbaan?, in De Economist $1877 \mathrm{I} \mathrm{blz} 384 \mathrm{tm} 390$.

113. A. Postma, t.a.p., blz. 36 nt. 72 , vermeldt, dat gebleken is, dat ongeveer 70 antwoorden op de vraagpunten zijn binnengekomen bij Justitie, waarvan er 24 te achterhalen bleken te zijn. Deze zijn door hem weergegeven in Econ. Soc. Hist. Jaarboek $1973 \mathrm{blz} 219 \mathrm{t} / \mathrm{m} \mathrm{259}$. Het antwoord van de Vereeniging ter bevordering van Fabrieks-en Handwerksnijverheid is te vinden in wetten 114. Zie voor het vraagpunt van de afzonderlijke inspecteurs A. Postma, t.a.p., bz. $127-128$.

114. Hand. Eerste Kamer, Bijbld. Stcrt. 1878 - 1879 1, blz. 66 (Hfdst. IV begroting Justitie ).

115. Ingesteld bij Wet van 19 december 1877 , Stb. 285.

116. Hand. Eerste Kamer, Bijbld. Stcrt. $1878-1879$ I; blz. $76-77$ ( Hfdst. IV begroting Justitie).

117. G. Bosch, in De Economist $1877 \mathrm{I}$ blz. $200 \mathrm{U} / \mathrm{m}$ 210. Zie voor een commentaar van de redactie van De Economist 1877 I blz. 210.

118. S.Sr. Coronel, in De Economist $1877 \mathrm{I}$ blz. $384 \mathrm{t} / \mathrm{m} 390$.

119. Het adres was opgesteld namens de algemene vergadering van het ANWV van 25 en 26 december 1877 te Amsterdam; zie wetten 114. 
120. "De Wet op den kinderarbeid, voorstellen tot hare verbetering, door eene gemengde commissie", Amsterdam 1880 .

De commissieleden waren:

- van de Maatschappij tot Nut van t Algemeen. H.B. Greven en N.G. Pierson (rapporteur);

- van de Maatschappij ter bevordering van Nijverheid. H.A.L. Hamelberg en A.P. Ledeboer;

- van het ANWV: B.H. Heldt en J. Weelink;

- van de Maatschappij tot bevordering van Fabrieks- en Handwerksnijverheid: J.Th. Mouton en G. Royaards

121. Een pleidooi, dat onderschreven werd door A. Kerdijk, Een belangrijk rapport, in Vragen des Tijds $1880 \mathrm{II} \mathrm{blz} .155 \mathrm{t} / \mathrm{m} 177$, die overigens ook pleitte voor een van staatswege benoemde enquête-commissie naar de werking van de Kinderwet-Van Houten.

122. A. Kerdijk, in Vragen des Tijds $1878 \mathrm{I} \mathrm{blz.} 93 \mathrm{t} / \mathrm{m}$ 149. Dit artikel heeft geleid tot correspondentie tussen Kerdijk en de al meer genoemde Beelaerts van Blokland; zie A. Postma, t.a.p., blz. $40 \mathrm{t} / \mathrm{m} 42$.

123. Wet van 17 augustus 1878 tot herziening der wet van 13 augustus 1857 (Stb. 103) tot regeling van het lager onderwijs, Stb. 127 (in werking getreden op 1 november 1880, Stb. 18801155 ).

124. Tweede Kamer, zitting $1877-1878,130.3$ ( memorie van toelichting ) blz. 21.

125. Tweede Kamer, zitting 1877 - 1878, 130.4 ( voorlopig verslag ) blz. 53.

126. Tweede Kamer, zitting $1877-1878,130.5$ ( memorie van antwoord ) blz. 30 .

127. Tweede Kamer, zitting 1877 - 1878, 130.11; zie Hand. Tweede Kamer, Bijblad Stcrt. $1877-1878$ II, blz. 1001.

128. Hand. Tweede Kamer, Bijblad Stcrt. 1877 - 1878 II, blz. 1380.

129. Hand. Tweede Kamer, Bijblad Stcrt. 1877 - 1878 II, blz. 1380. Overigens werd het amendement met 48 tegen 30 stemmen verworpen ( zie Hand. Tweede Kamer, Bijblad Stcrt. 1877 - 1878 M, blz, 1381). Wel dient men zich er rekenschap van te geven, dat de minister met name het oog had op de veldarbeid, waarop het verbod van kinderarbeid niet van toepassing was ( zie artikel 2 van de Kinderwet-Van Houten).

130. Afd. 3550, Afd. B.B.; zie wetten 114.

131. Zie A. Postma, t.a.p., blz. $43-44$.

132. A. Kerdijk, De werkzaamheden der gemeenten tot beteugeling van de kinderarbeid, in Vragen des Tijds $1882 \mathrm{I} \mathrm{blz.} 231 \mathrm{t} / \mathrm{m} 257$.

133. A. Kerdijk, in Vragen des Tijds 1882 I blz. 236 nt. 1: weergegeven door A. Postma, t.a.p., blz. 44 nt. 44. Zie over de werking van artikel 82 van de Wet op het lager onderwijs het Verslag van de parlementaire enquête-commissie 1886, Bijlagen Tweede Kamer, zitting $1886-1887,105.5$ (verslag der commissie) blz. 79 t/m 84 (Par. 9 Toepassing der Wet op den kinderarbeid. Hare redactie. Werking van art. 82 der wet op het lager onderwijs).

134. Bijlagen Tweede Kamer (Bijlage A), zitting $1881-1882$, no. 13 (Hfdst. IV begroting Justitie) blz. 4. 
135. Bijlagen Tweede Kamer (Bijlage A ) zitting 1881 -1882, no. 14 ( Hfdst. IV begroting Justitie) blz. 12. De "bevoegde specialiteit" waar Modderman over spreekt, duidt met grote waarschijnlijkheid op Kerdijk, die een grote invloed op het ontwerp heeft gehad; Modderman nam verschillende wijzigingsvoorstellen en opmerkingen van hem over in het ontwerp van wet zoals het naar de Raad van State werd gezonden; zie wetten 114 en A. Postma, t.a.p., blz. $47 \mathrm{t} / \mathrm{m} 50$.

136. Hand. Tweede Kamer, zitting 1881 - 1882 II, blz. 440 .

137. Hand. Tweede Kamer, zitting $1881-1882 \mathrm{II}$, blz. 453 .

138. 2e Afd. A. no. 64 ; zie wetten 114 .

139. In het wetswoorstel werd een onderscheid gemaakt tussen kinderen beneden de 12 jaar en kinderen boven de 12 jaar maar beneden de 16 jaar.

140. Artikel 5 van het wetsvoorstel luidde:

"Door ons wordt bij Algemeenen Maatregel van Inwendig Bestuur bepaald, welke arbeid, hetzij onvoorwaardelijk, hetzij anders dan onder voorwaarden door Ons te stellen, verboden is aan kinderen die den leeftijd van dertien jaren en nog niet van zestien jaren hebben bereikt".

141. Deze plaatselijke commissies van toezicht kwamen voor in het voorontwerp van wet, maar werden op voorstel van Kerdijk geschrapt, waarbij zijn motivering werd overgenomen; zie A. Postma, t.a.p., blz. 49.

142. Artikel 153 van de Grondwet luidde:

"Niemand mag de woning eens ingezetenen diens ondanks betreden, dan op last eener magt, door de wet bevoegd verklaard dien last te geven, en volgens de normen in de wet bepaald".

Zie J.A. Fruin, De Nederlandse Wetboeken, Utrecht 1879.

143. Advies van de Raad van State van 14 februari 1882, no. 16; Rijksarchief - Raad van State - inv, no. 296.

144. Nader rapport van 21 april 1882 - Rijksarchief - Raad van State - inv. no. 887.

145. Ontwerp van wet, houdende wettelijke bepalingen tot het tegengaan van overmatigen arbeid en verwaarloozing van kinderen, Bijlagen Tweede Kamer, zitting $1881-1882,153.1 \mathrm{t} / \mathrm{m} 3$.

146. Dit is dus te vergelijken met het indirect strafbaar stellen van een aantal bepalingen van de Arbeidsomstandighedenwet door middel van een aanwijzing; zie de artikelen 35 en 57 van die wet. Zie ook hfdst. 12 par. 3.2.5. (Instrumenten ter beschikking van de arbeidsinspectie).

147. Bijlagen Tweede Kamer, zitting 1882 - 1883, 58.1 (voorlopig verslag ) blz. 4 - 5. De commissie van rapporteurs bestond uit de leden Goeman Borgesius, De Jong, Ruys van Beerenbroek en Van der Kaay.

148. Bedoeld werd artikel 18 van het wetswoorstel.

149. Zie Bijlagen Tweede Kamer, zitting 1881 - 1882, 153.3 (memorie van toelichting) blz. 3; Bijlagen Tweede Kamer, zitting 1882 - 1883, 58.1 (voorlopig verslag) blz. 1. Zie over het voorlopig verslag A. Kerdijk, 
Het voorlopig verslag over het wetsontwerp op den kinderarbeid, in Vragen des Tijds $1883 \mathrm{II}$ blz. $278 \mathrm{t} / \mathrm{m}$ 311.

150. A. Kerdijk, in Vragen des Tijds 1883 II blz. $282-283$.

151. Het kabinet- Van Lynden van Sandenburgh viel op 26 februari 1883, toen met 66 tegen 12 stemmen het voorstel om de wijziging van de Kieswet in behandeling werd verworpen; zie P.J. Oud, Honderd jaren, een eeuw van staatkundige vormgeving in Nederland (1840 - 1940), Assen 7e herziene druk 1979, blz. $125-126$ en W.J. van Welderen Rengers, Schets eener parlementaire geschiedenis van Nederland deell 1849-1891, 's-Gravenhage 1950 4e bijgewerkte druk, blz. $623 \mathrm{t} / \mathrm{m} 625$.

152. Bijlagen Tweede Kamer, zitting 1882 - 1883 , 58.2. blz. 7 .

153. Brief van 21 december 1883 , Afd. 2 e no. 77 ; zie wetten 114.

154. Zie A. Postma, t.a.p., blz. 64. De brief en antwoorden, voor zover te achterhalen gebleken, zijn weergegeven door A. Postma. Een enquête uit 1883, in Econ. en Soc. Hist. Jaarboek 1973 blz. 261 t/m 276.

155. Bestaande uit de leden Van Blom, Van Baar, Van de Werk, Van der Kaay en Mackay.

156. Bijlagen Tweede Kamer (Bijlage A ), zitting $1883-1884$, no. 13 ( Hfdst. IV begroting Justitie ) blz. 1.

157. Bijlagen Tweede Kamer ( Bijlage A ), zitting 1883 - 1884, no. 13 ( Hfdst. IV begroting Justitie ) blz. 5.

158. Hand. Tweede Kamer, zitting 1883 - 1884, blz. 456.

159. Hand. Tweede Kamer, zitting 1883 - 1884, blz. 471.

Artikel 253 van het Wetboek van Strafrecht luidt:

"Hij die een onder zijn wettig gezag staand kind beneden den leeftijd van twaalf jaren aan een ander afstaat of overlaat, wetende dat het tot of bij het uitoefenen van bedelarij, van gevaarlijke kunstverrichtingen of van gevaarlijken of de gezondheid ondermijnende arbeid zal worden gebruikt, wordt gestraft met gevangenisstraf van ten hoogste drie jaren".

Het bewuste artikel zou echter pas op 1 september 1886 in werking treden. Het artikell geldt heden ten dage nog, maar lijkt volledig in de vergetelheid geraakt.

160. De commissie van rapporteurs bestond wit de leden De Ruiter, Zylker, Kist, Beelaerts van Blokland, Van der Kaay en Oldenhuis Gratema.

161. Bijlagen Tweede Kamer ( Bijlage A ), zitting 1884 - 1885, no. 2 ( Hfdst. IV begroting Justitie ) blz. 1.

162. Bijlagen Tweede Kamer ( Bijlage A ), zitting 1884 - 1885, no. 3 ( Hfdst. Iv begroting Justitie ) blz. 5.

163. Brief van 20 december 1884 , Afd. 2 e no. 84 ; zie wetten 114.

164. Artikel 11 van het Wetboek van Strafvordering luidde:

"Met het opsporen der misdrijven zijn, volgens de onderscheidingen bij de wet gemaakt, de hiernavolgende ambtenaren belast, elk voor zoveell aangaat de uitgestrektheid van het grondgebied, voor hetwelk hij is aangesteld en beëdigd: 
1e. De veld- en boschwachters;

2e. De officieren en onder-officieren der marechaussé;

3e. De directeuren en commissarissen van policie en de waterschouten;

4e. De burgemeesters, of degenen, die hen vervangen, doch alleen in de gemeenten, alwaar geene commissarissen van policie zijn;

5e. De kantonregters;

6e. De ambtenaren van het openbaar ministerie; $7 \mathrm{e}$. Alle andere ambtenaren in zaken, bij bijzondere wetten en wettige verordeningen aan hunne waakzaamheid toevertrouwd".

Zie J. de Bosch Kemper, Het Wetboek van Strafvordering I, Amsterdam 1838, blz. 111 en J.A. Fruyn, De Nederlandsche Wetboeken, Utrecht 1879.

165. Advies van 10 februari 1885, no. 37; Rijksarchief - Raad van State - inv. no. 302.

166. Nader rapport van 7 april 1885 , 2e Afd. no. 167; zie wetten 114.

167. Evenals het geval was in 1882 bij het ontwerp-Modderman werden de onderwijsbepalingen dus pas geschrapt na aandringen van de Raad van State; zie A. Postma, t.a.p., blz. 65.

168. Bijlagen Tweede Kamer, zitting 1884 - 1885 ( $2 \mathrm{e}$ zitting ), 121.1 blz. 1.

169. Bestaande uit de leden De Ranitz, Fabius, Dirks, Van Alphen en Godin de Beaufort.

170. Bijlagen Tweede Kamer, zitting 1885 - 1886, 37.1 blz. 1.

171. Bijlagen Tweede Kamer, zitting 1885 - 1886, 37.1 blz. 3 - 4; zie over het voorlopig verslag onder andere S.Sr. Coronel, in De Tijdspiegel 1888 II blz. 36 en A. Kerdijk, IJdele hoop, in Vragen des Tijds 1886 I blz. $139 \mathrm{t} / \mathrm{m} 158$.

172. Zie K.b. van 11 mei 1886, betreffende de sluiting van de tegenwoordige zitting der Staten-Generaal en de ontbinding van de Tweede Kamer, Stb. 105. Deze Kamerontbinding was het gevolg van het verwerpen van het wetsontwerp tot herziening van hoofdstuk X van de Grondwet - bepalingen inhoudend betreffende het onderwijs - door de Tweede Kamer; zie hierover onder meer W.J. van Welderen Rengers, t.a.p. deel I, blz. 649 t/m 666 en P.J. Oud, t.a.p., blz. $126 \mathrm{t} / \mathrm{m} 139$.

173. Tweede Kamer, buitengewone zitting 1886, 48.1 (Voorstel van den heer Goeman Borgesius en tien andere leden tot het houden van een onderzoek (enquête) - geleidende brief). Deze tien andere leden waren: Bahlmann, Beelaerts van Blokland, Fabius, Gildemeester, Gleichman; Heldt, Van der Kaay, Ruys van Beerenbroek, Van der Sleyden en Smit. Zie voor de argumentatie van het houden van de parlementaire enquête Tweede Kamer, Buitengewone zitting 1886, 48.3 (memorie van toelichting).

174. Bijlagen Tweede Kamer, zitting 1886 - 1887, $26.1 \mathrm{blz}$. 1. De commissie van rapporteurs bestond uit de leden De Savornin Lohman, Visser van Hazerswoude, Mees; Schaepman en Schepsel.

175. Hand. Tweede Kamer, zitting 1886 - 1887, blz. 80; het voorstel werd met 68 stemmen voor en 3 tegen aangenomen.

176. De enquête-commissie bestond uit de volgende leden: Verniers van der Loeff (voorzitter ), Goeman Borgesius (ondervoorzitter), Veegens ( rapporteur ), Beelaerts van Blokland, Bahlmann, Ruys van Beerenbroek, Heldt, Smit en Van Alphen. 
177. Bijlagen Tweede Kamer, zitting 1886 - 1887, 26.3 (voorstel van den heer Goeman Borgesius en tien andere leden tot het houden van een onderzoek (enquête ) - gewijzigd voorstel).

178. Bijlagen Tweede Kamer, zitting 1886 - 1887, 105.5 (Enquete betreffende werking en uitbreiding der wet van 9 september 1874 ( Staatsblad no. 130) en naar den toestand van fabrieken en werkplaatsen - verslag der commissic). Zie ook S.Sr. Coronel; in De Tijdspiegel 1888 II blz. $36 \mathrm{t} / \mathrm{m}$ 58; P.A. Diepenhorst, t.a.p. deel I, blz. 152 - 153; J. Zaaijer Az., De arbeidsenquete, in De Gids 1887 III blz. 36 t/m 71; Fr. de Jong Edz., De enquêteurs geënquêteerd (Maastricht en de enquête naar arbeidstoestanden 1886/1887), in S.M.A. 1960 biz. $681 \mathrm{t} / \mathrm{m}$ 692; Joh. Kerkvliet Asz., Van Van Houten tot Ruys de Beerenbrouck Sr., in K.S. W. 1925 blz. $457 \mathrm{t} / \mathrm{m} 461$.

179. Bijlagen Tweede Kamer, zitting 1886 - 1887, 105.5 (verslag der commissie) blz. 72 - 73 (par. 8 . Toestand van fabrieken en werkplaatsen. Fabrieksinspecteurs ).

180. De commissie verwees daarbij naar de informatie die haar naar aanleiding van de ruime mate door haar verspreide "Schets van hoofdpunten van het onderzoek betreffende werking en uitbreiding der wet van 19 September 1874 ( Staatsblad no. 130) en naar den toestand van fabrieken en werkplaatsen" (Bijlagen Tweede Kamer, zitting 1886 - 1887, 105.5 (verslag der commissie, bijlage I )) werd verstrekt, namelijk van de Zaanlandsche Kamer van Koophandel en Fabrieken van 18/20 november 1886; de Kamer van Koophandel en Fabrieken te Zwolle van 30 november / 1 december 1886 ( resp. Bijlagen Tweede Kamer, zitting 1886 1887, 105.5 ( verslag der commissie ), bijlage A nos. 8 en 36); de Maatschappij tot Nut van 't Algemeen van 20 december 1886 (Bijlagen Tweede Kamer, zitting 1886-1887, 105.5 (verslag der commissie ), bijlage B no. 21 ); Typografische vereeniging "Onderling Hulpbetoon" te Tiel van 20 november 1886; Meubelmakersvereeniging "De Toekomst" te Rotterdam van 30 november 1886; Schildersvereeniging "St. Lukas" te Arnhem van 30 november 1886; Bestuur de Werkliedenvereeniging "Eigen Hulp" te Goes van $29 / 30$ november 1886; Afdeeling Rotterdam van het ANWV van 4 december 1886 ( resp. Bijlagen Tweede Kamer, zitting 1886 $1887,105.5$ (verslag der commissie ), bijlage C nos $7,64,74,81$ en 96 .

181. De commisie verwees naar het voorlopig verslag over het ontwerp-Modderman, waarbij de daarin voorgestelde instelling van inspecteurs en adjudant-inspecteurs door de meerderheid onvoorwaardelijk werd afgekeurd. Die afkeuring vond hoofdzakelijk haar grond, zo vervolgde de commissie, in de vrees, dat die ambtenaren overdreven talrijk zouden zijn en dat de adjunct-inspecteurs door de wens naar spoedige bevordering te zeer zouden worden geprikkeld tot het doen van een groot aantal bekeuringen.

182. De commissie verwees daarbij naar het verhoor van A.A. Bekaar ( ingenieur van den waterstaat te Maastricht), die wees op het feit, dat de fabrieksinspecteurs "vooral practische menschen" behoorden te zijn.

"Zijn het zuiver theoretische menschen, dan kunnen zij beter achterwege blijven. Het' is eene gewichtige betrekking. Men mag toch aan een fabrikant geen te hooge eischen stellen, maar de eischen die men stelt moeten doorgedreven worden. Dat kan alleen een practicus en niet een technoloog, die de polytechnische school pas verlaten heeft. Hij moet in het vak geweest zijn".

183. De commissie merkte daarbij op, dat een dergelijke regeling door sommigen van het geneeskundig staatstoezicht zelf gewenst werd. Zij verwees daarbij naar de rapportten en missiven van openbare ambtenaren naar aanleiding van de schets van hoofdpunten, van de inspecteur van het geneeskundig staatstoezicht voor de provinciën Gelderland en Utrecht van 14/16 december 1886; de adjunct-inspecteur voor het geneeskundig staatstoezicht voor de provincie Noordholland van $20 / 21$ december 1886 en de inspecteur voor het geneeskundig staatstoezicht voor de provinciën Friesland en Groningen van 9 februari 1887 (Bijlagen Tweede Kamer, zitting 1886 - 1887, 105.5 (verslag der commissie ), bijlage E nos. 10, 13 en 20 ). 
184. J.D. Veegens, Wettelijke maatregelen omtrent kinderarbeid en werklokalen, in Vragen des Tijds 1887 II blz. $71 \mathrm{t} / \mathrm{m} 73$ en blz. $90 \mathrm{t} / \mathrm{m} 92$.

185. S.Sr. Coronel, in De Tijdspiegel 1888 II blz. 47 - 48 en blz. 57 - 58.

186. J.Th. Mouton, Wettelijke voorschriften betreffende gezondheid en veiligheid voor werklieden in fabrieken en werkplaatsen, Nijmegen 1886 ( geschriften over sociale vragen uitgegeven vanwege de Liberale Unie no. 2 ).

187. Dit aldus Du Tour van Bellinchave in de memorie van toelichting:

"Op een paar uitzonderingen na is toch nevenstaande voordracht geschoeid op de leest van de Commissie voor de enquête aanbevolen"

Zie Bijlagen Tweede Kamer, zitting 1887 - 1888, 77.3 ( memorie van toelichting) blz. 3 .

188. Wetten 114.

189. Brief van 25 oktober 1887,2 e Afd. A. no. 108 ; zie wetten 114 .

190. Advies van de Raad van State van 22 november 1887 , no. 33 - afzonderlijk advies van de staatsraden Boot, De Jong, Swart, Des Amorie en Van der Hoeven - Rijksarchief - Raad van State inv. no. 307. De Raad van State had geen opmerkingen over het toezicht noch over de controlemiddelen. Het strijdpunt was al dan niet een verbod van zondagarbeid voor Israëlieten.

191. Nader rapport van 1 december/15 december 1887, no. 106-5367 en Afd. 2A B.B.; zie wetten 114.

192. Nota van 9 december 1887 ; zie wetten 114. Zie W.P. Ruysch, Hygiëne en Fabrieksarbeid, in Vragen des Tijds 1888 I blz. $141 \mathrm{t} / \mathrm{m} 168$.

193. Zie hierover par. 3 - artikelen $21 \mathrm{t} / \mathrm{m} 26$ - van de Wet van 1 juni 1865 , regelende het geneeskundig Staatstoezigt, Stb. 58.

194. Zie de brief aan zijn ambtgenoot van Justitie van 13 december 1887, Afd. B.B. no. 5193; zie wetten 114 .

195. Zie de brief aan zijn ambtgenoot van Binnenlandse Zaken van 14 december 1887, Afd. 2A no. 107; zie wetten 114.

196. Bijlagen Tweede Kamer, zitting $1887-1888$, 77.1 .

197. Bijlagen Tweede Kamer, zittíng 1887 - 1888, 77.2 ( ontwerp van wet houdende bepalingen tot het tegengaan van overmatigen arbeid en verwaarloozing van jeugdige personen).

198. Artikel 8 van het Wetboek van Strafvordering luidde:

"Met het opsporen der strafbare feiten zijn, volgens de onderscheidingen bij de wet gemaakt, de hiernavolgende ambtenaren belast, elk voor zooveel aangaat de uitgestrektheid van het grondgebied voor hetwelk hij is aangesteld en beëdigd:

le. De veld- en boschwachters;

2e. De officieren en onderofficieren der marechaussée;

3e. De directeuren en commissarissen van policie en de waterschouten; 
4e. De burgemeesters, of degene die hem vervangen, doch alleen in de gemeenten alwaar geen commissarisen van policie zijn;

5e. De kantonregters;

6e. De ambtenaren van het openbaar ministerie, behalve die bij de kantongeregten;

7e. Alle andere beambten in zaken bij bijzondere wetten en wettige verordeningen aan hunne waakzaamheid toevertrouwd".

Zie J.A. Fruin, De Nederlandsche Wetboeken, 's-Gravenhage 188820 druk; zie voorts D. Simons, Beknopte handleiding tot het Wetboek van Strafvordering, Haarlem $18922 \mathrm{e} \mathrm{herbewerkte} \mathrm{druk,} \mathrm{blz.} 30 \mathrm{t} / \mathrm{m} 38$.

199. Bijlagen Tweede Kamer, zitting 1887 - 1888, 77.3 (memorie van toelichting ) blz. 6 .

200. Artikel 4 van het wetsvoorstel luidde:

"Bij algemeenen maatregel van bestuur kan door Ons, hetzij onvoorwaardelijk, hetzij voorwaardelijk, worden verboden kinderen beneden zestien jaren bepaalde soorten van arbeid te doen verrichten, op grond van de gevaren voor de gezondheid of het leven van kinderen, welke die soort van arbeid, hetzij in het algemeen, hetzij bij niet achtneming van zekere voorwaarden, door de verwerkt wordende stoffen of door de wijze van bewerking opleveren $^{\text {". }}$

201. Bijlagen Tweede Kamer, zitting 1887 - 1888, 77.3 (memorie van toelichting ) blz. 6 .

202. Tweede Kamer, zitting 1888 - 1889, 53.3 (memorie van toelichting Arbeidswet 1889) blz. 1. Zie over de grondwetsherziening W.J. van Welderen Rengers, t.a.p., deel I, blz. $682 \mathrm{t} / \mathrm{m} 724$.

203. H. Goeman Borgesius, De Arbeidswet - Wet van 5 mei 1889 (Staatsblad no. 48), houdende bepalingen tot het tegengaan van overmatigen en gevaarlijken arbeid van jeugdige personen en van vrouwen - met inleiding en aantekeningen, Sneek 1889 , blz 7 .

204. Tweede Kamer, zitting $1888-1889,53.3$ (memorie van toelichting) blz. 1.

205. Brief van 5 september 1888, Afd. 2 A no. 104; zie advies van de Raad van State van 25 september 1888 , no. 15 ; zie wetten 114 .

206. Advies van de Raad van State van 25 september 1888, no. 15 met afzonderlijke adviezen van de staatsraden Beyen, Van Zuylen van Nijevelt en Rochussen.

207. Nader rapport aan de koning van 26 oktober 1888, Afd. 2 A no. 179; zie wetten 114 .

208. Zie nt. 91.

209. Artikel 6 van de Wet regelende het geneeskundig Staatstoezicht bepaalde onder meer:

"De in het voorgaand artikel genoemde personen zijn bevoegd, van overtreding der wetten en algemeene, provinciale of plaatselijke verordeningen, ter bevordering der volksgezondheid vastgesteld, proces-verbaal op te maken ....".

210. Tweede Kamer, zitting 1888 - 1889, 53.1.

211. Tweede Kamer, zitting 1888 - 1889, 53.2. 
213. Tweede Kamer, zitting 1888 - $1889,53.3$ (memorie van toelichting) blz. 5.

Artikel 3 van het wetsvoorstel luidde:

"Bij algemeenen maatregel van bestuur wordt door Ons, hetzij onvoorwaardelijk, hetzij voorwaardelijk, verboden een kind beneden zestien jaren bepaalde soorten van arbeid te doen verrichten, op grond van de gevaren voor de gezondheid of het leven van kinderen, welke die soorten van arbeid, hetzij in het algemeen, hetzij bij niet inachtneming van zekere voorwaarden, door de verwerkt wordende stoffen of door de wijze van bewerking opleveren:"

Artikel 4 van het wetswoorstel laidde:

"Het is verboden den arbeid van een persoon beneden achttien jaren of in fabrieken en werkplaatsen dien van eene vrouw vroeger te doen aanvangen of later te doen eindigen dan, in het tijdvak van 1 April tot 30 September te 5 uren des morgens en te 7 uren des avonds, in den overigen tijd van het jaar te 7 uren des morgens en te 7 uren des avonds. Voor bepaalde bedrijven kan door Ons bij algemeenen maatregel van bestuur van dit verbod vrijstelling worden verleend voor jeugdige mannelijke personen, onder zoodanige voorwaarden als zullen noodig blijken."

214. Zie artikel 67 van de Arbeidswet 1919 (Wet van 1 november 1919, Stb. 624 ).

215. Tweede Kamer, zitting 1888 - 1889, 53.3 (memorie van toelichting) blz. 4.

216. Zie artikel 68 van de Arbeidswet 1919.

217. Tweede Kamer, zitting $1888-1889,53.3$ (memorie van toelichting) blz. 4.

218. Tweede Kamer, zitting 1888 - 1889, 53.4 ( voorlopig verslag) blz. 1. De commissie van rapporteurs bestond uit de leden Van Alphen, Goeman Borgesius, Van Houten, Schaepman en Heldt.

219. Tweede Kamer, zitting 1888 - 1889, 53.4 ( voorlopig verslag) par. 4.

220. Tweede Kamer, zitting 1888 - 1889, 53.5 (memorie van antwoord) blz. 1 .

221. Zie nt. 136 en 137.

222. Tweede Kamer, zitting $1888-1889,53.4$ (voorlopig verslag) blz. 2 t/m 4 .

223. Tweede Kamer, zitting 1888 - 1889, 53.5 ( memorie van antwoord) blz. 3 .

224. Tweede Kamer, zitting 1888 - 1889, 53.4 (voorlopig verslag ) blz. 4 .

225. Tweede Kamer, zitting $1888-1889,53.5$ ( memorie van antwoord ) blz. 4 .

Zowel in het voorlopig verslag als in de memorie van antwoord werd herhaaldelijk gesproken over de werkzaambeden van H.W.E. Struve en A.A. Bekaar. Deze werkzaamheden vloeiden voort uit een tweetal voorstellen van de enquête-commissie. Deze had er namelijk op aangedrongen, dat enige deskundigen zouden worden benoemd om dadelijk te beginnen in alle fabrieken in het land een plaatselijk onderzoek in te stellen en een nijverheidsstatistiek te bewerken (Bijlagen Tweede Kamer, zitting $1886-1887,105.5$ ( verslag der commissie ) par. 7 blz. $66 \mathrm{t} / \mathrm{m} \mathrm{71}$ ). Even daarvoor (Bijlagen Tweede Kamer, zitting 1886 - 1887, 105.5 (ver- 
slag der commissie ) par. $6 \mathrm{blz}$. 65 ) behandelde de commissie de vraag hoe het onderzoek door haar begonnen zou moeten worden voortgezet.

"Mochten evenwel de staatkundige omstandigheden doen voorzien, dat hervatting en voltooiing van het onderzoek door eene parlementaire commissie te groote vertraging dreigden te ondervinden, zoo zou de vraag kunnen rijzen, of ..... geen termen zouden zijn om dien arbeid met bekwamen spoed aan eene Staatscommissie op te dragen".

In februari 1888 riep de regering de leden van de enquête-commissie nog eens voor het laatst bijeen om advies te vragen over een instructie omtrent de op te dragen bewerking van een nijverheidsstatistiek. In dezelfde maand was de instructie klaar en kon de algemene fabrieksinspectie tot voorbereiding van een nijverheidsstatistiek op 1 maart 1888 beginnen ( K.b. van 20 februari 1888, no. 2; zie Stcrt. 21 februari 1888 , no. 44 ). Begin 1890 waren de werkzaamheden van Struve en Bekaar nagenoeg beëindigd. Bij K.b. van 23 januari 1890, Stb. 20, werden Bekaar, met ingang van 1 februari, en Struve, met ingang van 1 maart van dat jaar, ontheven van de hun opgedragen taak.

Zie C.W. de Vries, Van de Kinderwet-Van Houten tot de Arbeidswet 1889, in Soc. Jaarboek voor Nederland jrg. 1920 (deel MI 1922) blz. 12 t/m 14; Joh. Kerkvliet Asz, in K.S.W. 1925 blz. 460 en Verslagen van de Inspecteurs van den Arbeid in het Koninkrijk der Nederlanden over 1890 - verslag van derde inspectie, blz. 366 (zie ook aldaar bijlage I en II blz. $349 \mathrm{t} / \mathrm{m}$ 391).

De bij de regering binnengekomen adressen zijn te vinden in wetten 114 . Zie voor een overzicht van de bij de Tweede Kamer binnengekomen adressen: Tweede Kamer, zitting 1888 - 1889, 53.10 (verslag van de commissie van rapporteurs omtrent de verzoekschriften betreffende het ontwerp van wet ).

226. Artikel XVI van de nota van wijzigingen ( Tweede Kamer, zitting $1888-1889,53.6$ ).

227. Tweede Kamer, zitting 1888 - $1889,53.5$ ( memorie van antwoord) blz. 10 .

228. Tweede Kamer, zitting 1888 - $1889,53.8$ ( verslag ).

229. Tweede Kamer, zitting $1888-1889,53.9$ blz. 2 - 3 .

230. Tweede Kamer, zitting $1888-1889,53.17$.

231. Tweede Kamer, zitting $1888-1889,53.19$ ( nota van wijzigingen ).

232. Dit wijzigingsvoorstel werd gesteund door de leden Van Velzen, Van Kempen, Van Alphen, Schreinemacher en Bevers; zie Hand. Tweede Kamer, zitting 1888 - 1889 II, blz. 1087 - 1088.

233. Hand. Tweede Kamer, zitting 1888 - $1889 \mathrm{H}$, blz. 1089 .

234. De wijziging werd met 53 tegen 29 stemmen aangenomen; zie Hand. Tweede Kamer, zitting 1888 - 1889 II, blz.1098. Overigens werd het aldus gewijzigde artikel zonder hoofdelijke stemming aangenomen.

235. Hand. Tweede Kamer, zitting 1888 - 1889 II, blz. 1089 - 1090. Ook dit artikel werd zonder hoofdelijke stemming aangenomen.

236. Hand. Tweede Kamer, zitting 1888 - 1889 II, blz. 1090. Dit artikel werd ook zonder hoofdelijke stemming aaingenomen.

237. Eerste Kamer, zitting 1888 - 1889, 60 ( voorlopig verslag ). De commissie bestond uit de leden Prins, Melvil van Lynden, Van der Goes van Dirxland, Pijnappel en Regout. 
238. Eerste Kamer, zitting $1888-1889,60 \mathrm{a}$ ( eindverslag bevattend de memorie van antwoord).

239. Hand. Tweede Kamer, zitting $1888-1889 \mathrm{I}$, blz $1090 \mathrm{t} / \mathrm{m} 1098$. Het artikel werd overigens met 62 tegen 16 stemmen aangenomen.

240. Tweede Kamer, zitting 1888 - 1889, 53.40. De wijziging werd gesteund door Van Alphen, Hintzen, Heemskerk, W. Cremers en Reuther en werd met 59 tegen 10 stemmen aangenomen; zie Hand. Tweede Kamer, zitting $1888-1889 \mathrm{H}$, blz. 1100 .

241. Hand. Tweede Kamer, zitting 1888 - 1889 I, blz. 1099.

242. Hand. Tweede Kamer, zitting 1888-1889 II, blz, 1099.

243. Tweede Kamer, zitting 1888 - 1889, 53.47.

244. De wijziging werd met 52 tegen 31 stemmen aangenomen; zie Hand. Tweede Kamer, zitting 1888 - 1889 II, blz. 1123 .

245. Tweede Kamer, zitting 1888 - 1889 II, 53.39, 41 en 44.

246. Wet van 2 juni 1875 tot regeling van het toezigt bij het oprigten van inrigtingen, welke gevaar, schade of hinder kunnen veroorzaken, Stb. 95 .

Deze inrichtingen zijn:

"1e. de buskruitfabriek "de Krijgsman" te Muiden;

2e. alle rijksbuskruitmagazijnen, rijksbewaarplaatsen van dynamiet en schietkatoen;

3e. de rijkspyrotechnische werkplaatsen en de patroonfabriek;

4e. een bewaarplaats van dynamiet van de firma Rietschoten en Houwens te Rotterdam;

5e. enkele buskruitmagazijnen van particulieren en gemeentebesturen, waarin van 100 tot 1000 kilo buskruit mag worden bewaard;

6e. eenige bewaarplaatsen van patronen, behorende aan gemeentebesturen en weerbaar heidsverenigingen;

7e. alle bergplaatsen van kooplieden, geweermakers of andere winkeliers, die kleinhandel in buskruit drijven;

met uitzondering van de werkplaatsen en bewaarplaatsen van lustvuurwerken".

Van deze zeven categoriën vielen er echter al vijf buiten de werkingssfeer van de Arbeidswet 1889, namelijk de nos. 2, 4, 5, 6 en 7, omdat het om bewaarplaatsen handelde van ontplofbare stoffen waarin geen arbeid werd verricht anders dan het inbrengen en/of uithalen van deze stoffen. Ook no. 3 kwam niet in aanmerking, gezien het feit, dat voor bedoelde inrichtingen een afzonderlijke regeling werd voorgesteld. Bleef dus over de buskruitfabriek "de Krijgsman" te Muiden (zie Hand. Tweede Kamer, zitting 1888 - 1889 II, blz. 1121).

247. Hand. Tweede Kamer, zitting 1888 - 1889 II, blz. 1122. De minister bedoelde onder meer het adres tan het bestuur van de buskruitfabriek "de Krijgsman" aan de Kamer, waarin verzocht werd of de wet in het geheel niet op deze inrichting van toepassing te verklaren of daarvoor een speciale regeling te treffen; zie Tweede Kamer, zitting 1888 - 1889, 53.10 (verslag omtrent de verzoekschriften) blz. 3 . Het eerste punt vond gehoor bij de commissie van rapporteurs, die een dergelijk voorstel deed (zie Tweede Kamer, zitting 1888 $1889,53.9$ (voorgestelde amendementen) blz. 3 ), dat door de minister werd overgenomen (zie Tweede Kamer, zitting 1888 - 1889, 53.37 ( gewijzigd ontwerp van wet, gelijk het luidt na de daarin tot 8 april 1889 gebrachte wijzigingen )). 
248. Zie Tweede Kamer, zitting 1888 - 1889, 53.4 (voorlopig verslag) blz. 18; Tweede Kamer, zitting 1888 $1889,53.6$ ( nota van wijzigingen ).

249. Deze lagere ambtenaren zijn:

"de bosch- en veldwachters, de onderofficieren en minderen der marechaussee en de ambtenaren van Rijks- en gemeentepolitie beneden den rang van commissaris ....".

250. Tweede Kamer, zitting 1888 - $1889,53.4$ (voorlopig verslag ) blz. 19.

251. Artikel 272 van het Wetboek van Strafrecht luidde:

"Hij die opzettelijk eenig geheim, hetwelk hij, uit hoofde van zijn hetzij tegenwoordig hetzij vroeger ambt of beroep, verplicht is te bewaren, bekend maakt, wordt gestraft met gevangenisstraf van ten hoogste zes maanden of geldboete van ten hoogste zes honderd gulden. Indien dit misdrijf tegen een bepaald per:oon gepleegd is, wordt het slechts vervolgd op diens klacht".

Zie A.J. Fruyn, De Nederlandsche Wetboeken, Den Haag 2 e druk 1888.

Artikel 272 luidt thans:

"Hij die enig geheim, waarvan hij weet of redelijkerwijs moet vermoeden, dat hij uit hoofde van ambt, beroep of wettelijk voorschrift, dan wel vroeger ambt of beroep verplicht is het te bewaren, opzettelijk schendt, wordt gestraft met gevangenisstraf van ten hoogste een jaar of geldboete van ten hoogste zes duizend gulden.

Indien dit misdrijf tegen een bepaald persoon gepleegd is, wordt het slechts vervolgd op diens klachte".

252. Tweede Kamer, zitting 1888 - 1889, 53.5 ( memorie van antwoord) blz. 11.

253. Hand. Tweede Kamer, zitting 1888 - 1889 II, blz. 1126 t/m 1128.

254. Zie onder meer Tweede Kamer, zitting 1888 - 1889, 53.34 en 36 ( nota's van wijzigingen ); zie voor de mondelinge beraadslaging en stemmingen Hand. Tweede Kamer, zitting 1888 - $1889 \mathrm{II}$, blz. 1066 en blz. 1068 t/m 1079 .

255. Hand. Tweede Kamer, zitting 1888 - 1889 II, blz. 1147.

256. Hand. Tweede Kamer, ziting 1888 - 1889 II, blz. 843.

257. Na de stemming verklaarde Blijdestein (wakker geworden?) het volgende:

"Mijnheer de Voorzitter! Bij vergissing heb ik mijne stem uitgebracht w66r het wetsontwerp.

Zoals uit mijne rede voldoende gebleken is, was het mijn voornemen om tegen te stemmen".

Zie Hand. Eerste Kamer, zitting 1888 - 1889 I, blz. 281.

258. Wet van 5 mei 1889, Stb. 48. Blijkens artikel 26 trad de wet op 1 januari 1890 in werking, terwijl op datzelfde moment de Kinderwet-Van Houten kwam te vervallen.

Zie over de Arbeidswet 1889 onder meer: J. Oppenheim, De Wet van 5 Mei 1889 ( Staatsblad no. 48 ) tot het tegengaan van overmatigen en gevaarlijken arbeid van jeugdige personen en van vrouwen, Groningen 1889; H. Goeman Borgesius, De Arbeidswet, Sneek 1889; A. Diepen, De Arbeidswet, toelichtingen en beschouwingen, voornamelijk met het oog op de Tilburgsche wolindustrie ( zie hierover H. Goeman Borgesius, De Arbeidswet en hare uitvoering, in De Economist $1889 \mathrm{blz}$. $659 \mathrm{t} / \mathrm{m} 678$ ); A.D. van Assendelft de Co- 
ningh, De wet op den vrouwen- en kinderarbeid, in De Economist $1889 \mathrm{blz} .280 \mathrm{t} / \mathrm{m} .295 \mathrm{en}$ blz. $353 \mathrm{t} / \mathrm{m} 361$; J.Th. Mouton, Op weg, in Vragen des Tijds $1889 \mathrm{II} \mathrm{blz.} 131 \mathrm{t} / \mathrm{m} 151$.

259. Zie onder meer A.J.W. Camijn, Een eeuw vol bedrijvigheid. De industrialisatie van Nederland, 1814 1914, Utrecht/Antwerpen 1987, blz. 27; J. de Vries, t.a.p., blz. $63 \mathrm{t} / \mathrm{m} 66$.

260. International Labour Office, The Organisation of Labour Inspection in Industrial and Commercial Undertakings, Geneva 1939, p. 5 - 6. Het hier gegeven overzicht is gebaseerd op het jaar waarin een dergelijke inspectie bij wet is ingesteld.

261. Zie hierover onder meer B.L. Hutchins/A. Harrison, A History of Factory Legislation, London $2 \mathrm{~d}$ ed. 1911; M.W. Thomas, The early Factory Legislation, Leigh-on-Sea 1948. Zie ook T. Wilthagen, Hoe werkt de Engelse arbeidsinspectie, in SR $1989 \mathrm{blz} .6 \mathrm{t} / \mathrm{m} 11$.

262. Zie C.W. de Vries, in Soc. Jaarboek woor Nederland jrg. 1920 ( deel III 1922) blz. 14.

263. Zie ook C.W. de Vries, in Soc. Jaarboek voor Nederland jrg. 1920 (deel III 1922) blz. 2 t/m 27 . Zie voorts hfdst. 3 par. 3 ( roep om uitbreiding) en par. 4 (maatregelen in het belang van de veiligheid en gezondheid ). 


\section{Inleiding}

\subsection{De industrialisatie en het ontstaan van de moderne arbeldsverhoudingen}

Uit de inleidlende paragraaf van het vorige hoofdstuk valt al af te leiden, dat in ons land omstreeks 1870 een nieuwe tijd aanbrak; een gestaag toenemende industrialisatie, die zich afspeelde in de periode 1870 tot 1914. Een kenmerk van de industrialisatie is concentratie, zij het dat dit in ons land minder sterk gebeurde dan elders. Een bepaald industriegebied kende ons land niet; iedere industrie had zijn eigen concentratiegebied, die vaak door tal van historische oorzaken ontstonden. De textielindustrie bijvoorbeeld vestigde zich in Twente en het oostelijke deel van Noord-Brabant; de industrie van voedings- en genotmiddelen zetelde in de Zaanstreek; de belangrijkste landbouwindustriën waren te winden in de veenkoloniën. Noch de aanwezigheid van ertsen, noch die van mijnen - de Limburgse mijnen werden te laat op grote schaal tot ontginning gebracht om de vestigingsplaats van de industrie te beinvloeden ${ }^{\prime}$, noch die wan waterkracht, kon de industrie op bepaalde gebieden samentrekken. Juist het goedkope transport te water had tot gevolg, dat de vestigingsmogelijkheden van de industrie tallijk waren. Meermalen waren het als gevolg daarvan de kosten van de arbeidskrachten die beslissend waren ${ }^{2}$.

Een belangrijk kenmerk van de als gevolg van de industrialisatie gevormde modern kapitalistische tijd is het bestaan van een arbeidersklasse, die zich als een klasse voelt en als zodanig tegenover een andere klasse, in dit geval die van de ondernemers staat ${ }^{3}$. Kuczynski ${ }^{4}$ verwoordde dit als volgt:

"De moderne arbeidersklasse is het produkt van de machine. $\mathrm{Zij}$ is geen vereniging van mensen, gevormd door persoonlijke toetreding van gelijkgezinden op grond van persoonlijke gevoelens op politiek of ander gebied. $\mathrm{Zij}$ is het resultaat van de ontwikkeling van de krachten in de produktie. $\mathrm{Zij}$ is een schepping van de machine, om precies te zijn: van het machinale werktuig. Zonder machines geen arbeidersklasse".

Van omstreeks 1870 af gaat de arbeidende klasse zich dan in vakverenigingen organiseren. Daarvoor associeerden de arbeiders zich voor twee doeleinden, namelijk gezellig samenzijn en de vorming van fondsen tot onderlinge bijstand. Van een vakbeweging kan eerst gesproken vanaf 1866, het jaar waarin de Algemeene Nederlandsche Typografenbond werd opgericht. Andere groepen handwerkers en geschoolde arbeiders volgden het voorbeeld van de typografen en stichtten eveneens vakverenigingen. In de verdere ontwikkeling van deze vakverenigingen komt de actie voor verbetering van de arbeidswoorwaarden door middel van collectieve arbeidsovereenkomsten steeds meer centraal te staan. Verder werden de patroons van het lidmaatschap uitgesloten ${ }^{5}$. In 1869 volgde het "Nederlandsch Werklieden Verbond, Afdeeling der Internationale Arbeidersvereeniging", een Nederlandse afdeling van de in 1864 te Londen gestichte "Internationale", de radikale internationale stroming die haar impulsen kreeg uit de socialistische theorieèn. In de inleidende paragraaf van het worige hoofdstuk is al het ontstaan van het eerste vakverbond - het Algemeen Nederlandsch Werkliedlen Verbond - in 1872 gememoreerd, de gematigde, meer liberale stroming ${ }^{8}$. De ontluikende vakbeweging zou derhalve al snel uiteenlopende richtingen inslaan. In 1876 wiel het besluit om een specifiek protestantse werkliedenvereniging op te richten, namelijk het "Nederlandsch Werklieden Verbond "Patrimonium" overigens ook patroons lid konden worden, hetgeen derhalve een stap terug betekende voor de ontwikkeling van het vakverenigingsbeginsel. In de aanvangsjaren van de Nederllandse vakbeweging waren dus drie richtingen waar te nemen: de christelijke, de gematigde en de radicale. Rooms-katholieke organisaties waren nog slechts in de kiem aanwezig; pas in 1889 ontstond de eerste rooms-katholieke vakvereniging te Ensche$\mathrm{de}^{7}$. 
Naarmate de arbeiders tot het oprichten van vakverenigingen en -bonden overgingen, groeide bij de werkgevers het besef, dat ook voor hen organisatie onvermijdelijk was. Tegen het einde van de negentiende eeurw manifesteerde zich dit streven van werkgeverskant in de vorm van "getuigende" verenigingen, dat wil zeggen verenigingen die het standpunt van de werkgevers ten aanzien van actuele economische gebeurtenissen en sociale vraagstukken weergaven; een voorbeeld daarvan was de eerste, nog van voor de eeuwwisseling daterende Vereniging van Nederlandse Werkgevers ${ }^{b}$.

In het begin van deze eeuw ontstonden echter ook werkgeversvakverenigingen, die minder naar buiten traden en slechts ten doel hadden, de belangen van de werkgevers te behartigen tegenover de georganiseerde arbeiders, zoals het in 1907 opgerichte Verbond van sigarenfabrikanten. Ook de werkgevers konden zich niet onttrekken aan de algemene ontwikkeling; de overgang van individueel naar collectief optreden ${ }^{9}$.

Van groot belang voor de Nederlandse vakbeweging waren de spoorwegstakingen van $1903^{10}$. De strijd ging niet om verbetering van de arbeidsvoorwaarden, maar om de verhouding tussen de werkgevers en de werknemersorganisaties. Uiteindelijk zou de richtingenstrijd in de vakbeweging resulteren in de oprichting van drie landelijke organisaties. Op 1 januari 1906 begon het neutrale "Nederlandsch Verbond van Vakverenigingen" zijn werkzaamheden. In 1909 werd het "Christelijk Nationaal Vakverbond" opgericht, dat aanvankelijk een interconfessionele grondslag had ${ }^{11}$. In de praktijk zou het echter een protestantse organisatie worden, met name door de houding van de roomse geestelijkheid ${ }^{12}$. Hoewel van rooms-katholieke zijde moeilijker dan anderen de stap gezet kon worden tot het oprichten van een vakcentrale ${ }^{13}$, zou in 1909 toch een landelijk "Bureau voor Roomsch-Katholieke Vakorganisatie" worden opgericht ${ }^{14}$.

Overigens richtte vooral de eerstgenoemde vakorganisatie zich sterk op de sociale wetgeving, waarbij aanvankelijk alleen de arbeidsduur centraal stond en de rol die het parlement daarbij kon spelen. Hoewel al sinds 1 mei 1890 jaarlijks werd gedemonstreerd voor een achturige werkdag, werd de tienurige werkdag als overgangsfase nagestreefd. Gezamelijk met de Sociaal Democratische Arbeiderspartij werd in het najaar van 1907 een enquête gehouden naar de arbeidsomstandigheden. Het jaar daarop werden de resultaten van deze enquête gepubliceerd ${ }^{15}$. Uit deze enquête bleek, dat vaker langer dan elf uren werd gewerkt; in bijvoorbeeld winkels, magazijnen, bakkerijen en in de strokartonindustrie werden nog langere werktijden aangetroffen. Bovendien werd aangetekend, dat het nog een gunstig beeld was, omdat de informatie niet afkomstig was "van de slechtst gestelde arbeiders, integendeel het zijn de georganiseerden of in elk geval degenen, in wier midden de organisatie haar zegenbrengend werk heeft verricht" ${ }^{\text {t16 }}$.

Maar al snel zou ook de veiligheid en de gezondheid op haar verlanglijst komen te staan. Van den Tempel ${ }^{17}$ bepleitte

"mede in verband met de toeneming van den fabrieksmatigen arbeid en het onophoudelijk

invoeren van nieuwe procédés"

nieuwe wettelijke voorschriften of de aanscherping van bestaande

"ter beveiliging van den arbeid bij machines"

en de bescherming van

"de gezondheid en het leven van groote groepen arbeiders".

Daarbij noemde hij onderwerpen als verlichting, lucht, dampen, kleed- en schaftlokalen en temperatuur ${ }^{18}$.

\subsection{Motieven voor overheldsingrijpen}

$\mathrm{Na} 1850 \mathrm{kregen}$ de liberale economische beginselen meer ruimte. De toen heersende liberale opvatting over de rol van de overheid werd het duidelijkst weergegeven in het volgende in het Sociaal Weekblad van 1889 aangehaalde citaat van Bastiat $^{19}$ :

"Te waken voor onze veiligheid, het gemeenschappelijk domein te beheeren en de belastingen te innen - dat is, geloof ik, de kring waarbinnen de attributen van de staat moet beperkt blijven of teruggebracht worden". 
De industrie kon zich, toen de industrialisatie eenmaal op gang was gekomen, gestaag ontwikkelen: er was vrijheid van vestiging, van produktie en van prijsworming. En, hoewel er vanouds een overheidstoezicht was op stoomtoestellen en op gevaarlijke of hinderlijke fabrieken, strekte dit toezicht zich niet uit tot de kwaliteit van het produkt. De rol van de overheid in relatie tot de nijverheid beperkte zich tot een aantal wettelijke maatregelen, die er niet op gericht waren om de industrie aan banden te leggen, maar om bet liberale beginsel van vrije concurrentie tot uitdrukking te brengen. Gedacht moet hierbij worden aan de regelingen terzake van het octrooi-, merken- en auteursrecht. De octrooiregeling, aanvankelijk in 1869 ingetrokken ${ }^{20}$, hetgeen er toe leidde, dat de uitvinder niet langer van overheidwege werd beschermd, zodat diens uitvindingen ongehinderd ter beschikking van de gemeenschap kwamen, zou in 1910 als Octrooiwet ${ }^{21}$ opnieuw het daglicht zien. Hiermee kwam een einde aan de wonderlijke situatie, dat Nederlandse uitvindingen in het buitenland wel, maar in ons land geen bescherming vonden. De Merkenwet van $1893^{22}$ bestreed een vorm van concurrentie die bestond uit het namaken van fabrieks- en handelswaren en daarmee het misleiden van de consument. Sinds 1881 beschermde de Auteurswet de geestelijke eigendom van Nederlandse schrijvers. De reikwijdte van deze regeling beperkte zich slechts tot jns eigen land; in het buitenland waren de Nederlandse schrijvers vogelvrij. De Auteurswet $1912^{23}$ zou hieraan een einde maken.

Overheidsingrijpen op economisch gebied ten einde de vrije concurrentie te waarborgen werd derhalve geaccepteerd; daarbij speelt een belangrijke rol, dat de overheid neutraal dient te blijven. Maar het betrof niet alleen louter de gememoreerde maatregelen. Zeker niet onvermeld mag blijven het afschaffen van het coalitieverbod. Arbeiders die zich wilden verenigen werd geen strobreed in de weg gelegd, maar een bepaalle uitingsvorm van deze vereniging, de werkstaking, was in artikel 415 van de Code Pénal verboden. Hét kenmerk van de bepalingen 414 tot en met 416 van de Code Pénal was, dat de patroon en de arbeiders in deze artikelen niet gelijk werden behandeld. Eerst in 1872 werden deze bepalingen afgeschaft ${ }^{24}$. Waarom zo laat? De bezwaren tegen de artikelen waren meer dogmatisch dan van praktische aard en gebaseerd op het principe van de vrije concurrentie. Eerst toen met het optreden van de vakbeweging de bewuste bepaling knellend werd, werden de gewraakte artikelen afgeschaft. De artikelen druisten in tegen de heersende liberale opvattingen, omdat zij de vrije concurrentie van de koopwaar "arbeid" belemmerden. In De Economist van 1859 stond daaromtrent al het volgende geschreven ${ }^{26_{*}}$.

"Bij het bestaan van vrije concurrentie kan het beginsel niet gewraakt worden om den arbeider, de eene partij, even zoo goed vrijheid te laten, als zulks de andere partij, den meester, vrijstaat... De taak van het gouvernement is dan ook hier geenszins, om alle dergelijke arbeidersafspraken bepaald te onderdrukken".

Van Houten was eveneens voorstander van staatsingrijpen op dit gebied. De reden daarvoor was eenvoudig. De staat was niet neutraal; door haar wetgevende maatregelen was juist de positie van de kapitaalbezittende klasse versterkt ten koste van de arbeidende klasse. Ten aanzien van het coalitieverbod merkte hij het volgende op ${ }^{2 e}$ :

"Heeft toch niet de strafwet de organisatie van arbeidersvereenigingen belemmerd, en de loontrekkenden verhinderd in vakvereenigingen voor de verkrijging en handhaving van billijke loonen en arbeidscondities een hecht bolwerk tegen de magt van het kapitaal op te rig$\operatorname{ten}^{H} ?^{27}$

Maar hoe zit het nu met de motieven voor overheidsingrijpen door middel van arbeidsbeschermende wetgeving? Er kan te dienaangaande een aantal motieven worden onderscheiden, die zowel alleen of gecombineerd voorkomen: het economische, het humanitair-christelijke, het culturele, het politieke en het militaire motief. Het millitaire motief wordt al in 1860 door De Vries Robbe genoemd. De reden hiervoor vloeide voort uit het feit, dat in Leiden ongeveer de helft van de dienstplichtigen voor de nationale militie werd afgekeurd $^{28}$. Coronel had dit verschijnsel eveneens waargenomen ${ }^{26}$. Ook de door de toenmalige bewindsman van Binnenlandse Zaken Thorbecke op 30 september 1863 ingestelde commissie om een ondezoek in te stellen naar de kinderarbeid gaf aan dat dit motief voor haar belangrijk was. 
Behalve de deelneming in hun lot, zal ook dit motief krachtig moeten wegen om het door ons voorgeslagen middel in overweging te doen nemen ${ }^{130}$.

Het humanitaire-christelijke motief is aan te treffen bij bijvoorbeeld Cremer ${ }^{34}$, Van Assendelft de Koningh $^{32}$ en niet te vergeten Coronel ${ }^{33}$, daar waar hij een regeling voor zwangere vrouwen voorstaat. Oppenheim voert dit motief aan als hij de redenen die aan het verbod van nachtarbeid door vrouwen in de Arbeidswet 1889 ten grondslag liggen, noemt, namelijk bevordering van het huwelijksleven en vrijwaring van een vroege dood ${ }^{34}$. Ook de toenmalige bewindsman Ruys van Beerenbroek hanteert dit motief, bij de regeling wan de vrouwenarbeid, ter wille van het familieleven en de huiselijke belangen ${ }^{35}$. Het economische motief wordt door de toenmalige minister Du Tour van Bellichave gebezigd ${ }^{36}$, maar komt heel duidelijk naar voren in een adres van de Friese Maatschappij van Landbouw aan Koning Willem III ${ }^{37}$, waarin wordt aangedrongen op een verbod van landbouwarbeid door kinderen. De motivering is als volgt:

"De landbouw heeft behoefte aan ontwikkelde arbeiders, die op oordeelkundige wijze den arbeid, die van hun gevorderd wordt kunnen verrigten. Immers sedert de landbouw eene wetenschap is geworden en de handarbeid veelal moet plaats maken voor werktuigen, waaronder vele van ingewikkelde zamenstelling, heeft men arbeiders noodig met onwtikkeld verstand. De Maatschappij van landbouw meent, dat er nimmer zoodanige arbeiders zullen groeien uit kinderen, die weinig of niets hebben geleerd, en door te vroegtijdigen arbeid als het ware zijn verstompt".

Huet $^{38}$ meent, dat wetten die in het belang van de staat zijn, moeten worden ingevoerd, hetgeen een verwijzing inhoudt naar het politiek motief. Rommerts, een afgevaardigde van de Friesche Werkliedenvereeniging stelde daar het volgende over tijdens "Het Paaschcongres" van het Algemeen Nederlandsch Werklieden Verbond $^{30}$ :

"In naam der rust en orde van de maatschappij vragen wij zo'n wet, omdat we de ruwe kracht der verwaarloosde vreezen en die wenschen te besctrijden door het aankweeken van ontwikkeling en beschaving door bekwaamheden, die ten grondslag moeten leggen om de nietsbezittende massa - die niets meent te verliezen te hebben maar alles bij eene gewelddadige omverwerping der bestaande orde te kunnen winnen - bezitters te maken en hen alzoo belang te doen hebben bij de algemeene rust em orde en eerbiediging van wetten in den Staat" ${ }^{\prime \prime 40}$.

Tot slot het culturele motief. Dit is te vinden in de statuten van het Algemeen Nederlandsch Werklieden Verbond, waarin wordt gepleit voor een tien-urige werdag

"opdat de werkman gelegenheid verkrijge zijne kennis en wetenschappelijke ontwikkeling te vermeerderen ${ }^{\prime \prime 4}$.

In veel gevallen werd voor staatsingrijpen gepleit op grond van verschillende motieven. Van Houten bijvoorbeeld hanteerde zowel het christelijke-humanitaire als het economische motief.

"Niet eene enkele misdaad ten aanzien van kinderen gepleegd beweegt mij hier, maar de overtuiging, dat de kinderarbeid den oekonomischen toestand van de maatschappij desorganiseert",

aldus Van Houten tijdens de verdediging van zijn wetsvoorstel in de Tweede Kamer ${ }^{42}$. In de toelichting op zijn wetsvoorstel benadrukte hij tevens het volgende:

Het ontwerp bevat niet alles wat gewenscht is. Het bepaalt zich tot hetgeen thans bereikbaar geacht wordt. Later zal meer moeten en kunnen worden gedaan. Niet op eenmaal is een organisatie van de volksbedrijvigheid te bereiken, waarbij niet meer ten koste van den mensch zal worden voortgebragt; - waarbij de gezondheid en het huisselijk leven des werkenden, en de ontwikkeling zijner kinderen ten volle gewaarborgd zullen zijn. Voortdurend zullen alle krachten, ook der wetgevende magt, op dit doel gerigt moeten worden ${ }^{\text {th43 }}$.

Een zelfde combinatie van motieven is te vinden in het adres van de Nederlandsche Maatschappij ter bevordering van Nijverheid aan Koning Willem III. In dit adres werd de aandacht gevestigd op 
"de nadeelige gevolgen, welke een overmatige arbeid dier kinderen op hunnen ligchamelijke en zedelijke ontwikkeling hebben moet",

maar tevens op het feit,

"dat de Nijverheid op den duur groote schade zou lijden, wanneer een ziekelijk en verwaar-

loosd geslacht opgroeide ${ }^{\mathrm{n} 44}$.

Een commissie van het Nederlandsch Schoolverbond voegde hier nog een derde motief aan toe. Het economische motief ligt in de verwijzing naar de bedreiging van het toekomstige kapitaal van de maatschappij; het humanitair-christelijke motief verwijst naar het feiten, dat er mensen, die te krachteloos en te machteloos zijn om voor hun eigen belangen op te komen, en tot slot het politieke motief, dat aan de staat niet alleen de bevoegdheid toekomt, maar dat er tevens een verplichting op haar rust om in te grijpen, wanneer orde en rust van de maatschappij kunnen worden verstoord ${ }^{45}$. Ook Veegens ${ }^{46}$ bezigde deze drie motieven voor staatsingrijpen ${ }^{47}$.

Conchuderend kan gesteld worden, dat aan het overheidsingrijpen op sociaal terrein verscheidene motieven ten grondslag lagen, die regelmatig terugkeerden; én en ander betekent, dat het moeilijk is om het ingrijpen terug te voeren tot éen motief. Wellicht, dat het humanitair-christelijke motief het zwaarst gewogen heeft ${ }^{48}$.

\subsection{De toenemende overheidszorg}

Met de Kinderwet-Van Houten was een belangrijke mijlpaal bereikt. De staat was gerechtigd om in te grijpen. De volgende was hoe ver de staat zijn beschermende hand diende uit te strekken. Beschermde de wetgever in 1874 zich principieel tot de onmondigen, voorzover er te hunnen aanzien misstanden niet op een andere wijze bestreden konden worden, bij de totstandkoming van de Arbeidswet 1889 betoogde de toenmalige bewindsman van Justitie het volgende ${ }^{48}$ :

"De grenzen der staatsbemoeiing moeten worden uitgebreid in weerwil van een vroeger aangenomen beginsel, indien veranderde toestanden het eischen".

De reikwijdte van de Arbeidswet 1889 strekte zich niet uit over volwassen mannen; omdat het nog niet nodig werd geacht ook hen onder de beschermende wetgeving te brengen:

"Alleen noodzakelijkheid zou dien stap kunnen wettigen, en die is vooralsnog niet geble$\mathrm{ken}^{\text {ingo }}$.

Dat in een korte periode snel veel kan veranderen blijkt uit het feit, dat in de periode tussen 1890 en 1914 een stelselmatige uitbreidling van het arbeidsomstandighedenrecht plaatsvindt en verschillendle pogingen werden ondernomen waarbij ook volwassen mannen onderwerp van regeling zouden zijn. Overigens merkte de wetgever ten aanzien van de gehuldigde gedachte, dat de Arbeidswet 1889 zijn bescherming zou uitstrekken over wat genoemd wordt de "personae miserabiles", op, dat het

"niet gemakkelijk zoude vallen deze stelling met ene beroep op de geschiedenis dier wet te bewijzen ${ }^{\text {not }}$.

Maar de bescherming van de loonarbeider bleef in deze periode niet alleen beperkt tot de arbeidsomstandigheden. De liberale opvattingen ondergingen een wijziging onder invloed van de gewijzigde economische en sociale omstandigheden. Te denken valt aan de Leerplichtwet $1900^{62}$, waarmee een definitief einde werd gemaakt aan het nog niet uitgeroeide analfabetisme. Van principiële betekenis was vervolgens de Woningwet van $1901^{53}$, waarmee de wetgever een eerste stap zette op een terrein, waar de gemeentebesturen al vele stappen hadden gezet. Ondanks het feit, dat vele gemeenten een verordening bezaten, waarbij aan bestaande en nieuw te bouwen woningen bepaalde eisen werden gesteld, was de woningvoorziening op het breukvlak van twee eeuwen nog treurig gesteld. In hetzelfde jaar werd nog een belangrijke andere mijlpaal geslagen, namelijk het begin van de sociale verzekering.

Tot slot moet nog gewezen worden op de Wet op de arbeidsovereenkomst van $1907^{54}$. Formeel was dit niets meer dan een wijziging van het Burgerlijk Wetboek, maar de nieuwe wet bracht een belangrijke verbe- 
tering van de rechtspositie van de arbeiders als zwakste partij bij het sluiten van een arbeidsovereenkomst. De drie daarvoor geldende bepalingen in het Burgerlijk Wetboek waren verouderd en onrechtvaardig jegens de arbeider ${ }^{55}$. De nieuwe regelgeving is om een andere reden nog belangrijk; het bevatte een, zij het summiere regeling van de collectieve arbeidsovereenkomst, waarmee dit rechtsinstituut een wettelijke status kreeg.

\section{In den beginne waren er slechts drle}

Naast het verbod van kinderarbeid bevatte de Arbeidswet 1889 beschermende bepalingen ten aanzien van de arbeids-en rusttijden voor jeugdige personen en voor vrouwen voor zover zij arbeid verrichten in fabrieken en werkplaatsen. In artikel 4 van de wet was bovendien de mogelijkheid geopend om voor deze arbeiders bij algemene maatregel van bestuur op grond van gevaren voor de gezondheid of het leven bepaalde soorten van arbeid te verbieden of slechts onder bepaalde voorwaarden toe te staan. Blijkens artikel 12 werd het toezicht op de uitvoering van de wet opgedragen aan drie door de Kroon te benoemen inspecteurs; 6 én en ander onder de bevelen van de met de uitvoering van de wet belaste bewindsman van Justitie. Hetzelfde artikel bepaalde voorts, dat de werkkring en de bevoegdheden van deze inspecteurs bij algemene maatregel van bestuur geregeld dienden te worden. Naast het toezicht op de uitvoering waren de inspecteurs op grond van artikel 18 van de wet tevens belast met de opsporing van overtredingen hiervan ${ }^{58}$.

Hoewel de Arbeidswet 1889 zelf op 1 januari 1890 in werking trad ${ }^{57}$, zou de in artikel 12 bedoelde algemene maatregel van bestuur eerst op 28 februari van dat jaar van kracht worden ${ }^{58}$. Ten behoeve van de "Inspecteurs van den arbeid", zoals de officiële naam van de betreffende ambtenaren zou luiden ${ }^{\text {Bg }}$, werd het Rijk verdeeld in drie "arbeidsinspectiê $\mathrm{n}^{\text {"1800 }}$. Bij deze verdeling is met name de bereikbaarheid via de spoorwegen van grote betekenis geweest. Door de minister van Justitie werd aan elke inspecteur van de arbeid een "arbeidsinspectie" toegewezen, waarin hij bevoegd was. Voorts wees de bewindsman ook hun standplaats $\operatorname{aan}^{\text {"1. }}$.

Hierna konden de drie inspecteurs - Kuyper, Van Löben Sels en Struve - op 1 maart 1890 met hun werkzaamheden aanvangen ${ }^{62}$. Bij de benoeming van de inspecteurs hebben de politieke verhoudingen van dat moment een rol gespeeld. Zo behoorde Kuyper tot de Rooms-Katholieke Staatspartij, was Van Löben Sels anti-revolutionair en werd Struve tot de liberale partij gerekend. Uit de door hen voordien beklede functies, respectievelijk scheikunde-leraar aan de H.B.S. te Zwolle, ingenieur van het Waterschap De Berkel en ingenieur van het stoomwezen ${ }^{63} \mathrm{kan}$ worden afgeleid, dat bij hun benoeming tegemoet gekomen is aan de door de parlementaire enquête-commissie van 1886 naar voren gebrachte voorkeur voor technische ambtenaren $^{64}$.

$\mathrm{De}$ ( nadere ) uitwerking van het aan de inspecteurs van de arbeid opgedragen toezicht op de uitvoering was geregeld in het op artikel 12 van de wet gebaseerde Besluit van 21 februari $1890^{\circ 5}$. In de eerste plaats werd in dit Besluit herhaald, dat de inspecteurs belast zijn met het toezicht op de uitvoering van de wet onder de toevoeging met de naar aanileiding daarvan uitgevaardigde Koninklijke besluiten en ministeriële voorschriften $^{\text {e6 }}$, waartoe zij naarmate zulks nodig werd geoordeeld; bezoeken hadden te brengen aan de plaatsen, waar arbeid werd verricht of pleegde te worden verricht. Teneinde een gelijkvormige toepassing van de Arbeidswet 1889 en de daarop gebaseerde uitvoeringsbesluiten en ministeriele voorschriften te bevorderen, dienden de inspecteurs van de arbeid met elkaar in overleg te treden ${ }^{\text {e7 }}$. Hiertoe werd door hen een college gevormd, waarvan tén van hen voorzitter was; een functie die het eerst door Struve werd vervuld. In de tweede plaats moesten zij zoveel mogelijk overeenstemming bevorderen tussen de eisen van de wetgeving en de belangen van alle bij de arbeid betrokken personen en aan hen, die arbeid doen verrichten, alle zodanige inlichtingen verstrekken en voorstellen doen, die konden leiden tot het wegnemen van bezwaren, die anders uit de toepassing van de wettelijke voorschriften voor de nijverheid zouden kunnen voortvloeien ${ }^{*}$. Deze taakomschrijving van de inspecteurs geeft een aardige indicatie van de toenmalige verhoudingen: het 
geven van inlichtingen en het doen van voorstellen die ertoe moeten leiden, dat de bedoelde bezwaren weggenomen moeten worden, is gericht tot degene(n) die arbeid doet (doen) verrichten en niet tot degene die de arbeid verricht. De te beschermen arbeiders werden (nog) als objecten beschouwd. In de derde plaats hadden de inspecteurs tot taak in het kader van een juiste uitvoering van artikel 4 van de wet ${ }^{\text {eq }}$ in het bijzonder te letten op de gevaren die bepaalde soorten van arbeid opleverden ${ }^{70}$ voor de gezondheid of het leven van personen beneden de zestien jaar en van vrouwen, hetzij in het algemeen, hetzij bij niet inachtneming van zekere voorwaarden of door de wijze waarop zij verricht worden of door de verwerkt wordende stoffen. In de vierde en laatste plaats hadden de inspecteurs de betrokken bewindsman desgevraagd van bericht en advies te dienen aangaande alle onderwerpen van wetgeving betreffende de arbeid en konden zij hem te dienaangaande voorstellen doen die zij nodig of wenselijk achtten. Desgevraagd dienden zij de commissarissen van de Koning en de burgemeesters van advies omtrent het verlenen van overwerkvergunningen en vergunningen omtrent het toestaan van arbeid op zondag in verband met onderhoud- en herstelwerkzaamheden ${ }^{71}$. Het bedoelde Besluit gaf bovendien aan wat uitdrukkelijk niet tot de taak van de inspecteurs behoorde,namelijk het geven van algemene voorschriften door middel van reglementen, instructies of circulaires $^{72}$. Tot slot moet nog vermeld worden, dat de inspecteurs op grond van artikel 16 van de wet zelf jaarlijks ${ }^{73}$ een beredeneerd verslag over hun ambtsbezigheden dienden op te stellen en dit aan de verantwoordelijke minister te zenden.

De ruime taakstelling in het eerderbedoelde Besluit van 21 februari 1890 leidde ertoe, dat de inspecteurs zich naast het toezicht op de uitvoering van de Arbeidswet 1889 bezig hielden met het opnemen van de toestanden in fabrieken en werkplaatsen, het verzamelen van gegevens en het adviseren over de hygiëne en de beveiliging tegen ongevallen, het instellen van een onderzoek naar de sociale instellingen in het belang van de arbeiders alsmede de verdere voltooiing van de nijverheidsstatistiek, waarmee een begin was gemaakt door Struve - inmiddels inspecteur in de derde "arbeidsinspectie" - en Bekaar ${ }^{74}$.

De taak met betrekking tot de Arbeidswet 1889 hield in het zich op de hoogte stellen van de wijze waarop en de mate waarin de wet werd nageleefd. Het opsporen van overtredingen rekenden de inspecteurs niet in de eerste plaats tot hun taak, maar werd als de plicht van de politie beschouwd; men kan zich afvragen of deze restrictieve taakopvatting van de inspecteurs wel overeenkomstig het wettelijk gegeven voorschrift is. De inspecteurs zouden alleen hebben te zorgen voor ${ }^{75}$

"wetsdadige en gelijkmatige toepassing en voor het verkrijgen van rechterlijke uitspraken in hoogste ressort omtrent de uitlegging der wettelijke bepalingen".

Bij schrijven van 24 mei $1890^{7 \theta}$ was door de toenmalige minister van Justitie aan onder andere de officieren van justitie en aan ambtenaren van het openbaar ministerie bij de kantongerechten opgedragen elke veroordeling terzake van de wet - door toezending van een afschrift van het vonnis - ter kennis te brengen aan de inspecteurs van de arbeid. Uit een later schrijven ${ }^{77}$ an de procureurs-generaal van de gerechtshoven blijkt, dat hieraan onvoldoende gevolg werd gegeven. Bovendien werd aldaar aangedrongen om ook rechterlijke uitspraken die ontslag van rechtsvervolging bevatten binnen acht dagen - dus woor het verstrijken van de termijn voor hoger beroep - aan de inspecteurs toe te zenden, zodat over de wenselijkheid van beroep nog overleg mogelijk was tussen de inspecteurs en het openbaar ministerie. Een dergelijk overleg werd, blijkens de bedoelde brief, ook gewenst geacht met betrekking tot het laten instellen van cassatie in het belang van de wet. Volstaan kon nu echter worden met een kennisgeving in een voorgeschreven briefvorm.

Waar de Arbeidswet 1889 afwijking van de aldaar gegeven voorschriften mogelijk maakte, waren het de commissarissen van de Koning en de burgemeesters die de vereiste vergunningen verleenden; dit speelde bij het verrichten van overwerk en het verrichten van bepaalde arbeid op zondag ${ }^{78}$. Het waren ook de burgemeesters, die de lijsten met de namen van de in het bedrijf werkzame vrouwen en jeugdige personen met de aanduiding van de arbeids- en rusttijden moesten waarmerken en die de arbeidskaart afgaven ${ }^{7 \theta}$. Van de ongevallen die in de fabrieken en werkplaatsen plaatsvonden, werd door de burgemeesters mededeling gedaan aan de inspecteurs, evenals van het door deze autoriteiten ingestelde onderzoek naar de oorzaken en de ge- 
volgen ervan ${ }^{\mathrm{B}}$. Deze werkzaamheden en de omstandigheid, dat de inspecteurs voor de goede gang van zaken van de commissarissen van de Koning en de burgemeesters op hun verzoek afschriften ontvingen van de verleende vergunningen, alsmede de verplichting om ${ }^{8 \cdot 1}$

"aantekening te houden van de door hen bezochte plaatsen waar arbeid verricht wordt of

pleegt verricht te worden en van hunne bevindingen aldaar,

brachten een aanzienlijke administratieve arbeid met zich. Dit laatste zou nog toenemen toen aan de inspecteurs de rapporten omtrent het gehouden politie-toezicht werden toegezonden en zij belast werden met het adviseren over verzoeken om vergunningen op grond van de Arbeidswet 1889. Het motief voor dit laatste is te vinden in een ministeriéle circulaire uit 1891 , namelijk

inde wenschelijkheid, dat bij de beslissing op verzoeken om overwerk zoveel mogelijk naar dezelfde beginselen wordt gehandeld".

Het beoogde doel was derhalve de noodzakelijke eentheid van toepassing van de wet voor het gehele land. Hiertoe moest het geregelde overleg tussen de inspecteurs van de arbeid bijdragen ${ }^{82}$. Voor het administratieve werk was echter slechts een ambtenaar met een tijdelijke aanstelling beschikbaar. In 1892 zou de aanstelling van een tweede administratieve ambtenaar plaatsvinden op dezelfde condities ${ }^{83}$.

De inspecteurs van de arbeid waren aanvankelijk vrij optimistisch gestemd over het resultaat van het politietoezicht op de naleving van de bepalingen ten aanzien van het verbod van kinderarbeid en de bepalingen waarbij de arbeidsduur voor jeugdige personen en vrouwen beperkt werd. Een en ander hing samen met een circulaire vam 28 juli 1891 aan de procureurs-generaal bij de gerechtshoven, waarin de wenselijkheid werd uitgesproken dat het toezicht op de handhaving van de Arbeidswet 1889 en de daaruit voortvloeiende algemene maatregelen van bestuur, geregeld werd in overleg met de bevoegde inspecteurs; deze laatsten moesten zich daartoe in verbinding stellen met de betreffende hoofden van de marechaussee en de rijkspolitie. Blijkens de verslagen van de inspecteurs van de arbeid over het jaar 1891 heeft deze circulaire bijgedragen tot een belangrijke verbetering van het toezicht ${ }^{84}$. Verder meenden de inspecteurs een toenemende verbetering te constateren door besprekingen met fabrikanten, burgemeesters en politie-ambtenaren. De mate waarim medewerking werd verleend, liep echter van plaats tot plaats sterk witeen.

Daarentegen is van de zijde van de inspecteurs ten aanzien van de naleving van het eerste Arbeidsbesluit ${ }^{85}$, waarin voorschriften waren neergelegd met betrekking tot de veiligheid en de gezondheid in fabrieken en werkplaatsen waar jeugdige personen en vrouwen arbeid verrichten, nooit een optimistisch geluid gekomen. In de praktijk bleek namelijk, dat de in dit Arbeidsbesluit voorgeschreven verbeteringen in de arbeidsomstandigheden slechts gerealiseerd konden worden door persoonlijk overleg tussen de inspecteur en de betrokken fabrikant. Daarbij moest gezocht worden naar mogelijkheden om tot betere arbeidsomstandigheden te komen waarbij echter ondoelmatige en kostbare veranderingen vermeden moesten worden. Bovendien had het feit, dat het onderzoek van de ongevallen van de zijde van de gemeenten onbevredigend was tot gevolg, dat de inspecteurs in vele gevallen zelf een onderzoek moesten instellen, waardoor een uitvoerige correspondentie over de ingezonden rapporten met de burgemeesters ontstond ${ }^{\mathrm{at}}$.

\section{Roep om uitbreiding}

Uit het voorgaande blijkt, dat het aantal van drie inspecteurs in geen enkele verhouding stond tot de werkzaamlieden die door hen verricht moesten worden. Vandaar dat zij in 1893 in een gezamenlijke nota ${ }^{87}$ aan de toenmalige verantwoordelijke bewindsman, inmiddels was dif de minister van Waterstaat, Handel en Nijverheid Lely ${ }^{e \theta}$ geworden, onder meer het volgende schreven:

"Het groote belang der zaak doet het derhalve wenschelijk voorkomen, dat, onder bevelen van leder der Inspecteurs van den Arbeid, een bezadigd, beschaafd en, technisch goed ontwikkeld persoon, met den titel Assistent-Inspecteur, worde aangesteld. Naar de mening van genoemde Inspecteurs, zouden voor deze gewichtige betrekking in de eerste plaats gediplomeerde werktuigkundige-ingenieurs in aanmerking moeten komen. Ten einde te kunnen na- 
gaan, of de benoemden in de praktijk blijk geven voor de betrekking de noodige geschiktheid te bezitten, zoude het overweging verdienen, hunne aanstelling gedurende de eerste jaren van tijdelijken aard te doen zijn. Deze Assistent-Inspecteurs zouden de bevoegdheid moeten bezitten tot het bezoeken wan fabrieken en werkplaatsen, alsmede tot het opmaken van processenverbaal der door hen waargenomen overtredingen inzake de Arbeidswet. Tenzij de mogelijkheid bestaat, aan deze Assistent-Inspecteurs, ter zake van de Arbeidswet eene bevoegdheid te verleenen overeenkomende met die der hulpofficieren van Justitie, zal wellicht wenschelijk zijn, hunne bevoegdheid bij afzonderlijke wet te regelen".

Over deze nota is de nodige correspondentie gevoerd met het betrokken ministerie ${ }^{\mathrm{ss}}$.

Deze roep om uitbreiding van de organisatie zou al snel weerklank vinden. Op de begroting van het ministerie van Waterstaat, Handel en Nijverbeid voor 1894 werden gelden opgevoerd om drie tijdelijke ambtenaren aan de inspecteurs van de arbeid toe te voegen ${ }^{90}$. Hoewel vanuit de Tweede Kamer erkend werd ${ }^{\theta 1}$, dat de werkzaamheden van de fabrieksinspecteurs zeer groot waren en tegen maatregelen om hun taak te verlichten geen bezwaren bestonden, bleek het voorstel van de bewindsman veel vragen op te werpen, onder andere over de positie en de bevoegdheden van deze tijdelijke assistent-inspecteurs. Vandaar dat de betrokken minister het advies kreeg om, indien hij het staatstoezicht op de arbeid wenste uit te breiden, een voorstel tot wijziging van de Arbeidswet 1889 in te dienen. Aan de wens van de Tweede Kamer om het begrotingsvoorstel voorlopig terug te nemen, werd door de bewindsman gevolg gegeven.

De suggestie vanuit de Tweede Kamer kwam overeen met de aanbeveling van de bij de Wet van 19 januari $1890^{92}$ ingestelde staatscommissie, die het werk van de parlementaire enquête-commissie van 1886 moest voltooien. Deze commissie, bekend als de staatscommissie-Rochussen naar haar voorzitter ${ }^{\text {, }}$, had de opdracht $^{24}$

"tot verzameling van gegevens voor de kennis van de maatschappelijke toetanden der arbeiders, van de verhoudingen tusschen werkgevers en arbeiders in de verschillende bedrijven en van den toestand van fabrieken en werkplaatsen met het oog op de veiligheid en de gezondheid der arbeiders".

In het eindverslag van de commissie ${ }^{95}$ is onder meer de aanbeveling gegeven om artikel 12 van de Arbeidswet 1889 zo te wijzigen, dat of het aantal inspecteurs vermeerderd zou worden of aan de inspecteurs adjunctinspecteurs zouden worden toegevoegd ${ }^{90}$.

\section{Maatregelen in het belang van de velligheid en gezondheid}

Hoewel het op grond van artikel 4 van de Arbeidswet 1889 uitgevaardigde Arbeidsbesluit alleen voorschriften bevatte met betrekking tot de veiligheid en de gezondheid ten aanzien van jeugdige personen en vrouwen, werden verdergaande maatregelen en dan met name, de bescherming van mannen te dien aangaande op voorhand niet uitgesloten. Dit blijkt uit een passage uit de troonrede van $1891^{\text {g7 }}$ waarin het volgende werd aangekondigd:

"Maatregelen in het belang van de veiligheid en gezondheid in fabrieken en werkplaatsen

..... zullen naarmate het door den wetgever bevolen onderzoek vordert, worden ontworpen".

Deze passage verwijst naar de al eerder genoemde staatscommissie-Rochussen. Door deze commissie werd een grote hoeveelheid materiaal gepubliceerd, waaruit blijkt, dat de situatie met betrekking tot de arbeid bijzonder slecht was en veel te wensen overliet ${ }^{\text {so; }}$,een en ander resulteerde in het eindverslag van de commissie $^{20}$ in onder meer een voorstel van wet

"tot vaststelling van voorschriften in het bellang wan de veiligheid, de gezondheid en hett welzajn der werklieden in fabrieken en werkplaatsen, zoodat aan de werkgevers de verplichting wordt opgelegd de noodige voorzorgen te nemen tegen het gevaar van brand; de werklieden te beschermen tegen het in aanraking komen met drijfwerk of in beweging zijnde werktuigen, die gevaar opleveren; te zorgen voor voldoende lucht en licht, voor behoorlijke luchtverversing, voor afvoer van stof, dampen en gassen, alsmede voor drinkwater; de werk- 
lieden wan beide seksen, voor zooveel noodig en mogelijk, van elkaar gescheiden te houden, in ieder geval afzonderlijke privaten voor elke sekse beschikbaar te stellen; betamelijkheid en reinheid te bevorderen, en zoodanige bijzondere voorzieningen te treffen als inhet belang der gezondheid der werklieden door den aard der grondstoffen en de wijze van hare bewerking worden geëischt; ........"

In het bedoelde wetswoorstell zou eveneens moeten worden voorzien in het toezicht daarop ${ }^{100}$ :

".... het toezicht wordt opgedragen aan de inspecteurs van den arbeid, aan wie bevoegdheid wordt gegeven tot het doen van aanwijzingen en het geven van voorschriften, tot naleving waarvan de bestuurder der inrichting verplicht is, behoudens beroep op den Minister, met de uitvoering der wet belast; die beslist na ingewonnen advies van de Kamer van Arbeid, of bij gebreke daarvan, van Burgemeester en Wethouders; ....."

Het onderzoek van de staatscommissie-Rochussen, gelegd naast de verslagen der inspecteurs van de arbeid over de jaren 1890 en 1891 over hun ambtsbezigheden ${ }^{101}$ toont aan, dat de gevaren voor leven en gezondheid voor de arbeiders in fabrieken en werkplaaten groot waren en de beveiliging daartegen over het geheel nog veel te wensen overliet. Dit gaf, volgens de minister vin Waterstaat, Handel en Nijverheid te denken, blijkens de toelichting op het ontwerp-Veiligheidswet ${ }^{102}$, dat nog voor het verschijnen van het eindverslag van de staatscommissie-Rochussen aan de Tweede Kamer werd aangeboden ${ }^{109}$. Zowel acute als chronische ziekten die ontstonden door schadelijke invloeden, die eigen zijn of aan de arbeid zelf of aan de omstandigheden waaronder deze wordt of worden verricht, onttrokken zich grotendleels aan de waarneming van de inspecteurs, aldus de bewindsman ${ }^{104}$. Uit hun verslagen blijkt desalniettemin, dat zij oorzaken aanwijzen die klaarblijkelijk het ontstaan van ziekten in de hand kunnen werken ${ }^{105}$ en doen zij bovendien verscheidene voorstellen om die ziekten te voorkomen ${ }^{108}$.

Van belang is verder hetgeen aan het verslag over 1891 door de inspecteur van de derde "arbeidsinspectie" Struve is ontleend ${ }^{\text {tor }}$ :

"Bij' mij vestigt zich de overtuiging dat een deel der werkgevers zonder wettelijke voorschriften zeer lang wachten zal voor en alleer zij tot maatregelen van beveiliging overgaan; en al is het nu een feit, dat slechts een gedeelte der ongelukken, die ter zake van arbeid ontstaan, door beveiligingen voorkomen kumnen worden, het is ook een feit, dat er zijn die

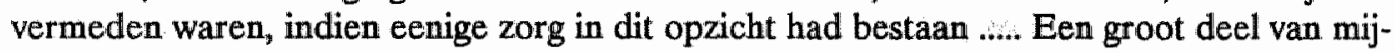
nen tijd wordt dan ook in beslag genomen door bemoeiingen te dezer zake."

Dit ontlokte aan de bewindsman de volgende opmerking ${ }^{108}$ :

"Te meer macht zal van die bemoeiingen van hem en zijne ambtgenooten, ook langs den weg van raadgeving en overreding in het werk gesteld, zijn te verwachten, indien zij rechtstreeks worden gesteund door het gezag der wet."

Nu de wenselijkheid wan wettelijke voorschriften tot beveiliging niet alleen van jeugdige personen en vrouwen, maar ook van volwassen mannen was gebleken en vrij algemeen erkend werd, achtte de verantwoordelijke minister het moment gekomen tot het treffen van wettelijke voorzieningen.

Uit het bovenstaande, dat betrekking heeft op de ontstaansgeschiedenis van de Wet van 20 juli 1895 houdende bepalingen tot beveiliging bij het verblijven in fabrieken of werkplaatsen, beter bekend als de Veiligheidswet ${ }^{100}$, blijkt, dat de ervaringen die de inspecteurs hadden opgedaan bij de uitoefening van de bij de Arbeidswet 1889 opgedragen taak mede de grondslag vormden voor de totstandkoming van deze nieuwe wet; een wet die bovendien van belang is, omdat de wetgever nu principieel de beperking van zijn beschermende hand tot kinderen, jeugdige personen en vrouwen had losgelaten. Dit, ondanks het feit, dat nog enkele Tweede Kamerleden zich in het voorlopig verslag ${ }^{110}$ tegen het voorliggende wetsvoorstel hadden verklaard, omdat het

"een uiting van ziekelijke philantropie is de volwassen mannelijke arbeiders te willen behoe-

den voor de gevaren, die hun arbeid noodzakelijk met zich brengt"

en dit voorts een 
betekende.

"te kort doen aan de vrijheid van arbeid"

5. De Veiligheidswet en een wijziging van de Arbeidswet 1889; de organisatie van de arbeidsinspectie ter discussie in het parlement

\subsection{Ontwerp-Veiligheidswet}

In het ontwerp-Veiligheidswet ${ }^{1111}$ werd in artikel 8 voorgesteld om onder de bevelen van de verantwoordelijke minister van Waterstaat, Handel en Nijverheid het toezicht op de nalleving op te dragen aan door de Kroon te benoemen ambtenaren, wier werkkring en bevoegdheden bij algemene maatregel van bestuur geregeld moesten worden. Daarnaast werd in artikel 19 van dit wetsvoorstel voorgesteld om artikel 12 van de Arbeidswet 1889 overeenkomstig de redactie van dit artikel te wijzigen. Blijkens de toelichting ${ }^{112}$ lag het in de bedoeling om het toezicht op de beide wetten door dezelfde personen te laten uitoefenen. In plaats van de term "inspecteurs" was gekozen voor "ambtenaren", omdat het wenselijk voorkwam de regering vrij te laten om de titulatuur van deze ambtenaren nader te regelen. De reden daarvoor was de in overweging zijnde gedachte om het korps van de inspecteurs van de arbeid en dat van ambtenaren van het stoomwezen te reorganiseren door het samensmelten van beide tot één enkel korps met een nadere regeling van hun werkkring.

Tijdens de schriftelijke behandeling van dit wetsvoorstel bleek de arbeidsinspectie bij alle Kamerfracties een punt van discussie te zijn. Vrij algemeen werd erkend, dat het noodzakelijk was om het aantal ambtenaren, belast met het toezicht op de arbeid, uit te breiden ${ }^{113}$.

"Reeds voor de uitvoering van de arbeidswet zou dit, blijkens de opgedane ondervinding, noodig zijn, en zooveel te meer bij aanneming van dit wetsontwerp."

Over de wijze waarop deze uitbreiding van het aantal ambtenaren tot stand gebracht zou moeten worden en hoe de organisatie van de arbeidsinspectie er uit zou moeten zien, werd verschillend gedacht. Zo werd er op aangedrongen het korps van ambtenaren te laten bestaan uit éen hoofdinspecteur, een beperkt aantal inspecteurs en een groter aantal adjunct-inspecteurs. Bij de hoofdinspecteur zou de leiding moeten berusten waarvoor dan ook een man benoemd zou moeten

"niet alleen van technische, maar ook van algemeene maatschappelijke ontwikkeling, die het

geheele toezicht zou hebben te doordringen van eén geest, die, ....., tevens een betrouwbaar

adviseur voor de Regeering en den wetgever zou kunnen zijn."

De eigenlijke inspectie zou moeten worden opgedragen aan de inspecteurs en de onder hen fungerende, met name technisch geschoolde adjunct-inspecteurs. Op deze manier zou eenheid in deze tak van dienst gebracht kunnen worden, wat niet goed mogelijk was als een betrekkelijk groot aantal inspecteurs, elk in hun eigen district, geheel zelfstandig naast elkaar kwam te staan. Deze hiërarchische opbouw van de organisatie werd van verschillende zijden weer bestreden. Gewezen werd op de mogelijkheid,

"dat allicht het bezoeken der fabrieken en werkplaatsen aan de adjunct-inspecteurs, zou

worden overgellaten, terwijl de hoogere ambtenaren op hunne bureaux zouden blijven, de

administratie te voeren, rapporten op te stellen, enz.".

Zou daarentegen de huidige organisatie van de arbeidsinspectie behouden blijven en alleen het aantal inspecteurs worden uitgebreid - onder inkrimping van hun ressorten -, dan zou men bij minder administratieve bezigheden meer waarborgen hebben voor een deugdelijk toezicht.

"Frisheid van eigen - zij het uiteenloopende - inzichten ware juist te waardeeren, en verwer-

king van bouwstoffen, niet slaafsche overneming van voorstellen van éen hoofd-inspecteur door de ministerieele bureaux, ware te wenschen."

Voorts werd van sommige zijden vanuit de Tweede Kamer met klem aangedrongen op het benoemen van vrouwen bij het toezicht op de uitvoering van de arbeids- en veiligheidswetten.

"Wellicht zou er iets voor te zeggen zijn, enkele vrouwelijke deskundigen aan te wijzen bij 
wie de arbeidsters bezwaren zouden kunnen indienen, die kieschheidshalve moeilijk aan mannelijke ambtenaren kunnen worden medegedleeld",

aldus de tegenstanders van dit denkbeeld, die daarop lieten volgen, dat het

"uit een menschkundig oogpunt geen aanbeveling verdient, naast de inspecteurs ook inspec-

trices in gelijken rang en met gelijken werkkring te benoemen".

Een ander belangrijk punt vormde de samensmelting van het toezicht op de stoomstellen en de arbeidsinspectie. Enerzijds werd in de Tweede Kamer gesteld, dat dit logisch en eenvoudig was, daar het toezicht in beide gevallen deel uitmaakte van maatregelen ter bevordering van de veiligheid bij arbeid. Anderzijds werd er op gewezen, dat voor de inspecteurs wan het stoomwezen uitsluitend technische kennis vereist is, terwijl de werkzaamheden van een inspecteur van de arbeid ook andersoortige kennis en vooral allerlei persoonlijke eigenschappen vereisten. Samensmelting van de beide inspecties zou, of minder geschikte inspecteurs van de arbeid of een minder deugdelijk toezicht op de stoomtoestellen, tot gevolg kunnen hebben. Want, zo stelde men, éen en ander was afhankelijk van het feit of bij benoeming meer op de eisen van de arbeidsimspectie of meer op die van het toezicht op de stoomtoestellen gelet werd.

Vanuit de Tweede Kamer werd de wenselijkheid uit gesproken om het regeringsstandpunt met betrekking tot de organisatie van de arbeidsinspectie te vernemen. Enkele Tweede Kamerleden verweten de regering zelfs, dat zij een wetswoorstel had ingediend, zonder zich - naar het scheen - over de reorganisatie van het korps ambtenaren in kwestie een nauwkeurige voorstelling van zaken te hebben gemaakt. Dit verwijt nu kwam de betrokken bewindsman onbegrijpelijk voor ${ }^{114}$, want was die reorganisatie niet juist eén van de onderwerpen waaraan hij bij zijn optreden als minister in de eerste plaats zijn aandacht op richtte?

Naar aanleiding van het verzoek omtrent de grondtrekken van een eventuele organisatie van het toezicht, stelde minister Van der Sleyden, dat bij die organisatie-uitgangspunt diende te zijn: toezicht door deskundige ambtenaren. In hoofdzaak kon, zo vervolgde hij, worden voortgebouwd op de grondslagen van het toezicht. op de naleving van de Arbeidswet 1889, daar het karakter van deze wet en dat van de Velligheidswet met elkaar overeenstemde. Geen verschil van mening bestond zijns inziens over de wenselijkheid om het toezicht op de naleving van de beide wetten aan dezelfde ambtenaren op te dragen. Als gevolg daarvan zouden de inspecteurs van de arbeid deel uit moeten maken van het krachtens het ontwerp-Veiligheidswet in het leven te roepen toezicht. Uiteraard moest dan wel het aantal ambtenaren uitgebreid worden, alleen al op grond van het feit, dat het aantal voor hun huidige taak al ontoereikend was. Vandaar, aldus de bewindsman, dat in het betreffende artikel van het ontwerp-Veiligheidswet de mogelijkheid geopend werd om adjunct-inspecteurs te benoemen. Hij meende met deze beide categorieën van ambtenaren - inspecteurs en adjunct-inspecteurs - te kunnen volstaan. Er waren zeer veel werkzaamheden bij de arbeidsinspectie, zo vervolgde hij, die door een deskundig ambtenaar behoorden te gebeuren, maar waarvoor een ambtenaar in de positie van een inspecteur niet vereist was. De adjunct-inspecteur zou kunnen nagaan waar voor een bezoek van de inspecteur demeeste aanleiding bestond, terwijl hij tevens de aangewezen persoon zou kunnen zijn om na te gaan of de door de inspecteur gegeven voorschriften werden nagekomen. Ook waar vermoed werd, dat een aan de arbeider overkomen ongeval toe te schrijven was aan een gebrekkige inrichting of beveiliging, zou de adjunct-inspecteur voor het instellen van een aanvankelijk onderzoek van groot nut kunnen zijn. De opvatting, dat de aanstelling van adjunct-inspecteurs er toe zou leiden, dat het bezoeken van fabrieken en werkplaatsen aan de jongste en minst ervarenen onder de ambtenaren zou worden overgelaten, terwijl de hogere ambtenaren op hun bureaus zouden blijven om de administratie te voeren, rapporten op te stellen en dergelijke, werd door de bewindsman niet gedeeld. Bovendien stelde hij, dat, indien dit onverhoopt toch mocht gebeuren, de regering niet zou aarzelen om al datgene te doen wat nodig was om hieraan een einde te maken. Ook moest niet vergeten worden, dat de betrekking van adjunctinspecteur een oefenschool zall zijn voor die van inspecteur, aldus de minister. Onder de leiding van de inspecteur zou hij zich eén van de hoofdeigenschappen van een zodanig ambtenaar - het bezitten van de nodige tact bij het optreden in zijn betrekking - eigen kunnen maken. Daarnaast gaf het de regering de mogelijkheid om met kennis van zaken en van personen een keuze te doen als een plaats van inspecteur openvalt. Op de vraag of er in de organisatie plaats was voor een hoofdinspecteur, gaf de bewindsman alsnog een ontkennend antwoord. Hij zag niet in, dat zonder een 
hoofd van een dienstvak geen eenheid in toepassing van de wettelijke voorschriften zou zijn te verkrijgen. Maar hij wilde in ieder geval afwachten wat de praktijkervaringen zouden uitwijzen.

Ook voelde hij niet veel voor het benoemen van vrouwelijke ambtenaren, die met het toezicht op de uitvoering van de arbeids- en veiligheidswetten zouden worden belast. De minister kon zich niet voorstellen, dat het in de bedoeling van de Kamerleden die hierop hadden aangedrongen, lag om aan deze alle werkzaamheden van hun mannelijke collega's op te dragen. Zij zouden hoogstens als assistenten of inspectrices ad hoc boven de gewone formatie moeten worden aangesteld. Naast financiële bezwaren zou er weer een nieuwe categorie van ambtenaren de bevoegdheid worden verleend om werkplaatsen te betreden; iets waartoe alleen in geval van absolute noodzaak overgegaan mocht worden. Van deze noodzaak was niets gebleken, aldus de bewindsman.

Over de samensmelting van het toezicht op de stoomtoestellen en de arbeidsinspectie merkte minister Van der Sleyden het volgende op. Verreweg het voornaamste deel van de ambtsbezigheden van de inspecteurs van de arbeid waren van technische aard, terwijl het hoofddoel van de arbeidsinspectie beveiliging in ruime zin was van de arbeider. Het lag dan ook naar zijn mening voor de hand, dat voor beveiliging van de arbeiders ter zake van de aanstelling het oog zou vallen op technische ambtenaren, die al belast waren te waken ten aanzien van een specifieke veiligheid, en daartoe te allen tijde vrije toegang hadden tot de plaatsen waar de stoomketels en toebehoren zich bevonden. Naar aanleiding van negatieve publicaties in buitenlandse tijdschriften over een dergelijke combinatie op grond van praktijkervaringen was besloten om het hoofd van de afdeling arbeid en fabriekswezen ${ }^{15}$ en de inspecteur van de arbeid Struve een onderzoek te laten verrichten in Würtemberg, Saksen, Pruisen en Denemarken, naar een dergelijke combinatie. Volgens de bewindsman was het oordeel over een dergelijke combinatie zonder uitzondering gunstig ${ }^{116}$. Eén en ander overwegende concludeerde hij;

"dat het alleszins aanbeveling verdient voor de eventuele uitbreiding van het toezicht gebruik te maken van de ambtenaren van het Stoomwezen.

Mocht het hem derhalve gegeven zijn het toezicht te reorganiseren, dan is het zijn voornemen een korps te vormen van inspecteurs, adjunct-inspecteurs en opzichters; de beide eerste categorieen te belasten met het toezicht op de naleving der arbeidswet, der veiligheidswet en der wet regelende het toezicht op het gebruik van stoomtoestellen, en de opzichters in hoofdzaak te blijven belasten met hunne tegenwoordige ambtsbezigheden."

Vanuit de Tweede Kamer werd te kennen gegeven ${ }^{117}$, dat men ernstige bezwaren had tegen de organisatie van de arbeidsinspectie zoals de bewindsman zich die voorstelde en de gedachtengang, die hij in zijn antwoord had ontvouwd. Om die reden wilde de commissie van rapporteurs met de bewindsman daarover van gedachten wisselen. Maar aangezien de betreffende commissie van rapporteurs ten aanzien van het wetsvoorstel tot wijziging van de Arbeidswet 1889 al tot het aanvragen van een mondeling overleg met de minister over dit onderwerp had besloten, hadden de beide commissies die voor een deel uit dezelfde personen be$\operatorname{staan}^{118}$, zich voor deze gelegenheid verenigd. Vermelding van het feit, dat men zich eenstemmig verenigde met het door die commissie van rapporteurs voor de wijziging van de Arbeidswet 1889 ten aanzien van de organisatie van de arbeidsinspectie ontwikkelde standpunt en dat haar inzichten geheel werden onderschreven, achtte men voldoende.

Vanuit de Tweede Kamer had men bezwaar tegen het laten vervallen van de titel "inspecteur", omdat deze benaming is ingeburgerd en

"het publiek het ambt er door begrijpt",

maar voorts werd met klem aangedrongen om artikel 19, waarin een wijziging van de Arbeidswet 1889 werd voorgesteld uit het wetsvoorstel te lichten en als afzonderlijk wetswoorstel in te dienen ${ }^{119}$. Bij een bij de memorie van antwoord gevoegd gewijzigd wetsvoorstel ${ }^{120}$ honoreerde de minister de wens om de naam "inspecteur" te handhaven. In artikel 10 van het gewijzigde wetsvoorstel werd nu bepaald, dat onder de bevelen van de verantwoordelijke minister, belast met de uitvoering van de wet, het toezicht wordt opgedragen 
aan door de Kroon te benoemen "inspecteurs en adjunct-inspecteurs", wier werkkring en bevoegdheden bij algemene maatregel van bestuur moesten worden geregeld. Artikel 19 van het oorspronkelijk ontwerp-Veiligheidswet, waarbij onder meer artikel 12 van de Arbeidswet 1889 werd gewijzigd, was uit het gewijzigde ontwerp verdwenen. De wijziging van de Arbeidswet 1889 werd voorgesteld bij een afzonderlijk wetsvoorstel $^{121}$, dat op 19 december 1894 de Tweede Kamer werd aangeboden ${ }^{122}$. De behandeling van de beide wetsvoorstellen vond dus in dezelfde periode plaats.

\subsection{Wetsvoorstel tot wijziging van de Arbeidswet 1889}

Het wetsvoorstel waarbij de Arbeidswet 1889 gewijzigd werd, beoogde in feite niets anders dan het amendement-Schaepman, als gevolg waarvan het aantal inspecteurs, dat belast is met het toezicht op de uitvoering van die wet, wettelijk was vastgelegd, weer ongedaan te maken. Niet verwonderlijk is, dat de minister in de toelichting behorend bij het wetsvoorstel ${ }^{123}$ verwees naar de behandeling van het ontwerp-Veiligheidswet. Maar de toelichting bevatte echter ook meer informatie. De bewindsman verklaarde namelijk, dat het voornemen bestond om de uitbreiding van het korps ambtenaren aanvankelijk te beperken tot de aanstelling van drie adjunct-inspecteurs en daartoe te benoemen werktuigkundige ingenieurs. Het regeringsvoornemen kwam dus overeen met hetgeen de inspecteurs van de arbeid in hun gezamenlijke nota uit 1893 uiteen hadden gezet. Over de door de adjunct-inspecteurs te verrichten werkzaamheden deelde de minister het volgende mede:

"Zullen deze ambtenaren, wier bevoegdheden zullen worden geregeld bij algemeene maatregel van bestuur, in elke llatere organisatie van het toezicht op hunne plaats zijn, ook afgescheiden daarvan zullen zij de aangewezen personen zijn om onder de tegenwoordige inspecteurs werkzaam te zijn. Eene voorname taak van de inspecteurs is toch nu reeds het toezicht op alles wat voor het leven, voor de gezondheid en voor de veiligheid van vrouwen en jeugdige personen in fabrieken en werkplaatsen gevaar kan opleveren. Daaromtrent wenken en voorschriften te geven, hoofden of bestuurders der inrichtingen desverlangd ook van advies te dienen bij het beveiligen van werktuigen en werktuigdeelen en zulks aan de hand van en voorgelicht door de inspecteurs, is eene taak, die het best aan zoodanige technische ambtenaren kan worden toevertrouwd. Ook voor het instellen van het bij art. 15 der wet van 1889 bedoelde onderzoek naar de oorzaak en de plaats gehad hebbende ongelukken kunnen zij geacht worden de aangewezen personen te zijn".

Uit de reactie vanuit de Tweede Kamer op dit wetswoorstell blijkt ${ }^{124}$, dat er een aantal Kamerleden niet overtuigd bleek van de noodzaak en de wenselijkheid van een uitbreiding van de arbeidsinspectie.

"Huns inziens wordt de arbeidswet over het algemeen voldoende nageleefd en zal zij, naarmate zij langer werkt en in de zeden en gewoonten doordringt, steeds minder worden ontdoken".(1)

Een groter aantal inspecteurs gaf in dit opzicht naar bun mening niet meer waarborgen. In hun visie leidde dit alleen maar tot allerlei bemoeiingen met de industrie, waar de fabrikanten het slachtoffer van werden. Hoogstens konden deze Kamerlleden instemmen met de bemoeïng van enkele opzichters, die, als geheel ondergeschikt personeel door de inspecteurs in technische aangelegentheden zouden kunnen worden gebruikt. Een grote meerderheid van de Kamer stelde daarentegen, dat de noodzakelijkheid van de uitbreiding van de arbeidsinspectie vaststond. De inspecteurs waren overladen met werk ${ }^{125}$ en waren niet in staat alle onder hen ressorterende fabrieken en werkplaatsen, zij het ook maar énmaal, in de eerste jaren te bezoeken. Dat de wet niet of slechts zelden werd ontdoken kon dan ook geenszins toegegeven worden

Uitbreiding van het personeel is een "onafwijsbare eisch" en zeker bij het aannemen van het ontwerp-Veiligheidswet, omdat de taak van de bedoelde ambtenaren nog aanzienlijk zou worden uitgebreid.

"Bovendien moeten zij, die vexatiën voor de industrieelen vreezen, niet over het hoofd zien, dat het toezicht op de naleving der wet, voor zover het niet door inspecteurs geschiedt, neerkomt op de politie-ambtenaren, hetgeen zeker voor de belanghebbenden geenszins ver- 
Kieslijk is"

Alleen over de wijze van uitbreiding verschilde men van mening, namelijk door onder de inspecteurs adjunctinspecteurs te benoemen of door uitbreiding van het aantal inspecteurs onder inkrimping van hun ressort. Velen konden zich vinden in het voorstel van de bewindsman om adjunct-inspecteurs aan te stellen op de gronden zoals die door hem uiteen waren gezet in de toelichting bij dit wetsvoorstel alsook in de memorie van antwoord bij het ontwerp-Veiligheidswet. Wel bepleitten zij de bevordering van eenheid in de uitvoering van de wet(ten); reden waarom men bedenkingen had tegen het uitbreiden van het aantal inspecteurs. Zeer veel andere leden hadden juist bezwaar tegen dit ministeriële voorstel en gaven juist de voorkeur aan de uitbreiding van het aantal inspecteurs. De voornaamste argumenten werden als volgt samengevat. De taak van de inspectie vereiste te veel tact en mensenkennis om aan adjunct-inspecteurs op te dragen. Maar zelfs als in deze opzichten geschikte adjunct-inspecteurs te vinden zouden zijn, dan nog verminderde het rechtstreekse contact tussen de industrieel en de inspecteur. En ontleende de inspectie niet juist haar grote betekenis aan haar veelzijdigheid: deze kon alleen in voldoende mate verkregen worden, als de inspecteurs zich persoonlijk van alles op de hoogte stelden en met $d ?$ hoofden van inrichtingen in persoonlijk contact stonden. Rapporten en mededelingen konden hiervoor niet in de plaats treden. Voorts bestond enerzijds het gevaar, dat bij de taakverdeling tussen inspecteur en adjunct-inspecteur eestgenoemde achter zijn bureau zou blijven, rapporten zou schrijven en om de rapporten van de adjunct-inspecteurs beslissingen zou nemen waardoor de inspectie een omslachtig bureaucratisch karakter zou krijgen, terwijl anderzijds de kans bestond dat de inspecteur alles zelf wilde doen, met het gevaar dat hij zijn werk onmogelijk naar behoren zou kunnen verrichten. De verzekering van de bewindsman in de memorie van antwoord bij het ontwerp-Veiligheidswet, dat de regering wel in staat zou zijn tegen dergelijke ontwikkelingen te waken, maakte op hen geen enkele indruk.

Ook het argument, dat de functie van adjunct-inspecteur als een oefenschool voor dat van inspecteur moest worden gezien, werd door de betrokken Kamerleden allerminst een "onvermengd voordeel" genoemd, gezien het feit, dat deze jonge ambtenaren dan in dienst zouden treden met het vooruitzicht, althans de hoop, later tot inspecteur bevorderd te worden. Maar er was meer. De minister stelde voor alleen "technische ambtena-

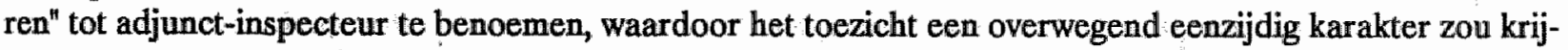
gen, wat weer tot gevolg zou hebben dat het doel voor een groot deel gemist zou worden. De technische kant van de arbeidsinspectie is zeker belangrijk,

"maar evenzeer zeker is, dat dit Staatsorgaan eene hooge roeping wan maatschappelijke

aard heeft te vervullen als verzoenend element in den strijd tusschen arbeid en kapitaal".

Om die reden zouden ook hygiënisten en sociologen in het korps vertegenwoordigd moeten zijn. Met andere woorden: zowel bij het toezicht op de uitwoering van de tot stand gebrachte wetten, als bij het verzamelen van bouwstoffen voor verdere wetgeving zou het oog van de inspectie ook op andere zaken dan die van zuiver technische aard gericht moeten zijn. Deze voorstanders van de uitbreiding van het aantal inspecteurs stelden, dat tegen een dergelijke uitbreiding geen zwaarwegende bezwaren werden aangevoerd. Inkrimping van het ressort zou immers geen devaluatie van de functie van inspecteur als zodanig met zich brengen. Voorts zou bevordering van eenheid in de uitvoering gevonden kunnen worden in het stelselmatige overleg van de inspecteurs, nog afgezien van de vraag of in dit licht de aanstelling van een hoofdinspecteur wenselijk zou zijn. Anders was het met het argument, dat de uitbreiding van het aantal inspecteurs meerdere kosten met zich zou brengen. Maar, zo stelden deze leden, aan dit financiële aspect mocht geen doorslaggevende betekenis toegekend worden, omdat nu eenmaal woor een goede werking van de arbeidswetgeving een goede organisatie nodig was. Hoewel deze leden geen voorstanders waren van de door de minister voorgestelde regeling, ondersteunden zij wel het denkbeeld om aan de inspecteurs enige technische hulp toe te voegen, waarbij gedacht werd aan ondergeschikt personeel met een technische achtergrond, met de benaming van "opzichter". De taak van deze "opzichters" zou met name gericht moeten zijn op het verlenen van technische bijstand zonder deel uit te maken van de eigenlijke inspectie. Hun verhouding tot de inspecteurs zou overeen moeten komen met die van de opzichters bij het stoomwezen tot de ingenieurs van dat dienstvak. In dat geval zouden de bezwaren die tegen de adjunct-inspecteurs zijn aangevoerd niet, althans in veel mindere mate 
gelden, terwijl de opzichters de inspecteurs goede diensten zouden kunnen bewijzen. Ook bij de behandeling van dit wetsvoorstel tot wijziging van de Arbeidswet 1889 werd op dezelfde gronden als tijdens de behandeling van het ontwerp-Veiligheidswet gepleit, zowel voor als tegen het aanstellen van zowel een hoofdinspecteur als vrouwelijke inspecteurs. Ook het denkbeeld over de samensmelting van de arbeidsinspectie en de dienst voor het stoomwezen werd op dezelfde gronden als aangevoerd tijdens de behandeling van het ontwerp-Veiligheidswet ten zeerste betreurd. De ingenomenheid over een dergelijke combinatie in met name sommige Duitse staten was niet zo algemeen als de minister in de memorie van antwoord bij het laatstbedoelde wetsvoorstel deed voorkomen. Integendeel, er heerste bij vele deskundigen aldaar de overtuiging, dat juist de arbeidsinspectie te lijden had van deze combinatie ten opzichte van de inspectie op de stoomtoestellen.

Vanuit de Tweede Kamer werd voorgesteld ${ }^{128}$, om de in het voorgestelde artikel 12 van de Arbeidswet 1889 voorkomende termen "inspecteurs en adjunct-inspecteurs" te vervangen door "ambtenaren". Daarvoor werd een tweetal argumenten aangevoerd. In de eerste plaats de bij de Kamerleden levende angst, dat het aannemen van de in dit wetswoorstel gebruikte terminologie zou leiden tot het aanvaarden van de, door de Kamer niet gewilde organisatie zoals de minister zich die voorstelde en in de tweede plaats werd door deze formulering de mogelijkheid opengehouden om in de toekomst ook een hoofdinspecteur en én ofmeer vrouwelijke inspecteurs te kunnen benoemen voor het geval dit nodig mocht blijken te zijn. Hier doet zich dus het wonderlijke verschijnsel voor, dat de oorspronkelijk, door de minister voorgestelde terminologie "ambtenaren" op aandrang van de Kamer bij het ontwerp-Veiligheidswet werd veranderd in "inspecteurs en adjunct-inspecteurs, waarna vervolgens de Kamer bij de wijziging van de Arbeidswet weer voorstelde om deze terminologie te wijzigen in "ambtenaren".

Daar ernstige bezwaren bestonden tegen de door de bewindsman voorgestelde organisatie van de arbeidsinspectie besloot de commissie van rapporteurs de bewindsman door tussenkomst van de voorzitter van de Tweede Kamer uit te nodigen voor een mondeling overleg. Nadat hij aan dit verzoek had voldaan, kon dit overleg op 15 maart 1895 plaatsvinden. Dit overleg werd bijgewoond door de commissie van rapporteurs voor het ontwerp-Veiligheidswet, die naar het verslag van dit overleg en het daarbij door de Kamer ingenomen standpunt zou verwijzen.

\subsection{Verslag van het mondeling overleg}

Het zal geen verbazing wekken, dat het verslag van dit mondelinge overleg ${ }^{127}$ veelal een weergave bevat van de al eerder over en weer uitgewisselde ideeën en opmerkingen.

Het eerste bezwaar, dat vanuit de Kamer aan de bewindsman werd voorgehouden, namelijk dat een deel van het toezicht feitelijk zou worden uitgeoefend door jonge ambtenaren - de adjunct-inspecteurs - die tegenover krachten van bedrijven en ondernemingen de tact en het zedelijk overwicht missen, die er zoveel toe hadden bijgedragen om ook de industriëlen met de inspectie te verzoenen, ontlokte de bewindsman de opmerking, dat hij met genoegen kennis had genomen van het feit dat over de uitbreiding van de arbeidsinspectie als zodanig geen verschil van mening bestond. Over de positie die de adjunct-inspecteurs in de organisatie in zouden nemen voerde hij nauwelijks nieuwe gezichtspunten aan: zij zouden niet zelfstandig optreden en geen werkzaamheden verrichten die per sé door de inspecteur zelf gedaan moesten worden. Maar daar stelde de commissie van rapporteurs tegenover, dat dit toch niet goed te rijmen viel met de tekst van artikel 8 van het gewijzigde ontwerp-Veiligheidswet, waarin toch bepaald was, dat de hoofden en bestuurders van fabrieken en werkplaatsen zich zouden hebben te gedragen naar de voorschriften uitgevaardigd door de inspecteur en de adjunct-inspecteur. Bovendien opende artikel 17 van hetzelfde wetsvoorstel zelfs de mogelijkheid van beroep op de inspecteur tegen een beslissing van de adjunct-inspecteur. Hieruit werd dan ook geconcludeerd, dat de werkzaamheden van de adjunct-inspecteur minder beperkt waren en ook minder onschuldig waren dan de bewindsman deed voorkomen, waarop een pleidooi zou volgen om opzichters aan 
te stellen. De reactie van de minister hield in, dat het moeilijk was om in de wet formeel de bevoegdheden van de adjunct-inspecteurs beperkter te regelen dan die van de inspecteurs; de ambtelijke instructie bood echter de gelegenheid tegen misbruiken te waken. Ook de minister was van oordeel, dat de positie van de adjunct-inspecteur ondergeschikt diende te blijven aan die van de inspecteur, die in alle belangrijke zaken zelf tegen de industrielen op moest blijven treden. Hij verklaarde zich echter bereid te overwegen

"of het mogelijk zou zijn, ter opheffing van de bezwaren, in het ontwerp-Veiligheidswet, als-

nog waarborgen op te nemen om te voorkomen, dat het gedeelte van de taak, hetwelk de

inspecteurs zelven moeten behartigen, door de adjuncten zou worden waargenomen."

Op het tweede bezwaar, dat door het denkbeeld van de minister het gevaar bestond, dat de arbeidsinspectie zou ontaarden in een louter technisch toezicht, antwoordde de bewindsman, dat de werkkring van de inspecteurs toch in de eerste plaats een technisch karakter had, wat nog versterkt zou worden bij aanneming van het ontwerp-Veiligheidswet.

"Het zullen wel uitsluitend technici zijn, die voor de betrekking in aanmerking zullen kunnen komen .

Dat nam overigens volgens de bewindsman niet weg, dat bij benoeming niet uitsluitend gelet zou worden op technische kennis, maar ook op algemene ontwikkeling, tact en karaktereigenschappen, waarna hij zijn argumentatie herhaalde over het kiezen van inspecteurs uit de rangen van de adjunct-inspecteurs. Ook deze argumentatie vond de commissie van rapporteurs niet voldoende.

"Tact, kennis der arbeidswetgeving, zoo hier te lande als elders, en een ruime blik op maatschappelijke en economische verhoudingen, moeten minstens evenveel gewicht in de schaal leggen als zuiver technische bekwaamheden".

Aangezien de minister voorstelde om de inspecteurs te benoemen uit de rangen van de adjunct-inspecteurs, die toch, ook wanneer men niet overtuigd was van het hebben van de voor het hogere ambt benodigde eigenschappen, niet snel voor bevordering gepasseerd zouden worden, en hierbij in de eerste plaats gedacht werd aan werktuigkundige ingenieurs, kon met zekerheid vastgesteld worden, aldus de commissie van rapporteurs, dat de arbeidsinspectie een korps zou worden met overwegend technische opvattingen en tradities. De bewindsman hield echter vast aan het beginsel, dat, waar de inspectie moest dienen om toezicht te houden op de Arbeidswet 1889 en op de nieuwe Veiligheidswet, haar technische karakter diende te prevaleren.

Het derde en laatste bezwaar betreft de samemsmelting van de arbeidsinspectie en de dienst van het stoomwezen. De al gememoreerde argumenten werden opnieuw aangevoerd. Nieuw echter was het voor de commissie zwaarwegende argument omtrent de moeilijkheden die aan een overgangstermijn verbonden zouden zijn. De bewindsman gaf toe, dat de overgangstermijn wel enige moeilijkheden zou opleveren, maar stelde ook dat deze niet onoplosbaar waren. Want een organisatie, die voor een lange tijd zou moeten functioneren, mocht toch niet afstuiten op bezwaren van tijdelijke aard, zeker niet als die organisatie op zich voordelen bood. Dit laatste was het geval bij een combinatie van de arbeidsinspectie en de dienst van het stoomwezen. Het onderzoek van stoomtoestellen maakte uit zijn aard een zeer belangrijk onderdeel uit van de overheidsbemoeiing in het belang van de veiligheid in fabrieken en werkplaatsen. Wat was dan logischer, aldus de bewindsman, om bij de totstandkoming van de Veiligheidswet beide diensten samen te smelten ${ }^{128}$. Bovendien zou het gescheiden houden van de beide diensten allicht kunnen leiden tot conflicten en verwarring. Dit, omdat in de praktijk niet altijd een grens kon worden getrokken tussen de taak van de ingenieur van het stoomwezen die bemoeienis had met de stoomtoestellen en de toebehoren en de taak van de inspecteur van de arbeid die veiligheidsvoorschriften voorschreef in het belang van de werklieden waartoe toch ook de machinisten en stokers behoorden. Een ander voordeel van deze samenvoeging was, dat er in plaats van twee kleine korpsen é́n groter korps van ambtenaren was, waardoor er een ruimere keuze ontstond met als gevolg, dat de juiste personen op de verschillende plaatsen konden komen en er in het algemeen een meer geleidelijke opklimmen in rang bevorderd werd. Daarnaast leverde de mogelijkheid, dat dezelfde ambtenaren bij de inspectie van een fabriek en werkplaats gelijktijdig de stoomtoestellen konden onderzoeken een aanmerkelijke besparing van tijd en geld op. 
De commissie van rapporteurs gaf te kennen een dusdanige omschrijving in de wet opgenomen te willen zien, dat ook zonder een wetswijziging een mogelijkheid zou bestaan om een hoofdinspecteur en eén of meer vrouwelijke inspecteurs te kunnen benoemen, wanneer en voor zover de ervaringen de noodzakelijkheid van de uitbreiding van de arbeidsinspectie mochten aantonen. Over de vraag of een dergelijke uitbreiding nu al noodzakelijk was, verschilde men in de commissie van rapporteurs van mening maar verscheidene leden wilden voor de toekomst hun oordeel voorbehowden. Onder hetzelfde voorbehoud verklaarde de bewindsman op dit punt geen bezwaar te hebben en zou hij nagaan hoe hier het beste aan tegemoet kon worden gekomen.

Het verslag van het mondeling overleg eindigde met de voor de hand liggende conclusie; dat de minister en de commissie van rapporteurs over en weer bij de ingenomen standpunten volhardden.

\subsection{Vervolg van de behandeling van het wetsvoorstel tot wijziging van de Arbeidswet 1889}

Na het verslag van het mondeling overleg zou dememorie van antwoord op het voorlopig verslag met betrekking tot de voorgestelde wijziging van de Arbeidswet 1889 uitgebracht worden. De bewindsman verwees ${ }^{120}$ ten aanzien van een aantal punten die aanleiding waren geweest tot het maken van opmerkingen naar dit verslag. Tegelijkertijd werd bij de memorie van antwoord een gewijzigd wetsvoorstel ${ }^{130}$ ingediend. In artikel 12 van de Arbeidswet 1889 werd nu voorgesteld het toezicht op de uitvoering op te dragen aan door de Kroon te benoemen "inspecteurs en verdere ambtenaren", waarmee de bewindsman zijn toezegging tijdens het mondeling overleg gestand deed om een dusdanige omschrijving in de wet op te nemen dat ook zonder wetswijziging bijvoorbeeld een hoofdinspecteur of vrouwelijke inspecteurs zouden kunnen worden benoemd.

\subsection{Terug naar het ontwerp-Veiligheidswet en de afloop van de parlementaire discussie}

Nadat de memorie van antwoord bij het wetswoorstel tot wijziging van de Arbeidswet 1889 was uitgebracht verplaatste de problematiek van de organisatie zich weer naar de behandeling van het ontwerp-Veiligheidswet. In artikel 10 van dit wetsvoorstel werd bij nota van wijzigingen ${ }^{131}$ het toezicht op de naleving opgedragen aan door de Kroon te benoemen "inspecteurs en verdere ambtenaren". De commissie van rapporteurs stelde bij amendement ${ }^{132}$ voor om aan dit artikel 10 een nieuw tweede lid toe te voegen, waarin uitdrukkelijk werd gesteld, dat de inspeeteurs van de arbeid en verdere ambtenaren niet belast zouden worden met het toezicht op het gebruik van stoomtoestellen. Voor de toelichting werd verwezen maar hetgeen in het voorlopig verslag naar aanleiding van het wetsvoorstel tot wijziging van de Arbeidswet 1889 en het daarop volgend verslag van het mondeling overleg vanuit de Tweede Kamer was gezegd.

Tijdens de mondelinge beraadslaging van het ontwerp-Veiligheidswet werd afzonderlijk aandacht besteed aan het toezicht.

Bahlmann, lid van de commissie van rapporteurs, gaf een uiteenzetting van de denkbeelden zoals die in de Tweede Kamer leefden aangaande de organisatie en uitbreiding van de arbeidsinspectie ${ }^{133}$ en beval het bedoelde amendement "in goedgunstige overweging" aan, waarna een discussie ontstond tussen een aantal Kamerleden ${ }^{134}$ enerzijds en de minister anderzijds. Deze laatste hield vol ${ }^{135}$, dat een samansmelting van de beide diensten wenselijk was en op den duur plaats zou behoren te vinden, maar erkende zijn nederlaag op dit punt met de volgende woorden:

"Intusschen is mij voldoende uit de stemming van deze Kamer gebleken dat er zeer weinig, ja geen uitzicht bestaat, dat het denkbeeld der Regeering zal worden omhelsd. Om tijdsverlies te voorkomen meen ik daarom goed te doen het amendement van de Commissie van Rapporteurs over te nemen."

Hierna werd het aldus gewijzigde artikel zonder hoofdelijke stemming op 13 juni 1895 aangenomen ${ }^{130}$. Een dag later zou het gewijzigde artikel 12 van de Arbeidswet 1889 worden aangenomen, ook weer zonder hoof- 
delijke stemming $^{137}$.

Tijdens de schriftelijke behandeling van het laatstbedoelde wetsvoorstel in de Eerste Kamer verzekerde de minister, dat hij met de uitbreiding van de arbeidsinspectie zeer voorzichtig te werk wenste te gaan ${ }^{138}$.

Rest nog te vermelden, dat de beide wetsvoorstellen door de Eerste Kamer zonder hoofdelijke stemming werden aangenomen ${ }^{139}$, en dat zij na ondertekening door de Koningin-moeder Emma op 1 augustus 1895 in het Staatsblad konden verschijnen ${ }^{140}$.

\section{Uitbreiding van de arbeidsinspectie}

$\mathrm{Na}$ deze discussie over de organisatie stond voor de bewindsman van Waterstaat, Handel en Nijverheid de weg open voor uitbreiding. Hoe de bewindsman zich deze uitbreiding concreet voorstelde, bleek uit de toelichting op de begroting voor het jaar $1896^{141}$. Na re constatering, dat noch de arbeidsinspectie gecombineerd diende te worden met de dienst van het stoomwezen, noch adjunct-inspecteurs, die zelfstandig voorschriften zouden kunnen geven, behoorden te worden aangesteld, stelde de bewindsman vast dat een ding vaststond, namelijk de uitbreiding van het aantal inspecteurs. Daarnaast rees de vraag of, nu de adjunct-inspecteurs geen bevoegdheid zouden krijgen om zelfstandig voorschriften te geven, de aanstelling van dergelijke ambtenaren de voorkeur verdiende boven die van opzichters. Als argument werd datgene aangevoerd wat de minister al in de memorie van antwoord op het ontwerp-Veiligheidswet had gesteld, namelijk dat de functie van adjunct-inspecteurs een voorbereiding zou zijn voor de functie van inspecteur.

Opmerkelijk is echter wel, dat de minister uitdrukkelijk zijn voorkeur aansprak om aan eén van de inspecteurs de rang te geven van hoofdinspecteur. Dit is opmerkelijk, daar de bewindsman bij eerdere gelegenheid nog ontkende, dat er in de organisatie plaats was voor een hoofdinspecteur, omdat hij niet inzag, dat anderszins geen eenheid in toepassing van de wettelijke voorschriften zou zijn te verkrijgen. In ieder geval wilde hij op dit punt afwachten wat de praktijkervaringen zouden uitwijzen. En wat voerde de bewindsman nu aan? Indien drie nieuwe inspecteurs zouden worden benoemd, dan was het zijns inziens aanbevelingswaardig van het begin van het inwerkingtreden van de nieuwe organisatie é́n van de inspecteurs aan te wijzen, om, voor zover nodig, uniforme toepassing van de voorschriften te bewerkstelligen. De inspecteurs zouden zich in geval van twijfel kunnen wenden tot deze aangewezen ambtenaar, die "meer bepaald de chef in algemeenen dienst" zou zijn. Een organisatiestructuur die, zo vervolgde de bewindsman, goed had gewerkt en nog werkte bij de dienst van het stoomwezen.

Op dit voorstel van de minister werd vanuit de Tweede Kamer verdeeld gereageerd ${ }^{142}$. Een aantal Kamerleden was tegen de aanstelling van een hoofdinspecteur, omdat daardoor de inrichting van het toezicht gecentraliseerd zou worden, waarbij het toezicht afhankelijk zou zijn van de persoonlijke inzichten van de hoofdinspecteur en waarbij de inspecteurs hun zelfstandigheid zouden verliezen. Anderen konden zich echter wel vinden in het voorstel, omdat daardoor een uniforme inrichting van het toezicht zou worden bevorderd. Mocht de benaming van hoofdinspecteur op bezwaren stuiten, dan zou deze kunnen worden vervangen door "inspecteur in algemeenen dienst". Ook het voorstel om adjunct-inspecteurs te benoemen werd in de Tweede Kamer met gemengde gevoelens ontvangen. Een aantal Kamerleden verzette zich tegen dit voorstel, vanwege strijd

"zoo niet met de letter, dan toch met de toelichting van het door de Kamer aangenomen amendement der Commissie van Rapporteurs op art. 8 van de Veiligheidswet."

Sommigen meenden echter juist, dat bij de stemming over het bedoelde amendement geenszins was beslist, dat er geen adjunct-inspecteurs zouden worden aangesteld ${ }^{143}$. Beslist was namelijk, zo vervolgden zij, dat alleen inspecteurs bevoegd zouden zijn tot het geven van voorschriften aan bestuurders van fabrieken en werkplaatsen; een standpunt dat overigens door de minister werd gedeeld ${ }^{144}$. Wat betreft de hoofdinspecteur merkte de laatstgenoemde op, dat het niet de bedoeling was, deze de bevoegdheid te geven om het toezicht naar zijn persoonlijke inzichten te regelen. De inrichting van het toezicht zou toch, evenals nu het geval 
was, bij algemene maatregel van bestuur geregeld worden. Hij vond echter wel, dat aan de naar voren gebrachte bezwaren niet tegemoet gekomen werd, door efen van de inspecteurs niet de titel van hoofdinspecteur te geven, maar "inspecteur in algemeenen dienst".

Tjjens de begrotingsbehandeling werden twee amendementen ingediend. Het eerste was van de hand van Van Alphen ${ }^{145}$ en had tot doel de Kamer te laten uitspreken, dat geen hoofdinspecteur behoorde te worden aangesteld, maar de inspectie in de verschillende districten ook voortaan opgedragen moest worden aan inspecteurs van zowel onderling gelijkwaardige positie als gelijkwaardige taak en bevoegdheid. Het tweede was van Bahlmann ${ }^{148}$ en beoogde de uitbreiding van de arbeidsinspectie te beperken tol drie adjunctinspecteurs.

De mondelinge beraadslaging ${ }^{14 \%}$ had als uitkomst, dat het amendement van Bahlmann werd verworpen ${ }^{148}$ en dat van Van Alphen werd aangenomen ${ }^{149}$; het aldus gewijzigde begrotingsartikel werd hierna zonder hoofdelijke stemming aangenomen ${ }^{160}$.

Nadat de wijziging van de Arbeidswet 1889 op 21 augustus 1895 in werking was getreden, had de betrokken minister na deze begrotingsbehandeling de beschikking over voldoende financiële middelen om tot de uitbreiding van de arbeidsinspectiemet drie inspecteurs en zes adjunct-inspecteurs over te gaan. Alvorens dit echter gerealiseerd kon worden moest het op artikel 12 van de Arbeidswet 1889 gebaseerde Besluit van 21 februari 1890 waarin de werkkring en de bevoegdheden van alleen de inspecteur van de arbeid geregeld was, worden aangepast. Dit gebeurde bij het Besluit van 2 april $1896^{151}$. In artikel 1 van dit nieuwe Besluit werd aangegeven, dat de bij het gewijzigde artikel 12 van de Arbeidswet 1889 bedoelde "inspecteurs en verdere ambtenaren" de titel zouden dragen van "inspecteurs en adjunct-inspecteurs". Voor het toezicht op de uitvoering van de wet werd het rijk nu verdeeld in zes "arbeidsinspectiën"152. In iedere "arbeidsinspectie" werd het toezicht opgedragen aan een inspecteur onder wiens bevelen éen of meer adjunct-inspecteurs konden worden aangesteld. De betrokken minister wees voor iedere (adjunct-)inspecteur een standplaats aan ${ }^{153}$. Wat overbodig lijkt het voorschrift, dat de bedoelde ambtenaren de bevelen van de verantwoordelijke bewindsman hadden op te volgen ${ }^{154}$. Opnieuw werd nu herhaald, dat de inspecteurs belast waren met het toezicht op de uitvoering van de wet en van de naar aanleiding van die wet uitgevaardigde Koninklijke besluiten en ministeriële voorschriften. Daartoe hadden zij de plaatsen te bezoeken, die aan hun toezicht onderworpen waren. Ook nu was voorgeschreven, dat de inspecteurs teneinde tot een gelijkvonmige toepassing van de arbeidswettelijke voorschriften te komen met elkaar in overleg dienden te treden, zodat het eerder gememoreerde college onder leiding van Struve in stand bleef ${ }^{56}$. Daarnaast werd opnieuw voorgeschreven, dat zij moesten proberen zoveel mogelijk overeenstemming te bevorderen tussen de eisen van de wetgeving en de belangen van alle bij de arbeid betrokken personen ${ }^{168}$. De taak die hun op grond van het eerdere besluit was opgelegd om aan hen, die arbeid doen verrichten, alle zodanige inlichtingen te verstrekken en voorstellen te doen die konden leiden tot het wegnemen van bezwaren, die uit de toepassing van de wettelijke voorschriften voor de nijverheid zouden kunnen voortvloeien kwam nu niet meer voor. Hetzelfde geldt ten aanzien van de taak die de inspecteurs hadden in het kader van de uitvoering van artikel 4 van de wet, dat zij in het bijzonder te letten hadden op de gevaren voor de gezondheid of het leven van jeugdige personen en van vrouwen die bepaalde soorten van arbeid opleverden. Het schrappen van deze specifieke taakstellingen houdt ongetwijfeld verband met het uitvaardigen van de Veiligheidswet. Wel gehandhaafd bleef, dat de inspecteurs desgevraagd de betrokken minister van bericht en advies dienen en hem voorstellen konden doen, alsook het desgevraagd adviseren van de commissarissen van de koningin en de burgemeesters omtrent het ingevolge de Arbeidswet 1889 verlenen van vergunningen ${ }^{157}$. Ook dit nieuwe Besluit gaf aan wat niet tot de taak van de inspecteurs behoorde, namelijk het geven van algemene voorschriften bij wijze van reglementen, instructies of circulaires ${ }^{158}$. Tot slot moet vermeld worden, dat op grond van een nieuw artikel 16 van de Arbeidswet $1889^{169}$ de inspecteurs elke twee jaar een beredeneerd verslag over hun ambtsbezigheden dienden op te stellen en dit aan de verantwoordelijke minister moesten zenden. Wat betreft de adjunct-inspecteurs bepaalde het Besluit, dat zij de inspecteurs bij dienden te staan in de vervulling van hun taak en dat in het bijzonder deze laatsten belast werden met het bezoeken van de plaatsen die aan hun toe- 
zicht waren onderworpan en met het opsporen van overtredingen. Zij hadden daartoe de bevellen van de inspecteurs op te volgen en hen de verlangde inllichtingen zowel mondeling als schriftelijk te verstrekken ${ }^{160}$. Als tegenhanger was de inspecteur de verplichting opgelegd toezicht te houden op de verrichtingen van de onder zijn bevelen staande ambtenaren ${ }^{161}$.

Nadat met ingang van 1 april 1896 drie nieuwe inspecteurs - Deinse, Arendsen de Wolff en Van Thienen waren benoemd ${ }^{102}$, konden zij op 1 mei van dat jaar hun werkzaamheden aanvangen. Na het afleggen van een vergelijkend examen werden tot adjunct-inspecteurs benoemd: Bakema, Blansen-Henkemans, Klompe, Last, Raven en De Vooys: de eerstgenoemde met ingang van 1 oktober 1896 en de overigen met ingang van 1 september van dat jaar ${ }^{163}$.

Toch zou het bovenbedoelde Besluit van 2 april 1896 slechts een kort leven beschoren zijn. Het werd namelijk al bij Besluit van 23 december van dat jaar ${ }^{164}$ ingetrokken, Dit was het gevolg van het inwerkingtreden op 1 januari 1897 van de Veiligheidswet ${ }^{165}$. Als reden voor de intrekking van het eerstgenoemde Besluit gaf de verantwoordelijke minister ${ }^{168}$ :

"door het vaststellen van eener nieuwe instructie (wordt) het groote voordeel verkregen, dat uit den titel van het besluit duidelijk blijkt, dat naast de regeling van den werkkring en de bevoegdheden van de in art. 12 der Arbeidswet bedoelde ambtenaren zoodanige regeling plaats vindt ook van de in art. 9 der Veiligheidswet bedoelde ambtenaren".

Het nieuwe Besluit regelde dus zowel de werkkring en de bevoegdheden van de ambtenaren van de arbeidsinspectie, als bedoeld in artikel 12 van de Arbeidswet 1889 als van de ambtenaren, als bedoeld in artikel 9 van de Veiligheidswet. Inhoudelijk werd het nieuwe Besluit ten opzichte van het eerdere Besluit echter niet gewijzigd.

\section{De Veiligheidswet en de Hinderwet}

In tegenstelling tot de Arbeidswet 1889 haakte de Veiligheidswet niet in op de werkende personen, maar op de inrichting waar gewerkt werd. De wet gold woor fabrieken en werkplaatsen voor zover aldaar een krachtwerktuig of een oven werd gebruikt of tien of meer personen plachten te werken ${ }^{187}$.

In de artikelen 6 en 7 van de wet werd de mogelijkheid geopend om bij algemene maatregel van bestuur woorschriften te geven met betrekking tot de veiligheid respectievelijk ten aanzien van de inrichting waarin het bedrijf werd uitgeoefend ${ }^{168}$ en ten aanzien van het gebruik dat van die inrichting werd gemaakt ${ }^{10 \theta}$. De voorschriften, die betrekking hadden op de (vaste) inrichting waarin het bedrijf werd uitgeoefend, brachten de Veiligheidswet in aanraking met de Wet vam 2 juni 1875 , tot regeling van het toezicht bij het oprichten van inrichtingen welke gevaar, schade of hinder kunnen veroorzaken ${ }^{170}$. Een groot aantal inrichtingen die onder het regiem van deze laatst genoemde wet vielen en die niet zonder voorafgaande vergunning van het gemeentebestuur mochten worden opgericht ${ }^{171}$ waren fabrieken en werkplaatsen in de zin van de Veiligheidswet en moesten voldoen aan de voorschriften die op grond daarvan gesteld waren ten aanzien van inrichtingen waar dat bedrijf werd uitgeoefend. De bedoeling van de Wet van 2 juni 1875 was om de omgeving van een inrichting te vrijwaren tegen gevaar, schade en hinder ( externe veiligheid); de Veiligheidswett 1895 daarentegen beoogde juist de arbeiders werkzaam in een bedrijf te beschermen (interne veiligheid). De vergunningverlenende instantie, het gemeentebestuur, kon, aldus de bewindsman ${ }^{172}$, geen rekening houden met deze interne veiligheidsaspecten ten gunste van de arbeiders.

"Het natuurlijk gevolg van dat stelsel kan en zal dikwijls zijn, dat door de zorg voor de belangen der naburen veelal in de hand gewerkt, zoo al niet veroorzaakt wordt, dat de belangen vande personen, die, in de inrichting werkzaam zijn en die veelal geen andere keus hebben dan of geen werk en derhalve geen verdienste te hebben, of arbeid te verrichten, die wellicht in hooge mate nadeelig en ongezond is, worden opgeofferd aan de belangen der omgeving. Het gemeentebestuur zal bijv. vergunning verleenen voor de oprichting van 
eene fabriek, waar zich schadelijke dampen ontwikkelen, op zoodanige voorwaarden, dat de omgeving in geen geval de onaangename gevolgen ondervinde, dat de schadelijke dampen niet dan op bepaald aangegeven wijze kumnen ontsnappen; het gevolg kan dan zijn, dat de dampen langer in de fabriek blijven dan voor het welzijn en de gezondheid der arbeiders wenschelijk is. Het blijkt echter hoe licht de eischen krachtens de eene wet aan eene inrichting te stellen, in botsing kunnen komen met die, welke van de andere wet het gevolg zijn en hoe noodig het is ervoor te waken, dat de industrieelen hiervan geene nadeelige gevolgen ondervinden."

Met het oog hierop werden bij de Wet van 4 september $1896^{173}$ in de Hinderwet, zoals de Wet van 2 juni 1875 nu genoemd zou worden ${ }^{174}$, de zogenaamde "bis"-artikelen opgenomen ten einde te voorkomen, dat de krachtens die wet verleende vergunningen of de daaraan verbonden voorwaarden botsten met de voorschriften uitgevaardigd op grond van artikel 6 van de Veiligheidswet; een taak die werd opgedragen aan de inspecteurs van de arbeid ${ }^{176}$. Artikel 7 van de Veiligheidswet is van belang, omdat daarin voor de inspecteurs van de arbeid de mogelijkheid werd geopend voorschriften te geven ten aanzien van de tijd gedurende welke personen mogen vertoeven in ruimten, waar het onvermijdelijk is, dat hoge of lage temperaturen, schadelijke dampen, of gassen of stof voorkomen, en ten aanzien van het verstrekken van goed drinkbaar water.

\section{Verdere uitbreiding van de arbeidsinspectie}

Dat het inwerking treden van de nieuwe wettelijke bepalingen op 1 januari $1897^{178}$ tot een niet onaanzienlijke uitbreiding van de werkzaamheden van de inspecteurs zou leiden ${ }^{17}$, zal niemand verbazen.

De taak van de inspecteurs viel duidelijk in twee aspecten te splitsen, namelijk in een sociaal en een technisch aspect. Het eerste aspect omvatte de zorg voor de naleving van de Arbeidswet 1889, waartoe geregeld bezoeken aan fabrieken en werkplaatsen werden gebracht en voortdurend overleg werd gepleegd met gemeentelijke autoriteiten ${ }^{178}$. Het bezoeken van de fabrieken in de avonduren ten aanzien van controle op de naleving van de bepalingen omtrent de arbeidsduur werd echter door sommige inspecteurs nadrukkelijk overgelaten aan de politie ${ }^{179}$. Voor het tweede aspect, de naleving van de bepalingen ter bevordering van de veiligheid en de hygiëne moesten eveneens vele fabrieksbezoeken worden afgelegd. Daarvoor was het nodig om op de hoogte te zijn van de technologie van de bedrijven, van de oorzaken van bedrijfsongevallen en van de methoden en hulpmiddelen, die elders toepassing vonden ter verbetering van onhygiënische of onveilige toestanden.

De bij herhaling gebleken behoefte aan medische voorlichting werd verkregen door samenwerking te zoeken met het geneeskundige staatstoezicht en door met medici van deze dienst gezamenlijk bezoeken te brengen
aan fabrieken ${ }^{100}$.

Tenslotte was niet het minst belangrijke deel van de taak van de arbeidsinspectie het rapporteren over arbeidstoestanden in verschillende bedrijfstakken, waarvan verschillende voorbeelden te vinden zijn in de jaarverslagen zoals bijvoorbeeld onderzoeken in bakkerijen ${ }^{101}$, aardewerk- ${ }^{182}$ en luciferfabrieken ${ }^{183}$, alsmede om na te gaan wat door verschillende bedrijven werd gedaan in het belang van de arbeiders ${ }^{104}$.

Voor de praktische uitvoering van de inspectie-taak was van belang het preventieve toezicht opnieuw opgerichte fabrieken en werkplaatsen en op inrichtingen die uitgebreid werden, daar het verlenen van een vergunning ingevolge de Hinderwet afhankelijk werd gesteld van do verklaring van de inspecteur, dat de ontworpen plannen voor een fabriek of werkplaats niet in strijd waren met de voorschriften van de Veiligheidswet. Het in de Hinderwet gelegde verband met de Veiligheidswet had tevens tot gevolg, dat de inspectie ook langs deze weg in contact kwam met de gemeentelijke autoriteiten, hetgeen leidde tot het vragen door deze autoriteiten van adviezen over aangelegenheden met betrekking tot het tegengaan van gevaar, schade of hinder in verband met fabrieken. Ook werden de inspecteurs nu en dan belast met een onderzoek met betrekking tot de beoordeling van beroepszaken, ingesteld krachtens de Hinderwet ${ }^{125}$.

Al deze omstandigheden maakten, dat, waar de inspecteur in den beginne geheel vrij was geweest in de keu- 
ze van de fabrieken die hij wilde bezoeken, het steeds meer en meer noodzakelijk werd zich te richten naar de eisen van het ogenblik. Ondanks de uitbreiding van de arbeidsinspectie in 1896 namen deze werkzaamheden een zodanige omvang aan, dat haar taak, volgens de minister van Waterstaat, Handel en Nijverheid in de toelichting op de begroting voor het jaar $1899^{186}$, te zwaar te noemen was. Ten einde een goede naleving van de Arbeidswet 1889, de Veiligheidswet en de Hinderwet, voor zover deze laatste bemoeienis van de arbeidsinspectie vereiste, mogelijk te maken, achtte hij de noodzaak aanwezig om de (adjunct) inspecteurs zoveel mogelijk van (de vele ) administratieve werkzaamheden te ontlasten, zodat zij zich meer met het eigenlijke toezicht konden bezighouden. Hieraan werd tegemoet gekomen door aan elke inspecteur een chefde-bureau en een klerk toe te voegen, waardoor de inspecteurs de beschikking kregen over twee vaste ambtenaren in plaats van een tijdelijke ambtenaar die het schrijfwerk deed ${ }^{187}$. Omdat voorts was gebleken, dat in een enkele "arbeidsinspectie" technische hulp aan de inspecteur toegevoegd moest worden, werd het korps uitgebreid met twee adjunct-inspecteurs.

Daar tijdens de begrotingsbehandeling voor het jaar 1898 was gebleken, dat er geen principiële bezwaren bestonden, wilde de bewindsman bij wijze van proef overgaan tot het benoemen van een adjunct-inspectrice. Daartegen bestond vanuit de Tweede Kamer geen bezwaar ${ }^{188}$; immers er waren tal van misstanden in fabrieken en werkplaatsen, waarin door vrouwen arbeid werd verricht en waarover een vrouw beter kan oordelen dan een man, omdat vrouwelijke arbeiders haar grieven eerder mede zouden delen aan een lid harer sekse $^{189}$. Wel werd vanuit de Tweede Kamer door een aantal leden geopperd, dat de aanstelling van vrouwen alleen wenselijk was voor "speciale vakken" en zich zou beperken tot het toezicht op vrouwenarbeid. Een gehele gelijkstelling met adjunct-inspecteurs, waardoor haar werkkring zich ook zou uitstrekken tot fabrieken en werkplaatsen, waar uitsluitend mannen werkten, werd op grond van twee argumenten bezwaarlijk gevonden. In de eerste plaats werd een vrouw daarvoor minder geschikt geacht, en in de tweede plaats wenste men op geen enkele wijze in te stemmen met de denkbeelden over gelijkstelling van mannen en vrouwen. Aan de bewindsman werd gevraagd of hij de adjunct-inspectrice in een later stadium tot inspectrice wilde benoemen. Ook werd gevraagd of de werkkring van de adjunct-inspectrice zich voor "bepaalde vakken" over het gehele land zou uitstrekken of zich tot een bepaalde streek in een "arbeidsinspectie" zou beperken. De voorkeur ging daarbij uit naar het laatste en dan tot dat gedeelte van het land waar veel confectie-industrie voorkwam, omdat daarin veel vrouwen werkzaam waren.

De bewindsman maakte kenbaar ${ }^{180}$, dat het niet in de bedoeling lag om te bevorderen, dat de eventueel aan te stellen adjunct-inspectrice geheel gelijk staan met adjunct-inspecteurs; haar werkterrein zou slechts die fabrieken of werkplaatsen of gedeelten daarvan beslaan, waar uitsluitend of voor het overgrote deel door vrouwen arbeid werd of pleegde te worden verricht. Over de positie van de adjunct-inspectrice stelde hij, dat het toezicht op de uitvoering van de wetten, voor zover dat aan de arbeidsinspectie was opgedragen, bleef berusten bij de inspecteur; de andere ambtenaren - dus ook de adjunct-inspectrice - stonden hem bij bij het vervullen van die taak. Of de adjunct-inspectrice in een later stadium een meer zelfstandige positie zou kunnen innemen, kon nog niet worden beslist, omdat de proef met een vrouwelijke ambtenaar nog moest beginnen. De minister stelde, dat het de bedoeling was om de werkkring van de adjunct-inspectrice over het gehele land uit te strekken, en haar daar het toezicht te doen uitoefenen waar dat op een gegeven moment het meest gewenst was. De beperking tot de confectie-industrie werd door hem verworpen, omdat alle andere bedrijven waar ook in het land, waar misschien meer vrouwen werkzaam waren van toezicht verstoken zouden blijven. Deze reactie van de bewindsman was voor de volksvertegenwoordiging voldoende en zo kon tot de benoeming van éen adjunct-inspectrice, te weten mej. Nuysink, worden overgegaan ${ }^{191}$.

Een korte tijd daarna, werd, eveneens met een beroep op de noodzakelijkheid, in de begroting voor het jaar 1900 voorgesteld de arbeidsinspectie opnieuw, zij het geleidelijk, uit te breiden ${ }^{192}$. Daartoe moesten, volgens de minister in zijn toelichting, de "arbeidsinspectiën" in twee of meer delen gesplitst worden en moest aan het hoofd van elke aldus gevormde "arbeidsinspectie" een inspecteur van de arbeid geplaatst worden; een dergelijke splitsing diende zorgvuldig te gebeuren, waarbij met de verschillende belangen rekening gehouden zou moeten worden. Ook de uitbreiding van het hulppersoneel zou gelleidelijk moeten gebeuren, omdat een 
te snelle uitbreiding hiervan het de inspecteur onmogelijk zou maken hen tot "geschikte krachten bij de arbeidsinspectie op te leiden en dit bovendien te veel van zijn tijd in beslag zou nemen. Maar ook moest de toevoeging van hulppersoneel pas dan plaatsvinden als de reeds toegevoegde ambtenaren in staat zouden zijn om min of meer zelfstandig op te treden in die zin, dat op hun activiteiten niet dagelijks toezicht behoefde te worden gehouden. Eén en ander overwegende stelde de minister voor om in de loop van het begrotingsjaar drie inspecteurs, twee adjunct-inspectrices, vanwege de positieve ervaringen met een dergelijke vrouwelijke ambtenaar, en een opzichter, bij wijze van proef, te benoemen. Met betrekking tot de nieuwe

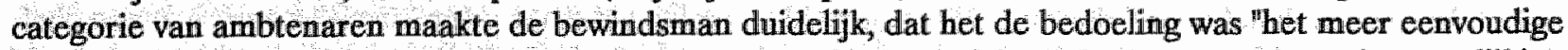
werk", dat op het terrein van de arbeidsinspectie lag, te laten verrichten door personen met in vergelijking tot de adjunct-inspecteurs/inspectrices, een "minder wetenschappelijke opleiding en ontwikkeling". Vanuit de Tweede Kamer werden door een aantal Kamerleden bedenkingen geuit tegen de voorgestelde uitbreidingen ${ }^{1199}$. Behalve op de al door de bewindsman aangegeven bezwaren tegen een splitsing van "arbeidsinspectien" werd gewezen op het feit dat toch nawwelijks sprake kon zijn wan een geleidelijke uitbreiding van de arbeidsinspectie wanneer het korps van vijftien ambtenaren met zes uitgebreid zou worden. Ook werd gevraagd naar de betekenis van de termen "het meer eenvoudige werk". Er mocht in geen geval een situatie ontstaan, waardoor de goede verstandhouding tussen de dienst en de nijverheid zou vertroebelen, wat zou kunnen gebeuren, als de inspecteurs van achter hun bureau bevelen en wenken zouden geven en zelf minder met de fabrikanten in aanraking zouden komen. Andere Kamerleden stemden echter volledig in met de voorgestelde uitbreiding. Van deze voorstanders meenden een aantal, dat tot de opzichter

"een persoon behoort gekozen te worden, die goed met de kringen der arbeiders bekend

is, bij voorkeur een uitstekend werkman".

De reactie van de bewindsman hierop ${ }^{184}$ kan vrijblijvend genoemd worden. Zo was het niet mogelijk nauwkeurig aan te geven wat onder "het meer eenvoudige werk" van de opzichter moest worden verstaan. Maar tot de werkkring van de opzichter werd in het bijzonder geacht te behoren het controleren van de op grond van de Arbeidswet 1889 en de Veiligheidswet gegeven voorschriften ${ }^{195}$. Juist door de inspecteur het meer eenvoudige werk uit handen te nemen werd hem de mogelijkheid geboden om met de fabrikanten in aanraking te doen komen. Overigens was hij eerst met het voorstel gekomen na zowel schriftelijk als mondeling advies van de inspecteurs van de arbeid.

En zo kon, nadat de begroting was afgehandeld en goedgekeurd de volgende uitbreiding van de arbeidsinspectie met drie inspecteurs, twee adjunct-inspectrices en een opzichter van de arbeid wordlen doorgevoerd ${ }^{180}$.

Deze uitbreiding werd geformaliseerd door de intrekking van het Besluit van 23 december 1896 en de uitvaardiging van het Besluit van 18 mei 1900, regelende de werkkring en de bevoegdheden van "inspecteurs en verdere ambtenaren ${ }^{\mathrm{m} 167}$. Naast de al bestaande benamingen van (adjunct-) inspecteur van de arbeid werden nu ook de benamingen adjunct-inspectrice en opzichter van de arbeid officieel ingevoerd. Bovendien werd het rijk, als gevolg van het benoemen van drie inspecteurs, in plaats van zes in negen "arbeidsinspectiën" verdeeld ${ }^{108}$. Inhoudelijk werd het Besluit niet gewijzigd.

\section{Voorstellen om de arbeiders te betrekken bij de handhaving van de arbeidswetgeving}

Na verloop van tijd begonnen de ondernemers en de arbeiders enigszins gewend te raken aan de Arbeidswet 1889 en het daarop gebaseerde optreden van de inspecteurs van de arbeid.

De inspecteur van de arbeid Struve verwoordde het als volgt ${ }^{109}$ :

"Bij mijnen bezoeken stuitte ik op geene bezwaren, mijne verhouding tot de werkgevers

bleef aangenaam.

Waar ik bij de inspectiën in aanraking kwam met de werklieden ondervond ik meestal alle medewerking, terwijl de gevraagde inlichtingen mij bereidwillig en juist werden verstrekt". In sommige bedrijven waar veel vrouwen en jeugdigen werkten, had de wet zelfs een positief effect, in die zin, dat de daarin werkzame mannen eveneens de door de wet voorgeschreven rusttijd genoten ${ }^{200}$. 
Ondanks de aanvankelijk vrij optimistische stemming van de inspecteurs over het resultaat van het politietoezicht op de naleving van de wet; was er ook veel kritiek ten aanzien van zowel de wet als de handhaving. In het Sociaal Weekblad van $1898^{201}$ werd betoogd, dat zowel de inhoud van

"dat akelig wetje, 't welk men gemeend heeft te moeten betitelen met den naam Arbeidswet ${ }^{\text {in202, }}$

als de controle en de inspectie niet deugden. De auteur merkte tevens op, dat de arbeiders wel van het bestaan van de wet op de hoogte waren, maar haar niet serieus namen; zij werd alleen maar gezien als een middel

"om Nederland's fatsoen op te houden tegenover de andere naties, omdat de regering, en over het algemeen de handhavers der wetten juist bij deze wet, waarvan immers zoo luid werd uitgeroepen dat ze was ten gerieve en tot heil van den werkman, maar al te gaarne en met all te groot gemak een oogje toeknijpen, eene overtreding voorbijgaan ${ }^{\text {ins }}$.

De handhaving van de wet door de marechaussee, rijks- en gemeentepolitie en de inspecteurs van de arbeid noemde hij onvoldoende.

"Wat is de marechaussee? Een corps soldaten dat politie-diensten doet, meer niet. Jonge kerels, die misschien den uitwendigen dienst, zoover nodig, in de puntjes kennen, die vechtenden kunnen "opbrengen", en bedronkenen kunnen arresteeren; die op hun paarden goed dienst kunnen doen om het plattelandsvolk ontzag in te boezemen, maar die over eenigerlei wet, over hare grenzen en bedoeling geen jota verstand hebben, en, waar' $t$ hen niet geleerd is, niet kunnen hebben, die onbekenden blijven overall waar men ze plaatst, en die het allereerste, wat noodig is voor de sporing der overtredingen van de arbeidswet, nl. locale kennis ten eenenmale missen".

Hij stelde zich dan ook voor, dat wanneer de marechaussée ooit een overtreding van de Arbeidswet had geverbaliseerd, hilj gestruikeld moet zijn over een kind van 12 jaar, dat na acht uur 's avonds nog stenen sjouwde of vlak voor de deur van een fabriek werkte en er bij uitzondering iemand onder zijn collega's was, die wist dat dat niet mocht. Zijn conclusie was dan ook:

"De marechaussee is wel het minst geschikt om de arbeidswet te controleeren!".

En met de rijks- en gemeentepolitie was het al niet beter.

"De eerste is te klein in aantal en te veel ook nog met transporten en andere dingen belast, en moet op het plaateland al te veell straat- of liever velddienst doen, om zich ook nog met het toezicht op de arbeidswet zeer druk te kunnen maken; bovendien wordt ook de rijksveldwachter dikwijls overgeplaatst, zoodat ook hem de noodige plaatselijke kennis ontbreekt".

Blijft over de gemeente-politie.

"Gemeente-politie! Wat beteekent zij? Wat is zij? $\mathrm{Zij}$ mag op groote plaatsen .... al goed georganiseerd zijn; - haar boodschapjongen-achtige karakter op het platteland en in de kleinere steden is reeds door anderen al te dikwijls in "t licht gesteld".

De conclusie laat aan duidelijkheid niet te wensen over:

". de politie als zoodanig er niet voor deugt, op te treden als handhaafster der arbeidswet" En de inspecteurs van de arbeid. Daarvan stelde de auteur, dat zij zelfs niet een klein gedeelte van de aan hun toebedeelde inspecties behoorlijk konden controleren. $\mathrm{Zij}$ misten daarvoor de tijd, zij kwamen slechts nu eens hier en dan weer daar.

${ }^{7} \mathrm{Zjj}$ er tekortkomingen in de inrichting van werkplaatsen en fabrieken, welnu dan weet de patroon dit altijd wel goed te praten, en de inspecteurs, die door de patroons zeer hoffelijk behandeld worden, hebben dikwijls weinig lust als bullebakken tegenover hun standgenooten op te treden en stellen zich vaak tevreden met de vage verzekering, dat "het nu wel spoedig in orde zal komen".

Bovendien kunnen de inspecteurs de aan hen ter uitvoering opgedragen wet niet anders dan gebrekkig controleeren. $\mathrm{Zj}$ kunnen hoogstens inspecteeren, in hoeverre de kaarten en 
verdere bescheiden aanwezig en in behoorlijke orde zijn; en hoeveel tekortkomingen ze

hierin ook al mogen ontdekken, zij kunnen nlet nagaan, hoever de wet ontdoken of

overtreden wordt door hen, die hun kaarten wèl in behoorlijke orde hebben ${ }^{\text {"204 }}$.

Zijn algehele conclusie is duidelijk

"De naleving wordt verwaarloosd!

Het toezicht deugt niet; het is in verkeerde, der zake onkundige handen!

De straffen zijn te licht!".

Hij bepleitte dan ook, dat de arbeiders in deze meer macht zouden krijgen en dat de vakverenigingen opgedragen zou worden mede voor de naleving van de wet zorg te dragen. En, zo vervolgde hij, de inspecteurs begrijpen zelf maar al te goed, dat alleen de arbeidlers in staat zijn de gewenste verbetering(en) aan te brengen. Hij citeerde de inspecteur van de arbeid Kuyper:

"Wenschelijk blijft het, maar lang niet genoeg komt het voor, dat de arbeiders zelf de ont-

duikingen der wet aan het licht brengen"

Langzamerhand moest toch ook de moderne wetgever zich met het idee vertrouwd maken, dat

"de wetten op den arbeid geen beter opzichturs en uitvoerders vinden dan de be-

langhebbenden, dat zijn de arbeiders ${ }^{\text {"1205 }}$ "

Het vorenstaande leidde tot een ingezonden brief, waarbij werd voorgesteld om ter zake van de arbeidswetgeving arbeiders aan te stellen als onbezoldigd rijksverldwachter ${ }^{206}$. De redactie van het genoemd weekblad stelde in een reactie ${ }^{207}$, dat daartegen geen wettelijke bezwaren bestonden, maar dat dit tot veel verbetering zou leiden werd strekt betwijfeld.

"Het zou tot zonderlinge toestanden leiden, indien werklieden in hun kwaliteit van onbezoldigde veldwachters processen-verbaal gingen opmaken tegen hunne patroons wegens overtreding van de arbeidswet".

Een dergelijke aanstelling zou zich hebben te beperken tot belangstellenden en niet tot belanghebbenden. Bovendien moest het bewaren van beroepsgeheimen geen gevaar lopen.

"Zoolang de ambtelijke contrôle op de naleving der arbeidswet niet voldoende zal zijn geregeld, zal men door de aanstelling van vrijwilligers die leemte niet kunnen aanvullen. Vrijwilligers kunnen eene op de hoogte van haar taak zijnde ambtelijke contrôle aanvullen, maar niet vervangen ${ }^{\prime 20 a}$.

Overigens was dit denkbeeld om de arbeiders te betrekken bij de handhaving van en het toezicht op de Arbeidswet niet nieuw. Kerdijk $\mathrm{k}^{209}$ had dit reeds eerder naar voren gebracht. Hij drong aan op de instelling van "Commissièn uit werklieden-vereenigingen" die tot taak zouden moeten hebben

"de uitvoering der arbeidswet na te gaan, klachten over niet-naleving dier wet in ontvangst

te nemen, naar aanleiding daarvan overleg te plegen met de inspecteurs van den arbeid", en op deze wijze

"voor hun deel de bereiking van het doel des wetgevers te bevorderen"210.

Over de inspecteurs van de arbeid stelde hij het volgende:

"Doch niemand make zichzelven of anderen wijs, dat die ambtenaren ooit bij machte zullen zijn, door eigen krachtsinspanning alleên .... ik zeg niet: alle wetsovertredingen te verhoeden of te ontdekken ( want dit is in elk geval een hersenschim ), maar althans een werkelijk bevredigende toepassing der voorschriften te verzekeren. Hiertoe zullen zij, zonder hulp van elders onmachtig blijven, ook al worden zij nog talrijker, en zelfs al worden zij door de gewone politie beter gesteund, dan totdusver veelal geschiedt. Men denk slechts aan het ontzaglijke getal der fabrieken en werkplaatsen, waarop de wet van toepassing is; en men vergete niet, dat deze ten deele ook de huisindustrie omvat".

Een bevredigende, laat staan volledige uitvoering van arbeidsbeschermende wetgeving, kan niet wanmeer niet dodk degenen, in wier belang zij tot stand is gebracht, voor dat doel hun medewerking verlenen.

"Terecht zijn de inspecteurs bij het volvoeren hunner taak uitgegaan van het standpunt, dat 
zij meer bereiken kunnen, zoo wij welwillend-vermanend de werkgevers tegemoet treden, dan indien zij zich met de vijandige gestrengheid van den slechts bevelenden ambtenaar tegenover hen plaatsen; en aan het volgen dier gedragslijn zal het wel goeddeels te danken zijn, dat de arbeidswet in ruimen kring geen verzet vindt, maar door velen nauwgezet wordt nageleefd. Niettemin echter zullen vermoedelijk de inspecteurs de eersten willen zijn om te erkennen, dat, hetgeen gezegd kan worden van velen, op geen voeten en vamen na geldt van allen. Er zijn er helaas, bovenal onder de kleinere werkgevers, genoeg - en er zullen er ten gevolge van de veiligheidswet nog wel meer komen -, die of op ontduiking der wetsvoorschriften bepaaldelijk zich toeleggen, of althans allerminst de neiging hebben om ze op te volgen, zoolang zij hiertoe niet met nadruk worden aangehouden".

Het officiële toezicht is juist ten aanzien van de zeer talrijke kleinere werkplaatsen zeer moeilijk en om daar ook een vrij algemene eerbiediging van de wet te bereiken, kunnen de ambtenaren de voorlichting van de arbeiders zelf niet missen; zij zijn op hoogte van hetgeen er gedaan en nagelaten wordt, en zijn in staat de aandacht te vestigen op dingen, die anders aan de ambtenaren ontsnappen, aldus Kerdijk. Van de arbeiders kan echter, zo vervolgde hij, niet verwacht worden, dat zij die voorlichting individueel en rechtstreeks verstrekken zullen. Tegenwerkende krachten zijn traagheid en onvoldoende belangstelling, maar ook angst om inlichtingen te verschaffen. De inspecteur mag dan geheimhoudingsplicht hebben, maar

"nochtans blijft voorzichtigheid de moeder van de porceleinkast".

Waar broodwinning in het spel is, is wraakneming door de werkgever een schrikbeeld. Vandaar het voorstel van Kerdijk om een commissie, door de arbeiders zelf uit hun kring aangewezen, met deze taak te belasten, en wel uit tweeërlei oogpunt. In de eerste plaats kunnen zij in arbeiderskringen de onverschilligheid bestrijden, het besef van de plicht tot medewerking wakker roepen of versterken, en aansporen om feiten, die in strijd zijn met de wet niet te verzwijgen. In de tweede plaats bieden zij een betere waarborg, dat de herkomst van de klachten, die overgebracht worden, verborgen zal blijven. Met enige fantasie zou men dit voorstel van Kerdijk een voorloper van de in de Arbeidsomstandighedenwet in het leven geroepen commissie voor veiligheid, gezondheid en welzijn - de Arbocommissie - kunnen noemen ${ }^{211}$.

\section{De Ongevallenwet 1901 en de Phosphorluciferwet 1901}

\subsection{De Ongevallenwet 1901}

Inmiddels was met medewerking van de inspecteurs van de arbeid onze oudste sociale verzekeringswet, de Ongevallenwet $1901^{212}$ tot stand gekomen. Deze wet was gebaseerd op het beginsel van het "risque professionnel", wat inhield, dat de lasten van bedrijfsongevallen - de geneeskundige behandeling en de geldelijke schadeloosstelling van het slachtoffer - gerekend moesten worden te behoren tot de normale bedrijfslasten. In deze wet was dit beginsel beperkt gebleven tot de meest gevaarlijke bedrijven, terwijl de regeling als zodanig een publiekrechtelijk karakter had. Voor de uitvoering werd een op te richten Rijksverzekeringsbank aangewezen. Deze wet maakte, dat vele werkgevers geldelijk belang kregen bij een vermindering van het aantal ongevallen. Trouwens ook ten opzichte van de premiebetaling aan de Rijksverzekeringsbank trad dit geldelijk belang op de voorgrond, daar de hoogte van de premie binnen zekere grenzen afhankelijk kon worden gemaakt van de door de werkgevers in het belang van de veiligheid te nemen maatregelen ${ }^{213}$. Het zal geen verbazing wekken, dat in deze wet de inspecteurs van de arbeid de verplichting was opgelegd desgevraagd aan het bestuur van de Rijksverzekeringsbank mee te delen, wat hun ten aanzien van een bepaalde onderneming bekend was, voor zover het relevant was in het kader van deze wet ${ }^{214}$. Het was niet de bedoeling de inspecteurs van de arbeid te belasten met het instellen van een onderzoek. $\mathrm{Zij}$ zouden alleen hebben mee te delen wat hun op grond van vroegere bezoeken omtrent de toestand van een bepaald bedrijf uit het oogpunt van gevaar voor de daarin werkzame arbeiders bekend mocht zijn ${ }^{215}$.

De rijksverzekeringsbank op haar beurt deed elke aangifte van een ongeval zo snel mogelijk toekomen aan de inspecteur van de arbeid binnen wiens "arbeidsinspectie" het ongeval had plaatsgevonden ${ }^{216}$. Deze laatste 
kon dan indien mogelijk en nodig maatregelen gelasten, of, waar dit niet kon die in overweging te geven opdat herhaling van het gebeurde kon worden voorkomen. Zo ontstond tevens controle op de naleving van artikel 12 van de Veiligheidswet, waarin het hoofd of de bestuurder van een inrichting, waarin fabrieks- of handwerknijverheid werd uitgeoefend, verplicht was een ongeval ter kennis te brengen aan de burgemeester wan de gemeente, waar het ongeval plaatsvond. De burgemeester moest op grond van dit artikel een onderzoek instellen naar de oorzaken en gevolgen van een ongeval en de uitslag hiervan ter kennis van de inspecteur brengen, die de bevoegdheid had een nader onderzoek in te stellen ${ }^{217}$.

De Ongevallenwet 1901 opende de mogelijkheid om via een omweg de invloed van de arbeidsinspectie op het gebied van de veiligheid uit te breiden. Misstanden op het gebied van de veiligheid dienden, zowel in het belang van de Rijksverzekeringsbank als in het belang van de werkgever, zo snel mogelijk weggenomen te worden. De beste manier was door deze ter kennis te brengen van de inspecteurs van de arbeid. En waar die kennisgeving een bedrijf mocht betreffen, dat geen fabriek of werkplaats was in de zin van de Arbeidswet 1889 of van de Veiligheidswet ${ }^{218}$, zou het voorschrift, dat de inspecteur desgevraagd de Rijkswerzekeringsbank moest mededelen wat hem over dat bedrijf bekend was, er toe leiden dat de werkgever rekening zou houden met diens raadgevingen en opmerkingen ${ }^{219}$.

Eén en ander had tot gevolg dat de Ongevallenwet 1901 nogal wat werkzaamheden voor de inspecteurs van de arbeid met zich bracht ${ }^{220}$.

\subsection{De Phosphorluciferwet 1901}

Niet lang na de Ongevallenwet 1901 zouden de activiteiten van de inspecteur van de arbeid van de eerste arbeidsinspectie Kuyper leiden tot ingrijpen van overheidswege voor één bepaalde bedrijfsoort. Deze inspecteur had geconstateerd, dat in ons land meerdere gevallen van phosphornekrose waren aangetroffen en had dit onder de aandacht van de regering gebracht ${ }^{221}$. Zijn onderzoek met de medewerking van het geneeskundig staatstoezicht ${ }^{222}$ leidde in eerste instantie tot het op artikel 4 van de Arbeidswet 1889 gebaseerde Phosphorbesluit $^{223}$, dat zich door de werkingssfeer van de bedoelde wet alleen richtte tot jeugdige personen en vrouwen. Nader onderzoek van de bedoelde inspecteur ${ }^{224}$ leidde uiteindelijk tot de Phosphorluciferwet $1901^{225}$ waarbij niet alleen bij de fabricage van lucifers het gebruik van de ( schadelijke) witte fosfor - welke eenvoudig door de niet-schadelijke, zij het iets duurdere, rode fosfor vervangen kon worden - verboden werd, maar ook het invoeren, vervoeren of te koop aanbieden van lucifers met witte fosfor. Niet zonder reden noemde Levenbach ${ }^{220}$ deze wet zeer radicaal. Met de opsporing van overtredingen voor wat betreft de vervaardiging van fosforlucifers waren onder meer belast de inspecteurs en verdere ambtenaren als bedoeld in artikel 12 van de Arbeidswet $1889^{227}$.

\section{Opnieuw uitbrelding van de arbeidsinspectie met onder andere "specialiteiten"}

Tijdens de mondelinge beraadslaging over de begroting voor het jaar 1900 merkte het Tweede Kamerlid Smeenge op ${ }^{228}$, dat de door de minister voorgestelde en door hem toegejuichte uitbreiding van de arbeidsinspectie ten goede kon komen aan een betere zorg woor sommige onderdelen van het toezicht. Maar, zo stelde hij, de bewindsman kon deze gelegenheid te baat nemen om voor bijzondere onderdelen van het toezicht speciale personen aan te stellen. Destijds was de grief tegen het geneeskundig staatstoezicht, dat alle techniek was uitgesloten; bij de arbeidsinspectie vergat men echter in het bijzonder aan hygiëne aandacht te schenken. Hij sprak dan ook de hoop uit, dat de bewindsman zijn standpunt deelde, dat

"het aanstellen van een geneeskundige thans behoort te geschieden."

De bewindsman meende, dat aan het naar voren gebrachte denkbeeld uitvoering gegeven zou kunnen worden bij het bestaan van een centrale inspectie. Daarvoor was echter de aanstelling van een hoofdinspecteur nodig, wat niet kon zonder een yoorafgaande whijziging van de Arbeidswet 1889 en de Veilligheidswet ${ }^{229}$. Deze reactie kwam Smeenge onbegrijpelijk voor; zolang er geen hoofdinspecteur was, kon een dergelijke plaats toch even goed door het hoofd van het departement worden vervuld. Hij bepleitte nogmaals de benoeming van 
een geneeskundige bij de arbeidsinspectie, echter zonder succes ${ }^{230}$. Toch zou de kern van het pleidooi van Smeenge, namelijk meer aandacht van de arbeidsinspectie voor hygiëne, opgepakt worden door onder andere Bruinsma in een bijdrage in Vragen des Tijds ${ }^{231}$ naar aanleiding van het in de Tweede Kamer ingediende wetsvoorstel houdende regeling van het staatstoezicht op de volksgezondheid ${ }^{2 a 2}$. Hij stelde daarin, dat de Veiligheidswet een wet was

"die het leven en de gezondheid moet beschermen van de bewoners wan Nederland, die

werkzaam zijn in fabrieken enz, dus rechtstreeks eene gezondheidswet".

Het bevreemdde hem, dat de regering er niet aan had gedacht, ook niet bij de Veiligheidswet, dat de Wet regelende het geneeskundig staatstoezicht ${ }^{233}$ de mogelijkheid opende onderdelen van de gezondheidszorg, die in afzonderlijke wetten geregeld werden, in efen wet te brengen. Weliswaar had de laatste wet zelf slechts de aanstelling van een zeker aantal zogenaamde geneeskundige inspecteurs verplicht gesteld, maar artikel 2 van deze wet bepaalde toch uitdrukkelijk, dat voor enig onderdeel van het staatstoezicht tijdelijk of voortdurend bijzondere inspecteurs konden worden aangesteld ${ }^{234}$. Het was dus; aldus de schrijver, voldoende geweest de zorg voor onder meer de veiligheid en de gezondheid tot een onderdeel van dit staatstoezicht te verklaren. Bruinsma bepleitte derhalve een samenwerking tussen het geneeskundig staatstoezicht door middel van bijzondere inspecteurs en de arbeidsinspectie ${ }^{235}$.

Toch zou het niet zo lang meer duren, voordat de inmiddels voor de arbeidsinspectie verantwoordelijk geworden minister van Binnenlandse Zaken Kuyper ${ }^{239}$ een voorstel zou doen overeenkomstig het pleidooi van Smeenge. Dit gebeurde in de begroting voor het jaar 1903. Voorgesteld werd niet alleen het hulppersoneel van de arbeidsinspectie uit te breiden met vier opzichters en én opzichteres, maar tevens om een medisch adviseur en een elektrotechnicus te benoemen ${ }^{237}$. Wat betreft de uitbreiding van het hulppersoneel deelde de bewindsman mede, dat vijf inspecteurs op een dergelijke uitbreiding hadden aangedrongen ${ }^{238}$. De ervaring met de in dienst zijnde opzichter was dusdanig, dat er alle aanleiding was om een proef te nemen met de aanstelling van een opzichteres, die zich in het bijzonder bezig zou hebben te houden met het bezoeken van de talrijke werkplaatsen waar nagenoeg uitsluitend door vrouwen en meisjes arbeid werd verricht. Vele Tweede Kamerieden juichten toe ${ }^{239}$, dat

"bij de vrij algemeen als noodzakelijk erkende uitbreiding van het opzichterspersoneel, ook

het vrouwelijke element bij dat personeel zall worden opgenomen."

Het aanstellen van een medisch adviseur en een elektrotechnicus achtte de minister noodzakelijk. Een deug delijke naleving van een aantal geldende woorschriften vorderde een zodanige kennis op medisch en elektro* technisch gebied; die van een inspecteur van de arbeid niet verwacht mocht worden. Deze inspecteur moest tot dusverre informatie inwinnen bij personen die geheel buiten de dienst van de arbeidsinspectie stonden en voor wie het bezoeken van fabrieken en werkplaatsen uiteraard bijzaak was. Dit laatste was een bezwaar, waaraan, aldus de bewindsman, alleen tegemoet kon worden gekomen door een medicus aan het personeel van de arbeidsinspectie toe te voegen. Men kan zich echter afvragen of dit argument van de minister slechts het enige obstakel kan zijn geweest. Even goed kan namelijk een rol hebben gespeeld, dat deze personen problemen hadden juist met het kunnen betreden van fabrieken en werkplaatsen; mogelijk was, dat zij daarvoor te afhankelijk waren van de toestemming van het hoofd of de bestuurder van de betreffende inrichting. Over de aan de medisch adviseur op te dragen taak deelde de bewindsman mede ${ }^{240}$, dat deze

"zich in de eerste plaats voortdurend op de hoogte zal hebben te houden van al hetgeen

in verband staatmet de bescherming van arbeiders uit hygiènisch oogpunt."

Daartoe zou hij onder andere dagelijks allerlei inrichtingen, waar arbeiders aan nadelige invloeden bloot stonden, hebben te bezoeken en zou hij tal van arbeiders hebben te onderzoeken, ten einde te beoordelen of zij al of niet geschikt waren om bepaalde arbeid te verrichten ${ }^{241}$.

Deze (nadere) omschrijving van de taak van de medisch adviseur was voor het Tweede Kamerlid Roessimgh $^{242}$ reden om op te merken, dat er niet alleen sprake was van medische adviezen, maar van een geheel nieuwe taak van de arbeidsinspectie. Daaraan koppelde hij de vraag of er een nieuw soort van medische dienst voor de "arbeidsinspectiën" zou ontstaan, zeker als in de toekomst in elke "arbeidsinspectie" een me- 
disch adviseur zou ( moeten ) worden aangesteld. Tegen een dergelijke ontwikkeling had hij grote bezwaren, daarbij verwijzend naar de Gezondheidswet en het aldaar geregelde regiem waardoor toch de mogelijkheid aanwezig was voor de arbeidsinspectie om goed bruikbare adviezen te krijgen. De minister gaf in zijn repliek te kennen ${ }^{243}$, dat bij arbeidsaangelegenheden een speciaal soort medische vraagstukken gold, zodat niet volstaan kon worden met thet in de Gezondheidswet geregelde regiem. Of het bij het aanstellen van een medische adviseur zou blijven hing af van de vraag, of het wezenlijke belang van de arbeiders in deze meer een uitgebreider medisch advies noodzakelijk maakte. Mocht deze vraag in de toekomst positief beantwoord worden, dan zou het verkeerd zijn terug te deinzen voor het aanstellen van meerdere medische adviseurs, aldus de bewindsman.

Het voorstel om een elektrotechnicus aan te stellen werd als volgt onderbouwd ${ }^{244}$. De elektrotechniek had zich dusdanig ontwikkeld, dat, als gevolg van de werkzaamheden, de kennis van de inspecteurs daarmede geen gelijke tred had kunnen houden. Ten einde hen toch in staat te stellen een bepaald voorschrift te geven op grond van het Veiligheidsbesluit ${ }^{245}$, leek het hem wenselijk hen bij te laten staan en te laten voorlichten door een bekwaam deskundige, die vervolgens belast zou kunnen worden met periodiek onderzoek naar elektrische inrichtingen. Zowel de benoeming van een medisch adviseur en een elektrotechnicus vond alom instemming, zij het dat wel gevreesd werd dat het ontbreken van een leiding bij de arbeidsinspectie belemmerend zou kunnen werken op het zo effectief mogelijk gebruiken van deze krachten ${ }^{248}$. Dit hield verder echter het aannemen van het voorstel niet tegen en bij Besluit van 29 april $1903^{247}$ werd het eerdere Besluit ingetrokken.

In het nieuwe Besluit werd bepaald, dat de in artikel 12 van de Arbeidswet 1889 en artikel 9 van de Veiligheidswet bedoelde "inspecteurs en verdere ambtenaren" de titel zouden dragen van ${ }^{248}$ :

a. inspecteur, adjunct-inspecteur, adjunct-inspectrice, opzichter of opzichteres van de arbeid;

b. medisch-adviseur of elektro-technicus bij de arbeidsinspectie.

De verdeling van het Rijk in negen "arbeidsinspectiën" bleef ongewijzigd ${ }^{249}$. Het toezicht in een "arbeidsinspectie" zou worden uitgeoefend door een inspecteur, onder wiens bevelen éen of meer van de overige hierboven onder a. bedoelde ambtenaren werkzaam konden worden gesteld, zodat gesteld kan worden dat er in dit opzicht in vergelijking met het eerdere Besluit niets veranderde ${ }^{250}$. Ten aanzien van de beide "specialiteiten" werd bepaald, dat zij toezicht uitoefenden in het gehele rijk ${ }^{251}$. De medische adviseur was naast de inspecteur belast met het toezicht op de uitvoering van de bij of krachtens de Arbeidswet 1889 en de Veiligheidswet gegeven voorschriften, die in belang van de gezondheid van bij de arbeid betrokken personen waren vastgesteld. Bij de uitoefening van dit toezicht diende hij zoveel mogelijk in overleg met de bevoegde inspecteur te handelen. Evenals de inspecteur had de medisch adviseur tot taak zoveel mogelijk overeenstemming te bevorderen tussen de eisen van de wetgeving en de belangen van alle bij de arbeid betrokken personen en diende hij de verantwoordelijke bewindsman desgevraagd van toezicht en advies en kon hij voorstellen doen. Tot slot moest hij de minister een beredeneerd verslag zenden over zijn ambtsbezigheden ${ }^{252}$. De elektrotechnicus had tot taak de inspecteurs in het bijzonder bij te staan in het uitoefenen van het toezicht op de uitvoering van de bij of krachtens de Arbeidswet 1889 en de Veiligheidswet bepaalde voorschriften, voor zover deze van toepassing waren op elektrische toestellen en geleidingen. Hij diende de bevelen op te volgen van de bevoegde inspecteur en hij moest hem zowel mondeling als schriftelijk de verlangde inlichtingen verstrekken, tenzij $\epsilon^{6}$ en en ander in strijd zou zijn met de hem door deminister gegeven bevelen. Wel kon ook deze nieuwe ambtenaar de minister desgevraagd van bericht en advies dienen en hem voorstellen doen ${ }^{269}$. De positie van de elektrotechnicus verschilde dus aanmerkelijk van die van de medisch adviseur, die volledig zelfstandig kon optreden, en die daarmee naar mijn mening in wezen de eerste stap was naar een centrale dienst van de arbeidsinspectie. Daar hun taak het gehele rijk omvatte, kon het niet anders zijn dan dat zij rechtstreeks onder de minister van Binnenlandse Zaken opereerden. Ook nu legde het Besluit de inspecteurs de verplichting op om met elkaar in overleg te treden ten einde een uniforme toepassing van de Arbeidswet 1889 en de Veiligheidswet te bevorderen ${ }^{254}$. Het al eerder genoemde college van inspecteurs bleef in stand. De voorzittershamer van Struve was in 1901 overgenomen door Kuyper die hem 
op zijn beurt in 1905 weer zou overdragen aan Van Deinse ${ }^{255}$. Wel werd in het Besluit bepaald, dat zowel de medisch adviseur als de elektrotechnicus vergaderingen van dit college geheel of gedeeltelijk konden bijwonen voor zover dit door de minister was gelast ${ }^{258}$

Rest tot slot van deze paragraaf nog te vermelden, dat met ingang van 1 april 1903 Wintgens benoemd werd tot medisch adviseur bij de arbeidsinspectie, met ingang van 1 juni van dat jaar Doppler aangesteld werd tot elektrotechnicus bij de arbeidsinspectie en dat mevrouw Visser met ingang van 1 september 1903 de eerste opzichteres van de arbeid werd ${ }^{267}$.

\section{De Caissonwet 1905}

Dat de tot dan opererende dienst belangrijke resultaten kon bereiken en bereikte alls gevolg van grote persoonlijke toewijding van de ambtenaren hadden de voorafgaande jaren aangetoond en bleek opnieuw door de totstandkoming van de Caissonwet $1905^{258}$.

Toen in het voorjaar van 1904 bij werkzaamheden voor de onderbouw van de spoorwegbrug over het Noordzeekanaal bleek, dat door de inspecteur van de arbeid voor de vierde "arbeidsinspectie" op grond van de geldende wettelijke bepalingen in het belang van de arbeiders geen lange schafttijd kon worden voorgeschreven, zou dit leiden tot deze nieuwe wet. Daar de werkzaamheden aan de "Nieuwe Hembrug" zowel onder de bevoegdheid van de inspecteur van de arbeid voor de vierde als die voor de vijfde "arbeidsinspectie" vielen, vond tussen deze beiden overleg plaats, en werd door hen op 31 oktober van dat jaar gezamenlijk een onderzoek ingesteld naar een viertal ongelukken. In een gezamenlijke brief van 14 november 1904 werd aan de verantwoordelijke bewindsman gerapporteerd, dat deze ongevallen een gevolg zouden kunnen zijn van caissonarbeid, zonder dat voldoende rekening zou zijn gehouden met ervaringen die waren opgedaan bij vorige, soortgelijke werkzaamheden. Op 25 november van dat jaar volgde een nieuwe gezamenlijke brief aan de bewindsman, waarin verzocht werd om een wettelijke regeling, die aan de inspecteurs van de arbeid het recht zou toekemnen om voorschriften te geven ten aanzien van caissonarbeid. Dit verzoek vond algehele instemming; een half jaar later, op 22 mei 1905, was de Caissonwet 1905 een feit ${ }^{258}$. Het toezicht op de naleving alsmede de opsporing van overtredingen van deze wet was opgedragen aan de inspecteurs van de arbeid, de onder hun bevelen staande ambtenaren en de medisch adviseur bij de arbeidsinspectie ${ }^{260}$. Tot de voorschriften die krachtens deze wet gegeven konden worden, behoorde ook het bepalen van de tijd waarin een persoon onder een grotere dan de atmosferische luchtdruk arbeid mocht verrichten ${ }^{201}$.

\section{De adviezen inzake de wettelijke beperking van de arbeidsduur voor alle volwassen arbeiders}

Eén van de taken van de inspecteurs van de arbeid was desgevraagd adviseren van de verantwoordelijke bewindsman. Naar aanleiding van de door het Kamerlid Schaper in 1906 ingediende motie betreffende de wettelijke beperking van de arbeidsduur voor alle volwassen arbeiders tot 10 uren per etmaal ${ }^{202}$ won de toenmalige minister van Landbouw, Nijverheid en Handel, het advies in van de inspecteurs van de arbeid. De bewindsman maakte weliswaar bezwaar tegen het volledig mededelen van de rapporten, maar bij schrijven van 30 december 1907 werd een wittreksel van de adviezen, dat door de inspecteurs van de arbeid zelf was gerangschikt en beknopt systematisch was samengesteld, de Tweede Kamer overgelegd ${ }^{203}$.

De adviezen van de inspecteurs betroffen niet de wenselijkheidd van de wettelijke beperking van de arbeidsduur per dag voor volwassenen tot 10 uren per dag, maar slechts de vraag, in welke bedrijven deze beperking tot 10 uren per dag overwegende bezwaren zou ontmoeten en wat die bezwaren in de bedrijfstakken waren. Duidelijk blijkt uit dit uittreksel, dat in vele bedrijven niet zomaar zonder slag of stoot door de wet de 10-urige werkdag ingevoerd kon worden. Meijers ${ }^{284}$ plaatst bij deze adviezen echter een grote "maar" "Hij vraagt zich in de eerste plaats af of de gevolgde wijze of de praktische uitwoerbaarheid van een sociale maatregel te onderzoeken wel de meest aangewezen weg was. De inspecteurs waren overladen met werkzaamheden, terwijl het advies werd gevraagd toen zij bezig waren met de voorbereiding van uitvoerige, nieuwe 
algemene maatregelen van bestuur en de jaarverslagen.

Daarnaast werd het advies met spoed verlangd, zodat het niet te verwonderen is, dat sommige inspecteurs hun advies begonnen met de opmerking dat deze stukken niet konden worden beschouwd als een studie over de beperking van de arbeidsduur van volwassenen, aangezien over dit onderwerp slechts van enkele industrieën voldoende materiaal ter zake beschikbaar was. Bovendien, zo vervolgt de schrijver, was de vraag, of een bedrijf de verkorting van de arbeidsduur toeliet. Verder speelde het feit, dat de inspecteurs niet altijd over voldoende ervaring beschikten, om zonder specifieke voorlichting van werkgevers en arbeiders tot een verantwoord oordeel te komen. Was een andere verdeling van de arbeid of een verandering van een tweeploegen- door een drieploegendienst mogelijk? Zouden de produktiekosten voor de werkgever door de verkorting van de arbeidsduur niet teveel stijgen? Zou door de verkorting van de arbeidsdag de Nederlandse industrie zijn concurrentiepositie ten opzichte van het buitenland behouden? Dit alle waren vragen, waarop de inspecteurs slechts in betrekkelijke mate antwoord konden geven, aldus Meijers. De ontbrekende kennis zouden zij op hun beurt moeten aanvullen via informatie-inwinning bij werkgevers en arbeiders. Lag het dan niet voor de hand om praktische uitvoerbaarheid van een dergelijke maatregel te toetsen bij hen die het meeste recht van spreken hebben: de werkgevers en de arbeiders zelf.

De adviezen bevatten in het algemeen een de 10-urige werkdag weinig gunstig gezinde stemming. Hoewel dit grotendeels een gevolg was van de vraagstelling, in welke bedrijven beperking van de arbeidsduur tot 10 uur per etmaal overwegende bezwaren zou ontmoeten, vindt men ook vele bezwaren van algemene aard tegen een 10-urige arbeidsdag ontwikkeld. Een drietal inspecteurs maakte in het algemeen bezwaar tegen de verkorting. Dat de overigen daartegen echter geen bezwaar hadden, was slechts indirect af te leiden. De bezwaren waren vrijwel dezelfde, namelijk dat de verkorting van de arbeidsdag niet gepaard zou gaan met een evenredige produktiviteitsstijging per arbeider, wat voor Meijers ${ }^{205}$ een al te pessimistische voorstelling van zaken was. Een wel gegrond bezwaar vond hij, dat controle op de wettelijke arbeidsdag in de huisindustrie vrijwel onmogelijk zou zijn, terwijl een wettelijke verkorting van de arbeidsdag die alleen in de industrie van toepassing zou zijn, de huisindustrie zou doen toenemen ${ }^{268}$. Andere bezwaren betroffen hoofdzakelijk de continubedrijven, de samenhang tussen diverse bedrijven, seizoenbedrijven en de concurrentiepositie. De adviezen van de inspecteurs bevatten regelmatig een zodanige tegenspraak ${ }^{267}$, welke alleen door centralisatie tegengegaan kon worden, aldus de auteur. Hij kon toen nog niet weten, dat zeer kort daarop de reorganisatie van de arbeidsinspectie met de instelling van een centrale leiding zou worden doorgevoerd ${ }^{263}$. Tot een wettelijke voorziening heeft eén en ander evenwel niet geleid.

\section{De inspecteur van de arbeld op bezoek}

In de Nieuwe Tijd van 8 augustus 1908 is onder het Enschedese nieuws een bericht opgenomen over een bezoek van een ambtenaar van de arbeidsinspectie, onder de titel "De Inspekteur van dem Arbeid op bezoek (Historisch)".

" "Tingeling," ging de bel aan de fabriekspoort. De baas van 't kleine fabriekje keek uit 't raam en ging naar buiten. Een portier hield men niet er op na: op kleine fabrieken gaat het huiselijker toe dan op groot.

"Goeden middag, meneer," klonk de groet van den baas, terwijl hij 't voor de poort staand heertje aangaapte.

"Goeden middag, ik ben de Inspekteur van den Arbeid; mag ik binnen komen?"

"Zeker, meneer, komt u maar mee naar 't kantoorl"

$\mathrm{Na}$ bescheiden te hebben aangeklopt ging de inspekteur naar binnen en stelde zich aan "meneer" voor. "Meneer" was zeer welwillend, liet 't inspekteurtje plaats nemen, presenteerde sigaren, maakte komplimentjes. 't Inspekteurtje lachte vereerd, was erg beleefd, verzocht meneer hem de fabriek te laten zien. "All right" zei "meneer", "eerst naar de machinekamer!"

De Veiligheidswet schrijft voor, dat bij 't aanzetten der machine een ijzeren koevoet moet 
gebruikt worden. De stoker, tevens machinist, meende dlat die wet verbazend lastig was en hij had de gewoonte om door zijn eigen gewicht tusschen de spaken van 't vliegwiel staande, de machine aan te zetten. Dat mocht, nu de inspekteur aanwezig was, niet op die wijze gebeuren. De stoker was stiekem gewaarschuwd, om dit keer den koevoet te gebruiken. 't Ging hem verbazend onhandig af, - wolken stoom ontsnapten -; eindelijk lukte het.

De inspekteur had het "in de gaten"; zei echter niets, maar vergenoegde zich met terloops te vragen: "Dat ding wordt zeker nooit gebruikt, hê?"

De stoker had bijna "nee" gezegd; "meneer" was hem echter voor met te antwoorden: "Zeker wel meneer, we gebruiken hem geregeld, maar wilt u de konfektiezaal niet inspecteeren?" "Als-'t-u-blieft," zei 't inspekteurtje; nederig en met bedeesde trippelpasjes liep 't achter "meneer" aan.

De direktrice der konfektie-zaak had juist de lijst der personen beneden de 16 jaar en der vrouwen nagekeken, de inkt was nog nat; zij had er inderhaast nog een paar namen bij opgekrabbeld, maar 't was nog lang niet volledig.

Misschien had "t inspekteurtje een flauw vermoede, bij den neus genomen te worden, doch "meneer", met grenzeloose brutaliteit, veel buigingen en strijkages, vroeg hem of-ie de lijst niet wilde inzien; merkte echter tegelijk op, dat "t toch wel in orde zou zijn;" "t was totaal onnoodig na te zien.

't Inspekteurtje, gevleid door "meneers" mooie woorden, lachte vereerd, nam nog een "havannah" aan, en ging weer op een sukkeldrafje achter "meneer" aan, die hem naar de z.g. snijzaal bracht. Hier stond een machine om de stof te snijden, waaraan later boorden, manchetten, overhemden en Engelsche hemden gemaakt worden.

De arbeiders moeten bij 't bedienen hiervan eene handschoen van staaldraad dragen. "t Ding werd nooit gebruikt, 't was zoek: eindelijk vond men het. De snijder trok het schielijk aan.

$\mathrm{Nu}$ vond de inspekteur 't toch een beetje bar, hij gaf aan meneer te kennen dat "t veranderen moest; zei in niet al te krasse termen, dat 't schande was. "Meneer", heel deemoedig, beaamde alles, zei geen woord, knikte met z'n buldoggengezicht, en ging 't inspekteurtje voor naar 't kantoor.

Hier werd "t inspekteurtje getrakteerd en toen "meneer" hem eindelijk wilde uitlate, zei het: "Wacht even, ik heb nog iets vergeten: de verabndkist, wilt u die even laten halen?"

"Met genoegen," zei meneer en de jongste bediende van "t kantoor werd naar den baas gestuurd met verzoek, even de verbandkist te brengen. De baas schrok erg, vloekte in $z^{3} n$ eigen, de werklui grinnikten van de pret, maar niet luidop!

't Inspekteurtje zei, dat 't onbehoorlijk was, konstateerde dat er bijna niets inzat, vroeg opheldering aan den baas. De baas stotterde, wist niet wat te zgegen, keek "meneer" hulpeloos aan. Meneer gaf den baas een standje; zei, ervoor te zullen zorgen; vó6r den avond zou alles in orde zijn; gaf den inspekteur de verzekering, dat alles terecht zou komen.

"t Inspekteurtje was "al lang lekker", gaf "meneer" een hand, groette "t kantoorpersoneel en ging, nagekeken door "meneer", baas, enz., die stikten van 't lachen, de poort üt.

Een werkman lachte niet, doch zei, dat 't wetsverkrkachting was; gedienstige geesten brachten " $t$ meneer over; de werkman moest de laan uit.

Het is op die fabriek nog steeds best mogelijk, dat bij "t snijden de snijder zich in den pols verwondt; de man zal dan gevaar loopen dood te bloeden omdat er geen verbandstof is;, "meneer" maakt intusschen de balans op, telt gulden bij guldens en denkt met de vakantie een reisje naar Baden-Baden te maken!" 
De opsteller van dit bericht is ontegenzeggelijk de arbeiders goed gezind en vindt hun veiligheid en gezondheid een belangrijk beschermwaardig feit. Het beeld dat van de betrokken ambtenaar van de arbeidsinspectie geschets werd, is niet al te fraai. Maar wat gebeurde er? Ruim een maand later, op 19 september 1908, zou een rectificatie geplaatst worden. Bij nader onderzoek was gebleken, dat deze berichtgever onjuiste informatie had verstrekt. Volstaan werd met de opmerking, dat de betrokken ambtenaar zijn plicht niet verwaarloosd had, maar de gegeven opvatting omtrent de arbeidsinspectie en haar wijze van optreden klinkt niet onbekend in de oren. 
moten

1. Zie L.H.M. Kreukels. Mijnarbeid: volgzaamheid en strijdbaarbeid. Geschiedenis van de arbeidsverhoudingen in de Nederlandse steenkolenmijnen, 1900 - 1940, Assen/ Maastricht 1986, blz. 13 U/m 26. Zie ook D. van Blom, Mijnwezen, in Nederlandsch bestuursrecht, Alphen a/d Rijn 2e druk 1934, ble. 699 t/m 717.

2. Zie I.J. Brugmans, Honderd jaren Nederlandse nijverheid $1830-1930$, in Welvaart en Historie. Tien studiën, 's-Gravenhage 1970, blz. $118 \mathrm{t} / \mathrm{m} 139$.

3. Zie I.J. Brugmans, t.a.p., blz. 222.

4. J. Kuczynski, Het ontstaan van de arbeidersklasse, Nijmegen ( z.j. ), blz. 50.

5. Een voorbeeld van een vereniging, waarvan zowel patroons als werklieden gezamenlijk lid waren, was de Amsterdamse "Maatschappij tot verbetering van den werkenden stand" van 1855; zie I.J. Brugmans, Paardenkracht en mensenmacht, blz. 280.

6. Zie J.J. Giele, De eerste Internationale in Nederland. Een onderzoek naar het ontstaan van de Nedlerlandse arbeidersbeweging van 1868 tot 1876 , Nijmegen 1973.

7. Zie I.J. Brugmans, t.a.p., blz. $258 \mathrm{t} / \mathrm{m} 271$.

8. Zie B. Bölger, De werkgeversorganisatie in Nederland, in De Economist $1927 \mathrm{blz} .216 \mathrm{t} / \mathrm{m} \mathrm{231;} \mathrm{B.} \mathrm{Bölger,}$ Organisatorische verhoudingen tusschen werkgevers en arbeiders, Haarlem 1929. Zie ook I.J. Brugmans, Paardenkracht en mensenmacht, blz. 497; J.A.M. Cornelissens, Van individualistische naar institutionele vorming van arbeidsvoorwaarden, Deventer ( z.j. ), blz. $67 \mathrm{t} / \mathrm{m} \mathrm{70;} \mathrm{Verbond} \mathrm{van} \mathrm{Nederlandse} \mathrm{Ondernemingen,}$ De ontstaansgeschiedenis van het Verbond van Nederlandse Ondernemingen in kort bestek, (juni ) 1987.

9. Zie I.J. Brugmans, Paardenkracht en mensenmacht, blz. 497.

10. Zie hierover A.J.C. Rüter, De spoorwegstakingen van 1903. Een spiegel der arbeidersbeweging in Nederland, Nijmegen 1972 (reprint).

11. Dat wil zeggen dat het openstond voor zowel protestantse als rooms-katholieke arbeiders.

12. In juli 1906 deden de bisschoppen gezamenlijk een verklaring uitgaan, waarin zij kenbaar maakten, dat het

"hun ernstig en uitdrukkelijk verlangen is, de hun onderhorige Katholieken te verenigen en verenigd te houden in Katholieke organisatiën".

Zie R. Hagoort, De Christelijk-sociale beweging, Franeker 1955, blz. 120. Die overigens eveneens constateert, dat er in dit opzicht weinig verschil bestaat met het mendament van 1954.

13. Allereerst door de weerstand tegen de vakorganisatie in het algemeen. vervolgens door het discussiepunt of de vakorganisatie alleen plaatselijk of ook landelijk een zelfstandig karakter mocht hebben. Een ander van groot belang zijnd punt was de taakverdeling tussen standorganistaies, die zich beperkten tot het gebied van éen bisdom ( de zgn. diocesane bonden ) en de vakorganisaties die steeds meer in landelijk verband opereerden. Zie G. Harmsen/B. Reinalda, t.a.p., blz. $102-103$. 
14. Zie W.G. Versluis, Beknopte geschiedenis van de Katholieke arbeidersbeweging in Nederland, Utrecht/Nijmegen 1949.

15. SDAP/NVV, Arbeidersleven in Nederland. Resultaten der enquête, ingesteld door het NVV in het najaar van 1907 naar de wenschelijkheid en mogelijkheid van beperking van den arbeidsduur voor volwassenen tot 10 uren per etmaal en afschaffing, respectievelijk beperking van nacht- en kinderarbeid, (z.p.) 1908 (hierna: Arbeidersleven in Nederland).

16. Arbeidersleven in Nederland, blz. 148.

17. J. van den Tempel, De Nederlandsche vakbeweging en haar toekomst, Rotterdam 1910, blz. 116; Van den Tempel was bestuurslid van het NVV.

18. Zie ook A.J.C.M. Geers, t.a.p., blz. 49 - 50.

19. Sociaal Weekblad 1889 blz. 107.

20. Wet van 15 juli 1869 , Stb. 126.

21. Wet van 7 november 1910 , Stb. 313 .

22. Wet van 13 september 1893, Stb. 146.

23. Wet van 23 september 1912, Stb. 280; zie D.W.F. Verkade/J.H. Spoor, Auteursrecht, Deventer 1985, blz. $14-15$.

24. Wet van 12 april 1872 , Stb. 24 .

25. De Economist 1859 Bijblad blz. 330. 26. Zie S. van Houten, De staatsleer van Mr. J.R. Thorbecke, Groningen 1872, blz. 57 - 58; zie ook A.
Postma, t.a.p., blz. 136 - 137.

27. Zie over het coalitieverbod onder meer Ferd. Worthmann, Geschichte des Coalitionsverbot und seiner Aufhebung in den Niederlanden, in Zeitschrift für die gesammte Staatswissenschaft 1876 S. 320 bis zum 351 und S. 583 bis zum 630; J.C.J. van den Schalk, Art. 414 en 415 van den Code Pénal beschouwd in verband met de theorie van het loon, Leyden 1853; A.H. Huussen jr, Coalitieverbod en stakingsvrijheid. Sociaalrechtshistorische aspecten van de wet van 12 april 1872 ( Stb. 24 ), in Econ. en Soc. Hist. Jaarboek 1982 blz. $96 \mathrm{t} / \mathrm{m} \mathrm{113}$; S. van Houten, De regtstoestand der werklieden in Nederland. Ontwerp van wet met memorie van toelichting, 's-Gravenhage 1870.

28. Zie N.W. Posthumus, in Econ. Hist Jaarboek deel IV, blz. 31. Overigens werden in De Economist 1865 blz. 245 eveneens recruteringsmoeilijkheden genoemd.

29. S.Sr. Coronel, Middelburg voorheen en thans, Middelburg 1859, blz. 243. Zie ook S.Sr. Coronel, De toestand der kinderen in onze fabrieken en het gewigt eener regeling van hunnen arbeid, in Tijdsch. Mij. van Nijverheid 1863 blz. 259; G.B. Lalleman, in De Economist 1855 blz. 34 - 35 . 
30. Rapport der Commissie belast met het onderzoek naar den toestand der kinderen in fabrieken arbeidende. Eindverslag, blz. 26. De commissie bestond uit twee geneeskundigen ( J. Zeeman, secretaris van het hoofdbestuur van de Nederlandsche Maatschappij tot bevordering der geneeksunst, en J.G.G. Evers), een fabrikant ( J. van Heulekom jr. te Leiden ), W.C.D. Olivier ( secretaris van de Leidse Kamer van Koophandel ) en A.C.C. de Vries Robbe ( voorzitter ); zie ook J.C. Vleggeert, t.a.p., blz. 78.

31. J.J. Cremer, Fabriekskinderen. Een bede doch niet om geld, Arnhem 1863, blz. 38

32. A.D. van Assendelft de Koningh, in De Economist 1889 blz. 280.

33. S.Sr. Coronel, Kinderarbeid, Culemborg 1879, blz. 243.

34. J. Oppenheim, t.a.p., blz. 4.

35. Tweede Kamer, zitting 1888 - 189, 53.5 ( memorie van antwoord) blz. 16.

36. Zie Bijlagen Tweede Kamer, zitting 1884 - 1885, 121.3 (memorie van toelichting) blz. 3.

37. Weergegeven in A. Postma, in Econ. Soc.Hist. Jaarboek 1973 blz. 259.

38. P.A. Huet, Beschouwingen over de toestanden in de industrie in Nederland in verband met het Verslag der Commissie van Enquête, Amsterdam 1887, blz. 16.

39. Zie hfdst. 2 par. 6 ( Het initiatief-wetsvoorstel van Van Houten).

40. Toespraak van O. Rommerts, geciteerd door J.C. Vleggeert, Kinderarbeid in Nederland, blz. 163. A. Postma, t.a.p., blz. 147, stelt, dat het opmerkelijk is, dat het politieke motief hier ook aanwezig blijkt te zijn aan werknemerszijde. Zo verwonderlijk is dat echter, gezien onder meer de doelstellingen van het A.N.W.V., waarin ordelijke en wettige wegen de doorlopende leidraad dienen te zijn voor verbeteringen van de arbeiders; zie hfdst. 2 nt. 18.

41. Zie artikel 4 van de statuten, weergegeven in B.H. Heldt, t.a.p., bijlage B.

42. Hand. Tweede Kamer, Bijblad Stcrt. 1873 - 1874 II, blz. 1375.

43. Bijlagen Tweede Kamer, Bijblad stcrt. 1872 - 1873, 113.3 blz. 2 - 3. J. Mannoury, Honderd jaar na de Kinderwet van 1874. De politieke rehabilitatie van mr. S. van Houten, in S.M.A. 1974 blz. $353 \mathrm{t} / \mathrm{m}$ 369, betoogt, dat bij Van Houten zijn inspanningen voor de Kinderwet voor een groot deel ingegeven waren door publicitaire overwegingen, omdat zijn Kamerzetel op het spel stond. Zie ook A.J.C.M. Geers, t.a.p., blz. 63 64.

44. Aangehaald door A. Postma, t.a.p., blz. 147.

45. Rapport Schoolverbond, blz. $24-25$.

46. J.D. Veegens, in Vragen des Tijds $1887 \mathrm{II}$ blz. 94 - 95.

47. Zie over de motieven voor staatsingrijpen op sociaal terrein ook A. Postma, t.a.p., blz. $135 \mathrm{t} / \mathrm{m} 148$. 
48. Zie ook A. Postma, ta.p, blz. 148 .

49. Tweede Kamer, zitting $1888-1889,53.5$ (memorie van antwoord) blz. 2 .

50. Tweede Kamer, zitting 1888 - 1889, 53.5 ( memorie van antwoord) blz. 3.

51. Zie Bijlagen Tweede Kamer, zitting 1894 - 1895, 15.2 ( memorie van antwoord ) blz. 14.

52. Wet van 7 juli 1900, Stb. 111 .

53. Wet van 22 juni 1901 , Stb. 158.

54. Wet $\operatorname{van} 13$ juli 1907 , Stb. 193.

55. Zie hierover onder meer M.G. Levenbach, Het honderdjarig Burgerlijk Wetboek en het arbeidsrecht, in Arbeidsrecht. Een bundel opstellen, Alphen a/d Rijn 1951, blz. 256 t/m 276.

56. Behalve de inspecteurs waren met de opsporing belast de bij artikel 8 van het Wetboek van Strafvordering aangewezen personen, de marechaussee, alle ambtenaren van rijks- en gemeentepolitie (zie artikel 18, eerste lid, van de Arbeidswet 1889 ). Ten aanzien van inrichtingen als bedoeld in artikel 24 van de Wet van 2 juni 1875, tot regeling van het toezigt op het inrigten van inrigtingen; welke gevaar, schade of hinder kunnen veroorzaken, Stb. 95, waren met opsporingen van overtredingen uitsluitend belast de inspecteurs van de arbeid en de bij artikel 24 , tweede lid, van bedoelde wet aangewezen ambtenaren en officieren ( zie artikel 18, tweede lid, van de Arbeidswet 1889 ). Wat betreft het toezicht op de rijkswerkplaatsen en -fabrieken bepaalde het derde lid van artikel 18 van de Arbeidswet 1889 , dat dit gebeurde door de hoofden van de betreffende ministeries.

Naast deze aanduiding als opsporingsambtenaar zijn de insepcteurs van de arbeid op grond van artikel 7, onder 7, van het Wetboek van Strafvordering ( 1838 ) opsporingsambtenaar in de zin van dat wetboek. Dat is van belang voor het toepassen van dwangmiddelen en de bewijskracht van het door hem opgemaakte proces-verbaal; zie J.M. Reijntjes, Strafrechtelijk bewijs in wet en praktijk, Arnhem 1980, blz. 195; G.P.A. Aler, De politiebevoegdheid bij opsporing en controle, Zwolle 1982, blz. 54. De bevoegdheid om bij geconstateerde overtreding proces-verbaal op te maken, wordt beschouwd als én van de belangrijkste aspecten van de opsporingsbevoegdheid; zie A.J. Blok/L.Ch. Besier, Het Nederlandsche strafproces. deel I, Haarlem 1925, blz. 419.

57. Artikel 26 van de Arbeidswet 1889.

58. Artikel 16 van het Besluit van 21 februari 1890 , Stb. 27.

59. Artikel 1 van het Besluit van 21 februari 1890, Stb. 27. De minister had oorspronkelijk als benaming voorgesteld "inspecteur voor den arbeid". De Raad van State gaf, gezien het karakter van de betrekking, de voorkeur aan de benaming "inspecteur van den arbeid in fabrieken en werkplaatsen". Mocht deze benaming echter te lang gevonden worden, dan bepleitte hij de titel "inspecteurs van den arbeid", een voorstel, dat door de minister werd overgenomen; zie het advies van de Raad van State van 18 februari 1890, no. lb, Rijksarchief - Raad van State - inv.no. 312.

60. Artikel 2, eerste lid, van het Besluit van 21 februari 1890, Stb. 27. De verdeling van het Rijk was oorspronkelijk in drie arbeidsdistricten. De Raad van State, verwijzend naar artikel 1 van het Besluit van 22 januari 1880, tot regeling van het ambtsgebied der inspecteurs, districts- en arrondissements-schoolopzieners 
en van de verdeeling hunner werkzaamheden, Stb. 5 , gaf de voorkeur aan arbeidsinspectiën. Ook dit werd door de minister overgenomen; zie het advies van de Raad van State van 18 februari 1890, no. 1 b.

Artikel 2, eerste lid, luidde:

"Voor het toezicht op de uitvoering van de in art. 1 genoemde wet wordt het Rijk verdeeld in drie arbeidsinspectiën, waarvan het lste omvat de provincie Noordbrabant, het gedeelte der provincie Gelderland, dat gelegen is ten zuiden van den linker Rijn- en Lekoever, het gedeelte der provincie Zuidholland, dat gelegen is ten zuiden van den linker Lek-, Nieuwe Maas-, Scheur- en Nieuwen Waterwegoever, de provinciën Zeeland en Limburg; het 2de het gedeelte van de provincie Gelderland, dat gelegen is ten noorden van den linker $\mathrm{Rij}$ noever, de provinciën Friesland, Overijssel, Groningen en Drenthe; de 3de het gedeelte der provincie Zuidholland, dat gelegen is ten noorden van den linker Lek-, Nieuwe Maas-, Scheur-en Nieuwen Waterwegoever, de provinciën Noordholland en Utrecht, benevens het niet tot eenige provincie behoorende watergebied des Rijks".

61. Artikel 2, tweede lid, van het Besluit van 21 februari 1890, Stb. 27.

62. Koninklijk besluit van 15 februari 1890 , no. 30 , Stcrt. 1890, no. 41 . Bij besluit van de minister van Justitie van 25 februari 1890, Stcrt. 1890, no. 49, werd aan H.F. Kuyper de eerste "arbeidsinspectie" met als standplaats Breda aangewezen, aan A.D.P.V. van Löben Sels de tweede "arbeidsinspectie" met als standplaats Zwolle en aan H.W.E. Struve de derde "arbeidsinspectie" met als standplaats Haarlem. Zie ook H.A. van IJsselstein, dr. H.F. Kuyper, in den Ingenieur 1910 blz. 964 - 965 en Verslagen van den Inspecteurs van den Arbeid over 1890.

63. Zie het besluit van de minister van Justitie van 25 februari 1890 , Stcrt. 1890 , no. 41. Zie ook H.A. van IJsstelstein, in Vijf en twintig jaren Arbeidsinspectie 1890 - 1915, blz. XI.

64. Bijlagen Tweede Kamer, zitting 1886 - 1887, 105.5 (verslag der commissie ) blz. 72 - 73 ( par. 8 Toestand van fabrieken en werkplaatsen. Fabrieksinspecteurs ).

65. Besluit van 21 februari 1890, Stb. 27.

66. Artikel 7 van het Besluit van 21 februari 1890, Stb. 27.

67. Artikel 14, eerste lid, van het Besluit van 21 februari 1890, Stb 27. Het tweede lid van genoemd artikel bepaalde, dat zij voor hetzelfde doel eens per kwartaal of zo vaak als de minister verder noodzakelijk achtte, op het departement bijeenkwamen om met hem of éen of meer door hem aangewezen ambtenaren overleg te plegen over de werking van de Arbeidswet 1889.

68. Artikel 8 van het Besluit van 21 februari 1890, Stb. 27.

69. Artikel 4 van de wet luidde:

"Bij algemeenen maatregel van bestuur wordt door Ons, hetzij onvoorwaardelijk, hetzij voorwaardelijk, verboden een persoon beneden zestien jaren en in fabrieken en werkplaatsen eene vrouw bepaalde soorten van arbeid te doen verrichten, op grond van de gevaren voor de gezondheid of het leven, welke die soorten van arbeid, hetzij in het algemeen, hetzij bij niet inachtneming van zekere voorwaarden, door de wijze waarop zij verricht worden of door de verwerkt wordende stoffen, voor een persoon beneden de zestien jaren of voor een vrouw opleveren". 
70. Artikel 10 van het Besluit van 21 februari 1890 , Stb. 27.

71. Artikel 13 van het Besluit van 21 februari 1890 , Stb. 27 . De mogelijkheid van het verlenen van vergunningen was neergelegd in de artikelen 5 , derde lid, en 7 , vierde Jid, van de Arbeidswet 1889. Naast de bepalingen betreffende de ( nadere) uitwerking van de taak - toezicht op deuitvoering van de wet - zijn in het Besluit van 21 februari 1890, Stb. 27 , bepalingen te vinden die met de term "instructie-bepalingen" aangeduid kunnen worden; zie bijvoorbeeld artikel 11 ( het houden van aantekening van de bezochte plaatsen en de bevindingen aldaar), artikel 12 ( het zenden van afschriften, rapporten en verslagen omtrent het nader onderzoek in verband met ongevallen) en artikel 14 ( de aan de inspecteurs opgelegde plicht tot onderling overleg)

72. Artikel 9 van het Besluit van 21 februari 1890, Stb. 27.

73. Bij de wijziging van de Arbeidswet 1889 in 1895 (Wet van 20 juli 1895, Stb. 138) werd dit gewijzigd in "elke twee jaren".

74. Zie hidst. 2 nt. 225 .

75. Zie A.L. Scholtens, De uitvoering onzer Arbeidswetgeving, in Staatsrechtelijke opstellen aangeboden aan H. Krabbe,'s-Gravenhage 1927, blz. 146-147; N.C. Winkel, De taak van de arbeidsinspectie, in Gedenkboek ter herinnering aan het vijftig-jarig bestaan der arbeidsinspectie ( hierna Gedenkboek 50 jaar ), Groningen/Batavia 1940, blz. 14.

76. Brief van 24 mei 1890,2 e Afd. A. mo. 211.

77. Brief van 28 juli 1891; zie Lut. Chron. Verz. 28 juli 1891. Zie Verslagen van de Inspecteurs van de Arbeid over 1890, blz. 8 .

78. Zie de artikelen 5, derde lid, en 7, vierde lid, van de Arbeidswet 1889.

79. Zie resp. de artikelen 11, eerste lid, en 10, tweede lid, van de Arbeidswet 1889 .

80. Zie artikel 15, vierde lid, van de Arbeidswet 1889.

81. Zie artikel 11 van het Besluit van 21 februari 1890, Stb. 27.

82. Zie N.C. Winkel, in Gedenkboek 50 jaar, blz. 15. In een schrijven van 16 september 1891 van de commissaris der Koningin in de provincie Overijssel aan de burgemeesters van de gemeenten in de betreffende provincie wordt van deze circulaire gewag gemaakt; zie Lut. Chron. Verz. 16 september 1891.

83. Resp. J. de Groot per 1 mei 1890 en H. Poelman per 1 januari 1892. Zie H.A. van IJsselstein, in Vijf en twintig jaren Arbeidsinspectie 1890 - 1915, blz. XXIV - XXV.

84. Zie de Verslagen van de Inspecteurs van de Arbeid over 1891, blz. 10 en 165 .

85. Besluit van 15 juli 1891, Stb. 147; gewijzigd bij Besluit van 11 augustus 1892, Stb. 199.

86. Zie N.C. Winkel, in Gedenkboek 50 jaar, blz. 15 . 
87. Nota der Inspecteurs van den Arbeid betreffende aanstelling van hulppersoneel, 's-Gravenhage 1893. Deze nota is te vinden in het departementaal historisch archief te Breda (magazijnlijst archief tweede district van de arbeidsinspectie te Breda ( $1890-1934)$, doos/dossnr. 1 - 1).

88. Zie het Besluit van 29 november 1892, waarbij werd bepaald, dat de zorg voor de uitvoering van de Arbeidswet 1889 van het departement van Justitie werd overgebracht naar het departement van Waterstaat, Handel en Nijverheid, Stb. 257, en wel met ingang van 1 januari 1893.

89. Daarvan getuigt een stuk "Uit de eerste jaren der Arbeidsinspectie" in het archief van het directoraatgeneraal van de Arbeid, waarin een tweetal stukken van de inspecteur van de arbeid van de eerste "arbeidsinspectie" worden aangehaald, namelijk no. 1253 memorie van 6 november 1893 en no. $12622 \mathrm{e}$ memorie omtrent werkzaamheden Inspecteurs van den Arbeid ( zie no. 1253). Deze stukken zijn echter niet meer te achterhallen:

90. Bijlagen Tweede Kamer ( Bijlage A ), zitting 1893 - 1894, no. 1. (Hfdst. IX begroting Waterstaat, Handel en Nijverheid) blz. 8.

91. Bijlagen Tweede Kamer ( Bijlage A ), zitting 1893 - 1894, no, 21 ( Hfdst. IX begroting Waterstaat, Handel en Nijverbeid ) blz. 13.

92. Wet van 19 januari 1890 , houdende voorbereidende maatregelen tot het verkrijgen van noodige kennis van feiten en toestanden ter beoordeling in hoeverre aanvulling van de sociale wetgeving vereischt wordt, Stb. 1. Daar in artikel 18 van de wet de werkingsduur beperkt was tot 1 januari 1892 was verlenging hiervan noodzakelijk. Dit gebeurde bij de Wet van 28 december 1891, Stb. 243. Bij Besluit van 29 december 1892, no. 50 , werd de staatscommissie in dezelfde samenstelling in een commissie omgezet ten einde verslagen van de verzamelde gegevens uit te brengen en eventuele voorstellen op grond daarvan te doen; zie Eindverslag der Commissie 1894, blz. 3.

93. De samenstelling van de staatscommissie-Rochussen was als volgt: W.F. Rochussen (voorzitter ), J.C.Th. Heyligers ( secretaris ), J. van Alphen, J.Ph. Bordes, J.F. Jansen, A. Kerdijk, M.J.C.M. Kolkman, N. Reeling Brouwer, O.Q. van Swinderen, J.D. Veegens, W.M. Visser en S.M. van Wijck; zie Eindverslag der Commissie, 's-Gravenhage 1894, blz. 18.

94. Zie artikel 1 van de Wet van 19 januari 1890, Stb. 1 en Eindverslag der commissie 1894, blz. 3.

95. Eindverslag der Commissie, aangaande de werkzaamheden der Staatscommissie, bedoeld bij de wet van 19 januari 1890 ( Staatsblad no. 1), zooals die is gewijzigd bij de Wet van 28 december 1891 ( Staatsblad no. 243 ), tevens behelzende de voorstellen, tot het doen waarvan het door die Staatscommissie gehouden onderzoek aanleiding heeft gegeven, 's-Gravenhage 1894.

96. Eindverslag 1894, blz, 13.

97. E. van Raalte, Troonredes - Openingsredes - Inhuldigingsredes 1814 - 1963, 's-Gravenhage 1964, blz. 178. Zie ook M.G. Levenbach, Arbeid, in Nederlands bestuursrecht, blz. 442.

98. Uiteindelijk zouden er 29 verslagen gepubliceerd worden in totaal 13 delen.

99. Zie Eindverslag 1894, blz. 14. 
100. Zie Eindverslag 1894, blz. 14.

101. Resp. 1509 ongevallen waarvan 41 met dodelijke afloop en 1920 ongevallen waarvan 54 met dodelijke afloop; zie Verslagen der Inspecteurs van den Arbeid over 1890, blz. 90, 212 en 324, en Versllagen der Inspecteurs van den Arbeid over 1891, blz. 122, 230 en 309.

102. Zie Tweede Kamer, zitting 1893 - 1894, 111.3. (memorie van toelichting) blz. 2.

103. Het wetsvoorstel werd bij Koninklijke boodschap van 30 november 1893 ( Tweede Kamer, zitting 1893 1894, 111.1. ) de Tweede Kamer aangeboden.

"De wettelijke regeling van de overheidsmaatregelen tot voorkoming van ongellukken in fabrieken en werkplaatsen, tot beveiliging van den industrieelen arbeid en tot bescherming van de gezondheid der arbeiders kon niet langer op het advies van de Staatscommissie wachten",

aldus C.W. de Vries; Bijdrage tot een staatkundige geschiedenis der arbeidswetgeving in Nederland, in Themis 1924, blz. 227. Genoemde auteur concludeert in De systematiek van het arbeidsrecht, in Vijftig jaar Arbeidswet 1889 - 1939, Haarlem 1939, blz. 28 - 29, dat het eindverslag van de commissie als "werkplan" voor onze sociale wetgeving volledig mislukte.

104. Zie Tweede Kamer, zitting 1893 - 1894, 111.3. ( memorie van toelichting ) blz. 2.

105. Zie Verslagen der Inspecteurs van den Arbeid over 1890 , blz. $78 \mathrm{t} / \mathrm{m} 84,191 \mathrm{t} / \mathrm{m} 204$ en $312 \mathrm{t} / \mathrm{m} 317$, en Verslagen der Inspecteurs van den Arbeid over 1891, blz. 94 t/m 99, 223 t/m 228 en 299 t/m 305.

106. Zie Verslagen der Inspecteurs van den Arbeid over 1890, blz. $85 \mathrm{t} / \mathrm{m} \mathrm{108,205} \mathrm{t} / \mathrm{m} \mathrm{231}$, en $318 \mathrm{t} / \mathrm{m} 336$, enVerslagen der Inspecteurs van den Arbeid over 1891, blz. $100 \mathrm{t} / \mathrm{m} \mathrm{120,229} \mathrm{t} / \mathrm{m} \mathrm{248,306} \mathrm{t/m} 325$.

107. Zie Verslagen der Inspecteurs van den Arbeid over 1891, blz. 307. Zie over deze eerste verslagen: S.Sr. Coronel, De eerste verslagen der inspecteurs van den arbeid, in Vragen des Tijds 1892 I blz. $345 \mathrm{t} / \mathrm{m} 380$.

108. Tweede Kamer, zitting 1893 - 1894, 111.3 (memorie van toelichting ) blz. 2 - 3 .

109. Wet van 20 juli 1895 , houdende bepalingen tot beveiliging het verblijven in fabrieken en werkplaatsen, Stb. 137.

110. Bijlagen Tweede Kamer, zitting 1894 - 1895, 15.1 ( voorlopig verslag ) blz. 2.

11. Bijlagen Tweede Kamer, zitting 1893 - 1894, 111.2. Nog voordat het voorlopig verslag kon verschijnen kwam het wetsvoorstel te vervalien als gevolg van een Kamerontbinding (zie hierover W.J. van Welderen Rengers, t.a.p. II, 's-Gravenhage 1948 4e bijgewerkte druk, blz. 58 t/m 81; P.J. Oud, t.a.p., blz. 150 t/m 154). Het wetsvoorstel werd met toelichting door de nieuwe verantwoordelijke minister nagenoeg ongewijzigd weer ingediend bij Koninklijke boodschap van 29 mei 1894 (Bijlagen Tweede Kamer, zitting 1894 - 1895, 32.1).

112. Bijlagen Tweede Kamer, zitting 1893 - 1894, 111.3 ( memorie van toelichting ) blz. 9.

113. Bijlagen Tweede Kamer, zitting 1894 - 1895, 15.1 ( voorlopig vers]ag ) par. 6, blz. 4.

114. Bijlagen Tweede Kamer, zitting 1894 - 1895, 15.2 ( memorie van antwoord ) blz. 15 - 16. 
115. J.W.S.A. Versteeg, zie Staatsalmanak over het jaar 1896, 's-Gravenhage 1895.

116. De minister merkte op, dat én van de oudste Gewerberäthe in Pruissen, wiens standplaats in het district Düsseldorf was gevestigd, een district waarin zeer veel fabrieken gevestigd waren en waar de combinatie het eerst werd ingevoerd, zich bij de bespreking een tegenstander toonde van de combinatie zoals die in Pruissen bestaat. Als argument voerde deze aan, dat het ketelonderzoek te veel tijd vorderde en de Gewerbe-Inspektoren daardoor te veel onttrokken werden aan de fabrieksinspectie en aan vele bezigheden, die hun bij de verschillende arbeidswetten was opgedragen. Toen hem echter werd medegedeeld hoe het ketelonderzoek in ons land was geregeld en dat in verreweg de meeste gevallen het inwendig ketelonderzoek gebeurde door opzichters bij het stoomwezen, verklaarde hij dat onder die omstandigheden zijns inziens geen redelijk bezwaar tegen een dergelijke combinatie kon worden ingebracht. In het algemeen bleken dan ook de bezwaren voor zover hier en daar geopperd, hun grondslag te vinden in het ontbreken in het buitenland van een klasse van ambtenaren als de opzichters van het stoomwezen zoals in ons land. In Denemarken, waar sinds 1889 het ketelonderzoek was opgedragen aan ambtenaren van de fabrieksinspectie, was het oordeel over de combinatie onverdeeld gunstig ( Bijlagen Tweede Kamer, zitting 1894 - 1895, 15:2. (memorie van antwoord ) blz. 16).

117. Bijlagen Tweede Kamer, zitting 1894 - 1895, 15.5 ( verslag ) blz. 29.

118. De commissie van rapporteurs voor het ontwerp-Veilligheidswet bestond uit de leden: Van Alphen, Kerdijk, Tijdeman, Bahlmann en Hartogh. De commissie van rapporteurs voor het wetsvoorstel tot wijziging van de Arbeidswet 1889 bestond uit de leden: Tijdeman, Kerdijk, Goeman Borgesius, Heemskerk en Pyttersen.

119. Bijlagen Tweede Kamer, zitting 1894 - 1895, 15.1 (voorlopig verslag ) blz. 9 en 11.

120. Bijlagen Tweede Kamer, zitting 1894 - 1895, 15.3.

121. Bijlagen Tweede Kamer, zitting 1894 - 1895, 113.2.

122. Bijlagen Tweede Kamer, zitting 1894 - 1895, 113.1.

123. Bijlagen Tweede Kamer, zitting 1894 - 1895, 113.3 (memorie van toelichting ) blz. 1.

124. Bijlagen Tweede Kamer, zitting 1894 - 1895, 113.4 (voorlopig verslag ) blz. 3 t/m 5 .

125. In dit verband werd verwezen naar de memorie van antwoord voor de begroting voor het dienstjaar 1894; Bijlagen Tweede Kamer ( Bijlage A ), zitting 1894 - 1895, no. 22 ( Hfdst. IX begroting Waterstaat, Handel en Nijverheid) blz. 4 - 5 .

126. Bijlagen Tweede Kamer, zitting 1893 - 1894, 111:3 ( memorie van toelichting) blz. 9.

127. Bijlagen Tweede Kamer, zitting 1894 - 1895, 113.4 (verslag van het mondeling overleg ) blz. 5 t/m 8 .

128. Tegelijkertijd nam de minister een voorschot op het in de toekomst samenvoegen in eén wet van alle wetten die betrekking hebben op de gehele materie van het fabriekswezen, dus ook de Stoomwet (Wet van 28 mei 1869, Stb. 97)(Bijlagen Tweede Kamer, zitting 1894-1895, 113.4 (verslag van het mondeling overleg)), blz. 8. 
129. Bijlagen Tweede Kamer, zitting 1894 - 1895, 113.5 (memorie van antwoord) blz. 8 - 9 .

130. Bijlagen Tweede Kamer, zitting 1894 - 1895, 113.6.

131. Bijlagen Tweede Kamer, zitting 1894 - 1895, 15.6 .

132. Bijlagen Tweede Kamer, zitting 1894 - 1895, 15.8 (amendementen van de commissie van rapporteurs) onder $\mathrm{V}$.

133. Hand. Tweede Kamer, zitting 1894 - 1895, blz. $1216 \mathrm{t} / \mathrm{m} 1218$.

134. Vos de Wael, Van Dedem en Goeman Borgesius ( Hand. Tweede Kamer, zitting 1894 - 1895, blz. 1218 t/m 1321).

135. Hand. Tweede Kamer, zitting 1894 - 1895, blz. 1325.

136. Hand. Tweede Kamer, zitting 1894 - 1895, blz. 1325.

Het artikel met betrekking tot het toezicht zou vernummerd worden tot artikel 9 als gevolg van het verwerpen van artikel 2 ( zie Hand. Tweede Kamer, zitting $1894-1895$, blz. 1303 t/m 1310 ).

137. Hand. Tweede Kamer, zitting 1894 - 1895, blz, 1348.

138. Hand. Eerste Kamer, zitting 1894 - 1895, 113 ( eindverslag bevattende de memorie van antwoord ) blz. 378.

139. Hand. Eerste Kamer, zitting 1894 - 1895, blz. 389 en 399.

140. Wetten van 20 juli 1895, Stb. 137 en Stb. 138. Overigens zij er op gewezen dat tijdens de behandeling van de Wet van 15 april 1896, Stb. 69 , houdende regeling van het toezicht op het gebruik van stoomtoestellen, die de Wet van 28 mei 1869, Stb. 97, verving ( de Stoomwet) de problematiek rond de samensmelting van de arbeidsinspectie en de dienst van het stoomwezen opnieuw aan de orde is geweest. Zie Bijlagen Tweede Kamer, zitting 1894 - 1895, 179.4 ( voorlopig verslag) blz. 2 - 3 en Bijlagen Tweede Kamer, zitting 1895 - 1896, 14.1 ( memorie van antwoord) blz. 1 - 2.

141. Bijlagen Tweede Kamer ( Bijlage A ), zitting 1895 - 1896, no. 2 ( Hfdst. IX begroting Waterstaat, Handel en Nijverheid) ble. $16-17$.

142. Bijlagen Tweede Kamer (Bijlage A ), zitting 1895 - 1896, no. 20 ( Hfdst. IX begroting Waterstaat, Handel en Nijverheid) bli. $9-10$.

143. Als gevolg van het verwerpen van artikel 2 werd artikel 8 van het ontwerp vernummerd tot artikel 7 .

144. Bijlagen Tweede Kamer ( Bijlage A ), zitting 1895 - 1896, no. 21 ( Hfdst. IX begroting Waterstaat, Handel en Nijverheid ) blz. 29.

145. Het amendement luidde:

"De ondergetekende heeft de eer voor te stellen art. 178 te verminderen met fl. $500,-$-"; $^{\text {" }}$

Bijlagen Tweede Kamer ( Bijlage A ), zitting 1895 - 1896, no. 26 ( Hfdst. IX begroting Waterstaat, Handel 
en Nijwerheid ). Het amendement werd gesteund door: Mutsaers, Staalman, Mackay, Zijp en Goedkoop. Zie voorts Hand. Tweede Kamer, zitting 1895 - 1896, blz. 791 - 792.

146. Het amendement luidde:

"De ondergetekende heeft de eer voor de stellen art. 178 te verminderen met fl. $12.500,-\ldots$ ".

Bijlagen Tweede Kamer ( Bijlage A ), zitting 1895 - 1896, no. 27 ( Hfdst. IX begroting Waterstaat, Handel en Nijwerheid ).

147. Zie Hand. Tweede Kamer, zitting 1895 - 1896, blz. 791 t/m 798.

148. Met 44 tegen 20 stemmen; zie Hand. Tweede Kamer, zitting $1895-1896$, blz. 798.

149. Met 40 tegen 25 stemmen; zie Hand. Tweede Kamer, zitting $1895-1896$, blz. 798.

150. Hand. Tweede Kamer, zitting 1895 - 1896, blz. 798.

151. Besluit van 2 april 1896, Stb. 63 .

152. Artikel 2 van het Besluit van 2 april 1896, Stb. 63 luidde:

"Voor de toezicht op de uitwoering van de arbeidswet wordt het Rijk verdeeld in zes arbeidsinspectiën, waarvan de lste omvat de provinciën Limburg en Noordbrabant; de 2 de de provincie Zeelland en dat gedeelte der provincie Zuidholland, dat gelegen is bezuiden den rechter oever van de Lek, de Nieuwe Maas, het Scheur, en den Nieuwen Waterweg, benevens de gemeente Rotterdam; de 3de de provincie Utrecht, en dat gedeelte der provincie Zuidholland, dat gelegen is benoorden den rechter oever van de Lek, de Nieuwe Maas, het Scheur en den Nieuwen Waterweg, met uitzondering van de gemeente Rotterdam; de 4de de provincie Noordholland benevens het niet tot eenige provincie behoorende watergebied des Rijks; de 5de de provinciën Gelderland en Overijssel; de 6 de de provinciën Drenthe, Friesland en Groningen".

153. Artikel 3 van het Besluit van 2 april 1896, Stb. 63 .

Onder intrekking van de beschikking van 25 februari 1890 , no. 105, 2de Afdeeling A, van de minister van Justitie, heeft de minister van Waterstaat, Handel en Nijverheid bepaald, dat vanaf 1 mei 1896 bevoegd zal żjin:

- in de 1e arbeidsinspectie de inspecteur van de arbeid H.F. Kuyper, met als standplaats Breda;

- in de 2 de arbeidsinspectie de inspecteur van de arbeid J. Arendsen de Wolff, met als standplaats Rotter dam;

- in de 3de arbeidsinspectie de inspecteur van de arbeid H.W.E. Struve, met als standplaats "s-Gravenhage;

- in de 4de arbeidsinspectie de inspecteur van de arbeid J.H.L. Deinse, met als standplaats Amsterdam;

- in de 5e arbeidsinspectie de inspecteur van de arbeid A.D.P.V. van Löben Sels, met als standplaats Zwolle; - in de 6de arbeidsinspectie de inspecteur van de arbeid G.J. van Thienen, met als standplaats Groningen. Beschikking van 18 april 1896, no. 151, Afdeeling Arbeid en Fabriekswezen; te vinden in het Departementaal Historisch Archief te Breda (doos/dossnr. 1 - 1).

154. Artikel 9 van het Besluit van 2 aprill 1896, Stb. 63 .

155. Artikelen 11 en 18 van het Besluit van 2 april 1896 , Stb. 63.

156. Artikel 13 van het Besluit van 2 april 1896, Stb. 63. 
157. Artikel 17 van het Besluit van 2 april 1896, Stb. 63.

158. Artikel 14 van het Besluit van 2 april 1896, Stb. 63.

159. Artikel 16 van de Arbeidswet 1889 was eveneens gewijzigd bij de Wet van 20 juli 1895 , Stb. 138.

160. Artikel 12 van het Beshit van 2 april 1896, Stb. 63.

161. Artikel 10 van het Besluit van 2 april 1896, Stb. 63 .

162. Besluit van 29 februari 1896, no. 10, Stcrt. 1896, no. 52. Hun vorige functies waren resp.: inspecteur der Nederlandsche Vereeniging van assuradeuren te Amsterdam; assistent aan de Polytechnische School te Delft en leraar aan de Nederlandsche School voor nijverheid en handel te Enschede.

163. Besluit van 30 juli 1896, no. 31, Stcrt. 1896 no. 179. Hun worige functies waren resp.: tweede chef der afdeling fabrikage van de Nederlandsche Gist- en Spiritusfabriek te Delft; werktuigkundige bij de Koninklijke Paketvaartmaatschappij te Oppenheim: technoloog te 's-Gravenhage; luitenant ter zee 2e klasse te Willemsoort; technisch ambtenaar bij het ministerie van Koloniën en werktuigkundig ingenieur te Delft.

Het vergelijkend examen is ingesteld bij ministeriële beschikking van 10 februari 1896; zie A. Kerdijk, Vrouwelijke ambtenaren bij de Arbeidsinspectie, in Vragen des Tijds 1898 ( overdruk ), blz. 16.

164. Besluit van 23 december 1896 , Stb. 228 .

165. Zie Besluit van 7 december 1896, Stb. 216.

166. Zie voordracht van de minister van Waterstaat, Handel en Nijverheid van 14 november 1896, L.A.E., afdeeling Arbeids- en Fabriekswezen. De zienswijze werd gedeeld door de Raad van State; zie advies van 15 december 1896, no. 6 ( Rijksarchief - Raad van State - inv.no. 328 ).

167. Zie artikel 1 van de Veiligheidswet. De wet gold eveneens voor vlasbraakhokken en zwingelketen. Bij de wet van 1 juli 1909, Stb. 245 werd de werkingssfeer uitgebreid tot elektrische centrales

"voor zoover aldaar in of voor eenig bedrijf electrische energie wordt opgewekt, getrans-

formeerd of bewaard".

168. Deze voorschriften konden betrekking hebben op: de hoogte van de werklokalen en de vrije luchtruimte voor elke arbeider, de luchtverversing, de verlichting, het voorkomen van brand en van ongevallen bij brand, de kleedkamers, schaftlokalen en privaten.

169. Deze voorschriften konden betrekking hebben op: de zindelijkheid, een dragelijke temperatuur, het tegengaan, het verspreiden en het verwijderen van schadelijke dampen, gassen en stof, het voorkomen van ongevallen door onder meer de gebruikte werktuigen en vallende voorwerpen, kokende of bijtende vloeistoffen, gloeiende of gesmolten metalen of ontplofbare stoffen.

170. Wet van 2 juni 1875 , Stb. 95 .

171. Zie artikel 1 van de Wet van 2 juni 1875, Stb. 95, dat luidde als volgt:

"Het is verboden inrigtingen, welke gevaar, schade ofhinder kunnen veroorzaken, op te rigten zonder vergunning, welke, behoudens de bij deze wet gemaakte uitzonderingen, door het gemeentebestuur wordt gegeven". 
172. Zie Tweede Kamer, zitting $1895-1896,92.3$ ( memorie van toelichting) blz. 1 .

173. Wet van 4 september 1896 , houdende wijziging en aanvulling der wet van 2 juni 1875 ( Staatsblad no. 95) tot regeling van het toezigt bij het oprigten van inrigtingen, welke gevaar, schade of hinder kunnen veroorzaken, Stb. 152 .

174. Zie artikel 20 van de Wet van 4 september 1896 , Stb. 152.

175. Zie ook A.N. Molenaar, t.a.p. IIB, Zwolle 1958, blz. 1381 - 1382.

176. Zie de besluiten van 7 december 1896, Stb. 216 , en van 12 december 1896, Stb. 215. Het op de artikelen 6 en 7 van de eerstgenoemde wet gebaseerde Besluit van 7 december 1896 ( Stb. 215) zou op grond van artikel 25 van deze wet eerst op 1 januari 1898 inwerkingtreden. Het op artikel 4 van de Arbeidswet 1889 gebaseerde Besluit van 15 juli 1891 ( Stb. 147 ), dat voorschriften bevat terzake van de veiligheid en de gezondheid van jeugdige personen en vrouwen in fabrieken en werkplaatsen, zou bij Besluit van 21 januari 1897 ( Stb. 46 ) zodanig gewijzigd worden dat er meer samenhang bestond met de op grond van de Veiligheidswet 1895 uitgevaardigde voorschriften.

177. Zie Verslagen van de Inspecteurs van de Arbeid over $1897-1898$, blz. 3, blz. 133, blz. 224, blz. 320 , blz. 405 en blz. 507.

178. Zie Verslagen van de Inspecteurs van de Arbeid over $1897-1898$, blz. 134 en blz. 320 .

179. Zie Verslagen van de Inspecteurs van de Arbeid over 1897 - 1898, blz. 507.

180. Zie Verslagen van de Inspecteurs van de Arbeid over 1898 - 1899, blz. 231 en blz. 549; over 1899 - 1900 , blz. 1900 - 1901 en blz. 1175 t/m 1214.

181. Zie Verslagen van de Inspecteurs van de Arbeid over 1897 - 1898, blz. 332 - 333; over 1899 - 1900 , blz. 470 .

182. Zie Verslagen van de Inspecteurs van de Arbeid over $1899-1900$, blz. $1175 \mathrm{t} / \mathrm{m} 1214$.

183. Zie Verslagen van de Inspecteurs van de Arbeid over $1895-1896$, blz. $23-24$ en blz. $56 \mathrm{t} / \mathrm{m} 59$; over 1897 - 1898, blz. 40 t/m 45.

184. Zie N.C. Winkel, in Gedenkboek 50 jaar, blz. 21.

185. Zie artikel $15 \mathrm{t} / \mathrm{m} 17$ van de Hinderwet.

186. Tweede Kamer ( Bijlage A ), zitting 1898 - 1899, no. 2 ( Hfdst. IX begroting Waterstaat, Handel en Nijverheid ) blz. 18.

187. Bij Besluit van 11 maart 1899, no. 29, Stcrt. 1899 no. 63 zijn met ingang van 1 april 1899 benoemd: - als chef de bureau: J. de Groot, te Breda; J.C. Abraham, te Rotterdam; D. Teekens, te 's-Gravenhage; S.J. Boss, te Groningen; F. Nieuwenhuizen, te Amsterdam en A. Folmer, te Arnhem;

- als klerk: H. Paalman, te Armhem; J. Schenk, te Amsterdam; C.J.B. Abraham, te Rotterdam, mej. A.W. Bosch, te Breda en mej. J. van Konijnenburg, te Groningen. 
188. Tweede Kamer ( Bijlage A), zitting 1898 - 1899, no. 21 ( Hfdst. IX begroting Waterstaat, Handel en Nijwerheid ) blz. 9 - 10.

189. Vanuit de Tweede Kamer werd door de voorstanders verwezen naar de ervaringen die in de Verenigde Staten waren opgedaan met inspectrices. Overigens meende de bewindsman dat het argument, dat vrouwelijke arbeiders haar grieven eerder mededelen aan een lid van haar sekse, in de praktijk niet algemeen scheen to zijn. Ook hij verwees naar de situaties in de Verenigde Staten; zie Tweede Kamer ( Bijlage A ), zitting $1898-1899$, no. 22 ( Hfdst. IX begroting Waterstaat, Handel en Nijverheid) blz. 19.

190. Tweede Kamer ( Bijlage A ), zitting $1898-1899$, no. 24 ( Hfdst. IX begroting Waterstaat, Handel en Nijverheid ) blz. 32.

191. Bij Besluit van 25 april 1899 , no. 61 , Stert. 1899 , no. 99 is, met ingang van 16 mei 1899 tot adjunct-inspectrice van de arbeid benoemd mej. A.A. Nuysink, apotheker te Arnhem.

192. Tweede Kamer ( Bijlage A ), zitting 1899 - 1900, no. 2 ( Hfdst. IX begroting Waterstaat, Handel en Nijverheid ) blz 16a. De minister verwees daarbij naar zijn eerdere opmerking in de memorie van toelichting van het ontwerp van wet tot regeling van de arbeids- en rusttijden in fabrieken en werkplaatsen voor personen op wier arbeid deArbeidswet 1889 niet van toepassing is ( Bijlagen Tweede Kamer, zitting 1898 $1899,118.3$ (memorie van toelichting) blz. 5). Dit wetsvoorstel, dat bij Koninklijk besluit van 26 november 1898 ( Bijlagen Tweede Kamer, zitting 1898 - 1899, 118.1) aan de Tweede Kamer was aangeboden had betrekking op arbeiders die werkzaam zijn in schadelijke en gevaarlijke bedrijven, wier arbeidstijd tot 11 uur per dag zou worden beperkt, alsmede op bakkers. Maar tevens bevatte het enige beperkende bepalingen voor volwassen arbeiders in het algemeen, met name om roulering bij nachtarbeid te bevorderen en om zondagsarbeid tegen te gaan. Het wetsvoorstel is nooit verder gekomen dan het voorlopig verslag ( Bijlagen Tweede Kamer, zitting 1898 - 1899, 118.4 ), waarin het ontwerp, mede door de tweeslachtige opzet, een ongunstig onthaal kreeg. Zie M.G. Levenbach, Arbeid, in Nederlands bestuursrecht, blz. 444.

193. Tweede Kamer ( Bijlage A ), zitting 1899 - 1900, no. 22 ( Hfdst. IX begroting Waterstaat, Handel en Nijverheid ) bli. 10.

194. Tweede Kamer (Bijlage A ), zitting $1899-1900$, no. 23 ( Hfdst. LX begroting Waterstaat, Handel en Nijverheid ) blz. 28 - 29.

195. De minister verwees naar onder meer de artikelen 12 en 13 van de Veiligheidswet en de artikelen 3 en 5 t/m 11 van de Arbeidswet 1889.

196. Bij Besluit van 14 april 1900, no. 63, Stcrt 1900, no. 88, werden met ingang van 1 juni 1900 tot inspecteur van de arbeid benoemd: E.H. Dekker, leraar aan de Nederlandsche School voor nijverheid en handel, te Enschede; D. Blanson Henkemans, adjunct-inspecteur van de arbeid, te Groningen; S.R. Smit, technisch adviseur van de Ermelo Spoorwegmaatschappij, gevestigd de Pretoria.

Bij Besluit van 30 april 1900, no. 158, Stcrt. 1900, no. 102, werd tot adjunct-inspectrice van de arbeid benoemd: met ingang van 16 mei 1900 E.J. Tilanus, echtgenote van R.K.H. Kuyper, doctorandus in de artsenijbereidkunde en apotheker te Amsterdam. Zie over vrouwelijke ambtenaren bij de arbeidsinspectie: A. Kerdijk, in Vragen des Tijds 1898 ( overdruk ); M.C.H. Bousardt, Onder vrouwelijke hoede. Vrouwen bij de Arbeidsinspectie, 's-Gravenhage 1990.

Bij Besluit van 7 mei 1900, no. 57, Stcrt. 1900, no. 108, is met ingang van 1 september 1900 tot opzichter van de arbeid benoemd: B. Quispel, te Rotterdam, opzichter over de werktuigen, tevens tekenaar aan de fabrieken voor gas en elektriciteit van genoemde gemeente. 
197. Besluit van 18 mei 1900, tot regeling van de werkkring en de bevoegdheden van de bij art. 12 der Arbeidswet en art. 9 der Veiligheidswet bedoelde inspecteurs en verdere ambtenaren, Stb. 74; dit Besluit zou worden gewijzigd bij Besluit van 13 februari 1902, Stb. 32.

198. Artikel 2 van het Besluit van 18 mei 1900, Stb. 74 .

Dit artikel luidde:

"Voor het toezicht op de uitvoering van de Arbeidswet en van de Veiligheidswet wordt het Rijk verdeeld in negen arbeidsinspectiën, waarvan het lste omvat de provinciën Limburg en Noord-Brabant;

de 2de de provincie Zeeland en dat gedeelte der provincie Zuid-Holland, dat gelegen is bezuiden den rechter oever van de Lek, de Nieuwe Maas, het Scheur en den Nieuwen Waterweg, benevens de gemeente Rotterdam;

de 3de dat gedeelte van de provincie Zuid-Holland, dat gelegen is benoorden den rechter oever van de Lek, de Nieuwe Maas, het Scheur en den Nieuwen Waterweg, met uitzondering van de gemeente Rotterdam;

de 4de dat gedeelte der provincie Noord-Holland, dat gelegen is bezuiden de noordelijke oevers van het Noordzeekanaal en het $Y$, met uitzondering van het bezuiden die oevers gelegen gedeelte der gemeente Zaandam, de benoorden de genoemde oevers gelegen gedeelten van de gemeente Amsterdam en Velsen; het niet tot eenige provincie behoorende watergebied des Rijks;

de 5 de dat gedeelte der provincie Noord-Holland, dat gelegen is benoorden de noordelijke oevers van het Noordzeekanaal en het $Y$, met uitzondering van de benoorden die oevers gelegen gedeelten van de gemeenten Amsterdam en Velzen; het bezuiden de genoemde oevers gelegen gedeelte der gemeente Zaandam;

de 6 de de provincie Utrecht;

de 7de de provincie Gelderland;

de 8ste de provinciën Overijssel, Drenthe en Groningen;

de 9 de de provincie Friesland".

Dit artikel werd bij de al eerder genoemde wijziging aldus gewijzigd: de 7de arbeidsinspectie omvatte nu de provincies Gelderland en Overijssel, terwijl de 8ste arbeidsinspectie de provincies Drenthe en Groningen omvatte.

199. Verslagen van de Inspecteurs van de Arbeid over 1894, 's-Gravenhage ( z.j.), blz. 275.

200. Zie Th, van Tijn, Het sociale leven in Nederland, in Algemene geschiedenis der Nederlanden deel 13, Haarlem ( z.j. ), blz. 89.

201. H.S., Over kinderarbeid en Arbeidswet, in Sociaal Weekblad 1898 blz. 256 - 257, blz. 264 - 265 en blz. $272 \mathrm{t} / \mathrm{m} 274$.

202. H.S., in Sociaal Weekblad 1898 blz. 256.

203. H.S., in Sociaal Weekblad 1898 blz. $256-257$.

204. H.S., in Sociaal Weekblad 1898 blz. 272 - 273.

205. H.S., in Sociaal Weekblad 1898 blz. 274.

206. Zie C.J.D., Overtreding der Arbeidswet, in Sociaal Weekblad 1898 blz. 299. 
207. Sociaal Weekblad $1898 \mathrm{blz} .299$.

208. Zie ook A.J.C.M. Geers, t.a.p., blz. 42.

209. A. Kerdijk, Noodige medewerking, in Sociaal Weekblad $1896 \mathrm{blz}, 241-242$ en blz. $249-250$.

210. A. Kerdijk, in Sociaal Weekblad 1896 blz. 241.

211. Zie artikel 14 van de Arbeidsomstandighedenwet.

212. Wet van 2 januari 1901, Stb. 1. Literatuur over deze wet: onder meer M.G. Levenbach, Arbeid, in Nederlands bestuursrecht, blz, 544; W. de Vries Wzn, De totstandkoming van de Ongevallenwet 1901, Deventer (z.j. ); H.L. Duyl/A. Heringa, Literatuur en rechtspraak betreffende de Ongevallenwet 1901 en Beroepswet, Haarlem 1905; E. Fokker, De Ongevallenwet 1901, Haarlem 1901/1903 ( 2 dln.); A. Slotenmaker LHzn, De Ongevallenwet geschetst voor werkgevers en werklieden, Amsterdam 1902.

213. G.M.J. Veldkamp, Inleiding tot de sociale zekerheid en de toepassing ervan in Nederland en België deel I karakter en geschiedenis, Deventer (z.j. ), blz 64-65; M.G. Levenbach, Arbeid, in Nederlands bestuursrecht, blz. 544; H.A. van IJsselstein, in Vijfentwintig jaren Arbeidsinspectie 1890 - 1915, blz. VIII - IX.

214. Zie artikel 41 van de Ongevallenwet 1901 . De ratio van deze bepaling was, dat het bestuur van de rijksverzekeringsbank moest proberen elk bedrijf zo juist mogelijk in te delen naar het gevaar dat hett opleverde.

215. Tweede Kamer, zitting 1896 - 1897, 159.3 (memorie van toelichting ) blz. 30.

216. Zie artikel 61 , zesde lid, van de Ongevallenwet 1901 .

217. Tweede Kamer, zitting 1896 - 1897, 159.3 (memorie van toelichting ) blz. 31.

218. Zie resp. artikel 1 van de Veiligheidswet en artikel 2 van de Arbeidswet 1889.

219. Zie artikel 85 wan de Ongevallenwet 1901; Tweede Kamer, zitting 1896 - 1897, 159.3 ( memorie van toelichting) blz. 34 .

220. Zie bijwoorbeeld Verslagen van de Inspecteurs van de Arbeid over 1901 - 1902, blz. 131, blz. 264, blz. 849 en blz. 1160 - 1161. Vermeldenswaard is, dat met ingang van 1 jumi 1901 de inspecteur van de arbeid Struve benoemd werd tot én van de directeuren van de Rijksverzekeringsbank ( zie H.A. van IJsselstein, in Vijf en twintig jaren Arbeidsinspectie $1890-1915$, blz. XXI ).

221. De aanleiding tot het door Kuyper instellen van een onderzoek naar phosphornekrose was, naar zijn schrijven een krantenbericht in het begin van 1896 , waarin melding wordt gemaakt van het wegnemen van een gedeelte van een kaak van een arbeidster in een luciferfabriek. Zie Verslagen van de Inspecteurs van de Arbeid over 1895 - 1896, blz. 23.

222. Zie Verslagen van de Inspecteurs van de Arbeid over 1895 - 1896, blz. 23 - 24 .

223. Besluit van 24 juli 1898 , Stb. 148. Het besluit bevatte (on)voorwaardelijke verboden om jeugdige personen en vrouwen in fabrieken en werkplaatsen arbeid te doen verrichten waar fosfordampen kunnen ontstaan. 
224. Zie Verslagen van de Inspecteurs van de Arbeid over 1897 - 1898, blz, $40 \mathrm{t} / \mathrm{m}$ 50. In de memorie van toelichting werd uitgebreid op de voorgeschiedenis ingegaan; zie Bijlagen Tweede Kamer, zitting 1899 - 1900, 187.3.

225. Wet van 28 mei 1901, Stb. 133.

226. M.G. Levenbach, Arbeid, in Nederlands bestuursrecht, blz. 444.

227. Artikel 6, tweede lid, van de Phosphorluciferwet 1901. Met het opsporen van overtredingen waren tevens belast naast de bij artikel 8 van het Wetboek van Strafvordering aangewezen personen, de marechaussée, alle ambtenaren van rijks- en gemeentepolitie, alsmede de ambtenaren van de invoerrechten en accijnzen; deze laatsten voor wat betreft het vervoeren, invoeren alsmede het ten verkoop voorhanden hebben.

228. Hand. Tweede Kamer, zitting 1899 - 1900 II, blz. 973 - 974.

229. Hand. Tweede Kamer, zitting 1899 - 1900 II, blz. 974.

230. Hand. Tweede Kamer, zitting 1899 - $1900 \mathrm{II}$, blz. 974.

231. G.W. Bruinsma, De gezondheidswet; in Vragen des Tijds $1900 \mathrm{I}$ blz. $207 \mathrm{t} / \mathrm{m} 250$.

232. Bijlagen Tweede Kamer, zitting 1900 - 1901, 35.1 en 2. Het wetsvoorstel resulteerde in de Wet van 21 juni 1901 (Gezondheidswet). Zie voor een korte inhoudsbeschrijving onder andere: De Gezondheidswet, in Sociaal Weekblad 1901 blz. $157-158$ en in K.S.W. 1902 blz. $286-287$.

233. Wet van 1 juni 1865, Stb. 58.

234. Het tweede lid van artikel 2 van de Wet regelende het geneeskundig Staatstoezicht luidde:

"Des noods worden voor eenig onderdeel van het geneeskundig Staatstoezigt tijdelijk of voortdurend bijzondere inspecteurs door Ons benoemd".

Overigens ontbreekt een dergelijke bepaling in de Gezondheidswet.

235. Zie ook I.P. de Vooys, Arbeidsinspectie, in Vragen des Tijds 1901 ( overdruk ), blz. 24.

236. Zie het Besluit 26 augustus 1901, tot overbrenging van de zorg voor de uitvoering van wetten en Koninklijke besluiten, betreffende landbouw, voor zooveel het Departement van Binnenlandsche Zaken thans daarmede belast is, naar dat vanWaterstaat, Handel en Nijverheid en betreffende Arbeid in Fabriekswezen, voor zooveel het Departement van Waterstaat, Handel en Nijverheid thans daarmede belast is, naar dat van Binnenlandsche Zaken, Stb. 206 (en wel met ingang van 1 september 1901 ).

237. Tweede Kamer ( Bijlage A ), zitting 1902 - 1903, no. 2 ( Hfdst. V begroting Binnenlandsche Zaken ) blz. 27 - 28.

238. Vier inspecteurs hadden aangedrongen op de aanstelling in hun "arbeidsinspectie" van een opzichter, terwijl én inspecteur in zijn "arbeidsinspectie" een opzichteres aangesteld wilde zien.

239. Tweede Kamer (Bijlage A), zitting 1902 - 1903, no. 12 (Hfdst. V begroting Binnenlandsche Zaken) blz. 25. 
240. Tweede Kamer (Bijlage A), zitting 1902 - 1903, no. 13 (Hfdst. V begroting Binnenlandsche Zaken) blz. 63.

241. Zie het Besluit van 16 maart 1903 tot vaststelling van een algemene maatregel van bestuur, als bedoeld bij artikel 4 van de Arbeidswet, Stb. 83.

Bij dit Besluit werd het Besluit van 21 januari 1897, Stb. 46, ingetrokken.

Zie ook het Besluit van 18 maart 1903 tot vaststelling van een algemene maatregel van bestuur als bedoeld bij artikel 5, vierde lid, van de Arbeidswet, Stb. 86. Als geneeskundige als bedoeld in artikel 2, onder 2a en d, van het Besluit van 16 maart 1903, Stb. 83 en als bedoeld in artikel 8 van het Besluit van 18 maart 1903, Stb. 86, werd aangewezen de medisch-adviseur bij de arbeidinspectie (zie de beschikking van 28 maart 1903, Stert. 1903 no. 75 ).

242. Hand. Tweede Kamer, zitting 1902 - 1903 II, blz. 628 - 629.

243. Hand. Tweede Kamer, zitting 1902 - 1903 II, blz. 628 - 629.

244. Tweede Kamer ( Bijlage A ), zitting 1902 - 1903, no. 2 (Hfdst. V begroting Binnenlandse Zaken ) blz. $27-28$.

245. Zie artikel 19, onder 18 tot 26 , van het Besluit, tot vaststelling van een algemene maatregel van bestuur als bedoeld in de artikelen 6 en 7 van de Veiligheidswet, Stb. 215 (op grond van artikel 23 van genoemd Besluit in werking getreden op 7 december 1897 ).

246. Tweede Kamer ( Bijlage A ), zitting 1902 - 1903, no. 12 ( Hfdst. V begroting Binnenlandse Zaken ) blz. 25.

247. Besluit van 24 april 1903, Stb. 107.

248. Artikel 1 van het Besluit van 24 april 1903, Stb. 107.

249. Artikel 2 van het Besluit van 24 april 1903, Stb. 107.

Dit artikel zou worden gewijzigd bij Besluit van 14 april 1906, Stb. 64 en kwam te luiden als volgt: "Artikel 2 van Ons Besluit van 24 april 1903 (Staatsblad no. 107) wordt gelezen als volgt: "Voor het toezicht op de uitvoering van de Arbeidwet en van de Veiligheidswet wordt het Rijk verdeeld in negen arbeidsinspectiën, waarvan omvatten:

de 1ste de provincie Limburg en het gedeelte der provincie Noordbrabant, dat behoort tot het rechtsgebied van de kantongerechten Oss, Veghel, Boxmeer, Eindhoven, Oirschot, Weert en Helmond;

de 2 de het gedeelte der provincie Noordbrabant, dat niet behoort tot de lste inspectie, benevens de provincie Zeeland;

de 3de het gedeelde der provincie Zuidholland, dat behoort tot het rechtsgebied van de kantongerechten Rotterdam, no. 1, no. 2 en no. 3, Schoonhoven, Brielle, Sommelsdijk, Dordrecht, Oud-Beijerland, Ridderkerk, Gorinchem, Sliedrecht en Vianen;

de 4de het gedeelte der provincie Zuidholland, dat niet behoort tot de 3de inspectie, benevens de provincie Utrecht; de 5de het gedeelte der provincie Noordholland, dat behoort tot het rechtsgebied van de kantongerechten Amsterdam, no. 1, no. 2, no. 3 en no. 4, benevens het niet tot eenige provincie behoorende watergebied des Rijks; de 6de het gedeelte der provincie Noordholland, dat niet behoort tot de 5de inspectie; de 7de de provincie Gelderland; 
de 8ste de provincie Overijssel;

de 9de de provinciën Groningen, Friesland en Drenthe"..".

250. Artikelen 10 t/m 12 van het Besluit van 24 april 1903, Stb. 107.

251. Artikel 3 van het Besluit van 24 april 1903, Stb. 107.

252. Artikelen 13, 15, 17 en 21 van het Besluit van 24 april 1903, Stb. 107. Zie W.R.H. Kranenburg, De medische dienst bij de arbeidsinspectie, in Gedenkboek 1909 - 1 september - 1934, blz. 27 t/m 34.

253. Artikelen 16 en 21 van het Besluit van 24 april 1903, Stb. 107.

254. Artikel 22 van het Besluit van 24 april 1903, Stb. 107.

255. Zie H.A. Usselstein, in Vijf en twintig jaren Arbeidsinspectie $1890-1915$, blz. XIV.

256. Artikel 22 van het Besluit van 24 april 1903, Stb. 107.

257. Bij Besluit van 20 februari 1903, no. 14, Stcrt. 1903 no. 44. Voorheen was E. Wintgens inspecteur van de volksgezondheid. Als standplaats werd aangewezen 's-Gravenhage ( zie de beschikking van 18 mei 1903, Stcrt. 1903 no. 119 ). Bij Besluit van 2 mei 1903, no. 27, Stcrt. 1903 no. 104. Voorheen was N.M.H. Doppler eerste luitenant der artillerie op non-activiteit en hoofd van het technische bedrijf van het elektrisch centraal station der Maatschappij "Elektra" te Amsterdam. Als standplaats werd Arnhem aangewezen ( zie de beschikking van 2 juni 1903, Stcrt. 1903 no. 127 ). Als opzichteres van de arbeid werd benoemd C.A. Visser, echtgenote van I.J. Dermout, te 's-Gravenhage ( zie Besluit van 15 juni 1903, no. 61, Stcrt. 1903, no. 140 ).

258. Wet van 22 mei 1905, houdende bepalingen tot beveiliging bij het uitvoeren van bouwwerken onder groteren dan den atmosferischen luchtdruk, Stb. 143.

259. Al op 28 december van dat jaar werd een voorontwerp van wet op het departement in het college van inspecteurs besproken. Op 22 mei 1905 was de Caissonwet een feit.

Zie Verslagen van de Inspecteurs van den Arbeid over 1903 - 1904, IV blz. 41 - 42 en V blz. 54 - 55. In de memorie van toelichting ( Tweede Kamer, zitting 1904 - 1905, 161.3 blz. 1) bij het wetsvoorstel (aangeboden bij K.b. van 23 februari 1905; Tweede Kamer, zitting 1904 - 1905, 161.1) is te lezen, dat eerdere berichtgeving van de inspecteur van de vierde "arbeidsinspectie" aanleiding is geweest voor de minister van Binnenlandse Zaken om de Gezondheidsraad op 29 september 1904 advies te vragen in verband met de beveiliging van arbeiders tegen caissonziekte. De Gezondheidsraad meende evenals de inspecteurs, dat bedoelde voorschriften noodzakelijk waren.

260. De artikelen 3 en 11 van de Caissonwet 1905.

261. Zie de artikelen 1 en 4 van de Caissonwet 1905.

262. Hand. Tweede Kamer, zitting 1906 - 1907 II, blz. 1380 - 1381.

263. Bijlagen Tweede Kamer, zitting 1907 - 1908, 125.1 en 2. Het rapport is integraal weergegeven in Arbeidsduur I, in K.S.W. $1908 \mathrm{blz} .18 \mathrm{t} / \mathrm{m} 20$; II, in K.S.W. $1908 \mathrm{blz} .28 \mathrm{t} / \mathrm{m}$ 31; III in K.S.W. blz. $40 \mathrm{t} / \mathrm{m}$ 43; IV in K.S.W. blz. 53 - 54. Zie E.M. Meijers, De inspecteurs van den arbeid over den 10-urigen arbeidsdag, in 
Sociaal Weekblad 1908 blz. 57. Zie ook Chr. Raaymakers S.J., Arbeidsduur voor volwassen mannen, Leiden $1908, \mathrm{blz} .59 \mathrm{t} / \mathrm{m} 63$.

Niet alleen de inspecteurs van de arbeid hadden tedienaangaande geadviseerd, maar ook de commissie van onderzoek voor het havenbedrijf te Rotterdam en de tijdelijke controleurs van de havenarbeid te Amsterdam en Rotterdam; zie over deze instituten A.N. Molenaar, t.a.p. IIB, blz. $1326 \mathrm{t} / \mathrm{m} 1328$.

264. E.M. Meijers, in Sociaal Weekblad 1908 blz. 57.

265. E.M. Meijers, in Sociaal Weekblad 1908 blz. 58.

266. Om dit bezwaar te ondervangen zou dan ook tegelijkertijd met of spoedig na de indiening van een wet op de 10-urige arbeidsdag de zo noodzakelijke regeling van de huisindustrie moeten volgen, aldus de auteur in Sociaal Weekblad $1908 \mathrm{blz} .65$.

267. Zie voor voorbeelden E.M. Meijers, in Sociaal Weekblad 1908 blz. 58, 66 en 67.

268. E.M. Meijers, in Sociaal Weekblad 1908 blz. 67. 


\section{Inleiding}

Bij een terugblik aan het begin van dit hoofdstuk kan geconstateerd worden, dat het karakter van de arbeidsinspectie het best omschreven kan worden als een gedeconcentreerde dienst ${ }^{t}$. De verantwoordelijke minister vormt de top van de organisatiestructuur. Onder hem functioneren de inspecteurs van de arbeid, die een eigen verantwoordelijkheid hebben met betrekking tot de door hen uit te oefenen taak. Onder hen functioneren weer de "verdere ambtenaren", de adjunct-inspecteur en adjunct-inspectrice, de opzichter en opzichteres van de arbeid. De medisch adviseur en de elektrotechnicus bij de arbeidsinspectie staan daarentegen min of meer buiten deze organisatie-opbouw, zij het dat dit voor de eerstgenoemde sterker geldt dan voor de laatstgenoemde.

De vraag rees, of al deze uiteenlopende beschikbare krachten nu wel zo effectief mogelijk benut werden of dat een centrale leiding wenselijk was. Werd vanuit het parlement bij onder meer de behandeling van de Veiligheidswet en de begrotingsbehandelingen van het ministerie van Waterstaat, Handel en Nijverheid voor het dienstjaar 1896 en van het ministerie van Binnenlandse Zaken voor het dienstjaar 1903 aangedrongen op een meer centrale leiding aan de zich steeds maar uitbreidende arbeidsinspectie.

Ook buiten het parlement werd om een centralisatie gevraagd. Zo schreef De Vooys in een artikel over de arbeidsinspectie in Vragen des Tijds van $1901^{2}$, dat de hygiënische en sociale taak van de arbeidsinspectie een centrale leiding gewenst maakten, maar dat een centrale ook bij de handhaving van de betreffende wetten van groot nut kon zijn.

"Door vergelifking van toestanden in verschillende streken kan vaak beter het belang van scherp toezicht worden begrepen, terwijl eenheid van toepassing, dus rechtvaardigheid, betracht kan worden. Ook dit kan bijdragen tot betere invoering, terwijl de regeering een orgaan heeft waarmee op gemakkelijker wijze is te overleggen, dan met verschillende personen met afwijkende inzichten."

In het Sociaal Weekblad van $1905^{\circ}$ werd als een punt van verbetering van de arbeidsinspectie eveneens centralisatie genoemd:

"Wij achten thans het oogenblik gekomen om de algemeene leiding van het korps in eén hand te geven ...... In grove trekken stellen wij ons voor, dat dan een hoofdambtenaar als hoofd van een centraal arbeidsinspectie-bureau zou moeten worden aangesteld, waaronder de medisch adviseur, de elektrotechnicus, wellicht een inspecteur en ook de vrouwelijke ambtenaren zouden behooren te ressorteren."

Als in aanmerking genomen wordt, dat de arbeidsinspectie in een korte periode een aanzienlijke uitbreiding had ondergaan, dan kon een reorganisatie niet uitblijven; de vraag was alleen nog wanneer deze zou plaatsvinden.

\section{Het ontwerp-Kuyper}

Een eerste aanzet om een reorganisatie mogelijk te maken werd gedaan door de minister van Binnenlandse Zaken Kuyper. Tijdens zijn ambtsperiode diende hij bij de Tweede Kamer een wetswoorstel, houdende bepalingen ter bescherming van de arbeid ${ }^{4}$, in.

De voor de orgamisatie van de arbeidsinspectie van belang zijnde bepaling is artikel $370^{\circ}$. Daarin werd bepaald, dat ter bevordering van een behoorlijke uitvoering van de wet door de Kroon ambtenaren zouden worden benoemd en dat hun werkkring en bevoegdheden bij algemene maatregel van bestuur zouden worden geregeld. 
Voorts bepaalde dit artikel, dat het rijk zou worden verdeeld in "arbeidsinspectiën". Als een in de wetgeving ingeburgerd orgaan behoefde de arbeidsinspectie naar de mening van de bewindsman geen toelichting ${ }^{6}$. Hij achitte het voldoende om aan te geven in welk opzicht er een afwijking was ten opzichte van de regeling in de Arbeidswet 1889 en de Veiligheidswet. De grootste afwijking was, dat in het onderhavige wetsvoorstel niet was opgenomen, "het toezicht op de naleving van de wet".

Op zich was dit logisch, omdat ook andere ambtenaren dan die van de Arbeidsinspectie met het toezicht op de naleving belast waren ${ }^{7}$. Bovendien hadden de ambtenaren van de arbeidsinspectie nog een andere taak hadden dan toezicht op de naleving, namelijk het geven van voorschriften die door het hoofd of de bestuurder van een fabriek of werkplaats in acht genomen moesten worden ${ }^{8}$. Eén en ander overwegende kon naar het oordeel van de bewindsman worden volstaan met een voorschrift, dat de instelling van een arbeidsinspectie regelde, terwijl de werkkring en de bevoegdheden van de betreffende ambtenaren bij algemene maatregel van bestuur geregeld zou worden. Wenselijk was wel, dat dit laatste uiteindelijk bij wet zou worden geregeld, nadat enige ervaring was opgedaan aan de hand van deze algemene maatregel van bestuur. Wanneer dit zou moeten gebeuren, was niet aan te geven, omdat de invoering van de voorliggende Arbeidswet een algehele herziening van de organisatie tot gevolg zou moeten hebben en de organisatie na haar invoering nog wel wijziging zou hebben te ondergaan.

Een bepaling overeenkomstig het tweede lid van artikel 9 van de Veiligheidswet, dat de ambtenaren van de arbeidsinspectie niet tevens belast konden worden met het toezicht op het gebruik van stoomtoestellen, kon gemist worden, omdat na de principiële strijd die daaromtrent tijdens het tot stand komen van de Veiligheidswet was gestreden, nu vrijwel niemand meer over een combinatie van de arbeids- en stoomtoestelleninspectie dacht.

Vanuit de Tweede Kamer $^{\natural}$ werd de minister verweten, dat, hoewel hij aangaf, dat een algehele herziening van de organisatie van de arbeidsinspectie als gevolg van de invoering van de Arbeidswet noodzakelijk geacht werd, dat niet vergezeld ging van een, uiteenzetting waarlangs zich die algehele herziening zou bewegen. Zeker, omdat de bewindsman zelf de indruk had gewekt, dat hij tamelijk tevreden was met de arbeidsinspectie, die zozeer in onze wetgeving was ingeburgerd.

Daar men dus in het duister tastte over de wijze, waarop het ambtelijk toezicht op de behoorlijke uitvoering van de wet zou worden geregeld, achtte men het raadzaam op enige punten te wijzen die men bij die regeling graag in acht genomen zou zien. In de eerste plaats werd betoogd, dat na de invoering van het ontwerp de inrichtingen die aan het toezicht zouden worden onderworpen aanzienlijk uitgebreid zouden worden. Teneinde voldoende bezoek van fabrieken en inrichtingen mogelijk te maken, behoorde het personeel belangrijk te worden uitgebreid. In de tweede plaats werd de organisatie van het korps en de verhouding waarin het zou komen te staan tot het departement van belang geacht. Men meende, dat de "arbeidsinspectiën" niet te groot moesten zijn, zodat elke ambtenaar al datgene, dat binnen zijn ambtskring te doen viel, persoonlijk kon verrichten. In de derde plaats werd benadrukt, dat de inspecteurs een ruime mate van zelfstandigheid moesten hebben, zodat niet voortdurend met het departement ruggespraak gehouden behoefde te worden. Dat uit deze grotere zelfstandigheid mogelijk de uniformiteit van de toepassing van de wet gevaar zou kunnen lopen, kon ondervangen worden door hen bijeenkomsten te laten houden teneinde tot overeenstemming te komen. In de vierde plaats werd de benoeming van personen die voortkwamen uit de bedrijven en van vrouwen tot inspecteurs wenselijk geacht. In de vijfde plaats werd, met een verwijzing naar een regeling als in Würtenberg naar voren gebracht om arbeiders "Vertrauenspersonen" te laten aanwijzen. Deze moesten dan in voortdurend contact staan met de arbeidsinspectie, om zo te bewerkstelligen dat de ambtenaren van de arbeidsinspectie het vertrouwen kregen van de arbeiders.

Overigens werd ook de redactie van het eerste lid van artikel 370 weinig gelukkig geacht ${ }^{10}$, en wilde men een nadere uiteenzetting over de toekomstige algemene maatregel van bestuur waarin de werkkring en de bevoegdheden van de betrokken ambtenaren zouden worden geregeld.

Verder dan het voorlopig verslag zou de parlementaire behandeling van het ontwerp-Kuyper het niet brengen; het verdween na de val van het kabinet in $1905^{11}$. 


\section{Het vooruitschuiven van de reorganisatie}

Tijdens de begrotingsbehandeling voor het dienstjaar 1907 van het ministerie van Landbouw, Nijwerheid en Handel waaronder de afdeling arbeid en de arbeidsinspectie nu ressorteerde ${ }^{12}$, werd de verantwoordelijke bewindsman Veegens herinnerd ${ }^{13}$ aan hetgeen tijdens de behandeling van het ontwerp-Kuyper naar voren was gebracht. Daarnaast was een aantal Tweede Kamerleden van mening, dat, ter bevordering van de eenheid in inspectie, de aanstelling van een hoofdinspecteur gewenst was. Deze ambtenaar zou kunnen bevorderen, dat de onderzoekingen van de inspecteurs meer stelselmatig plaatsvinden en dat hun verslagen eenvormig zouden worden ingericht. Bovendien zou hij enkele inspecteurs tot "meer jjver kunnen aansporen". Bovendien zou door het aanstellen van een hoofdinspecteur voorkomen worden, dat de inspecteurs te vaak vergaderden, waardoor meer tijd besteed kon worden aan het bezoeken van inrichtingen. De betrokken bewindsman meende echter, dat de tijd nog niet rijp was om een min of meer ingrijpende reorganisatie van de arbeidsinspectie ter hand te nemen ${ }^{14}$. Hij verwees naar een recent tot stand gebrachte meer gelijkmatige verdeling van het Rijk in "arbeidsinspectiën" ${ }^{415}$. Verder stelde hij, dat geen zekerheid bestond over de taak die de arbeidsinspectie in de naaste toekomst zou hebben te vervullen. Indien de toegezegde wettelijke maatregelen op het gebied van arbeidswetgeving tot stand zouden komen, zou dit leiden tot een niet geringe taakwijziging; welke eisen in dat geval aan de arbeidsinspectie gesteld zouden worden, viel evenwel nog niet uit te maken. Hij meende dan ook te moeten volstaan met de toezegging, dat te zijner tijd alle aandacht aan de naar voren gebrachte wensen via de Tweede Kamer gewijd zou worden.

Bij de begrotingsbehandeling voor het daarop volgende jaar werden vanuit de Tweede Kamer opnieuw verschillende wensen geuit met betrekking tot de organisatie van de arbeidsinspectie ${ }^{16}$. Enkele Kamerleden spraken de hoop uit, dat de bewindsman inmiddels overtuigd was geraakt van de noodzaak een reorganisatie door te voeren. De wensen die werden geuit hadden betrekking op het aanstellen van een hoofdinspecteur, het benoemen van meer inspecteurs, van meer medische adviseurs en op een betere samenwerking tussen de inspecteurs van de arbeid en de ambtenaren van het staatstoezicht op de volksgezondheid. De minister verwees ${ }^{17}$ naar zijn al eerder ingenomen standpunt, onder de verzekering dat hij zijn aandacht op deze zaak gevestigd hield en dat hij niet zou nalaten haar tijdig ter hand te nemen; zo zag de bewindsman kans zonder veel problemen de reorganisatie van de arbeidsinspectie voor zich uit te schuiven.

\section{De eerste stap van de reorganisatie; de benoeming van de directeur-generaal van de Arbeld}

Hoe anders ging dat met zijn opvolger op het bedoelde departement, minister Talma. Deze zette vaart achter de reorganisatie door middel van een wetsvoorstel tot verhoging en aanvulling van de begroting voor het dienstjaar $1908^{18}$ en maakte duidelijk ${ }^{10}$, dat hij de noodzakelijkheid van uitstel van de reorganisatie, die door zijn voorganger bepleit was, niet deelde. De organisatie die nu al aan de arbeidsinspectie gegeven moest worden, zou bij uitbreiding van de arbeidswetgeving in hoofdtrekken onveranderd kunen blijven. Bovendien was een uitstel van een reorganisatie uiterst nadelig, omdat een goede organisatie van de arbeidsinspectie een onmisbare voorwaarde was voor een gezonde ontwikkeling van de arbeidswetgeving. Het voornaamste gebrek dat aan de bestaande organisatie kleefde, was, aldus de bewindsman, het gemis van een hoofd van de arbeidsinspectie. De inspecteurs waren elk in hun ressort werkzaam onder de bevelen van de minister. Naast hen waren de medisch adviseur en de elektro-technicus bij de arbeidsinspectie ieder op hun gebied werkzaam; ook zij stonden onder de bevelen van de minister. Op hem rustte dus de taak leiding te geven aan elf ambtenaren, maar het was uiteraard ondenkbaar dat hij zich zelfstandig een oordeel kon vormen over de leiding die hij aan de activiteiten van deze ambtenaren te geven had, omdat daarvoor bekendheid met details een eerste vereiste was, die hij zich onmogelijk eigen kon maken. De verantwoordelijke minister moest in deze derhalve steunen op deze ambtenaren van de arbeidsinspectie alsmede op het hoofd van de departementale afdeling waar zaken betreffende de arbeid behandeld werden. Het behoefde geen betoog, zo vervolgde de bewindsman, dat een behoorlijke leiding van de inspectie-arbeid onder die omstan- 
digheden allerminst gewaarborgd was. Het kon wel haast niet anders of de verantwoordelijke minister werd in veel gevallen voor de keuze gesteld tussen tegengestelde adviezen.

Zelfs als hij van de inspecteurs een gezamenlijk advies innam, dan werd hij soms geconfronteerd met een minderheids - en een meerderheidsstandpunt; in deze situatie een juiste keuze maken was uiterst moeilijk, ondat de daarvoor benodigde detailkennis bij een bewindsman ontbrak. Een dergelijke detailkennis kon al evenmin gevonden worden op het departement zelf bij het hoofd van de afdeling Arbeid, die met werkzaamheden van wetgevende en administratieve aard belast was; alleen ten koste van andere aangelegenheden zou deze zich op de hoogte kunnen stellen van diverse zaken en feiten buiten het departement zelve, niet alleen ten aanzien van de leiding van het eigenlijke inspectiewerk, maar even goed voor het ontwerpen van nieuwe maatregelen op het terrein van de arbeidsbescherming en de volgorde waarin die maatregelen ter hand genomen moesten worden. Daarbij kwam nog, dat de inspectieambtenaren voor het samenstellen van de nodige adviezen over onderwerpen van wetgevende aard, alsmede over onderwerpen die de arbeidsinspectie in het algemeen betreffen, veelvuldig moesten vergaderen. Hetzelfde gold voor het bij de bestaande toestand nog zoveel mogelijk bewaren van de eenheid in de toepassing van de wetten, op de naleving waarvan zij hebben toe te zien. Eén en ander had tot gevolg dat deze inspectieambtenaren aan het belangrijkste deel van hun taak toezicht op de naleving - werden onttrokken. Het mocht dan ook, aldus de minister,

"verwondering baren, dat tot dusver bij deze gebrekkige inrichting der inspectie tot stand kon komen wat tot stand is gebracht. Ongetwijfeld is dit te danken aan de toewijding en kennis der bij een dezen dienst betrokken ambtenaren niet het minst ook aan de verdiensten der tegenwoordige en gewezen inspecteurs van den arbeid."

Op korte termijn moest hierin verbetering worden gebracht. De allereerste maatregel was zijns inziems het benoemen van een "hoofdinspecteur van den arbeid"; een hoofdambtenaar die door voortdurend contact met de inspecteurs en door zelfstandig onderzoek zich een oordeel moest kunnen vormen over de toestanden in de verschillende delen van het land en daardoor niet alleen leiding zou kunnen geven aan de inspectie-arbeid, maar ook als adviseur zou kunnen optreden bij wetgevende werkzaamheden, althans wat betreft de materiële inhoud daarvan. De te benoemen hoofdambtenaar zou echter niet direct als "hoofdinspecteur van den arbeid" kunnen worden aangesteld. Hoewel zowel artikel 12 van de Abeidswet 1889 als artikel 9 van de Veiligheidswet spraken van inspecteurs en "verdere ambtenaren" bestond er twijfel over of in overeenstemming met de geest van die artikelen onder "verdere ambtenaren" een hoofdinspecteur viel te rangschikken. Vandaar dat de minister in het wetsvoorstel gekozen had voor het benoemen van een "inspecteur van den arbeid" die bevoegd was in alle "arbeidsinspectiën". Na de nodige wetswijzigingen kon dan worden overgegaan tot het benoemen van een hoofdinspecteur. Hij raadde af om in de bedoelde wetswijzigingen op voorhand de benoeming van een hoofdinspecteur te verwezenlijken, omdat afgewacht moest worden of de reorganisatie van de arbeidsinspectie niet nog andere wetswijzigingen met zich zou brengen; naar alle waarschijnlijkheid was de benoeming van een hoofdinspecteur niet de enige maatregel om een goede inrichting van dit dienstvak te verwezenlijken. Hoewel de bewindsman verklaarde zich wel over de te nemen maatregelen een oordeel te hebben gevormd, wilde hij de te benoemen hoofdinspecteur de gelegenheid geven zich daarover uit te spreken. Het lag overigens niet in de bedoeling deze hoofdinspecteur onmiddellijk na zijn benoeming met de rechtstreekse bemoeiingen met de dienst van de arbeidsinspectie te belasten, maar om hem in staat te stellen zich zowel hier te lande, als in het buitenland op de hoogte te stellen van de inrichting van deze tak van dienst. De minister vertrouwde er tot slot op bij de begrotingsbehandeling voor het dienstjaar 1909 verdere plannen ten aanzien van de reorganisatie en de daaruit voortvloeiende kosten te kunnen mededelen.

Vanuit de Tweede Kamer werd verdeeld gereageerd op dit voorstel ${ }^{20}$. Zo hadden verscheidene Kamerleden overwegend bezwaar tegen het op het gegeven tijdstip nemen van een beslissing over het gedane voorstel. Deze leden stelden dan ook voor dat de bewindsman de begrotingspost zou terugnemen om deze dan op de volgende begroting op te nemen. Enkelen twijfelden er aan of de aanstelling van een hoofdinspecteur wel noodzakelijk was: de minister kan toch door het houden van vergaderingen met de gezamenlijke inspecteurs al meer eenheid in hun werkzaamheden brengen. Enkele andere waren daarentegen van mening, dat aan 
een dergelijke aanstelling in elk geval eerst de noodzakelijke wetswijzigingen vooraf dienden te gaan, omdat anders de positie van de hoofdinspecteur ten opzichte van de inspecteurs ongeregeld zou zijn, waaruit dan weer moeilijkheden zouden kunnen voortvloeien.

Verder was het een aantal Kamerleden niet duidelijk wat nu de positie van deze hoofdambtenaar zou moeten zijn; was dit primair adviseur van de minister in het kader van de wetgeving of was het de bedoeling om de inspecteurs aan zijn gezag te onderwerpen, waardoor zij hun adviezen niet meer rechtstreeks aan de bewindsman, maar aan de hoofdinspecteur zonden uitbrengen? De toelichting van de Minister wees in de richting van dit laatste wat bij sommigen de vrees deed ontstaan, dat de arbeidsinspectie al te veel gecentraliseerd zou worden. Ook zagen enkele leden wel enig bezwaar in het feit, dat de inspecteurs, die nog een zelfstandige positie hadden, onder leiding werden gestell van een ( buiten het korps) gekozen hoofdambtenaar.

Andere Kamerleden waren bereid het voorstel van de bewindsman aan te nemen, omdat de aanstelling van een hoofdinspecteur die meer eenheid en continuiteit in de gang van zaken zou kunnen brengen, zeer gewenst was. Ook stemden zij in met het voornemen om, alvorens verdere voorstellen te doen omtrent de reorganisatie met deze hoofdambtenaar daarover te overleggen. Het mocht dan wel minder prettig zijn voor de inspecteurs om onder leiding van een hoofdambtenaar te worden gebracht, maar een goede organisatie van de arbeidsinspectie moest hier van doorslaggevend belang worden geacht.

De bewindsman maakte daarop nog eens kenbaar", dat het hier ging om een beslissing van één van de hoofdbeginselen van een toekomstige regeling en niet meer dan dat. Welke wijzigingen in de wetten zouden moeten worden aangebracht en hoe de relatie ten opzichte van het departement en de inspecteurs zou moeten zijn, waren vragen waarover al was opgemerkt dat beantwoording daarvan uitgesteld moest worden, totdat de nieuwe regeling ontworpen zou zijn. Zijn wens om een spoedige behandeling en gunstige overweging van het voorstel ging in vervulling ${ }^{22}$, waarop bij Besluit van 6 augustus 1908 met ingang van 1 oktober van dat jaar, H.A. van IJsselstein ${ }^{23}$ benoemd kon worden tot "inspecteur van de arbeid onder den persoonlijken titel van directeur-generaal van den arbeid"24. Van IJsselstein zei over het aanvaarden van de functie later zelf het volgende ${ }^{25}$ :

"Niet zonder groote aarzeling heb ik de mij aangeboden functie aanvaard en niet dan nadat mij een voor dien tijd hoog salaris was toegezegd ${ }^{\text {t7. }}$.

\section{Vertraging}

Bij het begrotingsvoorstel voor det dienstjaar 1909 herhaalde minister Talma ${ }^{26}$ zijn al eerder gedane toezegging aangaande verdere reorganisatieplannen, hetgeen vanuit de Tweede Kamer leidde tot enige aandrang tot spoed ${ }^{27}$. Daarnaast wilde men weten op welke manier de werkzaamheid van de directeur-generaal geregeld was, en, voorzover dit met die regeling in verband stond, welke moeilijkheden ten aanzien van de benoeming van deze hoofdambtenaar tussen de minister en hem hadden bestaan. De bewindsman deed zijn eerder gedane toezegging gestand en zette, alvorens op deze vragen in te gaan, in zijn reactie ${ }^{28}$ uiteen op welke wijze dit dienstvak naar zijn mening behoorde te worden ingericht.

Aan de directeur-generaal van de Arbeid zou de leiding van de arbeidsinspectie opgedragen worden, zulks met inachtneming van de bevelen van de verantwoordelijke minister, en hij zou, hetzij uit eigen beweging, hetzij na opdracht daartoe, de minister van advies hebben te dienen over het nemen van nieuwe maatregelen op het terrein van de arbeidsbescherming alsook over andere zaken die dit onderwerp betreffen. Aan de directeur-generaal zouden worden toegevoegd: én van de inspecteurs, de medisch adviseur en de elektrotechnicus bij de arbeidsinspectie. De bedoelde inspecteur zou in algemene zin als adviseur van de directeur-generaal moeten optreden. De medisch adviseur en de elektrotechnicus zouden de directeur-generaal hebben voor te lichten over en bij te staan bij de behandeling van alle zaken die op hun terrein lagen. Bovendien zouden zij, naast de inspecteurs belast blijven met het toezicht op de naleving, ieder voor zover het zijn terrein betreft ${ }^{20}$. De directeur-generaal zou tesamen met deze drie ambtenaren de centrale dienst van de arbeidsinspectie vormen met als vestigingsplaats 's-Gravenhage. Het benodigde hulppersoneel zou aan 
hen moeten worden toegevoegd.

Naast de al genoemde taken van de centrale dienst zag de minister als taken:

- het verwerken van door de inspecteurs en de hun toegevoegde ambtenaren verzamelde gegevens aangaande onderzoeken naar arbeidsomstandigheden en andere feiten en zaken die voor de arbeidsbescherming van belang zijn;

- het opdragen aan daartoe geschikte personen tot het doen van bepaalde onderzoeken;

- het uitbrengen van een centraal jaarverslag waarin de afzonderlijke verslagen wan de inspecteurs worden verwerkt;

- het verzorgen van publikatie van verslagen over bijzondere onderwerpen en rapporten die door de inspecteurs zijn samengesteld.

Om het nodige contact tussen de centrale dienst en de inspecteurs en de inspecteurs onderling tot stand te brengen, zouden zij op gezette tijden met de directeurgeneraal samen moeten komen.

Met betrekking tot de reorganisatie van de dienst en het personeel in de "arbeidsinspectiën", waarvoor in het vervolg de term "districten" zou worden gebezigd, merkte de bewindsman op, dat hij vooralsnog een wijziging van de indeling van het rijk in districten niet gewenst achtte; er was zijns inziens geen reden om aan te nemen, dat de inspecteurs niet zouden zijn opgewassen tegen de eisen die het beheer van de negen omvangrijke districten onder de nieuwe organisatie aan hun zou stellen. Uitbreiding van de taak van de arbeidsinspectie als zodanig zou er natuurlijk toe kunnen leiden, dat zij aan de toename van de werkzaambeden niet meer het hoofd zouden kunnen bieden, als gevolg van de uitbreiding van het onder hen werkzame personeel. In een dergelijke situatic zou overgegaan moeten worden tot een uitbreiding van het aantal districten. De positie van de inspecteurs, de hoofden van de districten, behoorde, aldus de bewindsman, zo min mogelijk gewijzigd te worden. Het zou namelijk een miskenning inhouden van de grote verdiensten van de inspecteurs, wanneer hun zelfstandige positie meer aangetast werd, dan het benoemen van een hoofd van de arbeidsinspectie noodzakelijk maakte. Wel hadden zij de aanwijzingen van de directeur-generaal, die tenslotte leiding had te geven aan de inspectiearbeid, op te volgen

"met betrekking tot het bezoeken van bepaalde fabrieken en werkplaatsen of tot het uitoefenen van controle op bepaalde wettelijke voorschriften, in het algemeen met betrekking tot de richting, waarin zij hebben werkzaam te zijn."

In de nieuwe organisatie zouden evenals daarvoor ambtenaren onder de bevelen van de inspecteurs werkzaam zijn, die een theoretische opleiding hadden gevolgd gelijk de adjunct-inspecteurs. Voor zover aan een inspecteur nog geen adjunct-inspecteur was toegevoegd, lag het in de bedoeling dit gelleidelijk aan te verwezenlijken, gezien het belang dat daarmee gediend werd. Zo zou dan een inspecteur over belangrijke zaken met "iemand van gelijke ontwikkeling" overleg kunnen plegen. Bovendien zou er als gevolg hiervan een ruime keuze bestaan uit personen die in de dienst gevormd waren en die daarin nodige ervaring hadden opgedaan om een opengevallen inspecteursplaats op te kunnen vullen. Maar zo zou ook gebroken kunnen worden met het huidige regiem om bij tijdelijke ontstentenis, verhindering of langdurige afwezigheid van de inspecteur diens ambt te laten waarnemen door een collega-inspecteur. In een district diende een ambtenaar aanwezig te zijn die met de dienst vertrouwd was en die voor het beheer ervan berekend was om de inspecteur, indien nodig, te vervangen. Volgens de minister was het op voorhand niet nodig om wijziging te brengen in de bestaande organisatie voor zover het vrouwelijke ambtenaren en opzichters van de arbeid aanging. Wel bestond er zijns inziens aanleiding om over te gaan tot een nieuwe klasse van ambtenaren die onder de titel "controleurs van den arbeid" in het bijzonder uit arbeiders benoemd, onder de bevelen van de inspecteurs werkzaam zouden zijn.

Tot zover de reorganisatieplannen van minister Talma.

Op de vanuit de Tweede Kamer naar voren gebrachte vragen over de regeling van de werkwijze van de directeur-generaal en over de moeilijkheden tussen hem en de minister over zijn benoeming, reageerde de bewindsman als volgt ${ }^{30}$. De directeur-generaal verrichtte werkzaamheden die ook na de reorganisatie van de arbeidsinspectie tot zijn taak zouden gaan behoren, maar alleen voor zover dit bij het ontbreken van een wettelijke regeling van zijn positie mogelijk alsook wenselijk was ${ }^{31}$. Er was inderdaad een misverstand geweest 
over de positie die de eerstbedoelde zou innemen, maar aangezien dit probleem uit de wereld geholpen was, vond de bewindsman het niet nodig daarover nog in details te treden.

Om de reorganisatie financieel mogelijk te maken waren bij nota van wijzigingen ${ }^{32}$ de betreffende begrotingsartikelen verhoogd.

Ondanks de uitvoerige toelichting van de minister was men in de Tweede Kamer toch van mening ${ }^{33}$, dat de openbare behandeling van deze belangrijke en ingrijpende voorstellen onvoldoende was voorbereid. Vandaar ook het bij amendement door de commissie van rapporteurs ${ }^{34}$ gedane voorstel aan de bewindsman om in overweging te nemen de voorgestelde wijzigingen die in verband stonden met de reorganisatie terug te nemen en de zaak bij afzonderlijk ontwerp van wet bij de Kamer aanhangig te maken. Het Tweede Kamerlid Schaper merkte tijdens de mondelinge beraadslaging ${ }^{35}$ op, dat het door de minister ontworpen organisatie-schema van de arbeidsinspectie op hem een goede indruk had gemaakt. Hij verzette zich dan ook tegen het bovenbedoelde amendement omdat dit alleen maar uitstel zou betekenen. Hetgeen namelijk in het schema was voorgesteld, was al jarenlang gevraagd door deskundigen en door Kamerleden. Voortdurend was gevraagd om een hoofd van de arbeidsinspectie. Daarbij stond én en ander wel niet zo precies voor ogen als nu werd voorgesteld, maar dat was een zaak die de uitwerking betrof. Dat er een chef van de arbeidsinspectie, een betere organisatie in het algemeen, zou moeten komen, was toch een zaak waarover iedereen het wel eens was $^{30}$. En nu kwam nog eens het voorstel om de reorganisatieplannen uit te stellen. De mening van Schaper hierover laat aan duidelijkheid niet te wensen over.

"Ik hoop, dat wij nog eens Ministers zullen krijgen, die sterk genoeg zijn om aan dat spelletje voor goed een eind te maken en te zeggen: mijne heeren! neemt het aan of verwerpt het desnoods, maar komt niet eeuwig en altijd met de vraag: stel het uit en dien een suppletoire begrooting in .

Hoewel hij toegaf zelf wel een aantal opmerkingen te hebben over de reorganisatieplannen als zodanig, waren deze plannen echter niet absoluut, zodat dit hem niet belette om vór de betreffende begrotingspost te stemmen en dus tegen het amendement van de commissie van rapporteurs.

De discussie die daarop zou volgen ${ }^{37}$ kon echter niet verhinderen, dat het door Schaper zo bestreden amendement werd aangenomen ${ }^{38}$ en het uitstel van de reorganisatie van de arbeidsinspectie een feit was.

\section{De goedkeuring van de reorganisatieplannen}

Op 12 februari 1909 werd het door de Tweede Kamer gevraagde afzonderlijke wetsvoorstel ingediend ${ }^{39}$. De minister stelde zich op het standpunt, dat het amendement van de commissie van rapporteurs, althans blijkens de toelichting daarop, niet gericht was tegen de reorganisatieplannen als zodanig, zoals die bij eerdere gelegenheid uiteen waren gezet. Het amendement had slechts ten doell uiting te geven aan het gevoelen van de Kamer, dat zij de gevraagde gelden niet kon voteren, omdat zij niet in de gelegenheid was geweest zich daarover een behoorlijk oordeel te vormen. Aan dit bezwaar werd ten volle tegemoet gekomen door de indiening van de suppletoire begroting, aldus de bewindsman. Het zal niemand verbazen, dat de toelichting op dit wetsvoorstel ${ }^{40}$ inhoudelijk overeenkwam met een vrijwel gelijkluidend was aan de betreffende passage in de eerderbedoelde memorie van antwoord.

Bij verscheidene Tweede Kamerleden ${ }^{41}$ - van meer dan cén zijde - bleken echter ernstig bezwaren te bestaan tegen de reorganisatieplannen. Een aantal van hen twijfelde aan de noodzaak van die reorganisatie, waaraan het gestelde in de toelichting weinig veranderde. Anderen voerden daartegen de al bekende argumenten van uniformiteit en continuiteit in de gang van zaken aan. Een andere vraag was evenwel of bij suppletoire begrotingswet een dergelijke reorganisatie tot stand gebracht kon worden.

Verscheidene Kamerleden meenden van niet; aan die reorganisatie behoorde in ieder geval een wijziging van de Arbeidswet 1889 en van de Veiligheidswet vooraf te gaan. Niet alleen omdat deze wijziging van genoemde wetten van invloed was op de taak van de arbeidsinspectie, zodat de reorganisatie voorbarig was, maar ook, omdat zolang deze wetten niet waren gewijzigd, de verhouding van de directeur-generaal tot de inspecteurs ongeregeld zou zijn en daaruit problemen zouden kunnen voortvloeien. Bovendien spraken de 
betreffende wetsbepalingen van "inspecteurs en verdere ambtenaren" waarmee de wetgever diidelijk had aangegeven, dat de inspecteurs onder de minister de hoogste ambtenaren zouden zijn, zodat het niet in overeenstemming met de wet was deze inspecteurs ondergeschikt te maken aan de directeur-generaal. Los hiervan had een aantal leden problemen met de centralisatie die onvermijdelijk uit de ontworpen regeling zou voortvloeien.

Tegen de instelling van de nieuwe categorie van ambtenaren, de "controleurs van den arbeid", bestonden bij vele leden ernstige bedenkingen, omdat het moeilijk zou zijn geschikte personen wat betreft ontwikkeling te vinden en deze personen in een moeilijke positie zouden komen te verkeren, namelijk tussen de arbeiders en de werkgevers. Bovendien werden twijfels geuit ten aanzien van hun objectiviteit.

In zijn antwoord ${ }^{42}$ verwees de bewindsman voor de vraag naar de noodzaak van de reorganisatie naar de suppletoire begrotingswet voor het dienstjaar $1908^{43}$ en de aanneming daarvan zonder hoofdelijke stemming. Op de vraag of de ontworpen reorganisatie bij begrotingspost tot stand gebracht kon worden, antwoordde hij ontkennend. Maar, zo stelde hij, noch de Arbeidswet 1889 noch de Veiligheidswet bevatten een organisatie van de arbeidsinspectie, zelfs niet in hoofdlijnen. Wel veronderstellen zij een regeling van de arbeidsinspectie waarbij de directeurgeneraal niet anders dan een adviserende bevoegdheid werd gegeven. Voor het tot stand brengen van de reorganisatie moeten de genoemde wetten worden gewijzigd; een wijziging die van eenvoudige aard zou kunnen zijn. Wel maakte de bewindsman kenbaar, dat een daartoe strekkend wetsontwerp bij de Raad van State voor advies aanhangig was. Hij benadrukte nogmaals, dat een goede organisatie van de arbeidsinspectie essentieel was voor een gezonde ontwikkeling van de arbeidswetgeving. Voor een te ver doorgevoerde centralisatie bestond zijns inziens geen gevaar. Beoogd werd tenslotte alleen maar een grotere uniformiteit via een meer envoudige en doelmatige wijze te bewerkstelligen. Op de opmerkingen met betrekking tot de "controleurs van den arbeid" antwoordde de minister met een verwijzing naar de toelichting met de opmerking, dat hij de geschetste moeilijkheden over het vinden van geschikte personen had onderkend, maar deze niet onoverkomelijk te vinden. Verder achtte hij de positie van deze ambtenaren in de organisatie zodanig ondergeschikt aan de inspecteur, dat zij door persoonlijk optreden geen invloed op de toèpassing van de wetgeving zouden kunnen uitoefenen. Ook de vrees voor moeilijkheden als gevolg van het feit dat zij tussen arbeiders en werkgevers zouden staan, vond hij voorbarig.

Tijdens de mondelinge beraadslaging over de suppletoire begroting speelden voornamelijk twee zaken, namelijk de positie van de directeur-generaal en de zelfstandige positie van de inspecteurs.

Het Tweede Kamerlid Treub merkte over de positie van de directeur-generaal op ${ }^{44}$, dat deze blijkens de toelichting een tweeledige taak zou hebben: het leiden van de dienst en het adviseren ten aanzien van nieuwe maatregelen op het gebied van de arbeidersbescherming. Deze laatste taak behoorde volgens de spreker als een zeer bijkomstige te worden beschouwd. Het gevaar was namelijk aanwezig, dat de directeur-generaal zozeer door deze advisering in beslag zou worden genomen, dat van het feitelijk leiden van de dienst weinig terecht kwam. Teneinde dit te voorkomen zou voor het adviserende gedeelte van haar taak de arbeidsinspectie aangevuld moeten worden met personen die niet uitsluitend een technische opleiding, maar een staatsrechtelijke, economische opleiding hadden genoten. De bewindsman antwoordde ${ }^{45}$ daarop, dat de voorbereiding van wetgeving niet uitsluitend moet worden overgelaten aan technici, maar dat dit eigenlijk ook niet het werk is van de arbeidsinspectie; dit werk moet meer bij het departement zelf - de afdeling arbeid - gebeuren ${ }^{48}$, een antwoord waar Treub niet tevreden mee was ${ }^{47}$.

Met betrekking tot de zelfstandige positie van de inspecteur van de arbeid gaf het Kamerlid Schaper ${ }^{48}$ te kennen, dat hij wilde vasthouden aan het beginsel, dat de inspecteurs zelfstandig jaarverslagen opstelden. Het gecentraliseerd verwerken van de door hen aangebrachte informatie mocht uiteindelijk niet leiden tot een

"flauw verslag ...... van hetgeen gebeurd is, een verslag dat alleen van formeel belang is ......... De beteekenis van dit verslag mag niet worden verkleind, want het heeft een sociaal belang voor het gehele volk, voor allen, die zich bezighouden met sociale studie. Het mag dus niet verwaterd worden en moet op hetzelfde peil blijven".

Het Tweede Kamerlid Visser merkte ${ }^{49}$, dat de in de toelichting neergelegde gedachtengang er zijns in- 
ziens toe leidde, dat de inspecteurs voortaan nog uitsluitend technische politie zouden zijn en niet meer als adviseurs voor de sociale wetgeving dienst zouden doen. Daarin lag naar zijn mening een groot gevaar; want tot op heden was het een groot voordeel, dat mannen, die dagelijks leven in de praktijk van fabrieken en werkplaatsen, in direct contact traden met de minister en in staat waren min of meer eenzijdige theoretische voorbereiding van de sociale wetgeving te verbeteren door hun adviezen, gegrond op de praktijk. Werden de inspecteurs teruggebracht tot uitsluitend technische politie, dan was het gevaar aanwezig, dat de minister deze degelijke praktische voorlichting zou ontberen; een voorlichting die juist bij de sociale wetgeving zo hoogst noodzakelijk was. De bewindsman vatte dit als volgt samen ${ }^{50}$ :

"Gij verandert iets in uw regeling, dat eigenlijk miet veranderd moet worden; gij tast nl. de zelfstandigheid der inspecteurs aan".

Zijn reactie daarop begon met de opmerking, dat hij als minister, waar het zaken betrof, waarover alle inspecteurs gehoord moesten worden, bijna nooit anders onder ogen had gekregen dan adviezen van de vergadering van inspecteurs. Deze waren dus verzonken in de anonieme meerderheid van die vergadering. De zelfstandigheid van het advies was er dus niet. Op twee manieren had hij, zo vervolgde hij, dit wel eens vermeden. Een keer door aan de inspecteurs persoonlijk te vragen hem hun advies over een zaak te doen toekomen. Daarover waren zij echter niet geheel en al tevreden.

Toen hij namelijk alle adviezen had, zeiden zij, dat zij niet gehoord waren, omdat geen advies aan de vergadering was gevraagd. Een andere keer had hij dit gedaan door de vergadering van inspecteurs bij te wonen. Dit bleek echter geen begaanbare weg.

Het in die vergadering gevolgde meerderheidssysteem bracht alleen maar compromisadviezen, waarmee de bewindsman het dan maar moest doen. Nu zouden, zo werd dus gesteld, de inspecteurs geen adviseurs van de minister meer zijn. Welnu, de bewindsman stelde, dat zij dat al jaren niet waren. Zij waren slechts lid van een vergadering die de minister adviseerde. Hij geloofde dan ook

"dat een directeur-generaal, die niet zou begrijpen, dat hij aan de inspecteurs de meest mo-

gelijke zelfstandigheid moet laten in de wijze waarop zij hun taak uitvoeren, een direc-

teur-generaal zou zijn, die zijn ambt niet zou verstaan".

Daar zou een ieder mee instemmen, die zich de moeilijke taak, die de inspecteurs hadden te vervullen, juist inschatte; maar dat wil niet zeggen, dat deze inspecteurs te hoog zouden zijn om leiding te aanvaarden.

Hij vroeg zich af, wat het betekende om wettelijk vast te leggen, dat de inspecteurs onder de bevelen van de minister werkzaam zouden zijn en om te bepalen, dat de minister aangewezen was om hun werkzaamheden te leiden, voor een man die het ministersambt aanvaardde, en die misschien voor het eerst met de inspecteurs van de overheid in aanraking kwam. De wet gaf toch alleen maar aan, dat de inspecteurs hun werk niet zonder leiding zouden verrichten, dat er een gezag zou zijn, dat leiding gaf. Dan lag het toch voor de hand, zo vervolgde hij, daarvoor iemand te nemen, die dat als wekelijks doet, dan iemand, waarvan iedereen kan begrijpen, dat hij er niet veel van terecht kan brengen.

Hoewel Treub dus niet tevreden was met het antwoord van de minister, werd hij afgevallen door de overige sprekers $^{51}$, waarna het wetsvoorstel zonder hoofdelijke stemming op 6 mei 1909 door de Tweede Kamer werd aangenomen ${ }^{52}$ om vervolgens op 29 juni van dat jaar zonder beraadslaging en zonder hoofdelijke stemming in de Eerste Kamer te worden aangenomen ${ }^{53}$.

\section{De reorganisatie van de arbeidsinspectie en de reactie buiten het parlement}

Niet alleen in maar ook buiten het parlement hield de reorganisatie van de arbeidsinspectie de gemoederen bezig. Zo verzocht het bestuur van de Sociaal-technische Vereeniging van democratische ingenieurs en architecten bij de reorganisatie onder meer het volgende in acht te nemen ${ }^{54}$. Het toezicht op elektrische toestellen en leidingen zou moeten worden opgedragen aan elektrotechnische ambtenaren. De elektrotechnicus, bij de arbeidsinspectie die daadwerkelijk bij uitstek belast was met het toezicht zou een meer verlichte taak moeten krijgen. De inspecteurs zouden dan zelf de betreffende voorschriften moeten gaan geven en (doen) toezien op de naleving daarvan; de daarvoor benodigde specialistische kennis kan van hen niet verlangd wor- 
den.

Aan de medisch-adviseur bij de arbeidsinspectie zouden meer medici toegevoegd moeten worden; voor zover keuringen en dergelijke niet door deze medische ambtenaren zouden worden verricht, diende dit te gebeuren door van de wetgever onafhankelijke geneesheren, die geregell contact zouden moeten onderhouden met de medisch adviseur.

Ook Burger ${ }^{55}$ betreurde, dat de medisch adviseur Wintgens nog een eenling was. Het feit, dat deze echter ontheven was van de tijdrovende keuringen, was zijns inziens een stap in de goede richting, zij het toch niet meer dan een enkele stap. Dit diende gezien te worden in het licht van de door hem aangehaalde Sommerfeld, die de verwachting had uitgesproken, dat het optreden van de medisch adviseur in Nederland zou worden gevolgd door de aanstelling van een geneeskundig adviseur voor elk der negen districten van het arbeidstoezicht ${ }^{58}$. Op de vraag in welke verhouding de geneeskundig ambtenaar stond ten opzichte van de inspecteur antwoordde Burger, dat deze arts zou moeten optreden naast en met de inspecteur, maar toch van deze volkomen onafhankelijk. Hem zou de bevoegdheid moeten worden gegeven werkplaatsen te bezoeken om zo de arbeider in zijn werkomgeving te kunnen gadeslaan. Botsingen zowel met het technische toezicht van de inspecteurs als met de werkgevers moesten worden vermeden. De daaruit voortvloeiende regeling moest zo zijn, dat de geneeskundige dienst geheel onafhankelijk zou blijven van de inspecteurs, dat aan de geneeskundige ambtenaren geen gebiedende bevoegdheid zou worden opgedragen, maar hun voorstellen bij de directeur-generaal zouden worden ingediend, die dan verder moest beslissen over de praktische maatregelen, die er uit zouden moeten volgen.

Deze geneeskundige ambtenaren konden, aldus Burger, geen praktiserende artsen zijn, aan wie de geneeskundige taak bij het arbeidstoezicht moest worden opgedragen. Evenmin echter zouden dit de ambtenaren van het Staatstoezicht op de Volksgezondheid kunnen zijn ${ }^{57}$.

De veelzijdige bezigheid waarmee deze heren zouden zijn belast, maakte het hen, volgens de schrijver, onmogelijk zich met het wezen van het nijverheidsbedrijf intensief bezig te houden, wat voor een vruchtdragende vervulling van deze taak noodzakelijk was. Die taak zou dan onvermijdelijk worden teruggebracht tot een toezicht op de naleving van wettelijke voorschriften. Van een creërende arbeid op dit grotendeels nog onbewerkte veld zou geen sprake kunnen zijn.

Tot slot zij nog opgemerkt, dat diverse organisaties verzochten om met name een gelijke behandeling van vrouwelijke en mannelijke ambtenaren bij de arbeidsinspectie ${ }^{58}$.

\section{De wijziging van de Arbeidswet 1889 en de Veiligheidswet}

Teneinde de reorganisatie van de arbeidsinspectie te kunnen doorvoeren, dienden de Arbeidswet 1889 en de Veiligheidswet te worden gewijzigd. Wetsvoorstellen daartoe werden nog tijdens de behandeling van de suppletoire begroting van het ministerie van Landbouw, Nijverheid en Handel ingediend ${ }^{59}$.

In artikel 12 van de Arbeidswet 1889 werd bepaald dat er een arbeidsinspectie bestond en dat ten behoeve van cleze dienst het rijk door de Kroon in districten werd verdeeld. Verder werd bepaald, dat de ambtenaren van de arbeidsinspectie behalve met de taak hun bij andere wetten opgedragen, belast waren met de handhaving van deze wet en met de medewerking aan de uitvoering ervan. Zij waren werkzaam onder de bevelen van de met de uitvoering van de wet belaste minister ( van Landbouw, Nijverheid en Handel ). Hun werkkring en bevoegdheden moesten bij algemene maatregel van bestuur geregeld worden, voorts dat en op welke wijze voor de arbeidsinspectie en voor elk district een ambtenaar als hoofd van dienst werd aangewezen. Ook de "instructiën" voor de ambtenaren van de arbeidsinspectie werden bij algemene maatregel van bestuur geregeld ${ }^{80}$.

Een nieuw artikel 12 bis van de wet voorzag in de mogelijkheid, dat aan de ambtenaren als bedoeld in artikel 12 van de wet ambtenaren en bedienden, wier "instructiën" bij ministerieel besluit worden vastgesteld, worden toegevoegd, die zij voor de uitvoering van hun taak nodig hebben ${ }^{61}$.

Artikel 9 van de Veiligheidswet werd zo gewijzigd, dat nu alleen nog bepaald werd, dat de ambtenaren als 
bedoeld in artikel 12 van de Arbeidswet 1889 belast zijn met de handhaving van deze wet en met de medewerking aan de uitvoering ervan.

De hinderpaal tegen de reorganisatie die in het oude artikel 12 van de Arbeidswet 1889 was gelegen, werd, aldus de toelichting ${ }^{62}$, uit de weg geruimd. De redactie van het nieuwe artikel 12 was zodanig, dat de wettelijke grondslag voor de organisatie van de arbeidsinspectie uitsluitend in de Arbeidswet 1889, de oudste vam de bestaande arbeidsbeschermende wetten, gelegen was. Bovendien was gekozen voor een indeling van het rijk in districten bij Koninklijk besluit, omdat zonder bezwaar deze meer eenvoudige en minder tijdrovende wijze van vaststelling van de grenzen van de districten in de plaats kon treden van de indeling bij algemene maatregel van bestuur, zoals voorgeschreven was bij de te vervangen bepalingen.

De in het nieuwe artikel 12 geformuleerde taakstelling beoogde duidelijk te maken, dat tot de taak van de arbeidsinspectie ook werkzaamheden behoren, die uit andere wetten dan de Arbeidswet 1889 voortvloeiden, en dat die taak, voor zover deze met laatstgenoemde wet verband hield, meer omvatte dan het houden van toezicht op de naleving, namelijk nog andere verrichtingen die voor de uitvoering van de wet noodzakelijk waren $^{83}$.

Ten aanzien van de zogenaamde toegevoegde ambtenaren en bedienden, werd opgemerkt, dat dergelijke (bureel-)ambtenaren al sedert een aantal jaren aan de inspecteurs van de arbeid waren toegevoegd, en deze nu ook aan de reorganisatie aan de centrale dienst moesten worden verbonden, terwijl tevens een bediende (bode-conciërge) werkzaam gesteld diende te worden. Daar voor deze personen niet dezelfde regels konden galden als voor de ambtenaren van de arbeidsinspectie, als bedoeld in artikel 12 van de wet; werd het nodig geacht voor hun de nodige bepalingen in een afzonderlijk wetsartikel vast te stellen.

Omdat de organisatie van de arbeidsinspectie uitsluitend in de Arbeidswet 1889 geregeld was, konden die bepalingen in de Veiligheidswet die betrekking hadden op de organisatie vervallen en kon volstaan worden met alleen een omschrijving in algemene lijnen van de taak, die voor de arbeidsinspectie uit die wet voortvloeide, aldus de toelichting. Aangezien niemand er meer aandacht het toezicht op de stoomtoestellen aan de arbeidsinspectie op te dragen, had het betreffende artikellid in de Veiligheidswet alleen nog een historische betekenis en kon om die reden, zo vervolgde de toelichting, vervallen.

Vanuit de Tweede Kamer werd door enkele leden de vrees geuit ${ }^{04}$, dat de nieuwe regeling van de arbeidsinspectie onvoldoende zelfstandigheid zou toekennen aan de districtshoofden, omdat de directeur-generaal belast was met de leiding van hun werkzaamheden en die leiding op een wijze zou kunnen plaatsvinden die aan hun alle zelfstandigheid kon ontnemen. Hoewel ervan uitgegaan werd, dat dit niet in de bedoeling, was enige zekerheid over de bepalingen omtrent de verhouding van de directeurgeneraal tot de districtshoofden van groot belang. Ook meende men, dat ten aanzien van inspecteurs, die geen districtshoofden zouden worden en aan de adjunct-inspecteurs een zekere mate van zelfstandigheid gewaarborgd moest zijn. Vandaar dat een aantal Kamerleden wilde, dat de werkkring en de bevoegdheden van de ambtenaren van de arbeidsinspectie niet bij algemene maatregel van bestuur, maar in de wet zouden worden geregeld. Anderen wilden, dat althans het ontwerp van een dergelijke algemene maatregelen van bestuur nog tijdens de behandeling van dit wetswoorstel aan de Kamer zou worden voorgelegd.

Tot slot waren sommige Kamerleden niet gelukkig met de titel "districtshoofd der arbeidsinspectie". In zijn reactie verwees de bewindsman ${ }^{66}$ ten aanzien van de verhouding van de directeur-generaal tot de districtshoofden en de zelfstandigheid van de districtshoofden en anderen naar de behandeling van de suppletoire begroting voor het dienstjaar $1909^{68}$. Naar aanleiding van de geuite wens om de werkkring en de bevoegdheden van de ambtenaren van de arbeidsinspectie bij de wet te regelen, merkte de minister op, dat die regeling in hoofdlijnen in de wet vastgelegd was; meer uitgewerkte bepalingen te dienaangaande in de wet op te nemen leek hem minder gewenst, daar na de invoering van de nieuwe organisatie daarin wellicht nog wijzigingen aangebracht zouden moeten worden. Een wetswijziging zou te veel tijd vorderen en omslachtig zijn. Aan het verzoek om een ontwerp van de betreffende algemene maatregel van bestuur aan de Tweede Kamer over te leggen kon hij tot zijn spijt niet voldoen, daar deze nog in bewerking was. Ten aanzien van de term "districtshoofd der arbeidsinspectie" maakte de bewindsman kenbaar, dat geprobeerd was. 
deze door een andere term te vervangen, maar dat het niet gelukt was een synoniem te vinden, dat even kort en duidelijk was.

De ingediende wetsvoorstellen werden daarna zonder problemen door zowel de Tweede als de Eerste Kamer aangenomen ${ }^{67}$ en konden na ondertekening door koningin Wilhelmina in het Staatsblad verschijnen ${ }^{68}$ om vervolgens op 1 september 1909 in werking te treden ${ }^{20}$.

\section{De uitwerking van de reorganisatie van de arbeidsinspectie}

Het rijk werd verdeeld in negen districten, zodat geen wijziging werd aangebracht ten aanzien van de eerdere verdeling zij het in toen nog "arbeidsinspectiën ${ }^{m 70}$. Op grond van artikel 1 van het zogenaamde Organisatiebesluit ${ }^{71}$ droegen de ambtenaren van de arbeidsinspectie, die, behalve met de taak hun bij andere wetten, belast waren met de handhaving van de Arbeidswet 1889 en met de medewerking aan de uitvoering ervan, én en ander onder de bevelen van de verantwoordelijke minister, de titel van:

a. directeur-generaal van de Arbeid;

b. hoofdinspecteur van de arbeid, inspecteur van de arbeid ( eerste of tweede klasse), adjunct-inspecteur, inspectrice, adjunctinspectrice, opzichter of controleur van de arbeid;

c. medisch adviseur bij de arbeidsinspectie;

d. elektrotechnisch ingenieur bij de arbeidsinspectie.

Deze ambtenaren van de arbeidsinspectie dienden te proberen zoveel mogelijk overeenstemming te bevorderen tussen de eisen van de wetgeving, bij de uitvoering waarvan zij betrokken waren en de belangen van alle bij de arbeid betrokken personen.

Aan het hoofd van de arbeidsinspectie stond de directeur-generaal van de Arbeid, aan wie werd opgedragen leiding te geven aan en toezicht uit te oefenen op de dienst van de arbeidsinspectie. De directeur-generaal had voorts tot taak zowel uit eigen beweging als desgevraagd de betreffende minister van advies te dienen en hem voorstellen te doen, alsmede deze hetzij mondeling, hetzij schriftelijk de gevraagde inlichtingen te verschaffen ${ }^{72}$. Op deze wijze werd een vereenvoudiging van het overleg tussen regering en arbeidsinspectie bewerkstelligd ${ }^{73}$. Ten opzichte van de districtshoofden van de arbeidsinspectie was de taak van de directeur-generaal het geven van leiding aan de inspectie-arbeid, in het bijzonder ook ten aanzien van de eenheid van uitvoering van de wetten, daaronder begrepen de eenheid van oordeel over de wenselijkheid van overwerkvergunningen en de eenheid van opvatting omtrent beveiligingen ${ }^{74}$. Uit deze taakstelling vloeit voort, "dat de inspecteurs zijne aanwijzingen opvolgen met betrekking tot het bezoeken van bepaalde fabrieken en werkplaatsen of tot het uitoefenen van controle op bepaalde wettelijke voorschriften, in het algemeen met betrekking tot de richting, waarin zij hebben werkzaam te zijn".

Op deze wijze ontstond de gelegenheid om de omstandigheden in de verschillende districten te vergelijken. Aan de directeur-generaal werden naast een inspecteur en het nodige administratieve personeel, de medisch adviseur en de elektrotechnicus bij de arbeidsinspectie toegevoegd die de door hem opgegeven opdrachten uit dienden te voeren ${ }^{75}$. De medisch adviseur $\mathrm{kreeg} \mathrm{mu}$ in het bijzonder tot taak het adviseren van de directeur-generaal voor de behandeling van zaken, die de gezondheid van de bij de arbeid betrokken personen betroffen, al bleef de opdracht bestaan tot het houden van toezicht op de naleving van de arbeidswetgeving op zijn terrein. De elektrotechnisch-ingenieur werd eveneens adviseur van de directeurgeneraal voor de behandeling van zaken, die de beveiliging van elektrische toestellen en geleidingen betroffen, maar bleef daarnaast belast met het geven van algemene voorlichting te dezen aan de districtshoofden. Het toezicht op de naleving van gegeven voorschriften ten aanzien van elektrische toestellen en geleidingen werd grotendeels tot de taak van de districtshoofden en de onder hun bevelen werkzame ambtenaren gerekend ${ }^{70}$. De bedoelde ambtenaren vormden tesamen de centrale dienst, waaraan de minister zelf de naam directie van de arbeid had gegeven; hun ambtsgebied bestreek geheel Nederland, terwijl hun standplaats 's-Gravenhage was" Verder was nog als taak voor de directeur-generaal weggelegd het verwerken van in districten verzamelde 
gegevens over arbeidstoestanden, het instellen van bepaalde onderzoekingen of het verzamelen van bepaalde gegevens door personen, die geen ambtenaren van de arbeidsinspectie zijn en onder zijn bevelen zijn gesteld, het samenstellen van een algemeen - centraal - jaarverslag verkregen uit de informatie van de districtshoofden, de medisch-adviseur en de elektrotechnisch-ingenieur, het samenstellen van verslagen over bijzondere onderwerpen, die, indien de minister dit wenselijk achtte, konden worden gepubliceerd ${ }^{78}$ en het overleg over allerlei zaken die de dienst aangaan met vertegenwoordigers van werkgevers- en arbeidersorganisaties $\operatorname{van}^{79}$. In plaats van de veelvuldige en tijdrovende inspecteursvergaderingen kwamen de minder talrijke en meer beknopte vergaderingen van de directeur-generaal en de districtshoofden, bekend als de districtshoofdenvergaderingen ${ }^{\mathrm{BO}}$.

Naast het bevorderen van de uniformiteit heeft de reorganisatie tot gevolg dat de districtshoofden werden ontheven van de werkzaamheden, die hen afhield van hun eigenlijke inspectietaak. De omvang van de bureauwerkzaamheden was zodanig toegenomen, dat Schaper daarover in 1909 het volgende opmerkte ${ }^{81}$ :

"De negen inspecteurs zelven zijn langzamerhand meerendeels bureau-heeren geworden voor wie het inspecteeren te min wordt".

Aan dit bezwaar werd tegemoet gekomen en bovendien werd in ieder district een inspecteur aan het districtshoofd toegevoegd, althans voor zover dit nog niet het geval was. In de nieuwe organisatie werden nu ook de inspectrices aan de districtshoofden toegevoegd. Overigens bleef de zelfstandigheid van de districtshoofden gehandhaafd; dezen behielden het recht met de minister te corresponderen en deze voorstellen te doen, zij het ook door tussenkomst van de directeur-generaal ${ }^{82}$. De hun door verschillende wetten toegekende bevoegdheden werden in geen enkel opzicht beperkt ${ }^{83}$. Wel werd hun taakstelling in het Organisatiebesluit uitgebreid. Zij dienden zich nu ook op de hoogte te houden van de arbeidstoestanden in hun district en van gebeurtenissen die van belang waren voor de kennis van de arbeidsverhoudingen ${ }^{\text {s4 }}$.

Niet alleen werd een meer gestructureerd overleg ingevoerd met vertegenwoordigers van werkgevers- en arbeidersorganisaties aangaande allerlei zaken die de dienst arbeidsinspectie betreffen, maar werd ook een andere belangrijke kwestie tot een oplossing gebracht, namelijk het deelnemen van arbeiders aan de inspectie. Had Domela Nieuwenhuis tijdens de parlementaire behandeling van de Arbeidswet $1888^{85}$ bezwaar tegen het voorstel, dat de inspecteurs door de Kroon benoemd werden, omdat dit zijns inziens behoorde te gebeuren door de verenigde arbeiders, de nieuwe categorie ambtenaren van de arbeidsinspectie, de controleurs van de arbeid, werden uit de arbeiders benoemd en werden in de districten werkzaam gesteld. Bovendien werd er zorg voor gedragen, dat de vakbeweging in zijn verschillende politieke schakeringen onder hen vertegenwoordigd was. De bedoeling van dit nieuwe instituut was enerzijds om voorlichting te krijgen van mannen die op velerlei gebied een ander licht zouden kunnen doen vallen op de taak die de arbeidsinspectie te behartigen heeft en anderzijds bij de dienst personen te betrekken die eerder het vertrouwen zouden hebben van hun klassegenoten, dan degenen, die tot dusver bij voorkeur tot ambtenaren van de arbeidsinspectie waren benoemd.

Deze nieuwe ambtenaren zouden gemakkelijker tal van mededelingen bereiken, die voor de handhaving van de wettelijke bepalingen van nut konden worden geacht ${ }^{30}$. 
noten

1. Onder deconcentratie wordt verstaan: de opdracht aan in het hiërarchisch verband van de centrale overheid staande ambtenaren, organen of diensten ter behartiging van bepaalde taken of bevoegdheden in een afgegrensd territoir, waarbij de uiteindelijke verantwoordelijkheid voor de taak- of bevoegdheidsuitoefening berust bij de minister onder wiens departement zij ressorteren. Zie Heroverweging gedeconcentreerde rijksdiensten, Eindrapport van de werkgroep (onder voorzitterschap van A.A.M.F. Staatsen), januari 1985, blz. 10.

\section{Is.P. de Vooys, Arbeidsinspectie, in Vragen des Tijds 1901 (overdruk).}

3. F., De organisatie van de Arbeidsinspectie in Nederland, in Sociaal Weekblad $1905 \mathrm{blz} .465 \mathrm{t} / \mathrm{m} \mathrm{467}$. De twee andere punten van verbetering waren: een betere verdeling van het rijk in "arbeidsinspectiën" en het verlenen van meerdere bevoegdheden aan de toegevoegde ambtenaren. Aan het eerste punt werd bij het Besluit van 14 april 1906, Stb. 64, gehoor gegeven.

4. Bij Besluit van 6 januari 1904, zie Bijlagen Tweede Kamer, zitting 1903 - 1904, 133, 1 en 2 . In het wetsvoorstel dat maar liefst $\mathbf{4 4 4}$ artikelen bevat, kwamen bepalingen voor over de arbeidsduur van volwassen mannen, die, hoewel beperkt tot bepaalde categorieën van voor de gezondheid gevaarlijke of schadelijke bedrijven, toch in verschillend opzicht al weer iets verder gingen dan het ontwerp-Lely. De enorme uitgebreidheid van het wetsvoorstel werd vooral daardoor veroorzaakt, dat niet alleen de regelingen, die al in de bestaande Arbeidswet voor vrouwen en jeugdige personen voorkwamen, opgenomen waren (met een verhoging van de leeftijd van jeugdigen en het verkorten van de normale arbeidsduur met én uur) alsmede de regelingen van de Veiligheidswet, maar ook de kern van de wat in algemene maatregelen van bestuur in en zal worden geregeld. Daarnaast was er een hoofdstuk over het leerlingwezen. Kortom, een breed en ook systematisch opgezet wetsontwerp, een geünificeerde codificatie van de wettelijke arbeidersbescherming, aldus M.G. Levenbach, Arbeid, in Nederlands bestuursrecht, blz. 446 - 447.

Zie over dit wetsvoorstel onder meer: Voorontwerp Arbeidswet 1903 (overzicht der ontworpen bepalingen ook in vergelijking met de geldende Arbeidswet en Veiligheidswet; in K.S.W. $1903 \mathrm{blz}$. $177 \mathrm{t} / \mathrm{m} \mathrm{179}$, blz. 260 $\mathrm{t} / \mathrm{m}$ 262; Studiën over de Arbeidswet, in K.S.W. 1904 blz. 225, blz. $232-233$, blz. $245 \mathrm{t} / \mathrm{m} \mathrm{248}$, blz. $256 \mathrm{t} / \mathrm{m}$

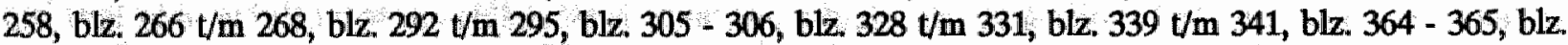
375 - 376, blz. $398 \mathrm{t} / \mathrm{m} 400$, blz. $423 \mathrm{t} / \mathrm{m} 425$, blz. 435 - 436, blz $508 \mathrm{t} / \mathrm{m} 510$, blz. $557 \mathrm{t} / \mathrm{m} \mathrm{559}$, blz. 604 - 605 , blz. $615 \mathrm{t} / \mathrm{m}$ 617; Beperking van den arbeidsduur van mannen, in Sociaal Weekblad $1904 \mathrm{blz} .213 \mathrm{t} / \mathrm{m} \mathrm{215}$; De vrouw en het ontwerp-Arbeidswet, in Sociaal Weekblad $1904 \mathrm{blz} .585 \mathrm{t} / \mathrm{m} 588$.

5. Hoofdstuk VII van het wetsvoorstel bevatte een afzonderlijke afdeling "Van de ambtenaren, met het toezicht belast", dat slechts drie artikelen besloeg. De beide andere artikelen 371 en 372 luidden resp. als volgt: "Het is aan de in artikel 370 bedoelde ambtenaren verboden middellijk of onmiddellijk deel te nemen aan ondernemingen, waarop deze wet van toepassing is".

"Onze Minister doet zich elke twee jaren op een door hem aan te geven tijdstip een beredeneerd verslag geven over de ambtsbezigheden van de in artikel 370 bedoelde ambtenaren".

6. Bijlagen Tweede Kamer, zitting 1903 - 1904, 133.3 (memorie van toelichting) blz. $80 \mathrm{t} / \mathrm{m} 82$. Tevens gaf de minister aan, dat de betreffende artikelen $370 \mathrm{t} / \mathrm{m} 372$ van zijn ontwerp van wet ontleend waren aan de artikelen 12, 14 en 16 van de Arbeidswet 1889 en de artikelen 9, 10 en 15 van de Veiligheidswet. 
7. Dit zijn naast de bij artikel 8 van het Wetboek van Strafvordering aangewezen personen, de marechaussée, alle ambtenaren van rijks- en gemeentepolitie.

8. Zie bijvoorbeeld artikel 7 van de Veiligheidswet.

9. Bijlagen Tweede Kamer, zitting 1904 - 1905, 30.1 ( voorlopig verslag ) blz. 48 - 49.

10. Het benoemen van ambtenaren ter "bevordering" van een "uitvoering" van de wet kwam enigzins zonderling voor.

11. Zie P.J. Oud, t.a.p., blz. 177 t/m 191; W.J. van Welderen Rengers, t.a.p. deel III 1901-1914, 's-Gravenhage 1950 4e bijgewerkte druk, blz. 1 t/m 91 en M.G. Levenbach, Arbeid, in Nederlands bestuursrecht, blz. 447.

12. Bij Besluit van 7 september 1905, tot instelling van een departement van Algemeen Bestuur, dat de naam zal dragen van ministerie van Landbouw, Nijverheid en Handel, en tot wijziging van de naam van het departement van Waterstaat, Handel en Nijverheid, Stb. 264.

13. Tweede Kamer ( Bijlage A ), zitting 1906 - 1907, no. 7 ( Hfdst. X begroting Landbouw, Nijverheid en Handel ) blz. 11.

14. Tweede Kamer ( Bijlage A ), zitting 1906 - 1907, no. 9 ( Hfdst. X begroting Landbouw, Nijverheid en Handel ) blz. 33 .

15. Besluit van 14 april 1906, Stb. 64.

16. Tweede Kamer ( Bijlage A ), zitting 1907 - 1908, no. 9 ( Hfdst. X begroting Landbouw, Nijverheid en Handel ) blz. 6.

17. Tweede Kamer ( Bijlage A ), zitting 1907 - 1908, no. 10 ( Hfdst. X begroting Landbouw, Nijverheid en Handel ) blz. 24.

18. Bijlagen Tweede Kamer, zitting 1907 - 1908, 314.4 (ontwerp van wet tot verhoging en aanvulling van het Xde Hfdst. der staatsbegroting voor het dienstjaar 1908 ).

19. Bijlagen Tweede Kamer, zitting 1907 - 1908, 314.5 (memorie van toelichting ), blz. 2 - 3. Talma had zich ten tijde van zijn lidmaatschap van de Tweede Kamer voor een reorganisatie uitgesproken; zie Hand. Tweede Kamer, zitting 1907 - 1908 II, blz. 634 t/m 637.

20. Bijlagen Tweede Kamer, zitting 1907 - 1908, 314.7 ( voorlopig verslag ) blz. 6.

21. Bijlagen Tweede Kamer, zitting 1907 - 1908, 314.8 ( memorie van antwoord) blz. 7.

22. Het wetsvoorstel werd zowel door de Tweede Kamer als door de Eerste Kamer zonder hoofdelijke stemming aangenomen. Zie Hand. Tweede Kamer, zitting 1907 - 1908 II, blz. 2332. Opgemerkt dient te worden, dat er over het wetsontwerp in de Tweede Kamer geen beraadslaging heeft plaatsgevonden; zie voorts Hand. Eerste Kamer, zitting 1907 - 1908 I, blz. 335 t/m. 343.

23. Besluit van 6 augustus 1908 , no. 46 , Stcrt. 1908, no. 190. Van IJsselstein was voor de benoeming tot "directeur-generaal van den arbeid" adjunct-directeur van gemeentewerken te Rotterdam. 
24. Deze betiteling van directeur-generaal is een uitvloeisel van een opmerking van Schaper tijdens de mondelinge beraadslaging naar aanleiding van de eerderbedoelde begroting voor het jaar 1908 (Hand. Tweede Kamer, zitting 1907 - $1908 \mathrm{II}, \mathrm{blz} .625$ ). Hij stelde, dat aan het hoofd van de (departementale) afdeling Arbeid een man diende de staan als die aan het hoofd van de (departementale) afdeling Landbouw stond. Deze blijkt, volgens het antwoord van minister Talma (Hand. Tweede Kamer, zitting 1907 - 1908 II, blz. 638) de titel van directeur-generaal te hebben. Deze betiteling keerde daarna regelmatig terug in de discussie. Tijdens de mondelinge beraadslaging in de Eerste Kamer naar aanleiding van het wetsontwerp tot wijziging van de begroting, merkte de minister (Hand. Eerste Kamer, zitting 1907 - 1908 I, blz. 339) op, dat het voor hem niet belangrijk was of de betreffende persoon nu directeur-generaal van de arbeid of hoofdinspecteur genoemd werd, als de man zelf er maar was.

25. H.A. van Usselstein, De Centrale Dienst der Arbeidsinspectie, in Gedenkboek 1909 - 1 september - 1934, blz. 8.

26. Zie nt. 88 van de toelichtende staat van Hfdst. $X$ van de begroting van Landbouw; Nijverheid en Handel.

27. Tweede Kamer ( Bijlage A ), zitting 1908 - 1909, no. 8 ( Hfdst. X begroting Landbouw, Nijverheid en Handel ) blz. 11.

28. Tweede Kamer ( Bijlage A ), zitting 1908 - 1909, no. 9 ( Hfdst. X begroting Landbouw, Nijverheid en Handel ) blz. 28.

29. Geprobeerd moest worden hun huidige taak te verlichten, aldus de minister. Zo konden de talloze voorgeschreven medische keuringen opgedragen worden aan met zorg te kiezen medici. Zo zou de elektrotechnicus niet meer in elk afzonderlijk geval aangaande voorschriften ter beveiliging van elektrische toestellen en geleidingen de inspecteur hoeven bij te staan, maar zou volstaan kunnen worden met een zoveel mogelijk in algemene zin het voorlichten van de inspecteurs omtrent voorzieningen die behoorden te worden getroffen. Het toezicht op de naleving van deze voorschriften zou voor een groot deel zonder bezwaar overgelaten kunnen worden aan de inspecteurs en de onder hun bevelen werkzame ambtenaren.

30. Zie Tweede Kamer (Bijlage A ), zitting 1908 - 1909, no. 9 ( Hfdst. X begroting Landbouw, Nijverheid en Handel ) blz. 28 - 29.

31. Dit wil zeggen het instellen van het nodige onderzoek en het uitbrengen van adviezen over onderwerpen waarover de minister voorlichting behoefde.

32. Tweede Kamer ( Bijlage A ), zitting 1908 - 1909, no. 10 ( Hfdst. X begroting Landbouw, Nijverheid en Handel ) blz. 34.

33. Tweede Kamer ( Bijlage A ), zitting 1908 - 1909, no. 12 ( Hfdst. X begroting Landbouw, Nijverheid en Handel ) blz. 44.

34. De commissie bestond uit de leden Janssen, Arts, Terf, Bos en Van Idsinga.

35. Hand. Tweede Kamer, zitting 1908 - 1909 II, blz. 1491 - 1492.

36. Verwezen zij naar het voorlopig verslag van de Eerste Kamer ( Hand. Eerste Kamer, zitting 1908 - 1909 I, blz. 229 ), waaruit blijkt, dat men in het algemeen instemde met het uitgangspunt van de reorganisatieplan- 
nen van de minister, zonder daarbij uitvoerig op deze plannen in te willen gaan, tén en ander in afwachting van het afzonderlijke wetsvoorstel.

37. Tussen Schaper, Helsdingen, Treub, De Savornin Lohman en minister Talma; zie Hand. Tweede Kamer, zitting 1908 - $1909 \mathrm{II}$, blz $1492 \mathrm{t} / \mathrm{m} 1494$.

38. Het amendement werd met 32 tegen 23 stemmen aangenomen; zie Hand. Tweede Kamer, zitting 1908 - 1909 II, blz. 1494.

39. Bijlagen Tweede Kamer, zitting 1908 - 1909, 211.1 en 2 (wetsontwerp tot wijziging van verhoging van het Xde Hfdst. der Staatsbegroting voor het dienstjaar 1909 ).

40. Bijlagen Tweede Kamer, zitting 1908 - 1909, 211.3 (memorie van toelichting) blz. 1 t/m 4.

41. Bijlagen Tweede Kamer, zitting 1908 - 1909, 211.4 ( voorlopig verslag ) blz. 5 - 6.

42. Bijlagen Tweede Kamer, zitting 1908 - 1909, 211.5 ( memorie van toelichting) blz. 7 - 8.

43. Bijlagen Tweede Kamer, zitting 1908 - 1909, 314.5 (memorie van toelichting).

44. Hand. Tweede Kamer, zitting 1908 - $1909 \mathrm{II}$, blz. 2146 t/m 2148.

45. Hand. Tweede Kamer, zitting 1908 - 1909 II, blz. 2154.

46. Hand. Tweede Kamer, zitting 1908 - 1909 II, blz. 2159 t/m 2161.

47. Over de relatie tussen de dienst van de arbeidsinspectie en de departementale afdeling Arbeid wordt in hoofdstuk 11 par. 2 ( De arbeidsinspectie en de afdeling Arbeid/Arbeidersbescherming; het ontstaan van het directoraat-generaal van de Arbeid ) uitgebreider ingegaan.

48. Hand. Tweede Kamer, zitting 1908 - 1909 II, blz. 2150 t/m 2152.

49. Hand. Tweede Kamer, zitting 1908 - 1909 II, blz. 2152 - 2153.

50. Hand. Tweede Kamer, zitting 1908 - 1909 II, blz. 2153 t/m 2155.

51. Dit waren Blooker, Van Idsinga en Schaper; zie Hand. Tweede Kamer, zitting 1908 - 1909 II, blz. 2161 $\mathrm{t} / \mathrm{m} 2163$.

52. Hand. Tweede Kamer, zitting 1908 - 1909 II, blz. 2165.

53. Hand. Eerste Kamer, zitting 1908 - 1909 I, blz. 584.

54. Sociaal-technische Vereeniging van democratische ingenieurs en architecten, brief van 20 maart 1909 met als bijlage: De reorganisatie der Arbeidsinspectie; zie ook Hand. Tweede Kamer, zitting 1908 - $1909 \mathrm{II}$, blz. 2145 .

55. H. Burger, De medewerking der geneeskundigen aan het staatstoezicht op den arbeid, in Nederlandsch Tijdschrift voor Geneeskunde 1909 II (overdruk). 
56. Th. Sommerfeld, Der Gewerbearzt, Jena 1905, blz. 139. Bovendien had de minister naar aanleiding van de opmerkingen van Blooker tijdens de mondelinge beraadslaging van de suppletoire begroting voor het dienstjaar 1909 ( zie Hand. Tweede Kamer, zitting 1908 - 1909 II, blz. 2148 - 2149) niet afwijzend gestaan tegen een dergelijk idee. Zijn voornaamste tegenargument was de moeilijkheid om voor dit werk geschikte geneeskundigen te vinden. Dat geneeskundige bemoeiing op het terrein van het arbeidstoezicht zou moeten toenemen, gaf hij volmondig toe; zie Hand. Tweede Kamer, zitting $1908-1909$ II, blz. $2153-2154$.

57. Anders G.W. Bruinsma, in Vragen des Tijds $1900 \mathrm{I}, \mathrm{blz} .207 \mathrm{t} / \mathrm{m} 250$.

58. Deze organisaties waren: de Nationale Vereeniging voor Vrouwenarbeid, de Vereeniging ter behartiging van de belangen der vrouw, de Vereeniging tot verbetering van den maatschappelijken en den rechtstoestand der vrouw in Nederland en de Nationale Vrouwenraad van Nederland en de Vereeniging van adjunct- inspecteurs en adjunct-inspectrices van den arbeid ( zie Hand. Tweede Kamer, zitting 1908 - 1909 II, blz. 2145 -2146 ).

59. Bij Koninklijke boodschap van 15 april 1909 (Bijlage Tweede Kamer, zitting 1908 - 1909, 263.1) werden een wijziging van de Arbeidswet 1889 (Bijlage Tweede Kamer, zitting 1908 - 1909, 263.2) en van de Veiligheidswet ( Bijlage Tweede Kamer, zitting 1908 1909, 263.3) aangeboden, alsmede wetswoorstellen tot wijziging van de Hinderwet, van de Phosphorluciferwet 1901, van de Caissonwet 1905 en van de Ongevallenwet 1901 ( Bijlage Tweede Kamer, zitting 1908 - 1909, 263.4 t/m 7 ). Laatstgenoemde wetsvoorstellen beogen slechts technische wijzigingen in verband met de reorganisatie van de arbeidsinspectie en blijven verder buiten beschouwing.

60. Zie over dit nieuwe artikel 12 van de Arbeidswet 1889 H. Smissaert, Economische Kroniek, in Onze Eeuw 1911, blz. $115 \mathrm{t} / \mathrm{m} 117$.

61. Artikel 12 van de Arbeidswet 1889 luidde na de wijziging:

"Er is een arbeidsinspectie.

Ten behoeve van den dienst der arbeidsinspectie wordt het Rijk door ons verdeeld in districten.

De ambtenaren der arbeidsinspectie zijn behalve met de taak, hun bij andere wetten opgedragen, belast met de handhaving van deze wet en met de medewerking aan de uitvoering ervan. $\mathrm{Zij}$ zijn werkzaam onder de bevelen van Onzen Minister, met de uitvoering van deze wet belast, en worden door Ons benoemd, geschorst en ontslagen.

Hun werkkring en bevoegdheden worden geregeld bij algemeenen maatregel van bestuur. Daarbij wordt bepaald, dat en op welke wijze voor de arbeidsinspectie en voor elk district een ambtenaar als hoofd van dienst wordt aangewezen.

De instructiën voor de ambtenaren der arbeidsinspectie worden door Ons vastgesteld. Jaarlijks wordt een verslag van de werkzaamheden der arbeidsinspectie aan de Staten-Generaal overgelegd".

Artikel 12bis van de Arbeidswet 1889 luidde:

"Aan de ambtenaren, bedoeld in het vorige artikel, worden toegevoegd de ambtenaren en bedienden, die zij voor de uitoefening van hunne taak behoeven. Deze worden door Ons of krachtens Onze machtiging door Onze Minister, met de uitvoering van deze wet belast, benoemd, geschorst en ontslagen.

Hunnen instructiën worden vastgesteld door Onzen voornoemden Minister".

62. Bijlagen Tweede Kamer, zitting $1908-1909,263.8$ (memorie van toelichting ) blz. 4 - 5 . 
63. Daarbij is vooral gedacht aan het geven van bindende voorschriften en aanwijzingen op grond van artikel 4 van de Arbeidswet 1889 en de daarop gebaseerde algemene maatregel van bestuur; verder aan het verzamelen van gegevens waaruit kan blijken of en - zo ja - welke maatregelen getroffen moeten worden ten behoeve van een juiste naleving van de wet, het uitbrengen van adviezen dienaangaande enz.

64. Bijlagen Tweede Kamer, zitting 1908 - 1909, 263.9 ( voorlopig verslag ) blz. 9.

65. Bijlagen Tweede Kamer, zitting 1908 - 1909, 263.10 (memorie van antwoord) blz. 11 - 12.

66. Bijlagen Tweede Kamer, zitting 1908 - 1909, 211.

67. Bijlagen Tweede Kamer, zitting 1908 - 1909, 263.8 ( memorie van toelichting) blz. 5 t/m 7.

68. Wet van 1 juli 1909 tot wijziging van de Arbeidswet 1889, Stb. 244; Wet van 1 juli 1909 tot wijziging van de Veiligheidswet, Stb. 245; Wet van 1 juli 1909 tot wijziging van de Hinderwet, Stb. 246; Wet van 1 juli 1909 tot wijziging van de Phosphorluciferwet 1901, Stb. 247; Wet van 1 juli 1909 tot wijziging van de Wet van 22 mei 1905 (Caissonwet 1905 ), Stb. 248; Wet van 1 juli 1909 tot wijziging van de Ongevallenwet 1901, Stb. 249.

69. Besluit van 10 augustus 1909 , Stb. 287.

70. Besluit van 10 augustus 1909, Stb. 288 (in werking getreden op 1 september 1909 ). Artikel 1 van dit Besluit luidde:

"Ten behoeve van den dienst der arbeidsinspectie wordt het Rijk verdeeld in negen districten waarvan omvatten:

het 1ste de provincie Limburg en het gedeelte der provincie Noordbrabant, dat behoort tot het rechtsgebied van de kantongerechten Oss, Veghel, Boxmeer, Eindhoven, Oirschot, Weert en Helmond;

het 2 de het gedeelte der provincie Noordbrabant, dat niet behoort tot het 1ste district, benevens de provincie Zeeland;

het 3de het gedeelte der provincie Zuidholland, dat behoort tot het rechtsgebied van de kantongerechten Rotterdam no. 1, no. 2 en no. 3, Schoonhoven, Brielle, Sommelsdijk, Dordrecht, Oud-Beijerland, Ridderkerk, Gorinchem, Sliedrecht en Vianen;

het 4de het gedeelte der provincie Zuidholland, dat niet behoort tot het 3de district, benevens de provincie Utrecht;

het 5 de het gedeelte der provincie Noordholland, dat behoort tot het rechtsgebied van de kantongerechten Amsterdam, no. 1, no. 2, no. 3 en no. 4, benevens het niet tot eenige provincie behoorende watergebied des Rijks;

het $6 \mathrm{de}$ het gedeelte der provincie Noordholland, dat niet behoort tot het $5 \mathrm{de}$ district;

het $7 \mathrm{de}$ de provincie Gelderland;

het 8ste de provincie Overijssel;

het 9de de provinciën Groningen, Friesland en Drenthe".

71. Besluit van 10 augustus 1909 , tot vaststelling van een algemene maatregel van bestuur als bedoeld in het vierde lid van artikel 12 van de Arbeidswet 1889, Stb. 289 ( het zgn. "Organisatiebesluit"; in werking getreden op 1 september 1909 ).

72. Artikelen 7 en 8 van het Organisatiebesluit. 
73. Zie N.C. Winkel, in Gedenkboek 50 jaar, blz. 26.

74. Zile artikel 9 van het Organisatiebesluit.

75. Zie artikel 9 van het Organisatiebesluit.

76. Zie de artikelen 9,16 en 17 van het Organisatiebesluit.

77. Zie artikel 2 van het Organisatiebesluit; zie ook Th.C. Geudeker, in Gedenkboek 1909 - 1 september 1934, blz. $75-76$.

78. Zie de artikelen 9,11 en 17 van het Organisatiebesluit.

79. Deze mogelijkheid was geopend door de brief van de minister van Landbouw, Nijverheid en Handel van 2 maart 1910, No. 412 afd. Arbeid, weergegeven in Centraal Jaarverslag der Arbeidsinspectie over 1910, 'sGravenhage 1911, blz 12 .

80. Zie artikel 9 van het Organisatiebesluit; De eerste districtshoofdenvergadering vond reeds op 9 september 1909 plaats; zie Th.C. Geudeker, in Gedenkboek 1909 - 1 september - 1934, blz. 76.

81. Aangehaalld door N.C. Winkel, in Gedenkboek 50 jaar, blz. 28.

82. Artikel 15 van bet Organisatiebesluit.

83. N.C. Winkel, in Gedenkboek 50 jaar, blz. $25 \mathrm{t} / \mathrm{m}$ 28; H.A. van IJsselstein, in Vijf en twintig jaren Arbeidsinspectie $1890-1915$, blz. XIII t/m XVI.

84. Zie artikel 11 van het Organisatiebesluit.

85. Hand. Tweede Kamer, zitting 1888 - 1889, blz. 841 .

86. N.C. Winkel, in Gedenkboek 50 jaar, blz. 28 - 29; J.J. Camminga, Iets over de taak van de Controleurs van den Arbeid, in Gedenkboek 1909 - 1 september - 1934, blz. 59 en H.A. van IJsselstein, in Vijf en twintig jaren Arbeidsinspectie $1890-1915$ blz. XV, die op blz. XVI schrijft, dat nog nimmer in enig land het arbeiderselement stelselmatig bij de arbeidsinspectie was betrokken; het systematisch gebruik maken van arbeiders-ambtenaren bij de behartiging van belangen, die de arbeiders zo nauw raken, was tot op dat moment nog niet geprobeerd. Zie ook het Centraal Jaarverslag der Arbeidsinspectie over 1909, 's-Gravenhage 1910, blz. 4 . 


\section{DE PERIODE VANAF DE REORGANISATIE TOT AAN DE EERSTE WERELDOOR- LOG}

\section{Opnieuw uitbreiding; de geneeskundige en de scheikundig-ingenieur bij de arbeidsinspectie}

Nog geen 2 jaar na de reorganisatie maakte de minister van Landbouw, Nijverheid en Handel tijdens de begrotingsbehandeling voor het dienstjaar $1911^{\prime}$ kenbaar, dat de taak van de medisch adviseur bij de arbeidsinspectie verlicht diende te worden. Niet alleen namen de activiteiten in deze toe, maar te verwachten was, aldus de bewindsman, dat het medische element bij de toepassing van de arbeidswetgeving nog sterk zou ontwikkelen, waarop tijdig ingespeeld diende te worden. Hij stelde dan ook voor een medicus te benoemen die de medisch adviseur bij de vervulling van diens ambt terzijde zou staan. Dit voorstel ondervond geen tegenwerking in het parlement, waarop W.R.H. Kranenburg met ingang van 1 augustus 1911 benoemd kon worden tot geneeskundige bij de arbeidsinspectie ${ }^{2}$, hoewel het formaliseren van deze benoeming eerst gebeurde bij het Besluit van 2 oktober $1911^{3}$.

De ingevolge de Hinderwet ingestelde beroepen, waarover adviezen werden gevraagd aan de arbeidsinspectie, hadden geleid tot bemoeiingen van de dienst met de waterverontreiniging. Het districtshoofd van het negende district bleef tot haar ontbinding op 15 maart 1913 deel uitmaken van de Rijkscommissie aan wie de bestudering van maatregelen tot reiniging van afvalwater van strokarton- en aardappelmeelfabrieken was opgedragen. De aan deze commissie toegevoegde scheikundig-ingenieur werd in 1910 bij de arbeidsinspectie te werk gesteld en kreeg in 1912 de beschikking over een eigen laboratorium, dat de mogelijkheid opende de scheikundige onderzoekingen te verrichten, die voor de inspectiedienst van belang waren ${ }^{4}$. Met ingang van 5 maart 1913 werd tot scheikundig-ingenieur bij de arbeidsinspectie benoemd H.J.N.H Hessener ${ }^{5}$. De taakstelling van deze aan de directeur-generaal toegevoegde ambtenaar werd in het Besluit van 18 april $1913^{6}$ wettelijk vastgesteld ${ }^{7}$.

In de loop der jaren nam het afvalwatervraagstuk steeds grotere afmetingen aan, en is daarvoor het Rijksinstituut voor Zuivering van Afvalwater opgericht, zodat het laboratorium van de arbeidsinspectie zich uitsluitend kon bezighouden met het onderzoek van stoffen, die gevaar op konden leveren voor de gezondheid van arbeiders in fabrieken, waardoor niet langer de gastvrijheid behoefde te worden gevraagd van de laboratoria van de Technische Hoogeschool en van de Koninklijke Militaire Academie ${ }^{\text {. }}$

\section{De Arbeidswet 1911}

Een belangrijke vermeerdering van de werkzaamheden van de arbeidsinspectie zou de wijziging van de Arbeidswet 1889 in 1911, wat zou uitmonden in de Arbeidswet 1911, met zich brengen ${ }^{10}$.

Een belangrijke oorzaak was, dat in plaats van de commissarissen van de Koningin en de burgemeesters, nu de arbeidsinspectie aangewezen werd als orgaan dat de overwerkvergunningen kon verlenen "1. Enerzijds was namelijk gebleken, dat de commissarissen van de Koningin in de regel op verzoeken om vergunningen beslisten overeenkomstig de adviezen van de districtshoofden, anderzijds was bij het verlenen van vergunnimgen door burgemeesters lang niet in alle gevallen een bevredigende gang van zaken verkregen ${ }^{12}$. Het beëindigen van het medebewind ${ }^{13}$ van provinciale en gemeentelijke organen vond, volgens Levenbach ${ }^{14}$, zijn basis in de reorganisatie van de arbeidsinspectie in 1909. Deze inkrimping van de gemeentelijke bemoeiing werd door de gemeenten in het algemeen niet betreurd. Ook waar de gemeente- (en de rijks-)politie meewerkte, was haar taak gaandeweg meer geconcentreerd op de naleving van de formele wetsbepalingen (als arbeidskaart en -lijsten) en van hetgeen op de openbare weg gebeurde, terwijl de controle op de materiële bepalingen hoofdzakelijk bij de arbeidsinspectie was gekomen. Toen dit op 23 en 24 juni 1911 uitvoerig werd 
besproken in de Nederlandsche Vereeniging voor Gemeentebelangen werd als hoofdvereiste voor het toekennen van medebewind gesteld, dat de wet een behoefte betrof, die uitsluitend door een plaatselijke voorziening vervuld kon worden. Maar juist bij de arbeidsbescherming ontbrak dit. Bij de beoordeling wat bijvoorbeeld de veiligheid in een fabriek eiste of van wat ten aanzien van de arbeidsduur moest worden bepaald, komt niet alleen een technische kennis als eis naar voren, die van een gemeentelijk bestuursorgaan niet kon worden verondersteld, maar is ook een vergelijking met andere gevallen buiten de gemeentegrenzen nodig; dikwijls een beoordeling van een gehele bedrijfstak, die een plaatselijk bepaald orgaan ongeschikt doet zijn voor beslissing of regeling in deze, aldus Scholtens ${ }^{15}$.

\section{Het ontwerp-Schaper}

Op 28 juli 1911. werd door het Tweede Kamerlid Schaper een initiatief-wetswoorstel ter zake van het vaststellen van bepalingen ter bescherming van de arbeid, in het bijzonder ten aanzien van de arbeidsduur ${ }^{18}$ bij de Tweede Kamer ingediend. Dit wetsvoorstel was een nasleep van de door Schaper op 24 december 1906 ingediende motie, waarin de wenselijkheid werd uitgesproken van een algemene wettelijke tien-uren-dag ${ }^{17}$. Deze motie zou eerst op 5 maart 1909 behandeld worden om uiteindelijk te worden verworpen ${ }^{18}$. Een iets anders geformuleerde motie van het Tweede Kamerlid Aalberse met een zelfde strekking ${ }^{19}$ zou echter wel aangenomen worden ${ }^{20}$. Het feit, dat de activiteiten van minister Talma op wetgevend terrein zich richtten op arbeid door kinderen, jeugdigen en vrouwen en er van zijn kant geen algemene wet op de arbeidsduur was te verwachten, was voor Schaper en de mede-ondertekenaars om nog tijdens de behandeling van het ontwerp-Arbeidswet 1911 van het initiatiefrecht gebruik te maken en een wetsvoorstel van een degelijke strekking in te dienen ${ }^{21}$.

Het was een volledig wetsvoorstel, dat wil zeggen dat niet volstaan werd met een aanvulling met de door hen gewenste bepalingen van de toen nog in te voeren Arbeidswet 1911 ${ }^{22}$, zodat er in het wetsvoorstel bepalingen waren opgenomen met betrekking tot de arbeidsinspectie. Een belangrijk verschil ten opzichte van de regeling van de arbeidsinspectie in de latere Arbeidswet 1911 was gelegen in het feit, dat in artikel 31, vierde lid, van het wetsvoorstel de werkkring en de bevoegdheden van de arbeidsinspectie voor zover nodig nader zouden kunnen worden geregeld bij algemene maatregel van bestuur. Het leek de indieners gewenst een dergelijke regeling niet geheel aan een algemene maatregel van bestuur over te laten, en in ieder geval de belangrijkste bepalingen in de wet zelf op te nemen, om zodoende het parlement in de gelegenheid te stellen hierover mede te beslissen. Zo kon worden voorkomen, dat bevoegdheden van de ambtenaren van de arbeidsinspectie, buiten het parlement werden overgeheveld, hetzij naar de directeur-generaal van de Arbeid hetzij naar departementsonderdelen. Vandaar dat het wetsvoorstel een aantal bepalingen bevatte ${ }^{23}$ die waren overgenomen uit het Organisatiebesluit ${ }^{24}$. De mogelijkheid tot "nadere" regeling van de werkkring en de bevoegdheden opende voldoende ruimte om de verdere onderdelen bij algemene maatregel van bestuur te regelen, aldus de initiatiefnemers ${ }^{25}$. Het voorlopig verslag zou eerst op 28 oktober $1915^{26}$ verschijnen. Daaruit blijkt onder andere, dat er getwijfeld werd aan de wenselijkheid van de voorgestelde regeling van de organisatie, omdat het aanbrengen van wijzigingen hierin bemoeilijkt zou worden; een argument dat de indieners van het wetsvoorstel niet kon overtuigen ${ }^{27}$. De gebeurtenissen die na het verschijnen van de memorie van antwoord op 18 oktober 1918 plaatsvonden, deden het initiatief-wetswoorstel van het politieke strijdtoneel verdwijnen.

\section{De Steenhouwerswet 1911}

Al lange tijd werd het steenhouwersbedrijf als een voor de gezondheid zeer schadelijk bedrijf beschouwd ${ }^{28}$. Tot het tegengaan van voor de gezondheid schadelijke invloeden, met name tuberculose, gaf de bestaande wetgeving onvoldoende mogelijkheden, omdat de Arbeidswet niet van toepassing was op volwassen mannen en de Veiligheidswet 1895 onder meer niet van toepassing was op fabrieken en werkplaatsen waar minder dan tien personen werken, wat maakt, dat kleine steenhouwerijen die het grootst in aantal waren buiten de 
werkingssfeer van die wet vielen. De gevaren waren zo ernstig, dat volgens de minister ${ }^{29}$ aanvulling van de wet op dit punt spoedeisend was. Dit zou resulteren in de Steenhouwerswet $1911^{30}$, die voor de betrokkenen zeer belangrijk was met oog op de gevreesde "steenhouwersziekte", maar die geen grote verandering bracht in de taak van de arbeidsinspectie ${ }^{31}$.

Tijdens de parlementaire behandeling van deze wet zou de problematiek rond de (sub)delegatie uitvoerig aan de orde komen.

In artikel 6 van het wetsvoorste ${ }^{32}$ werd de werkgever de verplichting opgelegd er voor te zorgen, dat voorschriften - onder andere met betrekking tot de inrichting van werklokalen - gegeven bij algemene maatregel van bestuur werden nageleefd met inachtneming van nadere schriftelijke voorschriften die door het districtshoofd van de arbeidsinspectie konden worden gegeven. Deze aan het districtshoofd toegekende bevoegdheid werd door verscheidene Tweede Kamerleden veel te groot geacht ${ }^{33}$ Men vroeg zich dan ook af, of, indien een dergelijke bepaling onmisbaar zou zijn, een waarborg tegen verkeerd gebruik in de wet vastgelegd moest worden. Bovendien was de redactie van artikel 6 zodanig dat deze niet overeen kwam met de blijkens de toelichting gegeven bedoeling ${ }^{34}$; de bevoegdheid strekte zich uit tot alle drie de onderdelen van het eerste lid wan dit artikel. Ten einde aan dit laatste bezwaar tegemoet te komen werd het bewuste artikel aangepast $^{35}$. Op het eerste bezwaar reageerde ${ }^{38}$ de bewindsman met er op te wijzen dat in artikel 8 van het wetsvoorstel een beroepsmogelijkheid was neergelegd, waaraan werd toegevoegd, dat de ervaring met de toepassing van de Veiligheidswet, die een soortgelijke regeling bevat, leerde, dat deze bevoegdheid niet tot bezwaren (met andere woorden: misbruik) had geleid.

Het Tweede Kamerlid De Visser bestreed ${ }^{37}$ de door de bewindsman naar voren gebrachte gedachtengang. In tegenstelling tot artikel 6 van het voorliggende wetsvoorstel, zo stelde hij, werden in artikel 7 van de Veiligheidswet nauwkeurig de onderwerpen aangegeven waartoe de bevoegdheid van het districtshoofd om nadere voorschriften te geven zich uitstrekte. De in genoemd artikel 6 gebezigde formulering maakte, dat het districtshoofd los van een algemene maatregel van bestuur nadere voorschriften zou kunnen geven.

Voor de duidelijkheid worden nu de bewuste artikelen naast elkaar gezet.

\begin{tabular}{|c|c|}
\hline $\begin{array}{l}\text { Artikel } 6 \text { van de antwerp-Steenhouvers- } \\
\text { wet } 1911\end{array}$ & Artikel 7 van de Veiligheidowet \\
\hline 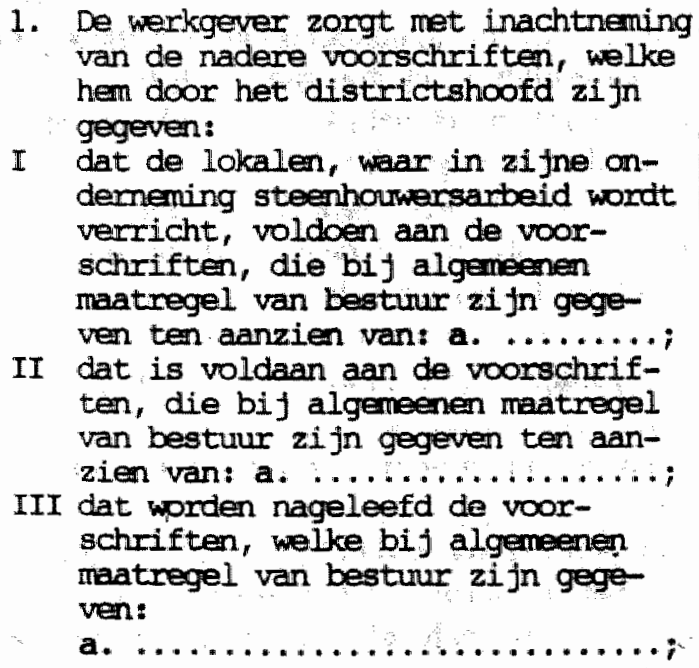 & 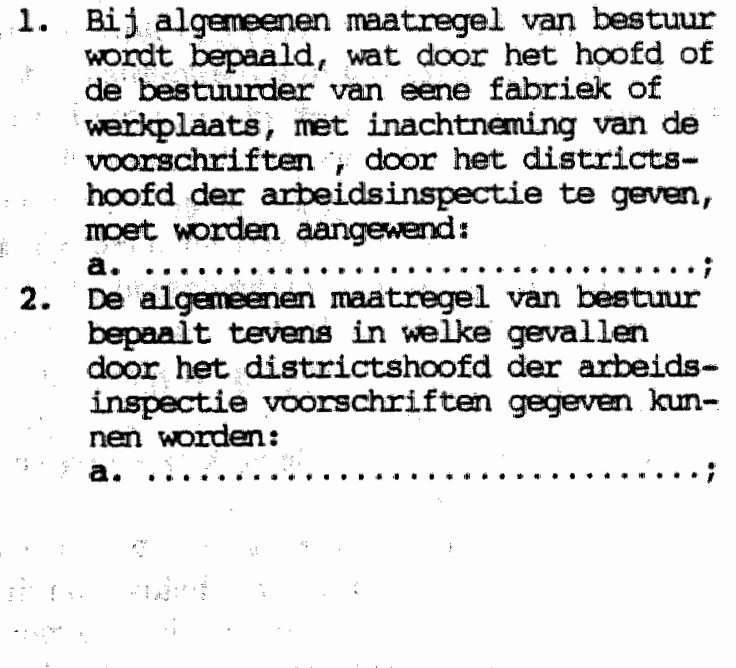 \\
\hline
\end{tabular}


Het Tweede Kamerlid De Visser wroeg zich allereerst af of een bepaling als artikel 6 van het wetsvoorstel wel geoorloofd was gezien het feit, dat artikel 56 van de Grondwet toch bepaalde, dat de Koning algemene maatregelen van bestuur kan vaststellen en dat wanneer deze maatregelen door straffen gehandhaafd moesten worden deze niet anders dan krachtens de wet uitgevaardigd konden worden. Vervolgens wroeg hij zich af waarom de minister zich bij het opstellen van het wetsvoorstel niet geconformeerd had aan wat hij noemde het "overzichtige" artikel 7 van de Veiligheidswet, zeker omdat de strafbepaling van deze wet - artikel 19 - een door hem bedoeld onderscheid maakte:

Met hechtenis van ten hoogste eene maand of geldboete van ten hoogste honderd gulden wordt gestraft: a. overtreding van een der artikelen enz, b. overtreding van eene der bepalingen van eenen algemeenen maatregel van bestuur als bedoeld in artikel 6 of artikel 7 en c. het niet voldoen aan een voorschrift" - dat is het voorschrift van het hoofd van de arbelidsinspectie - "krachtens eene algemeenen maatregel van bestuur uitgevaardigd ingevolge artikel $7^{\text {th}}$. Dit laatste was zijns inziens de juiste formulering: krachtens een allgemene maatregel van bestuur die steunde op de wet.

Overigens stelde artikel 20 van het ontwerp-Steenhouwerswet 1911 eenvoudig, dat overtreding van artikel 6 met een hechtenis van ten hoogste een maand of een geldboete van ten hoogste fl. 100,-- gestraft werd. Hij werd bijgevallen door het Tweede Kamerlid Tydeman ${ }^{38}$, in zoverre dat deze laatste stelde, dat het betreffende artikel van het wetsvoorstel niet aangaat, dat de bevoegdheid tot het geven van nadere voorschriften gold daar waar de algemene maatregel van bestuur omtrent werkplaatsen, schaftlokalen en dergelijke van toepassing zou zijn, maar zonder nadere beperking de nadere voorschriften van het districtshoofd van de arbeidsinspectie in acht gemomen zouden moeten worden. Indien er had gestaan "met inachtneming van de desbetreffende nadere schriftelijke voorschriften", dan zou aan dit bezwaar tegemoet gekomen worden en zou duidelijk zijn, dat het hier geen bevoegdheid betrof dat nadere voorschriften zouden kunnen worden gegeven los van de algemene maatregel van bestuur. Hij voorzag echter ook dat de bewindsman wel zou antwoorden dat dit ook in de bedoeling lag.

Overigens kon hij de zo door De Visser uitgesproken voorkeur voor de "voorzichtige" redactie van artikel 7 van de Veiligheidswet niet goed plaatsen. Het kwam hem voor dat het eerste lid van dit artikel eigenlijk precies hetzelfde standpunt huldigde als het thans voorgestelde artikel. Alleen is in dit artikellid door de zinswending duidelijker gemaakt, dat het hier gaat om voorschriften van het districtshoofd bij de uitvoering van de door nader genoemde zaken, zoals het bevorderen van zindelijkheid, het bevorderen van een dragelijke temperatuur, het verwijderen van schadelijke dampen, enz. Het tweede lid van artikel 7 van de Veiligheidswet bevatte een tweede verwijzing naar de door het districtshoofd te geven voorschriften, zij het meer concreet gesteld, daar bepaald was dat in de algemene maatregel van bestuur de gevallen aangegeven moesten worden waarin van de zijde van de arbeidsinspectie voorschriften gegeven konden worden.

De spreker had daarop naar het effect van deze bepaling gezocht in het betreffende Veiligheidsbesluit ${ }^{30}$ en had een artikel 22 gevonden waarin die gevallen zogenaamd werden genoemd.

"Maar dat is feitelijk, naar het schijmt, een onmogelijkheid gebleken, want dat artikel 22 is z 66 ruim en $z 606$ wijd, dat er van een aanduiding van bepaalde gevallen eigenlijk geen sprake meer is. Er wordt eenvoudig gezegd: "Het districtshoofd der arbeidsinspectie kan ten aanzien van het in de $\$ \$ 7$ tot en met 12 bepaalde en eveneens, wanneer naar zijn oordeel het in die paragraphen voorgeschrevene niet of niet voldoende wordt nageleefd, enz...... nadere voorschriften geven.

Dat is een tautologie voor de verklaring: gij kunt naar het u nog noodig voorkomt, nadere voorschriften geven."

Zijn conclusie was dan ook, dat de Veiligheidswet geen ander stelsel bevatte dan werd voorgesteld. Daarop vroeg hij zich af of het mogelijk was een arbeidswetgeving te maken waarbij een dergelijke bevoegdheid aan de districtshoofden zou ontbreken. Hoewel dit het terrein raakte van de techniek van deze wetgeving, waarop Tydeman vooralsnog niet in wilde gaan, voegde hij daar wel een aantal vragen aan toe.

"Is het mogelijk, indien men zoo diep ingrijpt in het bedrijfsleven als bij deze soort van wetgeving geschiedt, te blijven staan bij voorgeschreven, geformulleerde regelen, hetzij in de 
wet, hetzij in een algemeenen maatregel van bestuur?

Zal de practijk er dan niet toe leiden, dat men op den duur moet komen, zij het ook met ingevaarbrenging van de rechtszekerheid, tot toekenning van dergelijke uitgebreide bevoegdheden aan de arbeidsinspectie?"

Het was de vraag of het geoorloofd was dit te doen, of het in overeenstemming met de Grondwet was, en of, naar het stelsel van de Grondwet was, dat alleen dan in algemene maatregelen van bestuur voorschriften door strafbepalingen kunnen worden gesanctionneerd indien zij in de (formele) wet hun wortels vinden, als het ware een verlengstuk mag worden gezet op diezelfde maatregelen door een bevoegdheid te creëren tot het geven van ongenoemde, ongeformuleerde voorschriften en de niet-nakoming daarvan te bestraffen. Maar of dit punt al niet gepasseerd was, durfde hij niet te ontkennen, daar de HR in het arrest van 6 juni $1904^{40}$ had geoordeeld dat niet-nakoming van de voorschriften door de arbeidsinspectie gegeven op grond van artikel 7, eerste lid, van de Veiligheidswet gestraft moest worden. Hoewel de HR grondwettelijk niet kon en kan treden in de beoordeling van de grondwettigheid van wetten, werd het parlement niet ontslagen van de verplichting om na te gaan of deze wet geen strijd opleverde met de Grondwet.

Hij besloot zijn rede met de opmerking dat de praktijk nu eenmaal zo was en om die reden de weg gevolgd moest worden waarlangs deze regelingen zich tot dan hadden bewogen.

Dit laatste argument hield volgens het Tweede Kamerlid Van Idsinga geen stand ${ }^{41}$, want als erkend werd, dat de praktijk een verkeerde was, dan moest die praktijk veranderd worden. Dat bovendien de eisen van de praktijk subdelegatie noodzakelijk maakte, ontkende hij ten stelligste. Hij gaf toe, dat het in de praktijk nodig zou kunnen zijn, dat toezichthoudende ambtenaren de mogelijkheid moesten hebben met de werkgever in overleg te treden over maatregelen die genomen zouden moeten worden om aan de eisen van de wet of algemene maatregel van bestuur te voldoen en hem zekere aanwijzingen gegeven zouden moeten kunnen worden. Maar dit laatste mocht niet leiden tot het opleggen van verplichtingen die bij nietnakoming een strafbaar feit opleverden. De spreker stond eerder het tegenovergestelde systeem voor, namelijk een vrijwaren van de werkgever van strafvervolging; de toezichthoudende ambtenaren zouden als het ware tegen de werkgever moeten zeggen: wanneer die en die aanwijzingen zouden worden opgevolgd, wordt aan de wettelijke verplichting voldaan en zou strafvervolging achterwege blijven. Niet-naleving van die aanwijzingen, omdat de werkgever van mening is, dat hij aan de wettelijke verplichting voldoet, zou dan bij de overheid de beslissing liggen of hij zou moeten worden vervolgd of niet. Zou worden beslist dat vervolging diende te worden ingesteld, dan zou dit altijd moeten zijn wegens overtreding van een in de wet of een algemene maatregel van bestuur voorkomende bepaling dus niet in het voorschrift of de aanwijzing van een ambtenaar - en zou de rechter hebben te beslissen - of datgene wat de werkgever meende, dat voldoende was ook inderdaad voldoende is, éen en ander onafhankelijk van een ambtelijke aanwijzing. In het door de minister voorgestelde systeem was het niet van belang of de rechter uitmaakte dat hetgeen de werkgever deed voldoende was, omdat deze al door het niet voldoen aan het ambtelijk voorschrift gestraft zou moeten worden; zelfs ook al zou de rechter beslissen dat hetgeen door de werkgever was gedaan voldoende in overeenstemming was met het bepaalde bij wet of algemene maatregel van bestuur.

Dit systeem werd door Van Idsinga verworpen als zijnde in strijd met de algemene beginselen van de Grondwet.

De verschillende opmerkingen waren voor minister Talma reden om artikel 6 van het wetsvoorstel te wijzi$\operatorname{gen}^{42}$. Zo werd onder meer een vierde lid toegevoegd:

"De nadere voorschriften worden door het districtshoofd der arbeidsinspectie gegeven

krachtens den algemeenen maatregel van bestuur, uitgevaardigd ingevolge dit artikel".

Vervolgens wees de bewindsman erop, dat de rede van Van Idsinga voor een groot deel een interpretatie was van de rede van De Visser, zij het dat er éen belangrijk verschil was. De Visser had namelijk gesteld, dat het voorgestelde artikel strijdig was met artikel 56 van de Grondwet, terwijl Van Idsinga niet gesproken had van strijdig met de Grondwet maar van een systeem dat strijdig was met de algemene beginselen van de Grondwet.

Daarna vervolgde hij met de opmerking dat de juridische constructie van het wetsvoorstel zodanig was, dat 
in de algemene maatregel van bestuur een strafbepaling zou voorkomen door overtreding van artikel 6 van het wetswoorstel strafbaar was gesteld; het wetsvoorstel bevatte dus zowel de strafbepaling als de norm. Of deze constructie nu zo fraai was, was een punt waarover van mening kon worden verschild, maar, zo stelde minister Talma, daar het wetsvoorstel zowel de strafmaat als de norm aangaf ging het argument aangaande artikel 56 van de Grondwet niet op, daar dit Grondwetsartikel er alleen tegen waakte, dat in algemene maatregelen van bestuur zonder basis in een formele wet strafbepalingen werden opgenomen. Bovendien werd in het wetsvoorstell hetzelfde systeem gevolgd als in de Veiligheidswet. Dat wilde, aldus de bewindsman, niet zeggen, dat het voorliggende wetsvoorstel goed was, maar kon voor een aantal Kamerleden een aanwijzing inhouden, dat hier geen misdaad werd begaan, zoals verschillende Kamerleden wilden doen geloven.

In het wetsvoorstel, zo vervolgde de minister, werd gesproken van het door het districtshoofd en de arbeidsinspectie kunnen geven van "nadere voorschriften". Het sprak voor hem vanzelf, dat er door het woord "nader" een logisch verband was gelegd tussen de voorschriften bij algemene maatregel van bestuur en die gegeven door het districtshoofd. Van het systeem dat het kamerlid Van Idsinga voorstelde, liet de bewindsman niet veel over. Wanneer het door hem voorgestelde systeem in de wet zou staan, zou iedere werkgever er van uitgaan, dat hij strafrechtelijk gedekt is, wanneer hij een aanwijzing van het districtshoofd op zou volgen. Eén en ander zou er toe leiden, dat onmiddellijk het districtshoofd de werkgever aanwijzingen zou moeten geven over alle punten waarop de werkgever iets zou hebben te doen. Nog afgezien vam het feit, dat het te enen male onmogelijk was - vandaar dat het thans voorgestelde systeem gevolgd werd - waar zouden al die benodigde ambtenaren vandaan gehaald moeten worden, vroeg de bewindsman zich af. Die daaraan toevoegde, dat juist Van Idsinga in het verleden had geklaagd over de uitbreiding van het aantal ambtenaren, speciaal bij de arbeidsinspectie.

De bewindsman besloot zijn rede met de constatering, dat vanuit de Tweede Kamer tegen het wetsvoorstel geen praktische bezwaren naar voren waren gebracht, maar grondwettelijke en andere theorieën. Kortom: de oppositie tegen het wetsvoorstel berustte vooral op theoretische overwegingen, waarbij onvoldoende rekening werd gehouden met de eisen van de praktijk, waarmee bij wetten, als het voorgestelde, die diep in het bedrijfsleven ingrepen toch in de eerste plaats rekening gehouden diende te worden.

Daarna concentreerde de discussie ${ }^{43}$ zich rond een amendement van onder meer het Tweede Kamerlid De Savornin Lohman ${ }^{44}$, hetgeen beoogde de woorden:

"met inachtneming van de nadere voorschriften welke hem door het districtshoofd der arbeidsinspectie zijn gegeven"

in het eerste lid van artikel 6 van het wetsvoorstel te laten vervallen.

Het Tweede Kamerlid Janssen, die als lid van de commissie van rapporteurs, om een oordeel werd gevraagd over onder meer dit voorgestelde amendement, was daar kort over ${ }^{45}$ :

"Er mag worden aangenomen, dat in den loop der discussie niet duidelijk is angetoond de strijd van de bepalingen van artikel 6 met de letter en den geest van de Grondwet. Op zijn minst genomen is die strijd hoogst twijfelachtig. Wanneer men dit aanneemt - en men mag dit na de gehouden discussie doen - dan blijft ten slotte over de vraag, of het wenschelijk is te continueeren de practijk zooals die tot nog toe, o.a in de Veiligheidswet, is geweest, dan wel daarmede te breken en een stap terug te gaan.

De commissie meent, dat; waar de strijd met de bepalingen van de Grondwet door de voorstellers van het amendement niet is aangetoond, het voor de practijk beter is om de woorden in het artikel te handhaven, ten einde voorschriften in dezen zin door de arbeidsinspectie mogelijk te maken. Reeds hierom omdat daardoor, zooals terecht door den heer Drucker is gezegd, de werkgevers meer gebaat zullen zijn dan wanneer zij zich voor elk wissewasje aangaande de uitvoering van algemeene bestuursmaatregelen zouden moeten wenden tot den rechter in een strafgeding nog wel en waarvan de uitslag voor hen steeds onzeker is.

Daarom is de commissie van meening dat de practijk, zooals zij is en in de Arbeidswet en in de Veiligheidswet, moet gehandhaafd worden en ontraadt zij de aanneming van het 
amendement van den heer De Savornin Lohman c.s.".

Het amendement werd daarop verworpen ${ }^{46}$.

Tegen de door de regering aangebrachte wijziging had de commissie van rapporteurs geen bezwaar, waarop het voorgestelde artikel 6 zonder hoofdelijke stemming werd aangenomen ${ }^{47}$.

De discussie in de Eerste Kamer over de in het voorgestelde artikel 6 neergelegde subdelegatie zou geen nieuwe gezichtspunten naar voren brengen.

\section{Andere organen dan de arbeidsinspectie op het terrein van de arbeidsbeschermende wetgeving?}

Met betrekking tot plannen aan andere organen dan de arbeidsinspectie op het terrein van de arbeidsbeschermende wetgeving in te schakelen zou de minister van Landbouw, Nijverheid en Handel tot tweemaal toe schipbreuk leiden. Zo opperde hij het plan, binnen het kader van de wet, aan de Raden van Arbeid, bevoegdheden toe te kennen op het gebied van de arbeidsbescherming ${ }^{43}$. Het denkbeeld gaf uiting aan zijn streven om het georganiseerde bedrijfsleven bij de uitvoering van de wet te betrekken. Het eerder gememoreerde overleg met vertegenwoordigers van werkgevers en arbeidersorganisaties over allerlei zaken die de dienst arbeidsinspectie betreffen was daarvan een weerslag.

"Bij de uitbreiding der wettelijke arbeidsbescherming zal het gemis aan een organisatie van den arbeid eenerzijds leiden tot het maken van gebrekkige bepalingen, anderzijds tot klachten, tegelijk over belemmerende ambtenaarsbemoeiing en onvoldoende controle".

De Raden van Arbeid zouden echter alleen een witvoerende taak in het kader van de sociale verzekeringswetten krijgen ${ }^{49}$. De eerste nederlaag in dezen van minister Talma was hiermee een feit.

Scholtens ${ }^{50}$ zou hierover later opmerken, dat het territoriale karakter van de Raden van Arbeid in vele opzichten voor de sociale verzekering een voordeel, op het terrein van de arbeidsbescherming een nadeel zou zijn. Naarmate de arbeidswetgeving zich ontwikkelde, kon zij steeds minder in haar toepassing slechts districtsgewijs worden beschouwd. Door het volgen, in een bepaald district, van een streng beleid ten aanzien van met name de arbeidsduur, zou de nijverheid aldaar benadeeld worden bij concurrerende bedrijven in andere delen van het land, waardoor de centrale overheid toch weer veelvuldig zou hebben in te grijpen, hetzij via vernietiging of niet-goedkeuring hetzij door beslissingen in beroep. Bovendien zou de vereiste deskundigheid bij de Raad van Arbeid of zijn bestuur niet zijn gewaarborgd, omdat dit orgaan niet bedrijfstakgewijs was opgebouwd. De schrijver eindigde met de opmerking dat de arbeidsbescherming, in dit geval dus de arbeidsinspectie, als zij zich bewust is van haar taak, rekening zou hebben te houden met de bijzondere eisen van iedere bedrijfstak en dan over het gehele land.

Omtrent deze tijj leed minister Talma nog een tweede nederlaag ten aanzien van dezelfde gedachtengang. Aan een ontwerp-Bakkerswet ${ }^{51}$, waarvoor door de arbeidsinspectile voorbereidende werkzaamheden waren verricht $^{52}$, en waarin zondagsarbeid en nachtarbeid beperkt werden, zonder overigens een maximale arbeidsduur vast te leggen, zouden voor de nadere detaillering van onder meer de aanvangsuren, in een afzon-

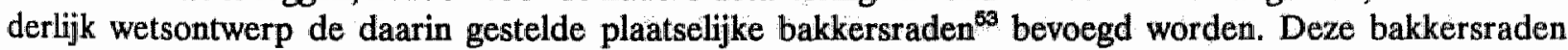
zouden zijn samengesteld uit een even aantal leden-patroon en een even aantal arbeiders; het voorzitterschap zou in handen zijn van (een ambtenaar van) de arbeidsinspectie. Beide ontwerpen zouden het niet halen; een gewijzigd ontwerp-Bakkerswet werd door de Tweede Kamer verworpen; het ontwerp over de bakkersraden werd ingetrokken ${ }^{54}$.

Vonden de ideeën van minister Talma in het parlement weinig weerklank, daarbuiten was dat iets anders gesteld. Zo zag Fokker ${ }^{55}$ de taak van de "bedrijvenraden" in de eerste plaats bestaan uit de toepassing en de uitwerking van de arbeidswetgeving. De wetgever diende alleen de algemene lijnen te trekken.

Deze hoofdlijnen zouden hun uitwerking vinden in, hetzij een algemene maatregel van bestuur, hetzij een verordening van de opperste arbeidsraad. Deze zouden op hun beurt worden uitgewerkt in bedrijfs- (of bedrijuen) verordeningen.

"Door de wetgevende macht wordt beslist, welke onderwerpen op het gebied van den ar- 
beid alsnog wettelijk geregeld zullen behooren te worden en in welke richting die zal moeten gaan; zij geeft als " $t$ ware een machtiging aan andere organen om de door haar noodig geachte regeling tot stand te brengen; zonder die machtiging kunnen die andere organen een regeling niet opzetten, de wetgever blijft de hoogste regelende macht in den Staat; maar hij onthoudt zich voortaan van een taak, welker behoorlijke vervulling hem gaandeweg onmogelijk is geworden, draagt die aan een andere over en spaart zijn krachten en zijn tijd voor het allerbelangrijkste en het beslissende".

Al eerder hadden de voorzitters van de Kamers van Arbeid ${ }^{58}$ in 1912 een motie van een soortgelijke strekking aangenomen. Huns inziens was bij een verdere uitbouw van de arbeidswetgeving decentralisatie gewenst in die zin, dat het geven van uitvoeringsvoorschriften en de vaststelling van uitvoeringsregelingen niet uitsluitend wordt toegekend aan ambtenaren, maar mede en in de eerste plaats aan vertegenwoordigers van werkgevers en van arbeiders, op wie die voorschriften en regelingen van toepassing zullen zijn. Zij stelden dan ook voor de reorganisatie van de Kamer van Arbeid zodanig te doen zijn, dat aan de nieuw te vormen colleges ook de bedoelde werkzaamheid ten aanzien van de arbeidswetgeving kon worden opgedragen, zij het dan onder nadere goedkeuring van de hogere autoriteit ${ }^{57}$.

Ondanks al deze ideeën bleef de arbeidsbescherming in handen van de overheid met als uitvoeringsorganisatie de arbeidsinspectie.

\section{Bijzondere opdrachten}

De reorganisatie heeft eveneens tot gevolg gehad, dat de directeur-generaal van de Arbeid jaarlijks een verslag over de werkzaamheden van de arbeidsinspectie moest uitbrengen. Deze Centrale Jaarverslagen der Arbeidsinspectie bevatten onder meer informatie over, wat aldaar genoemd wordt, bijzondere opdrachten. Deze geven een overzicht van het brede terrein dat de dienst bestrijkt. Hieronder zal - zonder uiteraard uitputtend te kunnen zijn - hiervan een beeld worden gegeven.

Sedert 1904 nam de medisch-adviseur via het geven van cursussen deel aan de bevordering van de nodige kennis van eerste hulp bij ongelukken ${ }^{58}$. Toen de taak van de medisch-adviseur om het toezicht op de vele cursussen behoorlijk uit te oefenen te omvangrijk werd, werd op 6 maart 1907 een Commissie tot het verlenen van Eerste Hulp bij Ongelukken ingesteld onder zijn voorzitterschap ${ }^{59}$. Deze commissie werd in 1910 ontbonden ${ }^{60}$, onder gelijktijdige instelling van een nieuwe commissie ${ }^{61}$ die de minister van Landbouw, Nijverheid en Handel diende te adviseren over het nemen van maatregelen ter bevordering van het onderwijs in eerste hulp bij ongelukken. De arbeidsinspectie was in deze commissie vertegenwoordigd door de directeur-generaal van de Arbeid (voorzitter) en de medisch-adviseur.

De organisatie van verbandcursussen werd in 1911 door de minister van Landbouw, Nijverheid en Handel zodanig geregeld dat vooraf de lijst van deelnemers moest worden vastgesteld in overleg met het bevoegde districtshoofd. Dit was noodzakelijk gebleken, omdat deze cursussen te vaak bezocht werden door personen die krachtens hun beroep betrekkelijk weinig in de gelegenheid zouden zijn het aldaar geleerde in praktijk te brengen.

Bovendien was in het belang van een goede gang van zaken bepaald, dat het onderwijs moest worden gegeven door een wettig bevoegd geneeskundige, daartoe aangewezen, nadat de medisch adviseur op de keuze zijn goedkeuring had verleend, terwijl deze laatste voorts met het toezicht op de cursussen belast was. Door deze regeling was dus aan de arbeidsinspectie een grote invloed op de organisatie van dit onderwijs toegekend ${ }^{\text {ge }}$.

In 1911 werd een Staatscommissie ingesteld ${ }^{63}$ met als taak om te adviseren over de vraag, welke maatregelen genomen zouden moeten worden om te bevorderen dat in de behoefte aan elektrische kracht, die in verschillende streken van het land en met name het platteland bestond op zo doeltreffende en zo economisch mogelijke wijze werd voorzien. De directeur-generaal van de Arbeid werd tot lid tevens voorzitter van deze 
Staatscommissie benoemd; de elektrotechnisch-ingenieur bij de arbeidsinspectie als lid ${ }^{84}$.

In hetzelfde jaar werd de directeur-generaal van de Arbeid benoemd tot lid van de Centrale Commissie voor de Statistiek ${ }^{\mathrm{BS}}$. De inspectrice van de arbeid mevr. E. Kleerekoper, die reeds enige jaren lid was, bleef zitting in deze commissie houden ${ }^{68}$.

Daarnaast was de directeur-generaal van de Arbeid tot buitengewoon lid van de Centrale Gezondheidsraad benoemd ${ }^{87}$. Door deze Raad en de directeur-generaal van de Arbeid werd een rapport, mede na onderzoek te dienaangaande door de medisch-adviseur en het bevoegde districtshoofd, samengesteld over het voorkomen van mijnworm in Limburg ${ }^{68}$.

Bij de directeur-generaal van de Arbeid berustte het lidmaat- tevens voorzitterschap van een bij beschikking ingestelde Commissie met als opdracht het voeren van onderhandelingen met de Koninklijke Maatschappij "De Schelde" te Vlissingen over het sluiten van een overeenkomst tussen de Staat der Nederlanden en de genoemde maatschappij tot vervanging van de overeenkomsten met betrekking tot de erfpacht van het voormalige marine-etablissement te Vlissingen en de overeenkomst tot exploitatie van de havens en haventerreinen aldaar ${ }^{199}$.

Voorts werd de directeur-generaal van de Arbeid benoemd tot lid van de Commissie van Toezicht van het Octrooi-gemachtigden-reglement ${ }^{70}$ en werd hij tezamen met de hoofdinspecteur van de arbeid S.R. Smit benoemd tot leden van het bestuur van de Stichting het Veiligheidsmuseum ${ }^{71}$.

De directeur-generaal van de Arbeid werd tevens door twee door de partijen benoemde arbiters tot "superarbiter" en voorzitter van de arbitragecommissie inzake de gerezen geschillen in de tabaks- en sigarenindustrie beneden de Moerdijk aangewezen. Deze commissie deed op 20 mei 1913 gemotiveerd uitspraak. Naar aanleiding van die beslissing werden later nog enige detailpunten aan de eindbeoordeling van de arbitragecommissie onderworpen. De controleur van de arbeid C. Foppele verrichtte ten behoeve van de commissie verschillende onderzoekingen ${ }^{72}$.

In de onderhavige periode had de overheid, in eerste instantie, de gemeenten vanaf rond de eeuwwisseling, grotere aandacht voor het werkloosheidsvraagstuk en deden de eerste overheidsbemoeiingen te dien aangaande intrede ${ }^{73}$. De centrale overheid hield zich vooralsnog afwezig, maar toen de economische crisis in 1907 - 1908 een omvangrijke werkloosheid veroorzaakte, stelde de toenmalige minister van Binnenlandse Zaken Heemskerk, dit naar aanleiding van een interpellatie van Troelstra in oktober $1908^{74}$, zich op het standpunt dat het rijk ten aanzien van de werkloosheid geen en de gemeenten nauwelijks een taak hadden ${ }^{75}$. Dit antwoord viel bij vele Kamerleden in slechte aarde. Hoewel een motie van Troelstra ${ }^{76}$, waarin de regering werd uitgenodigd de gemeentebesturen te ondersteunen om met of zonder medewerking van particulieren de nodige maatregelen tot bestrijding van de werkloosheid en haar gevolgen te nemen verworpen werd, werd een analoge motie-Treub ${ }^{7}$ aangenomen ${ }^{78}$. Als gevolg daarvan werd in $1909^{78}$ een Staatscommissie, onder voorzitterschap van laatstgenoemde, ingesteld waarvan de directeur-generaal van de Arbeid lid was en Is.P. Vooys, inspecteur van de arbeid, secretaris was ${ }^{80}$. Deze Staatscommissie had tot taak te onderzoe$\operatorname{ken}^{81}$ :

"a. in hoeverre de Regeering over de middelen beschikt om wel en voldoende ingelicht te worden over den stand van de binnenlandsche arbeidsgelegenheid en den omvang en den aard van werkloosheid in de verschillende vakken en welke aanvulling deze middelen behoeven;

b. wat de Regeering kan doen, hetzij door steun van personen of corporaties, hetzij zelfstandig, zoowel tot voorkoming of bestrijding van werkloosheid als tot leniging van de gevolgen daarvan".

Verslagen van deze Staatscommissie zouden in 1913 verschijnen, het eindverslag in $1914^{62}$. 
Tot slot van deze periode moet nog een andere taak van de directeur-generaal van de Arbeid nader beschouwd worden, namelijk het belast zijn met de zorg voor de samenstelling van verslagen, anders dan jaarverslagen, waarvan openbaarmaking gewenst werd geacht.

Ter openbaarmaking van de uitkomsten van verschillende enquêtes, hetzij verricht door ambtenaren van de arbeidsinspectie, hetzij verricht door speciale enqueteurs toegevoegd aan de directeur-generaal van de Arbeid $^{83}$, zijn in de betreffende periode onder meer de volgende rapporten en verslagen verschenen:

a. omtrent een onderzoek naar het leven der Polderjongens, hoofdzakelijk samengesteld uit gegevens door de tijdelijke enqueteur A.P. Staalman verzameld en aangevuld met hetgeen de directeur-generaal uit vroegere werkkring over het leven van deze categorie van arbeiders door jarenlange persoonlijke ervaring bekend was $^{84}$;

b. omtrent den Fabrieksarbeid der Gehuwde Vrouwen in Nederland. Tot het instellen van een dergelijk onderzoek was al in 1907 door de inspectrices van de arbeid aangedrongen. In 1908 en 1909 werd hieraan witvoering gegeven. Na het optreden van de directeur-generaal nam deze de leiding van het onderzoek in handen en werden de daarbij verzamelde gegevens onder zijn verantwoordelijkheid verwerkt ${ }^{85}$;

c. omtrent de Gedwongen Winkelnering in de Noord-brabantsche Schoenindustrie, in de Venen en in de Tabaksnijverheid en eenige andere bedrijfstakken. Deze verslagen bevatten de verwerking van gegevens door de tijdelijke enquêteur Staalman, bijgestaan door de controleur van de arbeid H.P. de Haas, verzameld, die opdracht had na te gaan in hoeverre de uitvoering van de Wet op de arbeidsovereenkomst ${ }^{86}$ enige invloed op het stelsel van de winkeldwang had uitgeoefend. Bij het eerste deel van dit onderzoek is een overzicht gevoegd van de evolutie, die de schoenindustrie in Noordbrabant voornamelijk in de laatste jaren heeft doorgemaakt, waarbij gebruik is gemaakt van enige historische gegevens die door N.W. Posthumus verzameld zijn in verband met het aan hem opgedragen onderzoek naar een deel van de huisindustrie in ons land. Het tweede deel heeft betrekking op de veenstreken van Drenthe, Groningen, Friesland, Overijssel, Noordholland, Noord-brabant, Limburg en Gelderland. Het derde en laatste deel betreft de gedwongen winkelnering in de tabaksindustrie, in de weefindustrie, bij de stroo- en hooibewerking, bij de boter- en margarinefabrikage, in de klompenindustrie en in de stoelenindustrie in Culemborg ${ }^{87}$;

d. Onderzoekingen naar de toestanden in de Nederlandsche huisindustrie. Het eerste deel bevat, naast inleidende hoofdstukken omtrent aanleiding en verloop van het onderzoek, definitie, oorsprong en hoofdvormen van de huisindustrie, gegevens over de aard en omvang van de huisindustrie in de bedrijven voor de bereiding of de verwerking van voedings- en genotmiddelen. Het tweede deel behandelt de huisnijverheid in diverse bedrijfstakken, zoals de diamantindustrie, het drukkersbedrijf, de schoenindustrie, goud-en zilversmeden en de houtverwerkende industrie. Het derde en laatste deel betreft de textiel-kleding en reinigingsindustrie $^{\text {se }}$;

e. Het onderzoek naar de in Nederland bestaande fondsen tot ondersteuning van arbeiders bij ziekte ${ }^{8 \theta}$;

f. De bestrijding van het gevaar voor loodvergiftiging in de Nederlandse diamantindustrie ${ }^{80}$;

g. De Looinijverheid in Nederland. Dit rapport; dat in hoofdzaak is samengesteld door de inspecteur van de arbeid H.J. Scholte, verschaft informatie over het voorkomen van miltvuurinfectie onder de leerlooiers. Deze monografie voor het leerlooiersbedrijf doet verder mededelingen over de ontwikkeling, omvang en betekenis van de leerlooierijen en hun verspreiding over Nederland. Voorts worden de verschillende looiprocessen beschreven, zoals die in het looiersbedrijf toegepast worden; worden gegevens verstrekt over de arbeidswoorwaarden, levensomstandigheden van de in het bedrijf werkende personen, de ongevallen in en de schadelijke invloeden van het looiersbedrijf aan de aan de looierij verwante bedrijven ${ }^{\text {et. }}$.

Sinds 1910 verscheen voorts ieder jaar een verslag verschenen over het uitgeoefend toezicht op de havenarbeid dat bijzonderheden bevatte over de arbeidstoestanden in de Nederlandse havens. Dit toezicht werd toen dit nog niet wettelijk geregeld was, geleid door de inspecteurs van de arbeid ${ }^{\text {e2 }}$. 
In 1910 verscheen een Adresboek van de Werkliedenorganisaties in Nederland ${ }^{93}$ en in 1913 een statistisch werk, namelijk De Fabrieken en Werkplaatsen vallende onder de Veiligheidswet, samengesteld uit het centrale kaartregister der Arbeidsinspectie in 1912 Bij het toen nog ontbreken van een bedrijfstelling in ons land gaf dit althans voor een groot deel van het bedrijfsleven een overzicht van de situatie ${ }^{\text {gu }}$. 
1. Zie nt. 78 van de Toelichtende staal Hfdst. X begroting Landbouw, Nijverheid en Handel.

2. Bij besluit van 3 juni 1911, no. 40, Stcrt. no. 134. Zijn standplaats was 's-Gravenhage.

3. Besluit van 2 oktober 1911, Stb. 309 ( in werking getreden op 1 november van dat jaar ). "Medisch adviseur bij de arbeidsinspectie" werd in artikel 1, onder c, van het Organisatiebesluit vervangen door "medisch adviseur of geneeskundige bij de arbeidsinspectie". De ambtskring van beiden besloeg het gehele rijk. Aan artikel 16 van het Organisatiebesluit werd tevens een tweede lid toegevoegd waarin bepaald werd, dat de medisch-adviseur bij de vervulling van zijn taak werd bijgestaan door de geneeskundige bij de arbeidsinspectie.

4. Zie Centraal Jaarverslag der Arbeidsinspectie over 1913, blz. 18.

5. Zie Th.C. Geudeker, in Gedenkboek 1909 - september - 1934, blz. 95.

6. Besluit van 18 april 1913 , Stb. 135 .

7. Aan artikel 1 van het Organisatiebesluit werd een onderdeel e toegevoegd, luidende: "scheikundig ingenieur bij de arbeidsinspectie", met als ambtskring het gehele Rijk. Verder werd aan artikel 9 van het Organisatiebesluit toegevoegd, dat de directeur-generaal van de arbeid in de vervulling van zijn ambt nu tevens werd bijgestaan door deze scheikundige ingenieur bij de arbeidsinspectie voor de behandeling van zaken, die met scheikundige onderzoekingen verband houden. Overigens werd voor het voornemen van deze benoeming voor de begroting voor het dienstjaar 1913 slechts volstaan met een eenvoudige vermelding ( zie nt. 89 van de Toelichtende staat Hfdst. X begroting Landbouw, Nijverheid en Handel. De enige opmerking is: "Voor benoeming van een adjunct-inspecteur tot scheikundige..... fl. 500,--" ).

8. N.C. Winkel, in Gedenkboek 50 jaar, blz. 29 - 30; Th.C. Geudeker, in Gedenkboek 1909 - 1 september - 1934, blz. 95.

9. Wet van 7 oktober 1911, Stb. 314; zie het Besluit van 20 oktober 1911, Stb. 319 ( de wet is op 1 januari 1912 in werking getreden - Besluit van 6 december 1911, Stb. 351 ).

10. Zie bijwoorbeeld Centraal Jaarverslag der Arbeidsinspectie over 1912, blz. 26 - 27.

11. Zie artike1 6, achtste lid, van de Arbeidswet 1911.

12. Aldus N.C. Winkel, in Gedenkboek 50 jaar, blz. 30. Zie Centraal Jaarverslag der Arbeidsinspectie over 1907 - 1908, blz. $55 \mathrm{t} / \mathrm{m}$ 57; zie ook Tweede Kamer, zitting 1909 - 1910, 257.3 (memorie van toelichting ) blz. $12-13$.

13. Van "medebewind" is sprake als de medewerking aan de uitvoering van hogere regelingen gevorderd wordt van bijvoorbeeld provinciale en gemeentelijke besturen; zie onder meer T. Koopmans, Compendium van het staatsrecht, Deventer 1972, blz. 156.

14. M.G. Levenbach, Arbeid, in Nederlands bestuursrecht, blz. 448. 
15. Zie A.L. Scholtens, in Staatsrechtelijke opstellen, blz, $146 \mathrm{t} / \mathrm{m}$ 148. De schrijver voegt toe, dat zijns inziens de toekomstige ontwikkeling niet in de richting van de gemeentelijke bemoeiing liggen. De medebewindvariant was in het kader van de arbeidsbescherming weer een rol toebedeeld in de zogenaamde heroverwegingsoperatie.

16. Bijlagen Tweede Kamer, zitting 1910 - 1911, 297.1 ( geleidende brief) en 297.2 (wetsvoorstel ). Het initiatief-wetsvoorstel was medeondertekend door Duys, Helsdingen, Hugenholtz, Ter Laan, Troelstra en Vliegen.

17. De motie luidde:

"De Kamer, van oordeel, dat naast de grootst mogelijke beperking van den nachtarbeid en betere bescherming van kinderen en jeugdige personen, de beperking van den arbeidsduur voor alle volwassen arbeiders en wel tot 10 uur per etmaal gewenscht is, gaat over tot de orde van den dag."

( zie Hand. Tweede Kamer, zitting 1906 - 1907 II, blz. 1380 ). Na wijziging door Schaper luidde de motie:

"De Kamer, van oordeel, dat naast de grootst mogelijke wettelijke beperking van dem nachtarbeid en betere bescherming van kinderen en jeugdige personen, de wettelijke beperking van den arbeidsduur voor alle volwassen arbeiders en wel tot 10 uur per etmaal gewenscht is".

( zie Hand. Tweede Kamer, zitting 1906 - 1907 II, blz. 1380 - 1381; de motie werd ondersteund door Duymaer van Twist, Aalberse, Van Kol, Van de Velde, Ketelaar, Ter Laan en Treub ).

18. Zie voor de behandeling van de motie-Schaper Hand. Tweede Kamer, zitting 1908 - 1909 II, blz. 1705 t/m 1785. De motie werd met 49 tegen 28 stemmen verworpen ( zie Hand. Tweede Kamer, zitting 1908 1909 II, blz. 1785 ).

19. Deze motie luidde:

"De Kamer, van oordeel, dat behoudens dringende noodzakelijke uitzonderingen en overgangsbepalingen, de wettelijke beperking van den arbeidsduur voor de volwassen arbeiders, en wel tot tien uur per etmaal gewenscht is, gaat over tot de orde van de dag."

( zie Hand. Tweede Kamer, zitting 1908 - 1909 II, blz. 1773 ).

20. Deze motie werd aangenomen met 53 tegen 25 stemmen ( zie Hand. Tweede Kamer, zitting 1908 - 1909 II, blz. 1785 ).

21. Zie Bijlagen Tweede Kamer, zitting 1910 - 1911, 297.3 (memorie van toelichting ) blz. 12 - 13.

22. Bijlagen Tweede Kamer, zitting 1910 - 1911, 297.3 ( memorie van toelichting ) blz. 13.

23. Zie de artikelen 33,34 en 35 van het ontwerp-Schaper.

24. De artikelen $11 \mathrm{t} / \mathrm{m} 15$ van het Besluit van 10 augustus 1909, Stb. 289.

25. Bijlagen Tweede Kamer, zitting 1910 - 1911, 297.3 (memorie van toelichting ) blz. 26.

26. Bijlagen Tweede Kamer, zitting 1915 - 1916, 71.1 ( voorlopig verslag ) blz. 11.

27. Bijlagen Tweede Kamer, zitting 1917 - 1918, 68.1 ( memorie van antwoord) blz. 15. 
28. Zie onder meer Verslagen der Inspecteurs van den Arbeid over 1903 en 1904, blz. 120 t/m 126; S. Elias, Iets over steenhouwers en hun vak, Rotterdam 1909; L. Heyermans; Handleiding tot de kennis der beroepsziekten, Rotterdam 1908; Steenhouwersarbeid en steenhouwersziekte, Rapport van een commissie bestaande uit afgevaardigden van de Vereeniging van Delftsche ingenieurs, de Maatschappij tot bevordering der bouwkunst, het Genootschap "Architectuur et Amilcitia", de vakafdeeling voor bouw- en waterbouwkunde van het Koninklijk Instituut voor ingenieurs en de Sociaal-technische Vereeniging van demokratische ingenieurs en architecten, Rotterdam 1910.

29. Tweede Kamer, zitting $1909-1910,263.3$ (memorie van toelichting) blz. 2.

30. Wet van 7 oktober 1911, houdende bepalingen tot beveiliging van werklieden bij steenhouwersarbeid, Stb. 315 (in werking getreden op 1 maart 1913). Deze wet is aanmerkelijk gewijzigd bij de Wet van 11 november 1921, Stb. 1167, en heet vanaf dat moment de Steenhouwerswet 1921. Literatuur over deze wet onder meer: C. Broerse jr., De Steenhouwerswet. Het Steenhouwersbesluit, Zutphen 1916; A.N. Molenaar, t.a.p. II B, blz. $1317 \mathrm{t} / \mathrm{m} 1325$.

31. N.C. Winkel, in Gedenkboek 50 jaar, blz. 31 .

32. Bijlagen Tweede Kamer, zitting 1909 - 1910, 263.2.

33. Bijlagen Tweede Kamer, zitting 1909 - 1910, 263.4 (voorlopig verslag ) blz. 12.

34. Bijlagen Tweede Kamer, zitting 1909 - 1910, 263.3 ( memorie van toelichting) blz. 8 .

35. Bijlagen Tweede Kamer, zitting 1910 - 1911, 40.2 ( nota van wijziging).

36. Bijlagen Tweede Kamer, zitting 1910 - 1911, 40.1 ( memorie van antwoord) blz. 17.

37. Hand. Tweede Kamer, zitting $1910-1911$, blz. 2139.

38. Hand. Tweede Kamer, zitting 1910 - 1911, blz. 2141.

39. Besluit van 7 december 1896, Stb. 215 .

40. HR 6 juni 1904 , W.8077.

41. Hand. Tweede Kamer, zitting 1910 - 1911, blz. 2145.

42. Hand. Tweede Kamer, zitting $1910-1911$, blz. $2146 \mathrm{t} / \mathrm{m} 2153$.

43. Hieraan namen onder meer deel: de Kamerleden Tydeman ( Hand. Tweede Kamer, zitting 1910 - 1911, blz. 2159 - 2160), Drucker (Hand. Tweede Kamer, zitting 1910 - 1911, blz. 2161 - 2162), De Savornin Lohman ( Hand. Tweede Kamer, zitting 1910 - 1911, blz. $2156 \mathrm{t} / \mathrm{m}$ 2158, blz. $2163 \mathrm{t} / \mathrm{m} 2164$ ) en minister Talma ( Hand. Tweede Kamer, zitting 1910-1911, blz. 2162 - 2163).

44. Mede ingediend namens de Tweede Kamerleden Van Idsinga, De Beaufort, Van Karnebeek, De Visser, Van Doorn, De Dam, Van Best, De Stues en Van Wassenaar van Catwrijck; Hand. Tweede Kamer, zitting 1910 - 1911, blz. 2158. 
45. Hand. Tweede Kamer, zitting $1910-1911$, blz, 2165 .

46. Met 51 tegen 14 stemmen; Hand. Tweede Kamer, zitting $1910-1911$, blz 2165 .

47. Hand. Tweede Kamer, zitting $1910-1911$, blz. 2166; alle overige amendementen op artikel 6 werden eveneens verworpen.

48. Zie Bilagen Tweede Kamer, zitting $1909-1910,302$ ( hel zgn. onwerp-Radenwet).

49. Zie onder meer A.N. Molenaar, ta.p. I, blz. $714 \mathrm{v} / \mathrm{m}$ 725; B. Böger, ta.p., blz. 80 - 81; M.G. Levenbach, Historische overzicht van de sociale-verzekeringswetgeving, in Nederlands bestuursrecht, blz. 545; A.L. Scholtens, in Staatsrechtelijke opstellen, blz. 148.

50. A.L. Scholtens, in Staatsrechtelijke opstellen, blz. 149.

51. Zie Bijlagen Tweede Kamer, zitting 1908 - 1909, 296 en Bijlagen Tweede Kamer, zitting 1909 - $1910,59$.

52. Zie CJ.Ph. Zaalberg, Voordracht over zijn ervaringen bij de arbeidsinspectie, in Rotary Holland 1932 blz. 532 en onderzoek naar de bedrijfstoestanden in de Nederlandsche broodbakkerijen, "s-Gravenhage 1911, ingevolge een daartoe verstrekte opdracht van de minister van Landbouw, Nijverheid en Handel door de arbeidsinspectie uitgevoerd met het oog op het eventueel ontwerpen van bepalingen omtrent de arbeidstijd van bakkersgezellen. Zie ook Centraal Jaarversiag der Arbelidsinspectie over 1911, 's-Gravenhage 1912, blz. $227 \mathrm{~lm} 297$.

53. Zie Bylagen Tweede Kamer, zitting 1909 - 1910, 132. Zie hierover D. Bos, De Bakkerswet, in Vragen des Tyds 1913, blz. $335 \mathrm{vm}$ 368; R. Kranenburg, Decentralisatie van wetgeving en de arbeidsraden, in Vragen des Tijds 19171 , blz. $125 \mathrm{tm} 135$.

54. Zie A.N. Molenaar, t.a.p. L, blz.725 v/m 734; M.G. Levenbach, Arbeid, in Nederlands bestuursrecht, blz. 447 - 448 .

55. E. Fokker, Hand. van de Nederlandsche Juristenvereeniging 1917, blz 199 - 200; zie A.N. Molenaar, t.a.p. I, bl2. $733-734$.

56. Deze Kamers zijn ingestelld bij de Wet van 2 mei 1897, Stb. 141. Krachtens deze wet konden plaatselijk voor ến of meer bedrijfstakken bij Koninklijk besluit Kamers van Arbeid worden opgericht, bestaande uit een gelijk aantal werkgevers en arbeiders in de desbetreffende bedrijfistak, die op kiezerslijsten geplaatst waren. Een vertegenwoordiger van éen van de beide groepen nam het voorzitterschap waar (bij toerbeurt). De Kamers van Arbeid hadden ten doel "de belangen van patroons en werklieden in onderlinge samenwerking te bevorderen" door het verzamelen van inlichtingen over arbeidsaangelegenheden, het dienen van advies aan autoriteiten en belanghebbenden en het voorkomen en vereffenen van geschillen over arbeidsaangelegenheden, ook, woor zover nodig door te bewerkstelligen, dat een scheidsrechterlijke uitspraak tussen de partijen tot stand komt., Deze Kamers van Arbeid zijn bij de Wet van 24 november 1923, Stb. 626 ( de Arbeidsgeschillenwet 1923 ) afgeschaft. Zie M.G. Levenbach, Arbeid, in Nederlands bestuursrecht, blz. 443.

Zie over de Kamers van Arbeid onder meer: J.G. Schlingemann, Het voorkomen en beslechten van arbeidsgeschillen, 's-Gravenhage 1933, blz. $62 \mathrm{t} / \mathrm{m}$ 69; H. Pyttersen, Beknopte handleiding bij de wet op de Kamers van Arbeid, Sneek 1897; C. Beekenkamp, Bedrijfsorganisatie van antirevolutionair standpunt beschouwd, Kampen 1932, blz. $73 \mathrm{t} / \mathrm{m} 83$. 
Zie over de Arbeidsgeschillenwet onder meer: J.G. Schlingemann, t.a.p., blz. 70 t/m 77; A.C. Josephus Jitta, De practijk der Arbeidsgeschillenwot, 's-Gravenhage 1929; M.B. Vos, Arbeidsgeschillenwet 1923, Alphen a/d Rijn 1924; B. Bölger, t.a.p., blz. 156 t/m 163.

57. Zie A.N. Molenaar, t.a.p. I, blz. 233 - 234 nt. 2.

58. Eén en ander met behulp van rijkssubsidie en met medewerking van onder meer het Roode Kruis, het Witte Kruis, het Groene Kruis, de Vereeniging voor het verleenen van eerste hulp bij ongelukken, de Maatschappij van Nijverheid, de Maatschappij tot Nut van het Algemeen en gemeentebesturen; zie Centraal Jaarverslag der Arbeidsinspectie over 1907 - 1908, 's-Gravenhage 1909, blz. 14.

59. Deze commissie bestond naast de medisch-adviseur nog uit acht leden, wier woonplaatsen over het gehele land verspreid waren; zie Centraal Jaarverslag der Arbeidsinspectie over 1907 - 1908, blz. 14.

60. Bij Besluit van 10 december 1910, no. 52; zie Centraal Jaarverslag der Arbeidsinspectie over 1910, blz. 13.

61. Bij Besluit van 10 december 1910, no. 13; zie Centraal Jaarverslag der Arbeidsinspectie over 1911, blz. 23.

62. Zie Centraal Jaarverslag der Arbeidsinspectie over 1907 - 1908, blz. 14; over 1910, blz. 13 - 14 en over 1911, blz. 23.

63. Bij Besluit van 14 juli 1911; zie Centraal Jaarverslag der Arbeidsinspectie over 1911, blz. 23.

64. Centraal Jaarverslag der Arbeidsinspectie over 1911, blz. 23.

65. Bij K.b. van 8 juli 1911, no. 53; zie Centraal Jaarverslag der Arbeidsinspectie over 1911, blz. 23. Deze commissie is ingesteld bij K.b. van 6 oktober 1892, Stb. 232; zie over deze commissie onder meer Gedenkboek uitgegeven ter gelegenheid van het vijfentwintig jarig bestaan der Centrale Commissie voor de Statistiek 1892 - 1917, 's-Gravenhage 1917.

66. Zie Centraal Jaarverslag der Arbeidsinspectie over 1910, blz. 14 en over 1911, blz. 23.

67. Bij Besluit van 25 mei 1909, no. 7; zie Centraal Jaarverslag der Arbeidsinspectie over 1909, 's-Gravenhage' 1910, blz. 31 .

68. Centraal Jaarverslag der Arbeidsinspectie over 1907 - 1908, blz. 14 en over 1910, blz. 13; Zie het Verslag over het voorkomen van den Mijnworm boven den grond in Limburg ( samengesteld door den Centralen Gezondheidsraad en den Directeur-Generaal van den Arbeid ), 's-Gravenhage 1910.

69. Centraal Jaarverlag der Arbeidsinspectie over 1911, blz. 23 en over 1912, blz. 18.

70. Zie artikel 8 van het Reglement betreffende het optreden als gemachtigde voor den Octrooiraad (Besluit van 18 maart 1912, Stb. 106 ); zie Centraal Jaarverslag der Arbeidsinspectie over 1912, blz. 19 en over 1913, blz. 18. 
71. Bij beschikking van 30 januari 1913, no. 252 , afd. Arbeid, krachtens artikel 3 van het Algemeen Reglement der Stichting het Veiligheidsmuseum (Museum van voorwerpen ter voorkoming van Ongelukken en Ziekten in Fabrieken en werkplaatsen ); zie Centraal Jaarverslag der Arbeidsinspectie over 1913, 's-Gravenhage 1914, blz. 18.

72. Centraal Jaarverslag der Arbeidsinspectie over 1913, blz. 18.

73. Zie M.G. Levenbach, Arbeid, in Nederlands bestuursrecht, blz. 449.

74. Hand. Tweede Kamer, zitting 1908 - 1909 II, blz. 75 t/m 166 .

75. Zie Hand. Tweede Kamer, zitting 1908 - 1909 II, blz. 166.

76. Zie Hand. Tweede Kamer, zitting 1908 - 1909 II, blz. 153.

77. Zie Hand. Tweede Kamer, zitting 1908 - 1909 II, blz. 162.

78. Zie M.G. Levenbach, Arbeid, in Nederlands bestuursrecht, blz. 449.

79. Zie Besluit 30 juli 1909, no. 42; zie Centraal Jaarverslag der Arbeidsinspectie over 1909, blz. 31 en Algemeene Inleiding tot de Verslagen der Staatscommissie over de Werkloosheid betreffende Aard en Omvang der Werkloosheid in de verschillende bedrijfstakken, benevens omtrent de stand der middelen tot bestrijding der werkloosheid of ter leniging harer gevolgen, 's-Gravenhage 1913, blz. 1.

80. Centraal Jaarverslag der Arbeidsinspectie over 1909, blz. 31; Staatscommissie over de werkloosheid, Algemeene Inleiding, blz. 2.

81. Zie Centraal Jaarverslag der Arbeidsinspectie over 1909, blz. 31; Staatscommissie over de werkloosheid, Algemeene Inleiding, blz. $1 \mathrm{t} / \mathrm{m} 3$.

82. Staatscommissie over de Werkloosheid, Eindverslag, 's-Gravenhage 1914.

83. Dit kon op grond van artikel 9 van het Besluit van 10 augustus 1909, Stb. 289.

84. Verslag omtrent een onderzoek naar het leven der polderjongens (met 1 kaart ), 's-Gravenhage 1911 ( uitgave Directie van den Arbeid no. 3 ). Een polderjongen is een werkman bij het aanleggen en onderhouden van polders, een dijkwerker.

85. Onderzoek naar den fabrieksarbeid van gehuwde vrouwen in Nederland (met 1 kaart), 's-Gravenhge 1911 ( uitgave Directie van den Arbeid no. 4 ).

86. Zie voor het tegengaan van gedwongen winkelnering de artikelen $1637 \mathrm{p}$ en $1637 \mathrm{~s}$ van het B.W.. H.L. Bakels, Macht en onmacht in het privaatrecht, Deventer/Antwerpen 1965, blz. 7, vraagt zich terzake hiervan het volgende af:

"Is bijvoorbeeld het verdwijnen van het truckstelsel- waaronder men verstaat bepaalde afspraken om het loon niet in geld doch in natura te betalen - alsmede het verdwijnen van de gedwongen winkelnering, niet eerder te wijten aan de gewijzigde maatschappelijke opvattingen en machtsverhoudingen dan aan de privaatrechtelijke verbodsregels van de artikel 1637p en s B.W.?". 
De resultaten van het door De Haas uitgevoerde onderzoek naar de gedwongen winkelnering geeft hem hierin gelijk.

87. Gedwongen winkelnering in de Noordbrabantsche schoenenindustrie (met 1 kaart), 's-Gravenhage 1911 ( uitgave Directie van de Arbeid no. 6); De gedwongen winkelnering in de venen, 's-Gravenhage 1913 ( uitgave Directie van den Arbeid no. 12 ); Gedwongen winkelnering in de tabaksnijverheid en eenige andere bedrijfstakken, 's-Gravenhage 1914 ( uiltgave Directie van den Arbeid no. 16). Zie ook: Gedwongen winkelnering in onderscheidene bedrijfstakken in verschillende deelen des lands, (overzicht van het geheele onderzoek ) met 1 kaart, 'sGravenhage 1917 ( uitgave Directie van den Arbeid no. 23 ).

88. Onderzoekingen naar de toestanden in de Nederlandsche huisindustrie, Deel I voedings- en genotmiddelen, "s-Gravenhage 1911 ( uitgave Directie van den Arbeid no. 7a ); Deel II Diamantbewerking. -Drukkersbedrijf. -Chemische industrie. -Hout- en stroobewerking. -Metaalbewerking. -Papierbewerking. -Schoenmakers, 's-Gravenhage 1912 ( uitgave Directie van den Arbeid no. 7b ); Deel III Textielindustrie -Kleeding en Reiniging. 's-Gravenhage 1914 ( uitgave Directie van den Arbeid no. 7c ).

89. Onderzoek naar de in Nederland bestaande fondsen tot ondersteuning van arbeiders bij ziekte, 's-Gravenhage" 1912 ( uitgave Directie van den Arbeid no. 8).

90. De bestrijding van het gevaar voor loodvergiftiging in de Nederlandsche diamantindustrie, "s-Gravenhage 1912 (uitgave Directie van den Arbeid no. 9 ).

91. De looinijverheid in Nederland, 's-Gravenhage 1913 ( uitgave Directie van den Arbeid no. 13 ).

92. Zie H.A. van IJsselstein, in Vijf en twintig jaren Arbeidsinspectie $1890-1915$, blz. XX. Dit toezicht - de inspectie van de havenarbeid - werd ingesteld bij de Stuwadoorswet, Stb. 1914486.

93. Adresboek van de Werklieden-organisaties in Nederland, 's-Gravenhage 1910 ( uitgave Directie van den Arbeid no. 1 ). Zie ook Adresboek van de Werklieden- en Ambtenarenorganisaties in Nederland in 1920, "s-Gravenhage 1920 ( uitgave Directie van den Arbeid no. 25 ).

94. De Fabrieken en Werkplaatsen vallende onder de Veiligheidswet ( samengesteld uit het Centrale kaartregister der Arbeidsinspectie in 1912 ) met verschillende kaarten en grafische voorstellingen, 's-Gravenhage 1913 ( uitgave Directie van den Arbeid no. 11 ). Zie ook C.J.P. Zaalberg, Arbeidersbescherming; Berechting van overtredingen der Arbeidswetten; de Arbeidsinspectie en haar werk, in Sociaal Jaarboek voor Nederland, Leiden 1918 I, blz. 108. 


\section{Hoofdstuk 6 \\ DE EERSTE WERELDOORLOG}

\section{Inleiding}

Hoewel in de voorafgaande periode een toenemende spanning tussen de grote Europese mogendheden viel waar te nemen, waarbij een aantal malen een oorlog nabij leek, zou het uitbreken van de vijandelijkheden in juli in begin augustus $1914^{1}$ leiden tot de Eerste Wereldoorlog. Ondanks het feit, dat de Nederlandse regering het beginsel van volstrekte neutraliteit ${ }^{2}$ huldigde, leek de Duise inval in Belgiè ons land niet woor een directe betrokkenheid te vrijwaren. Als gevolg daarvan werd het leger gemobiliseerd. Dit plotseling onder de wapenen roepen van vele arbeiders ontwrichtte niet alleen de arbeidsmarkt maar het gehele economische leven. Bovendien stagneerde de uitvoer wat een grote werkloosheid teweeg bracht ${ }^{3}$. Eén en ander leidde ertoe, dat een verdergaande overheidsbemoeienis met het economische leven dan tot op dat moment het geval was, noodzakelijk werd geacht, hetgeen ook voor de arbeidsinspectie gevolgen zou hebben. Zo werden vele van haar ambtsbezigheden, die bijvoorbeeld niet uit de mobilisatie en de daarmee samenhangende problemen voortkwamen, uitgesteld ${ }^{4}$. De nieuwe aan haar toebedeelde taken waren erop gericht om te proberen het toch al verstoorde economische leven voor nog meer nadelen te behoeden en de als gevolg daarvan ontstane economische nood te lenigen.

\section{De arbeidsbeschermende wetgeving en het verleggen van de prioriteiten}

De uitzonderlijke situatie maakte, dat het van de zijde van de arbeidsinspectie te houden toezicht op de naleving van de bepalingen van de Arbeidswet 1911, de Veiligheidswet en de Steenhouwerswet 1911, hetgeen in normale tijden tot haar werkterrein behoorde, voor een belangrijk deel niet alleen ongewenst maar ook misplaatst was. Zo leidde de mobilisatie waardoor op grote schaal arbeidskrachten aan de bedrijven werden onttrokken in zeer veel gevallen tot grote moeilijkheden. De in het geding zijnde belangen aangaande de voortgang van de produktie in de bedrijven werden geacht ruimschoots op te wegen tegen het veronachtzamen van de arbeidswettelijke bepalingen. Ten aanzien van bedrijven, die met grote spoed hadden te voorzien in de behoeften van leger en vloot, werd ook door de arbeidsinspectie voorrang gegeven aan de defensiebelangen ${ }^{5}$.

Een zelfde beeld was te zien ten aanzien van het toezicht van bepalingen van de Veiligheidswet. Hêt aanbrengen van veranderingen in fabrieken en werkplaatsen had gedurende het eerste halfjaar van de mobilisatie geen prioriteit, niet alleen vanwege het onzekere toekomstbeeld, maar tevens vanwege het gegeven, dat zeer veel bedrijven werden geconfronteerd met een direct merkbare achteruitgang of een volledige produktiestilstand. Dit, terwijl juist op 1 juli 1914 het nieuwe Veiligheidsbesluit ${ }^{8}$ in werking was getreden en er niet alleen al voorbereidende maatregelen waren getroffen maar tevens een begin was gemaakt met een toetsing aan de bepalingen van dit nieuwe Besluit van de fabrieken en werkplaatsen die onder de werkingssfeer van deze wet vielen. De vele aanvragen om ontheffing voor bestaande fabrieken en werkplaatsen waren toen nog maar net in behandeling genomen. De oorlogshandelingen deden de afhandeling hiervan stagneren, nog afgezien van het feit, dat als gevolg van de nieuwe situatie aan de ontheffingen nauwelijks enige termijnen konden worden gesteld ${ }^{7}$. De bepalingen van de Steenhouwerswet 1911 vereisten bijna geen toezicht van de zijde van de arbeidsinspectie. Bij het uitbreken van de oorlog trad er namelijk onmiddellijk een stagnatie op in het bouwbedrijf, zodat de meeste steenhouwerijen meestal niet voldoende werk voor handen hadden om de arbeiders nog enigszins aan het werk te houden. Onder die omstandigheden was het misplaatst deze zwaargetroffen bedrijven te dwingen de eerder vastgestelde tijdstippen na te komen waarop verbeteringen moesten zijn aangebracht, waarvoor in verband met de invoering van de wet in 1913 uitstel was verleend.

De bemoeienis van de dienst arbeidsinspectie met de Hinderwet daalde aanmerkelijk, daar het aantal aan- 
vragen tot oprichting of uitbreiding van industriële inrichtingen ver achter bleef bij dat aantal onder normale omstandigheden ${ }^{2}$.

Vanaf 1915 zou de handhaving van de arbeidsbeschermende wetgeving weer min of meer ter hand worden genomen ${ }^{\theta}$.

\section{Arbeidsbemiddeling}

De ontwrichte arbeidsmarkt had tot gevolg dat één van de eerste nieuwe activiteiten van de dienst arbeidsinspectie lag op het terrein van de arbeidsbemiddeling.

Arbeidsbemiddeling was in het begin van deze eeuw door de gemeenten ter hand genomen toen bleek dat particuliere organisaties niet voldoende in de toenemende behoefte aan de hulp bij het zoeken van arbeidskrachten en arbeidsgelegenheid konden voorzien. Langs de weg van vrijwillige samenwerking en onder leiding van de Vereeniging van Nederlandsche Arbeidsbeurzen ${ }^{10}$, waarvan de statuten in augustus 1908 , dus bijna een jaar voor het instellen van de Staatscommissie over de Werkloosheid ${ }^{11}$, was er een nationaal verband gecreëerd, in het bijzonder voor het "bevorderen van samenwerking door onderlinge mededeeling van de bij arbeidsbeurzen ingekomen aanvragen", de intercommunale arbeidsbemiddeling. Al twee maanden na het verschijnen van het eindverslag van de zojuist bedoelde staatscommissie ${ }^{12}$, gingen haar wensen, althans wat betreft de organisatie van de arbeidsbemiddeling in vervulling. Door de ontstane situatie werd de Vereeniging van Nederlandsche Arbeidsbeurzen, voor wie de Haagse Arbeidsbeurs als centrale arbeidsbeurs fungeert, voor een taak gesteld waarop zij niet berekend was. Daarop richtte zij een verzoek aan de directeur-generaal van de Arbeid opdat deze een tijdelijke centralle voor arbeidsbemiddeling zou vormen tot wie de verschillende arbeidsbeurzen zich zouden kunnen wenden. Deze gaf aan dit verzoek gehoor en richtte een schrijven met instructies aan de districtshoofden ${ }^{13}$.

Veel effect heeft dit verder echter niet gehad, omdat al op 3 oktober daaropvolgende de tijdelijke Centrale Arbeidsbeurs tot Rijksinstelling werd verheven; de werkzaamheden daarvan zouden weldra een omvangrijk arbeidsveld beslaan die overigens verder buiten het werkterrein van de dienst arbeidsinspectie vielen ${ }^{14}$.

\section{Het Koninklijk Nationaal Steuncomité}

Van langduriger en meer omvattende aard waren de bemoeienissen die voor de dienst arbeidsinspectie voortvloeiden uit de activiteiten van het Koninklijk Nationaal Steuncomité. Dit Comité, dat tot stand kwam op initiatief van Koningin Wilhelmina, had tot taak activiteiten van in verschillende plaatsen van ons land in de eerste dagen van augustus 1914 spontaan ontstane steuncomite's ter voorkoming en leniging van nood in geregelde banen te leiden. Daardoor kon een grotere en nuttigere uitwerking van de hulp en steun verwacht worden.

De constituerende vergadering was door de Koningith op 10 augustus 1914 bijeengeroepen. De Koningin sprak bij deze gelegenheid vertegenwoordigers van de uitgenodigde organisaties, waaronder de vakbeweging, toe, hetgeen volgens Levenbach deze organisaties officieel hun plaats in het maatschappelijk bestel gaf ${ }^{15}$. Het algemeen secretariaat werd opgedragen aan de directeur-generaal van de Arbeid. In zijn antwoord zei de minister van Landbouw, Nijverheid en Handel Treub over deze regeling het volgende ${ }^{16}$ :

"Op mijn verzoek heeft de Directeur-Generaal van den Arbeid zich bereid verklaard, de leiding van het algemeen secretariaat van het comité op zich te nemen. Dit heeft het voordeel, dat daarmede ook de over het geheele land vertakte, met de industrie in nauwe aanraking staande Arbeidsinspectie, aan welke die stoornissen in bedoelde bedrijven niet kunnen ontgaan, voor het werk van het comité ter beschikking staat."

Na de constituerende vergadering werd in een direct daaropvolgende vergadering besloten dat de verdere voorbereiding en de uitvoering van hetgeen zou hebben te gebeuren over te laten aan de te benoemen Uitvoerende Commissie ${ }^{17}$. Overeenkomstig het door minister Treub gedane voorstel werd de directeur-generaal 
neraal van de Arbeid Van IJsselsteyn aangewezen alls algemeen secretaris ${ }^{18}$.

Over deze keuze schrijft Treub het volgende ${ }^{i g}$.

"De opdracht van het secretariaat aan den Directeur-Generaal van den Arbeid is een gelukkige greep geweest.

Niet alleen omdat de heer Van Usselsteyn alles wat hij op zich neemt met groote toewijding volvoert, maar bovendien bleek de bedoeling, dat op die wijze het Steuncomite door de organisatie van den dienst der arbeidsinspectie, van den stand der arbeidsmarkt voortdurend op de hoogte zou zijn, geheel tot haar recht te komen. De combinatie van het secretariaat van het Kon. Nationaal Steuncomité met den dienst der arbeidsinspectie heeft zeer veel er toe bijgedragen om het werk van het comite aan de daarvan gekoesterde verwachting te doen beantwoorden. Vooral ook ter controlering van sommige plaatselijke comite's, die de zaak wat gemoedelijk opnamen en niet voldoende doordrongen waren van de nadeelen van het geven zonder goede contrôle of hetgeen men gaf, well goed besteed was, is de medewerking van den dienst der arbeidsinspectie en in de eerste plaats van den algemeen secretaris zelf niet slechts zeer nuttig, maar onmisbaar gebleken."

Waar bestond de bijdrage van de arbeidsinspectie dan zoal uit? $\mathrm{Al}$ snel na de totstandkoming van het $\mathrm{Ko}$ ninklijk Nationaal Steuncomité werd een afzonderlijke commissie ter behartiging van de economische belangen van nijverheid en landbouw, kortheidshalve de commissie voor economische belangen ${ }^{20}$ gevormd, met als taakstelling het op gang houden van de nijverheid, land- en tuinbouw en wel speciaal de voortbrenging van levensmiddelen ${ }^{21}$.

Deze commissie heeft in de eerste oorlogsmaanden steun en voorlichting van de arbeidsinspectie gekregen. Dit laatste met name wat betreft de toestanden der bedrijven; aan 3600 meer belangrijke industriëlen werden vragenlijsten gezonden teneinde inzicht te verkrijgen omtrent de vragen in hoeverre de verschillende industrieën nog kunnen doorwerken en welke moeilijkheden in dat opzicht werden ondervonden ${ }^{22}$.

Van de 3600 verzonden vragenlijsten werden er 3000 ingevuld teruggezonden waardoor de gelegenheid geboden werd direct aan vele problemen tegemoet te komen. De hulp bestond uit:

a. het adviseren met betrekking tot overheidsmaatregelen of tot het wijzigen van al getroffen maatregelen, waarvan als belangrijkste genoemd kunnen worden de uitvoerverboden en de regeling van thet spoorwegverkeer;

b. het al dan niet met overheidssteun proberen te verkrijgen van een aantal noodzakelijke grondstoffen uit het buitenland, zoals kalksteen, zwavelzuur, koper en teerkleurstoffen;

c. het geven van informatie aan ondernemers waar in het binnenland de door hen benodigde artikelen verkrijgbaar waren;

d. het streven naar de opheffing van verkeersbelemmeringen als gevolg van militaire maatregellen, in het bijzonder van die welke verband hielden met de inundatie;

e. het vestigen van de aandacht van bewindslieden ${ }^{23}$ op moeilijkheden bij de in- of witvoer van bepaalde goederen;

f. het bevorderen van snelle uitbetaling voor enkele aan het Rijk en gemeenten geleverde goederen;

g. directe werkverschaffing ${ }^{24}$.

Tot de hierboven onder g. bedoelde directe werkverschaffing behoorde onder meer het op aanwijzing van de arbeidsinspectie opdragen van het vervaardigen van meubelen voor verschillende ministeries. De meubelindustrie was namelijk in hoge mate door de ontstane crisis getroffen en nagenoeg stilgevallen. Van overheidszijde werd overgegaan tot het bestellen van partijen meubelen, ook al waren deze nog niet direct nodig, om zo de ontstane werkloosheid te bestrijden. Hetzelfde gold ten aanzien van drukkers- en bindersbedrijven $^{25}$.

Naast afbraak van werk ontstond er ook een ruime werkgelegenheid, als gevolg van een grote behoefte aan legergoederen. Ook hierop richtte de arbeidsinspectie haar aandacht. De minister van Oorlog droeg begin augustus 1914 de directeur van de Centrale Magazijnen voor Militaire Kleeding en Uitrusting op hiertoe zijn 
medewerking te verlenen ${ }^{26}$. Al direct werd bereikt, dat werkloos geworden (burger)kleermakers in Utrecht en 's-Gravenhage vanuit de Centralo Magazijnen te Woerden en Delft van werk voorzien werden.

Ook in Rotterdam droeg het uniformwerk bij tot een vermindering van de werkloosheid. Een groot deel van de uitwoering gebeurde door de districtshoofden van de arbeidsinspectie.

Deze, in eerste aanleg bescheiden opzet, zou in september 1915 aanmerkelijk uitgebreid worden via het Centrale Magazijn te Amsterdam. De door de directeur der Centrale Magazijnen voor Militaire Kleeding en Uitrusting en de directeur-generaal van de Arbelid getroffen regeling, na overleg met vertegenwoordigers van de Nationale Werkloosheidsraad, van de gemeentelijke Commissie voor Werkverschaffing te Amsterdam en werkgevers- en arbeidsvakverenigingen, voorzag in uitgifte van uniformwerk aan zowel kleermakers als aan confectiefabrikanten en atelierhouders. De uitvoering vam, alsook het toezicht op de regeling werd in Amsterdam opgedragen aan een speciaal daartoe ingestelde commissie. De regeling voorzag ook in uitgifte van uniformwerk aan kleermakers buiten Amsterdam, zodat in diverse plaatsen soortgelijke commissies werden ingesteld. In een deel daarvan werd voortdurend door ambtenaren van de arbeidsinspectie aan de werkzaamheden deelgenomen; bij de overige werd door deze dienst toezicht uitgeoefend en werden, waar nodig, adviezen gegeven.

Voor wat betreft de uitgifte van uniformwerk aan confectiefabrikanten en atelierhouders vond een wekelijkse verdeling van het werk plaats op aanwijzing van ambtenaren van de arbeidsinspectie. Door het voorschrijven, dat het werk uitsluitend in eigen werkplaatsen diende te gebeuren, werd het verschijnsel van tussenpersonen tegengegaan. Daardoor kon worden voorkomen dat de lonen van de arbeiders in bedoelde bedrijven zouden dalen, daar de minister van Oorlog de prijs voor het werk had vastgesteld ${ }^{27}$.

In de loop van 1916 werd de regeling in zoverre gewijzigd, dat het werk aan confectiefabrikanten en atelierhouders te Amsterdam rechtstreeks door de Amsterdamse commissie werd uitgegeven, terwijl in de tweede helft van 1917 de uitgifte van uniformwerk dusdanig werd ingekrompen, dat niet langer werk aan de bedoelde werkgevers kon worden opgedragen.

Deze regeling heeft ertoe geleid, dat de ontwrichting van de kledingindustrie gedurende de oorlogsjaren tot een minimum werd teruggebracht en dat, zonder uitbreiding van de huisarbeid, overal in het land de kleermakers voldoende werkgelegenheid hadden ${ }^{28}$. Bijzondere aandacht vereiste voorts het grote aantal werkloze bouwvakkers. Een brief van de directeur-generaal van de Arbeid aan de minister van Landbouw, Nijverheid en Handel $^{2 \theta}$ bracht uiteindelijk diens ambtgenoot van Binnenlandse Zaken ertoe de commissarissen van de Koningin bij circulaire uit te nodigen te bevorderen, dat provinciale en gemeentelijke besturen in de geest van deze brief zouden handelen, namelijk het zonder verder uitstel aanbesteden van al geheel gereed liggende bestekken.

De aanhoudende werkloosheid in de bouwbedrijven alsook de woningnood maakte, dat de directeur-generaal van de Arbeid herhaaldelijk adviseerde om op zodanige wijze subsidie woor de woningbouw te verstrekken, dat, ondanks de duurte van de bouwmaterialen, het particuliere bouwbedrijf zou kunnen voortgaan met de woningbouw.

Waar de woningbouw voor de arbeiders, op grond van de betreffende bepalingen van de Woningwet ${ }^{30}$, door de ministeries van Binnenlandse Zaken en Financiën bevorderd werd, deed het Koninklijk Nationaal Steuncomité het nodige om de woningbouw voor de kleine middenstand te bevorderen ${ }^{3 !}$.

\section{Verlof-aanvragen voor dienstplichtigen}

Een andere bemoeienis van de arbeidsinspectie in het belang van het bedrijfsleven was het bevorderen van verlof voor dienstplichtigen, wier aanwezigheid in het bedrijf van groot algemeen belang werd geacht. Al snel was gebleken, dat (ook vrij omvangrijke) bedrijven moesten worden stopgezet, uitsluitend en alleen omdat de patroon onder de wapenen was geroepen. De minister van Oorlog gaf, na op dit probleem door zijn ambtgenoot van Landbouw, Nijverheid en Handel attent te zijn gemaakt, de directeur-generaal van de Arbeid te kennen $^{32}$, dat, wanneer uit een door de arbeidsinspectie ingesteld (grondig) onderzoek de stellige overtuiging bestond, dat grote sociale belangen werden geschaad door het verblijf onder de wapenen van 
een niet te vervangen patroon, hij bereid was in een dergelijk geval een voorstel van de dürecteur-generaal van de Arbeid tot vrijstelling van dienst in overweging te nemen.

Na enige tijd verminderde het onmiddellijke oorlogsgevaar, waarop tijdens de mobilisatie was gerekend. De langdurige afwezigheid van vele onmisbare en onvervangbare personen maakte de voortzetting van menig bedrijf onzeker. Toen het economische leven zich in zoverre hersteld had, dat de productie hetzij kon worden hervat, hetzij kon worden voortgezet, werd deze vrijstellingsmogelijkheid om economische redenen uitgebreid tot die personen, die hoewel zij geen patroon waren, toch voor de activiteiten van het bedrijf min of meer onmisbaar waren. Daar ieder verzoek om een dergelijke vrijstelling afzonderlijk via een bezoek aan het betrokken bedrijf onderzocht moest worden, eiste deze taak van de arbeidsinspectie cen dusdanige inspanning, dat een deel van de normale activiteiten veronachtzaamd werd op grond van het algemeen belang, omdat in deze toch al moeilijke tijden voor handel en industrie ernstige bedrijfsbelemmeringen konden worden weggenomen. De betreffende verzoeken hadden niet alleen betrekking op industriële vestigingen, maar ook op vele, die behoorden tot bedrijfstakken, waarmee de arbeidsinspectie onder normale omstandigheden generlei bemoeienis had, zoals bijvoorbeeld de bloembollenkwekerij, de bollenhandel, banken, handels- en rederskantoren en winkels ${ }^{33}$.

Deze nieuwe taak zou een steeds drukkender last voor de arbeidsinspectie worden, omdat het benodigde onderzoek door de inspecterende ambtenaren diende te geschieden. In juni 1915 zou het komen tot een botsing tussen de directeur-generaal van de Arbeid en de minister van Oorlog. De oorzaken waren in de eerste plaats een uitgevaardigde legerorder, waarbij voor de verlofregeling in nog sterkere mate beslag op de dienst werd gelegd en in de tweede plaats de verklaring van de minister van Oorlog, dat het onmogelijk was om de dienst arbeidsinspectie mededeling te doen van de beslissingen op de behandelde verlofaanvragen. Dit laatste had namelijk tot gevolg, dat de arbeidsinspectie, onkundig van het verlof dat een dienstplichtige of anderen in dezelfde onderneming al hadden genoten, in ieder geval ook daarnaar een onderzoek moesten instellen wat in dit verband weer leidde tot een nog zwaardere werkbelasting. Bovendien had de dienst geen inzicht meer in de maatstaven die bij een beoordeling gehanteerd moesten worden. De directeur-generaal van de Arbeid maakte daarop dan ook kenbaar, dat het onmogelijk was op deze wijze zijn adviezen te geven, waarop aan deze vrijwillig aanvaarde taak, zij het voor korte tijd, een einde kwam.

Toen namelijk de minister van Oorlog op zijn hierboven bedoelde verklaring terugkwam en toezegde dat als te voren van de verleende verloven mededeling zou worden gedaan, verklaarde de directeur-generaal van de Arbeid zich begin september 1915 weer bereid het onderzoek aangaande verlofsaanvragen en de daarmee gepaard gaande advisering te verrichten. De feitelijke hervatting van de bedoelde onderzoeken zou echter eerst plaatsvinden na de uitvaardiging van een legerorder op 13 oktober 1915 met vorenbedoelde strekking. Hoewel al onmiddellijk de verwachting bestond, dat de manier waarop bij die legerorder het onderzoek van verlofaanvragen was geregeld, voor de arbeidsinspectie een enorme hoeveelheid werk zou meebrengen, bleef de dienst bereid te proberen of deze regeling gevolgd kon worden. De compagniescommandanten zonden alle verzoekschriften, waarvan zij meenden dat deze tot het arbeidsveld van de directeur-generaal van de Arbeid behoorden, aan laatstgenoemde door, opdat deze ze na onderzoek aan de minister van Oorlog doorstuurde. Het aantal verzoekschriften, dat op die wijze binnenkwam, werd echter zo groot, dat de arbeidsinspectie vrijwel haar gehele capaciteit daarvoor diende te gebruiken. De verwaarlozing van de eigenlijke taak van de arbeidsinspectie zou, ondanks de verhoogde inspanning acceptabel żjin, wanneer, evenals in het begin van de mobilisatie, het voordeel hiervan opwoog tegen het nadeel. Het onderzoek dat in het merendeel van de gevallen plaats diende te vinden vereiste niet een specifieke kennis van de bedrijven, zodat ook andere organen in deze gevallen konden adviseren. Een voorstel aan de minister van Oorlog om aan de arbeidsinspectie alleen nog advies te vragen over die gevallen waarin getwijfeld werd aan de gegrondheid van het verzoek of alleen over die welke betrekking hadden op de eigenlijke fabrieksnijverheid - het werkterrein arbeidsinspectie - werd door de bewindsman afgewezen ${ }^{34}$.

Als gevolg van het vorenstaande werden deze activiteiten ten behoeve van het ministerie van Oorlog in januari 1916 beëindigd.

Hierdoor werd de arbeidsinspectie ontlast van een hoogst ondankbare taak, die meer dan enige andere mo- 
bilisatiewerkzaamheid een belangrijk deel van haar tijd in beslag heeft genomen.

Dat wil echter niet zeggen, dat het betreffende onderwerp niet voortdurend de aandacht van de arbeidsinspectie heeft gehouden.

Vele werkgevers wendden zich tot de voor de arbeidsinspectie verantwoordelijke bewindsman op het ministerie van Landbouw, Nijverheid en Handel met het verzoek om verlofaanvragen van hun personeel in het belang van hun bedrijf te ondersteunen, welke veelal toch weer aan de arbeidsinspectie in onderzoek werden gegeven. Bovendien kreeg de arbeidsinspectie een groot aantal verzoeken voor uitstel van opkomst van dienstplichtigen te onderzoeken, waarover de minister van Oorlog het advies inwon van zijn ambtgenoot van Landbouw, Nijverheid en Handel en bleven enkele militaire autoriteiten inlichtingen aan de directeur-generaal van de Arbeid vragen ${ }^{35}$.

\section{Certificaten van oorsprong}

Een andere werkzaamheid van de dienst arbeidsinspectie die voortvloeide uit de oorlogsomstandigheden had betrekking op zogenaamde certificaten van oorsprong. De maatregelen die door de verbonden mogendheden, bekend onder de naam Entente ${ }^{36}$, waren genomen om de uitvoer van alle Duitse en Oostenrijks-Hongaarse produkten te beletten, maakten het noodzakelijk, dat deze certificaten werden afgegeven, om zodoende te voorkomen, dat de gehele Nederlandse exportindustrie zou stagneren, daar de stoomvaartlijnen geen goederen wilden vervoerden die niet aldus gecertificeerd waren.

Terzake van de afgifte van deze certificaten was de hoofdrol toebedeeld aan de dienst der Invoerrechten en Accijnzen ${ }^{37}$. De inspecteurs van deze dienst vroegen echter advies aan de districtshoofden van de arbeidsinspectie. Nadat deze activiteiten in maart 1915 een aanvang namen, zouden de bemoeienissen van de arbeidsinspectie in mei daaropvolgend nog verzwaard worden, omdat vanaf dat moment ook voor verzendingen naar andere landen dan Engeland en Frankrijk dezelfde formaliteiten vereist werden en er bovendien moest worden nagegaan of voor Frankrijk en Engeland - vanaf december 1915 ook de Engelse koloniën bestemde Nederlandse fabrikaten voor niet meer dan $25 \%$ van de waarde bestonden uit materialen of arbeid van Duitse, Oostenrijk-Hongaarse of Turkse origine. Vanaf december 1915 gold deze norm voor alle door de zogenaamde centrale mogendheden bezette gebieden ${ }^{38}$. Vanaf oktober 1915 was de situatie zelfs zo, dat de juiste verhouding tussen nationale materialen of arbeid en die van aan Engeland vijandige oorsprong in de uit te voeren goederen voorkwamen moest worden vastgesteld ${ }^{39}$.

De districtshoofden van de arbeidsinspectie konden zich hierbij voorzover nodig laten bijstaan door een accountant, maar well op kosten van de belanghebbende(n) ${ }^{40}$. Het onderzoek dat door de arbeidsinspectie in deze werd verricht was zeer omvangrijk en tijdrovend. De in de volgende jaren herhaaldelijk door de regeringen van de Entente-mogendheden aangebrachte wijzigingen in de bepalingen betreffende de percentages van vreemde - dus hun vijandige - en van binmenlandse oorsprong, bemoeilijkten dit werk in hoge ma$\mathrm{te}^{\mathrm{A1}}$. Uit het jaarverslag over $1916^{42}$ blijkt, dat het onderzoek in veel gevallen betrekking had op zendingen over zee van bijzonder gering belang zoals postpakketten van particulieren. Daarentegen hing vaak het bestaan van een bloeiende exportnijverheid af van het verkrijgen van een certificaat van oorsprong. Niet iedereen nam de activiteiten van de arbeidsinspectie in deze in dank af, zoals opnieuw blijkt uit het jaarverslag over 1916. In bedrijven waar tegelijk fabrikage en handel werden uitgeoefend en de fabrikage zich soms beperkte tot detailverpakking, vermenging of verdunning (vervalsing) van een produkt uit eén van de "besmette gebieden" leidde het resultaat van de onderzoekingen van dergelijke "fabrikaten" dikwijls tot de opmerking, dat de ambtenaren van de arbeidsinspectie "den bloei der vaderlandsche industrie" tegenwerkten.

\section{Tewerkstelling van geïnterneerden}

Een andere taak, die door de uitzonderlijke situatie aan de arbeidsinspectie werd toebedeeld was een gevolg van een op 12 mei 1915 door het hoofd van de Afdeling Internering van het Algemeen Hoofdkwartier aan de directeur-generaal van de Arbeid gerichte adviesaanvraag naar aanleiding van de directie van een machi- 
nefabriek omgeïnterneerde Belgische militairen te mogen te werk stellen. Na enkele soortgelijke adviesaanvragen in de maanden mei, juni en juli nam het aantal vanaf begin augustus zeer snel toe. De aanvragen werden beoordeeld aan de hand van de vraag in hoeverre Nederlandse belangen door een inwilliging geschaad zouden kunnen worden. Daarbij werd allereerst overwogen of Nederlandse arbeidskrachten beschikbaar waren en of de in het vooruitzicht gestelde lonen niet beneden de (ter plaatse) geldende loonstandaard lagen. Vervolgens werd nagegaan of de industrie gebaat was bij een tijdelijke produktievermeerdering, omdat het in een aantal gevallen bijvoorbeeld ten aanzien van de sigarenindustrie, de voorkeur verdiende de beperkte grondstofvoorraad op normale wijze met Nederlandse arbeidskrachten te verwerken boven een versneld uitputten van die voorraad, wat zou kunnen leiden tot werkloosheid en ontwrichting van bedrijven en/of de bedrijfstak. In vele gevallen betrof het echter Belgische arbeidskrachten met dusdanige capaciteiten, dat deze geen arbeidsplaatsen zouden bezetten waarvoor voldoende bekwame Nederlandse arbeidskrachten waren, dit ondanks het feit, dat er een aanbod van Nederlandse arbeidskrachten op het betreffende gebied was ${ }^{49}$. Daarnaast werden voor ons land nieuwe bedrijfstakken gecreëerd of werkmethoden gehanteerd, waarbij de Belgische arbeidskrachten zorgden voor de opleiding van de binnenlandse arbeidskrachten. Dit was onder meer het geval bij de fabrikage van handschoenen, mandenwerk en bij de vlasverwerking.

Afhankelijk van de in het geding zijnde belangen werd als onderdeel van het in te stellen onderzoek, al dan niet door meerdere districtshoofden, advies gevraagd van de arbeidsbeurzen, vakverenigingen en deskundigen uit de diverse bedrijfstakken.

Deze taak van de arbeidsinspectie zou in november 1915, althans ten aanzien van alle aanvragen tot het tewerkstellen van geïnterneerden, alweer beëindigd worden toen de minister van Financiën waarbij de verantwoordelijkheid van de arbeidsbemiddeling berustte, bepaalde, dat de betreffende onderzoeken in het vervolg bij de Centrale Arbeidsbeurs thuishoorde ${ }^{44}$. Ten aanzien van een deel van de aanvragen liep de bemoeienis van de arbeidsinspectie in deze nog door in 1916. Zo werden onderzoeken ingesteld naar het al of niet toelaatbaar zijn van het tewerkstellen van geïnterneerden in kleer- en mandemakerijen, steen- en mineraalwaterfabrieken, goudslagerijen, hennepspinnerij en fabrieken van lichtgevoelig papier en elektrische toestellen ${ }^{46}$.

\section{Kolendistributie}

Van de werkzaamheden van de arbeidsinspectie in belang van de nijverheid moeten zeker de activiteiten in verband met de brandstoffendistributie genoemd worden. De al eerder gememoreerde Commissie voor economische belangen van het Koninklijk Nationaal Steuncomite zag zich geconfronteerd met een dreiging op economisch terrein, die voor de gehele nijverheid noodlottige gevolgen zou kunnen hebben, namelijk kolennood. Dit vanwege het feit dat ons land in normale omstandigheden voor ongeveer $75 \%$ afhankelijk was voor kolenleveringen uit het buitenland, en met name uit Duitsland, België en Engeland, De gegeven situatie maakte, dat niet alleen gezorgd moest worden voor kolenaanvoer, maar ook voor een zoveel mogelijk gelijkmatige verdeling van hetgeen aangevoerd werd; een zorg voor zowel de bedoelde Commissie van het Koninklijk Nationaal Steuncomite als de minister van Landbouw, Nijverheid en Handel. Een en ander heeft er toe geleid, dat de Commissie voor economische belangen werd opgesplitst in een tweetal andere commissies waaronder de Nijverheidscommissie ${ }^{46}$, die op 5 januari 1915 werd ingesteld. Uit deze omvangrijke commissie werd weer het bureau der Nijverheidscommissie samengestell, dat geregeld tweemaal per week vergaderde. In de eerste vergadering van de laatstgenoemde commissie werd hoofdzakelijk over het vraagstuk van de kolenvoorziening gesproken. Al tijdens de tweede vergadering op 13 januari 1915 werd de kolencommissie ingesteld met als taak de leiding van de steenkolendistributie. Eind februari 1915 werd daarop uit deze commissie het Kolenbureau ${ }^{47}$ gevormd Via centralisering van de kolenaflevering werd gepoogd om enerzijds een goede distributie van de beschikbaar komende steenkollen te waarborgen en om anderzijds het opdrijven van de kolenprijzen als gevolg van schaarste te voorkomen.

$\mathrm{Na}$ enkele maanden gefunctioneerd te hebben onderkende het Kolenbureau, dat de aanvoer van buitenlandse steenkolen ernstig verstoord zou kunnen worden en werd op zijn initiatief ${ }^{48}$ de N.V. Onderlinge Kolenreserve Maatschappij ${ }^{49}$ opgericht, met als doelstelling het op gezamenlijke kosten, dat wil zeggen industriëllen 
en andere belanghebbenden als ook de lagere overheden en de rijksoverheid, een reserve-woorraad steenkolen op te slaan om in gewal van aan roerstagnatie hierop te kunnen terugvallen ${ }^{50}$.

Doordat het plan een averechts effect leek te gaan sorteren, omdat de steenkolen-exporterende landen er niet veel voor voelden - een gevolg van de door hen ondervonden moeilijkheden in hun mijnindustrie door de oorlogsomstandigheden -, om naast het voorzien in de rechtstreekse behoefte aan steenkolen, ons land ook nog eens in staat te stellen een reserve-voorraad steenkolen op te bouwen, werd het niet verder uitgevoerd en werden de zaken van de Kolenreserve Maatschappij geliquideerd ${ }^{51}$.

Daarop volgend werden de activiteiten van het Kolenbureau op 1 april 1916 stopgezet: Zijn taak werd overgenomen door een Rijkskolenbureau, bijgestaan door een commissie van advies voor de kolenindustrie ${ }^{52}$. Vermeld moet nog worden, dat de mogelijkheden om van overheidszijde distributieregelingen uit te vaardigen als ook de prijzen van goederen vast te stellen gebaseerd is op artikel 8 van de op 20 augustus 1916 in werking getreden Distributiewet $1916^{63}$.

Industrielen wier bedrijf belemmering ondervond door gebrek aan brandstof, richtten een groot aantal verzoeken, wat betreft de brandstof steenkool aan de directeur van de Rijkskolendistributie, die op diens verzoek door de arbeidsinspectie werden onderzocht. De toewijzing van de steenkolen door de Rijkskolendistributie was aanvankelijk gebaseerd op het verbruik in vroegere perioden, waarvan voor enkele bedrijfstakken (voedingsmiddelen, wasserijen, munitiefabrieken) in voor hun gunstige zin werd afgeweken, terwijl afwijkingen voor "afzonderlijke fabrieken werden gebaseerd op een onderzoek van ieder geval. Toen de kolenvoorziening achterbleef bij de behoefte aan deze brandstof werd tussen de directeur van de Rijkskolendistributie, de Commissie van Toezicht daarop en de arbeidsinspectie overleg gepleegd over algemene maatregelen om zodoende een zo economisch mogelijk verbruik van steenkool in de industrie te bewerkstelligen en een zo billijk mogelijke toewijzing, waarbij de basis van toewijzing anders diende te zijn dan het verbruik in vroegere perioden. Deze omstandigheden maakte een nauwere samenwerking tussen de Rijkskolendistributie en de arbeidsinspectie gewenst.

Een gevolg was dat vanaf 1 september 1917 alle toewijzingen aan de groot-verbruikers in de industrie ${ }^{54}$ door de Rijkskolendistributie eerst werden gedaan na overleg met de arbeidsinspectie.

De taak die de arbeidsinspectie in deze had was vierledig. In de eerste plaats moesten de voorraden op alle fabrieken bekend worden. In de tweede plaats moest worden nagegaan welk verbruik iedere fabriek bij normale produktie.. In de derde plaats moest worden gecontroleerd of alle mogelijke zuinigheid in acht werd genomen en moest in verband hiermee voorlichting worden gegeven. In de vierde plaats moest aan de hand van de gegevens en de belangen die in het geding waren bij het doorwerken van iedere fabriek - het nut van haar produkt, het aantal arbeiders - in verband met de beschikbare hoeveelheid steenkolen worden geadviseerd over de maandelijkse toewijzing.

Ter voorbereiding was aan alle fabrikanten die rechtstreeks door de Rijkskolendistributie brandstof toegewezen kregen een vragenlijst toegezonden, teneinde de benodigde informatie te krijgen ${ }^{55}$. Zo snel mogelijk werden de ruim 2000 bedrijven door de onder leiding van de directeur-generaal van de Arbeid te werk gestelde controleurs van de Rijkskolendistributie ${ }^{56}$ bezocht om in de eerste plaats de juistheid van de gegeven antwoorden na te gaan. Bij deze controle bleek meerdere malen een te laag opgegeven nog aanwezige voorraad, terwijl ook een aantal keren een verborgen voorraad werd ontdekt. In de tweede plaats werd nagegaan welk kolenverbruik de aanwezige stoomketel(s) en machines konden hebben. Daarbij werd door de controleurs gewezen op gebreken in de installaties en in de stookwijze, waardoor warmteverlies optrad. Toen door dit eerste onderzoek én van de grondslagen voor de toewijzing van steenkolen was gelegd, kon meer aandacht besteed worden aan afzonderlijke gevallen, zoals pas opgerichte of uitgebreide fabrieken of fabrieken dit produkten leverden waaraan grote behoefte bestond en aan specifieke bedrijfstakken, waar vermoedelijk veel brandstof bespaard zou kunnen worden. Voor wat dit laatste betreft was dit onder meer het geval bij de beetwortelfabrieken, de diamantslijperijen, de meelfabrieken en de steenbakkerijen ${ }^{67}$. 


\section{Turfdistributie}

Naast de kolendistributie had de arbeidsinspectie nog te maken met een andere brandstof, namelijk turf. Deze activiteiten namen een aanvang toen tegen de winter van 1915 alle soorten turf ${ }^{\$ 3}$ aan sterke prijsstijgingen onderhevig waren, wat voor de minister van Landbouw, Nijwerheid en Handel aanleiding was om de directeur-generaal van de Arbeid te vragen een onderzoek te laten instellen naar de aanwezige voorraden turf als ook naar de prijzen daarvan ${ }^{59}$. Alleen al voor de inventarisatie werden 1550 vragenliysten aan de verveners gezonden, waarvan er ongeveer 1000 beantwoord werden. Deze aldus verkregen informatie werd door onderzoek ter plaatse aangevuld en hier en daar gecontroleerd. Het onderzoek zou witeindelijk leiden tot de vaststelling van maximumprijzen; op grond van een door de oorlogssituatie gewijzigde Onteigeningswet $^{e 0}$. Het toezicht op de handhaving van deze maximum-prijsregeling kwam voor een groot deel voor rekening van de arbeidsinspectie.

De ingevoerde maximum-prijsregeling voor met name fabrieksturf stuitte al snel op hevig verzet van de zijde van de verveners en de met het vervoer belaste schippers, terwijl ontduiking van de regeling, ondanks een krachtig optreden van overheidszijde, niet verhinderd kon worden. De reden van het bedoelde ongenoegen was, dat de toch niet onbillijke prijszetting voor een groot deel gebaseerd was op de overweging dat de noodijdend geachte steenindustrie voornamelijk op turf als brandstof was aangewezen, terwijl ook andere bloeiende industrieën, zoals de aardappelmeelen strokartonfabrieken, van deze maximum-prijsregeling profteerden. Dit profijt kwam voort wit het enerzijds kunnen bedingen van buitengewoon hoge winsten door een vei hoogde vraag naar hun produkten, tegenower anderzijds een gegarandeerde betrekkelijk goedkope brandstof. Nadat aanvankelijk overleg met de vervenersorganisaties en andere belanghebbenden weinig resultaat opleverde, zou, na een uitgebreid onderzoek in het vervenersbedriff en hernieuwd overleg, door de betreffende minister op voorstel van de directeur-generaal van de Arbeid op 25 augustus $1916^{61}$ een nieuwe maximum-prijsregeling vastgesteld worden ${ }^{02}$. Deze maximum-prijsregeling zou nu gebaseerd worden op artikel 8 van de Distributiewet 1916. Hoewel, althans voor een belangrijk deel aan de geschetste grieven aangaande de fabrieksturf tegemoet werd gekomen, doordat de maximumprijs hiervan uitsluitend gold bij levering voor steenfabrieken, kalkbranderijen en bakkerijen en dus niet meer voor de levering van turf aan andere nijverheidsondernemingen en een ander element van de nieuwe regeling, namelijk dat een bepaald deel van de produktie tegen de vastgestelde prijs ter beschikking gesteld diende te worden van de steenfabrieken en de andere hierboven bedoelde bedrijfstakken, door de verveners slechts met moeite werd geaccepteerd, met andere woorden er enige concensus over de regeling was, werd de uitvoering van de nieuwe regeling in belangrijke mate vergemakkelijkt, doordat tegen opzettelijke niet-nakoming door de verveners van enige verplichting voorgeschreven bij een distributieregeling als bedoeld in artikel 8 van de Distributiewet 1916 via artikel 12 van die wet strafrechtelijk werd gesanctioneerd ${ }^{\mathrm{E3}}$.

Het door de verveners te reserveren deel van de produktie van de fabrieksturf diende ter beschikking te worden gesteld van een door de minister van Landbouw, Nijverheid en Handel in oktober $1916^{64}$ ingestelde Distributiecommissie ${ }^{65}$. Deze commissie diende allereerst na te gaan wat de behoefte aan fabrieksturf in de steenfabrieken, als grootste verbruiker, was. Vervolgens moesten de voorraden bij de veenderijen nauwkeurig worden opgenomen teneinde de hoogte van het te reserveren produktiedeel te kunnen vaststellen. De toekenning van de bij haar aangevraagde hoeveelheden fabrieksturf was onderworpen aan de goedkeuring van de directeur-generaal van de Arbeid. Tegen een onthouding van deze goedkeuring kon de Distributiecommissie bij de verantwoordelijke bewindsman in beroep gaan. Overigens hadden zowell de directeurgeneraal van de Arbeid als de directeur van de Rijkskolendistributie en de door hen aan te wijzen ambtenaren recht van toegang tot alle vergaderingen van deze commissie ${ }^{18}$.

In het najaar van 1916 waren er opnieuw moeilijkheden, nu met de verscheping van turf. Als gevolg van de toen zeer sterke vraag naar scheepsruimte voor het vervoer van bieten en aardappelen, werd de snelle verzending van fabrieksturf voor de steenindustrie aanzienlijk belemmerd. De zeer sterke vorst, die in het voorjaar van 1917 optrad, legde het vervoer bovendien voor ongeveer twee maanden stil. Bovendien hadden de zeer strenge winter en de stagnatie van de aanvoer van steenkolen tot gevolg dat de prijs van turf onder druk 
kwam te staan. De ternauwernood bezworen speculatiehandel dreigde opnieuw de kop op te steken. Eén en ander was voor de directeurgeneaal van de Arbeid aanleiding zijn minister te adviseren een vervoersverbod voor turf per schip uit te vaardigen, waarvan alleen ontheffing zou worden verleend, indien de vervoerder kon aantonen, dat de lading bestemd was voor een gemeentebestuur of een lokaal distributiebedrijf. Nadat dit gebeurd was, was de opgedane ervaring met een verbodregeling voor het vervoer met een ontheffingsmogelijkheid, zo gunstig, dat de bedoelde vervoerregeling algemeen geldend werd verklaard en ook van toepassing werd op het vervoer per spoor ${ }^{67}$.

De toegenomen vraag naar turf maakte een algemene distributieregeling noodzakelijk. Opnieuw was ter voorbereiding hiervan nodig, dat de nog in de venen beschikbare voorraden geĩnventariseerd werden. Toen de winter eindelijk achter de rug was en de werkzaambeden in de venen weer aangevangen konden worden, leidde de speculatiezucht wederom tot problemen. De veenarbeiders stelden als reactie op de extra winsten van de verveners, hoge looneisen. In nagenoeg alle belangrijke veendistricten ontstonden arbeidsvoorwaardenconflicten, die niet via overleg opgelost konden worden. De afgelopen strenge winter had al veel verlies met zich gebracht wat betreft de produktie van turf; iedere stakingsdag zou dit verlies alleen maar doen stijgen. Al met al een situatie die voor de minister van Landbouw, Nijverheid en Handel reden was, om in die gevallen, waar werkgevers en arbeiders niet tot een oplossing in deze arbeidswoorwaardenconflicten konden komen, voor te stellen deze via een door hem te benoemen arbiter te doen beslissen. Dit voorstel werd tenslotte voor een aantal veenderijen - Barger Oosterveen, Emmer-Compascuum en Nieuw-Weerdingen - geaccepteerd. Als arbiter werd de directeur-generaal van de Arbeid aangewezen die deze taak slechts aanvaardde na de uitdrukkelijke verzekering dat beide bij het geschil betrokken partijen zich onvoorwaardelijk bij zijn uitspraak zouden neerleggen en de stakende partij het werk onmiddellijk zou hervatten in afwachting van de uitspraak, doe die dan ook zou uitvallen.

In de veenderijen te Valthermond accepteerden de arbeiders geen arbitrage en handhaafden zij onverkort hun eisen. Pogingen van zowel de burgemeester als de directeur-generaal van de Arbeid om deze laatsten tot een soepelere houding te bewegen, mislukten, zodat daar de werkstaking nog geruime tijd voortging en eerst eindigde toen de belangrijkste afgraaftijd voorbij was.

Duidelijk zal zijn, dat, aangezien de waarde van de turf voor de helft door het arbeidsloon bepaald werd, de voor de turf vast te stellen maximum-prijsregeling voor 1917 , samenhing met de uitspraken van de directeur-generaal van de Arbeid als arbiter over de loonhoogte in de arbeidsconflicten. Toen in alle gevallen diens uitspraak gewezen was, bleek, dat de lonen hoger gesteld waren (gemiddeld 64\%) dan die welke in 1916 hadden gegolden en was een verhoging van de maximumprijs voor turf (met $32 \%$ ) redelijk. De directeur-generaal van de Arbeid baseerde hierop zijn voorstel tot vaststelling van de nieuwe maximum-prijsregeling, een voorstel dat niet in alle opzichten werd gevolgd. Bij de vaststelling van de nieuwe prijsregeling op 14 juli $1917^{68}$, werd tevens de hele kwestie van de prijsregeling van turf overgedragen aan de Rijkskolendistributie, zodat de dienst arbeidsinspectie voor een belangrijk deel van de met deze brandstof samenhangende activiteiten ontheven werd. Als gevolg van deze overdracht leek er bestaansrecht meer te zijn voor de een jaar eerder ingestelde (turf)Distributiecommissie voor de steenindustrie.

Deze commissie beèindigde daarop haar taak, welke werd overgedragen aan de Rijkskolendistributie, begin augustus $1917^{\mathrm{6e}}$.

\section{Andere activiteiten}

Naast de hierboven wat uitgebreider behandelde activiteiten kunnen als andere bemoeiingen van de arbeidsinspectie in het belang van het bedrijfsleven of in verband met de industrie onder andere genoemd worden: - het maken van overzichten van het verbruik in normale jaren van bepaalde grondstoffen door verschillende fabrieken en hun capaciteit gedurende de oorlogsjaren; dit gebeurde voor katoen, voor wol en voor zink. De uit hernieuwd onderzoek door de arbeidsinspectie verkregen gegevens van de wolverbruikende fabrieken werden in 1917 verstrekt aan de zogenaamde Wol-commissie, ingesteld op advies van de Nijverheidscommissie van het Koninklijk Nationaal Steuncomite, om te dienen bij haar bemoeiingen in het buitenland ter ver- 
krijging van wolinvoer en bij de verdeling van de beschikbare grondstof voor de fabrieken. In de tweede helft van 1917 kreeg het Koninklijk Nationaal Steuncomite de beschikking over alle ruwe wol, woorzover deze niet voor legerdoeleinden nodig waren. Van deze ruwe wol werd eerst een hoeveelheid bestemd voor de fabrikage van de door dit Steuncomite te verdelen (wol)garen, terwijl het resterende deel werd toegewezen aan andere wolverbruikende fabrieken. Voor deze regeling werd herhaaldelijk het advies van de districtshoofden van de arbeidsinspectie gevraagd ${ }^{70}$.

- het wijzen op de nadelen die de Nederlandse baksteenindustrie ondervond door het gebruik van Belgisch steen. Eén en ander leidde in 1915 tot een verbod door de minister van Binnenlandse Zaken van het gebruik van buitenlands baksteen voor woningen, die met overheidssteun werden gebouwd. De directeur-generaal van de Arbeid wees in de loop van 1916 de steenfabrikanten erop, dat de inmiddels steeds verdergaande stijging van de baksteenprijzen onvermijdelijk moest leiden tot een intrekking van het verbod, wat uileindelijk tegen het einde van dat jaar ook gebeurde $\mathrm{e}^{71}$;

- een onderzoek naar de prijzen en aanvoer van hout;

- een onderzoek naar de wenselijkheid van enige uitwoerverboden;

- een onderzoek naar de benadeling van Nederlandse kantwerksters door de verkoop van in vluchtelingenkampen vervaardigde kant tegen een lage prijs;

- bemiddeling bij bedrijfsbelemmering door huisvesting van militairen in fabrieksgebouwen ${ }^{72}$;

- een onderzoek naar de binnenlandse produktie van chloorkalk en soda, op verzoek van de minister van Landbouw, Nijverheid en Handel;

- een advies over een aantal bedrijven op verzoek van de Opperbevelhebber van Land- en Zeemacht werd in verband met de aanmaak van munitie;

- een onderzoek naar het aantal in aanbouw zijnde sleepboten op verzoek van de Minister van Landbouw, Nijverheid en Handel;

- een onderzoek naar het voorkomen van kleine bedrijven in de sigarenindustrie in verband met de distributie van tabak ${ }^{73}$.

\section{De arbeidsinspectie en het overheidsingrijpen in de economie}

Op 2 november $1914^{74}$ werd op verzoek van het Tweede Kamerlid Troelstra door de minister van Landbouw, Nijverheid en Handel Treub een Nota betreffende den economischen toestand ${ }^{75}$ aan de Tweede Kamer aangeboden. Gedurende de oorlogsjaren zouden er in totaal negen van deze Economische Nota's kwartaaisgewijs - verschijnen ${ }^{76}$. Voor wat de Nijverheid betreft werden de gegevens verzameld door de districtshoofden van de arbeidsinspectie. De bewerking van deze nota's gebeurde voor een belangrijk deel bij de Centrale Dienst van de arbeidsinspectie.

Keesing ${ }^{77}$ concludeert wat betreft het economische gebeuren tijdens de Eerste Wereldoorlog het navolgende:

"Van een eigenlijke oorlogseconomie was geen sprake, veeleer van een compilatie van crisismaatregelen ad hoc",

wat hij vooral toeschrijft aan een gebrekkige kennis ${ }^{78}$. Dit was niet zo verwonderlijk, aldus De Hen ${ }^{79}$, daar $^{2}$ het betreffende ministerie van Landbouw, Nijverheid en Handel onder meer

"via de arbeidsinspectie maar net geleerd had hoe de Nederlandse economie ongeveer in

elkaar stak - laat staan dat het die economie naar zijn hand zou kunnen zetten, mocht al iemand werkelijk die ambitie hebben gekoesterd".

De getroffen maatregelen waren noodmaatregelen, die niet woor niets crisismaatregelen genoemd werden, waarbij zoals uit het vorenstaande blijkt nauw werd samengewerkt met het particuliere initiatief. In met name in de oorlogsperiode wilde men van overheidszijde maar al te graag profijt trekken van de bij de werkgevers aanwezige deskundigheid. Zo zeer zelfs, dat de belangrijkste organisaties die in het begin van de oorlogsperiode op economisch terrein tot stand kwamen, waaronder het Koninklijk Nationaal Steuncomite, niet eens overheidsinstellingen waren, noch werden ${ }^{80}$. 
De arbeidsinspectie was na de reorganisatie in 1909 al snel het machtigste apparaat in de sociaal-economische sector van de rijksoverheid geworden ${ }^{a}$. Deze dienst had de beschikking over een onmis: baar gegeven, namelijk directe kennis van het Nederlandse bedrijfsleven. In de (semi)ambtelijke sfeer speelde op grond juist van die kennis de arbeidsinspectie een belangrijke rol bij het overheidsingrijpen in de economie in de oorlogsjaren.

Zaalberg ${ }^{82}$ beschrijft dit als volgt:

"Deze organisatie heeft ....... van de arbeidsinspectie een geheel gemaakt, dat als instrument van de Overheid tot de meest uiteenloopende diensten in staat en bereid was ...... Ontelbare autoriteiten, organisaties, ondernemers en particulieren richtten zich naar den Nieuwen Uitleg ${ }^{83}$ met de meest uiteenloopende moeilijkheden. Doch ook buiten verband met de oorlogsgevolgen werd de arbeidsinspectie benut voor diensten, die niet direct tot haar eigenlijke taak behoorden, doch alleen omdat zij over enorme ervaring en veelzijdig beproefde krachten beschikte. Dit is niet het gevolg van eenig toeval of van de aanwezigheid van een bijzondere liefhebberij. Geen orgaan komt door den aard van zijn taak in zoo voortdurend en innig contact met het bedrijfsleven en andere onderdelen der samenleving als de Arbeidsinspectie, die haar taak en plaats begrijpt. Telkens weer moet zij zich in practische onderwerpen verdiepen, de verschijnselen met elkaar in verband brengen, mogelijkheden overwegen, wetenschap opdoen en toepassen, zelf mede de wetenschap opbouwen. $\mathrm{Zij}$ beschikt in haar uitgebreide ambtenarencorps over menschen met uiteenloopende kennis en aanleg en dit maakt het aan de leiding mogelijk, om voor bijzondere behoeften in technische of economische of sociale richting een selectie te houden en bijzonder werk op te dragen aan den meestbevoegde."

Hacke $^{\text {B4 }}$ voegt daar aan toe, dat ruim gebruik werd gemaakt van het apparaat van de arbeidsinspectie, "dlat vertrouwen genoot, over gegevens beschikte of binnen zeer korten tijd gegevens kon verzamelen over alle onderwerpen, welke in verband stonden met de industrie."

\section{Op de valreep: uitbreiding van het aantal districten}

Na een wijziging in 1911 van de verdeling van het Rijk in districten ${ }^{85}$, waarbij het Rijk overigens in 9 districten verdeeld bleef, zou de districtsindeling nog voor het einde van de Eerste Wereldoorlog tijdens de behandeling van de begroting van het ministerie van Landbouw, Nijverheid en Handel voor het dienstjaar 1918 uitvoerig aan de orde komen. In de toelichting op deze begroting ${ }^{86}$ gaf de betrokken bewindsman, dat door de uitbreiding van de industrie en de aanvulling van wettelijke bepalingen op het terrein van de arbeidsbescherming in de loop der jaren steeds hogere eisen werden gesteld aan de arbeidsinspectie. Daaraan was steeds het hoofd geboden door onder meer het personeel, dat in de districten werkzaam was, uit te breiden. In de behoefte aan versterking van de arbeidsinspectie kon, aldus de bewindsman, niet meer voorzien worden door personeelsuitbreiding. In enkele districten werden door de dienstleiding te hoge eisen gesteld aan de werkkracht van het districtshoofd; meer dan van een man verlangd kon worden. Daarbij had de minister met name het oog op het derde district, dat hij in omvang wilde beperken.

Dit district omvatte de stad Rotterdam en het zuidelijke deel van Zuid-Holland. Het aantal arbeiders dat in dat district in inrichtingen, die onder het toezicht van de arbeidsinspectie vielen, werkte, overtrof in belangrijke mate het aantal in de andere districten. Het feit, dat langs de waterwegen in de nabijheid van Rotterdam tal van nieuwe industrièle inrichtingen - vooral voor de scheepsbouw - waren opgericht en in de stad zelf het aantal nijverheidsondernemingen uitbreidde en een sterkere uitbreiding na afloop van de Eerste Wereldoorlog verwacht werd, was voor de minister reden het derde district te beperken tot Rotterdam en omgeving $^{87}$. Voor dit nieuwe district zou als standplaats Dordrecht aangewezen kunnen worden, dat het centrum van een zeer belangrijke scheepsbouwnijverheid was geworden. Als daarnaast nog enkele wijzigingen zouden worden aăngebracht in de grenzen van een aantal andere districten, zou een indeling worden verkregen die aan de eisen van de inspectiedienst beantwoordde. 
Vanuit de Tweede Kamer werd deze motivering voor uitbreiding door een aantal leden onvoldoende gevonden $^{28}$. Het belangrijkste argament dat zij aanvoerden, dat niet het aantal arbeiders van doorslaggevende betekenis van de werkzaamheden van de arbeidsinspectie was, maar het soort van fabrieken ${ }^{69}$. Daarnaast was men er niet zo van overtuigd dat de door de minister verwachte verdere uitbreiding van activiteiten ook bewaarheid zou worden, daar de oorlog nog voortduurde en een vrede nog niet in zicht was. Anderen hadden meer principiele bezwaren. Uitbreiding van het aantal districten zou huns inziens de te behartigen belangen schaden. De betrekkelijke omvangrijkheid van de districten wat zowel in de oorlogsjaren als daarvoor een groot voordeel is gebleken. Daardoor waren de adviezen van de districtshoofden, die de bedrijven en toestanden in verschillende gemeenten kenden en deze in onderling verband met elkaar konden beschouwen, van buitengewoon groot nut geweest. Overbelasting van de districtshoofden was dan ook zeker niet toe te schrijven aan de omvang van de districten, maar aan de administratieve omslag. Als voldoende bekwaam personeel aan het districtshoofd werd toegevoegd, zodat deze zich kon beperken tot de algemene leiding van het district en de details overgelaten konden worden aan de onder hem werkzame ambtenaren, dan zou de ruime blik die hij in een groot district verkreeg hem juist het oplossen van moeilijke vraagstukken zeer vereenvoudigen. Trouwens, zo vervolgden zij, de hele organisatie wees er al op, dat de districtshoofden geen detailwerkzaamheden behoorden te verrichten, maar dat zij zich hadden te bepalen tot de organisatie van het toezicht in hun district, tot de zorg dat hun ambtenaren goed werk leverden, tot het geven van adviezen en tot het oplossen van die vraagstukken, die ingrijpend waren en grotere belangen raakten. Daarbij beriepen zij zich op de toename van sociale wetten waardoor meer en meer in die richting gewezen werd. Maar in de Tweede Kamer waren ook voorstanders voor (een snelle) uitbreiding alleen al vanwege het feit, dat de vele werkzaamheden die de arbeidsinspectie in verband met de uitzonderlijke situatie verrichtte, een achterstand op het tot haar in normale omstandigheden behorende werkterrein tot gevolg had.

Dat de bewindsman niet onder de indruk was van de naar voren gebrachte bezwaren is niet verwonderlijk $^{\oplus 0}$. Tegen de praktische bezwaren voerde hij aan, dat de uitbreiding van het aantal districten zo was gekozen, dat tegemoet gekomen kan worden aan de eis om het derde district te ontlasten, maar eveneens (reeds) belangrijke en steeds belangrijker wordende industrie gebieden - Rotterdam en omgeving, Zeeuws-Vlaanderen en de westelijke helft van Noord-Brabant - tot hwn recht te doen komen. Tegen de principiële bezwaren voerde de bewindsman aan, dat bij de uitbreiding van het aantal districten met een in een periode van bijna 20 jaar - een periode waarin door industriële expansie en door aanvulling van wettelijke bepalingen op het terrein van de arbeidersbescherming aan de arbeidsinspectie steeds hogere eisen waren gesteld - toch moeillijk van een verandering van het systeem gesproken kan worden, in die zin dat gebroken zou worden met het bestaande stelsel van betrekkelijk omvangrijke districten.

Belangrijker echter was zijn stellingname tegen de weergegeven opvattingen over de taak van het districtshoofd. Het districtshoofd diende zich door persoonlijk onderzoek op de hoogte te houden van de toestanden in zijn district. Een te groot of uitgestrekt district leidde er toe, dat hij deze taak niet meer naar behoren kon vervullen, zodat tot inkrimping van een dergelijk district overgegaan moest worden. Een steeds weer zoeken van een oplossing in de uitbreiding van het aan hem toegevoegde personeel, zou uiteindelijk alleen maar tot gevolg hebben, dat het districtshoofd door de ogen van deze aan hem toegevoegde personen ging zien. Bovendien moest niet vergeten worden, dat het districtshoofd de volle verantwoordelijkheid had te dragen. van de door hem te geven "voorschriften" of "nadere aanwijzingen", met vaak zeer ingrijpende consequenties voor de betrokken ondernemingen; een verantwoordelijkheid die toch alleen gedragen kon worden, wanneer het districtshoofd of zelf de onderneming met het oog hierop had bezocht of voldoende op de hoogte was van de betrokken inrichting. Het argument, dat de districtshoofden te veel in beslag waren genomen door de administratieve omslag werd door de minister bestreden, met de opmerking, dat woor het soepel kunnen werken met een omvangrijke diensttak een nauwkeurige administratie noodzakelijk was.

Trouwens, zo vervolgde hij, gedurende de oorlogsjaren had de arbeidsinspectie op allerlei gebied onschatbare diensten bewezen wat niet in geringe mate te danken was aan een uitmuntende registratie waardoor met grote snelheid gegevens konden worden verstrekt, waarvoor anders tijdrovende en moeilijke onderzoekingen nodig zouden zijn geweest. Een goede administratie was dus van groot belang, zodat het districtshoofd zich 
daaraan niet geheel kon onttrekken. Veel tijd had hij daaraan overigens niet te besteden, omdat aan hem een aantal ambtenaren waren toegevoegd die onder leiding werkten van een chef de bureau aan wie de gewone administratile kon worden overgelaten. Het districtshoofd kon en moest zich dan ook hoofdzakelijk bepalen tot zijn zeer belangrijke technische, sociale arbeid, aldus de bewindsman.

De voorstanders van uitbreiding van het aantal districten deelde hij tot slot mede, dat bevorderd zou worden dit zo snel mogelijk na het vaststellen van de begroting te verwezenlijken; een toezegging die hij gestand zou doen. Op 13 juli 1918 werd de nieuwe verdeling van het Rijk in nu 10 districten vastgesteld ${ }^{91}$.

\section{Bijzondere opdrachten}

Evenals in de vorige periode bevatten de Centrale Jaarverslagen der Arbeidsinspectie opnieuw onder meer informatie onder de naam bijzondere opdrachten, dus los van de werkzaamheden die als gevolg van de bijzondere tijdsomstandigheden besproken zijn, hoewel deze bijzondere opdrachten in deze periode wel tot een minimum beperkt zijn gebleven.

De minister van Landbouw, Nijverheid en Handel richtte zich in november 1913 bij schrijven ${ }^{\text {e2 }}$ aan zijn ambtgenoten, met uitzondering van die van Buitenllandse Zaken. In dit schrijven deelde hij mee het een dringende eis te achten

"dat bij aanbesteding van Rijkswerken den aannemers de verplichtingen werden opgelegd welke noodig zijn om aan de arbeiders behoorlijk arbeidsvoorwaarden te waarborgen, die niet achterstaan bij de ter plaatse gebruikelijke en om hen te beschermen tegen den invloed van voor hunne gezondheid nadeelige werkzaamheden".

Evenzeer kwam het hem noodzakelijk voor,

"dat in deze door de verschillende takken van staatsdienst zoveel mogelijk eenzelfde gedragslijn werde gevolgd".

Elk van de ministeries wees daarop naar aanleiding van dit schrijven éen of meer vertegenwoordigers ${ }^{83}$ aan, die op 2 mei onder leiding van de directeur-generaal van de Arbeid, de besprekingen geopend hebben die tot doel hadden eenheid in de bedoelde bepalingen te brengen. $\mathrm{Na}$ een tweetal vergaderingen werden de werkzaamheden als gevolg van de oorlogssituatie gestaakt ${ }^{84}$.

Op verzoek van de directeur-generaal der Posterijen, werd een onderzoek ingesteld naar de voorwaarden, waaronder postillans hun arbeid verrichten; ên en ander gebeurde in verband met de aanbesteding van postritten, die in begin 1915 zou plaatshebben.

Uit het onderzoek bleek, dat verschillende vastgestelde dienstvoorwaarden niet of onvoldoende werden nageleefd, en dat wijziging van een aantal dienstvoorwaarden gewenst was, waartoe voorstellen werden gedaan. Nadat de bedoelde aanbesteding had plaatsgevonden, bleek het toezicht op de naleving van de arbeidsvoorwaarden van de postillans onvoldoende. Als gevolg van het daarover gevoerde overleg werd besloten dit toezicht nà de eerstvolgende aanbesteding aan de arbeidsinspectie op te dragen ${ }^{25}$.

De werkzaamheden van de in 1911 ingestelde staatscommissie inzake Electriciteitsvoorziening, alsook van de Electriciteitscommissie - de directeur-generaal van de Arbeid was van beide commissies voorzitter - zouden in augustus 1916 worden beëindigd ${ }^{06}$.

Een verzoek van de Rijksbouwkundige voor de gebouwen van Onderwijs om voorlichting ten aanzien van de regeling van de arbeidsvoorwaarden voor de arbeiders bij in uitvoering zijnde Rijksbouwwerken te Leiden, was voor de directeur-generaal van de Arbeid aanleiding een onderzoek te doen instellen naar de hoogte van de loonstandaard in het bouwbedrijf in die gemeente. De resultaten van dat onderzoek werden aan de Rijksbouwkundige medegedeeld, teneinde bij de bedoelde regeling als maatstaf te kunnen dienen ${ }^{87}$. 


\section{Rapporten en verslagen}

Ter openbaarmaking van de uitkomsten van verschillende enquêtes, hetzij verricht door ambtenaren van de arbeidsinspectie, hetzij verricht door speciale enquêteurs toegevoegd aan de directeurgeneraal van de arbeid, zijn in de betreffende periode onder meer de volgende rapporten en verslagen verschenen:

a. omtrent de Handvlasserij in Friesland ${ }^{\mathrm{s8}}$;

b. omtrent de Arbeid van vrouwen en meisjes in het winkelbedrijf, benevens eenige mededeelingen omtrent dit laatste. Tot het instellen van een dergelijk onderzoek was al in 1909 besloten. Met het onderzoek was belast de tijdelijke enquêtrice mevrouw C.G. van Herwerden-Steffens ${ }^{99}$. Door ziekte werd het onderzoek belangrijk vertraagd. Toen bleek dat zij haar taak niet meer kon voortzetten, werd het onderzoek in 1912 overgenomen door mevrouw S.F.M.E, van Deth-den Ouden ${ }^{100}$. De controleur van de arbeid H.P.de Haas heeft de bouwstoffen geleverd voor de mededelingen over het winkelbedrijf. Hoewel het winkelbedrijf slechts bij uitzondering onder de werkingssfeer van de Arbeidswet 1911 of de Veiligheildswet 1895 valt, waardoor het voor een belangrijk deel buiten het gezichtsveld van de arbeidsinspectie bleef en er een zekere angst bestond voor het ingrijpen van de overheid in het dan toe vrije bedrijf, hebben de enquêtrices niet te klagen gehad over gebrek aan medewerking. Het onderzoek omvat in hoofdzaak de werktijd en de lonen ${ }^{101}$, c. omtrent de Gedwongen Winkelnering in onderscheidene bedrijfstakken in verschillende deelen des lands; d. omtrent het oudbakken worden van brood en de middelen om dit te voorkomen. Het eerste deel van dit onderzoek, dat verricht is door J.R.Katz, beschrijft het gehele procédé van de broodfabrikage en deelt de methoden mee, die gebruikt kunnen worden om het brood vers te houden, met andere woorden: de meer praktische uitkomsten van het onderzoek, terwijl het tweede deel in hoofdzaak een verslag is van het eigenlijke wetenschappelijke onderzoek ${ }^{102}$;

e. omtrent Arbeidersbudgets gedurende de crisis. Tijdens het onderzoek naar de economische toestand van de bevolking, dat sinds augustus 1914 herhaaldelijk door de arbeidsinspectie werd ingesteld, heeft de vraag, in welke mate de noodzakelijke uitgaven van het arbeidersgezin, door de sterke prijsstijging van alle levensbehoeften, zijn gestegen in verschillende delen van het land, deze dienst beziggehouden. Het onderzoek van S.J. van Thienen betreft de arbeidersbudgets in Gelderland. Door J. Goudriaan Jr., mevrouw E.J. Tilanus en J.W. Sleeft zijn gegevens verzameld over de arbeidersbudgets in de hoofdstad. Daarnaast zijn er nog verschillende gegevens van anderen opgenomen ${ }^{100}$. 
noten

1. Nadat op 28 juli 1914 Oostenrijk-Hongarje aan Servië de oorlog had verklaard, volgde op 1 augustus de Duitse oorlogsverklaring aan Rusland en op 3 augustus aan Frankrijk. Toen op 2 augustus Duitsland, niettegenstaande het partij was bij de in 1839 aan België gegarandeerde permanente neutraliteit, dat land was binnengevallen, ging Engeland op 4 augustus tot een oorlogsverklaring aan Duitsland over. Reeds enkele weken later kreeg de strijd ook een buiten-Europees karakter, toen Japan zich op 23 augustus aan de zijde van de geallieerden - Frankrijk, Engeland, Rusland, Servië en België - tegen de Centralen - Duitsland en Oostenrijk-Hongarije - schaarden.

2. Op 30 juli 1914 vaardigde de Nederlandse regering met betrekking tot de oorlog tussen Oostenrijk-Hongarije en Servie een neutraliteitsverklaring wit - Stcrt. no. 176 -, waarop zij bij elke volgende oorlogsverklaring tot een soortgelijke stap overging.

3. Zie onder meer de troonrede van 15 september 1914, weergegeven door $E$. van Raalte, t.a.p., blz. 215 en Centraal Verslag der Arbeidsinspectie over 1914 's-Gravenhage 1916, blz. 375. Zie ook G. Harmsen/B. Reinalda, ta.p., blz. $122-123$.

4. Zoals bijvoorbeeld het uitbrengen van het jaarverslag, dat eerst met ongeveer én jaar vertraging in 1916 werd gepubliceerd.

5. Centraal Verslag der Arbeidsïnspectie over 1914, blz. 375.

6. Besluit van 27 juni 1913, Stb. 317 ; gewijzigd bij Besluit van 20 april 1914, Stb. 185. De inwerkingtreding van het bedoelde Besluit van 27 juni 1913 op 1 juni 1914 is geregeld in artikel 264 aldaar. Dit besluit zou vervangen worden door het Besluit van 19 augustus 1916, Stb. 417. De inwerkingtreding - behoudens E6n uitzondering - op 1 oktober 1916 is geregeld in artikel 272 aldaar.

7. Zie Centraal Verslag der Arbeidsinspectie over 1914, blz. 16 - 17 en blz. 375.

8. Zie Centraal Verslag der Arbeidsinspectie over 1914, blz. 375 - 376.

9. Zie Centraal Verslag der Arbeidsinspectie over 1915, over 1916 en over 1917, Arnhem (z.j.), resp. blz. 14, blz. 20 en blz. 15 .

10. Zie over het ontstaan van de Vereeniging het Eindverslag Staatscommissie over de Werkloosheid, blz. $626-627$

11. Bij Besluit van 30 juli 1909 , no. 42 .

12. Juni 1914.

13. Brief van 3 augustus 1914; weergegeven in Centraal Verslag der Arbeidsinspectie over 1914, blz. 377; Rijksarchief, $2 \mathrm{e}$ afdelling, Hoogerhuisinventaris no. 1434.

14. Anth. Folmer, Arbeidsmarkt en Arbeidsbemiddeling; Voorkoming en bestrijding van werkloosheid; Werkloosheidsvoorziening, in Het Departement van Arbeid, Handel en Nijverheid onder minister Aalberse 1918 - 1925, Alphen a/d Rijn 1926, blz. 170 - 171; A.N. Molenaar, t.a.p. IIB, blz. 2168 - 2169; M.G. Levenbach, 
Arbeid, in Nederlands Bestuursrecht, blz. 451; S. Mok, Arbeidsrecht, Amsterdam 1936, blz. 88 - 89; M.W.F. Treub, Oorlogstijd, Haarlem/Amsterdam 1916, blz. 165 t/m 171. Zie voorts G.J. Goedhart/A. Roeterink, De ontwikkeling der arbeidsbemiddeling in Nederland, Amsterdam 1929.

15. Zoals de Nationale Werkloosheidsraad ( een particuliere organisatie, die op 19 juni 1914 haar beslag kreeg ), de Algemeene Armencommissie, de Nationalen Vrouwenraad, de Tuinbouwraad, het Landbouwcomité, de Maatschappij van Nijverheid, de plaatselijke comite's uit de vier grote steden - Amsterdam, Rotterdam, 's-Gravenhage en Utrecht - alsook het Nederlandsch Verbond van Vakvereenigingen, het Bureau van de Roomsch Katholieke Vakorganisatie, het Christelijk Vaksecretariaat, het Nederlandsch Verbond van Neutrale Vakvereenigingen. Zie M.W.F. Treub, t.a.p, blz. 118 - 119; P.E. de Hen, Actieve en reactieve industrie-politiek in Nederland, De overheid en de ontwikkeling van de Nederlandsche industrie in de jaren dertig en tussen 1945 en 1950, Amsterdam, blz. 66; M.G. Levenbach, Arbeid, in Nederlands bestuursrecht, blz. 450.

16. M.W.F. Treub, t.a.p., blz. 123; Centraal Verslag der Arbeidsinspectie over 1914, blz. 378.

17. De voorzitters van de Werkloosheidsraad, de Algemeene Armencommissie, de Nationale Vrouwenraad, de Nederlandsche Tuinbouwraad, het Nederlandsch Landbouwcomitê en van de Maatschappij van Nijverheid zouden gezamenlijk bepalen wie de Uitvoerende Commissie zouden vormen

"en daarbij in het oog zullen houden eenerzijds dat het uitvoerende comité vertegenwoordigers der genoemde organisaties en ook van de vakorganisaties moet bevatten, anderzijds dat zoo mogelijk de verschillende politieke richtingen in de Uitvoerende Commissie vertegenwoordigd moeten zijn";

zie M.W.F. Treub, t.a.p, blz. 125.

18. De samenstelling van de Uitvoerende Commissie was als volgt: M.W.F. Treub (voorzitter), Is. P. de Vooys (vice-voorzitter), mevrouw H. van Biema-Hymans ( Nationale Vrouwenraad), W.Th.C. van Doorn (Nederlandsche Tuinbouwraad, tevens penningmeester ), J. van Hasselt (Maatschappij van Nijverheid), J.R. Snoeck Henkemans (Algemeene Armencommissie ), J.T. Linthorst Homan (Nederlandsch Landbouwcomite ), W.H. Nolens, J. Oudegeest, A.S. Talma (Werkloosheidsraad), H.A. van IJsselsteyn ( directeurgeneraal van de Arbeid - secretaris: hem werden als adjunct-secretarissen toegevoegd J.W. Albarda, W.M. de Brauw, J.G. Meilink, W.A.J.M. van Waterschoot van der Gracht en J.A. de Wilde ); zie M.W.F. Treub, t.a.p., blz. 126 .

19. M.W.F. Treub, t.a.p., blz. 126.

20. De samenstelling van deze commissie was als volgt: A. Plate (voorzitter), A.G. Kröller, Jhr. H. London, F.G. Waller en vertegenwoordigers van de Tuinbouwraad, het Landbouwcomite en de Maatschappij en de directeur-generaal van Landbouw en het hoofd van de Afdeling Handel van het Ministerie van Landbouw, Nijverheid en Handel; zie M.W.F. Treub t.a.p., blz. 268.

21. Haar taak werd in de notulen van de oprichtingsvergadering als volgt gezien:

"De taak der Commissie zal vooral omvatten:

1e. het voorkomen, dat voedingsmiddelen, die op het oogenblik geen of geen voldoende markt vinden, bederven en verloren gaan;

2e. de fabriekmatige produktie en conserveering van levensmiddelen gaan te houden;

$3 \mathrm{e}$. de regelmatige en doelmatige distributie van voedingsmiddelen te verzekeren.

Hiertoe zal, in samenwerking met de daarmede alreeds belaste Afdeelingen van het Departement van Landbouw vooral aandacht gewijd worden aan de distributie van noodzakelijke 
grondstoffen en hulpmiddelen, als steenkolen, die in de eerste plaats ten goede moeten komen aan de productie en distributie van voedingsmiddelen.

Tenslotte zal deze Commissie met de Regeering samenwerken in hare pogingen tot beperking van verdere uitbreiding der werkeloosheid. Met het oog op het laatste wordt alreeds in beginsel besloten, dat men zich dadelijk zal wenden tot de plaatselijke steuncommissies en de organisaties op het gebied van den arbeid, met het verzoek het Comite te willen inlichten, ingeval eenige industrie dreigt te worden stopgezet, onder mededeeling van de redenen hiervan en van eventueele middelen om zulks te voorkomen.

De Afdeeling Arbeid zal zich ten deze wenden tot de fabrieken zelve, aangezien dit meer op haar weg ligt. Overigens zullen de Afdeelingen van het Departement ten deze in alles met het Comité samenwerken, en worden hier de noodige gegevens en cijfers verzameld, die men voor de beoordeling van den toestand nodig heeft."

Zie M.W.F. Treub, t.a.p., blz. 268 - 269.

22. Brief van 11 augustus 1914. Zie het Centraal Verslag der Arbeidsinspectie over 1914, blz. 378; de vragenformulieren zijn aldaar weergegeven op blz. $379 \mathrm{t} / \mathrm{m} 381$.

23. De ministers van Buitenlandse Zaken, van Landbouw, Nijverheid en Handel, van Oorlog en van Financiën.

24. Centraal Verslag der Arbeidsinspectie over 1914, blz. 382.

25. Zie M.W.F. Treub, t.a.p., blz. 158; Centraal Verslag der Arbeidsinspectie over 1914, blz. 382.

26. Brief van 11 augustus 1914, VIde Afdeling no. 90; Rijksarchief, 2e afdeling, Hoogerhuis-inventaris no. 1390. Blijkens onder andere de brief van 7 juli 1915, no. 19832, van de directeur-generaal van de Arbeid aan de minister van Landbouw, Nijverheid en Handel, verliep de samenwerking niet altijd even vlekkeloos; Rijksarchief, 2e afdeling, Hoogerhuis-inventaris no. 1390.

27. Zie de brief van de directeur-generaal van de Arbeid van 21 september 1915 , no. 23489, aan de directeur der Centrale Magazijnen; Rijksarchief, 2e afdeling, Hoogerhuis-inventaris nr. 1390.

Zie de brief van de directeur-generaal van de Arbeid aan de minister van Oorlog van 4 maart 1915 , no. 5325. Daarin komt de volgende passage voor:

"Uit het onderhoud dat ik met de vertegenwoordigers van den in den aanhef van dit schryven genoemde Bond had, en door het, trouwens zeer voorloopige onderzoek dat ik dienaangaande heb laten instellen, is mij gebleken, dat er thans op groote schaal uitgifte van kleederen plaats heeft aan confectiefabrikanten. Het gevolg daarvan is, dat, terwyl honderden kleedermakers in de hoofdstad werkloos zyn, een groot deel van den door het Centrale Magazyn uitgegeven arbeid geschiedt door meisjes, die daarmee een hongerloon verdienen, terwyl het Ryk aan de tussenpersonen voor het maakloon bedragen betaalt, die zeer belangryk hooger zyn, dan hetgeen zelfs aan volwassen arbeiders zou behoeven te worden uitgekeerd".

De in deze passage voorkomende verwijzing naar "genoemden Bond" betreft de Nederlandsche Bond van mannelijke en vrouwelijke arbeiders in de kleedingindustrie en aanverwante vakken, die zich bijschrijven van 18 februari 1915, no. 96, gewend had tot de directeur-generaal van de Arbeid. Beide brieven zijn te vinden bij Rijksarchief, $2 \mathrm{e}$ afdeling, Hoogerhuisinventaris no. 1390 .

28. Centraal Verslag der Arbeidsinspectie over 1914, over 1915, over 1916 en over 1917, resp. blz. 382, blz. $299-300$, blz. $394-395$ en blz. $379-380$. 
29. Zie Centraal Verslag der Arbeidsinspectie over 1914, blz 383 - 384.

30. Wet van 22 juni 1901 , Stb. 158 .

31. Centraal Verslag der Arbeidsinspectie over 1914 en over 1916 , resp. blz. 382 t/m 385 en blz. 394 .

32. Bij brief van 19 augustus 1914; zie Centraal Verslag der Arbeidsinspectie over 1914, blz. 385.

33. Centraal Verslag der Arbeidsinspectie over 1914, blz. 385; zie voor de omvang van deze bemoelienis Centraal Verslag der Arbeidsinspectie over 1915, blz. 301.

34. Centraal Verslag der Arbeidsinspectie over 1915, blz. $294-295$.

35. Centraal Verslag der Arbeidsinspectie over 1915 en over 1916, resp. blz. 295 en blz. 393. Zie voor een omvang van deze bemoeienis Centraal Verslag der Arbeidsinspectie over 1916, over 1917 en over 1918, resp. blz. 397 , blz. 378 en blz. 368 .

36. Sinds 1904 bestond er cen Entente Cordiale tussen Engeland en Frankrijk die aanvankelijk betrekking had op koloniale invloedssferen. De Entente Cordiale leidde uiteindelijk tot een Engels-Franse samenwerking tegen Duitsland. In 1912 werd de Entente-Cordiale uitgebreid tot een algemeen militair verband, waarbij werd bepaald, dat Engeland Frankrijks noordkust zou beschermen in geval van een oorlog.

Nadat Engeland met Rusland een overeenkomst had getekend over de verdeling van Perziè in invloedssferen ontstond in augustus 1907 een Triple Entente. Deze Entente raakte in 1914 in oorlog met Duitsland en Oostenrijk-Hongarije ( tesamen met Turkije de Triple Alliantie vormend, welke met haar bondgenoten ook well de Centralen genoemd, terwijl de Triple Entente met haar bondgenoten onder de naam Geallieerden bekend zijn ).

37. Zie de brief van 11 maart 1915, no. 5570, van de directeur-genèraal van de Arbeid aan de districtshoofden van de arbeidsinspectie; Rijksarchief, $2 \mathrm{e}$ afdeling, Hoogerhuisinventaris no. 1365. Zie voor een model van een certificaat van oorsprong de brief van de minister van Financiën van 26 maart 1917, no. 110; Rijksarchief, $2 \mathrm{e}$ afdeling, Hoogerhuis-inventaris no. 1365.

38. Brief van de minister van Financiën van 15 mei 1915, Afd. Invoerrechten no. 160, aan de directeuren der directe belastingen, en van de directeur-generaal van de Arbeid van 21 mei 1915, no. 13386, aan de districtshoofden van de arbeidsinspectie. Brief van de minister van Financiẻn van 23 december 1915, Afd. Invoerrechten no. 163, aan de directeuren der Directe Belastingen. Brief van de minister van Financiën van 30 december 1915, Afd. Invoerrechten no. 190, aan de directeuren der Directe Belastingen; Rijksarchief, 2e afdeling, Hoogerhuis-inventaris no. 1365 .

39. Brief van de minister van Financiën van 11 oktober 1915 , Afd. Invoerrechten no. 158, aan de directeuren der Directe Belastingen; Rijksarchief, 2e afdeling, Hoogerhuis-inventaris no. 1365.

40. Brief van de directeur-generaal van de Arbeid van 21 oktober 1915, no. 25303, aan de districtshoofden; Rijksarchief, 2e afdeling, Hoogerhuis-inventaris no. 1365. Zie ook Centraal Verslag der Arbeidsinspectie over 1915, blz. 296 - 297.

41. Centraal Verslag der Arbeidsinspectie over 1916, over 1917 en over 1918 resp. blz. 396 - 397, blz. 379 en 367. 
42. Centraal Verslag der Arbeidsinspectie over 1916, blz. 397.

43. In dit verband kan opgemerkt worden, dat hiermee de basis is gelegd voor de Wet tot regeling van arbeid in loondienst door vreemdelingen 1934 (Stb. 257), de directe voorganger van de Wet arbeidsvergunning vreemdelingen (Stb. 1964, 72) welke wet werd ingetrokken door de Wet arbeid buitenlandse werknemers (Stb. 1978, 737). Deze laatste op 2 november 1979 in werking getreden wet gaat er van uit, dat de inschakeling van buitenlandse werknemers slechts wordt toegestaan indien de arbeidsmarkt geen redelijke andere mogelijkheden - werkloze Nederlandse werknemers of andere buitenlandse werknemers zonder werk - biedt. Zie D. Christe, Arbeidsovereenkomst, Deventer, losbladig, WABW: cons. blz. $1 \mathrm{t} / \mathrm{m} 3$.

44. Centraal Verslag der Arbeidsinspectie over 1915, blz. 295 - 296. Een dergelijke, wat genoemd wordt, competentiestrijd zal in het vervolg herhaaldelijk terugkeren.

45. Centraal Verslag der Arbeidsinspectie over 1916, blz. 395.

46. De andere commissie, die bedoeld wordt, is de commissie voor de voeding van mensch en dier - ingesteld op 4 januari 1915. De Nijverheidscommissie werd gesteld onder voorzitterschap van Is. P. de Vooys, als voorzitter van de uitvoerende commissie van het Koninklijk Nationaal Steuncomite. Als leden werden opgenomen zij die reeds zitting hadden in de Commissie voor economische belangen (zie nt. 20); voorts werd zij samengesteld uit de voorzitters van de verschillende algemene verenigingen en bonden op industrieel gebied en werden bovendien als leden opgenomen S. Hoogewerf, D.W. IJssel de Schepper, W.F.J. Frowein (directeur van de Staatsmijnen), A. Haex (secretaris van de Commissie voor de afzet van Limburgse kolen), de directeur-generaal van de Arbeid als algemeen secretaris (tevens algemeen secretaris van het Koninklijk Nationaal Steuncomite) en het hoofd van de Afdeling Handel van het ministerie van Landbouw, Nijverheid en Handel (adviserend lid); zie M.W.F. Treub, t.a.p., blz. 274.

47. Bestaande uit de leden. Is. P. de Vooys (voorzitter), D.G. van Beuningen, F.H. Fentener van Vlissingen ( beiden directeur van de Steenkolenhandelsvereeniging), W. van der Vorm (directeur van de Scheepvaarten Steenkolen Maatschappij ),W.F.J. Frowein ( directeur van de Staatsmijnen ), W. Schweitser ( directeur van de Lanva en Vereeniging ( tevens vertegenwoordiger van de mijnondernemingen Willem-Sophia en de Domaniale Mijnen), D.W. Stork, F.G. Waller, ( beiden grootverbruikers van kolen ); zie M.W.F. Treub, t.a.p., blz. 276.

Een verslag van het Kolenbureau met 5 bijlagen, "s-Gravenhage, is te vinden in het Rijksarchief, $2 \mathrm{e}$ afdeling, Hoogerhuis-inventaris no. 1314.

48. Zie hiervoor voorstellen van de Kolencommissie aangaande Kolenreserve, Amsterdam; Rijksarchief, 2e afdeling, Hoogerhuis-inventaris no. 1314.

49. Zie voor de statuten van deże maatschappij, Bijvoegsel ( no. 560 ) Stcrt. 10 augustus 1915, no. 185; bewilliging is verleend bij Koninklijk Besluit van 13 juli 1915 , no. 11. De directeur-generaal van de Arbeid was in juli 1915 als regeringsvertegenwoordiger in de raad van beheer van de Kolenreserve Maatschappij aangewezen.

50. Deze opzet is te vergelijken met de opbouw van de strategische oliereserves sinds de oliecrisis van 1973; een aangelegenheid waarbij de arbeidsinspectie geen rol heeft gespeeld.

51. De raad van beheer werd met uitvoering van de liquidatie bellast, aldus het Algemeen Handelsblad van 21 mei 1916; Rijksarchief, 2e afdeling Hoogerhuis-inventaris no. 1315. 
52. Centraal Verslag der Arbeidsinspectie over 1915, blz. 297; M.W.F. Treub, t.a.p, bla. 269 t/m 281, zie ook de Zesde Nota betreffende den economischen toestand, blz. $33-34$.

53. Wet van 16 augustus 1916 , tot vaststelling van bepalingen in het belang van de volksvoeding en van eene doelmatige distributie var goederen, Stb. 416.

54. Dat wil zeggen verbruikers van meer dan 20 ton steenkolen per maand.

55. Deze vragenlijst is te vinden in het Centraal Verslag der Arbeidsinspectie over 1917, blz. $382-383$.

56. Deze controleurs der Rijkskolendistributie waren: J.M. Steffelaar ( ingenieur bij de Octrooiraad ); W.F.H. Bönnekamp (opzichter van de arbeid); J.D. ter Hart (opzichter van de arbeid); N.J. Veen ( agent van de Rijksverzekeringsbank ); M. Herman ( agent van de Rijksverzekeringsbank); G.J.K. Both (opzichter van het Stoomwezen ); H.F. Petit (opzichter van de Provinciale Waterstaat van Zuid-Holland ); G. Hartman (opzichter van de Provinciale Waterstaat van Zuid-Holland); R. Gorter ( werktuigkundig ingenieur ); J. Koopman ( oud-officier machinist van de Marine ); B. de Groot (oud- officier machinist van de Marine); G.P.WJ. van der Klugt (oud-officier machinist van de Marine); B. Verhey (oud-officier machinist van de Marine ); J.P.A.M. Ohr ( oud-machinist van de Marine ); W.G. Ouwehand ( gepen. officier-machinist van de Marine ); H.G. Borghstijn (gepen. officier-machinist van de Marine ); W.F. de Loenen (oud-machinist van de Marine ); H. Lansdorp ( oud-officier-machinist van de Marine ); G.J. Klaase ( machinist ter koopvaardij ); W.C.A. Hofkamp (oud-directeur van Gemeentewerken ) en J.H. Ruigrok ( oud-officier van de Administratie van de Marine en oud-wasindustrieel ).

57. Centraal Verslag der Arbeidsinspectie over 1915, over 1916 en over 1917, resp. blz. 297, blz. 396 en blz. $380 \mathrm{t} / \mathrm{m} 385$.

58. Zie daarvoor, alsook voor andere informatie, Centraal Verslag der Arbeidsinspectie over 1915, Hfdst. XXI Prijsregeling van turf, blz. $434 \mathrm{t} / \mathrm{m}$ 444. Zie ook J. Mulder, Het Nederlandsche veen, in Gedenkboek 50 jaar, blz. $150 \mathrm{t} / \mathrm{m} \mathrm{177;} \mathrm{S.} \mathrm{van} \mathrm{der} \mathrm{Hoek,} \mathrm{Het} \mathrm{Bruine} \mathrm{Goud,} \mathrm{kroniek} \mathrm{van} \mathrm{de} \mathrm{turfgravers} \mathrm{in} \mathrm{Nederland,} \mathrm{Am-}$ sterdam 1985. Dit gebeurde door de directeur-generaal van de Arbeid bij brief van 8 november 1915 , no. 75687 , aan alle verveners in Nederland. Deze laatsten moesten uiterlijk 15 november van dat jaar reageren.

59. Dat de arbeidsinspectie bekend was met het vervenersbedrijf en de plaatselijke toestanden in de uitgestrekte en ver uiteenliggende veenplaatsen in ons land moge onder meer blijken uit het onderzoek neergelegd in "De gedwongen winkelnering in de venen", 's-Gravenhage 1913 ( uitgave Directie van de Arbeid no. 12).

60. Wet van 28 augustus 1851, Stb. 125; gewijzigd bij de Wet van 3 augustus 1914, tot aanvulling van de Onteigeningswet ter voorkoming van vasthouding en prijsopdrijving van waren, $S t b$. 351. De maximum-prijsregeling voor turf is echter gedifferentieerd tot stand gekomen: eind december 1915 voor de noordelijke provincies ( circulaire van 20 december 1915, Afd. Handel, no. 56645; Rijksarchief, 2e afdeling, Hoogerhuis-inventaris no. 1340), om op 10 januari 1916 uitgebreid te worden voor de turf afkomstig uit de provincies Noord-Brabant en Limburg ( circulaire van 10 januari 1916, Afd. Handel no. 526; Rijksarchief, 2e afdeling, Hoogerhuis-inventaris no. 1340 ), waarna enige tijd later de vaststelling volgde voor Holllandse en Utrechtse turf. Zie Centraal Verslag der Arbeidsinspectie over 1916, blz. 451.

61. Zie circulaire van 25 augustus 1916 , Afd. Handel no. 64702; Rijksarchief, 2e afdeling Hoogerhuis inventaris no. 1343. 
62. In feite al aangekondigd door de minister van Landbouw, Nijverheid en Handel in de beantwoording op 13 maart 1916 op vragen van het Tweede Kamerlid Sannes inzake turfvoorziening (ingezonden 6 maart 1916); zie Aanhangsel Hand. Tweede Kamer, zitting 1915 - 1916, blz. 89.

63. De strafsanctie - gevangenisstraf van ten hoogste vier jaren of geldboete van ten hoogste tienduizend gulden - gold eveneens voor het opzettelijk te koop aanbieden of verkopen van goederen tegen hogere prijzen dan zijn toegestaan.

64. Beschikking van 9 oktober 1916, no. 79418, Afd. Handel.

65. Deze bestond uit de leden A. de Witte (voorzitter), M.T. Omzeele (secretaris), A. de Vries, C.J. Hendricks, W.J. Holthuis, A. Goedewaagen jr. en W.A. Hoying; zie Centraal Versllag der Arbeidsinspectie over 1916 en over 1917 , blz. 454 - 455 en blz. 486 .

66. De directeur-generaal van de Arbeid heeft, blijkens het Centraal Verslag der Arbeidsinspectie over 1916, blz. 455 , sllechts éenmaal van deze bevoegdheid gebruik gemaakt.

67. Beschikking van 1 oktober 1917, Afd. Crisiszaken bureau volksvoeding no. 202374, krachtens de Wet van 1 september 1917, waarbij de Wet van 3 augustus 1914, houdende verbod tot uit- en vervoer van sommige artikelen, Stb. 344, werd gewijzigd, Stb. 578. De beschikkingen van 27 april 1917, afd. Handel no. 36396, en 12 mei 1917, afd. Handel no. 39063, werden bij deze gelegenheid ingetrokken ( beide beschïkingen waren gebaseerd op artikel 8 van de Distributiewet 1916).

68. Beschikking van 14 juli 1917, afd. Handel, no. 58049. Deze werd enigszins herzien bij de beschikking van 9 oktober 1917, afd. Crisiszaken bureau nijverheid, no. 10367. Zie Centraal Verslag der Arbeidsinspectie over 1917, blz. 486; Rijksarchief, 2e afdeling Hoogerhuis-inventaris no. 1347/1346.

69. Centraal Verslag der Arbeidsinspectie over 1915, over 1916 en over 1917, resp. blz. 297 - 298, blz. 451 t/m 456 en blz. $484 \mathrm{t} / \mathrm{m} 486$.

70. Centraal Verslag der Arbeidsinspectie over 1915, over 1916 en over 1917, resp. blz. 298, blz. 393 en blz. 385; Zie ook M.W.F. Treub, t.a.p., blz. $281-282$.

71. Centraal Verslag der Arbeidsinspectie over 1915 en over 1916, resp. blz. 298 en blz. 394.

72. Centraal Verslag der Arbeidsinspectie over 1915, blz. 298.

73. Centraal Verslag der Arbeidsinspectie over 1916, blz. 396.

74. Brief van 2 november 1914, Tweede Kamer, zitting $1914-1915,212.1$.

75. Tweede Kamer, zitting 1914 - 1915, 212.2.

76. Tweede Nota betreffende den economischen toestand, Tweede Kamer, zitting 1914 - 1915, 212.4; Derde Nota betreffende den economischen toestand; Tweede Kamer, zitting 1914-1915, 212.6; Vierde Nota betreffende den economischen toestand, Tweede Kamer, zitting 1914 - 1915, 212.8; Vijfde Nota betreffende den economischen toestand, Tweede Kamer, zitting 1914 - 1915, 212.11; Zesde Nota betreffende den economischen toestand, Tweede Kamer, zitting 1914 - 1915, 212.13; Zevende Nota betreffende den economischen toestand, Tweede Kamer, zitting 1915 - 1916, 127.2; Achtste Nota betreffende den economischen toestand, 
Tweede Kamer, zitting 1915 - 1916, 127.4; (Negende) Nota betreffende den economischen toestand, Tweede Kamer, zitting $1916-1917,440.2$.

77. F,A,G. Keesing, De conjuncturele ontwikkeling van Nederland en de evolutie van de economische overheidspolitiek 1918 - 1939, Nijmegen (reprint), blz, 9 - 10. Zie ook P.E. de Hen, t.a.p., blz. 44.

78. F.A.G. Keesing, t.a.p., blz. 9.

79. P.E. de Hen, t.a.p., blz. 44.

80. J.A. de Jonge, t.a.p., blz. 338; P.E. de Hen, t.a.p., blz. 44 - 45. Zie over de mantregelen op economisch terrein ook onder meer M.W.F. Treub, t.a.p, blz. $188 \mathrm{t} / \mathrm{m} 391$ ( resp. de hfdst. IV Geld en krediet in den oorlogstijd, V Het op gang houden der bedrijven, en VI De oorlogstoestand en de schatkist ).

81. Aldus de naar mijn mening niet onterechte clain van C.J.Ph. Zaalberg, die H.A. van IJsselsteyn als directeur-generaal van de Arbeid opvolgde, in: Vijf en twintig jaar Centrale Dienst, in Gedenkboek 1909 - 1 september - 1934, blz. 16.

82. C.J.Ph. Zaalberg, in Gedenkboek 1909 - 1 september - 1934, blz. 16 t/m 19.

83. Aan de Nieuwen Uitleg 12 te 's-Gravemhage was de Centrale Dienst van de arbeidsinspectie gevestigd.

84. A.H.W. Hacke, die C.J.Ph. Zaalberg als directeur-generaal van de Arbeid opvolgde, in: Na vijf en twintig jaren Centrale Dienst der Arbeidsinspectie, in Gedenkboek 1909 - 1 september - 1934, blz. 21.

85. Besluit van 18 juli 1911, tot verdeling van het Rijk in districten ten behoeve van de dienst der Arbeidsinspectie, Stb. 257. De wijziging betreft het 3 de en het 5 de district. Het derde district omvatte nu:

"... het gedeelte der provincie Zuid-Holland dat gelegen is bezuiden den rechteroever van de Lek, de Nieuwe Maas, het Scheur en den Nieuwen Waterweg - met uitzondering van het rechtsgebied der kantongerechten Vianen en Gorinchem voor zoover dit laatste zich binnen de provincie Zuid-Holland uitstrekt - voorts het gedeelte dier provincie, dat behoort tot het rechtsgebied van het kantongerecht Schiedam, alsmede de gemeenten Rotterdam, Bergschenhoek, Capelle aan den IJssel, Hillegersberg, Schiebroek, Delft, Hof van Delft, De Lier, Monster, Naaldwijk, Schipluiden, Vrijenban en Wateringen;".

Het 5de district omvatte nu:

"... het gedeelte der provincie Noord-Holland, dat behoort tot het rechtsgebied van het kantongerecht Amsterdam, benevens het niet tot eenige provicie behoorende watergebied des Rijks;".

86. Tweede Kamer ( Bijlage A ), zitting 1917 - 1918, no. 2 ( Hfdst. X begroting Landbouw, Nijverheid en Handel ) blz. 13 - 14.

87. Zoals de steden Schiedam, Vlaardingen, Maassluis en Delft en de Zuidelijke Maasoever.

88. Tweede Kamer ( Bijlage A ), zitting 1917 - 1918, no. 10 ( Hfdst. X begroting Landbouw, Nijverheid en Handel ) blz. 7 - 8 . 
89. Daarbij werd gesteld dat bijvoorbeeld een spinnerij oneindig meer bemoeienissen voor het districtshoofd met zich bracht dan bijvoorbeeld eet scheepswerf of een machinefabriek. In het eerstgenoemde geval deden zich problemen voor van slotenbuiging, bestrijding van hoge temperaturen, beroepsziekten, enz., terwijl in het laatstgenoemde geval de nadruk lag op de beveiliging van werktuigen, hetgeen minder persoonlijke bemoeienissen van het districtshoofd vorderde.

90. Tweede Kamer ( Bijlage A ), zitting 1917 - 1918, no. 11 ( Hfdst. X begroting Landbouw, Nijverheid en Handel ) blz. $25-26$.

91. Besluit van 13 juli 1918, Stb. 449, onder intrekking van het Besluit van 18 juli 1911, Stb. 257. Artikel 1 van het nieuwe Besluit luidde:

"Ten behoeve van den dienst der arbeidsinspectie wordt het Rijk verdeeld in tien districten, waarvan omvatten:

het 1ste de provincie Limburg en het gedeelte der provincie NoordBrabant, dat behoort tot het rechtsgebied van de kantongerechten Veghel, Boxmeer, Eindhoven, Oirschot, Weert en Helmond;

het 2 de het gedeelte der provincie Noord-Brabant dat niet behoort tot het 1ste district; 'het 3de het gedeelte der provincie Zuid-Holland, dat behoort tot het rechtsgebied van de kantongerechten Schiedam en Rotterdam, alsmede de gemeenten Berkel, Delft, 's- Gravenhage, Hof van Delft, de Lier, Monster, Naaldwijk, Nootdorp, Pijnacker, Schipluiden, Vrijenban, Wateringen en IJsselmonde;

het 4de de provincie Utrecht, het gedeelte der provincie Zuid-Holland, dat behoort tot het rechtsgebied der kantongerechten 's-Gravenhage, Leiden, Gouda, Woerden, Alphen en Haarlemmermeer, het gedeelte van het rechtsgebied van het kantongerecht Delft, dat niet behoort tot het 3de district, het rechtsgebied van het kantongerecht Schoonhoven - met uitzondering van de gemeente Krimpen a/d IJssel, Krimpen a/d Lek en Lekkerkerk - benevens de gemeenten Vianen en Hagestein;

het 5 de het gedeelte der provincie Noord-Holland, dat behoort tot het rechtsgebied van het kantongerecht Amsterdam benevens het niet tot eenige provincie behoorende watergebied des Rijks;

het 6 de het gedeelte der provincie Noord-Holland, dat niet behoort tot het 5 de district; het $7 \mathrm{de}$ de provincie Gelderland;

het 8 ste de provincie Overijssel;

het $9 \mathrm{de}$ de provinciën Groningen, Friesland en Drenthe;

het $10 \mathrm{de}$ de provincie Zeeland en het gedeelte der provincie Zuid-Holland, dat niet behoort tot het 3 de en het 4 de district.".

92. Brief van 12 november 1913, no. 2958, Afd. Arbeid.

93. Bedoelde vertegenwoordigers zijn: V.I.E. de Blog van Kuffelen (Waterstaat ); J.A., Visman ( Binnenlandse Zaken ); W.H. Kam jr. ( Justitie ); C.H. Peters, D.E.C. Knuffel en A.G. Verhoeven ( Financiën ); jhr. J. van Heemskerk van Beest (Oorlog); J. 't Hooft (Marine) en J.E. Inchil (Koloniën ). Aan deze commissie werd de inspecteur van de arbeid C.J.P. Zaalberg als secretaris toegevoegd.

94. Centraal Verslag der Arbeidsinspectie over 1914, blz. 15 - 16.

95. Centraal Verslag der Arbeidsinspectie over 1914 en over 1915, resp. blz. 16 en blz. 13.

96. Centraal Verslag der Arbeidsinspectie over 1916, blz. 19. 
97. Centraal Verslag der Arbeidsinspectie over 1916, blz. 19 - 20.

98. De handvlasserij in Friesland, 's-Gravenvage 1915 ( uitgave Directie van de Arbeid no, 18).

99. Blijkens de ministeriële beschikking van 19 november 1909 , no. 3352, Afd. Arbeid.

100. Blijkens de ministeriële beschikking van 2 december 1912, no. 2863, Afd. Arbeid.

101. De arbeid van vrouwen en meisjes in het winkelbedrijf benevens eenige mededeelingen omtrent dit laatste, "s-Gravenhage ( uitgave Directie van de Arbeid no. 19). Zie omtrent pogingen om verbeteringen te brengen aan het lot van staande winkeljuffrouwen: A. Jacobs, Herinneringen, Nijmegen 1978 (reprint), met name hfdst. VII Mijne bemoeiingen ten opzichte van het vrouwelijke winkelpersoneel, blz. $117 \mathrm{t} / \mathrm{m} 131$.

102. Onderzoekingen naar het oudbakken worden van brood en de middelen om dit te voorkomen, Deel II Het versch houden van brood, "s-Gravenhage 1917 ( uitgave Directie van den Arbeid no. 21a), Deel II Het oudbakken worden van brood (een Physiologisch-Chemische Studie) 's-Gravenhage 1917 (uitgave Directie van de Arbeid no. 21b ).

103. Arbeidersbudgets gedurende de crisis, 's-Gravenhage 1917 ( uitgave Directie van de Arbeid no. 22 ). 


\section{Inleiding}

De met de oorlogsomstandigheden in verband staande crisismaatregelen, die een groot beslag hadden gelegd op de arbeidsinspectie, zouden al snel in betekenis afnemen na het beëindigen van de vijandelijkheden door middel van een aantal wapenstilstandovereenkomsten, waarvan de laatste op 11 november 1918 werd gesloten". De eerste na-oorlogse jaren, waarin ons land zich snel herstelde van de "wereldbrand", hetgeen mogelijk was omdat hier te lande geen materiële oorlogsschade was geleden, zouden nog de meeste bemoeienissen te zien geven ten aanzien van de zogenaamde certificaten van oorsprong, waarvoor nog vrij veel onderzoek diende te worden verricht. Onderzoeken naar aanleiding van verlofaanvragen van dienstplichtigen zouden nog slechts sporadisch voorkomen. Ook de activiteiten ten behoeve van het Nationaal Steuncomité zouden beduidend in omvang afnemen; hetzelfde gellt voor de werkzaamheden van het aan de arbeidsinspectie verbonden secretariaat van het Steuncomite. Na de liquidatie van de steunbeweging met ingang van 1 november 1919, waarbij een groot deel van de activiteit van het Steuncomite overging naar het ministerie van Binnenlandse Zaken en het nieuwe ministerie van Arbeid ${ }^{2}$, stonden de resterende bezigheden van dit secretariaat geheel in het teken van deze liquidatie ${ }^{3}$.

Louter gunstig was de economische situatie nà november 1918 echter niet; zo duurde de brandstofschaarste voort"; trad de arbeidende klasse naar voren met eisen tot loonsverhoging en arbeidstijdverkorting, die de produktiekosten zouden doen stijgen; de groothandelsprijzen zouden tot halverwege 1919 dalen, als gevolg van de grote hoeveelheid goederen, die door het herstel van de internationale betrekkingen op de wereldmarkt kwamen. Na een economiche opleving in 1919 en 1920 zou een crisis volgen, daar oorlog altijd tot verarming leidt zodat ook ons land, zozeer door handel en verkeer met het buitenland verbonden, de economische gevolgen van de oorlog zou merken. In de zomer van 1923 zou aan de economische crisis een einde komen; de neergang maakte plaats voor een situatie van malaise, met zwakke tendensen tot verbetering. Dit versterkte de opvatting, dat de overheidsbemoeienis met het economisch leven, die gedurende de oorlog gerechtvaardigd was, overbodig was geworden nu "normale" verhoudingen waren teruggekeerd en derhalve kon worden geliquideerd. De malaiseperiode, die zich in 1923 aankondigde zou twee jaar later gevolgd worden door een duidelijke economische verbetering die zich tot het einde van deze periode zou blijven manifesteren $^{5}$.

Als het primaire werkterrein van de arbeidsinspectie in ogenschouw wordt genomen, kan zonder enige twijlel worden geconstateerd, dat de Eerste Wereldoorlog remmend heeft gewerkt op de totstandkoming en uitbouw van de arbeidsbeschermende wetgeving. In feite kunnen op dit terrein slechts twee wapenfeiten genoemd worden, namelijk de totstandkoming van Stuwadoorswet ${ }^{\natural}$, die nog tijdens de oorlogsjaren in werking zou treden ${ }^{7}$ en een op 19 juni 1915 tot stand gekomen wijziging van de Veiligheidswet ${ }^{8}$, waarbij de werkingssfeer aanmerkelijk zou worden uitgebreid ${ }^{\theta}$, maar waarvan de inwerkingtreding eerst na afoop van de Eerste Wereldoorlog zou worden gerealiseerd ${ }^{10}$. Enige uitbreiding van de arbeidsbeschermende wetgeving viel ook niet te verwachten, gezien de in de troonrede van 17 september $1918^{11}$ voorkomende passage, dat de opbouw van de sociale wetgeving zou worden voortgezet. Het einde van de oorlog en de grote onrust in Midden-Europa waaronder Duitsland, alsook de novembergebeurtenissen in ons eigen land - denk daarbij aan wat genoemd wordt de "vergissing van Troelstra"12 , zouden daarin echter verandering brengen. De onrust leidde ertoe, dat vanuit het parlement - ook door politieke partijen die tot voor kort dergelijke maatregelen in het geheel zouden hebben verworpen - op de regering druk werd uitgeoefend om maatregelen op het terrein van de arbeidersbescherming te nemen. Niet voor niets sprak de Koningin in de proclamatie van 20 november $1918^{13}$ dan ook van

"het verlangen de voorgenomen hervormingen door te zetten en aan te vullen met de snel- 
heid, die past bij den polsslag van deze tijd".

Op 10 december daaropvolgend kondigde Ruys dle Beerenbrouck, die optrad als tijdelijk minister-president, in het parlement tal van hervormingen op het terrein van de arbeid aan ${ }^{14}$, die zouden berusten op een werkplan dat minister Aalberse bij de vorming van het kabinet als voorwaarde voor zijn optreden als minister van het nieuwe ministerie van Arbeid had gesteld. Hierbij gaf hij te kennen,

"dat door de veranderenden omstandigheden in Europa men een stap verder kan gaan dan

bij den oorlogstoestand mogelijk was".

Al in 1919 werd een belangrijk deel van dit werkplan gerealiseerd door het tot stand komen van de Hooge Raad van Arbeid en de Arbeidswet 1919.

\section{De Hooge Raad van Arbeid}

De overheid was zich steeds meer bewust geworden van de mogelijkheid, dat zij bij de maatregelen die haar voor ogen stonden, profijt kon hebben van adviezen van de zich steeds verder ontwikkelende organisaties van werkgevers en van arbeiders ${ }^{15}$. De samenwerking tussen de overheid en deze belangenorganisaties had vooral gestalte gekregen gedurende de Eerste Wereldoorlog en zou na afloop daarvan voor een belangrijk deel haar betekenis behouden.

In het verlengde hiervan creëerde de regering een aantal vaste organen ${ }^{18}$, waarin het bedoelde overleg regelmatig zou worden gepleegd ${ }^{17}$. Eén van deze colleges was de op 4 oktober $1919^{18}$ ingestelde Hooge Raad van Arbeid. Over de doelstelling van dit orgaan wijdde minister Aalberse is zijn installatierede van 20 februari 1920 de volgende passage ${ }^{10}$ :

"De Hooge Raad van Arbeid zal zijn de trait d'union tusschen Maatschappij en Overheid, - een permanente vertegenwoordiging van het volle sociale leven bij de organen van de Staat, - een instelling van georganiseerd overleg tusschen vereenigingen van werkgevers en arbeiders eenerzijds en het Ministerie van Arbeid anderzijds".

De gedachte van de toenmalige bewindsman, dat de Hooge Raad van Arbeid of zijn commissies ${ }^{20}$ op den duur feitelijk verordenend zouden optreden ${ }^{21}$, zou niet verwezenlijkt worden ${ }^{22}$.Van meet af aan was de Hooge Raad van Arbeid bedoeld als adviesorgaan ${ }^{23}$, waarbij Levenbach ${ }^{24}$ aantekent, dat deze adviserende werkzaamheid zeer omvangrijk was ${ }^{25}$, waardoor de invloed van het in de Raad gekanaliseerde georganiseerde bedrijfsleven gedurende zijn effectief bestaan $^{26}$ zeer belangrijk was.

De Hooge Raad van Arbeid bestond uit werkgevers- en een gelijk aantal arbeidersleden ${ }^{27}$, deskundigen op sociaal-economisch gebied ${ }^{26}$ en een zestal ambtenaren die ambtshalve lid waren ${ }^{29}$. Deze beide laatstgenoemde categorieën van leden dienden het algemeen belang te dienen ${ }^{30}$; een gedachte die overigens in de praktijk nauwelijks verwezenlijkt zou worden ${ }^{31}$.

Eén van de ambtellijke leden was de directeur-generaal van de Arbeid ${ }^{32}$, die ten behoeve van de Raad gedurende zijn effectief bestaan herhaaldelijk de onder hem ressorterende arbeidsinspectie zou inschakelen.

\section{De Arbeidswet 1919}

Nog voordat de Hooge Raad van Arbeild in functie, had minister Aalberse al een wetsvoorstel, houdende bepalingen tot beperking van de arbeidsduur in het algemeen en tot het tegengaan van gevaarlijke arbeid van jeugdige personen en van vrouwen, bij de Tweede Kamer ingediend ${ }^{33}$, welke uiteindelijk zou resulteren in de Arbeidswet 1919 ${ }^{34}$; een wet die diep zou ingrijpen in het economisch leven en waarvan de totstandkoming ongetwijfeld het gevolg was van de in de inleiding van dit hoofdstuk aangeduide gebeurtenissen in november 1918. Toen namelijk op 26 oktober 1918 vanuit de Tweede Kamer ${ }^{35}$ werd geinformeerd of er van regeringszijjde initiatieven te verwachten waren omtrent de regeling van de arbeidsduur van volwassen werklieden, werd daarop op 9 november $1918^{36}$ uiterst terughoudend op gereageerd en verwezen naar de uitkomst van de parlementaire behandeling van het ontwerp-Schaper ${ }^{37}$. Een maand later, op 10 december, werd duidelijk dat de regering het initiatief aan zich trok en zij voornemens was zo spoedig mogelijk een 
wettelijke regeling van de arbeidsduur als voor volwassen arbeiders in fabrieken of werkplaatsen woor te stel$\mathrm{len}^{38}$. Pogingen van regeringszijde om enige relatie tussen de gewijzigde houding ${ }^{39}$ en de novembergebeurtenissen te ontkenmen ${ }^{40}$ werden met veel scepsis tegemoet getreden; zeker toen bekend werd, dat op 20 november 1918 aan de arbeidsinspectie en de afdeling Arbeid van het departement opdracht was gegeven een voorlopig wetsvoorste: samen te stellen ${ }^{41}$.

Blijkens de toelichting ${ }^{42}$ gold als hoofdmotief voor de wettelijke regeling van de arbeidsduur in het algemeen, waarmee een beperking werd beoogd binnen redelijke grenzen, de

"groote zoowel geestelijke als stoffelijke voordeelen.... voor den arbeider voor diens gezin

en voor de maatschappij".

De rechtsgronden die minister Aalberse voor de regeling van de arbeidsduar aanvoerde, waren in beginsel dezelfde, die door hem reeds tijdens de mondelinge gedachtenwisseling naar aanleiding wan de motie-Schaper over de wenselijkheid van een algemene wettelijke 10-urige werkdag ${ }^{43}$ waren ontwikkeld.

Het gaat om een tweeledige begrenzing van de arbeidsduur: niet alleen diende in ogenschouw genomen te worden het noodzakelijke behoud en herstel van de arbeidskracht van de arbeiders en de bescherming van de gezondheid van de arbeidende bevolking teneinde de economische volkskracht duurzaam te houden - de stoffelijke ( economische ) begrenzing , maar evengoed waren er andere factoren waar acht op geslagen moest worden, namelijk de noodzakelijke volksontwikkeling, het gezinsleven van de arbeider, diens godsdienstige en zedelijke leven en de eisen van het staatsburgerschap en het sociale leven - de zedelijke of geestelijke begrenzing -. De eerste begrenzing was voor iedere soort arbeid verschillend, omdat deze afhankelijk was van de aard van de te verrichten werkzaamheden; de tweede begrenzing bracht met zich, dat er woor iedere soort arbeid een minimum was. Dit uitgangspunt maakte, dat niet meer noodzakelijk was, dat telkens aangetoond moest worden, dat voor een bepaalde soort arbeid vanwege de schadelijke werking van een langere arbeidstijd een door de staat op te leggen beperking geoorloofd was zonder dat er schade voor het economisch leven mogelijk was. Integendeel: voor afwijking van de voor allen aanvaarde regel moest nu aangetoond worden, dat economische of andere feitelijke omstandigheden langer werken noodzakelijk $\operatorname{maakten}^{44}$.

Juist op de zedelijke of geestelijke begrenzing zou bij de behandeling van het wetsvoorstel door zowel de regering als het parlement de nadruk gelegd worden, niet alleen wat betreft de beperking van de arbeidsduur, maar evenzeer ten aanzien van de regeling van de dagelijkse en wekelijkse (onafgebroken) rusttijd ${ }^{45}$. Deze constatering is niet zonder belang. Voor de eerste maal in de geschiedenis van de arbeidsbescherming werd niet het zwaartepunt gelegd op economische, maar op ethisch-sociale maatstaven. Het Tweede Kamerlid Nolens zei daarover het volgende. Na allereerst vastgesteld te hebben, dat men bij de verdediging, van de beperking van de arbeidsduur er met economische motieven alleen niet witkwam, voegde hij daar vervol. gens aan toe:

Maar behalve dat heeft men - en dat is meen ik, hier het hoofdmotief - het z.g. ethischsociale motief. Er zijn tijden geweest, waarin men in het bedrijfsleven en in het staatsbestuur vergat, dat de mensch niet is een arbeidsmachine, maar een redelijk, zedelijk wezen, met; in overeenstemming met zijn wezen en bestemming, verschillende vermogens en behoeften, waarvan de ontwikkeling, volmaking en bevrediging tijd in beslag neemt. Men vergat, dat het economisch leven in zijn geheelen omvang er is voor de menschheid, ook voor den arbeider, en niet omgekeerd, dat de economische arbeid enkel het middel is en niet het doel en dat speciaal de economische arbeid een bepaald doel in zich heeft, waarmede bij de beoordeling van de omstandigheden, waarin die arbeid wordt verricht, rekening gehouden moet worden" ${ }^{146}$.

Eén en ander brengt met zich, dat de Arbeidswet 1919 als regeling een ander karakter zou dragen dan de wettelijke regelingen, die daaraan vooraf waren gegaan. Er werd niet uitsluitend gedaan wat de eerdere wetten wel deden, namelijk het bestrijden van misstanden, maar in feite zou zij een regeling van de arbeid geven $^{47}$. 


\section{De Arbeidswet 1919 en de regeling van de arbeidsinspectie}

In artikel 77 wan de Arbeidswet 1919 werd onder meer bepaald, dat er een arbeidsinspectie was en dat het Rijk ten behoeve van deze dienst in districten diende te worden verdeeld. Vervolgens werd bepaald, dat de ambtenaren van de arbeidsinspectie behalve met de taak hun bij andere wetten opgelegd, belast waren met de handhaving van deze wet en met de medewerking van de uitvoering ervan.

$\mathrm{Zij}$ waren werkzaam onder de bevelen van de minister van Arbeid en werden door de Kroon benoemd, geschorst en ontslagen. Hun werkkring en bevoegdheden moesten bij algemene maatregel van bestuur geregeld worden. Daarbij werd bepaald, dat en op welke wijze voor de arbeidsinspectie en voor elk district een ambtenaar als hoofd van dienst werd aangewezen. Ook de "instructiën" voor de ambtenaren van de arbeidsinspectie werden door de Kroon vastgesteld.

Het daaropvolgende artikel 78 bepaalde, dat aan de ambtenaren als bedoeld in artikel 77 ambtenaren en bedienden die zij voor de uitoefening van hun taak nodig hadden, zouden worden toegevoegd. Deze worden of door de Kroon of door de minister benoemd, geschorst en ontslagen. Ook voor hen moesten "instructiën" worden vastgesteld, maar dan bij ministeriële regeling.

Worden deze beide bepalingen gelegd naast die welke destijds door middel van een wijzigingswet in 1909 in de Arbeidswet 1889 waren opgenomen ten einde de reorganisatie van de arbeidsinspectie te verwezenlijken en"die in de Arbeidswet 1911 worden overgenomen, dan blijken deze bepalingen gelijkluidend te zijijn $\mathbf{n}^{4 \mathrm{a}}$.

Eén en ander wil niet zeggen, dat de wettelijke regeling van de arbeidsinspectie tijdens de behandeling van het ontwerp-Arbeidswet niet aan de orde is geweest. Zo werd door een aantal Tweede Kamerleden betreurd $^{49}$, dat de regeling van de werkkring en de inrichting van de arbeidsinspectie zoals die in het ontwerpSchaper was voorgesteld, niet was overgenomen. Minister Aalberse antwoordde daarop ${ }^{50}$ dat dit ook niet nodig was en bovendien ook minder gewenst. Zo vloeiden de voornaamste bevoegdheden van deze ambtenaren onmiddellijk uit wetsbepalingen ${ }^{51}$ voort. Deze bevoegdheden kunnen zonder een wetswijziging niet op andere dan bij die artikelem aangewezen ambtenaren overgaan. Maar ook een reorganisatie van het dienstvak die belangrijke wijzigingen zou brengen in hun bevoegdheden, voor zover het de interne organisatie betrof, kan niet tot stand komen zonder dat het parlement op grond van het budgetrecht daarin zeggenschap zouden hebben, waarbij verwezen werd naar de in 1909 tot stand gebrachte reorganisatie. Het voorgestelde in het ontwerp-Schaper was bovendien ongewenst, omdat in de wet dan allerlei minder belangrijke voorschriften omtrent de interne organisatie zouden moeten worden neergelegd, die daarin niet thuishoren. De betrokken voorschriften konden nu zonder veel omhaal, indien nodig, gemakkelijk worden gewijzigd. Een Kamerlid achtte uitbreiding van de arbeidsinspectie nodig ${ }^{52}$. De noodzaak van deze uitbreiding werd door de bewindsman onderschreven wanneer het wetswoorstel de status van wet zou verkrijgen ${ }^{53}$. Dit zelfde Kamerlid meende verder, dat de arbeidsinspectie onder de controle van de organisaties van werkgevers en werknemers behoorde te worden gestell. Met dit voorstell was minister Aalberse echter minder gelukkig. Het zou met zich brengen, dat aan vertegenwoordigers van die lichamen toegang werd gegeven tot alle fabrieken en andere inrichtingen; waar de arbeidsinspectie toezicht hield. Hiertegen zouden zijns inziens terecht gegronde bezwaren worden aangevoerd ${ }^{54}$.

Tijdens de mondelinge behandeling van het wetsvoorstel in de Tweede Kamer werd omtrent de regeling van mijnarbeid door de minister van Landbouw, Nijverheid en Handel Van IJsselsteyn ${ }^{55}$ opgemerkt ${ }^{56}$, dat het de bedoeling was de ambtenaren van het Staatstoezicht op de mijnen, die belast waren met het toezicht op het Mijnreglement ${ }^{57}$, bij de arbeidsinspectie een positie te geven, zodat bij een eventueel proces-verbaal betrokkenen zich geen rekenschap zouden hoeven te geven of er nu sprake was van een arbeidswettelijke overtreding of een overtreding van het Mijnreglement. Deze opmerking als de mededeling in de memorie van antwoord ${ }^{58}$ dat het in de bedoeling lag te bevorderen, dat het toezicht op de naleving van de sociale wetten en voorschriften betreffende de boven- en ondergrondse werken van mijnen, die niet onder de Arbeidswet zouden vallen, onder leiding zou komen van de directeur-generaal van de Arbeid, ontlokte in de 
Eerste $\mathrm{Kamer}^{59}$ de reactie, dat de hoofdingenieur van de mijten niet ondergeschikt mocht worden gemaakt aan de directeur-generaal van de Arbeid; het zou gerechtvaardigd zijn, wanneer bij de nieuwe regeling voor deze (hoofd)ambtenaar een gelijkwaardige, zelfstandige positie als nu bekleed, gewaarborgd zou blijven. De minister van Arbeid Aalberse reageerde hierop met het antwoord ${ }^{60}$, dat de bemoeienissen wan deze ambtenaar met de exploitatie vau de mijnen, de mijnpolitiek in het algemeen en de concessines uitsluitend en direct onder de verantwoordelijkheid van de minister van Landbouw, Nijverheid en Handel zouden blijven ressorteren. Alleen indien er voor zover deze ambtenaar betrokken zou worden bij het toezicht op de naleving van de sociale wetten, zouden zijn activiteiten ressorteren onder het ministerie van Arbeid. Om alle, terecht gevreesde bezwaren van tweeërlei toezicht op de arbeid in mijn(bouw)ondernemingen te ondervangen, zo vervolgde hij, zou het toezicht op de ondergrondse arbeid in mijnen onder leiding van de directeur-generaal van de Arbeid hebben te staan. Overigens zij opgemerkt, dat het door de beide bewindslieden naar voren gebrachte slechts voornemens betrof en dat het daarbij ook bleef.

Voorts werd van de Eerste Kamer ${ }^{\theta 1}$ de wens uitgesproken, dat bij de keuze van ambtenaren bij de arbeidsinspectie vooral gezocht werd naar in de praktijk van het industriele bedriff geschoolde mensen. De bewinds$\operatorname{man}^{62}$ antwoordde daarop, dat dit ook gebeurde. Voor de categorie opzichters en controlleurs werd dit zoeken in de regel met succes bekroond, maar voor inspecteurs bleven de pogingen zonder succes, hetgeen niet zo verwonderlijk was. Ingenieurs, die boven de middelmaat uitstaken, hadden, als zij in het industriële bedrijf geschoold waren, daarin een dusdanige positie verworven, dat een overheidsbetrekking bij de arbeidsinspectie voor hun geen verbetering betekende. De praktijk leidde er dan ook toe, dat in de regel jonge ingenieurs het korps kwamen aanvullen, aldus de minister ${ }^{\text {as }}$.

\section{Uitbreiding van de arbeidsinspectie}

De tijdens de behandeling van het ontwerp-Arbeidswet in de Tweede Kamer door de minister beaamde noodzaak van uitbreiding van de arbeidsinspectie wanneer het ontwerp de status van wet zou krijgen, zou al snel een vervolg krijgen. In september 1919 al zou de bewindsman bij het parlement een wetsvoorstel aanhangig maken om het personeelsbestand van de arbeidsinspectie uit te breiden ${ }^{04}$, teneinde de invoering van de toekomstige wet mogelijk te maken; in ieder geval moest voorkomen worden, dat de inwerkingtreding ervan zou worden vertraagd door het niet tijdig treffen van de nodige maatregelen ${ }^{65}$. De uitbreiding gold zowel de districten, de centrale dienst als het administratieve personeel.

Uitbreiding van het lager personeel, met name van het aantal opzichters en controleurs, moest het toezicht. op de naleving van de wet verzekeren. De "opzichter" zou veranderd worden in "technisch ambtenaar" in verband met het voorstel om een nieuwe categorie van vrouwelijke ambtenaren in het leven te roepen, die de inspectrices van de arbeid zou hebben bij te staan in het meer eenvoudige controle-werk, onder de titel "opzichteres van den arbeid". Een bruikbare titel waaruit zou blijken, de werkkring van de opzichteres van de arbeid op één lijn gesteld diende te worden met de controleurs van de arbeid was, aldus de bewindsman, moeilijk te vinden.

Bij de centrale dienst moest eveneens uiltbreiding plaatsvinden.

De werkzaamheden op electro-technisch gebied waren te omvangrijk geworden voor de enige deskundige ambtenaar op dit terrein die aan de directeur-generaal van de Arbeid was toegevoegd, zodat een nieuwe regeling niet langer kon uitblijven. De minister stelde dan ook voor de ambtenaar met de titell van electrotechnisch adviseur met de leiding van gelijknamige afdeling te belasten en aan hem een electrotechnisch ingenieur toe te voegen. De omvang van de scheikundige dienst vereiste, zo vervolgde hij, een soortgelijke regeling. Hij stelde derhalve voor de rang van scheikundig adviseur in te voeren aan wie een scheikundig ingenieur alsmede een scheikundig assistent, met voldoende kennis en ervaring om het meer materiële werk van hem over te nemen zouden worden toegevoegd. Met het oog op de wettelijke bescherming van de landbouwarbeiders stelde de bewindsman voor aan de directeur-generaal van de Arbeid een ambtenaar toe te voegen, die op het terrein van de landbouwarbeid de nodige kennis en ervaring had om het herstel van de dienst bij alle bemoeienissen op het gebied van de land-, tuin- en bosbouw terzijde te staan, onder de titel van 
"landbouwkundige bij de arbeidsinspectie".

Ter behandeling van zaken die de landarbeid betreffen, hoewel een ontwerp-Landarbeiderswet werd voorbereid $^{\text {e8 }}$, en ondanks een latere belofte dat dit nog in 1919 aan de Tweede Kamer zou worden aangeboden ${ }^{87}$, zou eerst in 1921 een voorontwerp gepubliceerd worden; tot een parlementaire behandeling hiervan zou het echter niet komen, omdat de uitvoering ervan te kostbaar zou zijn ${ }^{68}$.

De voorgestelde uitbreiding ontmoette in het parlement geen enkele weerstand en zou geformaliseerd worden door middel van een wijziging van het Organisatiebesluit ${ }^{\text {at }}$.

\section{De uitwerking van de regeling van de arbeidsinspectie}

Reeds lang voordat de Arbeidswet 1919 was afgekondigd, werd de voorbereiding van de uitvoeringsmaatregelen van de wet door de Arbeidsinspectie ter hand genomen. Kennis van de bedrijven en van de praktijk van de arbeidswetgeving was noodzakelijk, zodat dit werk niet aan buitenstaanders of tijdelijke ambtenaren kon worden opgedragen. Om die reden werd de voorbereiding van de nieuwe bepalingen grotendeels opgedragen aan personen, die de gewone inspectie-arbeid verrichten ${ }^{70}$.

Toen het Tweede Kamerlid Schaper op 3 juni 1920 via een interpellatie ${ }^{71}$ aan de betrokken bewindsman vroeg wanneer de inwerkingtreding van de Arbeidswet 1919 tegemoet kon worden gezien en waarom dit naar het scheen in de komende maanden niet was te verwachten, gaf minister Aalberse in zijn antwoord ${ }^{72}$ een uiteenzetting van de reusachtige hoeveelheid arbeid, die de voorbereiding van de invoering met zich bracht. Tevens sprak hij daarbij de hoop uit, dat de wet op 1 oktober, zo mogelijk eerder, gedeeltelijk in werking zou kunnen treden. Uiteindelijk zou de wet voor fabrieken of werkplaatsen in het algemeen en voor broodbakkerijen - zij het met een overgangsperiode voor de dag-en de weekmaxima op 24 oktober 1920 in werking treden; de dag waarop ook de Arbeidswet 1919 in het algemeen in werking trad ${ }^{73}$ en derhalve ook de regeling van de arbeidsinspectie. Na alle voorafgaande wijzigingen die de arbeidsinspectie had ondergaan is thans, het moment aangebroken om nader in te gaan op de wettelijke regeling van deze overheidsdienst. Bij besluit van 11 augustus $1920^{74}$ werd het Rijk ten behoeve van de arbeidsinspectie verdeeld in 10 districten. Op grond van artikel 1 van het op 23 augustus daaropvolgend uitgevaardigde Organisatiebesluit ${ }^{75}$ droegen de in artikel 77 van de Arbeidswet bedoelde ambtenaren van de arbeidsinspectie, die werkzaam waren onder de bevelen van de verantwoordelijke bewindsman, de titel van:

a. directeur-generaal van de Arbeid;

b. hoofdinspecteur van de arbeid, (adjunct-)inspecteur van de arbeid, (adjunct-)inspectrice van de arbeid, technisch ambtenaar bij de arbeidsinspectie, controleur van de arbeid of opzichteres van de arbeid;

c. medisch-adviseur of geneeskundige bij de arbeidsinspectie;

d. electrotechnisch-adviseur of electrotechnisch-ingenieur bij de arbeidsinspectie;

e. scheikundig-adviseur of scheikundig-ingenieur bij de arbeidsinspectie;

f. landbouwkundige bij de arbeidsinspectie.

De ambtenaren van de arbeidsinspectie dienden te proberen zoveel mogelijk overeenstemming te bevorderen tussen de eisen van de wetgeving, bij de uitvoering waarvan zij betrokken waren, en de belangen van alle bij de arbeid betrokken personen.

Aan het hoofd van de dienst stond de directeur-generaal van de Arbeid, aan wie werd opgedragen leiding te geven aan en toezicht uit te oefenen op de dienst van de arbeidsinspectie. Hij diende zoveel mogelijk eenheid in de vervulling van de taak van de overige ambtenaren van de arbeidsinspectie bevorderen. Daarnaast diende hij zowel uit eigen beweging als desgevraagd de betreffende bewindsman van advies dienen en hem voorstellen te doen alsmede deze hetzij mondeling, hetzij schriftelijk de gevraagde inlichtingen te verschaffen. In de vervulling van zijn ambt werd de directeur-generaal bijgestaan door:

- Én of meer van de hierboven onder $b$ bedoelde ambtenaren;

- de medisch-adviseur en de geneeskundigen bij de arbeidsinspectie voor de behandeling van zaken betreffende de gezondheid van bij de arbeid betrokken personen;

- de electrotechnisch-adviseur en de electrotechnisch ingenieur bij de arbeidsinspectie voor de behandeling 
van zaken betreffende de beveiliging van electrische toestellen en geleidingen;

- de scheiknndig-adviseur en de scheikundig ingenieur bij de arbeidsinpectie voor de behandeling van zaken betreffende scheikundige onderzoekingen;

- de landbouwkundige bij de arbeidsinspectie voor de behandeling van zaken betreffende de landarbeid, die de door hem gegeven opdrachten dienden uit te voeren. De bedoelde ambtenaren vormden de centrale dienst; hun ambtsgebied bestreek heel Nederland, met als standplaats 's-Gravenhage.

Verder was de directeur-generaal van de Arbeid nog belast met het verwerken van in de districten verzamelde gegevens, het instellen van bepaalde onderzoekingen of het verzamelen van bepaalde gegevens door personen die geen ambtenaren van de arbeidsinspectie zijn en die door de minister onder zijn bevelen waren gesteld, het samenstellen van een algemeen - centraal - jaarverslag verkregen uil de informatie van de districtshoofden, de medisch adviseur, de electrotechnisch-adviseur en de landbouwkundige bij de arbeidsinspectie, het samenstellen van verslagen over bijzondere onderwerpen, die, indien de minister dit wenselijk achtte, gepubliceerd konden worden. In het belang van de eenheid in de uitoefening van de dienst van de arbeidsinspectie in de districten diende de directeur-generaal ten minste vier maal per jaar een districtshoofden-vergadering bijeen te roepen die overigens op zijn uitnodiging bijgewoond werden door de overige ambtenaren van de arbeidsinspectie. Bovendien diende hij vergaderingen en besprekingen te houden met de ambtenaren van de arbeidsinspectie, voor zover dit door hem over de vervulling van zijn taak nodig geacht werd $^{76}$.

Aan het hoofd van een district stond een door de minister te benoemen districtshoofd. Dit districtshoofd droeg de zorg voor en oefende daartoe het benodigde toezicht uit op de handhaving van en de medewerking aan de witvoering van wettelijke voorschriften alsmede het opsporen van overtredingen daarvan voor zover dit aan de ambtenaren van de arbeidsinspectie opgedragen was. Voorts adviseerde hij de bewindsman en de directeur-generaal van de Arbeid en gaf hij hen zowel schriftelijk als mondeling de verlangde inlichtingen. Verder diende hij zich op de hoogte te houden van de arbeidstoestanden in zijn district en van de gebeurtenissen die van belang konden zijn voor de kennis van de arbeidsverhoudingen; stelde hij onderzoekingen in en verzamelde hij gegevens die voor de arbeidsinspectie van bellang konden zijn en diende hij jaarlijks een verslag uit te brengen aan de directeur-generaal van de Arbeid over zijn werkzaamheden en over die van de onder hem werkzame ambtenaren. Het districtshoofd diende de plaatsen te bezoeken die aan zijn toezicht onderworpen waren. In de vervulling van zijn taak werd hij bijgestaan door de ambtenaren die in zijn district werkzaam waren gesteld, die onder zijn bevelen stonden en door hem in het bijzonder belast werden met het opsporen van overtredingen van wettelijke voorschriften op de naleving waarvan zij hadden toe te zien. Hij diende er voor te zorgen, dat werd voldaan aan de opdrachten van de directeur-generaal van de Arbeid tot het bezoeken van bepaalde plaatsen, die aan hun toezicht waren onderworpen en tot het uitoefenen van toezicht op de naleving van bepaalde wettelijke voorschriften. Overigens diende hij zich bij de handhaving van wetten en de medewerking aan de uitvoering ervan wel te onthouden van het geven van algemene voorschriften bij wijze van reglement, instructies of circulaires. Tot slot kon het districtshoofd zowel de bewindsman als de directeur-generaal van de Arbeid voorstellen doen. Bij inzending hiervan aan de betreffende bewindsman moest hij dan wel gelijktijdig een afschrift aan de directeur-generaal sturen ${ }^{77}$.

Naast de al eerder omschreven taak waren de medisch-adviseur, de electrotechnisch-adviseur en de landbouwkundige bij de arbeidsinspectie naast de districtshoofden belast met het toezicht voor zover het betrof de handhaving van en de medewerking aan de uitvoering van wettelijke voorschriften alsmede het opsporen van overtredingen; ieder voor het hun toebedeelde werkterrein. De medisch-adviseur werd daarin bijgestaan door de geneeskundigen van de arbeidsinspectie; de electrotechnisch-adviseur door de electrotechnisch-ingenieur en door één of meer technische ambtenaren bij de arbeidsinspectie. Zij dienden hun werkzaamheden in overeenstemming te brengen met de door de directeur-generaal van de Arbeid deswege gegeven voorschriften. Ook zij dienden jaarlijks verslag uit te brengen aan de directeur-generaal over hun werkzaamheden en konden zij de minister desgevraagd van advies dienen, waarbij zij dezelfde bevoegdheden hadden als de districtshoofden ${ }^{78}$.

De scheikundig-adviseur had een bijzondere positie in de organisatie. Hij diende de opdrachten te vervullen 
die hem door de directeur-generaal van de Arbeid gegeven werden; verder niets. De verhouding tussen de scheikundig-adviseur en de scheikundig-ingenieur was niet geregeld, noch de relatie tot het districtshoofd.

Hoewel de bewindsman bij suppletoire begroting voor het dienstjaar 1920 ook gelden vroeg om een scheikundig assistent bij de arbeidsinspectie aan te stellen, ontbrak deze in het Organisatiebesluit. Daarin zou eerst in 1927 verandering gebracht worden ${ }^{79}$, zonder dat overigens de positie van de betreffende ambtenaren bij de centrale dienst gewijzigd zou worden. Het toen vastgestelde Organisatiebesluit zou wat betreft de ambtenaren van de arbeidsinspectie niet meer gewijzigd worden ${ }^{80}$.

\section{De invoerings-perikelen van de Arbeidswet 1919}

Niet verwonderlijk is, dat door de inwerkingtreding van de nieuwe wet de arbeidsinspectie overspoeld werd met werk. Het beschikbare personeel bleek onder deze buitengewone omstandigheid niet in staat om de plotseling opgetreden vloed van overstelpende drukte het hoofd te bieden; door het aanstellen van tijdelijk administratief personeel werd zoveel mogelijk getracht aan de drukte het hoofd te bieden. De toeloop op de districtskantoren van werkgevers en werknemers die inlichtingen verlangden over de in werking getreden nieuwe bepalingen was $\mathrm{z} 6$ groot, dat op verschillende kantoren de ruimte onvoldoende bleek om zelfs het aantal wachtenden te bevatten ${ }^{81}$. Was het aantal ingekomen, al dan niet anonieme klachten, in 1919 gestegen tot het tot dusver nog nooit gehaalde aantal van 811, in 1920 werd het aantal van 1360 en in 1921 zelfs het aantal van 3910 bereikt; een stijging die onmiskenbaar samenhing met de invoering van de Arbeidswet 1919. Opvallend werd genoemd de toename van het aantal klachten van de zijde van de vakverenigingen. Deze sterk toegenomen bemoeienis van de arbeidsorganisaties werd toegeschreven aan het feit, dat de nieuwe wet zich niet meer beperkte tot de bescherming van jeugdige personen en vrouwen, maar nu ook volwassen mannen betrof. Het groeiend contact tussen de bedoelde organisaties en de arbeidsinspectie werd "zeer toe te juichen" genoemd, omdat op deze wijze de eerstgenoemde duidelijkheid verkrijgen over

"welke soort klachten voor een juiste wetsnaleving van beteekenis zijn en welke gegevens

verstrekt moeten worden om een klacht met kans op succes te kunnen onderzoeken".

Ook vindt men in de Centrale Verslagen een weergave van de klachten van de arbeidsinspectie over de klagers. Ter staving van de stelling dat er vaak maar op los geklaagd werd, zonder enige zekerheid omtrent de juistheid van feiten waarop de aandacht gevestigd wordt, wordt het volgende voorbeeld gegeven, over een mondelinge klacht over zeer ernstige hinder van dampen en stank in een nieuw gebouwde teerdistilleerderij.

"Bij een bezoek eenigen tijd daarna aan deze fabriek gebracht, bleek, dat de machines al-

daar nog niet eens opgesteld waren en zelfs de bouw der fabriek nog niet geheel af was."

Als typerend voorbeeld van een klacht uit wat genoemd werd "wangunst en uit concurrentie-overwegingen gedaan" werd het geval van twee bakkers aangehaald ${ }^{\mathrm{a2}}$,

"die ten bureele der Arbeidsinspectie hunne collega's kwamen aanklagen, doch die zelf bij controle eveneens geverbaliseerd moesten worden wegens verboden nachtarbeid".

\section{Opnieuw uitbreiding van het aantal districten}

De invoering van de Arbeidswet 1919 had voor de arbeidsinspectie een dusdanige vermeerdering van werkzaamheden met zich gebracht, dat het niet meer mogelijk was op behoorlijke wijze te voorzien in toezicht op de naleving van onder meer de Veiligheidswet en andere wettelijke regelingen waarvoor een geregelde inspectie van fabrieken of werkplaatsen vereist was, aldus de bewindsman tijdens de begrotingsbehandeling voor het dienstjaar $1922^{\text {B3 }}$. Niet volstaan kon worden met een uitbreiding van het aantal ambtenaren; noodzakelijk was een uitbreiding van het aantal districten. Eén van deze districten - het vierde - was van een zodanige omvang, dat te grote eisen moesten worden gesteld aan de werkkracht van het betreffende districtshoofd. Voorts waren ook de omliggende districten zo met werk overladen, dat met een wijziging in de indeling niet volstaan kon worden zonder een daarmee gepaard gaande uitbreiding van het aantal districten. Ove- 
rigens bestond volgens de bewindsman in 1918 bij de toenmalige uitbreiding van het aantal districten al het voornemen om een elfde district te creëren, waaraan toen als gevolg van de crisistoestand niet toe over was gegaan. Nu kon, na de grote uitbreiding van de bemoeienissen van de arbeidsinspectie, een dergelijke uitbreiding niet langer worden uitgesteld.

Een aantal Tweede Kamerleden had ernstig bezwaar tegen deze uitbreiding ${ }^{94}$. Zij kregen de indruk,

"dat de Minister niet genoeg is doordrongen van de noodzakelijkheid van bezuiniging".

De voorgestelde uitbreiding zou naar hun mening grote kosten met zich brengen. Zij stelden dan ook voor, dat, waar een district te groot mocht blijken te zijn door een andere verdeling meer gelijkheid in werk zou worden gebracht ${ }^{85}$.

De minister reageerde ${ }^{86}$ met een verwijzing naar het feit, dat al die jaren daarvoor splitsing van het vierde district was overwogen. Daarvan was toen afgezien, enerzijds vanwege de crisistoestand, anderzijds omdat het betreffende districtshoofd meende, dat hij met de hem toebedeelde uitbreiding van het aantal ambtenaren voorlopig zou kunnen volstaan. De bestaande indeling kon dan ook niet ongewijzigd blijven zonder schade te doen aan de belangen van de dienst, maar vooral aan de belangen van de bij de toepassing van de Arbeidswet 1919 en andere wetten betrokken werkgevers en arbeiders. Maar de bedoelde Kamerleden gaven niet op. Tijdens de mondelinge beraadslaging stelden zij bij amendement voor het in een aantal begrotingsartikelen gevraagde bedrag te verlagen teneinde de voorgestelde uitbreiding tegen te gaan ${ }^{87}$. Het amendement werd na een discussie tussen het Kamerlid Drion en minister Aalberse verworpen ${ }^{88}$, waarna het voorstel geen tegenstand meer ondervond en zodoende op 11 juli 1922 de verdeling van het Rijk in elf districten kon worden uitgevaardigd ${ }^{89}$.

\section{Wijziging van de Arbeidswet 1919}

Nadat het toenmalige Tweede Kamerlid Aalberse al in $1903^{\circ 0}$ voor het eerst zijn denkbeelden in het parlement omtrent de sociale wetgeving geformuleerd had, sprak hij tevens uit dat de gebruikelijke methode van wetgeving naar zijn mening niet deugde.

De Tweede Kamer moet, aldus Aalberse, vaak beslissen over vraagstukken van technische aard en aan bedrijfsregelingen waarvoor zij niet is toegerust. Bij de behandeling van de door minister Talma voorgestelde wijziging van de Arbeidswet 1889, welke zou resulteren in de Arbeidswet 1911, verklaarde dezelfde Aalber$\mathrm{se}^{\mathrm{et}}$, dat men vór alles had moeten aanvangen met een regeling, die hij aanduidde als een herziening van de Wet op de Kamers van Arbeid ${ }^{92}$, waarbij lichamen - nieuwe Kamers van Arbeid - gecreëerd zouden worden, waaraan allerlei regelingen overgelaten zouden kunnen worden, die onder meer zouden leiden tot een verdere uitbouw van de sociale wetgeving. Bij de behandeling van de Arbeidswet 1919 heeft nu minister Aalberse zijn opvatting gepreciseerd ${ }^{83}$ :

"Een arbeidswet als de nu voorgestelde, zou onnodig zijn, wanneer bij werkgevers en werknemers de organisatie in voldoende mate tot ontwikkeling ware gekomen, en de Overheid zou kunnen volstaan met wettelijke sanctie te verleenen aan tusschen de wederzijdsche organisaties, na vrij overleg, tot stand gekomen regelingen".

Hoe stelde de bewindsman zich nu voor, dat de Hooge Raad van Arbeid tot de hem beoogde wijziging in de arbeidswetgeving zou kunnen bijdragen? Nog vóor deze Raad was ingesteld, gaf hij daarvan bij de behandeling van de Arbeidswet 1919 een sprekend voorbeeld ${ }^{94}$. Als gevolg van de behandeling in de commissies van de Hooge Raad van Arbeid zouden de uitvoeringsmaatregelen van de Arbeidswet 1919 een soort publiekrechtelijk collectieve arbeidsovereenkomst worden. Zoveel mogelijk zou men die regelingen overlaten aan het overleg van de organisaties van werkgevers en arbeiders, die in die commissies vertegenwoordigd zouden zijn. De aldus vervaardigde uitvoeringsmaatregelen zouden dan alleen een sanctie van overheidswege behoeven, omdat zij algemene maatregelen van bestuur zijn ${ }^{\circ 5}$.

$\mathrm{Al}$ in december $1920^{\circ 6}$ zou minister Aalberse een aantal vraagpunten over de bedrijfsorganisatie, de regeling van de collectieve arbeidsovereenkomst en aanverwante zaken aan de Hooge Raad van Arbeid voorleggen en daarbij de wens uitspreken, dat de bespreking daarvan zou worden begonnen met de beantwoording 
van de vraag die als volgt luidde:

"Is het gewenscht, dat bij regellingen tusschen werkgevers en arbeiders kan worden afgeweken van de wettelijke voorschriften betreffende den arbeidsduur? En zoo ja, op welke wijze en onder welke beperkingen?"

Hierop werd al op 14 mei $1921^{\text {} 77}$ door het adviescollege een uitvoerig advies uitgebracht.

Binnen twee maanden, in juli 1921, maakte de bewindsman een voorontwerp tot wijziging van de Arbeidswet 1919 bij het advies-college aanhangig, waarbij onder meer voorzien was in een wijziging van de regeling van overwerkvergunningen, dus in de sfeer van de uitvoering. Zo werd de mogelijkheid geopend van algemene vergunningen, te verlenen door de minister of algemene machtigingen aan de districtshoofden van de arbeidsinspectie voor een groep van ondernemingen, waarin bepaalde, dezelfde omstandigheden een afwijken van de wettelijke normen nodig maakten. Ook werd een vereenvoudiging van de procedure voor "gewone" overwerkvergunningen voorgesteld. Naast deze technische wijzigingsvoorstellen werd tevens voorgesteld bij ministeriële vergunningen afwijkingen van de voorschriften inzake arbeids- en rusttijden toe te staan op initiatief van vakverenigingen van werkgevers en van arbeiders, ook bij het ontbreken van opeenhoping van werk op bepaalde tijden van het jaar en bijzondere omstandigheden, de criteria aan de hand waarvan beoordeeld werd of het verlenen van een overwerkvergunning gerechtvaardigd was. Opmerkelijk voor deze nieuwe soort van vergunningen was het feit, dat een jaarmaximum van 2.500 uren werd gehanteerd, wat overeenkomt met ongeveer een gemiddelde 48-urige werkweek. Deze verruiming van het (gemiddelde ) weekmaximum was opvallend, omdat in het voorontwerp, waarover de Hooge Raad van Arbeid op 15 oktober 1921 adviseerde, de 8-urige werkdag en de 45-urige werkweek als norm van de Arbeidswet 1919 behouden bleef ${ }^{98}$. Sedert het tijdstip dat minister Aalberse het hiervoor bedoelde voorontwerp bij de Hooge Raad van Arbeid aanhangig had gemaakt, zorgde een toenemende economische malaise ervoor, dat de situatie van het Nederlandse bedrijfsleven al meer ongunstiger werd. Liet het voorontwerp van wet tot wijziging van de Arbeidswet 1919 waarover de Hooge Raad van Arbeid had geadviseerd, nog de 8-urige werkdag en de 45-urige werk-

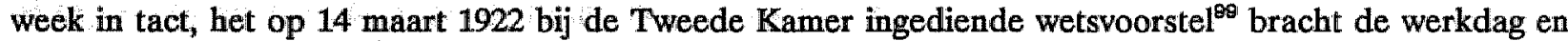
de werkweek op respectievelijk 8,5 uur en 48 uren, wat zonder meer een klinkende overwinning van de reactie kan worden genoemd. Kort daarvoor was namelijk de uitvoering van de Arbeidwet 1919 door middel van overwerkvergunningen onderwerp van discussie geweest in het parlement en wel via een interpellatie van het Tweede Kamerlid Drion ${ }^{100}$. De interpellatie richtte zich op de loonvoorwaarden die aan de bedoelde vergunningen verbonden werden; tegen de dwang, die af en toe door de Arbeidsinspectie op de werkgevers werd uitgeoefend om met de arbeidersvakverenigingen over verzoeken om deze vergunningen vooraf overleg te plegen, om zich aan te sluiten bij een bepaalde organisatie of om zich te onderwerpen aan door deze organisatie te stellen regels alsook tegen het feit, dat vaak een lange tijd verliep tussen het moment van aanvraag van deze vergunning en het moment van beslissen ${ }^{104}$. Dat minister Aalberse niet onwelgevallig stond tegenover deze interpellatie; blijkt uit de openingswoorden van zijn antwoord ${ }^{102}$ :

"Deze interpellatie is mij zeer welkom".

Hem werd namelijk de gelegenheid geboden zich te verdedigen tegen de felle aanvallen, waaraan hij ter zake van de invoering van de 8-urige arbeidsdag en de uitvoering van de Arbeidswet 1919 al sinds maanden bloot stond, althans op het punt van de overwerkvergunningen. Na een schets van de atmosfeer waarin de wet tot stand was gekomen en in verband daarmede de geschiedenis van de wet aangaande de overwerkvergunningen, verdedigde hij de toepassing die aan de bepalingen omtrent de overwerkvergunningen werd gegeven $^{100}$ en bepleitte hij het goed recht van de overheid om daaraan onder meer loonvoorwaarden te verbinden $^{104}$. Hij wees tot besluit ook op de gevaren en morele nadelen die zouden ontstaan als hij zou toegeven aan een onbekookte reactie ${ }^{105}$.

Maar nu kwam de bewindsman zelf voornamelijk op grond van economische argumenten - buitenlandse concurrentie $^{106}$ - met voorstellen die een verlenging van de arbeidstijd met zich brachten. Niet verwonderlijk is dan ook het verwijt ${ }^{107}$, dat hij kreeg, dat hij had moeten zwichten

"voor de stelselmatige propaganda, van werkgeverszijde gevoerd voor de revisie van de door hen onjuist geachte Arbeidswet". 
Het wetsvoorstel wijkt overigens verder niet af van het voorontwerp dat aan de Hooge Raad van Arbeid voor advies was voorgelegd. Er werden voorstellen gedaan om een snellere procedure voor het afgeven van overwerkvergunningen te bewerkstelligen ${ }^{108}$, ondanks de klacht vanuit de Tweede Kamer dat er veel te veel overwerkvergunningen werden verleend ${ }^{109}$. De eerste vereenvoudiging betrof de machtigingsprocedure. Het voor het districtshoofd van de arbeidsinspectie voor bepaalde situaties moeten hebben van een machtiging van de minister voor het verlenen van een overwerkvergunning werd vervangen door het moeten hebben van een machtiging van de directeur-generaal van de Arbeid. Als gevolg van deze wijziging werd artikel 77 van de Arbeidswet 1919 aangepast. Toegevoegd werd namelijk, dat aan het hoofd van de arbeidsinspectie een directeur-generaal van de Arbeid staat. De tweede vereenvoudiging betrof de mogelijkheid voor de minister om, indien ten aanzien van een groep van ondernemingen in alle of bepaalde gemeenten daartoe aanleiding bestaat; voor alle ondernemingen (on)voorwaardelijk een overwerkvergunning te verlenen. De minister kon echter het districtshoofd op dit punt machtigen om dit te doen voor alle of een aantal ondernemingen. De derde vereenvoudiging betrof eenzelfde machtigingsmogelijkheid ten aanzien van de zogenaamde couponboekjes, die gebruikt kunnen worden in spoedeisende gevallen waarbij het tijdig aanvragen van een overwerkvergunning niet mogelijk is. Voor alle deze vergunningsmogelijkheden gelden twee beoordelingscriteria voor de vraag of al dan niet een vergunning kan worden verleend, namelijk opeenhoping van werk gedurende bepaalde perioden van het jaar of bijzondere omstandigheden ${ }^{110}$. Overeenkomstig het voorontwerp waarover de Hooge Raad van Arbeid geadviseerd had, bevatte het wijzigingsontwerp een voorstel, dat ook zonder dat er sprake was van opeenhoping van werk op bepaalde tijden van het jaar of bijzondere omstandigheden, door de minister afwijking omtrent de arbeids- en rusttijden kan worden toegestaan, indien werkgevers- en arbeidersvakverenigingen daarom verzoeken ${ }^{111}$. Dit soort vergunningen zijn zogenaamde verschuivingsvergunningen waarbij een jaarmaximum van 2500 uren niet mag worden overschreden. Het betreft dus geen overwerkvergunningen. Dit wijzigingsvoorstel ligt zonder twijfel in het verlengde van de al eerder vermelde ideeën van minister Aalberse; het is een belichaming van het beginsel van decentralisatie van de uitvoering van de sociale wetgeving. In de Tweede Kamer werd verschillend gedacht over deze mogelijkheid van verschuivingsvergunningen. $Z$ o werd het voorstel bestreden ${ }^{112}$ met het argument, dat het streven naar regularisatie van het werk, naar een meer regelmatige verdeling van de arbeid over de verschillende perioden van het jaar er door zal worden geremd; de wettelijk gegarandeerde 8,5-urige werkdag zou daardoor geheel teniet gedaan worden.

"Alles wordt overgelaten aan de wisselvallige sterkte van twee economische groepen. Daardoor wordt de gelegenheid geschapen voor overheersching van de arbeiders door de economisch sterkere werkgevers, evenals in den tijd; toen nog geen sociale wetgeving bestond. Vooral in de tegenwoordige tijdsomstandigheden, nu de arbeiders noodgedwongen vrijwel alles bebben te aanvaarden, wat de patroon als zijn wensch te kennen geeft, kan dit stelsel tot ongewenschte gevolgen aanleiding geven...... Een regeling, waarbij onder sanctie van den Minister wordt overgelaten aan hen, die bij het bedrijf betrokken zijn, om zelf een regeling vast te stellen, is dan ook in strijd met het algemeen belang. De vrees is geenszins denkbeeldig, dat de aldus totstandgekomen regelingen haar inhoud zullen ontleenen aan de machtspositie van een der partijen. Bij menig werkman zal de neiging bestaan om, zij het dan ook noodgedwongen, het redelijk voordeel van een niet te langen werkdag prijs te geven voor eenige guldens meer loon. Ook kan vrees voor ontslag hem nopen tot het aanvaarden van een ongunstige regeling".

Een aantal van de voorstanders daarentegen meende, dat de voorgestelde regeling niet ver genoeg ging ${ }^{113}$. Immers, wanneer de werkgevers en de arbeiders het samen eens waren, dat in een (groep van) onderneming(en) op een van de normen van de Arbeidswet 1919 afwijkende wijze moet worden gewerkt, dan behoort een dergelijke regeling alleen door de minister tegengehouden te worden als het algemeen belang of de openbare orde dit vereist. Het voorgestelde jaarmaximum diende dan ook te worden geschrapt. Toch was er onder de voorstanders ook een groep die tegen het in deze regeling neergelegde denkbeeld bedenkingen had ${ }^{14}$. 
"Duidelijk blijkt hieruit, dat men steeds meer naar de vrijheid terug wil; een vrijheid, die voor de arbeiders geestelijke en sociale ellende betekent..... De Overheid moet blijven waken tegen een te ongunstige afwijking van de wettelijke normen. Wordt het voorgestelde jaarmaximum losgelaten, dan is de ellende niet te overzien".

Een standpunt waaraan de bewindsman zich conformeerde ${ }^{115}$.

Zijn voor een vollwdig terugtreden der overheid op het gebied van de beperking van de arbeidsduur de tijden nog verre van rijp, wel kan aan de bedrijfsgenooten worden overgelaten binnen de door de wet gestelde grenzen onderlinge regelingen te treffen, waarbij met handhaving van het beginsel der wet, met de bijzondere eischen van het bedrijf rekening wordt gehouden. Maar zelfs hier past nog een beperking en wel in dezen zin, dat zoodanige regelingen niet kunnen werken dan in de vorm van een door de overheid te verleenen vergunning tot het volgen van de overeengekomen werktijdregelingen";

dit, omdat ook de bewindsman onderkende, dat de vakverenigingen van werkgevers en van arbeiders niet steeds als gelijkwaardige partijen zijn te beschouwen. Het wetsvoorstel werd met een ruime meerderheid door de Tweede Kamer ${ }^{16}$ aangenomen. Tot de tegenstemmers behoorde onder meer de Sociaal-Democratische Arbeiderspartij. Dat in sociaal-democratische kring niet eensluidend gedacht werd op dit punt, blijkt bijwoorbeeld uit het feit, dat van vakbondszijde - het Nederlandsch Verbond van Vakverenigingen - slechts zwakjes werd geprotesteerd. Kennelijk was men in die kring, aldus Van Peijpe ${ }^{117}$ bereid - waarschijnlijk vertrouwend op eigen $\mathrm{kracht}^{118}$ - een regeling waarbij via het collectief overleg van de wettelijk voorgeschreven arbeidsduur kon worden afgeweken eventueel te aanvaarden. Confessionele volksvertegenwoordigers juichten een nog verdergaande verlenging van de arbeidsduur langs de weg van het collectief toe, en betreurden dat niet dezelfde weg was bewandeld bij de verlenging van de arbeidsduur per week van 45 naar 48 uren. Zo werd in confessionele kring, evenals trouwens door de vrijzinnig democraten, het collectieve overleg verheven tot een op zichzelf na te streven doel, waarmee de terugtred van de overheid op het terrein van de behartiging van arbeidsbelangen werd gelegitimeerd ${ }^{149}$. Minister Aalberse speelde deze ook wel binnen het genoemde vakbond voorkomende opvatting uit tegen de sociaal-democraten in de Tweede Kamer. Het Nederlandsch Verbond van Vakwerenigingen had met betrekking tot de Ziektewet aangedrongen op uitvoering door de vakorganisaties ${ }^{120}$; zou het dan ook niet consequent zijn, zo vroeg hij zich af, het beleid ten aanzien van de arbeidsduur zoveel mogelijk aan de vakorganisaties zelf over te laten in plaats van aan de overheid? Van Peijpe meent ${ }^{12 !}$, dat minister Aalberse door deze voorstelling van zaken het verschil in positie van de arbeidersvakorganisaties tot de beide vraagstukken miskende. De ziekteverzekering was een voor het grote deel door collectief overleg reeds gerealiseerde sociale voorziening, terwijl bij de op dit terrein ontworpen wettelijke voorziening de vraag aan de orde kwam in hoeverre aan de vakbeweging taken zouden worden toebedeeld in het kader van de uitvoering. Bij de nu tot stand gekomen wijziging van de Arbeidswet 1919 staat niet slechts de uitvoering van een wettelijke voorziening centraal, maar de inhoud van de sociale wetgeving als zodanig en dan met name om de verslechtering daarvan, aldus genoemde schijver. Ik denk dat deze stelling van Van Peijpe niet geheel juist is. Wel degelijk beoogde het zevende lid van artikel 28 van de Arbeidswet 1919 een deel van de uitvoering van de wet over te hevelen naar het georganiseerde bedrijfsleven. Wat betreft de inhoud die de in aanmerking komende organisaties aan de regeling kunnen geven, bleef de wet zelf een aantal beperkingen (dag-en weekmaxima) opleggen, terwijl de overheid als vergunningverlener ongewenste ontwikkelingen op dat terrein zou kunnen, maar ook zou moeten, blokkeren, zodat van een ongelimiteerde regelingsvrijheid geen sprake is.

Overigens zijn de verwachtingen die men destijds koesterde omtrent de werking van de in artikel 28 , zevende lid, yan de Arbeidswet 1919 neergelegde regelling nooit verwezenlijkt geweest. Voor het uitbreken van de Tweede Wereldoorlog was deze mogelijkheid slechts op zeer beperkte schaal benut en nog bijna uitsluitend in, wat Westhoff ${ }^{22}$ noemde; middenstandsbedrijven, zoals bijvoorbeeld de boek- en steendrukkerijen, boekbinderijen, houtbedrijwen, schoenfabrieken en sigarenmakerijen. Voor de regeling van de arbeids- en rusttijden in de grootindustrie heeft deze bepaling weinig effect gehad. Ook in de periode vlak na het beëindigen 
digen van de Tweede Wereldoorlog werd deze vergunningsmogelijkheid slechts sporadisch gebruikt. Zo vermeldt Tinga ${ }^{123}$, dat slechts een viertal bedrijfstakken, namelijk de bierbrouwerijen, de schoen- en textielindustrie en het grafisch bedrijf, hiervan gebruik maakten. Naar mijn weten zijn er thans geen vergunningen op grond van artikel 28, zevende lid, van de Arbeidswet 1919 verleend.

\section{De districtshoofden en de machtigingsprocedure}

Met name de machtigingsprocedure zoals die bij de wijziging van de Arbeidswet 1919 werd ingevoerd, is bij Last, districtshoofd van het derde district te Rotterdam, blijkens een artikel in Sociale Voorzorg van $1923^{124}$ verkeerd gevallen; wellicht was Last niet het enige districtshoofd, dat problemen had met deze nieuwe machtigingsprocedure. Last gaf daarbij tevens zijn kijk op de relatie tussen de districtshoofden en de directeur-generaal van de Arbeid.

Door de directeur-generaal als hoofd van de dienst van de arbeidsinspectie aan te stellen, zo schreef hij, kon het niet anders dan dat de onafhankelijke positie van de inspecteurs van de arbeid, die met het oog op de speciale toestanden in een bepaald industriegebied zo gewenst was, in het gedrang kwam. Een gevolg van het feit, dat het voor de directeur-generaal zeer gewenst was, om zich, naast het op de hoogte blijven van de verrichtingen van de inspecteurs en de hun toegevoegde ambtenaren, onafhankelijk van de inspecteurs op de hoogte te stellen van de toestanden in de verschillende districten. Dit leidde niet alleen tot een veel vitvoeriger correspondentie tussen de districten en de centrale dienst dan vroeger, maar maakte tevens dat het zwaartepunt van de dienst zich meer verlegde van de districten naar de centrale dienst. Vooral na de laatste wijziging van de Arbeidswet 1919, waarbij bevoegdheden op het gebied van overwerk ${ }^{125}$ van de minister in handen van de directeur-generaal van de Arbeid overgingen, kwam het zwaartepunt en het gehele beheer van de inspectie in nog meerdere mate naar de centrale dienst. Werkgevers en vakverenigingen voelden zijns inziens meer en meer, dat het niet meer de districtshoofden waren, maar in hoofdzaak de directeur-generaal van de Arbeid aan wie hun belangen in hoogste instantie waren toevertrouwd. Tal van aangelegenheden werden buiten de districtshoofden om door hem beslist. Dat het met name de machtigingsprocedure is, waar Last moeite mee heeft; blijkt uit het feit, dat hij voorstelde de Arbeidswet 1919 zo te wijzigen, dat de districtshoofden ook langdurige overwerkvergunningen bijvoorbeeld tot drie maanden zonder nadere machtiging zouden kunnen verlenen. Als het nu niet meer nodig was dat deze machtiging door de minister zelf zou worden verleend, maar deze bevoegdheid aan een ambtenaar was gegeven, kon men zonder bezwaar nog een stap verder gaan en dit overlaten aan hen, die gerekend zouden kunnen worden nog het beste met plaatselijke toestanden en behoeften op de hoogte te zijn. Misbruik van deze grotere bevoegdheid was niet te verwachten, aangezien voor de werkgevers en voor de vakverenigingen beroep bij de minister openstond. Daar deze wel altijd bij een dergelijk beroep het advies van de directeur-generaal van de Arbeid zou moeten inwinnen, zou tevens de ongerijmdheid ophouden, dat bij beroep tegen een weigering die het gevolg was van het niet verkrijgen van een machtiging van de directeur-generaal deze in een eigen zaak moet adviseren, aldus de schrijver. Dit laatste is echter niet helemaal juist, omdat de schrijver vergeet dat beroepszaken in eerste instantie terecht kwamen bij de departementale afdeling Arbeid en deze afdeling de minister diende te adviseren met betrekking tot de beslissing in beroep. Mede onder de druk van de noodzakelijk geachte bezuinigingen stelde hij een andere organisatie van de arbeidsinspectie voor.

De bemoeiingen van de directeur-generaal van de Arbeid moesten beperkt worden tot het zijn van een technisch adviseur van de minister en moesten zich slechts uitstrekken tot die zaken die de uniforme toepassing van de wet over het gehele land raakten. De grotere onafhankelijkheid van de districtshoofden had vór de aanstelling van de directeur-generaal van de Arbeid nooit tot enige praktische bezwaren of tot klachten van de industrie aanleiding gegeven. Er was geen enkele reden waarom dit nu wel het geval zou zijn. Het Rijk kon volgens hem verdeeld worden in vijf districten, een aantal waarvan hij zelf zei, dat dit enigszins willekeurig was, maar dat een goede territoriale verdeling waarborgde. Als nu in ieder district onder een districtshoofd drie inspecteurs zouden worden aangesteld, die zich afzonderlijk bezighouden met de Arbeidswet 1919, de Veiligheidswet 1934 en Hinderwetaangelegenheden en algemene zaken, dan zouden deze ambtena- 
ren met een vereenvoudigde administratie hun taak naar behoren kunnen vervullen. Aan elk van deze inspecteurs zou een aantal lagere ambtenaren - technische ambtenaren en controleurs - toegevoegd kunnen worden. Aan het districtshoofd zou een inspectrice toegevoegd kunnen worden en voor zover noodzakelijk zou deze laatste bijgestaan kunnen worden door een adjunct-inspectrice of een opzichteres. Aan het districtshoofd zou tevens een geneesheer toegevoegd kunnen worden, terwijl de medisch-adviseur de richting kon blijven aangeven waarin zijns inziens behoorde te worden gewerkt. Een zelfde voorstel gold de elektrotechnisch-adviseur die de algemene lijnen van het beleid uitzette, terwijl tén van de technische ambtenaren in een district speciaal belast zou zijn met het toezicht op de ellektrische installaties. De scheikundig-adviseur kon naar zijn mening gemist worden en de door hem te verrichten onderzoekingen konden aan het laboratorium van de volksgezondheid worden opgedragen.

De voordelen van de door hem geschetste situatie waren zijns inziens de navolgende:

1. grote bezuiniging door opheffing van diverse kantoorgebouwen en door vermindering van het aantal ambtenaren;

2. vereenvoudiging van de administratie;

3. betere en vluggere afdoening van de in de districtshoofdenvergadering besproken zaken, doordat deze uit zes in plaats van uit twaalf personen zou bestaan;

4. verruiming van het gezichtsveld van de districtshoofden waardoor hun adviezen meer waarde krijgen;

5. de mogelijkheid om het toezicht op de Arbeidswet 1919 en de Veiligheidswet aan verschillende personen op te dragen en daarvoor de meest gesehikte personen te kiezen;

6. het beter in staat zijn om bij het in werking treden van wetten, die voor enig deel van het land meer toezicht eisen van een bepaalde categorie van ambtenaren, bijvoorbeeld een Landarbeidswet, deze aan het districtshoofd toe te voegen, zonder diens werkzaamheden direct te vermeerderen;

7. het meer tot zijn recht komen van de speciale eisen, welke aan elke categorie van ambtenaren bij hun benoeming worden gesteld.

Het bovenstaande in ogenschouw nemend, kan ik mij niet aan de indruk onttrekken dat de diverse suggesties van Last in zijn artikel alleen maar beoogden de onafhankelijke positie van de districtshoofden, die zijns inziens aangetast was door de bedoelde machtigingsprocedure, te herkrijgen en te verstevigen. Dit, terwijl toch het volgen van aanwijzingen en opdrachten van de directeur-generaal als hoofd van de dienst een logisch gevolg hiervan is. De door Last bestreden machtigingsprocedure, die alleen maar de uniformiteit in de toepassing van de wet bevordert, past geheel in dit stelsel, zonder dat de zelfstandigheid van de districtshoofden van de arbeidsinspectie ook maar enigszins aangetast wordt.

\section{De uitvoering van de Arbeidswet 1919}

Eén van de criteria om overwerk of werktijdgrensverschuiving toe te staan is het begrip "bijzondere omstandigheden". Dit begrip is zoveel omvattend, dat het uitvoerend orgaan feitelijk veel vrijheid is gegeven om dergelijke vergunningen te verlenen, wanneer het van mening is, dat dit nodig is. De meest voorkomende omstandigheden die onder dit begrip werden gebracht, zijn spoedbestellingen, bedrijfsstoornissen door defecten, ketelkeuringen, verkeersstremmingen, achterstand in sommige afdelingen van een fabriek en kerkelijke en plaatselijke feestdagen, maar ook de hittegolf, die in 1923 in ons land heerste, waardoor overdag werken vaak onmogelijk was, zodat de werkzaamheden via een vergunning op andere tijdstippen konden plaatsvinden $^{120}$.

Ook als een bijzondere omstandigheid werd beschouwd de buitenlandse concurrentie als gevolg van de waardedaling van valuta in verschillende landen ${ }^{127}$. Op grond daarvan zijn onder andere in de aardewerk-, de glas-, de chemische-, de metaal-, de textielindustrie en in de scheepsbouw overwerkvergunningen verleend; vergunningen die in normale omstandigheden niet verleend zouden zijn. Bij het verlenen van deze vergunningen speelde nog een tweede motief, namelijk het streven om het weekloon van de arbeiders bij de sterke daling van de uurlonen, die een gevolg is van de economische malaise, niet beneden een bepaald peil te laten dalen. Deze crisisvergunningen zijn bekend geworden onder de benaming "armoede-vergunningen"128. 
Wat betreft de uitvoering van de Arbeidswet 1919 door middel van vergunningen tot afwijking van de door die wet voorgeschreven arbeids- en rusttijden, werd al eerder gemeld, dat in het parlement geklaagd was over de hoeveetheid overwerkvergunningen die werd verleend. Dit, ondanks de eerder gedane toezegging van de bewindsman ${ }^{129}$, dat van de vergunningsmogelijkheid slechts op beperkte schaal gebruik zou worden gemaakt:

Dat deze klacht niet zonder grond was, blijkt uit de volgende gegevens. In 1922 werden ongeveer 24.000 vergunningen verleend, waarvan een deel ook betrekking had op de werktijdgrensverschuiving, terwijl er 1.184 machtigingen - couponboekjes - werden verstrekt ${ }^{130}$, in het daarop volgende jaar bedroeg dit aantal respectievelijk circa 35.000 en $1.288^{131}$. In 1924 bedroegen deze aantallen respectievelijk circa 25.000 en $1.343^{132}$. De uitvoering van de betreffende wetsartikelen nam een belangrijk deell van de tijd van de arbeidsinspectie in beslag. De sinds 1922 bestaande vereenvoudiging van de procedure woor het afgeven van overwerkvergunningen heeft wel een belangrijke arbeidsbesparing voor de dienst tot gevolg gehad ${ }^{139}$.

In het centraal verslag over $1925^{134}$ wordt nog melding gemaakt van het feit, dat het instituut van de overwerkvergunningen in de propaganda van een - niet met name genoemde - politieke partij een niet onbelangrijke rol speelde in de verkiezingsstrijd van 1925 . Door deze betreffende partij was een verkiezingsfilm vervaardigd, die in de voornaamste centra werd vertoond en waarin ruim aandacht werd geschonken aan het optreden van de arbeidsinspectie en de procedure die aan het verkrijgen van een overwerkwergunning was verbonden. Het doel van de film was om de desbetreffende wetsartikelen en het met de uitvoering belaste orgaan in een belachelijk daglicht te stellen. De toelichter bij de film betoogde herhaaldlelijk, dat de vertoonde situaties op feiten berustten en volledig aan de gangbare praktijk ontlleend waren. Dit was voor de directeur-generaal van de Arbeid reden om de bedoelde toeliehter, die voorheen Tweede Kamerlid was geweest, bijj brief te verzoeken in welke gevallen zich de beweerde situaties hadden voorgedaan, opdat een onderzoek kon worden ingesteld; tenslotte was het toch "zijn" dienst die werd aangevallen en in een kwaad daglicht werd gesteld. Toen na twee maanden op deze brief niet was gereageerd; werd een rappel uitgestuurd. Het antwoord van de geadresseerde daarop was, dat de bedoelde brief hem onbekend was. Toen deze hem opnieuw toegezonden was, antwoordde de betrokkene dat hij voor de inhoud niet verantwoordelijk was en hij uitsluitend de vertoning van de film op zich genomen had. De namen van de drie personen die de inhoud van de film hadden samengesteld, werden wel aan de directeur-generaal van de Arbeid bekend gemaakt. Noch de aanschrijving van de opgegeven persoon die in de partij die de vertoning had geênsceneerd een zéér belangrijke plaats bekleedde, noch het rappell na drie maanden, leidde tot enig resultaat; er werd volhard in een volstrekt stilzwijgen. In het centraal verslag wordt dan ook geëindigd met de conclusie dat de reeds bestaande ernstige twijfel over de juistheid van de voorstelling van zaken bij een onderzoek alleen maar bevestigd zou worden en dat

"de als historisch aangediende voorstelling, zacht uitgedrukt, met de juiste toedracht der feiten niet in overeenstemming is geweest".

Volgens Engels ${ }^{135}$ past op een dergelijk optreden slechts éen kwalificatie, en dat was: "schandelijk". "Dat men niet gediend is van belemmeringen, door den Staat opgelegd, op den weg naar de jacht op rijkdommen, het valt te begrijpen. Dat men geen oog heeft voor het leven, de gezondheid of het huiselijk leven van den arbeider, het kan verklaard worden uit de beginselen, welke zekere politieke partij hier te lande nog steeds aanhangt. Maar dat men zich niet ontziet gebruik te maken van leugens en oneerlijke middelen om een wet te bestrijden, die in gemeen overleg met de Staten-Generaal dan toch wet geworden is en gehandhaafd moet worden, zoolang ze wet is, dat valt allerminst te begrijpen van hooggeplatste persoonlijkheden, die in de omgeving waar ze hun wetten en gezag kunnen doen gelden, heelemaal geen gekheid verstaan.

Doch met ijzeren vuist de naleving van hun bevelen weten af te dwingen".

De schrijver eindigde met de opmerking, dat hij versteld stond, toen hij het gebeurde las, én over de feiten op zich ên over de persoonlijkheden, lid (of leden ) van de Staten-Generaal, die zich tot deze laagheden 
Overigens leveren de centrale verslagen steeds opnieuw het bewijs, dat de Arbeidswet 1919 maar moeilijk inburgerde in het bedrijfsleven. Engels ${ }^{138}$ constateerde, dat het er wel enigszins de schijn van heeft, dat menig werkgever niet de moeite nam, om zich de kennis eigen te maken van de meest eenvoudige verplichtingen uit de Arbeidswet 1919.

"Of zou het niet alleen onkunde zijn, die hier in het spel is?",

zo vraagt deze schrijver zich af. Wat men echter vergat, was; dat door de nonchalante of zeer gebrekkige medewerking van werkgeverszijde de taak van de arbeidsinspectie onnodig werd bemoeilijkt. Dit heeft, zo vervolgde Engels ${ }^{137}$, tot gevolg, dat een aantal ambtenaren onnodig belast werd met allerlei correcties van foutieve opgaven; dat daardoor allicht de eigenlijke taak van de arbeidsinspectie "toezicht op de naleving van de wet" belemmerd werd, onvolkomen werd en dit voor anderen weer aanleiding was om te eisen dat deze dienst werd uitgebreid en dus dat er meer ambtenaren aangesteld moesten worden.

De Arbeidswet 1919 en de daarin voorgeschreven 48-urige werkweek was alles behalve populair. Maar gezien de praktijk ten aanzien van het verlenen van overwerkvergunningen, vroeg Engels zich af of er in ons land nog well eén bedrijf was waarin die werkweek gold. Bovendien moest nog in aanmerking worden genomen, dat een groot aantal categoriën van bedrijven (nog) niet onder de werkingssfeer viel. Engels ${ }^{138}$ noemde het geschetter tegen de Arbeidswet 1919 dan ook voos, en dat het afgeven op deze wet dan ook grotendeels voortvloeide uit onkunde en voor de rest uit onwil of boos opzet.

Een aantal grepen uit het centraal verslag der arbeidsinspectie over 1926 mogen eén en ander illustreren. De handhaving van een wet als de Arbeidswet 1919 was voor de daarmede belaste dienst een zeer omvangrijke taak, De verzoeken ex artikel 99 , tot het aanwijzen van meer dan én hoofd der onderneming, waarvan het onderzoek vaak tijdrovend was, vele overwerkvergunningen en alle beroepen eisen plaatselijk onderzoek en overleg. Hetzelfde gold voor de vaak ingewikkelde werktijdregelingen, ( als gevolg der overwerkvergunningen ), welke met gebruikmaking van de bepalingen van het Werktijdenbesluit en het Rusttijden- en Arbeidstijdenbesluit $^{139}$ mogelijk zijn, om in de behoeften der industrie te voorzien ${ }^{140}$. In het tweede district van de arbeidsinspectie werden 4.187 afschiften van arbeidslijsten ontvangen, waarvan 1.084 foutief waren; 659 arbeidslijsten bevatten informatie die strijdig was met de wet; 184 arbeidslijsten bevatten onnauwkeurig of onvolledig ingevulde arbeids- en rusttijden; 149 arbeidslijsten regelingen vermelden niet voor wie de arbeidsen rusttijdenregelingen zouden gelden; 92 arbeidslijsten vermeldden niet de naam van de onderneming, dat wil zeggen circa $25 \%$, een percentage dat nagenoeg gelijk was aan het in het zesde district geconstateerde foutieve arbeidslijsten. In het tiende district werd $33 \%$ en in het vierde district ruim $40 \%$ foutieve arbeidslijsten geregistreerd ${ }^{141}$. Bij dergelijke percentages kan toch mauwelijks meer van onkunde worden gesproken, zeker niet gezien de plaatsen en de bedrijven waar de "fouten" werden begaan ${ }^{142}$.

Een ander voorbeeld 143 :

"De gang van zaken in den zeescheepsbouw en bij de scheepsreparaties maakte het niet langer noodzakelijk, om voor het behouden van de werkgelegenheid den verlengden werktijd te handhaven. Daarom werd het toegestane overwerk geleidelijk verminderd tot 51 uren per week",

terwijl ook de grote scheepswerven protesteerden tegen de 8-urige werkdag ${ }^{144}$. Bij de op kosten van de Staat uitgevoerde Zuiderzeewerken, werden door de arbeidsinspectie werkweken geconstateerd van 69 tot 90 of meer uren. Onkunde bij de uitvoerders van de Zuiderzeewerken? ${ }^{145}$. Tot slot het gebeurde in een wollenstoffenfabriek te Tilburg ${ }^{148}$. In deze fabriek werd in een tweeploegendienst gewerkt, maar de arbeiders werkten in beide ploegen van 05.00 tot 23.00 uur. Toen om 20.00 uur door controlerende politie-agenten arbeiders werden aangetroffen, verklaarden deze om 14.00 uur met de arbeid te zijn begonnen.

Eenmaal op het politiebureau bekenden zij de waarheid, waarop tegen hun een proces-verbaal werd opgemaakt wegens het geven van onjuiste inlichtingen. Ook tegen het hoofd van de onderneming werd een proces-verbaal opgemaakt, die over aan het licht komen van de overtreding zo verbolgen was, dat hij in zijn fabriek een bekendmaking liet ophangen, waarin werd medegedeeld, dat fl. 100,-- zou worden uitgekeerd aan 
degene, die hem zou mededeelen, wie de overtreding had aangebracht. Engels ${ }^{147}$ heeft over dit voorval een duidelijke mening: schandelijk.

"Wat maakt deze heer van zijn arbeiders? Eerst overtreders der Wet, vervolgens leugenaars, want uit angst voor het verlies van hun betrekking durven ze de waarheid niet te zeggen, tenslotte poogt hij voor den prijs van $11,100,-$ de arbeiders er toe te brengen elkander te verraden!"

Zijn conclusie was dan ook dat de onkunde van sommige werkgevers ten aanzien van de toepassing van de Arbeidswet 1919 wel ver gaat.

\section{De kacheltjes van Jamin; de uitvoering van de Arbeidswet 1919 onder 's rechters hamer}

De uitvoering van de Arbeidswet 1919 zou in de onderhavige periodede onderwerp zijn van een juridisch steekspel, dat uiteindelijk zouden uitmonden in twee arresten van de HR van 17 november $1924^{148}$ en 26 januari $1926^{149}$. Het eerste arrest heeft betrekking op de bevoegdheden van de minister van Arbeid in administratiefrechtelijke beroepsprocedures; het tweede arrest heeft betrekking op de sub-delegatie van wetgeving.

Redenen om uitvoerig aan de zogenaamde "kacheltjes van Jamin" aandacht te besteden.

Centraal in deze procedures staan de artikelen 10, eerste lid, van de Arbeidswet 1919 en 59, eerste lid, aanhef en onder c, en 68 van het Arbeidsbesluit 1920 $0^{150}$. Het in artikel 10, eerste lid, van de Arbeidswet 1919 bepaalde, dat bij algemene maatregel van bestuur wordt voorgeschreven, dat bepaalde arbeid door jeugdige personen of vrouwen niet mag worden verricht of slechts mag worden verricht

"onder bij dien algemeenem maatregel gestelde voorwaarden"

was onder meer uitgewerkt in artikel 59, eerste lid, aanhef en onder c, van het Arbeidsbesluit 1920; de bedoelde personen mogen geen arbeid verrichten in een winkel,

"indien niet is nageleefd wat door het districtshoofd is geëischt ten aanzien van de verwar-

ming van den winkel.....

Artikel 68 van genoemd besluit regelde onder meer de beroepsmogelijkheid bij de minister ${ }^{151}$.

In de eerste helft van 1921 werd in een aantal gemeenten door de bevoegde districtshoofden schriftelijk geëist dat winkels van de firma C. Jamin te Rotterdam in de winter verwarmd moesten worden, hetzij door een kolenkachel, hetzij door een elektrische kachel of door een gaskachel met afvoer.

De bedoelde firma had over het gehele land verspreid een groot aantal winkels, waarin, door de grote aanloop van klanten, éen of meer verkoopsters een groot gedeelte van de dag verbleven. Deze winkels, die 7 dagen van de week zo lang mogelijk geopend waren, waren vaak in hoekhuizen gevestigd en door hun grote glaspuien veelal zếr koud. Voor de in Amsterdam gevestigde winkels werd geëist zorg te dragen, dat deze winkels in het koude jaargetijde doelmatig zijn verwarmd door het aanbrengen van een stookgelegenheid, waarbij het plaatsen van petroleumkacheltjes was uitgesloten in verband met onvoldoende afvoermogelijkheden van de verbrandingsprodukten. Tegen deze eis voor de in Amsterdam gevestigde winkels, in een latere fase ook voor de in andere plaatsen gevestigde winkels, werd beroep bij de minister aangetekend. Daarbij werd door de betrokken onderneming aangevoerd, dat het verblijf in de winkel telkens maar van korte duur was en terugkeer in de woonkamer mogelijk was. Gebleken was echter, dat vooral in de drukke decembermaand voor het personeel nauwelijks tijd overbleef om te eten, laat staan om zich te verwarmen; een groot deel van het personeel had gezwollen winterhanden ${ }^{162}$. In beroep handhaafde de minister de eis onder wijziging van de voorwaarde in die zin, dat de winkels in het koude jaargetijde behoorlijk moeten worden verwarmd door een verwarmingsinrichting, waarvan de verbrandingsprodukten door een stel gesloten buizen en kanalen naar de buitenlucht worden afgevoerd. Daarenboven stelde de minister tevens, dat het districtshoofd de bevoegdheid had om de wijze van verwarmen voor te schrijven. Als termijn waarbinnen aan de gestelde eis diende te worden voldaan, werd het begin van het koude jaargetijde 1922 - 1923 gesteld. Bij controle door de arbeidsinspectie bleek, dat de firma Jamin niet aan de gestelde eisen had voldaan door toch petroleumkachels in te voeren. De in januari 1923 als gevolg daarvan in Amsterdam opgemaakte proces- 
sen-verbaal zouden uiteindelijk resulteren in een veroordeling. De firma Jamin volhardde in haar standpunt; opnieuw diverse beroepsprocedures, waarop door de minister gelijkluidende beslissingen werden genomen. Wel benoemde de bewindsman op 14 september 1923, dit in verband met de door de firma Jamin geopperde bezwaren, een commissie ${ }^{153}$ die hem van advies moest dienen over de wijze waarop in het koude jaargetijde de betreffende winkels verwarmd behoorden te worden. Nadat deze commissie op 2 oktober haar advies had uitgebracht, herzag de minister op 22 oktober daaropvolgend zijn in beroep genomen beslissingen en bepaalde nu, dat de bedoelde winkels in het koude jaargetijde moesten zijn verwarmd, hetzij door een verwarmingsinrichting, waarvan de verbrandingsprodukten door een stel gesloten buizen en kanalen in de buitenlucht worden afgewoerd, en die de gehele winkelruimte op voldoende temperatuur brengt, hetzij door een elektrische kachel waarvan de uitstraling het bedienend personeel voldoende verwarmde. Aan deze nieuwe eisen moest worden voldaan bij de aanvang van het koude jaargetijde 1923 - 1924. Opnieuw stoorde de firma Jamin zich niet aan de genomen beslissingen, wat bij controle op 12 december in Amsterdam leidde tot een proces-verbaal. Op 10 maart 1924 werden de vervolgde firmanten door de kantonrechter te Amsterdam ${ }^{154}$ in een uitvoerig en gemotiveerd vonnis ontslagen van rechtsvervolging. Op de strafbaarheid van hetgeen de beklaagden ten laste was gelegd, kon, aldus de kantonrechter, geen invloed worden toegekend als gevolg van hetgeen door de minister op 22 oktober 1923 is beslist; er was namelijk sprake van een door de minister eigenmachtige wijziging van een te voren in beroep gegeven beschikking zonder dat een wettelijke bepaling de minister een dergelijke bevoegdheid heeft gegeven, zodat die beslissing voor de beoordeling van de strafbaarheid van de ten laste gelegde feiten buiten behandeling moet blijven. Voorts overwoog de kantonrechter, dat een wettelijke basis voor (sub-)delegatie van bevoegdheden aanwezig moet zijn, en dat hier niet het geval was, omdat

"artikel 59, sub 1c, van het Arbeidsbesluit eene bepaling omvat door straf te handhaven, welke niet krachtens eenige wet in het Arbeidsbesluit is opgenomen en derhalve strafrechtelijk niet verbindend is".

Op 3 juni daaropvolgend vernietigde de rechtbank te Amsterdam ${ }^{155}$ dit vonnis van de kantonrechter; het ten laste gelegde werd wettig en overtuigend bewezen geacht, maar het feit was niet strafbaar, zodat ook hier het resultaat was, ontslag van rechtsvervolging. In cassatie bevestigde de HR bij arrest van 17 november $1929^{156}$ de gemaakte uitspraak van de Rechtbank met de overweging;

"dat toen eenmaal de Minister in hooger beroep zijne beslissing had genomen, de zaak voorgoed was afgedaan en nergens aan den Minister den bevoegdheid is gegeven om zonder dat een beroep bij hem is ingesteld een eisch te doen, als bedoeld in artikel 59-1c van het Arbeidsbesluit en in werkelijkheid dit hier heeft plaats gehad, toen de Minister, na op het beroep te hebben beslist zelfstandig buiten het districtshoofd om den eisch nogmaals. wijzigde".

De door de kantonrechter te Amsterdam aangesneden problematiek rond (sub-)delegatie bleef verder buiten beschouwing. Dat deze ten principale toch aan de orde zou komen, kan niet uitblijven.

In de door de firma Jamin ingestelde beroepen tegen de gestelde eisen voor winkels in een aantal gemeenten, waaronder Hoorn, besliste de minister op 24 december 1923 overeenkomstig zijn al eerder gememoreerde beschikking van 22 oktober van dat jaar, wat uiteindelijk erin resulteerde, dat op 26 januari 1925 proces-verbaal werd opgemaakt. Op 22 september 1925 vernietigde de rechtbank te Alkmaar ${ }^{157}$ in hoger beroep het door de kantonrechter te Hoorn op 13 mei $1925^{158}$ gevelde vonnis en ontsloeg de aangeklaagden van rechtsvervolging. In het arrest van 25 januari 1926 verklaarde de $\mathrm{HR}^{159}$ artikel 59 , eerste lid, onder c, van het Arbeidsbesluit 1920 onverbindend, omdat in de betreffende bepaling niets te vinden was over de wijze van verwarming, zodat hetgeen het districtshoofd had geëist niet als uitvoering gezien kan worden, maar als regeling, zonder dat artikel 10, eerste lid, van de Arbeidswet 1919, noch enige andere wettelijke bepaling daarvoor een grondslag vormde. Met het uitvaardigen van artikel 10 van de Arbeidswet 1919 heeft; aldus de HR, de wetgever hier kennelijk een algemeen geldende regel gewild en

"niet een regeling, afhankelijk van de inzichten der verschillende districtshoofden"100.

De consequentie die de verantwoordelijke bewindsman uit dit arrest trok, kwam erop neer, dat, hoewel de 
uitspraak wan de HR betrekking had op een bijzonder geval in het Arbeidsbesluit 1920, ook de wettigheid van een aantal andere arbeidswettelijke bepalingen betwistbaar was geworden. Teneinde een en ander te corrigeren werd een voorontwerp van wet van de Arbeidswet 1919 vervaardigd, dat met memorie van toelichting bij brief van 4 maart $1927^{161}$ aan de Hooge Raad van Arbeid voor advies werd toegezonden. In de toelichting stond centraal, dat de Arbeidswet 1919, evenals haar voorgangers met betrekking tot de bevoegdheden, die de districtshoofden zijn toegekend, tot het stelden van voorwaarden, eisen en dergelijke geen bepalingen bevatte, dit in afwijking van andere wetten op het gebied van de arbeidersbescherming uit de latere tijden, welke uitdrukkelijk vaststellen wat zij ter regeling aan de districtshoofden of in beroep aan de minister wilden overlaten en hoever zij wilden, dat daarbij zou kunnen worden gegaan. Als voorbeelden werden gegeven: artikel 7, eerste en derde lid van de Veiligheidswet, artikel 4 van de Caissonwet, artikel 5 van de Steenhouwerswet 1921 en artikel 12 van de Stuwadoorswet. Wel konden reeds op grond van het Besluit van 15 juli $1891^{162}$, tot vaststelling van een algemene maatregel van bestuur als bedoeld bij artikel 4 van de Arbeidswet 1889 , inspecteurs van de arbeid en in beroep de minister aanwijzingen, voorschriften of oordelen geven. De behoefte aan de bedoelde bewoegdheden was in de praktijk vanaf het begin van de arbeidswetgeving gebleken en dat deze behoefte zich thans bij het uitgestrekte terrein, dat de Arbeidswet 1919 bestreek en bij de ontwikkeling van de techniek op ieder gebied nog veel sterker deed gevoelen, lag, aldus de bewinds$\operatorname{man}^{163}$, voor de hand.

Uit het op 27 juni 1927 door de Hooge Raad van Arbeid uitgebrachte advies ${ }^{164}$ blijkt, dat het standpunt van de minister in het algemeen gedeeld werd; een volledige wettelijke regeling van de bevoegdheid tot delegatie door de Arbeidswet 1919 en de daarop berustende uitvoeringsbesluiten aan de minister, de directeurgeneraal van de Arbeid en de districtshoofden van de arbeidsinspectie - sub-delegatie dus - mocht niet achterwege blijven. Maar, met name de door de voorstanders van het wijzigingsvoorste ${ }^{165}$ geponeerde stelling, dat de leer, in de praktijk door nagenoeg niemand meer werd aanvaard, dat sub-delegatie in strijd met de Grondwet zou zijn' bleek voorbarig. Juist het grondwettelijke aspect van sub-delegatie zou in het parlement zowel schriftelijke als mondelinge bij de behandeling in de beide Kamers van het bij Koninklijke boodschap van 29 december $1927^{166}$ aan de Tweede Kamer aangeboden wetsontwerp een belangrijke rol spelen. Het tweede lid van artikel 55 van de Grondwet bepaalde, dat bepalingen, door straffen te handhaven, in algemene maatregelen van bestuur, niet worden gemaakt dan krachtens de wet. Vanuit het parlement ${ }^{167}$ werd met een beroep op de visie van de staatscommissie tot herziening van de Grondwet ${ }^{168}$ en het kabinet onder wiens verantwoordelijkheid in 1913 de op de arbeid van deze staatscommissie gebaseerde voorstellen tot herziening van de Grondwet werden ingediend, uit deze bepaling afgeleid, dat, die overdracht niet kan plaatsvinden aan andere organen; het voorliggende wetsvoorstel bevatten dan ook deze vorm van verboden (sub) delegatie.

De bewindsman reageerde ${ }^{168}$ hierop, dat, noch het Grondwetsartikel zelf, noch de wordingsgeschiedenis een argument kunnen opleveren voor de stelling dat het voorliggende wetsvoorstel een verboden delegatie zou bevatten. Het tweede lid van artikel 55 van de Grondwet verbood niet de zogenaamde sub-delegatie, maar eiste wel, dat de wet de sub-delegatie moest toestaan. Dit was onder meer het geval in de Veiligheidswet, de Cailssonwet, Stuwadoorswet en de Steenhouwerswet 1921. De voorgestelde wijziging van de Arbeidswet 1919 beoogt niet anders dan deze praktijk ook voor deze wet mogelijk te maken. Ook de wordingsgeschiedenis van de betreffende Grondwetbepaling geeft geen steun aan de naar voren gebrachte opvatting. De bedoelde staatscommissie lichtte haar voorstel tot wijziging van de betreffende Grondwetbepaling als volgt toe:

"Ter wettiging van hetgeen de praktijk blijkt te vorderen, wordt thans in het tweede lid ook de mógelijkheid voorzien, dat uit kracht van den algemeenen maatregel van bestuur door een orgaan van het uitvoerend gezag voorschriften worden gegeven. Aldus getroffen voorschriften zullen om door straffen of met den sterken arm te worden gehandhaafd, uitdrukkelijk steun moeten vinden in de wet."

In de betreffende toelichting op het regeringsvoorstel werd als standpunt in deze door de regering het volgende naar voren gebracht: 
"Wat het uitvoeren van wetten aangaat, is het hier wellicht de plaats om duidelijk te doen uitkomen, dat daartoe ook andere organen dan de Grondwet met name noemt, kunnen geroepen worden. $\mathrm{Na}$ tuurlijk dat alsdan zoodanige organen ook met de bevoegdheid noodig ter wille van een richtige uitwoering van de wet, bekleed behooren te worden."

De minister concludeerde ${ }^{170}$ dan $00 k$, dat de betreffende bepaling alleen maar beoogde

"elken twijfel aangaande de grondwettigheid wan regelingen als de hier besprokene weg te nemen".

Na aanname van het wetsontwerp door de Tweede Kamer op 21 maart $1920^{171}$ en door de Eerste Kamer op 12 juni daaropvolgend ${ }^{172}$, in beide gevallen zonder hoofdelijke stemming, zou de grondwettelijke discussie rond de sub-delegatie afgesloten worden.

\section{Vertraging van de verdere invoering Arbeidswet 1919}

De ongunstige tijdsomstandigheden hebben niet alleen hun stempel gedrukt op de uitvoering van de Arbeidswet 1919 door middel van het verlenen van vergunningen, voor wat betreft de categorieën van arbeid in fabrieken of werkplaatsen en broodbakkerijen, waarvoor de wet in werking was getreden. De verdere invoering van de Arbeidswet 1919 voor andere categorieën van arbeid werd vertraagd. Zo werd in $1919^{173}$ begonnen met de totstandkoming van een Werktijdenbesluit voor kantoren; een besluit dat zowel voor mannelijke, vrouwelijke als jeugdige arbeiders zou moeten gelden. De bezuinigingen op de staatsfinanciën maakten echter, dat onvoldoende ambtenaren beschikbaar waren om naast andere bezigheden ook nog eens de uitwerking en controle in deze sector, waar nog geen enkele ervaring was opgedaan, te verzorgen ${ }^{174}$. Het uiteindelijke resultaat was, dat op 31 december 1922 de bepalingen ter zake van de arbeids- en rusttijden voor kantoren alleen ten aanzien van jeugdige personen in werking traden ${ }^{175}$. Daarmee was het voorlopig gedaan.

Het dieptepunt van de economische malaise lag omstreeks 1923, waarna zich een economische opleving aankondigde. Eerst toen deze zich enige tijd had doorgezet, werd door minister Slotemaker de Bruïne arbeidsen rusttijdenbepaling voor enkele andere categorieen van arbeid, zij het zeer voorzichtig in werking gesteld; voor verplegingsinrichtingen op 1 januari $1929^{178}$; per 1 januari 1930 voor het transportbedrijf te land en voor toonkunstenaars in bioscopen, in beide gevallen voor zover het de wekelijkse rustdag betreft ${ }^{177} \mathrm{en}$ voor winkels ${ }^{178}$. De Winkelsluitingswet $1930^{170}$ die een noodzakelijk correlaat werd geacht van de regeling van de arbeids-en rusttijden van het winkelpersoneel, zoals neergelegd in het betreffende werktijdenbesluit en waarvan de voorbereiding deels parallel had gellopen met die van het werktijdenbesluit, was uiteindelijk achterop geraakt en zou eerst op 1 mei 1932 in werking treden ${ }^{180}$. Als gevolg van de nauwe samenhang tussen de regeling van de werktijden en de winkelshiting, stelde de betreffende bewindsman, dat het in de rede lag, de ambtenaren van de arbeidsinspectie die met de controle op de naleving van het Werktijdenbesluit belast waren, tevens te betrekken in het toezicht op de naleving van de bepalingen van deze nieuwe wet ${ }^{10 t}$.

Hoewel de voorbereiding van de bedoelde werktijdenbesluiten natuurlijk hun beslag legden op de arbeidsinspectie, zou de invoering ervan nauwelijks ernstige problemen opleveren ${ }^{182}$.

\section{De Steenhouwerswet 1921}

Ook de inwoering van de aan de normen van de Arbeidswet 1919 aangepaste Steenhouwerswet 1911, die overigens nog een aantal andere inhoudelijke wijzigingen onderging en bekend was onder de naam Steenhouwerswet $1921^{123}$ leverde weinig problemen op, mede als gevolg van de in die bedrijfstak heersende slapte door een gering gebruik van natuursteen en door buitenlandse concurrentie ${ }^{184}$.

Een typerend voorbeeld van de klacht waarmee de arbeidsinspectie geconfronteerd werd in deze periode heeft betrekking op de Steenhouwerswet. Een steenhouwerspatroon klaagde over oneerlijke concurrentie van een klein baasje. Laatstgenoemde zou met een knecht steenhouwersarbeid verrichten in een niet behoor- 
lijk ingerichte steenhouwerswerkplaats. De algemene onkosten van dat kleine baasje zouden daardoor zoveel lager zijn, dat aan de klager veel werk door de steenhouwer werd afgenomen. Bij onderzoek door de Arbeidsinspectie bleek inderdaad, dat er in het opgegeven pand een steenhouwersbedrijf was gevestigd, terwijl het woonhuisje met afdak absoluut niet voldeed aan enig voorschrift van de Steenhouwerswet. De steenhouwer werkte echter zonder personeel en maakte granito-grafmonumenten. Deze steenhouwer was 20 jaar in dienst geweest bij de klager. Afgeleefd en niet meer in staat tot een volledige arbeidsprestatie was hij door de klager ontslagen en hij probeerde nu door de beschreven werkzaamheden in het onderhoud van zijn gezin te voorzien ${ }^{185}$.

Overigens gold evenzeer voor de Caissonwet 1905 en Phosphorluciferswet 1901, dat deze voor de arbeidsinspectie nauwelijks problemen gaf.

\section{De Veiligheidswet}

Hoewel uit het voorgaande de indruk kan ontstaan, dat de arbeidsinspectie zich in deze periode uitsluitend en alleen bezighield met de in- en uitvoering van de Arbeidswet 1919, is het tegendeel waar.

Door een vermindering van de werkzaamheden in verband met de oorlogssituatie kon de arbeidsinspectie in 1919 al aanzienlijk meer tijd aan het inspecteren van fabrieken en werkplaatsen besteed worden. Doordat de aanvoer van grondstoffen en materialen, die nodig waren woor het aanbrengen van beveiligingen en dergelijke, verbeterde, werd het stellen en doorvoeren van eisen weer vergemakkelijkt. Toch was die aanvoer in het begin nog niet voldoende, zodat hier en daar nog met minder gewenste situaties genoegen genomen moest worden. Als nawerking van de crisissituatie, waarin weinig geïnspecteerd kan worden en veel door de vingers gezien moest worden, was bij sommige werkgevers een geringe neiging merkbaar, om uit eigen beweging te zorgen voor zelfs de meest gewone en vanzelfsprekende beveiligingsmaatregelen. Waar materiaalgebrek geen reden meer voor excuus was, werden andere uitvluchten, zoals bijvoorbeeld de duurte ervan, gezocht, om aan de eisen van de wet te ontkomen; dit maakte het werk van de arbeidsinspectie niet gemakkelijker en noodzaakte haar soms dwingend op te treden.

Het feit, dat met ingang van 1 januari $1919^{186}$ de tijdens de oorlogsjaren tot stand gekomen wijziging van de Veiligheidswet in werking trad; waardoor deze wet nu van toepassing was op bemalingsinrichtingen en op fabrieken en werkplaatsen met 5 tot 10 personen, bracht veel extra werk met zich.

Dat de activiteiten rond de naleving van de bepalingen van de Veiligheidswet van de zijde van de arbeidsinspectie na de afloop van de wereldoorlog toenamen, blijkt uit het volgende. Werden in 1913 en 1914 respectievelijk 18.800 en 15.300 schriftelijke eisen gesteld en schriftelijke aanwijzingen gegeven, in 1915 werd wat dit betreft het absolute "dieptepunt" bereikt met 8.748; in 1922 daarentegen was dit aantall opgelopen tot 30.090 om uiteindelijk een "hoogtepunt" te bereiken in 1923 met 34.451. Daarna zou dit aantal in deze periode jaarlijks circa 25.000 bedragen ${ }^{187}$. Wel moet bij deze cijfers opgemerkt worden, dat in vele gevallen persoonlijke of zakelijke omstandigheden ertoe leidden, dat mondelinge aanwijzingen werden gegeven die dezelfde uitwerking hadden als schriftelijke eisen.

In het centraal verslag der arbeidsinspectie over 1928 werd in herinnering gebracht, dat op 1 januari 1898 het Veiligheidsbesluit in werking trad ${ }^{183}$. De zojuist gegeven cijfers, alsook zeer veel van wat met betrekking tot de naleving van de bepalingen van de Veiligheidswet in het jaarverslag was neergelegd, getuigen van de hoeveelheid, werk, die nodig was om de naleving hiervan af te dwingen. De conclusie, dat al dat werk in de afgelopen jaren maar weinig vruchen had afgeworpen, werd ten stelligste als onjuist bestempeld. Een vergelijking tussen de toestanden, wat betreft hygiëne en veiligheid, in de fabrieken en werkplaatsen in die tijd, toen de eerste technische bemoeienissen van de overheid een aanvang namen en die van de jaren twintig, deed een verschil ten goede zien; niet te ontkennen viel de positieve invloed van de wettelijke normering, al was die in de loop der jaren uitgebreid ${ }^{180}$. Dat de spreekwoordelijke Hollandse zindelijkheid zich niet demonstreerde in een aantal inrichtingen, die onder de werkingssfeer van de Veiligheidswet vielen, blijkt uit 
enkele staaltjes van onzindelijkheid, die in de jaarverslagen werden vermeld. Eén hiervan betrof een graanmalerij en is een markant voorbeeld. In deze inrichting werd blijkbaar nooit aan schoonmaken gedacht, want de vervuiling van deze werkplaats ging alle perken te buiten, Overall lag het vuil opgehoopt; in de vensterbanken, achter deuren, op en langs stapels zakken, enzovoort. De hele zolder en balklaag waren overdekt met spinnewebben, die weer wol zaten met meelstuif en vuil, het geheel had een zodanige grauwzwarte kleur, zodat de vervuiling duidelijk niet van vandaag of gisteren was. Het bordes rond de maalstoel lag geheel vol met opgehoopt vuil. Uit deze vuilnishoop werden achtereenvolgens te voorschijn gehaald: een oude handschoen, die werd gebruikt door de persoon, die eens per drie maanden de stenen kwam scherpen - van deze handschoen stak alleen éen vinger boven het vuil uit - een leeg inktflesje, enige klemschroeven, plankjes van een leeg sigarenkistje, een in elkaar getrapt lucifersdoosje, een verroest hakmes, een vol, maar gedeeltelijk uitgedroogd doosje zebra-kachelglans, een timmermanswaterpas en een gedeelte van de boekhouding van het hoofd of de bestuurder van het bedrijf ${ }^{100}$.

Met betrekking tot onbeschutte tandraderen, zeer gevaarlijke onderdelen van werktuigen, die herhaaldelijk een aantal ernstige ongevallen veroorzaakten, werd gewezen op het feit dat de grootste omzichtigheid nodig is bij werkzaamheden in de nabijheid van deze onderdelen. Een voorbeeld over de afloop van een procesverbaal van de Arbeidsinspectie in deze. Bij het reinigen van een lompenmolen in een textielfabriek raakte een vrouw bekneld tussen een paar tandraderen. Dit reinigen moest gebeuren terwijl de bewuste molen draaide, daar de lompenmolens, ondanks de gestelde eis, geen losse riemschijf bezaten. Bij het behandelen van het over deze en nog meer tekortkomingen opgemaakte proces-verbaal werd van de zijde van het openbaar ministerie slechts een boete gedraagd van 35 maal $\mathrm{fl}, 1,-$, ; de officier van justitie meende, dat hier te snel een proces-verbaal was opgemaakt, terwijl in andere Veiligheidswet-gevallen gewoonlijk eerst 25 maal werd gewaarschuwd. De verzuchting laat aan duidelijkheid niet te wensen ${ }^{191}$ :

"Het blijft moeilijk het iedereen naar den zin te maken."

16. Werkzaamheden in verband met andere wetten waarvan de handhaving en de medewerking aan de uitvoering geheel of gedeeltelijk aan de arbeidsinspectie was opgedragen

Een belangrijk deel van de tijd van de ambtenaren van de arbeidsinspectie werd gevorderd voor besprekingen met burgemeesters, rechtelijke en politie-ambtenaren, school-en andere activiteiten, architecten, werkgevers- en vakverenigingen, alsook voor het bijwonen van zittingen van rechtelijke colleges, hetzij als getuige, hetzij voor het afleggen van deskundige verklaringen.

\subsection{De Hinderwet}

Zo waren er nogal wat klachten van de districtshoofden over de toepassing van de Hinderwetbepalingen door de gemeentebesturen.

Vrijwel dagelijks moest over gepleegde verzuimen of verkeerde toepassing van de wetsartikelen gecorrespondeerd werden:

Herhaaldelijk kwam het voor, dat voorwaarden werden opgelegd, zonder dat die aan het oordeel van een districtshoofd waren onderworpen en dat een vergunning werd verleend, zonder dat de vereiste verklaring omtrent het voldoen van de inrichting aan de eisen, gesteld in de Veiligheidswet, was afgegeven. Daarentegen namen steeds meer belanghebbenden contact op met de arbeidsinspectie alvorens een Hinderwetvergunning aan te vragen. Het aantal verleende vergunningen was onderhevig aan sterke fluctuaties ${ }^{182}$ als gevolg van de economisch mallaise, slechte vooruitzichten, valutaschommelingen en het voltooien van wat genoemd wordt de elektrificatie van oude bedrijven ${ }^{193}$. De voor de ontwikkeling van een vergunningsaanvraag gestelde termijn werd herhaaldelijk overschreden. Voor een deel lag dit aan de aanvragers zelf, daar zij verzuimden tijdig de nodige inlichtingen te verschaffen en daarmede overigens ook geen haast maakten, omdat zij toch mochten door blijven werken, als de beslissing om de een of andere reden werd verdaagd. In één gemeente bijvoorbeeld gebeurde dit bij de 49 aanvragen niet minder dan 42 keer, omdat het opstellen van de 
werp-voorwaarden niet tijdig gebeurde; 6 gevallen hiervan kwamen op rekening van de aanvragers. Van de zijde van de arbeidsinspectie werd vooral geklaagd over de traagheid van het toezenden van de schema's van de elektrische geleidingen; als mogelijke oorzaak van deze klacht werd wel gewezen op het feit, dat de installateur daaraan zijn medewerking moest verlenen. Dat deze klacht van de arbeidsinspectie niet zonder grond is, blijkt uit het feit, dat het districtshoofd van het elfde district in 1923311 brieven verzond over de inlevering van een schakelschema en daarenboven nog eens 209 rappel-brieven en het districtshoofd in 1925 respectievelijk 237 en 169 van dergelijke brieven moest versturen. Ook werd geconstateerd, dat een Hinderwetvergunning werd aangevraagd en behandeld, terwijl de betreffende inrichting niet onder de werkingssfeer van de Hinderwet viel ${ }^{104}$. Hoeveel beslag het werk in verband met de behandeling van de Hinderwetvergunningen op de arbeidsinspectie legde, kan enigszins blijken uit de informatie van het districtshoofd van het derde district; voor de behandeling van de 422 ingekomen aanvragen moesten 213 bezoeken worden gebracht, moesten 151 bezoeken worden ontvangen en daarenboven niet minder dan 1.581 brieven verzonden worden ${ }^{195}$.

\subsection{De Ongevallenwet 1901/1921}

In het kader van de samenwerking met (de ambtenaren van) de Rijksverzekeringsbank in verband met de uitvoering van de Ongevallenwet $1901^{180}$ en de Beroepswet werden in 19221540 mededelingen ontvangen orntrent beveiligingstoestanden in fabrieken of werkplaatsen, die volgens de Rijksverzekeringsbank voorziening behoefden; ten aanzien van 471 mededelingen werd op verzoek een nader onderzoek ter plaatse ingesteld. Verschillende malen gaf een dergelijk onderzoek aanleiding tot het geven van aanwijzingen en voorschriften, alsmede tot het opmaken van processen-verbaal ${ }^{197}$.

In de jaren 1923, 1924 en 1925 zijn de aantallen respectievelijk 684 en 339,371 en 151,362 en $194^{108}$. Daarnaast werden de districtshoofden herhaaldelijk door de voorzitter van é́n van de Raden van Beroep en van de Centrale Raad van Beroep belast met het instellen van een nader onderzoek naar de al of niet verzekeringsplichtigheid van een bepaald bedrijf of werd hen gevraagd te adviseren over de indeling in een gevarenklasse of het daaraan toe te kennen gevarencijfer, dan wel de juistheid van de toegekende ongevalsrente of over de billijkheid van een verlaging van deze rente ${ }^{109}$.

\subsection{Overige}

Voor zowel de Caissonwet 1905 als de Phosphorluciferswet 1901 gold, dat deze voor de arbeidsinspectie geen of nauwelijks problemen gaven.

\section{Bijzondere opdrachten}

Met betrekking tot de bijzondere opdrachten die in deze periode door de arbeidsinspectie zijn uitgevoerd, blijkt opnieuw dat de bemoeienissen van deze dienst vele zaken van het rijk geschakeerde maatschappelijke leven raakten. Naast het lidmaatschap van de Hooge Raad van Arbeid met diverse sub-comissies was de directeur-generaal van de Arbeid in deze periode lid van onder meer de volgende commissies of verenigingen: de centrale commissie voor georganiseerd overleg in ambtenarenzaken, de commissie van advies inzake bezuinigingsmaatregelen voor burgerlijk overheidspersoneel, de centrale reorganisatiecommissie, de centrale commissie voor, de statistiek (evenals de inspectrice van de arbeid, mevrouw E. Kleerekoper) met verschillende sub-commissies, de centrale gezondheidsraad met sub-commissies (tezamen met de medisch adviseur), het bestuur van het veiligheildsmuseum (waarvan het directeurschap alsook het secretariaat aan de arbeidsinspectie toebedeeld waren), het Carnegie-Heldenfonds, de Nederlandsche Vereeniging tot bevordering van den arbeid voor onvolwaardigen arbeidskrachten, de commissie van deskundigen tot onderzoek naar de mogelijkheid van bezuiniging bij het nijverheidsonderwijs, de Koninklijke Nederlandsche brandweervereeniging (als regeringsvertegenwoordiger), de rijkscommissie voor verruiming en regularisatie van werkgelegenheid, 
de rijkscommissie van advies en regularisatie van werkgelegenheid, de rijkscommissie van advies voor werkverschaffing, de rijkscommissie voor werkverruiming. Daarnaast was hij voorzitter van de interdepartementale commissie voor werkloozensteun, de commissie in het belang van het verlenen van eerste hulp bij bedrijfsongevallen (waarvan het vice-voorzitterschap aan de medisch-adviseur toeviel), de commissie van toezicht op het instituut voor zuivering van afvalwater (waarvan de scheikundig-adviseur directeur was), de commissie van advies over benzinebewaarplaatsen en het vervoer van benzine in verband met de Hinderwet, de interdepartementale adviescommissie, inzake de steunverlening aan werkloozen, de zomertijd-commissie, de commissie van advies voor de veenafgraving (met de landbouwkundige bij de arbeidsinspectie als secretaris) van een door werkgevers- en werknemersorganisaties in het bakkersbebrijf samengestelde commissie tot overleg inzake de werktijdregeling in dit bedrijf (waarvan het secretariaat aan de arbeidsinspectie toeviel) ${ }^{200}$.

Uit het bovenstaande blijkt, dat een deel van de bemoeienissen van de arbeidsinspectie betrekking had op de werkloosheidsbestrijding en de werkverschaffing, hetgeen op zich niet zo verwonderlijk is, gezien haar activiteiten voor het Koninklijk Nationaal Steuncomité gedurende de Eerste Wereldoorlog. Toen het Steuncomite in 1919 werd geliquideerd, adviseerde de voorzitter hiervoor op grond van zijn ervaringen een permanente commissie voor de werkverruiming in te stellen ${ }^{201}$. Het in 1917 door de Nederlandsche Werkloosheidsraad in samenwerking met het Koninklijk Nationaal Steuncomité opgerichte centraal comité voor Verruiming van werkgelegenheid werd na de liquidatie van het Steuncomite uitgebreid en omgezet in een rijkscomité voor werkverruiming en regularisatie van werkgelegenheid. Bij die gelegenheid nam de rijksoverheid de werkverruimingsactiviteiten van het Steuncomite over in meil 1920. De taakstelling van de rijkscommissie was min en vaag, namelijk

"het uitbrengen van adviezen en het doen van voorstellen betreffende datgene wat kan worden gedaan of nagelaten om door het verschaffen van werkgelegenheid werkloosheid te voorkomen of te verminderen".

In hoofdzaak werden echter adviezen uitgebracht over allerlei plannen tot werkverschaffing, die nu van de grond kwamen. Werkverschaffing was tenslotte:

"in normale tijden een lapmiddel dat niet bij ieder hoog staat aangeschreven, gevolg mede van het geliefhebber van vele onbevoegden".

Maar

"nu duizenden reeds jaar en dag van den arbeid vervreemden, is werkschaffing van het allergrootste belang. Zienderoogen gaat een groot deel der arbeiders achteruit in arbeidskracht, in arbeidslust, in eergevoel",

zoals Zaalberg, de latere directeur-generaal van de Arbeid, in 1917 schreef ${ }^{202}$. De rijkscommissie voldeed in de praktijk niet aan de verwachtingen; ook op het ministerie van Arbeid was men maar matig tevreden over de omvang en het tempo van de activiteiten. Minister Aalberse vroeg zich dan ook af, of hij de vrij omvangrijke rijkscommissie niet beter kon opheffen. Dat opheffen werd aanvankelijk tegengehouden. Nadat van regeringszijde na de verziezingen van 1922 nog eens werd benadrukt, dat de interesse vooral gericht was op werkverschaffing als alternatief voor de steunregeling, werd de rijkscommissie opgeheven en vervangen door een Rijkscommissie van advies voor werkverschaffing ${ }^{203}$. Dit was een tripartiet samengestelde commissie; naast vertegenwoordigers van werkgevers en van werknemers zaten er vier ambtenaren in, waaronder Zaalberg; inmiddels directeur-generaal van de Arbeid $^{204}$. Deze vier ambtenaren vormden onderling een commissie van advies voor de werkloozensteun, naar haar voorzitter gewoonlijk aangeduid als de commissie-Zaalberg. Deze moest naar buiten toe de indruk wekken, dat zij was opgezet om het interdepartementale overleg te bevorderen en om besluiten van de rijkscommissie uit te voeren, maar in feite trad zij veel actiever op. Naast het rechtstreeks (on)gevraagd adviseren aan de regering over een groot aantal onderwerpen die met werklozenzorg en werkloosheidsbestrijding samenhingen, werkte zij als een goedwerkende zeef, waarin tal van voorstellen van de rijkscommissie bleven hangen. De functie van deze laatste commissie werd dan ook sterk beperkt; zij deed niet veel meer dan ambtelijk al geheel voorbereide werkverschaffingsprojecten beoordelen en wat propaganda maken voor het Nederlands fabrikaat. Nolens, als voorzitter en Gerritsz, als 
secretaris van zowel de Nederlandsche Werkloosheidsraad als de rijkscommissie, die zichzelf ondanks haar officiele benaming Rijkscommissie voor werkverruiming noemde, hetgeen overigens eerst in 1926 haar officiële benaming werd ${ }^{205}$, hadden een bredere taakstelling voor ogen, namelijk het uitbrengen van adviezen over een breed scala van mogelijkheden om het economische leven te bevorderen, zoals regularisatie, scholing, stimulering van de industrie en dergelijke. Het versehil van opvattingen, die leefden over welke politiek er gevoerd moest worden om aan de economische problemen het hoofd te kunnen bieden, blijkt uit het volgende. Gerritsz bepleitte in 1925, dat de rijkscommissie zich zou gaan bezighouden met het bevorderen van de zogenaamde "welvaartspolitiek". Onmiddellijk reageerde Zaalberg met een honende nota:

"Kan men redelijkerwijs verwachten, dat een Regeering aan de adviezen van zoodanig zich-

zelf overschattend bureau eenige waarde hecht".

De commissie-Zaalberg, vooral onder invloed van Zaalberg zelf en de thesaurier-generaal Van Doorninck ${ }^{206}$, was een tegenstander van het voeren van welvaartspolitiek ${ }^{207}$. De werkloosheidszorg diende niet gekoppeld te worden aan een actieve economische politiek. De werklozen konden moreel en fysiek wat opgelapt worden, de wekelijkse slag werd geleverd op de internationale markt onder aanvoering van "energieke, bekwame, moedige bedrijfsleiders". Het zou in Nederland goed blijven gaan, als de internationale concurrentiepositie behouden kon blijven, wat inhield dat "overdreven" looneisen resoluut afgewezen dienden te worden en de werklozen krachtiger dan tot nu toe de arbeidsmarkt "ingedwongen" moesten worden ${ }^{208}$.

Toch was de invloed van de commissie-Zaalberg kleiner dan zij wenste. Belangrijke beslissingen werden buiten haar om genomen ${ }^{200}$, zodat zich een zekere moedeloosheid van de leden meester maakte; Zaalberg bepleitte zelfs de opheffing van de commissie ${ }^{210}$. Maar zover kwam het niet en in mei 1929 hielden de commissieleden zich in een kalm tempo bezig met het ontwikkelen van een werkloosheidsbeleid, zoals dat gevoerd zou moeten worden "bij wijze van droge zwemles"1211.

En de rijkscommissie met de haar zeer nauw verbonden Nederlandsche Werkloosheidsraad, die dachten nog steeds aan een actiever, centraal geleid economisch beleid dat ook de werkverruiming en werkloosheidsbestrijding ten goede zou komen.

Het herhaaldelijk aandringen op een dergelijke centralisatie bleef tot na 1930 onbeantwoord ${ }^{212}$.

Evenals in de vorige periode werd de directeur-generaal van de Arbeid te hulp geroepen om in arbeidsgeschillen als arbiter op te treden. Zo trad de directeur-generaal van de Arbeid in deze periode als arbiter op in een loongeschil in de bouwbedrijven te 's-Gravenhage; het geschilpunt had betrekking op de verhoging van de lonen als gevolg van het invoeren van de 8-urige werkdag. De standpunten verhardden zich na enige tijd en leidden tot stiptheidsacties - "lijntrekken" - van werknemerszijde, waarop van werkgeverszijde geantwoord werd met uitsluiting en collectief ontslag. Bemiddelingspogingen faalden. Een aanbod tot bemiddeling van de wethouder van 's-Gravenhage W. Drees werd van werkgeverszijde afgehouden. Uiteindelijk lukte het minister Aalberse de strijdende partijen rond de tafel te krijgen en zich te onderwerpen aan arbitrage, waarbij als arbiter werd aangewezen de directeur-generaal van de Arbeid, waarbij partijen overeengekomen waren dat zij zich onvoorwaardelijk aan de uitspraak op 12 november van dat jaar zouden onderwerpen, geen rancunemaatregelen zouden toepassen en ook zouden afzien van schadevergoedingsacties ${ }^{213}$. In 1921 was een loongeschil gerezen in het landbouwbedrijf in het Noordelijke Westerkwartier van Groningen. Nadat door ieder der partijen ${ }^{214}$ twee arbiters waren aangewezen, werd de directeur-generaal van de Arbeid aangezocht om als vijfde arbiter tevens voorzitter van de arbitragecommissie op te treden, aan welk verzoek werd voldaan. Overeengekomen werd, dat, indien in de arbitrage-commissie geen overeenstemming kan worden bereikt, de voorzitter zou een bindende uitspraak doen. Een tweetal controleurs van de arbeid werd daarna opgedragen een onderzoek in te stellen naar de prijzen van de meest gebruikte levensmiddelen, alsook naar de budgetten van de arbeidersgezinnen. Uiteindelijk zou de directeur-generaal als voorzitter als enige arbiter - in de commissie was geen overeenstemming bereikt - uitspraken doen ${ }^{215}$. In 1923 zou opnieuw een loongeschil, nu tussen een aantal steenfabrikanten en drie samenwerkende organisaties van steenfabrieksarbeiders ${ }^{218}$, onderwerp van arbitrage zijn. Op 8 mei van dat jaar aanvaardde de directeur-generaal na een bespreking met de betrokkenen het arbiterschap, waarbij een acte van 
compromis ${ }^{217}$ werd ondertekend. Na onder meer een onderzoek ter zake door de arbeidsinspectie werd na drie weken uitspraak gedaan. In de loop van dat jaar zou de directeur-generaal van de Arbeid nog viermaal als arbiter optreden in op steenfabrieken gerezen verschillen. Tweemaal zou hij echter arbitrage weigeren, toen bleek, dat enige bij het hierbowen bedoelde geschil betrokken fabrikanten de beslissing naast zich neer hadden gelegd ${ }^{219}$.

Tevens werd een onderzoek ingesteld naar de schade die overstromingen in het voorjaar van 1920 aan de steenvoorraden op de steenfabrieken hadden aangericht ${ }^{219}$. Een verzoek van een gemeentebestuur om inlichtingen in verband met de omvang van bepaalde industrieën in die gemeente, die zouden moeten dienen als grondslag voor het heffen van een plaatselijke bedrijfsbelasting, werd daartegen afgewezen, met een verwijzing naar het op de arbeidsinspectie opgelegde ambtsgeheim ${ }^{220}$.

Voor het door het Internationale Bureau van Arbeid te Genève ondernomen onderzoek naar de omvang en oorzaken van de industriële crisis werden verschillende gegevens verstrekt.

Daarnaast werden aan de Dienst der Werkloosheidsverzekering en Arbeidsbemiddeling inlichtingen verschaft over het tewerkstellen van buitenlandse arbeiders ${ }^{221}$.

Op verzoek van de commissaris van de Koningin in de provincie Drenthe gaf de minister van Arbeid, Handel en Nijverheid machtiging de controleur van de arbeid J. Mulder te belasten met de regeling van en het toezicht op het verhuren van woningen in het belang van de opruiming van keten en krotten in de gemeente Emmen $^{222}$.

\section{Rapporten en verslagen}

In de betreffende periode zijn onder meer de volgende rapporten en verslagen, niet zijnde jaarverslagen, verschenen:

a. Gedwongen winkelnering in onderscheidene bedrijfstakken in verschillende delen des lands ${ }^{223}$;

b. Arbeidsvoorwaarden van het personeel op handelskantoren ${ }^{24}$;

c. Adresboek van de werklieden-en ambtenarenorganisaties in Nederland in $1920^{225}$. 
1. De wapenstilstandovereenkomsten werden als volgt gesloten: Rusland 15 december 1917 , Bulgarije 29 september 1918, Turkije 30 oktober 1918, Oostenrijk-Hongarije 3 november 1918 en Duitsland 11 november 1918. Deze wapenstilstandovereenkomsten werden gevolgd door de volgende vredesverdragen: Brest-Litovsk 3 maart 1918, Versailles 28 juni 1919, Saint-Germain-en Laye 10 september 1919, Neuilly 27 november 1919, Trianon 4 juni 1920 en Sèvres 10 augustus 1920 .

2. Ingesteld bij Besluit van 25 september 1918, Stb. 551. De nu verantwoordelijke departementsafdelingen waren resp. de afdeling armwezen en de dienst der werkloosheidsverzekering en arbeidsbemiddeling.

3. Zie Centraal Verslag der Arbeidsinspectie over 1918, 1919, 1920 en 1921, resp. 's-Gravenhage 1919, 1920, 1921 en 1922, resp. blz. $367-368$, blz. 11 - 12, blz. $16-17$ en blz. 15.

4. Als gevolg van een lage arbeidsproduktiviteit van onze mijnen en de aan Duitsland opgelegde verplichte levering van steenkolen aan Frankrijk en Engeland.

5. Zie I.J. Brugmans, Paardenkracht en mensenmacht, blz. $458 \mathrm{t} / \mathrm{m} 471$.

6. Wet van 16 oktober 1914, houdende bepalingen in het belang van de personen, werkzaam bij het laden en lossen van zeeschepen, Stb. 486. Bij deze wet is de inspectie van de havenarbeid ingesteld.

7. Zie het Besluit van 5 september 1916, Stb. 437.

8. Wet van 19 juni 1915, Stb. 281. Bij. Besluit van 2 juli 1915, Stb. 304, is de tekst van de Veiligheidswet 1895 met inbegrip van de wijzigingen opnieuw bekend gemaakt.

9. Op grond van een gewijzigd artikel 1 van de wet gold nu niet meer het criterium, dat in fabrieken en werkplaatsen tien of meer personen plegen te verblijven, maar een halvering van dit aantal namelijk tot vijf of meer personen. Bovendien was de wet nu tevens van toepassing op bemalingsinrichtingen.

10. Zie Centraal Verslag der Arbeidsinspectie over 1919, blz. 2.

11. Zie E. van Raalte, t.a.p., blz. 223 - 224.

12. Zie Hand. Tweede Kamer, zitting 1918 - 1919, blz. $341 \mathrm{t} / \mathrm{m}$ 471. Zie voorts onder meer P.J. Troelstra, Gedenkschriften IV (Storm), Amsterdam 1931, blz. 162 t/m 299; E. Hueting/F. de Jong/R. Hey, Troelstra en het model van de nieuwe staat, Assen 1980, blz. 76 t/m 93; W.H. Vliegen, Oorsprong, geschiedenis en hedendaagsche stand der socialistische beweging, Amsterdam 1931, blz. 227 - 228; E. Vermeer, Pieter Jelles Troelstra, Amsterdam 1960, blz. 79 t/m 89; H.J. Schaeffer, November 1918 Journaal van een revolutie die niet doorging, Utrecht 1984.

13. Zie M.G. Levenbach, Arbeid, in Nederlands bestuursrecht, blz. 452.

14. Zie Hand. Tweede Kamer, zitting 1918 - 1919, blz. 660 - 661. 
15. Zie over dit laatste onder andere B. Bölger, t.a.p., blz. $8 \mathrm{t} / \mathrm{m}$ 54; J.P. Windmuller/C. de Galan/A.F. wan Zweeden, Arbeidsverhoudingen in Nederland, Utrecht/ Antwerpen, blz. $13 \mathrm{t} / \mathrm{m} 82$; Vereeniging van Nederlandsche Werkgevers, De organisatie van werkgevers deel $\mathrm{V}$ Nederland (verslag uitgebracht door de commissie ter bestudeering van werkgeversvereenigingen ), 's-Gravenhage 1909.

16. Naast de Hooge Raad van Arbeid kunnen onder andere genoemd worden de Nijwerheidsraad (Besluit van 4 september 1919, no. 49 ) en de Middenstandsraad (Besluit van 4 september 1919, no. 50 ).

17. $\mathrm{Bij}$ de herziening van de grondwet van 1922 kregen deze vaste colleges van bijstand en advies een grondwettelijke basis; artikel 78 van de Grondwet 1922 luidde als volgt:

"De instelling van vaste colleges van advies en bijstand aan de Regeering geschiedt krach-

tens de wet, die tevens regelen inhoudt omtrent hunne benoeming, samenstelling, werkwijze en bevoegdheid".

Zie hierover F.J.A. Huart, Grondwetsherziening 1917 en 1922, Arnhem 1925, blz. 120 t/m 127.

18. Besluit van 9 oktober 1919, Stb. 591. Bij de Wet van 24 december 1927, houdende wettelijke regeling van de Hooge Raad van Arbeid, Stb. 407, werd dit orgaan verzelfstandigd en kreeg het de wettelijke basis die op grond van artikel 78 van de Grondwet van 1922 vereist was; zie Tweede Kamer, zitting 1926 - 1927, no. 246.3 ( memorie van toelichting) blz. 1 en Hooge Raad van Arbeid, Advies van 14 mei 1925 inzake de reorganisatie; no. 69, s-Gravenhage 1925.

19. Zie A.W. Quint, Twintig jaar Hooge Raad van Arbeid, in R.B.A. XXV blz. 57; M.G. Levenbach, Arbeid, in Nederlands bestuursrecht, blz. 452.

20. Zie artikel 5 van het Besluit van 4 oktober 1919 , Stb. 591 , en artikel 5 van de Wet op den Hooge Raad van Arbeid 1927, waarin de mogelijkheid tot het instellen van commissies is neergelegd.

21. De basis hiervoor was gelegd in artikel 1, derde lid, van het Besluit van 4 oktober 1919, Stb. 591, dat luidt als volgt:

"In opdracht van Onzen Minister van Arbeid ontwerpt de Raad regelingen, als in het vorige lid bedoeld".

Een dergelijke bepaling is in de Wet op den Hoogen Raad van Arbeid 1927 niet meer terug te vinden.

22. Zie A.W. Quint, in R.B.A. XXV blz. 57 nt. 5; M.G. Levenbach, Arbeid, In Nederlands bestuursrecht, blz. 453; T. van Peype, De ontwikkeling van het loonvormingsrecht, Nijmegen 1985, blz. 156.

23. Aanvankelijk werd aan de Hooge Raad van Arbeid opgedragen de regering op haar verzoek te adviseren (zie artikel 1, tweede lid, van het Besluit van 4 oktober 1919, Stb. 591 ). Na de reorganisatie zou de Hooge Raad van Arbeid ook zonder verzoekvan de regering adviezen mogen uitbrengen ( zie artikel 1, derde lid, van de Wet op den Hooge Raad van Arbeid 1927).

24. M.G. Levenbach, Arbeid, In Nederlands bestuursrecht, blz. 453.

25. Zie hierover A.W. Quint, in R.B.A. XXV blz. 65 t/m 69.

26. Hoewel de Hooge Raad van Arbeid sinds het begin van de Tweede Wereldoorlog niet meer heeft gefunctioneerd - de zittingsperiode van de niet-ambtelijke leden eindigde op 30 juni 1944 - zou dit adviesorgaan eerst op 1 juni 1950 ( zie Besluit van 29 april 1950, Stb. K.168) op grond van artikel 148 van de Wet 
op de Bedrijfsorganisatie ( Stb. K.22) opgeheven worden; zie ook M.G. Levenbach, Arbeid, in Nederlands bestuursrecht, blz. 453 .

27. Zij werden door de Kroon benoemd na overleg van de verantwoordelijke minister met "de voornaamste vereenigingen van werkgevers" respectievelijk "de voornaamste vakcentrales van arbeiders" ( zie artikel 2 , vierde lid, van het Besluit van 9 oktober 1919, Stb. 591, en artikel 2, derde lid, van de Wet op den Hoogen Raad van Arbeid 1927 ).

28. Of wel "personen, die studie hebben gemaakt van sociaaleconomische vraagstukken of van sociale wetgeving" ( zie artikel 2, vierde lid, van het Besluit van 4 oktober 1919, Stb. 591, en artikel 2, derde lid, van de Wet op den Hoogen Raad van Arbeid 1927).

29. Zie artikel 2, derde lid, van het Besluit van 4 oktober 1919, Stb. 591, en artikel 2, tweede lid, van de Wet op den Hoogen Raad van Arbeid 1927.

30. Zie A.C. Josephus Jitta/E.H. Bisschop Boele, Sociale Wetgeving, in Practische Sociologie, Groningen/ "s-Gravenhage/Batavia 1931, blz. 61- 62; A.W. Quint, in R.B.A. XXV blz. 58.

31. Zie A.W. Quint, in R.B.A. XXV blz. 58.

32. De andere ambtelijke leden waren: de secretaris-generaal van het ministerie van Arbeid, de directeur van het Centraal Bureau voor de Statistiek, de hoofden van de afdelingen Arbeid en Arbeidersverzekering van genoemd ministerie en de directeur van de Rijksdienst der Werkloosheidsverzekering en Arbeidsbemiddeling. Zie A.W. Quint, in R.B.A. XXV blz. 58; P.A. Diepenhorst, t.a.p. I, blz. 128 - 129.

33. Bij Koninklijk besluit van 11 april 1919; Tweede Kamer, zitting 1918 - 1919, 408.1.

34. Wet van 1 november 1919 , Stb. 624 .

35. Bijlagen Tweede Kamer (Bijlage A), zitting 1918 - 1919, no. 3 (Hfdst. I begroting Huis der Koningin) blz. 11 .

36. Bijlagen Tweede Kamer (Bijlage A), zitting 1918 - 1919, mo. 6 (Hfdst. I begroting Huis der Koningin) blz. $18-19$.

37. Zie hfdst. 5 par. 3 ( het ontwerp-Schaper).

38. Hand. Tweede Kamer, zitting 1918 - 1919, blz. 661.

39. Als reden voor de gewijzigde houding werd gegeven, dat een wetswoorstel met een dergelijke strekking en de daarmee samenhangende moeilijkheden eigenlijk niet via het initiatiefrecht tot stand gebracht kon worden.

40. Hand. Tweede Kamer, zitting 1918 - 1919, blz. 661; zie ook Hand. Tweede Kamer, zitting 1918 - 1919, blz. 1553 en blz. 1555 - 1556.

41. Zie Hand. Tweede Kamer, zitting 1918 - 1919, blz. 1555.

42. Tweede Kamer, zitting 1918 - 1919, 408.3 (memorie van toelichting ) blz. 1. 
43. Zie Hand. Tweede Kamer, zitting 1908 - 1909, blz. 1728 - 1729; zie ook Hfdst. 5 par. 3 ( het ontwerpSchaper ).

44. Zie M.G. Levenbach, Arbeid, in Nederlands bestuursrecht, blz. 453; J. Westhoff, Arbeidersbescherming in engeren zin, in Het Departement van Arbeid, Handel en Nijverheid onder minister Aalberse 1918 - 1925 , Alphen a/d Rijn 1926, blz. 9 - 10; A.C. Josephus Jitta/E.H. Bisschop Boele, t.a.p.; blz. 51 t/m 55.

45. Zie J. Westhoff, t.a.p., blz. 14.

46. Hand. Tweede Kamer, zitting 1918 - 1919, blz. 2870.

47. Zie ook A.C. Josephus Jitta/E.H. Bisschop Boele, t.a.p., blz. 44.

48. Zie ook Tweede Kamer, zitting 1918 - 1919, 408.3 ( memorie van toelichting) blz. 45 .

49. Tweede Kamer, zitting $1918-1919,408.4$ ( voorlopig verslag ) blz. 21.

50. Tweede Kamer, zitting 1918 - 1919, 408.5 (memorie van antwoord) blz. 42 .

51. Zie bijvoorbeeld de artikelen 6, achtste lid, en 7, tweede lid, van de Arbeidswet 1911, de artikellen 7 en 8 van de Veiligheidswet; artikel 6 van de Steenhouwerswet 1911 en artikel 4 van de Caissonwet.

52. Tweede Kamer, zitting 1918 - 1919, 408.4 (voorlopig verslag ) blz. 21. Zie over het betrekken van werkgevers en werknemers bij de uitvoering van de wet: Tweede Kamer, zitting 1918 - 1919, no. 408.4 (voorlopig verslag ) blz. $11-12$.

53. Tweede Kamer, zitting 1918 - 1919, 408.5 (memorie van antwoord) blz. 42. Zie voor het antwoord van de minister over het betrekken van werkgevers en werknemers bij de uitvoering van de wet: Tweede Kamer, zitting 1918 - 1919, 408.5 (memorie van antwoord) blz. $25-26$.

54. Niet onder de werkingssfeer van de wet valt blijkens artikel 1 , eerste lid, aanhef en onder $b$, de arbeid in ondergrondse mijnen, benevens in de daarbij behorende bovengronds gelegen werken en inrichtingen bij algemene maatregel van bestuur aangewezen.

55. H.A. van IJsselsteyn was van 1908 tot 1918 directeur-generaal van de Arbeid geweest. Ten gevolge van zijn benoeming tot minister van Landbouw, Nijverheid en Handel is hij voor de tijd, dat hij aan het hoofd van dat departement staat, ontheven van de waarneming van het ambt van directeur-generaal. Overeenkomstig artikel 7, tweede lid, van het Besluit van 10 augustus 1909 , Stb. 289 , is in de tijdelijke waarneming van het ambt voorzien door C.J.Ph: Zaalberg ( zie Tweede Kamer, zitting 1918 - 1919, no. 3 ( Hfdst. Xa begro-
ting Arbeid ) blz. $3-4$.

56. Hand. Tweede Kamer, zitting 1918 - 1919 II, blz. 2893.

57. Besluit van 22 september 1906, tot vaststelling van een algemene maatregel van bestuur, als bedoeld in artikel 9, eerste lid, van de Wet van 27 april 1904 (Staatsblad no. 73), houdende nadere bepalingen betreffende de mijnontginning, met wijziging van de Wet van 21 april 1810 (Bulletin des Lois no. 285 ).

58. Tweede Kamer, zitting 1918 - 1919, 408.5 (memorie van antwoord) blz. 27. Deze mededeling geschiedde mede namens de minister van Landbouw, Nijverheid en Handel. 
59. Eerste Kamer, zitting 1918 - 1919, 408 ( Tweede Kamer) 202 ( voorlopig verslag ) blz. 15.

60. Eerste Kamer, zitting 1918 - 1919, 408 ( Tweede Kamer) 5 (eindverslag bevattend de memorie van antwoord ) blz. 17 .

61. Eerste Kamer, zitting 1918 - 1919, 408 ( Tweede Kamer ) 202 (oorlopig verslag ) blz. 15.

62. Eerste Kamer, zitting 1918 - 1919, 408 ( Tweede Kamer) 5 ( eindverslag bevattend de memorie van antwoord ) blz. 17 .

63. Goed beschouwd deden zich ten aanzien van de overheid en het bedrijfsleven voor wat betreft de arbeidswoorwaarden dezelfde problemen voor die thans spelen.

64. Tweede Kamer, zitting 1919 - 1920, 217.2 (ontwerp van wet).

65. Tweede Kamer, zitting $1919-1920,217.3$ ( memorie van toelichting ) blz. $1 \mathrm{t} / \mathrm{m} 3$.

66. Zie Tweede Kamer, zitting 1918 - 1919, 408.5 ( memorie van antwoord) blz. 17.

67. Hand. Tweede Kamer, zitting 1918 - 1919, blz. 2878.

68. Hand. Tweede Kamer, zitting 1923-1924, blz. 1727. Zie hierover J.L.J. van de Kamp, Geschiedenis der pogingen tot wettelijke regeling van den landbouwarbeid, in R.B.A. XXIV blz. $85 \mathrm{t} / \mathrm{m}$ 88; M.G. Levenbach, Arbeid in een onderneming van landbouw, in R.B.A. XXVII blz. $49 \mathrm{t} / \mathrm{m} \mathrm{51,} \mathrm{blz.} 73-74$ en blz. $77 \mathrm{t} / \mathrm{m} 79$.

69. Bij Besluit van 5 februari 1920, Stb. 56. De dienst kon uitgebreid worden met ( uitgezonderd de administratieve ambtenaren ): 2 geneeskundigen, 2 inspecteurs of adjunct-inspecteurs, 1 elektrotechnisch ingenieur, 1 scheikundig ingenieur, 1 landbouwkundige, 2 inspectrices of adjunct-inspectrices, 10 oprichters ( technisch ambtenaren ), 1 scheikundig assistent, 10 controlleurs en 3 opzichteressen. De totale personeelsterkte werd hierdoor gebracht op 99 inspecterende, 4 medische en 84 administratieve ambtenaren; zie Centraal Verslag der Arbeidsinpectie over 1919, blz. 2.

70. Centraal Verslag der Arbeidsinspectie over 1919 en over 1920, resp. blz. 2 en blz. 1...

71. Hand. Tweede Kamer, zitting 1919 - 1920, blz. 2539, blz. 2551 en blz. 2557 t/m 2571.

72. Hand. Tweede Kamer, zitting 1919 - 1920, blz. $2543 \mathrm{t} / \mathrm{m} 2546$.

73. Besluit van 27 september 1920, Stb. 756. Er zouden overigens nog 9 algemene maatregelen van bestuur uitgevaardigd worden, waaronder het Werktijdenbesluit voor fabrieken of werkplaatsen 1920, Stb. 747, het Rusttijden- en Arbeidstijdenbesluit voor fabrieken- of werkplaatsen 1920, Stb. 758, het Overgangsbesluit 1920 , Stb. 757; en het Arbeidsbesluit 1920, Stb. 694.

74. Besluit van 11 augustus 1920, Stb. 700 .

75. Besluit van 23 augustus 1920 , Stb. 720 .

76. Zie de artikelen $2,7 \mathrm{t} / \mathrm{m} 9$ van het Organisatiebesluit. 
77. Zie de artikelen $10 \mathrm{t} / \mathrm{m} 15$ van het Organisatiebesluit.

78. Zie de artikelen 16 en 17 van het Organisatiebesluit.

79. Besluit van 1 september 1927, Stb. 297.

80. Wel zou het Besluit op 31 maart 1931, Stb. 81 en op 28 november 1949, Stb. J.516, gewijzigd worden, waarbij de handhaving van het bij of krachtens de Arbeidswet 1919 bepaalde en de medewerking aan de uitvoering ervan, voor zover die bepalingen betrekking hebben op inrichtingen voor het verplegen van zieken, ieder binnen zijn ambtsgebied, mede opgedragen wordt aan:

1. inspecteurs voor het Staatstoezicht op krankzinnigen en krankzinnigengestichten ten aanzien van krankzinnigengestichten en inrichtingen tot het verplegen van zwakzinnigen;

2. de hoofdinspecteur en de inspecteurs van de volksgezondheid, behorende tot de dienst, die in het bijzonder belast is met de handhaving van wettelijke bepalingen betreffende besmettelijke ziekten, en tot de dienst, die belast is met de zaken betreffende de hygiëne van het kind, de tuberculosebestrijding en de bestrijding van geslachtsziekten, ten aanzien van de overige inrichtingen tot het verplegen van zieken.

(zie de artikelen 17bis t/m 17quater van het Besluit van 23 augustus 1920, Stb. 720. Het artikel 17quater zou bij Besluit van 1 juni 1957 tot hernieuwde vaststelling van een algemene maatregel van bestuur als bedoeld in de artikelen 65, 68, elfde lid en 91 der Arbeidswet 1919 (Verplegingsbesluit), Stb. 196, nog een technische wijziging ondergaan ).

Met de handhaving van het bij of krachtens de Arbeidswet 1919 bepaalle en met de medewerking aan de uitvoering ervan, voor zover die bepalingen betrekking hebben op vaartuigen, zijn, ieder binnen zijn ambtsgebied, mede belast de ambtenaren, als bedoeld in artikel 17, eerste lid, van de Stuwadoorswet (Wet van 16 oktober 1914, Stb. 486 )( zie artikel 17quinquies van het Besluit van 23 augustus 1920, Stb. 720 ).

81. Centraal Verslag der Arbeidsinspectie over 1920, blz. 19.

82. Zie Centraal Verslag der Arbeidsinspectie over 1920 en 1921, resp. blz. 26 en blz. 26.

83. Tweede Kamer, zitting $1921-1922$, no. 2.2 ( Hfdst. Xa begroting Arbeid) blz. 1 - 2.

84. Tweede Kamer, zitting 1921 - 1922, no. 2.8 ( Hfdst. Xa begroting Arbeid) blz. 4.

85. Deze leden verwezen naar een artikel van C.J.P. Zaalberg, De 8-urendag in Nederland, in Sociale Voorzorg $1921 \mathrm{blz} 598 \mathrm{t} / \mathrm{m} 607$, die er op wijst, dat de arbeidsinspectie, die in de eerste tijd na de invoering van de Arbeidswet 1919 met werk was overladen, thans de handen wat vrijer krijgt.

86. Tweede Kamer, zitting 1921 - 1922, no. 2.9 ( Hfdst. Xa begroting Arbeid) blz. 4.

87. Tweede Kamer, zitting 1921 - 1922, no. 2.13. Het amendement was ondertekend door Drion, De Groot, Dresselhuis, Otto en Visser van Yzendoorn.

88. Zie Hand. Tweede Kamer, zitting $1921-1922$ II, blz. $1346 \mathrm{t} / \mathrm{m} 1353$. Zie over het amendement Drion c.s. Guide, Bezuiniging bij arbeid, in Tijdschrift der Nederlandsche Maatschappij voor Nijverheid en Handel $1922 \mathrm{blz} .47 \mathrm{t} / \mathrm{m} 49$.

89. Besluit van 11 juli 1922 , Stb. 445 .

Artikel 1 luidde: 
Ten behoeve van den dienst der arbeidsinspectie wordt het Rijk verdeeld in elf districten, waarvan omvatten:

het 1ste de provincie Limburg en het gedeelte der provincie Noord-Brabant, dat behoort tot het rechtsgebied van de kantongerechten Veghel, Boxmeer, Eindhoven, Oirschot, Weert en Helmond;

het 2 de het gedeelte der provincie Noord-Brabant, dat niet behoort tot het 1ste district; het 3 de het gedeelte der provincie Zuid-Holland, dat behoort tot het rechtsgebied van de kantongerechten Schiedam en Rotterdam, alsmede de gemeenten Berkel, Delft, 's-Gravenzande, de Lier, Monster, Naaldwijk, Nootdorp, Pijnacker, Schipluiden, Wateringen en IJsselmonde;

het 4de de provincie Utrecht, de gemeenten Vianen en Hagestein, het gedeelte der provincie Noord-Holland, dat behoort tot het rechtsgebied van het kantongerecht Hilversum, het gedeelte der provincie Gelderland dat behoort tot het rechtsgebied van het kantongerecht Harderwijk en de gemeente Oldebroek;

het 5 de het gedeelte der provincie Noord-Holland, dat behoort tot het rechtsgebied van het kantongerecht Amsterdam, benevens het niet tot eenige provincie behoorende watergebied des Rijks;

het 6 de het gedeelte der provincie Noord-Holland, dat niet behoort tot het 4de, het $5 \mathrm{de}$ en het 9 de district;

het 7 de het gedeelte der provincie Gelderland, dat miet behoort tot het 4de district;

het 8 ste de provincie Overijssel;

het 9 de de provinciën Groningen, Frieslland en Drenthe, benevens de eilanden Vlieland en Terschelling;

het 10de de provincie Zeeland en het gedeelte der provincie Zuid-Holland, dat niet behoort tot het 3 de, het 4 de en het 11 de district;

het 11de het gedeelte der provincie Zuid-Holland, dat behoort tot het rechtsgebied der kantongerechten 's-Gravenhage, Leiden, Gouda, Woerden, Alphen en Haarlemmermeer, het gedeelte van het rechtsgebied van het kantongerecht Delft, dat niet behoort tot het $3 \mathrm{de}$ district, en het rechtsgebied van het kantongerecht Schoonhoven, met uitzondering van de gemeenten Krimpen a/d IJssel, Krimpen a/d Lek en Lekkerkerk" .

90. Hand. Tweede Kamer, zitting 1903 - 1904, blz. 618 e.v..

91. Hand. Tweede Kamer, zitting $1910-1911$, blz. 1789.

92. Wet van 2 mei 1897 , Stb. 141.

93. Tweede Kamer, zitting 1918 - 1919, 408.5 ( memorie van antwoord ) blz. 6.

94. Hand. Tweede Kamer, zitting 1918 - 1919, blz. 2878.

95. Zie A.C. Josephus Jitta/E.H. Bisschop Boele, t.a.p.; blz. 58 - 59.

96. Zie T. van Peype, t.a.p., bla. 168 t/m 177; J. Westhoff, in Het Departement van Arbeid, Handel en Nijverheid, blz. 20 .

97. Hooge Raad van Arbeid, Voorlopig Advies over vraagpunten betreffende bedrijfsorganisatie, van 14 mei 1921, no. 222, 's-Gravenhage 1921; Centraal Historisch Archief doss.nr. 1303. 
98. Hooge Raad van Arbeid, Advies betreffende het voorontwerp van wet tot wijziging van de Arbeidswet 1919 van 15 oktober 1921, no. 546, 's-Gravenhage 1921; Centraal Historisch Archief doss.nr. 1303. Zie ook J. Westhoff, in Het Departement van Arbeid, Handel en Nijverheid, blz. 21.

99. Zie Tweede Kamer, zitting $1921-1922,438.1$ en 2.

100. Hand. Tweede Kamer, zitting $1921-1922$, blz. $168 \mathrm{t} / \mathrm{m} 208$.

101. Hand. Tweede Kamer, zitting 1921-1922, blz. $160-170$. De vragen, die het genoemde Kamerlid stelde, luidden als volgt:

"1. Waaraan ontleent de Minister het recht bij het verleenen van overwerk voorwaarden te stellen:

a. omtrent het zich aansluiten van den werkgever bij een bepaalde organisatie of het zich onderwerpen aan door deze te stellen regelen;

b. omtrent het overleg van de werkgevers met de vertegenwoordigers van arbeidsorganisaties;

c. omtrent het door den werkgever te betalen loon?

2. Naar welke algemeene regelen beslist de Minister over het weigeren of al of niet voorwaardelijk toestaan van overwerk?

3. Kan de Minister een regeling treffen, ten gevolge waarvan in het vervolg spoediger dan meestal thans het geval is over vergoeding voor overwerk beslist wordt?"

102. Hand. Tweede Kamer, zitting $1921-1922$, blz. 171.

103. Hand. Tweede Kamer, zitting 1921 - 1922, blz. 175 .

104. Hand. Tweede Kamer, zitting $1921-1922$, blz. $175 \mathrm{t} / \mathrm{m} 179$.

105. Hand. Tweede Kamer, zitting $1921-1922$, blz. 180 - 181; zie J. Westhoff, in Het Departement van Arbeid, Handel en Nijverheid, blz. $21-22$.

106. Zie Tweede Kamer, zitting 1921 - 1922, 458.3 (memorie van toelichting ) blz. 1 - 2 .

107. Tweede Kamer, zitting 1921 - 1922, 458.5 ( voorlopig verslag ) blz. 2.

In zijn verweer verwees minister Aalberse naar de buitenlandse (wettelijke) normen voor de arbeidsduur en naar de op 28 juni 1918 in het Verdrag van Versailles (deel XIII) genoemde 48-urige werkweek als richtsnoer voor de internationale arbeidersbescherming en artikel 2 , onder $b$, van het ontwerp-Verdrag van Washington strekkende tot beperking van de arbeidsduur in nijverheidsondernemingen ( "indien ingevolge een wet, krachtens gewoonte of krachtens overeenkomsten tusschen de vereenigingen der werkgevers en der arbeiders (of, indien zoodanige vereenigingen er niet zijn, tusschen vertegenwoordigers der werkgevers en der arbeiders ) de arbeidsduur op een of meer dagen der week korter is dan acht uur, kan het overschrijden van de grens van acht uren op de overige dagen der week worden toegestaan door een daad van wetgeving van de bevoegde overheid of door een overeenkomst tusschen de bovengenoemde vereenigingen of vertegenwoordigers. De krachtens deze alinea toegestane overschrijding zal nooit meer dan één uur per dag moeten bedragen" ). Dit laatste gebruikte de bewindsman met name om zijn bewering te staven, dat de gemiddelde 8-urige werkdag niet werd aangetast doordat de vrije zaterdagmiddag gehandhaafd bleef.

Aanvankelijk was minister Aalberse echter van mening dat het ontwerp-Verdrag van Washington geen wijziging van de Arbeidswet 1919 met zich zou moeten brengen. Zo schreef hij aan zijn ambtgenoot van Landbouw, Nijverheid en Handel: 
Het ontwerp-verdrag geeft de grenzen aan voor de regeling van den arbeidsduur in de toegetreden landen. De bekrachtiging van het ontwerp-verdrag behoeft derhalve op zich zelf te leiden tot wijziging van de bepalingen, die binnen de grenzen van het ontwerp-verdrag blijuen."

De ommezwaai vond eerst plaats na "rijp beraad"; zie J.P. Gribling, P.J.M. Aalberse 1871 - 1948, Utrecht 1961, blz. 371.

108. Zie bijwoorbeeld Tweede Kamer, zitting 1921 - 1922, 458.6 ( memorie van antwoord ) blz. 13.

109. Hand. Tweede Kamer, zitting $1921-1922$, blz. 2520. Het Kamerlid Schaper verwoordde het als volgt: "Het stortregent overwerkvergunningen".

110. Zie bijvoorbeeld de artikelen 28, derde, vijfde en zesde lid, en 29, eerste lid, van de Arbeidswet 1919.

111. Bij het ontbreken van werkgevers- en arbeidersvakverenigingen een behoorlijke vertegenwoordiging van werkgevers en arbeiders uit een bedrijf(stak). Zie artikel 28, zevende lid, van de Arbeidswet 1919.

112. Tweede Kamer, zitting 1921 - 1922, 458.5 (voorlopig verslag ) blz. 10 - 11.

113. Tweede Kamer, zitting 1921 - 1922, 458.5 ( voorlopig verslag ) blz. 11 - 12.

114. Tweede Kamer, zitting 1921 - 1922, 458.5 ( voorlopig verslag ) blz. 12.

115. Tweede Kamer, zitting 1921 - 1922, 458.6 (memorie van antwoord) blz. 9 - 10.

116. Zie Hand. Tweede Kamer, zitting 1921 - 1922, blz. 2718; de stemming viel als volgt uit: 54 voor en 23 tegen het wetsontwerp. In de Eerste Kamer bedroeg het aantal voorstemmers 32, terwijl slechts 4 Kamerleden tegen stemden; zie Hand. Eerste Kamer, zitting 1921 1922, blz. 1045.

117. Zie T. van Peijpe, t.a.p., blz. 147.

118. Het groeiend zelfvertrouwen vindt, aldus T. van Peijpe, t.a.p., blz. 147 en blz. 167-168, vermoedelijk zijn oorzaken in de sterke groei van het ledental en in het succes bij de onderhandelingen over collectieve arbeidsovereenkomsten in de periode $1918-1920$.

119. Zie T. van Peijpe, t.a.p., blz. 147 - 148.

120. Zie T. van Peijpe, t.a.p., blz. 148, die vervolgens op blz. 166 constateert, dat wat de uitvoering van de Ziektewet betreft zich een op het eerste gezicht merkwaardig feit voordeed, dat het voorstel tot samenwerking van werkgevers en arbeidersorganisaties op dit gebied afkomstig was van groeperingen die in het samenwerkingsstreven niet vooropliepen, namelijk de liberalle werkgevers en de moderne vakbeweging. In de commissie voor de Arbeidersverzekering van de Hooge Raad van Arbeid had de toenmalige president-directeur van Centraal Beheer, Posthuma, gepleit woor de erkenning van de werkgeversziekenkassen als uitwoeringsorganen van de Ziektewet. In het najaar van 1920 begon hij onderhandelingen over dit onderwerp met de vertegenwoordiger van het NVV Kupers. Deze besprekingen resulteerden in een gemeenschappelijke Proeve van een ontwerp-Ziektewet, bekend als de Proeve Posthuma-Kupers, waarin de uitvoering werd afgedragen aan bedrijfsverenigingen van werkgevers- en arbeidersorganisaties.

121. T. van Peijpe, t.a.p., blz. 148. 
122. J. Westhoff, in Het Departement van Arbeid, Handel en Nijverheid, blz. 35. Zie bijvoorbeeld Centraal Verslag der Arbeidsinspectie over 1922, 's-Gravenhage 1924, over 1923, 's-Gravenhage 1925, over 1925, 's-Gravenhage 1926, resp. blz. $86,92 \mathrm{t} / \mathrm{m} 95$ en blz. $91 \mathrm{t} / \mathrm{m} 95$.

123. E. Tinga, Artikel 28, zevende en achtste liid van de Arbeidswet 1919, in Arbeid 1950 blz. 71 - 72.

124. C.C.A. Last, Arbeidsinspectie, in Sociale Voorzorg $1923 \mathrm{blz} .136 \mathrm{t} / \mathrm{m} 145$.

125. Opgemerkt zij, dat bijwoorbeeld artikel 28, eerste lid, van de Arbeidswet 1919 niet alleen betrekking heeft op overwerk, maar tevens op werktijdgrensverschuiving en arbeid op zaterdagmiddag ( respectievelijk artikel 24, tweede lid, en artikel 23 van de Arbeidswet 1919 ). Slechts bij afwijking van artikell 24, eerste lid, van de Arbeidswet 1919 ("een arbeider mag in fabrieken of werkplaatsen niet langer arbeid verrichten dan acht en een half uur per dag en acht en veertig uur per week" ) is er sprake van overwerk in de zin van bedoelde wet; zie J. van Drongelen, in S.M.A. 1983 blz. $78 \mathrm{t} / \mathrm{m} 83$.

126. Centraal Verslag der Arbeidsinspectie over 1923, blz. 78; J. Westhoff, in Het Departement van Arbeid, Handel en Nijverheid, blz. 33.

127. Centraal Verslag der Arbeidsinspectie over 1923, blz. 77.

128. Zie J. Westhoff, in Het Departement van Arbeid, Handel en Nijverheid, blz. 33.

129. Zie Tweede Kamer, zitting 1918 - 1919, 458.5 ( memorie van antwoord ) blz. 6 .

130. Centraal Verslag der Arbeidsinspectie over 1922, blz. 76 en blz. 86.

131. Centraal Verslag der Arbeidsinspectie over 1923, blz. 95 en blz. $380-381$.

132. Centraal Verslag der Arbeidsinspectie over 1924, 's-Gravenhage 1925, blz. 396 en blz. 399.

133. Zie Centraal Verslag der Arbeidsinspectie over 1922, blz. 76.

134. Centraal Verslag der Arbeidsinspectie over 1925, blz. 95 - 96; zie ook J.H.A. Engels, Het Centraal Verslag der arbeidsinspectie over 1925-I, in K.S.W. 1927 blz. 17 t/m 19.

135. J.H.A. Engels, in K.S.W. 1927 blz. 19.

136. J.H.A Engels, Centraal Jaarverslag der arbeidsinspectie over 1926-I, in K.S.W. 1927 blz. 647.

137. J.H.A. Engels, in K.S.W. 1927 blz. 647.

138. J.H.A. Engels, Centraal Jaarverslag der arbeidsinspectie over 1926-II, in K.S.W. 1927 blz. $661-662$.

139. Resp. Werktijdenbesluit voor fabrieken of werkplaatsen 1923, Stb. 442, en Rusttijden- en Arbeidstijdenbesluit voor fabrieken of werkplaatsen 1923 , Stb. 443 .

140. Centraal Verslag der Arbeidsinspectie over 1926, 's-Gravenhage 1927, blz. 43.

141. Centraal Verslag der Arbeidsinspectie over 1926, blz. 43. 
142. Zie J.H.A. Engels, in K.S.W. 1927, blz. 648.

143. Centraal Verslag voor Arbeidsinspectie over 1926, blz. 62 .

144. Zie J.H.A. Engels, in K.S.W. 1927, blz. 648.

145. Zie J.H.A. Engels, in K.S.W. 1927, blz. 648.

146. Centraal Verslag der Arbeidsinspectie over 1926, blz. 70.

147. Zie J.H.A. Engels, in K.S.W. 1927, blz. 648.

148. HR 17 november 1924, W.11304.

149. HR 26 januari 1926 , NJ 1926 blz. 246 , W.11464.

150. Beslluit van 10 augustus 1920, Stb. 694 .

151. De van belang zijnde leden van artikel 68 van het Arbeidsbesluit 1920 luidden:

"Heeft het hoofd of de bestuurder bezwaar tegen een eisch, aanwijzing of oordeel van het districtshoofd of tegen eene wijziging op een verzoek, ingevolge eenige bepaling van dit besluit tot het districtshoofd gericht, dan kan hij daarvan binnen 14 dagen na de dagteekening in beroep komen bij Onzen Minister. Deze beslist na onderzoek.

Van de met redenen omkleede beslissing wordt afschrift gezonden aan het hoofd of den bestuurder van de onderneming.

Wordt bij de beslissing de eisch of de aanwijzing geheel of ten deele vernietigd of wel het oordeel of de weigering geheel of ten deele onjuist verklaard; dan treedt de beslissing in beroep gegeven, in de plaats van den eisch, de aanwijzing, het oordeel of de weigering, waartegen beroep werd ingesteld.

Voor het hoofd of den bestuurder vloeit geenerlei verplichting voort uit een eisch, eene aanwijzing of een oordeel, zolang daartegen beroep kan worden ingesteld en zolang omtrent een ingesteld beroep niet is beslist".

152. Centraal Verslag der Arbeidsinspectie over 1921, blz. 57 - 58.

153. Deze commissie bestond uit: H.A. van IJsselstein, C. Eykman ( hoogleraar in de hygine ) en G.L. Voerman ( directeur Rijksbureau tot onderzoek van handelswaren ). Zie Centraal Verslag der Arbeidsinspectie over 1923, 's-Gravenhage 1924, blz. 57; zie ook Aanhangsel Hand. Tweede Kamer zitting 1923 - 1924 , blz. $64-65$.

154. Ktg. Amsterdam 10 maart 1924, Centraal Verslag der Arbeidsinspectie over 1924, 's-Gravenhage 1925, blz. $57 \mathrm{t} / \mathrm{m} 59$.

155. Rb. Amsterdam 3 juni 1924.

156. HR 17 november 1924, W.11304. Zie ook Centraal Verslag der Arbeidsinspectie over 1924, blz. 245 246.

157. Rb. Alkmaar 22 september 1925. 
158. Ktg. Hoorn 13 mei 1925.

159. HR 25 januari 1926, W.11464; zie Centraal Verslag der Arbeidsinspectie over 1925, blz. 217 - 218.

160. Zie Centraal Verslag der Arbeidsinspectie over 1921, 1922, 1923, 1924 en 1925, resp. blz. 57 - 58, blz. $61-62$, blz. $57 \mathrm{t} / \mathrm{m} 59$, blz. $59 \mathrm{t} / \mathrm{m} 65$ en blz. $216 \mathrm{t} / \mathrm{m} 218$.

161. Brief van 4 maart 1927, afd. Arbeid no. 79; Centraal Historisch Archief doss.nr. 1325.

162. Besluit van 15 juli 1891, Stb. 147.

163. Memorie van toelichting bij het voorontwerp van wet; bijlage brief van 4 maart 1927, afd. Arbeid, no. 79.

164. Hooge Raad van Arbeid, advies betreffende voorontwerp tot wijziging van de Arbeidswet 1919,27 juni 1927, no. 122, zie voor een reactie van de directeur-generaal van de Arbeid, brief van 28 juli 1927, no. 8186; Centraal Historisch Archief doss.nr. 1326.

165. Hooge Raad van Arbeid, advies 27 juni 1927, no. 122, blz. 1 - 2.

166. Tweede Kamer, zitting 1927 - 1928, no. 235.1 .

167. Tweede Kamer, zitting $1927-1928,255.6$ ( voorlopig verslag ) blz. 1 - 2.

168. Ingesteld bij Koninklijk besluit van 24 maart 1910.

169. Tweede Kamer, zitting $1927-1928$, no. 255.7 ( memorie van antwoord) blz. $1-2$.

170. Een standpunt dat overigens ook door een aantal leden van de Tweede Kamer ingenomen is; zie Tweede Kamer, zitting 1927 - 1928, 235.6 (voorlopig verslag ) blz. 2 - 3.

171. Hand. Tweede Kamer, zitting 1929 - 1930, blz. 1832.

172. Hand. Eerste Kamer, zitting 1929 - 1930, blz. 651.

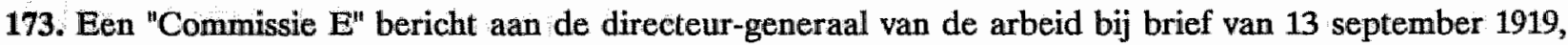
no. 2681, van een gedeeltelijke uitvoering van een opdracht neergelegd in de brief van 16 juni 1919, no. 2429. Daarbij is een ontwerp algemene maatregel van bestuur gevoegd betreffende zaterdagmiddagarbeid door arbeiders, dus zowel mannen, vrouwen als jeugdigen. Bij brief van 7 januari 1921, no. 180, zond de directeur-generaal van de Arbeid een ontwerp-werktijdenbesluit voor kantoren aan de bewindsman, welke eveneens zou moeten gelden voor mannen, vrouwen en jeugdigen. Op 15 oktober 1921 brengt de Hooge Raad van Arbeid over dit ontwerpbesluit advies uit (Advies over een werktijdenbesluit voor kantoren, no. 548), waarop op 5 september 1922, de Raad van State advies witbrengt (onder no. 15); de stukken zijn te vinden in het Centraal Historisch Archief.

174. In de brief van 6 november 1922, no. 15993, schrijft de directeur-generaal van de Arbeid aan de minister van Arbeid, dat het antwoord op de vraag wanneer en in hoeverre het werktijdenbesluit voor kantoren in werking zal behoeven te treden, wordt beheerst door drie factoren, namelijk de mate van noodzakelijkheid van de bescherming, de draagkracht van de ondernemingen in verband met deze nieuwe last en de 
mogelijkheid van toezicht op de naleving. Wat dit laatste punt betreft, merkt de directeur-generaal van de Arbeid het volgende op:

"De invoering van het werktijdenbesluit voor al het kantoorpersoneel zal voor de arbeidsinspectie een hoeveelheid contrôle-arbeid, zoowel door inspectie als langs administratieven weg medebrenges, dat zij zonder personeelsuitbreiding niet behoorlijk zal kunnen bewerkstelligen. Daar nu vaststaat, dat behoudens vervulling der vacatures, uitbreiding van personeel in geen jaren te wachten is, kan de invoering slechts geleidelijk plaats hebben. Is een deel van het terrein eenmaal bewerkt en zijn de nieuwe ambtenaren bekwaamd, dan kan weer een schrede verder worden gegaan".

De brief is te vinden in het Centraal Historisch Archief.

175. Conform het voorstel van de directeur-generaal van de Arbeid in de brief van 6 november 1922 , no. 15993. Zie het Besluit van de 25 november 1922, voor zoover betreft den arbeid van jeugdige personen in kantoren, Stb. 634.

176. Zie artikel 19 van het Besluit van 3 September 1928 ( Verplegingsbesluit 1928), Stb. 359 .

177. Zie resp. de artikelen 6 van het Rustdagbesluit voor toonkunstenaars in bioscopen 1929 , Stb. 380, en 8 van het Rustdagbesluit voor transportarbeiders te land 1929, Stb. 306.

178. Zie artikel 22 van het Werktijdenbesluit voor winkels 1929, Stb. 313.

179. Wet van 29 november 1930 , Stb. 460 .

180. Als gevolg hiervan werd een nieuw Werktijdenbesluit voor artikel 1932, Stb. 84, uitgevaardigd, dat eveneens op 1 mei 1932 in werking trad ( zie artikel 31 van dat Besluit ). Zie M.G. Levenbach, Arbeid, in Nederlands bestuursrecht, blz. 435 nt. 1; Centraal Verslag der Arbeidsinspectie over 1929, 's-Gravenhage 1930, blz. 1 - 2 .

181. Tweede Kamer; zitting 1927 - 1928, 363.3 (memorie van toelichting ) blz. 5. Zie artikel 12, eerste lid, van de Winkelsluitingswet 1930.

182. Zie Centraal Verslag der Arbeidsinspectie over 1925, blz. 1 - 2.

183. Wet van 11 november 1921, Stb. 1167; in werking getreden op 16 juli 1923 (zie Besluit van 23 juni 1923 , Stb. 296).

184. Zie Centraal Verslag der Arbeidsinspectie over 1923, blz. 216 en 219.

185. Centraal Verslag der Arbeidsinspectie over 1922, blz. 27.

186. Zie Centraal Verslag der Arbeidsinspectie over 1919, blz. 2.

187. Centraal Verslag der Arbeidsinspectie over 1922 en 1929, resp. blz. 105 en blz. 99.

188. Besluit van 7 december 1896 , Stb. 215 .

189. Centraal Verslag der Arbeidsinspectie over 1928, 's-Gravenhage 1929, blz. 101 - 102. 
190. Centraal Versllag der Arbeidsinspectie over 1925, blz. 120 - 121. Overigens geeft dit voorbeeld een beeld van de wel zeer nauwgezette wijze waarop door de arbeidsinspectie werd gecontroleerd, alsook van de nauwgezette wijze waarop verslag werd gedaan van de activiteiten.

191. Centraal Verslag der Arbeidsinspectie over 1925, blz. 128.

192. Dit blijkt uit het volgende overzicht: in 1918 betrof het aantal oprichtingen van nieuwe bedrijven 1149 en het aantal uitbreidingen van oude bedrijven 1469 (totaal: 2618); in 1919 was dit resp. 1804 en 1732 (totaal: 3536 ); in 1920 resp. 2440 en 2632 (totaal: 5072 ); in 1921 resp. 2440 en 2963 (totaal: 5403); in 1922 resp. 2504 en 3957 (totaal: 5861 ); in 1923 resp. 2438 en 2736 (totaal: 5172 ; in 1924 resp. 2334 en 2779 (totaal: 3113 ) en in 1925 resp. 2266 en 2761 (totaal: 5027). Zie Centraal Verslag der Arbeidsinspectie over 1925, blz. 26.

193. Zie Centraal Verslag der Arbeidsinspectie over 1923, blz. 40.

194. Centraal Verslag der Arbeidsinspectie over 1923 en 1925, resp. blz. 33 - 34 en blz. 30; zie ook Centraal Verslag der Arbeidsinspectie over 1926, over 1927,'s-Gravenhage 1928 en over 1928, 's-Gravenhage 1928, resp. blz. $39-40$, blz. 30 en blz. $34 \mathrm{t} / \mathrm{m} 38$.

195. Centraal Verslag der Arbeidsinspectie over 1929, 's-Gravenhage 1930, blz. 34.

196. De werkingssfeer van deze wet werd aanzilenlijk uitgebreid en zou voortaan de Ongevallenwet 1921 heten: zie G.J.M. Veldkamp, t.a.p., blz. 74 - 75.

197. Zie Centraal Verslag der Arbeidsinspectie over 1922, blz. 41. Verschillende mededelingen betroffen inlichtingen, die niet aan het toezicht van de Arbeidsinspectie onderworpen waren.

198. Zie Centraal Verslag der Arbeidsinspectie over 1923, 1924 en 1925 , resp. blz. 34 , blz. 33 en blz. 30 - 31 .

199. Zie Centraal Verslag der Arbeidsinspectie over 1922, over 1923, over 1924 en over 1925, resp. blz. 41, blz. 24 , blz. 33 en blz. 31 .

200. Zie Centraal Verslag der Arbeidsinspectie over 1921, over 1922, over 1923, over 1924, over 1925, over 1926 , over 1927 , over 1928 en over 1929 , resp. blz. $15-16$, blz. $16-17$, blz. 14 , blz. 14 , blz. 13 , blz. 25 , blz. 15, blz. 16 en blz. 15 .

201. Is.P. de Vooys; deze was zowel voorzitter van het Koninklijk Nationaal Steuncomite als de Nederlandsche Werkloosheidsraad. Zie P.E. de Hen, t.a.p., blz. 63.

202. C.J.P. Zaalberg, Het K.N.S, en de werkloosheid, in T.N.V.W. 1917 blz. 644.

203. Bij besluit van 19 december 1922; zie P.E. de Hen, t.a.p., blz. 329 nt. 129.

204. De overige ambtelijke leden waren: A. Folma (hoofd van de afdeling Arbeidsbemiddeling en Werkloosheidsverzekering), M.A. Harders (hoofd van de afdeling Armenzorg) en A. van Doorninck (thesaurier-generaal). Zie P. de Rooy, Werklozenzorg en werkloosheidsbestrijding 1917 - 1940, Landelijk en Amsterdams beleid, Amsterdam 1979, blz. 41; zie ook P.E. de Hen, t.a.p., blz. 67.

205. Besluit van 28 mei 1926. 
206. Zie P. de Rooy, t.a.p., blz. 41 .

207. De Commissie-Zaalberg was er zelfs trots op, dat pogingen daartoe vanuit de Nederlandsche Werkloosheidsraad werkzaam waren, getuige deze passage uit een brief van de directeur-generaal van de Arbeid van 13 juli 1927, no. 7675 :

"Zoo werd ons advies gevraagd over verschillende voorstellen van den Werkloosheidsraad en mochten wij het genoegen smaken, dat overeenkomstig onze adviezen, plannen als het instellen van een met groote macht bekleed orgaan voor de volkswelvaart of voor werkverruiming worden afgewezen en dat die belangrijke taak van Overheidsbemoeiing in handen der betrokken ministers bleef en deze voor betere samenwerking een commissie van vier vormden".

(Rijksarchief: Commissie-Archieven doss.no. 1).

208. Zie P. de Rooy, t.a.p., blz. 59.

209. Zie bijvoorbeeld de brief van de directeur-generaal van de Arbeid aan de minister-president van 13 juli 1927, no. 7675; van 26 maart 1928, no. 3368; van 1 maart 1929, no. 2118 ( Rijksarchief: Commissie-Archieven doss. no. 1).

210. Brief van de directeur-generaal van de Arbeid aan de minister-president van 9 april 1929, no. 4124 (Rijksarchief: Commissie-Archieven doss.no. 1).

211. Nota van C.J.P. Zaalberg aan de leden van de Commissie van 3 mei 1929, no. 5557 ( Rijksarchief: Commissie-Archieven doss.no. 12).

212. Zie P. de Rooy, t.a.p., blz. 27 t/m 65; P.E. de Hen, t.a.p., blz. 63 t/m 66.

213. Centraal Verslag der Arbeidsinspectie over 1929, blz. 395 t/m 398.

214. Als partijen stonden tegenover elkaar de Nederlandsche Bond van Christelijke Landbouw-, Tuinbouwen Zuivelarbeiders en de Nederlandsche Bond van Arbeiders in het Landbouw-, Tuinbouw- en Zuivelbedrijf enerzijds en de Christelijke Werkgeversbond in het Landbouwbedrijf, Afdeling Ezinge en Oldehove en de Bond van. Werkgevers in het Landbouwbedrijf, gevestigd te Oldehove; zie Centraal Verslag der Arbeidsinspectie over 1921 , blz. 260 .

215. Centraal Verslag der Arbeidsinspectie over 1921, blz. 260 t/m 262.

216. De partijen die bij het geschil betrokken waren, waren een aantal steenfabrikanten, verenigd in de afdelingen Boven-IJssel, Lobith, Nijmegen-Millingen, Nijmegen-Tiel, Arnhem-Millingen en Arnhem-Wijk bij Duurstede, en de drie samenwerkende organisaties van Steenfabrieksarbeiders, namelijk de Nederlandsche Bond van Christelijke Fabrieks- en Transportarbeiders, de Nederlandsche Roomsch-Katholieke Steenfabrieksarbeidersbond "St. Stephanus" en de Nederlandsche Vereeniging wan Fabrieksarbeiders; zie Centraal Verslag der Arbeidsinspectie over 1923, blz. 336.

217. In de acte van compromis verbinden de bij het geschil betrokken partijen zich aan de beslissing te zullen onderwerpen; Zie Centraal Verslag der Arbeidsinspectie over 1923, blz. 339.

218. Centraal Verslag der Arbeidsinspectie over 1923, blz. $336 \mathrm{t} / \mathrm{m} 348$. 
219. Centraal Verslag der Arbeidsinspectie over 1920, blz. 18.

220. Centraal Verslag der Arbeidsinspectie over 1920, blz. 18.

221. Centraal Verslag der Arbeidsinspectie over 1921, blz. 17.

222. Centraal Versllag der Arbeidsinspectie over 1927 en 1928 , resp. blz. 15 en blz. 17.

223. Gedwongen winkelnering in verscheidene bedrijfstakken in verschillende deelen des lands, "s-Gravenhage 1917 ( uitgave Directie van den Arbeid no. 23).

224. Arbeidsvoorwaarden van het personeel op handelskantoren, 's-Gravenhage 1919 (uitgave Directie van den Arbeid no. 24).

225. Adresboek van de werklieden en ambtenaarenorganisaties in Nederland in 1920, 's-Gravenhage 1920 ( uitgave Directie van den Arbeid no. 25). 


\section{Inleiding}

Toen in de vroege ochtend van donderdag 29 oktober 1929 het Amerikaanse volk aan het werk ging, kon niemand vermoeden dat zich op deze dag op de beurs van New York een ramp zou voltrekken; een ramp die zijn weerga niet kende" en die ertoe zou leiden dat deze dag de geschiedenis in zou gaan als "Black Thursday", "zwarte donderdag". De op deze dag uitgebroken paniek in Wallstreet mondde uit in een langdurige economische en uiteindellijk ook een politiake wereldcrisis.

De Europese landen die de kwade gevolgen van de gebeurtenissen in Amerika het eerst ondervonden, waren Duitsland en Engeland. In de eerste maanden van 1930 was in ons land nog geen sprake van een ernstige algemene inzinking, zoals in Duitsland en Engeland. Maar met het vorderen van het jaar verslechterde de situatie. Het jaar 1930 kan dan ook als het jaar van de omslag worden getypeerd.

De al ingezette, zij het gematigde, prijsdaling zette zich voort, waardoor steeds meer ondernemingen in de problemen kwamen. De werkloosheid begon te stijgen; in november 1930 lag deze al ruim boven de 100.000 werklozen tegen circa 18.000 medio 1929 . Er zouden nog ettelijke honderdduizenden volgen ${ }^{2}$. Eerst na het loslaten van de zogenaamde gouden standaard in september 1936 zette enige economische opleving in ${ }^{3}$.

De economische problemen, de strijd voor het nationale economische bestaan, hadden hun weerslag op het politieke leven. De houding van de Nederlandse regering ten opzichte van de werkloosheid kan als passief omschreven worden, een deflatie-politiek onder handhaving van de gouden standaard; alles werd verwacht van het aanpassen aan de gegeven situatie:

"het vrije spel der maatschappelijke krachten",

wat niets anders betekent dan loonsverlaging. Fel werd gestreden over de vraag: aanpassing of ordening? Economische crisiswetgeving werd tot stand gebracht om zo het bedrijfsleven overeind te houden tegenover de moordende concurrentie van het ook om zijn bestaan vechtende buitenland. Allereerst werd dit tot stand gebracht op het terrein van de landbouw, bijwoorbeeld via de Tarwewet 1931, de Crisiszuivelwet 1932, de Crisispachtwet 1932 en de Crisisvarkenswet $1932^{4}$. Eerst bij de Landbouwcrisiswet $1933^{5}$ werd de grondslag gelegd voor een gereorganiseerde en gesystematiseerde landbouwpolitiek. Vervolgens zou al snel het gehele terrein van de handelspolitiek worden bestreken, bijwoorbeeld door middel van de Crisisinvoerwet 1931, de Crisisuitvoerwet 1931 en de Tariefmachtigingswet $1934^{\circ}$. Aanvankelijk tijdelijk gedachte wetgeving kreeg een langdurig karakter en greep steeds meer en steeds dieper regelend in in de structuur van het bedrijfsleven. Uiteindelijk resulteerde het in het aanvaarden van economische ordeningsmaatregelen, zoals de Wet op het algemeen verbindend en onverbindend verklaren van ondernemersovereenkomsten 1935 - de voorloper van het Kartelbesluit uit 1941 en van de Wet economische mededinging - en de Bedrijfsvergunningenwet $1938^{7}$. De ordeningsgedachte kwam woor de door de crisis geteisterde middenstand ook naar voren in de Winkelsluitingswet 1930, de Wet op het uitverkopen en opruimen in het winkelbedrijf 1935, de Afbetalingswet 1936 en vooral de Vestigingswet Kleinbedrijf $1937^{8}$.

\section{Bezuinigingen bij de arbeidsinspectie}

Op 26 oktober $1931^{\oplus}$ werd de staatscommissie voor de verlaging van de rijksuitgaven ingesteld, bekend onder de naam commissie-Welter naar haar voorzitter. Deze commissie, waarvan overigens ook de directeur-generaal van de Arbeid Zaalberg deel uitmaakte ${ }^{10}$, had tot taak ${ }^{11}$ :

"binmen zoo kort mogelijken termijn ... zoodanige voorstellen te doen als in verband met de noodzakelijkheid van een blijvende en aànzienlijke verlaging van het peil der Rijksuitgaven dienstig zullen zijn". 
Een half jaar later, op 26 april 1932 bracht de commissie-Welter haar rapport uit. De uitkomst van de door deze commissie gedane bezuinigingsvoorstellen zou niet zonder gevolgen blijven voor de arbeidsinspectie.

Ten aanzien van de uitgaven voor de arbeidsinspectie werd in het rapport gesteld ${ }^{12}$, dat deze afhankelijk zijn van: het te bewerken gebied, de intensiteit van het toezicht en de efficiency.

Het te bewerken gebied is afhankelijk van de uit te voeren wetgeving en de bedrijven, waarop deze toepasselijk is verklaard, terwijl, zo vervolgde het rapport, aan een vermindering van de intensiteit van het toezicht zeer grote bezwaren waren verbonden.

Een gevolg zou zijn, dat de wetsgetrouwe ondernemers op unfaire wijze beconcurreerd zouden worden door hen, die er op rekenen, dat overtredingen niet ontdekt zullen worden.

Een gelijkmatige toepassing der wetten eischt niet alleen een afdoende controle, zoowel van arbeidstijd als van veiligheid en hygiëne, doch ook een degelijk onderzoek van de aanvragen om diverse vergunnimgen en vrijstellingen."

Een verminderd toezicht leidde, aldus de commissie-Welter, tot directe schade voor zowel de arbeiders ten aanzien van de veiligheid en de hygiene in fabrieken of werkplaatsen - hetgeen in verschillende perioden, zoals de oorlog en eerdere bezuinigingen, al duidelijk was gebleken -, als de ondernemers, als gevolg van het langzaam behandelen van Hinderwetvergunningaanvragen en verzoeken om vrijstellingen en overwerkvergunningen.

Ter illustratie werden de activiteiten aangehaald wan de in totaal zes medici bij de arbeidsinspectie, wier werkzaamheden uitsluitend van hygiënisch belang werden genoemd. Een groot deel van hun arbeid vloeide rechtstreeks voort uit wettelijke bepalingen ten aanzien van verplichte medische keuringen. Daarnaast stonden zij de districtshoofden van de arbeidsinspectie bij en werden door hen onderzoeken in verschillende bedrijven verricht. Het aanvankelijke plan om in ieder van de elf districten van de arbeidsinspectie een geneeskundige te hebben, had men om bezuinigingsredenen laten varen, met als gevolg dat veel werkzaamheden achterwege bleven, die toch allang waren opgedragen.

Over de efficiency werd in het rapport gesteld, dat deze voortdurend op alle mogelijke wijzen, zowel ten aanzien van de werkmethoden, de personeelsuitbreiding, als de kantoortechniek, in acht werd genomen. Omtrent de werkmethoden werd vastgesteld, dat een vèrgaande decentralisatie van bevoegdheden en verantwoordelijkheden de kern is van de organisatie van de arbeidsinspectie, waarna een schets van de organisatieopbouw van de arbeidsinspectie werd gegeven. Afzonderlijk werd aandacht besteed aan het toezicht op de naleving van de arbeids - en rusttijdbepalingen, dat zeer vergemakkelijkt werd door het systeem van de arbeidslijsten; in iedere inrichting waarop de Arbeidswet 1919 van toepassing is, moest de arbeidsregeling, die gevolgd werd, opgehangen zijn. Zo werd het mogelijk gemaakt om de controle aan eenvoudig politiepersoneel op te dragen, hetgeen weer leidde tot een tot een zeer goede samenwerking met de politie, waarvan overigens gesteld werd, dat in geen enkel land iets te vinden was, dat daarmee in effect te vergelijken was. De normale bezetting van een district gaf de volgende personeelsindeling te zien: 1 hoofdinspecteur, 1 inspecteur, 2 of 3 technische ambtenaren en 3 controleurs; een zelfde indelingssysteem werd gehanteerd voor het administratief personeel:

De omvangrijke en veelzijdlige administratie had, om de inspectiedienst vlot te doen werken, al vroeg de noodzaak met zich gebracht van een kaartsysteem, het decimale stelsell en kantoormachines. Desalniettemin waren er, aldus het rapport, in de loop der jaren verschillen in werkwijze op de diverse districtskantoren ont-
staan.

Om die reden was dan ook in 1929 door de directeur-generaal van de Arbeid een commissie, bestaande uit zowel inspecterend als administratief personeel, ingesteld om én en ander na te gaan en voorstellen te doen ten einde een vereenvoudiging en uniformiteit te bewerkstelligen. Dit had niet alleen geresulteerd in belangrijke verbeteringen, maar eveneens geleid tot het besef, dat aan efficiency voortdurend aandacht diende te
worden besteed.

De conclusie in het rapport van de commissie-Welter luidde: 
"Dankzij de hooger geschetste organisatie en werkwijze van den dienst der Arbeidsinspectie

is de personeelsbezetting daarvan naar onze mening sober te achten."

Desalniettemin meende de commissie, dat het noodzakelijk was om de personeelsformatiekosten met $12 \%$ te verminderen ${ }^{13}$, zonder dat daardoor overigens de intensiteit en de doelmatigheid van het toezicht ontwricht zouden worden. Een deel van deze bezuiniging kon worden verkregen via de financiële middelen die op de begroting voor personeelsuitbreiding beschikbaar waren gesteld, zonder dat daadwerkelijk tot die uitbreiding was overgegaan. Een ander deel van de bezuiniging kon worden bereikt door het aantal districten van elf naar tien terug te brengen.

Nog tijdens de begrotingsbehandeling van het ministerie van Arbeid, Handel en Nijverheid voor het dienstjaar 1932 werden bij nota van wijzigingen ${ }^{14}$ onder meer deze voorstellen van de commissie-Welter doorgevoerd $^{15}$, hetgeen in het parlement weinig tegenstand ondervond ${ }^{16}$. Zo kon bij besluit van 6 september $1932^{17}$ de nieuwe districtsindeling worden geformaliseerd.

\section{Bezuinigingen en de verdere invoering van de Arbeidswet 1919}

$\mathrm{Na}$ de invoering van het Verplegingsbesluit $1928^{18}$ in 1929 , wat van de arbeidsinspectie een bijzondere inspanning vorderde ${ }^{19}$, zou 1930 , dat voor het bedrijfsleven bekend zal blijven als helt crisisjaar, zich voor de activiteiten van de arbeidsinspectie kenmerken als het jaar van de invoering van het Werktijdenbesluit voor winkels 1929, het Rustdagbesluit voor toonkunstenaars in bioscopen en het Rustdagbesluit voor transportarbeiders te land $^{20}$.

In een korte tijd was het terrein, dat aan het toezicht van de arbeidsinspectie was onderworpen, aanzienlijk uitgebreid.

Vooral de arbeids- en rusttijdenregeling voor winkelpersoneel bracht een grote hoeveelheid werk met zich; zo werd de arbeidsinspectie bekend met 25524 winkels ${ }^{21}$, hetzij door het inzenden van arbeidslijsten, hetzij door afgelegde bezoeken. Het aantal ontvangen afschriften van arbeidslijsten overtreft de 100.000. In Amsterdam bijvoorbeeld werden circa 22.500 afschriften ontvangen, waarvan er circa 10.000 fout waren. Om verbetering van deze lijsten te krijgen, gingen er 9920 aanschrijvingen uit, terwijl daarnaast vele telefoongesprekken gevoerd moesten worden en er vele bezoeken aan winkels gebracht moeten worden om een goede invulling van de arbeidslijsten te krijgen. Overigens waren er aan het eind van 1930 nog 2300 foutieve arbeidslijsten te behandelen. Dat de controle op de naleving van de administratieve bepalingen, het verschaffen van inlichtingen over de nieuwe voorschriften, het toezicht op de naleving daarvan en het behandelen van verzoeken om vrijstelling of afwijking van die bepalingen voor deze categorie van arbeid een geweldige hoeveelheid werk meebracht behoeft geen betoog ${ }^{22}$.

Toen de gevolgen van de crisis zich echter duidelijk manifesteerden, werd van regeringszijde herhaaldelijk betoogd, dat wetgeving "niets mocht kosten", dat wil zeggen dat dit noch voor het bedrijfsleven, noch voor de rijksbegroting tot een lastenverzwaring mocht leiden ${ }^{23}$. Uitbreiding van de toepasselijkheid van de Arbeidswet 1919, die gepaard zou moeten gaan met uitbreiding van het personeel van de arbeidsinspectie was uit den boze.

Nadat eerder in 1922 als gevolg van de toen aan de orde zijnde bezuinigingen een arbeids- en rusttijdenregeling voor kantoren beperkt bleef tot jeugdigen, werd begin 1930 opnieuw geprobeerd een dergelijke regeling ook voor volwassenen te volbrengen ${ }^{24}$; dit zou echter tot een poging blijven. In 1931 werden de districtshoofden op de hoogte gesteld dat het betreffende werktijdenbesluit niet ingevoerd zou worden ${ }^{26}$.

Ook de voorgenomen invoering van een Werktijdenbesluit voor koffiehuis- en hotelpersoneel ging niet door; éen en ander moest worden uitgesteld tot betere tijden ${ }^{26}$. De in dit verband toegestane uitbreiding van de arbeidsinspectie werd niet benut ${ }^{27}$.

Eerst op 1 juni 1937 zouden de bepalingen inzake de arbeids- en rusttijden voor kantoren voor volwassenen in werking treden ${ }^{28}$, waarna voor koffiehuizen en hotels op 1 januari 1938 de bepalingen voor jeugdigen in hun geheel in werking zouden treden en voor volwassenen alleen die welke de dagelijkse onafgebroken 
rusttijd van 10 uren voorschreefer.

Overigens zou nog wel de arbeids- en rusttijdenregeling voor apotheken op 1 februari $1933^{30}$ ingevoerd worden, daar dit zonder personeelsuitbreiding van de arbeidsinspectie en dus zonder bezwaar kon gebeuren $^{31}$.

4. Werkzaamheden in verband met wetten waarvan de handhaving en de medewerking aan de uitvoering geheel of gedeeltelijk aan de arbeidsinspectie was opgedragen

\subsection{De Arbeidswet 1919, de Veiligheidswet, de Steenhouwerswet 1921}

De afnemende bedrijvigheid in een groot deel van de nijverheid als gevolg van de crisis had tot gevolg, dat er minder fabrieken of werkplaatsen werden opgericht en uitgebreid, er minder behoefte was aan overwerk, er minder ongevallen plaats vonden, maar ook, dat er minder mogelijkheden waren om verbeteringen op het terrein van de arbeidsomstandigheden door te voeren.

Zo werd de arbeidsduur door de noodzaak gedwongen verkort tot 40,36 of 32 uren per week. De typische overwerksituatie als gevolg van een opeenhoping van werk werd zeldzaam. Daarentegen moest vele malen te midden van bedrijfsslapte in een deel van de fabriek worden overgewerkt, hetzij omdat alleen de snelle levering een order in het land hield, hetzij omdat men een ongewoon produkt ging maken, waardoor een deel van de machines meer dan normaal moest produceren, terwijl andere ongebruikt stonden. Voorts vloeide een verzoek om overwerk te mogen verrichten vaak voort wit het feit, dat de fabrikant een korte leveringstermijn had moeten aanvaarden, daar anders de order geannuleerd en veelal in het buitenland geplaatst zou zijn, of vloeide voort uit de contigenteringsmaatregelen in het kader van de Crisisinvoerwet $1931^{32}$.

Bij de toepassing van de Veiligheidswet moest vaak duidelijk rekening gehouden worden met de financiële aspecten en de onzekerheid omtrent de continuitteit van het bedriif; in veel gevallen was meer overredingskracht nodig om zelfs de eenvoudigste beveiligingen doorgevoerd te krijgen ${ }^{33}$.

Ten behoeve van de handhaving van de Arbeidswet 1919, de Veiligheidswet en de Steenhouwerswet 1921 werden aanvankelijk in deze periode, in vergelijking met de voorafgaande periode, meer bezoeken aan fabrieken of werkplaatsen en dergelijke afgelegd ${ }^{34}$. In 1933 zou het aantal bezoeken echter dalen, waarvan de oorzaak werd toegeschreven aan de bezuinigingen bij de arbeidsinspectie ${ }^{35}$, zodat daarmee de stelling van de commissie-Welter, dat bezuinigd kon worden zonder dat de intensiteit van het toezicht zou verminderen, ondergraven werd, alsook aan de vele bemoeiingen die de arbeidsinspectie dat jaar had met het onderzoek naar de mogelijkheid om een kortere arbeidsduur in te voeren en andere crisismaatregelen ${ }^{38}$. Vanaf 1934 zou het aantal bedrijfsbezoeken weer gestaag oplopen ${ }^{37}$; de stijging werd mede toegeschreven aan de steeds toenemende bemoeiingen van de arbeidsinspectie als gevolg van nieuwe wetgeving en onderzoekingen in de verschillende ondernemingen naar de getalsverhouding van de daarin werkzame categorieën van arbeiders in verband met de voorgenomen maatregelen om te komen tot een betere verdeling van de beschikbare arbeid alsmede als gevolg van bijzondere werkzaamheden ten behoeve van defensiedoeleinden ${ }^{38}$, waaraan in dit hoofdstuk afzonderlijk aandacht zal worden besteed. Werd ten aanzien van 1935 nog opgemerkt dat in de slechte economische toestand geen noemenswaardige verandering $\mathrm{kwam}^{39}$, ten aanzien van 1936 werd een merkbare verbetering op economisch gebied geconstateerd ${ }^{40}$, welke zich in 1937 versterkte, zij het, dat zich tegen het einde van dit jaar in sommige industrieën enige vermindering van werkgelegenheid voordeed $^{41}$. In 1938 werd de economische situatie ook nog positief geoordeeld, dank zij ten behoeve van de defensie genomen maatregelen. Bovendien profiteerden in ons land verschillende bedrijfstakken, onder andere de confectieindustrie van de omstandigheid, dat door de internationale spanningen enkele landen hun afzet op de wereldmarkt zagen verminderen. In het najaar leidde het dreigende oorlogsgevaar tot een stijgende vraag naar allerlei levensbehoeften, wat de bedrijvigheid in verscheidene ondernemingen opnieuw gunstig beïnvloedde. De werkloosheid als zodanig zou echter weinig verminderen. Bedroeg eind december 1937 het aantal geregistreerde werklozen 437.469 , eind december 1938 was dit aantal $433.646^{42}$. De in 1938 waargenomen vooruitgang van de economische bedrijvigheid bleef ook in 1939 voortduren, wat niet in geringe mate 
het gevolg was van de opdrachten die van defensiezijde werden geplaatst. Na de algehele mobilisatie van de Nederlandse strijdkrachten zouden de leveringen aan leger en vloot in vele opzichten nog in omvang toenemen. Hoewel de positie van de arbeidsmarkt eind december 1939 aanzienlijk verbeterde ( het aantal geregistreerde werklozen bedroeg 270.811 ), bleek de verwachting, dat de mobilisatie van de strijdkrachten een scherpe daling van het werkloosheidscijfer zou teweegbrengen, niet verwezenlijkt; alsdus het jaarverslag over $1939^{43}$. De directeur-generaal van de Arbeid Hacke, opvolger van Zaalberg, betoogde herhaaldelijk ${ }^{44}$, dat de beste werkloosheidsbestrijding bestond in het terugbrengen van de werklozen naar het normale bedrijfsleven. Daarbij legde hij een relatie tussen de uitvoering van de Arbeidswet 1919 en het toezicht op de naleving ervan en werkloosheidsbestrijding. Als voorbeeld daarvan verwees hij naar de Zuiderzeewerken.

"Toen wij (de arbeidsinspectie; JvD) in 1939 de beschikking kregen over een motorboot en op ongeregelde tijden konden controleren, steeg het aantal tewerkgestelden met vele honderden ten opzichte van 1938 en dat met ongeveer denzelfden omvang der weken".

Ten aanzien van het verrichten overwerk stelde hij:

"Zelfs indien slechts een klein gedeelte van dit aantal uren opgevangen zou worden door het te werk stellen van nieuwe arbeiders beteekent dit toch werk voor enkele duizenden arbeiders",

daarbij overigens wel erkennend, dat de arbeiders zelf ook niet altijd meewerkten, om binnen de arbeidswettelijke normen te blijven, juist omdat zij zelf veelal rechtstreeks voordeel hadden bij het verrichten van overwerk.

Bedroeg het aantal overwerkvergunningen voor de belangrijke categorie van arbeid, namelijk in fabrieken en werkplaatsen in $193511.548^{45}$, in 1936 was dit opgelopen tot $12.911^{46}$, in 1937 tot $14.728^{47}$ en in 1938 tot $15.679^{48}$. Bedroeg het aantal overwerkuren in dit laatste jaar 4350949 , in 1939 zou dit nagenoeg verdubbeld worden tot $8256736^{49}$. Het streven van de arbeidsinspectie om het overwerk te beperken waardoor meer arbeiders aan werk geholpen konden worden, zonodig na scholing, her- of omscholing, botste herhaaldelijk met de in de bedrijven heersende problemen als gevolg van de algemene situatie in ons land en had niet het verwachte succes. Eèn van deze problemen had betrekking op een tekort aan vakbekwaam personeel. Desalniettemin werd bij een verzoek om een overwerkvergunning dat gemotiveerd werd met een gebrek aan vakbekwame arbeiders, wanneer dit op waarheid berustte, niet geschuwd aan de vergunning de voorwaarde te verbinden, dat een bepaald aantal arbeiders opgeleid moest worden ${ }^{50}$. Daarnaast was het aantal vrouwelijke arbeidskrachten dat beschikbaar was, zeer gering ten opzichte van de vraag. Bovendien had het merendeel van de door de bedrijven uit te voeren opdrachten een spoedeisend karakter ${ }^{\text {st }}$. Het onderzoek, dat naar aanleiding van aanvragen om een overwerkvergunning werd ingesteld, waarbij tevens onderzocht werd of de mogelijkheid aanwezig was om door indienstneming van nieuwe arbeiders het overwerk onnodig te maken, eiste van de ambtenaren van de arbeidsinspectie intussen veel tijd ${ }^{52}$.

Overigens zou niet alleen het aantal overwerkvergunningen stijgen; hetzelfde geldt ten aanzien van het totaal aantal processenverbaal wegens overtreding van de Arbeidswet 1919; in 1935 bedroeg dit aantal 2159, na een daling in 1936 tot 2076 , zou dit in 1937 oplopen tot 2531 , om vervolgens in 1938 en 1939 respectievelijk 2590 en 2684 te bedragen ${ }^{53}$.

Ten aanzien van arbeid in broodbakkerijen werden nogal wat overtredingen geconstateerd, waarbij vaak als oorzaak werd genoemd de groeiende concurrentie in deze bedrijfstak. Teneinde de dans te ontspringen waren er broodbakkers die hun bakkerij vrijwel ontoegankelijk hadden gemaakt; ramen en eventuele kleine gaatjes waren vaak geblindeerd, zodat van buiten af niets waargenomen kon worden. Een tweetal voorbeelden ter illustratie. Toen enige ambtenaren zich 's nachts woor een bakkerij bevonden, hoorden zij lawaai, dat veell leek op het geluid, dat bij het verplaatsen van blikken en bakplaten gemaakt werd. Het rammelen aan de poort en het bellen aan het woonhuis hadden niet het gewenste resultaat; alles bleek dicht. Na lang kloppen aan en roepen door een kelderraampje werd geantwoord, dat opengedaan zou worden, als het brood in de oven was gedaan. Tenslotte werd na lang wachten toegang tot de bakkerij verleend. Bij hun binnentreden verklaarde de patroon aan de ambtenaren ${ }^{54}$ : 
"Tk zal het jullie maar eerlijk zeggen: ik wou jullie er voór houden!".

Anders was het met een bakker in het Sticht. Deze man, die als een notoire overtreder bekend stond, had zijn bakkerij vrijwel ontoegankelijk weten te maken voor alle controle. Na heel veel moeite en niet zonder gevaar lukte het aan ambtenaren van de gemeentepolitie om deze bijna "onneembare vesting" binnen te brengen; waarbij een flinke overtreding geconstateerd werd. De bakkerspatroon, die vermoedde, dat de politie via het dak of over een muur de bakkerij binnengedrongen was, droeg de andere dag een smid op om rondom het gehele perceel, $66 \mathrm{k}$ op de muren en daken, een twee meter hoge prikkeldraadversperring te maken. Dit leidde er toe, dat de dagbladen spraken van een "concentratiekamp" en van een "tot fort omgebouwde bakkerij". Niettegenstaande deze nieuwe belemmeringen slaagden ambtenaren van de gemeentepolitie er opnieuw in de bakkerij binnen te dringen, zij het niet zonder levensgevaar en ten koste van gehavende kleding, maar ook nu weer hadden zij succes en constateerden zij een overtreding. Bovendien kreeg de bakkerspatroon een bevel, dat steunde op een brandweerverordening, om binnen acht dagen de prikkeldraadversperring van het perceel te verwijderen. Deed hij dat niet dan zou de gemeente dit op zijn kosten laten doen ${ }^{55}$ : Maar ook de administratieve bepalingen, leidden herhaaldelijk tot processen-verbaal, wegens bijvoorbeeld het niet opgehangen hebben van een geldige arbeidslijst, op een voor alle arbeiders vrij toegankelijke plaats $^{56}$. Een advocaat meende niet beter aan zijn afkeer van de krachtens deze bepalingen geëiste bescheiden uitdrukking te kunnen geven, dan door deze op een toilet te doen opgehangen, terwijl hij bij controle betoogde, dat hiermede was voldaan aan het voorschrift, dat de arbeidslijst op een voor ieder vrij toegankelijke plaats moet zijn opgehangen. Overigens bleken de arbeidslijsten op een bijkantoor van een grote verzekeringsmaatschappij eveneens een plaats te hebben gevonden in eerder bedoeld vertrek; daartoe zou de directie van het hoofdkantoor te 's-Gravenhage uitdrukkelijk opdracht hebben gegeven ${ }^{57}$. Bij de komst van controlerende ambtenaren in een papierfabriek verwijderden zich enige vrouwen; hun klokkaarten wezen uit, dat hun arbeids- en rusttijden afweken van de arbeidslijst. Aan de hand van de opgevraagde loonadministratie werden niet minder dan 2533 overtredingen geconstateerd over een tijdvak van ruim vijf maanden $^{58}$.

Wel werd opnieuw veel tijd van de arbeidsinspectie gevergd door de correctie van verkeerd ingevulde arbeidslijsten en roosters en de daarmede gepaard gaande correspondentie. Vooral de administratie ondervond de gevolgen van het op 1 juni 1937 inwerkingtreding van het Werktijdenbesluit voor kantoren $1937^{59}$, en het op 1 jamuari 1938 nog eens in werking treden van het Rusttijdbesluit voor volwassen koffiehuis- en hotelpersoneel 1937 en het Werktijdenbesluit voor jeugdige personen, werkzaam in koffiehuizen en hotels $1937^{60}$. Gevolgen: het aantal bezoekers, dat zich op de districtskantoren meldde om inlichtingen nam aanzienlijk toe, terwijl op sommige districtskantoren de telefoonlijnen overbelast raakten en er zelfs nieuwe verbindingen moesten worden aangelegd ${ }^{\text {ey }}$.

Met betrekking tot het aantal eisen en anwijzigingen, dat in deze periode werd gesteld en werd gegeven in het kader van de Arbeidswet 1919, de Veiligheidswet en de Steenhouwerswet 1921 kan worden opgemerkt, dat, na een aanvankelijke daling die in 1937 een dieptepunt bereikte, het aantal eisen en aanwijzingen weer zou stijgen. Ter illustratie mogen de volgende cijfers gegeven worden: In 1930 bedroeg het aantal eisen en aanwijzingen 25.710, in 1937 slechts 16.609 en in $193922.252^{62}$. Hierbij werd echter well steeds weer de opmerking gemaakt, dat de vele door de arbeidsinspectie gewenste veranderingen op mondelinge aanwijzing tot stand kwamen.

Ook in deze periode werden er weer tal van klachten bij de arbeidsinspectie ingediend. In het begin van de jaren dertig zou het aantal sterk oplopen ${ }^{83}$; een stijging die voor een zeer groot deel zijn oorzaak vond in de uitbreiding van de werkingssfeer van de Arbeidswet 1919 per 1 januari $1930^{64}$. In de daarop volgende jaren zou het aantal klachten weer sterker afnemen ${ }^{05}$. De vermindering werd, zij het voorzichtig, toegeschreven aan de economische crisis, wat de arbeiders ertoe brengt meer door de vingers te zien en niet zo gauw te klagen; in deze tijd van grote werkloosheid wenste de arbeider zo weinig mogelijk het risico te lopen om ontslagen te worden ${ }^{66}$.

Met de verdere uitbreiding van de toepasselijkheid van de Arbeidswet 1919 in de tweede helft van de dertiger jaren zou het aantal klachten weer toenemen ${ }^{67}$. Veel van de klachten, die werden ingediend, hadden 
betrekking op zaken, die niet tot het werkterrein van de arbeidsinspectie behoorden, met name over ontslag, het plakken van rentezegels, het ontvangen van ongevallenuitkering en allerlei zaken over onbillijke en onrechtvaardige behandeling van huishoudelijk personeel. Deze klachten werden veelall doorverwezen naar de betreffende, bevoegde instanties.

Wegens onvolledigheid of onjuistheden in de omschrijving van de klacht of het ontbreken van elke redelijke grond bezorgden tal van klachten bij het onderzoek aan de controlerende ambtenaren veel overbodig werk. Zo werd eenmaal gemeld, dat op een bouwwerk in een met name genoemde straat te lang gewerkt zou worden. Bij controle bleek, dat in de genoemde straat geen bouwwerk te bekennen was. Dit was vooral het geval bij anonieme klachten die over het algemeen een derde deel van het totale aantal klachten uitmaakte. Bezorgdheid over een minder juiste naleving van de wettelijke bepalingen was lang niet altijd de drijfveer bij het indienen van klachten, integendeel: vele klachten vloeiden voort uit minder edele gevoelens, zoals concurrentie-overwegingen, zucht naar wraak, bij welke laatste categorie burengeschillen, ontstemdheid over een gekregen ontslag, jalouzie over grotere verdiensten van anderen een belangrijke plaats innamen. Vandaar de verzuchting in een jaarverslag:

"Nog al te velen zien in de Arbeidsinspectie een soort wraakinstrument".

Zo bleek eenmaal bij onderzoek van een schriftelijke klacht, dat deze van een valse handtekening was voorzien; de arbeider, wiens naam als ondertekening was wermeld, vermoedde dat hier een wraakneming in het spel was.

De koude winter van 1938 - 1939 bracht tal van klachten over te lage temperaturen. Hoewel deze klachten over het algemeen wel gegrond waren, bleek het echter niet altijd mogelijk om direct verbeteringen te bewerkstelligen, omdat de capaciteit van de verwarming vaak niet op de zeer lage buitentemperatuur was berekend. Van geheel andere aard was een klacht over een inrichting, waar goederen chemisch gereinigd werden. In die inrichting zou het personeel hinder ondervinden van trichlooraethyleendampen, waardoor het soms in een toestand verkeerde alsof het dronken was. Het door een inspecteur van de arbeid in samenwerking met een geneeskundige bij de arbeidsinspectie ingestelde onderzoek toonde aan, dat in die richting een tweedehands apparaat voor het zogenaamde "tri"-wassen en centrifugeren in én ruimte was opgesteld. Vooral bij het uithalen van gecentrifugeerde goederen kwam veel trichlooraethyleendamp vrij. Dit onderzoek leidde tot het stellen wan een eis, waarna geen klachten meer werden vernomen. Regelmatig werd van de zijde van de arbeidsinspectie opgemerkt, dat de medewerking van de arbeiders bij het onderzoek van klachten meermalen te wensen overliet, soms door gegronde vrees voor ontslag, maar ook al te vaak door het verlangen naar extra verdiensten, door de controlerende ambtenaren de verlangde gegevens te onthouden en deze door het afleggen van onjuiste verklaringen om de tuin te leiden. Onuitputtelijk bleven de overtreders in het vinden van middelen om ontdekking van niet geoorloofd overwerk te voorkomen. Zo werd vaak de toegang tot de werkplaats versperd, werden de ramen dichtgeplakt, werden de arbeiders op afgelegen plaatsen gebracht waarbij de al gememoreerde toiletten voor dit doel zeer geliefde schuilplaatsen waren, werd tegen het einde van de werktijd de klok teruggezet, werd in woonkamers gewerkt met de deur op slot, werden er bijvoorbeeld bijzondere seinen gegeven, zodra vermoed werd, dat controlerende ambtenaren in aantocht waren en dergelijke. Desalniettemin lukte het de controlerende ambtenaren nog menige overtreding te constateren ${ }^{68}$.

\subsection{De Ongevallenwet 1921}

In het kader van de samenwerking met ( ambtenaren van ) de Rijksverzekeringsbank in verband met de uitvoering van de Ongevallenwet 1921 en de Beroepswet werden in $1930^{\circ 9} 389$ mededelingen ontvangen omtrent beveiligingstoestanden in fabricken of werkplaatsen, die naar de mening van de Rijksverzekeringsbank voorziening behoefden; in 11 gevallen werd op verzoek een nader onderzoek ingesteld, wat meermalen leidde tot het geven van voorschriften, aanwijzingen en waarschuwingen, terwijl enkele malen een proces-verbaal werd opgemaakt ${ }^{70}$.

In de daaropvolgende jaren zijn deze aantallen sterk gedaald ${ }^{71}$. Zonder enige twijfel kan de scherpe daling in het aantal gevallen, waarvoor een nader onderzoek ingesteld moest worden, toegeschreven worden aan 
de economische crisis; slapte in het bedrijf leidde dus tot een daling van het aantal bedrijfsongevallen. Ook in deze jaren werden de districtshoofden van de arbeidsinspectie weer herhaaldelijk door de voorzitter van Gen van de Raden van Beroep en van de Centrale Raad van Beroep belast met een onderzoek met het oog op de te geven adviezen over de indeling van een onderneming in een gevarenklasse, en de toekenning van een gevarenciffer, de aard van de inrichting of de toekenning van een schadeloosstelling ${ }^{72}$.

\subsection{De Hinderwet}

Het preventieve toezicht op fabrieken of werkplaatsen, dat, ingevolge de zogenaamde bis-artikelen van de Hinderwet, werd uitgeoefend, wond een noodzakelijke en belangrijke aanvulling in het overleg met hoofden van ondernemingen, architecten en anderen, die plannen hadden tot oprichting van een fabriek of werkplaats. Gebruik werd daarbij gemaakt van de goede samenwerking met bouw- en woningtoezicht in verschillende gemeenten, waardoor bouwplannen ter kennis van de arbeidsinspectie werden gebracht en gebouwen, die men als fabriek of werkplaats wilde inrichten, tijdig konden worden gekeurd, waardoor de betrokkenen zo nodig op tekortkomingen konden worden gewezen en zo belangrijke onkosten werden vermeden. Een andere wijze van samenwerking, die de naleving van de Veiligheidswet 1934 ten goede kwam, bestond in sommige districten door het regelmatig ontwangen van de elektriciteitsbedrijven van kennisgevingen over de krachtaansluitingen in niet Hinderwetplichtige bedrijven. Op deze wijze werd de arbeidsinspectie attent gemaakt op vele van deze (kleine) inrichtingen ${ }^{73}$. Naast deze positieve geluiden werd de oude klacht over de wijze waarop de Hinderwet werd nageleefd herhaald, namelijk dat dit niet alleen van de zijde van de aanvragers weel te wensen overliet, maar ook dat gemeentebesturen zich aan allerlei nalatigheden schuldig maakten. Waar menigmaal, zo luidde de klacht, moest worden geconstateerd, dat een Hinderwetvergunning was verleend, zonder dat daar het districtshoofd de vereiste verklaring was afgegeven. Weer menigmaal lieten de aanvragers, vooral de kleine fabrikanten, na de schakelschema's van de elektrische installaties in te zenden, wat weer leidde tot de nodige correspondentie ${ }^{74}$. Overigens zou het aantal verleende vergunningen in het kader van de Hinderwet in deze periode een daling vertonen.

\subsection{De Phosphorluciferwet 1901, de Caissonwet 1905}

Hoewel de Phosphorluciferwet 1901 en de Caissonwet 1905 nauwelijks tot problemen leidden - alleen in 1938 werd onder verhoogde luchtdruk arbeid verricht in verband met de bouw van de Maastunnel ${ }^{75}$ - werd in 1939 melding gemaakt van het feit van het verrichten van arbeid onder verminderde luchtdruk in verband met werkzaamheden aan de Maastunnel, om de diverse tunnelstukken op dichtheid te beproeven. Hiertoe werd een tunnelstuk met de bovenkant onder water gebracht en gedeeltelijk luchtledig gezogen. Inwendig zou door enkele mensen worden nagegaan of zich lekkage zou voordoen. Aangezien hierop geen enkele wettelijke bepaling van toepassing was en voor zover bekend een dergelijke werkwijze nog niet toegepast was, werd contact gezocht met de hoogleraar Noyons te Utrecht teneinde de nodige voorlichting te verkrijgen. $\mathrm{Na}$ overleg tussen arbeidsinspectie en de N.V. Maastunnel werd overeengekomen, een aantal veiligheidsvoorschriften in acht te nemen ${ }^{76}$.

\section{Röntgenstralenwet}

Van regeringszijde werd vastgesteld, dat steeds meer gebruik werd gemaakt van röntgen- en daarmee gelijk te stellen stralen. In de geneeskunde waren deze stralen, zowel bij het onderzoek als bij de behandeling van patiënten een onmisbaar hulpmiddel geworden. Daarnaast trokken de bijzondere eigenschappen van de röntgenstralen de belangstelling van de natuurkundigen, met als gevolg, dat in het kader van de natuurwetenschap in de natuurkundige laboratoria proeven met stralen aan de orde van de dag zijn. Zelfs de techniek had zich al meester gemaakt van deze stralen voor het doen van onderzoekingen. Maar aan het gebruik van deze stralen kleefden bezwaren, namelijk dat het menselijk organisme aangetast kon worden, aldus de toen- 
malige minister van Arbeid, Handel en Nijverheid ${ }^{77}$. Het gevaar dreigde niet alleen voor degene die dagelijks röntgenstralen gebruikt, zijn patiënten, maar ook het personeel, dat hem daarbij behulpzaam is. De kracht van de straling ging, blijkens de ervaring, zelfs zover, dat personen, die niet in het lokaal waar het toestel werd gebruikt, maar in een nabijgelegen yertrek of woning aanwezig waren, daarvan de gevolgen konden ondervinden, zo vervolgde de minister. In de litteratuur werden tal van mededelingen over de mogelijke nadelige invloeden van de röntgenstralen en stralen, afkomstig van radio-actieve stoffen. De bewindsman stelde, dat de overheid hier regelend diende in te grijpen om de gevaren zoveel mogelijk te beperken, zeker nu zogenaamde verplaatsbare toestellen meer algemeen in de handel werden gebracht. In de inrichtingen, waar een niet-verplaatsbaar toestel was opgesteld, was men in de gelegenheid de benodigde veiligheidsmaatregelen duurzaam aan te brengen en een ter zake deskundig persoon er de leiding over zou hebben. Bij de verplaatsbare toestellen waren beveiligingsmaatregelen slechts op onvolodende wijze te verkrijgen en was de kans, dat er niet door deskundigen werd omgegaan, groter. Daarnaast bestond het gevaar, dat ongelukken plaatsvonden door aanraking van die onderdelen van het röntgentoestel, die onder hoge elektrische spanning stonden.

"De gevaren, die de ondergetekende meent, dat door wettelijke maatregelen zooveel mogelijk moeten worden ondervangen, bedreigen echter, zooals hierboven reeds werd opgemerkt, niet alleen de personen, die met de toestellen om-gaan, maar eveneens personen in de omgeving er van, die van eenig gevaar zich niet bewust kunnen zijn. Daar deze gevaren in hooge mate afhankelijk zijn van den bouw der gebruikte toestellen, moet een onderscheid worden gemaakt tusschen de beveiliging tegen gevaar van kleine toestellen, waarbij het gevaar uitsluitend de daarmede werkende personen betreft, en de beveiliging tegen gevaar van het toestel te zamen met de werkruimte, waarin het zich bevindt, indien de spanning van het toestel zoodanig is opgevoerd, dat de stralen, wier doordringskracht van de spanning of energie aflhankelijk is, ook personen in de omgeving bedreigen. Daarnaast zullen voorschriften moeten kunnen worden gegeven, waaraan bij het in voorraad houden van radio-actieve stoffen moet worden voldaan".

Een afdoende bestrijding van de gevaren, die van de verschillende bedoelde soorten stralen uitgingen, was slechts mogelijk, indien onder de nodige beveiligingsmaatregelen het gebruik slechts aan hen zou worden toegestaan, waarbij waarborgen bestonden tegen onoordeelkundige toepassing. Ten einde dit doel te bereiken bevatte de Röntgenstralenwet ${ }^{78}$ als algemene regel, dat de bevoegdheid om een röntgen- of een daarmee gelijk te stellen toestel te hebben, verbonden werd aan een vergunning, in dien zin, dat het hebben van een dergelijk toestel verboden was aan een ieder, die niet in het bezit was van een daartoe verleende vergunning. De beslissing omtrent het al dan niet verlenen van een vergunning was alleen afhankelijk van de waarborgen voor beveiliging en van de bekwaamheid om het toestel te gebruiken ${ }^{7 \theta}$.

Met het opsporen van overtreding waren onder meer belast de ambtenaren van de arbeidsinspectie ${ }^{80}$. Hoewel er op 31 maart 1933 het zogenaamde Röntgenstrallenbesluit ${ }^{61}$ werd uitgevaardigd, zou de Röntgenstralenwet niet in werking worden gesteld ${ }^{\mathrm{k2}}$.

\section{De Huisarbeidswet 1933}

In deze periode werd door de wetgever ingegrepen op het gebied van de huisarbeid. De ongunstige sociale toestand van de huisarbeiders had al sinds lange tijd de aandacht op zich gevestigd ${ }^{23}$. In de jaren voor de Eerste Wereldoorlog was naar deze toestanden door de arbeidsinspectie een grondig onderzoek ingesteld ${ }^{84}$. Daarbij bleek, voor zover dat nog niet bekend was, dat de huisindustrie zich kenmerkte door onder meer zeer lage lonen, lange werktijden, kinderarbeid, en slechte hygiënische omstandigheden. Daar kwam bij, dat de organisatiegraad van de in de huisindustrie werkzame arbeiders bijzonder laag was, zodat via deze weg geen verbetering van hun arbeidsvoorwaarden te verwachten was. De bestaansreden van de huisindustrie is duidelijk: lage produktiekosten, mede als gevolg van de zeer lage lonen. Bovendien onttrokken de werkgevers zich via de huisindustrie aan de werking van de Arbeidswet 1919, de Veiligheidswet en diverse sociale verze- 
keringswetten $^{65}$. Hoewel ten tijde wan de indiening van een ontwerp-Huisarbeidswet ${ }^{8 \theta}$ een belangrijke vermindering van de huisarbeid viel te constateren ${ }^{27}$, wenste de regering een wettelijke regeling ervan niet achterwege te laten ${ }^{88}$, zowel ter bestrijding van de bestaande misstanden, als ter voorkoming van een toename van de huisarbeid bijvoorbeeld bij een wijziging van de conjunctuur ${ }^{89}$.

De Huisarbeidswet $1933^{\circ 0}$ beoogt een kader te scheppen om de vaak erbarmelijke arbeidsomstandigheden door middel van bindende voorschriften te verbeteren. Maar van nog groter belang is het gegeven, dat het beginsel van onthouding van de overheid op het gebied van de loonvorming door het vaststellen van minimumlonen, uitdrukkelijk werd verlaten. Dit laatste ondervond in de Tweede Kamer enige weerstand; een directe overheidsbemoeiing met de lonen in het particuliere bedrijfsleven werd verwerpelijk geacht. De loonvorming was een zaak van de werkgever en de arbeiders. De inmenging van de overheid in deze ten aanzien van de huisindustrie leidde ertoe dat het van overheidswege ingrijpen in de loonvorming aanvaard werd ${ }^{\text {B1 }}$. Zowel vanuit de Tweede Kamer $^{102}$ als van regeringszijde ${ }^{93}$ werd gesteld, dat de overheid zich in de regel niet met de loonvorming diende te bemoeien. De toenmalige minister van Socialle Zaken Slotemaker de Bruine stelde ${ }^{84}$ dat de overheid voor de loonhoogte geen verantwoordelijkheid kon aanvaarden; loonvorming is een "maatschappijtaak", waarbij de organisaties van het georganiseerde bedrijfsleven dienden op te treden. Uitzonderingen op deze algemene regel zijn echter acceptabel en voor een dergelijke uitzondering was hier nu aanleiding, niet alleen, omdat de lonen in de huisindustrie buitengewoon laag waren, maar ook omdat het afsluiten van een collectieve arbeidsovereenkomst niet mogelijk was ${ }^{25}$.

"Middelen tot het tegengaan van de nadelen der huisindustrie zijn allerwege beproefd, zowell door den wetgever als door de vakorganisatie. Beide zijn echter zo goed als machteloos gebleven, totdat de wetgever de kwaal in zijn oorsprong aantastte en zich met het loon ging bemoeien".

De latere directeur-generaal van de Arbeid Zaalberg merkte, na de ontwikkeling van de wetgeving op de arbeidsbescherming voor wat betreft de arbeidsduur, de veiligheid en dergelijke geschetst te hebben, bij eerdere gelegenheid al op ${ }^{96}$, dat een wettelijke regeling van het minimumloon slechts een consequente voortschrijding was op de weg van steun van de economisch-zwakke in de ongelijke strijd, die hij tegenover zijn werkgever te voeren had.

De in de Huisarbeidswet 1933 gekozen constructie is dusdanig, dat de leden van de in het leven te roepen huisarbeidscommissies ${ }^{97}$ de plaats in zouden nemen van de in andere bedrijfstakken met elkaar overleggende vertegenwoordigers van werkgevers- en arbeidsorganisaties.

Deze constructie lag geheel in de lijn van de wijziging van de Arbeidswet 1919 in 1922, waarbij een deel van de uitvoering werd overgebracht naar het georganiseerde bedrijfsleven ${ }^{88}$. De uiteindelijke vaststelling van de minimumlonen door de minister moest; aldus de toelichting ${ }^{\oplus \theta}$, gezien worden als een waarborg voor de belangen van derden.

De handhaving van de Huisarbeidswet 1933 alsmede de medewerking aan de uitvoering ervan werd opgedragen aan de arbeidsinspectie ${ }^{100}$, welke dienst tevens belast werd met de opsporing van strafbare feiten ${ }^{101}$. Eén en ander leidde ertoe, dat de arbeidsinspectie nu officieel het gebied van de loonvorming betrad.

Zowel de Huisarbeidswet 1933 als het daarop gebaseerde Huisarbeidsbesluit $1936^{102}$ zouden eerst op 1 oktober 1936 in werking treden. De werking van deze wet is met haar primaire doelstelling, het vaststellen van een minimumloon, in de kiem gesmoord. Van de bevoegdheid tot het vaststellen van een minimumlloon in dit verband is nooit gebruik gemaakt.

Ter controle van de naleving van de wettelijke bepalingen werd onder meer gebruik gemaakt van het in de wet voorgeschreven, door de burgemeester afgegeven loonboekje ${ }^{103}$. Uit de door de districtshoofden van de arbeidsinspectie ontvangen opgaven over 1936, bleek dat door of vanwege de burgemeester in totaal 3474 loonboekjes waren afgegeven, waarbij aangetekend dient te worden, dat veel gemeenten de vereiste opgave niet hadden ingezonden ${ }^{104}$, zodat dit aangegeven aantal niet in overeenstemming was met de werkelijkheid. In 1937 zou dit aantal 5197 bedragen en in de jaren daaropvolgend respectievelijk 4934 en 5055 . De vele werkzaamheden waarmee de arbeidsinspectie al was belast, maakten het onmogelijk om alle bekende huisarbeiders een controlebezoek te brengen en een regelmatig toezicht op de naleving van de wettelijke bepalin- 
gen uit te oefenen, alsook speciale onderzoeken naar werktijden en lonen in de huisindustrie in te stellen. Wel werd geconstateerd, dat de huisarbeid in het algemeen uit armoede werd verricht ter aanvulling van te geringe verdiensten uit een beroep of door steuntrekkenden. De lonen waren doorgaans abnormaal laag, wat tot gevolg had, dat veel te lange werktijden gemaakt moesten worden om aan een enigszins acceptabel loon te komen. Eén geval van lange werkdagen als gevolg van geringe loonbetaling werd geconstateerd bij een weduwe en haar dochter. De dochter, die als dienstbode werkzaam was, was vanwege de hulpbehoevendheid van de moeder met deze gaan samenwonen. Nadat het spaargeld was opgeteerd, werd naar inkomsten gezocht en gevonden met het verrichten van borduurwerk voor een tricotagefabriek. Bij een controlebezoek bleek, dat het meisje voor het borduren van 609 stuks, meest broekjes en jurkjes, een bedrag van f1.21, 12 had ontvangen. Hiervoor had zij een maand lang tot laat in de avond en zelfs op zondag moeten werken; onder andere had zij voor het borduren van 26 jurkjes en 28 kruipbroekjes, waarvoor zij respectievelijk fl:1,20 en fl.0,84 betaald kreeg, ruim twee dagen achtereen van 's morgens vroeg tot 's avonds laat ( 23.00 uur) moeten werken.

De huisarbeider moest altijd klaar staan voor de werkgever, althans als hij zijn werk niet wilde verliezen. Bij een huisarbeider kwam het voor, dat op zaterdag om 21.30 uur nog werk werd gebracht, waaraan vijf uren arbeid viel te verrichten, met de opdracht dit direct af te maken ${ }^{105}$.

\section{De Velligheidswet 1934}

De Veiligheidswet wan 1895 bleek lang bestand te zijn tegen verandering, hetgeen zijn oorzaak vond in het feit, dat de voornaamste materiële bepalingen in het Veiligheidsbesluit stonden, welk besluit herhaaldelijk was aangepast. Maar met name de voortschrijding van de techniek maakte een herziening van deze wet gewenst ${ }^{100}$. De Veiligheidswet van 1895 beoogde alleen beveiliging van arbeiders bij het verblijven in fabrieken en werkplaatsen. Zij liet zich niet in met de gevaren voor bedrijfsongevallen en beroepsziekten waaraan arbeiders blootstaan bij het verrichten van arbeid buiten deze inrichtingen. De beveiliging tegen die nieuwe aan bepaalde soorten van arbeid verbonden gevaren kon telkens bij afzonderlijke wetten gebeuren (zoals tot nu toe al was gebeurd ). De betrokken bewindsman gaf echter de voorkeur aan het ontwerpen van een wet die naast de gevaren, welke voortvloeien uit het verblijven in fabrieken of werkplaatsen, ook die bestreed, welke allerlei soorten van arbeid buiten fabrieken of werkplaatsen met zich brengen.

Deze opzet had als groot voordeel, dat steeds wanneer een nieuw element van gewenste veiligheidsvoorzieningen optrad, de gelegenheid aanwezig was om tegen de eventuele nieuwe gevaarsituatie regelend op te treden.

Voor fabrieken of werkplaatsen bleef, zij het met aanvullingen en wijzigingen, de in de Veiligheidswet vervatte regeling behouden. In afzonderlijke paragrafen werden regelen gegeven met betrekking tot de arbeid in de landbouw, bij het vervoer te water met en het laden en lossen van binnenschepen ${ }^{107}$. Ten aanzien wan alle of bepaalde soorten van arbeid, die niet onder deze rubrieken vielen, werd de mogelijkheid geopend om maatregelen te treffen om de arbeiders te beveiligen ${ }^{108}$. Verder waren nog voorzieningen getroffen ten aanzien van het gebruik van loodhoudende stoffen bij het schilderswerk, de veiligheid op kleine bouwwerken en die in eigen beheer en de handel in gevaarlijke toestellen en werktuigen ${ }^{109}$ "Kortom: de nieuwe wet, de Veiligheidswet $1934^{110}$ beoogde in hoofdzaak een uitbreiding te geven aan de Nederlandse veiligheidswetgeving. De kern van de regeling voor fabrieken of werkplaatsen lag evenals in de Veiligheidswet van 1895 in de artikelen 6 en 7 van de wet; de inhoud ervan stemde vrijwel overeen met die van de oude wet met onderscheid tussen voorschriften die betrekking hebben op de inrichting van de fabrieken of werkplaatsen (artikel 6) en voorschriften die beveiliging beogen te geven tegen de gevaren, die uit het werken zelf in die fabrieken konden voortvloeien (artikel 7). Ook in deze wet was bepaald, dat de krachtens artikel 7 te geven voorschriften moesten worden nageleefd met inachtneming van de eisen die door het districtshoofd van de arbeidsinspectie gesteld (konden) worden. Dezelfde bevoegdheid kreeg het districtshoofd van de arbeidsinspectie ten aanzien van de andere categorieën van arbeid, waaronder het aanbrengen of verwijderen van loodhoudende verven of plamuren. Voor de overige bepalingen aangaande loodhoudende stoffen bij schilder- 
werk alsook aangaande de bepalingen inzake gevaarlijke toestellen kon het districtshoofd van de arbeidsinspectie ontheffing verlenen ${ }^{111}$.

Voor wat betreft de uitvoering was van belang, dat de Veiligheidswet 1934 de mogelijkheid opende om veiligheidscommissies in een (groep van) onderneming(en) in te stellen. Basis van dit artikel was de instelling van veiligheidscommissies door de overheid, naast de mogelijkheid van het steunen van vrijwillig opgerichte veiligheidscommissies ${ }^{12}$. Deze veiligheidscommissies zouden uitsluitend een adviserende taak hebben, die zou bestaan uit het bevorderen van de veiligheid en het voorkomen van schade voor de gezondheid bij en door de arbeid in een (groep van) onderneming(en $)^{13}$. Voor de veiligheidscommissies die van overheidswege zouden worden ingesteld, zou bij algemene maatregel van bestuur een reglement worden vastgesteld ${ }^{14}$, waarover de bedrijfsraad als bedoeld in de Bedrijfsradenwet $1933^{115}$, of bij het ontbreken hiervan de door de minister aangewezen werkgevers en werknemersorganisaties zouden worden gehoord ${ }^{116}$. De mogelijkheid van vrijwillig opgerichte veiligheidscommissies dankte zijn ontstaan aan de mogelijkheid om arbeiders voor het niet opvolgen van veiligheidswoorschriften strafbaar te stellen ${ }^{117}$. Toen het voorontwerp van de nieuwe Veiligheidswet in de Hooge Raad van de Arbeid in behandeling was, leidde deze strafbaarstelling van de arbeider(s) tot de vraag of het geen aanbeveling verdiende de instelling van veiligheidscommissies wettelijk te regelen. Tussen het Verbond van Nederlandse werkgevers, het Nederlands Verbond van Vakverenigingen, het Rooms-Katholiek Werkliedenverbond en het Christelijk Nationaal Vakverbond werd in de Hooge Raad van Arbeid een akkoord bereikt en dit leidde tot een woorstel om veiligheidscommissies in te stellen, respectievelijk te erkennen; essentieel daarbij was, dat de voorkeur werd gegeven aan de erkenning van in vrijwillig overleg tot stand gekomen veiligheidscommissies ${ }^{18}$. De verantwoordelijke minister nam het voorstel over ${ }^{118}$ :

"Aangezien echter aan vrijwillig opgerichte commissies de voorkeur moet worden gegeven boven commissies, welker oprichting is gelast, wordt het mogelijk gemaakt eerstbedoelde commissies te erkennen, op welke dan de bepalingen van het reglement niet van toepassing zullen zijn. Wel kunnen deze bepalingen tot richtsnoer dienen bij de beoordeling van de vraag, of erkenning van een commissie gerechtvaardigd is".

Hoewel de taak van de veiligheidscommissie uitsluitend adviserend bedoeld was, was de bewindsman ervan overtuigd, dat zij nuttig werkzaam zouden kunnen zijn door de directie van de onderneming, de arbeiders en de arbeidsinspectie desgevraagd of uit eigen beweging voor te lichten ${ }^{\| 20}$.

In de Tweede Kamer kwam de vraag aan de orde ${ }^{121}$ of de tijd niet al rijp was geworden om geheel of ten dele met het streng ambtelijke karakter van de Veiligheidswet te breken, hoewel men onmiddellijk daaraan toevoegde, dat de te regelen materie zich er niet toe leende om in alle onderdelen in de wet zelf te worden uitgewerkt. De centralisatie zowel op het terrein van de veiligheidsvoorschriften als zodanig als op dat van de uitwoering; was onvermijdelijk; de reden daarvoor lag in de grote verscheidenheid en de omstandigheden waarmee rekening gehouden moest worden. Deze decentralisatie werd bereikt door evenals bij de oude Veiligheidswet veel ter regeling over te laten aan algemene maatregelen van bestuur en aan de ambtenaren van de arbeidsinspectie. De hoofdzaak van de nieuwe wet lag dan ook in het mogelijk maken van deze delegatie; deze constructie had in het verleden niet onbevredigend gewerkt en bovendien tot weinig klachten aanleiding gegeven. Maar, zo werd vanuit de Tweede Kamer opgemerkt, toch kon niet worden ontkend, dat in de Nederlandse sociale wetgeving, met name op het gebied van de arbeidsverzekeringen, zich een andere richting begon af te tekenen, met andere woorden zou er niet meer bewegingsvrijheild aan de organen van het maatschappelijk leven moeten worden gelaten. Uitgangspunt moest blijven, dat de overheid bij de beveiliging van de arbeid een belangrijke taak behoorde te vervullen; was de ontwikkeling van het sociale organisatiewezen al dusdanig ontwikkeld, om een deel van de overheidstaak op dit gebied over te nemen.

Daarover werd in de Tweede Kamer verschillend gedacht, maar in zijn algemeentheid werd de instelling voor de veiligheidcommissies, waarbij de belangstelling van de werkgevers en de werknemers rond de veiligheid en gezondheid bij de arbeid opgewekt kon worden, een stap in de goede richting gevonden. Uitvoering van de Veiligheidswet door de bedrijfsorganen werd (vooralsnog) niet wenselijk geacht; dit behoorde (vooralsnog) een overheidstaak te blijven. Hierop antwoordde de bewindsman ${ }^{122}$, dat alleen de toekomst uitsluitsel 
kon geven of er op deze eerste stap - de instelling van veiligheidscommissies - nog meerdere zouden kunnen volgen.

Overigens zou de Veiligheidswet 1934 eerst op 1 januari $1939^{123}$ in werking treden, en dan ook nog niet terstond op een veel ruimer gebied dan reeds door de oude Veiligheidswet werd bestreken. Hierbij werd well het Veiligheidsbesluit $1916^{124}$ vervangen door het Veiligheidsbesluit voor fabrieken of werkplaatsen $1938^{125}$, dat evenals op de genoemde datum in werking trad, gevolgd door het Veiligheidsbesluit loodwit, het Electrotechnisch Veiligheidsbesluit 1938 en het Veiligheidsbesluit voor veenderijen $1938^{128}$. Overigens zou de Veiligheidswet 1934 nooit volledig in werking treden, aan de bepaling omtrent de veiligheidscommissie $^{127}$ is nooit nadere uitvoering gegeven.

\section{De Rijtijdenwet 1936}

Eerder hebben we gezien, dat op grond van de Arbeidswet 1919 het Rustdagbesluit voor transportarbeiders te land in 1929 was uitgevaardigd. Al snel bleek echter, dat in een toenemend aantal gevallen door motorrijtuigen ongevallen werden veroorzaakt als gevolg van oververmoeidheid van de bestuurders, onverschillig of zij in loondienst waren of niet. Dit maakte een wettelijke regeling in breder verband noodzakelijk; een zaak waarop al meerdere malen vanuit het parlement was aangedrongen ${ }^{128}$. Alleen deed de vraag zich voor op welke grondslag de nieuwe wettelijke regeling zou moeten worden gebaseerd. In de eerste plaats betrof het voorschriften, die zouden moeten dienen om de verkeersveiligheid te bevorderen, hetgeen onder de competentie van het toenmalige ministerie van Waterstaat viel. In de tweede plaats hield het verschijnsel van oververmoeidheid verband met het feit, dat de arbeiders onder de bestuurders van motorrijtuigen niet zelf bepaalden wanneer voor hen een rusttijd zou gelden. Dit laatste leidde ertoe, dat op het ministerie van Sociale Zaken een regeling zou worden ontworpen op grondslag van de Arbeidswet 1919 waarop op het ministerie van Waterstaat zo nodig een aanvillende regeling tot stand zou brengen voor die gevallen, waarin op grond van de Arbeidswet 1919 geen voorziening mogelijk zou blijken.

Deze gescheiden opzet zou echter op bezwaren stuiten, zodat de oplossing werd gezocht in het ontwerpen van Eên wettelijke regeling, waarbij zowel de verkeersveiligheid als de bescherming van de bestuurders tegen overmatige arbeidstijden zouden worden samengevoegd ${ }^{128}$. Dit resulteerde in de Rijtijdenwet $1936^{130}$. De eigenlijke regeling van de arbeids- en rusttijden werd opgedragen aan een algemene maatregel van bestuur. Bij deze algemene maatregel van bestuur zouden met het oog op bijzondere omstandigheden bepalingen kunnen worden opgenomen omtrent het verlenen en intrekken van vergunningen of ontheffingen en in het algemeen omtrent het nemen wan beslissingen en voorzieningen ter uitvoering van de bepalingen inzake de arbeids- en rusttijden door de beide verantwoordelijke bewindslieden, de districtshoofden van de arbeidsinspectie en door de inspecteur-generaal van het Verkeer ${ }^{134}$. Vanuit de Tweede Kamer werd opgemerkt ${ }^{132}$, dat ingevolge de gekozen opzet wel erg veel werd overgelaten aan regelingen bij algemene maatregel van bestuur, waardoor het wetsvoorstel weinig meer was

"dan een voorstel voor een bevoegdhedenwet, zij het dat enige grenzen voor de uitoefening

van die bewoegdheden gesteld worden".

Wel werd echter erkend, dat op deze wijze de vereiste soepelheid bij de uitvoering van de wettelijke maatregelen gemakkelijker kon worden bereikt dan wanneer alle bijzonderheden in de wet zouden worden geregeld. Om die reden had men dan ook over het algemeen tegen de voorgestelde delegatie van wetgeving geen overwegend bezwaar. Daarnaast werd de vrees geuit, dat de naleving van de uit te vaardigen voorsehriften moeilijk te controleren zou zijn: het gevaar voor ontduiking werd zeer groot geacht, zodat een scherp toezicht geboden wás. In het verlengde daarvan werd opgemerkt, dat een effectieve controle een leger van nieuwe ambtenaren zou eisen; en doordat het aanstellen van controleurs op ruime schaal niet mogelijk zou blijken werd de praktische betekenis, althans door een aantal Tweede Kamerleden ${ }^{133}$ niet hoog aangeslagen. De bewindsman van Sociale Zaken antwoordde ${ }^{134}$ daarop, dat de nadruk moest liggen op de preventieve werking van de wet, terwijl overigens het opsporen van strafbare feiten werd opgedragen aan de ambtenaren van de arbeidsinspectie, de ambtenaren als bedoeld in Motor- en Rijwielverkeerswet ${ }^{135}$, de ambtenaren 
wan de rijkswerkeersinspectie, rijks- en provinciale waterstaat alsmede alle ambtenaren van de rijks- en gemeentepolitie ${ }^{130}$.

Evenals de Veiligheidswet 1934 zouden de Rijtijdenwet 1936 en het daarop gebaseerde Rijtijdenbesluit ${ }^{137}$ eerst in 1939 en well op 13 augustus in werking treden ${ }^{136}$. Door de internationale spanningen, die de mobilisatie van de Nederlandse strijdkrachten tot gevolg had, was het voor de arbeidsinspectie niet mogelijk om over het jaar 1939 een juist beeld te geven over de invloed van de nileuwe bepalingen op het transportwezen. Wel getuigden alle districtsverslagen van een grote drukte, die de invoering van de wet en het besluit op de districtskantoren veroorzaakte. Niet alleen, dat zeer veel mondelinge, schriftelijke en telefonische verzoeken om inlichtingen moesten worden beantwoord, maar tegelijkertijd moest een stroom van verzoeken om gelijkstelling met of erkenning als handelsreiziger en particulier chauffeur, respectievelijk 8017 en 1204 personen worden behandeld ${ }^{139}$. Bovendien was de distributie van werkboekjes ${ }^{140}$ van de gemeentebesturen aan de arbeidsinspectie overgedragen, als gevolg waarvan de districtskantoren belast werden met veel extra expeditiewerk en daarmede samenhangende boekhoudkundige werkzaamheden. Alleen al in die laatste maanden van 1939 werden 76.987 werkboekjes uitgereikt. De invulling van de werkboekjes was dikwijls onjuist, onduidelijk en onvolledig, en dat niet alleen uit onwetendheid, maar ook door opzettelijke knoeierijen. Gedurende de eerste tijd van de inwerkingtreding van de wet en het besluit werd volstaan met het geven van waarschuwingen en het geven van inlichtingen. Eerst na het waarschuwend optreden van onder meer de arbeidsinspectie werden processen-verbaal opgemaakt - in totaal 2252 - omdat de overtredingen bleven doorgaan.

Vrees voor ontslag weerhïeld de arbeiders vaak ervan de werkelijk door hen gemaakte werktijden naar waarheid te noteren. Uit het werkboekje van een vrachtwagenbestuurder, die de werktijden well naar waarheid noteerde, bleek onder andere, dat hij gedurende drie achtereenvolgende weken veel te lang had gewerkt. Deze chauffeur werd met een collega, die eveneens veel te lang had gewerkt, doch de werktijden ook naar waarheid in zijn werkboekje had genoteerd, ontslagen, toen tegen de werkgever proces-verbaal werd opgemaakt. Later zou de werkgever dit ontslag echter weer ongedaan maken. Vaak bleek ook dat de arbeiders, die zowel "achter het stuur zaten" als andere werkzaamheden verrichtten, in het werkboekje alleen de rijtijden invulden ${ }^{14}$.

\section{De Wet houdende tijdelijke maatregelen betreffende de mechanisatie in de sigarenindustrie}

De gedachte om de werkloosheid te voorkomen door een te snelle mechanisatie in de crisistijd af te remmen $^{142}$ heeft voor één bedrijfstak geleid tot een wettelijke regeling, namelijk de Wet van 5 november 1936, houdende tijdelijke maatregelen betreffende de mechanisatie in de sigarenindustrie ${ }^{143}$. In artikel 2 ; eerste lid, van deze wet is het verbod neergelegd om in een tabaksbe-en -verwerkingsruimte een machine voorhanden te hebben, tenzij die machine op 26 mei 1936 reeds in die ruimte voorhanden was, het bewijs hiervan kon slechts worden geleverd door overlegging van een schriftelijke verklaring van het bevoegde districtshoofd van de arbeidsinspectie. In het ontwerp van wet werd ten aanzien van de hoofdregeling van het ontwerp nog de datum van 15 mei 1935 genoemd $^{144}$. Op deze datum was namelijk het voornemen van de regeling tot het treffen van de maatregel zoals werd voorgesteld in de dagbladen bekend gemaakt. Daarnaast sloot de voorgestelde regeling aan bij de inventarisatie, die de ambtenaren van de arbeidsinspectie onmiddellijk na die datum in de daarvoor in aanmerking komende fabrieken hebben gehouden ${ }^{145}$.

Het Tweede Kamerlid Van der Putt voerde tijdens de openbare beraadslaging van het wetsvoorstel aan ${ }^{14}$, dat de redengeving van de in het artikellid genoemde datum ter zake van het waarschuwen via een persbericht, hetgeen overigens eerst een jaar later geëffectueerd zou worden, niet opging. Zijn amendement ${ }^{147}$ om de genoemde datum te stellen op 26 mei 1936 werd aangenomen $^{148}$, zij het niet dan na enige discussie $^{148}$. Teneinde aan de wettelijke verplichting te kunnen voldoen had de arbeidsinspectie in de maanden juni en juli 1936 een enquête ingesteld naar de toestand op 26 mei $1936^{160}$. 
Op grond van het tweede lid van artikel 2 van deze wet kon de minister van Sociale Zaken schriftelijk, en al dan niet onder voorwaarden, ontheffing verlenen, nadat hij de bedrijfsraad in de sigarenindustrie had gehoord ${ }^{151}$.

Artikel 3 van de wet was een noodzakelijke aanvulling van het in artikel 2 neergelegde verbod en beoogde een controle mogelijk te maken vam het aantal in ons land aanwezige machines, die nog niet voor de sigarenindustrie gebruikt worden, via een aangifteverplichting voor degene die een dergelijke machine voorhanden heeft. De aangifte diende via een daartoe bestemd formulier te gebeuren aan het bevoegde districtshoofd van de arbeidsinspectie.

Niet-naleving van het bepaalde in deze beide artikelen leverde een strafbaar feit op; met de opsporing daarvan zijn onder meer de ambtenaren van de arbeidsinspectie belast ${ }^{152}$. Dat het hier een tijdelijke wettelijke maatregel betrof, blijkt uit het feit dat de wet, die op 19 december 1936 in werking trad, met 1 januari 1939 zou vervallen ${ }^{153}$. Bij de Wet van 30 december $1938^{154}$ zou deze termijn echter worden verlengd tot 1 januari 1941. Overigens zou het toezicht op deze wet voor de arbeidsinspectie nauwelijks problemen geven.

\section{De Wet tot regeling van het verrichten van arbeid door vreemdelingen}

Ons land had met betrekking tot het door vreemdelingen hier te lande verrichten van arbeid steeds een, wat Levenbach $^{155}$ noemt, open-deur-politiek gevoerd, zij het met een korte onderbreking. Toen namelijk in 1923 een invasie van vreemde arbeiders in ons land dreigde te ontstaan vooral uit landen met een hoog inflatiepercentage en een grote werkloosheid, heeft het Rijkspaspoortenkantoor ${ }^{156}$ op voorstel van de toenmalige minister van Arbeid, Handel en Nijverheid met ingang van 1 januari 1924 ten aanzien van het verlenen van visa aan vreemdelingen overlegging gevraagd van een zogenaamde werkgeversverklaring en een verklaring van de directeur van het betreffende districtsarbeidsbeurs ${ }^{157}$. Al heeft deze regeling niet alle buitenlandse arbeidskrachten waaraan in ons land geen behoefte bestond, kunnen weren, toch heeft zij ertoe geleid dat de trek van vreemde arbeidskrachten, naar ons land enigermate werd geregulariseerd. Voorkomen werd, dat Nederlandse arbeiders door vreemde arbeidskrachten werden verdrongen. Desalniettemin bleef de mogelijkheid open om buitenlandse arbeidskrachten in dienst te nemen, voor het verrichten van arbeid, wanneer geen geschikte Nederlandse arbeidskrachten beschikbaar waren. Deze arbeidsmarktmaatregel werd bij de opheffing van het Rijkspaspoortenkantoor met ingang van 16 oktober 1926 vervangen door een door de minister van Buitenlandse Zaken afgegeven visuminstructie, dat visa aan vreemdelingen die in Nederland arbeid wilden verrichten niet mochten worden verleend, tenzij de betrokken consulaire ambtenaar terzake een verklaring van geen bezwaar had verkregen van de directeur van de Rijksdienst van de werkloosheidsverzekering en arbeidsbemiddeling. Dat deze regeling niet werkte, is niet verwonderlijk. In de eerste plaats omdat het feitelijk gedrag van de vreemdeling in Nederland zich geheel onttrok aan de waarneming van de consul, die het visum verleende. In de tweede plaats waren de vreemde arbeidskrachten voor het grootste deel onderdanen van landen, waarvoor geen visumplicht gold. Met andere woorden: eenmaal in Nederland was de vreemdeling net zo vrij als de Nederlander, althans wat betreft het verrichten van arbeid ${ }^{15 s}$.

Ten einde een middel in handen te hebben om, indien de omstandigheden het noodzakelijk maakten, van overheidswege regelend te kunnen optreden, ten aanzien van het werken van buitenlandse arbeiders in Nederland, kwam de Wet tot regeling van het verrichten van arbeid door vreemdelingen in $1937^{150}$ tot stand, en trad op 30 mei 1937 in werking ${ }^{180}$. Volgens deze wet kan de Kroon bepalen, dat werkgevers (bepaalde soorten van) arbeid niet door vreemdelingen mogen doen verrichten, zonder schiriftelijke vergunning van de directeur van de Rijksdienst der Werkloosheidsverzekering en Arbeidsbemiddeling ${ }^{\text {161 }}$. Hoewel aanvankelijk slechts een aantal bedrijven aangewezen werd, waarvoor vergunning vereist was, werd dit al snel voor alle arbeid, behoudens enkele uitzonderingen voorgeschreven ${ }^{162}$. De wet leende zich uitdrukkelijk tot het maken van uitzonderingen krachtens verdragen met vreemde mogendheden ${ }^{\text {163 }}$. Overtreding van de wet leverde een strafbaar feit op; één van de diensten die belast was met de opsporing, was de arbeidsinspectie ind. $^{\text {194. }}$

Deze wet zou door de Wet arbeidsvergunning vreemdelingen ${ }^{165}$ worden vervangen, welke wet weer zou 
worden ingetrokken door de thans van kracht zijnde Wet arbeid buitenlandse werknemers ${ }^{160}$. Met het opsporen van overtredingen van de thans geldende wet zijn niet meer mede de ambtenaren van de arbeidsinspectie belast, maar die van de loontechnische dienst ${ }^{167}$.

In verband met de bepalingen van de Wet tot regeling wan het verrichten van arbeid door vreemdelingen diende de arbeidsinspectie de directeur van de Rijksdienst der Werkloosheidsverzekering en Arbeidsbemiddeling wan advies bij aanwragen om vergunning. Bovendien werden de inspectiebezoeken benut om controle uit te oefenen op de naleving van deze wet. Vaak werd volstaan met een waarschuwing, dat een arbeidsvergunning moest worden aangevraagd of werd de zojuist genoemde dienst met het ontbreken van een vergunning in kennis gesteld. Ook werd bij de beoordeling van aanvragen ingevolge artikel 94 van de Arbeidswet 1919, dus bij verzoeken aan het districtshoofd van de arbeidsinspectie om een mede-hoofd of bestuurder aan te wijzen, indien hierbij personen met een niet-Nederlandse nationaliteit waren betrokken, steeds nagegaan, of wellicht de bedoeling voorzat, de bepalingen van de Wet tot regeling van het verrichten van arbeid door vreemdelingen te ontduiken.

Naar aanleiding van een klacht over de arbeid op een bouwwerk van een Duitse glas-in-lood-zetter in dienst van een schildersonderneming, werd in 1937 een onderzoek ingesteld, waaraan de betrokken arbeider zich wist te.onttrekken door zich bij de komst van de inspectie-ambtenaren te verstoppen. Hij bleef onvindbaar op het werk. Toen de betrokken ambtenaren hem dezelfde dag bij een bezoek aan zijn woning thuis aantroffen, ontkende hij pertinent ooit op het bouwwerk te hebben gewerkt of loon te hebben ontvangen, hoewel uit de verklaringen van de uitwoerder was gebleken, dat dit wel het geval was, waarbij zelfs het bedrag van het loon was genoemd. Daar geen arbeidsvergunning was verleend; werd uiteindelijk een proces-verbaal opgemaakt. Bowendien bleek de betrokken Duitser in de week, waarin hij loon had ontvangen, nog te hebben "gestempeld". De officier van justitie werd daarvan in kennis gesteld.

Dat controle niet altijd gemakkelijk was, bewijst ook nog het volgende uit 1938 daterende geval. In een schoenmakerij te Amsterdam werden twee personen aangetroffen die werkzaamheden verrichtten, van wie eén onmiddellijk als vreemdeling herkend werd. Een werkvergunning voor deze arbeider ontbrak. Ten aanzien van de andere arbeider verklaarde de werkgever, die het onderzoek zoveel mogelijk probeerde te belemmeren, dat deze Nederlander was. Hoewel deze persoon een oerdegelijke Nederlandse naam had, namelijk Jansen, klonken de weinige woorden die hij sprak zo on-Nederlands dat er gerede twijfel bestond of de man werkelijk Nederlander was. De werkgever probeerde de gebrekkige Nederlandse uitspraak van de arbeider te verklaren door de mededeling, dat deze lang in het buitenland had gewerkt. Bij nader onderzoek bij de burgerlijke stand bleken naam en geboortedatum van de arbeider juist te zijn opgegeven.

Toen daarop een bezoek werd gebracht aan de woning van de werkgever, werd door de genoemde Jansen opengedaan, Deze verklaarde nu, inderdaad vreemdeling te zijn, maar ontkende de controlerende ambtenaar ooit te hebben gezien. Tegen de werkgever werd proces-verbaal opgemaakt, terwijl later door de via de situatie op de hoogte gestelde vreemdelingendienst van de gemeentepolitie nog tweemaal geverbaliseerd werd, omdat ook door familieleden van de werkgever, die ons land zogenaamd eens kwamen bezoeken, in de onderneming werd gewerkt. Deze familieleden kregen tenslotte de aanzegging Nederland te verlaten.

Ontduiking van de wet werd herhaaldelijk gepleegd. Zo ging een werkgever met zijn buitenlandse knecht een compagnonschap aan, ten einde hem op deze wijze aan de toepasselijkheid van de wet te onttrekken. Voorts had men in een grote schoenfabriek een Duitse reparateur in dienst, aan wie men, toen de werkvergunning vervallen was, de reparatiewerkplaats verhuurde. Hierdoor was het dienstverband met de schoenfabriek verbroken en werd de Duitser zelfstandig hoofd van een onderneming, waardoor de Wet op het verrichten van arbeid door vreemdelingen niet meer voor hem gold ${ }^{168}$.

\section{De Wet inzake verdeling van de beschikbare arbeid 1937}

Het verschijnsel dat in de crisisjaren ter besparing op de loonkosten, mannelijke arbeiders door vrouwelijke 
en oudere arbeiders door jeugdigen werden vervangen, ontlokte reactie vanuit de Tweede Kamer; tijdens de begrotingsbehandeling voor het dienstjaar 1937 werd aangedrongen op maatregelen ${ }^{169}$.

Dit mondde uit in de Wet inzake de verdeling van de beschikbare arbeid $1937^{170}$. Uitgangspunt van de regeling was het volgende ${ }^{171}$ :

"Werkloosheid is een ramp voor ieder, die er door getroffen wordt, maar voor het gezinshoofd werkt zuj veel meer funest dan voor iemand, die niet met de zorg voor het levensonderhoud van anderen belast is. Op den man nu rust, naar den natuurlijken gang van zaken, de plicht om ook voor zijn vrouw en kinderen het levensonderhoud te verdienen".

De werkloosheidscijfers over $1936^{172}$ deden de wraag rijzen of niet, naast de bestrijding van de werkloosheid in het algemeen, als crisismaatregel - dus van tijdelijke duur - iets gedaan zou kunnen worden om de werkloosheid onder de mannelijke arbeidskrachten enigszins te verminderen door op bepaalde terreinen de bestaande werkgelegenheid voor vrouwen en meisjes enigszins in te perken ${ }^{173}$.

De wet opende de mogelijkheid om de fabrieksarbeid van vrouwen of meisjes voor zover deze zich na 1 januari 1934 had uitgebreid weer terug te dringen door minimumsgetalsverhoudingen voor mannen van 25 jaar of ouder in de diverse in aanmerking komende soorten van arbeid bij algemene maatregel van bestuur vast te stellen ${ }^{74}$. Met de handhaving van deze wet en met de medewerking aan de uitvoering ervan zouden de ambtenaren van de arbeidsinspectie belast worden ${ }^{175}$. Zo zou het districtshoofd schriftelijk en al dan niet onder voorwaarden voor ten hoogste 3 maanden kunnen vergunnen - in beroep de betrokken minister - dat van het hierboven gestelde afgeweken kan worden ${ }^{176}$. Niet-naleving van het bepaalde bij of krachtens deze wet levert een strafbaar feit op - overtreding -; met de opsporing daarvan zouden onder meer de ambtenaren van de arbeidsinspectie belast worden ${ }^{177}$.

Een ontwerp van de zojuist bedoelde algemene maatregel van bestuur werd voor advies aan de Hooge Raad van Arbeid gezonden en stuitte daar op grote meningsverschillen, waarop de toenmalige bewindsman Damme besloot het op 31 juli 1939 terug te nemen. Dit had tot gevolg dat de hele wet alleen een papieren maatregel is gebleven ${ }^{178}$.

\section{De Wet op het algemeen verbindend en onverbindend verklaren van bepalingen van collectieve arbeids- overeenkomsten}

Werden in de troonrede van $1930^{179}$ door de regering nog zowel een ontwerp voor de zogenaamde publiekrechtelijke regeling van de collectieve arbeidsovereenkomst, dat wil zeggen het algemeen verbindend verklaren van bepalingen van de collectieve arbeidsovereenkomst, als een ontwerp voor de bedrijfsraden door de regering in het vooruitzicht gesteld, in de daarop volgende troonrede ${ }^{180}$ had de regering een ander standpunt ingenomen:

"Terwijl deze tijd van druk de bindendverklaring der cao's aan urgentie doet verliezen, ver-

sterkt hij de wenschelijkheid eener wettelijke bedrijfsorganisatie".

Dit nieuwe standpunt werd door de betrokken bewindsman toegelicht met een verwijzing naar de crisissituatie, waardoor een eventueel ontwerp met betrekking tot de algemeen verbindendverklaring van collectieve arbeidsovereenkomst het risico zou lopen verkeerd te worden beoordeeld.

Bedrijfsorganisatie daarentegen zou nuttig kunnen zijn voor

"aanpassing van de bedrijfsverhoudingen aan de tijdsomstandigheden"181.

Volgens Van Peype ${ }^{182}$ bedoelde de minister, dat een stelsel van bedrijfsorganisatie kan worden ingeschakeld ongeveer op de manier waarop dit later zou gebeuren ten aanzien van de landbouw op grond van de Landbouwcrisiswet 1933 - doel van deze wet was voornamelijk door steunverlening en beperking van produktie en handel te komen tot een aanpassing van de produktie aan de beperkte afzetmogelijkheden ${ }^{183}$, terwijl van de algemeen verbindendverklaring juist gevreesd werd, dat deze loon- en prijsdalingen zou belemmeren. Met de bedrijfsraden zou de betrokken bewindsman dan ook doorzetten, hetgeen zou resulteren in de Bedrijfsradenwet $1933^{184}$.

Maar de voorstanders van de algemeen verbindendverklaring vreesden juist dat het instituut van de collectie- 
ve arbeidsovereenkonst ondergraven werd, doordat werkgevers zich door opzegging van hun lidmaatschap van hun organisaties aan nieuw af te sluiten collectieve arbeidsovereenkomsten gingen onttrekken, terwijl de regering de algemeen verbindendverklaring bleef afwijzen met het oog op de noodzakelijke "aanpassing" ten behoeve van het onbeschutte bedrijf. De betrokken minister sprak zelfs de volgende woorden ${ }^{165}$ :

"Indien op het oogenblik een wet werkte, waarbij zoowel verbindendverklaring als ontbindendverklaring zou mogelijk zijn, dan zou naar mijn inzicht de kans op ontbindendverklaring onvergelijkbaar veel grooter zijn dan op bindendverklaring".

Zijn opvolger achtte een koppeling tussen een algemeen verbindend- en onverbindendverklaring eveneens noodzakelijk ${ }^{18 \theta}$, teneinde verstarring in de lonen te voorkomen en de consument te beschermen. Levenbach $^{187}$ stelt, dat het tot stand komen van de Wet op het algemeen verbindend en onverbindend verklaren van ondernemingsovereenkomsten $1935^{188}$ op grond waarvan kartelafspraken, die in de betreffende bedrijfstak een overwegende betekenis hadden, algemeen verbindend en onverbindend verklaard konden worden ${ }^{188}$, hieraan niet vreemd was.

Toen na de devaluatie in september 1936 de economische situatie snel verbeterde werd in de troonrede ${ }^{100}$ naast het losmaken van de "te knellende boorden" van de crisismaatregelen, de indiening van een wetsvoorstel op de algemeen verbindend-en onverbindendverklaring van bepalingen van collectieve arbeidsovereenkomsten aangekondigd. Het bedoelde wetsvoorstel, dat overigens al in 1930 gereed lag, werd op 4 december 1936 bij de Tweede Kamer ${ }^{191}$ aanhangig gemaakt. Het wetswoorstel en de daarbij behorende memorie van toelichting waren vrijwel gelijk aan hetgeen de toenmalige minister van Arbeid Aalberse in 1925 voor advies aan de Hooge Raad van Arbeid had voorgelegd met als belangrijkste verschil, dat het wetsvoorstel nu ook een regeling aangaande de onverbindendverklaring bevatte ${ }^{192}$. De toenmalige minister van Sociale Zaken Slingenberg maakte in de toelichting het vollgende kenbaar $^{193}$.

"De eerstondergetekende heeft, na zijn optreden, aanvankelijk gemeend, bij het treffen van een regeling op het gebied van de verbindendverklaring van collectieve arbeidsovereenkomsten zich in zooverre te moeten beperken, dat niet de loonen, maar wel andere bepalingen van collectieve arbeidsovereenkomsten zouden kunnen worden verbindend verklaard; hij heeft, overeenkomstig de door hem gedane toezeggingen, de mogelijkheid daarvan nader onder de oogen gezien. Daarbij is hij tot de overtuiging gekomen, dat op deze wijze een oplossing, welke voldoende steun biedt aan het instituut van de collectieve arbeidsovereenkomst, niet verkregen kan worden. In het hierbij aangeboden wetsontwerp is daarom de mogelijkheid tot verbindendverklaring van bepalingen, welke op de loonen betrekking hebben, niet uitgesloten".

De collectieve arbeidsovereenkomst was, volgens de bewindslieden ${ }^{194}$, voor de behoorlijke gang van het bedrijfsleven, het bevorderen van de samenwerking tussen werkgevers en arbeiders en het scheppen van redelijke arbeidswoorwaarden van zo grote betekenis gebleken, dat het wegruimen van belemmeringen die haar verdere ontwikkeling in de weg staan, van groot maatschappelijk nut was te achten.

Niet alleen zou een wettelijke regeling van de verbindendverklaring het sluiten van collectieve arbeidsovereenkomsten bevorderen, maar werd daardoor tevens een stap gezet in de richting om de vaststelling van voorschriften op het gebied van de arbeidersbescherming, die op grond van de aard van de daarbij betrokken belangen in een bedrijfstak algemeen behoorden te gelden, zoveel mogelijk zouden moeten gebeuren door belanghebbenden in die bedrijfstak. Hoe meer, zo vervolgden zij, zodanige regelingen uit de bedrijfstak zelf voortkwamen, des te meer zou ingrijpen van de wetgever door middel van gebods- en verbodsbepalingen met de nadelen die daaraan kleefden, op de achtergrond kunnen treden. Teneinde dit evolutieproces voldoende in de hand te werken; was het noodzakelijk om de in een bedrijfstak ontstane regelingen ook aan minderheden, die zich daaraan onttrokken, op te leggen; een mogelijkheid die geopend werd via de algemeen verbindendverklaring.

Maar ook nu weer werden bezwaren vanuit de Tweede Kamer aangevoerd tegen de algemeen verbindendverklaring uit vrees voor vooral verstarring van het economische leven, wat in strijd was met het algemeen belang $^{195}$. 
Bij veranderingen op de internationale markt moet het Nederlandsche bedrijfsleven zich snel aan de gewijzigde omstandigheden kunnen aanpassen ten einde zijn positie in de wereld te kunnen behouden. Daartoe kan ook verandering in de arbeidsvoorwaarden op korte termijn nodig zijn, en zulk een verandering wordt bij toepassing aan het ontwerp sterk bemoeilikt".

Als reactie daarop stelden de bewindslieden ${ }^{160}$ onder meer, dat op grond van artikel 2 wan het wetswoorstel de verbindendverklaring alleen kon geschieden voor de duur van een collectieve arbeidsovereenkomst, maar in geen geval voor een periode vam meer dan é́n jaar. Mochten na de inwerkingtreding van de algemeen verbindendverklaring de omstandigheden zich belangrijk wijzigen, zo vervolgden zij, en de betrokken partijen onwillig zijn om tot de nodige wijziging van de collectieve arbeidsovereenkomst te komen, dan kan gebruik gemaakt worden van de aan de in artikel 6 van het wetsvoorstel aan de minister gegeven bevoegdheid de verbindendverklaring in te trekken. De verbindendverklaring leidde dus niet automatisch tot de zogenaamde loonverstarring. Als een ernstige leemte in het wetswoorstel werd in de Tweede Kamer beschouwd ${ }^{197}$ het ontbreken van een controle-instantie, die op de naleving van de verbindendverklaarde bepalingen had toe te zien, omdat zonder toezicht het wetsvoorstel zijn praktische effect zou missen.

"Overtreedt een ongeorganiseerde werkgever een der voor hem verbindend verklaarde bepalingen, dan zal de ongeorganiseerde arbeider, die daardoor benadeeld wordt, er niet gemakkelijk toe komen zich daarover te beklagen. Er bestaan in elk geval heel wat minder waarborgen voor een goede naleving van de verbindend verklaarde overeenkomst, wanneer het een niet georganiseerde patroon dan wanneer het een georganiseerden betreft. Dit kan niet in de bedoeling der Regering liggen. Er moet ten aanzien van beide categorieën even grote zekerheid bestaan, dat de bepalingen worden nageleefd. Dit nu is alleen mogelijk, wanneer een onpartijdig met de controle belast wordt en aan dat lichaam ruime bevoegdheden worden verleend".

Het ontbreken van controlle bevreemdde deze Kamerleden des te meer, daar in artikel 12 van de Wet op het algemeen verbindend en onverbindend verklaren van ondernemersovereenkomsten 1935 een regeling van dit onderwerp well voorkwam.

Vanuit de Tweede Kamer werd gevraagd, of de arbeidsinspectie niet met dit toezicht kon worden belast. Deze suggestie tot het inschakelen van een controle-instantie, belast met het toezicht op de naleving van verbindend verklaarde bepalingen, werd door de betrokken bewindslieden blijkens hun reactie ${ }^{10.3}$ "vooralsnog" niet overgenomen, omdat zij van mening waren, dat de algemeen verbindendverklaring zich niet op zuiver publiekrechtelijk terrein bevond.

"Dit wetsontwerp wil niet anders dan mogelijk maken, dat civielrechtelijk voor hem, die niet onder een collectief contract valt, hetzelfde komt te gelden als voor iemand, voor wie de collectieve arbeidsovereenkomst wel geldt.

De arbeider, die onder minder gunstige arbeidsvoorwaarden werkt dan het collectief contract garandeert, zal na verbindendverklaring op dezelfde gunstige regeling recht hebben, als welke in het georganiseerde bedrijf geldt en hij zal dat recht bij den burgerlijken rechter kunnen opvorderen. Dit is de betekenis van de verbindendverklaring".

Zou een controle-instantie gecreëerd worden, zo vervolgden zij, dan zou daarmede een stap verder gezet worden in de richting van een publiekrechtelijke regeling, hoewel zij moesten toegeven, dat de kans op naleving van verbindend verklaarde bepalingen groter zou worden, zeker naar mate de machtsmiddelen waarover dan beschikt zou kunnen worden, krachtiger waren. Maar zij vroegen zich af, of die weg wel ingeslagen moest worden. $\mathrm{Zij}$ benadrukten dan ook nogmaals dat het wetsvoorstel zou leiden tot een versterking van het organisatiewezen; het past de organisaties op de goede weg te helpen, maar niet om haar taak over te nemen. De verwijzing naar de Wet op het allgemeen verbindend en onverbindend verklaren van ondernemersovereenkomsten 1935 werd door de bewindslieden afgedaan met de opmerking dat de doelstellingen van die wet geheel anders lagen dan van het onderhavige wetsvoorstel, ook al, vertoonden beide formeel veel gelijkenis. Tot besluit stelden zij, dat tegen de inschakeling van de arbeidsinspectie op dit terrein alleen al 
vanwege de aard van de materie op overwegend bezwaar zou stuiten. Tijdens de verdere behandeling van het wetswoorstel voegden de bewindslieden onder druk van de Tweede Kamer ${ }^{190}$ echter, een bepaling toe ${ }^{200}$, dat de bedrijfsraad, indien vermoed werd dat in een onderneming een algemeen verbindend verklaarde bepaling niet werd nageleefd, aan de minister zou kunnen verzoeken een onderzoek te doen instellen door de arbeidsinspectie. De directeur-generaal diende volgens deze nieuwe bepaling verslag aan de betrokken bewindsman uit te brengen omtrent hetgeen bij het onderzoek was gebleken, waarop deze laatste weer de bedrififsraad zou inlichten.

Vanuit de Tweede Kamer was echter door middel van een aantal amendementen kenbaar gemaakt, dat de voorkeur uitging naar controle door de bedrijfsraad. Het Kamerlid-Kuiper ${ }^{201}$ vatte de opvattingen als volgt samen. Het amendement-Smeenk ${ }^{202}$ beoogde aan de bedrijfsraad opdracht te geven om te controleren, om te komen tot een systeem van controle, tot een min of meer permanente controle, die regelmatig toezag of de verbindend verklaarde bepalingen van een collectieve arbeidsovereenkomst worden nageleefd. De subamendementen van de leden Kupers en Donker ${ }^{203}$ stemden daar principieel mee in. Het ging hier dus om een controle-systeem dat erop berekend en gericht zou zijn om regelmatig toe te zien op de naleving en niet alleen als er een klacht zou komen. De van regeringszijde voorgestelde controle was een controleregeling, die slechts incidenteel was. Als er klachten zouden komen, zou daarnaar door de arbeidsinspectie een onderzoek worden ingesteld op dezelfde voet dus als regelmatig gebeurde bij andere klachten. De bewindsman van Sociale Zaken reageerde hierop ${ }^{204}$ met de opmerking dat zijn voorstel een taak voor de bedrijfsraad inhield, door hem het recht te geven om een waakzaam oog te houden of de algemeen verbindend verklarende bepalingen nageleefd werden. De overige bezwaren vond hij niet steekhoudend. Het Tweede Kamerlid Smeen ${ }^{205}$ was, met waardering van de goede bedoeling, toch van mening dat controle van regeringszijde voorgesteld niet afdoende zou zijn en dat zij in een te langzaam tempo zou gebeuren. Hij gaf daarbij een schets van een langdurige procedure, die hier mogelijk zou zijn en meende dat door de unschakeling van de arbeidsinspectie tal van mensen, die bij de collectieve arbeidsovereenkomst betrokken waren, al overleden zouden kunnen zijn alvorens het administratieve apparaat voldoende werkzaam was geweest. De bewindsman wees erop, dat ook de afgevaardigde een administratief apparaat voor het onderzoek nodig had en het tempo van beide onderzoekingen elkaar niet zo veel zou ontlopen. De minister bestreed dat door de inschakeling van de arbeidsinspectie een vertraging tot stand zou komen, want bij uitstek was de arbeidsinspectie geschikt voor deze taak, en dat terwijl dezelfde minister tien dagen daarvoor in de memorie van antwoord nog had gesteld, dat tegen het inschakelen van de arbeidsinspectie, gezien de aard van de materie, overwegend bezwaar bestond. Deze dienst was niet alleen geschikt om, zoals de afgevaardigde Kupers ${ }^{200}$ stelde, een onderzoek in te stellen naar de lonen, maar even goed om een onderzoek in te stellen naar de nakoming van andere bepalingen van de collectieve arbeidsovereenkomst. Bovendien was het contact tussen de arbeidsinspectie en de bedrijven van dien aard, dat deze dienst over eem schat aan gegevens bezat over alles wat er voorkwam. Het zou de arbeïdsinspectie dan ook gemakkelijk vallen snel een dergelijk onderzoek in te stellen.

Met betrekking tot de bedrijfsraden merkte de bewindsman op, dat hij de ontwikkeling van het instituut een goed hart toedroeg en hij er naar streefde de bedrijfsraden meer en meer een positie van betekemis te geven in het bedrijfsleven. Men stelde nu voor de bedrijfsraden het recht van onderzoek te geven naar all hetgeen voor de goede uitoefening van het toezicht van belang zou kunnen zijn, zoals het betreden van plaatsen en ruimten, het inbeslag nemen van boeken en bescheiden en misschien een verplichting tot geheimhouding. Het geven van deze ingrijpende bevoegdheden aan de bedrijfsraden ontlokte de bewindsman de opmerking, dat hij onoverkomelijke bezwaren had, waarop het Kamerlid Smeenk ${ }^{207}$ vroeg naar de betekenis van deze waarden. De bewindsman deelde mede ${ }^{208}$, dat hij daaraan de taalkundige betekenis moest hechten, namelijk dat hij bezwaren tegen zijn amendement had, die hij niet te boven kon komen. Het Kamerlid Smeenk haalde bakzeil en trok zijn amendement in, met als gevolg dat de subamendementen van Kupers en Donker vervielen $^{209}$. Voor wat betreft de situatie, dat er in een bedrijf geen bedrijfsraad bestond maakte de minister duidelijk, dat uit de aard der zaak een organisatie die bij de collectieve arbeidsovereenkomst betrokken was en zich benadeeld achtte, zich tot de minister, zou kunnen worden met een verzoek om een onderzoek 
door de arbeidsinspectie te doen instellen ${ }^{210}$.

De op 25 mei 1937 tot stand gekomen Wet op het algemeen verbindend en het onverbindend verklaren van bepalingen van collectieve arbeidsovereenkomsten ${ }^{211}$, zou dit controle-artikel bij de Wet op de bedrijfsorganisatie gewijzigd worden, in die zin dat verzoek om een onderzoek door de arbeidsinspectie kan worden gedaan door één of meer verenigingen van werkgevers of van arbeiders op wier verzoek een verbindend verklaring is uitgesproken. Op 1 oktober 1937 de wet in werking $\operatorname{trad}^{212}$.

Uit de in artikell 10 van de Wet op de algemeen verbindend en onverbindend verklaren van bepalingen van collectieve arbeidsovereenkomsten voorkomende formulering "Onze Minister kan het onderzoek opdragen aan de Arbeidsinspectie", waarbij de nadruk op het woord "kan" ligt, kon volgens $\mathrm{Mok}^{213}$ niet afgeleid worden dat de bewindsman het onderzoek eventueel ook aan een ander orgaan zal opdragen. Maar hij vroeg zich wel af, of de arbeidsinspectie voor het uitvoeren van deze taak wel het juiste orgaan was. Overigens daaraan toevoegend, dat dit niet de bedoeling had

"twijfel te trekken aan den ijver en de deskundigheid van de arbeidsinspectie. Wie regelmatig kennis neemt van haar jaarlijks Centraal Verslag weet, dat haar sociale beteekenis zeer groot is. Niet alleen, omdat zij haar eigenlijke taak op zoo voortreffelijke wijze verricht, maar niet minder om de groote moeite, welke zij zich pleegt te geven om misstanden in het arbeidsleven op te sporen en zoodoende de gelegenheid te geven deze uit den weg te ruimen. Het aantal wetten, voor welker uitvoering en handhaving de arbeidsinspectie zorg moet dragen, is in de laatste twintig jaren sterk gegroeid. De financiële toestand van het Rijk heeft het niet mogelijk gemaakt het aantal ambtenaren der arbeidsinspectie uit te breiden in overeenstemming met den groei van haar taak. Zij is zeer sterk belast. Het is ook de vraag, of zij het geschiktste orgaan is voor een controle als haar in deze wet is opgedragen en of niet veeleer een orgaan, waarin bedrijfsdeskundigen zitting hebben, had moeten zijn gekozen".

Ook Van Haersolte $e^{214}$ verwachtte al bij een eerdere gelegenheid geen resultaten van controle door de arbeidsinspectie op de naleving van collectieve arbeidsovereenkomsten en de daarbij te hanteren administratiefrechtelijke sancties. Zijn bezwaren kwamen erop neer, dat administratieve organen, zoals de arbeidsinspectie, op een dergelijke manier

"eigenlijk rechter zouden worden over de c.a.o., tot welke functie zij niet geroepen en niet geschikt zijn, terwijl de rechtszekerheid geschaad zou worden".

Deze bezwaren werden door Levenbach ${ }^{215}$ in een reactie daarop onjuist geacht. Administratieve organen wogen al zo vaak belangen af en toetsten subtiele aangelegenheden, dat men hen tot een toetsing van het naleven van de collectieve arbeidsovereenkomst zeker niet ongeschikt kan achten. Zo werd de arbeidsinspectie wel in staat geacht een beslissing te nemen over het al of niet wenselijk zijn van het verlenen van een gevraagde overwerkvergunning, maar kan daarbij niet toetsen of de werkgever het loon betaalde conform de collectieve arbeidsovereenkomst; iets dat de schrijver weinig aannemelijk vond. Overigens nam dit niet weg, dat Levenbach geen voorstander was van een controle op de naleving van bepalingen van collectieve arbeidsovereenkomsten, en de daarbij behorende administratiefrechtelijke sancties. Zijn argument daarvoor was dat de innerlijke samenhang tussen een dergelijke maatregel en de collectieve arbeidsovereenkomst ontbrak. Overwerkvergunningen konden om verschillende redenen gewenst zijn, zodat het toetsen of de werkgever soms een overtreding van de collectieve arbeidsovereenkomst beging, hier niet beslissend mocht zijn en dus niet per se als voorwaarde worden gesteld ${ }^{218}$.

Maar waaruit bestonden de activiteiten, die de arbeidsinspectie in het kader van deze wet uitvoerde; het verrichten van onderzoek na verzoek van aanvankelijk een bedrijfsraad aan de betrokken bewindsman.In 1938 waren slechts enkele bepalingen van de collectieve arbeidsovereenkomst voor de schoenindustrie verbindend verklaard. In totaal werd 64 maal een onderzoek gevraagd naar de naleving van die bepalingen in 61 bedrijven, naar aanleiding waarvan 35 rapporten werden uitgebracht. In 1939 werd ten aanzien van de naleving van de verbindend verklaarde bepalingen der collectieve arbeidsovereenkomsten voor het boekdrukkers- en 
rasterdiepdrukbedrijf aan de arbeidsinspectie opgedragen een onderzoek in een viertal ondernemingen in te stellen. Veel meer werk vereist het onderzoek naar de vele klachten, die de bedrijfsraad voor de schoenindustrie over verschillende fabrieken ter kennis had gebracht. Over 30 ondernemingen werd in dit jaar rapport uitgebracht. Het onderzoek naar de naleving van de loonnormen was zeer tijdrovend; de administratie van de bedrijven bood niet altijd een goede gellegenheid tot controle, maar ook het verzamelen van de gegevens en vooral het narekenen ervan vorderde veel tijd. Allerlei oorzaken waren daarvoor aan te wijzen zoals gedeelten van uren moesten worden berekend, het afwisselend werken in uur- en stukloon ${ }^{217}$.

\section{Bedrijfsvergumningenwet 1938}

Voor de industriële ordening had de regering met de totstandkoming van deze laatste wet nu een tweetal wetten tot haar beschikking, namelijk de Wet op het algemeen verbindend en onverbindend verklaren van ondernemersovereenkomsten 1935 en de Wet op het algemeen verbindend en onverbindend verklaren van bepalingen van collectieve arbeidsovereenkomsten 1937. Had de eerstbedoelde wet tot gevolg dat de overheid enerzijds aan bedrijfsgenoten een gewenste ordening die door een deel van hun tot stand was gebracht op kan leggen, anderzijds kan de overheid de rechtskracht aan een door de bedrijfsgenoten tot stand gebrachte ordening ontnemen. De overheid had dus niet de bevoegdheid om op eigen initiatief kartelregelingen in het leven te roepen, maar kon slechts uitsluitend reageren op overeenkomsten die uit wilsovereenstemming van ondernemerszijde waren voortgekomen. Een algemene verbindend- verklaring was slechts mogelijk indien de overwegende betekenis van de vakkundigen in de betrokken bedrijfstak en het algemeen belang dit eisten en nadat een of meer ondernemers, die bij de overeenkomst partij waren, een daartoe strekkend verzoek hadden ingediend. Een onverbindend-verklaring van een overeenkomst was mogelijk wanneer het algemene belang dit vorderde. De Wet op het algemeen verbindend en onverbindend verklaren van bepalingen van collectieve arbeidsovereenkomsten 1937 wordt als een logische consequentie van deze wet van 1935 genoemd; ongeorganiseerden behoorden in bepaalde gevallen gedwongen te worden, de door de georganiseerden getroffen regelingen te volgen. Onverbindendverklaring van bepalingen van collectieve arbeidsovereenkomsten werd met het oog op het algemeen belang noodzakelijk geacht ${ }^{218}$.

Voor de industriële ordening zou de overheid nog een derde wet, de Bedrijfsvergunningenwet $1938^{219}$ tot haar beschikking krijgen, waarover Brugmans ${ }^{220}$ opmerkt, dat het een kenmerkend voorbeeld oplevert van samenwerking tussen overheid en bedrijfsleven. De overheid kreeg de bevoegdheid de vestiging of uitbreiding van ondernemingen in een bepaalde bedrijfstak te verbieden, maar alleen op verzoek van én of meer ondernemers uit het bedrijf en wanneer het algemeen belang dit wenste ${ }^{221}$. Niet-naleving van het bij of krachtens deze wet bepaalde leverde een strafbaar feit ${ }^{222}$ op; met de opsporing hiervan waren onder meer de ambtenaren van de arbeidsinspectie belast ${ }^{223}$. De aanwijzing van de ambtenaren van de arbeidsinspectie verdedigde de betrokken bewindsman ${ }^{224}$ met de verwijzing naar het feit, dat deze uit hoofde van hun eigenlijke functie al in voortdurend contact stonden met het bedrijfsleven en dus in de eerste plaats in aanmerking kwamen voor de beoordeling van de vraag, of in een bepaald geval een overtreding werd begaan.

\section{Andere organen dan de arbeidsinspectie op het terrein van de arbeidsbeschermende wetgeving?}

Tijdens de op 23 en 24 juni 1939 gehouden algemene vergadering van de Nederlandse maatschappij voor nijverheid en handel werd de uitvoering van bijwoorbeeld de Arbeidswet 1919 en de Veiligheidswet 1939 door andere organen dan de arbeidsinspectie geopperd bij monde van haar voorzitter Plate.

In zijn rede schetste hij allereerst de relatie overheid en bedrijfsleven. Hij begon met de stelling dat in deze tijden van hevige beroering en snelle veranderingen het regeersysteem een ontwikkeling te zien gaf, dat de neiging had van een vertraagd handelen, dit in tegenstelling tot het bedrijfsleven dat steeds sneller wilde produceren, de handel die steeds sneller wilde leveren, hetgeen bovendien mogelijk werd door snellere communicatie- en transportmogelijkheden. Hij bepleitte dan ook dat de overheid zodanig moest zijn of worden uitgerust, dat het verschil in tempo tussen de werking van haar organen en die van het bedrijfsleven zoveel mo- 
gelijk moest worden opgeheven. Zijn redenering kwam erop neer, dat wanneer vaststond, dat de regering overging om op uitgebreide schaal regelingen aangaande het economisch leven te treffen, deze regelingen zo vlot en doeltreffend mogelijk in de praktijk werden gebracht.

Een ander punt was de werking van adviescolleges. Terwijl in het maatschappelijk leven het tempo versnelde, kostte de voorbereiding van wettelijke maatregelen meer zorg en meer tijd. De toegenomen ingewikkeldheid van verschillende vraagstukken op sociaal en economisch terrein, was voor de regering aanleiding gaandeweg nieuwe adviescolleges in te stellen, die waren samengesteld uit personen, die als vertegenwoordigers van betrokken groepen uit de samenleving of als speciale deskundigen werden beschouwd ${ }^{225}$. Als voorbeelden noemde hij de Hoge Raad van Arbeid en de Economische Raad. Over de Hoge Raad van Arbeid merkte hij op, dat dit adviesorgaan, oorspronkelijk opgezet om de verantwoordelijke bewindsman bij de sociale wetgeving beter beslagen ten ijs te doen komen, niet meer het snelwerkende instrument was, dat de regering de zekerheid kan geven, dat het departementale werk afdoende werd gecorrigeerd. Het tijdsverlies, dat bij de totstandkoming van wettelijke regeling op sociaal terrein onherroepelijk voortvloeide uit de advisering door dit orgaan, was groot ${ }^{228}$. Hervorming van dit orgaan achtte Plate langzamerhand nodig, waarbij hij wees op de evolutionaire ontwikkeling die in de richting ging van een zeker beslissingsrecht van de Hoge Raad van Arbeid zelf met een ontlasting van het parlement van de behandeling. In dit verband werd ook gewezen op de sociale wetgeving en wel op dat gedeelte dat meer speciaal van belang was voor groepen werkgevers en arbeiders, die erbij betrokken waren en waarbij motieven van algemeen belang geen rol speelden. Ook de Economische Raad werkte soms vertragend bij de afhandeling van verschillende, van regeringszijde te nemen economische maatregelen. Dit bedoelde hij opnieuw niet als verwijt, maar als een opmerking over het mechanisme van ons regeersysteem, waarin deze Raad een schakel was geworden. In een tijd die gekenmerkt werd door snelle ontwikkelingen, vooral ook met het oog op het werkloosheidsvraagstuk, was het tijdig treffen van bepaalde economische maatregelen van regeringszijde van zeer groot belang. Voorbereiding hiervan nam (veel) tijd in beslag; reden te meer om de benodigde tijd niet meer te verlengen dan strikt noodzakelijk was. Elk nieuw ingeschakeld adviesorgaan kostte alleen maar meer tijd, waardoor de snelheid van het handelen van regeringszijde geen gelijke tred kon houden met de al maar sneller gaande maatschappelijke ontwikkelingen. Plate opperde dan ook de gedachte om noodzakelijk geworden nieuwe organen binnen beperkt terrein beslissende bevoegdheden toe te kennen met gelijktijdige onttrekking van die bevoegdheden aan stroever werkende organen, aan welke deze tot dan toe waren toegekend.

Verdere uitbreiding van ambtelijke bemoeienis met het bedrijfsleven kan alleen dan worden voorkomen, als het bedrijfsleven zelf initiatieven nam. Vele van de maatregelen op economisch terrein en sommige op sociaal terrein waren door de regering uitgevaardigd, als gevolg van drang uit de kringen van het bedrijfsleven zelf, met als gevolg ambtelijke invloed op menig gebied. Dit kon, aldus de spreker, alleen worden beperkt wanneer het bedrijfsleven zelf de taak van de ambtelijke bureaus overnam. Zo zag hij niet in waarom bijvoorbeeld de Veiligheidswet en een belangrijk deel van de Arbeidswet 1919 niet even goed of beter zouden kunnen worden uitgevoerd door paritair, uit werkgevers- en werknemersvertegenwoordigers samengestelde bedrijfscommissies. De taak van de ambtenaren, in veel geringer aantal dan tot nu toe, van de arbeidsinspectie zou dan beperkt kunnen worden tot beroepsinstantie, maar het merendeel van de beslissingen zou buiten hen om genomen kunnen worden. De bedoeling van een dergelijke operatie:

"Uitgaven zouden zoodoende bespaard kunnen worden".

Voor zijn suggestie verwees Plate naar de ervaringen met de bedrijfsverenigingen, die goed functionerende instituten bleken te zijn ${ }^{227}$. Als reactie daarop kan worden gezegd, dat deze suggestie op het eerste gezicht sympathiek overkomt. Zij lijkt, gezien het eerder door de spreker gestelde, min of meer gebaseerd te zijn op de gedachte, dat alleen werkgevers- en arbeidersbelangen in het geding zijn en niet het algemeen belang. De totstandkoming van onder meer de Arbeidswet 1919 en de gedachten die daaraan ten grondslag liggen, wijzen echter in een andere richting.

Bovendien blijft het nog maar de vraag of een organisatie als een bedrijfsvereniging sneller en efficiënter zou kunnen werken, gezien juist de grote, bijvoorbeeld financiële en economische belangen die bij de arbeidersbeschermende wetgeving (kunnen) spelen. Voorts kan men zich afvragen of de vereiste deskundigheid bij- 
voorbeeld op het terrein wan de veiligheidswetgeving wel aanwezig is bij de bedrijfsverenigingen en kan men zich afvragen of dan ook niet bureaucratisering optreedt.

\section{Bijzondere opdrachten}

Ook in deze periode blijkt uit de zogenaamde bijzondere opdrachten weer hoe veelzijdig de activiteiten van de arbeidsinspectie ten aanzien van het maatschappelijk leven waren. Naast het lidmaatschap van de Hooge Raad van Arbeid met diverse subcommissies was de directeur-generaal van de Arbeid lid van de volgende commissies of verenigingen waarbij men zich moet realiseren dat dit slechts een greep uit het vele is: de centrale commissie voor de statistiek (evenals de inspectrice van de Arbeid, mevrouw E. Kleerekoper), met verschillende subcommissies, de centrale reorganisatiecommissie, de commissie van deskundigen inzake het nijverheidsonderwijs, de rijkscommissie voor werkwerruiming, de commissie van toezicht op het rijksinstituut voor zuivering van afvalwater (waarvan het directeurschap toebedeeld was aan de scheikundig adviseur bij de arbeidsinspectie), het bestuur van het Veiligheidsmuseum (waarvan het directeurschap alsook het secretariaat aan de arbeidsinspectie waren toebedeeld), het Carnegie-Heldenfonds, de centrale gezondheidsraad met sub-commissies (te zamen met de medisch adviseur bij de arbeidsinspectie), de Nederlandse Vereeniging tot bevordering van den arbeid van onvolwaardige arbeidskrachten, de raad van toezicht op den electrotechnischen keuringsdienst, het instituut voor preventileve geneeskunde (tezamen met de medisch adviseur bij de arbeidsinspectie), het Nederlandsch instituut voor lifttechniek (tezamen met de elektrotechnisch adviseur bij de arbeidsinspectie), de economischen raad, de vereeniging "Nederlandsch Fabrikaat", de raad van advies van het Nederlands instituut voor efficiency, de nijverheidsorganisatie voor toegepast natuurwetenschappelijk onderzoek, de rijkscommissie van advies inzake het vraagstuk van de jeugdwerkloosheid, de rijkscommissie van advies inzake verlaging kosten van het noodzakelijk levensonderhoud, het Werkfonds 1934, de interdepartementale commissie van advies inzake aangelegenheden die het Werkfonds en de werkverschaffing betreffen, de werkcommissie tot bestrijding van de werkloosheid en de interdepartementale commissie inzake economische verdedigingsvoorbereiding ${ }^{228}$.

Op 8 oktober 1931 kreeg de directeur-generaal van de Arbeid van de verantwoordelijke bewindsman schriftelijk opdracht om op korte termijn een administratief onderzoek in te stellen naar de bedrijfstoestanden in de verschillende industrieën om zodoende na te gaan, in hoeverre de crisisinvloed zich in het bedrijfsleven deed gelden ${ }^{22 \theta}$. Dit administratieve onderzoek gebeurde door het aan de hoofden van de industriële bedrijven; die normaal ten minste tien arbeiders plegen te hebben, een beknopte vragenlijst toe te zenden. Er werden op 14 oktober van dat jaar 8706 circulaires met een vragenlijst door de districtshoofden van de arbeidsinspectie verzonden ${ }^{230}$. Aan verschillende centrale werkgeversorganisaties werd medewerking gevraagd en verleend om de spoedige en volledige invulling van de vragenlijsten bij hun leden te bevorderen. Alls termijn voor terugzending was 21 oktober gestell, maar op de genoemde datum was nog slechts iets meer dan de helft van de vragenlijst ingevuld terug ontvangen. Het bleek noodzakelijk de betrokkenen schriftellijk, telefonisch of door persoonlijk bezoek aan de inzending te herinneren. Uiteindelijk werden er 7324 ingevuld vragenlijsten ontvangen en verwerkt. Verschillende ondernemers gaven te kennen, dat men het nut van dergelijke onderzoekingen niet inzag, anderen weigerden dun medewerking op grond van het feit, dat al langs andere weg dergelijke gegevens gevraagd waren ${ }^{231}$, weer een ander was gekrenkt, doordat de toon van de circulaire door hem

"te autoritair en te weinig vriendelijk"

werd geacht, en weer anderen oordeelden een onderzoek, dat rentabiliteit van de ondernemingen buiten beschouwing liet, zinloos. Over het algemeen, aldus de directeur-generaal van de Arbeid, bestond de indruk, dat de betrokkenen slechts traag aan dit onderzoek had willen medewerken. Dit bleek ook uit de wijze waarop de vragenlijst werd beantwoord, terwijl de inhoud daarvan juist beknopt was gehouden, om de administratieve belasting zo beperkt mogelijk te doen zijn. Het onderzoek beoogde slechts de verschaffing van 4 gegevens: 
1. de personeelsbezetting op 3 data, namelijk 1 oktober 1929,10 oktober 1930 en 1 oktober 1931, zonder uitsplitsing naar leeftijd of sekse en alleen onderscheiden in werkplaats- en beambtenperosneel;

2. de wijzigingen in de lonen en salarissen na 1 januari 1931, slechts aan te geven door in procenten verhoogd of verlaagd;

3. de werktijd per week, die op 1 oktober 1931 werd gevolgd;

4. de vermelding van eventuele crisismaatregelen of eventuele opmerkingen die men wenste te maken.

De antwoorden waren vaak dermate onvolledig ingevuld, dat herhaaldelijk navraag noodzakelijk was; het aantal ondernemers, die naast de verstrekking van cijfermatig materiaal, de waarde van hun inzending verhoogden door uitvoerige, zakelijke opmerkingen, was gering, aldus de directeur-generaal van de Arbeid.

Het beeld dat uit het onderzoek naar voren komt is als volgt. In de periode van 2 jaren was de totale personeelsbezetting van 664177 teruggelopen naar 570796 personen, ofwel een achteruitgang met 93381 of circa $14 \%$. Het zwaarst getroffen was de metaalindustrie, waar de bezetting daalde met 52307 personen. De gevolgde werktijd bleek in circa $84 \%$ normaal en in circa $16 \%$ (soms belangrijk) verkort: Lonen en salarissen gaf een zeer gevraieerd beeld, naast verlaging, kwam ook verhoging voor, terwijl in veel gevallen sprake was van een ongewijzigd loon of salaris. De directeur-generaal van de Arbeid maakte nog de kanttekening, dat sinds 1 oktober van het bedoelde jaar de situatie zich nog zeer sterk in negatieve zin had gewijzigd en dat tal van fabrikanten met grote zorg de toekomst tegemoet zagen; wijzigingen die bijna uitsluitend de uitvoer van goederen betroffen ${ }^{232}$.

Evenals in de vorige periode het geval was bewoog een niet onbelangrijk deel van deze bijzondere bemoeienissen van de arbeidsinspectie zich op het terrein van de werkloosheidsbestrijding en de werkverschaffing. In het vorige hoofdstuk was reeds vastgesteld, dat de commissie van advies voor de werkloozensteun - de commissie Zaalberg - in tegenstelling tot de rijkscommissie voor werkverruiming een actiever, centraal geleid economisch beleid categorisch afwees.

Wat nodig was, was inkrimping en versobering van de staatsdienst. Maar een ander economisch beleid ontstond sluipend op basis van het nieuw opgezette ambtelijke apparaat, met de instelling van het nieuwe ministerie van Economische Zaken en Arbeid op $1 \mathrm{mei} 1932$ als economische potentaat waarom gevraagd was $^{233}$ "Het liberale principe was in zoverre losgelaten, dat de regering zich bereid toonde om hulp te bieden, waar dit op grond van de omstandigheden geboden scheen, maar zo stelde Keesing ${ }^{234}$, er bestond geen enkel beginsel dat aan de overheidspolitiek stelselmatigheid verleende. Het ingrijpen was zuiver incidenteel en werd volledig gedicteerd door de loop der gebeurtenissen; de methoden van steunverlening liepen sterk uiteen, terwijl de aard van de geboden hulp door betrekkelijk toevallige overwegingen werd bepaald. De overheidsinterventie was repressief en niet gericht op het wegnemen van de kwaal; de regering constateerde dat de omstandigheden op één of ander gebied een noodtoestand hadden doen ontstaan waarop vervolgens pijnstillende maatregelen werden genomen, door middel van de zogenaamde crisiswetgeving, zoals de Crisiszuivelwet en de Landbouwcrisiswet. Maar hij voegde daar aan toe, dat betwijfeld moet worden of in de eerste fase van de depressie, waarin door oorzaken buiten onze grenzen en derhalve niet voor Nederlandse beïnvloeding vatbaar, de economische afbraak onafwendbaar overschreden werd, zij principieel anders had kunnen handelen. Bovendien werd pas geleidelijk de omvang van de crisis duidelijk.

Zo gaf de minister van Arbeid, Handel en Nijverheid Verschuur eerst op 8 oktober $1931^{235}$ de directeurgeneraal van de Arbeid Zaalberg opdracht om ( op korte termijn) een onderzoek in te stellen naar de bedrijfstoestanden in de verschillende industrieën teneinde te kunnen nagaan in hoeverre de crisisinvloed zich in het bedrijfsleven deed gelden ${ }^{236}$.

De directeur-generaal van de Arbeid Zaalberg trad het nieuwe actieve beleid kritisch tegemoet, hetgeen blijkt wit het feit, dat hij al begin 1931 als voorzitter van de naar hem genoemde commissie aan de ministerpresident een uitvoerige brief schreef waarin hij namens de meerderheid van de commissie klaagde, dat zij inzake het nieuwe actieve landbouwbeleid was gepasseerd, terwijl de commissie haar taak toch altijd ruim had opgevat. Vooral de als ingrijpend beschouwde Tarwewet maakte dat Zaalberg moest constateren, dat de eerdere door de commissie uitgebrachte adviezen gebaseerd waren op economische opvattingen die haaks 
stonden tegenover die welke aan de Tarwewet ten grondslag lagen ${ }^{237}$. Daarop werd besloten, dat de commissie-Zaalberg haar taken zou behouden, maar voorlopig alleen de landbouwcrisismaatregelen niet zou behandelen ${ }^{23 e}$.

Na het terugtreden van Zaalberg als directeur-generaal van de Arbeid in 1932, kennelijk wegens onmin met zijn minister, raakte de eens zo machtige commissie-werklozensteun wat in de versukkeling ${ }^{239}$.

De meeste betrokken ambtenaren, die in de commissie-Zaalberg een in hun ogen uiterst nuttig interdepartementaal overlegpunt hadden, waren hier niet gelukkig mee. Nadat in de zomer van 1933 het departementsonderdeel Arbeid was afgescheiden van Economische Zaken en werd ondergebracht bij Sociale Zaken, werd aan hun wensen gevolg gegeven en zou de commissie-Zaalberg nieuw leven ingeblazen worden. Dit gebeurde door het op 5 juli van dat jaar instellen van de interdepartementale commissie werkloosheidszorg onder voorzitterschap van de nieuwe directeur-generaal van de Arbeid A.H.W. Hacke, ook wel de commissie- Hacke of commissie-" $\mathrm{H}^{\mathrm{n} 240}$ genoemd, die tot taak had door interdepartementaal overleg de totstandkoming voor te bereiden van besluiten met betrekking tot het voorkomen en bestrijden van werkloosheid ${ }^{24 \|}$. De commissie ging woortvarend aan het werk. In september 1933 werd een advies uitgebracht met algemene richtlijnen voor de voorkoming en bestrijding van de werkloosheid ${ }^{242}$, waarop in januari 1934 een meer gedetailleerd advies volgde op dezelfde basis als dit eerste advies ${ }^{243}$. Terwille van het gezond maken van de economie werd een "verlaging van het levensniveau in Nederland" voorgesteld ${ }^{244}$.

De hiervoor al gememoreerde wijziging in de economische politiek van de overheid kan geillustreerd worden met een citaat uit de regeringsverklaring van 31 mei $1933^{245}$ :

"Om herstel van de welvaart voor te bereiden, zal ordening van het bedrijfsleven, tot aan-

passing aan de gewijzigde economische wereldstructuur, van overheidswege moeten worden

bevorderd".

In de troonrede van september $1933^{246}$ volgde daarop de aankondiging, dat, zodra de begroting in evenwicht was gebracht, op grote schaal produktieve werken in het kader van de werkverruiming uitgevoerd zouden worden. Hoewel de begroting tot de Tweede Wereldoorlog nooit in evenwicht is gekomen, werd in maart 1934 een wetsvoorstel bij de Tweede Kamer ingediend waarbij voor deze "werkverruiming" een apart fonds werd opgericht, dat gevoed zou worden met zestig milljoen gulden ${ }^{247}$. De bedoeling was enerzijds de economie te ondersteunen met behulp van aanzienlijke investeringen zowel in openbare werken als in het bedrijfsleven, terwijl anderzijds het fonds zou moeten dienen als stimulans voor loonsverlagingen in het vrije bedrijf ${ }^{248}$.

De bestuursstructuur die Zaalberg het zogenaamde Werkfonds 1934 had gegeven, was buitengewoon omslachtig. Algemeen voorzitter was de minister-president. Hij presideerde de ministeriële commissie voor het Werkfonds 1934 waarin als leden zitting hadden de ministers van Waterstaat, Economische Zaken, Sociale Zaken, Binnenlandse Zaken en Financiën. Deze commissie besliste welke objecten al dan niet uitgevoerd konden worden als Werkfondsobject. Bij de instelling werd Zaalberg tot voorzitter van het bestuur ${ }^{248}$ benoemd. Hij zou deze functie tot 29 juli 1934 bekleden, om opgevolgd te worden tot 25 september van dat jaar door de directeur-generaal van de Arbeid Hacke, die op zajn beurt tot 1 mei 1935 zou worden opgevolgd door Beyen, directeur van de Rotterdamse Bankvereniging. Sindsdien werd er geen voorzitter meer benoemd. Algemeen secretaris was de directeur-generaal van de Arbeid, die tevens ondervoorzitter was tot de opheffing van het Werkfonds 1934. Over de rol van de directeur-generaal van de Arbeid zei Zaalberg tijdens de installatie van het Werkfonds $1934^{250}$.

"... Wij verheugen er ons in, dat een belangrijke plaats in dit nieuwe orgaan van samenwerking tusschen Regeering en burgerij is toevertrouwd aan den heer Hacke, die als Hoofd der Arbeidsinspectie en als voorzitter eener krachtig werkende interdepartementale commissie een gids en een verbindingsschakel zal zijn, waarvan wij groote steun verwachten...". Daarnaast bestond er een raad van bijstand en advies die uit 34 personen bestond ${ }^{251}$ die een keur van belangen en richtingen vertegenwoordigden.

Uit het Bestuur en de raad van bijstand en advies vormden zich binnen enkele maanden een aantal subcommissies: de looncommissie, die tot taak kreeg onderhandelingen met werkgevers en arbeiders te voeren; een 
industriële commissie, die zich bezighield met het terrein van de industriële projecten, in casu de industriefinanciering en een commissie inzake de bouw van volkswoningen.

Het bureau van het Werkfonds 1934 had vanaf de oprichting onder leiding gestaan van de algemeen secretaris Hacke, de directeur-generaal van de Arbeid. Uit kostenbesparende overwegingen was het secretariaat gevestigd in het gebouw van de centrale dienst van de arbeidsinspectie. De arbeidsinspectie verrichte tal van onderzoekingen ten behoeve van het Werkfonds $1934^{252}$.

Op 12 juli 1935 werd al een grondige reorganisatie van het Werkfonds in het vooruitzicht gesteld. Een scherpe scheiding tussen openbare werken en steunverlening aan de industrie werd gemaakt; de eerste categorie zou onder het ministerie van Waterstaat ressorteren, de tweede onder het ministerie van Economische Zaken. Als overkoeperlend orgaan bleef de ministerieële commissie gehandhaafd. Het bestuur van het Werkfonds bleef bestaan als adviesorgaan, zij het dat die taak nog nader uitgewerkt moest worden. Vooral Drees maakte zich tolk van de teleurstelling over de reorganisatie, waarbij hij echter wel uitvoerig zijn waardering uitsprak over het werk dat de directeur-generaal van de Arbeid met zijn kleine Werkfondsbureau had verricht. Twee weken later kwam de minister van Waterstaat de reorganisatie nog eens toelichten, waarna het bijna een jaar zou duren voordat het Bestuur opnieuw bijeen geroepen werd. Alleen de looncommissie functioneerde nog, als een soort dagelijks bestuur.

Uiteindelijk zou de algemeen secretaris van het Werkfonds 1934, de directeur-generaal van de Arbeid, officieel op 1 juni 1939 de zaken overdragen aan de in april van dat jaar opgerichte Rijksdienst voor de Werkverruiming. Met deze rijksdienst werd door de arbeidsinspectie een regeling getroffen, dat de beslissing omtrent de toepassing van alle materialen en/of onderdellen van buitenlandse herkomst werd overgelaten aan de directeur-generaal van de Arbeid ${ }^{253}$. De rijksdienst voor de werkverruiming zou in 1948 vervangen worden door de Rijksdienst voor de Uitvoering van Werken ${ }^{254}$.

In het begin van de jaren dertig werd van verschillende zijden waaronder de vakbeweging ${ }^{255}$ voortdurend actie gevoerd om de 40 -urige werkweek in te voeren. Butler ${ }^{256}$ zou in 1937 opmerken dat de gedachte van de 40-urige werkweek in de voorafgaande jaren niet was voortgekomen uit een verlangen naar meer uren rust. De voorstanders van deze maatregel beschouwden dit als een middel om de verminderde hoeveelheid arbeid over een groot aantal personen te verdelen.

Nadat op 18 oktober 1932 een aantal leden ${ }^{257}$ bij de voorzitter van de Hooge Raad van Arbeid een voorstel daartoe had ingediend, werd op 28 december van dat jaar een commissie ingesteld ${ }^{258}$,

"welke aan den Raad pre-advies zal uitbrengen omtrent de vraag, of het al dan niet noodig of gewenscht is, ter beperking van de crisiswerkloosheid tijdelijke wettelijke maatregelen te nemen, welke kunnen leiden tot verkorting van den arbeidsduur, en eventueel daartoe strekkende voorstellen te doen".

Ten aanzien van de te volgen procedure werd door deze commissie in haar eerste vergadering besloten, dat wegens het haar ontbreken van de benodigde gegevens door de arbeidsinspectie een uitgebreide enquête zou worden gehouden in door haar aan te wijzen bedrijfstakken. In verband hiermee zouden na overleg met werkgevers- en werknemersorganisaties uit de betrokken bedrijfstakken uiteindelijk een drietal vragenlijsten door de commissie worden opgesteld, respectievelijk voor de industriële bedrijven, voor de landbouw en voor de kantoren. De ontvangen vragenlijsten werden in handen gesteld van de arbeidsinspectie, die verder de enquête uitvoerde. Daartoe werden in de 10 districten in elk van de uitgekozen bedrijfstakken een aantal grote, middelgrote en kleine ondernemingen aangewezen, waaraan een vragenlijst zou worden toegezonden. In totaal werden \pm 3.000 ondernemingen bij de enquête betrokken. Voor de landbouw werd een enigszins andere wijze van enquêteren gehanteerd, in die zin, dat de gewestelijke organisaties in ruime mate hebben bijgedragen tot de verspreiding van de vragenlijsten onder haar leden. De bedrijfsgewijze rapporten van de enquête werden door de arbeidsinspectie aan de Hooge Raad overgelegd, in sommige gevallen vergezeld door een samenvattende nota van de betrokken rapporteurs van de arbeidsinspectie. In de bijlagen van het op 27 mei 1933 rapport van de Hooge Raad in deze was een samenvatting van het aldus binnengekomen materiaal verwerkt, waardoor een indruk verkregen kan worden van de waardevolle medewerking die door de 
arbeidsinspectie was verleend $\mathrm{d}^{259}$.

Ten aanzien van de praktische betekenis van de 40-urige werkweek als middel om de werkloosheid als gevolg van de crisis te beperken, merkte de Hooge $\operatorname{Raad}^{260}$ op, dat arbeidstijdverkorting in dit kader geen overdreven verwachtingen mocht wekken ${ }^{281}$.

"Niettemin is de werkloosheid, zoals wij die thans kennen, uit velerlei oogpunt zo"n grote ramp, dat niets verzuimd mag worden wat tot vermindering van de ellende kan bijdragen. In het bijzonder zal hier ook gedacht moeten worden aan tewerkstelling van jeugdige arbeiders, waardoor als bijkomstig voordeel wordt verkregen dat de vakbekwaamheid weder wordt opgevoerd, hetgeen zowel in het algemeen maatschappelijk belang als in dat der ondernemingen is.":

Ten aanzien van de aard van de te treffen regeling en de rol van de arbeidsinspectie daarin, maakte de Hooge Raad kenbaar, dat een algemeen via de Arbeidswet 1919 te realiseren, wettelijk verplichte regeling in grote meerderheid werd afgewezen ${ }^{202}$. Dat betekende echter niet, dat voor de overheid in deze geen taak was toebedeeld en zich van het nemen van maatregelen zou hebben te onthouden. Die maatregelen zouden een bedrijfstaksgewijs karakter moeten hebben ${ }^{263}$. De taak van de overheid in deze was het bevorderen van het tot stand komen van vrijwillige regelingen, door middel van een stimulerende invloed op het overleg van de sociale partners uit te oefenen, via bijvoorbeeld het toekennen van geldelijke steun van overheidszijde. Mocht er ondanks de stimulerende functie van de overheid geen vrijwillige regeling tot stand komen, dan rechtvaardigde het algemeen belang dat de overheid de betrokken bedrijfstak de arbeidstijdverkorting dwingend oplegde, middels een tijdelijke machtigingswet in het kader van de Arbeidswet 1919 waarbij de minister van Economische Zaken en Arbeid bevoegdheden diende te worden toegekend, zij het met de nodige waarborgen, zoals het verplicht stellen van overleg met de betrokken werkgevers- en arbeidersorganisaties c.q. de bedrijfsraad, naast het inwinnen van advies van een commissie uit de Hooge $\mathbf{R a a d}^{264}$. Ten aanzien van de relatie tussen het verkorten van de arbeidstijd en het verlenen van overwerkvergunningen was men in meerderheid van oordeel, dat het beleid van de arbeidsinspectie in deze waarbij bij het verlenen van overwerkvergunningen een grote terughoudendheid betracht werd, voortgezet diende te worden ${ }^{285}$. In zijn advies stelde de Hooge Raad van Arbeid aangaande de principiële kwestie ten aanzien van de rol van de overheid het volgende ${ }^{268}$ :

"De Raad is er zich van bewust, dat, indien hij ten slotte Uwe Excellentie adviseert tot het treffen van een wettelijken maatregel, welke het opleggen van een verkorten arbeidstijd aan bepaalde bedrijfstakken zal mogelijk maken, hiermee over een bezwaar wordt heengestapt, dat voor sommigen principieel is en hetwelk tegen een gedwongen 40-urige werkweek zou kunnen worden opgeworpen. Men zou zich namelijk kunnen afvragen, of een dergelijke inbreuk op de persoonlijke vrijheid van den individueelen arbeider nog wel geoorloofd is, nu het immers niet gaat om arbeidersbescherming in engeren zin, doch uitsluitend om het tewerkstellen van werklooze arbeiders. Wat zou de rechtsgrond voor de Overheid zijn in een dergelijk gevall? Betreedt zij hier niet een terrein waarvan zij verre behoorde te blijven, aangezien het uitsluitend van de betrokkenen behoort af te hangen of zij al of niet korter zullen werken dan een algemeen als "mormaal" erkende diensttijd meebrengt?".

Voor deze bezwaren van principiële aard mocht, aldus een meerderheid van de Hooge Raad van Arbeid, niet op zij gegaan worden, daar het algemeen belang bij cen vermindering van de heersende werkloosheid zodanig in het geding was, dat de overheid eventueel dwingend de 40 -urige werkweek zou kunnen opleg$\operatorname{gen}^{267}$

Nadat in februari 1936 door een aantal leden, waaronder Kupers een verzoek aan de voorzitter van de Hooge Raad van Arbeid was gericht om te willen nagaan of er aanleiding zou kunnen bestaan om de vraag te onderzoeken, of Nederland met een omvangrijke blijvende werkloosheid rekening diende te houden en zo ja, hoe groot de vermoedelijke omvang hiervan zou zijn, werd op 6 maart 1936 besloten over de mogelijkheid en de kosten van het voorgestelde onderzoek advies in te winnen bij de directeurgeneraal van het Cen- 
traal Bureau voor de Statistiek en de directeur-generaal van de Arbeid.

Uiteindelijk zou bij beschikking van 18 december 1936 een studiecommissie ${ }^{269}$ met de uit het onderzoek voortvloeiende arbeid belast worden ${ }^{269}$. Teneinde de benodigde financiële middelen van dit onderzoek te verkrijgen wendde de voorzitter van de Hooge Raad van Arbeid zich tot de regering. Een schriftelijke reactie van 19 maart 1937 van de ministers van Sociale Zaken, Handel, Nijverheid en Scheepvaart en Landbouw en Visserij gaf blijk van instemming met het ingestelde onderzoek, maar wel werd gesteld dat bij het onderzoek gebruik gemaakt diende te worden van de hulp van de ambtenaren van de industrie-documentatie van de afdeling nijverheid van de directie van handel en nijverheid. Eén en ander leidde ertoe, dat het onderzoek naar de arbeidsproduktiviteit verricht werd door samenwerking van het Centraal Bureau voor de Statistiek, de centrale dienst van de arbeidsinspectie, de directie van Handel en Nijverheid, de directie van de Landbouw en de afdeling Statistiek van het Landbouw-crisis-bureau ${ }^{270}$.

Als voorbeelden van de middelen, die de commissie aanbeval, kunnen genoemd worden de arbeidsspreiding in industrie, handel en verkeer door de 40-urige werkweek als crisismaatregel voor tu schrijwen en het verhogen van de minimum leeftijd met 2 jaren, waarop jeugdigen mogen worden toegelaten tot het arbeidspro$\operatorname{ces}^{271}$.

Uit met name dit onderdeel bijzondere opdrachten blijkt, dat de positie van de arbeidsinspectie op het sociaal-economische terrein veranderde. De directeur-generaal van de Arbeid Hacke als opvolger van Zaalberg zag alle traditionele bemoeiïngen van zijn dienst ondergraven worden door de reorganisatie van de overheid en de daarmee gepaard gaande uitbreiding als gevolg van de toenemende overheidsbemoeienis op het sociaal-economisch leven; denk daarbij aan het ministerie van Economische Zaken en de haar toebedeelde taken. De $\mathrm{Hen}^{272}$ geeft een voorbeeld van een typerend incident uit de tweede helft van de dertiger jaren. Eind 1936 organiseerde de arbeidsinspectie een produkten-enquête, waar de afdeling Handel en Nijverheid van het ministerie van Economische Zaken niets van afwist. Toen de betrokken directeur-generaal daarvan hoogte kreeg, volgde een officieel protest in de richting van de directeur-generaal van de Arbeid ${ }^{273}$.

\section{Werkzaamheden ten behoeve van defensie-doeleinden}

Tot slot moet nog enige aandacht besteed worden aan de werkzaamheden van de arbeidsinspectie ten behoeve van defensiedoeleinden. Dit betrof niet alleen een zeer groot aantal verlofaanvragen van militairen, die onderzocht werden, maar ook een onderzoek dat werd ingesteld naar de outillage, de capaciteit en de personeelscijfers van bedrijven, die zich toelegden op het vervaardigen van herenboven- en/of bedrijfskleding. Bovendien werden gegevens verzameld van firma"s, die in aanmerking kwamen voor opdrachten tot het vervaardigen van militaire hemden; hierbij werd nagegaan wat de omvang van de fabriekscapaciteit bij een normale werkweek was ${ }^{274}$.

Voorts wil ik nog de aandacht op het volgende vestigen. In april 1939 werden door de minister van Defensie in samenwerking met zijn ambtgenoot van Sociale Zaken maatregellen genomen voor het vervangen van onder de wapenen geroepen dienstplichtigen door dienstplichtige werklozen.

Deze regeling beoogde te bewerkstelligen, dat het bedrijfsleven zoveel mogelijk zijn taak ongehinderd kon voortzetten en de vrijstelling van militaire dienst te bepalen tot diegenen, die een eigen zaak hadden en tot de vakbekwame arbeiders, die moeilijk gemist konden worden. Ter uitvoering van deze regeling werd aan het ministerie van Defensie een aparte afdeling opgericht, namelijk het Bureau vervanging personeel B.O.U.V., waarvoor de arbeidsinspectie als administratie optrad. Het genoemde bureau zou echter slechts zeer korte tijd bestaan; als gevolg van de algemene mobilisatie kwam aan de uitwisseling van dienstplichtigen een einde en werd het bureau op 6 september 1937 opgeheven. De arbeidsinspectie zou echter ook na de mobilisatie belast blijven met het uitbrengen van advies omtrent de aanvragen om toekenning van verlof uit de militaire dienst ( de zogenaamde zakenverloven). Dat bracht nogal wat werk met zich; in de periode van 25 oktober tot en met 31 december 1939 werden in totaal 6.351 verzoeken om zakenverlof, nagenoeg zonder 
uitzondering, ter plaatse onderzochit.

Als gevolg van de mobilisatie werden van de zijde van het ministerie van Defensie grote opdrachten verstrekt aan het Nederlandse bedrijfsleven, waarbij niet altijd rekening werd gehouden met de capaciteit van de betrokken ondernemingen. Dit had tot gevolg, dat er in die bedrijven een noodzaak ontstond om overwerk te verrichten, terwijl dit vermeden kon worden, wanneer de opdrachten verdeeld werden over meerdere bedrijven, die evenzeer in staat waren deze uit te voeren.

Deze situatie leidde tot samenwerking tussen de arbeidsinspectie en het centraal orgaan voorziening weermacht van het ministerie van Defensie, hetgeen resulteerde in een zo groot mogelijke spreiding van opdrachten daar waar dit mogelijk was ${ }^{275}$. 
noten

1. J.K. Galbraith noemt die 29ste oktober 1929 "de meest verwoestende dag in de historie van de Newyorkse effectenbeurs" ( De krach van "29, Amsterdam 2e druk 1967, aangehaald door J. Beishuizen/E. Werkman, De magere jaren, Nederland in de crisistijd 1929 - 1939, Leiden 2e druk 1967, blz. 18 ).

2. Het jaargemiddelde der werkloosheidsdagen bedroeg in $193115,2 \%$, in $193226,9 \%$ en bleef stijgen tot in 1935 en 1936 resp. $31,7 \%$ en 32,7\%; zie M.G. Levenbach, Arbeid, in Nederlands bestuursrecht, blz. 459 -460 .

3. In 1937 en 1938 bedroeg het werkloosheidsgemiddelde resp. $26,9 \%$ en pas in 1939 zou dit tot $19,9 \%$ dalen; zie M.G. Levenbach, Arbeid, in Nederlands bestuursrecht, blz. 460.

4. Resp. Wet van 21 februari 1931, Stb. 65, Wet van 10 juni 1932, Stb. 290 , Wet van 17 juni 1932, Stb. 301 en de Wet van 25 juli 1932, Stb. 374. Zie F.A.G. Keesing, t.a.p., blz. $151 \mathrm{t} / \mathrm{m} \mathrm{154;} \mathrm{I.G.} \mathrm{Brugmans,}$ Paardenkracht en mensenmacht, blz. 519 - 570.

Zie voor commentaar op bet genoemde werk van Keesing; P.W. Klein, Depressie en beleid tijdens de jaren dertig, in Lof der Historie; opstellen over geschiedenis en maatschappij, Rotterdam 1973, blz. 287 t/m 335; zie ook F. Becker/G.J. van Oenen, De economische politiek van de jaren dertig, in Tijdschrift van politieke economie 1978, blz. $115 \mathrm{t} / \mathrm{m} 127$.

5. Wet van 5 mei 1933, Stb. 261. Zie hierover onder meer F.A.G. Keesing, t.a.p., blz. 186 t/m 188; I.J. Brugmans, Paardenkracht en mensenmacht, blz. 50 - 52.

6. Resp. de Wet van 23 december 1931, Stb. 535, de Wet van 24 december 1931, Stb. 553 en de Wet van 1934, Stb. 26. Zie hierover onder meer F.A.G. Keesing, t.a.p., blz. 154 - 155; I.J. Brugmans, Paardenkracht en mensenmacht, blz. 522 - 525 .

7. Resp. de Wet van 24 mei 1935, Stb. 310, Besluit van 5 november 1941, Verordeningenblad 1941/46 ( 10 november 1941 ), de Wet van 28 juni 1956, Stb. 401, en de Wet van 20 mei 1938, Stb. 619. Zie M.G. Levenbach, Arbeid, in Nederlands bestuursrecht, blz. 460 .

Zie over deze periode naast de reeds genoemde literatuur onder meer: A.J.M. Rövenkamp, Amsterdam in bewogen jaren, Herinneringen van een wetsbemiddelaar 1925 - 1956, Amsterdam 1978; P. Posthumus/H. van de Wetering, Harde guldens, Harde tijden, beeld van de Jordaanoproer 1934, Amsterdam; W. Krelich, Jordaners op de barricaden, Het oproer van 1934, Zutphen (z.j. ); C, Cillekens/W. Roebroeks, Krisis in Maastricht, werk en werkloosheid in de jaren dertig, Maastricht (z.j. ); M. Schouten, Voor de oorlog, herinneringen aan de jaren '30, Leiden 1982 ( 2 dln. ); J.H.M. Bakker/E. Nijhof, Het "Jordaan-oproer" - verzet tegen de steunverlaging in juli 1934, in TvSG 1978, blz. $35 \mathrm{t} / \mathrm{m}$ 69; E. Nijhof/P. Schrage/M. Sturkenboom, "De geesel van onzen tijd", een onderzoek naar werklozenbeleid en werkloosheidsbeleving in de jaren dertig te Utrecht, Leiden 1983.

8. Resp. Wet van 29 november 1930, Stb. 460, Wet van 13 september 1935, Stb. 564, Wet van 23 april 1936, Stb. 202, en Wet van 13 maart 1937, Stb. 619.

9. Besluit van 29 oktober 1931 , no. 21 . 
10. Naast de al genoemde Ch.J.I.M. Welter en C.J.P. Zaalberg waren lid van deze commissie: L.A. van Royen ( hoogleraar aan de Technische Hogeschool te Wassenaar), Is.P. de Vooys (directeur van de Algemeene Kunstzijde Unie te Arnhem), E.P. Wetserveld ( algemeen secretaris van het Koloniaal Instituut te Amsterdam ), F.H. Fentener van Vlissingen (industrieel te Utrecht), W.M. Westerman ( chef van het Kabinet van de burgemeester van "s-Gravenhage), A. van Doorninck (thesauriergeneraal van Financiën ), M.H. Damme ( directeur-generaal van de P.T.T.), J.H.R. Sinninghe Damsté (directeur-generaal der Belastingen), J. Woltman ( secretaris-generaal van het ministerie van Defensie ). Zie het Rapport van de staatscommissie voor de verlaging van de Rijksuitgaven ( hierna Rapport van de commissie-Welter ), 's-Gravenhage 1932, blz. 5 .

11. Rapport van de commissie-Welter, ble. 5 .

12. Rapport van de commissie-Welter, blz. $391 \mathrm{t} / \mathrm{m} 395$.

13. Rapport van de commissie-Welter, blz. 55.

14. Tweede Kamer, zitting 1931 - 1932, no. 2.10 ( Hfdst. X begroting Arbeid, Nijverheid en Handel).

15. De totale bezuiniging voor het betreffende departement bedroeg f. 840.233 ,--; een bezuiniging die door eên Kamerlid onvoldoende werd geacht. Hij was van mening, dat het hele departement overbodig was geworden en dat

"ons volk zich de weelde van sociale voorzorg niet kan veroorloven".

Zie Tweede Kamer, zitting 1931 - 1932, no. 2.7 ( Hfdst. X begroting Arbeid, Nijverheid en Handel) blz. 1.

16. Zie Hand. Tweede Kamer, zitting 1931 - 1932 II, blz. 967 t/m 979 en blz. 1015 t/m 1021; Eerste Kamer, zitting 1931 - 1932, no. 2 ( Tweede Kamer) 82 blz. 1 t/m 5 en Hand. Eerste Kamer, zitting 1931 - 1932 I, blz. $385 \mathrm{t} / \mathrm{m} 413$.

17. Besluit 6 september 1932, tot verdeeling van het Rijk in districten ten behoeve van den dienst der arbeidsinspectie, Stb. 462 .

18. Besluit van 3 september 1928 , Stb. 359.

19. Zie Centraal Verslag der Arbeidsinspectie over 1929, blz. 1.

20. Resp. Besluit van 13 juni 1929, Stb. 313; Besluit van 4 juli 1929, Stb. 380; Besluit van 6 juni 1929, Stb. 306. 21. Met niet tot het gezin van de winkelier behorend personeel; Zie Centraal Verslag der Arbeidsinspectie
over 1930, "s-Gravenhage 1931, blz. 99 .

22. Centraal Verslag der Arbeidsinspectie over 1930, blz. 1, blz. 44 en blz. 99.

23. M.G. Levenbach, Arbeid, in Nederlands bestuursrecht, blz. 463.

24. Bij brief van 20 meï 1930, no. 6637, zond de directeur-generaal van de Arbeid een voorontwerp Werktijdenbesluit voor kantoren met toelichting voor commentaar aan de districtshoofden van de arbeidsinspectie.
Daarbij stelde hij het volgende: "Bij mijn schrijven van 7 januari 1921 , no. 185 , werd $U$ een vroeger ontwerp met toelichting
gezonden, waarop het huidige zich aansluit". 
25. Brief van 9 oktober 1931, no. 10090; Centraal Historisch Archief doss. nr. 1844. De brief was kort en liet aan duidelijkheid niet te wensen over:

"Zijne Excellentie de Minister van Arbeid, Handel en Nijverheid deelt mij mede, dat besloten is, met het oog op den economischen toestand, het Kantorenbesluit voorlopig niet in te voeren en de controleursbenoemingen niet te doen plaats hebben ${ }^{\text {th. }}$

Zie ook Centraal Verslag der Arbeidsinspectie over 1931, 's-Gravenhage 1932, blz. 1.

26. Rapport van de commissie-Welter, blz. $394-395$.

27. Het hoofd van de afdeling. Arbeid J. Westhoff formuleerde het in een nota van 27 juli 1931 aan zijn bewindsman als volgt:

"De bij de begroting voor 1931 toegestane uitbreiding der Arbeidsinspectie met 11 contro" leurs en 11 man administratief personeel, welke gemotiveerd werd "met het oog op de voorgenomen verdere invoering van de A.W. voor kantoren, koffiehuizen en hotels", wordt dan voorts moeilijker te effectueren, als men voorloopig toch niets uitvoert".

Zie ook Centraal Verslag der Arbeidsinspectie over 1931, blz. 1.

28. Zie Besluit van 8 mei 1937 , Stb. 844 .

29. Zie Rusttijdenbesluit voor volwassen koffiehuis- en hotelpersoneel van 7 december 1937, Stb. 863 en Werktijdenbesluit voor jeugdige personen werkzaam in koffiehuizen en hotels van 7 december 1937, Stb. 864.

30. Besluit van 17 november 1932, Stb. 537.

31. Rapport van de commissie-Welter, blz. 392 .

32. Centraal Verslag der Arbeidsinspectie over 1931, over 1932, over 1933, Over 1934, resp. 's-Gravenhage 1932, 1933, 1934 en 1935, resp. blz. 1, blz. 1, blz. 1 en blz. 1.

Zie over de Crisisinvoerwet 1931 onder meer P.E. de Hen, t.a.p. blz. $90 \mathrm{t} / \mathrm{m}$ 102; I.J. Brugmans, Paarden* kracht en mensenmacht, blz. $522 \mathrm{t} / \mathrm{m}$ 524; F.A.G. Keesing, t.a.p. blz. $205 \mathrm{t} / \mathrm{m} 208$.

33. Zie Centraal Verslag der Arbeidsinspectie over 1933, blz. 66.

34. Zie Centraal Verslag der Arbeidsinspectie over 1931, en over 1933, 's-Gravenhage 1934, resp. blz. 12 en blz. 12.

35. Ook het Centraal Verslag zou niet ontkomen aan de bezuinigingen; zo was in het Centraal Verslag over 1931, staat 1a, waarin de gegevens weergegeven zijn omtrent de aanwezige inrichtingen op 31 december 1931 , weggelaten, om in het Centraal Verslag over 1932 overigens weer gepubliceerd te worden, en in het Centraal Verslag over 1933 een aantal gebruikelijke hoofdstukken - "Eenige mededeelingen omtrent arbeidstoestanden in bedrijven, samenhangende met de visscherij" en "Eenige mededeelingen omtrent arbeidstoestanden in de veenderijen" - vervallen.

36. Centraal Verslag der Arbeidsinspectie over 1933, blz. 13. Zie over het bedoelde onderzoek in de andere crisismaatregelen onder bijzondere opdrachten. 
37. Zie Centraal Verslag der Arbeidsinspectie over 1935, over 1936 en over 1939, resp. 's-Gravenhage 1936 , 1937 en 1940, resp. bla. 13, blz. 17 en blz. $20-21$.

38. Centraal Verslag der Arbeidsinspectie over 1936 en over 1937, 's-Gravenhage 1938, resp. blz. 17 - 18 en blz.. 18 .

39. Centraal Verslag der Arbeidsinspectie over 1935 , blz. 1 .

40. Centraal Verslag der Arbeidsinspectie over 1936, blz. 1.

41. Centraal Verslag der Arbeidsinspectie over 1937, blz. 1.

42. Centraal Verslag der Arbeidsinspectie over 1938, blz. 1.

43. Centraal Verslag der Arbeidsinspectie over 1939 , blz. 1. Ten opzichte van het werkloosheidscijfer van augustus 1939, 191308, voor het seizoen gecorrigeerd, gaf dit dus een aanzienlijke stijging te zien.

44. Rede van 8 december 1939 en rede van 26 september 1939: Centraal Historisch Archief doss.nr. 11.

45. Centraal Verslag der Arbeidsinspectie over 1935, blz. 52.

46. Centraal Verslag der Arbeidsinspectie over 1936, blz. 58 - 59.

47. Centraal Verslag der Arbeidsinspectie over 1937, blz. 62 - 63.

48. Centraal Verslag der Arbeidsinspectie over 1938, blz. 65 - 66. Voor het jaar 1939 kan geen opgave gedaan worden over het aantal eigenlijke overwerkvergunuingen, omdat het totaal aantal overwerkvergunningen van 28634 ook een (niet gering) aantal vergunningen bevat die betrekking hebben op verschuiving van de werktijdbegrenzing, zonder dat de arbeïdstijd per dag en per week wordt verlengd; Centraal Verslag der Arbeidsinspectic over 1939, blz. $70-71$.

49. Centraal Verslag der Arbeidsinspectie over 1938 en 1939, resp. blz. 67 en 71.

50. Rede directeur-generaal van de Arbeid van 26 september 1939.

51. Centraal Verslag der Arbeidsinspectie over 1939, blz. 71.

52. Centraal Verslag der Arbeidsinspectie over 1938, blz. 1.

53. Centraal Verslag der Arbeidsinspectie over 1935, 1936, 1937, 1938 en 1939, resp. blz. 264, blz. 285, 1935, blz. 261 en blz. 287. De genoemde aantallen processen-verbaal vormen het totaal van de activiteiten van de arbeidsinspectie, gemeente- en rijkspolitie.

54. Centraal Verslag der Arbeidsinspectie over 1936, blz. 63. De vervolging werd afgedaan met een schikking van fl. $4, \cdots$.

55. Centraal Verslag der Arbeidsinspectie over 1936, blz. 63 - 64. De betrokken bakkerspatronen werd door de $\mathrm{Rb}$. te Utrecht voor de eerste overtreding veroordeeld tot fl. 60 ,-- boete en 6 dagen voorwaardelijke hechtenis en voor de tweede overtreding tot fl. $20,--$ boete en 2 dagen voorwaardelijke hechtenis. 
56. Artikel 68, eerste lid, onder a, van de Arbeidswet 1919.

57. Centraal Verslag der Arbeidsinspectie over 1938, blz. 87.

58. Centraal Verslag der Arbeidsinspectie over 1938, blz. 81. Het opgemaakte proces-verbaal leidde tot een schikking van fl. $1.000,-\cdots$.

59. Besluit van 8 mei 1937 , Stb. 844.

60. Resp. Besluit van 7 december 1937 , Stb. 863 en Besluit van 7 december 1937, Stb. 864 .

61. Centraal Verslag der Arbeidsinspectie over 1937 en 1938, resp. blz. 18 en blz. 17.

62. Centraal Verslag der Arbeidsinspectie over $1930 \mathrm{t} / \mathrm{m}$ 1939, resp. blz. 120 , blz. 327, blz. 67 , blz. 66 , blz. 76, blz. 76, blz. 85, blz. 95, blz. 99, blz. 116 .

63. Centraal Verslag der Arbeidsinspectie over 1930, 1931 en 1932, resp. blz. 29, blz. 13 en blz. 22.

64. De invoering van het Werktijdenbesluit voor winkels 1929 , het Rustdagbesluit voor toonkunstenaars in bioscopen en het Rustdagbesluit voor transportarbeiders te land leidde in 1930 tot resp. 1663, 24 en 180 en in 1931 tot resp. 1419, 19 en 99 klachten. Zie Centraal Verslag der Arbeidsinspectie over 1930 en 1931, resp. blz. 27 en blz. 16 .

65. Zie Centraal Verslag der Arbeidsinspectie over 1932, 1933 en 1934, resp. blz. 20, blz. 15 en blz. 17.

66. Zie Centraal Verslag der Arbeidsinspectie over 1934, blz. 16.

67. Zie Centraal Verslag der Arbeidsinspectie over 1935, over 1936, over 1937, over 1938 en over 1939, resp. blz. 16, blz. 20, blz. 20, blz. 20 en blz. 24 .

68. Centraal Verslag der Arbeidsinspectie over 1935, over 1936, over 1937, over 1938 en over 1939, resp. blz. 16 , blz. $20-21$, blz. $20-21$, blz. $20-21$ en blz. $24-25$.

69. Centraal Verslag der Arbeidsinspectie over 1930, blz. 39.

70. Centraal Verslag der Arbeidsinspectie over 1930, blz. 39.

71. Zie Centraal Verslag der Arbeidsinspectie over 1931 t/m 1939, resp. blz. 25, blz. 27, blz. 23, blz. 24, blz. $24-25$, blz. $30-31$, blz. $30-31$, blz. $30-31$ en blz. $34-35$.

72. Zie bijwoorbeeld Centraal Verslag der Arbeidsinspectie over 1931, blz. 26.

73. Centraal Verslag der Arbeidsinspectie over 1939, blz. 116 - 117.

74. Zie bijvoorbeeld Centraal Verslag der Arbeidsinspectie over 1937 en over 1938, resp. blz. $27 \mathrm{t} / \mathrm{m} 30$ en blz. $31 \mathrm{t} / \mathrm{m} 34$.

75. Zie hierover Centraal Verslag der Arbeidsinspectie over 1938, blz. $312 \mathrm{t} / \mathrm{m} 318$. 
76. Zie Centraal Verslag der Arbeidsinspectie over 1939, blz. 38 - 39; zie ook blz. 344 t/m 346.

77. Bijlagen Tweede Kamer, zitting 1930 - 1931, 202.3 (memorie van toelichting ) blz. 3.

78. Wet van 9 juli 1931, Stb. 299.

79. Zie artikel 2 van de Röntgenstralenwet.

80. Zie artikel 8 van de Röntgenstralenwet. Overige opsporingsambtenaren waren: de bij artikel 141 van het Wetboek van Strafvordering aangewezen personen, de inspecteurs van het Staatstoezicht op de Volksgezondheid, de ambtenaren van de gemeentelijke geneeskundige dienst aangewezen door de burgemeester en wethouders van de betreffende gemeente.

81. Besluit van 31 maart 1931 , Stb. 130.

82. Het Algemeen Handelsblad van 28 december 1934 maakt melding van het feit, dat de regering niet voornemens was de inwerkingstreding van wet en besluit te bevorderen.

83. Zo werd onder meer in 1909 onder leiding van W.H. Nolens te Amsterdam een congres over de huisindustrie gehouden, waaraan een tentoonstelling werd verbonden. Het Tweede Kamerlid Kupers deelde daarover in het parlement mede, dat door de pers deze tentoonstelling "een ellendetentoonstelling" werd genoemd; Hand. Tweede Kamer, zitting 1933 - 1934, blz. 57. Zie A.N. Molenaar, t.a.p. deel IIb, blz. 1419.

84. Zie Hfdst. 5 par. 7 ( rapporten en verslagen).

85. Zie Bijlagen Tweede Kamer, zitting 1931 - 1932, 442.3 (memorie van toelichting ) blz. 1 - 2.

86. Bijlagen Tweede Kamer, zitting 1931 - 1932, 442.1 en 2.

87. Bijlagen Tweede Kamer, zitting 1931 - 1932, 442.3 ( memorie van toelichting ) blz. 2. Zie ook Hand. Tweede Kamer, zitting 1933 - 1934, blz. 54, blz. $57 \mathrm{t} / \mathrm{m} 60$.

88. Een wetsontwerp tot vaststelling van minimumlonen in de huisindustrie was overigens in de Troonrede van 1928 al aangekondigd: zie E. van Raalte, t.a.p., blz. 239.

89. Bijlagen Tweede Kamer, zitting 1931 - 1932, 442.3 (memorie van toelichting) blz. 8.

90. Wet van 17 november 1933 , Stb. 597.

91. Bijlagen Tweede Kamer, zitting 1932 - 1933, 113.1 ( voorlopig verslag ) blz. 3.

92. Hand. Tweede Kamer, zitting 1933 - 1934, blz. 55; zie ook blz. 59.

93. Bijlagen Tweede Kamer, zitting 1933, 43.1 (memorie van antwoord) blz. 4; Hand. Tweede Kamer, zitting $1933-1934$, blz. $63-64$.

94. Bijlagen Tweede Kamer, zitting 1931 - 1932, 442.3 (memorie van toelichting) blz. 2. Zie ook Bijlagen Tweede Kamer, zitting 1933, 43.1 ( memarie van antwoord) blz. 1; Hand. Tweede Kamer, zitting 1933 1934, blz. 63. 
95. De rechtsgronden van het overheidsingrijpen waren dus de misstanden op het terrein van de huisindustrie, ook op het gebied van de lonen. Tijdens het in 1909 gehouden congres over de huisindustrie zou Ruys de Beerenbroeck onder meer het volgende betogen:

"Zodra de rechten van individu en familie door de omstandigheden zodanig in het gedrang komen, dat die rechten niet meer op behoorlijke wijze worden uitgevoerd, heeft de Staat het recht d.i. de plicht, in te grijpen.

Waar derhalve de Overheid op grond van de feitelijke toestand in de arbeidsverhoudingen van fabrieken en werkplaatsen regelend moest optreden, is zij daartoe te eerder bij de huisindustrie bevoegd".

Zie Hand. Tweede Kamer, zitting 1933 - 1934, blz. 57 - 58; A.N. Molenaar, t.a.p., deel IIB, blz. 1422.

96. C.J.P. Zaalberg, Wettelijk minimumloon voor de huisindustrie, in Vragen des Tijds 1912 II (overdruk) blz. 5 .

97. Zie de artikelen 5 en 10 van de Huisarbeidswet 1933.

98. Zie Hfdst. 7 par. 9 ( wijziging van de Arbeidswet 1919 ).

99. Bijlagen Tweede Kamer, zitting 1931 - 1932, 442.3 (memorie van toelichting ) blz. 12.

100. Zie artikel 14 van de Huisarbeidswet 1933.

101. Zie artikel 18 van de Huisarbeidswet 1933. Naast de ambtenaren van de arbeidsinspectie zijn de bij artikel 141 van het Wetboek van Strafvervolging aangewezen personen, de ambtenaren van rijks- en gemeentepolitie belast met de opsporing van overtredingen.

102. Besluit van 6 mei 1936 , Stb. $853 \mathrm{Na}$ het in werking treden van de wet zijn er 4 centrale huisarbeidscommissies ingesteld, namelijk voor de schoenindustrie (beschikking van 1 oktober 1936, no. 4425 afd. Arbeid) voor het maatkledingbedrijf (beschikking van 11 juli 1939, no. 2240A, afd. Arbeid), voor de confectie-industrie (beschikking van 11 juli 1939, no. 2240B, afd. Arbeid), en voor de tricotage-industrie (beschikking van 11 juli 1939, no. 2240C, afd. Arbeid); zie Centraal Verslag der Arbeidsinspectie over 1939, blz. 388. A.N. Molenaar, f.a.p., deel IIB, blz. $1429-1430$.

103. Zie artikel 4, eerste lid, van de Huisarbeidswet 1933.

104. In totaal hadden 232 gemeenten aan deze verplichting voldaan.

105. Centraal Verslag der Arbeidsinspectie over 1936, over 1937, over 1938 en over 1939, resp. blz.. 35 - 36, blz. 311 - 312, blz. 354 en blz. 388 .

106. Zie Bijlagen Tweede Kamer, zitting 1931 - 1932, 217.3. (memorie van toelichting ) blz. 1. Overigens was in de Troonrede van 1927 al melding gemaakt van het feit, dat een voorstel tot herziening van de Veiligheidswet in voorbereiding was; zie E. van Raalte, t.a.p., blz. 237.

107. Resp. par. 4 ( de artikelen 10 en 11 ) en par. 5 ( artikel 12) van de Veiligheidswet 1934.

108. Paragraaf 3 ( artikel 9 ) van de Veiligheidswet 1934.

109. Resp. par. 6 ( de artikelen $13 \mathrm{t} / \mathrm{m} 18$ ), artikel 2 en par. 7 ( artikel 19) van de Veiligheidswet 1934. 
110. Wet van 2 juli 1934, Stb. 352 .

111. Zie de artikelen 9, eerste lid, 11 , eerste lid, en 12 , eerste lid, en 16 , eerste lid, en de artikelen 14 , eerste lid, 15, tweede lid, en 19, eerste lid, tweede volzin, van de Veiligheidswet 1934. In het laatstbedoelde artikellid is eenzelfde bevoegdheid toegekend, een en ander aan een door de minister aangewezen ambtenaar.

112. Resp. artikel 20 , eerste $t / m$ vijfde lid, en artikel 20 , zesde lid, van de Veiligheidswet 1934 . Deze regeling komt overeen met het bij Wet van 27 juli 1931, Stb. 331, in de Stuwadoorswet opgenomen artikel $19 \mathrm{bis.}$

113. Zie artikel 20 , eerste lid, van de Veiligheidswet 1934.

114. Deze reglementen moeten de in het derde en vierde lid van artikel 20 van de Veiligheidswet 1934 genoemde onderwerpen regelen: samenstelling, bevoegdheden en werkwijze van de commissie en, een nadere omschrijving van hun taak en voorts de op de hoofden en bestuurders van een onderneming rustende verplichtingen met betrekking tot deze commissies. Deze bedrijfsgewijze reglementering heeft de voorkeur boven de vaststelling van een uniform reglement om het mogelijk te maken

"met het bijzondere karakter en de bijzondere behoeften van elk bedrijf rekening te houden".

Zie Bijlagen Tweede Kamer, zitting 1931 - 1932, 217.3 ( memorie van toelichting ) blz. 16.

115. Wet van 7 aprill 1933 , Stb. 160.

116. Zie artikel 20, tweede lid, van de Veiligheidswet 1934.

117. In artikel 7, zesde lid, van de Veiligheidswet 1934, is bepaald dat de arbeider mede verantwoordelijk kan worden gesteld voor de goede naleving van de gestelde voorschriften. Het wordt dus nu mogelijk, dat de naast het hoofd of de bestuurder van de onderneming eventueel ook de arbeider strafbaar zal zijn, indien hij bepaalde voorschriften of eisen niet naleeft. Voor strafbaarheid zal het echter nodig zijn, dat de arbeider redelijkerwijze kan geacht worden met het voorschrift of de eis, waarvan overtreding plaats had, bekend te zijn.

De in de bedoelde gevallen mogelijke strafbaarheid van de arbeider is echter geen novum in de Nederlandse veiligheidswetgeving; zij werd het eerst ingevoerd in de Stuwadoorswet bij de wijzigingswet van 27 juli 1931 , Stb. 331. Zie ook de Veiligheid 1932 blz. 3.

118. Hooge Raad van Arbeid, Advies betreffende: voorontwerp van een nieuwe Veiligheidswet, van 10 december 1929, no. 105, Bijlage.

119. Bijlagen Tweede Kamer, zitting 1931 - 1932, 217.3 (memorie van toelichting ) blz. 16.

120. Bijlagen Tweede Kamer, zitting 1931 - 1933, 217.3 (memorie van toelichting ) blz. 15.

121. Byjlagen Tweede Kamer, zitting 1933 - 1934, 71.1 ( verslag ) blz. 2 - 3 .

122. Bijlagen Tweede Kamer, zitting 1933 - 1934, 71.1 (verslag ) blz. 3 - 4.

123. Besluit van 19 november 1938, Stb. 886 .

124. Besluit van 21 augustus 1916, Stb. 418. 
125. Besluit van 19 november 1938 , Stb. 872 .

126. Resp. Besluit van 8 augustus 1939, Stb. 865 en de Besluiten van 19 november 1938 , Stb. 873 en 874 .

127. Artikel 20 van de Veiligheidswet 1934.

128. Zie bijvoorbeeld Bijlagen Tweede Kamer, zitting 1933 - 1934, no. 2.6 ( voorlopig verslag - Hfdst. Xa begroting Sociale Zaken) blz. 3; Bijlagen Tweede Kamer, zitting 1934 - 1935, no. 2.5 (voorlopig verslag Hfdst. Xa begroting Sociale Zaken ) blz. 4.

129. Tweede Kamer, zitting 1933 - 1934, 221.3 (memorie van toelichting ) blz. 1.

130. Wet van 9 november 1936, Stb. 802.

131. Zie artikel 1 , derde lid, van de Rijtijdenwet 1936.

132. Bijlagen Tweede Kamer, zitting 1933 - 1934, 221.4 (voorlopig verslag ) blz. 2.

133. Bijlagen Tweede Kamer, zitting 1933 - 1934, 221.4 ( voorlopig verslag ) blz. 2; Hand. Tweede Kamer, zitting 1935 - 1936, blz. 2227.

134. Hand. Tweede Kamer, zitting 1935 - 1936, blz. 2235 - 2236.

135. Zie artikel 34 van de Motor- en Rijwielverkeerswet ( Wet van 10 februari 1905, Stb. 69 ).

136. Zie artikel 8 van de Rijtijdenwet 1936.

137. Besluit van 17 februari 1939, Stb. 892 .

138. Besluit van 13 augustus 1939, Stb. 888 .

139. Zie artikel 43 van het Rijtijdenbesluit.

140. Zie de artikelen 46 en 47 van het Rijtijdenbesluit.

141. Centraal Verslag der Arbeidsinspectie over 1939, blz. 393 t/m 405.

142. De vakbeweging verzette zich fel tegen de mechanisering, die volgens haar mede verantwoordelijk was voor de geweldige toeneming van de werkloosheid in de branche. Zie A. Eillebrecht/J. Grimbergen/P. Schipper, De sigarennijverheid in Culemborg, mensen en fabrieken, Culemborg ( z.j. ), blz. 57; W. van der Hoeven, De Nederlandse sigarenmakers en tabakswerkersbond opgericht op 26 december 1887 zijn geschiedenis, werken en streven, (z.p./z.j. ) blz. $164 \mathrm{t} / \mathrm{m} 173$.

143. Wet van 5 november 1936, Stb. 639E.

144. Tweede Kamer, zitting 1935 - 1936, 282.2 (ontwerp van wet ).

145. Tweede Kamer, zitting 1935 - 1936, 282.3 (memorie van toelichting ). 
146. Hand. Tweede Kamer, zitting 1935 - 1936, blz. 1923.

147. Tweede Kamer, zitting $1935-1936,282.13$.

148. Hand. Tweede Kamer, zitting 1935 - 1936, blz. 1929.

149. Hand. Tweede Kamer, zitting $1935-1936$, blz. $1923 \mathrm{t} / \mathrm{m} 1927$.

150. Centraal Verslag der Arbeidsinspectie over 1936, 's-Gravenhage 1937, blz. 37.

151. Dit laatste is een gevolg van het amendement van het Tweede Kamerlid Van der Waarden ( Tweede Kamer, zitting 1935 - 1936, 282.9) dat met ruime meerderheid was aangenomen ( Hand. Tweede Kamer, zitting 1935 - 1936, blz. 1929 ).

152. Artikel 7, eerste lid, van de Wet van 5 november 1936, Stb. 639E.

153. Artikel 10 van de Wet van 5 november 1936 , Stb. $639 \mathrm{E}$.

154. Wet van 30 december 1938 , Stb. $639 \mathrm{PP}$.

155. M.G. Levenbach, Arbeid, in Nederlands bestuursrecht, blz. 462.

156. Het Rijkspaspoortenkantoor besliste onder meer of door Nederlandse consulaire ambtenaren in het bujtenland visa mochten worden verleend op paspoorten van vreemdelingen.

157. De zogenaamde werkgeversverklaring hield in, dat de betrokken vreemdeling door een bepaalde werkgever in dienst zou worden genomen. De zogenaamde verklaring van geen bezwaar betrof een verklaring van de directeur van de districtsarbeidsbeurs in welker ressort de vreemdeling arbeid zou verrichten, dat geen geschikte arbeidskrachten aanwezig waren, die bereid en geschikt waren om die arbeid te verrichten.

158. Tweede Kamer, zitting 1933, 268.3 (memorie van toelichting ) blz. $1-2$.

159. Wet van 16 mei 1937 , Stb. 257.

160. Zie artikel 12 van de Wet tot regeling van het verrichten van arbeid door vreemdelingen.

161. Zie artikel 2 van de Wet tot regeling van het verrichten van arbeid door vreemdelingen juncto artikel 2 van het Besluit van 11 augustus 1937 tot vaststelling van voorschriften bedoeld in artikel 11 van die wet, Stb. 473 .

162. Zie bijvoorbeeld de Besluiten van 14 september 1934 , no. 10 ; van 3 april 1935, no. 10; van 17 augustus 1935, no. 903.

163. Zie artikel 10 van de Wet tot regeling van het verrichten van arbeid door vreemdelingen.

164. Zie de artikelen 3 en 6 van de Wet tot regeling van het verrichten van arbeid door vreemdelingen. Tevens waren met de opsporing van overtredingen belast de bij of krachtens artikel 141 van het Wetboek van Strafvordering aangewezen personem, de ambtenaren van rijks- en gemeentepolitie alsmede zij, die daartoe bij algemeen maatregel van bestuur zijn aangewezen. 
165. Zie artikel 15 van de Wet van 20 februari 1964 , Stb. 72.

166. Zie artikel 25 van de Wet van 9 november 1978, Stb. 737.

167. Overtreding van de Wet arbeid buitenlandse werknemers is op grond van artikel 23 van die wet een economisch delict. Op grond van artikel 17 van de Wet op de economische delicten (Wet van 22 juni 1950 , Stb. K 258 ) juncto het besluit van 26 oktober 1979, no. 880/279, Stcrt. 212, zijn de bedoelde ambtenaren aangewezen.

168. Zie Centraal Verslag der Arbeidsinspectie over 1935, over 1936, over 1937, over 1938 en over 1939, resp. blz. 27 , blz. $33-34$, blz. 34 - 35 , blz. $34-35$ en blz. 40 .

169. Zie Tweede Kamer, zitting 1936 - 1937, 328.3 (memorie van toelichting ) blz. 1. Zie ook onder meer: K.L. Henri van der Putt, Naar een betere verdeling van de beschikbare arbeid Vrouwenarbeid Mechanisatie, Eindhoven 1935.

170. Wet van 28 mei 1937 , Stb. 802 .

171. Bijlagen Tweede Kamer, zitting 1936 - 1937, 328.3 (memorie van toelichting) blz. 2.

172. Op 14 november 1936 waren er bij de organen van openbare arbeidsbemiddleling als werkzoekenden ingeschreven 384.875 mannen en 17.880 (merendeels Nederlandse) vrouwen (geraamd werd dat in ons land ruim 45.000 buitenlandse vrouwen waren ): zie Bijlagen Tweede Kamer, zitting 1936 - 1937 , 328.3 (memorie van toelichting ) blz. 1 .

173. Bijlagen Tweede Kamer, zitting 1936 - 1937, 328.3 (memorie van toelichting) blz. 1.

174. Artikelen 2 en 3 van de Wet inzake de verdeling van de beschikbare arbeid 1937.

175. Artikel 9 van de Wet inzake de verdeling van de beschikbare arbeid 1937.

176. Artikel 4, eerste en derde lid van de Wet inzake de verdeling van de beschikbare arbeid 1937.

177. Artikelen $10 \mathrm{t} / \mathrm{m} 12$ van de Wet inzake de verdeling van de beschikbare arbeid. Met het opsporen van overtredingen zouden tevens belast worden de bij artikel 141 van het Wetboek van Strafvordering aangewezen personen alsmede de ambtenaren van rijks- en gemeentepolitie.

178. Zie M.G. Levenbach, Arbeid, in Nederlands besturursrecht, blz 461 - 462.

179. E. van Raalte, t.a.p., blz. 243.

180. E. van Raalte, t.a.p., blz. 244 .

181. T. van Peype, t.a.p., blz. 244.

182. T. van Peype, t.a.p., blz. 244.

183. Via voorwaarden bij de steunverlening werden de boeren gedwongen deel te nemen aan de crisisorganisaties; zie onder meer F.A.G. Keesing, t.a.p, blz. 186; T. van Peype, t.a.p., blz. 229. 
184. Wet van 7 april 1933, Stb. 610. Zie hierover onder meer M.G. Levenbach, Arbeid, in Nederlands besturursrecht, blz. 465 - 466.

185. Hand. Tweede Kamer, zitting 1934 - 1935, blz. 807; zie ook T. van Peype, t.a.p., blz. 244.

186. Hand. Tweede Kamer, zitting 1935 - 1936, blz. 572; zie ook T. van Peype, t.a.p., blz. 245.

187. M.G. Levenbach, Arbeid, in Nederlands bestuursrecht, blz. 467; zie ook I.J. Brugmans, Paardenkracht en mensenmacht, blz, 542 .

188. Wet van 24 mei 1935. Stb. 310. Zie over deze wet onder meer W.C.L. van der Grinten, De algemeen verbindende ondernemersovereenkomst, in De Naamlooze Vennootschap 1939, blz. $193 \mathrm{t} / \mathrm{m} 197$ en blz. 238 t/m 241 .

189. Zie T. van Peype, t.a.p., blz. 232.

190. E. van Raalte, t.a.p, blz. 253 - 254.

191. Bijlagen Tweede Kamer, zitting 1936 - 1937, 274.1 .

192. Zoals enkele leden van de Hooge Raad van Arbeid, blijkens het advies over een voorontwerp regelende de verbindendverklaring van collectieve arbeidsovereenkomsten, 's-Gravenhage, 28 mei 1926, al hadden gewild; zie T. van Peype, t.a.p., blz. 246; Bijlagen Tweede Kamer, zitting 1936 - 1937, 274.3 ( memorie van toelichting ) blz. 3 .

193. Bijlagen Tweede Kámer, zitting 1936 - 1937, 274.3 (memorie van toelichting) blz. 3. De eerste ondergetekende was minister Slingenberg, de tweede was de minister van Justitie Van Schaik.

194. Bijlagen Tweede Kamer, zitting 1936 - 1937, 274.3 ( memorie van toelichting ) blz. 3 - 4.

195. Bijlagen Tweede Kamer, zitting 1936 - 1937, 274.4 (voorlopig verslag) blz. 1. Overigens bevatte dit pleidooi niet alleen bezwaren tegen de algemeen verbindendverklaring als zodanig maar ook tegen het instituut van de collectieve arbeidsovereenkomst zelf: Zie Bijlagen Tweede Kamer, zitting 1936 - 1937, 274.4 (voorlopig verslag) blz. 3 - 4; zie ook Bijlagen Tweede Kamer, zitting 1936 - 1937, 274.5 (memorie van antwoord) blz. 1.

196. Bijlagen Tweede Kamer, zitting 1936 - 1937, 274.5 ( memorie van antwoord) blz. $1-2$.

197. Bijlagen Tweede Kamer; zitting 1936 - 1937, 274.4 (voorlopig verslag ) blz. 11.

198. Bijlagen Tweede Kamer, zitting 1936 - 1937, 274.5 (memorie van antwoord ) blz. 8 .

199. Zie Hand. Tweede Kamer, zitting 1936 - 1937, blz. 1991.

200. Bijlagen Tweede Kamer, zitting 1936 - 1937, 274.15 ( gewijzigd ontwerp van wet).

201. Hand. Tweede Kamer, zitting 1936 - 1937, blz. 2021.

202. Bijlagen Tweede Kamer, zitting 1936 - 1937, 274.11 III. 
203. Bijlagen Tweede Kamer, zitting $1936-1937,274.13$ I en II:

204. Hand. Tweede Kamer, zitting $1936-1937$, blz. $2021-2022$.

205. Hand. Tweede Kamer, zitting 1936 - 1937, blz. 2019.

206. Hand. Tweede Kamer, zitting $1936-1937$, blz. $2020-2021$.

207. Hand. Tweede Kamer, zitting 1936 - 1937, blz. 2023.

208. Hand. Tweede Kamer, zitting 1936 - 1937, blz. 2023.

209. Hand. Tweede Kamer, zitting 1936 - 1937, blz. 2023.

210. Hand. Tweede Kamer, zitting 1936 - 1937, blz. 2023. Zie ook Bijlagen Eerste Kamer, zitting 1936 - 1937 , 274.161a ( eindverslag bevattende de memorie van antwoord ), blz. 2.

211. Wet van 25 mei 1937, Stb. 801.

212. Besluit van 7 september 1937 , Stb. 892 .

213. S. Mok, Het algemeen verbindend en het onverbindend verklaren van bepalingen van collectieve arbeidsovereenkomsten, Haarlem 1939, blz. 184 - 185.

214. W.F.A. van Haersolte, De bescherming van de collectieve arbeidsovereenkomst door het recht, Amsterdam 1931, blz. 33 .

215. M.G. Levenbach, Opmerkingen over de collectieve arbeidsovereenkomst, in R.M. 1933 blz. 301.

216. M.G. Levenbach, in R.M. 1933 blz. $301-302$.

217. Centraal Verslag der Arbeidsinspectie over 1938 en over 1939, resp. blz. $37 \mathrm{t} / \mathrm{m} 39$ en blz. $42 \mathrm{t} / \mathrm{m} 45$.

218. I.J. Brugmans, Paardenkracht en mensenmacht, blz. 541 t/m 543; F.A.G. Keesing, t.a.p., blz. 290.

219. Wet van 20 mei 1938, Stb. 619.

220. I.J. Brugmans, Paardenkracht en mensenmacht, blz. 543.

221. Zie artikel 3 van de Bedrijfsvergunningenwet 1938.

222. Zie artikel 11 van de Bedrijfsvergunningenwet 1938.

223. Zie artikel 13 van de Bedrijfsvergunningenwet 1938. Verder waren met de opsporing van overtredingen van deze wet belast: de bij of krachtens artikel 141 van het Wetboek van Strafvordering aangewezen personen, de ambtenaren van rijks- en gemeentepolitie en zij die daartoe door de minister van Handel, Nijverheid en Scheepvaart.

224. Bijlagen Tweede Kamer, zitting 1936 - 1937, 343.3 ( memorie van toelichting ) blz. 6 . 
225. "Dat bij de keuze angstvallig op politieke kleuren tevens wordt gelet, spreekt, gezien de volksaard, van zelf',

aldus A. Plate; zie Maatschappijbelangen, 1939 blz. 116:

226. "Politieke tegenstellingen spelen zich sterk af en als uitvloeisel ervan geven de adviezen een waar spectrum van meeningen, hetwelk voor de regeering maar van zeer betrekkelijke waarde kan zijn",

aldus A. Plate; zie Maatschappijbelangen, 1939 blz. 116.

227. Zie Maatschappijbelangen $1939 \mathrm{blz} .115 \mathrm{t} / \mathrm{m} 118$.

228. Zie Centraal Verslag der Arbeidsinspectie over 1930, over 1934, over 1935 en over 1938, resp. blz. 15, blz. 9, blz. $9-10$ en blz. $10-11$.

Het hoofdbestuur-lidmaatschap van de Koninklijke Nederlandsche Brandweervereeniging werd in 1930 overgedragen aan de aan de directeur-generaal toegevoegde hoofdinspecteur van de arbeid G.W.J. van Sierenberg de Boer.

229. Schrijven van 8 oktober 1931, no. 2479, Afd. Arbeid; zie De crisisinvloed op het bedrijfsleven. Resultaten van een onderzoek naar de bedrijvigheid op 1 October 1931 in de fabrieks- en scheepsbouwnijverheid, het mijnwezen, de koopvaardij en in het havenbedrijf, ingesteld met medewerking van de Arbeidsinspectie, van de Inspectie van de Havenarbeid, het Mijntoezicht en de Scheepvaartinspectie. Bewerkt door de Directie van den Arbeid ( hierma De crisisinvloed op het bedrijfsleven ), 's-Gravenhage ( z.j. ), blz. VII.

230. Zie voor de inhoud van de circulaire en de vragenlijst: De crisisinvloed op het bedrijfsleven, blz. 154 $\mathrm{t} / \mathrm{m} 156$.

231. Enkele werkgeversorganisaties hadden onder haar leden gelijktijdig een dergelijk crisisonderzoek georganiseerd, terwijl de in 1929 in Amsterdam ingestelde Crisis-Industriecommissie eveneens gelijktijdig voor de hoofdstad een schriftelijke enquête had ingesteld; zie De crisisinvloed op het bedrijfsleven, blz. VIII.

232. Zie De crisisinvloed op het bedrijfsleven, blz. VII $\mathrm{t} / \mathrm{m} X I$.

233. Zie P.E. de Hen, t.a.p., blz. $66 \mathrm{l} / \mathrm{m} 76$.

234. F.A.G. Keesing, t.a.p., blz. 157.

235. Brief van 8 okttober 1931, no. 2479, Afd. Arbeid.

236. Zie nt. 229. De crisisinvloed op het bedrijfsleven, resultaten van een onderzoek naar de bedrijvigheid op 1 oktober 1931 in de techniek-en scheepsbouwnijverheid, het mijnwezen, de koopvaardij en in het havenbedrijf, 's- Gravenhage (december) 1931, werd ook als bijlage gepubliceerd in de november-aflevering 1931 van het Maandschrift van het Centraal Bureau voor de Statistiek.

237. Brief $\operatorname{van} 2$ januari 1931; zie P.E. de Hen, t.a.p., blz. 86.

238. Zie P.E. de Hen, blz. 86.

239. Blijkens de brief van 30 maart 1933, Rijksarchief-archief van de Commissie-Hacke. Overigens bleef Zaalberg wel aan als voorzitter van de naar hem genoemde commissie. 
240. De samenstelling was als volgt: voorzitter - de directeurgeneraal van de Arbeid A.H.W. Hacke; leden de directeur-generaal van Handel en Nijverheid, van Waterstaat, van Werkverschaffing en Steunverlening; de directeur van de Rijksdienst Werkvoorziening en Arbeidsbemiddeling en de thesauriër-generaal. Zie W. Veerman, Inventaris van het Archief van het Werkfonds 1934 en de Interdepartementale Commissie Werkloosheidszorg de Commissie Hacke ("H"), 's-Gravenhage 1970, blz. 14.

241. W. Veerman, t.a.p., blz. 14.

242. Eerste advies inzake werkloosheidsbestrijding, ( september) 1933; Rijksarchief-archief van de Commissie-Hacke.

243. Tweede advies inzake werkloosheidsbestrijding, ( januari) 1934; Rijksarchief-archief van de CommissieHacke:

244. Zie P.E. de Hen, t.a.p., blz. 106.

245. P.E. de Hen, t.a.p., blz. 105.

246. E. van Raalte, t.a.p., blz. 248; zie ook F.A.G. Keesing, t.a.p., blz. 193.

247. Bijlagen Tweede Kamer, zitting 1933 - 1934, 339.2; zie de Wet van 2 juli 1934, Stb. 348.

248. Blijkens de installatie-rede op 4 april 1934 van M. Colijn:

".... Het Rijk getroost zich met het oog daarop het offer, dat het zijn Kapitaaldienst belangrijk verzwaart. Daaruit volgt zonder meer, dat de kosten van de aldus ondernomen (werkverruimings-) werken beneden het normale peil moet liggen. Dit geldt met name voor de loonen".

Zie W. Veerman, t.a.p., blz. 9; zie ook P.E. de Hen, t.a.p., blz. 106 - 107.

249. Tot het bestuur behoorden naast de al genoemde bewindslieden: D. Bean-Lent O.F.M., J.W. Beyen, W. Drees, P.L. de Gaay Fortman, G. Jansen, W. Maas Geesternaus, J.J.M. Nobach en Ch.J.I.M. Welter, zie W. Veerman, t.a.p., blz. 10.

250. G.J. Tuyl, Werkfonds 1934, 1949; Rijksarchief-archief Werkfonds 1934.

251. Dit waren: H. Amelink, H.B. Berghuis, J. Bierens de Haan, H.P.J. Bloemers, H. de Bordes, Joh. Brautigam, A.C. de Bruyn, P.A. Colijn, D. Cremer de Jongh, B. van Eesteren, J. Eykman, H.C.J.H. Gelissen, J. Gerritsz, A. Hanemaayer, A.C. Josephus Jitta, P. Keulemans, H.J.L. Klein Schiphorst, L.G. Kortenhorst, H. Kruithof, Th. Ligthart, S.L. Louwes, W.G.A. van der Lucht, T. van Maanen, W. Meyer Timmermans Thijssen, A. Plate, J.E. van Riet, J. Schouten, M.G.A. Treep, W. van der Vegt, L.T. van de Wal, F. van der Walle, C. Wijdenes Spaans, D.W. de Monchy sr. en J.G. Suurhof.

Overigens is de installatie-vergadering tevens de enige vergadering geweest, waarin de raad van bijstand en advies en het bestuur gezamenlijk vergaderd hebben. Zie W. Veerman, t.a.p., blz. 9 - 10.

252. Zie Centraal Verslag der Arbeidsinspectie over 1935 en over 1936, resp. blz. 9 en blz, 12.

253. Bij Besluit van 20 april 1939, Stb. 882. (Organisatiebesluit Werkloosheidsbestrijding 1939); zie A. Veerman, t.a.p., blz. 12. Zie Centraal Verslag der Arbeidsinspectie over 1939, blz. 20. 
255. Het N,V.V. had op haar crisiscongres van 3 oktober 1931 te Rotterdam en daarna op 22 juni 1932 en daarop volgende dagen tijdens het 3-jaarlijks congres restricties aangenomen, waarin op invoering van een wettelijke internationale 40-urige werkweek werd aangedrongen. In zijn congreswergadering van $1932 \mathrm{sprak}$ het RICWV zich ook wit voor een bevordering van de 40 -urige werkweek. Zie B. Bölger, De actie inzake de 40-urige werkweek, in De Economist 1932, blz. 709.

256. H. Butler was directeur van het Internationaal Arbeidsbureau; zie A.J.R. Maurits, De 40-urige werkweek in De Economist 1937, blz. 378.

257. Door de leden A.C. de Bruijn, J.A. Schutte, Alb v.d. Meijs en A.J. Loerakker; zie Rapport van den Hoogen Raad van Arbeid inzake wettelijke verkorting van den arbeidsduur ter bepaling van de crisiswerkloosheid van 27 mei 1933, no. 15 ( hierna Rapport betreffende verkorting arbeidsduur ), 's-Gravenhage 1933 , blz. 1 .

258. Deze commissie bestond uit de volgende ( plv. ) leden: A.L. Scholtens (voorzitter), S. de la Bella jr., F.L. van der Blom, A.C. de Bruijn, P.WJ.H. Cort van der Linden ( plv. B.C. Slotemaker ), P. Danz, A.M. Engels, P.S. Gerbrandy, J. Goudriaan jr., A.H.W. Macke ( plv. G.W.J. van Sierenberg de Boer ), J.A.G.M. van Hellenberg Hubar, H.A. Kaag, A. de Kanter, A. van der Meijs, J.G. Oortuyn Botjes, N.J. Polak, C. Smeenk, M.P.L. Steenberghe (plv. L.G. Kortenhorst) R.A. Verwey en F.M. Wibaut; zie Rapport betreffende verkorting arbeidsduur, blz. 3 .

259. Aldus het Rapport betreffende verkorting arbeidsduur, blz. 5, waarvoor de Hooge Raad zijn zeer bijzondere erkentelijkheid betuigde.

260. Rapport betreffende verkorting arbeidsduur, blz. $7 \mathrm{t} / \mathrm{m} 9$.

261. Het aantall arbeiders dat op grond van deze arbeidstijdverkorting aan het werk zou kunnen komen werd geraamd op circa 37.000; zie Nota van de directeur-generaal van de Arbeid, Rapport betreffende verkorting arbeidsduur, blz. $46 \mathrm{t} / \mathrm{m} 48$ alsook blz. $7 \mathrm{t} / \mathrm{m} 9$.

262. Daarvoor werd een aantal argumenten gegeven: op deze wijze werd geen rekening gehouden met de zeer uiteenlopende omstandigheden, waarim de verschillende bedrijfstakken verkeren, waardoor de economische en technische mogelijkheden van arbeidstijdverkorting van bedrijf tot bedrijf geheel verschillend zijn; de kostprijsverhogende werking ervan, die, vooral in de concurrentieverhoudingen met het buitenland, negatief zou kunnen werken; de mogelijke verhoging van de algemene kosten van bedrijven als gevolg van een mogelijke verkorting van de bedrijfstijd en een mogelijke uitbreiding van het machinepark c.q. bedrijfsruimte wat niet te rijmen was met het gegeven dat het hier een crisis-maatregel, en dus een tijdelijke maatregel betrof. Zie Rapport betreffende verkorting arbeidsduur, blz. $9 \mathrm{t} / \mathrm{m} 13$.

263. De argumenten hiervoor waren: er kan rekening gehouden worden met de bijzondere omstandigheden van iedere bedrijfstak; er werd aangesloten bij de bedrijfstakgewijze gevoerde onderhandelingen tussen werkgevers en arbeiders(verenigingen) over arbeidsvoorwaarden en bovendien werden de concurrentieverhoudingen van de ondernemingen in een bedrijfstak op deze wijze niet verstoord. Zie Rapport betreffende verkorting arbeidsduur, blz. $13-14$. 
264. Dit standpunt werd gehuldigd door de helft van het aantal leden van de Hooge Raad van Arbeid; zie Rapport betreffende verkorting arbeidsduur, blz. 14 - 15. Een ontwerp van de bedoelde machtigingswet was neergelegd in het Rapport betreffende verkorting arbeidsduur, blz. $15-16$.

265. Rapport betreffende verkorting arbeidsduur, blz. $22-23$.

266. Rapport betreffende verkorting arbeidsduur, blz. 28 - 29.

267. Bovendien was al in een aantal gevallen over deze bezwaren heengestapt, zoals bij het verbod van nachtarbeid van de alleenwerkende bakkerspatroon en de Winkelsluitingswet.

268. De commissie was als volgt samengesteld: Th. van der Woerden ( voorzitter ), M.J.H. Cobbenhagen, F.N.E. Gulje, A.H.W. Hacke, J. Klopper ( tot november 1938 ), E. Kupers, P. Lieftinck, H.W. Methorst. Als secretaris werd benoemd A.W. Quint, met als adjunct-secretarissen B.W. Haverman en H.J. Schölvinck; zie Hooge Raad van Arbeid, Onderzoek naar de "blijvende werkloosheid" en haar bestrijding, rapport van de commissie, ingesteld bij beschikking van den Voorzitter van den Hoogen Raad van Arbeid d.d. 18 december 1936, 's-Gravenhage 1938, blz. 7 ( hierna Onderzoek "blijvende werkloosheid").

269. De taakopdracht luidde:

$1^{\circ}$ zich een oordeel te vormen omtrent de aanwezige gegevens aangaande de te verwachten blijvende werkloosheid;

$2^{\circ}$ zich een oordeel te vormen over de nog ontbrekende gegevens, waarvan de kennis voor de beoordeling van dit vraagstuk gewenscht zou zijn en een raming te maken van de kosten voor aanvulling nodig; $3^{\circ}$ voorlopige conclusies te trekken, indien zij meent, dat dit uit de reeds aanwezige gegevens mogelijk is. Op 20 maart 1937 werd door de Hooge Raad van Arbeid ingestemd met een verruiming van de opdracht in die mate, dat het haar mogelijk zou zijn onderzoekingen te doen instellen om het ontbrekende materiaal zoveel mogelijk bijeen te brengen en daarna eventueel met conclusies en voorstellen te komen. Zie Onderzoek "blijvende werkloosheid", blz. 7 - 8 .

270. Onderzoek "blijvende werkloosheid", blz. 7 - 8.

271. Onderzoek "blijvende werkloosheid", blz. 49.

272. P.E. de Hen, t.a.p., blz. 119.

273. Bij brief van 31 december 1936; zie P.E. de Hen, t.a.p. blz., 339 nt. 147.

274. Centraal Verslag der Arbeidsinspectie over 1935, blz. 21.

275. Centraal Verslag der Arbeidsinspectie over 1939, blz. 18 t/m 20 . 


\section{Hoofdstuk 9 \\ DE TWEEDE WERELDOORLOG}

\section{Inleiding}

De inval van Hitler-Duitsland in Polen op 1 september 1939 's morgens om 04.45 uur was de druppel die de emmer deed overlopen. Engeland en Frankrijk stelden ultimata dat Hitler de vijandelijkheden zou staken en de gebieden zou ontruimen die zijn troepen in Polen hadden bezet ${ }^{4}$. Op 3 september van dat jaar liepen deze ultimata $\mathrm{af}^{2}$. Duitsland bevond zich vanaf dat moment in oorlog met de beide westelijke mogendheden. Het Duits-Poolse conflict was overgegaan in de Tweede Wereldoorlog; een nog massaler krachtmeting dan de Eerste Wereldoorlog. Hij duurde langer, verbreidde zich over grotere gebieden en werd met nog meedogenlozere hardheid gevoerd.

Ook ons land zou niet gespaard worden. Op 10 mei 1940, 's morgens om vijf minuten voor vier, viel het Duitse leger als een dief in de nacht ons land binnen. Hoewel tegenstand werd geboden, en soms zelfs effectiever dan in de Duitse krijgsplannen was voorzien legden onze strijdkrachten het na acht maanden mobilisatie in vijf dagen op 14 mei 1940 af tegen de Duitse tegenstander; de bezetting was een feit.

Het intreden van de oorlogssituatie hier te lande en de bezetting van ons land had verstrekkende gevolgen voor het Nederlandse bedrijfsleven, dat bijwoorbeeld werd geconfronteerd met een gebrek aan grondstoffen en (motor) brandstoffen, sterk verminderde transportmogelijkheden, verduisteringsmaatregelen en distributieperikelen, waardoor de produktie moest worden ingeperkt of geheel worden gestaakt. Ten einde een totale chaos op het terrein van de arbeidsmarkt te voorkomen werden door of vanwege de bezetter talloze voorschriften uitgevaardigd die het karakter van tijdelijk noodrecht bezaten; maatregelen die aanvankelijk nog een sociale strekking haddem en nog de Nederlandse belangen behartigden en waarvan de uitvoering nog in betrouwbare Nederlandse handen lag. Deze maatregelen hebben niet alleen praktische betekenis gehad; principieel nieuw was, dat de centrale overheid zich bemoeide met en verantwoordelijk was voor de duur van de arbeidsverhouding en de loonpolitiek. Al snel echter werd de arbeidsmarktpolitiek op de Duitse belangen ingesteld ${ }^{3}$, waardoor de greep van de bezetter op ons arbeidspotentieel werd vereenvoudigd. Daar werkgevers en arbeiders zelf begonnen te saboteren, was de greep op het "arbeidsbestel" dusdanig onvoldoende naar de zin van de bezetter, dat hoe langer hoe meer dwangvoorschriften werden uitgevaardigd ten einde tewerkstelling in Duitsland of andere Duitse belangen te bevorderen, om uiteindelijk te resulteren in een slavenjacht en razzia's "voor de arbeidsinzet"4.

Het behoeft nauwelijks betoog, dat de uitzonderlijke situatie op de werkzaamheden van de arbeidsinspectie grote invloed heeft uitgeoefend.

2. Werkzaamheden in verband met de belangrijkste wetten waarvan de handhaving en de medewerking aan de uitvoering geheel of gedeeltelijk aan de arbeidsinspectie was opgedragen

Tot de belangrijkste wetten, waarvan de handhaving en de medewerking aan de uitvoering geheel of gedeeltelijk aan de arbeidsinspectie was opgedragen, moeten gerekend worden de Arbeidswet 1919, de Steenhouwerswet 1921, de Huisarbeidswet 1933, de Veiligheidswet 1934 en de Rijtijdenwet 1936.

Het normale inspectiewerk kwam aanvankelijk als gevolg van de problemen waarmee het bedrijfsleven geconfronteerd werd praktisch stil te liggen. Voorts leverden de beperkte bus-en treinverbindingen en de benzineschaarste een beletsel voor geregelde inspectiereizen, terwijl ook de gewijzigde werktijdindeling in de bedrijven, in verband met de verduisteringsvoorschriften, van ongunstige invloed was ${ }^{5}$. 
Enerzijds maakten de bijzondere omstandigheden de bemoeienis van de arbeidsinspectie ten dele overbodig, omdat in verschillende bedrijven de werktijden moesten worden ingekort of de produktie geheel moest worden gestopt, anderzijds veroorzaakten zij voor vele andere bedrijven een abnormale bedrijvigheid vooral als gevolg van opdrachten van het Duitse leger. In de laatstbedoelde categorie van bedrijven moest in verband met het spoedeisende karakter van de opdrachten op grote schaal overgewerkt worden. Aanvankelijk werd daarbij veelal uitgegaan van de veronderstelling, dat het verlenen van dergelijke opdrachten de ondernemingen ontsloeg van de verplichting tot naleving van de Arbeidswet 1919, hetgeen niet het geval was. In overleg met de Duitse autoriteiten werd voor het overwerk ten behoeve van Duitse legerorders een bijzondere regeling getroffen ${ }^{*}$.

Ter illustratie van de gedlaalde activiteiten van de arbeidsinspectie ten aanzien van de Arbeidswet 1919 in de eerste oorlogsjaren kunmen de volgende voorbeelden gegeven worden ten aanzien van arbeild in fabrieken of werkplaatsen. Werden in 1939 nog 28634 vergunningen verleend, in 1940 was dit aantal al gedaald tot 14289 , om een jaar later nog verder te dalen tot $10738^{7}$. Het aantal processen-verbaal opgemaakt door de arbeidsinspectie daalde van 716 in 1939 tot 259 in 1940 en tot 190 in $1941^{8}$.

In de tweede helft van 1942 werden de moeilijkheden yoor het Nederlandse bedrijfsleven nog vergroot toen de bezetter arbeiders uit de fabrieken vorderde voor tewerkstelling in Duitsland. Ten einde de uit deze maatregell voortvloeiende bezwaren te ondervangen, werd van de zijde van de bezetter aangedrongen op de invoering van de 54-urige werkweek. Tal van werkgevers vatte deze aanwijzing op als een imperatief voorschrift en voerde de verlengde werkweek in, ervan uitgaande, dat de zaak daarmee in orde was. In deze gevallen werd via voorlichting van de arbeidsinspectie bewerkstelligd, dat alsnog de vereiste vergunningen werden gevraagd $^{9}$. In het jaarverslag over de jaren 1944 en 1945 , dat eerst na het einde van de oorlog zou verschijnen, en derhalve minder yoorzichtige bewoordingen bezigde, werd gewag gemaakt van een niet gewild bijkomend effect van deze werktijdverlenging ${ }^{10}$. De door de bezetter getoonde belangstelling voor bedrijven waar slechts 48 uren per week werd gewerkt, had tot gevolg, dat verschillende werkgevers het deden voorkomen, dat een 54-urige werkweek in hun onderneming regel was. Anderen vroegen overwerkvergunningen onder het voorwendsel van drukte, ten einde aldus het weghalen van personeel te voorkomen.

Het aantal vergunningen voor fabrieken of werkplaatsen zou na de daling in de eerste oorlogsjaren in 1942 stijgen tot 12204, om overigens als gevolg van de hierboven bedoelde werktijdverlenging in 1943 weer te dalen tot 8306. In de beide laatste oorlogsjaren bedroeg het aantal vergunningen respectievelijk 1838 en 1736. De daling was niet alleen het gevolg van de werktijdverlenging, waaraan overigens in deze jaren in het algemeen geen behoefte bestond, maar tevens van het steeds toenemende gebrek aan grondstoffen of verkoopartikelen waardoor de normale produktie of verkoop steeds verder verminderde ${ }^{11}$.

Het aantal processen-verbaal daalde nog verder: in 1942 bedroeg het aantal 68; in 1943 nog slechts 12 en in de beide laatste oorlogsjaren bedroeg het totaal slechts $51^{12}$.

\subsection{De Veiligheidswet 1934}

Nadat vo6r de oorlog al een aantal veiligheidsbesluiten krachtens de Veiligheidswet 1934 was uitgevaardigd en in werking getreden - het Veiligheidsbesluit voor fabrieken of werkplaatsen 1938, voor veenderijen 1938, loodwit en het Elektrotechnisch Veiligheidsbesluit 1938 - trad het op 28 maart 1940 uitgevaardigde Veiligheidsbesluit gevaarlijke werktuigen ${ }^{13}$ op 1 juni 1940 in werking.

Maar ook ten aanzien van de Veiligheidswet 1934 gold, dat gebrek aan materialen in sommige bedrijven en de beperkte reisgelegenheden grote problemen opleverden aangaande de naleving van de wet. Werden in 1939 door de arbeidsinspectie nog 21702 eisen gesteld en aanwijzingen gegeven, in 1940 daalde dit aantal tot $12051^{14}$. In 1941 zou dit aantal weer stijgen tot $18263^{15}$. In de beide daaropvolgende oorlogsjaren bedroeg het aantal respectievelijk 14959, 16620, waarna een drastische daling optrad in 1944 en 1945 , namelijk respectievelijk 6970 en $3550^{16}$. 
Het aantal processen-verbaal opgemaakt in het kader van het Veiligheidsbesluit voor fabrieken of werkplaatsen 1938 geeft het volgende beeld te zien. Zo werden er in 1939 nog 40 processen-verbaal opgemaakt, in de twee eerste oorlogsjaren bedroeg dit aantal respectievelijk 13 en 21 , terwijl het aantal in 1942 opliep tot 41; in 1943 zouden slechts 6 processen-verbaal worden opgemaakt, terwijl de beide laatste oorlogsjaren een totaal kenden van $2^{17}$.

De uitzonderlijke situatie bracht met zich dat noodzakelijke beveiligingen en verbetering van werkplaatsen moesten worden uitgesteld tot betere tijden. Het aantal ongevallen, waarvan een kennisgeving ingevolge de Ongevallenwet de arbeidsinspectie bereikte, loog er dan ook niet om. In 1939 bedroeg het aantall ongevallen in fabrieken of werkplaatsen $173.315^{18}$; in de oorlogsjaren bedroeg het aantal respectievelijk 156.289 , $255.710,275.720,286.708,138.400$ en $80.904^{119}$. De cijfers over beide laatste jaren hebben slechts beperkte waarde daar van enkele districten als gevolg van de oorlogsomstandigheden geen of slechts onvolledige gegevens konden worden verkregen.

Toch kan wel als vaststaand worden aangenomen, dat het aantal ongevallen in 1945 aanmerkelijk lager was dan in 1944, terwijl dat jaar ook al een zeer aanzienlijke teruggang te zien gaf in vergelijking met 1943. Eén en ander was waarschijnlijk het gevolg van het geleidelijk stopzetten van zeer veel fabrieken; relatief is het aantal gevallen dan aanzienlijk en ongetwijfeld toe te rekenen aan de allertreurigste toestand waarin de bedrijven over het algemeen verkeerden ${ }^{20}$.

\subsection{De Rijtijdenwet 1936}

De bijzondere omstandigheden hebben ook hun sporen nagelaten wat betreft de toepassing van de Rijtijdenwet 1936. Deze wet was nog maar net op 13 augustus 1939 in werking getreden of de mobilisatie werd afgekondigd in verband met de internationale situatie. Dit had tot gevolg dat het spoorwegverkeer overbelast werd, waardoor enerzijds aan het autoverkeer bijzondere eisen werden gesteld, terwijl anderzijds een groot aantal automobielen aan zijn bestemming werd onttrokken op grond van vordering door de militaire autoriteiten. Nog los van het feit dat vele chauffeurs in militaire dienst werden geroepen. Eén en ander maakte dat de arbeids- en rusttijden voor de chauffeurs in vele gevallen moeilijk in acht genomen konden worden en vele overtredingen werden begaan.

$\mathrm{Na}$ de capitulatie werd het autoverkeer opnieuw geconfronteerd met nieuwe vorderingen, nu van de zijde van de bezetter. Bovendien trad al snel een schaarste aan motorbrandstof en smeerolie in, waardoor het aantal bedrijfsauto's snel verminderde; vele autoverhuurinrichtingen en transportondernemingen werden in haar werkzaamheden beperkt of moesten geheel worden stopgezet.

Hierdoor moest een belangrijk deel van het personen- en goederenvervoer worden overgenomen door de spoorwegen ${ }^{21}$. In het verdere verloop van de oorlogsjaren kwam in de situatie geen verbetering, integendeel; een nog sterker toenemend gebrek aan brandstoffen en smeermiddelen, de zeer slechte toestand, waarin de motorrijtuigen over het algemeen verkeerden, en de verdere vordering van vele motorrijtuigen, deed het aantal voertuigen nog verminderen. Het reizigersverkeer door middel van particuliere auto's staakte nagenoeg geheel. Het algemeen voorkomend gebrek aan geschoolde arbeidskrachten deed zich ook gevoelen ten aanzien van het transportbedrijf te land, zodat de naleving van de wettelijke voorschriften, welke toch al ernstig in het gedrang kwam, vanwege veelvuldige stagnatie in het vervoer door allerlei omstandigheden, nog eens extra bemoeilijkt werd, doordat men aangewezen was op minder bekwaam rijdend personeel. Bij controle van de zijde van de arbeidsinspectie werd de indruk verkregen, dat het met de naleving van de administratieve bepalingen niet zo nauw genomen werd. Veelvuldig kwam het voor, dat chauffeurs bij aanhouding geen of een ongeldig werkboekje in hun bezit hadden, waarbij de opmerking werd gemaakt, dat men in de veronderstelling verkeerde, dat de Rijtijdenwet 1936 niet meer van kracht was. Vanwege de bijzondere situatie, waarmee de werkgevers te kampen hadden, alsmede het algemeen belang, dat het transportwezen had te dienen, werd zoveel mogelijk volstaan met het geven van waarschuwingen ${ }^{22}$.

Een aantal cijfers geven aan, dat de Rijtijdenwet 1936 zienderogen aan betekenis inboette ${ }^{23}$. 
Zo werden in 1939 vanaf 13 augustus 107 ontheffingen voor het werkboekje en chauffeursregister verleend en werden er 903 ontheffingen van de bepalingen inzake arbeids-, rust- en diensttijden en nachtarbeid verleend. In 1940 bedroegen deze aantallen respectievelijk 1422 en 837 , om in 1941 enorm te dalen namelijk tot respectievelijk 28 en 175 . In de beide daaropvolgende jaren waren deze aantallen respectievelijk 54 en 79,33 en 57. Daarna werden in 1944 nog maar respectievelijk 20 en 21 ontheffingen verleend ${ }^{24}$.

\subsection{De Huisarbeidswet 1933}

De tijdsomstandigheden deden eveneens hun imvloed gelden op de omvang van de huisarbeid. De aanmaak van militaire kleding werd geheel stopgezet en reparatie-inrichtingen voor militaire kleding, wat vele werknemers van werk voorzag, werden opgeheven. De omvang van de huisarbeid zou als gevolg van een gebrek aan grondstoffen gestaag afnemen en dan met name in de kledingindustrie. Gedurende het eerste oorlogsjaar was hierop een uitzondering, namelijk in het maatkledingbedrijf. Dit beleefde een ongekende activiteit als gevolg van het feit, dat het publiek zich nog van kleding wilde voorzien van nog in voorraad zijnde goede stoffen, zowel vóór het van kracht worden van de distributiebepalingen als daarna in verband met het verstrijken van de geldigheidsduur van textielpunten ${ }^{26}$.

\subsection{De Steenhouwerswet 1921}

Eenzelfde beeld gold ten aanzien van de steenhouwersarbeid. In 1941 constateerde een aantal districtshoofden van de arbeidsinspectie een opleving in de branche. Als oorzaken hiervan werden onder meer gegeven, de moeilijkheden bij het betrekken van steen uit het buitenland, een toenemend gebruik van natuursteen en de wederopbouw werkzaamheden. Daarbij werd wel opgemerkt, dat een aantal grote bedrijven een spoedige teruggang in bedrijvigheid verwachtte wegens gebrek aan grondstoffen. Vandaar dat enige grote(re) bedrijven zich dan ook al gingen toeleggen op het vervaardigen van grof werk, waardoor kleinere bedrijven die in hoofdzaak hieraan hun bestaansrecht ontleenden, in de problemen zouden komen. De problemen die zich voordeden en nog voor zouden doen waren dusdanig, dat in 1945 de vrees uitgesproken werd, dat wanneer er niet iets gebeurde, de steenhouwerij in ons land verloren zou gaan ${ }^{26}$.

\section{Maatregelen betreffende het beperken van werk}

Naast de uitvoering van haar wettelijke taak, waarin de arbeidsinspectie door de bijzondere situatie belemmerd werd en welke naar de achtergrond werd verdrongen, was met name haar bekendheid met de bedrijven de oorzaak van het feit, dat verreweg het grootste gedeelte van haar werkzaamheden betrekking had op maatregelen uitgevaardigd door of namens de bezetter.

De bijzondere omstandigheden, waarin ons land sinds 10 mei 1940 verkeerde, hebben het bedrijfsleven uiteraard niet ongemoeid gelaten. De onzekere toekomst, ook op financieel gebied, leidde al direct tot een streven naar onmiddellijke verlaging van de produktiekosten, waarbij werd overgegaan tot een vermindering van de personeelskosten door middel van ontslag van werknemers en een vermindering van de werktijd.

Teneinde de werkgelegenheid op peil te houden en ontwrichting van de arbeidsmarkt door massaontslagen en ook verdere onbillijke ontslagen te voorkomen, was de bezetter genoodzaakt maatregelen te treffen om een volledige chaos te voorkomen ${ }^{27}$.

Zo werd op 27 mei 1940 een besluit van de opperbevelhebber van land-en zeemacht betreffende het verbod van stopzetting van de arbeid ${ }^{28}$ uitgevaardigd.

Dit besluit bevatte een verbod om nà $27 \mathrm{mei}$, zonder vooraf verkregen schriftelijke vergunning van of namens de directeur-generaal van de Arbeid, de arbeid in een onderneming blijvend of tijdelijk stop te zetten, de arbeidsduur te verminderen tot minder dan 36 uren per week of gedurende een tijkvak van 30 achtereenvolgende dagen 25 of meer arbeiders in een onderneming, al of niet tegelijkertijd, te ontslaan ${ }^{20}$. 
De uitvoering en toepassing van het besluit werd derhalve in handen van de arbeidsinspectie gelegd, die zich hiermee een voor haar geheel nieuwe taak zag toebedeeld. De werkzaamheden, die uit dit besluit voortvloeiden, legden nauwelijks beslag op de arbeidsinspectie, gezien de beperkte strekking van het besluit - het zou slechts van kracht zijn van 28 mei tot 13 juni 1940 - en het feit, dat de genoemde handeling nà 27 mei 1940 verboden werd, terwijl juist voor die datum zeer vele ontslagen hadden plaatsgevonden, die niet aan enige goedkeuring waren onderworpen ${ }^{30}$. Aan de werkgevers werd de verplichting opgelegd vóór 3 juni 1940 het districtshoofd van de arbeidsinspectie in kennis te stellen van het gedurende 10 tot 28 meil 1940 hetzij doen stopzetten van de arbeid in de onderneming, hetzij al dan niet tegelijkertijd ontslaan van 25 of meer arbeiders $^{\text {at }}$.

Het aantal kennisgevingen bedroeg respectievelijk 356 en 216 . Het aantall ontslagvergunningen bedroeg slechts 16 , terwijl niet meer dan 13 vergunningen terzake van het verbod van werktijdverkorting werden verleend ${ }^{32}$.

Anders zou het worden toen op 11 juni daaropvolgend dit besluit werd vervangen door de verordening van 11 juni 1940 betreffende het beperken van werk van de Rijkscommissaris voor het bezette Nederlandse gebied, waarbij de secretaris-generaal van het Ministerie van Sociale Zaken gemachtigd werd voorschriften uit te vaardigen betreffende het stilleggen van ondernemingen, de invoering van werktijdverkorting en het ontslaan van werknemers, zonodig onder strafbedreiging ${ }^{33}$.

Deze Verordening werd uitgewerkt in het Eerste Uitvoeringsbesluit van genoemde secretaris-generaal eveneeus van 11 juni $1940^{34}$.

Hierbij werden de voorheen geldende voorschriften aldus uitgebreid, dat ontslag van werknemers voortaan werd verboden, tenzij artikel 1639 p van het Burgerlijk Wetboek toepasselijk was ${ }^{35}$.

Verder moesten alle op 9 mei 1940 gegeven ontslagen terstond weer ongedaan gemaakt worden, tenzij deze door de directeur-generaal van de Arbeid waren goedgekeurd ${ }^{36}$. Uitvoering van dit besluit was opnieuw in handen van de arbeidsinspectie gelegd ${ }^{37}$. Nieuw aan dit uitvoeringsbesluit was de strafbedreiging die aan het eerdere besluit had ontbroken; opsporing van overtredingen was onder meer opgedragen aan de arbeidsinspectie $^{38}$. De meeste beslissingen aangaande dit besluit zouden op centraal niveau door de directeur-generaal zelf genomen worden. Daarbij heeft hij een systeem opgezet waardoor het mogelijk was zich op ruime schaal de medewerking te verzekeren van deskundigen in allerlei bedrijfstakkn, mannen uit het organisatieleven, en, waar de verhoudingen het toelieten, paritair ingestelde instanties van werkgevers en van arbeiders. De zogenaamde vertrouwensinstanties ${ }^{39}$ beoordeelden het verzoek en bereidden de beslissing voor, die aan de directeur-generaal voorbehouden bleef ${ }^{40}$. Dit Eerste Uitvoeringsbesluit had het gevolg, dat vrijwel iedere ontslagaanvraag van werkgeverszijde onder de controle van de arbeidsinspectie was gebracht. Volgens Levenbach $^{41}$ had dit beslluit nog in hoofdzaak een sociale strekking - het behoud van werkgelegenheid en bescherming van de individuele arbeider -, waarbij de uitvoering in betrouwbare Nederlandse handen lag, namelijk de arbeidsinspectie.

Het besluit bracht een enorm hoeveelheid werk met zich mee voor de arbeidsinspectie, en well zodanig dat deze met de bestaande personeelsbezetting niet te verwerken was. Het personeel van de arbeidsinspectie moest dan ook in belangrijke mate versterkt worden door tijdelijke arbeidskrachten ${ }^{42}$.

Zo werden in 194016021 vergunningen verleend aangaande ontslag ten gevolge van abnormale omstandigheden, zoals bijvoorbeeld gebrek aan grondstoffen, orders en benzine, 54086 vergunningen aangaande ontslag ten gevolge van normale omstandigheden, zoals bijvoorbeeld het gereedkomen van tijdelijke werken. Voorts werden 1464 ontheffingen van het verbod van werktijdverkorting afgegeven en 569 ontheffingen om een bedrijf voorgoed of tijdelijk stil te leggen ${ }^{43}$. Voor het daaropvolgende jaar bedragen de aantallen respectievelijk $8372,37805,3185$ en $241^{44}$. Als oorzaak van de daling kan onder andere gewezen worden op het uitvaardigen van algemene vergunningen onderscheidenlijk ontheffingen ${ }^{45}$.

Ten aanzien van het verbod van werktijdverkorting en het ontslagverbod werden in 1940 door de arbeidsinspectie respectievelijk 3 en 503 processen-verbaal opgemaakt, terwijl in 1941 aangaande het verbod om een bedrijf voorgoed of tijdelijk stil te leggen slechts 1 proces-verbaal werd opgemaakt; hetzelfde gold voor het 
verbod van werktijdverkorting. Varwege overtreding van het ontslagverbod werden 357 processen-verbaal opgemaakt ${ }^{48}$.

Onmiddellijk na het in werking treden van het Eerste Uitwoeringsbesluit werd de arbeidsinspectie overspoeld met mondelinge en schriftelijke klachten. Een aantal van deze klachten vergde geen verdere bemoeienissen van de arbeidsinspectie, omdat de ontslagen, die meer een gevolg waren van de enerverende omstandigheden dan uilt noodzaak bleken te zijn verleend, weer werden ingetrokken. Van de zijde van de arbeidsinspectie werd aangenomen, dat over 1940 ettelijke tienduizenden klachten met betrekking tot het besluit aan haar ter behandeling werden voorgelegd. Alle daarvoor in aanmerking komende klachten werden onderzocht; terwijl de uitkomst aan de klagers werd medegedeeld ${ }^{47}$. In het daaropvolgende jaar liep het aantal klachten aanzienlijk terug. Het jaarverslag over 1941 vermeldde een tweetal klachten die illustratief genoemd wer$\operatorname{den}^{48}$ :

"Een klager was ontslagen op het motief "inkrimping van het bedrijf". Bij een in verband hiermede nader ingesteld onderzoek bleek, dat de inkrimping van het bedrijf betrekking had op de inbeslagneming van 125 varkens door den Crisiscontrolledienst. De ontslagvergunning werd ingetrokken. Een bedrijfsleider was wegens diefstal ontslagen en diende hierover een klacht in. $\mathrm{Bij}$ het ingestelde onderzoek kwam de gepleegde diefstall echter volledig aan het licht, zoodat de brutale klager weinig genoegen van zijn klacht beleefde."

De belangen van de Duitse oorlogsvoering zouden, naarmate de tijd verstreek, steeds meer op de voorgrond treden. Een gevolg daarvan was, dat de arbeidsmarktpolitiek van de bezetter daar langzaam maar zeker op werd afgestemd. De oorlogsdoeleinden vereisten het overbrengen van Nederlandse arbeidskrachten naar Duitsland - "Arbeitseinsatz" - en maakten een streng doorgevoerde gecentraliseerde organisatie van de arbeidsbemiddeling nodig. Een aanzet daartoe was al het Besluit van 24 september $1940^{49}$ van de secretarisgeneraal van het ministerie van Sociale Zaken en de daarmee in verband staande oprichting van het $R$ ijksarbeidsbureau als orgaan van openbare arbeidsbemiddeling, bestaande uit een hoofdbureau en gewestelijke arbeidsbureaus $^{50}$. Daarmee was een einde gemaakt aan het onderscheid, dat de Arbeidsbemiddelingswet $1930^{51}$ maakte tussen openbare en bijzondere - de niet van de overheid uitgaande - arbeidsbemiddeling. De wet onderscheidde een drietal organen van openbare arbeidsbemiddeling, namelijk de gemeentelijke arbeidsbeurzen, de districtsbeurzen en het rijksorgaan voor de arbeidsbemiddeling ${ }^{52}$. Nadat aanvankelijk alleen het Rijksarbeidsbureau werd georganiseerd, werden de gemeenten in de nieuwe situatie bij circulaire van de waarnemend secretaris-generaal van het ministerie van Sociale Zaken van 27 maart 1941 bericht over het feil, dat op 1 mei van dat jaar de gewestelijke arbeidsbureaus hun werkzaamheden zouden aanvangen ${ }^{53}$.

De eerste bemoeienis van deze nieuwe arbeidsbemiddelingsorganen met het ontslagrecht vond plaats op grond van het Derde Uitvoeringsbesluit van de secretaris-generaal van het ministerie van Sociale Zaken van 20 februari $1942^{54}$, waarbij het Eerste Uitwoeringsbesluit werd ingetrokken met ingang van dezelfde datum.Naast het verbod van werktijdverkorting beneden 48 uren per week werd het ontslagverbod, dat echter ook nu weer niet gold wanneer artikel 1639 p van het Burgerlijk Wetboek van toepassing was, gehandhaafd; eén en ander behoudens toestemming van de directeur-generaal van de Arbeid of de door hem gemachtigde districtshoofden van de arbeidsinspectie ${ }^{55}$. Opnieuw was de uitvoering in handen van de arbeidsinspectie gelegd, die eveneens belast was met de opsporing van overtredingen ${ }^{66}$. Nieuw echter was dat, voordat een beslissing genomen werd, de directeur-generaal van de Arbeid en de districtshoofden van de arbeidsinspectie, respectievelijk de directeur-generaal van het Rijksarbeidsbureau en de directeuren van de bevoegde gewestelijke arbeidsbureaus moesten horen ${ }^{57}$. Dit betekende een wijziging in de tot dan toe door de directeur-generaal van de Arbeid en de districtshoofden van de arbeidsinspectie gevolgde procedure; er waren nu immers twee adviesinstanties, namelijk de vertrouwensinstanties en het Rijks- dan wel gewestelijk arbeidsbureau. In een brief van 7 april 1942 aan de directeur-generaal van het Rijksarbeidsbureau deelde de directeur-generaal van de Arbeid mee, dat alleen die aanvragen voor advies aan het Rijks- dan wel gewestelijk arbeidsbureau zouden worden gezonden als het advies van de vertrouwensinstantie positief was. De directeur-generaal van het Rijksarbeidsbureau had namelijk in een ontwerpcirculaire van 7 maart 1942 aan de 
directeuren van de gewestelijke arbeidsbureaus gesteld, dat er overeenstemming diende te worden bereikt tussen de beide overheidsinstanties over de te nemen beslissing: een stelling die overigens niet noodzakelijkerwijs voortvloeide uit de redactie van het Derde Uitvoeringsbesluit ${ }^{53}$.

Gedurende het jaar 1942 werden er door de arbeidsinspectie 5211 ontslagvergunningen verleend ten gevolge van abnormale omstandig heden en 18818 ontslagvergunningen ten gevolge van normale omstandigheden. Van het verbod van werktijdverkorting werden 14234 ontheffingen verleend, terwijl tot 23 februari 194249 ontheffingen werden verleend om bedrijven voorgoed of tijdelijk te kunnen sluiten. Bovendien werden in dat jaar 228 processen-verbaal opgemaakt ${ }^{59}$.

Hoewel het aantal klachten in 1942 daalde tot in totaal 6480, werden zij wel als een belangrijk onderdeel van de uitvoering van het Derde Uitvoeringsbesluit beschouwd. Een niet gering percentage van de klachten had betrekking op ontslag op staande voet wegens bonnen-tekorten, waarbij de werkgever in het algemeen diefstal aannam, terwijl de arbeider allerlei omstandigheden buiten zijn schuld als oorzaak opgaf. Kon bij het ingestelde onderzoek niet voldoende resultaat worden bereikt, dan werd de klager naar de kantonrechter verwezen en werd, wanneer daar aanleiding voor was, tegen de werkgever proces-verbaal opgemaakt.

Betrof het ontslag op staande voet aangelegenheden die minder ernstig van aard waren, zoals brutaliteit, te laat komen, vechten en dergelijke, dan werd via overleg een gunstige oplossing bereikt, zodat de betrokkene weer in dienst werd genomen. Ook nu wordt een klacht uitvoeriger vermeld om enig inzicht te geven in de aard van de klachten ${ }^{60}$.

"De eigenares van eenige parfumeriezaken wenschte een filiaalhouder te ontsllaan, omdat de omzet van het filiaal wegens gebrek aan goederen sterk was teruggelopen. De werkgeefster bleek in haar motiveering niet te goeder trouw te zijn. De filiaalhouder kon namelijk aantoonen, dat de omzet in het laatste jaar aanmerkelijk hooger was geweest dan in de voorafgaande jaren. Voorts bleek nog een groote voorraad goederen in het magazijn aanwezig te zijn. Mitsdien werd de vergunning geweigerd. Hierna volgde een nieuwe aanvraag, waarin als motivering werd gebezigd, dat aanvraagster het filiaal om gezondheidsredenen niet kon aanhouden. Ook dat verzoek werd afgewezen.

Kort daarna werd de filiaalhouder op staande voet ontslagen op grond van een onverwacht opgemaakte balans, welke een tekort van fl. 500,-- aanwees. Klager liet op advies van zijn advocaat een contra-ballans opmaken, welke uitwees, dat er een overwaarde van fl: $300,--$ aanwezig was. Thans werd een proces-verbaal opgemaakt. De door den klager ingestelde vordering werd door den rechter toegewezen."

Voor zover het de beëindiging van de dienstbetrekking betreft zou het Derde Uitvoeringsbesluit vervangen worden door een Verordening van 1 maart 1943 over de beperking ten aanzien van het veranderen van betrekking $^{\text {o1 }}$. De uitvoering van deze Verordening werd in handen gelegd van de directeuren van de gewestelijke arbeidsbureaus, die nu toestemming moesten verlenen, wilde de dienstbetrekking hetzij door de werkgever, hetzij door de werknemer opgezegd kunnen worden ${ }^{62}$. De beslissing op ontslagaanvragen kan nu genomen worden zonder de tot dan bestaande advies-procedure, welke de bezetter, gezien de vaak lange duur ervan, een doorn in het oog was geweest ${ }^{63}$. De rol van de arbeidsinspectie, als ook van haar vertrouwensinstanties bij ontslagzaken gedurende de bezettingstijd was ten einde. Tot 1 maart 1943 werden er nog 418 ontslagvergunningen wegens abnormale omstandigheden en 2218 ontslagvergunningen ten gevolge van normale omstandigheden verleend en werden er 16 processenverbaal opgemaakt. Het aantal klachten bedroeg in die periode nog slechts 667. De bemoeienissen van de arbeidsinspectie met het Derde Uitvoeringsbesluit werden beperkt tot het verbod van werktijdverkorting. De als gevolg hiervan ingetreden werkvermindering maakte de taak van de vertrouwensinstanties vrijwel overbodig, zodat zij op 1 maart 1943 door de directeur-generaal van de Arbeid werden opgeheven ${ }^{84}$. Met deze Verordening heeft de Duitse bezetter bewerkstelligd, dat zowel de arbeidsbemiddeling, als de hantering van het ontslagverbod in een, de bezetter niet onwillige, hand was gekomen, namelijk het Rijksarbeidsbureau en het gewestelijke arbeidsbureau, waardoor zijn greep op het arbeidspotentieel in ons land aanmerkelijk vereenvoudigd was.

Maar de bezetter had bij deze manoeuvre é́n ding over het hoofd gezien. Aan de goedkeuring van de ar- 
beidsinspectie bleef echter onderworpen het toepassen van werktijdverkorting. Dit bracht, om de woorden van Kuiper an te halen; de directeur-generaal van de arbeid Hacke op én van zijn lumineuze ideeën. Hij vervolgde met de volgende woorden:

"Welmu, men kan dus in plaats van ontslag, dat de arbeiders in handen der Duitsers dreef, ook vergunning vragen om de werktijd te verkorten .....tot 0 uur."

De werkgevers werd aangeraden om in plaats van een ontslagvergunning voor overtollige arbeiders een verzoek in te dienen voor cen zogenaamde "nul-uren"-vergunning. Hierdoor bleef het dienstverband met de onderneming bestaan en werden de betrokkenen aan de directe greep van de bezetter onttrokken. Van deze mogelijkheid werd op zeer ruime schaal gebruik gemaakt. Kuiper spreekt van vele duizenden "nul-uren"-vergunningen ${ }^{88}$.

\section{Maatregelen omtrent lonen, salarissen en andere arbeidswoorwaarden}

Door de bezettende militaire autoriteiten werd onmiddellijk naast een verbod van loonsverhoging zonder vergunning, een verbod van verhoging van de prijzen en andere vergoedingen uitgevaardigd ${ }^{67}$. Hiermee werd beoogd te voorkomen dat er een economische chaos zou ontstaan als gevolg van het plotseling stijgen van lonen en prijzen. Het voorschrift is echter nooit verder uitgewerkt ${ }^{68}$. Vrij kort na de bezetting bleken er echter eerder ontwrichtingen in een andere richting te vrezen, namelijk in die van willekeurige loonsverlaging. Aangezien staking en uitsluiting en het bewegen van anderen daartoe eveneens door de bezetter verboden waren ten einde het zoveel mogelijk ongestoord doorfunctioneren van de produktie te bevorderen, moest er derhalve een andere instantie de mogelijkheid hebben hierin te voorzien. Bij het besluit van 24 mei 1940 van de opperbevelhebber van land-en zeemacht ${ }^{69}$ werd de mogelijkheid gecreëerd een bindende beslissing over arbeidsvoorwaarden door een overheidsorgaan uit te lokken. Deze taak werd toevertrouwd aan functionarissen die ook tot dusverre in arbeidsgeschillen namens de overheid een oplossing plachten te bevorderen, namelijk aan de rijksbemiddelaars ${ }^{70}$. Het genoemde besluit kende aan ieder van die partijen van een collectieve arbeidsovereenkomst, die meende, dat deze gewijzigd diende te worden, maar daarvoor geen medewerking kreeg van de wederpartij, het recht toe zich tot het College van Rijksbemiddelaars te wenden ${ }^{71}$. Hetzelfde kon de werknemer doen van wie het loon thà 9 mei 1940 in onredelijke mate was verlaagd of van wie de arbeidsvoorwaarden na die datum belangrijk ongunstiger waren geworden ${ }^{72}$. Het college van Rijksbemiddelaars probeerde in eerste instantie, evenals de rijksbemiddelaars tot dan deden, in de minne een voor beide partijen bevredigende regeling te vinden. Eerst wanneer dit niet mogelijk was, stelde het college zelf een voor partijen bindende regeling vast ${ }^{73}$.

Het besluit werd op 27 augustus 1940 ingetrokken door de Verordening van de rijkscommissaris voor het bezette Nederlandse gebied betreffende het verbod van verlaging van lonen en salarissen ${ }^{74}$. De strekking van deze Verordening was, dat verlaging van lonen en salarissen zonder toestemming, voor zover er in het kader van een (collectieve) arbeidsovereenkomst geen overeenstemming was bereikt, verboden was ${ }^{75}$. De secretaris-generaal van het ministerie van Sociale Zaken werd gemachtigd voorschriften, zonodig onder strafbedreiging, uit te vaardigen ${ }^{76}$. Eén en ander gebeurde in het Eerste Uitvoeringsbesluit van 2 september $1940^{77}$, dat op dezelfde datum in werking trad. De uitwoering van dit besluit werd in handen gelegd van het College van Rijksbemiddelaars, dat toestemming kon geven om de lonen en salarissen te verlagen hetzij bij individuele, hetzij bij collectieve arbeidsovereenkomst ${ }^{78}$. De voldoende gemotiveerde, schriftelijke verzoeken om vergunning moesten bij het College van Rijksbemiddelaars worden ingediend; de vergunning kon voor bepaalde tijd en voorwaardelijk worden verleend ${ }^{7 \theta}$. Deze bepaling gaf aan het college van Rijksbemiddelaars een ruimerrijheid om doelmatig-regelend op te treden. Door deze bepaling was het mogelijk, indien het onderzoek omtrent de hoogte van de verlaging, geruime tijd in beslag dreigde te nemen, een voorlopige, voor een korte tijd durende vergunning te verlenen ${ }^{80}$.

De werkgever was verplicht aan het College van Rijksbemiddelaars op diens verzoek alle gegevens te verstrekken, die nodig waren voor de behandeling wan het verzoek. Voordat een vergunning tot verlaging van bij een collectieve arbeidsovereenkomst geregelde lonen, verleend werd, werd aan de bij deze collectieve 
arbeidsovereenkomst betrokken partijen gelegenheid geboden hun standpunt uiteen te zetten ${ }^{81}$.

De beslissing werd aan de werkgever schriftelijk medegedeeld, terwijl tevens een afschrift werd gezonden aan het bevoegde districtshoofd van de arbeidsinspectie, hetgeen doelmatig was, omdat ambtenaren van de arbeidsinspectie met de opsporing van de strafbaar gestelde handelingen waren belast ${ }^{82}$. Daarnaast werd het College van Rijksbemiddelaars in 1941 door de arbeidsinspectie van advies gediend omtrent 10, in 1942 11, aanvragen om loonsverlaging te mogen doorvoeren en was de arbeidsinspectie belast met het onderzoek van ingekomen klachten, mede ten behoeve van het college van rijksbemiddelaars; in 1941 en 1942 zou dit respectievelijk 37 en 14 maal gebeuren ${ }^{23}$. Bij de Verordening van 28 november 1940 van de rijkscommissaris voor het bezette Nederlandse gebied betreffende de totstandkoming van regelingen inzake lonen, salarissen en andere voorwaarden ${ }^{34}$ werd verordeneerd, dat nieuwe collectieve arbeidsovereenkomsten, alsmede wijzigingen van bestaande collectieve arbeidsovereenkomsten goedkeuring behoefden voor zover daarbij loonof salarisverhogingen waren getroffen ${ }^{85}$. Bovendien werd de secretaris-generaal van het ministerie van Sociale Zaken gemachtigd een onder hem ressorterende instantie bindende regelingen te laten voorschrijven inzake lonen, salarissen en andere arbeidsvoorwaarden, alsmede bepalingen van collectieve arbeidsovereenkomsten algemeen verbindend of onverbindend te laten verklaren ${ }^{86}$. Eên en ander werd uitgewerkt in het Eerste Uitvoeringsbesluit van 30 november 1940 , dat op dezelfde dag in werking trad ${ }^{87}$. De bevoegde instantie werd het College van Rijksbemiddelaars. Een beslissing omtrent een bindende regeling, dan wel algemeen verbindend of onverbindend verklaren van bepalingen van een collectieve arbeidsovereenkomst werd aan het bevoegde districtshoofd van de arbeidsinspectie gezonden, ook weer omdat ambtenaren van de arbeidsinspectie belast waren met de opsporing van de strafbaar gestelde handelingen ${ }^{88}$. Dit zelfde gold ook ten aanzien van het Derde Uitvoeringsbesluit van 30 juli 1941, dat eerst op 25 augustus in werking zou treden $^{39}$. De strekking van dit besluit was te voorkomen, dat door het aanbieden van een hoger loon of andere gunstiger arbeidswoorwaarden werknemers uit de dienstbetrekking, waarin zij werkzaam waren, zouden worden weggelokt ${ }^{\theta 0}$. De werkzaamheden ten behoeve van de beide Verordeningen namen in 1941 toe in omvang als gevolg van een belangrijke toeneming van het aantal algemeen verbindend te verklaren bepalingen van collectieve arbeidsovereenkomsten en het bindend vaststellen van regelingen van arbeidsvoorwaarden. Door de arbeidsinspectie werden onderzoeken verricht naar aanleiding van klachten over de niet-naleving van deze Verordening. Ook werden onderzoeken ingesteld ten behoeve van het College van Rijksbemiddelaars naar de gegrondheid van verzoeken om vergunning tot afwijking van vastgestelde regelingen. Zo werden er op verzoek van het College van Rijksbemiddelaars in 194113 onderzoeken ingesteld naar de naleving van algemeen verbindend verklaarde bepalingen van collectieve arbeidsovereenkomsten naar aanleiding van bij dat college ingekomen klachten. Bovendien werd in verschillende gevallen aandacht besteed aan rechtstreeks bij de arbeidsinspectie ontvangen analoge klachten. Daarnaast werden er onder meer 35 bij het College van Rijksbemiddelaars binnengekomen klachten van werknemers over een te laag loon onderzocht en werden er 15 klachten door het college van Rijksbemiddelaars ontvangen klachten van werkgevers omtrent overtreding van het Derde Uitvoeringsbesluit onderzocht ${ }^{\theta \|}$.

Beide hiervoor genoemde Verordeningen, alsmede de Arbeidsgeschillenwet 1923, de Wet op de collectieve arbeidsovereenkomst en de Wet op het algemeen verbindend en het onverbindend verklaren van bepalingen van collectieve arbeidsovereenkomsten 1937 werden ingevolge de Verordening van 13 oktober 1942 van de rijkscommissaris voor het bezette Nederlandse gebied betreffende-de ordening van de arbeid, op 1 november van dat jaar buiten werking gesteld ${ }^{82}$. Daarmee werd een einde gemaakt aan de collectief-contractuele basis van algemene regelingen van arbeidswoorwaarden, alsmede aan het Nederlandse College van Fijksbemiddelaars. De regelende bewoegdheid inzake arbeidsvoorwaarden werd opgedragen aan de gemachtigde van de arbeid $^{\text {} 3}$.

Met de uitvoering van deze Verordening had de arbeidsinspectie officieel geen bemoeienis, maar er werden desalniettemin voor de gemachtigde van de arbeid overeenkomstige werkzaamheden verricht als voordien voor het College van Rijksbemiddelaars. Zo werden in 1942 op verzoek van het college van Rijksbemiddelaars of de gemachtigde van de arbeid bijwoorbeeld 48 onderzoeken ingesteld naar aanleiding van ingekomen klachten over het niet-naleven van bindende vastgestelde regelingen van arbeidswoorwaarden; en werden 75 
onderzoeken verricht in verband met verzoeken om vergunning tot afwijking van bepalingen van een regeling van arbeidsvoorwaarden. Ten aanzien van het Derde Uitvoeringsbesluit omtrent het aanbieden van "loklonen" werden 41 klachten onderzocht ${ }^{94}$.

\section{Het Bedriflsvergunnilingenbesluit 1941 en het Kartelbesluit}

\subsection{Het Bedrijfsvergunningenbesluit 1941}

In de loop van 1941 werd de arbeidsinspectie ingeschakeld bij de controle op de naleving van het Bedrijfsvergunningenbesluit $1941^{\circ 5}$, dat op 28 juni 1941 in werking trad. Op grond van dit besluit, dat de Bedrijfsvergunningenwet 1938 verving, was het vestigen en het uitbreiden van een industrieel bedrijf of het daarin ter hand nemen van de fabrikage van andere goederen, alsmede het vestigen van een handelsbedrijf of het daarin gaan verhandelen van andere goederen dan op het tijdstip van de inwerkingtreding van het besluit in het algemeen in soortgelijke bedrijven werden verhandeld, verboden voor zover daartoe geen toestemming door de secretaris-generaal van het ministerie van Handel, Nijverheid en Scheepvaart ${ }^{96}$ was verleend. Betrof het echter bedrijven, die zich bewogen op het terrein van de voedselvoorziening, als omschreven in artikel 1 van het Organisatiebesluit Voedselvoorziening $1941^{97}$, dan moest de vereiste toestemming verleend worden door het ministerie van Landbouw en Visserij. Een en ander leidde ertoe, dat er tussen de arbeidsinspectie en deze genoemde ministeries en de daaronder ressorterende rijksbureaus samengewerkt werd. Deze rijksbureaus riepen herhaaldelijk de bemiddeling in van de arbeidsinspectie om in bepaalde gevallen controle uit te oefenen en adviezen te verstrekken. Daarnaast werd in het bijzonder bij de behandeling van Hinderwetaanvragen nagegaan, of de betrokken onderneming aan de bepalingen van thet Bedrijfsvergunningenbesluit 1941 had voldaan ${ }^{88}$.

\subsection{Het Kartelbesluilt}

Nog in hetzelfde jaar zou de arbeidsinspectie betrokken worden bij de controle op de naleving van het Kartelbesluit $^{\text {9日e}}$, dat op 12 november 1941 in werking trad. Dit besluit stelde de Wet op het algemeen verbindend en onverbindend verklaren van ondernemingsovereenkomsten 1935 buiten werking ${ }^{100}$ en gaf een regeling ter zake van het algemeen verbindend verklaren dan well vaststellen van algemeen verbindende bedrijfsregelingen ${ }^{101}$, alsook ter zake van het geheel of gedeeltelijk onverbindend verklaren hiervan door de secretaris-generaal van het ministerie van Handel, Nijverheid en Scheepvaart ${ }^{102}$. Over de activiteiten van de arbeidsinspectie in dezen ontbreekt naar mijn weten nadere informatie.

\section{Distributie}

Aan het centraal distributiekantoor werd medewerking verleend omtrent het vaststellen van richtlijnen voor de uitvoering van de distributiemaatregel tot het verstrekken van extra zeep aan die arbeiders, die als gevolg van het door hen uitgeoefende beroep blootgesteld werden aan grote vervuiling van lichaam en/of kleding, alsook bij de toewijzing van deze rantsoenen. Tevens werden aan dit distributiekantoor adviezen uitgebracht over het verstrekken van extra broodrantsoenen en extra rantsoenen van andere levensmiddelen aan de daarvoor in aanmerking komende arbeiders; werd geadviseerd omtrent het toewijzen van koffie en thee aan kantines en schaftlokalen van ondernemingen en extra rantsoenen melk aan arbeiders die daarvoor op grond van zware of van voor de gezond heid schadelijke arbeid in aanmerking kwamen en werd voorlichting gegeven omtrent de toewijzing van schoenen, werkschoenen en klompen aan arbeiders, die als gevolg van de soort arbeid die zij verrichtten, bescherming van de voeten nodig hadden. Eén en ander maakte het instellen van tal van onderzoeken in de betreffende bedrijven/bedrijfstakken door de arbeidsinspectie noodzakelijk. In 1943 kwain hierin een belangrijke wijziging, daar vanaf 1 februari van dat jaar alleen over aanvragen van chemische bedrijven nog maar advies behoefde te worden gegeven ${ }^{103}$. 
Ook bracht de arbeidsinspectie adviezen uit aan het rijksbureau voor verwerkenden industrieën, sectie metaalverwerkende industrie ten aanzien van aanvragen, die betrekking hadden op de distributie van elektrotechnische produkten.

Op 5 september 1942 trad een regeling voor de distributie van drijfriemen in werking, waarbij, voor wat betreft de uitvoering, de arbeidsinspectie werd betrokken. De ambtenaren van deze dienst controleerden ter plaatse de door de aanvragers verstrekte gegevens, waarna hun bevindingen werden gezonden aan de rijksnijverheidsdienst, waarna aan de hand van deze laatste dienst opgemaakte rapporten door het rijksbureau voor huiden en leder werd beslist of toestemming tot aanschaffing verleend kon worden. Een onderzoek naar de gegrondheid van de aanvragen leidde de ambtenaren van de arbeidsinspectie vaak naar de meest afgelegen oorden, wat in verband met de grote problemen, die zich ten aanzien van de reismogelijkheden voordeden, uiterst tijdrovend was. Bovendien was de administratieve verwerking nogal omvangrijk.

In 1943 kwam contact tot stand met het rijksbureau voor de distributie van textielprodukten dat door de arbeidsinspectie verschillende malen voor advies werd gediend met betrekking tot vergunningen voor het betrekken van werkkleding ${ }^{104}$.

\section{Andere activiteiten}

Aan de algemeen gemachtigde voor de wederopbouw en voor de bouwnijverheid werd, voor zover het industriële projecten betrof, advies uitgebracht over aanvragen tot goedkeuring van de uitvoering van bouwwerken. In 1940 werd over 642 gevallen gerapporteerd; in 1941 was dit aantal 882. Noopte de positie van de bouwmaterialen, zoals bijvoorbeeld hout, in 1940 tot grote voorzichtigheid omtrent de goedkeuring van de uitvoering van een bouwproject, in 1941 werd de positie van de materialen steeds nijpender, zodat de aan de urgentie van de objecten te stellen normen alsmaar werden verzwaard. In het laatstgenoemde jaar werd steeds meer afgezien van de voorgenomen uitvoering van een bouwwerk en daalde derhalve het aantal aanvragen om goedkeuring, met name in de tweede helft van dit jaar. Daar de genoemde omstandigheden een steeds intensiever onderzoek noodzakelijk maakten, namen de bemoeienissen van de arbeidsinspectie in deze periode nog toe. Het gebrek aan benodigde bouwmaterialen werd echter dusdanig, dat het aantal uit te brengen adviezen te verwaarlozen was, waarop in januari 1942, besloten werd de door de arbeidsinspectie uit te voeren werkzaamheden in deze te staken ${ }^{105}$.

\section{De Stichting van de Arbeid}

Al snel na de bezetting op 15 juli 1940 werd een einde gemaakt aan het zelfstandige bestaan van het Nederlandse Verbond van Vakverenigingen, doordat deze organisatie onder het bewind van H.J. Woudenberg werd gesteld ${ }^{100}$. Ruim een jaar later, op 25 juli 1941, werd dezelfde Woudenberg tot commissaris van het Roomsch-Katholiek Werkliedenverbond en van het Chistelijk Nationaal Vakverbond benoemd, waarop de arbeiders in grote getale hun vakbonden verlieten, zodat er al snel van deze organisaties niet veel meer overbleef $^{107}$. Eén en ander leidde ertoe, dat de werkgevers ter zake hun standpunt moesten bepalen. Onder de invloed van de oorlogsdreiging was kort vó6r de bezetting door de centrale werkgeversorganisaties op instigatie van het Verbond van Nederlandsche Werkgevers een Commissie van Overleg voor Centrale Bonden van Werkgevers ten behoeve van de samenwerking op sociaal terrein opgericht. De behoefte aan verdergaande samenwerking tegenover de bezetters leidde in juni 1940 tot de oprichting van het Orgaan van overleg in arbeidszaken, waarin de centrale-organisaties van werkgevers, arbeiders, middenstanders en boeren vertegenwoordigd waren.

Het eenheidsstreven van de bezetter, dat uiteindelijk ertoe leidde, dat het Nederlandsch Arbeidsfront op 1 mei $1942^{108}$ werd opgericht, maakte dat eind 1940 op voorstel van werkgeverszijde werd besloten tot de oprichting van een Raad van Bestuur in Arbeidszaken, die op 1 maart 1941 werd geinstalleerd; een organisatievorm die slechts een kort leven beschoren zou zijn. Op 6 augustus van dat jaar werd besloten, dat het niet langer gerechtvaardigd was met de aan arbeiderszijde bestaande organisaties, die inmiddels niet meer de 
geestelijke stromingen in Nederland veregenwoordigden, samen te werken. Op 11 augustus daaropvolgend werden zowel de Raad van Bestuur in Arbeidszaken als de centrale werkgeversorganisaties ontbonden ${ }^{109}$. De bestaande contacten met de vertegenwoordigers van de arbeidersorganisaties werden echter in het geheim voortgezet; er was behoefte aan overleg, hoe informeel ook, dat een beeld kon geven van hetgeen in het land gebeurde ${ }^{110}$. Het eerste overleg vond plaats op het kantoor van de directeur-generaal van de $\mathrm{Ar}$ beid Hacke ${ }^{111}$. Dit kantoor werd het contactpunt voor een regelmatig overleg, dat overigens ook door hem werd bijgewoond ${ }^{112}$. Aanvankelijk waren het de gebeurtenissen van de dag die de aandacht opeisten, zoals bijvoorbeeld het arbeidsfront, de arbeidsinzet en de winterhulp en wat de houding van werkgevers en arbeiders in deze moest zijn. Maar al snel kwamen in wat Stikker noemt ${ }^{13}$ de Hacke-groep andere vragen aan de orde. Hoe zou de toekomstige samenwerking moeten zijn? Hoe zou bereikt kunnen worden dat werkgevers en arbeiders na de bevrijding in de grootst mogelijke eenheid hun bijdrage zouden kunnen leveren aan de reconstructie van ons land? De eensgezindheid was er, maar de uitgangspunten lagen nog ver uiteen, omdat een ieder van de deelnemers aan het overleg zijn eigen achterban en levensbeschouwing had, die aan zijn denken richting gaf ${ }^{14}$. Verschillende plannen werden ontworpen en uitgewerkt en na in de kringen van werkgewers- en arbeidersorganisaties te zijn besproken, is het overleg nader uitgewerkt. Van Molenaar kwam in én van deze consultaties de gedachte, dat men voor de belichaming van de naoorlogse samenwerking tussen de werkgevers en arbeiders moest zoeken naar een zelfstandige, autonome organisatie in de privaatrechtelijke sfeer, waarop Stikker de stichtingsvorm opperde, daar de nieuwe organisatie rechtspersoonlijkheid moest bezitten en in ons recht kan een stichting op eenvoudige wijze worden opgericht. Molenaar stelde voor de nieuwe organisatie "Stichting van de Arbeid" te noemen. Toen de structuur van de Stichting eenmaal vaststond, werd besloten, om het uiteindelijke succes van de plannen zoveel mogelijk te verzekeren, een kernachtig en overtuigend manifest op te stellen; er moest een appel worden gericht tot alle geledingen van de maatschappij om samen te werken. Deze proclamatie moest op de dag van de bevrijding klaar liggen om in een zo groot mogelijk aantal door het gehele land te worden aangeplakt. Lang werd aan de tekst gewerkt, maar in begin 1945 werd overeenstemming bereikt. Uiteindelijk lukte het ook om voor de bevrijding de handtekeningen bijeen te brengen van alle 14 centrale organisaties, die de Stichting ten doop zouden houden ${ }^{115}$. Na de bevrijding werd het manifest ${ }^{110}$ alom in ons land aangeplakt, waarin onder meer melding werd gemaakt van het geheime overleg, dat na de opheffing van de centrale werkgevers- en arbeidersorganisaties, had plaatsgevonden. Tevens werd vermeld, dat de directeurgeneraal van de Arbeid Hacke aan dit overleg had deelgenomen. Het feit, dat hij bovendien het manifest had ondertekend en de doopplechtigheid - het passeren van de stichtingsakte op 17 mei 1945 - gezamenlijk met Molenaar als peetvader bijwoonde, bevestigt de stelling van Kuiper ${ }^{117}$, dat de directeur-generaal van de Arbeid in de totstandkoming van de Stichting van de Arbeid een sterk samenbindende en stimulerende rol heeft gespeeld.

\section{Het Buitengewoon Besluit Arbeidsverhoudingen}

De vanaf mei 1940 tijdens de oorlogsjaren naar Londen uitgeweken Nederlandse regering stelde zonder enig parlementair overleg in de zomer en het najaar van 1944 met een beroep op het staatsnoodrecht ${ }^{118}$ een aantal maatregelen vast, die onder meer ten doel hadden een chaos op sociaal-economisch terrein na de bevrijding te voorkomen. De belangrijkste algemene regeling is neergelegd in het Buitengewoon Besluit Arbeidsverhoudingen. Aanvankelijk was dit het Besluit van 17 juli $1944^{110}$, dat

"in afwachting van een nadere wettelijke regeling"

op 4 september van dat jaar werd afgekondigd. In het betreffende besluit was het de werkgever verboden wijziging in bestaande arbeidsvoorwaarden of arbeidsregelingen aan te brengen dan wel daarvan afwijkende arbeidsvoorwaarden of arbeidsregelingen in nieuwe arbeidsovereenkomsten op te nemen; 6 én en ander behoudens toestemming hetzij op verzoek, hetzij ambtshalve door of namens de rijksbemiddelaar, die door de minister van Sociale Zaken diende te worden benoemd ${ }^{120}$. Daarnaast gold een eenzijdig aan de werkgever opgelegd ontslagverbod, behoudens toestemming van de directeur van het gewestelijk arbeidsbureau of bijkantoor. Hierbij was echter wel een beroepsmogelijkheid gecreëerd op de al eerder bedoelde te benoemen 
Rijksbemiddelaar ${ }^{124}$. Daarnaast voorzag het besluit in de mogelijkheid, dat het georganiseerde bedrijfsleven via de instelling van commissies van advies voor de arbeidsverhoudingen en de werkgelegenheid, die zowel aan de minister als aan de rijksbemiddelaars adviezen zou kunnen uitbrengen, enigszins betrokken zou worden bij het sociale beleid ${ }^{122}$.

Al snel zouden de ontslagbepalingen van het Buitengewoon Besluit Arbeidsverhoudingen gewijzigd worden. Allereerst werd aan de werkgevers een ruimere mogelijkheid geboden om zich te ontdoen van sympathisanten en collaborateurs van de bezetters en daarmee bevriende organisaties, zonder verder overigens wijziging te brengen in het eenzijdige ontslagverbod als zodanig ${ }^{123}$. Een tweede wijziging van het besluit had een veel wijdere strekking ${ }^{124}$; zo gold bijvoorbeeld het ontslagverbod voor zowel werkgevers als werknemers en had de werkgever in bepaalde situaties een aanstellingsvergunning nodig van de directeur van het gewestelijk arbeidsbureau ${ }^{125}$.

In maart 1944 was in Londen een Ontwerp Souverein Noodbesluit, dat was opgesteld door de illegale Commissie-Van Meurs waaraan vanaf begin 1941 was gewerkt, aangekomen. Het ontwerp voorzag in een ontslagverbod, een verbod tot vermindering van de werktijd beneden de 36 uren en een verbod van staking en uitsluiting; lonen zouden worden bevroren, behoudens door de directeur-generaal van de Arbeid te verlenen ontheffingen. Daarbij zou de minister richtlijnen verstrekken en de directeur-generaal van de Arbeid zelf nadere regelen stellen ${ }^{128}$. Een aantal van deze onderwerpen vindt men ook terug in het in de loop van hetzelfde jaar in Londen aangekomen ontwerp-sociaal program van Nederlandse werkgevers en werknemers ${ }^{127}$. Hoewel de toenmalige bewindsman van Sociale Zaken Van den Tempel stelde, dat de in het besluit neergelegde voorstellen weinig afweken van dit laatstbedoelde urgentie-programma' werd het door de oprichters van de Stichting van de Arbeid in een in het voorjaar van 1945 geschreven nota aan de regering, bekend onder de naam nota-Stikker ${ }^{128}$.

"Wanneer er nu in Nederland tussen overheid, waar de voorstanders der exclusieve Rijkszorg behoorlijk vertegenwoordigd waren, en de Stichting van den Arbeid tot overeenstemming was gekomen over de urgent te nemen noodmaatregelen, dan is dat een even verheugend verschijnsel als het bedroevend is, dat Londen, dat toch via de Vertrouwensmannen van de Stichting van den Arbeid, dus van de nieuwe ontwikkeling hier te lande moet hebben gehoord, op eigen autoriteit tal van uiterst principiële beslissingen neemt, welke in verschillende gevallen overbodig zijn, maar in alle gevallen lijnrecht ingaan tegen de wens van werkgevers en werknemers naar het gemeenschappelijk zelf- doen onder staatstoezicht."

Uitvoerig werd in de nota-Stikker ingegaan op het Buitengewoon Besluit Arbeidsverhoudingen.

"In naam schaft de Groene Tafel in Londen nu wel de Gemachtigde (van de Arbeid) af, maar in feite herleeft hij weer als de Rijksbemiddelaar, alleen terzijde gestaan door een Commissie van Advies, die niet vrij uit het bedrijfsleven voortkomt, maar wordt benoemd door den Minister. Het enige verschil is dus, dat in plaats van de dictatuur der partij, de macht van de Minister is gekomen. Er is geen sprake van dat deze vorm door werkgevers of werknemers geaccepteerd zal worden en ik acht het waarschijnlijk dat evenmin als de Gemachtigde adviseurs kan vinden, ook de Minister geen werkgevers of werknemers zal aantreffen die zich een benoeming tot adviseur zullen laten welgevallen. Men heeft hier te lande genoeg van de dictatuur en wil weer terug naar de democratie. De enige oplossing ligt in de Stichting van den Arbeid. Nu begrijpt deze Stichting volkomen, dat in de aanvang de bevoegdheden bij de Minister moeten berusten; buitendien zal die stichting nog moeten bewijzen, dat zij niet alleen een droom is van enkele personen, maar algemeen ingang zal vinden. Ten slotte hangt het loonniveau direct samen met de prijsvorming en onze monetaire verhoudingen met het buitenland, zodat een strenge controle op het moment, dat de Stichting zou worden ingeschakeld, nodig is. Deze mogelijkheid staat open in de Noodregeling Arbeidszaken 1944, en is geheel iets anders dan de bewuste uitschakeling welke in Londen is uitgedacht".

Over het instituut van de rijksbemiddelaar werd opgemerkt, dat gehoopt werd, dat door deze figuren dan 
het werk van de Stichting van de Arbeid overbodig zou blijken te zijn. Ook scherpe kritiek werd geleverd van de zijde van de door de regering in het bezette Nederland benoemde Vertrouwensmannen. Zij lieten in april 1945 aan de regering weten, dat onder andere het Buitengewoon Besluult Arbeidsverhoudingen gewijzigd zou moeten worden, vanwege de ${ }^{128}$

"sterke afwijking van hetgeen hier door deskundigen en wat sociale aangelegenheden betreft, mede door de Stichting van den Arbeid voorbereid is, en met het oog op de verhoudingen onder de bevolking gewenscht wordt geacht"

Over de taak die de gewestelijke arbeidsbureaus in het Besluit was toebedeeld, inzake het verlenen van ontslagvergunningen werd op 7 oktober 1944 door generaal Kruls, chef staf militair gezag vanuit zijn hoofdkantoor te Brussel aan de minister van Sociale Zaken in Londen geschreven ${ }^{130}$ over de rol die zij hadden gespeeld onder de bezetter

"In de volksmond hebben de Rijksarbeidsbureaux die vereerende bijnaam van "Slavenholen"t". Bovendien maakte hij kenbaar, dat hem was medegedeeld, dat bestuurders van vakorganisaties en anderen in het bevrijdle deel van Nederlland het betreurden, dat de beslissing over een ontslagvergunning was overgelaten aan de directeur van het gewestelijk arbeidsburean, daar men meer vertrouwen had in de arbeidsinspectie. Ondanks de afkondiging van het Buitengewoon Besluit Arbeidsverhoudingen werd door Scholtens, de afgezette secretarisgeneraal van het ministerie van Sociale Zaken met behulp van Levenbach, hoogleraar arbeidsrecht aan de universiteit van Amsterdam $^{131}$ in het bezette deel van ons land doorgewerkt aan de voorbereiding van een ontwerp, waarmee reeds in 1941 een begin was gemaakt op initiatief van de directeurgeneraal van de Arbeid en heimelijk overleg van de vertegenwoordigers van werkgevers- en arbeidersorganisaties, en dat het laatst de titel "Noodregeling Arbeidszaken" droeg ${ }^{132}$.

Deze Noodregeling Arbeidszaken ${ }^{133}$ bevatte onder meer een eenzijdig tot de werkgever gericht ontslagverbod, bepalingen over maximum- en minimumwerktijden, herplaatsing van werknemers en een verbod van werkstaking en uitsluiting. Vele bevoegdheden werden toegekend aan de directeur-generaal van de Arbeid, over wie De Gaay Fortman opmerkt ${ }^{134}$ dat hij

"de enige (was) die het vertrouwen van werkgevers en werknemers had behouden".

Omtrent de loonvorming was in de Noodregeling aan de werkgevers een verbod opgelegd geldende loonnormen te wijzigen, uitgezonderd in de gevallen dat de directeur-generaal van de Arbeid een bindende loonregeling $^{135}$ had opgelegd. Voorts kon de directeur-generaal van de Arbeid ontheffingen verlenen. De bevoegdheden die de Wet op het algemeen verbindend en onverbindend verklaren van bepalingen van collectieve arbeidsovereenkomsten aan de minister toekende, werden tijdelijk aan de directeur-generaal van de Arbeid overgedragen. Belangrijk in de Noodregeling Arbeidszaken voor de rol die later de Stichting van de Arbeid zou innemen, is het bepaalde over het centraal orgaan van den arbeid. Ter bevordering van een doeltreffende en deskundige uitvoering van dit besluit zou de secretaris-generaal de bevoegdheden van de directeur-generaal van de Arbeid kunnen overdragen aan een centraal orgaan van georganiseerde samenwerking tussen werkgevers en werknemers. Loonregelingen van dit centrale orgaan hadden wel weer de goedkeuring van de directeur-generaal van de Arbeid nodig. Deze goedkeuringen konden door de secretaris-generaal vernietigd worden ${ }^{106}$. Overigens kon de secretaris-generaal de in de Wet op het algemeen verbindend en onverbindend verklaarde bepalingen van collectieve arbeidsovereenkomsten aan de Hooge Raad van Arbeid toegekende bevoegdheden aan het centrale orgaan overdragen ${ }^{1 / 37}$. Het zal niemand na het vorenstaande verbazen; dat Hacke, directeur-generaal van de Arbeid, uiterst verbitterd was over de gang van zaken, waarvan hij uiting gaf in een pamflet van eind mei $1945^{1 / 38}$. Niet alleen hekelde hij fel de rol die de gewestelijke arbeidsbureaus tijdens de bezetting hadden gespeeld maar ook de positie die hen nu was toebedeeld. Hij verweet de Londense regering onder meer niet al vóor de bevrijding de door haar beoogde maatregelen getoetst te hebben aan hetgeen hier te lande was gegroeid en hij vroeg de regering onder andere het Buitengewoon Besluit Arbeidsverhoudingen in te trekken en de "Noodregeling Arbeidszaken" in te voeren. 
Nog voor het uitbreken van de oorlog stond in het blad de Banket Bakkerij een bijdrage van Kluiver, die de moeite van het vermelden waard is en waarbij een ambtenaar van de arbeidsinspectie opnieuw het mikpunt is ${ }^{139}$.

"Kent het zakenleven een verguisder manmensch dan den ambtenaar? Deze dierbare is de verpersoonlijking van alle overheidsbemoeiïng en velerlij onheil dat zich over onze wankele zakelijke existentie uitstort, wordt hem aangewreven. Toch is zoo'n ambtenaar in feite een nuttig wezen. Want hij dient en vertegenwoordigt het meerderheidsbelang. En welbeschouwd hebben we alleen maar wat tegen hem als we in een minderheidspositie verkeeren. En dat dit nogal eens voorkormt, kan hij niet helpen.

Nuchter bekeken is een ambtenaar dus eigenlijk iemand, wiens bestaan je zegent, als je voldoende gebrek aan pretenties hebt om in de massa op te gaan, populair gezegd, als je een kuddedier bent en dien je verwenscht, als je op je eigen kompas probeert te varen. Omdat ie op de meest hachelijke momenten je vaarwater onveilig maakt".

Na deze algemene beschouwing over de ambtenaar verplaatste Kluiver zich in zijn betoog naar de bedoelde ambtenaar van de arbeidsinspectie.

"Ook het doornenpad eens Kluiver wordt wel eens door ambtenaren doorkruist. En omdat het geslacht Kluiver befaamde vrijheidshelden heeft opgeleverd, stemt ambtelijk bezoek mij wel eens wrevelig. In het bijzonder plegen ambtenaren van de Arbeidsinspectie m'n ontvlambaar gemoed te prikkelen. Want die hebben de nare gewoonte bij voorkeur te verschijnen als er toevallig iets aan den knikker is. Toevallig is toevallig het juiste woord niet. Want het is gewoonlijk nòch aangeboren speurzin nòch het bezit van een zesde zintuig, als ze hun opwachting nauwkeurig op het psychologisch moment maken. Ze beschikken eenvoudig als alle belligerenten over een "intelligence service".

De arbeidscontroleur die ik van tijd tot tijd in mijn domein welkom mag heeten, is onbetwistbaar een ambtenaar van de goede soort. Zijn plicht is hem heilig, maar muggenziften is hem vreemd en hij is ontvankelijk voor de moeilijkheden des bedrijfs. Hij interpreteert de wet zoo noodig naar den letter, zoo mogelijk naar den geest. We dragen elkaar onomstootelijke een zekere mate van waardeering toe, maar .... naar de geldende leer is hij mijn antipode en daarom verontschuldig ik hem graag als hij verhinderd is".

Vervolgens deed Kluiver een middel aan de hand om van deze lastige ambtenaar af te komen.

"Z'n laatste bezoek bracht hij enkele dagen na Sinterklaas. Dat was netjes, want er viel toen niet veel meer te overtreden. Er had zich juist een incident voorgedaan. Een dag tevoren waren de overuren uitbetaald en een der bedienden was zoo onfortuinlijk geweest het sommetje waarvoor hij jammerlijk hard had moeten werken, te verliezen. Dat was een heel hard gelag, want in het vooruitzicht van het extraatje, had hij zich al een nieuw pak uitgezocht. De man was de wanhoop nabij.

Wat doe je in zoo'n geval?

Ik hield een inzameling en toen ik de helft bij elkaar had, nam ik mij voor de rest voor mijn rekening te nemen.

Toen, als een gave des hemels, verscheen de ambtenaar. Er werd van het gebeurde een omstandig verhaal opgehangen. Bewust werd op zijn gemoed gewerkt en terloops werd hem te verstaan gegeven, dat hij eigenlijk de werknemersschutspatroon bij uitnemendheid was. Met het gevolg dat met een zuurzoet gezicht, een blinkende zilverling op het plechtanker des beroeps geofferd werd"

Het resultaat:

"Ik heb hem sindsdien niet meer teruggezien. En ik begin gaandeweg te gelooven, dat ik andermaal een belangrijke uitvinding heb gedaan. Een middel tot wering van ambtenaren". 
Kluiver besloot zijn verhaal met de opmerking, dat gegadigden voor de licentie zich vol vertrouwen tot hem konden wenden. 
1. De intocht in Praag op 15 maart 1939 van Hitler leidde ertoe, dat Engeland onderhandelingen voerde met Frankrijk, Polen en Rusland over de middelen om nieuwe machtovernames in Oost- en Zuidoost-Europa te voorkomen. Al snel nam de Britse regering vergaande verplichtingen op zich; zij garandeerde op 31 maart 1939 Polens onafhankelijkheid en integriteit, een garantie die op 14 april uitgestrekt zou worden tot Roemenië en Griekenland. Frankrijk had na de vrede van Versailles in het kader van het door dit land gevoerde ( eigen ) veiligheidspolitiek tegen een nieuwe Duitse inval diverse allianties gesloten met een aantal Oost-europese staten, waaronder Polen. Zie hierover onder meer W.L. Shirer, 20th Century Journey. A Memoir of a Life and the Times, volume II, The Nightmare Years, New York 1985 (export edition ).

2. De termijn van het Engelse ultimatum liep af om 11 uur 's-morgens; die van het Franse om 5 uur 's-middags.

3. Zo werd werk in Duitsland voor werklozen "passend werk" verkllaard en werd door Verordening no. 166/1940 "de arbeidsbemiddeling in nieuwe banen" geleid in die zin, dat deze activiteit van de gemeenten overgebracht werd naar de centrale overheid via de instelling van het Rijksarbeidsbureau met een hoofdbureau, gewestelijke arbeidsbureaus en bijkantoren; zie M.G. Levenbach, Arbeid, in Nederlands bestuursrecht, blz, 468.

Zit over de reorganisatie van de arbeidsbemiddeling onder meer: H.J. Morren, Het Rijksarbeidsbureau, in E.S.B. 1940 blz. $670 \mathrm{t} / \mathrm{m}$ 672; W. v.d. Mast, De voorgeschiedenis van de reorganisatie der openbare arbeidsbemiddeling in Nederland; in E.S.B. 1942 blz. $388 \mathrm{t} / \mathrm{m} \mathrm{340;} \mathrm{W.} \mathrm{v.d.} \mathrm{Mast,} \mathrm{De} \mathrm{beteekenis} \mathrm{der} \mathrm{reorganisatie}$ van de openbare arbeidsbemiddeling in Nederland, in E.S.B. 1942 blz. $349 \mathrm{t} / \mathrm{m}$ 351; F.J.H.M. van der Ven, Inleiding tot het arbeidsrecht, Tilburg 1941, blz. 68 - 69.

4. M.G. Levenbach, Arbeid, in Nederlands bestuursrecht, blz. $467 \mathrm{t} / \mathrm{m} 469$. Zie onder meer Centraal Verslag der Arbeidsinspectie over 1940 en over 1941, resp. 's-Gravenhage 1941 en 1942, resp. blz. 17 en blz. 16 17.

5. Centraal Verslag der Arbeidsinspectie over 1940, over 1941 en over 1942, 's-Gravenhage 1943, resp. blz. 17 , blz. 17 en blz. 18 .

6. Centraal Verslag der Arbeidsinspectie over 1941, blz. 34.

7. Centraal Verslag der Arbeidsinspectie over 1941, blz. 46. Het aantal vergunningen op grond van artikel 28, eerste lid, van de Arbeidswet 1919 bevat zowel overwerk- als verschuivingsvergunningen.

8. Centraal Verslag der Arbeidsinspectie over 1939, over 1940 en over 1941, resp. blz. $61 \mathrm{t} / \mathrm{m}$ 64, blz. 41 42 en blz. $42-43$.

9. Centraal Verslag der Arbeidsinspectie over 1942, blz. 37. Bij besluit van de secretaris-generaal van het ministerie van Sociale Zaken van 22 maart 1943, Afd. Arbeid I no. 499, Stcrt. 81 ( in werking getreden op 28 maart 1943) werd toegestaan, de werktijd van arbeiders van 16 jaar of ouder in fabrieken of werkplaatsen op 9 3/4 uur per dag en 54 uren per week te stellen alsook de werktijd om 06.00 uur te doen aanvangen. Verdergaand overwerk, met inbegrip van nachtarbeid, in fabrieken of werkplaatsen (met inbegrip van bakkerijen ) en in winkels werd toegestaan bij besluit van 25 augustus 1943, Afd. Arbeid I no. 1461, Stcrt. 167 (in werking getreden op 30 augustus 1943 ); zie Centraal Verslag der Arbeidsinspectie over 1943, 's-Gravenhage 1944, blz. 28 . 
10. Centraal Verslag der Arbeidsinspectie over 1944 en 1945, 's-Gravenhage 1947, blz. 35.

11. Centraal Verslag der Arbeidsinspectie over 1942, over 1943 en over 1944 en 1945, resp. blz. 48 - 49, blz. $36-37$ en blz. 43 - 44 .

12. Centraal Verslag der Arbeidsinspectie over 1942, over 1943 en over 1944 en 1945 , resp. blz. 44 - 45 , blz. 34 - 35 en blz. 42-43. Het totale aantal processen-verbaal, opgemaakt door de arbeidsinspectie, gemeenteen rijkspolitie bedroeg resp. 386,77 en 59 .

13. Besluit van 28 maart 1940 , Stb. 842 .

14. Centraal Verslag der Arbeidsinspectie over 1940, blz. 66.

15. Centraal Verslag der Arbeidsinspectie over 1944 en 1945, blz. 63.

16. Centraal Verslag der Arbeidsinspectie over 1944 en 1945, blz. 63.

17. Centraal Verslag der Arbeidsinspectie over 1939, over 1940, over 1941, over 1942, over 1943, over 1944 en 1945 , resp. blz. 117 t/m 129 , blz. 67 , blz. 69 , blz. 71 , blz. 57 - 58 en blz. 64 .

18. Dit cijfer is unclusief de ongevallen in veenderijen; zie Centraal Verslag der Arbeidsinspectie over 1939 , blz. 130 .

19. Centraal Verslag der Arbeidsinspectie over 1943 en over 1944 en 1945, resp. blz. 71 en blz. 74 .

$\mathrm{Bij}$ deze gegevens zijn niet vermeld de ongevallen in ondernemingen met een erkende geneeskundige dienst met een verzuim van 2 dagen of minder. Het aantal dodelijke ongevallen bedroeg in de oorlogsjaren resp. $84,143,148,268$ ( waarvan voor zover kon worden nagegaan ten ministe 171 het gevolg waren van oorlogsgewell ), 159 ( resp. 85), en 106 ( resp. 41 ).

20. Centraal Verslag der Arbeidsinspectie over 1944 en 1945, blz. 74.

21. Het Centraal Verslag der Arbeidsinspectie over 1940, blz. 221, vermeldt, dat verscheidene transportondernemingen hun bedrijf in stand trachtten te houden door de toepassing van paardetractie.

22. Zie Centraal Verslag der Arbeidsinspectie over 1943, blz. 271.

23. Overigens werd de Rijtijdenwet 1936 onmiddellijk na de bevrijding van het zuiden van ons land door de chef staf militair gezag bij verordening van 12 september 1944, no. 20, tijdelijk buiten werking gesteld; een verordening die naar gelang de bevrijding van de overige delen van ons land vorderde, ook daar van kracht werd. Zie Centraal Verslag der Arbeidsinspectie over 1944 en 1945, blz. 217.

24. Zie Centraal Verslag der Arbeidsinspectie over 1939, Over 1940, over 1941, over 1942, over 1943 en over 1944 en 1945, resp. blz. 403 - 404, blz. 226 - 227, blz. $239-240$, blz. $289-290$, blz. $274-275$ en blz. 219.

25. Centraal Verslag der Arbeidsinspectie over 1940, blz. 205.

26. Centraal Verslag der Arbeidsinspectie over 1941 en over 1944 en 1945, resp. blz. 171 em blz. 166 - 167. 
27. Centraal Verslag der Arbeidsinspectie over 1940, blz. 229; zie M.G. Levenbach, Nieuwe regelingen, in R.B.A. XXVIe serie blz. 18.

28. Besluit van 27 mei 1940, Stb. O 801; weergegeven door P.A.G. Ubink, Tekstuitgaven van nieuwe regelingen ten aanzien van het arbeidsrecht, Alphen a/d Rijn 1943, blz. 14 - 15.

29. Artikel 1 van het besluit van 27 mei 1940, Stb. O 801. Het verzoek om vergunning moest ingevolge artikel 2 van dit besluit worden gericht aan het districtshoofd van de arbeidsinsepctie met vermelding van de redenen die aan het verzoek ten grondslag lagen alsook van het aantal en de soort arbeiders waarop het verzoek betrekking had.

30. Centraal Verslag der Arbeidsinspectie over 1940, blz. 14.

31. Artikel 3 van het besluit van 27 mei 1940, Stb. O 801.

32. Centraal Verslag der Arbeidsinspectie over 1940, blz. 231. Aan de kennisgevingen en wergunningen lagen onder meer de volgende beweegredenen ten grondslag: gebrek aan brandstof, benzine, olie en grondstoffen, wegvallen van Defensie- en exportorders, vervoermoeilijkheden, financiële moelijkheden en vernietiging van bet bedrijf.

33. Verordening no. 8/1940; weergegeven door P.A.G. Ubink, t.a.p., blz. 15 - 16; G.W. Caron, Regeling der verhoudingen tusschen werkgever en werknemer, Wassenaar 1941, blz. 4; H. Naber, Van een preventief ontslagverbod terug naar een repressief ontlsagrecht, Deventer (z.j. ), blz. 340.

34. Eerste Uitwoeringsbesluit van 11 juni 1940 van de secretaris-generaal van het departement van Socialle Zaken ingevolge Verordening no. 8/1940 van de rijkscommisssaris voor het bezette Nederlandse gebied betreffende het beperken van werk, Stb. S. 800 ( de zgn. Ontslagverordening); weergegeven door P.A.G. Ubink, t.a.p., blz. 16 t/m 18; W.W. Caron, t.a.p., blz. $5 \mathrm{t} / \mathrm{m} 12$ ( met toelichting ); H. Naber, t.a.p., blz. 34. Op grond van art. 4 werd het besluit van de opperbevelhebber van land- en zeemacht van 27 mei 1940 buiten werking gesteld.

35. In het eerste lid van artikel $1639 \mathrm{p}$ van het Burgerlijk Wetboek worden voor de werkgever als dringende reden voor ontslag op staande voet beschouwd

"zodanige daden, eigenschappen of gedragingen van de arbeider, die ten gevolge hebben, dat van de werkgever redelijkerwijs niet gevergd kan worden de dienstbetrekking te laten voortduren".

36. Zie par. 1 van het Eerste Uitvoeringsbesluit. Dit onderdeel zou bij besluit van de secretaris-generaal van 1 maart 1941 no. 64 stuk 13, komen te vervallen.

37. Zie par. 2 van het Eerste Uitvoeringsbesluit; de daarbij te volgen procedure was gelijk aan die van het besluit van 27 mei 1940, Stb. O 801; zie nt. 29 .

38. Zie par. 3 van het Eerste Uitvoeringsbesluit.

39. Zie voor een overzicht van deze vertrouwensinstanties G.W. Caron, t.a.p., blz. $26 \mathrm{t} / \mathrm{m} 40$.

40. Zie J. van Drongelen, De rol van de arbeidsinspectie bij ontslagzaken, in Blinde vlekken in het sociaal recht, Deventer 1986, blz. 101; M.G. Levenbach, in R.B.A. XXVle serie blz. 37; D. Kuiper, dr.ir. A.H.W. Hacke, in S.M.A. 1961 blz. 616; H. Naber, t.a.p., blz. 40. 
41. M.G. Levenbach, Waar staan we met het arbeidsrecht, in S.M. 1946 blz. 9. Zie ook J.H.A. Ringeling, Rechtvaardig ontslag, Amsterdam ( z.j. ), blz. 31.

42. Centraal Verslag der Arbeidsinspectie over 1940, blz. 14.

43. Centraal Verslag der Arbeidsinspectie over 1940, blz. 232. Overigens werden in het totaal 3537 verzoeken van werkgevers afgewezen.

44. Centraal Verslag der Arbeidsinspectic over 1941, blz. 244. Het aantal weigeringen bedroeg in totaal 2972; een aantal dat echter geen juist beeld geeft, daar na bespreking ervan het verzoek werd ingetrokken of door vórbespreking geen verzoek werd ingediend.

45. Centraal Verslag der Arbeidsinspectie over 1941, blz. 247.

46. Centraal Verslag der Arbeidsinspectie over 1940 en over 1941, resp. blz. 238 en blz. 248.

47. Centraal Verslag der Arbeidsinspectie over 1940, blz. $239-240$.

48. Centraal Verslag der Arbeidsinspectie over 1941, blz. $249-250$.

49. Besluit van 24 september 1940 tot wijziging van de Arbeidsbemiddelingswet, Verordeningenblad 1940 stuk no. 166

50. Bij het besluit van 5 oktober 1940 van de genoemde secretaris-generaal, Verordeningeblad 1940 stuk no. 30, zou het rijksarbeidsbureau als orgaan van openbare arbeidsbemiddeling aangeduid worden; zie H.J. Morren, in E.S.B. 1940 blz. 670 t/m 672; W. v.d. Mast, in E.S.B. 1942 blz. 349 t/m 351.

51. Wet van 29 november 1930, Stb. 433.

52. Zie artikel 3 van de Arbeidsbemiddelingswet 1930.

53. Zie H. Naber, t.a.p., blz. 40; A.N. Molenaar, t.a.p. deel IIB, blz. 2180 . Zie de beschikking van 31 maart 1941, no. 335, Afd. AB Rijksarbeidsbureau; zie A.N. Molenaar, t.a.p. deel IIB, blz. 2180 mt. 1.

54. Besluit van 20 februari 1942, Verordeningenblad 1942 no. 14 aflevering 5; weergegeven door P.A.G. Ubink, t.a.p., blz. 21 t/m 23; H. Naber, t.a.p., blz. 42 .

55. Zie artikel 3, eerste lid, van het Derde Uitvoeringsbesluit. De te volgen procedure kwam, blijkens artikel 2 van dit besluit overeen met de al eerder in deze gevolgde procedure; zie nt. 29.

56. Zie artikel 5 van het Derde Uitvoeringsbesluit.

57. Zie artikel 3 , eerste lid, van het Derde Uitvoeringsbesluit.

58. Zie H. Naber, t.a.p., blz. 43 - 44. Ten gunste van wie dit geschil is beslecht is niet bekend. Gezien het vervolg vermoed ik, dat het de directeur-generaal van de Arbeid is geweest.

59. Centraal Verslag der Arbeidsinspectie over 1942, blz. 294 en blz. 297. 
60. Centraal Verslag der Arbeidsinspectie over 1942, blz, $299-300$.

61. Verordening van 1 maart 1943 van de rijkscommissaris voor het bezette Nedelandse gebied betreffende de beperking ten aanzien van het veranderen van betrekking (Verordening Verandering van betrekking), Verordeningenblad 1943 no. 20 aflevering 7; weergegeven door P.A.G. Ubink, t.a.p., blz. 108 t/m 116; H. Naber, t.a.p., blz. $342 \mathrm{t} / \mathrm{m} 348$.

62. Artikel 1 van de Verordening verandering van betrekking.

63. Zie H. Naber, t.a.p., blz. 50, die schrijft, dat van de zijde van de gewestelijke arbeidsbureaus werd geklaagd over vertraagde ontvangst van lijsten met namen en adressen van werknemers die met een ontslagvergunning van de directeur-generaal van de Arbeid waren ontslagen. Hij vraagt zich af of deze vertragende handelwijze van de arbeidsinspectie bedoeld of onbedoeld is geweest. Uit het gestelde in het Centraal Verslag der Arbeidsinspectie over 1944 en 1945, blz. 18, blijkt, dat op verschillende wijzen dusdanig gemanouvreerd werd met de toepassing van de Uitvoeringsbesluiten, dat zoveel mogelijk afbreuk wrd gedaan aan het Duitse oogmerk. De vertragende handelwijze lijkt dus bewust te zijn geweest.

64. Zie Centraal Verslag der Arbeidsinspectie over 1943, blz. $277 \mathrm{t} / \mathrm{m} 279$.

65. D. Kuiper, in S.M.A. 1961 blz. 617.

66. D. Kuiper, in S.M.A. 1961 blz. 617; Centraal Verslag der Arbeidsinspectie over 1944 en 1945, blz. 18 19; H. Naber, t.a.p., blz. 50 - 51; J. van Drongelen, in Blinde vlekken in het sociaal recht, blz. 103 - 104.

67. Deze verboden waren opgenomen in het Heeresgruppen-Verordnungsblatt für die besetzten Gebiete van 10 mei 1940 , blz. 5 . De tekst luidt:

"VIII. Die Erhöhung von Preisen und Entgelten jeder Art. sowie von Löhnen über den Stand vom Tage der Besetzung hinaus ist verboten, soweit nicht Ausnahmen ausdrücklich zugelassen sind".

Het verbod is in de Nederlandse pers op 17 mei van dat jaar gepubliceerd en aangeplakt. Zie M.G. Levenbach, De loonsverlagingsregeling, in R.B.A. XXVIe serie blz. 49 nt. 1.

68. Met name is geen verdere regeling getroffen ten aanzien van het verlenen van vergunningen.

69. Besluit van 24 mei 1940 , Stb. O 800.

70. Zie de Arbeidsgeschillenwet 1923. Zie hierover onder meer A.C. Josephus Jitta, De practijk van de Arbeidsgeschillenwet, 's-Gravenhage 1929.

71. F.J.H.M. van der Ven, Inleiding tot het arbeidsrecht, Tilburg 2e druk 1946, blz. 87, stelt, dat het besluit ten onrechte sprak van een college van Rijksbemiddelaars, daar dit rechtens in het kader van de Arbeidsgeschillenwet 1923 niet bestond. Zie echter M.G. Levenbach, in R.B.A. XXVIe serie blz. 42 nt. 8.

72. Zie artikel 2 van het besluit van 24 mei 1940 , Stb. 0800 .

73. M.G. Levenbach, in R.B.A. XXVIe serie blz. 17.

74. Verordening van 27 augustus 1940 , Verordeningenblad 1940 no. 111 stuk 23 (in werking getreden op 29 augustus 1940 ); weergegeven door P.A.G. Ubink, t.a.p., blz. 24 - 25. 
75. Zie artikel 1 van de Verordening van 27 augustus 1940, Verordeningenblad 1940 no. 111 stuk 23.

76. Zie artikel 3 van de Verordening van 27 augustus 1940, Verordeningenblad 1940 no. 111 stuk 23.

77. Besluit van 2 september 1940, Stert. 170; weergegeven door P.A.G. Ubink, t.a.p., blz. 26 - 27. Zie over dit besluit M.G. Levenbach, in R.B.A. XXVIe serie blz $49 \mathrm{t} / \mathrm{m} 53$.

78. Zie artikel 1, eerste lid, van het besluit van 2 september 1940, Stcrt. 170.

79. Artikel 2 van het besluit van 2 september 1940 , Stcrt. 170 .

80. Zie M.G. Levenbach, in R.B.A. XXVle serie blz. 52.

81. Artikel 3 van het besluit van 2 september 1940 , Stcrt. 170 .

82. Resp. de artikelen 2, tweede lid, en 4, tweede lid, van het besluit van 2 september 1940. Stcrt. 170.

83. Centraal Verslag der Arbeidsinspectie over 1940, over 1941 en over 1942, resp. blz. 15, blz. 31 en blz. $34-35$.

84. Verordening van 28 november 1940 , Verordeningenblad 1940 no. 217 stuk 39 (in werking getreden op 30 november 1940 ); weergegeven door P.A.G. Ubink, t.a.p., blz. $29 \mathrm{t} / \mathrm{m} 32$.

85. Artikel 3 van de Verordening van 28 november 1940, Verordeningenblad 1940 no. 217 stuk 39.

86. Artikelen 7 en 8 van de Verordening van 28 november 1940, Verordeningenblad 1940 no. 217 stuk 39.

87. Eerste Uitvoeringsbesluit van 30 november 1940, Stcrt. 235; weergegeven door P.A.G. Ubink, t.a.p., blz. 33 - 34 .

88. Zie de artikelen $2 \mathrm{t} / \mathrm{m} 5$ en 7 van het Eerste Uitvoeringsbesluit.

89. Besluit van 30 juli 1941, Stert. 164 ( het zgn. Loklonenbesluit ); weergegeven door P.A.G. Ubink, t.a.p, blz. 3.

90. Zie de artikelen 1 en 2 van het Loklonenbesluit.

91. Centraal Verslag der Arbeidsinspectie over 1941, blz 30 - 31 .

92. Zie artikel 19 van de Verordening van 13 oktober 1942 , Verordeningenblad 1942 no. 114 aflevering 27 ; weergegeven door P.A.G. Ubink, t.a.p, blz. 73 t/m 81 .

93. Zie artikel 4, eerste lid, van de Verordening van 13 oktober 1942, Verordeningenblad 1942 no. 113 aflevering 27. Zie over deze Verordening onder meer F.J.H.M. van der Ven, t.a.p., blz. 87 - 88; W.C.L. van der Grinten, Nieuw arbeidsrecht, Alphen a/d Rijn 4e druk 1942, blz. $58 \mathrm{t} / \mathrm{m} \mathrm{74.} \mathrm{Overigens} \mathrm{werden} \mathrm{in} \mathrm{het}$ Eerste Besluit van 21 oktober 1942 van de secretaris-generaal van het ministerie van Sociale Zaken ter uitvoering van deze Verordening ( Verordeningenblag 1942 no. 121 aflevering 28; weergegeven door P.A.G. Ubink, t.a.p., blz. 82 ) de lopende regelingen van het college van Rijksbemiddelaars van kracht - zij werden 
beschouwd als regelingen in de zin van de nieuwe Verordening - totdat zij door de gemachtigde van de arbeid werden opgeheven.

94. Centraal Verslag der Arbeidsinspectie over 1942, blz. 34. Het Centraal Verslag der Arbeidsinspectie over 1943 , blz. 25, maakt slechts melding van het doen van dergelijke onderzoeken.

95. Zie artikel 17 van het Besluit van 24 juni 1941, Verordeningeblad 1941 no. 119 stuk 26.

96. Artikelen $2 \mathrm{t} / \mathrm{m} 6$ van het Bedrijfsvergunningenbesluit.

97. Besluit van 28 maart 1941, Verordeningenblad 1941 no. 69 stuk 14.

98. Centraal Verslag der Arbeidsinspectie over 1941, over 1942 en over 1943, resp. blz. 15, blz. 17 en blz. 14.

99. Zie artikel 19 van het Besluit van 5 november 1941, Verordeningenblad 1941 no. 208 stuk 46.

100. Zie artikel 26 van het Kartelbesluit.

101. Bedrijfsregelingen waren bepalingen ter regeling van de mededinging, financiële verplichtingen, waaronder begrepen tussenpersonen, die een bedrijf uitoefenden in enige tak van handel of nijverheid in de ruimste zin; zie artikel 1 van het Kartelbesluit.

102. Zie de artikelen $2 \mathrm{t} / \mathrm{m} 6$ van het Kartelbesluit.

103. Centraal Verslag der Arbeidsinspectie over 1940, over 1941 en over 1942, resp. blz. 15, blz. 14 - 15 en blz. 16.

104. Centraal Verslag der Arbeidsinspectie over 1940, over 1941, over 1942 en over 1943, resp. blz. 15, blz. 15 , blz. 17 en blz. $13-14$.

105. Centraal Verslag der Arbeidsinspectie over 1940 en over 1941, resp. blz. 15 en blz. 15.

106. Als reden voor deze onder bewindstelling van de nationaal-socialist ( A.N. Molenaar, t.a.p. deel $I$, blz. 830) of verrader ( M.G. Levenbach, Arbeid, in Nederlands bestuursrecht, blz. 469) Woudenberg, werd door de bezetter gegeven, dat het N.V.V.-bestuur geen waarborgen bood voor een goede samenwerking met de rijkscommissie, omdat gemeend werd, dat deze organisatie uitging van de klassestrijdgedachte en tot aan de oorlog met het internationaal Marxisme nauw verboden was; zie A.N. Molenaar, t.a.p. deel I, blz. 831.

107. S. Stokman, De Katholieke arbeidersbeweging in oorlogstijd, Utrecht/Brussel 1946, blz. 79 - 80 en blz. 100; zie A.N. Molenaar, t.a.p. deel I, blz. 832.

108. In tegenstelling tot het Duitse Arbeidsfront was het de bedoeling om in het Nederlandse Arbeidsfront ook de werkgevers te vertegenwoordigen, maar het lukte echter niet om de Nederlandse werkgevers ook zover te krijgen. Zie T. van Peijpe, t.a.p., blz. 280 nt. 34.

109. T. van Peijpe, t.a.p., blz. 284 - 285; A.N. Molenaar, t.a.p. deel I, blz. $830 \mathrm{t} / \mathrm{m}$ 832; D.U. Stikker, Memoires, Herinneringen uit de lange waarin ik betrokken was bij de voortdurende wereldcrisis, Rotterdam/'s-Gravenhage 1966 , blz. $31 \mathrm{t} / \mathrm{m} 39$. 
110. T. van Peijpe, t.a.p, blz, 284 - 285; D.U. Stikker, t.a.p., blz. 42 .

111. Zie D.U. Stikker, Het ontstaan van de Stichting van de Arbeid, in 10 jaar Stichting van de Arbeid, blz. $25-26$.

112. De protestant-christelijke werkgevers zouden aan dit overleg niet deelnemen.

"Na de arrestatie van hun secretaris in de zomer van 1941 had hun organisatie zich meer op "bezinning" dan op ondergrondse activiteiten toegelegd".

Zie A.N. Molenaar, t.a.p. deel I, blz. 833 nt. 1.

113. D.U. Stikker, t.a.p., blz. 43.

114. D.U. Stikker, t.a.p., blz. $42-43$.

115. Zie D.U. Stikker, t.a.p., blz. $43 \mathrm{t} / \mathrm{m} 47$.

116. Weergegeven door D.U. Stikker, t.a.p., blz. 64 t/m 66; A.N. Molenaar, t.a.p. deel I, blz. 839 t/m 843 en in Stichting van de Arbeid 40 jaar, 's-Gravenhage 1985, blz. 58 - 59.

117. D. Kuiper, in S.M.A. 1961 blz. 617. Zie ook A.N. Molenaar, t.a.p. deel I, blz. 844.

118. Zie hierover onder meer nt. D.G. Veegens bij HR 10 oktober 1946, NJ 1946337.

119. Besluit van 17 juli 1944, Stb. E. 52 ( hierna B.B.A.).

120. Zie de artikelen $3 \mathrm{t} / \mathrm{m} 5$ van het B.B.A. De benoeming van rijksbemiddelaars kon geschieden in afwijking van artikel 1 van de Arbeidsgeschillenwet 1923, voor wie ook de beperkingen neergelegd in artikel 7 van die wet niet bindend waren; zie artikel 7 van het B.B.A.

121. Zie artikel 6 van het B.B.A..

122. Zie artikel 8 van het B.B.A..

123. Besluit van 2 november 1944, Stb. E. 136.

124. Besluit van 29 december 1944 , Stb. E. 157.

125. Artikel 6a van het B.B.A. 1944. Zie over het B.B.A.: H. Naber, t.a.p., blz. 53 t/m 60 .

126. Zie T. van Peijpe, t.a.p., blz. $311-312$ nt. 190.

127. Dit urgentie-programma is weergegeven door T. van Peijpe, t.a.p., blz. 310 - 311.

128. Zie A.N. Molenaar, t.a.p. deel ILA, blz. 435. Fragmenten van de nota zijn weerggeven door D.U. Stikker, t.a.p., blz. $48 \mathrm{t} / \mathrm{m} 53$.

129. T. van Peijpe, t.a.p, blz. 312, H. Naber, t.a.p., blz. 60 .

130. Weergegeven door H. Naber, t.a.p., blz. 367 - 368 . 
131. Zie T. van Peijpe, t.a.p., blz. 312.

132. M.G. Levenbach, Rechtsherstel en het Buitengewoon Besluit Arbeidsverhoudingen 1945, in N.J.B. 1946 blz. 358 .

133. Een deel hiervan is weergegeven door $H$. Naber, t.a.p., blz. $372 \mathrm{t} / \mathrm{m}$ 376. Over deze versie merkt $T$. van Peijpe, t.a.p., blz. 312 nt. 193, op, dat dit waarschijnlijk niet de definitieve versie is, dit naar aanleiding van de door W.F. de Gaay Fortman, Problemen van de Arbeid, in Nederlands economische herstel, Amsterdam 1946, verschafte informatie.

134. W.F. de Gaay Fortman, in Nederlands economisch herstel, blz. 78.

135. Die de rechtswerking van algemeen verbindend verklaarde bepalingen van collectieve arbeidsovereenkomsten had; zie artikel 7, vierde lid, wan de Noodregeling Arbeidzaken.

136. Wegens strijd met de wet en met het algemeen belang of wegens ernstige schade aan bijzondere belangen.

137. Zie T. van Peijpe, t.a.p., blz. $312-313$.

138. Weergegeven door H. Naber, t.a.p., blz. $369 \mathrm{t} / \mathrm{m} 371$.

139. K. Kluiver, Middel tot wering van ambtenaren?, in Banket Bakkerij 21 februari 1940. 


\section{Inleîding}

De, op vijf dagen na, vijf volle jaren over Nederland razende orkaan van oorlog en bezetting, heeft ons land zwaar geschonden. Voor de bezetter telde slechts het eigen belang, waarbij de doeleinden van zijn oorlogvoering gepaard gingen met een onmenselijk verlangen naar vernielen, verdrukken en vernederen ${ }^{1}$. De oorlog heeft circa 250.000 landgenoten het leven gekost. Daaronder waren 104.000 joden van de 140.000 die in ons land hadden gelleefd. Zij waren in hoofdzaak omgebracht in de gaskamers van vernietigingskampen als Auschwitz en Sobibor. Andere Nederlanders waren gevallen in de strijd op de koopvaardijvloot, omgekomen in concentratiekampen, gevangenissen en voor vuurpelotons, als slachtoffers van bombardementen, door de hongerwinter, velen al eerder als gevolg van de sllechte situatie op het gebied van het voedsel. Ook van de honderdduizenden die voor de arbeidsinzet naar Duitsland waren gesleept, waren tienduizenden omgekomen $^{2}$. De schade die aan het economisch leven was toegebracht, was zowel veroorzaakt door militaire verwoestingen als door het achterwege blijven van in normale omstandigheden regelmatig plaatsvindende herstellingen en vernieuwingen. Naar het prijspeil van 1939 bedroeg de schade in geld uitgedrukt fl. 14,75 miljard, terwijl dit omgerekend naar het prijspeil van 1945 fl. 25 miljard zou bedragen ${ }^{3}$. De eerste jaren van de wederopbouw werden gekenmerkt door een sterke overheidsbemoeienis met het economische leven. Deze was enerzijds gebaseerd op vooroorlogse wetgeving zoals bijvoorbeeld de Distributiewet, op gehandhaafde bezettingsmaatregelen, zoals bijvoorbeeld het Kartelbesluit, en nieuw tot stand gekomen regelingen waaronder bijwoorbeeld het Besluit Wederopbouw $1945^{4}$, terwijl anderzijds een strakke loon- en prijspolitiek gevoerd werd. Dit laatste diende met name om de industrialisatie- en de exportpolitiek te ondersteunen: door het opvoeren van de produktiviteit en de handhaving van lage prijzen zou de Nederlandse industrie op de internationale markt beter kunnen concurreren. $\mathrm{Na}$ een eerste fase van economisch herstel zou de greep van de overheid op het economisch terrein geleidelijk aan afnemen. Geleidelijk groeide er een

"heimwee naar een vrijer bedrijfsleven".

Bovendien was in het kader van het zogenaamde Marshallplan liberalisatie van het economisch leven op het terrein van onder andere de distributie en de loon- en prijscontrole als voorwaarde gesteld ${ }^{\mathbf{}}$.

De discussie die de eerste jaren na de oorlog gevoerd zou worden aangaande de ordening van het sociaaleconomische leven richtte zich voornamelijk op het totstandkomen van de publiekrechtellike bedrijfsorganisatie. Daarnaast zou er in deze periode sociaal-economische wetgeving tot stand komen, waarbij een aantal reeds bestaande eerder uitgevaardigde regelingen werd vervangen, die, ten doel hadden door middel van verboden, vergunningen en ontheffingen, enige ordening te brengen door de concurrentie te beperken. Genoemd kunnen worden de Winkelsluitingswet 1951, de Bedrijfsvergunningenwet 1954, de Vestigingswet Bedrijven, de Uitverkopenwet 1956 en de Wet economische mededinging ${ }^{7}$, die het Kartelbesluit verving.

De discussie rond de publiekrechtelijke bedrijfsorganisatie zou uiteindelijk uitmonden in de Wet op de Bedrijfsorganisatie", waarbij de Sociaal-Economische Raad zou worden ingesteld als adviesorgaan van de regering. Daarbij kwamen tevens een aantal andere regelingen en instellingen op het gebied van de sociaal-economische ordening te vervallen, zoals de Bedrijfsradenwet 1933, de Wet op de ondernemersovereenkomsten 1935, de Hooge Raad van Arbeid en de Economische Raad. Deze regeling van de bedrijfsorganisatie is gebaseerd op het inzicht, dat de gewenste ordening niet alleen van de overheid alleen uit zou kunnen gaan en dat de direct betrokkenen, de werkgevers en de werknemers, daarbij een belangrijke rol zouden dienen te spelen $^{10}$.

Niet alleen de samenwerking op nationaal niveau en in de bedrijfstakken, maar ook die in de afzonderlijke 
ondernemingen kwam na de bevrijding in een nieuw stadium. V6or de oorlog waren reeds uit vrije wil en later ook wel krachtens collectieve arbeidsovereenkomsten in een aantal ondernemingen contactcommissies, personeels- of fabriekskernen ingesteld als personeelsvertegenwoordigingen, die zich vooral door middell van het geven van adviezen met sociale aangelegenheden in het bedrijf bezighielden. Daarbij werd vorm gegeven aan de overtuiging, dat ${ }^{11}$

"de onderneming niet slechts is een min of meer toevallig samentreffen, waaruit de ondernemer zijn winst en de arbeider zijn levensonderhoud put, maar dat zij een arbeidsgemeenschap behoort te zijn, die, behalve een economisch, ook een sociaal doel heeft en die slechts dan tot volle ontplooiing kan komen, indien zij wordt gedragen door een juist begrip, enerzijds voor de betekenis voor ieders bijdrage anderzijds voor de betekenis van deze bijdragen gezamenlijk voor het bereiken van het ondernemingsdoel".

Erkenning van de arbeider in zijn menselijke waardigheid, verbetering van de band tussen de arbeider en zijn arbeid, bevordering van de produktie door saamhorigheidsgevoel en het verlangen naar economische zeggenschap waren de motieven, die nà de oorlog de behoefte deden groeien om dergelijke samenwerking in de afzonderlijke bedrijven een bredere grondslag te geven. Het streven was gericht te komen tot ondernemingsraden, die als instellingen niet alleen de sociale belangen van de arbeiders tegenover de ondernemingen te behartigen, maar waarin in onderlinge samenwerking tussen bedrijfsleiding en vertegenwoordiging wan arbeiders een zo goed mogelijk functioneren van de onderneming wordt bevorderd. Eén en ander zou uitgewerkt worden in de Wet op de ondernemingsraden ${ }^{12}$, waarbij in het algemeen aan ondernemingen van een bepaalde omvang de verplichting werd opgelegd een ondernemingsraad in te stellen, waarin naast sociale ook economische onderwerpen die de onderneming aangaan aan de orde konden worden gesteld ${ }^{13}$. De ondernemingsraden kunnen worden beschouwd als een uiting van het streven naar een verbetering van het arbeidsklimaat in het afzonderlijke bedrijf. Hoewel ook hieraan vór de oorlog door een aantal bedrijven afzonderlijke aandacht was besteed, zou eerst nà de oorlog de bellangstelling hiervoor sterk toenemen. De bedrijfspsychologie als wetenschap en de sociale psychologie in het algemeen zouden zich in belangrijke mate ontwikkelen; men werd zich steeds meer bewust van de betekenis van het belang van goede menselijke verhoudingen zowel voor het persoonlijk welzijn van degene die werkt als voor de ontwikkeling van de bedrijven. Gespecialiseerd personeelsbeleid, deskundig personeelsbeheer, het onderrichten van het bedrijfskader in het leidinggeven en samenwerken in groepsverband, bedrijfsmaatschappelijk werk en bedrijfsgeneeskunde zouden aan belang winnen ${ }^{14}$.

Niet alleen deze ontwikkelingen, maar ook de stelselmatige afronding en uitbreiding van de wettelijke arbeidersbescherming, hetgeen vanzelfsprekend zijn weerslag heeft gevonden op het werkterrein en de werkzaamheden van de arbeidsinspectie.

\section{De Arbeidswet 1919}

In deze periode zou aan de al vanaf het Kinderwetje van Van Houten bestaande situatie, dat de arbeid in de landbouw in de ruimste zin ${ }^{15}$ buiten de bescherming van de Arbeidswet 1919 viel een einde komen door een wetswijziging in $1955^{16}$. De regeling van de arbeids- en rusttijden voor deze categorie van arbeid is afwijkend van de ten opzichte van de overige categorieën van arbeid gevolgde systematiek. De Kroon heeft de bevoegdheid gekregen, dus niet een verplichting, om bij algemene maatregel van bestuur een regeling te treffen, waarbij tevens wordt aangegeven binnen welk raam die regeling eventueel zou moeten worden vastgesteld. Het bijzondere van de regeling is $\mathrm{nu}$, dat de bedoelde algemene maatregel van bestuur achterwege blijft zolang en voor zover een verordening geldt krachtens artikel 10 van het Instellingsbesluit Landbouwschap $^{17}$ of krachtens artikel 8 van het Instellingsbesluit Bosschap ${ }^{18}$, waarin de arbeids- en rusttijden zijn geregeld; een dergelijke verordening geldt vanaf 1 mei 1960 ten aanzien van de arbeids- en rusttijden in de landbouw, sedert 1961 in de tuin- en bosbouw ${ }^{19}$. De centrale overheid onthoudt zich dus hier van optreden ingeval de publiekrechtelijke bedrijfslichamen een regeling tot stand brengen overeenkomstig de Wet op de 
Daarnaast zouden er in deze periode verschillende in de Arbeidswet 1919 opgenomen, maar nog steeds niet in werking getreden bepalingen aangaande arbeids- en rusttijden uitgevaardigd worden, zodat na ruim 40 jaren de wet, op een paar uitzonderingen na, in volle omvang in werking is getreden. In dit verband moet gewezen worden op het nieuwe Werktijdenbesluit voor koffiehuis- en hotelpersoneel $1949^{20}$, dat op 1 september 1949 in werking zou treden voor wat betreft de maximale arbeidsduur ook voor volwassen arbeiders, terwijl vanaf 1 januari 1954 voor hen ook een regeling zou gelden ten aanzien van de wekelijkse rustdag. Voorts werd het Werktijdenbesluit voor pakhuizen uitgevaardigd in 1954, gevolgd door het Werktijdenbesluit voor bioscopen, voor bad- en zweminrichtingen en voor de zogenaamde restgroepen ${ }^{21}$.

\subsection{Overwerk en ploegendienst}

Omtrent het toezicht op de naleving van de Arbeidswet 1919 kan worden opgemerkt, dat het gebrek aan grond- en brandstoffen in de eerste jaren na de oorlog een beletsel vormde voor het snel op gang komen van de industrie, terwijl vele ondernemingen niet of niet volledig konden deelnemen aan het op gang brengen van de produktie vanwege het feit dat het bedrijf was verwoest of de machines door de bezetter waren geroofd. Langzamerhand zou hier verbetering in komen, maar naar mate de bedrijvigheid toenam, was er echter in veel gevallen een gebrek aan personeel. Van de zijde van de arbeidsinspectie werd een grote mate van soepelheid vereist; door het verlenen van vergunningen onder andere voor het werken in ploegendienst en voor het verlengen van de arbeidstijd, werd zoveel mogelijk aan de ontstane moeilijkheden tegemoet gekomen. Het aantal vergunningen zou van 9208 in 1946 oplopen tot 25976 in 1949. Toch zou van de zijde van de arbeidsinspectie, ondanks het gebrek aan toezichthoudend en geschoold personeel en een tekort aan machines, geprobeerd worden het verrichten van overwerk zoveel mogelijk tegen te gaan en waar mogelijk daarvoor in de plaats het verrichten van ploegenarbeid te bevorderen, vanwege het feit, dat in de uitbreiding van de arbeid in een twee- of meerploegenstelsel de mogelijkheden aanwezig werden geacht om de werkgelegenheid in de industrie te bevorderen. Uit een onderzoek dat door de arbeidsinspectie was ingesteld naar de mate waarin in ons land in ploegen werd gewerkt, was onder andere de mogelijkheid naar voren gekomen dat op een dergelijke wijze nieuwe werkgelegenheid voor wellicht 20.000 werknemers geschapen kon worden, uitgaande van de veronderstelling dat een verhoogde produktie gepaard zou gaan met een kostprijsverlaging en er voldoende afzet gevonden zou worden op buitenlandse afzetmarkten ${ }^{22}$. Een hinderpaal voor het invoeren van een ploegendienstregeling was echter vaak een gebrek aan geschoolde en ook ervaren arbeidskrachten. Waar mogelijk werd in bedrijven waar veelvuldig overwerk voorkwam op verzoek van het districtshoofd van de arbeidsinspectie nagegaan of door bijvoorbeeld verbeteringen op het terrein van de bedrijfsorganisatie de behoefte aan overwerk kon worden verminderd. Desalniettemin zou het aantal overwerkvergunningen blijven stijgen met als piekjaar 1956 toen 48.335 van dergelijke vergunningen werden verleend. Als gevolg van een betrekkelijk zwakke economische recessie zou in de beide daaropvolgende jaren het aantal vergunningen afnemen tot 34.595 in 1958 , waarna zich weer een stijging zou manifesteren ${ }^{23}$.

\subsection{Het streven naar een vijfdaagse werkweek}

Een bijzonder probleem vlak na de oorlog vormde het streven van de arbeiders naar een vijfdaagse werkweek, waarbij of korter werd gewerkt of de arbeidstijd van 48 uren over deze dagen werd verdeeld. Als argumenten hiervoor werden onder andere aangevoerd: het bezwaar van buiten hun woonplaats werkende arbeiders tegen het heen en weer reizen op de zaterdag terwijl op die dag slechts korte tijd arbeid behoefte te worden verricht, en de wens om die dag te kunnen doorbrengen op een wijze zoals men zelf wilde. De werkgevers stonden vaak niet onwelwillend tegenover dit streven, waarbij met name brandstofbesparing en produktieverhoging als argumenten werden aangevoerd. Van de zijde van de arbeidsinspectie werd echter gesteld, dat de steun van de werkgevers in veel gevallen kon worden toegeschreven aan de dreigementen van 
de arbeiders en voornamelijk van de vrowwelijke arbeiders, dat zij het bedrijf zouden verlaten. Het $\mathrm{kwam}$ voor, dat de vrije zaterdag als lokmiddel werd gebruikt om aan vrouwelijk personeel te komen. De werkgevers die op zaterdag arbeid lieten verrichten, dreigden hiervan de dupe te worden. De minister van Sociale Zaken nam in deze het standpunt in, dat de invoering van de vijfdaagse werkweek in het algemeen niet moest worden gestimuleerd, zolang een werkweek van $5 \times 8,5$ uur of 42,5 uur economisch niet verantwoord was; een standpunt dat werd ingenomen mede op advies van de Stichting van de Arbeid. Dit beleidsstandpunt, dat door de arbeidsinspectie werd doorgevoerd in het kader van het vergunningenbeleid leidde tot talloze beroepszaken. Naar aanleiding hiervan en mede als gevolg van een toenemende drang van werknemerszijde, werd door de betrokken bewindsman de problematiek opnieuw voorgelegd aan de Stichting van de Arbeid, hetgeen uiteindelijk resulteerde in de handhaving van het reeds ingenomen standpunt, zij het met een gering aantal uitzonderingsmogelijkheden. Teneinde toch enigszins tegemoet te komen om op de zaterdag wat korter te werken om in ieder geval de vrije middlag meer tot zijn recht te doen komen, werd de mogellijkheid geopend tot het verlengen van de werktijd van de eerste 5 werkdagen tot 8 uren en 3 kwartier, waardoor de werktijd op zaterdag werd teruggebracht tot 4 uren en een kwartier ${ }^{24}$. Een dergelijk terughoudend beleid zou worden gevoerd tot het begin van de jaren zestig. In de jaren 1960 tot en met 1962 zou in ons land de 45 -urige vijfdaagse werkweek worden ingevoerd ${ }^{25}$. De daarvoor vereiste vergunningen werden door de arbeidsinspectie slechts verleend, behalve in gevallen waarin technische motieven een rol speelden, indien in het bedrijf de wekelijkse werktijd met goedkeuring van het college van Rijksbemiddelaars werd ingekort ${ }^{26}$. Overigens zou begin 1962 door de minister van Socialle Zaken en Volksgezondheid algemene vergunningen voor een werkweek van $5 \times 9$ uren voor jeugdige ${ }^{27}$ en volwassen werknemers uitvaardigen ${ }^{28}$, zodat het aantal individueel door de arbeidsinspectie te verlenen vergunningen drastisch zou afnemen ${ }^{28}$. In 1962 zoudlen er uiteindelijk toch nog 28.555 overwerkvergunningen worden verleend ${ }^{30}$.

\subsection{Contacten met de ondernemingsraden omtrent vergunningverlening; verdergaande medezeggenschap} in sommige bedrijfstakken ( slagersbedrijf)

De veranderende inzichten die onder meer zouden resulteren in de Wet op de ondernemingsraden hadden ook hun weerslag op de arbeidsinspectie en de uitvoering van de Arbeidswet 1919. Met betrekking tot het verlenen van overwerkvergunningen werd aanvankelijk in de jaren direct na de oorlog regelmatig overleg gepleegd met de werkgevers- en werknemersorganisaties alsmede met fabriekskernen, ten einde het overwerk in goede banen te geleiden. Daarbij werd dan wel de opmerking geplaatst, dat de arbeiders in sommige gevallen tegen zichzelf beschermd moesten worden, omdat zij uit een overigens begrijpelijk verlangen naar een vermeerdering van inkomsten dikwijls te vinden waren voor een soms bovenmatige verlenging van de arbeidstijd $^{31}$. Na de inwerkingtreding van de Wet op de ondernemingsraden werd bij het onderzoek naar aanleiding van de vergunningaanvragen zeer vaak ook het oordeel van de ondernemingsraden betrokken ${ }^{32}$.

In een aantall gevallen ging de inspraak van werkgevers en werknemers zelfs verder, zoals in het slagersbedrijf. Bij de vertegenwoordigers van werkgevers- en werknemersorganisaties werd bij de in 1949 geopende onderhandelingen om tot een collectieve arbeidsovereenkomst in het gehele slagersbedrijf te komen de wens naar voren gebracht, om aan het bedrijfsleven zelf bepaalde bevoegdheden toe te kennen in het bijzonder met betrekking tot het vaststellen van plaatselijke werktijdregelingen. De directeur-generaal van de Arbeid was in beginsel bereid zijn medewerking te verlenen aan de totstandkoming van een collectieve arbeidsovereenkomst, waarin deze gedachte was uitgewerkt, hetgeen dus in feite erop neerkwam, dat het georganiseerde bedrijfsleven zelf regelend zou kunnen optreden bij het vaststellen van arbeids- en rusttijden. Eén en ander leidde in de afsluiting van een collectieve arbeidsovereenkomst voor het slagersbedrijf per 1 januari 1952 , waarin aan de zogenaamde Landelijke Commissie, die paritair was samengesteld uit vertegenwoordigers van de betreffende organisaties, onder meer de bevoegdheid werd toegekend, om in overleg met het betrokken districtshoofd van de arbeidsinspectie plaatselijke werktijdregelingen toe te staan, alsmede eventueel hiervan afwijkende werktijdregelingen toe te staan, in het laatste geval echter alleen voor zover de betrokken regelingen niet ook een afwijking van het bij of krachtens de Arbeidswet 1919 bepaalde inhielden. Bovendien was 
in handen van de genoemde commissie de regeling gelegd van overwerk in spoedeisende gevallen door middel van de zogenaamde overwerk-coupons, waarbij de te volgen procedure ongeveer gelijk was aan die welke werd toegepast bij het betreffende artikel 29 van de Arbeidswet 1919. Aangezien deze werkwijze alleen mogelijk was, indien voor het overwerk tevens afwijking van de bepalingen van de Arbeidswet 1919 werd toegestaan, werd voor dit doel door de minister van Sociale Zaken en Volksgezondheid onder de nodige beperkingen en voorschriften een algemene vergunning verleend. Naast de Landelijke Commissie werden ook plaatselijke of streekcommissies ingesteld, die onder meer tot taak hadden voorstellen te doen betreffende de plaatselijke werktijdregelingen. Met name het instellen van de laatstbedoelde commissies ontmoette aanvankelijk nogal wat moeilijkheden. Ten einde de vitvoering van de opzet van de collectieve arbeidsovereenkomst met betrekking tot het vaststellen van plaatselijke regelingen hierdoor niet te laten vertragen, maakte de Landelijke Commissie gebruik van een haar in de collectieve arbeidsovereenkomst gegeven bevoegdheid en stelde zij een uniforme werktijdregeling vast voor alle plaatsen waarin op 1 februari 1953 nog geen plaatselijke commissie was gevormd of overeenstemming over de te volgen werktijdregeling was bereikt. Dit leidde er overigens weer toe dat in verschillende gemeenten bij de slagers een toenemende activiteit werd bespeurd om medewerking te verlenen bij het nader vaststellen van de voor hun bedrijf meest passende werktijdregeling $^{33}$. De hierbedoelde regelingsmogelijkheid ten aanzien van het slagersbedrijf geldt heden ten dage nog steeds.

\subsection{Bakkersarbeid}

De geleidelijke terugkeer van normale toestanden in de bedrijven wordt mede weerspiegeld in het aantal klachten, dat in toenemende mate binmenkwam en die voor een niet onaanzienlijk deel betrekking hadden op de nietnaleving van de arbeids- en rusttijdbepalingen en welke met een zekere regelmaat betrekking hadden op bakkersarbeid ${ }^{34}$.

Door de nawerking van de oorlogsomstandigheden hield men zich aanvankelijk niet altijd aan de wettelijke bepalingen aangaande de arbeids- en rusttijden, maar naar mate de situatie weer min of meer normaliseerde, kon een intensievere controle te dienaangaande geleidelijk aan weer ter hand genomen worden. Eén van de categorieën van arbeid die, evenals trouwens in eerdere perioden, in dit kader nogal wat capaciteit van de arbeidsinspectie opslokte was de broodbakkerijsector. De oorzaak hiervan had zijn basis in de oorlogsjaren. In het begin van 1944 bleef de situatie gehandhaafd waarbij het broodbakkersbedrijf zich zo goed mogelijk had aangepast aan de abnormale situatie. De grootste problemen werden toen veroorzaakt door de kleine brandstoffentoewijzing en de steeds krapper wordende personeelsbezetting, gevoegd bij de geringe mogelijkheid tot onderhoud en vernieuwing van de outillage en het bezorgmateriaal. De oorlogswinter van 1944 1945 bracht een noodtoestand, waarbij alle beperkingen inzake de arbeids- en rusttijden wegvielen en het enige oogmerk was de aanwezige voorraden grond- en brandstoffen zo economisch mogelijk te gebruiken ten behoeve van de bevolking. Met de bevrijding en de geleidelijke verhoging van het broodrantsoen tot een niveau dat hoger was dan woor de oorlog, was een terugkeer naar normale verhoudingen niet goed mogelijk waardoor in feite een chaotische situatie ontstond. Eên van de oorzaken was gelegen in een enorme stijging van het gebruik van kleinbrood, dat aanzienlijk meer voorbereidingstijd vergde dan groot brood, maar vanwege de grotere winst voor de bakkers aanleiding was om zoveel mogelijk aan de grote vraag te voldoen ${ }^{36}$. Dit leidde tot ernstige overtreding van het aanvangstijdstip, wat weer leidde tot grote onrust onder de bakkersgezellen en hier en daar tot moeilijkheden aanleiding gaf. Hoewel aanvankelijk van de zijde van de arbeidsinspectie de broodbakkerijsector welwillend tegemoet werd getreden, werd het met het oog op de toenemende excessen ten aanzien van de nachtarbeid en de onrust onder de bakkersgezellen, noodzakelijk geacht strenger op te treden en de bakkerspatroons duidelijk gemaakt dat de Arbeidswet 1919 ook ten aanzien van hun bedrijf van kracht was ${ }^{36}$. Ten aanzien van arbeidswettelijke kwesties werd door de arbeidsinspectie regelmatig overleg gepleegd met de in verschillende plaatsen ingestelde bakkerijadviescommissies ${ }^{37}$. Desalniettemin bleef doorlopende controle vereist, hetgeen in de eerste jaren na de oorlog onder meer leidde tot opleggen van principale hechtenis aan respectievelijk 15 bakkerspatronen in de jaren 1946 en 1947,11 bak- 
kerspatronen in 1948 en 43 bakkerspatronen in het jaar daarop ${ }^{38}$. De bedrijfsresultaten in het bakkersbedrijf en dan met name in het kleinbedrijf waren dusdanig, dat de noodzakelijke verbeteringen van de outillage ten einde aan de behoefte te kunnen voorzien achterwege bleven. Eén van de oorzaken was gelegen in het feit, dat er een gering aanbod was van jeugdig personeel, waardoor oudere arbeidskrachten de werkzaamheden die normaal door leerlingen werden gedaan, moesten verrichten. Ook het veranderende gedrag van de consument, die in toenemende mate w6ór 12.00 uur wilde worden bediend had consequenties. Er ontstond een grote behoefte aan faciliteiten waar de arbeidsinspectie aan tegemoet kwam, maar de neiging tot wetsovertreding was niet gering, zodat controle geboden bleef. Maar het bakkersbedrijf onderging ook een belangrijke verandering. Door de toegenomen mechanisatie ontstond in steeds sterkere mate een afscheiding tussen de broodbakkerij en de banketbakkerij, zodat voor de onderscheiden bedrijfsoorten meer en meer afzonderlijke werktijdregelingen werden vastgesteld. Maar de onrust in de bakkerswereld bleef toenemen; de problemen aangaande het personeel bleven aanwezig. Vele kleine bakkerijen werden opgeheven, terwijl andere zich probeerden te handhaven door of zelf te mechaniseren of door het betrekken van brood van grote bakkerijen. Dit laatste leidde tot een gestage groei van de omzet bij de grote bakkerijen, die, teneinde een zo goed mogelijk rendement uit de benodigde investeringen te behalen, wilden overgaan tot het verrichten van ploegenarbeid. De mogelijke invoering daarvan maakte, dat de eigenaren van kleine en middelgrote bedrijven zich bedreigd voelden in hun bestaansmogelijkheden. Om die reden voerde de arbeidsinspectie dan ook een terughoudend beleid; een vergunning om in ploegen bakkersarbeid te mogen verrichten werd slechts bij uitzondering verleend, onder andere als tijdelijke maatregel voor de tijd dat een uitbreiding van de produktiemiddelen werd gerealiseerd en indien de export van brood een te wankele basis was om grote investeringen te rechtvaardigen, terwijl bij het verlenen van dergelijke vergunningen steeds het advies werd gevraagd van het Georganiseerd Overleg van werkgevers- en werknemersorganisaties in deze bedrijfstak. De onrust in de bakkerswereld bereikte een hoogtepunt toen het advies van de Sociaal-Economische $\operatorname{Raad}^{3 \theta}$ bekend werd, waarin tot uiting werd gebracht dat de meerderheid van dit adviesorgaan zich een voorstander verklaarde van ploegenarbeid in het bakkersbedrijf. Dit advies, te zamen met de resultaten van een in januari 1960 door de arbeidsinspectie gehouden steekproefonderzoek naar aanleiding van in de Tweede Kamer gestelde vragen omtrent de naleving van de arbeidswettelijke bepalingen in broodbakkerijen met name wat betreft het aanvangstijdstip, leidde tot een toenemende aandrang van de zijde van de grote bakkerijen om vergunningen met een ( sterk) vervroegd aanvangsuur voor het vervoeren en het afleveren van brood gekoppeld aan ploegenarbeid. De arbeidsinspectie nam echter het standpunt in, dat er voorlopig geen aanleiding was om haar vergunningenbeleid in deze te wijzigen ${ }^{40}$. Twee jaar later was een wijziging van de zogenaamde "bakkerijparagraaf" van de Arbeidswet $1919^{41}$ een feit, waarbij en het aanvangstijdstip voor het vervoeren en het afleveren van brood werd vervroegd en de mogelijkheid om door middel van een vergunning van de arbeidsinspectie in bepaalde gevallen bakkersarbeid in afwisselende ploegen te verrichten werden gerealiseerd. Als gevolg van de moeilijkheden met de personeelsvoorziening liet de nalleving van de wettelijke arbeids- en rusttijdenbepalingen toch nog steeds te wensen over ${ }^{42}$.

\subsection{Vrouwelijke arbeidskrachten}

Hierboven is reeds zijdelings melding gemaakt van de problematiek rond de vrouwelijke arbeiders; de periode direct na de oorlog kenmerkte zich door een gebrek aan personeel en dan met name vrouwelijke arbeidskrachten. Voor de oorlog waren er in ons land betrekkelijk weinig gehuwde vrouwen in de industrie werkzaam. Van 6300 in 1932 daalde dit aantal in 1934 tot 5800 , waarna er weer een stijging plaatsvond tot 6600 in 1938; gemiddeld werkten in de jaren 1932 tot en met 19386300 gehuwde vrouwen als fabrieksarbeider. Sinds de oorlog is hierin grote verandering gekomen. Nadat tijdens de oorlogsjaren de vrouwenarbeid sterk was verminderd, veroorzaakte de grote vraag naar arbeidskrachten door de oplevende industrie een toename van het aantal gehuwde vrouwen. Zo waren er in 194815.200 en in 194920.000 gehuwde fabrieksargeconstateerd tussen de gehuwde vrouwelijke fabrieksarbeiders van vór en van nà de oorlog. Naast de eco- 
nomische noodzaak waren er een aantal typisch na-oorlogse verschijnselen mede van invloed op het gaan werken van gehuwde vrouwen in de fabrieken, zoals het onvolledige gezin (als gevolg van het feit dat de echtgenoot in militaire dienst was, buiten de woonplaats werkzaam was of gedetineerd was ), de kleine behuizing ( waardoor de vrouwen geen volledige dagtaak hadden in het gezinsverband ), echtscheidingen, de behoefte aan goederen die door de fabrieken naast het loon werden verstrekt ${ }^{44}$. In het daarop volgende jaarverslag werd gesteld, dat de fabrieksarbeid van gehuwde vrouwen in ons land in het algemeen als een armoede-verschijnsel moest worden beschouwd ${ }^{45}$.

In een aantal fabrieken waar zich met name een gebrek aan vrouwelijke arbeidskrachten voordeed, werd geprobeerd een oplossing te vinden door zogenaamde vaste avondploegen in te stellen voor 3 of 4 uren op maandag tot en met vrijdag; dergelijke avondploegen van gehuwde vrouwen werden zeer nadelig geacht voor de gezinnen, zodat de arbeidsinspectie ten aanzien van het verlenen van vergunningen voor dergelijke ploegen een terughoudend beleid voerde; slechts in die gevallen, waarin een dergelijke regeling onontbeerlijk moest worden geacht voor de goede gang van het bedrijf en door de werkgever kon worden aangetoond, dat het door de betrokken vrouwen werken in de avond niet zou leiden tot een onverantwoorde vermindering van de verzorging van het gezin; werd een vergunning verleend. Moeders van leerplichtige kinderen werden daarentegen in het algemeen van een dergelijke vergunning uitgesloten. Een zelfde beleid werd gevoerd ten aanzien van het door gehuwde vrouwen verrichten van overwerk; voor gehuwde vrouwen met kinderen beneden de 14 jaar werd geen overwerkvergunning verleend ${ }^{46}$.

Een dergelijk beleid waarbij een onderscheid werd gemaakt tussen gehuwde en ongehuwde vrouwen en dat van voor de oorlog stamt, bleef na de oorlog gehandhaafd en vond onder andere zijn weerslag in de op 1 september 1949 in werking getreden arbeids- en rusttijdenregeling voor koffiehuis- en hotelpersoneel waarin beperkende bepalingen waren opgenomen ten aanzien van de arbeid van vrouwen die een huishouding te verzorgen hadden. Dit had weer tot gevolg dat werkgevers in deze branche, ondanks een soepele toepassing van het bewuste besluit in de aanvang, de zekerste weg kozen en overgingen tot het aanstellen van arbeidskrachten waarvoor dergelijke beperkende bepalingen niet golden ${ }^{47}$. Overigens bracht de controle met betrekking tot dit nieuwe werktijdenbesluit, omdat de betrokken ondernemingen nogal wat aanpassingsproblemen hadden, voor de arbeidsinspectie veel werk met zich ${ }^{48}$; zo waren er van de in 1950 ontvangen 8613 arbeidslijsten en roosters niet minder dan 5563 foutief ingevuld ${ }^{49}$. De overige in deze periode in werking getreden nieuwe werk- en rusttijdenbepalingen voor pakhuizen, bioscopen en bad- en zweminrichtingen zouden overigens nauwelijks tot problemen aanleiding geven.

\section{De Veiligheidswet 1934}

Evenals het geval was met de Arbeidswet 1919 was in deze periode een gestage voortgang op het terrein van de bescherming van de veiligheid en de gezondheid waar te nemen. Diverse nieuwe algemene maatregelen van bestuur werden uitgevaardigd, zoals het Veiligheidsbesluit elektrische schrikdraden, het Landbouwveiligheidsbesluit en het Veiligheidsbesluit ioniserende stralen ${ }^{50}$, terwijl reeds bestaande besluiten werden aangepast en gemoderniseerd in verband met de veranderingen die op het gebied van de techniek en van de beveiligingsmethoden ${ }^{51}$.

\subsection{De bedrijfsgeneeskundige diensten}

In verband met de ontwikkeling van het industriële leven was in een steeds breder wordende kring het besef gegroeid, dat een doeltreffende preventieve gezondheidszorg in de bedrijven van uitermate groot belang is voor het lichamelijke en geestelijke welzijn van de arbeidende bevolking, maar dat niet alleen; het belang van de bedrijven en het belang van de gehele Nederlandse bevolking zijn daarmede evenzeer gediend. Om die reden was het niet verwonderlijk dat van overheidszijde de ontwikkeling van de bedrijfsgeneeskunde zoveel mogelijk werd bevorderd. De arbeidsinspectie richtte zich in ruime mate op de bescherming van de gezondheid en het leven van de arbeiders. Naast dit werk op veiligheidstechnisch gebied, werd door bij deze 
overheidsclienst werkzame geneeskundigen al vele tientallen jaren aandacht besteed aan bijvoorbeeld de bestrijding van beroepsziekten, aan de bevordering van de hygiënische toestanden in de bedrijven en de gevaren die aan bepaalde werkzaambeden voor de gezondheid met zich brengen, zoals bijvoorbeeld steenhouwersarbeid en de verwerking van loodhoudende stoffen. Maar niet ontkend kan worden, dat wanneer de gezondheidszorg door de bedrijven zelf ter hand zou worden genomen, dit veel sneller tot resultaten zou leiden. Vandaar dat de arbeidsinspectie ook met steeds meer klem aandrong op de instelling van bedrijfsgeneeskundige diensten. De eerste vrijwillige bedrijfsgeneeskundige dienst werd in 1928 in het leven geroepen, sindsdien volgden er meer.

In 1947 verscheen er een belangrijk rapport voor de ontwikkeling van de bedrijfsgeneeskunde van een werkcommissie van de sectie voor Arbeids- en Bedrijfsgeneeskunde van de Algemene Nederlandse Vereniging voor Sociale Geneeskunde ${ }^{52}$, waarin op de overheid een beroep werd gedaan om richtlijnen te geven voor de ontwikkeling van de bedrijfsgeneeskunde, de bedrijfsgeneeskundige diensten te onderwerpen aan een goedkeuring van overheidswege en wanneer de tijd daarvoor rijp was over te gaan tot het verplicht stellen van bedrijfsgeneeskundige diensten ${ }^{53}$. Van overheidszijde werd daarop, overtuigd van de betekenis van de conclusies en de algemene strekking van dit laatstgenoemde rapport, een commissie ingesteld ${ }^{54}$ die onder leiding van de directeur-generaal van de Arbeid Fetter, die met ingang van 1 oktober 1946 Hacke opvolg$\mathrm{de}^{55}$, een wettelijke regeling van de bedrijfsgeneeskundige diensten te ontwerpen. Het rapport van deze commissie werd in 1951 uitgebracht ${ }^{58}$; het bevat een uitvoerige schets van de ontwikkeling van de bedrijfsgeneeskunde in ons land, van de taak van de bedrijfsarts, van de verhouding van de bedrijfsgeneeskundige diensten tot andere organen, terwijl het uitvoerig ingaat op de wenselijkheid van een wettelijke regeling en op de vraag, wat de materiële inhoud van een dergelijke regeling zou moeten zijn. In 1955 zou een en ander resulteren in een wetsvoorstel tot wijziging van de Veiligheidswet 1934, waarbij de nadruk lag op arbeid verricht in fabrieken of werkplaatsen, die verplicht afzonderlijk of gezamenlijk een bedrijfsgeneeskundige dienst in stand diende te houden ${ }^{57}$, ten einde de vooralsnog noodzakelijke geleidelijkheid in acht te nemen. Het systeem van de wet verzette zich echter niet tegen uitbreiding van de werkingssfeer van het wetsvoorstel, indien de tijd daarvoor rijp kon worden geacht ${ }^{58}$. Ter verdediging van deze keuze voerde de betrokken bewindsman het volgende $\operatorname{aan}^{59}$ :

"De ondergetekende meent, dat de bedrijfsgeneeskundige zorg en het daaraan verbonden bedrijfsgeneeskundige toezicht op de meest aantrekkelijke wijze wordt geregeld, wanneer zodanige regeling een plaats vindt in het geheel der wettelijke bepalingen op het gebied der arbeidersbescherming, waarmede op gelukkige wijze wordt aangeknoopt bij de ontwikkeling, welke de bedrijfsgeneeskunde in thet kader van de ontwikkeling der arbeidersbescherming, als geheel gezien, heeft doorgemaakt. Bovendien is het gewenst, dat de plaats, welke de bedrijfsgeneeskundige dienst in de onderneming inneemt, ten naaste bij parallel loopt met de wijze, waarop de bemoeienis met de bedrijfsgeneeskunde in het geheel der Overheidsbemoeiingen met de bedrijven is ondergebracht..... de bedrijfsgeneeskundige dienst vindt zijn primaire taak in de sfeer van de bijzondere sociologische eenheid, die het bedrijf vormt. Alle gezondheidsstoringen krijgen in deze sfeer een bepaald aspect. Een wettelijke regeling van deze materie behoort dus ook thuis in het stelsel van wettelijke maatregelen, dat zich met de interne sfeer van het bedrijfsleven uit anderen hoofde reeds vele jaren bezighoudt. Daar komt bij, dat ten aanzien van de bevordering der bedrijfsgeneeskunde en het toezicht, dat daarop krachtens de wettelijke straks zal moeten worden uitgeoefend, een belangrijke taak toevalt aan de Arbeidsinspectie. Zoals ..... reeds werd opgemerkt, heeft de Medische Dienst der Arbeidsinspectie zich reeds jaren lang met bedrijfsgeneeskundig toezicht bezig gehouden, de totstandkoming van bedrijfsgeneeskundige diensten bevorderd en met de bestaande diensten een intensief contact onderhouden. Deze samenwerking zal, indien een wettelijke regeling, als thans is voorgesteld, tot stand komt, nog meer dan vroeger van node zijn. De ervaring heeft bovendien geleerd, dat deze taak alleen met goed gevolg kan worden vervuld in een zeer nauwe samenwerking tussen medische, technische en che- 
mische deskundigen. Samenstelling en werkwijze van de dienst der Arbeidsinspectie zijn een waarborg voor zodanige samenwerking. $\mathrm{Om}$ al deze redenen acht de ondergetekende het de juiste weg, de voorgenomen wettelijke regeling onder te brengen in de Veiligheids wet 1934, de wet, welke in het bijzonder de bescherming van de gezondheid en het leven van de arbeiders ten doel heeft. De considerans der Veiligheidswet spreekt de noodzakelijkheid uit "bepalingen vast te stellen tot beveiliging bij de arbeid". Het begrip "beveiliging bij de arbeid" moet ten deze - gezien de tegenwoordige inhoud van de Veiligheidswet ruim worden opgevat en is zeker niet beperkt tot de zorg voor de veiligheid in engere zin. Een wettelijke regeling alls de onderhavige valt derhalve ook binnen het door de considerans getrokken kader der wet".

Daar de bedrijfsgeneeskundige zorg zich geheel afspeelt binnen de bedrijfsgemeenschap, meende de betreffende bewindsman ${ }^{80}$, dat het van zelf sprak, dat het toezicht hierop diende te berusten bij de arbeidsinspectie, een overheidsdienst die tenslotte al reeds meer dan een halve eeuw belast was met het toezicht op de beveiliging bij de arbeid in het algemeen en bij het verblijven in fabrieken en werkplaatsen in het bijzonder. Dit als reactie op het advies van de Centrale Commissie voor de Volksgezondheid ${ }^{\text {e1 }}$ waarin onder meer gesteld werd, dat het toezicht op de bedrijfsgeneeskundige zorg de aangewezen taak was van het Staatstoezicht op de Volksgezondheid, die daarmede, aldus de toenmalige staatssecretaris van Sociale Zaken, de oorsprong en de ontwikkeling van de bedrijfshygiëne miskende ${ }^{62}$.

Het vanuit de Tweede Kamer naar voren gebrachte argument ${ }^{6}$, dat de nadruk ten aanzien van het toezicht te eenzijdig op de arbeidsinspectie zou zijn gelegd en dat dit ten nadele zou zijn van de taak die de geneeskundige inspectie op dit gebied heeft, vond de bewindsman weinig overtuigend ${ }^{64}$. Naar zijn mening had hij al duidelijk gemaakt, dat hij de taak van de geneeskundige diensten primair gericht zag op de arbeidersbescherming, maar dat wil niet zeggen dat de uit dien hoofde verrichtte werkzaamheden niet tevens van groot belang zouden kunnen zijn voor de volksgezondheid. Dit samengaan van belangen maakte, evenals in de praktijk al plaatsvond, samenwerking noodzakelijk tussen de overheidsdienst, die met de uitvoering van de wettelijke maatregelen op het terrein van de arbeidersbescherming belast is en die welke waakt over de volksgezondheid. Deze samenwerking zou, voor wat betreft de aan de orde zijnde materie, tot uiting kunnen komen in het gezamenlijk zitting hebben in verschillende college's, waaronder het bij de wet in te stellen College van Bijstand en Advies voor de Bedrijfsgeneeskunde en voorts in het meer incidentele vlak. Dit door de wet in te stellen adviesorgaan vond zijn basis in het feit, dat de verantwoordelijke bewindsman, zoals hierboven al bleek, zich er van bewust was ${ }^{65}$, dat de bevordering van de bedrijfsgeneeskunde in sterke mate afhankelijk was van een nauwe samenwerking tussen alle organen, die daarbij een taak hadden, tussen de medische wereld, de werkgevers- en de werknemersorganisaties en de overheid en het om dezelfde reden van groot was om bij de beantwoording van principiële vragen en bij het nemen van belangrijke beslissingen bij dezelfde kringen te rade te gaan. Aan dit College was bij de uitvoering van de wet een belangrijke taak toebedacht. Dit orgaan werd beschouwd als een waardevol adviesorgaan op het gebied van de bedrijfsgeneeskunde, waarvan de verantwoordelijke staatssecretaris van Sociale Zaken meldde, dat de regering er op de ruimst mogelijke wijze gebruik van wilde maken; het was daarom de bedoeling, dat dit College zich ook uit eigen beweging met adviezen en voorstellen tot de regering zou wenden. Een belangrijke taak voor het College was vooral gelegen in het uitbrengen van advies omtrent het verlenen of intrekken van een erkenning als bedrijfsgeneeskundige dienst. Die erkenning immers hield de uitspraak in, dat een bedrijfsgeneeskundige dienst voldeed aan de normen die de wet ten aanzien daarvan stelt. Het werd derhalve van het grootste belang geacht, dat de beslissing door het College werd voorbereid, dat in de eerste plaats bij uitstek deskundig werd geacht en in de tweede plaats de opvatting van alle betrokkenen voldoende tot zijn recht zou laten komen. Eerst na een langdurige voorbereiding zouden de bepalingen omtrent de preventieve gezondheidszorg in de bedrijven een wettelijke status bereiken door de wijziging van de Veiligheidswet 1934 bij de Wet van 19 februari $1959^{60}$. 


\subsection{Groeiend veillgheidsbesef}

Omtrent het toezicht op de naleving van de Veiligheidswet 1934 kan worden opgemerkt dat de door de oorlogsomstandigheden zoveel ongunstiger geworden situatie aangaande de veiligheid in fabrieken of werkplaatsen in de eerste jaren na het beëindigen van de oorlog nog niet veel verbeterde, zij het toch enige vooruitgang geboekt kon worden. Het totstandkomen van voorzieningen op het terrein van de veiligheid werd in ernstige mate belemmerd door de heersende schaarste aan materialen, zodat nieuwe machines daardoor in vele gevallen niet konden worden voorzien van de benodigde beveiligingen, terwijl aan de gedurende de laatste periode van de bezetting verdwenen en weer opgestelde machines de beveiligingen ontbraken of bij het opnieuw opstellen om welke reden dan ook werden weggelaten. Door de toenemende industriële bedrujvigheid en de grote achterstand kon de bouw respectievelijk de verbouwing van fabriekspanden geen gelijke tred houden met de behoefte. In vele gevallen moest derhalve nog een tijdelijke oplossing gevonden door het in gebruik nemen van voor het bedrijf minder geschikte ruimten. In verband hiermede werd van de zijde van de arbeidsinspectie in verscheidene gevallen tijdelijk vrijstelling verleend van tem of meer bepalingen van het Veiligheidsbesluit voor fabrieken of werkplaatsen 1938.

Ten aanzien van de veiligheid in de bedrijven werd door de werkgevers van grote ondernemingen meer en meer ingezien, dat bij de zorg voor de veiligheid de belangen van de arbeiders en die van het bedrijf parallel liepen. De praktijk wees uit dat het dagelijks toezicht van een deskundige op het gebruik van de beveiligingsmiddelen, op veilige werkmethoden en op alle andere aangelegenheden die ongevallen konden voorkomen, een zeer gunstige invloed op de ongevallenfrequentie hadden. Dit groeiend inzicht kwam vooral ook tot uiting in het in september 1946 te Amsterdam gehouden veiligheidscongres, waarin men tot de conclusie kwam, dat het naast stoffelijke beveiligingsmiddelen, vooral nodig was, dat alle betrokkenen bedrijfsveiligheid als hun eigen zaak zouden voelen en beseffen. Het werd van belang geacht, dat op korte termijn veiligheidstechnici en bedrijfsartsen zouden worden aangesteld om samen te werken met vrijwillig ingestelde veiligheidscommissies, wier werk daardoor bij voortduring zou worden gestimuleerd. Voor zover genoemde functionarissen door de omvang van het bedrijf geen volledige taak zouden hebben, zou de oplossing kunnen worden gezocht in combinatie van bedrijven of in combinatie van werkzaamheden. De reeds in dienst zijnde veiligheidsfunctionarissen in de bedrijven hadden al snel het nut ingezien van gezamenlijk overleg en uitwisseling van gedachten over hun werk, waartoe zij met steun van de werkgevers een werkgroep-veiligheidsinspecteurs oprichtten, waarvoor een grote belangstelling bestond. Vanaf het begin werd hierbij de samenwerking gezocht mot de arbeidsinspectie en zou een blijvend contact ontstaan ${ }^{67}$.

In vele gevallen werden door verschillende bedrijven, nadat daarop door de arbeidsinspectie was aangedrongen, veiligheidstechnici aangesteld. Bij een grote machinefabriek bijvoorbeeld, waar de zorg voor de veiligheid nogal te wensen overliet, hadden besprekingen aanvankelijk weinig resultaat. Hoewel wel een veiligheidstechnicus werd aangesteld en een veiligheidscommissie werd geinstalleerd, werd er geen verbetering geconstateerd in de feitelijke situatie, daar aan beide wel de nodige bevoegdheden waren gegeven, maar door gebrek aan steun en belangstelling "van boven af" niets kon worden uitgericht. Toen er uiteindelijk een verandering kwam in de samenstelling van de directie en de nieuwe directie in tegenstelling tot de oude wel een warme belangstelling voor het veiligheidswerk bleek te hebben werd een doelmatige organisatie van de veiligheidsdienst in nauwe samenwerking met de arbeidsinspectie bewerkstelligd, terwijl de aan het hoofd van deze veiligheidsdienst geplaatste veiligheids-inspecteur in de staf van het bedrijf werd opgenomen ${ }^{68}$.

Uit het bovenstaande kan worden afgeleid, dat de bevordering van veiligheid en hygiëne in de eerste plaats gebeurde door een zo intensief mogelijk contact met de bedrijven, voortvloeiende uit de wettelijke taak van de arbeidsinspectie toezicht te houden op de naleving van de Veiligheidswet. Daarbij was het doel niet alleen maar naleving van de wet naar de letter, met andere woorden het minimale vereiste, te bereiken, maar het streven was erop gericht om door overreding, advies en voorlichting de veiligheidsgedachte wortel te doen schieten, voor de betekenis van een doeltreffende en systematische ongevallenbestrijding de ogen te openen veiligheid en hygiëne vorm en inhoud te geven. Het streven naar zelfwerkzaamheid ten aanzien van indivi- 
duele bedrijven werd ondersteund door landelijke, regionale of op bepaalde bedrijfstakken gerichte activiteiten op het terrein van voorlichting door middel van publikatiebladen, persberichten, demonstraties, cursussen, lezingen, tentoonstellingen en dergelijke, waarbij nauw werd samengewerkt met Veiligheidsmuseum, dat sinds 1 november 1952 de naam van Veiligheidsinstituut zou dragen ${ }^{69}$. Hoewel vele activiteiten van de arbeidsinspectie ten aanzien van de problematiek rond de veiligheid en hygiêne van de arbeiders lagen in het preventieve vlak, nam dit uiteraard niet weg, dat bij het veiligheidstoezicht in de bedrijven veelvuldig het voorschrijven van verbeteringen van de aangetroffen situatie of werktuigen nodig bleek. Behalve in de vorm van eisen gebeurde dit vaak in de minder formele vorm van de aanwijzingen. In de eerste jaren na de oorlog zou het aantal eisen en aanwijzingen ten aanzien van arbeid verricht in fabrieken of werkplaatsen van 21.247 in 1946 oplopen tot 25.479 in 1949 - ter vergelijking in 1939 bedroeg dit aantal 21.096 - om daarna geleidelijk te dalen tot 8.801 in $1961^{70}$.

\section{Een bijzondere bevoegdheid van het districtshoofd van de arbeidsinspectie in liet kader van de Arbeids- wet 1919 en de Veiligheidswet 1934}

In het kader van de handhaving van en de medewerking aan de uitvoering van de Arbeidswet 1919 en de Veiligheidswet 1934 heeft het districtshoofd van de arbeidsinspectie ${ }^{71}$ een aantal bestuurlijke instrumenten tot zijn beschikking, zoals het verlenen van vergunningen en ontheffingen en de mogelijkheid tot het kunnen stellen van eisen. In 1951 zouden beide wetten gewijzigd worden ${ }^{72}$, waarbij een nieuw instrument aan deze reeks zou worden toegevoegd, namelijk het bevel tot stillegging van werk. In artikel $82 \mathrm{bis,}$,eerste lid, van de Arbeidswet 1919 is aan het districtshoofd van de arbeidsinspectie de bevoegdheid verleend om te bevelen, dat de door hem aangewezen werkzaamheden moeten worden gestaakt, of dat jeugdige personen of vrouwen niet in door hem aangewezen ruimten mogen verblijven. Van deze bevoegdheid mag echter alleen gebruik gemaakt worden als het districtshoofd van mening is, dat die werkzaamheden of dat verblijf ernstig gevaar opleveren voor jeugdige personen of vrouwen en dan nog als én en ander het gevolg is van het in een bepaalde onderneming niet naleven van het bepaalde bij arbeid 9 of krachtens artikel 10 van de Arbeidswet $1919^{73}$. In het vijfde lid van artikel $82 \mathrm{bis}$ van de Arbeidswet 1919 wordt bepaald, dat, wanneer in het kader van dit laatste artikel een eis is gesteld, waarvan de beroepstermijn nog niet is verstreken of waartegen beroep is ingesteld, waardoor uit een dergelijke eis nog generlei verplichting voortvloeit de zogenaamde schorsende werking ${ }^{74}$ - de bevoegdheid tot stillegging van werk onverkort geldt. Een bevel tot stillegging van werk kan op grond van het tweede lid van artikel $82 \mathrm{bis}$ van de Arbeidswet 1919 zowel mondeling als schriftelijk worden gegeven. Het districtshoofd van de arbeidsinspectie kan een mondeling bevel doen overbrengen door een andere, onder zijn bevelen werkzaam gestelde ambtenaar ${ }^{75}$. Het zal duidelijk zijn, dat de tijd kan ontbreken om in alle gevallen schriftelijke bevelen te geven, vooral als de gevaarsituatie wordt geconstateerd buiten de standplaats van het districtshoofd van de arbeidsinspectie. Om die reden is een mondeling bevel toegelaten, maar wordt in het bedoelde artikellid wel voorgeschreven, dat een dergelijke bevel zo spoedig mogelijk schriftelijk aan het betreffende hoofd of bestuurder van de onderneming moet worden bevestigd. Steeds echter zal het bevel door het districtshoofd uitgevaardigd moeten zijn ${ }^{70}$. Het zesde lid van artikel 82 bis van de Arbeidswet 1919 bepaalt, dat het bevel wordt ingetrokken, zodra de ambtenaar die het heeft uitgevaardigd, van mening is, dat er geen ernstig gevaar meer aanwezig is.

Een soortgelijke regeling is neergelegd in artikel $26 \mathrm{bis}$ van de Veiligheidswet 1934 . In het eerste lid van dit artikel heeft het districtshoofd van de arbeidsinspectie ${ }^{77}$ de bevoegdheid te bevellen, dat personen niet mogen verblijven in door hem aangewezen ruimten, of dat door hem aangewezen werkzaamheden moeten worden gestaakt, indien naar zijn oordeel dat verblijf of die werkzaamheden ernstig gevaar voor personen opleveren. Van deze bevoegdheid mag slechts gebruik gemaakt worden, indien de gevaarlijke toestand een gevolg was van het niet-naleven van het bij of krachtens de Veiligheidswet 1934 bepaalde $^{78}$. Een bepaling omtrent het uitvaardigen van een bevel tot stillegging van werk ingeval een eis is gesteld in het kader van de bedoelde wet, waaraan als gevolg van de schorsende werking nog geen uitvoering behoeft te worden gegeven, ontbreekt echter. 
Deze bijzondere, aan het districtshoofd van de arbeidsinspectie gegeven bevoegdheid vindt zijn basis in het op 11 juli 1947 door de dertigste Internationale Arbeidsconferentie te Geneve aangenomen Verdrag (no. 81) betreffende de arbeidsinspectie in de industrie en de handel ${ }^{79}$. Artikel 13, tweede lid, aanhef en onder b, van dit verdrag bepaalt namelijk, dat de inspecteurs van de arbeid - behoudens het recht van beroep op een gerecht of een administratieve autoriteit, voorzien bij nationale wetgeving - het recht zullen hebben te (doen) gelasten, dat in gevallen van dreigend gevaar voor de gezondheid en de veiligheid van werknemers onmiddellijk van kracht wordende maatregelen worden genomen ${ }^{20}$. Los van deze verdragsmatige regeling, makkte de toenmalige bewindsman van het ministerie van Sociale Zaken Joekes kenbaar, dat in de loop der jaren herhaaldelijk behoefte bestond aan een wettelijke voorziening, op grond waarvan aan een voor de arbeiders gevaarlijke situatie terstond een einde kon worden gemaakt. Daar voegde hij het volgende aan toe ${ }^{\text {st: }}$

"Wanneer thans een overtreding wordt geconstateerd, is het niet mogelijk om zonder medewerking van de werkgever onverwijld afdoende maatregelen tegen onmiddellijk dreigend gevaren te treffen. Tussen het opmaken van een proces-verbaal en de berechting van de overtreding verloopt in de regel geruime tijd, terwijl zelfs een veroordelend vonnis niet steeds een garantie voor het ophouden der overtreding inhoudt. Weliswaar wordt de werkgever, wanneer het gevaar evident is, in de regel bereid gevonden om onmiddellijk voorzieningen te treffen, doch in de gevallen, waarin die medewerking ontbreekt, wordt de moge-

lijkheid een einde te maken aan de gevaarlijke toestand slechts node gemist".

Op de vraag vanuit de Tweede Kamer ${ }^{32}$ waarom gekozen is voor de term "ernstig gevaar" en niet voor "onmiddellijk gevaar ${ }^{n 83}$, antwoordde de bewindsman ${ }^{84}$, dat de eerstbedoelde term een iets ruimere bevoegdheid verleent tot het geven van het bevel, Om dit te verduidelijken gaf hij een voorbeeld. In artikel 176 van het Veiligheidsbesluit voor fabrieken of werkplaatsen 1938 werd voorgeschreven, dat in een fabriek of werkplaats, waar gevaar voor verdrinking bestaat, doelmatige middelen voor het redden van drenkelingen op een goed zichtbare en doelmatige plaats beschikbaar moeten zijn. Onder bepaalde omstandigheden, aldus de minister, zijn ingevolge dit artikel bij het verrichten van schilderwerk aan bruggen de aanwezigheid van een boot vereist. Zou deze boot echter niet aanwezig zijn, dan zou ernstig gevaar voor verdrinking aanwezig kunnen zijn, maar geen onmiddellijk gevaar. Dit laatste, zo vervolgde hij, zou zich immers eerst voordoen, wanneer de arbeider van de brug in het water was gevallen.

Een belangrijke waarborg voor een juist gebruik voor deze aan ambtenaren gegeven bevoegdheid is gelegen in de omstandigheid dat een bevel, dat gegeven wordt voor een langere tijd stil te leggen door de rechter, in dit geval door de president van de rechtbank, bekrachtigd moet worden ${ }^{85}$; een niet-bekrachtigd bevel kan niet langer dan zeven dagen gelden. De beide artikelen 82 bis van de Arbeidswet 1919 en 26 bis van de Veiligheidswet 1934 geven in het derde en vierde lid voorschriften aangaande deze bekrachtigingsproceduret.

Naast deze bijzondere bevoegdheden van het districtshoofd van de arbeidsinspectie, die bij een eerdere gelegenheid maatregelen van vèiligheid zjjn genoemd ${ }^{87}$, om op te treden in geval van ernstig gevaar bevat de Arbeidswet 1919 in artikel 82 ter een bevoegdheid van het districtshoofd in geval van ernstige overtreding van de bij of krachtens deze wet gegeven voorschriften, de mogelijkheid om te voorkomen, dat een met de wet strijdige situatie blijft voortduren; deze bevoegdheid kan een maatregel van orde genoemd worden ${ }^{88}$. Op grond van het eerste lid van dit artikel kan het districtshoofd van de arbeidsinspectie bevelen, dat werkzaamheden die naar zijn oordeel in strijd met het bij of krachtens de Arbeidswet 1919 gegeven voorschriften zijn, worden gestaakt, wanneer bepaalde voorschriften in ernstige mate worden overtreden ${ }^{89}$. Bij dit bevel tot stillegging van werk moet het tijdstip worden aangegeven, waarop het werk, dat werd gestaakt weer mag worden hervat; dat overigens niet later gesteld kan worden dan ingevolge het bij of krachtens deze wet weer is geoorloofd. Ook dit bevel kan zowel mondeling als schriftelijk worden gegeven en moet een mondeling gegeven bevel zo spoedig mogelijk schriftelijk aan het hoofd of de bestuurder van de betreffende onderne- 
ming bevestigd worden. Ook hier geldt, dat het bevel door het districtshoofd moet worden uitgevaardigd. Teneinde het optreden tegen hardnekkige overtreders te vereenvoudigen is een tweede lid in artikel 82ter opgenomen, waarin is bepaald, dat een dergelijk bevel tot stillegging van werk ook gegeven kan worden door een onder de bevelen van het districtshoofd werkzame ambtenaar van de arbeidsinspectie, indien deze in het bezit is van een door eerstgenoemde ondertekende en op een bepaalde onderneming betrekking hebbende last. Wanneer in een onderneming bijvoorbeeld de arbeids- en rusttijden voortdurend worden overtreden, is het telkens opnieuw daarin betrekken van het districtshoofd van de arbeidsinspectie niet doelmatig, aldus de toenmalige bewindsman ${ }^{\mathrm{BO}}$, en moet volstaan kunnen worden met een vereenvoudigde regeling. Overigens lijkt een dergelijke vereenvoudigde regeling ook niet bezwaarlijk gezien het feit, dat deze maatregel van orde slechts een beperkte strekking heeft. De beperkte strekking van dit bevel tot stillegging heeft ook gevolgen ten aanzien van het beroep tegen een dergelijk bevel; overeenkomstig het verdrag van de Internationale arbeidsorganisatie bestaat een beroepsmogelijkheid op de minister, de administratieve autoriteit. De bewindsman was zich, blijkens de toelichting ${ }^{91}$, bewust van het feit, dat het bevel al lang zou hebben opgehouden te gelden voordat daarop zou zijn beslist. Maar, zo vervolgde hij, een beslissing waarbij het bevel wordt vernietigd, vrijwaart degene tegen wie het was gericht in de toekomst voor een dergelijk onder dezelfde of soortgelijke omstandigheden.

Voorts wordt aan degene die een bevel tot stillegging van werk kan uitvaardigen de bevoegdheid toegekend een aantal bijkomende maatregelen en aanwijzingen uit te vaardigen ${ }^{82}$, zonder dat daarbij een limitatieve opsomming wordt gegeven, wat zijn oorzaak vindt in het feit, dat de omstandigheden van geval tot geval kunnen verschillen ${ }^{83}$. Een ieder wie het aangaat is verplicht zich te gedragen overeenkomstig een bevel tot stillegging en de daarbij gegeven aanwijzingen ${ }^{\text {e4 }}$. Niet-naleving hiervan levert een strafbaar feit op, dat gekwalificeerd is als een misdrijf ${ }^{95}$; alle overige strafbare feiten in het kader van deze beide wetten leveren slechts overtredingen op.

In het kader van de Veiligheidswet 1934 werd bijvoorbeeld van deze bevoegdheid gebruik gemaakt ten aanzien van het werken met een grijperinstallatie waarvan de grijper herhaaldelijk viel. Gezien het feit, dat een verbod tot gebruik van de installatie stillegging van de gehele fabriek tot gevolg zou hebben, werd bevolen dat personen niet mochten verblijven in een door afbakening als gevaarlijk gekenmerkte ruimte gedurende de gevaarlijke periode. Het gevaar deed zich namelijk voor zodra de grijper boven het te lossen schip was gekomen. Telkens als de grijper zich daar bevond moesten ingevolge het bevel de arbeiders, die onder in het schip voorbereidende werkzaamheden verrichtten, zich verwijderen ${ }^{68}$. Een ander geval ${ }^{87}$ speelde zich af in een meubelfabriek, waar jeugdige personen in een op de tweede verdieping gelegen spuitlokaal arbeid verrichtten onder zeer gevaarlijke omstandigheden, zoals het aanwezig zijn van een houten vloer en een houten beschieting van het dak, de aanwezigheid van een aanzienlijke hoeveelheid nitrocelluloselak en van een brandende kachel, terwijl er niet voldoende dampafzuiging was noch een tweede uitgang ${ }^{\text {g8 }}$.

\section{De Steenhouwerswet 1921}

De materiaalvoorziening voor het steenhouwersbedrijf was in het eerste jaar na de oorlog in het algemeen nog onvoldoende, terwijl in het daaropvolgende de situatie alweer verbeterde vanwege de toegenomen invoer, waarbij aangetekend moet worden dat de prijzen van de geïmporteerde steensoorten erg hoog waren, hetgeen zijn weerslag vond in de prijs van het eindprodukt. Voor deze bedrijfstak was als gevolg van de herstelwerkzaamheden aan beschadigde kerken en andere openbare gebouwen alsmede voor de restauratie van monumentale gebouwen veel werk beschikbaar. De vraag naar grafwerk bleef bestaan, terwijl de vervaardiging van marmeren siervoorwerpen, waartoe vele bedrijven zich hadden gewend geleidelijk aan afnam en tot normale proporties werd teruggebracht.

Het al eerder gesignaleerde personeelsprobleem bleef onveranderd ${ }^{29}$. Na een aanvankelijk dalende bedrijvigheid zou vanaf 1953 een stijging te zien zijn, waardoor overigens het personeelstekort, dat er toch al was, 
steeds nijpender zou worden. De geringe animo voor het vak blijkt bijvoorbeeld uit het feit, dat in 1958 de rijkswerkplaatsen woor de omscholing tot steenhouwer, met uitzondering van die te Utrecht, bij gebrek aan voldoende deelneming werden opgeheven en dat de overgebleven werkplaats te Utrecht in 1959 nog slechts 5 leerlingen telde. Activiteiten van het Bedrijfschap voor het Steenhouwersbedrijf, in samenwerking met de Stichting Vakopleiding Bouwbedrijf in het kader van een vakopleiding voor de steenhouwerijen volgens het leerlingstelsel misten eveneens het beoogde effect ${ }^{100}$. Eén en ander had tot gevolg dat de bedrijfstak meer en meer gemechaniseerd werd.

Overigens liet de naleving van de voor steenhouwerijen geldende wettelijke bepalingen, behoudens enkele uitzonderingen, weinig te wensen over.

\section{De Silicosewet en de Wet op de gevaarlijke werktuigen}

\subsection{De Sllicosewet}

Het kader van de Veiligheidswet 1934, waarin centraal staat het beveiligen van arbeiders in bedrijven, bleek bij de enorm snelle ontwikkelingen die de techniek doormaakte toch te eng te zijn, waardoor het inspelen van de wetgever hierop soms te beperkt bleef of soms te laat kwam. Trouwens ook de Steenhouwerswet 1921 bleek onvoldoende mogrelijkheden te bieden om bepaalde ziekten die voortvloeiden uit het steenhouwersbedrijf te bestrijden. Een en ander heeft geleid tot een aantal afzonderijke wetten, zoals de Silicosewet ${ }^{101}$, waarmee het gevaar voor silicose ${ }^{102}$ en ander stoflongziekten, als gevolg van de inademing van stof, intensief en algemeen kon worden bestreden. De verantwoordelijke bewindsman stelde echter, dat de onderhavige materie zich beter leende voor een regeling bij algemene maatregel van bestuur dan tot regeling bij de wet zelf, daar het een bij uitstek technisch onderwerp betrof, dat door de wetenschap nog niet geheel doorvorst was. Regeling bij algemene maatregel van bestuur bood zijns inziens tevens het voordeel, dat op korte termijn doeltreffend gebleken maatregelen konden worden genomen en de bestrijding van het kwaad voet voor voet kon worden voortgezet ${ }^{103}$. De uitvoering van de wet was in handen gelegd van het districtshoofd van de arbeidsinspectie die naast het verlenen van ontheffing de gegeven voorschriften tevens eisen kon stellen omtrent de wijze van uitvoering van de bij algemene maatregel van bestuur gegeven voorschriften. De ambtenaren van de arbeidsinspectie waren tevens belast met de opsporing van overtredingen ${ }^{104}$.

Op deze wet berustten het Zandsteenbesluit ${ }^{105}$ op grond waarvan het voorhanden hebben en het bewerken of verwerken van zandsteen in het algemeen verboden was, hetgeen voor wat betreft de regeling duidelijk overeenstemming vertoont met de Phosphorluciferwet 1901, en het Zandstraalbesluit ${ }^{108}$.

Het merendeel van de ontheffingen in het kader van het eerstgenoemde besluit werden verleend ten behoeve van de restauratie van kerken en andere cultuurhistorische monumenten alsmede ten aanzien van het beletteren (voornamelijk met bronzen letters ) van grafmonumenten, waarvoor overigens een minimale bewerking van de steen benodigd was ${ }^{107}$. Ten aanzien van het verlenen van een ontheffing werd een onderscheid gemaakt tussen zogenaamde "kleine objecten"108 en andere objecten; in het eerste geval werd door het distrietshoofd van de arbeidsinspectie zelfstandig ontheffing verleend ${ }^{109}$, in het tweede geval diende het advies van adviescommissie-Zandsteenbesluit te worden ingewonnen ${ }^{10}$. $\mathrm{Na}$ het inwerkingtreden van het besluit moesten aanvankelijk op vrij grote schaal ontheffingen worden verleend van het verbod van het voorhanden hebben van zandsteen ${ }^{111}$, gezien het feit, dat de eigenaren zich onmogelijk, althans op korte termijn, van hun voorraad konden ontdoen. Zo werden er in 1952187 van dergelijke ontheffingen verleend, in 1953 was dit aantal 144. In 1961 bedroeg het aantal van dit soort ontheffingen $14^{112}$.

Sterke aandacht destijds trok de weigering op het verzoek van burgemeester en wethouders van Rotterdam om woor de restauratie van de Sint Laurenstoren te Rotterdam zandsteen te mogen gebruiken. Tegen deze weigering van de zijde van de arbeidsinspectie werd door Bakker ${ }^{113}$ geprotesteerd, daar hij meende dat beschikt kon worden over een afdoend beschermingsmiddel tegen silicose, namelijk het zogenaamde Van 
der Grinten verseluchtmasker; wanneer de steenhouwers zich maar beschermden was alle gevaar geweken. Dit Van der Grinten verseluchtmasker was al sinds 1905 bekend.Toen steeds meer behoefte ontstond aan een goed beschuttingsmiddel voor industrie-arbeiders tegen inademing van gevaarlijke stoffen, schadelijke dampen en nevels, had de arbeidsinspectie al in 1933 contact gezocht met Van der Grinten en vanaf dit moment was er herhaaldelijk overleg geweest over in de praktijk soms nodig gebleken veranderingen en verbeteringen van deze maskers, die tevens door de arbeidsinspectie op hun betrouwbaarheid en op het juiste gebruik door de arbeiders werden gecontroleerd. Daarbij bleken twee zaken. In de eerste plaats, dat het masker op zichzelf niet als ondeugdelijk beschermingsmiddel mocht worden gezien en in de tweede plaats, dat het bewuste masker bij steenhouwers tijdens langdurige restauraties geen ingang vond. Medische voorlichting, regelmatige instructie en controle, zelfs het dreigen met ontslag door de werkgever, brachten hierin geen verandering. De aanvankelijke geestdrift van de betrokken arbeiders hield op den duur geen stand en de maskers werden terzijde gelegd. Een van de afwijzingsgronden op het betreffende verzoek luidde dan ook $^{114}$ :

"er bestaan geen voldoende waarborgen dat de gevaren voor het leven en de gezondheid der arbeiders, die met be- en verwerken van zandsteen ten behoeve van bedoelde restauratie zouden worden belast, tijdens de lange duur van het werk ( ca 10 jaar) op afdoende wijze kunnen worden voorkomen;".

In eén van de districten kreeg de arbeidsinspectie klachten uit steenhouwerskrïngen, dat er nog geregeld zandstenen grafzerken werden vervaardigd. Bij controle in de steenhouwerswerkplaatsen konden echter geen overtredingen geconstateerd worden, waarna door de arbeidsinspectie op verschillende begraafplaatsen een onderzoek ingesteld werd. Hierbij bleek, dat na 25 november 1951, de datum van inwerkingtreding van het Zandsteenbesluit, inderdaad tientallen grafzerken van zandsteen waren geplaatst. Met behulp van de boekhouding van de opzichters van de begraafplaatsen spoorde de arbeidsinspectie de overtreders op en werd er tegen 10 steenhouwerspatroons proces-verbaal opgemaakt. Bij ernstige overtreders werden niet alleen boetes opgelegd, maar werd voorts de nog aanwezige hoeveelheid onbewerkte zandsteen bij vonnis verbeurd verklaard $^{115}$.

Begin 1957 werd door de arbeidsinspectie een onderzoek ingesteld om na te gaan, welke moeilijkheden zich bij de invoering van het Zandstraalbesluit, waarin een verbod werd uitgevaardigd om zand als straalmiddel te gebruiken, zouden kunnen voordoen. Hierbij bleek, dat ruim $50 \%$ van de bedrijven waar straalarbeid werd verricht reeds op dat tijdstip niet meer met zand straalden ${ }^{110}$. Na voorlichting van de zijde van de arbeidsinspectie ging voorts nog eens $20 \%$ van de overige bedrijven er eveneens v6ór de inwerkingtreding van het besluit over tot het gebruiken van een ander straalmiddel dan zand. In 1957, het jaar waarin het besluit werd ingevoerd, kwam een belangrijk aantal door de arbeidsinspectie op grond van het besluit toegelaten straalmiddelen op de markt. De prijs daarvan lag ten opzichte van die van zand niet zo veel hoger, zodat nog vele bedrijven die aanvankelijk economische bezwaren tegen de invoering van het besluit aanvoerden alsnog er toe overgingen niet meer met zand te stralen. In het algemeen leidde de invoering van het Zandstraalbesluit het bedrijfsleven niet voor onoverkomelijke economische en/of technische bezwaren. Werd in bepaalde gevallen ontheffing van het besluit verleend, dan gebeurde dit onder stringente voorschriften teneinde de grootst mogelijke zekerheid te hebben, dat de arbeiders voldoende beschermd waren tegen het gevaar van silicose bij het stralen van zand ${ }^{117}$. De naleving van het verbod om zand als straalmiddel te gebruiken vroeg echter toch steeds voortdurende aandacht van de arbeidsinspectie, waarbij meermalen werd geconstateerd dat toch zand voor het stralen werd gebruikt of dat het vervangingsmiddel met zand was vermengd ${ }^{118}$.

\subsection{De Wet op de gevaarlijke werktuigen}

Een andere wet is de Wet op de gevaarlijke werktuigen ${ }^{110}$, waar in het belang van de veiligheid en de gezondheid voorschriften werden neergelegd waaraan gevaarlijke werktuigen en beveiligingsmiddelen moesten 
voldoen of welke met betrekking tot gevaarlijke werktuigen en beveiligingsmiddelen in acht genomen moesten worden, De wet heeft ten doel de gevaren die aan gevaarlijke werktuigen al bij de bron, dus bij de fabrikage, te bestrijden. Een zelfde gedachte om in het belang van de veiligheid bepalingen vast te leggen betreffende de vervaardiging van en de handel in gevaarlijke werktuigen alsmede omtrent de keuring daarvan, lag reeds besloten in artikel 19 van de Veiligheidswet 1934, dat nader was uitgewerkt in het Veiligheidsbesluit gevaarlijke werktuigen. In de praktijk was echter gebleken, dat de desbetreffende voorschriften niet het gewenste effect sorteerden.

De oorzalak daarvan school, aldus de bewindsman van Sociale Zaken $^{120}$, in de eerste plaats in de uit zijn aard beperkte opzet van de Veiligheidswet 1934.

Deze heeft immers ten doel de beveiliging bij de arbeid in het algemeen en bij het verblijpen in fabrieken en werkplaatsen in het bijzonder. $\mathrm{Zij}$ beperkt het begrip "arbeid" tot de werkzaamheden van "arbeiders". In het kader van die wet passen dan ook alleen bepalingen, die daadwerkelijk bescherming van de arbeiders geven. In verband hiermede vond genoemd artikel 19 in de praktijk nimmer toepassing ten aanzien van werktuigen, waarvan niet tevoren vaststond, dat zij bij de arbeid in die zin der Veiligheidswet 1934 zouden worden gebruikt. Nu komen er echter steeds meer werktuigen, die zowel bij deze "arbeid", allsook elders (onder andere in de huishouding en in bedrijven zonder personeel ) worden gebezigd. ..... Teneinde na te gaan of een werktuig al dan niet zal worden gebruikt bij de arbeid in de zin de Veiligheidswet 1934, kan slechts worden afgegaan op de verklaringen van belanghebbenden. Bovendien is de eerste bestemming niet beslissend voor later gebruik, bij bijvoorbeeld bij verandering van eigenaar. De gevolgen van een en ander bleven niet uit; in bedrijven worden telkens weer gevaarlijke werktuigen aangetroffen zonder de voorgeschreven beveiligingen, zodat het in artikel 19 der Veiligheidswet 1934 nagestreefde doel niet wordt bereikt. Een tweede leemte kwam aan het licht, toen bleek, dat dit artikel 19 niet toeliet voorschriften vast te stellen omtrent de verschillende beveiligingstoestellen en middelen, zoals stofbrillen, maskers, blusmiddelen en dergelijke".

En, zo vervolgde de bewindsman, niets

"is evenwel zo gevaarlijk als het beveiligingsmiddel, dat op het kritieke moment - als ieder verwacht, dat het zijn diensten zal bewijzen - in zijn werking faalt"

De wet heeft als uitgangspunt, dat alle bij algemene maatregel van bestuur aan te wijzen gevaarlijke werktuigen en beveiligingsmiddelen aan voorschriften betreffende de constructie, beveiliging en dergelijke moeten voldoen en in verband daarmede moeten worden gekeurd, en eventueel herkeurd met dien verstande, dat in bepaalde gevallen met keuring van een het type kenmerkend monster kan worden volstaan ${ }^{121}$. Naast dit preventieve element, kent de wet ook een repressief element. Bij algemene maatregel van bestuur kunnen woorschriften worden gegeven aangaande het voorhanden hebben, het afleveren, het vervoeren, het gebruiken, het herstellen, het onderhouden en nazien alsook het tentoonstellen van gevaarlijke werktuigen en beveiligingsmiddelen $^{122}$. Ten aanzien van de invoer van een gevaarlijk werktuig of beveiligingsmiddel moet onverwijld aangifte worden gedaan bij het bevoegde districtshoofd van de arbeidsinspectie ${ }^{123}$. Het toezicht wordt onder meer uitgeoefend door de ambtenaren van de arbeidsinspectie, die naast het opsporen van overtredingen belast zijn met de medewerking aan de uitvoering door middel van het verlenen van ontheffin$\operatorname{gen}^{124}$.

Een en ander is uitgewerkt in het Dorsgarniturenbesluit, het Liftenbesluit $\mathbf{I}$, het Besluit spanninggevers voor schrikdraden en het Besluit Schoenfluoroscopen ${ }^{125}$.

\subsection{Gevolg van deze wettelijke regelingen}

De in deze paragraaf genoemde wettelijke regelingen zijn preventieve maatregelen tegen gevaren die zich niet alleen richten op het beschermen van arbeiders, maar een ruimere strekking kennen. In dat verband mag worden verwezen naar de stoomwetgeving waarin dit van oudsher al het geval is geweest. 
In navolging van Levenbach ${ }^{128}$ kan worden gesteld, dat de arbeidersbescherming hier uitgegroeid is tot een bescherming van arbeid in de ruimste zin en dat er eigenlijk bij dit soort wetgeving meer sprake is van volksbescherming.

\section{De Huisarbeidswet 1933}

Nadat gedurende de oorlogsjaren door een gebrek aan grondstoffen de huisarbeid bellangrijk was afgenomen, leefde deze na de bevrijding in sterke mate op. Dit betrof niet zozeer de in het Huisarbeidsbesluit 1936 als huisarbeid aangewezen werkzaamheden, daar de nog ongunstige grondstoffenpositie in verschillende gevallen een hervatting van de werkzaamheden in de vroegere omvang aanvankelijk niet mogelijk maakte. Werden in 1946 nog slechts 887 loonboekjes afgegeven, dit aantal zou oplopen tot 2669 in 1949 . In 1961 werden nog slechts 786 loonboekjes afgegeven ${ }^{127}$. Er waren nieuwe soorten van huisarbeid ontstaan die niet onder de werkingssfeer van de Huisarbeidswet 1933 vielen; éen en ander was onder meer het gevolg van de grote vaag naar artikelen en de hoge prijzen die hiervoor konden worden gemaakt. De arbeidskrachten die werden gebruikt waren voor het overgrote deel vrouwen, die de werkzaamheden verrichtten ter voorziening van hun eigen onderhouden, dan wel gehuwde vrouwen, die dit werk aannamen om daardoor een welkome aanvulling en in vele gevallen noodzakelijke verhoging van het gezinsinkomen te verkrijgen. Het lag van de hand dat bij de huisarbeid hulp werd verleend door de gezinsleden, waarbij kinderarbeid geen uitzondering was $^{128}$.

Daarnaast kwam er ook veel clandestiene huisarbeid voor door het meegeven van werk aan de arbeiders van een onderneming ${ }^{\dagger 2}$. Een voorbeeld daarvan kwam voor in de schoenindustrie. Nadat aan het betalen van zwarte lonen in deze bedrijfstak een einde was gekomen, werd door de arbeiders geprobeerd de vermindering van het inkomen op te vangen door huisarbeid, waarbij zelfs werd gedreigd met het nemen van ontslag, indien geen werk dat zich voor huisarbeid leende, werd meegegeven. Daar kwam nog bij, dat er een groot tekort bestond aan geschoolde stiksters en leersnijders ${ }^{130}$. Dit tekort nam alleen nog maar toe toen de lederwarenindustrie, die na de bevrijding een enorme uitbreiding onderging door het wegvallen van de invoer vanuit het buitenland, hoofdzakelijk stiksters en snijders uit de schoenindustrie wegtrok. De consequentie was, dat er hoge lonen werden gevorderd en betaald. De lonen in de schoenfabrieken waren afhankelijk van de leeftijd en het aantal gewerkte uren, eventueel verhoogd met gemiddeld $20 \%$ boven het uurloon, indien in stuk- of tariefloon werd gewerkt. Een andere mogelijkheid om de produktie te verhogen werd gezocht in de uitbreiding van de huisarbeid, watar niet per uur werd betaald, maar een bedrag als stukloon werd ontvangen, dat variabel was en afhankelijk was van de voorbewerking en de soort schoenen.

Bij de vraag of het stukloon te hoog was gesteld, zou moeten worden nagegaan, of dit loon bij overeenkomstige arbeid in de fabriek en naar de regeling in de loonregeling gesteld, hetzelfde was. Deze vergelijking was voor de vele fabrieken, die niet over fabrieksstiksters beschikten, maar dit werk uitsluitend in huisarbeid deden verrichten, zo niet onmogelijk, dan toch zeer moeilijk. Voor de andere, met name grote fabrieken, die over beide categorieën arbeidsters beschikten, was dit ook nog bezwaarlijk, omdat de omstandigheden, waaronder werd gewerkt, meestal niet te vergelijken waren. De wetenschap, dat door de vele bijkkomstige omstandigheden de loonregeling moeilijk te controleren was, werkte stimulerend op het verrichten van huisarbeid. Ten einde het tekort aan snijders, die met de stiksters de basis vormden voor de produktie van het overige deel van de fabriek, op te vangen zocht men ook hier zijn toevlucht in de huisarbeid. Dit gebeurde door arbeiders, die overdag als smijder in een fabriek werkzaam waren en die "s avonds voor deze of een andere fabriek werkten. Dat er buitensporig hoge lonen, die van het éen en ander het gevolg waren, werden betaald, blijkt uit de volgende voorbeelden.

Een schoenfabriek met 24 mannelijke arbeiders had voor het stikken van het bovenwerk van de schoenen 7 thuisstiksters in dienst. Bij een looncontrole bleek onder meer, dat aan 2 fabrieksarbeiders (niet thuiswerkers ) van 63 jaar fl. 32,16 per week werd betaald, terwijl een 29 -jarige thuisstikster een weekloon behaalde, dat in de gecontroleerde periode varieerde van fl. 61,-- tot fl. 104,--. Ook de overige thuisstiksters genoten een inkomen, dat ver boven de lonen van de mannelijke fabrieksarbeïders uitgingen. Een arbeider in een 
schoenfabriek, wiens vrouw voor dezelfde fabriek schoenen in huisarbeid stikte, werd ontslagen toen zijn vrouw voor een andere onderneming ging werken. De man bleef toen maar thuis om ter ontlasting van zijn vrouw de huishoudelijke bezigheden te verrichten, zodat zijn vrouw aan het schoenstikken kon blijven, waarmee zij een inkomen tot fl. 106,--per week behaalde. Een werkmeester in een schoenfabriek verdiende fl, 47,87 en vermeerderde zijn inkomsten met fl. 44,85 per week met het thuis, met behulp van zijn huisgenoten, overtrekken van hakken ${ }^{131}$.

Het betrof hier gereglementeerde huisarbeid, die met name in de Brabantse schoenindustrie een zeer grote vlucht onderging. Ook hier evenals in de nieuwe vormen van huisarbeid, die zich na de oorlog ontwikkelden, kwamen misstanden voor. Naast de bekende bezwaren die tegen huisarbeid bestonden waaronder het euvel van te lage lonen, werden in vele gevallen exorbitant hoge lonen betaald, waardoor personeel aan bona fide bedrijven werd onttrokken en de maatregelen, die door de overheid werden getroffen voor de noodzakelijke beheersing van het loonpeil werden doorkruist.

Hoewel de excessen onder meer met betrekking tot de hoge lonen slechts gedurende een korte periode voorkwamen, diende het mogelijk te zijn, dat tegen bestaande en eventuele nieuwe misstanden met meer succes zou moeten kunnen worden opgetreden dan ingevolge de Huisarbeidswet 1933 mogelijk is. De ervaringen die voŕr de oorlog waren opgedaan, hadden aangetoond dat de Huisarbeidswet 1933 onvoldoende mogelijkheden bood om aan de misstanden die uit deze tak van nijverheid voortvloeiden paal en perk te stellen. Dit was in de eerste plaats het gevolg van het feit, dat krachtens deze wet slechts kon worden opgetreden tegen de in het Huisarbeidsbesluit met name genoemde soorten van huisarbeid, zodat nieuwe vormen van huisarbeid aanvankelijk steeds buiten de werkingssfeer van de wettelijke bepalingen vielen, waardoor de mogelijkheid ontbrak om snel opkomende en soms weer snel verdwijnende soorten van huisarbeid, waaraan vaak grote bezwaren verbonden zijn, direct aan voorschriften te binden. In de tweede plaats was de werking van de wet beperkt, daar deze in de meeste gevallen uitsluitend het toezicht op de naleving van administratieve voorschriften vorderde ${ }^{32}$. Ten einde aan de gememoreerde bezwaren tegemoet te komen, werd door de bewindsman van Sociale Zaken aan de Sociaal-Economische Raad bij brief van 25 mei $1956^{133}$ advies gevraagd over een nieuwe Huisarbeidswet. Uitgangspunt van dit wetsvoorstel was, dat huisarbeid in beginsel verboden werd en dat van dit verbod alleen dan en zonodig onder voorschriften ontheffing zal worden verleend, indien uit sociaal oogpunt geen bedenkingen tegen een bepaalde vorm van huisarbeid bestaan. Het op 25 september 1958 door de Sociaal-Economische Raad uitgebrachte advies ${ }^{134}$ stelde iets meer nuancering voor, maar was overigens instemmerid. Op verzoek van de Sociaal-Economische Raad heeft de arbeidsinspectie in 1956 wel een uitgebreide inventarisatie gemaakt van de werkzaamheden die in het kader van de huisarbeid werden verricht. Deze inventarisatie bevestigt, dat de huisarbeid door de jaren sterk aan veranderingen onderhevig is geweest. Lag aanvankelijk de nadruk op textielindustrie en de voedings- en genotmiddelenindustrie, de inventarisatie geeft aan de ook andere bedrijfstakken gebruik maakten van huisarbeid, zoals de aardewerkindustrie, de chemische industrie en de metaalnijverheid; in totaal ging het om 87 verschillende vormen van huisarbeid ${ }^{135}$. Daarna zou het een zeer lange tijd stil blijven rond een nieuwe wettelijke regeling van de huisarbeid. De Huisarbeidswet 1933 zelf kreeg het predikaat een dode letter te zijn.

\section{De Rijtijdenwet 1936}

Nadat de Chef van Staf van het Militair Gezag met ingang van 12 september $1944^{136}$ de bepalingen van het Rijtijdenbesluit tijdelijk buiten werking had gesteld, zou het besluit op 4 maart 1946, de dag waarop de buitengewone staat van beleg eindigde, weer inwerkingtreden. Het aantal door de burgemeesters afgegeven werkboekjes kan in zekere mate als maatstaf genomen voor de toename van de intensiteit van het verkeer als gevolg van het voortschrijdend herstel van het bedrijfsleven in de eerste jaren na de oorlog. Werden in 1946 nog 17.810 werkboekjes afgegeven, in 1947 bedroeg dit aantal 67.185 , om vervolgens op te lopen tot 105.704 in 1959. In 1960 zou dit aantal dalen tot $94.579^{137}$. Met ingang van 1 januari 1961 zou een nieuw Rijtijdenbesluit ${ }^{138}$ in werking treden waarbij niet alleen de werkingssfeer van het besluit werd uitgebreid, 
maar waarbij gestreefd werd naar een meer effektievere controle, die moest worden verricht aan de hand van de door de bemanningsleden te houden aantekening van de arbeids, rust- en diensttijden in dat deel uitmaakt van een in hun bezit zijnde werkmap en voorts op het kantoor van de onderneming, waar afschriften van zich in het werkboekje bevindende weekstaten aanwezig moesten zijn.

De grote hoeveelheid werk die andere activiteiten met zich brachten, had gevolgen voor de mate waarin de arbeidsinspectie controle uitoefende op de naleving van de bepalingen van de Rijtijdenwet 1936. De steeds intensiever wordende controle op de naleving van de wettelijke bepalingen leidde onder meer tot een stroom van aanvragen bij de arbeidsinspectie om ontheffingen, erkenningen of gelijkstellingen. Werden er in 1946 slechts 31 ontheffingen verleend in verband met de bepalingen aangaande het werkboekje en het in de onderneming te hebben chauffeursregister ${ }^{139}$, in 1947 was dit aantal al opgelopen tot 1795 , terwijl in 1960 33.572 van dergelijke ontheffingen werden verleend ${ }^{140}$. Ten aanzien van erkenningen en gelijkstellingen

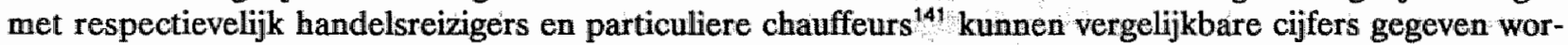
den; in 1946 bedroeg dit aantal in totaal 224, terwijl het jaar daarop dit aantal was opgelopen tot 2753 . In 1960 bedroeg het aantal maar liefst $18346^{142}$. De naleving van de arbeids- en rusttijdbepalingen en de administratieve bepalingen lieten nogal te wensen over. Ten aanzien van de eerste categorie werden in 1947 slechts 60 processen-verbaal opgemaakt; in 1959 13.407. Ten aanzien van de tweede categorie werden in dezelfde jaren respectievelijk 876 en 15.256 processen-verbaal opgemaakt ${ }^{143}$.

\section{Het Buitengewoon Besluit Arbeidsverhoudingen 1945.}

\subsection{Inleiding}

Naast de kritiek op de inhoud van het Buitengewoon Besluit Arbeidsverhoudingen gaf ook onvrede over het gebrekkig functioneren ervan aanleiding tot ingrijpende wijzigingen. Daarbij hebben de ideeën, zoals deze waren neergelegd in de Noodregeling Arbeidszaken een zekere invloed gehad op de inhoud van de nieuwe regeling, het op 15 oktober 1945 in werking getreden Buitengewoon Besluit Arbeidsverhoudingen $1945^{144}$. Opmerkelijk daarbij is echter, dat over de mate waarin die invloed zich deed gelden nogal uiteenlopende opvattingen bestaan. Zo stelde Drees, de toenmalige minister van Sociale Zaken die direct verantwoordelijk was voor de totstandkoming van het nieuwe Besluit, dat dit was voortgevloeid uit de Noodregeling Arbeidszaken $^{145}$. De Gaay Fortman ${ }^{148}$ stelde daarentegen, dat bij de herziening van het Londense besluit aan de Noodregeling Arbeidszaken aandacht was geschonken. Levenbach ${ }^{147}$, die zowel bij de totstandkoming van de Noodregeling Arbeidszaken als het Buitengewoon Besluit Arbeidsverhoudingen 1945 adviseerde, merkt op, dat "ettelijke gedachten en formuleringen" uit de Noodregeling hun weg hebben gevonden naar het nieuwe Besluit, dan wel dat bij de herziening tevens denkbeelden uit de Noodregeling werden ingevlochten. Stapelkamp en Schipper ${ }^{148}$ laten zelfs, na een uiterst kritische passage te hebben geschreven over de houding van de Londense regering ten aanzien van de informatie en ideeën die zij uit bezet Nederland had gekregen, uitdrukkelijk buiten beschouwing welke rol de Noodregeling Arbeidszaken bij de totstandkoming van het Buitengewoon Besluit Arbeidsverhoudingen 1945 heeft gespeeld. Ook de reactie van de Stichting van de Arbeid in haar advies van 13 augustus $1945^{149}$ over het ontwerp besluit was overwegend negatief; teleurstelling werd uitgesproken over het feit, dat de regering de Noodregeling Arbeidszaken niet had overgenomen ${ }^{150}$.

"Reeds in den bezettingstijd toch was tusschen de vertegenwoordigers van werkgevers en arbeiders en hoofdambtenaren van de Departementen van Sociale Zaken en van Financiën overeenstemming verkregen over den inhoud van een Noodbesluit arbeidsverhoudingen. Dit Ontwerp-Noodbesluit werd behandeld met de Vertrouwensmannen van de Regeering en later met de sectie Arbeidszaken van het Militair Gezag en zoowel Vertrouwensmannnen als de genoemde instantie van het M.G. betuigden met het ontwerp hun instemming".

Het Buitengewoon Besluit Arbeidsverhoudingen 1945 verving niet alleen het Londense besluit van 17 juli 
1944, maar ging voor wat betreft de inhoud ook verder. Het regelt in hoofdzaak het aangaan en beëindigen van de arbeidsverhoudingen, de herplaatsing van door de bezettingsmoeilijkheden ontslagen arbeiders, de normale arbeidstijd en het vaststellen van lonen en andere arbeidswoorwaarden; het week af van allerlei bestaande wetten, tén en ander in afwachting van een nadere regeling.

Als eerste werd voorzien in de herplaatsing van de werknemer, die na 9 mei 1940 door toedoen van de bezetter of in verband met de onder de bezetting heersende omstandigheden, anders dan uit vrije wil, of v6or 9 mei 1940 door oproeping in werkelijke dienst ontslagen was. De directeur van het gewestelijk arbeidsbureau kon in bijzondere omstandigheden al dan niet onder voorwaarden ontheffing verlenen van deze herplaatsingsverplichting. Bij geschillen over de herplaatsingsregeling kon hij bovendien een bindende beslissing geven $^{151}$. Een vergelijkbare bepaling was uitgevaardigd ten aanzien van terugkerende militairen ${ }^{152}$.

Vervolgens werd de ingrijpende beperking van het ontslagverbod gehandhaafd. Werkgevers en werknemers mogen hun arbeidsverhouding niet beëindigen zonder toestemming van de directeur van het gewestelijk arbeidsbureau, behoudens een aantal uitzonderingen. De ontslagvergunning wordt niet verleend dan nadat de directeur van het gewestelijk arbeidsbureau overleg heeft gevoerd met de arbeidsinspectie die vertegenwoordigers van werkgevers- en werknemersorganisaties hoort ${ }^{153}$. Daarnaast opende het besluit de mogelijkheid, dat ook voor het aangaan van arbeidsverhoudingen de toestemming van de directeur van het gewestelijk arbeidsbureau vereist was. De verantwoordelijke bewindsman van Sociale Zaken kon dit bepalen ten aanzien van door hem aangewezen (groepen van) werknemers ${ }^{154}$.

Voorts is het de werkgever verboden de werktijd van de (individuele) werknemer op minder dan 48 uren te stellen of gesteld te houden, behoudens een aantal uitzonderingen. Van dit verbod van werktijdverkorting kan door of namens de verantwoordelijke bewindsman van Sociale Zaken ontheffing worden verleend ${ }^{155}$. Tot slot de regeling van de lonen en andere arbeidswoorwaarden. Deze was opgedragen aan een College van Rijksbemiddelaars. Zowel op verzoek van werkgevers- en werknemersorganisaties als ambtshalve kon dit College bindende regelingen terzake van lonen en andere arbeidsvoorwaarden en daarmee verband houdende regelingen vaststellen. Deze regelingen hadden dezelfde rechtskracht als krachtens de Wet op het algemeen verbindend en onverbindend verklaren van bepalingen van collectieve arbeidsovereenkomsten verbindend verklaarde bepalingen. Wanneer het College van Rijksbemiddelaars lonen of andere voorwaarden had vastgesteld was het de werkgever verboden afwijkende lonen of andere arbeidswoorwaarden toe te kennen ${ }^{150}$.

\subsection{De ontslagvergunningverlening: arbeidsinspectie of gewestelijke arbeidsbureaus?}

Na deze korte beschrijving van de inhoud van het Buitengewoon Besluit Arbeidswerhoudingen 1945 is thans het moment daar om, alworens nader in te gaan op de taken die de arbeidsinspectie toebedeeld heeft gekregen, aandacht te besteden aan de strijd die gewoed heeft bij de totstandkoming van het besluit over de vraag arbeidsinspectie of arbeidsbemiddeling? $\mathrm{Bij}$ de aanwijzing van de autoriteit aan wie bevoegdheden werden toegekend deed zich een verschil van inzicht voor tussen de ontwerpers van het Londense Buitengewoon Besluit Arbeidsverhoudingen en de ontwerpers van de Noodregeling Arbeidszaken. De laatstgenoemden meenden, dat het toezicht op de herplaatsing, het verlenen van ontslagvergunningen en het toezicht op de handhaving van de loonstop in de eerste tijd na de bevrijding moest worden opgedragen aan de directeur-generaal van de Arbeid. Daarentegen heeft men in Londen gemeend dat het toezicht op de herplaatsing en het verlenen van ontslagvergunningen te moeten opdragen aan de directeur van het gewestelijk arbeidsbureau en de handhaving van de loonstop aan de Rijksbemiddelaars. De Gaay Fortman ${ }^{157}$ stelt daarover, dat men daar kennelijk de gedachte had laten prevaleren, dat deze taken moesten worden opgedragen aan de lichamen die daarvoor naar hun opdracht het meest aangewezen waren, waarbij wellicht de antipathie tegen de arbeidsbureaus enigszins onderschat werd. Maar aangezien men echter besloten had de organisatie van de arbeidsbemiddeling, zoals die onder de bezetting tot stand was gekomen - uiteraard na zuivering - te handha-
ven, was het logisch, zo vervolgt hij, dat men aan de organen daarvan niet een stuk arbeid wilde ontnemen,
dat naar zijn aard tot hun taak behooris dat naar zijn aard tot hun taak behoorde, daar anders van een ontplooiing van de gewestelijke arbeidsbureaus weinig terecht zou zijn gekomen, indien een zo belangrijk hulpmiddel voor de beheersing van de ar- 
beidsmarkt als het hanteren van de ontslagvergunning had ontbroken. Aan de andere kant werd aan de arbeidsinspectie geen onrecht gedaan door haar verschillende van de bovengenoemde taken niet op te dragen. Weliswaar was deze overheidsdienst gedurende de eerste jaren van de bezetting belast geweest met het verlenen van ontslagvergunningen, maar dit gebeurde, aldus De Gaay Fortman, omdat een andere, daarvoor in het bijzonder geëigende dienst nog niet bestond. Hoe betreurenswaardig ook uit nationaal oogpunt, zuiver organisatorisch gezien was het niet onjuist, dat het verlenen van ontslagvergunningen in de loop van 1943 werd opgedragen aan de gewestelijke arbeidsbureaus. De Gaay Fortman vervolgt met de opmerking, dat de taak van de arbeidsinspectie is het toezicht op de arbeidersbescherming, zoals die onder meer in de Arbeidswet 1919 en de Veiligheidswet 1934 is geregeld, en niet de arbeidsbemiddeling. Met de handhaving van de loonstop is, aldus De Gaay Fortman, de arbeidsinspectie nooit belast geweest, zodat na de bevrijding er uit organisatorisch oogpunt al evenmin reden was haar die taak op te dragen.

De vraag of de gewestelijke arbeidsbureaus en de arbeidsinspectie niet gecombineerd zouden moeten worden liet De Gaay Fortman onbesproken, dit in tegenstelling tot Havenman ${ }^{158}$. Deze laatste pleitte voor een samenvoeging van de beide overheidsdiensten met als belangrijkste argument

"een doelmatiger organisatie van de overheidsapparatuur".

Een dergelijke samenvoeging verdiende naar zijn mening verreweg de voorkeur boven

"het afzonderlijk voortbestaan van deze twee territoriaal opgebouwde organen".

De regeling in het Buitengewoon Besluit Arbeidsverhoudingen 1945 aangaande het verlenen van een ontslagvergunning door de directeur van het gewestelijk arbeidsbureau, die in overleg dient te treden met de arbeidsinspectie die de werkgevers- en werknemers-organisaties hoort, heeft alles in zich van een compromis; een compromis in de strijd tussen de directeur-generaal van de Arbeid en de directeur-generaal van het Rijksarbeidsbureau. Eén en ander blijkt bijvoorbeeld uit het feit; dat voordat het genoemde besluit in het Staatsblad werd gepubliceerd een vijftal ambtelijke ontwerpen heeft gecirculeerd. Nadat in de eerste twee ontwerpen de directeur van het gewestelijk arbeidsbureau was aangewezen als bevoegd orgaan om de ontslagvergunning te verlenen, werd in het derde ontwerp de directeur-generaal van de Arbeid als bevoegde autoriteit in deze aangewezen. Dat ontwerp zou al snel weer worden gevolgd door twee andere, waarin opnieuw de bevoegdheid was gegeven aan de directeur van het gewestelijk arbeidsbureau ${ }^{159}$. Eén van de eerste ontwerpen was aan de directeur-generaal van de Arbeid voor opmerkingen en advies voorgelegd. Zijn reactie hierop laat aan duidelijkheid niets te wensen over ${ }^{160}$.

"Het huidige ontwerp wijkt principieel niet af van de Londense besluiten. Weer zijn het de Arbeidsbureaux, die in alle luister worden hersteld. Gehaat als deze bureaux zich in de bezettingstijd hebben gemaakt, heeft de arbeidende bevolking, vooral in de groote steden, slechts eén wens n.l. dat zij evenals het instituut van den Gemachtigde van den Arbeid, zoo spoedig mogelijk van den aardbodem verdwijnen. Alleen al psychologische redenen moet men alles, wat aan het afschuwelijke wegvoeren van honderdduizenden arbeiders naar Duitsland herinnert, principieel uitbannen. Zuivering alleen is niet voldoende. Dat nog een aantal betrouwbare krachten bij de bureaux is overgebleven, is te danken aan de Verzetsbeweging, die haar posten had uitgezet en op deze wijze de heillooze activiteit van de bureaux belangrijk heeft belemmerd. Bovendien eischt de uitvoering der aan de Arbeidsbureaux toebedachte taak een technische outillage en een bekendheid met het bedrijfsleven, waarover zij niet beschikken en die zij zich ook niet in korten tijd kunnen verwerven".

Voorts stelde hij, dat de Noodregeling Arbeidszaken coördinatie en samensmelting impliceert van een aantal onderdelen van het ministerie van Sociale Zaken in éen orgaan. Daarop gaf de directeur-generaal van de Arbeid een beeld van de toen 55 -jarige arbeidsinspectie en haar bekendheid met en kennis van het bedrijfsleven, haar inzicht in het sociale gebeuren, de beschikbaarheid van een technisch en administratief apparaat, dat met de nodige aanvulling, volledig in staat kon worden geacht de nieuwe maatregelen uit te voeren, de bemoeienis met het ontslagverbod en de regelingen van loon- en arbeidsvoorwaarden gedurende de bezetting. 
"Soberheid en zakelijkheid zal den Staatsdienst in de toekomst meer dan ooit moeten kenmerken. Wat ligt, ook van dit standpunt uit gezien, meer voor de hand, dan dat men een technisch apparaat met rijke ervaring uitbouwt voor een grootere taak. Nu dreigt weer het gevaar, dat èn voor de uitwoering der ontslagbepalingen, èn voor de controle op de lloonen èn voor andere onderdelen nieuwe omvangrijke inspectiediensten zullen worden opgebouwd. Nog afgezien van het feit, dat Nederland zich een dergelijke weelde niet zal kunnen veroorloven, zou dit bij het bedrijfsleven en het publiek weinig instemming vinden, omdat dit evenals voor en tijdens den oorlog zal blijven zuchten onder een veelheid van ambtelijke organen, die eenzelfde of een gelijksoortig gebied bestrijken".

Bovendien maakte hij kenbaar, dat de verantwoordelijke bewindsman hem in een persoonlijk onderhoud toe had toegezegd, dat het verlenen van een ontslagvergunning bij de arbeidsinspectie zou komen.

De directeur-generaal van de Arbeid zou steun krijgen van de Stichting van de Arbeid. In het eerder genoemde advies van 13 augustus 1945 zou te kennen worden gegeven, dat de gewestelijke arbeidsbureaus niet de geëigende organen zijn om over de vergunningen terzake van ontslag en aanstelling van personeel definitief te beslissen, vanwege het feit dat

"het zuiver regionale organen (zijn), die niet zodanig zijn georiënteerd, dat zij de behoeften

van de verschillende bedrijfstakken kunnen overzien".

De Stichting van de Arbeid meende, dat inzake het verlenen van de bedoelde vergunningen de organisaties van werkgevers en werknemers uit de verschillende bedrijfstakken van advies zouden moeten dienen. Ten einde dit te verwezenlijken zou een zelfde of analoog systeem moeten worden ingevoerd als in de eerste oorlogsjaren waarbij de uitwoering van de terzake relevante verordeningen in handen van de arbeidsinspectie was gelegd die alvorens de vereiste toestemming te verlenen de bedrijfstaksgewijs ingestelde vertrouwensinstantie raadpleegde. Hier was sprake van een directe medewerking van de belanghebbenden, die in de praktijk had voldaan. De bewindsman van Sociale Zaken Drees leek gevoelig voor het standpunt van de Stichting van de Arbeid. Of om zijn woorden te gebruiken ${ }^{161}$ :

".. mijn indruk tot op het ogenblik is, dat de Arbeidsinspectie er beter op is ingericht de

ontslagkwesties te beoordelen dan de Arbeidsbureaux".

De bevoegdheid tot het verlenen van ontslagvergunning werd in het inmiddels derde ontwerp-besluit in handen van de arbeidsinspectie gelegd. In een niets aan duidelijkheid overlatende nota aan de bewindsman voerde de directeur-generaal van het Rijksarbeidsbureau Van Mill ${ }^{162}$ een aantal argumenten aan, met name ten aanzien van het terrein van de arbeidsmarktpolitiek, waarom naar zijn mening de hantering van het ontsllagverbod bij de directeur van het gewestelijk arbeidsbureau diende te liggen. De directeur-generaal van het Rijksarbeidsbureau begon zijn nota met de opmerking dat de bewindsman klaarblijkelijk slechts om een aantal praktische redenen ${ }^{103}$ had gekozen van de arbeidsinspectie en wel:

"a. omdat de Arbeidsinspectie momenteel slechts weinig werk had;

b. omdat de Arbeidsinspectie de bewuste taak in het verleden ook reeds had vervuld;

c. omdat de ontwikkeling van de gebeurtenissen gedurende den laatsten tijd voor den Di-

recteur-Generaal van den Arbeid telleurstellend is geweest".

Het eerste argument vond Van Mill geen klemmende reden, daar een tijdelijke detachering van overtollig personeel van de arbeidsinspectie bij het Rijksarbeidsbureau geen onmogelijkheid was, terwijl bovendien, zodra het bedrijfsleven weer tot ontwikkeling zou komen, bij de arbeidsinspectie een toename van werkzaamheden zou ontstaan. Bovendien zo vervolgde hij, kon een tijdelijke slapte bij enig rijksorgaan toch geen voldoende motief vormen, om een blijvende - en dan nog principieel en functioneel onjuiste - verandering in bevoegdheden van een ander rijksorgaan tot stand te brengen. En een dergelijke overdracht zou weer tot gevolg hebben, dat er ambtenaren bij de gewestelijke arbeidsbureaus overtollig zouden worden en dus ontsla-
gen zouden moeten.

Het totale effect is dus, dat het slapteverschijnsel bij de arbeidsinspectie wordt wegge-

werkt, doch bij de gewestelijke arbeidsbureaux weer te voorschijn komt", want een ontslagvergunning kon uiteindelijk slechts éénmaal verleend worden. Het tweede argument, dat 
de arbeidsinspectie in het verleden de bewuste taak ook reeds had vervuld, was evenmin overtuigend, daar de gewestelijke arbeidsbureaus destijds ontbraken en het doel van het ontslagverbod destijds niet lag op het voeren van een arbeidsmarktpolitiek, maar de bescherming van de arbeider tegen willekeurig ontslag dan wel de gevolgen daarvan. Toen het ontslagverbod in een later stadium, toen de gewestelijke arbeidsbureaus waren gevormd, en van Daitse zijde een duidelijke arbeidsmarktpolitiek werd gevoerd, werd het ontslagverbod dan ook naar die gewestelijke arbeidsbureaus overgebracht, aldus de directeur-generaal van het Rijksarbeidsbureau. Het lag dan ook in de rede, zo vervolgde hij, dat

"thans, nu van overheidswege over Gewestelijke Arbeidsbureaux kan worden beschikt en in de verdere toekomst een middels deze bureaux te voeren arbeidsmarktpolitiek niet zal kunnen worden gemist, de hantering van het ontslagverbod bij de Gewestelijke Arbeidsbureaux te laten".

Ook het derde argument was geen reden voor eem principieel en functioneel onjuiste beslissing. Daar kwam nog bij, aldus Van Mill, dat reeds kon worden bespeurd, dat onder het personeel van de arbeidsbureaus enige ongerustheid ontstaan was door het feit, dat de bemoeiing met de wachtgeldregeling ${ }^{164}$, welke principieel eigenlijk onder het Rijksarbeidsbureau behoorde te ressorteren, daaraan was onttrokken. Er werd door het personeel gevreesd voor een verdere afbraak van het Rijksarbeidsbureau, waaraan de stelselmatig door de directeur-generaal van de Arbeid gevoerde anti-propaganda tegen het Rijksarbeidsbureau, die in brede kring bekend was geworden, volgens Van Mill, hieraan vermoedelijk niet vreemd was. Als argument van dezelfde orde kon nog naar voren worden gebracht, dat het voor het personeel van de arbeidsbureaus, waarvani ongeveer $20 \%$ het slachtoffer is geworden van de Duitse druk en terreur, teleurstellend zou zijn, als het bij gebrek aan waardering voor hun verzetshouding, waaraan trouwens ook de al eerder bedoelde antipropaganda van de directeur-generaal van de Arbeid vermoedelijk niet vreemd was, ook nog zou moeten ervaren, dat een deel van hun bevoegdheden werd besnoeid en deze zou worden overgedragen aan die functionaris, die de anti-propaganda had verzorgd. Een dergelijke overdracht zou leiden tot een niet onbelangrijke uittocht van het ( kwalitatief) betere personeel van het Rijksarbeidsbureau wegens het ontbreken van enig perspectief.

Eén en ander leidde tot de conclusie, dat de directeur-generaal van het Rijksarbeidsbureau meende te moeten waarschuwen tegen het overbrengen van de hantering van het ontslagverbod naar de arbeidsinspectie, vanwege de daaruit voortvloeiende gevolgen, met name voor wat betreft de uitschakeling van de mogelijkheid een passende arbeidsmarktpolitiek te voeren en dat hij voor een dergelijke overdracht niet de allergeringste verantwoordelijkheid kon dragen.

Volgens Naber $^{165}$ is onmiddellijk na deze nota van de directeur-generaal van het Rijksarbeidsbureau definitief gekozen voor de directeur van het gewestelijk arbeidsbureau als bevoegd orgaan in het kader van de ontslagvergunning. Maar dit heeft tevens geleid tot de compromisachtige constructie, zoals die hierboven all is weergegeven.

\subsection{Betrokkenheid arbeidsinspectie}

Bij de uitwoering van de betreffende bepalingen van het Buitengewoon Besluit Arbeidsverhoudingen 1945 was de arbeidsinspectie op verschillende manieren betrokken; de door de dienst verrichte werkzaamheden vielen uiteen in een controlerende, een adviserende en een coördinerende taak.

De controlerende taak van de arbeidsinspectie vond zijn basis in artikel 26 van het besluit, waarin onder andere haar ambtenaren waren belast met de opsporing van de in het besluit strafbaar gestelde feiten ${ }^{18 B}$. Hieruit vloeide een omvangrijke taak uit voort, namelijk de controle op lonen en andere arbeidsvoorwaarden, maar daarnaast trad de dienst eveneens op ter verzekering van de naleving van het ontslagverbod en het verbod van werktijdverkorting.

De adviserende taak, waarmede de arbeidsinspectie belast werd, omvatte allereerst het overleg met organisa- 
ties van werkgevers en werknemers en met de directeur van het gewestelijk arbeidsbureau terzake van het verlenen van ontslagvergunningen ${ }^{167}$. Voorts diende arbeidsinspectie de minister van Sociale Zaken van advies over de goedkeuring van wachtgeldregelingen, die door ondernemingen, die daaraan behoefte hebben, konden worden getroffen. Daarnaast diende de arbeidsinspectie het College van Rijksbemiddelaars op ver-

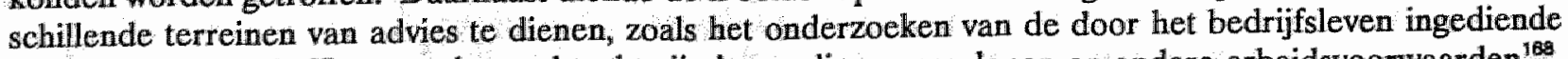
aanvragen om ontheffing van de van kracht zijnde regelingen van lonen en andere arbeidsvoorwaarden ${ }^{189}$. Bovendien moest het College van Rijksbemiddelaars van advies gediend worden over ontwerp-regelingen van lonen en andere arbeidsvoorwaarden en ontwerp-collectieve arbeidsovereenkomsten; voornamelijk met het oog op een goede controleerbaarheid van de vast te stellen bepalingen. Tot slot moest de arbeidsinspectie het College van Rijksbemiddelaars van advies dienen aangaande de ontheffingen van het verbod van werktijdverkorting $^{168}$.

De coördinerende taak op het gebied van de looncontrole in de ruime zin nam de directeur-generaal van de Arbeid op verzoek van de verantwoordelijke bewindsman op zich; een coördinatie die dringend noodzakelijk was, gezien de vele diensten die met de opsporing van de strafbare feiten belast waren ${ }^{170}$. Ten einde een eenheid van optreden te bevorderen en het zo nodig regelmatige contact tot stand te brengen werd een Looncontrolecommissie ingesteld onder voorzitterschap van de directeur-generaal van de Arbeid ${ }^{171}$.

In het hiervoorgaande is de taak van de arbeidsinspectie ter zake van de bepalingen van het Buitengewoon Besluit Arbeidsverhoudingen 1945 meer in het algemeen geschetst. Thans wordt aan de hand van de verschillende artikelen nader ingegaan op de verschillende onderdelen van die taak.

\subsection{Het ontslagverbod}

Ten aanzien van de bemoeienis met het ontslagverbod kan worden opgemerkt, dat door de arbeidsinspectie gedurende het jaar 1946 over totaal 23610 aanvragen om ontslagvergunning advies werd uitgebracht. In 2097 gevallen werd een nader onderzoek ter plaatse ingesteld. In het daarop volgende jaar steeg het aantal uitgebrachte adviezen snel; het totale aantal bedroeg 43641 , terwijl in 1778 gevallen een nader onderzoek noodzakelijk werd geacht. Het aantal ontvangen klachten bedroeg in 1947 ongeveer de helft van dat in 1946, namelijk respectievelijk 214 en $422^{172}$. In het daarop volgende jaar zou het aantal adviezen inzake ontslagvergunningen evenals het aantal klachten afnemen ${ }^{173}$, terwijl het aantal noodzakelijk geachte nadere onderzoeken ter plaatsen zou toenemen tot 3492 , waaruit de conclusie werd getrokken, dat de ontslagvergunningaanvragen ingewikkelder waren en dientengevolge moeilijker tot een verantwoorde beslissing kon worden gekomen ${ }^{174}$. De daarop volgende jaren geven grote schommelingen te zien als gevolg van de economische ontwikkelingen. Zo bedroeg het aantal ontslagvergunningaanvragen in 1953 in totaal 26931, waarvan 21242 afkomstig waren van werkgevers en 5479 van werknemers. De sterke daling van de aanvragen ten opzichte van de beilde voorgaande jaren van werkgeverszijde vond zijn oorzaak in het feit, dat er algemeen een groot tekort aan arbeiders bestond en slechts in uiterste noodzaak personeel werd ontslagen, terwijl van werknemerszijde van bijna een verdubbeling van het aantal aanvragen ten opzichte van de jaren er voor sprake was, omdat zij juist van de voor hen gunstige arbeidsmarkt wilden profiteren. In de daarop volgende jaren is een blijvende daling te constateren voor wat betreft de aanvragen van werkgeverszijde en een blijvende stijging ten aanzien van de werknemerszijde ingediende aanvragen. In 1957 zou dit beeld veranderen. In de tweede helft van dat jaar trad een daling van de werkgelegenheid op. Verschillende werkgevers gingen terstond over tot het verminderen van hun personeelsbezetting ten einde zich aan veranderende economische situatie aan te passen, een beeld dat zich doorzette in 1958, Daarna trad weer een economische verbetering op en daalde het aantal ontslagvergunningaanvragen weer met bijna de helft ${ }^{175}$. 


\subsection{Het verbod van werktijdverkorting}

Het verbod van werktijdverkorting beoogt allereerst te voorkomen, dat het loon van de betrokken werknemer als vervolg van werktijdverkorting een onaanvaardbare vermindering ondergaat ${ }^{176}$.Vervolgens voorkomt het verbod tevens, dat via het toepassen van werktijdverkorting het ontslagverbod omzeild kan worden, door bijwoorbeeld de werktijd op nul-uren te stellen ${ }^{177}$. In de eerste jaren na de oorlog werd echter door het verlenen van ontheffingen van het verbod van werktijdverkorting tot uitzonderingsgevallen te beperken bereikt, dat in ondernemingen, waar het aanwezige personeel niet ten volle 48 uren per week tewerk kon worden gesteld, de werktijd toch op dit aantal uren gehandhaafd bleef, waardoor het mogelijk werd, de overtollige arbeidskrachten te doen afvloeien naar bedrijven, die een tekort aan personeel hadden. Het verbod van werktijdverkorting werd met andere woorden dienstbaar gemaakt aan het verhogen, althans handhaven van de arbeidsproduktiviteit door het handhaven van de 48 -urige werkweek. Dit standpunt werd aanvankelijk ingenomen door het College van Rijksbemiddelaars, dat door de minister van Sociale Zaken was aangewezen als ontheffingverlenende instantie ${ }^{178}$, en door de arbeidsinspectie dat de verzoeken van werkgevers om een ontheffing van het verbod vrijwell zonder uitzondering van het College van Rijksbemiddelaars voor advies kreeg toegezonden. Geen artikel van het besluit heeft meer moeilijkheden bij de handhaving opgeleverd dan het onderhavige. Vooral in dle eerste jaren na de bevrijding bestond er een sterke drang naar werktijdverkorting, die voornamelijk zijn uitdrukking vond in de wens om tot een vijfdaagse werkweek te komen. Daar de regering, na nauw overleg met de in de Stichting van de Arbeid samenwerkende organisaties wan werkgevers en werknemers, zich op het standpunt had gesteld dat een vijfdaagse werkweek onder de bestaande situatie in het algemeen niet kon worden toegelaten, diende de controle van de arbeidsinspectie er op gericht te zijn, dat deze gedragslijn werd gevolgd. Een belangrijk hulpmiddel hierbij bestond in de mogelijkheid om aanvragen om vergunning ingevolge de Arbeidswet 1919 om op de eerste vijf werkdagen 9,5 te doen werken en aldus een werktijd van ongeveer 48 uren per week te halen, na nauwkeurig onderzoek van de daarvoor geldende motieven eventueel af te wijzen. De controle van de arbeidsinspectie op de naleving van dit artikel werd in de meeste tezamen met de gebruikelijke werktijdcontrole uitgevoerd. Vooral in de eerste tijd legde het uitbrengen van de bedoelde adviezen een zware last de op schouders van de arbeidsinspectie ${ }^{178}$. Teneinde een spoedige afdoening van de verzoeken om ontheffing te bevorderen werden de districtshoofden van de arbeidsinspectie al snel, namelijk in 1948, mede gemachtigd om dergelijke ontheffingen te verlenen ${ }^{180}$. Het: aantal ontheffingen dat van het verbod van werktijdverkorting werd verleend was, als gevolg van het hierboven aangehaalde standpunt, gering; in 1948 slechts ongeveer 160 , terwijl het aantal in 1949 slechts ongeveer 200 bedroeg $^{181}$. In 1950 werden naast 350 ontheffingen aan diverse ondernemingen uit verschillende bedrijfstakken, 950 ontheffingen verleend alleen al aan de sigarenfabrieken. De oorzaak hiervan was gelegen in afzetmoeilijkheden in de sigarenindustrie in de maanden maart en april. Hoewel er met klem bij de regering op was aangedrongen om het accijnspercentage voor de sigaren terug te brengen tot vooroorlogse niveau, bleek dit niet mogelijk in verband met het protocol inzake unificatie van accijnzen in de Benelux-landen. Een voorlopige oplossing van de moeilijkheden werd gevonden in het verlenen van ontheffingen van het verbod van werktijdverkorting ${ }^{192}$. In 1950 werd tevens door het hoogste rechtscollege in ons land beslist, dat het standpunt van zowel het College van Rijksbemiddelaars als van de arbeidsinspectie, dat het verbod van werktijdverkorting dienstbaar gemaakt kon worden aan het verhogen, althans handhaven van de arbeidsproduktiviteit door de handhaving van de 48 -urige werkweek was onjuist ${ }^{18}$. In het arrest van 31 oktober 1950 besliste de $\mathrm{HR}^{134}$ namelijk, dat het verbod niet betekende, dat door een werknemer ook feitelijk 48 uren per week diende te worden gewerkt. De besluitgever heeft slechts willen verbieden, dat de werkgever door het bepalen van een kortere werktijd dan 48 uren per week een werknemer verhindert een normaal weekloon te verdienen. Kortom: voldoende is, dat de werknemer in de gelegenheid wordt gesteld om over 48 uren per week loon te verdienen; maakt hij van deze gelegenheid geen gebruik, dan hoeft alleen over de gewerkte uren loon uitbetaald te worden.

Tot dusverre was de taak van de arbeidsinspectie op het terrein van het verlenen van ontheffingen van het 
verbod van werktijdverkorting van bescheiden omvang gebleven. Door de sterke vermindering van de vraag in vele sectoren van het bedrijfsleven als gevolg van verschillende samenvallende oorzaken werd het noodzakelijk om door het nemen van verschillende maatregelen aan de situatie dat er een teveel aan beschikbare arbeidskrachten tegemoet te komen. Als de voornaamste oorzaak van de vermindering van de vraag kan wel de reactie van consumentenzijde na de hamsteraankopen als gevolg van het conflict in Korea (1951) aangewezen worden. Bovendien werd het teruglopen van de vraag nog versterkt door het feit, dat de inhaalvraag, die ontstaan was door de tekorten ten gevolge van de Tweede Wereldoorlog min of meer bevredigd was: Daarnaast was er een versterkte reactie als gevolg van de consumptiebeperking van $5 \%$ en kwamen er problemen op het terrein van de export, die mede van invloed waren op de totale vraag. Dilt geheel van vrijwel tegelijkertijd optredende oorzaken had tot gevolg dat werkgevers in met name de industrieën van meer duurzame consumptiegoederen ${ }^{485}$, mede als gevolg van liquiditeitsproblemen als gevolg van gewijzigde prijzen en sterk gestegen voorraden, ten aanzien van de personeelsbezetting van de bedrijven in grote moeilijkheden kwamen en een beroep deden op de overheid om uit de impasse te komen. Voor de ontstane problemen waren drie mogelijke oplossingen voorhanden. In de eerste plaats via een ontheffing van het verbod van werktijdverkorting voor zover het tijdelijke vermindering van de bedrijvigheid betrof, al dan niet onder bepaalde voorwaarden met betrekking tot de loonbetaling over de niet gewerkte uren. Hierbij droegen dus werkgever en werknemers gezamenlijk de lasten van de ontstane werkwermindering; de werkgever door de vrijwel steeds opgelegde of vrijwillig aanvaarde verplichting om de niet gewerkte uren geheel of gedeeltelijk te vergoeden, de werknemer door het eventueel gedeeltelijk derven van loon over de niet gewerkte uren. In een dergelijke procedure had de arbeidsinspectie een beslissende stem; na een onderzoek ter plaatse en nadat in de daarvoor in aanmerking komende gevallen het advies van het gewestelijk arbeidsbureau was ingewonnen, verleende deze dienst al of niet de gevraagde ontheffing. Een tweede manier om aan de geschetste problemen het hoofd te bieden was het vragen van goedkeuring van de minister van Sociale Zaken en Volksgezondheid tot toepassing van de Wachtgeldregelling $1946^{188}$. In dit geval werden de lasten van de werkvermindering mede door de overheid gedragen door middel van het verstrekken van een subsidie voor de niet gewerkte uren en de sociale lasten ${ }^{1 / 7}$. Deze mogelijk werd gekozen voor het geval een vermindering van bedrijvigheid betrof van vrij ernstige en vrij langdurige aard. Over dergelijke aanvragen brachten zowel de arbeidsinspectie als de gewestelijke arbeidsbureaus advies uit ${ }^{18 s}$, terwijl de minister de uiteindelijke beslissing nam. De derde mogelijkheid betrof het aanwragen van een ontslagvergunning voor het overtollig personeel, wanneer de stagnatie in de bedrijvigheid van de onderneming van blijvende aard werd geacht te zijn $^{189}$. Ten einde de vereiste coördinatie in het algemene overheidsbeleid te brengen ten aanzien van het verlenen van ontslagvergunningen, het verlenen van ontheffingen van het verbod van werktijdverkorting en het goedkeuren van aanvragen tot toepassing van de Wachtgeldregeling 1946 werd door de verantwoordelijke bewindsman van Sociale Zaken en Volksgezondheid in de loop van 1951 een werkgroep gevormd, bestaande uit vertegenwoordigers van het ministerie van Sociale Zaken en Volksgezondheid, van het ministerie van Economische Zaken ${ }^{100}$, van het Rijksarbeidsbureau en van de arbeidsinspectie ${ }^{181}$. De ontstane situatie leidde ertoe, dat in 19512446 ontheffingen van het verbod van werktijdverkorting werden verleend, tegenover "slechts" 950 in het jaar ervoor ${ }^{182}$. Het jaar 1952 zou ingrijpende wijzigingen te zien geven aangaande het verbod van werktijdverkorting, als gevolg van het inwerkingtreden van de Werkloosheidswet ${ }^{103}$. Als gevolg hiervan werd de Wachtgelldregeling 1946 buiten werking gesteld ${ }^{194}$, zodat de adviserende activiteiten van de arbeidsinspectie en de gewestelijke arbeidsbureaus in deze werden beëindigd, terwijl nu in vrijwel alle gevallen, waarin sprake was van korter werken als gevolg van een tijdelijke inzinking van de bedrijvigheid alleen de weg nog open stond van een ontheffing van de arbeidsinspectie. Was een dergelijke ontheffing verleend, dan stelden de bedrijfsverenigingen, die met de uitwoering van de Werkloosheidswet waren belast, zich op het standpunt, dat in een zodanig geval sprake was van gedeeltelijke, onvrijwillige werkloosheid ${ }^{185}$, op grond waarvan zij, met behoud van de eigen verantwoordelijkheid in deze, tot uitkering overgingen ${ }^{106}$ ' ${ }^{\circ}$ De door de minister van Sociale Zaken en Volksgezondheid hierboven gememoreerde coördinatie-werkgroep werd bij het inwerkingtreden van de Werkloosheidswet opgeheven. Ten einde de nodige samenwerking tussen de betrokken afdelingen van het ministerie van Sociale Zaken en Volksgezondheid op het terrein van 
de werktijdverkorting te waarborgen; stelde de directeur-generaal van de Arbeid op 1 juli 1952 een ambtelijke adviescommissie in, bestaande uit vertegenwoordigers van het Rijksarbeidsbureau, de afdeling sociale verzekering, de afdeling sociale bijstand en complementaire arbeidswoorzieningen en de arbeidsinspectie. In deze commissie werd het algemene beleid, dat bij het verlenen van de ontheffingen van het verbod van werktijdverkorting diende te worden gevolgd, aan de orde gesteld. Ook vraagstukken waarbij het Algemeen Werkloosheidsfonds en de Federatie van Bedrijfsverenigingen waren betrokken, werden in deze commissie in het bijzijn van vertegenwoordigers van deze organisaties besproken.

De directeur-generaal van de Arbeid stelde interne richtlijne ${ }^{197}$ op voor de behandeling van ontheffingsaanvragen, waarbij aansluiting werd gezocht bij de (machtigings-)procedure die geldt ten aanzien van het aanvragen van overwerkvergunningen in het kader van de Arbeidswet 1919. Ten einde een zekere beroepsmogelijkheid te creëren werd naast de districtshoofden van de arbeidsinspectie ook de directeur-generaal van de Arbeid gemachtigd tot het verlenen van ontheffingen van het verbod van werktijdverkorting ${ }^{10 s}$. In de afwijzende beschikkingen van de districtshoofden werd nu de clausule opgenomen, dat de aanvrager zich binnen 14 dagen na dagtekening van de bestreden beschikking kon wenden met een hernieuwd verzoek tot de directeur-generaal van de Arbeid; het onderzoek vond dan opnieuw plaats en door laatstgenoemde werd op het nieuwe verzoek beslist ${ }^{199}$. Ten einde tot een zo juist mogelijke beslissing te komen had de arbeidsinspectie het nodig geoordeeld het georganiseerde bedrijfsleven zoveel mogelijk bij de behandeling van de aanvragen te betrekken. Dit heeft geleid tot het instellen van adviesinstanties in de voornaamste bedrijfstakken, de zogenaamde vertrouwensinstanties, paritair samengesteld uit vertegenwoordigers van werkgevers en werknemers, die bij het onderzoek naar de aanvragen om ontheffing van het verbod van werktijdverkorting werden ingeschakeld. In het grafisch bedrijf zou deze ontwikkeling nog verder voortschrijden. De minister van Sociale Zaken en Volksgezondheid zou het Centraal Bureau voor de Grafische Bedrijven in Nederland machtiging verlenen tot het geven van de bedoelde ontheffingen in deze bedrijfstak ${ }^{200}$. In 1958 zou hetzelfde gebeuren ten aanzien van de schoenindustrie. Het bestuur van het bedrijfschap voor de schoenindustrie werd toegestaan de bedoelde ontheffingen te verlene ${ }^{201}$. De omvang van de werkzaamheden van de arbeidsinspectie op het gebied van de werktijdverkorting bleek, zoals uit het voorgaande als duidelijk wordt, nauw verband te houden met de economische ontwikkeling. Zo leidde een verbetering van de conjunctuur en derhalve ook in de werkgelegenheid tot een daling van het totaal aantal verleende ontheffingen in 1953, namelijk 2586 tegenover 3348 in $1952^{202}$. In de jaren 1956 en 1957 bedroeg dit respectievelijk 313 en 1164 , terwijl in 1958 in totaal 7769 ontheffingen werden verleend ${ }^{203}$. In 1961 zou dit gedaald zijn tot 132 ontheffingen ${ }^{204}$.

\subsection{De wachtgeldregelingen}

Hierboven is al melding gemaakt van de activiteiten van de arbeidsinspectie in het kader van de wachtgeldregelingen als bedoeld in artikel 10 van het Buitengewoon Besluit Arbeidsverhoudingen 1945; een bezigheid die met ingang van 1 juli 1952 zou worden beëindigd. Voor de volledigheid wordt thans nog even nader ingegaan op de bedoelde werkzaamheden.

De bemoeiing van de arbeidsinspectie ten aanzien van dit artikel strekte zich over de controle op de naleving van de goedgekeurde wachtgeldregelingen en over het uitbrengen van advies over ingediende verzoeken om goedkeuring van dergelijke regelingen. De controletaak werd al snel, namelijk met ingang van 1 april 1946, aan de arbeidsinspectie onttrokken, zodat alleen nog de adviserende taak in deze resteerde, die overigens met ingang van 1 februari 1948 een einde nam. Voor bijzondere gevallen bleef inschakeling van de arbeidsinspectie mogelijk. Vervolgens zou de dienst weer volledig ingeschakeld worden bij het uitbrengen van de bedoelde adviezen en wel met ingang van 1 juli 1949. Werden er in 1946571 adviezen tedienaangaande uitgebracht, in 1947 was dit aanzienlijk minder, namelijk 264. Toen de adviserende taak weer op de schouders van de arbeidsinspectie werd gelegd, werd 215 van dergelijke adviezen uitgebracht. In 1950 waren dit er 359, terwijl het daaropvolgende jaar in verband met de al eerder gememoreerde economische problemen het ongekende aantal van 1048 te zien gaf. In het jaar dat de Werkloosheidswet volledig in werking zou treden was 
het aantal adviezen ten aanzien van wachtgeldregelingen al weer teruggelopen tot $288^{205}$.

\subsection{Lonen en andere arbeidsvoorwaarden}

De taak van de arbeidsinspectie ten aanzien van het bindend vaststellen van lonen en andere arbeidsvoorwaarden van werknemers en de goedkeuring van collectieve arbeidsovereenkomsten door het College van Rijksbemiddelaars droeg een adviserend karakter. Al snel werd het gebruikelijk, dat het College van Rijksbemiddelaars de bindend vast te stellen regelingen en de collectieve arbeidsovereenkomsten, die ter goedkeuring werden voorgelegd, aan de directeur-generaal van de Arbeid als coördinator op het terrein van de looncontrole toezond, ten einde de grootst mogelijke zekerheid te verkrijgen, dat de vast te stellen of goed te keuren bepalingen zodanig waren geformuleerd, dat een juiste naleving hiervan verzekerd was en de looncontrole niet op moeilijkheden zou stuiten. De door de directeur-generaal van de Arbeid te geven adviezen werden in het algemeen schriftelijk witgebracht, in verscheidene gevallen achtte het College van Rijksbemiddelaars het echter gewenst, dat een vertegenwoordiger van de directeur-generaal van de Arbeid bij de zogenaamde "hearings", het horen van vertegenwoordigers van werkgevers en werknemers, aanwezig was ${ }^{208}$. Per 1 februari 1950 zou een grondige reorganisatie van de looncontrole plaatsvinden. De looncontrole werd gecentraliseerd met de instelling van de looncontroledienst ${ }^{207}$, waarvan de directeur-generaal van de Arbeid als hoofd optrad. Een uitzondering werd echter gemaakt ten aanzien van loonregelingen, waarvan de controle een bijzonder karakter droeg, zoals bijwoorbeeld ten aanzien loonregelingen in de land-en tuinbouw en nauw verwante bedrijfstakken, hetgeen tot het werkterrein van de centrale inspectiedienst bleef behoren, ten aanzien van de loonregelingen op het gebied van de scheepvaart, dat aan de inspectie van de havenarbeid bleef toevertrouwd en ten aanzien van de loonregelingen voor de verplegingsinrichtingen, de wijkverpleegsters en de apotheken, waarvan de controle aan de arbeidsinspectie bleef respectievelijk werd opgedragen. De directeur-generaal van de Arbeid bleef optreden als coördinator voor de looncontrole; een taak die na de bovenbedoelde reorganisatie vereenvoudigd was ten aanzien van de samenwerkende diensten. Ook bleef de directeur-generaal van de Arbeid voorzitter van de looncontrole-commissie, waarin de vertegenwoordigers van het College van Rijksbemiddelaars en van de opsporings- en vervolgingsinstanties zitting hadden. Als gevolg van het feit, dat de directeur-generaal van de Arbeid tegelijkertijd hoofd van de looncontroledienst was, name hij desgevraagd zitting in de coördinatie commissie opsporing economische delicten. Deze commissie was in 1947 ingesteld met het doel te komen tot grotere coördinatie van de werkzaamheden van de verschillende opsporingsdiensten en van het opsporings- en vervolgingsbeleid ter zake van economische delicten. Bij het inwerkingtreden van de Wet op de economische delicten werd deze commissie, zij het in enigszins andere samenstelling, voortgezet als de coördinatie commissie handhaving economische voorschriften. Er bestond niet alleen een nauwe samenwerking tussen het College van Rijksbemiddelaars en de met de looncontrole belaste diensten ten aanzien van de looncontrolle, maar tevens tussen het College van Rijksbemiddelaars en de directeur-generaal van de Arbeid op loontechnisch gebied, waarvoor aan de centrale dienst van de arbeidsinspectie - zover ik kan nagaan sinds 1950 - een loontechnische afdeling, werd verbonden, die sinds 1952 de naam zou dragen afdeling arbeidsorganisatie- en loontechniek ${ }^{200}$. De taak van de arbeidsinspectie werd dan ook langzaam uitgebreid. Naast het uitbrengen van mondelinge of schriftelijke adviezen omtrent bindend vast te stellen loonregelingen en goed te keuren collectieve arbeidsovereenkomsten of wijziging daarvan, werd het College van Rijksbemiddelaars door deze laatstgenoemde afdeling van de centrale dienst van de arbeidsinspectie voorgelicht en geadviseerd omtrent loontechnische vraagstukken ${ }^{200}$. Voor een groot deel betroffen de adviezen op loontechnisch gebied al of niet op tijdmeting gebaseerde tariefregelingen en werkclassificatie alsmede systemen voor prestatiebeloning ( produktiepremies en de zogenaamde "merit-rating"). Overigens adviseerde de arbeidsinspectie terzake van arbeid onder gevaarlijke of bezwarende omstandigheden, voor zover met betrekking tot deze werkzaamheden aan het College van Rijksbemiddelaars toestemming voor het geven van loontoeslagen werd gevraagd. Het invoeren van op tijdmeting gebaseerde tarieven vereiste nogal wat organisatorische maatregelen en veranderingen. Nauw contact werd onderhouden met organisatieadviseurs in verband met de normen, die aan op tijdmeting gebaseerde tarieven 
ten grondslag liggen. In enkele gevallen bleken de tarieven van organisatiebureaus na onderzoek nogal af te wijken van de algemeen geldende normen, zodat op verbeteringen moest worden aangedrongen en soms ook afwijzingen moesten worden geadviseerd. Als gevolg van deze bemoeienissen moest cen minder deskundig organisatiebureau het opstellen van op tijdmeting gebaseerde tarieven staken. Deze onderzoekingen en de daaraan verbonden besprekingen vergden veel tijd, maar werden noodzakelijk geacht om het met veel moeite verkregen vertrouwen in volgems objectieve maatstaven gemeten tarieven geen afbreuk te doen. In veel gevallen werd op verzoek van het College van Rijksbemiddelaars in bedrijven nagegaan, in hoeverre invoering van op tijdmeting gebaseerde tarieven dan wel andere vormen van prestatiebeloning mogelijk zouden zijn. Vaak was het noodzakelijk de organisatie van het bedrijf - planning en werkvoorbereiding - en de mogelijkheden tot verbetering bij het onderzoek te betrekken ${ }^{210}$.

Een ander onderwerp ten aanzien van de loontechnische aangelegenheden waarmee de arbeidsinspectie steeds meer bemoeienis kreeg, was de werkclassificatie, waarbij voor een groot deel de genormaliseerde methode van werkclassificatie werd gehanteerd. Van Dreumel, hoofd van de al eerder genoemde afdeling arbeidsorganisatie- en loontechniek had als lid van de deskundigen-commissie voor werkclassificatie een belangrijk aandeel in de werkzaamheden daarvan. De bemoeienis hiermee van de zijde van de arbeidsinspectie vond niet alleen zijn oorzaak in het feit, dat het College van Rijksbemiddelaars bij loonvoorstellen die gebaseerd waren op werkclassificatie bijna altijd haar advies vroeg, maar ook doordat organisatiebureau en -deskundigen van bedrijven reeds vroegtijdig contact met haar zochten alvorens een ontheffing van bestaande loonregelingen bij het College van Rijksbemiddelaars aan te vragen ${ }^{2 * 1}$. Het aanvragen van deze ontheffingen ten aanzien van de loonregelingen gingen hoe langer hoe meer vergezeld van werkclassificatierapporten die betrekking hadden op een bepaalde onderneming, maar in toenemende mate op een gehele bedrijfstak $^{212}$. Beperkte de taak van de arbeidsinspectie met betrekking tot het uitbrengen van loontechnische adviezen zich aanvankelijk tot de door het bedrijfsleven ingestelde voorstellen, in de loop van 1957 werd deze taak uitgebreid tot de overheid. De Raad voor de Burgerlijke Rijksdienst besloot namelijk voor de werk- en vaklieden in de rijksdienst naast een functieloonvaststelling op basis van werkclassificatie over te gaan tot het geleidelijk invoering van prestatiebeloning voor dat personeel. Alvorens omtrent de vorm van de voor elk dienstonderdeel te hanteren prestatiebeloning te beslissen, werd het advies van de arbeidsinspectie gevraagd. In dat verband was het instellen van een onderzoek per dienstonderdeel naar de mogelijkheden van prestatiebeloning noodzakelijk, waarbij dan voor zover nodig tegelijkertijd de algemene organisatie en efficiency van dit dienstonderdeel aan een nadere beschouwing werd onderworpen, om zo enerzijds de produktiviteit in de overheidssector op te voeren en anderzijds de prestatiebeloning mogelijk te maken, overeenkomstig de maatstaven die ook voor het bedrijfsleven werden aangehouden. In 1959 werd door de commissie werkclassificatie overheidspersoneel een werkgroep ingesteld die taak had de vraag te beantwoorden of, en zo ja hoe het in rangorde brengen van andere dan handarbeidersfuncties per gezichtspunt en per totale functie zou kunnen gebeuren.

Daarnaast werden op uitgebreide schaal adviezen uitgebracht zowel aan de betrokken ministeries, aan de leiding van dienstonderdelen alls aan lagere overheden en werd nauw samengewerkt met de bij de rijksoverheid ingeschakelde particulier efficiencybureaus. Naarmate de opdrachten aan de particuliere efficiencybureaus een aflopend karakter hadden, werden van de zijde van de arbeidsinspectie gedetailleerde adviezen verstrekt over de gedetailleerde uitvoering van de prestatiebeloning ${ }^{213}$.

Ook op een ander terrein dan de loonvorming was de arbeidsinspectie overigens actief. Zo werd in een aantal bedrijven een onderzoek ingesteld naar de algehele organisatie en naar de produktiviteit in het bijzonder, én en ander in verband met het beoordelen van de noodzakelijkheid van het verlenen van overwerk-vergunningen in het kader van de Arbeidswet 1919. In het merendeel van de onderzochte gevallen bleek, dat een verbetering van de organisatie zonder aanzienlijke investeringen en wijziging van het loonstelsel betere resultaten terzake van de produktiviteit zouden opleveren, dan via het middel van overwerk werden bereikt ${ }^{214}$. Voorts werd meermalen een verondersteld verband tussen bedrijfsongevallen en het werken in een tariefsysteem onderzocht. Daarbij bleek de oorzaak van het ongeval niet bij het als gevolg van de tarifiëring geëiste 
tempo te liggen, maar in het hanteren van een verkeerde werkmethode $e^{215}$.

Het Buitengewoon Besluit Arbeildsverhoudingen 1945 bevatte een verbod voor de werkgever om lonen en andere arbeidsvoorwaarden toe te kennen die afwijken van van de in de door het College van Rijksbemiddelaars bindend vastgestelde regelingen, goedgekeurde collectieve arbeidsovereenkomsten en verbindend verklaarde bepalingen van collectieve arbeidsovereenkomsten vermelde lonen of andere arbeidsvoorwaarden ${ }^{218}$. De hoeksteen van het gehelle loonwormingssysteem was echter niet te vinden in het Besluit zelf, maar in de door het College van Rijksbemiddelaars op 15 oktober 1945 afgekondigde loonstop ${ }^{217}$. Deze loonstop bevroor alle lonen, in zoverre dat de lonen werden gesteld op $115 \%$ van die van 31 oktober 1942 dan wel $125 \%$ van die van 10 mei $1940^{218}$. In het kader van het eerdere Buttengewoon Besluit Arbeidsverhoudingen was een forfaitaire toeslag van $25 \%$ toegestaan op het loonpeil van 10 mei 1940 , maar in juli 1945 werden door de arbeidsinspectie $e^{218}$ al afwijkingen geconstateerd van 20 tot $30 \%$ van de officieel toegestane lonen ${ }^{220}$. Aanvankelijk kwam van de strafrechtelike handhaving van het Buitengewoon Besluit Arbeidsverhoudingen 1945 weinig terecht. De overstelpende drukte bij de vervolgingsinstanties en de onbekendheid van de rechterlijke instanties op het terrein van de lonen, maakten dat dit verbod nauwelijks effectief was ${ }^{221}$. Vanaf 1 maart 1946 werd een begin gemaakt met cen systematische looncontrole. Daar de overige met de looncontrole belaste diensten nog niet alle gereed waren voor het uitvoeren van de hun opgedragen taak, drukte deze taak in de eerste tijd vrijwel alleen op de schouders van de arbeidsinspectie. Zo werden in 1946 7118 ondernemingen gecontroleerd. Toen ook de andere controlediensten hun activiteit volledig begonnen te ontplooiien, ontstond de noodzaak om tot een taak verdeling te komen, die begin 1947 tot stand kwam. De arbeidsinspectie werd belast met de looncontrole in de diamantindustrie, de chemische nijverheid, het houtveren bewerkingsbedrijf, de lederverwerkende en aanverwante bedrijven, de mijnen, veenderijen, de stro-, hout- en strocartonfabrieken, de fabrieken van continu-draden en tabaksverwerkende bedrijven ${ }^{222}$. Daarnaast werd bepaald, dat, indien dit nodig zou zijn, de arbeidsinspectie ook in andere bedrijfstakken looncontrolle zou kunnen uitvoeren; een maatregel die verband hield met het feit, dat de arbeidsinspectie het College van Rijksbemiddelaars bij ontheffingsaanvragen van geldende loonvoorschriften van advies diende, waardoor het noodzakelijk kon zijn, dat de arbeidsinspectie ook controleerde in de niet tot haar taak behorende bedrijfstakken. Het toezicht op andere arbeidsvoorwaarden bleef echter uitsluitend voorbehouden aan de arbeidsinspectie. De taakverdeling had tot gevolg, dat de arbeidsinspectie in 1947 aanzienlijk minder bedrijven inspecteerde dan in 1946 , namelijk $3973^{223}$. In de beide daaropvolgende jaren zou het aantal gecontroleerde ondernemingen respectievelijk 8402 en 5495 bedragen ${ }^{224}$. Als gevolg van de reorganisatie van de looncontrole liep het aantal gecontroleerde ondernemingen door de arbeidsinspectie terug tot $351^{225}$, waarna het aantal zelfs nog verder terug zou lopen en nauwelijks nog enige betekenis heeft; één en ander is het gevolg van de beperkte taak die de arbeidsinspectie in deze nog had - verplegenden in particuliere verplegingsinrichtingen, wijkverpleegsters en apothekers-assistenten ${ }^{220}$.

\section{De Wet plaatsing minder-valide arbeidskrachten}

Deze wet is een gevolg van gewijzigde opvattingen over de mogelijkheid en wenselijkheid van de inschakeling van personen met aangeboren of verkregen lichamelijke of geestelijke gebreken, kwalen of afwijkingen in het arbeidsproces. Een ontwikkeling, die versneld werd door het feit, dat ons land na de oorlog ook zijn oorlogsinvaliden. De blijvende slachtoffers van een ramp die de gehele gemeenschap had getroffen; de militaire invaliden bovendien als gevolg van het feit, dat zij leven, gezondheid en validiteit ter verdediging van de onafhankelijkheid van ons land in en buiten Europa in de waagschaal hadden gesteld.

In vroegere jaren waren minder-valide arbeidskrachten, tot dusver "onvolwaardige arbeidskrachten" genoemd, de "non-valeurs" op de arbeidsmarkt.

"Het spel van vraag en aanbod stiet hen uit, vooral in een tijd van min of meer groote werkloosheid. Het feit, dat men hen niet in dezelfde werkzaamheden als valide personen wist te plaatsen en voor deze onmogelijkheid ook geen oplossing kende, werd als afdoende 
beschouwd".

Door de in 1927 opgerichte Nederlandsche Vereeniging tot bevordering van de arbeid van onvolwaardige arbeidskrachten een jaar later georganiseerde congres werd het besef geboren, dat aan deze situatie een einde gemaakt moest worden. De regering toonde met de instelling van een staatscommissie in $1929^{227}$ haar goede wil.

"Een van de grondfouten van de oude opvatting was, dat men de "onvolwaardigheid" als arbeidskracht zag als een statisch gegeven. De ervaring heeft geleerd, dat er veel meer dan te voren bekend was, mogelijkheden bestaan tot geschiktmaking of wedergeschiktmaking voor opneming in het arbeidsproces. De geneeskunst en haar hulpberoepen, de prothesevoorziening, de paedagogie in den vorm van buitengewoon onderwijs, de psychologische beoordeeling, de algemeene training, lichamelijk zoowel als psychisch, de vakopleiding, herscholing en omscholing, de arbeidsbemiddeling en de nazorg gaan hier hand in hand.... Gebleken is, dat niet alleen een belangrijk antal gerbeken op deze wijze is te verhelpen of te compenseeren; zelfs doet zich soms het verschijnsel van overcompensatie voor.... Zoodoende worden veel persomen, die te voren als armlastig zouden zijn beschouwd, tot produktieve krachten gevormd".

Maar deze economische kant van de zaak was niet het emige argument, dat van regeringszijde werd aangevoerd.

"Veelal toch zal een afwijking niet geheel zijn te verhelpen en sommige gebreken maken het dengenen, die ermee zijn behept, vooralsnog uiterst moeilijk om tot eenige productieve bezigheid te komen, waardoor zij in hun onderhoud kunnen voorzien. Ten aanzien van dezulken is men in breede kringen tot het inzicht gekomen, dat de maatschappij op ethische gronden gehouden moet worden geacht om hen in staat te stellen, althans zooveel mogelijk door eigen arbeid in hun levensonderhoud te voorzien en hen zoodoende evengoed als gevoel van eigenwaarde en een zekere onafhankelijkheid te geven. Deze ethische overwegingen gelden trouwens ook ten aanzien van degenen, wier gebreken wel te verhelpen en te compenseeren zijn, maar in het arbeidsproces toch bijzondere zorgen opleveren, tot het aanvaarden waarvan meer noodig is dan overwegingen van louter economischen aard"

Gebeurde tot dan toe éen en ander op basis van vrijwilligheid, thans was om een aantal redenen het moment daar om hiermee te breken. In de eerste plaats was het principieel onjuist, dat het uitsluitend van de goede wil bij de werkgevers zou afhangen of de minder-validen een plaats in het arbeidsproces zouden krijgen. In de tweede plaats werden bij het stelsel van vrijwilligheid de lasten, die voortvloeiden uit de bijzondere zorgen die de plaatsing van minder-valide arbeidskrachten met zich bracht, ongelijkmatig verdeeld. Sociaal voelende werkgevers kregen ze te dragen, terwijl bedrijven, die juist bijzonder goede mogelijkheden hadden, daarvan gevrijwaard bleven. In de derde plaats werd als gevolg van de vrijwilligheid slechts een bepaald gedeelte van de minder-valide arbeidskrachten geplaatst en in de vierde en laatste plaats zou het ontbreken van een wettelijke verplichting steeds het gevaar in zich dragen, dat bij een daling van de economische bedrijvigheid een groot deel van de minder-valide arbeidskrachten het eerst werkloos zou worden. De bedoelde staatscommissie achtte een wettelijke verplichting tot plaatsing van minder-valide arbeidskrachten niet wenselijk ${ }^{228}$, maar daarover merkte de bewindsman van Sociale Zaken op, dat zij geen rekening had te houden met de aanwezigheid van oorlogsinvaliden in ons land. Het bezwaar van de staatscommissie, dat ontleend was aan vrees voor schade aan de goede wil bij de werkgevers, die voor een goede verstandhouding, een onmisbare voorwaarde om de plaatsing te doen slagen, nodig was, werd door de verantwoordelijke bewindsman niet onderschat. Maar hij meende, dat enerzijds de goedwillende werkgevers een duidelijke uitspraak in de wet omtrent het bestaan van een verplichting die moreel al aanwezig was, zouden kunnen accepteren, terwijl anderzijds de werkgevers bij wie de goede wil ontbrak niet tot plaatsing zouden zijn overgegaan, indien er geen wettelijke verplichting bestond. Hij gaf echter tevens te kennen, dat het niet in zijn bedoeling lag de kracht van de wet te zien in de strafbepalingen ${ }^{229}$. 
In de wet ${ }^{230}$ zelf was de verplichting tot plaatsing niet in een bepaald percentage van het totaal bij de werkgever, zowel overheid als particulier, ook die huisarbeid gaf, in dienst zijnde werknemers uitgedrukt; de in artikel 3 , eerste lid, aangegeven verhouding berustte echter op een percentage van 2 . Dit artikel vormde de basis van de wet; een werkgever, in wiens onderneming meer dan 20 werknemers zijn, was verplicht bij aanstelling van nieuw personeel enkele minder-valide arbeidskrachten in dienst te nemen. Op een personeelsbestand van 21 tot en met 50 werknemers diende ten minste 1 minder-valide arbeidskracht te werk worden gesteld; bij een personeelsbestand van grotere omvang moet op elk geheel aantal van 50 werknemers ten minste 1 minder valide arbeidskracht worden aangesteld. Een en ander behoudens ontheffing van de directeur van het gewestelijk arbeidsbureau ${ }^{231}$. Voorts was de werkgever verplicht te zorgen, dat in zijn onderneming de door minder-valide arbeidskrachten te bedienen werktuigen of toestellen van zodanige inrichtingen en beveiligingen moeten zijn voorzien, als nodig waren om de bediening daarvan voor de betrokkene mogelijk of gemakkelijker te maken en in het bijzonder om het gevaar voor de betrokkene zo gering mogelijk te maken, eên en ander ter beoordeling van het districtshoofd van de arbeidsinspectie ${ }^{232}$. Daarnaast bevatte de wet een bepaling, dat de minder-valide werknemer in beginsel recht had op het normale loon ${ }^{233}$. Deze genoemde verplichtingen waren strafrechtelijk gesanctioneerd, met de opsporing waarvan onder meer de arbeidsinspectie was belast ${ }^{234}$. Ondanks alle goede bedoelingen gingen er in de praktijk van deze wet nauwelijks impulsen uit tot indienstneming van deze categorie van werknemers. Als oorzaak daarvan kan onder meer de te gebrekkige precisering van het begrip "minder-valide arbeidskracht"235 geven worden. De wet zou in 1986 worden vervangen door de Wet arbeid gehandicapte werknemers ${ }^{236}$.

\section{Werkzaamheden in verband met de overige wetten waarvan de handhaving van en de medewerking aan} de uitvoering geheel of gedeeltelijk aan de arbeidsinspectie was opgedragen

\subsection{De Ongevallenwet 1921}

In het kader van de samenwerking met ( ambtenaren van) de Rijksverzekeringsbank in verband met de uitvoering van de Ongevallenwet 1921 en de Beroepswet werden in de eerste jaren direct na het beëindigen van de oorlog in totaal 643 mededelingen omtrent de beveiligingstoestanden in fabrieken of werkplaatsen tegen 150 in de twee laatste oorlogsjaren ontvangen, ten aanzien waarvan omtrent 313 gevallen nader bericht werd gevraagd door het bestuur van het genoemd orgaan, dat werd verstrekt na een ter plaatse ingesteld onderzoek. In 1948 was dit aantal reeds gedaald tot 247 mededelingen. Deze mededelingen hadden onder meer betrekking op de beveiliging van drijfwerk, cirkel- en lintzagen, persen, walsen, slijpmachines, liften, houtbewerkingsmachines en hadden verder betrekking op onder andere afzuiging van giftige dampen en stof, ventillatie, slechte verlichting, veiligheidsbrillen, gasmaskers en ladders ${ }^{237}$. Na een aanvankelijke daling in 1949 zou het aantal mededelingen in het begin van de jaren vijftig opnieuw stijgen, om vervolgens geleidelijk te dalen tot een aantal van 97 waarvan omtrent 90 een nader bericht werd gevraagd ${ }^{238}$. Evenals in de voorgaande perioden werden de districtshoofden van de arbeidsinspectie door de voorzitter van eén van de Raden van Beroep en van de Centrale Raad van Beroep belast met een onderzoek naar en als gevolg daarvan te adviseren over de indeling van een onderneming in een gevarenklasse ${ }^{239}$.

\subsection{De Hinderwet}

Het aantal aanvragen om vergunning in het kader van de Hinderwet zou in de jaren na de oorlog een enorme groei doormaken, ten teken dat pogingen werden ondernomen tot een herstel van het bedrijfsleven. Het gebrek aan materialen en grondstoffen echter, had in de eerste jaren na de afloop van de oorlog tot gevolg, dat de tenuitvoerlegging van de plannen nogal verstoord werd. In 1946 en 1947 werden respectievelijk 3664 en 4397 aanvragen ingediend en ter beoordeling door de arbeidsinspectie ontvangen, tegen 2149 in de beide laatste oorlogsjaren. Dit aantal zou oplopen tot 4873 in 1949 om vervolgens in 1951 te dalen tot $4578^{240}$. In een aantal gevallen stond de arbeidsinspectie de gemeentebesturen op hun verzoek bij bij de opstelling 
van door hen nodig geachte, aan een vergunning te verbinden voorschiriften. In andere gevallen werd de wenselijkheid van het opleggen van voorschriften na te gaan en deze te formuleren.

Met de gemeentelijke diensten van bouw-en woningtoezicht bestond een zeer goede samenwerking; meermalen ontving de arbeidsinspectie, voorafgaande aan de definitieve aanvraag, de voorlopige plannen ter beoordeling, hetgeen voor de betrokken een kostenbesparing zou kunnen opleveren. Ten aanzien van Hinderwetvergunningaanvragen bestond ook contact met de brandweerautoriteiten ${ }^{24}$. Overigens waren er van de zijde van de arbeidsinspectie evenals in de voorgaande perioden klachten omtrent het niet tijdig verstrekken van gegevens door belanghebbenden waardoor meermalen vertraging optrad in de behandeling van de aanvragen, maar ook omtrent het feit dat de Hinderwet niet door gemeentebesturen werd nageleefd. Zo werden er Hinderwetvergunningen verleend zonder dat de vereiste verklaring van het districtshoofd van de arbeidsinspectie was afgegeven, maar werd ook geen afschrift gezonden van het proces-verbaal van de gehouden zitting, waarin belanghebbenden in de gelegenheid werden gesteld bezwaren tegen inwilliging van de aanvraag naar voren te brengen noch van de genomen beslissing ${ }^{242}$. Ook werd opnieuw geconstateerd, dat vaak een vlotte afhandeling van de Hinderwetvergunning werd belemmerd door het toedoen van de aanvragers zelf doordat bij de aanvrage de benodigde gegevens ontbraken; in het bijzonder betrof het de toezending van het schakelschema van elektrische installaties. Zo moest bijwoorbeeld in de jaren 1946 en 1947 maar liefst 1076 maal gerappeleerd, in verscheidene gevallen tot twee of driemaal to ${ }^{243}$. Herhaaldelijk werd van de zijde van de arbeidsinspectie geconstateerd, dat een groot aantal inrichtingen niet in het bezit waren van de vereiste Hinderwetvergunning, waarvan overigens de betrokken gemeentebesturen in kennis werden gesteld. Een belangrijk hulpmiddel voor het opsporen van dergelijke inrichtingen waren de regelmatig van de elektriciteitsbedrijven ontvangen mededelingen omtrent geplaatste elektromotoren. Niet alleen ten aanzien van de inrichting van fabrieken of werkplaatsen bleken deze mededelingen voordelen te bieden, maar ook met het oog op de veiligheid in de betrokken inrichtingen waren deze mededelingen zeer nuttig. Zo kon bijvoorbeeld in gevallen, waar de geplaatste elektromotoren dienden voor de aandrijving van houtbewerkingsmachines door de arbeidsinspectie vroegtijdig eisen worden omtrent de beveiliging van deze machines ${ }^{244}$.

In 1952 zou de Hinderwet worden gewijzigd ${ }^{245}$. Eén van de belangrijkste veranderingen was, dat de opsomming van de Hinderwetvergunningplichtige inrichtingen niet meer in de wet zelf was neergelegd, maar afzonderlijk bij algemene maatregel van bestuur gebeurde, hetgeen een vereenvoudiging met zich bracht in de eventuele wijziging van de opsomming. Tot de voor de arbeidsinspectie belangrijke veranderingen behoorde de zeer intentensieve bemoeiingen met de Hinderwetprocedure die deze dienst werden toebedeeld. Onder de oude wet ontvingen de districtshoofden van de arbeidsinspectie slechts de aanvragen ter behandeling van de inrichtingen die onder de bepalingen van de Veiligheidswet 1934 viellen; na de wetswijziging moesten alle aanvragen aan hen worden toegezonden. Het districtshoofd diende nu na te gaan of de inrichting onder de Veiligheidswet 1934 viel en zo ja, of aan de voorschriften krachtens artikel 6 van die wet werd voldaan. Op grond van artikel 35 bis van de Veiligheidswet 1934 diende hij dienaangaande een verklaring af te geven aan degene, die het verzoek om vergunning deed. Was de verklaring negatief dan kon, aangezien de verklaring op grond van de Veiligheidswet 1934 werd afgegeven, de aanvrager in beroep komen bij de minister van Sociale Zaken en Volksgezondheid. Werd een negatieve verklaring onherroepelijk, dan werd de aanvraag door het gemeentebestuur niet verder in behandeling genomen. Maar niet alleen voor wat betreft de Veiligheidswet 1934 werd het districtshoofd ingeschakeld. Hij was te allen tijde bevoegd het gemeentebestuur van advies te dienen ${ }^{246}$. In de praktijk kwam dat hierop neer, dat hij met name de kleinere gemeenten van advies diende, niet alleen op technisch maar ook op formeel terrein. Dit kwam in het bijzonder tot uiting bij de beoordeling van de ontwerp-beschilking, dat het gemeentebestuur, indien er aan de vergunning voorschriften werden verbonden, aan het districtshoofd voor commentaar diende te sturen ${ }^{247}$ "Mede als gevolg van de vele publikaties in de pers bij de invoering van de nieuwe Hinderwet, ontstond er een geweldige "hausse" in Hinderwetvergunning-aanvragen, niet alleen voor inrichtingen die niet onder de oude maar wel onder de nieuwe wet vielen, maar ook voor de eerst nu "ontdekte" inrichtingen die wel al onder de oude wet vielen. Eén en ander blijkt bijvoorbeeld uit het volgende gegeven. In 1952 ontving de arbeidsinspectie 3912 
aanvragen ter behandeling. In 19531113 aanvragen op grond van de oude wet en 7354 op grond van de nieuwe wet wat voor de dienst zowel in technisch als in administratief opzicht nogal wat werk met zich bracht $^{248}$. In 1954 zouden deze aantallen respectievelijk 228 en 8370 bedragen $^{249}$. In 1959 zouden door de arbeidsinspectie in deze periode de meeste aanvragen in behandeling worden genomen, namelijk $9398^{250}$. Overigens werden de klachten die door de arbeidsinspectie all eerder naar voren waren gebracht, zoals bijwoorbeeld ten aanzien van door de gemeentebesturen gemaakte procedurefouten, herhaald ${ }^{251}$.

\section{De Wet wekelijkse rustdag toonkunstenaars}

Met ingang van 11 augustus 1951 werd het tijdens de oorlogsjaren totstandgekomen Besluit wekelijkse rustdag toonkunstenaars $1941^{252}$ ( de "muziekloze dag") en dat een van de bezettingsmaatregelen vormde, die voorlopig na afloop van de oorlog werden gehandhaafd ${ }^{253}$, vervangen door de Wet wekelijkse rustdag toonkunstenaars ${ }^{254}$. In eerste instantie had de naleving van het genoemde besluit als gevolg van de gewijzigde verhoudingen sinds de totstandkoming ervan voor verscheidenen exploitanten van inrichtingen, waarin amusementsmuziek ten gehore werd gebracht ernstige moeilijkheden met zich gebracht, met name ten aanzien van de seizoenbedrijuen in de badplaatsen en voor de ondernemingen, die hetzij gezamenlijk hetzij in diverse plaatsen gebruik maakten van een vervangingsorkest. Ook bleek in verschillende plaatsen juist de maandag, de dag waarvoor het verbod gold, de drukste dag van de week te zijn ${ }^{255}$. Er was derhalve een behoefte aan een regeling, die het mogelijk zou maken, dat in dergelijke bedrijven zo nodig op alle dagen van de week muziek ten gehore mocht worden gebracht, zonder overigens dat daardoor de vrije dag per week voor de musici werd aangetast. De uitvoering van het betreffende besluit was in handen gelegd van de directeur-generaal van de Arbeid of de door hem gemachtigde ambtenaren, die ontheffing kon verlenen. Na overleg met werkgevers-en werknemersorganisaties stelde de directeur-generaal van de Arbeid in 1948 voor het verlenen van ontheffingen ten aanzien van de muziekloze dag nieuwe richtlijnen vast, die aan de ondervonden bezwaren tegemoet kwamen. Desalniettemin troffen de betreffende partijen elkaar opnieuw in november 1949, waarbij opnieuw de bezwaren die voor de seizoenbedrijven waren werbonden aan de muziekloze dag onderwerp van gesprek vormden. Dit overleg over een aanvaardbare oplossing zou eerst in 1951 tot enig resultaat leiden. Daarbij diende als uitgangspunt een voorstel van werkgeverszijde, om die musici van de voorgeschreven beperking te ontheffen, van wie het inkomen overeenkwam met de norm, die in artikel 19 van het Werktijdenbesluit voor koffiehuis- en hotelpersoneel 1949 is gesteld om buiten de werkingssfeer van dit besluit te vallen. Besloten werd om bij wijze van proef volgens dit beginsel ontheffingen te verlenen, waarbij echter wel als basis een hogere inkomensgrens werd gesteld en waarbij als voorschrift gehandhaafd bleef, dat de gederfde vrije dagen in de vorm van doorbetaalde dagen aaneengesloten zouden worden gegeven vo6r of na het seizoen ${ }^{25}$. In 1951, 1952 en vervolgens bijvoorbeeld in 1954 en 1959 werden respectievelijk $10,18,21$ en 12 van dergelijke ontheffingen verleend. Anderzins werd in de genoemde jaren respectievelijk $73,115,144$ en 213 afwijking van het verbod toegestaan ${ }^{267}$.

\subsection{Overige}

Het toezicht op de naleving van de bepalingen van de Phosphorluciferwet 1901 en de Caissonwet 1905 leverde geen noemenswaardige problemen met zich. Over de activiteiten van de arbeidsinspectie in het kader van de Winkelsluitingswet $1930^{258}$, de Wet tot regeling van het verrichten van arbeid door vreemdelingen, de Wet op het algemeen verbindend en onverbindend verklaren van bepalingen van collectieve arbeidskomsten, de Bedrijfswergunningenwet $1938^{259}$ valt niets te vermelden, omdat de activiteiten te dienaangaande zeer beperkt waren, mede als gevolg van de intrede van andere ( nieuwe ) overheidsinstanties.

\section{Bedrijfsmaatschappelijk werk en sociaal welaijn in de onderneming}

De in de inleiding van dit hoofdstuk aangestipte veranderende opvattingen omtrent de arbeider en zijn ar- 
beid hebben er toe geleid, dat er een ontwikkeling ontstond in die zin, dat de leiding van tal van ondernemingen en bedrijven de arbeidersbescherming niet meer zag als een lastig stuk overheidsbemoeiing, maar steeds meer ging beschouwen als een onderdeel van een goed bedrijfsbeheer. Deze ontwikkeling is in verschillende opzichten aanwijsbaar. Zo was er een uitbouw van het instituut van de bedrijfsgeneeskundige diensten, de aanstelling van veiligheidsinspecteurs en de instelling van veiligheidscommissies, maar vond ook het aanstellen van maatschappelijke werk(st)ers steeds meer ingang. De arbeidsinspectie volgde deze ontwikkeling met grote belangstelling en stelde alles in het werk om dit naar beste vermogen te stimuleren. De reden hiervoor was gelegen in het feit, dat zelfs bij een goede wettelijke regeling aangaande de arbeidersbescherming er altijd factoren aanwezig zouden zijn, waardoor bepaalde personen schade oplopen; factoren die echter een zodanig individueel karakter hebben, dat zij niet door wettelijke maatregelen voorkomen zoulden kunnen worden dan wel effectief bestreden, hoewel de schade voor de betreffende persoon soms ernstig is. Hier vond de arbeidsinspectie aanknopingspunten om haar sociale taak met meer succes in de bedrijven ingang te doen vinden en daarbij meer adviserend en stimulerend dan controlerend en verbaliserend te werk te gaan, in de hoop dat het daardoor mogelijk zou zijn om met het betrekkelijk kleine personeelsbestand toch het zich steeds uitbreidende arbeidsveld met vrucht te kunnen blijven bewerken ${ }^{200}$. Een goed personeelsbeleid werd derhalve een onderdeel van de arbeidersbescherming zonder dat overigens deze vorm van arbeidersbescherming nog voldoende omlijnd kon worden. Eén en ander wil niet zeggen dat er geen problemen waren ten aanzien van wat het bedrijfsmaatschappelijk werk genoemd kan worden. Zo kwam het nog te weinig voor dat de maatschappelijk werk(st)er weldoordacht de taak werd toebedeeld, de moeilijkheden met betrekking tot de onderlinge verhoudingen in het bedrijf op te sporen, te helpen oplossen en te helpen voorkomen. De aarzeling om dit "eigenlijke" terrein van het bedrijfsmaatschappelijk werk te betreden, was zowel bij de bedrijfsleiding als bij de maatschappelijk werk(st)ers zelf aanwezig. Dikwijls werd hun taak nog beperkt tot het wegnemen van hindernissen bij de arbeid; veroorzaakt door huiselijke omstandigheden, tot het verrichten van werkzaamheden voor het personeelsbeheer en tot het organisaren van ontwikkelingscursussen en ontspanning ten behoeve van het personeel. Zo waren er maatschappelijk werk(st)ers die geen toegang hadden tot werklokalen. Het aantal ondernemingen waarin de maatschappelijk werk(st)er volgens een vast plan werkte en werd betrokken in alle aangelegenheden, die op de menselijke verhouding in de ondernemingen van invloed zijn, was in die eerste na-oorlogse jaren nog te gering. Er werd zelfs geconstateerd, dat in vele ondernemingen nog grote weerstanden tegen het laatste werden ondervonden, waarschijnlijk althans voor een deel als gevolg van het feit, dat zowel de leiding van het bedrijf als het hoger kader bij de uitvoering van dit soort werk weinig leiding konden geven, daar al snel vakbekwaamheild was vereist. De vormgeving van de functie vereiste vakbekwaamheid, die verkregen kon worden door scholing en ervaring ${ }^{261}$.

Daar het maatschappelijk werk van groot belang kon zijn voor een goede arbeidersbescherming, maar dan nu in de ruime betekenis van dit begrip, werd in 1950 aan een aantal deskundigen verzocht een nadere omschrijving te geven van de in dat kader te vervullen functie en werd bovendien de door hen gegeven taakomschrijving opgenomen in het jaarverslag van dat jaar, teneinde de discussie over de functie als zodanig in een bredere kring te brengen en daardoor een goede ontwikkeling te bevorderen ${ }^{262}$. Als uitgangspunt voor de gegeven omschrijving werd gekozen een door het Instituut voor Praeventieve Geneeskunde uitgebracht rapport ${ }^{263}$, waarin het maatschappelijk werk in de onderneming als onderdeel van het personeelsbeleid werd beschouwd. In de lijn hiervan lag de door de bedoelde deskundigen toegedane mening, dat het personeelsbeleid een integrerend bestanddeel is van de algemene leiding van de onderneming en daardoor behoort tot een directie-functie. De uitvoering van dit beleid lag uiteraard bij alle leidinggevende personen, die daarvoor een eigen verantwoordelijkheid droegen; de verantwoordelijkheid van de totale uitvoering moest zijn gelegen in de handen van eén functionaris. Deze laatste zou moeten bijgestaan door de maatschappelijk werker, die deels een specifieke, deels een algemene taak had en daartoe een speciale opleiding had ontvangen. De omvang van de werkzaamheden die de maatschappelijk werk(st)er binnen de onderneming zou kunnen vervullen, was enigszins afhankelijk van de aard en grootte van de onderneming alsook van de samenstelling van het personeel. Wel stelde men vast, dat de functie als zodanig te allen tijde een vertrouwensfunctie was en 
dat de maatschappelijk werk(st)er derhalve geen werkzaamheden opgedragen zou moeten krijgen die daarmede in strijd zou zijn, noch dat geheimhoudingsplicht geweld aangedaan zou worden. Voorts werden, zij het onder het voorbehoud, dat het accent per onderneming zou kunnen verschillen, de volgende functies en werkzaamheden tot de taak van de maatschappelijk wer(st)er gerekend:

a. het bevorderen van de goede verhoudingen, bijvoorbeeld door het peilen van de gevoelens en de stemming van de personeelsleden en het onderkennen van fouten in de menselijke verhoudingen binnen de omlijsting van de onderneming en het medeontvangen van nieuwe werknemers;

b. de samenstelling van het personeel, bijwoorbeeld door het verzamelen van gegevens en het geven van adviezen over kandidaten ten behoeve van het selecterend orgaan;

c. de hygienische verzorging en de arbeidsomstandigheden, bijvoorbeeld het toezicht op de goede gang van zaken aangaande eerste hulp bij ongevallen ingeval een bedrijfsarts of verpleegster ontbreekt, schaftlokalen, wasgelegenheden en dergelijke alsook het signalleren van toevallig waargenomen tekortkomingen ten aanzien van orde, netheid, bedrijfshygiëne en veiligheid;

d. materiele verzorging van het personeel, bijvoorbeeld in verband met goederenverstrekking;

e. verstrekken van voorschotten en bijdragen uit fondsen, bijwoorbeeld door het toetsen aan gestelde normen en het adviseren over te verlenen voorschotten en uitkeringen;

f. hulpverlening bij individuele maatschappelijke moeilijkheden van niet-financiële aard;

g. ontwikkeling en ontspanning ${ }^{264}$.

Overigens was door de arbeidsinspectie in dat zelfde jaar een enquête uitgevoerd omtrent het personeelsbeleid in industriële bedrijven met meer dan 300 werknemers $^{265}$ en werd in het jaarverslag voor het eerst het begrip "sociaall welzijn in de onderneming" gebezigd. Door de snelle ontwikkeling van de techniek was er discrepantie ontstaan tussen de technologische kennis en bekwaamheid om het arbeidsproces op de voor de werkende mens beste wijze te organiseren; men tastte nog in het duister over de invloeden die het moderne arbeidsproces had op de mens en de bedrijfsgemeenschap. Er rezen talloze vragen, waarvan de antwoorden nog niet gegeven konden worden, maar die voor een goede arbeidersbescherming van belang waren,

Wat betekenen de ver doorgevoerde deelarbeid, de korte arbeidscyclus en het opgelegde tempo voor de werkende mens? Onder welke omstandigheden kan deze eenzijdige, psychische en fysieke belasting schadelijke invloed hebben op de persoon? Welke gevolgen hebben de onoverzichtelijkheid van het grootbedrijf, de vertechnisering en daarmee veelal gepaard gaande verarming van de menselijke betrekkingen, de geringe persoonlijke verantwoordelijkheid, voor de volwassen mens? Op welke wijze kunnen de arbeidsneurose en andere aanpassingsstoornissen in het bedrijf worden voorkomen?"

Aangezien het van belang was, dat op deze vragen binnen afzienbare tijd een antwoord kon worden gegeven, werd van de zijde van de arbeidsinspectie dan ook gepleit voor een overheidswege grootst mogelijke steun. De in dekringen van werkgevers en werknemers plaatsvindende bezinning op de sociale functie van de onderneming en het groeiende overleg tussen deze beide groepen, werd dan ook als zeer waardevol van het terrein van de arbeidersbescherming beschouwd.

Andere oorzaken die minder afhankelijk zijn van de gehele maatschappelijke ontwikkeling speelden eveneens een rol, oorzaken waarop de afzonderlijke ondernemers zelf gemakkelijk invloed op uit konden oefenen. Eén daarvan was, dat er in de bedrijven over het algemeen onvoldoende deskundigheid aanwezig was, om de sociaal-psychologische aspecten tot hun volle rechte te doen komen. In deze tijd werd voor het menswaardig functioneren van de onderneming een uitbreiding van de overwegend commerciële en technische leiding onmedici, psychologen, maatschappelijk werk(st)ers en andere door het bedrijf aangestelde specialisten. Een andere oorzaak was gelegen in het feit, dat de verbetering van de organisatie van de menselijke samenwerking een veranderde instelling van de daarbij betrokken personen vereist, wat vaak niet alleen een moeizaam, maar ook langdurig proces is. Tot slot moet nog worden gewezen op het feit, dat wijzigingen in het menselijke en sociale vlak vrijwel altijd economische consequenties met zich brengen, waarvan het gunstige effect 
vaak niet direct aantoonbaar is, zeker niet op korte termijn, als gevolg waarvan het van de ondernemer een groot sociaal verantwoordelijkheidsgevoel en brede visie om in dergelijke omstandigheden de veranderingen toch tot stand te brengen, vroeg ${ }^{267}$. Van de zijde van de arbeidsinspectie werd ook de aandacht gevestigd op een probleem, dat zich met het voortschrijden van de ontwikkeling steeds meer zou gaan voordoen. De vraag moest namelijk worden gesteld in hoeverre ons onderwijs een voldoende ondergrond verschafte, vooral aan de werknemers, om de functie te vervullen die een volledig tot zijn recht laten komen van de menselijke component en de democratisering van het bedrijf van hen vroeg. De ervaringen op dit punt werden zorgwekkend genoemd. Om de bestaande leemte aan te vullen was een aantal bedrijven er toe overgegaan door middel van cursussen onderricht en vorming te geven. Maar, werd daaraan toegevoegd, wil de ontwikkeling van de mens gelijke tred houden met de ontwikkeling van het bedrijfsleven, dan waren deze en soortgelijke initiatieven niet voldoende. De wijzigingen van het bedrijfsleven stelden nieuwe eisen aan ons onderwijs, waarin (nog) niet voldaan werd. Aan deze constatering werd het volgende toegevoegd $\mathrm{d}^{268}$.

"De voltooiing van de arbeidersbescherming in ons land is gelegen in het wegnemen van de gevaren, die de geestelijke gezondheid van de producerende mens bedreigen. De ontwikkeling van de menselijke kwaliteiten van de enkeling speelt daarbij een doorslaggevende rol. Uit een oogpunt van arbeidersbescherming moet daarom met klem op aanpassing van het onderwijs aan de eisen van de moderne samenleving worden aangedrongen".

Hoewel deze nieuwe ontwikkeling voor de arbeidsinspectie, zoals zij zelf zegt, niet iets geheel nieuws was, immers vanaf de eerste Arbeidswet stond de bescherming van de gehele mens voorop en waren tal van activiteiten sinds de eerste periode van de dienst ontplooid -, werd haar toch ook een nieuwe taak opgelegd.

"Zij zal de groeiende wetenschappelijke inzichten en de stroom van gegevens op sociaalpsychologisch terrein moeten bijhouden, kritisch waarderen en ordenen vanuit het oogpunt van de arbeidersbescherming. Daarbij zal zij, voor zover mogelijk, ook kennis moeten nemen van onderzoekingen die inde bedrijven worden gehouden en die een breder gebied dan dat van de arbeidersbescherming bestrijken. Daarbij worden immers dikwijls gegevens verzameld die een beter inzicht verschaffen in de moderne gevaren bij de arbeid en in de middelen om het welzijn van de arbeidende mens te verhogen. In de publikaties van de resultaten van deze onderzoekingen zullen deze echter zelden volgens bovengenoemde principes zijn gerangschikt. De dienst zou de gegevens die zich daartoe lenen moeten kunnen bewerken op een wijze dat zij ook ten dienste komen van de arbeidersbescherming".

Maar on deze taak te kunnen vervullen, werd het noodzakelijk geacht dat de arbeidsinspectie meedeed aan sociaal-psychologische onderzoekingen, omdat zij alleen dan de kennis eigen zou kunnen maken om de, zowel in ons land als het buitenland gepubliceerde onderzoeksresultaten, vanuit haar eiegen gezichtshoek en verantwoordelijkehid te bekijken en te beoordelen en een partner te zijn die een eigen inbreng kon hebben in de intensief gevoerde discussies daarover. Ook op meer praktisch niveau werd de dienst geconfronteerd met de sociaal-psychologische aspecten van de arbeid, zoals bijvoorbeeld op het terrein van de ploegenarbeid $^{269}$, de arbeid buitenshuis verricht door gehuwde vrouwen en de arbeid verricht door jeugdigen.

Er bestond een goede kans, dat een verdere industrialisatie zou leiden tot een verdere uitbreiding van het verrichten van arbeid in ploegendienst. Teneinde een verantwoord beleid in deze mogelijk te maken en de actuele problemen die zich nog steeds voordeden op een juiste wijze op te lossen, was het nodig een beter inzicht te hebben in de gevolgen van de ploegenarbeid voor de werkende mens, zijn gezin en zijn omgeving. Door een groep van sociologen, medici, psychologen, technici en economen werd in 1955 een onderzoek gestart, dat in de loop van 1959 voltooid zou worden ${ }^{270}$. Zowel bij de opzet als bij de uitvoering van dit onderzoek door de Stichting Onderzoek Ploegenarbeid was de de arbeidsinspectie zeer nauw betrolken. Daardoor was het mogelijk om de kennis en de ervaring in te brengen die de dienst ten aanzien van verschillende aspecten van het vraagstuk in de loop van de jaren had opgedaan. Anderzijds kon de arbeidsinspectie zich de resultaten van het onderzoek zo goed mogelijk eigen maken, waardoor de onderzoeksresultaten weer een 
grotere rol konden spelen bij een eventuele herziening van de Arbeidswet 1919 en het daarop gebaseerde Werktijdenbesluit voor fabrieken of werkplaatsen 1936 op het stuk ten aanzien van ploegenarbeid, alsmede ten aanzien van het hanteren van de bij de wet gegeven uitzonderings- of vergunningsbepalingen ${ }^{274}$.

Het onderwerp"de buitenshuis werkende gehuwde vrouw" had al de aandacht van de arbeidsinspectie, maar het onderwerp kwam in de tweede helft van de jaren vijftig nog meer in de belangstelling te staan daar het aandeel van de vrouw in het arbeidsproces zich in sterke mate uitbreidde. Bij de bestudering van de daaruit voortvloeiende problemen werd de arbeidsinspectie zowel op ambtelijk als niet-ambtelijk niveau betrokken. Vragen vanuit de Tweede Kamer over dit onderwerp leidden tot de vorming van een werkgroep van ambtenaren van het ministerie van Sociale Zaken en Volksgezondheid, waarin ook de arbeidsinspectie deelnam. Deze werkgroep kreeg tot taak het bestaande materiaal omtrent dit onderwerp te verzamelen. Ten behoeve hiervan werden de arbeidswettelijke bepalingen die betrekking hebben op de arbeid van de gehuwde wrouw geinventariseerd. Uit deze inventarisatie bleek overigens dat deze weinig homogeen waren, waaraan de stelling werd verbonden, dat de door de wetgever in deze gestelde normen in het verleden meer leken te zijn afgeleid van de gegroeide omstandigheden dan van een visie op het maatschappelijk verschijnsel als zodanig. Voorts werd van de zijde van de arbeidsinspectie medewerking verleend aan een onderzoek in opdracht van de Nederlandse Huishoudraad en dat werd verricht naar de huishoudelijke en financiële problemen van de buitenshuis werkende gehuwde vrouwen. Ook van de kant van het bedrijfsleven werd aangedrongen op een wetenschappelijk onderzoek naar de gevolgen van het buitenshuis werken van de gehuwde vrouw: Dit leidde tot de instelling van een werkgroep uit de Raad van toezicht op de Sociale en Sociaal-psychologische Projecten van de Contactgroep Opvoering Produktiviteit aangevuld met een aantal deskundigen. Deze werkgroep, onder het voorzitterschap van de directeur-generaal van de Arbeid Valentgoed ${ }^{272}$, had tot taak na te gaan, welke aspecten van het bovengenoemde verschijnsel voor een onderzoek in aanmerking kwamen. Ten behoeve van deze werkgroep werden een aantal werkzaamheden verricht, die bestonden uit het verzamelen van gegevens, het geven van adviezen en het mede ontwerpen van een probleemstelling. Hoe uitermate moeilijk het was de arbeid van de gehuwde vrouw als maatschappelijk verschijnsel op zijn merites te beoordelen en de in verschillende aspecten door te dringen, blijkt wel uit het moeizame werk dat bij elke poging om een van de vele facetten van dit probleem te onderkennen moest worden verricht ${ }^{273}$.

Een ander onderwerp op het terrein van het sociaal welzijn, was de zorg voor de jeugd in het bedrijf. In de loop van 1953 zou het rapport "Ontwikkelingsmogelijkheden voor de jeugdige fabrieksarbeiders" van de Commissie voor onderzoek naar de ontwikkelingsmogelijkheden van de Nederlandse jeugd en de rapporten van de onderzoekingen, in opdracht van de minister van Onderwijs, Kunsten en Wetenschappen door 7 sociologische en psychologische instituten in verschillende delen van het land alsook in een aantal grote steden naar die groepen van jeugdigen, die tot de wat genoemd werd de "massajeugd" moesten worden gerekend. De onderzoekingen hadden ten doel zo mogelijk tot concrete aanwijzingen te komen voor een gunstige beinvloeding van deze "massajeugd". De vele en veelzijdige problemen met betrekking tot de jeugdigen in het huidige tijdsbeeld werden door deze gedocumenteerde studies sterk onder de publieke belangstelling gebracht. De voorgestelde verbeteringen-lagen voor een deel op het terrein van de arbeidersbescherming en waren slechts mogelijk door nieuwe verbodsbepalingen uit te vaardigen, zoals bijvoorbeeld het verbod van het verrichten van arbeid door 14 en 15 -jarigen en een verbod van het verrichten van ploegenarbeid door jeugdigen. Ten aanzien van 14 -jarige meisjes zou een dergelijk verbod al in 1955 ingevoerd worden ${ }^{274}$. Hoewel het aantal meisjes, dat tot op dat moment op die leeftijd in een onderneming ging werken niet groot was ${ }^{275}$, kreeg het verbod, juist met name door de discussie in het parlement een verdergaande strekking. Bij de behandeling van het wetsvoorstel werd gewezen op de noodzaak jongens en meisjes een betere kans op ontwikkeling en vorming te waarborgen; de urgentie van de leerplichtverlenging tot 16 jaar en van partieel onderwijs werd daarbij zeer uitdrukkelijk aan de orde gesteld ${ }^{278}$.

Er werden in brede kring maatregelen genomen of voorgesteld ten behoeve van de werkende jeugd, maar deze hadden voornamelijk betrekking op de verbetering van de situatie buiten het bedrijf. Dat betekende 
echter niet dat $\mathrm{er}$ in de bedrijven zelf geen verbeteringen nodig zouden. Integendeel, wilden de maatregelen en woorzieningen op andere deelterreinen enig effect sorteren, dan moest ook de arbeidssituatie van de jeugd worden aangepast. Trouwens er waren ondernemers die zich hiervan terdage bewust waren en dan ook diverse maatregelen en voorzieningen voor hun jeugdige werknemers troffen. Een dergelijke ontwikkeling was van groot belang, omdat daarmede te kennen werd gegeven, dat jeugdigen geen volwassenen zijn; een opvatting die overigens nog niet door alle ondernemers gehuldigd werd. Teneinde de in bedoelde bedrijven opgedane ervaringen te verzamelen en te toetsen, stelde de bewindsman van Sociale Zaken en Volksgezondheid, een commissie "Jeugd in de Bedrijven" in, met het doel te onderzoeken welke middelen zouden kunnen worden aangewend om de positieve factoren ten aanzien van de persoonsontwikkeling van jeugdige werknemers bij de bedrijfsarbeid, te bevorderen en ongunstige invloeden te voorkomen of te verminderen. Deze commissie stond onder voorzitterschap van de directeur-generaal van de Arbeid en bestond behalve uit ambtelijke leden ook uit 4 nietambtelijke leden, te weten een medicus, een psycholoog, een socioloog en een sociaal-pedagoog ${ }^{277}$. Nadat een proefonderzoek ${ }^{278}$ door deze commissie was uitgevoerd in een aantal bedrijven, bleek het binnen het kader van een beperkt onderzoek niet mogelijk te zijn om na te gaan, welke positieve of negatieve invloeden van de door de jeugdigen in hun functie verrichte taken en handelingen uitgingen op de persoonsontwikkeling van betrokkenen. Geconcludeerd werd dan ook, dat een onderzoek naar de waarde van de arbeid en de invloed daarvan op jeugdigen voor de commissie te veel omvattend was en aan anderen overgelaten diende te worden. Wel besloot de commissie een onderzock te doen instellen naar de feitelijke situatie waarin de jeugd in de bedrijven verkeerde, waarbij de op het pedagogische aspect zou worden gelegd. Ten einde na te gaan op welke wijze de gegevens het beste konden worden verkregen werd een tweede proefonderzoek gestart ${ }^{279}$. Naar aanleiding van de bevindingen bij dit proefonderzoek stelde de commissie richtlijnen op voor het personeelsbeleid ten aanzien van jeugdigen. Men beschouwde het van het grootste belang, dat onderkend werd, dat de jeugd niet op dezelfde wijze als de volwassenen in de wereld staat en dat daarom een speciaal op de jeugdigen afgestemd beleid noodzakelijk was. De bedoelde richtlijnen behandelde onderwerpen als: de voorbereiding van de jeugdige op zijn taak in het bedrijf, keuring, selectie en plaatsing, introductie, voortgezet toezicht, pedagogische bekwaamheid van het lager leidinggevend personeel, taak en taakverruiming, promotielijnen, vakopleiding, takem van de sociale afdeling, bedrijfsgeneeskundige en psychologische diensten, algemene vorming en vakantiebesteding. Deze ideaal-criteria werden voorgelegd aan diverse instanties en personen uit het gehele land. Bovendien werd er een bespreking hierover gehouden met de vertegenwoordigers van de drie centrale werknemersorganisaties. De op-en aanmerkingen werden vervolgens verwerkt en werd er op basis van deze richtlijnen een enquêteformulier samengesteld waarna het onderzoek kon starten. Het enquêteformulier werd door de werkgeversorganisaties van de bedrijfstakken, waarin het onderzoek zou plaatsvinden, aan de daarvoor in aanmerking komende leden toegezonden en ingevuld via deze organisaties bij de arbeidsinspectie ingeleverd. Uit het onderzoek ${ }^{200}$ zou $^{2}$ blijken dat van een specifiek personeelsbeleid voor jeugdigen - zoals de richtlijnen aangaven - geen of nauwelijks sprake was. De verkregen gegevens wezen uit, dat het besef, dat jongeren in de puberteit een andere aanpak vergden dan volwassen arbeidskrachten en dat dit in een groter bedrijf zou resulteren in een aantal maatregelen, nog onvoldoende bij het bedrijfsleven leefde ${ }^{281}$. Maar een tendens om in de bedrijven meer rekening te houden met de speciale behoeften van de jeugd en om bijvoorbeeld speciale voorzieningen te treffen was er wel en zette zich door; steeds meer bedrijven namen in deze richting initiatieven. Inmiddels was de commissie Jeugd in de Bedrijven een tweede onderzoek gestart waarbij het ging om het daadwerkelijke verband tussen de personeelsvoorzieningen en de persoonsontwikkeling van de jeugdigen; dit onderzoek werd in de loop van 1960 beëindigd. De resultaten van het onderzoek werden neergelegd in een zeer uitvoerig rapport ${ }^{282}$, dat voornamelijk van betekenis is voor de wetenschappelijk geïnteresseerde lezer, en dat niet in boekworm werd gepubliceerd ${ }^{283}$. In de loop van 1964 zou het eindrapport van de commissie het daglicht zien $^{284}$; daarin werden de uitkomsten van de beide onderzoeken samengevat en geplaatst in het kader van een aantal zienswijzen die aan de literatumr waren ontleend. Op basis hiervan formuleerde de commissie eigen inzichten over de urgentie en de aard van de gewenste voorzieningen en gaf zij maatregelen aan die zij ten behoeve van de bedrijfsjeugd noodzakelijk achtte ${ }^{285}$. Het rapport belicht de situatie van 
jeugd en volwassenen in een veranderende wereld en stelt de wenselijkheid de jeugd te doen opgroeien to "open volwassentieid". Bij openheid moet men niet denken aan automatische aanpassing aan elke nieuwigheid, maar aan het vermogen om mee te groeien met de veranderende omgeving, de nieuwe situatie te beoordelen en en positie te bepalen vanuit de eigen gevormde volwassenheid. Het rapport stelt dat de bestaande situaties in ondernemingen op veel punten verbetering behoeven ten einde een harmonische groei naar deze "open volwassenheid" tot stand te brengen. Tot de maatregelen, met name die welke rechtstreeks in handen van de overheid lagen, behoorden onder meer een arbeidsverbod van 14 - en 15-jarigen, beperking van de arbeidstijden, leerplichtverlenging en verplicht part-time onderwijs en -vorming ${ }^{286}$.

\section{Bijzondere opdrachten}

In de onderhavige periode zou het alantal bijzondere opdrachten in vergelijking met eerdere perioden beduidend minder zijn. Zo maakten de directeur-generaal van de Arbeid alsmede vele andere ambtenaren van de arbeidsinspectie deel uit van verscheidene commissies en colleges, die werkzaam waren op sociaal en technisch terrein. De directeur-generaal werd benoemd tot lid van de Raad voor Rijkspersoneelsaangellegenheden, bleef hij lid van de Centrale Commissie voor de Statistiek, van het bestuur van het Veiligheidsmuseum, van de Raad van Bestuur van het Instituut voor Praeventieve Geneeskunde en als gedelegeerde van de minister van Sociale Zaken maakte hij deel uit van het bestuur van de Centrale Organisatie en van het dagelijks bestuur van de Nijverheidsorganisatie T.N.O. ${ }^{287}$. Voorts werd hij benoemd tot lid van de Contactgroep Opvoering Produktiviteit, die zich ten doel stelde in het algemeen de verhoging te propageren van de produktiviteit van het economisch leven in Nederland, en was hij lid van de Commissie ter bevordering van de arbeidsproduktiviteit en van de Staatscommissie ter voorbereiding van een herziening van de Pensioenwetgeving. Daarnaast was hij lid van de raad van bestuur, lid van het dagelijks bestuur en voorzitter van de raad van advies van het Instituut voor Onderzoek en Voorlichting op het gebied van bedrijfs- en bestuursefficiency, dat zich ten doel stelde het doen verrichten van alle beroepsmatige onderzoekingen, die kunnen bijdragen tot verhoging van de algemene efficiency, verhoging van het produktievermogen en verbetering van sociale verhoudingen $^{283}$.

Ook in deze periode werd van de zijde van de ministers van Oorlog en van Marine veelvuldig een beroep gedaan op de medewerking van de arbeidsinspectie bij het onderzoek van aanvragen om vrijstelling van militaire dienst als gewoon diensplichtige in min of meer ingewikkelde gevallen, waarin over het algemeen interne bedrijfswerhoudingen van ondernemingen in het geding waren. Ook in gevallen waarin beroep tegen afwijzende beschikkingen van de betrokken bewindslieden werd ingesteld werd de arbeidsinspectie veelvuldig ingeschakeld; vaak op uitdrukkelijk verzoek van de afdeling geschillen van bestuur van de Raad van State. Voor het onderzoeken van de aanvragen en beroepszaken werden de ondernemingen, waar de dienstplichtigen werkzaam waren, steeds en vaak meerdere malen bezocht. $\mathrm{Om}$ tot een juiste beoordeling van de aanvragen te kunnen komen was het ook meermalen nodig nadere inlichtingen in te winnen bij de gewestelijke arbeidsbureaus, de politie en andere autoriteiten ${ }^{2 a 9}$ " 
noten

1. Zie ook M. Weisglas, Woord vooraf, in Nederlands economisch herstel, Amsterdam/Brussel 1946, blz. 1.

2. W. Drees, Zestig jaar levenservaring, Amsterdam 1957, blz. 139.

3. J.H. Schmidt, Overgang van oorlogs- naar vredeseconomie, in Nederlands economisch herstel, blz. 13.

4. Besluit van 7 mei 1945 , Stb. F. 67.

5. Zie T. van Peijpe, t.a.p., blz. 367; Joh. de Vries, De Nederlandse economie tijdens de 20ste eeuw, Haarlem 1978, blz. 162 .

6. Zie over dit zgn. Marshall-plan onder andere T. van Peijpe, t.a.p., blz. $368-369$.

7. Resp. Wet van 24 januari 1952, Stb. 38, Wet van 7 juli 1954, Stb. 339, Wet van 25 februari 1954, Stb. 99 , Wet van 8 juni 1956 , Stb. 347 en de Wet van 28 juni 1956, Stb. 801 .

8. Wet van 27 januari 1950, Stb. K. 22; zie hierover onder meer J. Groenendaal, Dertig jaar publiekrechtelijke bedrijfsorganisatie in Nederland, in Econ. en Soc. Historisch Jaarboek 1982, blz. $187 \mathrm{t} / \mathrm{m} 231$.

9. Zie artikel l, eerste lid, van de Wet op de Bedrijfsorganisatie.

10. Zie J. Groenendaal, in Econ. en Soc. Historisch Jaarboek 1982 blz. 192, die stelt, dat de laatstgenoemden zelfs het initiatief in deze hadden genomen, terwijl de overheid aanvankelijk terughoudend bleef. De werkgevers begonnen onderling overeenkomsten te sluiten om zich te beschermen tegen vernietigende concurrentie. De werknemers sloten zich aaneen tot vakverenigingen, ter bereiking van betere arbeidsvoorwaarden. Dit laatste, zo vervolgt hij, leidde tot strijd met de ondernemers en niet tot samenwerking waardoor datgene wat men het begin van de bedrijfsorganisatie zou kunnen noemen in eerste instantie een onvolkomen karakter droeg. Bij velen ontstond het besef, dat werkgevers en werknemers tot op grote hoogte gelijke belangen hebben en dat zij deze belangen het beste in samenwerking zouden kunmen behartigen, waarmee de basis van de publiekrechtelijke bedrijfsorganisatie was gelegd.

11. Tweede Kamer, zitting 1947 - 1948, 884.3 (memorie van toelichting Wet op de ondernemingsraden ) blz. 7 en 9.

12. Wet van 4 mei 1950, Stb. K. 174. Zie over de totstandkoming van deze wet B. van Hijfte/J. de Jong/H. Keman/K de Pater, Medezeggenschap en neo-corporatisme. Hoe de Wet op de ondernemingsraden van 1950 tot stand kwam, in Intermediair 1983/18 blz. $19 \mathrm{t} / \mathrm{m} 29$.

13. Zie resp. de artikelen 6 en 4 van de Wet op de ondernemingsraden.

14. Zie M.G. Levenbach, Arbeid, in Nederlands bestuursrecht, blz. $474-475$.

15. Zie hierover M.G. Levenbach, Arbeid in een onderneming van landbouw, in R.B.A. XXVII blz. $49 \mathrm{t} / \mathrm{m}$ 51 , blz. 73 - 74 en blz. $77 \mathrm{t} / \mathrm{m} 79$ en J.L.J. van de Kamp, Geschiedenis der pogingen tot wettelijke regeling. van den landbouwarbeid, in R.B.A. XXIV blz. $85 \mathrm{t} / \mathrm{m} 88$. 
16. Wet van 19 januari 1955 , Stb. 49 .

17. Besluit van 16 februari 1954 , Stb. 54 .

18. Besluit van 17 februari 1954, Stb. 70 .

19. Thans gelden de volgende arbeids- en rusttijdenverordeningen: verordening arbeids- en rusttijden tuinbouw 1985, in PBO-blad 1986/12 LlO, verordening arbeids- en rusttijden boomkwekerij 1985, in PBOblad 1986/12 L11, verordening arbeids- en rusttijden bloembollenteelt in Noord- en Zuid-Holland, in PBOblad 1986/12 L12, verordening arbeids- en rusttijden landbouwambachten 1985, in PBO-blad 1986/12 L13, verordening arbeids- en rusttijden pluimveehouderij 1985, in PBO-blad 1986/12 L14, verordening arbeidsen rusttijden landbouw, in PBO-blad 1986/12 L15 en arbeids- en rusttijdenverordening particuliere bosbouw, in Verordeningenblad Bedrijfsorganisatie 1970/ 5.

20. Besluit van 3 augustus 1949, Stb. J. 352.

21. Resp. Besluit van 11 augustus 1954 , Stb. 391, Besluit van 30 januari 1958, Stb. 128, Besluit van 11 februari 1958, Stb. 127 en het Besluit van 28 augustus 1958, Stb. 492.

22. Zie Centraal Verslag Arbeidsinspectie over 1949 en over 1950, 's-Gravenhage 1952, resp. blz, 31 en blz. $36-37$.

23. Centraal Verslag Arbeidsinspectie over 1953, over 1958 en over 1961, resp. 's-Gravenhage 1955 , 1959 en 1962, resp. blz. 25 , blz. 31 en blz. 26.

24. Centraal Verslag Arbeidsinspectie over 1946 - 1947 en over 1949, resp. 's-Gravenhage 1948 en 1951 , resp. blz. $33 \mathrm{t} / \mathrm{m} 35$ en blz. 31 .

25. J.S. Dienske, Buitengewoon Arbeidsrecht, Alphen a/d Rijn 1965, blz. 75; A.J. van Bavel, Werktijdverkorting en Arbeidswet 1919, in S.M.A. 1961 blz. 19; P.H. Valentgoed, Werktijdverkorting, in S.M.A. 1962 blz.

26. Centraal Verslag Arbeidsinspectie over 1961, blz. 26. 27. Dat wil zeggen 16- en 17-jarigen; $\epsilon e ̂ n$ en ander voor zover zij in de avonduren geen vormend of op hun
vak gericht onderwijs genoten.

28. Resp. beschikkingen van 31 januari 1962 , no. $5102 \mathrm{~b}$ en no. $5102 \mathrm{a}$; zie Centraal Verslag Arbeidsinspectie over 1962, 's-Gravenhage 1963, blz. 25.

29. De te verlenen vergunningen zouden beperkt blijven tot die voor 14 - en 15 -jarige arbeiders die ten minste een halve dag per week vormend of op hun vak gericht onderwijs genoten, alsmede tot die voor 16- en 17jarigen die vormend of op hun vak gericht onderwijs in de avonduren genoten.

30. Centraal Verslag Arbeidsinspectie over $1962, \mathrm{blz} .24$

31. Zie bijwoorbeeld Centraal Verslag Arbeidsinspectie over 1948 en over 1949, resp. blz. 10 en blz. 10.

32. Zie onder andere Centraal Verslag Arbeidsinspectie over 1954, blz. 6. 
33. Zie Centraal Verslag Arbeidsinspectie over 1952 en over 1953, resp. 's-Gravenhage 1953 en 1955 , resp. blz. $26-27$ en blz. 26 .

34. Zo bedroeg het aantal klachten in 19482699 tegen 2524 in 1947 en 2468 in 1946 en 1234 in 1945 . De piek in deze periode lag in 1951 met 3416 waaraan een geleidelijke daling te zien is met een stabilisatie tussen circa 2000 tot 2500 per jaar. Zie Centraal Verslag Arbeidsinspectie over 1946-1947, over 1953, over 1958 en over 1961, resp. blz. 18, blz. 15, blz. 12 en blz. 12. Overigens moet hierbij wel de kanttekening worden gemaakt, dat klachten aangaande het Buitengewooon Besluit Arbeidsverhoudingen 1945 ( Stb. F. 214) hierin niet begrepen zijn.

35. Andere oorzaken waren: het vele "inbakken" door broodbakkers wier bakkerij verwoest was en in verband met de brandstoffenpositie, het gebrek aan personeel, de beperkte ovencapaciteit en de slechte toestand wan de transportmiddelen. Zie Centraal Verslag der Arbeidsinspectie over 1944 en 1945 , blz. 45.

36. Zie Centraal Verslag der Arbeidsinspectie over 1944 en 1945, blz. 45 - 46.

37. In deze commissies kwamen niet alleen Arbeidswetkwesties aan de orde, maar ook andere aangelegenheden als vakantie- en loonregelingen; zie Centraal Verslag Arbeidsinspectie over 1946 - 1947 en over 1948, resp. blz. 39 en blz. 35 .

38. In de jaren 1948 en 1949 werd,ter illustratie, aan resp. in totaal 22 en 88 werkgevers ten principale hechtenis opgelegd. Zie Centraal Verslag Arbeidsinspectie over 1948 en over 1949, resp. blz. 45 en blz. 43.

39. SER, Advies over een eventuele wijziging van de broodbakkerijparagraaf van de Arbeidswet 1919 van 25 september 1959, 's-Gravenhage 1959/5.

40. Centraal Verslag Arbeidsinspectie over 1950, over 1951, over 1953, over 1955, over 1959 en over 1961 , resp. blz. 38 - 39, blz. 34, blz. 33, blz. 36, blz. 34 en blz. 29.

41. Wet van 19 juli 1962 , Stb. 301 .

42. Jaarverslag van de Arbeidsinspectie over 1962, 's-Gravenhage 1962, blz. 27.

43. Centraal Verslag Arbeidsinspectie over 1948 en over 1949, resp. blz. 22 en blz. 22.

44. Centraal Verslag Arbeidsinspectie over 1946 en 1947, blz. 26,

45. Centraal Verslag Arbeidsinspectie over 1948, blz. 22.

46. Centraal Verslag Arbeidsinspectie over 1948 en over 1949, blz. 22 en blz. 22.

47. Centraal Verslag Arbeidsinspectie over 1949, blz. 22.

48. Centraal Verslag Arbeidsinspectie over 1950, blz; 11.

49. Centraal Verslag Arbeidsinspectie over 1950, blz, 45.

50. Resp Besluit van 2 november 1948, Stb. I. 482, het Besluit van 25 maart 1950, Stb. K. 107, en het Besluit van 20 maart 1957, Stb. 116. 
51. Zie ook M.G. Levenbach, Arbeid, in Nederlands bestuursrecht, blz. 483.

52. Rapport betreffende de bedrijfsgeneeskunde in Nederland, uitgebracht door de werkcommissie van de sectie voor Arbeids- en Bedrijfsgeneeskunde van de Algemeene Nederlandsche Vereeniging voor Sociale Geneeskunde, (z.p.) 1947 .

53. Rapport betreffende de bedrijfsgeneeskunde in Nederland; blz. 37 .

54. Bij beschikking van 29 april 1949, no. 673, Afd. Arbeidersbescherming.

55. In verband met het aanvaarden van het lidmaatschap van de Tweede Kamer werd A.H.W. Hacke met ingang van 4 juni 1946 als directeur-generaal van de Arbeid van rechtswege op non-actief gesteld. De benoeming van Z.Th. Fetter, directeur voor Sociale Zaken van de NV Philips' Gloeilampenfabrieken te Eindhoven, vond plaats bij Besluit van 22 augustus 1946, no. 9.

56. Rapport Commissie Bedrijfsgeneeskunde, ( z.p. )( juli ) 1951.

57. Dit gold voor alle bedrijven met een nader te bepalen minimumaantal arbeiders en voorts onafhankelijk van hun omvang voor bedrijven, waarin zich bijzondere gevaren voor leven voordoen; een en ander nader uit te werken bij algemene maatregel van bestuur. Bij Besluit van 20 juli 1960, Stb. 235, werd het minimumaantal gesteld op 750 arbeiders.

58. Zie voor een reactie op het wetsontwerp het Rapport wettelijke regeling van de bedrijfsgezondheidszorg, (z.p. ) (april ) 1955, van de Commissie-Ausums - een op 15 juni 1954 door het bestuur van het Centrum voor Staatkundige Vorming ingestelde commissie met de opdracht een met redenen omkleed antwoord te geven op de vraag, of een wettelijke regeling van de bedrijfsgeneeskundige diensten wenselijk is en zo ja, welke beginselen ten grondslag dienen te liggen aan en welke richtlijnen dienen te worden gevolgd bij zulk een regeling - blz. $32 \mathrm{t} / \mathrm{m} 42$.

59. Tweede Kamer, zitting 1954 - 1955, 3848.3 ( memorie van toelichting ) blz. 5 - 6 .

60. Tweede Kamer, zitting $1954-1955,38483$ (memorie van toelichting ) blz. 8.

61. Zie Tweede Kamer, zitting 1954 - 1955, 3848.4 ( bijlage I bij de memorie van toelichting ) bevattende het advies van de Centrale Commissie voor de Volksgezondheid van 28 juli 1953 aan de Staatssecretaris van Volksgezondheid.

62. Overigens kon de Sociale Commissie van de SER zich wel met de strekking en de inhoud van het wetsvoorstel verenigen; zie Tweede Kamer, zitting 1954 - 1955, 3848.5 (bijlage II bij de memorie van toelichting) bevattende het advies van genoemde commissie van 1 augustus 1953.

63. Zie Tweede Kamer, zitting 1956 - 1957, 3848.6 ( voorlopig verslag ) blz. 1 - 2 .

64. Tweede Kamer, zitting 1957 - 1958, 3848.7 ( memorie van antwoord) blz. 10.

65. Zie Tweede Kamer, zitting 1954 - 1955, 3848.3 ( memorie van toelichting ) blz. 6 .

66. Wet van 19 februari 1959 , Stb. 56. Bij dezelfde gelegenheid werd ook de Stuwadoorswet gewijzigd waarbij dezelfde bepalingen werden ingevoegd. 
67. Centraal Verslag Arbeidsinspectie over 1946 en 1947, over 1948, over 1949, over 1950, over 1956 en 1957 , resp. blz. 50 - 51, blz. 47 , blz. 45 , blz. 49 , blz. 53 .

68. Zie Centraal Verslag Arbeidsinspectie over 1952, bll. 44.

69. Centraal Verslag Arbeidsinspectie over 1952, over 1954 en over 1956 en 1957 , resp. blz. 44 - 45 , blz. 40 en blz. 53.

70. Centraal Verslag Arbeidsinspectie over 1946 - 1947, over 1950 en over 1961, resp. blz. 51 , blz. 52 en blz. 39.

71. Of een andere door de verantwoordelijke bewindsman aangewezen ambtenaar.

72. Wetten van 25 april 1951, resp. Stb. 135 en 136.

73. Het eerstgenoemde artikel betreft het verbod van kinderarbeid, terwijl het laatstgenoemde artikel de mogelijkheid opent tot het uitvaardigen van bijzondere voorschriften tot het tegengaan van gevaar van de gezondheid, voor het leven of de zedelijkheid van jeugdige personen of vrouwen. Eén en ander is uitgewerkt in het Arbeidsbesluit 1920 ( Stb. 694 ). Bij de Wet van 18 mei 1977, Stb. 360, zou de Arbeidswet 1919 gewijzigd worden, waarbij de bepalingen in die wet ten aanzien van jeugdigen vervangen zouden worden door een Jongerenstatuut. Daarbij werd ook artikel 82 bis, eerste lid, van de wet gewijzigd en werd de verwijzing naar artikel 10 van de wet vervangen door een verwijzing naar de artikel 90 en 10 van de wet.

74. Zie artikel 68 van het Arbeidsbesluit 1920.

75. Of door een andere door de directeur-generaal van de Arbeid aangewezen ambtenaar.

76. Zie Tweede Kamer, zitting 1949 - 1950, 1708.5 (memorie van toelichting ) blz. 4.

77. Of een andere door de verantwoordelijke bewindsman aangewezen ambtenaar. Bij beschikking van 3 augustus 1951, no. 1264, Afd. Arbeidersbescherming. Stcrt. 153, zijn daartoe aangewezen de elektrotechnisch adviseur en de ellektrotechnisch-ingenieur bij de arbeidsinspectie, met dien verstande, dat laatstgenoemde van de in artikel 26 bis van de Veiligheidswet 1934 vermelde bevoegdheid uitsluitend gebruik mag maken in geval van ziekte, verlof, afwezigheid of ontstentenis van de elektrotechnisch adviseur.

78. Deze beperking is ingevolge de wijzigingswet van 25 maart 1971, Stb. 225, nit het bedoelde artikellid geschrapt.

79. De tekst van het verdrag is weergegeven in Stb. 1949 J 424. Zie hoofdstuk 14 par 3 ( het Verdrag betreffende de arbeidsinspectie in industrie en handel).

80. Bij de Wet van 9 september 1949 , Stb. J 424, werd de bevoegdheid tot toetreding van Verdrag no. 81 aan de Kroon voorbehouden, omdat de in de bedoelde verdragsbepaling vermelde bevoegdheid in zowel de Arbeidswet 1919 als in de Veiligheidswet 1934 ontbrak. Nadat in de beide wetten bedoelde voorziening was opgenomen stond aan de bekrachtiging niets meer in de weg; het verdrag werd dan ook op 15 september 1951 geratificeerd, waardoor het op 15 september van het jaar daarop in werking trad; zie Trb. 1951 140.

81. Tweede Kamer, zitting 1949 - 1950, 1708.5 (memorie van toelichting ) blz. 3. 
82. Tweede Kamer, zitting $1949-1950,7408.6$ (voorlopig verslag) blz. $1-2$.

83. Deze term kwam voor in artikel 21 , eerste lid, $2^{\circ}$, onder b, van de Stuwadoorswet. In dit artikel was eveneens een bevel tot stillegging van werk geregeld.

84. Tweede Kamer, zitting $1949-1950,7408,7$ ( memorie van antwoord) blz. 2.

85. Overigens geheel overeenkomstig de hierboven gememoreerde verdragsbepaling.

86. Zie J. van Drongelen, De Arbeidswet 1919 en het bevel tot stillegging van werk, in S.M.A. 1987 blz. 470 -471 .

87. Zie J. van Drongelen, in S.M.A. 1987 blz. 468.

88. Zie J. van Drongelen, in S.M.A. 1987 blz. 471.

89. Het betreft de gevallen waarin het bepaalde bij of krachtens eén van de hoofdstukken IV (arbeids- en rusttijden van arbeiders van 18 jaar of ouder), $\mathrm{V}$ (administratieve bepalingen) en VI (aansprakelijkheid) in ernstige mate wordt overtreden.

90. Tweede Kamer, zitting $1949-1950,7408.3$ (memorie van toelichting) blz. 4 .

91. Tweede Kamer, zitting 1949 - 1950, 1708.3 ( memorie van toelichting) blz. 4.

92. Zie de artikelen 82quater van de Arbeidswet 1919 en 26ter van de Veiligheidswet 1934.

93. Tweede Kamer, zitting 1949 - 1950, 1708.5 ( memorie van toelichting ) blz. 5.

94. Zie de artikelen 82 quinquies van de Arbeidswet 1919 en $26 q u a t e r$ van de Veiligheidswet 1934.

95. Zie de artikelen 83, zesde lid, en 87 van de Arbeidswet 1919 en de artikelen 34 bis en 35 van de Veilligheidswet 1934.

96. Centraal Verslag Arbeidsinspectie over 1952, blz. 47.

97. Zie Centraal Verslag Arbeidsinspectie over 1954, blz. 40.

98. Zie voor een tweetal voorbeelden van een bevel tot stillegging van werk op het gebied van de Arbeidswet 1919 J. van Drongelen, in S.M.A. 1987 blz. $473-474$.

99. Zie bijwoorbeeld Centraal Verslag Arbeïdsinspectie over 1946 - 1947 en over 1949, resp. blz. 155 en blz. 124.

100. Zie Centraal Verslag Arbeidsinspectie over 1956 en 1957 en over 1959, resp. blz. 132 en blz. 111.

101. Wet van 25 april 1951, Stb. 134. Zie over deze wet onder meer A.N. Molenaar, t.a.p. deel IIB, blz. 1414 $\mathrm{t} / \mathrm{m} 1418$. 
102. Silicose is een longziekte die wordt veroorzaakt door de inademing van kwartsstof en heeft een sluipend karakter en ontstaat wanneer kwartsstof gedurende lange tijd wordt ingeademd; zie A.N. Molenaar, t.a.p., deel II B, blz. 1414.

103. Tweede Kamer, zitting 1949 - 1950, 1507.3 (memorie van toelichting) blz. 6.

104. Zie de artikelen 2 en 9 van de Silicosewet.

105. Besluit van 4 oktober 1951 , Stb. 443 (in werking getreden op 25 november 1951 ).

106. Besluit van 20 juli 1956 , Stb. 434 ( in werking getreden op 24 augustus 1957 ).

107. Zie bijwoorbeeld Centraal Verslag Arbeidsinspectie over 1954, over 1956 en 1957 en over 1959, resp. blz. 143, blz. 133 en blz. 112 .

108. Dit waren objecten van niet meer dan $1 / 2 \mathrm{~m}$ zandsteen, waarbij bovendien de aannemingssom van het uit te voeren een bedrag van fl. 500,-- (vanaf 1961 fl. 1000,-- ) niet overschreed.

109. Zie artikel 4 van het Zandsteenbesluit.

110. Zie artikel 5 van het Zandsteenbesluit. Deze commissie werd ingesteld bij beschikking van de minister van Sociale Zaken en Volksgezondheid van 8 januari 1952, no. 21 Afdeling Arbeidersbescherming, waarin zitting hadden: 1 werkgevers- en 1 werknemersvertegenwoordiger alsmede 1 vertegenwoordiger van monumentenzorg en 1 architect.

111. Zie artikel 3 van het Zandsteenbesluit.

112. Zie Centraal Verslag Arbeidsinspectie over 1952, over 1953 en over 1961, resp. blz. 136, blz. 133 en blz. 114.

113. Zie P. Bakker, in Elseviers Weekblad van 7 november 1953; zie A.N. Molenaar, t.a.p. deel II B, blz. $1417-1418$.

114. Zie Centraal Verslag Arbeidsinspectie over 1952, blz. 136 - 137 .

115. Centraal Verslag Arbeidsinspectie over 1953, blz. 134.

116. Onder "zandstralen" wordt in het besluit verstaan: het bewerken van voorwerpen waarbij zand of een andere stof, die kwarts of een andere vorm van kristallijn siliciumdioxyde bevat, met grote snelheid die voorwerpen treft, met uitzondering van die bewerkingen waardoor een laag materiaal op deze voorwerpen wordt aangebracht.

117. Centraal Verslag Arbeidsinspectie over 1956 en $1957, \mathrm{blz} .134-135$.

118. Centraal Verslag Arbeidsinspectie over 1959, over 1960 en over 1961, resp. blz. 112 - 113, blz. 118 - 119 en blz. $114-115$.

119. Wet van 5 maart 1952, Stb. 104. Zie over deze wet onder meer A.N. Mollenaar, t.a.p. Deel IIB, blz. 1411 t/m 1413. 
120. Tweede Kamer, zitting $1950-1951,2222.3$ (memorie van toelichting) blz. $7-8$.

121. Zie de artikelen $2 \mathrm{t} / \mathrm{m} 5$ van de Wet op de gevaarlijke werktuigen.

122. Zie artikel 6 van de Wet op de gevaarlijke werktuigen.

123. Zie artikel 8 van de Wet op de gevaarlijke werktuigen.

124. Zie de artikelen 11 en 16 van de Wet op de gevaarlijke werktuigen.

125. Resp. de Besluiten van 21 maart 1956, Stb. 150, van 23 maart 1956, Stb. 167, van 28 augustus 1958, Stb. 449 en van 1 september 1958, Stb. 434.

126. M.G. Levenbach, Arbeid, in Nederlands bestuursrecht, blz. 483.

127. Centraal Verslag Arbeidsinspectie over $1946-1947$, over 1950 en over 1961 , resp. blz. 208, blz. 161 en blz. 157 .

128. Centraal Versllag Arbeidsinspectie over 1948, blz. 159.

129. Overtreding van artikel 32 van de Arbeidswet 1919 , dat handelt over nevenarbeid was hierbij schering en inslag; zie Centraal Verslag Arbeidsinspectie over 1948, blz. 159. Zie over dit arbeidswettelijke artikel J. van Drongelen, Nevenarbeid of wel de grenzen ten aanzien van de wijze waarop de arbeider zijn vrije tijd naar eigen goeddunken kan indelen en besteden, in S.M.A. 1987 blz. 34 t/m 38.

130. Het tekort aan stiksters bestond reeds wo6r de oorlog. Gedurende de oorlog waren vele schoenfabrieken verplicht gesloten, zodat geen of althans onvoldoende jeugdig personeel tot geschoolde krachten kon worden opgeleid.

131. Centraal Verslag Arbeidsinspectie over 1948, blz. $159 \mathrm{t} / \mathrm{m} 165$.

132. Zie Centraal Verslag Arbeidsinspectie over 1948, blz 165.

133. Brief van 25 mei 1956, no. 2069, afdeling Arbeidersbescherming; zie SER, Advies over het ontwerp van een nieuwe Huisarbeidswet, $1958 / 3 \mathrm{blz} .53 \mathrm{t} / \mathrm{m} 79$ ( Bijlage II ).

134. SER, Advies over het ontwerp van een nieuwe Huisarbeidswet, 1958/3; zie over dit advies onder meer W. Dercksen/P. Fortuyn/T. Jaspers, Vijfendertig jaar SER-adviezen, deel I 1950 - 1964, Deventer 1982, blz. $362 \mathrm{t} / \mathrm{m} 364$.

135. Zie Arbeidsomstandigheden van thuiswerkers. Een inventariserend onderzoek naar de arbeidsomstandigheden van thuiswerkers, 's-Gravenhage januari 1989, blz. 10. Ter illustratie het volgende. Uit "Thuiswerk voor jou tien anderen", van de Vrouwenbond FNV, blijkt het aantal in 1979160 te bedragen, waarvan er nog slechts 11 uit de inventarisatie van de arbeidsinspectie uit 1956 overgebleven zijn.

136. Verordening van 12 september 1944 , no. 20 .

137. Centraal Verslag Arbeidsinspectie over 1946 - 1947, over 1959 en over 1960, resp. blz. 216 , blz. 140 en blz. 148. 
138. Besluit van 21 november 1960, Stb. 469.

139. Zie de artikelen 46,47 en 50 van het Rijtijdenbesluit.

140. Centraal Verslag Arbeidsinspectie over 1946 - 1947 en over 1960, resp. blz. blz. 216 en blz. 148.

141. Zie de artikelen $43 \mathrm{t} / \mathrm{m} 45$ van het Rijtijdenbesluit.

142. Centraal Verslag Arbeidsinspectie over 1946 - 1947 en over 1960, resp. blz. 215 en blz. 148.

143. Centraal Verslag Arbeidsinspectie over 1946 - 1947 en over 1959, resp. blz. 214 t/m 216 en blz. 141 142. Van de gegeven aantallen processen-verbaal was een niet noemenswaardig aantal opgemaakt door de arbeidsinspectie.

144. Besluit van 5 oktober 1945, Stb. F. 214 ( hierna B.B.A. 1945 ).

145. Zie W. Drees, Van mei tot mei, persoonlijke herinneringen aan bezetting en verzet, Assen 2 e druk 1959, blz. 176.

146. W.F. de Gaay Fortman, in Nederlands Economische Herstel, blz. 76.

147. M.G. Levenbach, Kanttekeningen bij het BBA, in S.M. 1947 blz. 38 en Arbeid, in Nederlands bestuursrecht, blz. 475. Uit de door Levenbach gekozen bewoordingen, leidt H. Naber, t.a.p., blz. 61, iets te gemakkelijk af, dat de Noodregeling Arbeidszaken "goeddeels model" heeft gestaan.

148. A. Stapelkamp/J. Schipper, De banier opnieuw geheven, Hoorn 1956, blz. 157.

149. Stichting van de Arbeild, Advies inzake het ontwerpBesluit, houdende vaststelling van het Buitengewoon Besluit Arbeidswerhoudingen 1945 van 13 augustus 1945, no. 790.V/CV; weergegeven door H. Naber, t.a.p., blz. $377 \mathrm{t} / \mathrm{m} 379$.

150. Zie T. van Peijpe, t.a.p., blz. 313.

151. Zie artikel 4 van het B.B.A. 1945. Zie hierover M.G. Levenbach, Rechtsherstel en het Buitengewoon Besluit Arbeidsverhoudingen 1945, in N.J.B. 1946 blz. 357 t/m 362.

152. Artikel 5 van het B.B.A. 1945. Zie hierover M.G. Levenbach, Het herplaatsingsrecht van terugkerende militairen volgens artikel 5 van het Buitengewoon Besluit Arbeidsverhoudingen, in S.M. $1950 \mathrm{blz} .2 \mathrm{t} / \mathrm{m} \mathrm{11}$, blz. 62; J.C. Sandick, Het einde van de arbeidsovereenkomst bij militaire dienst, in S.M. $1950 \mathrm{blz.} 98 \mathrm{t} / \mathrm{m}$ 108; J.H. Dijkman, Herplaatsing van militairen, in S.M. $1950 \mathrm{blz.} 136 \mathrm{t} / \mathrm{m} \mathrm{138;} \mathrm{M.G.} \mathrm{Levenbach,} \mathrm{Militaire}$ dienst, beëindiging van de arbeidsverhouding en herplaatsingsrecht, in S.M. $1950 \mathrm{blz.} 139 \mathrm{t} / \mathrm{m} 145$.

153. Artikel 6, vierde lid, van het B.B.A. 1945.

154. Artikel 7 van het B.B.A. 1945 .

155. Artikel 8 van het B.B.A. 1945. Zie hierover onder meer P.C. Rus, Enige opmerkingen over het verbod om de werktijd op minder dan 48 uren per week te stellen artikel 8 van het B.B.A. 1945 -, in S.M. 1948 blz. $230 \mathrm{t} / \mathrm{m}$ 234; A.J. van Bavel, in S.M.A. 1961 blz. 19 t/m 21; J.S. Dienske, t.a.p., blz.74 t/m 81; J.G.M. Arnold, 
Artikel 8 Buitengewoon Besluit Arbeidsverhoudingen 1945, in S.M.A. $1986 \mathrm{blz} .325 \mathrm{t} / \mathrm{m}$ 329; J. van Drongelen, Nogmaals artikel 8 van het Buitengewoon Besluit Arbeidsverhoudingen 1945, in S.M.A. 1986 blz. 661 t/m 664 en Werktijdverkorting, Deventer 1983.

156. Zie de artikelen $11 \mathrm{t} / \mathrm{m} 20$ van het B.B.A. 1945. Zie hierover onder meer J.C. Rutgers, Bevoegdheden van een lagere wetgever Het College van Rijksbemiddelaars, in S.M. $1949 \mathrm{blz} .20 \mathrm{t} / \mathrm{m} \mathrm{30;} \mathrm{M.G.} \mathrm{Levenbach,}$ De Nederlandse loonpolitiek, Alphen a/d Rijn 1955; M.G. Levenbach, Arbeid, in Nederlands bestuursrecht, blz. 475 - 476; W.I.P.M. Fase, t.a.p., blz. $47 \mathrm{t} / \mathrm{m}$ 51. Zie voorts R.J. Erdbrink, 30 jaren Rijksbemiddelaars I De periode tot 1942, II De periode na 1945, in E.S.B. 1954 resp. blz. $554 \mathrm{t} / \mathrm{m} 556$ en blz. $590 \mathrm{t} / \mathrm{m} 594$.

157. WF. de Gaay Fortman, in Nederlands economisch herstel, blz. $78-79$.

158. B.W. Havenman, Doelmatige organisatie. Arbeidsinspectie of Rijksarbeidsbureau, in Je Maintiendrai van 12 oktober 1945 .

159. Zie H. Naber, t.a.p., blz. 67.

160. Ontwerp-advies aan een niet nader genoemde collega-ambtenaar van het ministerie van Sociale Zaken van 15 juni 1945; weergegeven door H. Naber, t.a.p., blz. 382 -383.

161. Aantekening van de bewindsman op een nota van A.A. van Rhijn van 15 augustus 1945 naar aanleiding van het advies van de Stichting van de Arbeid; weergegeven door H. Naber, t.a.p., blz. 380 - 381.

162. A.N. van Mill, Nota van 27 augustus 1945; weergegeven door H. Naber, t.a.p., blz. 385 t/m 388 .

163. Uit een gesprek op 25 augustus 1945 met de bewindsman had Van Mill de indruk gekregen, dat de verlening van ontslagvergunningen in handen van de arbeidsinspectie zou worden, niet

"omdat de Gewestelijke Arbeidsbureaux daartoe niet in staat zouden zijn",

maar alleen vanwege de aangegeven praktische redenen. Dit lijkt echter in strijd met de aantekening van de minister op de nota van Van Rhijn, waaruit blijkt, dat de bewindsman meende, dat de arbeidsinspectie beter was ingericht, althans op dat moment, om de ontslagkwesties te beoordelen.

164. Zie de artikelen $10 j^{\circ} 8$, tweede lid, van het B.B.A. 1945.

165. H. Naber, t.a.p., blz. 104.

166. Deze bepaling is met de inwerkingtreding van de Wet op de economische delicten ( Wet van 22 juni 1950, Stb. K. 258; in werking getreden op 1 mei 1951 (zie besluit van 3 april 1951, Stb. 91 )) komen te vervallon.

167. Zie hierover J.H.A. Ringeling, t.a.p., blz. 31 - 32; J. van Drongelen, in Blinde vlekken in thet sociaal recht, blz. 105 - 106. Zie ook Centraal Verslag Arbeidsinspectie over 1946 - 1947, blz. 219.

168. Hierbij moet een onderscheid gemaakt worden tussen de aanvragen die betrekking hadden op afzonderlijke werknemers en die voornamelijk gebaseerd waren op bijzondere omstandigheden waarin deze werknemers verkeerden en aanvragen die betrekking hadden op eem algemene doorbreking van het geldende loonplafond op grond van het bestaan of de invoering van bepaalde tariefsystemen. In het laatste geval moest het terrein van de loontechniek in de meest ruime zin betreden worden, waardoor vraagstukken van arbeids- 
analyse, temposchatting, werkelassificatie en dergelijke aan de orde kwamen. Zie Centraall Verslag Arbeidsinspectie over 1946 - 1947, blz. 218 .

169. Het College van Rijksbemiddelaars was bij beschikking van 27 november 1945 , Stcrt. 129 , namens de minister van Sociale Zaken dergelijke ontheffingen te verlenen.

170. Naast de ambtenaren van de arbeidsinspectie waren hiermede belast:

a. de ambtenaren van de Inspectie van de Havenarbeid;

b. de inspecteurs en assistent-inspecteurs, toegevoegd aan het College van Rijksbemiddelaars;

c. de directeuren, de chefs van de afdeling Aanstelling en Ontslag, de chefs van de afdeling Bemiddeling en de ambtenaren van de buitendienst van de gewestelijke arbeidsbureaus;

d. de ambtenaren van de Raden van Arbeid als bedoeld in artikel 136 van de Ziektewet;

e. de controleurs van de Centrale Controledienst;

f. de controleurs van de Opsporingsdienst der Prijsbeheersing;

g. de controleurs bij de Centrale Dienst voor de Economische Controle;

h. de in artikel 141 van het Wetboek van Strafvordering aangewezen ambtenaren;

i. de ambtenaren van rijks- en gemeentepolitie. (Zie Wetsbesluiten tot stand gekomen tusschen 24 juni en 23 november 1945 met toelichting ( hierna Wetsbesluiten ), 's-Gravenhage 1947, blz. 294; beschikking van 16 november 1945, no. 5400, Afdeling Arbeid II - Centraal Verslag Arbeidsinspectie over 1946 - 1947, blz. 218 ).

171. In deze commissie hadden naast de afgevaardigden van de met de looncontrole belaste diensten zitting de vertegenwoordigers van de ministeries van Sociale Zaken en van Justitie en van het College van Rijksbemiddelaars; zie Centraal Verslag Arbeidsinspectie over 1946 - 1947, blz. 218 - 219.

172. Centraal verslag Arbeidsinspectie over 1946 - 1947, blz. 219 t/m 221.

173. De aantallen bedroegen resp. 35895 en 171; Centraal Verslag Arbeidsinspectie over 1948, blz. 171.

174. Centraal Verslag Arbeidsinspectie over 1948, blz. 171.

175. Zie Centraal Verslag Arbeidsinspectie over 1953, over 1956 en 1957 en over 1959, resp. blz. 172, blz. 182 en blz. 144.

176. Zie de toelichting in Wetsbesluiten, blz. 291.

177. Hetzelfde gold overigens voor de herplaatsingsverplichting, neergellegd in de artikelen 4 en 5 van het B.B.A. 1945.

178. Zie de beschikking van 27 november 1945 , Stcrt. 124 .

179. Centraal Verslag Arbeidsinspectie over 1946 - 1947, blz. $221-222$.

180. Evenals als trouwens de districtshoofden van de inspectie van de havenarbeid; zie de beschikking van 28 januari 1948, Stcrt. 19.

181. Centraal Verslag Arbeidsinspectie over 1948 en over 1949, resp. blz. 172 en blz. 161.

182. Centraal Verslag Arbeidsinspectie over 1950, blz. 169. 
183. Zie ook A.N. Molenaar, t.a.p. II A, blz. 453; J.C. Rutgers, in S.M. 1949 blz. 20 t/m 30; R.C. Rus, in S.M. 1948 blz. $230 \mathrm{t} / \mathrm{m}$ 239; J.S. Dienske, t.a.p., blz. 74. Overigens wordt in het bewuste jaarverslag van de arbeidsinspectie omtrent de uitspraak van de HR gesproken van "een nieuw gezichtspunt"; zie Centraal Verslag Arbeidsinspectie over 1950, blz. 170.

184. HR 31 oktober 1950 , S.M.A. 1953 blz. 56.

185. En dan vooral de schoen- en lederindustrie, de textielindustrie, de confectie-industrie en in minder mate de meubelindustrie.

186. Beschikking van 7 december 1945 , Stcrt. 131.

187. In het algemeen werd een subsidie toegekend van $50 \%$ volgens bepaalde normen die waren neergelegd in artikel 7 van de Wachtgeldregeling 1946.

188. Ten einde doublures in de werkzaamheden te voorkomen werd besloten, dat de arbeidsinspectie het feitelijk onderzoek in de onderneming zou verrichten, terwijl de gewestelijke arbeidsbureaus zich zouden beperken tot het geven van een overzicht over de toestand van de arbeidsmarkt en het verstrekken van aanvullende gegevens. Overigens werd in het kader van de Wachtgeldregeling 1946 de eis gesteld, dat de betrokken werknemers bij het gewestelijk arbeidsbureau werden ingeschreven en eventueel door dit bureau aangeboden werk hadden te aanvaarden.

189. Aangezien het aantal ontslagvergunningaanvragen in 1951 in vergelijking met het jaar er voor enigszins terugliep, werd afgeleid, dat van deze mogelijkheid on de bestaande problemen het hoofd te bieden niet op grote schaal gebruik werd gemaakt; zie Centraal Verslag Arbeidsinspectie over 1951, blz. 172.

190. Deze werkgroepleden toonden in thet bijzonder belangstelling voor de vraag, of bij het nemen van de beslissingen door de overheid op voldoende wijze rekening werd gehouden met het feit, dat het in het algemeen ongewenst was arbeidskrachten door middel van een wachtgeldregeling of een ontheffing van het verbod van werktijdverkorting aan een onderneming te binden, terwijl anderzijds de bedrijven die werknemers nodig hadden, deze niet of niet in voldoende mate konden krijgen; zie Centraal Verslag Arbeidsinspectie over 1951, blz. 173.

191. Centraal Verslag Arbeidsinspectie over 1951, blz. $171 \mathrm{t} / \mathrm{m} 173$.

192. Centraal Verslag Arbeidsinspectic over 1951, blz. 174.

193. Wet van 9 september 1949, Stb. J. 423. De Werkloosheidswet was gedeeltelijk in werking getreden op 1 juli 1949. De overige bepalingen traden in werking op 1 juli 1952.

194. Voor wat betreft de praktische nitvoering werd door de verantwoordelijke bewindsman bij beschikking van 28 juni 1952, no. 17306 afd. Socialle Verzekering bepaald, dat tot 1 oktober 1952 ten aanzien van werknemers, voor wie tot 1 juli 1952 een goedgekeurde wachtgeldregeling als bedoeld in artikel 10 van het B.B.A. 1945 van toepassing was, ontheffing werd verleend van het verbod van werktijdverkorting, met dien verstande dat de districtshoofden van de arbeidsinspectie (en van de haveninspectie) bevoegd waren deze ontheffing ten aanzien van bepaalde werknemers of groepen van werknemers vervallen te verklaren of aan voorschriften te binden; zie Centraal Verslag Arbeidsinspectie over 1952, blz. 169.

195. Zie artikel 30 , eerste lid, van de Werkloosheidswet. 
196. Van de zijde van het bedrijfsleven werd bij de inwerkingtreding van de Werkloosheidswet betoogd, dat het in artikel 8, eerste lid, van het B.B.A. 1945 neergelegde verbod van werktijdverkorting zijn geldigheid zou hebben verloren ten aanzien van de werknemers op wie deze wet van toepassing was, dit ingevolge de ratio van de uitzondering op het genoemde verbod ten aanzien van de wachtgeldregeling, als bedoeld in artikel 10. De verantwoordeliike bewindsman van Sociale Zaken en Volksgezondheid stelde echter, dat de totstandkoming van de wet geen invloed uitoefende op de werking van het genoemde verbod. Zie Centraal verslag Arbeidsinspectie over 1952, blz. 169.

197. Zie Hand. Eerste Kamer, zitting 1957 - 1958, IB 4900 90a blz. 2; SER, Advies inzake intrekking van de artikelen 6 en 8 BBA 1945, 's-Gravenhage 1969, 1969/5, blz. 7.

198. Beschikking van 11 juli 1952 , Stcrt. 135.

199. Centraal Verslag Arbeidsinspectie over 1952, blz. $168 \mathrm{t} / \mathrm{m} 170$.

200. Zie beschikking van 18 maart 1953, Stcrt. 57. Eén en ander voor zover het betrof degenen, die werknemers in de zin van de collectieve arbeidsovereenkomst voor het grafisch bedrijf in Nederland zijn. Gewijzigd bij beschikking van 25 februari 1955, Stcrt. 45. Nu gold de machtiging voor zover het betrof degenen, die werknemers zijn in de zin van de collectieve arbeidsovereenkomst voor het grafische bedrijf in Nederland, de collectieve arbeidsovereenkomst voor de chefs in het grafisch bedrijf in Nederland of de collectieve arbeidsovereenkomst voor het administratief personeel in de grafische bedrijven in Nederland. Deze overdracht van bevoegdheden aan het bedrijfsleven kan op grond van artikel 32 van het B.B.A. 1945.

201. Beschikking van 30 mei 1958, Stcrt. 104. Deze beschikking zou gewijzigd worden bij beschikking van 11 november 1966, Stcrt. 225, waarbij de machtiging tot het verlenen van ontheffingen van het verbod van werktijdverkorting werd verleend aan het bestuur van het bedrijfschap voor het Schoenherstellers-, het Maatschoenmakers- en het Orthopedisch Schoenmakersbedrijf.

202. Zie Centraal Verslag Arbeidsinspectie over 1952 en over 1953, resp. blz. 171 en blz. 171 t/m 173.

203. Zie Centraal Verslag Arbeidsinspectie over 1956 en 1957 en over 1958, resp. blz. 183 en blz. 165.

204. Centraal verslag Arbeidsinspectie over 1961, blz. 154.

205. Centraal Verslag Arbeidsinspectie over 1946 - 1947, over 1949, over 1950, over 1951 en over 1952 , resp. blz. 222, blz. 161, blz. 170, blz. 175 en blz. 172 .

206. Centraal Verslag Arbeidsinspectie over 1946 - 1947, over 1948 en over 1949, resp. blz. 223, blz. 173 en blz. 161 .

207. Beschikking van 28 januari 1950 , Stcrt. 22 .

208. Centraal Verslag Arbeidsinspectie over 1950, over 1951 en over 1952, resp. blz. 170 - 171, blz. 175 en blz. 173.

209. Zie over dit onderwerp bijvoorbeeld C.L.M. Kerkhoven, De grondslagen der loontechniek, Alphen a/d Rijn 3e druk ( z.j. ).

210. Centraal Verslag Arbeidsinspectie over 1953, blz. 177 - 178. Zie ook C.L.M. Kerkhoven, t.a.p., blz. 189. 
211. Centraal Verslag arbeidsinspectie over 1953 , blz. $179-180$.

212. Centraal Verslag Arbeidsinspectie over 1954, blz. 181 - 182.

213. Zie Centraal verslag Arbeidsinspectie over 1956 en 1957, over 1958, over 1959, over 1960 en over 1961 , resp. blz. 187 , blz. 168 , blz. 148 , blz. 154 en blz. 156 .

214. Centraal Verslag Arbeidsinspectie over 1954, blz. 183.

215. Centraal Verslag Arbeidsinspectie over 1953, blz. 181.

216. Zie de artikelen $16 \mathrm{t} / \mathrm{m} 18$ van het B.B.A. 1945 .

217. Zie de beschikking van 15 oktober 1945, Stcrt. 94. Zie ook W.J.P.M. Fase, t.a.p., blz. 48; J.S. Dienske, t.a.p., bliz. 82 .

218. Zie onder andere W.J.P.M. Fase, t.a.p., blz. 48.

219. Onderzoek inzake lonen en andere arbeidsvoorwaarden van volwassen mannelijke valide arbeiders in industriele bedrijven, juli/augustus 1945 ; zie W.J.P.M. Fase, t.a.p., blz. 50 en blz. 529 - 530 nt.51.

220. W.J.P.M. Fase, t.a.p., blz. 46.

221. Zie W.J.P.M. Fase, t.a.p., blz. 49.

222. De overige controlediensten kregen de navolgende bedrijfstakken toegewezen:

- de Centrale Dienst voor de Economische Controle: de aardewerk-, kalk-, glasindustrie, de kledingindustrie, de kunstsmederijen, de metaalnijverheid en de textielindustrie;

- de Centrale Controle Dienst: de bedrijven voor voedingsgenotmiddelen en de akker- en weidebouw en veehouderij;

- de gewestelijke arbeidsbureaus: het bouwbedrijf, de kunstnijverheid en de installatiebedrijven;

- de Prijscontrole-dienst: het kappersbedrijf, het wasserij- en reinigingsbedrijf, de banketbakkerijen, de handel en het hotelbedrijf;

- de Raden van Arbeid: het grafische bedrijf, de edelmetaalbedrijven, de papierindustrie, het beroepsver-voer over de weg, de bewakingsdiensten, het bankwezen en het verzekeringsbedrijf;

- de inspectie van de havenarbeid: het visserijbedrijf en de zgn. "natte bedrijven".

Zie Centraal Verslag Arbeidsinspectie over 1946 - 1947, blz. 224.

223. De cijfers over 1946 en 1947 zijn niet volledig beschikbaar. Eerst in 1947 werd namelijk ingevoerd, dat de directeur-generaal van de Arbeid maandelijks van elke controlerende dienst een volledig overzicht van de in die maand gehouden controles zou ontvangen. De directeur-generaal van de Arbeid stelde aan de hand hiervan periodiek een algemeen overzicht samen. Voor de eerste keer werd dit overzicht over het derde kwartaal van 1947 opgemaakt. Uit deze informatie blijkt, dat over het tweede halfjaar van 1947, door de controlediensten - uitgezonderd de arbeidsinspectie - te zamen 11.963 ondernemingen controleerden. Zie Centraal Verslag Arbeidsinspectie over $1946-1947$, blz. 225.

224. Centraal Verslag Arbeidsinspectie over 1949, blz. 162. Door alle controlediensten gezamenlijk werden in deze jaren resp. 44.112 en 38.200 ondernemingen gecontroleerd; zie Centraal Verslag Arbeidsinspectie over 1948 en over 1949, resp. blz. 174 en blz. 162 . 
225. Centraal Verslag Arbeidsinspectrie over 1950 , blz $171-172$.

226. Zie bijvoorbeeld Centraal Verslag Arbeidisnspectie over 1952 en over 1954 , resp. blz. 173 t/m 177 en blz. 184.

227. Staatscommissie inzake onvolwaardige arbeidskrachten, ingesteld bij Besluit van 12 april 1929, no. 27; zie Verslag Staatscommissie inzake onvolwaardige arbeidskrachten, 's-Gravenhage 1938, blz. 11.

228. Verslag Staatscommissie inzake onvolwaardige arbeidskrachten, blz. 29.

229. Tweede Kamer, zitting 1946 - 1947, 444.3 ( memorie van toelichting) blz. $1 \mathrm{t} / \mathrm{m} 3$.

230. Wet van 1 augustus 1947, Stb. H. 283. Zie hierover onder meer A.N. Molenaar, t.a.p. IIB, blz. 1435 t/m 1447; B.S. Frenkel/A.J.T.M. Jacobs, t.a.p., blz. 153 t/m 156.

231. Zie artikel 5 van de Wet plaatsing minder-valide arbeidskrachten.

232. Dan wel van het districtshoofd van de inspectie van de havenarbeid. Zie artikel 7 van de Wet plaatsing minder-valide arbeidskrachten.

233. Zie artikel 6 van de Wet plaatsing minder-valide arbeidskrachten.

234. De artikelen $8 \mathrm{t} / \mathrm{m} 11$ van de Wet plaatsing mindervalide arbeidskrachten. De overige personen die belast waren met de opsporing waren de in artikel 141 van het Wetboek van Strafvordering genoemde personen, de aangewezen ambtenaren van de gewestelijke arbeidsbureaus en de inspectie van de havenarbeid, alsmede de door de minister van Economische Zaken aangewezen ambtenaren van het Staatstoezicht op de mijnen.

235. Zie artikel 1, eerste lid, van de Wet plaatsing minder-valide arbeidskrachten. Zie ook B.S. Frenkel/ A.T.J.M. Jacobs, t.a.p., blz. 155.

236. Wet van 16 mei 1986, Stb. 300 .

237. Centraal Verslag Arbeidsinspectie over 1946 - 1947 en over 1948, resp. blz. 21 en blz. 14.

238. Zie onder meer Centraal Verslag Arbeidsinspectie over 1949, over 1950, over 1952, over 1954 , over 1956 en 1957 en over 1961, resp. blz. 14, blz. 15, blz. 11, blz. 10, blz, 13 en blz. 158.

239. Zie bijwoorbeeld Centraal Verslag Arbeidsinspectie over 1948 en over 1956 en 1957 , resp. blz. 14 en blz. 13.

240. Zie Centraal Verslag Arbeidsinspectie over 1949 en over 1951, resp. blz. 12 en blz. 8.

241. Zie Centraal Verslag Arbeidsinspectie over 1948 en over 1951, resp. blz. 12 en blz. 9.

242. Zie bijvoorbeeld Centraal Verslag Arbeidsinspectie over 1949 en over 1950, resp. blz. 12 en blz. 13.

243. Zie Centraal Verslag Arbeidsinspectie over 1946 1947, blz. 20. Zie ook bijvoorbeeld Centraal Verslag Arbeidsinspectie over 1950, blz. 13. 
244. Zie bijvoorbeeld Centraal Verslag Arbeidsinspectie over 1950, blz. 13.

245. Wet wan 15 mei 1952, Stb. 274 (in werking getreden op 1 februari 1953 ).

246. Zie artikel 8, tweede lid, van de Hinderwet.

247. Zie artikel 18 van de Hinderwet.

248. Zie Centraal Verslag Arbeidsinspectie over 1953 , blz, $8 \mathrm{t} / \mathrm{m} 10$.

249. Centraal Verslag Arbeidsinspectie over 1954, blz. 9.

250. Centraal Verslag Arbeidsinspectie over 1959, blz. 7.

251. Zie bijvoorbeeld Centraal Verslag Arbeidsinspectie over 1956 en 1957 en over 1960, resp. blz. 11 en blz. 8.

252. Besluit van de waarnemend secretaris-generaal van het ministerie van Sociale Zaken van 17 oktober 1941, no. 3163, Stcrt. 203.

253. Zie de Wet van 28 februari 1947 , Stb. H 70 .

254. Wet van 13 juli 1951 , Stb. 281.

255. Zie Centraal Verslag Arbeidsinspectie over 1946 1947, blz. 22.

256. Zie Centraal Verslag Arbeidsinspectie over 1950 en over 1951, resp. blz. 15 en blz. 11.

257. Centraal Verslag Arbeidsinspectie over 1951, over 1952, over 1954 en over 1959, resp. blz. 11, blz. 13, blz. 12 en blz. 10.

258. Vervangen door de Wet van 24 januari 1952, Stb. 38 (Winkelsluitingswet 1952 ).

259. Vervangen door de Wet van 7 juli 1954, Stb. 339 (Bedrijfsvergunningenwet 1954 ).

260. Centraal Verslag Arbeidsinspectie over 1946 - 1947 en over 1948, resp. blz. 1 en blz. 181.

261. In 1949 werden van 47 willekeurige ondernemingen de mutaties nagegaan. In deze ondernemingen waarvan er 2 de eerste maatschappelijk werker stelden in 1929,1 in 1930 en de overige na 1940, hadden in totaal 131 maatschappelijke werkers gewerkt met een totaal aan 250 dienstjaren. De gemiddelde dienstijd bedroeg dus nog geen 2 jaren, zodat van ervaring in een functie waar het aankwam op het peilen en verbeteren van menselijke verhoudingen, waarbij de factor tijd van grote betekenis was, niet of nauwelijks sprake was. Zie Centraal Verslag Arbeidsinspectie over 1949, blz. $171 \mathrm{t} / \mathrm{m} 173$.

262. Centraal Verslag Arbeidsinspectie over 1950, blz. 187 - 188.

263. Instituut voor Praeventieve Geneeskunde, Rapport, Leiden 1948.

264. Zie voor een uitgebreide opsomming Centraal Verslag Arbeidsinspectie over 1950, blz. 188 - 189. 
265. Centraal Verslag Arbeidsinspectie over 1950, blz. $178 \mathrm{t} / \mathrm{m} 186$; zie ook Centraal Verslag Arbeidsinspectie over 1951 , blz. $186 \mathrm{t} / \mathrm{m} 201$.

266. Zie Centraal Verslag Arbeidsinspectie over 1954, blz. 185.

267. Centraal Verslag Arbeidsinspectie over 1954, blz. 185 - 186.

268. Centraal Verslag Arbeidsinspectie over 1952, blz. 188.

269. Centraal Verslag Arbeidsinspectie over 1956 en 1957, blz. 188 - 189.

270. De vragen waarop men een antwoord probeerde te vinden luidden als volgt:

1. Bestaat er een schadelijke invloed van ploegenarbeid op het lichamelijk en geestelijk welzijn?

2. Wordt de arbeidsprestatie beïnvloed door afwijkingen van het normale arbeidsritme?

3. Zijn de thans gebruikelijke indelingen van ploegen optimaal?

4. Welke zijn de invloeden van de overgang van de ene ploeg naar de andere en na hoeveel tijd kan het best van ploeg gewisseld worden?

Zie Centraal Verslag Arbeidsinspectie over 1955, blz: 193.

271. Centraal Verslag Arbeidsinspectie over 1955, blz. 193.

272. Met ingang van 1 september 1953 had zijn voorganger Z.Th. Fetter zijn ambt als directeur-generaal in verband met het bereiken van de pensioengerechtigde leeftijd neergelegd; zie Centraal Verslag Arbeidsinspectie over 1953 , blz. 1 .

273. Centraal Verslag Arbeidsinspectie over 1956 en 1957, blz. 192.

274. Wet van 6 augustus 1954, Stb. 388 (in werking getreden op 1 juli 1955; zie artikel IX van deze wet ).

275. De schatting loopt van circa 8.000 tot circa 10.000 ; zie Centraall Verslag Arbeidsinspectie over 1954 , blz. 189.

276. Zie Tweede Kamer, zitting 1953 - 1954, 3319.4 ( voorlopig verslag ) blz. 3.

277. Zie Centraal Verslag Arbeidsinspectie over 1954, blz. 189 - 190.

278. Zie hierover Centraal Verslag Arbeidsinspectie over 1954, blz. 190 t/m 192.

279. Zie hierover Centraal Verslag Arbeidsinspectie over 1955, blz, 197 t/m 200.

280. Commissie Jeugd in de Bedrijven, Interimrapport "Personeelsbeleid voor jeugdigen. Wensen en feiten", 's-Gravenhage 1957.

281. Centraal Verslag Arbeidsinspectie over 1956 en 1957, blz. 193 - 194.

282. Commissie Jeugd in de Bedrijven, Personeelsbeleid voor jeugdigen en Persoonsontwikkeling, 's-Gravenhage 1961. 
283. Het rapport was in gestencilde vorm beschikbaar voor universiteiten en onderzoekinstituten en bepaalde categorieën van deskundigen; zie Centraal Verslag Arbeidsinspectie over 1961, blz. 162.

284. Commissie Jeugd in de Bedrijven, Persoonsvorming bedrijfsjeugd, 's-Gravenhage 1964.

285, Zie Centraal Verslag Arbeidsinspectie over 1960, over 1961 en over 1962, resp. blz. 156, blz. 162 en blz. 131.

286. Zie Centraal Verslag Arbeidsinspectie over 1964, 's-Gravenhage 1965, blz. 150.

287. Zulks tot 1 september 1952, waarna deze functie werd vervuld door de hoofdinspecteur-directeur J.G. Kraft; zie Centraal Verslag Arbeidsinspectie over 1952, blz. 6.

288. Zie Centraal verslag Arbeidsinspectie over 1948, over 1949, over 1950, over 1951, over 1952, resp. blz. 16, blz. 16, blz. 16 - 17 , blz. 12, blz. 6 .

289. Zie onder meer Centraal Verslag Arbeidsinspectie over 1949, over 1950 en over 1951, resp. blz. 15, blz. $16 \mathrm{en} \mathrm{blz.12}$. Hoewel deze activiteiten aangaande de vrijstelling van militaire dienst door de arbeidsinspectie verricht zouden blijven worden, werd vanaf 1952 hiervan in het jaarverslag geen melding meer gemaakt. 


\section{Inleiding}

In de jaren zestig kwam in de Nederlandse samenleving een aantal ontwikkelingen op gang. Deze ontwikkelingen hadden al eerder, zij het voorzichtig, hun wortels geschoten, maar zouden in deze periode voor een schokeffect zorgen. Er groeide langzaam het besef, dat er zich ingrijpende maatschappelijke veranderingen aan het aftekenen waren.

De vijf grote politieke partijen in ons land: de Katholieke Volkspartij, de Anti-Revolutionaire Partij, de Christelijk Historische Unie, de Partij van de Arbeid en de Volkspartij voor Vrijheid en Democratie werden in toenemende mate geconfronteerd met ideëen en gedachten van groeperingen, die de kaders van het institutionele denken te buiten gingen. Proteststemmen roerden zich buiten de bestaande institutionele overlegstructuren. In de landbouw waren dat de Vrije Boeren en de Boerenpartij, buiten de officieel "erkende" vakbonden stonden strijdvaardige "niet-erkende" bonden op, ontstond de provobeweging, de studentenbeweging en kwamen er actiegroepen die nieuwe vraagstukken aan de orde stelden en zich daarbij van allerlei nieuwe beïnvloedingsstactieken bedienden'.

De kwaliteit van de bestaande democratie, de verstarring en bureaucratisering van het leven vormde het onderwerp van discussie; er kwam een roep van de naoorlogse generatie die noch de jaren dertig, noch de Tweede Wereldoorlog bewust hadden meegemaakt om (verder gaande) democratisering, niet alleen in het politieke vlak, maar ook in andere maatschappelijke sectoren ${ }^{2}$. Zeer uiteenlopende vraagstukken werden aan de orde gesteld: huisvesting, huurbeleid, bedrijfsdemocratisering, milieu en onderwijs. Volgens Van den Berg en Molleman ${ }^{3}$ zijn de volgende drie "programmapunten" te herkennen:

- nadruk op het gelijkheidsideaal: gelijke kansen voor iedereen, spreiding van kennis, macht en inkomen'; - verzet tegen de machtspositie van de particuliere onderneming;

- verzet tegen het centralistische en bureaucratische overheidsoptreden en tegen het gesloten overlegsysteem; men eiste inspraak, democratisering en medebeslissingsrecht "aan de basis", of er werd overgegaan tot "directe actie": demonstraties, petities, teach-ins, bezettingen en stakingen.

In deze periode zou de ongebreidelde groei van de industrie en de ontwikkeling en het gebruik van vele nieuwe, vooral chemische en petro-chemische stoffen, en de betekenis daarvan voor de volksgezondheid en voor het milieu in een groeiende belangstelling komen te staan, hetgeen uiteindelijk zou uitmonden in de eerste milieuwetgeving.

Op het terrein van de arbeidswerhoudingen werden omstreeks 1960 de eerste stappen gezet tot decentralisatie en differentiatie in het loonvormingssysteem. De grondslag van de loonpolitiek werd verlegd van het algemeen belang naar de economische situatie per bedriifstak of onderneming. Maar aangezien het College van Rijksbemiddelaars de uiteindelijke verantwoordelijkheid bleef dragen voor de loonpolitiek was de grotere vijheid voor de betrokken onderhandelende partijen slechts van relatieve betekenis ${ }^{5}$. De zich voorspoedig ontwikkelende economie bracht voortdurend spanningen met zich op de arbeidsmarkt. Het gevolg: een weelderige praktijk van koppelbazen en zwarte lonen. De positie van de vakbonden werd onhoudbaar tegenover de werknemers en dit leidde tot een agressievere loonpolitiek, waarvoor zij de toestemming vroegen van de centrale organisaties. De gespannen arbeidsmarkt maakte iedere overheidspolitiek onmogelijk. Men wilde een nieuw systeem, waarbij de primaire verantwoordelijkheid voor de loonvorming werd gelegd bij de organisaties op bedrijfstakniveau. Ten einde de loonontwikkeling nog enigszins beheersbaar te houden werd een systeem ontwikkeld van onderlinge beïnvloeding van centrale werkgevers- en werknemersorganisaties, de Sociaal-Economische Raad, de Stichting van de Arbeid, het College van Rijksbemiddelaars en de overheid. 
Maar ook dit systeem mocht niet baten. In 1966 zou de vrijere loonpolitïek worden opgegeven en zou de geleide loonpolitiek terugkeren. Maar de loonvorming bleek niet meer langs de klassieke weg te beheersen ${ }^{\mathrm{B}}$. In het najaar van 1967 kwam de Stichting van de Arbeid tot de conclusie, dat het centraal georganiseerde bedrijfsleven geen medeverantwoordelijkheid voor de loonvorming meer kon aanvaarden. De partijen bij de collectieve arbeidsovereenkomst moesten zelf de volledige verantwoordelijkheid voor de loonvorming dragen, zonder preventief toezicht van overheidswege, zonder preventief toezicht van de centrale organisaties waarbij de partijen van een collectieve arbeidsovereenkomst zijn aangesloten. Wel bleef de overheid degene die uiteindelijk verantwoordelijk voor de loonvorming en moest zij ingrijpen bij een ernstige verstoring van het economische evenwicht ${ }^{7}$. Dit uitgangspunt zou van regeringszijde overgenomen worden ${ }^{8}$ en leidde tot de Wet op de loonvorming ${ }^{9}$.

De economische bloeiperiode van de jaren zestig versnelde de uitbouw van de sociale wetgeving. Het ging voornamelijk om vernieuwingen in het stelsel van sociale verzekeringen, maatregelen ter bevordering van de bezitsvorming en de uitbreidingen van de medezeggensct ap. Kort na de tot stand gekomen Algemene Ou-

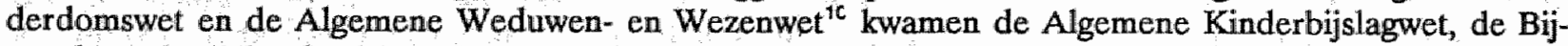
standwet, de Ziekenfondswet, de Wet op de arbeidsongeschiktheidswerzekering, de Wet Werkloosheidsvoorziening, en tot slot de Algemene Wet Bijzondere Ziektekosten ${ }^{11}$. Op het terrein van de bezitsvorming kwamen de Premiespaarwet voor werknemers en de Algemene Premiespaarwet tot stand, in 1971 gevolgd door de Wet Bezitsvormingsfonds ${ }^{12}$.

Naar gelang de loonvorming vrijer werd in de loop van de jaren, tekende zich een behoefte af aan een wettelijke regeling tot een algemeen geldend minimumloon, dat voorheen vastgesteld werd in de minimumloonbepalingen in collectieve arbeidsovereenkomsten dan wel de bindende loonregelingen van het College van Rijksbemiddelaars $^{13}$. Dit zou in 1968 leiden tot de Wet minimumloon en minimumvakantiebijslag ${ }^{14}$.

Naast deze regellingen zou ook de medezeggenschap niet achter blijwen. De ontwikkeling rond de Wet op de ondernemingsraden van 1950 verliepen teleurstellend, de publiekrechtelijke bedrijfsorganisatie stagneerde nog meer. Nieuwe bedrijfslichamen werden er bijna niet meer ingesteld en aan het einde van de jaren zestig werden er zelfs een aantal opgeheven ${ }^{15}$. Voorts werden wetten tot stand gebracht met betrekking tot de jaarrekening van de ondernemingen ${ }^{1 *}$, het enquêterecht ${ }^{17}$, de structuur van de naamloze en besloten vennootschap ${ }^{18}$.

Kwam in de jaren zestig de uitbreiding van de socialle wetgeving voor wat betreft de sociale zekerheid zonder al to veel verschillen van mening tot stand, ten aanzien van andere onderwerpen, zoals de medezeggenschap liepen de meningsverschillen hoog op. Dit onderwerp leidde tot felle debatten in de kringen van het georganiseerde bedrijfsleven, de politieke partijen en de beroepsmatig bij het arbeidsrecht betrokken juristen. Een discussie, die overigens nooit tot wetgeving zou leiden, was die over het stakingsrecht ${ }^{19}$.

Tegen het midden van de jaren zestig was een situatie ontstaan van een hoge materiële welvaartsgroei, optimistische verwachtingen jegens de toekomst en een vrij sterke internationale positie. Eén en ander resulteerde, zoals uit het hierboven geschrevene blijkt, in een uitbreiding van de sociale zekerheid en een stijging van de inkomens. De enige zorg vormde de inflatie die resulteerde uit het verschil tussen aanspraken en middelen. Maar er zouden belangrijke veranderingen optreden. In 1973 brak de olie-crisis uit, hetgeen neerkwam op een viervoudiging van de olieprijs en een enorme druk legde op internationale economische verhoudingen. De betalingsbalans in alle landen, arm en rijk, met uitzondering van de olie-exporterende landen, kwam in problemen. De wereldhandel stagneerde en zou zelfs teruglopen. Daarnaast trad er ook een vertraging op in de economische groei ${ }^{20}$. De gevolgen zouden niet uitblijven en ook aan de arbeidsinspectie niet onge-
merkt voorbijgaan. 
2. De arbeidsinspectie en de afdeling Arbeid/Arbeidersbescherming; het ontstaan van het directoraat-generaal van de Arbeid

\subsection{Inleiding}

Als de ministeriële zorg voor de arbeidersbescherming in ogenschouw wordt genomen, dan is deze, aldus Diepenhorst ${ }^{21}$, schuchter en verscholen voor het oog van de wereld aangevangen. De voorbereiding en de uitvoering van de Arbeidswet 1889 berustte bij de $2 \mathrm{e}$ afdeling van het ministerie van Justitie. Vanaf 1 januari 1893 was de uitvoering van de deze wet in handen gelegd van het ministerie van Waterstaat, Handel en Nijwerheid, waar een afzonderlijke afdeling Arbeid en Fabriekswezen werd gevormd. Toen in 1901 het kabinetKuyper $^{22}$ zijn intrede deed, trok de minister van Binnenlandse Zaken naar wie het kabinet was genoemd, de behandeling van de arbeidswetgeving aan zich. Dit had tot gevolg, dat de afdeling Arbeid en Fabriekswezen van het ministerie van Waterstaat, Handel en Nijverheid onder de naam van afdeling Arbeid met ingang van 1 september $1901^{23}$ bij het ministerie van Binnenlandse Zaken werd ondergebracht. Toen het kabinetKuyper werd opgevolgd door het kabinet-De Meester ${ }^{24}$, werd het bestaande ministerie van Waterstaat, Handel en Nijverheid gesplitst en werd er met ingang van 7 september 1905 een nieuw departement ingesteld, namelijk dat van Landbouw, Nijverheid en Handel ${ }^{25}$. De afdeling Arbeid verhuisde van Binnenlandse Zaken naar dit nieuwe departement, alwaar in 1908 de afdeling Arbeidersverzekering werd afgescheiden ${ }^{20}$. De afdeling Arbeid zou in 1918 overgaan naar het op 25 september van dat jaar ${ }^{27}$ ingestelde ministerie van Arbeid. Dit ministerie zou een aantal naamswijzigingen ondergaan ${ }^{28}$, om van ministerie van Sociale Za$\mathrm{ken}^{29}$ uiteindelijk in 1981 bij de benaming ministerie van Socialle Zaken en Werkgelegenheid terecht te ko$\operatorname{men}^{30}$.

Bij beschikking van 24 december $1941^{3 !}$ werd bepaald, dat met ingang van 1 januari van het jaar daarop de afdeling Arbeid werd gesplitst in de afdeling Arbeid I en de afdeling Arbeid II.

De werkkring van de afdeling Arbeid I omvatte de volgende onderwerpen: de voorbereiding van wettelijke maatregelen betreffende de arbeidersbescherming, de uitvoering van de Arbeidswet 1919, de Veiligheidswet 1934, de Caissonwet 1905, de Steenhouwerswet 1921, de Stuwadoorswet, de Phosphorlucioferswet 1901, de Huisarbeidswet 1933 en de Rijtijdenwet 1936, maatregelen ter bevordering van het onderwijs in eerste hulp bij bedrijfsongevallen en andere onderwerpen die met de arbeidersbescherming verband hielden, maar alleen voor zover deze niet tot de werkkring van én van de andere departementale afdelingen behoorden.

De werkkring van afdeling Arbeid II omvatte het volgende: de uitvoering van de Arbeidsgeschillenwet 1923, de Wet op de Hooge Raad van Arbeid, de Bedrijfsradenwet 1933, de Wet op het algemeen verbindend en onverbindend verklaren van collectieve arbeidsovereenkomsten, de Stoomwet, de Hinderwet en maatregelen ter bestrijding van waterverontreiniging.

Bij beschikking van 28 oktober $1947^{32}$ werden de beide afdelingen van een andere naam voorzien, en wel respectievelijk de afdeling Arbeidersbescherming en de afdeling Arbeidsverhoudingen.

2.2. De verhouding tussen de arbeidsinspectie en de afdeling Arbeid/Arbeidersbescherming, met andere woorden de technici versus de juristen

In het voorgaande heb ik in grote lijnen vastgehouden aan het te bespreken tijdvak. Voor het verschaffen van een goed inzicht in het thans te behandelen onderwerp is het noodzakelijk terug te grijpen naar een nog niet besproken onderdeel van de geschiedenis van de arbeidsinspectie.

Tijdens de reorganisatie van de arbeidsinspectie in 1909 kwam behalve de positie van de directeur-generaal van de Arbeid en de zelfstandige positie van de inspecteur van de arbeid ook de verhouding tussen de arbeidsinspectie en de toen nog genoemde afdeling Arbeid ter sprake. Het Tweede Kemerlid Treub ${ }^{33}$ merkte op, dat de directeur-generaal van de Arbeid, blijkens de toelichting op het wijzigingsvoorstel voor de begro- 
ting voor het dienstjaar $1907^{34}$, een tweeledige taak zou hebben, namelijk het leiden van de dienst van de arbeidsinspectie en het adviseren met betrekking tot nieuwe matregelen op het gebied van de arbeidersbescherming. Ten aanzien van dit laatste wees hij op een probleem. Hij kon zich vinden in een in hoofdzaak technische aanpak van de uitvoering van de arbeidswetgeving. Maar bij de adviseurswerkzaamheden en bij de werkzaamheden, die nodig zijn voor de uitbreiding van die wetgeving, komt technische kennis op de tweede of zelfs de derde plaats. Desalniettemin constateerde hij een organisatie met een centrale dienst met een adviserende taak met betrekking tot de uitbreiding van de arbeidswetgeving, waarbij witsluitend gebruik gemaakt zou worden van technische krachten. Hiertegen had hij grote bezwaren, omdat zo de indruk gewekt zou worden, dat bij de voorbereiding van die wetgeving juridische, staatsrechtelijke en economische kennis overbodig zouden zijn. Hij bepleitte dan ook om naast technisch geschoolde ook staatsrechtelijke en economisch gevormde ambtenaren op te nemen; een standpunt dat werd gedeeld door het Kamerlid Van Idsin$\mathrm{ga}^{35}$.

De verantwoordelijke bewindsman van Waterstaat, Handel en Nijverheid moest Treub toegeven ${ }^{36}$, dat de door hen genoemde elementen bij de arbeidsinspectie ontbraken. Bij de reorganisatie van deze dienst, zo stelde hij, werd begonnen met het yoorzien in de technische behoeften van de arbeidsinspectie. Uit praktische overwegingen was het nog niet het moment om aan de centrale dienst van de arbeidsinspectie een jurist toe te voegen. De taak die Treub door die persoon wilde laten verrichten en waarbij de juridische, staatsrechtelijke en economische aspecten bij de arbeidswetgeving tot hun recht zouden komen, berustte bij de departementale afdeling arbeid. Of het op dat moment, nu de verhouding van de arbeidsinspectie en de afdeling Arbeid vastere vormen kregen, verstandig was om de eerstgenoemde dienst zo uit te rusten, dat hij zich bezig zou houden met de samenstelling van wetsvoorstellen, was een vraag, die naar de mening van de minister moeilijk positief beantwoord kon worden.

Het Tweede Kamerlid Schaper zou nog een ander element in de discussie betrekken ${ }^{37}$; hij achtte het namelijk wenselijk, dat er een wetsvoorstel zou worden ingediend waarbij de arbeidsinspectie zou worden geregeld en in het bijzonder de verhouding tussen die inspectie en bijvoorbeeld de afdeling Arbeid ${ }^{38}$. Op deze manier zou de zelfstandigheid van de arbeidsinspectie behoorlijk geregell kunnen worden om zo te voorkomen, dat van de zijde van het departement voortdurend een zekere imvloed op die inspectie zou kunnen worden uitgeoefend. Eén en ander, omdat hij meende, dat de verhouding tussen de beide departementsonderdelen tot dan toe te wensen overliet. Dit laatste werd door de bewindsman niet ontkend ${ }^{39}$. Hij haalde daarbij een inspecteur van de arbeid aan, die hij jaren daarvoor had ontmoet:

"Een vervelende boel bij ons, wij zitten geheel onder den chef van de afdeeling Arbeid", terwijl dit in feite niet zo behoorde te zijn. Maar een wettelijke regeling van de arbeidsinspectie, waarin de verhouding van deze dienst met het departement zou worden geregeld, zou, aldus de minister, nooit kunnen. Hoe wil een wet, zo vroeg hij zich af, de werhouding bepalen ten opzichte van een ambtenaar van het departement, die geen zelfstandigheid heeft, maar die door of namens de minister geacht wordt te handellen? Een wettelijke regeling van de arbeidsinspectie zou daarom nooit iets anders kunnen bevatten dan het geven van bevoegdheden aan die dienst, afgegrensd tegenover de bewindsman. Dat was het doel van een wettelijke regeling. Maar, zo vervolgde hij, Schaper had een punt aangeroerd, dat altijd een lastig punt zal blijven, namelijk hoe de gehele dienst wan de arbeidersbescherming ten opzichte van het departement zou staan. Hij merkte op, dat hij zich de zaak altijd zo had voorgesteld en dat de ervaring van de afgelopen maanden sinds het optreden van de directeur-generaal van de Arbeid - hem niet had doen wankelen in zijn mening, dat dit een juiste regeling was. Van een behoorlijke verhouding ten aanzien van de taak van de arbeidersbescherming was naar zijn mening sprake, wanneer de directeur-generaal van de Arbeid, als hoofd, en de arbeidsinspectie als ruggegraat het materiaal voor de arbeidersbescherming aan zouden leveren en het eigenlijke wetgevende werk bij het departement zelf zou blijven. Het departement zou dus een eigen taak hebben naast de dienst van de arbeidsinspectie.

Ook buiten het parlement speelde de relatie tussen de arbeidsinspectie en de afdeling Arbeid. Zo verzocht het bestuur van de Sociaal-technische Vereeniging van democratische ingenieurs en architecten de verhou- 
ding tussen de centrale dienst van de arbeidsinspectie en de departementale afdeling Arbeid goed en blijvend te regelen, waarbij overigens niet werd uitgesloten de bedoelde afdeling op te heffen. Dit punt werd ter overweging gegeven, omdat het zo niet waarschijnlijk, dan toch zeer mogelijk was, dat er voortdurend wrijving zou bestaam tussen de dienst en de departementale afdeling. Gevreesd werd voor het ontstaan van verwikkelingen, die in

"hun gevolgen even schadelijk, als in hun oorsprong kleinzielig zijn" ${ }^{\mathrm{t} 40}$.

De verhouding tussen de beide departementsonderdelen was voor de verantwoordelijke minister in 1909 duidelijk: op de arbeidsinspectie rustte de taak van de arbeidersbescherming en het aandragen van bouwstenen voor nieuwe wetgeving, terwijl de departementale afdeling Arbeid het eigenlijke wetgevende werk zou verrichten.

Voor de reorganisatie van de arbeidsinspectie in 1909 bestond een dergelijke verhouding tussen de beide departementsonderdelen ook al, maar dat deze verhouding te wensen overliet, blijkt al uit de woorden van de door de minister aangehaalde inspecteur van de arbeid. Dat de relatie, die door de verantwoordelijke bewindsman was geschetst, beter tot zijn recht zou kunnen komen na de reorganisatie was alleszins mogelijk, omdat de afdeling arbeid niet meer zou worden geconfronteerd met samenwerkende inspecteurs van de arbeid, maar met een centrale dienst van de arbeidsinspectie onder leiding van de directeur-generaal.

De praktijk zou echter anders uitpakken. Dit blijkt onder meer uit een brief van 9 oktober 1922 van de directeur-generaal van de Arbeid Zaalberg aan zijn bewindsman Aalberse ${ }^{41}$. Na opgemerkt te hebben, dat hij de

"meest vriendschappelijke en erkentelijke gevoelens koester( $(t)$ voor de afdeeling en hare ambtenaren, aangezien het streven naar een goede samenwerking niets te wenschen overlaat en het voor ( hem) louter gemak en voordeel geeft, dat de afdeeling bestaat in haar tegenwoordigen vorm en bezetting",

vervolgde hij met een vermelden van een schaduwzijde, namelijk dat

"zij onwillekeurig, doch als gevolg der organisatie well eens oorzaak van een langdurig op-

onthoud is voor het totstandkomen van ontwerpen van wetten en besluiten".

De directeur-generaal van de Arbeid voerde als argument aan, dat zeer veel werk dubbel werd verricht ${ }^{42}$. Door de grotere omvang van de bemoeiingen had de afdeling Arbeid een uitbreiding ondergaan, die niet in overeenstemming was met het effect dat een dergelijke uitbreiding met zich bracht, waardoor onnodige vertraging in de afdoening van verscheidene voorstellen van haar hand ontstond. In feite is hier naar mijn mening sprake van een botsing tussen een beleidsafdeling - de arbeidsinspectie - en een niet-beleidsafdeling de afdeling Arbeid -, een verschijnsel dat heden ten dage ook niet onbekend is. De directeur-generaal van de Arbeid deed dan ook het voorstel om de beide departemenstonderdelen samen te doen smelten ${ }^{43}$. De directeur-generaal van de Arbeid zou dan als hoofd van de dienst moeten blijven en voor zover hij als adviseur van de minister werkzaam was, zou hij als chef van de nieuwe departementsafdeling kunnen optreden. Aan hem zouden dan twee juridisch geschoolde ambtenaren moeten worden toegevoegd; de oudste als juridisch adviseur en de jongste zou minder belangrijke werkzaamheden van juridische aard kunnen verrichten. De eerstbedoelde was dan vrij van alle administratieve bemoeienissen en zou dan uitsluitend wetenschappelijke arbeid kunnen verrichten, zoals de overige adviseurs bij de arbeidsinspectie. Het voorstel van Zaalberg was eigenlijk primair gebaseerd op bezuinigingsoverwegingen, althans voor wat betreft de bestaande formatieplaatsen ten departemente, omdat hij zelf geen kans zag om bij de arbeidsinspectie te bezuinigen zonder aan de taakstelling van zijn dienst afbreuk te doen.

Een reactie van Westhoff, hoofd van de afdeling Arbeid, bleef niet uit. In zijn aan de minister gerichte nota van 7 november $1922^{44}$ ontkende hij, voor wat betreft de wetgevende arbeid, dat de bestaande situatie tot zeer veel dubbel werk leidde.

"Het hoogere personeel der afdeeling heeft in de zeer drukke wetgevende periode der laatste 4 jaren de handen vol gehad om technisch misschien juist geformuleerde, maar admini- 
stratief en juridisch uiterst gebrekkige voorstellen van wet en van algemeene maatregelen van bestuur, die de Directeur-Generaal aan Uwe Excellentie deed toekomen, in een behoorlyken vorm te gieten",

waarna hij enkele voorbeelden gaf. Verder gaf hij te kennen, dat bij de afdeling Arbeid alle originelen zijn bewaard van voorontwerpen van wet en algemene maatregelen van bestuur, die door de arbeidsinspectie ontworpen zijn met de daarin door de afdeling Arbeid aangebrachte wijzigingen.

"Daarmede is een moeizame arbeid van maanden en maanden van de hoofdambtenaren der afdeeling gemoeid geweest en in geen enkel geval dubbele arbeid verricht, getuige het zoo herhaaldelyk gebleken onvermogen der Arbeidsinspectie om een eenigszins ingewikkelde technische gedachte, waarvoor nog geen administratieve of juridische schablone bestaat, behoorlyk te formuleeren. Een verkeerde eigenschap der technici, die ongunstig influënceert op de duidelijkheid der wetten en algemeene maatregelen van bestuur, is hun neiging tot juridische casuistiek. Geen geval, dat volgens het oordeel van een districtshoofd strafbaar behoort te zyn, doch dat volgens de uitspraak va a den een of anderen kantonrechter niet is, mag by wetswyziging of nieuwe wettelyke regeling ongeregeld blyven. Daardoor worden soms formuleeringen in voorontwerpen aangetroffen, die zoo zy bleven bestaan, de wet voor een deel niet alleen onleesbaar, maar als legislatief product ook belachelyk zouden maken... Eischt de formuleering van wetten en algemeen maatregelen van bestur een administratieve rypheid die by technici meestal ontbreekt, hetzelfde geldt voor het maken van memories van toelichting en van antwoord by wetsontwerpen ${ }^{\text {"45 }}$.

Hij meende evenzeer te moeten bestrijden, dat veel dubbel werk verricht werd bij de uitvoering van de arbeidswetgeving, omdat de arbeidsinspectie tot tak had de zaken in hoofdzaak technisch te bezien en de afdeling arbeid de juridische kan in ogenschouw nam.

"By klachten over de toepassing vam of beroepen ingevolge de Veiligheidswet en het Veiligheidsbesluit is verschillende malen gebleken, dat de districtshoofden door verwaarloozing van de formaliteiten, die de wet voorschryft of die hun door den Minister zyn aanbevolen, grove rechtsschennis tegen de aan die wet onderworpen ondernemers plegen. Ik zou het voor de rechtszekerheid een groote achteruitgang achten, indien de Minister over al die gevallen een beslissing moest nemen, zonder dat hy voorgelicht werd door van den DirecteurGeneraal onafhankelyke juridische adviseurs, omdat zoodoende het juridische element by die beslissingen geheel in de verdrukking zou komen...".

De bewering van de directeur-generaal over de uitbreiding van de afdeling Arbeid door de grotere omvang van de werkzaamheden werd door Westhoff naar het rijk der fabellen verwezen ${ }^{46}$. Het zal geen verbazing wekken, dat Westhoff niets zag in de plannen van Zaalberg om de beide departementsonderdelen samen te voegen. Daarvoor gaf hij vier argumenten. In de eerste plaats het vervallen van een van de directeur-generaal van de Arbeid onafhankelijke juridische staf, die de minister zowel bij de voorbereiding als bij de uitvoering bijstaat. In de tweede plaats het wegvallen van een natuurlijk evenwicht tegen de neiging van een dienst om zijn belangen zoveel mogelijk te doen gelden. In de derde plaats het feit, dat de bewindsman een hele afdelingschef verloor en er maar een halve voor terugkreeg. De directeur-generaal van de Arbeid was door de aard van zijn functie, slechts voor een deel van zijn tijd beschikbaar om als afdelingshoofd op te treden. In de vierde plaats - een argument, dat samenhangt met het vorige - het feit, dat de afdoening van stukken van de afdeling tot een behoorlijke vorm en accuratesse, waarmee dit diende te gebeuren ernstig geschaad zouden worden. Westhoff meende, dat ondanks zijn eerbied voor de prestaties en de dienstijver van de ambtenaren van de arbeidsinspectie, de wijze waarop de stukken afgedaan werden slordig en onvolledig gebeurde.

Dat met deze nota van Westhoff het laatste woord nog niet op papier was gezet, staat buiten twijfel ${ }^{47}$, en dat de verhouding tussen de beide departementsonderdelen niet optimaal was zal eveneens duidelijk zijn. Jammer is alleen, dat de diverse brief-nota-uitwisselingen niet volledig zijn. 
Niet alleen intern was de verhouding tussen de arbeidsinspectie en de afdeling Arbeid een punt van discussie. Bij de begrotings-behandeling van het ministerie van Arbeid voor het dienstjaar 1923 werd namelijk door een aantal Tweede Kamerleden het oordeel uitgesproken, dat voor de afdeling arbeid het aantal juridische ambtenaren te hoog was opgevoerd ${ }^{48}$. Voorts werd opgemerkt, dat sinds 1918 de bezetting van deze afdeling was verdubbeld. Hoswel men dit in een tijd van groeiende arbeidswetgeving begrijpelijk wond, werd toch de vrees uitgesproken, dat door deze ambtenaren veel werk werd gedaan dat ook al door de arbeidsinspectie was verricht en dus overbodig kon worden beschouwd. Een aantal andere Kamerleden vroeg of ter voorkoming van dubbel werk de afdeling Arbeid niet kon worden gecombineerd met de arbeidsinspectie. Hierdoor zou bereikt kunnen worden, dat de rapporten en adviezen van de inspecteurs rechtstreeks naar de minister zouden gaan in plaats van eerst door buiten de praktijk van de arbeildswetgeving staande ambtenaren te worden bewerkt. Dit zou een snellere afdoening van zaken tot gevolg hebben. Daarentegen meenden andere Kamerleden juist niet op een vermindering van het aantal juridische ambtenaren te moeten aandringen, omdat blijkens de ervaring, er eerder meer dan minder behoefte was aan juridische goed geschoolde ambtenaren, die in staat waren de te regelen materie in wetten en algemene matregelen van bestuur neer te leggen. Zij meenden, dat op dit punt eerder een versterking dan een verzwakking van de bezetting met juridische ambtenaren nodig was. Dergelijke werkzaamheden konden naar hun mening niet overgelaten worden aan ambtenaren van de arbeidsinspectie.

De minister sprak ${ }^{49}$ allereerst tegen, dat er sprake was van een verdubbeling van de afdeling Arbeid sinds 1918 ten aanzien van de formatieplaatsen ${ }^{50}$, om te vervolgen met de opmerking, dat hij kennis had genomen van de naar voren gebrachte denkbeelden. Het behoefte geen betoog, dat hij zich telkens rekenschap gaf van de vraag, hoe een goede inrichting van zijn departement, zo mogelijk, met minder kosten gepaard zou kunnen gaan. Tegen het denkbeeld om de beide departementsonderdelen samen te voegen en de afdeling Arbeid op te heffen, rezen bij hem vooralsnog overwegende bezwaren, terwijl anderzijds

"de tegenwoordige toestand niet die gebreken vertoont, welke sommige leden hebben gemeend te kunnen constateren".

De vrees dat de afdelling Arbeid veel dubbel werk verrichtte, noemde hij ongegrond. De arbeidsinspectie verschafte hem technische en de afdeling Arbeid juridische en administratieve voorlichting. De opmerking dat de laatstgenoemde soort werkzaamheden niet door de arbeidsinspectie moest worden verricht werd door hem onderschreven. Een wet of algemene maatregel van bestuur behoorde technische goed in elkaar te zitten, maar een behoorlijke juridische formulering van de te regelen materie was evenzeer noodzakelijk. De ervaring had geleerd, dat die formulering vaak zeer moeilijk was en daarom diende dit te gebeuren door ambtenaren met een administratieve en juridische scholing, die bij bij technici viteraard zelden aangetroffen wordt. Ook bij de uitvoering van de wet kan het juridische element niet ontbeerd worden. Aan de arbeidsinspectie zijn vele bevoegdheden toegekend, die verstrekkend invloed hebben op de nijverheid. Die bevoegdheden werden getemperd door het beroepsrecht dat belanghebbenden op de minister hebben en door het recht, dat de minister toegekend is om de arbeidsinspectie instructies te geven met betrekking tot de wijze van wetstoepassing. Maar om die taak te kunnen uitoefenen moest hij beschikken over juristen, die zijns inziens onafhankelijk van de arbeidsinspectie dienden te zijn. Bovendien was een dergelijke samenvoeging niet gewenst, omdat een niet onbelangrijk deel van de activiteiten van de afdeling Arbeid met de taak van de arbeidsinspectie weinig of niets uit had te $\operatorname{staan}^{51}$.

Tijdens de mondelinge beraadslaging kwam Van der Waerden ${ }^{52}$ op de zaak terug, waarbij hij de bewindsman wees op het feit, dat in het voorlopig verslag niet over gebreken in de bestaande situatie werd gerept, en dat er geen kritiek op de afdeling Arbeid werd geleverd, maar dat gevraagd was of het niet mogelijk was om een belangrijke bezuiniging en vereenvoudiging te krijgen. Het antwoord dat de minister had gegeven verbaasde hem en speciaal de door hem gemaakte onderscheiding en

"het atomistisch wit elkaar halen van technische en juridische en administratieve voorlichting".

Het enige dat de bewindsman duidelijk had gemaakt, was, dat hij vooralsnog bezwaar had tegen de opheffing van de afdeling Arbeid, hetgeen bij Van der Waerden de vraag ontlokte, of hij goed begrepen had, dat de 
minister het onderwerp in studie had en hij zijn eindoordeell nog niet geven had. Minister Aalberse antwoordde ${ }^{53}$, dat hij het jammer vond, dat het onderwerp in het voorlopig verslag was aangeroerd, waarna hij vervolgde met te zeggen, dat toen hij vier jaar eerder aan het hoofd van hel ministerie van Arbeid kwam, hij dit deed met de enigszins vooropgezette mening, dat het waarschijnlijk logisch zou zijn om tot een reorganisatie te besluiten. Hij kon zich ook niet voorstellen, dat het op den duur verstandig zou zijn om naast de directeur-generaal van de Arbeid met zijn staf van technisch personeel ook nog een zelfstandige departementale afdeling Arbeid te hebben, omdat bij hem de angst bestond, dat twee kapiteins op een schip onherroepelijk zou moeten leiden tot conflicten. Deze angst bleek echter ongegrond. Er was tussen de beide departementsonderdelen altijd een uitstekende samenwerking geweest. Hij had zich herhaaldelijk verheugd over het feit, dat de Kamer, hem verzekerde, dat de wetsvoorstellen die via deze samenwerking tot stand waren gebracht, technisch - ook juridusch-technisch -, altijd zo verbazend goed waren. Maar in het kader van de bezuinigingen moest worden nagegaan waar bezuinigd kon worden. Het lag voor de hand om te kijken of niet door een andere organisatie van hef departement iets uitgespaard kon worden zonder dat de kwaliteit van het werk ondergraven zou worden, aldus de bewindsman, waarbij gedacht kon worden aan de bedoelde samenvoeging. Maar voordat dat dit doorgevoerd kon worden, moesten allereerst goed de voor- en nadelen tegen elkaar afgewogen worden. Zijn tot dan toe gegeven antwoorden waren niet gebaseerd op onwil om de Kamer te informeren, maar vonden hun oorzaak in voorzichtigheid, daar de zaak nog niet in een zodanig stadium was, dat hij zijn standpunt al bepaald had. Hij besloot met de verzekering, dat hij de zaak objectief zou bekijken en dat hij daarbij het volgende zou overwegen: wat was de beste organisatie van het departement en was het mogelijk om zonder grote zakelijke verliezen hier tot een bezuiniging te komen? In deze benadering kon Van der Waerden zich vinden ${ }^{54}$.

Wat opvalt is, dat de bewindsman tijdens deze begrotingsbehandeling de verhouding tussen de beide departementsonderdelen rooskleuriger voorstelde, dan deze in werkelijkheid was. Maar de afloop van de nadere overweging is bekend: de afdeling Arbeid zou voorlopig haar zelfstandige status behouden.

Het zou nog tot 1950 duren eer de centrale dienst van de arbeidsinspectie over een eigen juridische afdeling zou beschikken ${ }^{55}$. Het zwaartepunt van de wetgeving op het terrein van de arbeidsbeschermende wetgeving werd verlegd naar de arbeidsinspectie waar tevens de technische kennis voor de materiële inhoud ervan voorhanden was. Het is de vraag of deze situatie de relatie met de inmiddels hernoemde afdeling Arbeidersbescherming ten goede is gekomen.

\section{Via de directie van de Arbeid naar directoraat-generaal van de Arbeid}

Deze toch wat wonderlijke situatie, een departementale afdeling Arbeid/Arbeidersbescherming en een arbeidsinspectie met een eigen, vooralsnog kleine juridische afdeling zou eerst in 1962 opgeheven worden. Daaryoor werd de meest woor de hand liggende oplossing gekozen, namelijk het samenvoegen van de beide departementsonderdelen en wel met ingang van 1 januari $1962^{56}$. Vanaf dat moment bestaat een directie van de Arbeid, die sinds 1964 het directoraat-generaal van de Arbeid ${ }^{57}$ wordt genoemd, met aan het hoofd de directeur-generaal van de Arbeid. Onder dit directoraat-generaal ressorteren als gevolg van deze reorganisatie naast de arbeidsinspectie en de inspectie van de havenarbeild tevens de dienst voor het stoomwezen.

\section{Veranderingen in de organisatie van de arbeidsinspectie}

De directie van de Arbeid bestond uit de volgende diensten en (hoofd)afdelingen: een algemene dienst, een medische dienst, een elektrotechnische dienst, een scheikundige dienst, een landbouwkundige afdeling ${ }^{\circ}$, een werktuigkundige dienst, een hoofdafdeling wetgevingsbeleid en een sociaal-pedagogische dienst ${ }^{50}$. In vergelijking met de in het vorige hoofdstuk behandelde periode is de afdeling Arbeidsorganisatie- en loontechniek verdwenen, hetgeen eveneens een gevolg is van een andere organisatie van het ministerie en een gewijzigde taakverdeling, waaraan verderop in dit hoofdstuk aandacht zal worden besteed. 
Uit het jaarverslag van de arbeidsinspectie over $1968^{\circ}$ blijkt het directoraat-generaal van de Arbeid in dat jaar uitgebreid te zijn met een kernfysische dienst met aan het hoofd een kernfysisch-adviseur ${ }^{\text {at }}$. Wel is het van belang om te vermelden, dat deze ambtelijke functie niet in artikel 1 van het Organisatiebesluit Arbeidsinspectie 1920 werd opgenomen, zodat de betrokkene als gevolg van de bewoordingen van artikel 77 van de Arbeidswet 1919, geen ambtenaar van de arbeidsinspectie, maar een toegevoegde ambtenaar was.

In dat zelfde jaar werd door het adviesbureau Bosboom en Hegener een rapport uitgebracht over een onderzoek naar de organisatie van het directoraat-generaal van de Arbeid ${ }^{12}$, waarin de vraag aanvankelijk centraal stond, op welke wijze dit departementsonderdeel moest zijn georganiseerd, opdat haar instelling op de zich voortdurend wijzigende maatschappelijke en industriële omstandigheden optimaal zou zijn. Hierbij sprongen twee aspecten naar voren, namelijk:

1. het feit, dat de arbeidsinspectie een sterk naar buiten gericht organisatie was in die zin, dat er een bereidheid bestaat om geformuleerde doelstellingen steeds opnieuw te bezien op hun volledigheid en nut en

2. de erkenning, dat de omstandigheden voortdurend wijzigden en om die reden een voortdurende bezinning op doelstellingen, en als gevolg daarvan, op de werkwijze vereisten.

De taak van de arbeidsinspectie was af te leiden uit het antwoord op de vraag, wat de taak was van de rijksoverheid met betrekking tot de mens in zijn werksituatie. Er waren drie gebieden waarop de arbeidsinspectie haar taken zou kunnen vinden, namelijk fysiek, milieu en arbeids- en rusttijden, menselijk organisatorische aspecten en menselijke verhoudingen; gebieden die van elkaar afhankelijk zijn. Daar de arbeidsinspectie haar aandacht richtte op zowel het psychisch als fysiek welbevinden van de arbeider in zijn werksituatie waren haar belangstelling en aandacht mede gericht op de beide laatstgenoemde aspecten. Een beeld van de veranderende omstandigheden blijkt onder meer uit het volgende voorbeeld. Met de Arbeidswet 1919 werd de arbeider gezien als een menselijk wezen, dat recht heeft op rust, een gezinsleven en vrije tijd voor ontspanning of ontwikkeling. In de veertiger jaren ontstond een grotere openheid van het bedrijfsleven voor verbeteringen op het terrein van de arbeidsomstandigheden, als gevolg waarvan de politionele of repressieve taak van de arbeidsinspectie kon verminderen ten dienste van de groei van de preventie. In de zestiger werd een wijziging in de aard en organisatie van de produktieprocessen, met alle consequenties van dien voor het type mens, dat in deze processen tewerk was gesteld duidelijk. Hieruit werd geconcludeerd, dat de arbeidsinspectie in het verleden een duidelijk technische taak had, die voornamelijk was gericht fysieke aangelegenheden, milieu en arbeids- en rusttijden. Maar als gevolg van de veranderende situatie namen andere elementen toe in belang, zoals werkstructurering, beoordelings-en beloningssystemen, de bijzondere jeugdzorg in de bedrijven, de medezeggenschap van de arbeider, de intermenselijke relaties, communicatie en dergelijke ${ }^{63}$. Deze beschouwing leverde de onderzoekers de mogelijkheid op tot een herformulering van de probleemstelling en wel:

"Op welke wijze worden door de Arbeidsinspectie de, reeds thans expliciete, nieuwe taken in haar organisatie geintegreerd, alsmede over welke middelen tot waarneming beschikt de Dienst teneinde op adequate wijze tot herformulering van zijn taken te kunnen komen?" ${ }^{\text {nat }}$. Bij de eisen die aan de topleiding dienden te worden gesteld, waren twee zeer wezenlijke elementen te onderkennen, namelijk het beleidsvormende deel van de functie enerijds en het daarmede samenhangende uitvoerende of beherende deel anderzijds. In de taak van de topleiding zouden de beide functies meer expliciet onderkend moeten worden. Bosboom en Hegener was opgevallen, dat de functie van plaatsvervangend directeur-generaal zich niet of nauwelijks manifesteerde ${ }^{\mathrm{es}}$. Zij bevolen aan de plaatsvervangende directeurgeneraal een taak toe te wijzen met betrekking het uitvoerende deel van de functie van de topleiding. Een dergelijke splitsing moest het huns inziens mogelijk maken om zowel de afstemming op de "buitenwereld" als het "beïnvloeden" van de districten blijvend mogelijk te maken. Het meer expliciet maken van de functie van de plaatsvervangend directeur-generaal moest deze splitsing zeer goed mogelijk maken, zeker, indien deze de managerstaak zou krijgen toegewezen zonder daarbij tegelijkertijd een afdeling te moeten leiden. Daar verwacht werd, dat de taak van de arbeidsinspectie zwaarder en veelzijder zou worden ${ }^{\oplus 6}$, werd zowel voor de beleidsbepaling als voor de leiding en uitvoe-ring, het kwantificeren ${ }^{67}$ van gegevens een noodzaak. 
Hieruit zou in vele gevallen een element te destilleren zijn waarop de taakstelling en daarmede de beheersing van de uitwoering rustte. Het organisatiebureau meende, dat de plaatsvervangend directeur-generaal hierin een zeer belangrijke rol zou kunnen spelen.

Een en ander leidde welhaast vanzelfsprekend naar de vraag welke disciplines bij voorkeur in de topleiding $^{68}$ vertegenwoordigd dienden te zijn. Bosboom en Hegener meenden, dat in deze groep, zowel een algemeen-juridische, een technische als een organisatorische dan wel sociaal-economische discipline vertegenwoordigd dienden te $\mathrm{zijn}^{60}$.

Ten aanzien van de organisatie van de districten van de arbeidsinspectie merkte het organisatiebureau op, dat het opvallend was, dat de structuur daarvan geheel werd overgelaten aan het inzicht van het districtshoofd. Het hanteren van de term opvallend hield zowel een positief als een negatief oordeel in. Positief was een dergelijke situatie gezien in het kader van het organisatorische denken van dat moment, waarbij een zo groot mogelijke vrijheid aan de samenstellende delen van een organisatie werd toevertrouwd en waarbij door de centrale leiding eerst werd opgetreden wanneer bepaalde, te voren gestelde grenzen werden overschreden. Negatief was een dergelijke situatie, wanneer men zich afvroeg of de bedoelde grenzen wel in voldoende mate tevoren werden gesteld en of overschrijding hiervan wel in voldoende mate bij de centrale leiding werd gesignaleerd. Bovendien rees de vraag of de groei in de belasting van de districten wel in voldoende mate weerspiegeld werd in de organsiatie dlaarvan. Evenals ten aanzien van bet directoraat-generaal van de arbeid was het organisatiebureau van mening, dat een splitsing in een zekere beleidsvormende en een zekere bedrijfswoerende taak zeer gewenst was. Aangezien verwacht werd dat de sociaal-economische elementen in de taak van het districtshoofd zouden toenemen, stelde men voor om in de structuur van de districtsorganisatie de technische en de sociaal-economische functie meer expliciet te maken. Dit zou kunnen gebeuren door onder het districtshoofd, naast de administratief-beherende functie, een technische functie (de huidige inspecteur ) en een sociaal-economische functie (een aan te stellen sociaal- of bedrijfseconoom ) te onderscheiden. Onder de inspecteur dienden bij voorkeur alle technische ambtenaren en technische controleurs ondergebracht te worden, terwijl onder de sociaal- of bedrijfseconoom dan de inspectrices en de algemene controleurs zouden ressorteren. Op de vraag waarom de functie van de sociaal- of bedrijfseconoom niet door de secretaris ${ }^{70}$ zou kunnen worden vervuld, zoals dat tot dan toe gebruikelijk was, werd geantwoord, dat deze bestaande situatie een zekere onderschatting van het sociaal-economische aspect, althans van de capaciteiten van de ambtenaren die zich met dit aspect bezighielden. De veranderende omstandigheden zouden leiden tot een steeds verder gaande specialisatie van de districtsambtenaren. Dit riep de vraag op hoe lang het districtshoofd dan wel de secretaris nog in staat zouden kunnen zijn leiding te geven aan deze zich steeds verder gaand specialiserende (groepen van) ambtenaren. Leiding en coördinatie van deze (groepen van) ambtenaren in de districten zou daarom bij voorkeur dienen te gebeuren door een leidinggevende groep, onder de uiteindelijke verantwoordelijkheid van het districtshoofd. Deze leidinggevende groep zou dienen te bestaan uit: het districtshoofd, de geneeskundige ${ }^{71}$, de inspecteur, de econoom en de secretaris ${ }^{72}$. Vervolgens werden ook nog enkele andere zaken behandeld zoals het functioneren van de dienst als geheel en de interne procedures.

Aan een aantal suggesties, die door het bedoelde organisatiebureau zijn gedaan, lijkt gevolg te zijn gegeven. Het jaarverslag van de arbeidsinspectie over $1969^{73}$ leert dat vanaf dat jaar, in ieder geval officieel, het instituut van de plaatsvervangend directeur-generaal van de Arbeid is ingevoerd ${ }^{74}$. Bovendien is in de districten de functie van een zogenaamde bedrijfsorganisatorische medewerker gekomen. Deze nieuwe soort ambtenaar bij de dienst van de arbeidsinspectie is echter geen ambtenaar van de arbeidsinspectie geworden, maar een toegevoegde ambtenaar. De nieuwe functie werd namelijk niet in het Organisatiebesluit arbeidsinspectie opgenomen. 


\section{De Arbeidswet 1919}

\subsection{Overwerk}

De industrie had in deze periode over het algemeen volop opdrachten, maar ondanks het feit dat het aanbod op de arbeidsmarkt gering was, bleef het overwerk aanvankelijk binnen redelijke grenzen. In de loop van 1962 werd in de industriële sector de invoering van de vijf-daagse werkweek vrijwel over de gehele linie gerealiseerd, maar ook daarbuiten; bijvoorbeeld in winkels en kantoren, won de arbeidstijdverkorting steeds meer veld. De hieruit voor de arbeidsinspectie voortvloeiende administratieve bemoeiingen verminderden ten opzichte van eerdere jaren in omvang, hoofdzakelijk door het uitvaardigen van een algemene ministeriële vergunning $^{75}$ tot afwijking van de wettelijke arbeids- en rusttijdenbepalingen, waardoor in vele gevallen individuele vergunmingen achterwege konden blijven. Wel werd overigens in het jaarverslag over 1963 al opgemerkt, dat de moeilijkheden als gevolg van het feit, dat de Arbeidswet 1919 nog niet aan de nieuwe situatie was aangepast nog steeds kenbaar waren. In 1964 zou het overwerkbeeld echter drastisch wijzigen; in dat jaar werden bij vergunningen in totaal 5.217.607 overwerkuren boven het wekelijkse maximum van 48 uren toegestaan, tegenover respectievelijk 3.903.203 en 3.255.828 overwerkuren in de jaren 1963 en 1962 . De sterke daling in 1962 ten opzichte van 1961 - 4.890 .567 overwerkuren - was in 1964 al weer ruimschoots teniet gedaan. De bedrijvigheid in de industrie nam vooral in de tweede helft van 1966 af waardoor het aantal aanvragen voor overwerkvergunningen eveneens afnam; het toegestane aantal overwerkuren bedroeg 4.249.130 te-

genover 4.513.263 in 1965. De zich mamifesterende recessie zette in thet dooropvolgende jaar door, maar in 1968 had de bedrijvigheid zich weer volledig hersteld. Het aantall toegestane overwerkuren boven thet wettelijk maximum van 48 uren zou echter niet meer stijgen en in 1970 uiteindelijk 2.587 .431 bedragen.

Het probleem van een dergelijke berekening van het aantal toegestane overwerkuren is echter dat als uitgangspunt genomen werd het aantal uren dat de Arbeidswet 1919 maximaal per week toestond, namelijk 48. Intussen was echter de feitelijke arbeidstijd per week stapsgewijs gedaald van 45 uren tot 42,5 uur in 1971 en uiteindelijk 40 uren in het midden van de jaren zeventig ${ }^{76}$. In 1971 werd dan ook overgegaan op een ander wijze van berekenen van het verleende aantal overwerkuren, waarbij echter wel de basis, namelijk de verleende overwerkwergunningen, gehandhaafd bleef. Sinds $1970 \mathrm{zou}$ het aantal overwerkuren voortdurend dalen, na de oliecrisis zou dit beeld zich nog versterkt doorzetten ${ }^{77}$.

Verreweg de meeste vergunningen die door de districtshoofden werden verleend betroffen de categorie van arbeid in fabrieken of werkplaatsen; werden er in 1961 nog 41.547 overwerkvergunningen verleend, door het uitvaardigen van de ministeriële vergunningen, hierboven is hier al melding van gemaakt; daalde dit tot 28.555 in 1962 en tot 17.184 in 1963. Een absoluut dieptepunt voor wat dit onderwerp levert het jaar 1970 op; in dat jaar werden slechts 13.523 owerwerkvergunningen verleend ${ }^{78}$.

\subsection{Bakkersarbeid}

In deze periode duurden de moeilijkheden met de personeelsvoorziening in de bakkerijsector, zowel wat het bakkerij- als het bezorgpersoneel betreft, onverminderd voort. Als gevolg daarvan liet de naleving van de wettelijke arbeids- en rusttijdbepalingen nog steeds te wensen over, dit ondanks het feit, dat bij de Wet vam 19 juli 1962 de toegestane aanvangstijd voor het vervoeren en het afleveren van vers brood werd vervroegd; én en ander gekoppeld aan ploegenarbeid $\mathrm{Bij}$ het behandelen van de vergunningaanvragen werd door de arbeidsinspectio steeds advies gevraagd aan het Georganiseerd Overleg van werkgevers- en werknemersorganisaties in het bakkersbedrijf dan wel aan de Adviescommissie voor Arbeidswoorwaarden in het Bakkersbedrijf. Het aflopen van de Wet wederverkoop brood ${ }^{79}$ op 1 januari 1968, waardoor een aantal beperkende bepalingen ten aanzien van de wederverkoop van brood werden opgeheven en had tot gevolg, dat het aantal verkoopplaatsen - winkels - aanzienlijk zou worden uitgebreid. Daar het produktieapparaat onvoldoende capaciteit bezat om in de beschikbare produktietijd de vereiste hoeveelheden te vervaardigen zouden de ge- 
bruikelijke distributiekanalen in moeilijkheden komen. Van de zijde van het Georganiseerd Overleg werd voorgesteld een aantal wettelijke belemmeringen die naar hun mening sociaal gezien gemist, althans verzacht zouden kunnen worden, af te schaffen dan wel te wijzigen ${ }^{20}$. Uiteindelijk zou er van 14 oktober tot 16 november 1968 een enquête worden gehouden teneinde inzicht te krijgen inzake de aanvangstijden van de broodproduktie, het vervoer en de aflevering van vers brood. De enquête richtte zich tot de in ploegendienst werkende bedrijven, op dat moment 142 in getal en tot 1001 broodbakkerijen waar niet in ploegendienst werd gewerkt, zodanig verdeeld over de districten van de arbeidsinspectie, dat in ieder district circa 100 bedrijven werden geënquêteerd ${ }^{\text {bit }}$. Nadere bijzonderheden zijn neergelegd in het verslag over de Enquête Bakkersarbeid $1968^{82}$. Deze enquête zou een belangrijke rol spelen bij het totstandbrengen van de wijziging van de Arbeidswet 1919, waarbij de bakkerijbepalingen die in de wet zelf voorkwamen kwamen te verval$\mathrm{len}^{33}$ en het opnemen van in een afzonderlijke paragraaf van het Werktijdenbesluit voor fabrieken of werkplaatsen 1936 werden $^{\text {a4 }}$; een wijziging die overigens tot stand kwam na een unaniem voorstel van het Georganiseerd Overleg van de werkgevers- en werknemersorganisaties in het Bakkersbedrijf ${ }^{\mathrm{fb}}$.

\subsection{Ploegenarbeid}

In het kader van de in het Werktijdenbesluit voor fabrieken of werkplaatsen $1936^{88}$ toegestane arbeid in ploegendienst werd in 1964 op bescheiden schaal geêxperimenteerd met de zogenaamde constante nachtploegen in plaats van wisseldiensten. Dit experiment werd gestart naar aanleiding van de bij sommige arbeiders levende verlangens tot het verrichten van deze zogenaamde permanente nachtarbeid. Daartoe werden door de arbeidsinspectie de vereiste vergunningen verleend voor 5 bedrijven, voor zover én en ander op basis van vrijwilligheid gebeurde en er medische en sociale begeleiding plaatsvond. In dat zelfde jaar staakten een aantal arbeiders deze permanente nachtarbeid, hetzij doordat zij medische klachten kregen, hetzij doordat, ondanks de aanvankelijke voorkeur, later toch sociale bezwaren naar voren traden, en keerden zij terug naar de "normale" ploegendienst. In het jaar daarop werd het experiment voortgezet in 14 bedrijven voor in totaal 54 arbeiders. In 3 bedrijven werd de permanente nachtarbeid gestaakt ${ }^{87}$. Circa de helft van de Nederlandse arbeiders die permanente nachtarbeid verrichtten, hielden daar later mee op om persoonlijke, huiselijke en/of maatschappelijke redenen. De deelnemende buitenlandse arbeiders zetten de werkwijze echter door, voornamelijk omdat zij op deze wijze een hoger weekinkomen verkregen en voor hen een gezinsleven ontbrak en het maatschappelijke contact gebrekkig was. In 1966 zou het aantal bedrijven dat bij het experiment betrokken was verminderen tot 10, te weten 8 textielbedrijven -63 arbeiders -, 1 metaalbedrijf - 57 arbeiders - en 1 landbouwcoöperatie - 14 arbeiders -. Uit de ervaringen die met het experiment in de beide eerdere jaren waren opgedaan, werd geconcludeerd, dat aan deze arbeid zowel bij de bedrijven als bij de arbeiders weinig behoefte bestond. Deze conclusie werd afgeleid uit het feit, dat slechts in én textielbedrijf met nagenoeg dezelfde arbeiders geruime tijd achtereen 's nachts werd gewerkt; terwijl in 3 andere van deze bedrijven zich slechts een gering aantal arbeiders in een dergelijke ploeg handhaafde. De bezetting van de permanente nachtploeg in de overige textielbedrijven was steeds wisselend. In hoofdzaak waren er twee motieven om in deze textielbedrijven permanente nachtploegen in te voeren. In de eerste plaats was het bij meerploegenarbeid in afdelingen, waar de arbeid voornamelijk door vrouwen werd verricht, noodzakelijk dat de derde ploeg een constante nachtploeg uit mannen bestaat ${ }^{\text {Bg }}$. In de tweede plaats werden in enkele bedrijven de bezwaren van sommige arbeiders tegen het verrichten van nachtarbeid in ploegendienst opgevangen door het verrichten van permanente nachtarbeid door anderen, die daaraan voorkeur gaven. Na enige tijd verdween deze voorkeur weer, waardoor in de praktijk veel wisselingen en wijzigingen voorkwamen. Ten aanzien van het metaalbedrijf is het nog van belang te vermelden, dat de arbeiders, die permanente nachtarbeid verrichtten vrijwel allen ex-mijnwerkers waren ${ }^{86}$. De motieven die aan deze werkwijze ten grondslag lagen, waren om deze ex-mijnwerkers (ondergrondse), die als gevolg van de aard van hun vroegere werk een hoog loon genoten en van wie velen al permanent 's nachts hadden gewerkt, de overgang naar een lager loonpeil niet te abrupt te doen plaatsvinden. $\mathrm{Na}$ een toename in 1969 viel vanaf 1970 in de bedrijven, waar dit systeem werd toegepast, een teruggang van het werken in permanente nachtarbeid waar te nemen ${ }^{\infty}$. Uitein- 
delijk werd van de zijde van de arbeidsinspectie geconstateerd, dat vanaf 1971 nog maar weinig verzoeken van Nederlandse arbeiders waren geweest om permanente nachtarbeid te mogen verrichten. Wel waren er circa 150 buitenlandse arbeiders in en dergelijk arbeidstijdenpatroon werkzaam ${ }^{91}$.

Vanaf 1957 waren er door de arbeidsinspectie om de drie jaar enquêtes gehouden naar de mate waarin door de industrie gebruik werd gemaakt van de mogelijkheid om in ploegenarbeid te werken. Uit de verkregen resultaten bleek, dat het verschijnsel ploegenarbeid sinds het genoemde jaar niet of nauwelijks was toegenomen. Aan de hand van de verkregen informatie bleek wel, dat er geleidelijk aan veranderingen te constateren waren in de verschijningsvorm van arbeid in ploegendienst. Zo was een verschuiving te constateren van semi-continu, dat wil zeggen een ploegenstelsel met een wekelijkse bedrijfsstilstand, naar volcontinu, waarbij er geen bedrijfsstildstand voorkomt. Bovendien gaf het beeld wijzigingen te zien in de frequentie van de ploegwisseling alsmede in de wisselmomenten. Zo werd arbeid in een twee-ploegenstelsel vroeger uitsluitend toegepast met een vroege en een late dienst ${ }^{22}$. Vanaf het begin van de zeventiger jaren werd meer en meer arbeid verricht in een twee-ploegenstelsel met een gewone dagdienst, waaraan een nachtdienst voorafging ${ }^{93}$ en vertoonden drie- en meer ploegenstelsels verschuivingen in de wisselmomenten ${ }^{94}$ om de bezwaren, die nu eenmaal aan het verrichten van ploegenarbeid kleven, te verlichten. Het werken in ploegen en de gevolgen daarvan, zouden in deze periode steeds meer een onderwerp van wetenschappelijke discussie vormen. Binnen de arbeidsinspectie zelf vond beraad plaats over de overheidstaak en het overheidsbeleid ten aanzien van dit werktijdpatroon ${ }^{95}$.

\subsection{Variabele werktijden}

In het begin van de jaren zeventig tekende zich een nieuwe behoefte ten aanzien van de arbeids- en rusttijden af, die de dagelijkse arbeidstijd opnieuw ter discussie bracht, namelijk de behoefte aan variabele werktij$\mathrm{den}^{\mathrm{os}}$. Een variabele werktijdregeling is een werktijdregeling, waarbij variatie mogelijk is in het aantal uren per dag en per week, alsmede variatie in de aanvangstijd, de duur van de pauze en het tijdstip van beëindiging van de werkzaamheden; volgens deze werktijdregeling is het mogelijk arbeidsuren te sparen en de aldus gespaarde uren op een gegeven moment om te zetten in vrije tijd. Aan deze werktijdregeling lag ten grondslag het verlangen naar meer inspraak bij het bepalen van de eigen werktijd. Was in de afgelopen periode de vijfdaagse werkweek gemeen goed geworden, de variabele werktijdregeling was in een aantal gevallen de basis om een vrije vrijdagmiddag in te voeren, derhalve dus de 4,5-daagse werkweek. Gezien het feit, dat in het kader van de vijfdaagse werkweek vergunningen waren verleend waarbij de arbeidsdag tot 9 uren werd verlengd, was het ondenkbaar, dat de 9-urige werkdag met meer vrijheid in het weekeinde nu in beginsel geweigerd zou kunnen worden. Desalniettemin werd vanuit de Stichting van de Arbeid terughoudend gereageerd op deze nieuwe ontwikkeling vanwege een aantal consequenties van onder andere medische, sociale en arbeidstechnische aard die nadere bestudering behoefden. Tegen experimenteren had men geen bezwaar, zolang dit niet zou leiden tot ongewenste ontwikkelingen die in een latere fase moeilijk teruggedraaid konden worden ${ }^{87}$. Nadere advisering van de Sociaal-Economische Raad ${ }^{89}$ bracht, dat de arbeidsinspectie op middellange termijn een restrictief beleid diende te voeren bij het toestaan wan variabele werktijden. De voorwaarden, die aan de door de districtshoofden van de arbeidsinspectie verleende vergunningen werden verbonden, waren daar dan ook een illustratie van ${ }^{\oplus 9}$. Maar met het verstrijken van de tijd bleek steeds meer, dat er een zekere spanning ontstond tussen de aan een vergunning voor een variabele werktijdregeling verbonden voorwaarden en de behoeften die in de praktijk bestonden. $\mathrm{Na}$ een nieuwe consultatie van de Stichting van de Arbeid ${ }^{100}$ zou een ministeriële vergunning variabele werktijden ${ }^{101}$ uitgevaardigd worden, waarbij de voorwaarden versoepeld werden ${ }^{102}$, en de variabele werktijdregeling zijn plaats in de arbeidstijdpatronen definitief veroverd had. 


\subsection{Het Jongerenstatuut}

Al in de vorige periode was er al op gewezen, dat tijdens de behandeling van de wet, waarbij het verbod om arbeid te verrichten voor meisjes werd verhoogd naar 14 jaar, was gewezen op de noodzaak jongens en meisjes een betere kans op ontwikkeling te geven, waarbij uitdrukkelijk de leerplichtverlenging tot 16 jaar en partieel onderwijs aan de orde was gesteld.

Op 1 november 1969 vond er te 's-Gravenhage een massamanifestatie plaats van werkende jongeren, die uiting gaven aan hun onvrede over het jongerenbeleid. De inzet was om te bereiken, dat zij een achterstand konden inhalen op hun beter toebedeelde leeftijdsgenoten, die het voorrecht hadden om tot of zelfs lang na hun achttiende jaar door te leren. Aangezien de Arbeidswet 1919 nog slechts een arbeidsverbod kende tot 15 jaar $^{103}$, had dit tot gevolg, dat velen bij het bereiken van die leeftijd direct aan het werk moesten. De werkende jongeren voelden zich in hun mogelijk-heid tot verdere vorming achtergesteld. De op die bewuste novemberdag door de allerijl toegesnelde bewindslieden van Onderwijs en Sociale Zaken gedane toezeggingen resulteerden al in september 1970 in een Nota inzake onderwijs en arbeidsmaatregelen voor werkende jongeren ${ }^{104}$. Hierin werd voorgesteld om in een streefperiode van ongeveer 10 jaar de status van werkende jongeren beneden de 18 jaar geleidelijk te veranderen van die van arbeider in die van leerling. Er zou begonnen worden met een partitieel en daarna volledig arbeidsverbod met een leerplicht voor 15-jarigen en dat zou in fasen worden uitgebreid naar de 16- en 17-jarigen. Tijdens de partiële leerplicht zouden de jongeren zowel onderwijs als algemene vorming krijgen. Dit zogenaamde participatieonderwijs zou de twee volgende componenten omvatten:

a. een schoolcomponent te volgen aan instituten voor vorming en opleiding en

b. een maatschappijcomponent te volgen in bedrijven en andere instellingen.

Om dit te bereiken zouden zowel de Arbeidswet 1919 als de Leerplichtwet $1969^{105}$ worden gewijzigd. Iedere opschuiving van het arbeidsverbod zou als spiegelbeeld een daarmee corresponderende uitbreiding van de leerplicht met zich brengen ${ }^{100}$.

Aan de realisering van hetgeen de regering zich in de Nota werkende jongeren had voorgesteld werd voortvarend gewerkt. Al op 6 mei 1971 werd zowel de Arbeidswet 1919 als de Leerplichtwet 1969 gewijzigd $^{107}$. Door de wijziging van de laatstgenoemde wet werd de leerplicht verhoogd tot 9 jaar, om vervolgens in 1975 verhoogd te worden tot $10 \mathrm{jaar}^{108}$. In hetzelfde jaar zou ook de Arbeidswet 1919 worden gewijzigd ${ }^{100}$.

De partiele leerplicht ving aan aan het einde van het leerjaar na afloop waarvan de minderjarige ten minste 10 leerjaren ${ }^{100}$ an een of meer scholen had doorlopen, of aan het einde van het leerjaar waarin de minderjarige de leeftijd van 16 jaar had bereikt ${ }^{111}$. Deze verplichting eindigt op de laatste dag van het tweede jaar. Als een minderjarige als leerling van een onderwijsinstituut is ingeschreven, is hij verplicht een bij algemene matregel van bestuur te bepalen aantal dagen per week onderwijs te volgen. Het aantal dagen door het eerste en tweede (partiële) leerjaar kan bij deze algemene maatregel van bestuur verschillend worden vastgesteld. De bedoeld algemene maatregel zou eerst in 1975 uitgevaardigd worden; daarin werd het aantal dagen voon het eerste leerjaar vastgesteld op $2^{112}$. Het aantal dagen voor het tweede leerjaar zou nooit worden vastgesteld.

Van de hooggestemde verwachtingen van 1970 is maar weinig terecht gekomen. Het is nooit verder gekomen dan een zeer gedeeltelijke invoering van de (partiële) leerplicht tot 18 jaar. En van wat wel tot stand kwam, wordt van de zijde van de algemene rekenkamer in haar rapportage over 1981 ook al weinig lovend gesproken: de partiele leerplicht fungeert slecht, er is een geringe maatschappelijke acceptatie en het ontduikingspercentage is hoog. Het vormingswerk komt er in de ogen van dit controleorgaan zo mogelijk nog slechter af: het is mislukt, niet voldoende ingesteld op de behoeften en de mogelijkheden van de deelnemer en de kosten per deelnemer zijn veel te hoog geworden. In het kader van de heroverwegingsoperatie werd in 1984 de rapportage van de algemene rekenkamer wel genuanceerd, zonder aan de algemene conclusie weinig te veranderen ${ }^{\text {1/3 }}$.

De reden voor deze weinig positieve gevolgtrekkingen is gelegen in de veranderende maatschappelijke om- 
standigheden, aldus Frenkel ${ }^{144}$. De beweging van jongeren aan het einde van de zestiger jaren was een gevolg van de sfeer van die jaren. Er was een aversie tegen het bedrijfsleven; de jongeren wilden vorming, onderwijs en maatschappijbewustwording en vooral geen beroepsgerichte of bedrijfsgerichte scholing, zo vervolgt Frenkel. De economische crisis heeft echter ontnuchterend gewerkt, ook voor de jongeren, en de opleiding, scholing, om- en bijscholing vormen het telkens terugkerend onderwerp van regeringsstandpunten, rapporten en enquêtes. Er is een tekort aan specialisten en goed opgeleide vaklieden. Het opleiden van jongeren opdat zij kunnen uitgroeien tot vaklieden en specialisten vergt tijd, veel tijd en het is tijd die men hen moet gunnen; vakbekwaamheid komt niet aanwaaien. Dit betekent, dat de door de werkgevers zo felbegeerde goedkope arbeidskrachten wel eens zouden kunnen verdwijnen.

\section{De Veiligheidswet 1934}

De Veiligheidswet 1934 lijkt in de vorige periode met het opnemen van bepalingen ten aanzien van de bedrijfsgezondheidszorg haar belangrijkste wijziging te hebben gehad. Dat wil niet zeggen, dat op het gebied van de wetgeving niets meer gebeurde. Zo werd het Veiligheidsbesluit binnenvaart ${ }^{115}$ uitgevaardigd, waarin regelen worden gesteld met betrekking tot de arbeid aan boord van binnenvaartuigen inclusief het laden en lossen, alsmede ten aanzien van het daarmede verband houdende verplaatsen, vervoeren en opslaan van goederen op laad- en losterreinen en in zich aldaar bevindende opslagplaatsen of voertuigen. Al bestaande veiligheidsbesluiten werden aangepast en gewijzigd aan de bestaande behoeften.

Ten aanzien van het toezicht op de naleving van de veiligheid en de hygiëne in de industrie en in de landen tuinbouw moesten wederom een aanzienlijk aantal eisen en aanwijzingen van de zijde van de arbeidsinspectie worden gegeven. In 1962 waren dit er voor wat betreft het Veiligheidsbesluit voor fabrieken en werkplaatsen 1938 en het Landbouwveiligheidsbesluit respectievelijk 6575 en 1488; in deze periode tevens het absolute topjaar op dit punt. In 1968 bijvoorbeeld bedroeg dit aantal respectievelijk 3324 en 180 , terwijl in 1974 dit aantal respectievelijk 2326 en 229 bedroeg $^{116}$. De invoering van het hierbovengenoemde Veiligheidsbesluitbinnenvaart op 1 juli 1963 bracht voor de arbeidsinspectie nogal wat werkzaamheden met zich, gezien het aantal eisen en aanwijzingen.

In 1964 bedroeg dit aantal 4002, om vervolgens snel te vermeerderen in de beide daaropvolgende jaren tot respectievelijk 6615 en 6759, waarna weer een daling intrad van 5121 in 1967 naar 309 in 1973, 699 in 1974 en 386 in $1975^{117}$.

Regelmatig en veelvuldig werd van de zijde van de arbeidsinspectie contact onderhouden met de verschillende veiligheidsdiensten en veiligheidsinspecteurs vam daarvoor in aanmerking komende bedrijven. Een nauwe

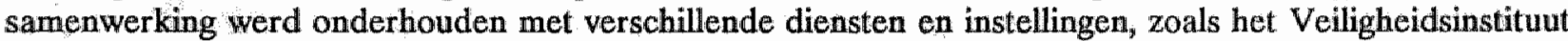
te Amsterdam, dat opnieuw belangrijke hulp verleende bij het verrichten van onderzoekingen en beproevirigen, voorts de organisatie T.N.O. en de afdelingen metaalkunde en hefwerktuigen en transporttechniek van de Technische Hogeschool Delft; beide laatstgenoemde in het bijzonder voor het vaststellen van de porzaak van ongevallen en het beoordelen van gereedschappen en werktuigen.

Vele toestellen, apparaten, onderdelen, beveiligingen en persoonlijke beschuttingsmiddelen werden v6 $60 \mathrm{r}$ zij in de handel werden gebracht de arbeidsinspectie ter beoordeling aangeboden. Deze beoordelingen brachten doorgaans veel werk met zich, vooral in de gevallen dat uitvoerige berekeningen en proefnemingen nodig waren voordat een gefundeerd oordeel kon worden gegeven. In het algemeen verleende de fabrikanten en importeurs veel medewerking bij het aanbrengen van verbeteringen wanneer van de zijde van de arbeidsinspectie uit veiligheidsoogpunt aanmerkingen werden gemaakt ${ }^{118}$.

De bestrijding van ongevallen op bouwwerken vereiste van de arbeidsinspectie bijzondere zorg, omdat het aantal ongevallen, dat jaarlijks in deze sector voorkwam, aanzienlijk was. De praktijk wees naar een aantal factoren, die hiervan mogelijk de oorzaak waren, zoals het systeem van aangenomen of tariefwerk; het uitvoe- 
ren van werken met behulp van onderaannemers, zonder dat voor de aanvang een duidelijk contract was opgemaakt waarin ieders aandeel in de uitvoering van het werk nauwkeurig was omschreven met name ten aanzien van het gebruik, de toepassing en het plaatsen van hulpmateriaal; de onverschilligheid en in vele gevallen onvoldoende geschooldheid van het personeel; de steeds meer toegepaste hoogbouw; die ongetwijfeld meer risico met zich bracht bij de uitvoering; de zogenaamde bedrijfsblindheid; die het ontstaan van ongevallen in de hand werkte en het verkeerde gebruik en misbruik van bouwliften. In samenwerking met de Stichting Vakopleiding Bouwbedrijf en met werkgevers- en arbeidersorganisaties werden activiteiten ontplooid waarbij veel aandacht werd besteed aan het controleren van steigers, hijsinrichtingen en dergelijke alsmede het gebruik van veiligheidshelmen tijdens de arbeid. Dit laatste leverde niet altijd het gewenste effect op; geconstateerd werd, dat er bij de arbeiders in het bouwbedrijf veel schroom bestond omtrent het dragen van veiligheidshelmen. Met betrekking tot de sociale en hygiënische voorzieningen (kleedkamers, schaftlokalen, privaten en dergelijke) op de bouwplaats werd van werkgeverszijde in het algemeen de bereidheid getoond on aan de wettelijke bepalingen te voldoen ${ }^{119}$.

"Het is echter vaak ergerlijk te constateren hoe getroffen maatregelen en woorzieningen van werknemerszijde worden genegeerd of soms gesaboteerd. Beschamend is hoe in sommige gevallen installaties en beschikbaar gestelde ruimte worden verwaarloosd, c.q. vernield".

Eén van de problemen was het gevaar van het vallen van grote hoogten. Geprobeerd werd op plaatsen, waar niet op een andere wijze een beveiliging tegen het van een hoogte vallen kon worden verkregen veiligheidsnetten te doen toepassen en dan met name bij de bouw van hoge schoorstenen en bruggen. De algemene indruk die bij de inspecties op de bouwwerken werd verkregen was, dat hoewel er zich verbeteringen voordeden, de toestand nog veel te wensen overliet. Nu werd niet ontkend, dat de aard van het bedrijf door de ongunstige omstandigheden, zoals het werken op grote hoogte en het tijdelijk karakter van het werk, een verhoogd risico met zich bracht; een reden temeer dat verwacht kon worden, dat aan de veiligheid extra zorg zou worden besteed en dat men niet zou door-gaan met het accepteren van gevaren. Maar uit de praktijk van het ongevalsonderzoek evenwel viel af te leiden, dat van een extra zorg als bedoeld in vele gevallen maar weinig te bespeuren was. De overheid kon met haar beperkt aantal ambtenaren slechts steekproeven uitoefenen. Ook al zou het aantal inspecterende ambtenaren aanmerkelijk worden witgebreid, dan nog was het onmogelijk een volledig toezicht op alle bouwwerken uit te oefenen. Het dagelijkse toezicht werd geacht te behoren tot de taak en de verantwoordelijkheid van de hoofden of bestuurders van de bouwbedrijven of van het toezichthoudende personeel. Wilde men tot een drastische verlaging van het aantal ongevallen komen, dan werd het beslist noodzakelijk geacht, dat de totale bouwnijverheid ten aanzien van de veiligheid een veel grotere zelfwerkzaamheid ging ontwikkelen dan tot dan toe het geval was ${ }^{120}$.

In 1963 ontsnapten op een nacht in een loods van een kunstmestfabriek, als gevolg van ontleding in een partij mengmest, grote hoeveelheden voor de gezondheid schadelijke nitreuze dampen, die zich over de omringende landerijen verspreidden. Tegen het middaguur was het gevaar geweken. Bij een andere windrichting zou zeker ernstig gevaar voor de gezondheid van grotere bevolkingsgroepen hebben bestaan. De bedrijfsbrandweer was niet voorbereid op een dergelijke gebeurtenis en had assistentie gevraagd en gekregen van brandweerploegen uit omliggende gemeenten. Een ambtenaar van de arbeidsinspectie, die snel op de plaats van het onheil aanwezig was, zag toe, dat in de gevaarlijke zone, naast het gebruik van de juiste beschermingsapparatuur voor de ademhaling, ook de veiligheid en persoonlijke hygiëne in acht werd genomen en hij gaf ook adviezen over de juiste wijze van blussen.

Eén en ander was voor de ministers van Sociale Zaken en Volksgezondheid en Binnenlandse Zaken reden om een stuurgroep rampenbestrijding in het leven te roepen. Deze stuurgroep stelde een commissie in voor het bestuderen van de veiligheidsmaatregelen, die getroffen zouden moeten worden bij de opslag en de verwerking van zeer gevaarlijke stoffen: de commissie gevaarlijke stoffen.

Uit deze commissie zouden weer diverse werkgroepen worden samengesteld, ter bestudering van verscheidene gevaarlijke stoffen, zoals de werkgroep nitraathoudende meststoffen, de werkgroep om de bij de opslag en het gebruik van chloor te nemen veiligheidsmaatregelen te bestuderen ${ }^{121}$. 


\section{De Bestrijdingsmiddelenwet 1962}

Het streven om tot een zo hoog mogelijke opbrengst per hectare cultuurgrond te komen leidde tot het gebruik van chemische bestrijdingmiddelen tegen ziekten en plagen in planten en plantaardige voortbrengselen van land-, tuin-en bosbouw. Vooral na de Tweede Wereldoorlog was er een grote toename van deze middelen, niet alleen wat betreft de kwantiteit, maar ook voor wat betreft het aantal type middelen waarbij vele met een sterk giftig karakter. Ten aanzien van de handel en het gebruik deden zich problemen voor, die met de bestaande wetgeving niet op te lossen waren. De Wet bestrijdingsmiddelen en meststoffen $1947^{122}$ met het daarop gebaseerde Bestrijdingsmiddelenbesluit $1948^{123}$ beoogden bedrog in de handel te voorkomen, maar de beperkte doelstelling van deze wet maakte het echter niet mogelijk op afdoende wijze de gevaren te beteugelen, welke met de giftigheid van de overigens deugdelijke middelen samenhingen. Deze gevaren beperkten zich niet alleen tot degene, die de middelen toepaste, maar ook een leder andere, die bij de handel of als consument van bespoten gewassen in aanraking kwam met giftige bestanddelen. Voorts kon de toepassing nadelige gevolgen hebben voor vee en dieren in het wild, voor gewassen op naburige percelen en voor de vruchtbaarheid van het bouwland. Het op de Veiligheidswet 1934 gebaseerde Landbouwveiligheidsbesluit bevatte een drietal bepalingen aangaande de etikettering, de opslag en het omgaan met giftige stoffen in landbouwondernemingen ter bescherming van de arbeider. Het landbouwbedrijf waar geen personeel werkzaam was, viel buiten de werkingssfeer van dit besluit. Ook de Warenwet en haar uitvoeringsbesluiten schoten tekort wanneer zich als gevolg van de handel in en de toepassing van bestrijdingsmiddelen gevaren voor de volksgezondheid voordeden. Ook de Plantenziektenwet ${ }^{124}$ schoot in dit opzicht tekort. Deze onvolkomenheden leidden ertoe, dat van overheidszijde een tweetal commissies werd ingesteld, namelijk de bestrijdingsmiddelencommissie teneinde de belanghebbende groepen de gelegenheid te geven met elkaar in overleg te treden en de commissie voor fytofarmacie, dat als ambtelijk orgaan zich bezig diende te houden met de technisch wetenschappelijke aspecten, die aan de toepassing van bestrijdingsmiddelen verbonden waren. Bovendien kreeg deze laatstgenoemde commissie de opdracht wettelijke maatregelen voor te bereiden met betrekking tot de handel in en het gebruik van middelen tot het bestrijden van ziekten en plagen in land-, tuin- en bosbouw en van daarmede gelijk te stellen middelen. Daarbij diende gelet te worden op zowel de deugdelijkheid van deze middelen tot het doel, waarvoor zij bestemd waren, als op de veiligheid en gezondheid van mens en dier. De activiteiten van deze commissie zouden uitmonden in de Bestrijdingsmiddelenwet $1962^{125}$. De kern van deze wet is het verbod om een bestrijdingsmiddel in de handel te brengen en toe te passen, indien dit middel niet tevoren door een bevoegde instantie op zijn deugdelijkheid is beproefd en indien geen waarborgen bestaan, dat redelijkerwijze bij zijn toepassing geen ontoelaatbare gevolgen zouden ontstaan. Bovendien moest het middel om te kunnen worden toegelaten aan een aantal andere algemene eisen, bijvoorbeeld wat betreft gehalte en samenstelling, voldoen ${ }^{126}$. De wet opende onder meer de mogelijkheid om bij of krachtems algemene maatregel van bestuur (nadere) voorschriften uit te vaardigen aangaande het verkopen, het in voorraad hebben, het vervoeren na aflevering aan de kleinhandel, anders dan in een vervoersonderneming, en door de gebruiker, en het gebruiken van bestrijdingsmiddelen, alsmede omtrent het bewaren, verwijderen en vernietigen van (lege) verpakkingen en restanten van bestrijdingsmiddelen $^{127}$. Bij nota van wijzigingen ${ }^{128}$. werd aan de districtshoofden van de arbeidsinspectie de bevoegdheid gegeven voor elk geval afzonderlijk nadere voorschriften te geven. Deze bevoegdheid werd gecreeërd, omdat de districtshoofden een dergelijke bevoegdheid reeds hadden in het kader van de Veiligheidswet 1934, maar deze zou komen te vervallen voor bestrijdingsmiddelen, wanneer deze niet meer onder de werking van die wet zouden vallen na de totstandkoming van de Bestrijdingsmiddelenwet ${ }^{\text {izo }}$. Naast deze bevoegdheid voor de districtshoofden, zouden de ambtenaren van de arbeidsinspectie belast worden met de opsporing van overtredingen en dan met name ten aanzien van de specifieke veiligheidsvoorschriften. Naast de arbeidsinspectie zouden ook andere bijzondere opsporingdiensten ingeschakeld worden, zoals bijvoorbeeld de algemene inspectiedienst. De betrokken bewindslieden van Landbouw en Visserij en van Sociale Zaken en Volksgezondheid realiseerden zich, dat de inschakeling van meer dan een opsporingsdienst bij de controle op de naleving van eenzelfde wet het gevaar in zich hield, dat aan de 
ondernemers, voor wie de wet zou gelden, onnodig overlast zou worden aangedaan door een te veel aan controlebezoeken, terwijl nog afgezien hiervan doublures zouden kunnen ontstaan, hetgeen uit een oogpunt van efficiency onaanvaardbaar was. Om én en ander te voorkomen, was een goede coördinatie en taakverdeling aan de hand van instructies en onderling contact onontbeerlijk. Een taakverdeling die zich overigens aan de hand van de wet al aftekende. Zo zou de arbeidsinspectie zich bezig moeten houden met de opsporing van overtredingen van specifieke veiligheidsvoorschriften aangaande de opslag en de toepassing van bestrijdingsmiddelen ${ }^{130}$.

Ten aanzien van de toezichthoudende taak zou de arbeidsinspectie in 1966 in totaal 3462 schriftelijke nadere voorschriften, aanwijzigingen en herinneringen verstrekken ${ }^{131}$, terwijl in dat jaar in het kader van de opsporing 13 processen-verbaal werden opgemaakt. Vanaf 1 mei 1967 vielen bewaarplaatsen voor bestrijdingsmiddelen onder de bepalingen van de Hinderwet. In de praktijk kwam het erop neer, dat de arbeidsinspectie adviezen moest geven inzake de van gemeentewege te stellen voorwaarden aan de vestiging van grote bestrijdingsmiddelendepôts, in het bijzonder van die inrichtinge a die in geval van brand een bron van gevaar voor de omgeving zouden kunnen vormen. Ondanks dit alles daalde evenwel het aantal door de arbeidsinspectie. gegeven voorschriften, aanwijzingen en herinneringen tot 2883 , terwijl het aantal processen-verbaal zou toenemen tot 18. Het jaar daarop zou hetzelfde beeld geven; 1103 nadere voorschriften, aanwijzingen en herinneringen en 63 processen-verbaal. In 1969 waren deze aantallen respectievelijk 2180 en 41 . Vanaf $1970 \mathrm{zou}$ het aantal voorschriften en aanwijzingen ten hoogste 473 bedragen en zou het aantal processen-verbaal in 1974 een dieptepunt kennen, namelijk $4^{132}$.

\section{De Kernenerglewet}

De betekenis van kernenergie voor de Nederlandse volkshuisvesting was uitgebreid in de Tweede Kamer ter sprake gekomen bij de schriftelijke behandeling van de nota inzake kernenergie ${ }^{133}$. In deze nota werd de taak van de overheid in deze niet alleen omschreven als het stimuleren ervan, maar het tevens binden aan aan regels bij de toepassing van kernenergie. Het van regeringszijde ingediende wetswoorstel, dat uiteindelijk zou uitmonden in de Kernenergiewet ${ }^{134}$, gaf uitvoering aan deze overheidstaakstelling door een gecoördineerd stimuleren van deze activiteit mogelijk te maken en bevatte beperkende regels die door de gevaren van radioactiviteit, verbonden aan de toepassing van kernenergie, ter bescherming van de samenleving noodzakelijk waren. In de wet werden verder restricties opgenomen ten aanzien van het gebruik van radioactieve stoffen en ioniserende straling uitzendende toestellen. Weliswaar kon in veel gevallen niet gesproken worden van toepassingen van kernenergie, maar de gevaren aan het gebruik van deze stoffen en toestellen verbonden, waren van dezelfde aard als die welke voortvloeiden uit het gebruik van kernenergie. Overigens waren de geschetste gevaren al eerder reden om van overheidszijde regelen te stellen. Daarbij kan gewezen worden op het Veiligheidsbesluit ioniserende stralen, een wijziging van het Hinderbesluit waardoor bij de verlening van een Hinderwetvergunning voor een inrichting, waarin ioniserende stralen vrijkomen of waarin radioactieve stoffen aanwezig zijn, voorwaarden kunnen worden opgelegd ter voorkoming van gevaar, schade of hinder voor de omgeving en het in 1958 totstandkomen van een Radioactieve-stoffenbesiuit in het kader van de Warenwet. Teneinde met name competentieproblemen terzake van het stellen van regels, alsook de eventuele strijdigheid van régels te vermijden, werd in de Kernenergiewet de mogelijkheid geopend de bij of krachtens andere wetten gestelde regels bij algemene maatregel van bestuur buiten werking te stellen ${ }^{135}$. De wet gaat uit van een vergunningenstelsel, waarbij de vergunninghouder individueel geldende voorschriften opgelegd zouden kunnen worden. Deze voorschriften dienden in belangrijke mate de bescherming van de volksgezondheid en van de arbeiders, waarbij bijvoorbeeld gedacht werd aan de wijze van bewaring van splijtstoffen en de wijze van lozen van afvalwater, alsook op de bewaking tegen spionage en sabotage ${ }^{136}$. De aan de vergunning verbonden voorschriften konden ook de verplichting inhouden, dat aan door overheidsorganen, die bij het voorschrift werden aangewezen, gestelde eisen voldaan moest worden ${ }^{137}$. Daarbij werd onder meer gedacht aan de arbeidsinspectie waar die concretere voorschriften, in de wettekst als eisen aangeduid, zou 


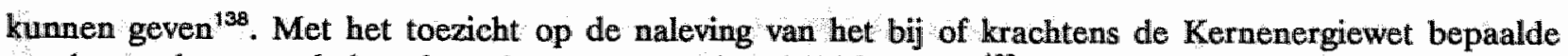
werden onder meer belast de ambtenaren van de arbeidsinspectie ${ }^{199}$, die tevens mede belast werden met de opsporing van overtredingen ${ }^{140}$.

De Kernenergiewet zou eerst in zijn geheel in werking treden op 1 januari 1970 . In de periode van totstandkoming van deze wet en tot haar volledige inwerkingtreding speelde de problematiek zich af rond kernenergie en dan met name het verlenen van vergunmingen voor kernreactoren in het kader van de Hinderwet. Bij de oprichting van kernreactoren diende rekening gehouden te worden met het feit, dat gevaar, schade of hinder wellicht niet beperkt zou blijven tot de gemeente van oprichting alleen en voorts dat het beoordelen van reactor-projecten en het opstellen van de op te leggen voorwaarden een zeer uiteenlopende en gespecialiseerde kennis vereisten, waarover de meeste gemeenten niet beschikten en waardoor zich in de praktijk voor dergelijke vergunningen een bijzondere procedure ontwikkelde. Deze procedure, die vorm kreeg bij de behandeling van de eerste reactor-projecten van het Reactor Centrum Nederland te Petten, verliep in de praktijk vlot en gaf alle betrokken overheidsinstanties een zodanige waarborg, dat met hun verantwoordelijkheden rekening werd gehouden. Deze gang van zaken werd ook bij latere vestiging van reactoren en grote radiologische inrichtingen gevolgd. De procedure kwam er in het kort op neer, dat naast de indiening van de aanvraag om een Hinderwet-vergunning bij het gemeentebestuur van de plaats van vestiging, tegelijkertijd een beschrijving van het reactorproject en een volledig veiligheidsrapport aan de minister van Sociale Zaken en Volksgezondheid werd voorgelegd. Deze stukken werden behandeld in de Gezondheidsraad, dat een samenvattend advies aan de bedoelde bewindsman uitbracht, nadat de directeur-generaal van de Arbeid geadviseerd had over de technische veiligheidsaspecten en de bedrijfsgeneeskundige problematiek en nadat de commissie vestigingsplaatsen beoordeeld had of het ten opzichte van de omgeving verantwoord was de reactor op de voorgenomen plaats op te richten. De ingestelde interdepartementale commissie kernenergie gaf tenslotte een eindoordeel.

Het advies van de directeur-generaal van de Arbeid werd voorbereid in ad hoc-commissies, waarvan het betrokken districtshoofd als voorzitter optrad en waarin onder meer zitting hadden de elektrotechnisch adviseur, de scheikundig adviseur, de medisch-fysicus en én van de medici van de arbeidsinspectie. Daarnaast werden ten behoeve van deze commissies deskundigen van buiten aangetrokken ${ }^{141}$.

In veel gevallen waren de volksgezondheidsaspecten, die in het geding waren met betrekking tot de lozing van radioactieve stoffen in de lucht of in openbaar water, niet beperkt tot de bevolking in de omgeving van de reactor, maar ook voor personen die werkzaam waren op de eigen terreinen van het reactorcomplex. Bij de vaststelling van de normen voor lozing werden de inspecteurs voor de hygiëne van het milieu en de districtshoofden van de arbeidsinspectie betrokken ${ }^{142}$.

Het gebruik van radioactieve preparaten, deeltjesversnellers en dergelijke zou zich zeer snel uitbreiden. Aan een verantwoorde ontplooiing van deze toepassingen van kernenergie verleende de arbeidsinspectie haar medewerking onder andere door beoordeling van de ingediende Hinderwetvergunningaanvragen, door het geven van adviezen over de inrichting van laboratoria, alsmede over het veilig toepassen en opstellen van radioactieve bronnen in fabrieken en wetenschappelijke instellingen. Als voorbeeld van nieuwe toepassing van nucleaire techniek buiten kernenergie inrichtingen en buiten de industrie werd gegeven de toepassing van radioactieve rookmelders voor branddetectie alsmede voor ventilatiebewaking in grote tunnels. Als voorbeeld van de wijze waarop nucleaire technieken zich in conventionele industrie een plaats wisten te verwerven werd verwezen naar de Koninklijke Nederlandse Hoogovens en Staalfabriek, waarbij de dikte van blik en de hierop gelegde tinlaag werd gemeten door een isotoop. De arbeidsinspectie stelde aan deze meetinrichtingen, gezien de omstandigheden ter plaatse, bepaalde eisen ten einde te voorkomen, dat ontoelaatbare verspreiding van radioactieve stoffen zou kunnen plaatsvinden. Toen deze meetinrichting een succes bleek te zijn, volgde een soortgelijke toepassing ten aanzien van de platenwalserij ${ }^{143}$.

In maart 1969 werd de eerste Nederlandse kernenergiecentrale te Dodeweerd officieel in gebruik gesteld, 
terwijl met de oprichting van de tweede te Borssele een begin werd gemaakt ${ }^{144}$. In datzelfde jaar werd ook overeenstemming bereikt over de bouw wan een fabriek voor de verrijking van uranium volgens de ultracentrifugemethode te Almelo. Tevens ontstond in het noorden van ons land een samenwerking tussen een aantal ziekenhuizen op het terrein van de nucleaire geneeskunde waardoor de aanschaf van zeer kostbare apparatuur mogelijk werd. Teneinde bet toezicht op de toenemende toepassing van kernenergie, voor wat betreft de de nucleaire veiligheid beter in de hand te kunnen houden ${ }^{145}$, werd een commissie reactorveiligheid in het leven geroepen. In deze commissie, waarvan het voorzitterschap was opgedragen aan de kernfysisch adviseut bij de arbeidsinspectie, waren verschillende deskundigen uit het bedrijfsleven en de overheid bijeengebracht ${ }^{16}$. Deze commissie reactorveiligheid kreeg in 1974 van de toenmalige minister van Socialle Zaken opdracht tot het maken van een studie over de veiligheidsaspecten van de splijtstofcyclus. Deze opdracht vloeide voort uit de door de regering uitgebrachte energienota ${ }^{47}$, waarin onder meer beschouwingen waren opgenomen over het kernenergiepotentieel tot een vermogen van in totaal 3500 megawatt $^{148}$. In 1975 zou deze studie afgerond worden en zou het advies over de veiligheidsaspecten van de spijtstofcyclus $^{149}$ uitgebracht worden als eén van de drie adviezen die uitgebracht werden in samenhang met het kabinetsvoornemen over te gaan tot de bouw van grote kerncentrales in Nederland ${ }^{150}$. Het zou echter bij een kabinetswoornemen blijven.

Ten einde een indicatie te geven van de activiteiten met betrekking tot de uitvoering van de wet het volgende. De met de uitvoering van het Radioactieve Stoffenbesluit ${ }^{15}$ belaste instanties dienden bij hun adviesprocedures in het algemeen een onderscheid te maken tussen de gebruikers die in het verleden al met radioactieve stoffen werkten en uit dien hoofde in het bezit waren van een toelating op grond van het oude Radioactieve Stoffenbesluit Warenwet ${ }^{152}$ en degenen die van plan waren radioactieve stoffen te gebruiken. In het eerste geval werd een hoofdzakelijk administratieve procedure gevolgd; in het tweede geval diende per aanvrage een onderzoek te worden ingesteld, opdat de inspectie voor de volksgezondheid en de arbeidsinspectie gezamenlijk over de op te leggen voorwaarden advies aan hun bewindsman konden uitbrengen. In dat kader werden er in 19701635 vergunningen aangevraagd, waarvan er 1160 werden verleend. In de jaren daaropvolgend zou het aantal verleende vergunningen respectievelijk circa 950 , ruim 800 en circa 900 bedragen $^{153}$.

Aan het Toestellenbeshuit ging geen vergunningstelsel vooraf op het voorhanden hebben en toepassen, zodat de gebruikers door vergunningen, die krachtens de Hinderwet waren afgegeven, via een aanschrijving eerst op de hoogte gebracht worden van de nieuwe situatie - meldingsplicht voor alle ioniserende strallen uitzendende toestellen -. In het besluit werd bovendien een onderscheid gemaakt tussen niet en wel vergunningplichtige toestellen; bij deze laatste moet men denken aan deeltjesversnellers, diffractie-meters, röntgenspectografen, röntgentoestellen. In het jaar van inwerkingtreding werden 1000 aanvragen ontvangen ten aanzien van 3000 toestellen, die niet alle in dat jaar konden worden afgedaan in verband met het feit, dat elke aanvraag afzonderlijk moest worden bezien, waarbij tevens rekening gehouden diende te wordemn met hetgeen in het op de Veilligheidswet 1934 gebaseerde Veiligheidsbesluit ioniserende stralen was bepaald ${ }^{154}$.

\section{De Wet Gevaarlijke Stoffen}

In de laatste decennia, en in het bijzondere gedurende en na de Tweede Wereldoorlog, was de produktie en het gebruik van chemicaliën stormachtig toegenomen, niet alleen wat betreft de kwantiteit van de produktie, maar ook was er snelle toename van nieuwe chemicaliën op de markt. Hiermede ging een toename van het vervoer van deze stoffen gepaard. Deze ontwikkeling zo werd verwacht zou zich nog verder voortzetten vanwege een voortdurende stijging van de vraag naar chemicalièn in de industrie en land- en tuinbouw, Niet alleen ten aanzien van het vervoer, maar ook ten aanzien van het gebruik in de bedrijven, werd een stijging verwacht van het aantal stoffen die specifieke gevaren zoals vergiftiging, huidverbranding of ontploffing, met zich konden brengen. Zoals reeds uit een aantal ernstige ongevallen was gebleken, konden de bedoelde stof- 
fen, zowel voor het publiek, als voor de meer rechtstreeks daarbij betrokken personen levensgevaarlijk zijn. Teneinde het publiek en de meer onmiddellijk bij het vervoer en het gebruik van gevaarlijke stoffen betrokken personen tegen de daaruit voortvloeiende gevaren te beschermen, werd het een "gebiedende eis" genoemd geëigende wettelijke maatregelen te treffen ${ }^{155}$, die zouden resulteren in de Wet Gevaarlijke Stoffen ${ }^{15 e}$. Van de zijde van de Tweede Kamer werd de vrees uitgesproken, dat door de veelheid van reeds bestaande en door deze wet te scheppen regelingen verwarring zou ontstaan. De bewindslieden werd dan ook gevraagd of het niet mogelijk was, het wetsvoorstel zodanig uit te breiden, dat nog enige soms verouderde wetten zouden kunnen worden ingetrokken of geïncorpereerd ${ }^{15 \%}$.

Van regeringszijde werd echter opgemerkt, dat het wetsvoorstel niets anders beoogde, dan een lacune op te heffen, die bestond op het terrein van het vervoer van gevaarlijke stoffen en dat het wetsvoorstel voor het overige slechts aanvullend was ${ }^{158}$. De bestaande verouderde wetten zouden worden vervangen en de regelen ten aanzien van het vervoer van gevaarlijke stoffen zouden worden gebaseerd op deze wet ${ }^{159}$.

Met deze wet werd de met de Silicosewet en de Wet op de gevaarlijke werktuigen ingeslagen weg voortgezet. De bescherming strekte zich verder uit dan alleen tot de arbeiders die in de bedrijven met gevaarlijke stoffen in aanraking kwamen. Zo werd de mogelijkheid geopend om in bepaalde gevallen voor aflevering aan het publiek, zoals de verkoop in de kleinhandel van vergiftigde chemicaliën, ter bescherning van de volksgezondheid maatregelen uit te vaardigen, danwel konden mede tot dit doel regelen worden gesteld ten aanzien van de verpakking en de aanduiding van de stoffen bij die aflevering ${ }^{160}$. Hetzelfde gold ten aanzien van ontplofbare stoffen, de wet beperkte zich in deze niet alleen tot het vervoer en de daarmede samenhangende handelingen zoals laden en lossen, maar strekte zich ook uit tot de aflevering in het algemeen en het bezigen van die stoffen ${ }^{161}$. Een probleem leverde het opslaan van gevaarlijke stoffen. Ten aanzien van dit onderdeel werd vanuit de Tweede Kamer gewezen op enige raakpunten met de Hinderwet ${ }^{102}$. Tot slot werd in de wet de mogelijkheid geopend om, met het oog op de openbare veiligheid en gezondheid, regels uit te vaardigen omtrent het zich ontdoen van nutteloos geworden gevaarlijke stoffen of van emballage die, hoewel leeg, resten bevat van deze stoffen ${ }^{163}$.

Met de zorg voor de naleving van de bij of krachtens deze wet gegeven voorschriften werden onder meer belast de ambtenaren van de arbeidsinspectie ${ }^{164}$, die tevens als taak kregen het opsporen van overtredingen $^{185}$.

De Wet Gevaarlijke Stoffen zou gelijktijdig met het Reglement Gevaarlijke Stoffen ${ }^{160}$ op 19 mei 1968 in werking treden. Aan deze inwerkingtreding was een intensief overleg met vertegenwoordigers van het bedrijfsleven, alsook van onder meer provincies en gemeenten vooraf gegaan. Aan dit overleg werd namens het ministerie van Sociale Zaken en Volksgezondheid deelgenomen door de scheikundig adviseur van de arbeidsinspectie. De Wet Gevaarlijke Stoffen ressorteerde onder het ministerie van Verkeer en Waterstaat. Ten aanzien van het vervoer van gevaarlijke stoffen trad de arbeidsinspectie op als advies-instantie voor dit laatstgenoemde departement, en dan met name ten aanzien van de chemisch-technische aspecten van dat vervoer. Voorts werd van de zijde van de arbeidsinspectie deelgenomen aan een groeiend aantal (inter)nationale commissies en werkgroepen die de aspecten van dit vervoer bestudeerden en daarvoor regels opstelden. De scheikundig adviseur bij de arbeidsinspectie was voorzitter van de commissie rubricering vergiftigde en bijtende stoffen, de permanente advies-commissie gevaarlijke stoffen scheepvaarinspectie en de subcommissie "dangerous cargoes" met diverse werkgroepen van de Intergovernmental Maritime Consultative Organization ${ }^{187}$.

\section{De Wet op het werken onder overdruk}

De Caissionwet 1905 was in het leven geroepen om personen te beschermen, die bij de uitvoering van bouwwerken moeten verblijven onder hogere dan atmosferische luchtdruk, en had haar naam te danken aan dat deel van de uitrusting, dat het verrichten van dergelijke arbeid mogelijk maakt, namelijk de "werkkamer" of 
"caisson". De strekking van deze wet was derhalve beperkt. Geen bescherming werd geboden aan personen, die werkzaamheden verrichten onder hogere dan atmosferische luchtdruk, wanneer daartoe andere dan de in de Caissonwet 1905 genoemde hulpmiddelen zoals de werkkamers, schutsluizen en schachten, werden gebruikt, zoals de individuele duikapparatuur en de zogenaamde duikerklok. De ervaring had geleerd, aldus de bewindsman ${ }^{168}$, dat de gezondheid van hen, die werkzaamheden onder verhoogde luchtdruk verrichtten met behulp van andere dan de in de caissonwetgeving genoemde middelen, eveneens door gevaren werd omringd. Om die reden werd het wenselijk geacht de Caissonwet 1905 een uitbreiding voor wat betreft zijn werkingssfeer te geven. Bovendien was het in het belang van de gezondheid niet alleen geboden om het verrichten van arbeid onder verhoogde luchtdruk te beschermen, maar ook al het verblijf onder die omstandigheden. Het betrof niet alleen de witwoering van bouwwerken, zoals bijvoorbeeld de bouw en het onderhoud van tunnels en bruggen; de werken waarbij onder hogere dan de atmosferische luchtdruk arbeid werd verricht waren zeer divers. Eén en ander zou resulteren in een wijziging van de Caissonwet 1905, waarbij tevens haar naam werd gewijzigd in de Wet op het werken onder overdruk ${ }^{109}$. Deze wet alsmede het Caissonbesluit zouden op 1 november 1970 inwerkingtreden ${ }^{170}$.

\section{De Wet inzake de luchtverontreiniging}

"De inademing van lucht is een levenswoorwaarde voor de mens en met hem voor vele andere levende organismen... Het in grote hoeveelheden beschikbaar zijn van frisse lucht met een normaal zuurstofgehalte is ..... voor de mens een levensbelang van de eerste orde", aldus de bewindsman van Sociale Zaken en Volksgezondheid ${ }^{171}$. De samenstelling van de lucht is over de gehele aarde voor wat betreft de hoofdbestanddelen stikstof en zuurstof betreft, zeer constant. Ook de andere normaal voorkomende bestanddelen, zoals edelgassen en kooldioxyde, komen steeds in nagenoeg dezelfde concentratie voor. Alleen de hoeveelheid waterdamp kan sterk variëren, afhankelijk van plaats en temperatuur. Het in de laatste

eeuw sterk toegenomen verbruik van fossiele bandstoffen (steenkool, minerale olie en aardgas) dreigde een zekere mate van evenwicht, dat was bereikt tussen de verbrandingsprocessen, die in de levende organismen plaatsvinden, te verstoren.

De grote betekenis van luchtverontreiniging voor de menselijke gezondheid kwam, aldus de staatssecretaris, voor het eerst duidelijk naar voren toen in de vorige eeuw een begin werd gemaakt met de systematische bestudering van bepaalde beroepsziekten, die in dat tijdperk als begeleidend verschijnsel van de invoering van machinale produktiemethoden in versterkte mate optraden. Daarbij bleek al snel dat deze ziekten wooral optraden, wanneer schadelijke stoffen als stof, gas, damp, nevel of rook, in de lucht van de werkruimten voorkwamen. Hiermee was de basis voor preventie gelegd. De bestrijding van beroepsziekten via wettelijke maatregelen, te beginnen met de Veiligheidswet, had haar vruchten afgeworpen. Vooruitgang werd geboekt, zo vervolgde de bewindsman, met het in de jaren twintig van deze eeuw ter beschilkking komen van lijsten met maximaal toelaatbare concentraties van schadelijke stoffen in de lucht van werkruimten, waardoor naast kwalitatieve nu ook kwantitatieve gegevens beschikbaar kwamen. Vervolgens vroeg de verantwoordelijke bewindsman zich af, in hoeverre deze voor arbeiders opgestelde grenswaarden een grondslag zouden kunnen vormen voor het vaststellen van maximaal toelaatbare concentraties in de buitenlucht, waarbij men zich moest realiseren, dat de eerstbedoelde waarden waren opgesteld voor gezonde, volwassen personen die alleen tijdens de arbeidsuren aan deze concentraties zijn blootgesteld. Voor de bevolking als geheel gold echter dat er ook kinderen, zieken en zwakken bij betrokken zijn en dat de blootstelling het gehele etmaal plaatsvond. Bovendien moest voor grenswaarden voor de verontreiniging van de buitenlucht in beschouwing worden genomen: de invloed op planten, dieren, gebouwen en andere bezittingen van de mens, die bij de luchtverontreiniging binnen de werkruimten niet oof in veel mindere mate van betekenis was ${ }^{172}$. Hoewel er regels bestaan op basis waarvan sommige maatregelen tegen luchtverontreiniging waren of zouden kunnen worden genomen, zoals bijwoorbeeld de Hinderwet; ontbrak een specifieke regelgeving gericht op de bestrijding van luchtverontreiniging, aldus de bewindsman ${ }^{173}$. Door middel van de Wet inzake de lucht- 
verontreiniging ${ }^{174}$ werd het mogelijk om voor enige noodzakelijke onderwerpen van algemene aard voorzieningen te treffen. Het kernstuk van de wet vormden de hoofdstukken III en IV. In Hoofdstuk III van deze wet beoogt artikel 13 een ruim aantal middelen te geven om de luchtverontreiniging door toestellen, brandstoffen en verontreinigde handelingen tegen te gaan; de te geven regels kunnen variëren van een algeheel verbod tot een simpele verplichting tot aangifte. In Hoofdstuk IV van deze wet opent artikel 19 de mogelijkheid om bij algemene maatregel van bestuur categorieën van inrichtingen aan te wijzen, die in belangrijke mate luchtverontreiniging kunnen veroorzaken. Eén en ander was opgezet via een vergunningstelsel. $\mathrm{Nu}$ de rol die de arbeidsinspectie terzake van deze wet toebedeeld was. Vergunningverlener in het kader van de uitvoering van Hoofdstuk IV van de wet zijn gedeputeerde staten van de provincie, waarin de inrichting geheel of in hoofdzaak is of zal zijn gelegen. Gedeputeerde staten dienen burgemeester en wethouders van de gemeente waarin de bedoelde inrichting gelegen is of zal zijn, alsook het betrokken districtshoofd van de arbeidsinspectie in de gelegenheid te stellen hen van advies te dienen omtrent de aanvraag en voorts, indien het verlenen van de gevraagde vergunning wordt overwogen, over het ontwerp hiervan ${ }^{176}$. De taak van de arbeidsinspectie bij de uitvoering van deze wet is er derhalve een van adviseur, niet meer en niet minder. De aanvrager van een vergunning zou er, volgens de bewindsman ${ }^{176}$, goed aan doen al voordat dit advies werd uitgebracht informeel contact op te nemen met de bedoelde adviseurs, teneinde bepaalde desiderata van hun kant op het gebied van het treffen van bepaalde voorzieningen te vernemen en in het algemeen met hen over de aspecten van luchtverontreiniging overleg te plegen in een stadium, dat met deze desiderata en de resultaten van dit overleg zonder veel bezwaren rekening zou kunnen worden gehouden.

Door de arbeidsinspectie werden op het terrein van de luchtverontreiniging aanvankelijk metingen verricht aan de uitworp van afvalgassen van industriële processen. In overleg met de ministerie van Volksgezondheid en Milieuhygiëne zouden de metingen sterk afnemen. $\mathrm{Zij}$ werden vanaf 1974 ook nauwelijks meer verricht. In de jaren 1974 en 1975 zou de arbeidsinspectie respectievelijk 70 en 110 aanvragen om advies ontvangen, waarover respectievelijk 49 en 68 adviezen werden afgegegeven. In deze jaren werden 70 onderscheidenlijk 78 ontwerp-vergunningen om advies ontvangen ${ }^{177}$.

\section{De Wet op de ondernemingsraden}

De eerste Wet op de ondernemingsraden was in 1950 tot stand gekomen. Deze wet legde aan het hoofd of de bestuurder van elke onderneming van een bepaalde omvang de verplichting op een ondernemingsraad in te stellen. De ondernemingsraad was gedacht als een orgaan, bestaande uit een aantal werknemers, afhankelijk van de grootte van de onderneming, èn het hoofd of de bestuurder van die onderneming of diens plaatsvervanger, die als voorzitter van de ondernemingsraad optrad. De taak van de ondernemingsraad was in de wet als volgt omschreven ${ }^{178}$ :

"De ondernemingsraad heeft tot taak, zulks onder erkenning van de zelfstandige functie van de ondernemer, naar vermogen bij te dragen tot een zo goed mogelijk functioneren der onderneming",

met andere woorden: de ondernemingsraad werd ten behoeve van de onderneming ingesteld. Zijn taak, zijn doel eigenlijk, was bij te dragen tot een zo goed mogelijk functioneren van de onderneming. De ondernemingsraad kon dus niet de vorm hebben van een personeelsvertegenwoordiging tegenover of zelfs bij de werkgever. Elke gedachte aan dualiteit, zoals die wel bestond bij bijvoorbeeld bedrijfskernen, was vreemd aan het wezen van de vanuit het ondernemingsdoel bepaalde ondernemingsraad ${ }^{179}$. De onderneming behoorde een gemeenschap te zijn, die behalve een economisch, ook een sociaal doel heeft en die slechts dan tot volle ontplooiing zou kunnen komen, indien zij werd gedragen door een juist begrip, enerzijds voor de betekenis van ieders bijdrage, anderzijds voor de betekenis van deze bijdragen gezamenlijk voor het bereiken van het ondernemingsdoel ${ }^{130}$. De bevoegdheden van de ondernemingsraad reikten niet verder dan een recht van medezeggenschap in de betekenis van een recht om "mede te weten" en "mede te spreken"; van het recht om "mede te beslissen" was geen sprake ${ }^{181}$. 
Deze wettelijke regeling van de medezeggenschap ondervond tot aan het midden van de jaren zestig geen weerstand. Het op 26 november 1964 verschenen rapport "Herziening van het ondernemingsrecht" van de commissie-Verdam ${ }^{102}$ wijdde een hoofdstuk aan de ondernemingsraden. De commissie deed een aantal bescheiden voorstellen om de wet te wijzigen waardoor het door de wet bedoelde overleg in de ondernemingsraad zou kunnen worden verbreed en verdiept ${ }^{133}$.

Dit rapport was reden woor de bewindslieden van Sociale Zaken en Volksgezondheid, Justitie en Economische Zaken om de Sociaal Economische Raad om advies te vragen. Uit dit in 1968 uitgebrachte advies ${ }^{184}$ zou blijken, dat de opvattingen aanmerkelijk gewijzigd waren. Volgens dit adviesorgaan moest de Wet op de ondernemingsraden van 1950 vooral gezien worden als een afsluiting en bekroning van de in de jaren veertig gegroeide, toenadering tussen werkgevers en werknemers op ondernemingsniveau. Dit kwam vooral tot uiting in de wettelijke opzet, waarbij als uitgangspunt gold de behartiging van gemeenschappelijke belangen. De ontwikkelingen na 1950 hadden echter laten zien, dat de belangen wel eens zodanig uiteen konden lopen, dat gemeenschappelijke behartiging daarvan door en in eén orgaan minder perspectieven bood dan bij het brengen van de wet werd gedacht.

Met andere woorden: de wet van 1950 beantwoordde niet langer meer aan de realiteit en diende aangepast te worden $^{135}$. De nieuwe ondernemingsraad zou een "dualistische", een tweeledige, functie moeten krijgen, namelijk het zijn van een orgaan van de onderneming als zodanig en een orgaan voor de behartiging van specifieke werknemersbelangen ${ }^{16 \theta}$. Dit advies werd door de regering overgenomen en zou leiden tot de Wet op de ondernemingsraden van 1971 .

In deze nieuwe Wet op de ondernemingsraden was een bepaling opgenomen, waarin de ondernemer die verplicht was eén of meer ondernemingsraden in te stellen, op verzoek aan het bevoegde districtshoofd van de arbeidsinspectie inlichtingen moest verstrekken over de werkzaamheden van de door hem ingestelde ondernemingsraad/-raden ${ }^{197}$. De reden voor deze bepaling was volgens de bewindslieden gelegen in de wenselijkheid dat de centrale overheid meer inzicht kon krijgen in het reilen en zeilen van de ondernemingsraden $^{168}$. Vanuit de Tweede Kamer werd gevraagd, waarom de arbeidsinspectie inlichtingen over het functioneren van de ondernemingsraad dienden te worden verstrekt. Voor een uitbreiding van de taak van de arbeidsinspectie was volgens een aantal kamerleden op voorhand weinig aanleiding. Anderen hadden tegen de bepaling op zich overwegende bezwaren, omdat zij niet inzagen waarom de centrale overheid meer inzicht diende te worden gegeven over de ondernemingsraad. Eén Kamerlid informeerde ${ }^{489}$, waarom het nodig was, dat de overheid politie-agent ging spelen in het Nederlandse bedrijfsleven ${ }^{180}$. De bewindslieden verdedigden $^{161}$ deze bepaling, met de opmerking dat deze voortsproot uit de gedachte, dat het wenselijk was de arbeidsinspectie, die wit hoofde van haar taak regelmatig in de ondernemingen kwam, de bevoegdheid te geven om gegevens te verzamelen omtrent de toepassing van de wet. Inzicht was gewenst om de ontwikkelingen op dit terrein beter te kunnen volgen dan in het verleden mogelijk was geweest. De taak die de arbeidsinspectie toebedeeld kreeg, was geen toezichthoudende taak in de juridische zin en dus geen politieagent spelen, daar de sanctie op de naleving van de wet niet via de arbeidsinspectie liep. Het ging slechts om een recht om inlichtingen te vragen en meer niet.

In het kader van deze taak hield de arbeidsinspectie in 1972 en 1973 een enquête naar de ontwikkeling van het aantal ondernemingsraden, die functioneerden op basis van de nieuwe wet ${ }^{192}$. In de beide daarop volgende jaren werd een aanvullend onderzoek verricht bij dié ondernemingen, die blijkens de uitkomsten van de jaren 1973 en 1974 nog niet voldeden aan de verplichting tot instelling van een ondernemingsraad.

In 1973 waren er 3822 ondernemingen, waarop, ingevolge het bepaalde in de Wet op de ondernemingsraden, de verplichting rustte een ondernemingsraad in te stellen. Blijkens de enquête bleken in dat jaar 1892 ondernemingen niet aan die verplichting te voldoen. Deze laatste groep werd in 1974 opnieuw geënquêteerd, waaruit bleek, dat er in 1974 nog 969 ondernemingen waren die nog niet aan die verplichting voldeden. Dit aantal zou echter in het daaropvolgende jaar nog verder dalen ${ }^{183}$. 
De activiteiten van de arbeidsinspectie in het kader van het Buitengewoon Besluit Arbeidsverhoudingen 1945 zouden met het aanvangen van deze periode een aanmerkelijke verandering ondergaan.

Als gevolg van een wijziging van de organisatie van het ministerie van Sociale Zaken en Volksgezondheid per 1 januari 1962 werd de band, die in de vorm van een personele unie bestond tussen de arbeidsinspectie en de looncontroledienst, de directeur-generaal van de Arbeid was tevens hoofd van de looncontroledienst, gestaakt $^{104}$. Sindsdien had de arbeidsinspectie geen bemoeienis meer met het geven van loontechnische adviezen aan het College van Rijksbemiddelaars en bestonden de activiteiten daardoor in hoofdzaak in het verstrekken wan adviezen aan de gewestelijke arbeidsbureaus inzake aanwragen om ontslagvergunning, het behandelen van aanvragen van werkgevers om ontheffing van het verbod van werktijdwerkorting en het houden van toezicht op de naleving van de andere arbeidsvoorwaarden dan de lonen, neergelegd in bindende loonregelingen en collectieve arbeidsovereenkomsten ${ }^{105}$.

\subsection{Het ontslagverbod}

Ten aanzien van de bemoeienis van de arbeidsinspectie met het ontslagverbod kan worden opgemerkt, dat in 1962 over 28.214 aanvragen advies werd uitgebracht, waarvan respectievelijk 9.111 en 19.103 afkomstig waren van werkgevers en werknemers, uit welke verhouding overigens afgeleid kan worden dat er sprake was van een zogenaamde gespannen arbeidsmarkt. In het daaropvolgende jaar zou het totaal aantal aanvragen dalen tot 27.685 aanvragen, waarvan respectievelijk 9.387 en 18.298 afkomstig waren wan werkgevers en werknemers. Het aantal door de arbeidsinspectie nader onderzochte aanvragen bedroeg in deze beide jaren respectievelijk 533 en 510 . Het daaropvolgende jaar zou hetzelfde beeld te zien geven. In 1965 echter zou het aantal aanvragen van werkgeverszijde nagenoeg gelijk zijn aan die van 1964, namelijk respectievelijk 10.602 en 10.167, terwijl het aantal aanvragen van werknemerszijde drastisch zou dalen namellik van 19.533 in 1.964 tot 14.060 in 1965 . Ook het aantal nader onderzochte aanvragen zou sterk dalen tot respectievelijk 322 en $315^{190}$. In $1966 \mathrm{zou}$ dit beeld veranderen als gevolg van veranderingen op economisch gebied. In totaal werd over 24.607 aanvragen om ontslagvergunning advies uitgebracht, waarvan 14.633 van werkgevers- en 9.9974 van werknemerszijde. Door de arbeidsinspectie werden in dat jaar maar liefst 4.429 aanvragen nader onderzocht $^{197}$. Vanaf $1970 \mathrm{zou}$ het aantal ontslagvergunningaanvragen toenemen, om vervolgens in de jaren 1974 en 1975 snel te stijgen als gevolg van de oliecrisis en de daarmede samemhangende economische gevol$\operatorname{gen}^{108}$.

\subsection{Het verbod van werktijdverkorting}

Ten aanzien van de activiteiten van de arbeidsinspectie ter zake van de ontheffing van het verbod van werktijdverkorting kan het volgende opgemerkt worden. In 1962 zou het aantal verleende ontheffingen nog minder bedragen dan het jaar er voor, namelijk 115 tegen 132, hoewel het aantal korter gewerkte uren aanzienlijk zou stijgen ${ }^{198}$ als gevolg van een tijdelijke vermindering van bedrijvigheid in de eerste helft van dit jaar in de textielindustrie. Het daarop volgende jaar gaf een omgekeerd beeld te zien, meer verleende ontheffingen, namelijk 1636, maar minder uren dat korter werd gewerkt ${ }^{20}$. De oorzaak daarvan lag in de strenge winter in januari en februari van dat jaar. Hierboven is al opgemerkt, dat zich in 1966 een afname in de bedrijvigheid manifesteerde. Dit leidde tot een enorme toename van verzoeken om ontheffing van het verbod van werktijdverkorting, namelijk 3.348 tegenover 556 in 1965. Daarna zou het aantal verleende ontheffingen weer sterk dalen. Als gevolg van de oliecrisis zou het aantal korter gewerkte uren dramatisch stijgen van 5.271 .316 in 1972 tot 31.371 .030 in $1975^{201}$. 


\section{3. "Andere" arbeidsvoorwaarden}

Aangaande het verbod om af te wijken van de "andere" arbeidswoorwaarden kan worden opgemerkt, dat voor zover de arbeidsinspectie daar bemoeienis mee had geen bijzonderheden zijn te vermelden.

13. Werkzaamheden in verband met andere wetten warvan de handhaving en de medewerking aan de uitvoering geheel of gedeeltelijk aan de arbeidsinspectie was opgedragen.

\subsection{De Rijtijdenwet 1936}

In het kader yan de Rijtijdenwet 1936 werd in 1962 door de rijks- en de gemeentepolitie op de weg een bijzonder intensieve controle witgeoefend, terwijl bij de regelmatig door de arbeidsinspectie en rijksverkeersinspectie uitgeoefende controles de nadruk werd gelegd op de bedrijfscontroles. In 1962 werd door de tijksverkeersinspectie, naast de normale controles, opnieuw een aantal zogenaamde landelijke controles uitgevoerd. De resultaten logen er niet om; bij 11342 staandehoudingen werden 1501 processen-verbaal opgemaakt, die betrekking hadden op 4911 overtredingen ${ }^{202}$. In 1965 was het resultaat al niet beter: 10.188 staandehoudingen met 1738 processen-verbaal voor in total 4241 overtredingen. Overigens was het totaal aantal bij proces-verbaal van zowel rijksverkeersinspectie, de politie en de arbeidsinspectie vastgelegde overtredingen maar liefst 31.180 tegenover 28.049 in het jaar daarvoor ${ }^{203}$.

Van de zijde van de arbeidsinspectie werden ontheffingen verleend van de bepalingen van het Rijtijdenbesluit. Bedroeg het aantal ontheffingen aangaande de administratieve bepalingen, waaronder het voor de bemanningsleden verplicht bij zich moeten hebben van werkmapjes in 196241.928 , in 1965 was dit 56.382 . In 1967 bedroeg dit aantal niet minder dan 61.088; het maximum in deze periode ${ }^{204}$.

In 1971 zorgde de inwerkingtreding van het nieuwe Rijtijdenbesluit 1971 en in het bijzonder de bepalingen van de EEG-Verordening $543 / 69$ tot harmonisatie van bepaalde voorschriften van sociale aard voor het wegvervoer, in de vervoerssector vele moeilijkheden. Van overheidszijde werd overleg gevoerd met de betrokken organisaties van werkgevers en van werknemers, waarbij het te voeren ontheffingenbeleid onderwerp van discussie was $^{205}$.

\subsection{De Huisarbeidswet 1933}

In het vorige hoofdstuk was al reeds geconstateerd, dat de Huisarbeidswet 1933 nagenoeg een dode letter was geworden. Voor het verrichten van bij het Huisarbeidsbesluit 1936 aangewezen huisarbeid, moest de arbeider in het bezit zijn van een door de burgemeester van de gemeente van inwoning afgegeven loonboekje. In 1963 werden nog 409 van dergelijke boekjes uitgereikt. Het jaar daarop was dit aantal teruggebracht tot $237^{200}$. In 1971 was dit aantal nog 319. Vanaf dat moment zou een sterke daling van de afgegeven loonboekjes plaatsvinden, namelijk 195 in 1972, 172 in 1973, 101 in 1974 en 32 in $1975^{207}$. Daaruit valt af te leiden, dat eerst in de jaren zeventig de Huisarbeidswet 1933 daadwerkelijk een dode letter is geworden.

\subsection{De Ongevallenwet 1921 :}

In het kader van de samenwerking met ( ambtenaren van) de Sociale Verzekeringsbank in verband met de uitvoering van de Ongevallenwet 1921 en de Beroepswet werden in de jaren 1962 tot en met 1966 jaarlijks enkele tientallen mededelingen omtrent de beveiligingstoestanden in fabrieken of werkplaatsen ontvangen, die naar de mening van de bedoelde bank voorziening behoefden. Ook nu weer werd in een (wisselend) aantal gevallen nader bericht gevraagd, dat van de zijde van de arbeidsinspectie werd verstrekt na cen ter plaatse ingesteld onderzoek. Evenals in de voorgaande perioden werden de districtshoofden van de arbeidsinspectie door de voorzitter van é́n van de Raden van beroep en van de Centrale Raad van Beroep ge- 
vraagd een onderzoek in te stellen of te adviseren inzake de indeling van een onderneming in een gevarenklasse 208 .

Op 1 juli 1967 werd de Ongevallenwet $1921^{209}$ buiten werking gesteld, zodat het door de arbeidsinspectie uitbrengen van de bedoelde adviezen vanaf die datum tot het verleden behoorde. Een en ander was het gevolg van het op die datum in werking treden van de Wet op de Arbeidsongeschiktheidsverzekering. Als gevolg van deze verandering, want noch de Wet op de Arbeidsongschiktheidsverzekering, noch de gewijzigde Ziektewet $^{210}$ maakte een onderscheid naar de oorzaak van arbeidsongeschilitheid, ziekte of ongeval, zou de arbeidsinspectie een bron van belangrijke gegevens betreffende bedrijfsongevallen moeten missen. Daartoe was een afzonderlijke ministeriële regeling ${ }^{211}$ in het kader van de Ziektewet ${ }^{212}$ noodzakelijk teneinde voortzetting van de meldingen van bedrijfsongevallen en beroepsziekten te verzekeren. Op grond van deze ministeriële regeling was de werkgewer verplicht gelijktijdig met de aangifte van de arbeidsongeschiktheid tevens een ongevalsformulier aan de bedrijfsvereniging te sturen, wanneer de verzekerde werknemer tijdens de uitoefening van zijn dienstbetrekking door een bedrijfsongeval was getroffen. Via de bedrijfsvereniging kwamen deze aanmeldingsformulieren bij het directoraat-generaal van de Arbeid ${ }^{213}$. De meldingen dienden in de praktijk alleen een inspectiedoel: op grond van de binnengekomen meldingen werd door de arbeidsinspectie actie ondernomen ${ }^{214}$. Voorts werd van de Sociale Verzekeringsbank de landelijke ongevallenregistratie en de daaruit voortvloeiende samenstelling van de ongevallenstatistieken in samenwerking met het Centraal Bureau voor de Statistiek ontvangen ${ }^{215}$.

\subsection{De Hinderwet}

Ten aanzien van de bezigheden van de arbeidsinspectie in het kader van de Hinderwet valt ten aanzien van de vorige perioden nawwelijks enig verschil te constateren. Zo stond de arbeidsinspectie gemeenten bij ten aanzien van de aan de Hinderwetvergunning op te leggen voorwaarden; werden wijzigingen van de voorwaarden, die aan een ontwerp-vergunning waren verbonden voorgesteld; werd samengewerkt mett de brandweerautoriteiten en waren er de bekende klachten over het niet of onvoldoende verstrekken van gegevens door de belanghebbenden, afwijkingen van de door de gemeenten te volgen procedures en dergelijke ${ }^{218}$.

$\mathrm{Bij}$ het weren van gevaar, schade en hinder werd veel aandacht besteed aan maatregelen ter beteugeling van de bodem-en water- en luchtverontreiniging. Eén en ander bijvoorbeeld in de chemische industrie als gevolg vam het toepassen van nieuwe produktiemethoden en het gebruik van grondstoffen waarvan de eigenschappen nog onvoldoende bekend waren. Juist in de chemische sector bleek het vooroverleg bij de voorgenomen vestiging van nieuwe bedrijven van belang te zijn, niet alleen voor de vergunningverlenende instantie en haar adviseurs, maar ook met name ook woor de ondernemer zelf vanwege de vaak zeer kostbare investeringen, zodat de bedrijfsleiding er veel aan gelegen was tijdig te weten welke eisen gesteld werden om een Hinderwetwergunning te kunnen verkrijgen. Zo leidde het bij de voorgenomen vestiging van een olieraffinaderij en de daarmede gepaard gaande petrochemische industrie in Amsterdam gevoerde vooroverleg tot besprekingen inzake problemen van water-, bodem- en luchtverontreiniging. Dit leidde tot het van overheidszijde publiceren van een zogenaamd "convenant", waarin de samenwerking tussen rijksoverheid, het provinciaal bestuur en het gemeentebestuur inzake de voorgenomen vestiging van bedoelde olieraffinaderij en eventuele zich ter plaatse te vestigen chemische verwerkingsindustrieën werd geregeld. Het convenant regelde tevens de algemene technische eisen ter bestrijding van de bedoelde verontreiniging stelde. Deze technische eisen werden, zonodig nader gespecificeerd, in de Hinderwetvergunning opgenomen ${ }^{217}$.

In 1967 werd het Hinderbesluit gewijzigd ${ }^{218}$; een wijziging die voornamelijk betrekking had op een betere bestrijding van de luchtverontreinging. Deze wijziging had het karakter van een voorlopige voorziening. Aan het einde van genoemde jaar zou de beslissing vallen; er zou een afzonderlijke Wet op de luchtverontreiniging komen. Als gevolg van deze wijziging werd het mogelijk om van een aantal inrichtingen, die tot de ergste luchtwerontreinigers moesten worden gerekend, specifieke inlichtingen te verkrijgen. Daarnaast werden de inspecteurs van de volksgezondheid, die belast waren met het toezicht op de milieuhygiëne, ingeschakeld 
bij Hinderwetwergunningenaanwragen voor een groot aantal inrichtingen, die als ernstige luchtverontreinigers te boek stonden ${ }^{219}$.

In dat zelfde jaar werd mededeling gedaan van de instelling van een Bureau Milieuhygiëne door de Raad van de Nederlandse werkgeversbonden, dat de taak had om activiteiten van het bedrijfsleven ten aanzien van de problemen op het terrein van water-, bodem-en luchtverontreiniging, éen ander in samenhang met de ruimtelijke ordening, te bundelen en te stimuleren. Tussen dit bureau en het directoraat-generaal van de Volksgezondheid en het directoraat-generaal van de Arbeid zouden regelmatig besprekingen plaatsvinden 220

Het aantal Hinderwetvergunningaanvragen zou in het begin van de jaren zeventig al maar toenemen; in 1971 bedroeg dit aantal 11.795, in de beide daaropvolgende jaren respectievelijk 14.605 en 15.755 . In 1974 zou dit aantal 15,660 bedragen, waarna in 1975 een daling inzette tot 13.693. In het overgrote deel van deze gevallen werd het advies gevraagd van de arbeidsinspectie, hetgeen van de dienst nogal wat capaciteit verg$\mathrm{de}^{221}$

\subsection{Overige}

Het toezicht op de naleving van de bepalingen van de overige wetten, waaronder de Phosphorluciferwet 1901, de Steenhouwerswet 1921, de Silicosewet, de Wet op de gevaarlijke werktuigen, de Wet inzake de wekelijkse rustdag voor toonkunstenaars, de Wet plaatsing minder-valide arbeidskrachten en de Winkelsluitingswet 1952 leverde geen of geen noemenswaardige problemen op.

\section{Bedrijfsmaatschappelijk werk en sociaal welzijn in de onderneming}

"Sociaal welzijn in de onderneming veronderstelt een menswaardige arbeidsomgeving en arbeidssituatie in de meest vérstrekkende betekenis: een milieu waar elk individu van hoog tot laag zich kan wèlbevinden, waar hij "veilig" kan zijn naar lichaam en geest",

aldus het jaarverslag over 1962. Maar tevens werd opgemerkt, dat overwegingen van economische aard aan de waarde van een vooruitstrevend sociaal beleid geen afbreuk behoeven te doen. Naast het menselijk inlevingsvermogen waren realiteitsbesef en gezond verstand onontbeerlijk. Dank zij een dergelijke benadering kon, zo werd vervolg, de personeelsvoorziening op een meer verantwoorde wijze plaatsvinden en kon de reputatie van een bedrijf worden verbeterd. Maar er was een nieuw element bijgekomen, een overtuiging, een inzicht dat nog geen gewoon goed was geworden, namelijk dat er wederkerigheid was in de relatie tussen de "nieuwe" werkgever en de "nieuwe" werknemer. Na de "doopcel" van de sollicitant mocht van de werkgever verwacht worden, dat hij de nieuwe werknemer even serieus ontving; na het tekenen van de arbeidsovereenkomst met rechten en verplichtingen mocht de nieuwkomer verlangen daadwerkelijk te ervaren, dat hij was "aangenomen", geaccepteerd en dat hij werd wijsgemaakt in de nieuwe omgeving.

Geregeld, dagelijks contact met het bedrijfsleven en kennisneming van hetgeen over doelstelling, taak en maatschappelijke functie van de onderneming, over de factor "arbeid" en vele aanverwante problemen werd gepubliceerd, maakte duidelijk, dat er in brede kringen wel aandacht was voor de kardinale vragen van sociaal beleid en dat er dikwijls met grote ernst werd gepleit voor de bevordering van menswaardige verhoudingen. In menig verslag of rapport, in talloze artikelen van werkgevers- en werknemersorganen en andere vakbladen werden beschouwingen van grote diepgang aangetroffen. Bij de bedrijfsleiding was vaak duidelijk een behoefte aanwezig met een "outsider" van gedachten te wisselen over het "waarom" en "hoe" van getroffen of te treffen maatregelen en voorzieningen. Maar tevens werd geconstateerd, dat in de vaart van het industriële leven, gekenmerkt door stoutmoedige beslissingen en omwentelingen van technische en economische aard, de consequenties hiervan op het terrein van het sociale beleid veel langzamer dórdringen. Met andere woorden: het menselijk verkeer binnen de muren van het bedrijf, de realiteit van de sociale verhoudingen, 
staken in veel gevallen minder gunstig af tegen hetgeen zo veelvuldig op papier werd beleden. Vastgesteld werd, dat een doordachte beleidsconceptie, een bewuste doelstelling op langere termijn vaak ontbrak. Het personeelsbeleid stond in menig bedrijf aan de periferie van het ondernemingsbeleid, waarbinnen de functie van degenen die met deze taak in het bijzonder waren belast in hoofdzaak ethisch werd gewaardeerd; dat arbeidsvraagstukken een essentieel deel vormden van het totale bedrijfsbeleid werd nog niet overal ingezien ${ }^{222}$.

De aandacht van de arbeidsinspectie voor het bedrijfsmaatschappelijk werk vond zijn oorzaalk in hel feil, dat de inspectrices van de arbeid door hun geregelle bedrijfsbezoeken en door deelneming aan discussieen werkgroepen - regionaal en landelijk - met de bedrijfsmaatschappelijk werk(st)ers contact onderhielden. Bovendien waren de inspectrices van de arbeid geïteresseerd in de ontwikkeling van dit jonge vak en in het welbevinden van hen die het beoefenden. De sterke groei van het bedriffsmaatschappelijk werk van de eerste jaren na de oorlog was al lang achter de rug; er werd een zekere stabiliteit geconstateerd Belangrijker echter werd gevonden, dat er meer begrip en inzicht voor de functie van het werk was; geleidelijk aan werd het duidelijk, dat een aantal voorwaarden. moest zijn vervuld om het werk levensvatbaar en zinvol te doen zijn ${ }^{223}$.

\section{Bijzondere opdrachten}

\subsection{Vrijstelling millitaire dienst.}

Ook in deze periode werden op verzoek van de minister van Defensie door de arbeidsinspectie aanvragen om vrijstelling van militaire dienstplicht, wegens onmisbaarheid van de dienstplichtige in het bedrijf waarin deze werkzaam is, beoordeeld. Dit oordeel werd gevraagd wanneer uit de reeds beschikbare gegevens en adviezen onvoldoende inzicht gaven voor een beslissing op de aan-vraag. De te beoordelen aanvragen, die daartoe ter plaatse moesten worden onderzocht, hadden voornamelijk op industriële en ambachtelijke bedrijvem betrekking. In de jaren 1971 tot en met 1975 werden tussen de 200 en 300 van dergelijke aanvragen ontvangen $^{224}$.

\subsection{Civiele verdediging}

Daarnaast verrichtte de arbeidsinspectie werkzaamheden in het kader van de civiele verdediging en dan in het bijzonder terzake van de gevaren die verbonden zijn aan de aanwezigheid van grote hoeveelheden gevaarlijke stoffen. Het evalueren van de risico's die door oorlogshandelingen ontstonden, kon niet los gezien worden van de risico's voor soortgelijke calamiteiten die hun oorzaak vonden in handelingen of omstandigheden in vredestijd. In het begin van de zeventiger jaren werd gewerkt aan een inventarisatie van de gevaarlijke stoffen in Nederland en vonden er studies en experimenten plaats ten einde kennis te verwerven die bij de preventie en de bestrijding van ongevallen in geval van oorlogsgevaar van nut zouden kuntnen zijn. Door de scheikundige dienst werd aan het werk van diverse commissies en instanties deelgenomen die rampenregelingen voorbereidden en werd meegewerkt aan het voorbereiden en uitvoeren van rampenoefeningen, zoals "Wintex" en "Oost" en een plaatselijke oefening te Vlaardingen ${ }^{225}$. 
noter

1. Zie H. van Goor, Pressiegroepen en sociale verandering, in Sociale Problemen deel 1, Sociale ontwikkelingen, Utrecht/Antwerpen 1978, blz. 165 en blz. 221 nt.3.

2. Zie H. van Goor, ta.p., blz. $163 \mathrm{t} / \mathrm{m} 165$. Zie ook onder meer A. Lijphart, Kentering in de Nederlandse politiek, in Acta Politica 1968/1969 blz $231 \mathrm{t} / \mathrm{m}$ 247; R. Kroes, New Left, Nieuw Links, New Left. Verzet, beweging, verandering in Amerika, Nederland, Engeland, Alphen a/d Rijn/Brussel 1975.

3. J.Th.J. van den Berg/H.A.A. Molleman, Crisis in de Nederlandse politiek, Alphen a/d Rijn 1974, blz. 99 t/m 106; zie H. van Goor, t.a.p., blz. 165 .

4. In feite werd de verdeling van de maatschappelijke welvaart centraal gesteld: zie $H$. van Goor, t.a.p., blz. 165; A. Lijphart, in Acta Politica $1968 / 1969$ blz. 241 - 242.

5. Zie W.H.J. Reynaerts/A.G. Nagelkerke, Arbeidsverhoudingen, theorie en praktijk deel 1, Leiden/Antwerpen, blz. 177 - 178 .

6. Zie W.J.P.M. Fase, t.a.p., blz. 290 t/m 305.

7. W.J.P.M. Fase, t.a.p., blz. 57 - 58. Zie over het systeem van de loonvorming T. van Peijpe, t.a.p., blz. 487 $\mathrm{t} / \mathrm{m} 540$.

8. Zie Tweede Kamer, zitting 1967 - 1968, 9716.3 (memorie van toelichting ) blz. 7 .

9. Wet van 12 februari 1970 , Stb. 69 .

10. Resp. Wet van 13 mei 1956, Stb. 281 en Wet van 9 april 1959, Stb. 139.

11. Resp. de Wet van 26 april 1962, Stb. 160, de Wet van 13 juni 1963, Stb. 284, de Wet van 15 oktober 1964, Stb. 392, de Wet van 18 februari 1966, Stb. 84, de Wet van 10 december 1964, Stb. 485 en de Wet van 14 december 1967 , Stb. 655 . 12. Resp. de Wet van 26 oktober 1961, Stb. 459 , de Wet van 1 oktober 1965 , Stb. 448 en de Wet van 8 april
1981, Stb. 214 .

13. Zie hierover W.J.M. Fase, t.a.p., blz. $345 \mathrm{t} / \mathrm{m} 369$.

14. Wet van 6 augustus $1968, \mathrm{Stb} .376$.

15. Zie T. van Peijpe, t.a.p., blz. 472 .

16. Wet van 10 september 1970 , Stb. 414 .

17. Wet van 10 september 1970 , Stb. 411 .

18. Wet van 6 mei 1971, Stb. 289. 
19. Zie onder meer T. van Peijpe, t.a.p., 472 t/m 474, WJ.P.M. Faise, ta.p., blz. 199 t/m 227 ; W.HJ. Reynaerts ( red. ), Arbeidsverhoudingen, theorie en praktijk deel 2, Leiden/Antwerpen 1983, blz. $222 \mathrm{t} / \mathrm{m} 269$.

20. Zie W. Albeda, De crisis van de werkgelegenheid en de verzorgingsstaat. Analyse en perspectief, Kampen 1984, blz. 18 - 19; J.P. Windmuller/C. de Galan, t.a.p. 2, blz. 178 - 179.

21. P.A. Diepenhorst, t.a.p. 1, blz. 125.

22. Zie hierover onder meer P.J. Oud, t.a.p., blz. $177 \mathrm{t} / \mathrm{m} \mathrm{186;} \mathrm{W.J.} \mathrm{van} \mathrm{Welderen} \mathrm{Rengers,} \mathrm{t.a.p.} \mathrm{III,} \mathrm{blz.}$ $1 \mathrm{t} / \mathrm{m} 91$.

23. Besluit van 26 augustus 1901, Stb. 206 .

24. Zie hierover onder meer P.J. Oud, t.a.p., blz. $191 \mathrm{t} / \mathrm{m}$ 196; W.J. van Welderen Rengers, t.a.p. III, blz. 92 $\mathrm{t} / \mathrm{m} 140$.

25. Besluit van 7 september 1905, Stb. 264.

26. Zie Bijlagen Tweede Kamer, zitting 1907 - 1908, 314.5 (ontwerp van wet tot verhoging en aanvulling van het Xde Hfdst. der Staatsbegroting voor het dienstjaar 1908) ( memorie van toelichting ) blz. 2.

27. Besluit van 25 september 1918, Stb. 551.

28. Besluit van 24 november 1922, Stb. 606 (ministerie van Arbeid, Handel en Nijverheid ); Besluit van 8 september 1931, Stb, 501 ( ministerie van Economische Zaken en Arbeid).

29. Besluit van 8 juni 1933 , Stb. 311.

30. Ook niet zonder naamsverandering. Zie het Besluit van 20 augustus 1951, Stb. 396 (ministerie van Sociale Zaken en Volksgezondheid); Besluit van 6 juli 1971, Stb. 451 (ministerie van Sociale Zaken). Zie voorts het Besluit van 11 september 1981, no. 3, Stcrt 1981177 (ministerie van Sociale Zaken en Werkgelegenheid).

31. Beschikking van 24 december 1941 , no. 1132 Kabinet Afdeling Comptabiliteit; archief directoraat-generaal van de arbeid. Zie ook $A$. Buyteweg, Inventaris archief van de afdeling Arbeid II, later de afdeling Arbeidswerhoudingen 1942 - 1949, 's-Gravenhage 1982, blz. 45 - 46.

32. Beschikking van 28 oktober 1947, Afdeling Personeel; archief directoraat-generaal van de Arbeid.

33. Hand. Tweede Kamer, zitting 1908 - $1909 \mathrm{II}, \mathrm{blz} .2146 \mathrm{t} / \mathrm{m} 2148$.

34. Bijlagen Tweede Kamer, zitting 1908 - 1909, 211.3 (memorie van toelichting) blz. $1 \mathrm{t} / \mathrm{m} 4$.

35. Zie Hand. Tweede Kamer, zitting $1908-1909$ II, blz. $2149-2150$.

36. Hand. Tweede Kamer, zitting 1908 - 1909 II, blz. $2154 \mathrm{t} / \mathrm{m} 2157$.

37. Hand. Tweede Kamer, zitting $1908-1909 \mathrm{II}, \mathrm{blz} .2150 \mathrm{t} / \mathrm{m} 2152$. 
38. Schaper had het over de verhouding van de arbeidsinspectie tot het ministerie van Arbeid. Hij kan niet anders bedoeld hebben dan de afdeling arbeid, omdat het bewuste departement eerst in 1918 zou worden ingesteld.

39. Hand. Tweede Kamer, zitting 1908 - $1909 \mathrm{I}$, blz. $2153 \mathrm{t} / \mathrm{m} 2155$.

40. Socizal-technische Vereeniging van democratische ingenieurs en architecten, brief van 20 maart 1909 met als bijlage: De reorganisatie der Arbeidsinspectie, zie ook Hand. Tweede Kamer, zitting $1908-1909$ I, blz. 2145.

41. Brief van 9 oktober 1922 , no. 6237 (voorbereiding van wetsontwerpen); archief directoraat-generaal van de arbeid.

42. De volgende passage, ontleend aan de bewuste brief, diende ter onderbouwing van deze opmerking: "Voor alle door Uwe Excellentie te nemen beslissingen, zelfs de eenvoudigste, moet, nadat zij geheel met kennis der feiten door de Arbeidsinspectie zijn voorbereid, een ambtenaar aan Uw Departement ( en uit den aard van het werk kan dat geen lage ambtenaar zijn ) zich de moeite geven zich geheel in te werken, teneinde een brief te concipiëren ter voorlegging aan Uwe Excellentie, voor welken brief hij en de chef der afdeeling verantwoordelijkheid hebben te dragen. De dubbele behandelingen, eerst bij de Arbeidsinspectie en daarna aan het Departement, geschieden na elkaar en geheel los van elkaar, behoudens het overleg, dat bij de tweede behandeling dikwijls met mij gepleegd wordt".

43. Het zal niemand verbazen, dat C.C.A. Last, districtshoofd van de arbeidsinspectie in zijn artikel over de arbeidsinspectie in Sociale Voorzorg 1923 een zelfde soort voorstel deed.

44. Nota van 7 november 1922; archief directoraat-generaal van de Arbeid.

45. Als "kras staaltje" van dergelijke casuistiek gaf Westhoff artikel 11 van het ontwerp-Landarbeiderswet. Dit artikel luidde als volgt:

"In de artikelen 12 tot en met 22 wordt de landbouwarbeid gerekend te beginnen by de komst op het werk en te eindigen by het verlaten daarvan, tenzy de plaats waar de arbeid moet worden verricht meer dan een half uur gaans verwyderd is van het dichtst by die plaats gelegen uitgangspunt voor den betrokken arbeider, in welk geval de arbeid gerekend wordt zooveel vroeger aan te vangen als noodig is om van het werk te voet of met het ter beschikking van den arbeider zynde vervoermiddel het eerder genoemde uitgangspunt te bereiken. Wanneer niet een dichter by het werk gelegen uitgangspunt als zoodanig kan gelden, wordt als uitgangspunt beschouwd de boerdery of de bedryfsgebouwen, waar door den arbeider in den regel wordt gewerkt".

46. De directeur-generaal van de Arbeid had gesteld, dat de afdeling Arbeid met 5 juristen en nog enige ambtenaren was uitgebreid. Het hoofd van de afdeling arbeid weerlegde dit met het argument, dat al sinds jaren 4 juristen werkzaam waren en dat het enige verschil was, dat nu 5 juristen aan de afdeling waren verbonden in plaats van 4 en dat het aantal ambtenaren van 11 in 1918 tot 14 was gekolommen. Vergelijking van dit aantal bij de toename van het aantal ambtenaren van de arbeidsinspectie - 139 volgens de begroting van 1918 en 237 volgens de begroting van 1923 - leerde volgens Westhoff, dat de stijging bij zijn afdeling gering was. 
47. Zie de brief van 22 november 1922 , no. 16648 Kabinet (van de hand van de directeur-generaal van de Arbeid); brief van 29 november 1922, no. 17096 Kabinet (idem); nota van 16 januari 1923 (van de hand van het hoofd afdeling Arbeid); brief van 9 februari 1923, no. 57 Kabinet (van de hand van de bewindsman) met als bijlage een beschouwing van de secretaris-generaal; brief van 12 februari 1923, no. 1628 Kabinet (directeur-generaal van de Arbeid); brief van 12 mei 1923, no. 4994 (idem); brief van 14 mei 1923, 5032 Kabinet (idem); nota van 9 augustus 1923 (hoofd afdeling Arbeid). Zie archief directoraat-generaal van de Arbeid.

48. Tweede Kamer, zitting 1922 - 1923, no. 2.6 ( Hfdst. Xa begroting Arbeid) blz. 1.

49. Tweede Kamer, zitting 1922 - 1923, no. 2.7 (Hfdst. Xa begroting Arbeid ) blz. 1 - 2.

50. Hij gaf daarbij dezelfde cijfers als het hoofd van de afdeling Arbeid Westhoff in zijn nota van 7 november 1922.

51. De bewindsman noemde als zodanig de uitvoering van de Stoomwet, de Hinderwet, de regeling van de arbeidsvoorwaarden van rijkswerklieden, de voorbereiding van een wettelijke regeling voor de vreedzame bijlegging van geschillen over arbeidsaangelegenheden en het in studie nemen van het vraagstuk van de publiekrechtelijke bedrijfsorganisatie en wat daarmee samenhangt; zie Tweede Kamer, zitting 1922 - 1923 , no. 2.7 ( Hfdst. Xa begroting Arbeid) blz. 2.

52. Hand. Tweede Kamer, zitting 1922 - $1923 \mathrm{II}$, blz. 378.

53. Hand. Tweede Kamer, zitting 1922 - 1923 II, blz. $378-379$.

54. Hand. Tweede Kamer, zitting 1922 - 1923 II, blz. 379.

55. In het Centraal Verslag Arbeidsinspectie over 1950 , blz. 4, wordt voor het eerst melding gemaakt van een juridische afdeling. In het Centraal Verslag Arbeidsinspectie over 1948, blz. 4, wordt voor het eerst melding gemaakt van een afzonderlijke jurist-ambtenaar en wel E. Tinga.

56. Besluit van de minister van Sociale Zaken en Volksgezondheid van 21 december 1961, bur.S.-G., no. 771/G; zie persbericht van 29 december 1961 no. 1739 en het Jaarverslag van de Arbeidsinspectie over 1962, blz. 1. Opgemerkt moet worden, dat tevens een band gelegd werd tussen de directie van de Arbeid - gezien als departementale afdeling - en de dienst voor het stoomwezen, welke dienst aanwankelijk onder de afdeling Arbeidsverhoudingen ressorteerde. Ook de aangelegenheden terzake van de Hinderwet gingen van deze departementale afdeling over naar de nieuwe directie. De sector pensioen- en spaarfondsen van de afdeling Arbeidersbescherming daarentegen werd ondergebracht bij de afdeling Sociale Verzekering.

57. Zie het Jaarverslag van de Arbeidsinspectie over 1964, 's-Gravenhage 1965, blz. 2.

58. Deze afdeling bestaat sinds 1950; zie het Centraal Verslag Arbeidsinspectie over 1950, blz. 4.

59. In totaal bedroeg het personeelsbestand van de directie van de arbeid 106 personen. Ter vergelijking: in de 10 districten van de arbeidsinspectie waren in totaal 322 personen werkzaam.

60. Jaarverslag van de Arbeidsinspectie over 1968, 's-Gravenhage 1969, blz. 11.

61. Met ingang van 1 november werd C.J.H. van Daatselaar tot kernfysisch-adviseur benoemd; zie besluit van 7 november 1968, Stcrt. 19694. 
62. Raadgevend efficiency bureau Bosboom en Hegener NV, Rapport betreffende het onderzoek naar de organisatie van het Directoraat-Generaal van de Arbeid van het Departement van Sociale Zaken en Volksgezondheid, Amsterdam 21 februari 1968/2150 ( hierna Rapport Bosboom en Hegener).

63. Zie Rapport Bosboom en Hegener, blz. 6 - 7. Voor deze analyse maakten zij gebruik van een bijdrage in Arbeid op de Tweesprong, Opstellen, uitgegeven ter gelegenheid van het vijfenzeventigjarig bestaan der arbeidsinspectie, "s-Gravenhage 1965, blz. $155 \mathrm{t} / \mathrm{m}$ 160, getiteld; Arbeid en Arbeidsinspectie.

64. Rapport Bosboom en Hegener, blx. 7.

65. Als gevolg van het feit, dat hij een eigen afdeling beheerde, zodat hij aan de problemen van de topleiding niet toekwam; Rapport Bosboom en Hegener, blz. 10.

66. Als gevolg van de te verwachten ontwikkelingen in de cconomische, sociaal-economische en intermenselijk probleemvelden, aldus het Rapport Bosboom en Hegener, blz, 11.

67. Dat wil zeggen alle cijfermatige presentatie van informatie; Rapport Bosboom en Hegener, blz. 11.

68. Dat wil zeggen de directeur-generaal, diens plaatsvervanger en de toegevoegde secretaris; Rapport Bosboom en Hegener, blz. 12.

69. Rapport Bosboom en Hegener, blz. $9 \mathrm{t} / \mathrm{m} 12$.

70. De taak van de secretaris werd ook bij het wegvallen van het sociaal-economische element zeer omvangrijk en zinvol geacht:

1. supervisor van de administratie en als zodanig hoogste lijnfunctionaris in de administratieve "produktie"sector;

2. assistent van het districtshoofd met delegatie van een gedeelte van diens bevoegdheden, speciaal op helt terrein van de wetskennis;

3. staf-employee ten behoeve van de bestudering en/of voorbereiding van diverse onderwerpen, die behoren bij diverse functies van het districtshoofd;

4. secretaris van het districtshoofd in de strikte betekenis van deze term zelf;

5. werkzaamheden als praktijkjurist.

Zie Rapport Bosboom en Hegener, blz. 16.

71. Met opzet werd de geneeskundige genoemd, ondanks het feit, dat het districtshoofd uiteraard nooit verantwoordelijk kan worden gesteld voor de medische aspecten. Zie Rapport Bosboom en Hegener, blz. 17.

72. Zie Rapport Bosboom en Hegener, blz. 14 t/m 19.

73. Jaarverslag van de Arbeidsinspectie over 1969, "s-Gravenhage 1970, blz. 9.

74. Met ingang van 1 maart 1969 werd als plaatsvervanger benoemd ir. M.H. Steenbergen, voorheen hoofdinspecteur-directeur, hoofd van de algemene dienst bij het directoraat-generaal van de Arbeid.

75. Beschikking van 31 januari 1962, no. $5102 \mathrm{a}$, waarbij tot wederopzegging een werkweek van arbeiders van 18 jaar of ouder werd toegestaan van 5-maal 9uren. Bij beschikking van 15 februari 1963, no. 115, werd een dergelijke algemene vergunning verleend ten aanzien van 16-en 17-jarige arbeiders, voor zover deze in de avonduren geen vormend of op hun vak gericht onderwijs volgden. 
76. Zie de ministeriële vergunningen van 28 juni 1967, nos. 5705 a (arbeiders van 18 jaar of ouder 5-maal 8,75 uur of 5-maal 9 uren) en 5705 b (voor 16- en 17-jarigen).

77. Jaarverslag van de arbeidsinspectie over 1962, 's-Gravenhage 1963, over 1963, 's-Gravenhage 1964, over 1964 ,'s-Gravenhage 1965 , over 1965, 's-Gravenhage 1966, over 1966, 's-Gravenhage 1967, over 1967, 's-Gravenhage 1969, over 1968, 's-Gravenhage 1970, resp. blz. 11 en $23-24$, blz. 9 en $27 \mathrm{t} / \mathrm{m} \mathrm{29}$, blz. 9 en 22, blz. 9 en 26, blz. 9 en $25-26$, blz. 11 en 38 en blz. 16 en 36. De arbeidsinspectie Verslag over 1971 - 1973, 'sGravenhage 1975, blz. 22. Jaarverslag Arbeidsinspectie 1974 en 1975, Voorburg 1976, blz. 19.

78. Jaarverslag van de Arbeidsinspectie over 1963 en over 1970, resp. blz. 29 en blz. 37. Vanaf 1971 wordt een dergelijke informatie niet meer in het jaarverslag vermeld.

79. Wet van 1 november 1962, Stb. 465. Deze wet beoogde destijds de verruiming van de mogelijkheden topt het wederverkopen van brood, die zou ontstaan bij het vervallen van het Erkenningsreglement Wederverkopers Bakkersartikelen, Voedselvoorzieningsblad 1946, 42, geleidelijk te doen verlopen. De verkoop en distributie van brood bleef daardoor nog gedurende een periode van 5 jaren aan bakkersondernemingen voorbehouden. Zie Jaarverslag van de Arbeidsinspectie over 1968, blz. 40.

80. Daarbij werd voorgesteld toe te staan, dat vers brood zou mogen worden verkocht en afgeleverd op werkdagen vanaf 08.00 uur, de bakkersarbeid van gezellen in niet in ploegen werkende bakkerijen met 1 uur te vervroegen alsmede het verrichten van nachtarbeid door hoofden of bestuurders van bakkerij-ondernemingen. Zie Jaarverslag van de Arbeidsinspectie over 1967, blz. 44.

81. Het aantal broodbakkerijen bedroeg op 1 juli 1968 volgens de Nederlandse Bakkerij Stichting 6253, waarvan 1549 é́nmansbedrijven, die in de enquête praktische niet vertegenwoordigd waren; zie Jaarverslag van de Arbeidsinspectie over 1968, blz. 41.

82. Jaarverslag van de arbeidsinspectie over 1962, over 1963, over 1964, over 1965, over 1966, over 1967, over 1968, over 1969, over 1970, resp. blz. 27 - 28, blz. 30 - 31, blz. 27 - 28, blz. 31 - 32, blz. blz. 30 - 31, blz. 44, blz. 40 t/m 42, blz. 41 en blz. 40. De Arbeidsinspectie Verslag over 1971 - 1973, blz. 23 - 24.

83. Wet van 25 juni 1975 , Stb. 403.

84. Wet van 25 juni 1975, Stb. 403. Ingevolge het Besluit van 19 december 1975, Stb. 770 is de arbeid in broodbakkerijen opgenomen in paragraaf $19 \mathrm{a}$ van genoemd werktijdenbesluit.

85. Zie Tweede Kamer, zitting 1973 - 1974, 12939.3 (memorie van toelichting) blz. 5.

86. Zie de artikelen 33 en 42 van het bedoelde werktijdenbesluit.

87. In én geval bestond geen behoefte meer aan deze aanvulling op de normale ploegenarbeid, hoewel de 8 overgebleven arbeiders bedoelde werkwijze liever hadden voortgezet. In het tweede bedrijf verkoos de enig overgebleven arbeider weer in de normale ploegendienst terug te keren. In het derde bedrijf bleek een gebrek aan contact te bestaan tussen de enig overgebleven arbeider in deze nachtdienst en de directie. Zie Jaarverslag van de Arbeidsinspectie over 1965, blz. 26.

88. Eén en ander in verband met het verbod van nachtarbeid voor vrouwen in fabrieken of werkplaatsen; zie artikel 30, eerste lid, van de Arbeidswet 1919 ( oud ). 
89. In 1967 was het aantal arbeiders, die in dit bedrijf permanente nachtarbeid verrichtten opgelopen tot 70 , waarwan 65 ex-mijnwerkers; zie Jaarverslag van de Arbeidsimspectie over 1967, blz. 27.

90. Jaarverslag van de Arbeidsinspectie over 1964, over 1965, over 1966, over 1967, over 1968, over 1969 en over 1970, resp. blz, 22, blz, 26, blz. 25, blz, 27, blz, $31 \mathrm{t} / \mathrm{m} 34$, blz. $29 \mathrm{t} / \mathrm{m} 31 \mathrm{en} \mathrm{blz.} 29 \mathrm{t} / \mathrm{m}$ 31. Jaarverslag Arbeidsinspectie 1974 en 1975 , blz, 20. Het Arbeidsinspectie Verslag over 1971 - 1973 vermeldt geen nadere informatie meer over het verrichten van permanente nachtarbeid.

91. De Arbeidsinspectie. Verslag over 1971 - 1973, blz. $20-21$.

92. Van 05.00 uur tot 14.00 uur en van 14.00 uur tot 23.00 uur met inbegrip van een half uur rust; zie ook artikel 33 van het Werktijdenbesluit voor fabrieken of werkplaatsen 1936.

93. Resp. van 08.00 uur tot 17.00 uur en 23.00 uur tot 08.00 uur met inbegrip van rust. Overigens zij opgemerkt, dat voor een dergelijk twee-ploegenstelsel een vergunning van het districtshoofd van de arbeidsinspectie noodzakelijk is.

94. Wisselde men vroeger nagenoeg unaniem om 06.00 uur, 14.00 uur en 22.00 uur, thans werden vaak verschuivingen gezien met 1,5 uur naar 730 uur, 15,30 uur en 23.30 uur.

95. Zie Jaarververslag van de Arbeidsinspectie over 1967, blz. 34 t/m 38. De Arbeidsinspectie. Verslag over $1971-1973$, blz. 20 - 21.

96. Zie hierover J. van Drongelen, Variabelle werktijdregeling. Van experiment naar een algemene vergunning, in S.M.A. 1986 blz. $297 \mathrm{t} / \mathrm{m} 306$.

97. Advies Stichting van de Arbeid, brief van 7 juli 1972, no. S.A. 35.043/E/Bu.

98. SER-advies inzake variabele werktijden, $1975 / 1$

99. De arbeidsduur per dag mocht ten hoogste 9 uren bedragen; de normaal geldende arbeidsduur per week mocht met ten hoogste 4 uren worden overschreden; het aantal te sparen uren mocht ten hoogste 10 bedragen; de invoering van de zgn. "bloktijd" ofwel aanwezigheidstijd en het verbod van arbeid op zaterdag.

100. Advies van de Stichting van de Arbeid van 8 april 1983, no. S.A. $457 /$ VI/Bu.

101. Beschikking van 29 november 1985, Stcrt. 258.

102. De maximale arbeidsduur per dag mocht niet meer dan 9 uren bedragen, terwijl per week niet meer dan 45 uren mocht worden gewerkt; de zgn. "bloktijd" werd minder dwingend en het aantal te sparen uren werd niet beperkt, zij het dat het aantal gespaarde uren binnen een tijdvak van 26 weken diende te worden opgenomen.

103. Ingewoerd bij de wijziging van de Arbeidswet 1919 bij de Wet van 22 jnauri 1966, Stb. 30 .

104. Deze nota werd op 15 september van dat jaar de Tweede Kamer aangeboden; zie Tweede Kamer, zitting $1970-1971,10904.1$ en 2.

105. Wet van 30 mei 1968 , Stb. 303 . 
106. Zie B.S. Frenkel, Scholing en vakopleiding als sociaal recht, Tilburg 1986, blz. $1 \mathrm{t} / \mathrm{m}$ 3. Zie ook de Nota partiële leerplicht die op 22 meli 1974 aan de Tweede Kamer werd aangeboden (Tweede kamer, zitting 1973 - 1974, 12930.1 en 2.) en de op 26 mei 1975 aan de Tweede Kamer aangeboden Nota naar het participatieonderwijs ( Tweede Kamer, zitting 1974 - 1975, 13415.1 en 2).

107. Wet van 6 mei 1971, Stb. 356. Tevens werd bij deze gelegenheid een aantal andere wetten gewijzigd.

108. Wet van 2 juli 1975 , Stb. 387.

109. Wet van 25 juni 1975 , Stb. 403.

110. Sedert de wijziging van de Leerplichtwet 1969 bij de Wet van 22 december 1983, Stb. 727 , geldt een periode van 11 jaren. Deze verlenging van de leerplicht gebeurde niet door de leeftijdsgrens van 16 jaar te verhogen, maar door de leerplicht te laten aanvangen op de eerste schooldag van de maand die volgt op die waarin de leeftijd van 5 jaar is bereikt.

111. Zie de artikelen 3, 4a en $4 b$ van de Leerplichtwet 1969.

112. Besluit van 11 juli 1975 , Stb. 392 .

113. Zie B.S. Frenkel, t.a.p., blz. 3 - 4.

114. Zie B.S. Frenkel, t.a.p., blz. $4-5$.

115. Besluit van 29 maart 1963, Stb. 98 ( in werking getreden op op 1 juli van dat jaar ).

116. Jaarverslag van de Arbeidsinspectie over 1962 en over 1968, resp. blz. 39 en blz. 54. Jaarverslag Arbeidsinspectie 1974 en 1975, blz. 103 en blz. $108 \mathrm{t} / \mathrm{m} 110$.

117. Jaarverslag van de Arbeidsinspectie over 1967, blz. 53. Jaarverslag Arbeidsinspectie 1974 en 1975 , blz. 112.

118. Jaarverslag van de Arbeidsinspectie over 1962 , over 1963, over 1964, over 1965 en over 1966, resp. blz. 37 , blz. 40 , blz. 36 , blz. 42 en blz. 40 .

119. Jaarverslag van de Arbeidsinspectie over 1962 en over 1963, resp. blz. 38 en blz. 40 .

120. Jaarverslag van de Arbeidsinspectie over 1964 en over 1965, resp. blz. 37 - 38 en blz. 41.

121. Jaarverslag van de Arbeidsinspectie over 1963 en over 1964, resp. blz. 43 - 44 en blz. 40 - 41 . In de loop van 1967 werden aan de beide bedoelde bewindslieden het rapport "Nitraathoudende Meststoffen" en het rapport "Chloor" aangeboden.

122. Wet van 19 april 1947 , Stb. H. 123.

123. Besluit van 13 augustus 1948, Stb. I.368.

124. Wet van 5 april 1951 , Stb. 96 . 
125. Wet van 12 juli 1962 , Stb. 288 .

126. Zie par. 2 van de Bestrijdingsmiddelenwet 1962.

127. Zie artikel 13 , eerste lid, van de Bestrijdingsmiddelenwet en het onder meer hierop gebaseerde Bestrijdingsmiddelenbesluit, Stb. 1964328.

128. Tweede Kamer, zitting 1960 - 1961, 6014.6.

129. Tweede Kamer, zitting 1960 - 1961, 6014.5 (memorie van antwoord) blz. 13 .

130. Zie Tweede Kamer, zitting 1959 - 1960, 6014.3 (memorie van toelichting ) blz, 9. Zie ook Jaarverslag van de Arbeidsinspectie over 1965 , blz. $155 \mathrm{t} / \mathrm{m} 157$.

131. Het merendeel betrof de verplichting bestrijdingsmiddelen in een deugdelijke bewaarplaats achter slot op te bergen (artikel 8 van het Bestrijdingsmiddelenbesluit), de deugdelijkheid van de bewaarplaatsen (artikel 9 van het genoemde besluit) en de persoonlijke beschuttingsmiddelen en de te nemen hygiënische maatregelen (artikel 6 van het genoemde besluit). Zie Jaarverslag van de Arbeidsinspectie over 1966 , blz. 111.

132. Jaarverslag van de Arbeidsinspectie over 1966, over 1967, over 1968, over 1969 en over 1970, resp. blz. 111, blz. 136, blz. 112, blz. 134 en blz. 108. Jaarverslag Arbeidsinspectie 1974 en 1975, blz. 111.

133. Tweede Kamer, zitting 1956 - 1957, 4727.

134. Wet van 21 februari 1963 , Stb. 82 .

135. Zie artikel 72 , eerste lid, van de Kernenergiewet.

136. Tweede Kamer, zitting 1959 - 1960, 5861.3 ( memorie van toelichting ) blz. 11 t/m 13.

137. Zie artikel 18, vierde lid, van de Kernenergiewet.

138. Tweede Kamer, zitting 1959 - 1960, 5961.3 ( memorie van toelichting ) blz. 17.

139. Zie beschikking van 24 november 1969 , Stcrt. 239.

140. Zie artikel 83 van de Kernenergiewet.

141. Bij de behandeling van deze projecten was de medewerking van de dienst voor het stoomwezen voor het beoordelen van alle onderdelen van deze projecten, die onder druk kwamen te staan, onmisbaar. Ook werd yan de waardevolle adviezen, die in vele gevallen door de inspectie voor het brandweerwezen werden verstrekt, gebruik gemaakt. Zie Jaarverslag van de Arbeidsinspectie over 1964, blz. 100.

142. Jaarverslag van de Arbeidsinspectie over 1964, blz. $100-101$.

143. Jaarverslag van de Arbeidsinspectie over 1966, blz. 104; Jaarverslag Arbeidsinspectie 1974 en 1975 , blz. 72. 
144. De ingebruikstelling van de kerncentrale te Borssele vond plaats in september 1973. Zie Jaarverslag Arbeidsinspectie 1974 en 1975 , blz. 71 .

145. Er werd al gedacht aan de bouw van een derde kerncentrale.

146. Jaarverslag van de Arbeidsinspectie over 1969, blz. $124-125$.

147. Tweede Kamer, zitting 1974 - 1975, 13122.2.

148. Ter illustratie: de kerncentrale te Dodeweerd was gestart met een vermogen van 164,3 megawatt thermisch. Overigens zou in 1972 vergunning worden gevraagd om dit vermogen op te voeren tot 184 megawatt. Zie De Arbeidsinspectie. Verslag over 1971 - 1973, blz. 83; zie ook Tweede Kamer, zitting 1974 - 1975, 13122.2 blz. 129 t/m 131.

149. Advies over de veiligheidsaspecten van de splijtstofcyclus in Nederland, Voorburg september 1975 ( revisie maart 1976 ).

150. Jaarverslag Arbeidsinspectie 1974 en 1975, blz. 71 - 72.

151. Besluit van 10 september 1969, Stb. 404.

152. Besluit van 15 mei 1963, Stb. 233.

153. Jaarverslag van de Arbeidsinspectie over 1970, blz. 103. De Arbeidsinspectie Verslag 1971 - 1973 , blz. 83. Ook dit is alle informatie die in de jaarverslagen is te vinden.

154. Jaarverslag van de Arbeidsinspectie over 1970, blz. 103 - 104. Verder is in de jaarverslagen hierover geen informatie te vinden.

155. Tweede Kamer, zitting 1961 - 1962, 6570.3 (memorie van toelichting ) blz. 5 .

156. Wet van 20 juni 1963 , Stb. 313 .

157. Tweede Kamer, zitting 1962 - 1963, 6570.4 ( voorlopig verslag) blz. 1.

158. Artikel 1 van de Wet Gevaarlijke Stoffen bepaalt, dat deze wet op de handelingen, bedoeld in de artikelen 3, eerste lid, 4, eerste lid, en 7, eerste lid, van toepassing is voor zover daarin niet is voorzien bij of krachtens de Phosphorluciferwet 1901, de Mijnwet 1903, de Schepenwet, de Stuwadoorswet, de Arbeidswet 1919, de Opiumwet, de Huisarbeidswet 1933, de Veiligheidswet 1934, de Warenwet ( Stb. 1935793 ), de Wet op de gevaarlijke werktuigen, de Brandweerwet, de Postwet 1954 en de Destructiewet.

159. Tweede Kamer, zitting 1962 - 1963, 6570.5 (memorie van antwoord ) blz. 1.

160. Zie artikel 7, eerste lid, van de Wet Gevaarlijke Stoffen en het daarop gebaseerde Besluit Aflevering Gevaarlijke Stoffen ( Stb. 1979764 ). Het genoemde artikel zou bij de Wet milieugevaarlijke stoffen (Stb. 1985639 ) worden ingetrokken, terwijl dit met het genoemde besluit zou gebeuren in het Beslluit verpakking en aanduiding milieugevaarlijke stoffen ( Stb. 198898 ). 
161. Tweede Kamer, zitting 1962 - 1963, 6570.3 (memorie van toelichting) blz. 8. Eén en ander werd witgewerkt in het Reglement Gevaarlijke Stoffen ( Stb. 1968207 ).

162. Zie Tweede Kamer, zitting 1962 - 1963, 6570.4 (voorlopig verslag) blz. 1. In dat kader werd onder meer gewezen op het feit, dat in artikel 2 , onder b, van het wetsvoorstel het "opslaan" van gevaarlijke stoffen krachtens een ingevolge de Hinderwet verleende vergunning buiten het in dat artikel gebezigde begrip "nederleggen" werd gehouden. Blijkens de toelichting was deze redactie met opzet gekozen teneinde niet alleen die gevallen van opslag onder het bereik van de (nieuwe) wet te brengen, waarvoor geen Hinderwetvergunning vereist was, maar ook de gevallen, waarbij een dergelijke vergunning wel vereist was, maar (nog) niet was verleend. Men vroeg zich af of dit juist was, daar niet alleen de procedure van de Hinderwet zich niet leende voor de beoordeling van dergelijke situaties, maar deze tijdelijke opslag niet gebeurde in inrichtingen die tot bewaring van gevaarlijke stoffen "bestemd" waren of "pleegden te worden gebezigd" (zie artikell 1 van het Hinderbesluit). Deze twijfel werd overigens door de bewindslieden onderschreven; zie Tweede Kamer, zitting $1962-1963,6570.5$ (memorie van antwoord) blz. 2.

163. Tweede Kamer, zitting 1961 - 1962, 6570.3 (memorie van toelichting) blz. 8. Zie artikel 7, eerste lid, van de Wet Gevaarlijke Stoffen.

164. Zie artikel 11, eerste lid, onder b, van de Wet Gevaarlijke Stoffen. Tevens werden hiermede belast:

a. de kommandant en de controleurs van het Korps Controleurs Gevaarlijke Stoffen;

b. de ambtenaren van de inspectie van de havenarbeid;

c. de hoofden van laboratoria en de ambtenaren van de keuringsdiensten van waren ( zie de artikel 18 en 33, tweede lid, van de Warenwet ( Stb. 1935793 );

d. de farmaceutische inspecteurs van de volksgezondheid;

e. andere door de minister van Verkeer en Waterstaat, van Sociale Zaken en Volksgezondheid of van Defensie daartoe aangewezen ambtenaren.

165. Zie artikel 11, tweede lid, van de Wet Gevaarlijke Stoffen. Overigens was de constructie ten aanzien van de opsporing aldus, dat de ambtenaren belast met de naleving van de gegeven voorschriften tevens tot taak hadden de opsporing van overtredingen en dat naast de in artikel 141 van het Wetboek van Strafvordering genoemde personen, ambtenaren tangewezen konden worden die alleen een opsporingstaak kregen (zie ook Tweede Kamer, zitting 1961 - 1962, 6570.3 (memorie van toelichting) blz, 11).

166. Besluit van 19 april 1968, Stb. 207.

167. Andere commissies zijn: de vaste commissie vervoersaangelegenheden, de commissie "bouw en uitrusting tankschepen", de commissie "verontreiniging van de zee", IMCO Maritime Safety Committee, IMCO Subcommittee "Ship design and equipment". Zie De Arbeidsinspectie Verslag over 1971 - ,1973, blz. 108. Jaarverslag Arbeidsinspectie 1974 en 1975, blz. 95. Meer informatie is in de jaarverslagen helaas niet te vinden.

168. Tweede Kamer, zitting 1967, 9069.3 (memorie van toelichting) blz. 1.

169. Wet van 20 juli 1967, Stb. 428. De gewijzigde wettekst is opnieuw volledig gepubliceerd in Stb. 196844 . De Wet op het werken onder overdruk zou worden ingetrokken bij de Arbeidsomstandighedenwet (zie artikel 46 , eerste lid, van die wet ).

170. Resp. het Besluit van 6 augustus 1968, Stb. 435, en het Besluit van 26 oktober 1970, Stb. 531 .

171. Tweede Kamer, zitting 1968 - 1969, 9816.3 (memorie van toelichting ) blz. 12. 
172. Tweede Kamer, zitting 1968 - 1969, 98163 (memorie van toelichting) blz. 12 - 13. De bewindsman wijdde vervolgens een aantal afzonderlijke paragrafen aan de invloeden van luchtverontreiniging op de menselijke gezondheid en op planten, dieren, gebouwen en goederen in ons land.

173. Tweede Kamer, zitting $1968-1969,9816.3$ (memorie van toelichting ) blz. $16 \mathrm{t} / \mathrm{m} 19$.

174. Wet van 26 november 1970 , Stb. 580 .

175. Een zelfde adviesrecht kwam ingevolge artikel 25 van de wet toe aan de inspecteur van het staatstoezicht op de volksgezondheid.

176. Tweede Kamer, zitting 1968 - 1969, 9816.3 (memorie van toelichting ), blz. 27.

177. De Arbeidsinspectie Verslag over 1971 - 1973, blz. 107. Jaarverslag Arbeidsinspectie $1974 \mathrm{en} 1975$, blz. 94 en blz. 125 .

178. Artikel 6 , eerste lid, van de Wet op de ondernemingsraden.

179. FJ.H.M. van der Ven, Bedrijfsleven en democratie, Leiden 1955, blz. 164 t/m 166.

180. Tweede Kamer, zitting 1947 - 1948, 884.3 (memorie van toelichting ) blz. 7.

181. Dit onderscheid is afkomstig van J.F.P. Dijkhuis, De rechtsgrond van de medezeggenschap. Een onderzoek naar de gezagswerhoudingen in de onderneming, Leiden 1938, blz. 17 - 18; zie ook I.A.C. van Haren, De ondernemingsraad. Een handleiding, Deventer 1979, blz. 7 - 8 .

182. Herziening van het ondernemingsrecht. Rapport van de Commissie ingesteld bij beschikking van de Minister van Justitie van 8 april 1960, 's-Gravenhage 1965 ( hierna Rapport commissie-Verdam ).

183. Rapport commissie-Verdam, blz, 86 t/m 97; zie ook Tweede Kamer, zitting 1969 - 1970, 10335.3 ( memorie van toelichting ) blz. 12 .

184. SER, Advies inzake uitbreiding bevoegdheden ondernemingsraden 1968/13.

185. Zie I.A.C. van Haren, t.a.p., blz 8 ; Tweede Kamer, zitting 1969 - 1970, 10335.3 ( memorie van toelichting ) blz. $12-13$.

186. Tweede Kamer, zitting 1969 - 1970, 10335.3 ( memorie van toelichting) blz. 13.

187. Zie artikel 48 van de Wet op de ondermemingsraden.

188. Tweede Kamer, zitting 1969 - 1970, 10335.3 (memorie van toelichting ) blz. 28.

189. Het Kamerlid Rietkerk; zie ook Hand. Tweede Kamer, zitting $1969-1970$, blz. $63-64$.

190. Tweede Kamer, zitting 1969 - 1970, 10335.5 ( voorlopig verslag ) blz. 21.

191. Tweede Kamer, zitting 1969 - 1970, 10335.6 (memorie van antwoord) blz. 18; zie ook Tweede Kamer, zitting 1969 - 1970, blz. 64 . 
192. Zie Verslag van de kleine enquête inzake de Wet op de ondernemingsraden, (november) 1972; Wet op de ondernemingsraden. Verslag van de enquête naar de toepassing van de Wet op de ondermingsraden in 1973, (december) 1974 .

193. De Arbeidsinspectie. Verslag over 1971 - 1973, blz. 105 - 106. Jaarverslag Arbeidsinspectie 1974 en 1975, blz. $92-93$.

194. De organisatiewijziging had voorts tot gevolg, dat de afdeling arbeidersbescherming van het departement en de centrale dienst van de arbeidsinspectie samengevoegd werden tot de directie van de arbeid, later het directoraat-generaal van de Arbeid, en dat een band werd gelegd tussen de directie van de arbeid en de dienst voor het stoomwezen. In 1964 werd de looncontroledienst vervangen door de loontechnische dienst ( zie beschikking van 7 juli 1964, Stcrt. 155), die evenals haar voorgangster, vanaf 1 januari 1962, viel onder de directie Sociale Voorzieningen en Arbeidsverhoudingen van het departement.

195. Jaarverslag van de Arbeidsinspectie over 1962, blz. 121 - 122.

196. Jaarverslag van de Arbeidsinspectie over 1963 en over 1965, resp. blz. 137 en blz. 152.

197. Jaarverslag van de Arbeidsinspectie over 1966, blz, 122.

198. Jaarverslag Arbeidsinspectie 1974 en 1975, blz, 2 en blz. 126.

199. Namelijk resp. 321.177 en 76.359 uren.

200. Namelijk 310.372 uren.

201. Jaarverslag van de Arbeidsinspectie over 1962, over 1963, over 1966 en over 1967, resp. blz. 123, blz. 138, blz. 123 - 124 en blz. 153 - 154. Jaarverslag Arbeidsinspectie 1974 en 1975, blz. 2.

202. Jaarverslag van de Arbeidsinspectie over 1962, blz. 115.

203. Jaarverslag van de Arbeidsinspectie over 1965, blz. 146.

204. Jaarverslag van de Arbeidsinspectie over 1962, over 1965 en over 1967, resp. blz. 119, blz. 150 en blz. 148.

205. De Arbeidsinspectie. Verslag over 1971 - 1973, blz. $25-26$.

206. Jaarverslag van de Arbeidsinspectie over 1964, blz. 144.

207. De Arbeidsinspectie. Verslag over 1971 - 1973, blz. 151; Jaarverslag Arbeidsinspectie 1974 en 1975 , blz. 141.

208. Jaarverslag der Arbeidsinspectie over 1962, over 1963, over 1964, over 1965 en over 1966, resp. blz. 124, blz. 139 , blz. 147 , blz. 155 en blz. 126 .

209. Bovendien werd de Land-en Tuinbouwongevallenwet 1922 buiten werking gesteld.

210. Bij Wet van 18 februari 1966, Stb. 85 . 
211. Beschikking van 21 juni 1967 , Stcrt. 124 .

212. Zie artikel 58 van de Ziektewet.

213. Jaarverslag der Arbeidsinspectie over 1967, blz. 4. Zie J.H.B.M. Willems, De melding van beroepsziekten. Een studie uitgevoerd in opdracht van het Directoraat-Generaal van de Arbeid door het Coronel Laboratorium, Universiteit van Amsterdam, Voorburg 1987, blz. 10.

214. Zie J.H.B.M. Willems, t.a.p., blz. 47.

215. Jaarverslag der Arbeidsinspectie over 1967 , blz. 4.

216. Zie onder meer Jaarverslag der Arbeidsinspectie over 1963, blz. 134.

217. Jaarverslag der Arbeidsinspectie over 1966, blz. 101.

218. Bij Besluit van 1 maart 1967, Stb. 172; in werking getreden op 1 mei 1967.

219. Bij deze wijziging werd overigens tevens gebruik gemaakt om onder meer de gasdrukregel- en meetstations, de skelterbanen en de opslagplaatsen van onder andere bestrijdingsmiddelen onder de Hinderwet te brengen.

220. Jaarverslag van de Arbeidsinspectie over 1967, blz. 127.

221. De Arbeidsinspectie. Verslag over 1971 - 1973, blz. 107; Jaarverslag Arbeidsinspectie 1974 en 1975 , blz. 94.

222. Jaarverslag van de Arbeidsinspectie over 1962, blz. 126 - 127.

223. Jaarverslag van de Arbeidsinspectie over 1962, blz. 127 - 128. Opgemerkt zij, dat in het Jaarverslag van de Arbeidsinspectie over 1964 voor het laatst een afzonderlijk hoofdstuk is opgenomen, dat gewijd is aan het sociaal welzijn en het bedrijfsmaatschappelijk werk in de onderneming.

224. Zie De Arbeidsinspectie. Verslag over 1971 - 1973, blz. 109. Jaarverslag Arbeidsinspectie 1974 en 1975, blz. 95 - 96. Alleen in deze beide jaarverslagen wordt melding gemaakt van deze activiteit.

225. De Arbeidsinspectie. Verslag over 1971 - 1973, blz. 109. Jaarverslag Arbeidsinspectie 1974 en 1975, blz. 95. 


\section{DE TOENEMENDE BELANGSTELLING VOOR DE ARBEIDSOMSTANDIGHEDEN EN KRITIEK OP DE ARBEIDSINSPECTIE: DE PERIODE 1975 TOT 1 MAART 1990}

\section{Inleiding}

\subsection{Toenemende belangstelling voor de arbeidsomstandigheden}

De belangstelling voor de arbeidsomstandigheden groeide in het midden van de jaren zeventig. De opvattingen over de kwaliteit van de arbeid en de arbeidsomstandigheden veranderen als gevolg van maatschappelijke en technische ontwikkelingen. Dit komt onder meer tot uitdrukking in de gedachten over volwaardige arbeid, de verbetering van de veiligheid en de gezondheid van werknemers in hun werkomgeving, sociale doelmatigheid in de arbeidsorganisatie en de kwalitatieve discrepantie tussen de vraag naar en het aanbod van werk. Deze onderwerpen worden ook wel aangeduid met de term "humanisering van de arbeid". In ons land heeft dat geleid tot een grotere aandacht van zowel de werkgevers- en werknemersorganisaties ${ }^{\prime}$ als de overheid voor de rol die zij hierbij dienen te vervillen.

De grotere aandacht van werkgevers- en werknemersorganisaties kan zijn weg vinden in het opnemen van bepalingen terzake in collectieve arbeidsovereenkomsten, zowel op bedrijfstaks- als ondernemingsniveau ${ }^{2}$. Uit een onderzoek van het loonbureau uit de jaren 1975 en $1976^{\circ}$ blijkt, dat van de 184 bij dit bureau geregistreerde collectieve arbeidsovereenkomsten er 107 bepalingen terzake bevatten, maar dat deze bepalingen grotendeels overeenkwamen met de bestaande wetgeving en zich met name richtten op algemene en organisatorische zaken en minder op technische veiligheidsvoorzieningen ${ }^{4}$. Geers ${ }^{5}$ verbindt hieraan de conclusie, dat weliswaar op grote schaal van deze mogelijkheid gebruik werd gemaakt, maar dat de praktische meerwaarde in verhouding tot de bestaande regelgeving niet erg groot is en het belang meer gezocht moet worden in de symbolische betekenis, dat de betrokken partijen zelf verantwoordelijk zijn voor behoorlijke arbeidsomstandigheden in de onderneming. Een onderzoek naar arbeidsomstandigheden in collectieve arbeidsovereenkomsten, verricht door de dienst collectieve arbeidswoorwaarden in de jaren 1985 en $1986^{6}$, laat zien, dat 18 van de 49 onderzochte collectieve arbeidsovereenkomsten in de bedrijfstakken bepalingen inzake arbeidsomstandigheden bevatten. Voor een deel gaat het om bepalingen waarin werkgevers en/of werknemers in algemene zin verplicht worden zorg te dragen voor veilige en gezonde arbeidsomstandigheden en/of voorschriften dienaangaande in acht dienen te nemen. Voor een ander deel betreft het afspraken met betrekking tot een of meer specifieke onderwerpen op het terrein van de arbeidsomstandigheden, bijvoorbeeld ten aanzien van werkkleding, een etiketteringssysteem, het dragen van veiligheidshelmen en ander veiligheidsmateriaal, de inhoud van een Arbo-beleidsplan. Een bellangrijke conclusie is, dat ten opzichte van het eerdere onderzoek een uitbreiding van afspraken in het kader van collectieve arbeidsovereenkomsten heeft plaatsgevonden. Zowel het aantal collectieve arbeidsovereenkomsten met afspraken over arbeidsomstandigheden is toegenomen, alsook het aantal afspraken in individuele collectieve arbeidsovereenkomsten ${ }^{7}$. Maar wel wordt geconstateerd, dat in veel gevallen over een bepaald onderwerp bepalingen letterlijk of met kleine wijzigingen gehandhaafd zijn. In andere gevallen zijn afspraken over een bepaald onderwerp verder uitgewerkt in vergelijking met het eerdere onderzoek. Speciale vermelding verdienen de collectieve arbeidsovereenkomsten voor het bouwbedrijf, voor het schilders- en afwerkingsbedrijf en voor het grafische bedrijf. voor deze bedrijfstakken zijn de collectieve arbeidsovereenkomsten voorzien van uitgebreide regelingen met betrekking tot ( het beleid inzake) arbeidsomstandigheden in vergelijking tot het eerdere onderzoek ${ }^{b}$. Ook Wouters ${ }^{\theta}$ constateert, na een onderzoek in 1987 naar een groot aantal collectieve arbeidsovereenkomsten, die door de Industriebond FNV zijn afgesloten, dat er in kwalitatieve zin weinig verbeterd is. Hoewel de wetgeving terzake gewijzigd is - gewezen dient te worden op de totstandkoming van de Arbeidsomstandighedenwet ${ }^{10}$, die een aantal oudere wetten vervangt - kan naar mijn mening de biervoor gememoreerde conclusie van 
Geers desalniettemin gehandhaafd blijven. De collectieve arbeidsovereenkomst lijkt veelal ten opzichte van de wetgeving op dit terrein een trendvolger te zijn ${ }^{1 /}$. Verandering hierin is zeker niet uitgesloten. Een aamzet daartoe is al gegeven. Gewezen kan allereerst worden op de op 1 januari 1988 in werking getreden collectieve arbeidsovereenkomst voor het bouwbedrijf, waarin bepalingen zijn opgenomen over het niet meer gebruiken van verpakkingseenheden (cement en dergelijke) die zwaarder zijn dan $25 \mathrm{~kg}$. en over het alleen met mechanische hulpmiddelen verwerken van metselblokken van $18 \mathrm{~kg}$. en meer ${ }^{12}$. Veel verdergaand is de bepaling in een aantal recent afgesloten collectieve arbeidsowereenkomsten waarin een gebruik van asbest wordt teruggedrongen en zelfs werboden ${ }^{13}$; in dit opzicht streeft de collectieve arbeidsovereenkomst de wetgeving terzake voorbij ${ }^{14}$. Bij het asbest deed trouwens een nieuw fenomeen, zij het indirect, zijn intrede in het arbeidsomstandighedenrecht. In februari 1989 sloot de minister van Volkshuisvesting, Ruimtelijke Ordening en Milienbeheer een convenant - "herenafspraak" - met de fabrikanten en importeurs van personenauto's en lichte vrachtwagens over de vervanging van asbesthoudende rem-en frictiematerialen ${ }^{15}$. Op 16 augustus gevolgd door een convenant over arbeidsomstandigheden bouwnijverheid ${ }^{t}$, dat eveneens werd ondertekend door de al bedoelde minister Nijpels ${ }^{17}$ en medeondertekend door de staatssecretaris van Sociale Zaken en Werkgelegenheid. De betrokken sociale partners in de bouw en de overheid vinden, dat een inspanning geboden is ter verbetering van de arbeidsomstandigheden in deze bedrijfstak. Dat draagt bij tot de vermindering van het ziekteverzuim, van arbeidsongeschiktheid en van het aantal ongevallen. Afgesproken is een intensivering van de voorlichting, een intensievere controle door de arbeidsinspectie terzake van de wettelijke verplichtingen en door de bedrijfstak zelf waar het bepalingen van de collectieve arbeidsovereenkomst betreft, het tegengaan van het gebruik van ongezonde en onveilige materialen en materieel, het streven naar het in de (rechts) verhouding tussen opdrachtgever en aannemer opnemen van aspecten betreffende de arbeidsomstandigheden en het ontwikkelen van voorbeeldprojecten op het gebied van arbeidsomstandigheden $^{18}$. Het betreft in feite een erkenning van de organisaties van werkgevers en werknemers dat het in eerste instantie op hun weg ligt om de arbeidsomstandigheden in de bedrijfstak te verbeteren, waarbij de overheid vanuit haar algemene verantwoordelijkheid voor veiligheid en gezondheid in arbeidssituaties haar bijdrage levert. Voorlopig zal de eerste tussentijdse evaluatie over naleving en uitvoering van dit convenant moeten worden afgewacht alvorens een oordeel hierover kan worden gegeven; wel is van belang daarbij te constateren, dat het convenant voornamelijk aan de betrokkenen een inspanningsverplichting oplegt.

\subsection{De rol van de overheid}

Betreffende de veranderende rol van de overheid in deze kan allereerst worden verwezen naar de toelichting op de begroting van het ministerie van Sociale Zaken voor het jaar 1975, waarin, voor wat betreft het sociaal beleid in de onderneming werd opgemerkt, dat dit steeds meer wordt geconfronteerd een toenemende bewustwording van de werknemers van hun eigenwaarde, onder meer door het stijgen van het opleidings- en ontwikkelingsniveau. Door de toenmalige bewindsman van Sociale Zaken Boersma werd bijyoorbeeld aangekondigd: een adviesaanvraag aan de Sociaal-Economische Raad over het treffen van voorzieningen die de basis vormen voor dat sociaal beleid ${ }^{19}$, de voorbereiding van een wettelijke regeling van het klachtrecht van werknemers ${ }^{20}$, vernieuwing van de arbeidswetgeving en een meer onderling samenhangende wettelijke regeling van arbeid, arbeidsomstandigheden en arbeidsverhoudingen in de onderneming. Door de bewindsman werd het belang van de immateriele arbeidsomstandigheden benadrukt ${ }^{21}$.

"... bij de uitvoerende organen - Arbeidsinspectie en Inspectie van de Havenarbeid - (moet) meer deskundigheid worden ingebouwd met betrekking tot de immateriële arbeidsomstandigheden. Hier moge mede de aandacht worden gevestigd op het feit dat het technische sociale beleid - gevaren, hinder - kan worden samengebracht met immaterieel sociaal beleid, onder meer het beleid dat gericht is op inspraak. De nieuw te ontwerpen Veiligheidswet zal - zoals reeds in de toelichting op de vorige begroting werd betoogd - hieraan een wettelijke grondslag geven".

Dit alles speelde zich af ten tijde van het kabinet-Den Uyl, toen er nog vrij weinig twijfel bestond over het 
conjuncturele karakter van de groeiende werkloosheid. De getroffen maatregelen waren dan ook van tijdelijke aard; via gerichte financiële injecties van overheidszijde zouden de investeringen gestimuleerd worden en zou de conjunctuur weer stabiliseren. In dat kader moeten bijvoorbeeld de subsidieregelingen arbeidsplaatsverbetering gezien worden. Aangekondigd in de Nota inzake de werkloosheid $1975^{22}$ zouden dergelijke subsidieregelingen een dubbele functie vervullen. Niet alleen investeringen, maar juist die investeringen, die gericht waren op de verbetering van arbeidsplaatsen, konden gestimuleerd worden. Bovendien kon tegenover een groeiend aantal werklozen, met een opmerkelijk hoog aantal moeilijk vervulbare arbeidsplaatsen, door concrete verbetering van de arbeidsplaatsen de vervulling hiervan vergemakkelijkt worden. Uit de Nota inzake de Werkgelegenheid 1975 is het volgende citaat ontleend ${ }^{23}$ :

"Ter vermindering van kwalitatieve discrepantie tussen vraag naar en aanbod van arbeid worden enkele maatregelen doorgevoerd die een kwalitatieve verbetering van de arbeidsplaats en de arbeidsomstandigheden beogen..... Daarmede wordt aangesloten bij het interimadvies van de Raad voor de Arbeidsmarkt voor de bestrijding van de werkloosheid, waarin de Raad stelt dat maatregelen ter verbetering van de arbeidsomstandigheden bijzonder zinvol zijn om verschillende, nu als onaangenaam ervaren werkzaamheden weer enigermate aantrekkelijk te maken".

In de tweede helft van de regeerperiode van het kabinet-Den Uyl groeide het besef, dat de werkloosheidsproblematiek van structurele aard was en om die reden een meer structurele aanpak was vereist. Naar aanleiding hiervan kwam 1976 de Nota inzake de selectieve groei tot stand. De centrale doelstelling, die hierin werd verwoord, was volledige en volwaardige werkgelegenheid. De beleidsvoornemens werden hierin als volgt aangegeven ${ }^{24}$ :

"Volwaardige werkgelegenheid achten de ondergetekenden, zoals eerder in deze nota is gesteld, een doelstelling die uitdrukkelijk geplaatst moet worden naast dic van volledige werkgelegenheid. Met het stijgende opleidings- en ontwikkelingsniveau van de beroepsbevolking gaat immers ook het niveau van capaciteiten en aspiraties ten aanzien van het arbeidsleven omhoog. Ook neemt de mondigheid toe. Dat betekent dat overheid en bedrijfsleven zich meer bewust gaan inrichten op het tot ontwikkeling brengen van sociale doelmatigheid in arbeidsorganisaties ( overheid, bedrijfsleven, ziekenhuizen e.d. ).

Deze is gericht op het "vermenselijken" van de arbeidsplaats en arbeidsomstandigheden binnen de organisatie, dus op microniveau. Bijzondere aandacht voor de ontwikkeling van sociale doelmatigheid als relatief zelfstandig aspect naast de economische en technische doelmatigheid van de arbeidsorganisaties is des te meer vereist, daar de sociale belangen en doeleinden van een arbeidsorganisatie in de praktijk niet steeds parallel lopen met de technische en economische doelmatigheid. Sociale doelmatigheid heeft vooral betrekking op een viertal aspecten van het arbeidsproces, te weten:

- beloning en werktijden

- kwaliteit van de arbeidsomstandigheden

- kwaliteit van de arbeid

- demokratisering".

Maar daarna treedt er een verandering op. In de toelichting op de begroting voor 1977 wordt allereerst nog vastgesteld, dat de bestaande medezeggenschapsregelingen nog verbeterd kunnen worden, hetgeen zal resulteren in een wijziging van de Wet op de ondernemingsraden ${ }^{25}$, maar wel wordt het volgende toegevoegd ${ }^{26}$ :

"Terwijl ten aanzien van de kwaliteit van de arbeid steeds hogere eisen worden gesteld, bieden economische en technologische ontwikkelingen slechts beperkte mogelijkheden om aan deze eisen tegemoet te komen. Soms bedreigen deze ontwikkelingen opnieuw de veiligheid, de gezondheid en het psychisch welzijn van de betrokken werknemers".

Daardoor kan een mogelijke vervreemding ontstaan, maar:

"Van overheidswege wordt gedaan wat mogelijk is .... Voor het proces zelf kan de overheid geen verantwoordelijkheid nemen. Dat moet het bedrijfsleven zelf doen en daarbij hebben 
zowel werkgevers alls werknemers een taak en een verantwoordelijkheid".

Met het aantreden van het eerste kabinet-Van Agt in december 1977 wijzigde de opvatting, dat stimulering van investeringen zou leiden tot herstel van de werkgelegenheid. Bestek 81 gaf de hoofdlijnen aan van het financiële en sociaal-economische beleid voor de middellange termijn en er werden de aanzetten gegeven voor een meer restrictief overheidsbeleid. Wel blijft het belang van de humanisering van de arbeid, de medezeggenschap van werknemers en de rol die de Arbeidsomstandighedenwet, die onder meer de Veiligheidswet 1934 zou vervangen en die uiteindelijk in 1980 tot stand zou komen, zou kunnen spelen, benadrukt. Daarbij werd overigens wel weer opnieuw gewezen op het feit, dat de overheid een terughoudende rol diende te spelen en dat de doelstellingen van deze nieuwe wet gestalte moeten krijgen op ondernemingsniveau ${ }^{27}$.

Eén van de doelstellingen van het middellange termijnbeleid van de regering was het streven naar terugdringing van onnodige werkloosheid en vermijdbaar verzuim wegens ziekte of arbeidsongeschiktheid. Dit zogenaamde volumebeleid speelt zich, blijkens de nota Volumebeleid ${ }^{28}$, af binnen smalle marges en dient nauw aan te sluiten bij het algemene belleid, dat gericht is op het wegnemen van knelpunten tussen vraag en aanbod op de arbeidsmarkt, en het algemene beleid dat gericht is op verbetering van de arbeidsomstandigheden en het arbeidsklimaat. Van een stringente afbakening kan, zo werd vervolgd, daarbij niet worden gesproken. Er treedt een vervlechting op tussen het sociale zekerheidsheidsbeleid enerzijds en het werkgelegenheids-, het arbeidsvoorzienings- en het arbeidsomstandighedenbeleid anderzijds. Deze vervlechting noopte, aldus de bewindslieden van Sociale Zaken, tot een benadering van het volumebeleid vanuit geïntegreerde beleidsdoelstellingen. De oorzaken van het ontstaan van ziekte en arbeidsongeschiktheid kunnen voor een belangrijk deel liggen in de arbeidssituatie. Ongunstige arbeidsomstandigheden, onregelmatige of lange werktijden, onaantrekkelijke arbeid, gebrek aan mogelijkheden tot ontplooiing en initiatief kunnen leiden tot psychissche of fysieke belasting voor de werknemer. Bovendien blijken in de praktijk de arbeidsplaatsen, die én of meer van deze kenmerken bezitten, moeilijk vervulbaar. Behalve deze moeilijk vervulbare arbeidsplaatsen die vaak gekenmerkt worden door een daaraan gekoppeld hoog ziekteverzuim, steeg ook het ziekteverzuim in het algemeen. Verbetering van de kwaliteit van de arbeid kan althans een deel van dit vermijdbare ziekteverzuim terugdringen. Om dergelijke arbeid meer aantrekkelijk te maken, om nadelige fysieke en psychische gevolgen van de arbeid op te heffen zijn compenserende maatregelen noodzakelijk. Primair leggen de bewindslieden de verantwoordelijkheid bij de werkgever. Wat de maatregelen betreft kan gedlacht worden aan de verbetering van de arbeildsomstandigheden en de humanisering van de arbeid. Een aanzienlijk stimulans op het gebied van de humanisering van de arbeid vormen, zo vervolgen de bewindslieden, onder meer de verschillende subsidieregelingen voor arbeidsplaatswerbetering. Daarnaast kan door overleg zowel op het niveau van de ondernemingsraad als per bedrijf of bedrijfstak door werkgevers en werknemers gezamenlijk getracht worden tot maatregelen te komen die ertoe leiden, dat de kwaliteit van werk en werkomstandigheden wordt verbeterd $^{29}$. Dat het arbeidsomstandighedenbeleid niet los gezien werd van het sociaal-economische beleid in engere zin blijkt uit de toelichting op de begroting van het ministerie van Sociale Zaken voor $1980^{30}$.

"Enerzijds zijn gelet op de moeilijke financieel-economische situatie van dit moment de mogelijkheden voor het op dit terrein te voeren beleid beperkt. Anderzijds hebben het terugdringen van factoren die de veiligheid en de gezondheid bedreigen en het vergroten van de betrokkenheid van de mens tot zijn arbeid een gunstige invloed op de kostenontwikkeling van de sociale verzekering door een vermindering van het arbeidsverzuim en de arbeidsongeschiktheid. Ook is naar mijn mening een grote betrokkenheid van de werker tot zijn arbeid een randvoorwaarde voor de zo noodzakelijke innovatie in het bedrijfsleven".

Nadat humanisering van de arbeid aanvankelijk als doel op zich zelf was beschouwd, werd deze gedachtengang later gecorrigeerd in die zin, dat humanisering van de arbeid als gevolg van de druk van de economische crisis, mede werd beschouwd als een voorwaarde voor de groel van de economische produktie en het terugdringen van het ziekteverzuim in het kader van het volumebeleid ${ }^{31}$.

"Daarom is het van belang, dat zowel sociale partners als de overheid in de komende jaren een systematische beleidsontwikkeling op het gebied van de humanisering van de arbeid en 
de sociale innovatie onderkennen als een koerskeuze van betekenis ${ }^{132}$.

In de toelichting op de begroting voor 1983 wordt de noodzaak van verbetering van de arbeidsomstandigheden nog eens onderstreept, maar zijn de mogelijkheden om deze verbeteringen aan te brengen steeds meer onder druk komen te staan; niet alleen voor het bedrijfsleven, waar de investeringsbereidheid afneemt met de daaraan verbonden gevolgen woor de kwaliteit van de arbeid, maar ook voor de owerheid ${ }^{33}$.

Als reactie op de (inter-)nationale economische crisis kenmerkt het regeringsbeleid van de beide kabinettenLubbers zich onder meer door het benadrukken van een vermindering van de tekorten van de overheid en een versterking van de marktsector, door onder meer lastenverlichting voor bedrijven, beperking van de arbeidskosten en vermindering van bureaucratie ${ }^{34}$. In het kader van dit kabinetsstreven spelen de zogenaamde grote operaties een belangrijke rol. Dit zijn de reorganisatie van de rijksdienst, decentralisatie, heroverweging, deregulering, privatisering en de $-2 \%$-operatie ${ }^{35}$. Bij deze grote operaties gaat het uiteindelijk om de visie op de taak van de overheid. De regeringscommissaris voor de reorganisatie van de rijksdienst Tjeenk Willink schrijft daarover het volgende:

"Er is een vrij algemeen gevoel, dat de taak van de overheid aan grenzen gebonden is. Daarvoor worden echter verschillende motieven aangevoerd: het motief, dat de overheid zich met te veel terreinen van het maatschappelijk leven bemoeit en de onafhankelijkheid van burgers, bedrijfsleven en lagere corporaties eerder vermindert dan vergroot; het motief, dat het sturend vermogen van de overheid tekort schiet, omdat zij teveel taken op zich heeft genomen; het motief van de inefficiency van het overheidsapparaat door bureaucratisering en het motief, dat er bezuinigd moet worden om het financieringstekort terug te dringen. Al naar gelang de situatie, worden deze motieven op heel verschillende manieren vermengd en onder de grote operaties geschoven".

Hij voegt er echter wel aan toe, en terecht, dat in een pluriforme samenleving als de onze éen (officiële) visie op de overheid niet mogelijk, maar ook niet wenselijk is.

Het zal miemand verbazen, dat deze grote operallies ook niet aan de arbeidsinspectie voorbij gegaan zijn. In het kader van de heroverwegingsoperatie ${ }^{38}$, zijn de doelstellingen in een later stadium nader toegespitst. Zo diende de arbeidsinspectie doorgelicht te worden in het kader van de gedeconcentreerde rijksdiensten en wel ter zake van de onderwerpen verzelfstandigen/functionele decentralisatie, medebewind en efficien$\mathrm{cy}^{37}$. Verwezen werd naar het Project Ontwikkeling Arbeidsinspectie. De medebewind variant is wel opmerkelijk. Evenzeer had deze doorlichting betrekking op de diensten met opsporingsbevoegdheid, waarbij aandacht werd besteed aan de verkeers- en vervoerswetgeving. Voor de arbeidsinspectie had dit betrekking op de taak van de Rijtijdenwet 1936, waarbij voor het controlebeleid werd verwezen naar het rapport over de controle Rijtijdenwet $1936^{38}$.

Binnen het ministerie van Sociale Zaken en Werkgelegenheid is de zogenaamde $2 \%$-operatie uitgevoerd volgens een herallocatie-operatie, waarbij door middel van het afstoten van taken voor de periode 1983 tot en met $198615 \%$ personeelscapaciteit vrijgemaakt moet worden, om enerzijds te voldoen aan de $8 \%$ capaciteitsreductie en anderzijds ruimte te scheppen voor nieuw beleid. In het kader van deze herallocatie-operatie werd een aantal voorstellen uitgewerkt tot afstoting van taken van de arbeidsinspectie, zoals de activiteiten in het kader van de ontslagprocedure op grond van artikel 6, vierde lid, en van het verbod van werktijdverkorting, als neergelegd in artikel 8 van het Buitengewoon Besluit Arbeidsverhoudingen 1945, van de subsidicregelingen arbeidsplaatsverbetering en een aantal hiermee corresponderende taken ${ }^{39}$.

Een ander punt is het vraagstuk van de regulering en de deregulering. De uitgangspunten voor de deregulering zijn als volgt. Het gaat bij het kabinet in de eerste plaats om doorzichtigheid van de verhoudingen tussen de overheid en de deelnemers aan het maatschappelijk verkeer. De voortschrijdende regeldichtheid wordt daarbij als een probleem gezien. Deregulering staat niet gelijk met het zonder meer afschaffen van regels. Stroomlijning, vereenvoudiging en vermindering van regelgeving op alle gebieden waarop de staat thans optreedt, zal - althans ten dele - het antwoord moeten geven op het probleem van de voortschrijdende regeldichtheid. Geen beleidsterrein mag bij voorbat uitgesloten worden van een kritische toetsing van het daar- 
voor geldende of in voorbereiding zijnde regelbestand. Meer dan voorheen zal terughoudendheid moeten worden betracht ten aanzien van het tot stand brengen van nieuwe regelingen ${ }^{40}$. Op basis van deze uilgangspunten zijn er verschillende commissies ingesteld. Voor zover het van belang is voor het beleidsterrein van de arbeidsomstandigheden zijn dit:

- vermindering en vereenvoudiging van overheidsregelingen, de zogenaamde commissie-Geelhoed; - stroomlijning en vermindering van wettelijke voorschriften in verband met de economische mededinging, de zogenaamde commissie-Van der Grinten, en

- deregulering inkomensvorming en arbeidsmarkt, ook wel het DIA-project genoemd ${ }^{41}$.

Bij de deregulerings-operatie is het gehele werkterrein van de arbeidsinspectie onder de loep genomen, variërend van de de Veiligheidswet 1934 vervangende Arbeidsomstandighedenwet, die toen nog niet eens (ten dele ) in werking was getreden, tot de Huisarbeidswet 1933.

\section{Arbeidswet 1919}

Nadat het, althans op wetgevend terrein, lange tijd rustig was geweest rondom de Arbeidswet 1919, zou dit in deze periode veranderen als gevolg van de gewijzigde social-economische en maatschappelijke denkbeelden, denk hierbij aan flexibilisering van arbeids- en rusttijden en de gelijke behandeling van mannen en vrouwen. Niet alleen zouden voorstellen gelanceerd worden om een nieuwe Arbeidswet tot stand te brengen, maar ook de geldende wet zou nog wijzigingen ondergaan.

\subsection{Bakkersarbeid}

Terugkijkend kan gesteld worden, dat bakkersarbeid en de regeling van de daarvoor geldende arbeids- en rusttijden veel beslag hebben gelegd op de arbeidsinspectie. Ook in deze periode zou dat het geval blijken te zijn. In het vorige hoofdstuk is al melding gemaakt van het feit, dat de inhoudelijke regeling van de arbeids- en rusttijden van de bakkerijsector uit de Arbeidswet 1919 werd verwijderd en werd overgebracht naar het Werktijdenbesluit voor fabrieken of werkplaatsen 1936, maar eerst na overleg met het Georganiseerd Overleg van werkgevers- en werknemersorganisaties en een enquête. Na een periode van voorlichting en instructie over de nieuwe arbeids- en rusttijdenregeling, werd in de eerste helft van 1977 een landelijke controle gehouden op de naleving van de nieuwe voorschriften. Er werden 1855 bakkerij-bedrijven bezocht. Het aantal geconstateerde overtredingen bedroeg $301^{42}$. De resultaten werden dusdanig gevonden, dat verdere wijziging van de wettelijke voorschriften of een scherpere controle op de naleving door de arbeidsinspectie niet tot een verbetering van de situatie in deze sector zou leiden ${ }^{43}$. Arbeidswettelijke bepalingen werden met regelmaat overtreden, terwijl ook de discrepantie tussen de wettelijke norm en de feitelijke arbeids- en rusttijden, zoals deze waren neergelegd in de collectieve arbeidsovereenkomst, problemen gaven met name ten aanzien van vergunningen voor arbeid in ploegendienst.

Naast deze problemen werd de bedrijfstak geconfronteerd met een overcapaciteit als gevolg van een dalende tendens van het broodverbruik. In 1975 werden er aanzetten gegeven tot een sanering van die overcapaciteit in het kader van de Bedrijfsvergunningenwet 1954. De maatregelen waren bedoeld voor een periode van 5 jaren om de bedrijfstak de gelegenheid te geven de overcapaciteit en de daarmede samenhangende problemen in eigen kring te regelen ${ }^{44}$. Aan het einde van deze periode bleek, dat nadere maatregelen voor de toekomst echter noodzakelijk waren, op zowel sociaal als economisch terrein. Daartoe werd een afzonderlijk overlegorgaan in het leven geroepen, namelijk het Sociaal Economisch Overleg in het Bakkersbedrijf. Op 7 oktober 1982 bood dit overleg de verantwoordelijke bewindslieden van Economische Zaken, van Landbouw en Visserij en van Sociale Zaken en Werkgelegenheid een pakket herstructureringsmaatregelen aan, waarmede beoogd werd de bakkerijsector weer gezond te maken. Naast een aantal economische maatregelen ${ }^{45}$ om- $^{-}$ vatte het pakket voorstellen om te komen tot een betere naleving van de arbeids- en rusttijdenregelingen. In dat zelfele jaar werden de resultaten van een onderzoek naar de arbeidsomstandigheden in de broodbakkerijen bekend gemaakt. Uit het onderzoek blijkt, dat de arbeidsomstandigheden in het bakkerijbedrijf onder 
druk staan. Vooral overtredingen van de arbeids- en rusttijden nemen daarbij een belangrijke plaats in. Met betrekking tot de rol van de arbeidsinspectie ten aanzien van de controle hierop, wordt geconstateerd, dat deze in feite weinig voorstelt. De beleidsadviserende aanpak waarvoor door de arbeidsinspectie is gekozen, leidt ertoe, dat de arbeids- en rusttijden op papier prima voldoen aan de eisen van de wettelijke regeling. In de praktijk weet men echter, dat de arbeidsinspectie over onvoldoende menskracht beschikt om de werktijden afdoende te controleren. Bovendien merkten de onderzoekers, dat er ondernemers zijn die handig inspelen op de beleidsintentie van de arbeidsinspectie on in de toekomst meer adviserend dan controlerend te werk te gaan.

"De Arbeidsinspectie dreigt hierdoor te verworden tot een fenomeen dat treffend gekarak-

teriseerd wordt met de term "papieren tijger"

Om een einde te maken aan deze onbevredigende situatie ten aanzien van controle en de strafsanctie, waarwan men vond dat deze veel te laag was en niet opwoog tegen het economisch voordeel, dat met de overtreding(en) werd bewerkstelligd, werd voorgesteld om de arbeids- en rusttijdenregeling in bakkerijen vast te leggen in een verordening van het Bedrijfschap voor het Bakkersbedrijf en overtredingen van die verordening voor te leggen aan een tuchtrechter. Opmerkelijk genoeg werd voorgesteld, dat de arbeidsinspectie de naleving van de verordening zou moeten controleren, omdat op die manier een adequater optreden tegen overtredingen zou zijn verzekerd. Een voorstel tot wijziging van het Instellingsbesluit ${ }^{47}$ werd de Sociaal-Economische Raad voor advies voorgelegd. De organisatie-commissie uit dit adviesorgaan verwees de zaak echter terug naar de minister van Justitie in verband met de bezwaren in de commissie tegen het ontstaan van twee rechtsgangen aangaande dezelfde materie, namelijk de verordening, cq tuchtrechter en de Arbeidswet 1919 , cq strafrechter. De bezwaren in het kader van de Wet op de Bedrijfsorganisatie zijn tweeledig. In de eerste plaats veronderstelt artikel 105, eerste lid, van deze wet onmiskenbaar, dat de daarin bedoelde tuchtrechtelijke voorzieningen uitsluitend door het bedrijfsschap zelf te scheppen "tuchtfeiten" kunnen betreffen. Met andere woorden: de tuchtrechtelijke sanctionering door het bedrijfsschap van voorschriften van andere origine, zoals het bij of krachtens de Arbeidswet 1919 bepaalde, is uitgesloten. In de tweede plaats moet worden voorkomen, dat er een confrontatie plaatsvindt tussen tegenstrijdige of onverenigbare publiekrechtelijke voorschriften van hierarchisch uiteenlopende organen. De genoemde wet voorziet hier dan ook in door in artikel 93, eerste lid, aan een bedrijfsschap de mogelijkheid te geven tot regeling of nadere regeling van onderwerpen, waaronder de lonen en andere arbeidswoorwaarden ${ }^{48}$. Bij een verordening van het bedrijfsschap zou uitsluitend het bij of krachtens de Arbeidswet 1919 bepaalde kunnen worden aangevuld: maar niet met de mogelijkheid van toepassing van een tuchtrechtelijke sanctie op de overtreding van de voorschriften van deze laatstgenoemde wet $^{49}$. Gezien het onbegaanbare van deze weg hebben de sociale partners afgezien van een dergelijke verordening. Vergunningverlening en controle blijven derhalve gebeuren aan de hand van de zogenaamde bakkerijparagraaf krachtens de Arbeidswet 1919.

\subsection{Winkels/Winkelsluitingswet 1976}

In 1976 werd de Winkelsluitingswet 1951 gewijzigd ${ }^{50}$. Tijdens de behandeling wan het ontwerp-Winkelslluitingswet 1976 werd door mevrouw Salomons een door de Tweede kamer aanvaarde motie ${ }^{51}$ ingediend, waarbij de regering werd gevraagd de controle op de naleving van het Werktijdenbesluit voor Winkels 1932 te intensiveren en zonodig de arbeidsinspectie uit te breiden. Dit als gevolg van het feit, dat de nieuwe Winkelsluitingswet aan het werken in de detailhandel op zogenaamde arbeidsonaangename uren als de koopavonden en de zaterdagmiddag een brede wettelijke basis geeft en dit alleen acceptabel is, wanneer de arbeids- en rusttijden-bepalingen strikt worden nageleefd. Naar aanleiding van deze motie is door de arbeidsinspectie een onderzoek ingesteld naar de feitelijke naleving van genoemd werktijdenbesluit en in het bijzonder naar de naleving van de bepalingen, die in verband met de koopavond zijn gesteld en waarbij de arbeid van jeugdigen een bijzondere plaats inneemt. Uit dit onderzoek bleek, dat $70 \%$ van de bezochte inrichtingen de administratieve verplichtingen - het hebben van een arbeidslijst of rooster - niet naleefde, en dat nog geen $5 \%$ van de gecontrolleerde inrichtingen de arbeids- en rusttijdbepalingen overtrad. Ook in een vervolg-onder- 
zoek in het tiende district in de periode september 1977 tot en met januari 1978 werden geen ernstige overtredingen geconstateerd ${ }^{52}$.

De wettelijke regeling van de openings- en sluitingstijden van winkels is een doorlopend onderwerp van discussie. Maatschappelijke en economische ontwikkelingen stelden verschillende, geleidelijk veranderende en soms ook tegenstrijdige eisen aan het stuitingstijdstip van winkels. Niet alleen het belang van de consument, ook dat van de ondernemer en het winkelspersoneel is daarbij in geding. Ook nu. Een initiatief wetsvoorstel $^{53}$ van het Tweede Kamerlid mevrouw Groenman waarbij latere openstellingstijden -

"mag de winkel een uurtje langer open"

- werden voorgesteld, zou het niet halen ${ }^{54}$. Met name de regeringsfracties gaven er de voorkeur aan

"....vooralsnog het plan van de regering af te wachten $"$ "155,

dan wel de huidige wet te handhaven ${ }^{68}$. Alvorens een eventuele wijziging van de Winkelsluitingswet 1976 tot stand is gebracht, zullen er nog vele discussies plaatsvinden en vele obstakels moeten worden overwonnen ${ }^{\text {s? }}$.

\subsection{Nachtarbeid vrouwen in de industrie}

Op 9 februari 1976 stelde de Raad van Europese Gemeenschappen een richtlijn vast betreffende de tenuitvoerlegging van het beginsel van gelijke behandeling van mannen en vrouwen ten aanzien van de toegang tot het arbeidsproces, de beroepsopleiding en de promotiekansen en ten aanzien van de arbeidsvoorwaarden, de zogenaamde "tweede richtlijn" ${ }^{\text {. De }}$. toepassing van dit beginsel van gelijke behandeling houdt volgens de richtlijn in, dat alle in de lidstaten voorkomende wettelijke en bestuursrechtelijke bepalingen, die in strijd zijn met dit beginsel, moeten worden ingetrokken of herzien ${ }^{59}$. Wat betreft dit laatste moeten die wettelijke of bestuursrechtelijke bepalingen worden herzien die

"aanvankelijk werdlen gemotiveerd door beschermende bedoelingen die niet meer gefundeerd zijn".

Dït soort bepalingen moet

"binnen een termijn van vier jaar volgende op de kennisgeving van deze richtlijn door de

Lid-staten een eerste maal onderzocht en eventueel een eerste maal herzien (worden )

Blijkens een gelijkluidende advies-aanvraag aan de Sociaal Economische Raad en aan de Emancipatiecommissie van 21 juni $1978^{61}$ zijn de minister van Sociale Zaken Albeda en de staatssecretaris van Cultuur, Recreatic en Maatschappelijk Werk mevrouw Kraaieveld-Wouters de mening toegedaan, dat de beschermende bepalingen, die in de Arbeidswet 1919 zijn gegeven voor vrouwen ten aanzien van onder meer arbeid op zondag en nachtarbeid in fabrieken of werkplaatsen, moeten worden verwijderd. In haar advies maakte de Emancipatiecommissie kenbaar, dat grote voorzichtigheid betracht moet worden met de opvatting, dat oplegging dan wel openstelling van "mannelijke" arbeidspatronen voor vrouwen een vanzelfsprekende bijdrage aan het emancipatieproces oplevert. Het beginsel van gelijke behandeling krijgt niet alleen gestalte door de voor mannen geldende wettelijke normen, zoals de bewindslieden zich dat voorstellen, als uitgangspunt te nemen. Evengoed is denkbaar, om van de bestaande wettelijke normen voor vrouwen uit te gaan. Aangaande de opheffing van het verbod van nachtarbeid voor vrouwen gaf de emancipatiecommissie te kennen, dat zij zwaar tille aan de mogelijkheid van verslechtering van de arbeidsmarktpositie van vrouwen die hieruit zou kunnen voortvloeien. Het advies was echter verdeeld. Een aantal leden van dit adviesorgaan achtte deze laatste mogelijkheid zo reëel, dat het verbod van nachtverbod eerst bij een algehele herziening van de arbeidswetgeving opgeheven zou kunnen worden, waarbij een aantal uitgangspunten gehanteerd diende te worden ${ }^{62}$. Anderen daarentegen gaven een doorslaggevende invloed aan het beginsel van gelijke behandeling van mannen en vrouwen, met als onvermijdelijke consequentie de opheffing van het verbod van nachtarbeid ${ }^{63}$.

Ook de Sociaal-Economische Raad zou een verdeeld advies uitbrengen. De meerderheid gaf als mening te kennen, dat de handhaving van de beschermende bepalingen aangaande nachtarbeid vrouwen in hun mogelijkheden bij de keuze van een beroep zou beperken. Ieder uitstel van het beginsel van gelijke behandeling van vrouwen zou belemmerend werken op de inpassing van vrouwen in het arbeidsproces. Daarbij nam dit 
deel van de Sociaal-Economische Raad in aanmerking, dat experimenten dienaangaande ${ }^{\text {, }}$, waarvan in de advies-aanvraag gewag was gemaakt, witwijzen, dat in die gevallen geen nadelige gevolgen voor de betrokken werkneemsters waren opgetreden. Integendeel, de opgedane ervaringen waren, zowel naar het oordeel van de betrokken vouwen, als naar dat van de verantwoordelijke ondernemingsleiding tot nu toe zeer positief, aldus ook de bewindslieden in de adviesaanvraag ${ }^{65}$. De minderheid daarentegen meende, dat mog niet vaststond, of en in welke mate de nadelige gevolgen, die mannen ondervinden van nachtarbeid, versterkt zou kunnen gelden voor vrouwen, gezien hun rol in de gezinssituatie. Om die reden werd de voorkeur gegeven aan het niet zonder meer opheffen van het verbod van nachtarbeid voor vrouwen, maar de gelijke behandeling van mannen en vrouwen voor wat betreft de nachtarbeid te realiseren in het kader van een algemene herbezinning op aan nachtarbeid te verbinden voorwaarden, die plaats dient te vinden bij de vernieuwing van de Arbeidswet $1919^{68}$.

De beide adviesinstanties hadden overigens geen bezwaar tegen het opheffen van het voor vrouwen geldende verbod tot het verrichten van arbeid op zondag ${ }^{67}$.

De discussie over de positie van de vrouw en dan met name ten aanzien van nachtarbeid zou volop plaatsvinden. Zo schreef de Nederlandse Vrouwenbeweging in een brief aan de beide verantwoordelijke bewindslieden het volgende ${ }^{68}$ :

"Duidelijk wordt dat wat volgens $\mathbf{u}$ een vooruitgang in de positie van de vrouw op de arbeidsmarkt zal betekenen, in werkelijkheid onder de gegeven omstandigheden een ernstige verslechtering van haar arbeidsvoorwaarden is ... Van "het ieder toekomend recht om binnen het mogelijke naar eigen voorkeur te kunnen kiezen voor welke soort van beroepsarbeid dan ook" ... zal dan ook in de praktijk geen sprake zijn. Uiteraard is de Nederlandse Vrouwenbeweging voorstander van een zo groot mogelijke gelijkwaardigheid van mannen en vrouwen op de arbeidsmarkt en heeft daarvoor dan ook tijdens haar bestaan een voortdurende strijd gevoerd. Maar zolang het zo is dat de situaties voor mannen en vrouwen verschillend zijn, dat vrouwen er in feite een paar maatschappelijke taken bij hebben, is het gerechtvaardigd en noodzakelijk dat vrouwen een in wetten vastgelegd stuk bescherming genieten tegen overmatige en uitputtende arbeid".

Siersema en $\mathrm{Hak}^{69}$ wijzen het opheffen van het verbod van nachtarbeid voor vrouwen af, waarvoor zij argumenten gebruiken, die ontleend zijn aan onderzoekingen van de effecten van nachtarbeid voor mannen en het gegeven, dat vrouwen veelal een dubbele taak hebben, namelijk het huishouden en de beroepsarbeid. Hun conclusie luidt dan ook, dat:

"opheffing van de bestaande beschermende maatregelen voor vrouwen zal leiden tot een aanmerkelijke verslechtering van de arbeidspositie van vrouwen. .... Inderdaad beschermt de huidige wetgeving vrouwen beter tegen de dubbele belasting van werk en huishouden dan mannen. Dit is een argument te meer ook voor mannen de bescherming in te voeren die nu voor vrouwen geldt".

Frenkel ${ }^{70}$ merkt het volgende op:

"De stelling van de regering .... dat de voor vrouwen geldende afwijkingen thans wel zonder meer kunnen worden opgeheven, lijkt op het eerste gezicht wat gemakkelijk neergeschreven....".

Desalniettemin dienden de bewindslieden bij de Tweede Kamer een wetswoorstel ${ }^{71}$ in, waarbij de Arbeidswet 1919 gewijzigd zou worden en waardoor onder meer nachtarbeid door vrouwen in fabrieken en werkplaatsen verricht zou kunnen worden. Hiervoor was dan wel een vergunning van het districtshoofd van de arbeidsinspectie vereist ${ }^{72}$.

In de wet worden de omstandigheden opgesomd op grond waarvan een dergelijke vergunning kan worden geweigerd ${ }^{73}$. Blijkens de toelichting ${ }^{74}$ wordt beoogd voor vrouwen de mogelijkheid te openen om in een drie- of vierploegendienst arbeid te verrichten, maar van een passende verdediging van het wetsvoorstel is geen sprake. Uit de reactie van de Tweede Kamer bleek, dat het wetsvoorstel met gemengde gevoelens is ontvangen. De leden van van twee van de drie grote fracties, het CDA, 
"het huidige verbod van nachtarbeid beperkt de keuzemogelijkheden van de vrouw en vormt

een extra handicap om te kunnen toetreden op de arbeidsmarkt"

en de VVD konden instemmen met het wetswoorstel. De PvdA wilde eveneens, zij het onder voorwaarden de nachtarbeid openstellen voor vrouwen, die een arbeidsplaats wensen, en waarbij een dergelijk arbeidspatroon noodzakelijk is ${ }^{75}$. De D'66-fractie is gereserveerder. Men heeft wel waardering voor het wetsvoorstel, maar tekent bezwaar aan tegen de gevolgde methodiek. In hun visie is niet zonder meer aan het beginsel van gelijke behandeling voldaan met het in formele zin aanpassen van de positie van vrouwen aan die, welke woor mannen geldt. Zeker wilde zij voorkomen het adagium "even slecht is ook gelijk". De bezwaarlijke aspecten van nachtarbeid van zowel sociaal-maatschappelijke als van psychologische aard moeten worden afgewogen tegen de technisch-economische noodzaak ervan. Eén van de punten waar deze fractie op wijst is, dat rekening gehouden moet worden met de buiten de arbeid te verrichten taken van arbeiders met name in de privesfeer ${ }^{7}$. Het verweer van de toenmalige staatssecretaris van Sociale Zaken en Werkgelegenheid komt erop neer, dat het hier een overgangsregeling betreft, terwijl onder meer deze zogenaamde "dubbele belasting" een belangrijk element zal vormen bij de algeh:le herziening van de Arbeidswet 1919. Tijdens de mondelinge beraadslaging maakte de bewindsvrouwe mevrouw Kappeyne van de Coppello duidelijk ${ }^{n}$, dat haar keuze voor het opheffen van het verbod van nachtarbeid voor vrouwen niet ingegeven is, omdat nachtarbeid vanuit het oogpunt van arbeidsomstandigheden een wenselijke vorm van arbeid is, maar omdat nachtarbeid om een aantal redenen een maatschappelijke realiteit is. In principe zag zij dan ook geen reden om vrouwen van deze vorm van arbeid uit te sluiten. Er kon in het algemeen niet gezegd worden, dat vrouwen fysiek of psychisch meer nadelen ondervonden van het werken in de kleine uurtjes dan mannen.

"Voorop staat dat vrouwen die geconfronteerd worden met een dubbele belasting zelf kun-

nen kiezen of zij al dan niet ook 's nachts willen werken".

Op de vraag vanuit het parlement ${ }^{78}$, in hoeverre de argumenten, die aan de beschermende maatregelen ten grondslag lagen - de bescherming van het gezinsleven (de vrouw heeft ook nog een taak in het gezin, die zo min mogelijk onder haar arbeid moet lijden ), de bescherming van de zedelijkheid en het tegengaan van de fysiek schadelijke gevolgen van nachtarbeid ${ }_{-19}^{70}$, antwoordde de bewindsvrouwe ${ }^{80}$ allereerst met de vraag of de situatie van nu precies dezelfde is alls die van 1889.

$\mathrm{Zij}$ bleef bij haar conclusie, dat het bepalingen betreft die niet meer gefundeerd zijn, omdat de maatschappelijke opvattingen omtrent arbeid door vrouwen en ook nachtarbeid door vrouwen zijn gewijzigd ${ }^{\text {Bt }}$.

Op 11 april 1986 trad de wijzigingswet in werking ${ }^{82}$. Uit een onderzoek naar nachtarbeid door vrouwen in de industrie blijkt, dat eind november 1987 door 1196 vrouwen in 97 bedrijwen van de wettelijk geboden mogelijkheid gebruik is gemaakt ${ }^{83}$. Uit het onderzoek blijkt tevens, dat het in de nacht kunnen werken door vrouwen in de industrie niet heeft geleid tot een vergroting van de arbeidsmogelijkheden voor vrouwen. De meeste vrouwen, die nachtarbeid verrichten; doen werkzaamheden die zij daarvoor ook al bij dezelfde werkgever in twee-ploegen of in dagdienst uitvoerden. Veelal is dit ongeschoold produktiewerk, bijvoorbeeld het inpakken wan brood, chips en dergelijke, het monteren van elektronische onderdelen en het stikken van schoudervullingen. Slechts een zeer klein percentage van de vrouwen verricht werkzaamheden in een traditioneel mannenberoep, zoals bijvoorbeeld heftrukchauffeur, kraandirifster en grafisch technicus. Uit het onderzoek wordt vervolgens geconcludeerd, dat een grote groep vrowwen een slechte arbeidspositie heeft; bijna een derde deel van de vrouwen, die bij de onderzochte bedrijven werkzaam zijn, werken via een uitzendbureau of heeft een tijdelijk contract. Het aantal vrouwen met een zogenaamd flexibel contract is bij deze groep veel hoger dan het landelijk percentage, namelijk respectievelijk 32,5\% en 10,7\%. Bovendien blijken de vrouwen in vergelijking tot de mannelijke collega's in lager betaalde functies te werken. Ook wat betreft de opleidings- en promotiemogelijkheden is geen rooskleurig beeld te geven; zo worden de vrouwen in een aantal bedrijven uitgesloten van opleidingen, omdat zij geen technische vooropleiding hebben genoten. Als enig lichtpunt(je) wordt gemeld, dat wel bijna alle vrouwen, die in een traditioneel mannenberoep werkzaam zijn, een opleiding in het bedrijf hebben gewolgd ${ }^{84}$. Omtrent de problematiek rond de zogenaamde "dubbele belasting" blijkt uit het onderzoek, dat de combinatie van 40 uren werken en het verantwoordelijk zijn voor het huishouden en soms het verzorgen van kinderen door de meeste vrouwen wel zwaar wordt gevonden. 
Maar opvallend wordt genoemd, dat de bij het onderzoek betrokken vrouwen, aangeven, dat juist door het feit, dat zij in wisselende diensten werken, zij meer tijd hebben voor het huishouden. Voordelen van ploegenarbeid zijn, dat de vrouwen meer ruimte hebben om hun eigen tijd in te delen, overdag boodschappen kunnen doen, hun sociale contacten met andere vrouwen kunnen onderhouden en meer verdienen dankzij de ploegentoeslag. Van de vouwen wil dan ook $72 \%$ in ploegendienst met nachtarbeid blijven werken, omdat de voordelen groter zijn dan de nadelen.

Maar er wordt wel bij aangetekend, dat een groot deel van de vrouwen maar een jaar of korter 's nachts heeft gewerkt. Bij mannen worden de effecten van het verrichten van arbeid in ploegendienst ook pas na een paar jaar duidelijk. Vijf vrouwen zijn gestopt met het werken in nachtarbeid, omdat de combinatie nachtarbeid en huishouden te zwaar was. Ook wat betreft het verzorgen van kinderen zien de vrouwen weinig nadelen; de meeste vrouwen hebben echter oudere kinderen, die minder verzorging nodig hebben ${ }^{85}$.

Uit het onderzoek blijkt tevens, dat van de in december 1986 verstrekte vergunningen er in november 1987 reeds $34 \%$ was vervallen. Hoewel daarna wel weer aan andere bedrijven vergunningen zijn verleend, leidt dit gegeven tot de conclusie, dat de "vrouwelijke nachtarbeiders" gebruikt worden als een "reserveleger", hetgeen trouwens al bleek uit de contracten die worden afgesloten ${ }^{88}$.

De motivering, die de wetgever bij eerdere gelegenheden had gegeven omtrent de bijzondere bescherming van vrouwen ten aanzien van het verrichten van nachtarbeid, is tijdens de parlementaire behandeling van het wetsvoorstel, waarbij dit mogelijk werd gemaakt, aan de orde geweest. Het argument van de bewindsvrouwe om aan deze bijzondere bescherming een einde te maken, concentreert zich rond de opmerking, dat een dergelijke bescherming niet meer gefundeerd is. Uit het evaluatieonderzoek blijkt zeer duidelijk, dat de regeling meer recht doet aan het formeel gelijk behandelen van mannen en vrouwen dan aan het toekennen van gelijke kansen. Maar in de hele regeling zit een vreemde dubbelzinnigheid. Zo is er een weigeringsgrond voor het verlenen van een vergunning opgenomen met betrekking tot bijzondere omstandigheden, waardoor het verrichten van arbeid door vrouwen minder geschikt is. Daarbij is gedacht aan onder meer het veilig vervoer van vrouwen in de nacht ${ }^{87}$. Andere categorièn van arbeid, zoals bijvoorbeeld arbeid in verplegingsinrichtingen, de zogenaamde restgroepen kennen voor vrouwen geen verbod van nachtarbeid, maar geven verder geen extra beschermingsnormen ten aanzien van het vervoer 's nachts. Bovendien geeft de wet geen mogelijkheid voor vrouwen om 's nachts te werken in kantoren, terwijl daar evenmin een verbod van nachtarbeid geld $t^{88}$. Uit het evaluatieonderzoek lijkt echter afgeleid te worden, dat een handhaven van een onderscheid tussen mannen en vrouwen in de industrie niet strikt noodzakelijk is uit het oogpunt van arbeidersbescherming $^{89}$. Om die reden werd op 5 september 1988 een wetswoorstel bij de Tweede Kamer ingediend ${ }^{\text {Do }}$ waarbij met betrekking tot nachtarbeid door vrouwen in fabrieken of werkplaatsen een wijziging wordt voorgesteld en waarbij het opheffen van de overige naar geslacht onderscheiden bepalingen aan de orde komt; op 11 april 1989 is de wetswijziging in werking getreden ${ }^{81}$. Wat opvallend is, is dat bij het opheffen van naar geslacht onderscheiden bepalingen voor vrouwen de zogenaamde mannennormen met betrekking tot de arbeidsduur zijn gaan gelden, en niet andersom; een punt dat overigens ook in het parlement tijdens de behandeling van het wetsvoorstel ter discussie was gesteld ${ }^{92}$. Het was wellicht beter geweest om vooraf een fundamentele discussie te voeren met onder andere het parlement over de problematiek rond het gelijk behandelen van mannen en vrouwen en de daarbij te hanteren uitgangspunten en normen ten aanzien van arbeids- en rusttijden.

\subsection{Jongerenstatuut}

De Nota inzake onderwijs en arbeidsmaatregelen voor werkende jongeren van de bewindsman van Sociale Zaken Roolvink en van Onderwijs en Wetenschappen Grosheide leidde in de vorige periode reeds tot een wijziging van de Arbeidswet 1919, waarbij de leeftijd van het arbeidsverbod in de wet werd verhoogd. Tevens werd in die periode aan de Sociaal-Economische Raad advies geviaagd ${ }^{93}$ over een wijziging van de Arbeidswet 1919 aangaande een algehele herziening van die hoofdstukken van de wet, die op jeugdige personen 
betrekking hebben; deze bepalingen zouden worden samengevoegd tot Een hoofdstuk van de Arbeidswet 1919, het zogenaamde Jongerenstatuut. Het adviesorgaan ${ }^{24}$ constateerde allereerst, dat ten gevolge van de maatschappelijke ontwikkeling een andere visie is verkregen op de plaats van de jonge mens in de samenleving en in het arbeidsproces en stemde vervolgens in met het uitvaardigen van een dergelijk Jongerenstatuut, een samenstel van voorschriften, die specifiek gelden voor werkende jongeren.

"Naar het oordeel van de Raad moet daarbij als uitgangspunt worden genomen, dat aan

deze naar wolwassenheid groeiende jongeren kansen dienen te worden geboden, om zich

op oudere leeftijd in de samenleving, waaronder begrepen het arbeidsproces, zoveel moge-

lijk te kunnen ontplooien".

In de eerste plaats werden daartoe maatregelen op het terrein van het onderwijs noodzakelijk geacht en in de tweede plaats - complementair - regels in het kader van de Arbeidswet 1919. In het voor advies voorgelegde wetsvoorstel werd voldoende rekening gehouden met de invoering van de partiele leerplicht en de daarmede verband houdende arbeidsmaatregelen. Volgens de Raad was het allereerst noodzakelijk om het arbeidsverbod te baseren op het ( partieel) leerplichtig zijn van een jongere en vervolgens op het beginsel van de 8-urige werkdag, waarbij de mogelijkheid van het verrichten van overwerk werd uitgesloten. Dat bracht met zïch, dat de vijfdaagse werkweek diende te worden verkort met het aantal dagen, waarop een jongere partieell leerplichtig is. Dat betekent, dat bij eén dag partiële leerplicht de arbeidstijd voor deze jongere $(40-8=) 32$ uren per week zal bedragen en bij twee dagen per week verplicht onderwijs $(40-2 \times 8=) 24$ uren per week ${ }^{\text {gs }}$.

De bewindsman van Sociale Zaken Boersma diende in september 1975 bij de Tweede Kamer een wetswoorstel in ${ }^{68}$, dat nauwelijks op problemen zou stuiten. Wel werd vanuit het parlement teleurstelling geuit over het feit, dat het wetswoorstel slechts een volgende stap betekende inzake de arbeidsbescherming vam de jeugdige personen in het kader van de geleidelijke verwezenlijking van het plan om tot een leerlingstatus te komen voor de jeugdigen in plaats van het voortzetten van de werknemersstatus ${ }^{97}$. Daarnaast werd vanuit het parlement opgemerkt ${ }^{98}$, dat het onderhavige wetsvoorstel slechts het eerste deel was van het aan de Sociaal-Economische Raad aangeboden voorontwerp. In de toelichting op dat bedoelde voorontwerp werden drie doelstellingen genoemd, namelijk:

1. het samenvoegen van de verspreide artikelen betreffende jongeren in een apart hoofdstuk;

2. een verandering van de op de jongeren van toepassing zijnde bepalingen, dit in verband met de maatschappelijke ontwikkelingen, waarbij in beginsel het recht op optimale ontplooiing wordt erkend;

3. het tot stand brengen van een jongerenreglement waarin regels zijn opgenomen ten aanzien van voorlichting, begeleiding en medische keuring.

De bewindsman reageerde ${ }^{9 \theta}$ op de opmerkingen vanuit het parlement met een korte schets te geven van de geschiedenis van het wetsvoorstel. Hij gaf daarbij te kennen, dat de Sociaal-Economische Raad had besloten over een gedeelte van het hem voor advies voorgelegde voorontwerp een interim-advies uit te brengen over de samenvoeging van de bepalingen terzake van jeugdigen, die verspreid in de diverse hoofdstukken van de Arbeidswet 1919 voorkwamen. De Raad kwam in dit interim-advies tevens tot de conclusie, dat het gedeelte van het voorontwerp, dat gaat over de voorlichting, de begeleiding van de jongere door een mentor en het jongerenreglement, een diepgaand overleg met het georganiseerde bedrijfsleven en met de desbetreffende jongerenorganisaties vereiste. Dit laatstbedoeld advies zou eerst op 19 december 1975 worden uitgebracht $^{100}$. Ten aanzien van de in de Nota inzake onderwijs- en arbeidsmaatregelen voor werkende jongeren aangekondigde maatregelen met betrekking tot de leerlingstatus merkte de bewindsman op, dat, waar hij sprak over de leerlingstatus, hij daarmee doelde op de rechtspositie van leerlingen, die werkzaamheden verrichten met het oog op hun vorming en opleiding. Voor de werknemersstatus daarentegen was van wezenlijke betekenis, dat een bijdrage aan het produktieproces werd geleverd. Het ging derhalve om de overgang van de rechtspositie van werknemer tot die van leerling ${ }^{101}$. Vanuit het parlement werd echter gevonden, dat de bewindsman wat al te gemakkelijk langs de problematiek van de leerlingstatus heen gegaan was. Zeker, daar hij gesproken had over de rechtspositie van leerlingen, was verwacht dat hij een visie daaromtrent had 
gegeven $^{102}$. De bewindsman antwoordde daarop, dat het wetsvoorstel geheel in de lijn lag van de Nota inzake onderwijs- en arbeidsmaatregelen en niet in tegenstelling is tot hetgeen daarin was vermeld over de wijziging van de rechtspositie van jongeren in het bedrijf van werknemerstatus naar leerlingstatus en nog uitging van de werknemerstatus. Hij wilde verder nog niet vooruitlopen op de minimunwaarborgen, die te zijner tijd voor de leerlingstatus wettelijk geboden dienen te worden, maar merkte wel op, dat verbeteringen op het terrein van de arbeids- en rusttijden van wezenlijke betekenis waren voor, zowel de jongeren met een werknemersstatus, als voor degene, die hetzij al een leerlingstatus bebben, hetzij wellicht veelvuldiger in de toekomst een ( volledige) leerlingstatus zouden krijgen. In elk geval zouden de wettelijke voorschriften ten aanzien van de arbeids- en rusttijden ten behoeve van de jongeren met een leerlingstatus vanzelfsprekend minstens moeten voldoen aan de normen, die gelden voor degenen, die thans nog de status van werknemer hebben. Een dieper gaande beschouwing over de problematiek van de leerlingstatus vond hij, gezien de aan de orde zijnde maatregelen, niet opportuun en veeleer voorbarig ${ }^{103}$. Dit antwoord was klaarblijkelijk voldoende. De voorgestelde wijziging van de Arbeidswet 1919 zou bij Wet van 18 mei $1977^{104}$ verwezenlijkt worden, maar eerst in 1981 in werking treden ${ }^{105}$, dus ruim tien jaar na de Nota, die er aan ten grondslag lag.

Ten aanzien van een onderdeel van het Jongerenstatuut, het verbod van kinderarbeid, merkte de SociaalEconomische Raad in het in 1972 uitgebrachte advies op, dat hij met instemming kennis had genomen van het feit, dat de arbeidsinspectie ten aanzien van kinderarbeid strenge maatstaven hanteerde. In dat verband vroeg de Raad bijzondere aandacht voor het feit, dat in toenemende mate kinderen werden ingeschakeld bij de produktie van radio- en televisieuitzendingen, opnamen van grammofoonplaten en dergelijke ${ }^{106}$. Juist deze vorm van kinderarbeid en het optreden van de arbeidsinspectie daartegen, zou de arbeidsinspectie herhaaldelijk in het nieuws brengen, zoals de perikelen rond Danny de Munk ${ }^{107}$ en het optreden van een Oegandees kinderkoor ${ }^{108}$.

Het districtshoofd van de arbeidsinspectie kan in afwijking van het verbod van kinderarbeid "in bijzondere gevallen" schriftelijk ontheffing verlenen ten aanzien van niet-industrële arbeid van lichte aard. Ingevolge interne richtlijnen werd naast de bescherming van het kind, de programmatische noodzaak van het optreden van het kind een sleutelrol bij het verlenen van een ontheffing toegekend. In de praktijk bleek dit echter op problemen te stuiten en tot misverstanden aanleiding te geven. Om die reden werden er nieuwe richtlijnen met betrekking tot het verbod van kinderarbeid ${ }^{109}$ uitgevaardigd, waarbij de toetsing van de programmatische noodzaak als ontheffingscriterium is komen te vervallen. Een nadere beschouwing van de richtlijnen geeft een complex beeld te zien, dat ten aanzien van deze materie wel haast onvermijdelijk is, maar well tevens een belangrijke bijdrage levert tot een betere beeldvorming omtrent de bij de wetgever levende gedachtengang rond het verbod van kinderarbeid ${ }^{100}$.

Hierboven is reeds melding gemaakt van het op 19 december 1975 - dus nog tijdens de parlementaire behandeling van dat deel van het Jongerenstatuut, dat handelt over de arbeids- en rusttijden - door de SociaalEconomische Raad uitgebrachte advies terzake van de voorlichting en begeleiding en het jongerenreglement, dat een onderdeel vormde van de in 1972 aan de Raad voorgelegde advies-aanvraag. In het advies ${ }^{111}$ constateerde de Sociaal-Economische Raad, dat van de ondernemer verwacht werd, dat hij een zekere mate van verantwoordelijkheid voor de ontplooiingsmogelijkheden van de jeugdige personen in en door hun arbeid op zich zou nemen. Hoewel niet ontkend werd, dat er redenen zijn voor bijzondere aandacht voor jeugdige personen, meende de Raad dat er evengoed aanleiding was voorlichting-en begeleidingactiviteiten te verrichten ten aanzien van andere werknemers. Met name de overgang van onderwijssituatie naar arbeidssituatie, ongeacht de leeftijd, vroeg om begeleiding. De bijzondere bepalingen voor de jeugdige personen, hoe zinvol op zichzelf ook, mochten niet geisoleerd van het totale beleid van de onderneming op het vlak van voorlichting en begeleiding van het personeel, worden bezien en toegepast ${ }^{12}$. Aan de begeleiding van jeugdigen moesten wel specifiek op hen gerichte eisen worden gesteld. Voorts zou het verantwoord en zelfs geboden kunnen zijn, dat een afzonderlijke functionaris zich binnen het raam van het sociale ondernemingsbeleid spe- 
ciaal met de belangen van de jeugdigen zou bezighouden.

In de toelichting op het op 12 oktober 1977 ingediende wetswoorstel ${ }^{1 / 3}$ maakte de bewindsman kenbaar, dat hij de bepalingen aangaande voorlichting en begeleiding en een jongerenreglement een belangrijke bijdrage achtte tot de verdere ontwikkeling van het sociaal ondernemingsbeleid ${ }^{114}$. Hij vervolgde met de opmerking, dat tot een dergelijk beleid ook de voorzieningen, die zijn neergelegd in het bij de Tweede Kamer ingediende ontwerp-Arbeidsomstandighedenwet ${ }^{115}$, bij zouden dragen ${ }^{10}$. De strekking van het wetsvoorstel zou in het parlement niet op bezwaren stuiten. Het wetsvoorstel is nooit verder gekomen dan het voorlopig verslag; een deel ervan zou worden opgenomen in het ontwerp-Arbeidsomstandighedenwet ${ }^{117}$.

Nauwelijks nog was de uitbreidende bescherming van de jeugdigen in het Jongerenstatuut verwezenlijkt en in werking getreden of een tegenbeweging zou in gang gezet worden. Het Jongerenstatuut kan tot organisatorische problemen leiden en de arbeidsmarktpositie van jeugdigen bemoeilijken, aldus de Stichting van de Arbeid in het hierna te behandelen advies nieuwe arbeidstijdpatronen. Dit adviesorgaan stelde voor om over eventuele wijzigingen van het Jongerenstatuut advies te vragen aan de Sociaal-Economische Raad. Alvorens deze adviesaanvraag zou worden verzonden werd een onderzoek ingesteld naar de positie van jeugdigen in het arbeidsproces ${ }^{1+0}$. Daarbij was de vraag aan de orde of de arbeidsmarktpositie van jeugdigen niet wordt verzwakt door de beschermende maatregelen van het Jongerenstatuut. Vooral met het oog op de gewenste versterking van de arbeidsmarktpositie van jeugdigen wenste men te bezien, welke bijzondere beschermende maatregelen voor jeugdigen moeten worden gehandhaafd en welke kunnen verdwijnen. Het huidige overheidsbeleid is er immers op gericht om de jeugdwerkloosheid terug te dringen en de positie van de jeugdigen op de arbeidsmarkt te verstevigen ${ }^{119}$. Uit het onderzoek blijkt, dat in de praktijk de consequenties van het bestaan van jeugdbeschermende maatregelen zich vooral bewegen op het niveau van de overheid als wetgever en de werkgevers- en werknemersorganisaties, die waken over de belangen van de objecten van wetgeving. Op het niveau van het individuele bedrijf wordt die belangstelling niet of nauwelijks weerspiegeld. De inhoud van het Jongerenstatuut maakt geen deel uit het van denken, doen en laten van de individuele werkgever. Geconstateerd wordt, dat de op de werkgever gerichte voorlichting over het Jongerenstatuut gefaald heeft. De belangrijkste doelgroep, de kleinere onderneming, werd niet of nauwelijks bereikt. Bovendien houdt de arbeidsinspectie als controle-instantie betrekkelijk weinig regelmatige contacten met de kleinere werkgevers. De onwetendheid, het gebrek aan kennis omtrent de bepalingen leidt ertoe, dat er bij de kleinere werkgevers nauwelijks knelpunten voorkomen. Is de kennis echter wel aanwezig, dan worden de bepalingen als gevolg van de geringe pakkans genegeerd. Bij grotere werkgevers ligt de zaak anders; deze kunnen zich een dergelijke houding niet permitteren. De jeugdigen kunnen vaak zonder probleem binnen de marges van het toelaatbare in het arbeidsproces ingeschakeld worden. Niet vergeten moet namelijk worden, dat het aantal jeugdigen dat deze werkgevers in dienst heeft meestal dusdanig is, dat zij geen wezenlijk bestanddeel vormen van de produktie- of dienstverleningscapaciteit. Bij de organisatie van het werk wordt er al rekening meegehouden, zodat, zolang het aantal jeugdigen gering is, dit niet leidt tot noemenswaardige knelpunten. Uit het onderzoek blijkt tevens, dat voor zover bedrijven moeite hebben met het Jongerenstatuut, dit eerder een afkeurende reactie was op de gedetailleerde overheidsbemoeienis met wat bedrijven wel en niet mogen, dan dat de inhoud van de specifieke bepalingen ter discussie werd gesteld. De wens om tot deregulering en vereenvoudiging van bedrijfsgerichte wetgeving te komen, leeft sterk, maar op het specifieke terrein van de jeugdbeschermende maatregelen leven nauwelijks veranderingswensen, zeker als de arbeids- en rusttijden centraal staan. Instemming werd betuigd met het feit, dat jeugdige werknemers een extra vorm van bescherming genieten en over het algemeen werd de kwetsbare positie van jeugdigen onderkend. Men onderstreepte, dat tegen malafide werkgevers, die jeugdigen zouden misbruiken, streng zou moeten worden opgetreden ${ }^{120}$. Eên en ander zou resulteren in een adviesaanvraag ${ }^{121}$ aan de Sociaal-Economische Raad, waarbij in het kader van de arbeïdsmarkt en de positie van jeugdigen wordt voorgesteld, om jeugdigen dezelfde mogelijkheden te geven als reeds aan mannen en vrouwen is toegestaan, zij het tot een maximum van 9 uren per dag en 160 uren in een periode van vier achtereenvolgende weken. Voorts wordt een mogelijkheid geopend om waar het werken op zaterdag voor mannen en vrouwen is toegestaan, dit voor jeugdigen eveneens mogelijk 
te maken. Voorgesteld wordt ook de werktijdbegrenzing, die ligt tussen 07.00 en 19.00 uur, te verruimen ${ }^{122}$.

Ten aanzien van de ontwikkelingen op het terrein van het Jongerenstatuut wil ik tot slot wijzen op een conclusie aan het slot van het rapport over het onderzoek naar de positie van jeugdigen in het arbeidsproces. Daarin wordt gesteld, dat de praktische betekenis van het Jongerenstatuut misschien niet groot is, maar dat het duidelijk is, dat het eèn emotioneel geladen onderwerp is, waarbij associaties met het Kinderwetje van Van Houten voor het oprapen liggen. In zijn hoedamigheid is het Jongerenstatuut een politiek document, waarin de normen en waarden neergelegd zijn die in onze maatschappij gelden ten aanzien van jeugd en arbeid. In die betekenis moet het dan ook gehandhaafd blijven. In de betekenis van een naar de letter uit te voeren en te controleren wet vertoont het mankementen en kan een vereenvoudiging gepast zijn ${ }^{123}$. Sinds zijn totstandkoming heeft de manier van denken over de verrichten van arbeid door jeugdigen een wijziging ondergaan. Hoe kan het ook anders; de tijden sinds het begin van de jaren zeventig zijn sterk veranderd. De accenten worden thans sterker gelegd op de deelname van jeugdigen aan het produktieproces, wat gezien de beperkte mogelijkheden op de arbeidsmarkt en de massale (jeugd-)werkloosheid misschien begrijpelijk is. Toch zou het te betreuren zijn, dat deze ontwikkelingen er toe zouden leiden, dat men zich te veel zou distantiëren van de gedachten, die aan het Jongerenstatuut ten grondslag liggen. Want moeten de jongeren aan het begin van hun maatschappelijke loopbaan niet eerst een leerproces doormaken, die, zowel hun vakopleiding, als hun algemene vorming betreft? Zou het anders niet leiden tot een verarming van onze samenleving, wanneer het jongeren terwille van de pragmatiek in toenemende mate aan ruime(re) ontplooiingsmogelijkheden zou ontbreken? Moeten deze jongeren niet de mogelijkheid krijgen zich voor te bereiden op hun verdere leven, wellicht in een maatschappij, die nog veel gecompliceerder lijkt te gaan worden dan die van hen, die in andere tijden leefden?

\subsection{Arbeidstijdverkorting, flexibele werktijden, het beperken van overwerk en het te voeren vergunningenbe- leid}

Evenals gedurende het interbellum zou de Arbeidswet 1919 in deze periode voor het voetlicht treden op het terrein van de werkloosheidsbestrijding.

Hoewel tegen het einde van 1976 de Industriebond FNV arbeidstijdverkorting als wapen tegen de werkloosheid introduceerde, duurde het enige tijd voordat arbeidstijdverkorting voor de vakbeweging een algemeen issue werd, maar in 1978 was het zover; dat jaar werd, ondanks de tegenzin van een aantal bonden, uitgeroepen tot het jaar van de arbeidsplaatsenovereenkomst. Dit instrument moest er voor zorgen, dat arbeidstijdverkorting ook tot meer werk zou leiden ${ }^{124}$. De werkgevers moesten van het verkorten van de arbeidstijd niets weten, hun remedie was: de lonen omlaag en de rendementen omhoog ${ }^{125}$. Deze opstelling van de werkgevers zou stand houden tot 1982, hoewel er ook vór die tijd langzaam maar zeker een verandering viell waar te nemen, zeker toen de vakbeweging zich bereid toonde de arbeidstijdverkorting zelf te willen betalen. In de onderhandelingen bleef de houding van de werkgevers echter defensief. Voor zover het de arbeidstijdverkorting betrof reageerden zij op de eisen, die de vakbonden stelden, en namen zij zelf geen initiatief.

In oktober 1980 toonden de werkgevers, zij het schoorvoetend, enig eigen initiatief met de publikatie van de nota De arbeidsduur ${ }^{126}$. In deze nota werden de begrippen bedrijfstijd en individuele arbeidstijd ${ }^{127}$ geîntroduceerd, terwijl voor het eerst het begrip flexibiliteit werd gehanteerd ${ }^{120}$. De commissie arbeids duur, die de discussienota had opgesteld, meende, dat bij ondernemingen

"veelal de behoefte ( bestond ) naar de mogelijkheid het arbeidspotentieel variabel te kunnen inzetten, afhankelijk van de bedrijfsbelasting"129

De commissie stelde daarna het volgende ${ }^{130}$ :

"Seizoengevoelige ondernemingen bijvoorbeeld zouden graag de per jaar overeengekomen arbeidsduur concentreren op een bepaalde periode. Aan werknemerskant lijkt die behoefte tot variabele inzet ook te bestaan. De toename van deeltijd- en uitzendarbeid en mogelijk 
een deel van het absenteisme wijzen in die richting. Het niet onderkennen van die behoeften en het niet inspelen daarop werkt contraproduktief en heeft een negatieve invloed op de arbeidsverhoudingen. Het zal daarom noodzakelijk zijn dat werkgevers zich daarop richten door en de arbeidsorganisatie en het arbeidsvoorwaardenpakket zodanig vorm te geven dat de flexibiliteit ontstaat om tijdens piekbelasting langere werktijden te hanteren, om deeltijdarbeid in allerlei vormen te aanvaarden en om te kunnen toelaten dat een werknemer een periode langer werkt om een langere vakantie te kunnen genieten, liever weekend-diensten heeft van 12 uur om meer weekenden vrij te zijn en dergelijke".

Twee jaar later was het bekende akkoord in de Stichting van de Arbeid tussen de centrale werkgevers- en werknemersorganisaties een feit ${ }^{13 t}$. Maar de situatie was wel volledig veranderd. De werkgevers hadden het initiatief van de vakbonden overgenomen. Hun benadering was, dat arbeidstijdverkorting moest worden ingepast in een nieuwe ondernemingsstrategie, die gericht moest worden op een flexibilisering van de bedrijfsvoering. Ten einde te voorkomen, dat met de arbeidstijd de bedrijfstijd werd verkort, moest het patroon van vaste werktijden worden doorbroken door het hanteren, hetzij een gemiddelde arbeidstijd per week, hetzij een fixatie van het aantal arbeidsuren per jaar, met andere woorden: flexibele werktijden ${ }^{\text {132. }}$.

Deze ontwikkelingen op het terrein van de arbeids- en rusttijden en de rol die de Arbeidswet 1919 daarbij zou kunnen spelen, vond zijn weerslag in het overheidsbeleid ter zake.

In het kader van het arbeidsvoorwaardenoverleg voor het jaar 1979 vatte de minister van Sociale zaken in een brief van 14 december 1978 aan de Stichting van de Arbeid en de Raad van Overleg voor de Handel een aantal gedachten samen met betrekking tot vraagstukken van de verdeling van de arbeid en het arbeidsmarktbeleid $^{133}$. Ten aanzien van het verrichten van overwerk ${ }^{134}$ vermeldde de brief de bereidheid van de regering om voorstellen voor te bereiden om de Arbeidswet 1919 zodanig te wijzigen, dat door de beperking van het aantal te werken uren de drempel werd verlaagd, waarbij het verrichten van overwerk aan een vergunning van de zijde van de arbeidsinspectie was onderworpen ${ }^{135}$. Tijdens de behandeling van deze brief in de Tweede Kamer op 28 maart 1979 werd ten behoeve van een eerlijke verdeling van arbeid ten aanzien van de beperking van het overwerk op spoed aangedrongen ${ }^{136}$, waarop door de bewindsman werd toegezegd, dat in dat kader zo spoedig mogelijk maatregelen zouden worden getroffen ${ }^{137}$. Deze toezegging zou resulteren in een voorontwerp van wet met toelichting waarbij de Arbeidswet 1919 zou worden gewijzigd. Bij brief van 7 februari $1980^{133}$ werd het voorontwerp aan de Social-Economische Raad voor advies gezonden. Dit zogenaamde "vijf-dagen"-wetje beoogde de discrepantie, die bestond tussen de arbeidswettelijke arbeids- en rusttijden en de feitelijke arbeids- en rusttijden, te verkleinen ${ }^{139}$, zodat er sneller een overwerkvergunning van de zijde van de arbeidsinspectie noodzalkelijk was. De betiteling van het voorontwerp zegt het al: de bedoeling was on te komen tot een algemene beperking van het aantal arbeidsdagen. Gekozen werd voor een stelsel, waarbij over een periode van 6 weken - de zogenaamde referteperiode - op niet meer dan 30 dagen arbeid zou mogen worden verricht, met andere woorden, dat gemiddeld op niet meer dan 5 dagen per week gewerkt zou mogen worden. Voor het werken op de zesde dag moest een vergunning van de arbeidsinspectie worden gevraagd, tenzij deze zesde dag in de referteperiode zou worden gecompenseerd ${ }^{40}$. Door het kiezen van deze constructie was geprobeerd een zo eenvoudig mogelijke regeling te treffen, waarbij vooralsnog wijziging van, zowel de structurur, als de systematiek van de Arbeidswet 1919 en de daarop gebaseerde werktijdenbesluiten tot een minimum beperkt zou blijven ${ }^{141}$.

Uit het door de Sociaal-Economische Raad in 1982 uitgebrachte advies blijkt, dat in het algemeen het belang van het beheersen van overwerk en dan met name structureel overwerk, zowel uit het oogpunt van arbeidsbescherming als vanuit een mogelijk betere verdeling van de beschikbare arbeid, werd onderschreven ${ }^{142}$. Over de keuze, die gemaakt was, om dit doel te bereiken, werd in de Raad echter verschillend gedacht. Zo achtte een meerderheid van de $\mathrm{Raad}^{143}$, dat in het wetsvoorstel te veel werd voortgebouwd op een wetgevingssysteem dat in feite verouderd is ${ }^{144}$. De starre en gedetailleerde systematiek van de Arbeidswet 1919 stond haaks op een flexibel en pluriform systeem van de arbeidsduur dat dit deel van de Raad voor- 
stiond; een systeem, dat met name bepleit was in de discussienota arbeidsduur. Andere bezwaren waren onder meer: de Arbeidswet 1919 kent als voornaamste doelstelling het beschermen van arbeiders, terwijl de voorgestelde regeling, via de weg van thet terugdringen van het overwerk, een ander doel nastreeft, namelijk herverdeling van arbeid, hetgeen een oneigenlijk element in de wet invoerde. Getwijfeld werd of het voorstel een bijdrage zou kunnen leveren om het mede beoogde doel, het scheppen van meer arbeidsplaatsen te bereiken; het voorstel zou tot grote organisatorische problemen kunnen leiden in vrijwel alle $\operatorname{sectoren}^{145_{5}}$; in een aantal sectoren geldt voor een groep werknemers een zesdaagse werkweek, hetgeen door het wetsvoorstel in de verdrukking zou komen. Hierdoor zou de noodzakelijke opvang van "seizoen"-gevoelige bedrijven bemoeilijkt kunnen worden ${ }^{146}$. Om de gesignaleerde knelpunten weg te nemen werd voorgesteld een verlenging van de referteperiode van bijwoorbeeld één jaar in combinatie met een uren- in plaats van een dagencriterium.

De minderheid van de $\operatorname{Raad}^{147}$ ondersteunde het voorstel ${ }^{148}$, omdat overwerk onder het vergunningenregiem van de Arbeidswet 1919 werd gebracht en daardoor onder controle van de arbeidsinspectie. Hoewel een kwantitatieve schatting van de effecten niet te geven was, werd wel gesteld, dat de betreffende regeling positieve gevolgen zou kunnen hebben woor de werkgelegenheid. Het voorstel gaf voldoende handreiking om aan eventuele knelpunten het hoofd te bieden. De verantwoordelijke bewindswrouwe mewrouw Kappeyne van de Coppello zou in een reactie op het advies de Sociaal-Economische Raad schrijven ${ }^{149}$, dat het wetsvoorstel niet zou worden doorgezet, omdat de invoering ervan niet overeenkwam met het door het kabinet voorgestane dereguleringsbeleid en bovendien slechts een geringe bijdrage met betrekking tot de oplossing van het werkloosheidsprobleem verwacht kon worden.

Ruim een jaar later zou dezelfde staatssecretaris van Sociale Zaken en Werkgelegentheid zich bij brief tot de Stichting van de Arbeid wenden ${ }^{150}$ ten einde dit advies-orgaan te raadplegen over de mogelijkheden die de Arbeidswet 1919 biedt om in te spelen op de hierboven geschetste ontwikkelingen ten aanzien van flexibiliteit en arbeidstijdverkorting ${ }^{151}$. Hierbij dient het volgende aangetekend te worden. Begin 1985 werd de flexibilisering van de arbeidsduur slechts in incidentele gevallen feitelijk toegepast; het gaat daarbij slechts om $2,9 \%$ van de bedrijven, die enige vorm van arbeidsduurverkorting toepassen ${ }^{152}$.

In de advies-aanvraag stelde de bewindsvrouwe, dat in de praktijk verschillende bedrijuen of bedrijfstakken gedurende kortere of langere tijd wellicht behoefte zullen kunnen hebben aan wat genoemd kan worden nieuwe arbeidstijdpatronen. Bij deze nieuwe arbeidstijdpatronen kunnen de volgende zaken spelen: de maximale arbeidsduur, de vierdaagse werkweek, de dagelijkse begin- en eindtijden ( de zogenaamde werktijdbegrenzing ), arbeid op de zesde dag en arbeid in zogenaamde weekend-ploegen ${ }^{153}$.

In een in opdracht van het directoraat-generaal wan de arbeid uitgevoerd literatuuronderzoek wordt eveneens de term nieuwe arbeidstijdpatronen gebezigd ${ }^{154}$. Daarbij worden genoemd: de samengedrukte werktijd ${ }^{165}$, onregelmatige en ploegenarbeid, waaronder de zogenaamde mini-shift en de weekend-ploeg ${ }^{156}, k^{2} u-$ ze en gespreide werktijden ${ }^{157}$ en flexibele arbeidstijden ${ }^{156}$. Opmerkelijk is, dat het overgrote deel van de aangehaalde arbeidstijden echter geenszins nieuw zijn, zoals bijvoorbeeld de mini-shift ${ }^{159}$.

Terug naar de advies-aanvraag. Terwille van de rendementspositie van bedrijven wordt de flexibelere benadering van de arbeidstijd benadrukt, waardoor een langere arbeidsdag dan ingevolge de Arbeidswet 1919 is toegestaan, nodig is. Deze ontwikkeling wilde de bewindsyrouwe niet ondergraven, maar de beschermingsdoelstelling diende daaraan echter niet opgeofferd te worden, zodat zij de volgende maxima voorstelde: 10 uren per dag, 180 uren per vier weken (gemiddeld 45 uren per week), 1850 uren per jaar (gemiddeld 40 uren per week ) ) $^{180}$. Een ( samengedrukte) vierdaagse werkweek werd door haar niet bezwaarlijk gewonden, evenmin een verruiming van de werktijdbegrenzing met én uur, waardoor de tijdstippen van het begin en het einde van de werktijd gelegen kunnen zijn tussen 06.00 uur en 18.00 uur dan wel 07.00 uur en 19.00 uur. De zogenaamde mini-shift wilde zij niet toestaan. Hetzelfde gold ten aanzien van de zogenaamde weekend-ploegen. Bij het werken op de zesde dag dacht zij eerder aan de zaterdag dan aan de zondag en daar is vanuit de doelstelling van arbeidersbescherming geen bezwaar tegen aan te voeren, mits een wekelijkse onafgebroken rusttijd onverkort van kracht blijft. Tot slot maakte zij kenbaar, dat zij het vergunningenbeleid 
wilde afstemmen op hetgeen in (collectieve) afspraken tussen bedrijfsgenoten wordt vastgelegd. Het vergunningenbeleid wilde zij in principe, binnen de gestelde grenzen, zonder nadere toetsing conformeren aan afspraken, die sociale partners maken bij collectieve arbeidsovereenkomsten. Bij gebreke daarvan dient op ondernemingsniveau overeenstemming bereikt te worden met de ondernemingsraad of, wanneer deze ontbreekt, met de meerderheid van de belanghebbende werknemers. Een en ander kan dan worden gehonoreerd in individuele en ministeriële vergunningen.

Nog geen jaar later op 10 mei $1985^{161}$ zou de Stichting van de Arbeid haar advies uitbrengen. Als gevolg van een door de staatssecretaris op 3 september 1984 bij de Stichting van de Arbeid ingediende adviesaanvrage "inzake een nieuwe wettelijke arbeids- en rusttijdenregeling" meenden zowel de vertegenwoordigers van de centrale werkgeversorganisaties als van het Christelijk Nationaal Vakverbond en de Unie voor Middelbaar en Hoger Personeel, dat met een advisering over de normen voor de maximale arbeidstijd per dag, per vier weken dan wel per jaar onvermijdelijk vooruitgelopen werd op een discussie over de voorstellen neergelegd in de genoemde discussienota. Om die reden wilden zij dan ook geen uitspraak doen over de aanvaardbaarheid van de in de voorliggende advies-aanvraag genoemde normen en de daarin omschreven nieuwe arbeidstijdpatronen. Wel meenden zij, dat, in afwachting van de herziening van de Arbeidswet 1919, zwaarwegende betekenis diende te worden toegekend aan hetgeen tussen werkgever(s) of werkgeversorganisaties en werknemersvertegenwoordiging op bedrijfstak-respectievelijk ondernemingsniveau wordt afgespro$k^{162}{ }^{46}$, hoewel zij tevens stelden, dat de overheid op grond van de Arbeidswet 1919 daarbij een eigen (publiekrechtelijke) verantwoordelijkheid bleef behouden.

De vertegenwoordigers van de Federatie van Nederlandse Vakverenigingen daarentegen meenden, dat de overheid, gegeven het verschijnsel van nieuwe arbeidstijdpatronen, er niet aan kon ontkomen dienaangaande een vergunningenbeleid te formuleren. In dat verband past het namelijk, dat de overheid, gezien haar verantwoordelijkheid, grenzen ten aanzien van de arbeidsduur stelt, tot waar uiterlijk vergunning in het kader van deze nieuwe arbeidstijdpatronen verleend zal worden. $\mathrm{Zij}$ begrepen niet, dat met het doen van uitspraken over deze in acht te nemen grenzen bij het op grond van de Arbeidswet 1919 te voeren onderhavige vergunningenbeleid vooruitgelopen werd op de nog te voeren discussies over de herziening van die wet. $\mathrm{Zij}$ adviseerden dan ook de volgende grenzen en criteria in acht te nemen. Voor nieuwe arbeidstijdpatronen, als hier bedoeld, zou slechts vergunning worden verleend, indien deze zouden samenhangen met overeengekomen maatregelen tot vermindering van de gemiddelde arbeidsduur; een maximale arbeidsduur van 9 uren per dag en 42 uren per week; een werktijdbegrenzing van 06.00 uur tot 19.00 uur, met dien verstande dat tussen het eindtijdstip en het begintijdstip van de arbeid een rustperiode van ten minste 12 uren dient te liggen; geen vergunning voor arbeild op zes dagen achtereen en geen vergunning voor de zogenaamde weekend-ploegen.

Het vergunningenbeleid van de arbeidsinspectie dat onder meer ten aanzien van de nieuwe arbeidstijdpatronen gevoerd zou gaan worden, is door de verantwoordelijke bewindsman De Graaf neergelegd in de nota Vergunningenbeleid arbeids- en rusttijden, die bij brief van 5 juni 1987 aan zowel de Stichting van de Arbeid, als de Voorzitter van de Tweede Kamer werd medegedeeld ${ }^{163}$. In de nota wordt uitgegaan van arbeid verricht door mannen in fabrieken of werkplaatsen ${ }^{164}$. Bedrijven kunnen in het kader van een structurele werktijdregeling desgevraagd individueel of per groep van ondernemingen in aanmerking komen voor een een- of meerjarige vergunning, die in de nota de flexibele jaarvergunning wordt genoemd. De uitgangspunten voor een dergelijke vergunning zijn als volgt. Toegestaan zal worden, dat per dag ten hoogste 9,5 uur arbeid wordt verricht, onder voorwaarde dat in elke periode van vier weken niet meer dan 180 uren (gemiddelde 45-urige werkweek) en per jaar niet meer dan 1850 uren (gemiddelde 40-urige werkweek) arbeid wordt verricht. Ten opzichte van de advies-aanvraag is alleen een wijziging aangebracht ten aanzien van de maximale arbeidstijd per dag. In deze flexibele jaarvergunning is echter een element ingebouwd, dat als een soort beloning voor het doorvoeren van arbeidstijdverkorting kan worden aangemerkt. Als een bedrijf namelijk een gemiddelde arbeidstijd van 40 uren per week heeft verkort tot bijvoorbeeld gemiddeld 36 of 38 uren kan, wanneer zich in het bedrijf bijzondere omstandigheden voordoen ${ }^{105}$, in de vergunning tevens worden opgenomen, dat op 30 dagen per jaar in plaats van 9,5 uur ten hoogste 11 uren wordt gewerkt, zij het onder voor- 
waarde, dat door een arbeider op niet meer dan 3 dagen per week langer dan 9,5 uur gewerkt mag worden. Is in een bedrijf de verkorting van de (gemiddelde) arbeidstijd achterwege gebleven, dan zal woor te extra te werken uren een daartoe strekkend verzoek aan het districtshoofd van de arbeidsinspectie dienen te worden gericht.

Voorts zijn er ten aanzien van de flexibele jaarvergunning nog voorwaarden opgenomen ten aanzien van de werktijdbegrenzing - het tijdstip van begin en eindle van de werktijd moet gelegen zijn tussen 06.00 uur en 19.00 uur -, de dagelijkse onafgebroken rusttijd moet ten minste 12 uren omvatten, en de werktijdregeling mag niet meer dan 6 dagen beslaan. Bij dit laatste bestaat geen bezwaar tegen het werken op zaterdag. mits de wettelijk gestelde wekelijkse onafgebroken rusttijd van kracht blijft. Wel wordt opgemerkt dat het verrichten van arbeid op zondag zoveel mogelijk buiten beschouwing dient te blijven. Ten aanzien van de weekendploegen geldt, evenals in de advies-aanvraag al was gesteld, dat daarvoor geen vergunning zou worden verleend, terwijl voor het werken in de zogenaamde mini-shift al in 1984 een vergunning voor een periode van 2 jaar werd verleend in het kader van een experiment ${ }^{106}$.

Maar met het verschijnen van de nota vergunningenbeleid was er nog geen einde gekomen aan de discussie rond de arbeids- en rusttijden. Zo maakte de bewindsman in een brief van 12 februari 1988 aan de Tweede Kamer bekend, dat er met werkgevers- en werknemersorganisaties gesprekken hadden plaatsgevonden over de inhoud van de bedoelde nota en dat deze hebben geleid tot een bijstelling ${ }^{167}$. Deze bijstelling had voornamelijk betrekking op de berekening van de jaarnorm, de maxima voor het noodzakelijke overwerk en de hoogte van de dagelijkse en wekelijkse rusttijden. Al tijdens de begrotingsbehandeling van Sociale Zaken en Werkgelegenheid was er kritiek geweest van de zijde van het Tweede Kamerlid Wolters ${ }^{183}$ op de uitgebrachte nota. Deze zou worden herhaald tijdens het mondeling overleg over de nota vergunningenbeleid ${ }^{100}$. Deze kritiek richtte zich vooral op het feit, dat de overheid wel heel nadrukkelijk op de stoel van de sociale partners zou gaan zitten, zelfs wanneer deze tot overeenstemming zijn gekomen. Bovendien is de voorgestelde regeling wel zeer gedetailleerd en daardoor ingewikkeld en wordt hierdoor de beoogde flexibilisering niet bevorderd. In het kader van de door de bewindsman aangegeven doelstellingen van de Arbeidswet 1919, waarbij bescherming van de gezondheid, de veiligheid en het welzijn van de werknemers centraal dient te staan, moet, aldus dit Kamerlid, een beleid ontwikkeld worden waarbij rekening gehouden wordt met de flexibilisering die voortvloeit uit veranderende omstandigheden waaronder de ondernemingen werken. De gedachte van flexibilisering behoeft namelijk niet op gespannen voet te staan met de noodzaak van bescherming van werknemers op grond van de huidige wet. Ook bij de werknemers is een toenemende behoefte aan flexibilisering van arbeidstijden te constateren, aldus dit Kamerlid. Bovendien meende dit lid, dat het beleid van de overheid op een eigentijdse wijze moet inspelen op de taken en verantwoordelijkheden van de sociale partners. Zijn fractie staat een beleid voor, waarin sociale partners samen een zware verantwoordelijkheid dragen voor de vormgeving van arbeids- en rusttijden en waarin de overheid niet meer exclusief verantwoordelijk is voor het vergunningenbeleid. Een door sociale partners gezamenlijk gedragen beleid zal en bescherming van de werknemers èn de flexibilisering van de arbeid ten goede komen. Dit door zijn fractie voorgestane beleid, wijkt op een aantal punten af van het raamwerk, dat in de nota is neergelegd. Zo is er geen behoefte aan een jaarnorm met betrekking tot structurele flexibele werktijden, omdat een jaarnorm niet thuishoort in wetgeving die bescherming van werknemers beoogt te regelen; immers, de gezondheid, de veiligheid en de sociale doeleinden van de arbeidswetgeving worden niet beschermd op jaarbasis, maar door beperkingen in kortere periodes. De keuze valt dientengevolge op een kwartaalnorm, terwijl woorts een verruiming van het aantal arbeidsuren per vier weken en de werktijdbegrenzing wordt voorgesteld. Mevrouw Rempt-Halmmans de Jongh ${ }^{170}$ sloot zich bij de door Wolters ontwikkelde ideëen aan. Van de zijde van de oppositie werd door het Kamerlid Moor ${ }^{171}$ opgemerkt, dat er een onderscheid gemaakt moet worden tussen de bedrijfstijd en de arbeidstijd. Een verruiming van de bedrijfstijd stuitte bij hem op geen bezwaar, maar ten aanzien van de arbeidstijd merkte hij op, dat de ruimte die, zowel de bewindsman, als in nog versterkte mate de regeringsfracties, voorstellen om individuele arbeiders arbeid te laten verrichten te groot is. Als gevolg van de druk die door het Kamerlid Wolters op de bewindsman werd gelegd, 
- "de door hem gedane wijzigingsvoorstellen ( moeten) gezien worden als én pakket" werden de normen van de nota vergunningenbeleid conform de wensen van het parlement aangepast ${ }^{172}$.

\subsection{Een nieuwe Arbeidswet}

Zoals hierboven reeds is geschreven heeft de Staatssecretaris van Sociale zaken en Werkgellegenheid mevrouw Kappeyne van de Coppello bij brief van 3 september 1984 een discussienota inzake een nieuwe wettelijke werk- en rusttijdenregeling ${ }^{n 173}$, als grondslag voor een herziening van de Arbeidswet 1919 aan de Stichting van de Arbeid voor advies voorgelegd. Na bijna drie jaar, in augustus 1987, zou de stichting haar advies uitbrengen $^{174}$. De discussienota ${ }^{175}$ stelt, dat een aantal maatschappelijke ontwikkelingen, die zich sinds de totstandkoming van de Arbeidswet 1919 hebben woorgedaan, alsook een aantal praktische bezwaren van de huidige wet, het opstellen van een nieuwe wettelijke regeling noodzakelijk maakt. Het traditionele begrip "arbeidersbescherming" heeft in de laatste decennia aan betekenis ingeboet en is gaandeweg vervangen door het begrip "bevordering van menswaardige arbeid" ${ }^{148}$. De evolutie van de Veiligheidswet 1934 naar de Arbeidsomstandighedenwet wordt daarvan een treffend voorbeeld genoemd. Arbeids-en rusttijden spelen een meer dan marginale rol bij het nastreven van doelstellingen op het terrein van veiligheid, gezondheid en welzijn in verband met de arbeid. De overheidstaak ter zake van de regeling van de arbeids- en rusttijden zall dan ook, aldus de discussienota, primair moeten worden gezien

"in het kader van het beleid inzake het bevorderen van menswaardige arbeid".

Daarnaast wordt gewezen op het tot stand gekomen overleg tussen werkgevers en werknemers, zowel op nationaal, bedrijfstak - als op ondernemingsniveau en de gewijzigde denkbeelden met betrekking tot de traditionele arbeidstijdpatronen, zoals bijvoorbeeld deeltijdarbeid, variabele werktijden, vijf-ploegendiensten en flexibilisering van arbeidstijden. Als praktische bezwaren tegen de huidige wettelijke regeling worden aangevoerd: het ingewikkelde systeem, de achterhaalde indeling in sectoren, het buiten de werkingssfeer vallen van de overheid $^{t 77}$, de discriminerende bepalingen ten aanzien van arbeid door mannen en vrouwen, de inkomensgrenzen en onderscheiden functies ${ }^{178}$ en de grote nadruk op de bemoeienis van de arbeidsinspectie tegenover de geringe rol van de ondernemingsraad, eén en ander ten koste van een effectieve handhaving.

Over de doelstelling van de nieuwe wettelijke regeling van de arbeids- en rusttijden zijn de werkgevers- en de werknemersvertegenwoordigers het, blijkens het advies ${ }^{178}$, niet geheel eens. Wel bestaat er overeenstemming over het feit, dat de nieuwe wet moet voorzien in de bescherming van de werknemers. Er zal echter een evenwicht moeten worden gevonden tussen deze doelstelling en de flexibiliseringsbehoefte van ondernemingen in het kader van hun economische doelstelling. Van werkgeverszijde wordt de aantekening gemaakt, dat ( her-) verdeling van arbeid niet onder de doelstelling van de nieuwe wet begrepen mag worden; de nieuwe wet mag dan ook niet als werkgelegenheidsinstrument gebruikt worden, omdat dit in strijd zou zijn met de collectieve contractsvrijheid ${ }^{100}$.

Van werknemerszijde daarentegen wordt opgemerkt, dat de discussienota de overheidstaak ten aanzien van de wettelijke regeling van de werktijden te beperkt ziet. Bij de totstandkoming van de Arbeidswet 1919 speelden tenslotte ook andere factoren dan alleen veiligheid en gezondheid een rol, waaronder de rol van man en vrouw in het gezin. Volgens de werknemersvertegenwoordigers moeten ook veranderingen in de participatie van mannen en vrouwen in betaalde en onbetaalde arbeid daarin verdisconteerd worden. Hoewel van werknemerszijde wordt erkend, dat de nieuwe wet geen rechtstreekse dwang tot verkorting van de feitelijke ( gemiddelde) arbeidstijd zou moeten bewerkstelligen, zou wel een indirecte bijdrage ${ }^{181}$ geleverd kunnen worden aan de beheersing van de arbeidsduur in het belang van spreiding van de werkgelegenheid.

De in de discussienota ${ }^{182}$ neergelegde gedachtengang, dat het stellen van grenzen aan arbeids- en rusttijden een taak van de overheid/wetgever behoort te blijven, wordt door de sociale partners niet bestreden ${ }^{103}$. Als de doelstelling van de nieuwe wet in ogenschouw wordt genomen, dan ligt het op de weg van de overheid/wetgever om het kader aan te geven, waarbinnen partijen een regelling op het gebied van de arbeidsduur en werktijden nader kunnen vaststellen. Rekening zal echter gehouden moeten worden met de toegenomen 
medezeggenschap van de werknemers in het besluitvormingsproces op de verschillende niveaus. Er zal in de nieuwe wet dan ook ruimte geboden moeten worden voor de mogelijkheid, dat sociale partners zelf collectief afspraken kunnen maken over de in de onderneming toe te passen arbeidsduur en/of werktijdenregeling.

Over de vraag, in welke mate van de wettelijk gegeven marges moet kunnen worden afgeweken en op welke wijze dit zou kunnen gebeuren, lopen de meningen binnen de Stichting van de Arbeid uiteen.

In de discussienota wordt als wettelijk stelsel het volgende voorgesteld. De wet geeft de maximale arbeidsduur aan. Indien de organisaties van werkgevers en van werknemers daarom verzoeken, kan de verantwoordelijke bewindsman daarvan vrijstelling verlenen. Deze vrijstelling gaat tot de grenzen, die de verzoekers zelf aangeven. Deze vrijstelling is uitsluitend vereist vanwege het aspect van naleving van de normen, die door de sociale partners zijn afgesproken en de controle daarop door de arbeidsinspectie ${ }^{184}$.

Uit het advies blijkt, dat in de Stichting van de Arbeid een drietal modellen van arbeidsduur en werktijden aan de orde is geweest ${ }^{185}$ :

1. een wettelijke standaardregeling, waarvan in overleg tussen sociale partners onbeperkt kan worden afgeweken;

2. een model waarbij de wet enkele absolute, dat wil zeggen maximale, grenzen bevat;

3. een model inhoudende een standaardregeling, waarvan in overleg tussen werkgever(s)- en werknemersvertegenwoordigers kan worden afgeweken, mits men binnen de in de wet neergelegde grenzen blijft.

Zowel de werkgevers- als de werknemersvertegenwoordigers hebben zich, gelet op hun standpunten over de uitgangspunten van de nieuwe wettelijke regeling in het onder 3. bedoelde model kunnen vinden; alleen over de uitwerking ervan bestaan verschillen van mening.

De werkgeversvertegenwoordigers ${ }^{188}$ staan een ruime standaardregeling voor, waarbinnen de werkgever in beginsel vrij is om de arbeidsduur en de werktijden vast te stellen, zodat hierdoor de organisatie van het werk en een optimale bedrijfsvoering beter op elkaar kunnen worden afgestemd. Zij wijzen daarbij op het instemmingsrecht van de ondernemingsraad in geval van een werktijdregeling ${ }^{187}$. Indien en voor zover de regeling van de werktijden in een collectieve arbeidsovereenkomst is neergelegd, vervalt het instemmingsrecht van de ondernemingsraad. De zogenaamde overlegregeling geeft de grenzen, waarbinnen in overleg tussen werkgevers- en werknemersorganisaties in het kader van het totstandkomen van een collectieve arbeidsovereenkomst van de standaardregeling kan worden worden afgeweken. Wanneer dit overleg echter in dit kader geen resultaat oplevert, dan dient een vergunning door de arbeidsinspectie te worden verleend.

De werknemersvertegenwoordigers ${ }^{18 s}$ staan een betrekkelijk restrictieve regeling voor en verwerpen de argumenten van de werkgevers. Daarbij stellen zij allereerst, dat de door de werkgevers voorgestelde rol van de ondernemingsraad via het instemmingsrecht niet opgaat, omdat deze te beperkt is, namelijk tot werktijden en niet tot arbeidsduur als primaire arbeidswoorwaarde. Vervolgens merken zij op, dat het belang van arbeidsbescherming uitstijgt boven de individuele onderneming en dat er ondernemingen zijn die geen ondernemingsraad hebben. Regeling bij collectieve arbeidsovereenkomst biedt een waarborg, dat de met de wet beoogde doelstellingen, die de belangen van de individuele ondernemingen overstijgen, voldoende tot gelding komen. De overlegregeling moet huns inziens dan ook inhouden, dat in beginsel alleen bij of krachtens collectieve arbeidsovereenkomst ${ }^{189}$ van de standaardregeling kan worden afgeweken. Wanneer deze ontbreekt is een vergunning van de arbeidsinspectie nodig.

Ten aanzien van de normen, die in acht zouden moeten worden genomen, kan worden opgemerkt, dat in de discussienota alleen gesproken wordt over de maximaal toegestane arbeidstijden, die overeenkomen met de normen die in een eerdere versie van de nota vergunningenbeleid waren neergelegd. Elementen zoals bijvoorbeeld de werktijdbegrenzing, de pauzeregeling, het verrichten van arbeid op zaterdag en/of zondag worden niet vermeld.

Zowel over de arbeidstijden als over deze elementen en zaken als nachtarbeid, overwerk, incidenten en ploegenarbeid verschillen de werkgevers- en de werknemersvertegenwoordigers, en deze weer onderling, sterk van mening ${ }^{100}$, maar de grondgedachte is, dat de werkgevers ruime grenzen gesteld willen zien, met zo 
min mogelijk bemoeienis van overheidszijde, terwijl de werknemers, ondanks de verschillen van mening beperktere grenzen voorstaan.

Het werkgeversargument in het advies inzake een nieuwe wettelijke regeling van de arbeids- en rusttijden, dat het eventueel gebruiken van de nieuwe wet in het kader wan het werkgelegenheidsbeleid in strijd zou zijn met de collectieve onderhandelingswrijheid, kan mij niet overtuigen. Het recht op collectief onderhandelen is weliswaar een grondrecht, dat van overheidszijde gerespecteerd dient te worden, maar levert geen argument op om regeling ter zake tot een monopolie van de sociale partners te maken ${ }^{181}$, zeker niet, omdat de overheid ook een ander grondrecht heeft te waarborgen, namelijk het recht op arbeid, in welk kader zij een werkgelegenheidsbeleid voert, althans dient te voeren. Wanneer beide grondrechten met elkaar botsen, dan dient er door de overheid een belangenafweging te worden gemaakt, die niet zonder meer ten gunste van de collectieve contractsvrijheid behoeft uit te vallen. Zeker wanneer de contractspartijen er niet in slagen zelf een werkgelegenheidsbeleid tot stand te brengen, kan er voor de overheid aanleiding zijn om in te grijpen ${ }^{122}$. Iets anders is echter of dit aspect in de wetgeving op het terrein van de arbeidersbescherming geregeld moet worden.

Voorts zal de participatie van de werknemers in de nieuwe wetgeving veel meer accent krijgen. Nu reeds kunnen werknemers in het kader van de Wet op de ondernemingsraden (mede)zeggenschap uitoefenen. Zo kan de ondernemingsraad een rol spelen in het kader van het toezicht en de uitoefening van het instemmingrecht met betrekking tot de werktijden, voor zover één en ander niet al geregeld is bij collectieve arbeidsovereenkomst ${ }^{183}$. Via deze laatste ingang, namelijk de vakorganisatie, kunnen zij eveneens invloed uitoefenen. Dit laatste is echter niet nieuw, want de rol van de vakorganisatie ter zake van de arbeids- en rusttijden door middel van collectieve arbeidsovereenkomsten bestaat al. De wettelijke regeling van de arbeids- en rusttijden, zoals die nu geldt, dient in feite tot het tegengaan van excessen. De feitelijke arbeidsen rusttijden worden bepaald door collectieve arbeidsovereenkomsten en liggen lager. In het verlengde van deze bestaande situatie ligt het dus in de lijn om bij wet ruimere grenzen te stellen om zo een afwijking van de wettelijk gegeven basisregeling bij collectieve arbeidsovereenkomst mogelijk te maken. In feite is dit geen nieuw systeem. Verwezen mag worden naar artikel 28, zevende lid, van de Arbeidswet 1919 en analoge bepalingen, waarin een dergelijk systeem reeds bestaat, maar waarvan zeer weinig gebruik is gemaakt. Het in dit artikellid neergelegde systeem schrijft echter voor, dat voor de aldaar bedoelde regeling een vergunning van de minister van Sociale Zaken en Werkgelegenheid nodig is. Dit brengt met zich, dat er een toetsing plaatsvindt, en daarmee wordt direct de mogelijkheid voor misbruik afgesneden. Dit zal ook bij een nieuwe wettelijke regeling de meest geëigende constructie zijn. Wanneer afwijking bij collectieve arbeidsoverkomst mogelijk zou worden gemaakt binnen wettelijk vastgestelde grenzen, dan zou de werkgever met een nietrepresentatieve vakorganisatie een dergelijke overeenkomst kunnen afsluiten om zo onder de arbeidswetgeving uit te komen ${ }^{104}$.

De directeur-generaal wan de Arbeid De Roos sprak tijdens de studiedag over werktijden op maat in oktober 1984, vlak nadat de discussienota aan de Stichting van de Arbeid voor advies was voorgelegd de volgende woorden:

"De overheid ziet zichzelf steeds minder als de exclusieve regelaar van werktijden maar trekt zïch meer en meer terug om plaats te maken voor de sociale partners".

Daaropvolgend zei hij, dat een aanpassing van de bestaande regelgeving:

"waarbij rekening gehouden wordt met de wens van de sociale partners om werktijden zo-

veel mogelijk naar eigen inzicht te regelen"

wenselijk wordt geacht. Tegen deze gedachten vallen weinig bedenkingen in te brengen, zolang de overheid zich niet aan haar eigen verantwoordelijkheid onttrekt en de wetgever duidelijke grenzen stelt. Niet uit het oog zal mogen worden verloren, dat het de mens is, die de arbeid levert, die schuil gaat achter de factor arbeid als produktiefactor. De overheid zal voldoende tegenwicht moeten kunnen bieden om te voorkomen, dat de mens die de arbeid verricht, wordt opgeofferd louter en alleen om de door hem te leveren produktie. 
Wat opvalt ten aanzien van de van overheidszijde voorgestelde normen, zoals die zijn neergelegd in de discussienota, is, dat zij erg pover zijn gemotiveerd, en dat onvoldoende wordt onderkend dat er vormen van arbeid zijn, waarbij bijvoorbeeld een 10-urige werkdag, bij langdurige uitoefening hiervan schadelijk kan $z_{i j} n^{105}$

De stellingname van de beide overige in het geding zijnde partijen ten aanzien van de in acht te nemen normen is duidelijk. Opmerkelijk is wel, dat de werkgevers degenen zijn geweest, die het begrip jaarnorm hebben geïntroduceerd, maar zij tevens degenen zijn, die ernstig bezwaar hebben tegen het invoeren van een wettelijke jaarnorm.

De toenmalige staatssecretaris van Sociale Zaken en Werkgelegenheid De Graaf heeft de Sociaal-Economische Raad gevraagd te adviseren over een voorstel voor een nieuwe Arbeidstijdenwet ${ }^{11}$. Het voorstel geeft aan werkgevers en werknemers de mogelijkheid om in onderling overleg af te wijken van de standaardnormen voor de maximale arbeidstijd. Het in augustus 1987 door de Stichting van de Arbeid uitgebrachte advies is bij het totstandkomen van het voorstel betrokken. De nieuwe wet zal gaan gelden voor zowel het bedrijfsleven, als de overheid en de gepremieerde en gesubsidieerde sector; haar doelstelling is het beschermen van werknemers tegen arbeidstijden, die de veiligheid en de gezondheid schaden of deelname aan het maatschappelijk verkeer te zeer belemmeren. In het voorstel is een standaardregeling opgenomen, die geldt voor arbeidsorganisaties waar werkgevers en werknemers niets overeengekomen zijn. Als normen voor deze regeling worden voorgesteld: ten hoogste 9 uren per dag, 180 uren per vier weken en 520 uren per kwartaal. In arbeidsorganisaties, waarvoor een collectieve arbeidsovereenkornst tot stand is gekomen of overeenstemming is bereikt in het kader van het georganiseerd overleg voor ambtenaren of waar de werkgever - bij het ontbreken van collectieve overeenkomst - een afspraak heeft gemaakt met het medezeggenschapsorgaan, geldt de overlegregeling. Voor deze regeling worden als normen voorgesteld: 9,5 uur per dag, 190 uren per vier weken en 552,5 uur per kwartaal. In het kader van de standaardregeling geldt een werktijdbegrenzing tussen 06.00 uur en 19.00 uur; voor de overlegregeling wordt gedacht aan een werktijdbegrenzing van 06.00 uur en 21.00 uur. Voor beide soorten van regelingen geldt een verbod van arbeid op zondag, met andere woorden: de werkweek beslaat de dagen maandag tot en met zaterdag.

Werknemers kunnen in beroep gaan, wanneer een werkgever een vergunning bij de arbeidsinspectie aanvraagt voor een afwijkende werktijdregeling, zoals voor overwerk of verschoven werktijden. Voorts kunnen werknemers de arbeidsinspectie verzoeken een onderzoek in te stellen naar de naleving van de arbeids- en rusttijden in hun arbeidsorganisatie, zij het dat een dergelijk verzoek via het medezeggenschapsorgaan dient te lopen.

Voorts bevat het voorstel een regeling voor het verbod van kinderarbeid, voor jeugdigen van 16 en 17 jaar, die overigens niet langer dan 45 uren per week en 160 uren per vier weken zouden mogen werken, oudere werknemers en zwangere werkneemsters, die op hun verzoek een aangepaste werktijddregeling kunnen krijgen. Voorts bevat de adviesaanvraag voorstellen omtrent een regeling voor meervoudige diensten, zoals ploegendienst, het beleid terzake van nachtarbeid en de normen voor overwerk ${ }^{197}$.

\section{De Veiligheidswet 1934 en de Arbeidsomstandighedenwet}

\subsection{Inleiding}

Niet alleen op het terrein van de arbeids- en rusttijden valt een toenemende activiteit van de wetgever te constateren, hetzelfde geldt voor de veiligheidswetgeving. De Veiligheidswet 1934 zou worden gewijzigd en uiteindelijk vervangen worden door een nieuwe wet, de Arbeidsomstandighedenwet. Ook op het terrein van de uitvoeringsmaatregelen gebeurde het $\epsilon e n$ en ander. Te noemen vallen onder meer het Besluit van 12 januari 1976 inzake propaansulton ${ }^{198}$, een substantiele wijziging van het Veiligheidsbesluit voor fabrieken of werkplaatsen 1938 door middel van de zogenaamde "vijf-vogels"19日 en het totstandkomen van een regeling terzake van de veiligheidssignalering op de arbeidsplaats ${ }^{200}$. Voorts zouden de in het kader van de Europe- 
se Gemeenschappen uitgevaardigde richtlijnen, waarin wordt beoogd bepalingen en maatregelen te harmoniseren, die de Lid-staten vaststellen ter bescherming van werknemers tegen de risico's van blootstelling aan chemische, fysische en biologische agentia op het werk ${ }^{201}$, een steeds toenemende rol van betekenis gaan spelen. Naast deze zogenaamde kaderrichthijn zijn een aantal bijzondere richtlijnen uitgevaardigd, zoals de loodrichtlijn ${ }^{202}$ en de asbestrichtlijn ${ }^{203}$, die beide zijn uitgewerkt in respectievelijk het Loodbesluit ${ }^{204}$ en het Asbestbesluit Arbeidsomstandighedenwet ter vervanging van het eerdere, op de Silicosewet gebaseerd Asbestbesluit ${ }^{205}$. De gemeenschappelijke principes van deze zogenaamde kaderrichtlijn hebben tevens geleid tot een wijziging van het op de Arbeidsomstandighedenwet gebaseerde Veiligheidsbesluit voor fabrieken of werkplaatsen 1938 bij Besluit van 30 augustus $1989^{206}$, waarmee wordt beoogd voorschriften uit te vaardigen ter bescherming van werknemers, die bij hun arbeid in aanraking komen met stoffen, die hun veligheid en gezondheid kunnen bedreigen, zonder dat die werknemers overigens met die stoffen zelf hoeven te werken.

\subsection{De Arbeidsomstandighedenwet}

\subsubsection{Inleiding}

In een brief van 19 juni 1975 vroeg de toenmalige minister van Sociale Zaken Boersma ${ }^{207}$ de Sociaal Economische Raad om advies over de herziening van de wetgeving op het terrein van de veiligheid en gezondheid van werknemers. Op 15 oktober 1976 zou het gevraagde advies worden uitgebracht ${ }^{208}$. Op 17 juni 1980 zou het wetsvoorstel-Arbeidsomstandighedenwet in de Tweede Kamer zonder stemming aangenomen worden $^{200}$. Het toenmalige Tweede Kamerlid Nijpels noemde het wetsvoorstel ${ }^{210}$

".... een van de belangrijkste stukken wetgeving van na de Tweede Wereldoorlog ...."

De bewindsman beaamde dit en sprak van een

"opvallende eensgezindheid in de Kamer en ook in de maatschappij ten opzichte van de

gewenstheid van deze wetgeving ${ }^{\text {n211 }}$.

Deze uitspraken rechtvaardigen een enigszins uitgebreidere behandeling van deze nieuwe wet.

\subsubsection{Het uitgangspunt en de hoofdlijnen}

Nadat de Eerste Kamer op 4 november van dat jaar het wetsvoorstel zonder stemming had aangenomen ${ }^{212}$, was de Arbeidsomstandighedenwet enkele dagen later een feit ${ }^{213}$.

De belangrijkste uitgangspunten van de nieuwe wet vinden hun basis in de technische onvolkomenheden, die aan de Veiligheidswet 1934 verbonden zijn en de veranderende opvattingen over arbeid, de rol van de overheid en het bedrijfsleven daarbij. In de toelichting ${ }^{214}$ wordt de benadering als volgt weergegeven:

"Aan de hoofdlijnen en, in het verlengde daarvan, aan het aangeboden ontwerp ligt een benadering - zo wil men een filosofie - ten grondslag, die niet alleen op de veiligheidswetgeving van toepassing is, doch evenzeer op andere delen van het terrein van de arbeidsbescherming. Deze kan zo worden verstaan dat naast de sterke motieven voortvloeiende uit de wens tot het voortdurend verhogen van de normen van bescherming, die op zichzelf al tot vernieuwing van de wetgeving dwingen, vooral geldt dat behalve aan economische welvaart in toenemende mate belang wordt gehecht aan het zich welbevinden van de werkende mens met betrekking tot zijn werk. Het zich welbevinden bij het werk moet geplaatst worden binnen het tijdsbestek en zal dan ook in overeenstemming moeten zijn met de heersende opvattingen onder de werknemers over de beleving van hun arbeid".

Dit uitgangspunt heeft geleid tot een aantal hoofdlijnen van de nieuwe wet, die tegelijkertijd de belangrijkste veranderingen met betrekking tot de huidige veiligheidswetgeving aangeven.

De reikwijdte van de Arbeidsomstandighedenwet is ruimer dan die van de Veiligheidswet 1934. De wet is zo opgezet, dat zoveel mogelijk een einde wordt gemaakt aan de bestaande wetgeving op een aantal deelge- 
bieden: zo zijn de Stuwadoorswet, althans voor wat het veiligheidsaspect betreft, de Silicosewet en de Wet op het werken onder overdruk in deze nieuwe wet opgegaan. Dit betekent, dat in tegenstelling tot de Veiligheidswet 1934, die in beginsel uitsluitend gericht is op de bescherming van arbeiders, de Arbeidsomstandighedenwet zich ook richt op de bescherming van anderen dan werknemers ${ }^{215}$. Wetten als bijvoorbeeld de Stoomwet en de Wet op de gevaarlijke werktuigen zijn primair gericht op het gebruik van veilige toestellen, machines en werktuigen en betreffen meer de produktveiligheid; een wetgevingsonderdeel dat een geheel andere aanpak vergt, aldus de bewindsman ${ }^{216}$.

De nieuwe wet richt zich, blijkens de considerans, op

"de arbeidsomstandigheden in het algemeen, en de veiligheid, de gezondheid en het welkijn

in verband met de arbeid in het bijzonder, zulks ter bevordering van menswaardige arbeid".

Nieuw ten opzichte van de oude wet is, naast de elementen veiligheid en gezondheid, het expliciet opnemen van het welzijnsaspect. Het welzijnselement heeft gestalte gekregen in een aantal algemeen geformuleerde grondbeginselen, die de werkgever in acht moet nemen en in een aantal eveneens tot hem gerichte beleidsopdrachten $^{217}$. Daarnaast beschouwt de nieuwe wet in tegenstelling tot de Veiligheidswet 1934 de werknemer niet langer als een te beschermen object, maar als een volwaardig en zelfstandig drager van rechten en plichten. Dit brengt met zich, dat het werkgever en werknemers gezamenlijk een verantwoord arbeidsklimaat dienen te scheppen en in stand te houden ${ }^{218}$. Maar de wet richt zich niet alleen op samenwerking tussen de werkgever en de werknemers onderling, maar ook op samenwerking met de arbeidsinspectie. In deze samenwerkingsgedachte passen ook nieuwe bevoegdheden van het districtshoofd van de arbeidsinspectie, namelijk de aanwijzing en het verzoek om wetstoepassing ${ }^{219}$. De uitgangspunten van de wet worden dan ook gekenmerkt door de begrippen harmonie, samenwerking en overleg, niet alleen in de ondernemingen en bedrijwen, maar op nationaal en districtsniveau, waarvoor nieuwe organen worden gecreëerd, namelijk de Arboraad en de districtscommissies ${ }^{220}$. In vergelijking met de Veiligheidswet 1934 wordt in de nieuwe wet een grotere waarde gehecht aan specifieke deskundigheid binnen de ondernemingen en bedrijven. Niet alleen worden de bedrijfsgezondheidsdiensten, die al bestonden, maar ook de veiligheidsdiensten en een combinatie van deze twee, de zogenaamde arbodiensten, geregeld ${ }^{221}$. Tot slot versterkt de nieuwe wet de beroepsmogelijkheden tegen door de overheid genomen maatregellen. Wel is de consequentie, dat overtredingen van voorschriften zwaarder gestraft kunnen worden dan op grond van de Veiligheidswet 1934 mogelijk was, doordat deze overtredingen onder het regiem van de Wet op de economische delicten zijn gebracht, waardoor niet alleen hogere, maar ook meerdere verschillende soorten straffen of maatregelen kunnen worden opgelegd.

\subsubsection{Het begrip "welzijn}

Hiervoor is al opgemerkt, dat het begrip welzijn in de Arbeidsomstandighedenwet voor het eerst uitdrukkelijk is genoemd, maar de betekenis ervan is voor meerdere uitleg vatbaar. Het feit, dat het begrip expliciet in de wet is opgenomen betekent, dat er een grote waarde aan gehecht wordt, maar de toelichting blijft omtrent de betekenis ervan vaag ${ }^{222}$.

"Allereerst zijn in de bestaande wet reeds een aantal onderwerpen geregeld welke naar de letter genomen, niet onder het begrip "'veiligheid" vallen: ik doel hier op de vanouds bestaande voorschriften met betrekking tot faciliteiten als schaftlokallen, bergplaatsen voor kleding, nachtverblijven en sanitaire voorzieningen. In het licht van de voorgestelde nieu-we wet zal echter ook, zoals hierna nog zal worden uiteengezet, aandacht worden besteed aan de humanisering van de arbeid.

De met het oog hierop in het ontwerp opgenomen bepalingen vormen een eerste stap op dit terrein, doch naar verwachting zal dit onderwerp in de toekomst een steeds belangrijker rol gaan spelen en het lijkt mij dan ook juist hiervoor in de naam en de considerans van de wet voor het begrip "welzijn" een plaats in te ruimen".

Desalniettemin wordt in de wet zelf geprobeerd het begrip enigszins te concretiseren door middel van een 
de werkgever opgelegde algemeen geformuleerde zorgverplichting ${ }^{223}$. Deze verplichting beperkt zich niet alleen tot het in acht nemen van hetgeen in de wet is voorgeschreven, maar kan zich uitstrekken tot maatregelen waarin de wet ( nog) niet voorziet. Voor zover de algemene verplichting zich richt op het welzijnsbegrip, kan deze allereerst omschreven worden als

"fitting the job to the worker",

wat betekent zowel aanpassing van machines en omgeving aan de werknemer, alsook aanpassing van de taak

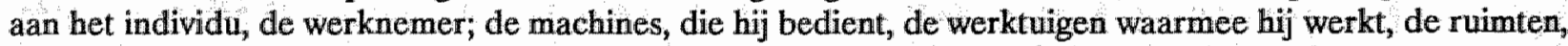
waarin hij werkt en de wijze, waarop deze zijn ingericht, verwarmd en verlicht, moeten aan de mens zijn aangepast. Maar daarnaast moet er bij de taakopdracht rekening gehouden worden met mogelijkheden en bekwaamheden van het individu, dat die taken moet verrichten, waarbij speciale aandacht vereist is voor de meer kwetsbare werknemers, zoals jeugdige personen, gehandicapten en ouderen ${ }^{224}$. Vervolgens richt deze algemene verplichting zich op wat genoemd kan worden, "job satisfation". In de eerste plaats door het zoveel mogelijk vermijden van monotone en kortcyclische arbeid en arbeid waarvan het tempo niet door de werknemer kan worden gereguleerd en in de tweede pla ats door de arbeid zodanig te organiseren,

"dat daarvan geen nadelige invloed uitgaat op de lichamelijke en geestelijke gezondheid van

de werknemer en dat de werknemer de mogelijkheid wordt geboden zich in en door zijn arbeid te ontwikkelen".

De kritiek op dit onderdeel van de wet was algemeen van zowel de Tweede Kamer als de sociale partners, en eigenlijk ook voorspelbaar. Een van de redenen daarvoor is gelegen in het feit, dat de bewindsman in zijn advies-aanvraag aan de Sociaal-Economische Raad well over de elementen veiligheid en gezondheid had gerept, maar zijn plannen omtrent het begrip welzijn niet kenbaar had gemaakt. Wat uiteindelijk een zeer belangrijk uitgangspunt van de wet zou worden, is dus in de Sociaal-Economische Raad geen onderwerp van discussie geweest $^{226}$. Belangrijk punten van kritiek waren, dat het eigenlijk nog een wazig, onvoldragen begrip was om daar beleid op te voeren en zeker een bij de wet te toetsen beleid ${ }^{227}$ en de mogelijke gevolgen daarvan. Bij een meningsverschil tussen werkgever en werknemers over de precieze invulling en toepassing van de betreffende bepalingen kan de arbeidsinspectie onder bepaalde voorwaarden bindende aanwijzingen geven, waarvan overtreding een strafbaar feit oplevert. Eén en ander zow er toe kunnen leiden, dat er door de overheid door middel van een soort rechtsprekende functie - want haar wordt een rol toebedacht van een afstandelijke boven de partijen staande instantie - een ongewenste inmenging in het gehele sociale beleid in de onderneming plaatsvindt ${ }^{228}$. In zijn antwoord zou de bewindsman proberen op al deze kritiekpunten ingaan. Zo zet hij het begrip welzijn, waarvan hij erkende, dat het

"inderdaad een abstract en moeilijk afgrensbaar begrip"

is, af tegen de begrippen "veiligheid" en "gezondheid", waarvoor, aldus de minister ${ }^{229}$, hetzelfde geldt. In het verleden was vooral aandacht besteed aan de fysieke arbeidsomstandigheden, waarbij deze begrippen een belangrijke rol speelden. Welzijn in verband met de arbeid heeft te maken met

"de ruimte, die de arbeidsomstandigheden, de arbeidsorganisatie en de arbeidsinhoud bie-

den voor de eigen verantwoordelijkheid, inbreng en creativiteit van de werknemers".

Met veiligheid, gezondheid en welzijn "in verband met de arbeid" is bedoeld: veiligheid, gezondheid en welzijn in zoverre deze factoren kunnen worden beïnvloed door de deelneming aan het arbeidsproces en het daarmee samenhangend verblijf van een werknemer binnen een bedrijf of een inrichting, waar bij het begrip welzijn bijvoorbeeld te denken is aan de inhoud van de taak, de afhankelijkheid van machines en de organisatie van de arbeid ${ }^{230}$.

Verder benadrukte de minister dat de volgorde, waarin de begrippen veiligheid, gezondheid en welzijn zijn gerangschikt, niet tot een waardeoordeel mag leiden. De aard van de omstandigheden maakt, dat nu eens op het ene en dan weer op het andere aspect de meeste nadruk zal dienen te liggen. Ondanks de toch wel geslaagde pogingen van de bewindsman om het begrip welzijn nader te concretiseren ${ }^{231}$, werden niet alle bezwaren weggenomen en dan met name de mogelijke inmenging van de overheid, die door middel van de arbeidsinspectie bindende aanwijzingen kan geven, om zo het begrip welzijn te concretiseren ${ }^{232}$. Tot slot moet nog gewezen worden op het feit, dat het begrip "redelijkheid" bij deze welzijnsbepaling een 


\subsubsection{Algemeen geformuleerde verplichtingen van de werkgever}

Een aantal grondbeginselen van de Arbeidsomstandighedenwet is geformuleerd als verplichtingen van de werkgever. In dit opzicht bestaat er een verschil met de Veiligheidswet 1934. Weliswaar was daar het hoofd of de bestuurder de adressant, maar daarbij ging het om concreet geformuleerde en niet on algemeen geformuleerde verplichtingen. Behalve de algemeen geformuleerde verplichtingen, die als een uitwerking van het welzijnsbegrip kunnen worden beschouwd, zijn er ook verplichtingen opgenomen die meer gerelateerd zijn aan de aloude veiligheids- en gezondheidsaspecten. Daarbij gaat het om produktie- en werkmethoden, het gebruik van stoffen, hulpmiddelen, werktuigen, machines en de inrichting van de arbeidsplaatsen ${ }^{234}$. Evenals bij de algemene verplichtingen ten aanzien van het welzijnsbegrip het geval is, zijn deze verplichtingen niet absoluut geredigeerd; zij dienen in acht genomen te worden,

"tenzij dit redelijkerwijze niet kan worden gevergd"

of

"gelet op de best bestaande regelen der techniek".

Ten aanzien van het ook hier bezigen van de term "redelijkerwijs" merkt de bewindsman op ${ }^{235}$

"Intussen blijft de formulering van de bedoelde beginselen dusdanig flexibel dat in de prak-

tijk geen onredelijke eisen zullen worden gesteld. Uit het bovenstaande volgt dat binnen

ieder bedrijf zal moeten worden nagegaan hoe ver met de toepassing van €én of meer der

grondbeginselen kan worden gegaan".

Evenals ten aanzien van het welzijnsbegrip is ook hier het districtshoofd van de arbeidsinspectie de mogelijkheid gegeven om een eis tot naleving te geven.

Het door de werkgever niet-naleven van deze grondbeginselen is niet rechtstreeks strafrechtelijk gesanctioneerd. En dit kan ook niet anders. Het bezigen van globaal geformuleerde bepalingen en het veelvuldig gebruik van termen als redelijkerwijs maken een strikte handhaving van deze bepalingen door de overheid al bijzonder lastig, maar voor het ontbreken van een rechtstreekse strafsanctie is er nog een belangrijke reden, aldus de bewindsman ${ }^{236}$

"Deze grondbeginselen ..... zijn niet te beschouwen als concrete voorschriften waaraan een directe strafsanctie is verbonden, doch als uitgangspunten voor het beleid binnen het bedrijf Hoever men in bepaalde bedrijven hiermee zou kunnen gaan, wordt in eerste instantie aan het overleg van werkgevers en werknemers overgelaten, doch dit sluit ..... ingrijpen van de zijde van de overheid niet uit".

Hiermee blijft dus de eerste verantwoordelijkheid in het bedrijf. Wanneer er tussen de betrokkenen geen overeenstemming kan worden bereikt, kan de arbeidsinspectie worden verzocht, door middel van een verzoek om wetstoepassing, een uitspraak te doen, hetzij in de vorm van een aanwijzing, hetzij in de vorm van de eis tot naleving. Het niet-naleven van een door het districtshoofd gegeven beslissing is strafbaar.

\subsubsection{Instrumenten ter beschikking van de arbeidsinspectie}

De eis tot naleving is niet nieuw. Ook in de Veiligheidswet 1934 is dit instrument neergelegd. Het districtshoofd van de arbeidsinspectie $e^{237}$ kan ter zake van de naleving van eén of meer regelein, die zijn gesteld krachtens met name genoemde artikelen van de Arbeidsomstandighedenwet ${ }^{238}$ aan een werkgever een eis stellen, voorzover er terzake van éen en ander regelen zijn gesteld ${ }^{2 a 9}$. Evenals bij de Veiligheidswet $1934^{240}$ geldt het uitgangspunt van schorsende werking ${ }^{24}$. Nieuw ten opzichte van de Veiligheidswet 1934 is echter, dat, indien de naleving van een eis in verband met gevaar voor de veiligheid of de gezondheid redelijkerwijs geen uitstel kan lijden, de schorsende werking niet van toepassing kan worden verklaard. Van de eis moet dan wel onverwijld de griffie van de rechtbank van het arrondissement waarbinnen het bedrijf 
of de inrichting, waarop de eis betrekking heeft, gelegen is, bericht worden gegeven ${ }^{242}$. De president van de rechtbank kan, na alle betrokkenen gehoord te hebben, dit ongedaan maken ${ }^{243}$. De eis dient gemotiveerd en schriftelijk te zijn gegeven en moet de termijn bevatten waarbinnen eraan voldaan moet zijn. $Z$ ij moet ter kennis worden gebracht van alle betrokkenen. De strafrechtelijk gesanctioneerde nakomingsverplichting rust in elk geval op de werkgever, maar ook op de werknemers, voorzover dat bij de eis is bepaald.

In de Arbeidsomstandighedenwet is naast de eis een mieuw instrument ingevoerd, de aanwijzing ${ }^{244} \mathrm{De}^{-}$ aanwijzing was aanvankelijk bedoeld om de vele algemeen geformuleerde voorschriften te concretiseren of om de vraag te beantwoorden of iets al dan niet in redelijkheid kon worden gevergd. Sommige van deze artikelen zijn dusdanig geformuleerd, dat hun naleving door middel van directe strafvervolging bezwaarlijk kan worden afgedwongen, aldus de toenmalige bewindsman. Anderzijds vond hij de eis niet het geëigende middel in aangelegenheden waarop deze artikelen betrekking hebben.

"Het doel van de "aanwijzing" is vooral door middel van overleg tussen de Arbeidsinspectie en de betrokken werkgever en werknemers tot bevredigende werksituaties te komen; eerst nadat dit overleg gefaald heeft, zal de overheid dwangmatig kunnen optreden ${ }^{1245}$.

Vanuit de Tweede Kamer werd daartegen en niet onterecht aangevoerd, dat het gevaar dan groot is, dat deze algemene inzetbaarheid ertoe kan leiden, dat dit instrument gehanteerd gaat worden als een milde variant van de al bestaande eis tot naleving. Het nieuwe instrument werd dan ook niet aanvaardbaar geacht als een alternatief voor concrete minimum-voorschriften ${ }^{246}$. De bewindsman was niet ongevoelig voor de naar voren gebrachte bezwaren. Het wetsvoorstel werd aangepast in die zin, dat zowel ten aanzien van de betrokken wetsartikelen, als ten aanzien van de uitvoeringsmaatregelen nu is aangegeven, in welke gevallen een eis kan worden gesteld en in welke gevallen een aanwijzing kan worden gegeven. Als algemeen criterium geldt, dat eis wordt toegepast wanneer de normen all zo concreet zijn, dat de wijze van naleving geen punt van discussie behoeft te zijn.

"Voor de meer algemeen gestelde normen, waar meer ruimte kan worden gegeven ten aanzien van de wijze, waarop zij moeten worden nageleefd, zie ik zekere marge voor overleg. Ik onderken hierbij twee categorieën, namelijk normen waarbij de gedachten reeds meer zijn uitgekristalliseerd en normen, waarmede nieuwe ontwikkelingen in beweging worden gezet",

aldus de bewindsman ${ }^{247}$. Hij maakte terzake van het optreden van de arbeidsinspectie een verschill tussen deze beide normen. Bij de eerste categorie zal de arbeidsinspectie meer actief moeten zijn dan bij de tweede, waar zij het initiatief bij werkgever en werknemers zelf zou willen leggen, waarbij hun, indien zij de overheid willen inschakelen, het instrument van het verzoek om wetstoepassing ter beschikking staat.

Indien het districtshoofd van de arbeidsinspectie van mening is, dat én of meer met name genoemde bepalingen $^{246}$ niet of in onvoldoende mate of op onjuiste wijze worden nageleefd, is hij bevoegd om de werkgever een aanwijzing te geven. Voor sommige bepalingen geeft hij geen aanwijzing, dan nadat bem hiertoe een verzoek om wetstoepassing ${ }^{249}$ is gedaan. De aanwijzing moet gemotiveerd aangeven op welke punten de wettelijke bepalingen niet, onvoldoende of onjuist zijn nageleefd en welke maatregelen nodig zijn om aan de wet te voldoen. De aanwijzing moet ter kennis gebracht worden van alle betrokkenen en moet tevens de termijn aangeven, waarbinnen er aan voldaan moet zijn. De aanwijzing kan niet alleen tot de werkgever zijn gericht, maar ook tot de werkmemers, voor zover de aanwijzing betrekking heeft op een verplichting die bij of krachtens de Arbeidsomstandighedenwet aan werknemers is opgelegd. Een eenmaal gegeven aanwijzing is net zo verplichtend en strafrechtelijk gesanctioneerd alls de eis.

Opmerkelijk is ook, dat het districtshoofd van de arbeidsinspectie de eis/aanwijzing alleen aan de werkgever kan richten, en niet tevens aan de werknemer(s), terwijl de aan de werkgever gegeven eis/aanwijzing (tevens) verplichtingen kan bevatten die alleen tot de werknemers gericht zijn. Toegegeven zij, dat dit wordt ondervangen door de werkgever weer een afzonderlijke verplichting op te leggen, dat hij de werknemers van de inhoud van de op hen rustende verplichting zo spoedig mogelijk in kennis stelt. De strekking van de bepalin- 
gen is duidelijk, maar misschien was een andere formulering vollediger geweest. Zeker wanneer daaraan een meningsverschil aan ten grondslag ligt en van de mogelijkheid van een verzoek om wetstoepassing gebruik gemaakt wordt.

Naast de eis tot naleving en de aanwijzing kent de Arbeidsomstandighedenwet de bevoegdheid van het districtshoofd van de arbeidsinspectie om een stillegging van het werk te bevelen, indien naar zijn redelijk oordeel het verblijf in door hem aangewezen plaatsen dan wel door hem aangewezen werkzaamheden moeten worden gestaakt of niet mogen worden aangevangen, dat verblijf of die werkzaamheden voor personen ernstig gevaar opleveren ${ }^{250}$. Evenals de eis tot naleving kent de Veiligheidswet 1934 dit instrument al; materieel is er geen verandering aangebracht ${ }^{251}$. In de jaren 1986 tot en met 1988 is van deze bevoegdheid respectievelijk 18,37 en 31 gebruik gemaakt ${ }^{252}$.

Indien tussen de werkgever en de werknemers een verschil van mening bestaat over de naleving van eén of meer van de bij of krachtens de Arbeidsomstandighedenwet gegeven voorschriften dan wel omtrent de aanwezigheid van ernstig gevaar voor personen ${ }^{253}$, kunnen zowel de werkgever als de ondernemingsraad dan wel de arbocommissie, bij het ontbreken van van deze beide een meerderheid van de belanghebbende werknemers, aan het districtshoofd van de arbeidsinspectie verzoeken een eis tot naleving, een aanwijzing of een bevel tot stillegging af te geven. De ondernemingsraad dan wel de arbocommissie, bij het ontbreken van deze beide een meerderheid van belanghebbende werknemers, kan/kunnen eveneens aan de directeur-generaal van de Arbeid vragen om een aanwijzing te geven voor een arbeidsveiligheidsrapport, een arbodienst, een bedrijfsgezondheidsdienst, een veiligheidisdienst of een veiligheidskundige. Deze bevoegdheid komt dus slechts aan de ondernemingsraad toe en niet aan de werkgever.

Het verzoek om wetstoepassing moet schriftelijk, gedagtekend en met redenen omkleed worden ingediend. De indiener van het verzoek moet zo snel mogelijk een afschrift sturen aan de andere partij. Degene aan wie het verzoek is gericht beslist zo snel mogelijk, na een onderzoek waarbij zowel de verzoeker, als de andere partij in de gelegenheid worden gesteld hun mening over de zaak te geven. De afwijzing van het verzoek om wetstoepassing wordt schriftelijk, gedagtekend en met redenen omkleed meegedeeld aan de betrokken partijen.

In 1983 is tweemaal gebruik gemaakt van het recht om een verzoek om wetstoepassing te richten aan het bevoegde districtshoofd. Het ene verzoek werd gedaan door een werkgever en had betrekking op het nietdragen van oogbescherming door werknemers. Het districtshoofd heeft na het horen van de directie en de ondernemingsraad een eis gesteld en de naleving ervan gecontroleerd. Het tweede verzoek werd gedaan door een ondernemingsraad. Het betrof hier onvoldoende afzuiging, daglicht en was/douchegelegenheid, waarover de directie niet wenste te spreken met het medezeggenschapsorgaan. Nadat twee eisen waren gesteld, waren alle tekortkomingen verholpen ${ }^{254}$. In 1984 werd slechts eenmaal gebruik gemaakt van dit recht en in 1985 geen enkele maal. Met andere woorden: van dit nieuwe recht wordt geen overmatig gebruik gemaakt.

Een enquête van de Industriebond FNV onder leden van ondernemingsraden wijst in de richting, dat, wanneer er zich problemen voordoen op het terrein van de veiligheid, de gezondheid en het welzijn, deze vooral worden opgelost door overleg en samenwerking en overleg tussen de partijen, zodat blijvende conflicten dan achterwege blijven ${ }^{255}$. Een andere verklaring voor het geringe gebruik van het nieuwe recht is wellicht gelegen in het bestaan van het klachtrecht van de individuele werknemer. Dit klachtrecht komt noch in de Veiligheidswet 1934, noch in de Arbeidsomstandighedenwet expliciet voor, maar beide bevatten er wel een verwijzing naar. Zo bepaalt in de beide wetten artikel 34, eerste lid, dat de ambtenaren van de arbeidsinspectie verplicht zijn tot onder meer geheimhouding van de namen van personen door wie een klacht is ingediend $^{258}$. Bovendien bevat de Grondwet in artikel 5 een algemeen klachtrecht, het zogenaamde petitierecht $^{257}$. Een verzoek om wetstoepassing is gebonden aan een aantal voorwaarden, zoals bijvoorbeeld het bestaan van een verschil van mening, het stellen van een eis of aanwijzing, die in het gewone klachtrecht niet gelden. Bovendien kan het verzoek om wetstoepassing niet gedaan worden door een individuele werknemer, 
zodat deze altijd aangewezen is op tussenkomst van bijwoorbeeld de ondernemingsraad. Mocht de relatie tussen de werkgever en de ondernemingsraad te wensen overlaten, dan kan het de voorkeur verdienen eerst van het individuele klachtrecht gebruik te maken. Pas wanneer het resultaat daarvan tegenvalt, kan de meer formele procedure van het verzoek orn wetstoepassing een uitkomst bieden.

Illustratief is, dat het aantal klachten in de jaren 1980 tot en met 1985 redelijk constant is gebleven. In 1980 bedroeg het totale aantal klachten 1475 , in de daarop volgende jaren respectievelijk 1132, 1240, 1240, 1199, 1321 en $1356^{258}$. De inwerkingtre ding van de bepaling terzake van het verzoek om wetstoepassing heeft daarin geen verandering gebracht. Na 1985 doet zich een daling voor in het aantal klachten. Van 1172 in 1986 en 937 in 1987 naar 814 in $1988^{259}$. Overigens is wel opmerkelijk het geringe aantal processen-verbaal, dat uit de klachten is voortgevloeid, namelijk respectievelijk $28,22,16,23,26,24,21,18$ en 11 . De oorzaak hiervan is het feit, dat de arbeidsinspectie eerst een proces-verbaal opmaakt, wanneer alle andere al dan niet juridische middelen niet het gewenste resultaat hebben ${ }^{260}$.

\subsubsection{Meer omschreven verplichtingen van de werkgever}

Andere meer omschreven verplichtingen voor de werkgever zijn het geven van voorlichting en onderricht ${ }^{261}$, de melding en registratie van ongevallen en beroepsziekten ${ }^{262}$, het maken van een jaarplan, een jaarverslag ${ }^{263}$ en een arbeidsveiligheidsrapport ${ }^{284}$.

De verplichting tot het geven van voorlichting en onderricht door de werkgever over veiligheid, gezondheid en weliijn van zijn werknemers vloeit voort uit de nieuwe positie van de werknemers; het medeverantwoordelijk zijn op zijn minst in een medeweten. De werknemer is overigens de verplichting opgelegd om hieraan mee te werken. Al eerder is melding gemaakt van het feit, dat een deel van het zogenaamde Jongerenstatuut, dat betrekking heeft op de voorlichting en begeleiding van jeugdige personen door mentoren, ingevoegd is in het ontwerp-Arbeidsomstandighedenwet.

Ongevallen die de dood of een ernstig lichamelijk letsel tot gevolg hebben, moeten, evenals vermoedelijke beroepsziekten ${ }^{265}$, onmiddellijk bij het districtshoofd van de arbeidsinspectie gemeld worden. Alle ongeval$\mathrm{len}_{\mathrm{r}}$ die enig letsel hebben veroorzaakt, alsook alle gebeurtenissen die bijna tot een ongeval hebben geleid $^{288}$ moeten tevens in een register in het bedrijf worden geregistreerd.

De verplichting tot het hebben van een jaarplan maakt, dat de werkgever het beleid gericht op veiligheid, gezondheid en welzijn voor een periode van ten minste éen jaar vast dient te leggen: de doelstellingen, die nagestreefd zullen worden en de middelen waarmee deze doelstellingen kunnen worden bereikt, zullen moeten worden aangegeven ${ }^{267}$. Er dient een zo breed mogelijk terrein bestreken te worden; niet alleen kantines en dergelijke, maar ook het invoeren van nieuwe produktie- en werkmethoden ${ }^{268}$.

Voordat de werkgever echter de inhoud van zijn plan vaststelt, moet hij overleg voeren met de ondernemingsraad, de arbocommissie of, in geval beide ontbreken, met de meerderheid van de belanghebbende werknemers. Tijdens de parlementaire behandeling werd vanuit de Tweede Kamer voorgesteld, dat de werkgever de instemming van de werkgever diende te hebben overeenkomstig het instemmingsrecht van de ondernemingsraad ter zake van een regeling op het gebied van de veiligheid, gezondheid of het welzijn in verband met de arbeid ${ }^{269}$. De bewindsman stond daar afwijzend tegenover. Het ging zijns inziens in de eerste plaats om de feitelijke mededeling en niet om de concrete regeling, waarvoor de ondernemingsraad instemming dient te verlenen ${ }^{270}$. Het jaarplan moet ter kennisneming aan het districtshoofd van de arbeidsinspectie worden gezonden, met inbegrip van het oordeel van de ondernemingsraad, de arbocommissie of de betrokken werknemers.

Het jaarverslag ligt in het verlengde van het jaarplan. Het moet namelijk een beschrijving bevatten van het beleid zoals dat het afgelopen jaar is gevoerd en dient gerelateerd te zijn aan dat jaarplan. Eventuele afwijkingen daarvan en de redenen daarvoor moeten eveneens worden vermeld. Het jaarverslag moet een be- 
schrijving bevatten aangaande de samenwerking binnen het bedrijf of de inrichting, cijfermatige informatie over ( bijna-)ongevallen en de getroffen maatregelen. Ook het jaarverslag dient aan het districtshoofd van de arbeidsinspectie gezonden te worden.

De regeling van het arbeidsveiligheidsrapport is niet nieuw. Het komt in de plaats van het in 1977 in de Veiligheidswet 1934 ingevoerde veiligheidsrapport ${ }^{27 \%}$. Het opleggen van de verplichting tot het opstellen van een (arbeids-) veiligheidsrapport heeft in eerste instantie tot doel de werkgever van de betreffende inrichting zich meer bewust te doen zijn van de gevaren die zich voor de werknemers in zijn inrichting kunnen voordoen en van de verantwoordelijkheid die in verband daarmee op hem rust. Daarnaast verschaft het rapport de arbeidsinspectie inzicht in de bedrijfssituatie waardoor zij haar toezicht beter kan uitoefenen ${ }^{272}$. Het rapport moet een beschrijving bevatten vam het bedrijf of de inrichting en de produktieprocessen daarin en de maatregelen, die genomen zijn om dreigende en redelijk voorzienbare storingen en fouten te voorkomen $^{273}$. Over het arbeidsveiligheidsrapport moet vooraf overleg gepleegd worden met de ondernemingsraad dan well de arbocommissie ${ }^{274}$. In tegenstelling tot het jaarplan is de houding van de arbeidsinspectie niet passief. Het districtshoofd kan eisen dat hem aanvullende gegevens worden gegeven dan wel andere of aanvullende voorzieningen worden getroffen. Het districtshoofd zendt een afschrift van het rapport of een wijziging daarvan aan andere overheidsdiensten, die actief zijn op het terrein van het milieu en de volksge-zondheid en de plaatselijke overheden in de gebieden, waarin het bedrijf of de inrichting ligt ${ }^{278}$.

De verplichting tot het opstellen van een arbeidsveiligheidsrapport geldt alleen voor die bedrijven of inrichtingen, waarin zich bijzondere gevaren voordoen en die daartoe zijn aangewezen ${ }^{276}$; daarbij wordt gedacht aan bedrijven of inrichtingen in de zogenaamde proces-industrie ${ }^{277}$. Trouwens ook de verplichting tot het hebben van een jaarplan en het maken van een jaarverslag geldt niet voor alle bedrijven; in ieder geval wel voor die, welke verplicht zijn tot het hebben van een arbeidsweiligheidsrapport ${ }^{278}$.

\subsection{Verplichtingen van de werknemer}

In het verlengde van de beleidsfilosofie is ook voor de werkmemer een algemeen geformuleerde verplichting in de wet neergelegd. Hij is verplicht in verband met de arbeid de nodige voorzichtigheid en zorgvuldigheid in acht te nemen ter vermijding van gevaren voor de veiligheid of de gezondheid van hem zelf of van anderen, dan wel met het oog op hun welzijn, met name ten aanzien van het gebruik van machines, stoffen, werktwigen, persoonlijke beschuttingsmiddelen en dergelijke ${ }^{278}$. Deze algemene verplichting van de werknemer is nu ook strafrechtelijk gesanctioneerd. In de Veiligheidswet 1934 gold dit slechts ten aanzien van een aantal concreet geformuleerde voorschriften. Bovendien was de arbeider slechts dan aansprakelijk, voor zover hij redelijkerwijs geacht kon worden met dat betreffende voorschrift op de hoogte te $z_{i j n^{280}}$. De motivering wan deze verandering is als volgt ${ }^{281}$ :

"Het (wetswoorstel) ziet de zorg voor een veilig en gezond arbeidsmilieu niet als een plicht die vrijwel eenzijdig op de werkgever rust. Het voorziet in voorlichting en veiligheidsonderricht van de werknemer, en geeft hun mede een stem in het bepalen van het beleid op het terrein van de veiligheid en gezondheid en geeft hun vertegenwoordigers bepaalde bevoegdheden en rechten. Onder deze omstandigheden mag van hen worden verwacht dat zij zich ook van hun verantwoordelijkheid bewust zijn en dat zij in dit verband bereid zijn ook een aantal verplichtingen en de daaruit voortvloeiende aansprakelijkheid te aanvaarden, al is deze uiteraard van veel beperkter omvang dan die van de werkgever".

Toch kan moeilijk worden volgehouden, dat dit argument omtrent de verplichting van de werkgever tot voorlichting en onderricht doorslaggevend genoemd kan worden. Er kunnen zich situaties voordoen, waarin de werknemers niet op de hoogte blijken te zijn van de tot hen gerichte verbods- en gebodsbepalingen. Vandaar dat vanuit het parlement gevraagd werd om een strafuitsluitingsgrond ${ }^{282}$. De bewindsman voelde daar niets voor en verwees naar de strafrechtelijke schulduitsluitingsgrond afwezigheid van alle schuld ${ }^{283}$. 


\subsubsection{Het recht van werkonderbreking}

Naast een aantal nieuwe rechten, die aan de werknemers worden toebedeeld en die voorall betrekking hebben op de medezeggenschapsaspecten, is er een recht dat speciale aandacht vraagt, namelijk het recht van werkonderbreking ${ }^{264}$, dat is het recht voor iedere werknemer om bij onmiddellijk dreigend gevaar het werk neer te leggen, wanneer de arbeidsinspectie niet tijdig kan worden gewaarschuwd ${ }^{285}$. De werknemer behoudt zijn loon gedurende de duur van de onderbreking. Wat van groot belang is, is de bepaling, dat degene, die meent dat de werknemer onredelijk heeft gehandeld, dit moet bewijzen. Wel is de werknemer verplicht de werkonderbreking onmïddellijk aan de bedrijfsleiding te melden.

\subsubsection{Overleg/medezeggenschap}

De doelstellingen van de wet en de verwezenlijking daarvan is voor een belangrijk deel afhankelijk gesteld van het overleg binnen het bedrijf of de inrichting. De basis daarvoor is gelegd in het voorschrift, dat de werkgever en de werknemers moeten samenwerken in het behartigen van de zorg voor de veiligheid, de gezondheid en het welzijn ${ }^{208}$. In nader te bepallen bedrijven moeten tén of meer commissies voor veiligheid, gezondheid en welzijn worden ingesteld, de zogenaamde arbocommissie ${ }^{287}$. Een dergelijke verplichting geldt niet, wanneer er al een ondernemingsraad aanwezig is. De bedrijven waarvoor een dergelijke verplichting geldt moeten worden aangewezen bij algemene maatregelen van bestuur, terwijl bovendien het districtshoofd van de arbeidsinspectie de bevoegdheid heeft gekregen afzonderlijke bedrijven aan te wijzen. De arbocommissie bestaat uit vertegenwoordigers van de werknemers, die uit hun midden worden gekozen. De arbocommissie heeft tot taak zich over de veiligheid, de gezondheid en het welzijn te beraden en daarover regelmatig overleg te voeren met de werkgever en hem te adviseren. De arbocommissie heeft evenals de ondernemingsraad instemmingsrecht ten aanzien van alle regelingen, die de werkgever wil treffen op het gebied van veiligheid, gezondheid en welzijn ${ }^{293}$. Daarnaast voorziet de wet in een aantal voorschriften, waardoor het de leden van een arbocommissie mogelijk wordt gemaakt hun taak naar behoren te kunnen vervullen ${ }^{289}$ en worden de leden van de arbocommissie beschermd tegem benadeling en ontslag ${ }^{200}$.

Naast dit geïnstitutionaliseerde overleg op ondernemingsniveau introduceert de Arbeidsomstandighedenwet het overleg op de werkvloer, het zogenaamde werkoverleg ${ }^{291}$. Als een bedrijf of inrichting uit afdelingen bestaat, die als een werkeenheid kunnen worden beschouwd, moet in die afdelingen regelmatig overleg gepleegd worden tussen de leiding van die afdeling en de in die afdeling werkzame personen. Het overleg mag ook plaatsvinden met personen die daartoe door de betrokken werknemers uit hun midden zijn aangewezen. Een dergelijke verplichting geldt echter niet als er een, al dan niet door de ondernemingsraad ingestelde, en speciaal voor die afdeling bestemde arbocommissie, werkzaam is.

Niet alleen op ondernemings- en afdelingsniveau voorziet de Arbeidsomstandighedenwet in een overlegstructuur. Ook is het overleg tussen overheid en sociale partners op nationaal niveau geregeld, namelijk in de Arboraad $^{202}$. De raad overlegt en adviseert de minister over onder andere de totstandkoming en uitvoering van de op de Arbeidsomstandighedenwet gebaseerde regelingen. Voorts hoort zij de indieners van een bezwaarschrift tegen beslissingen van de arbeidsinspectie ${ }^{203}$. Daarnaast fungeert de raad als een paraplu voor diverse commissies, waaronder de reeds bestaande adviescommissie Asbestbesluit, de commissie Grenswaarden Gezondheidschadelijke Stoffen ${ }^{204}$ en het College van Bijstand en Advies voor de bedrijfsgezondheids$\operatorname{zorg}^{205}$.

Naast dit landelijke overleg voorziet de wet in een regionaal overleg door de instelling van zogenaamde districtscommissies in ieder district van de arbeidsinspectie. Deze commissies hebben, evenals de Arboraad, een tripartiete samenstelling ${ }^{290}$. 


\subsection{Deskundige diensten}

Bestond in de Veiligheidswet 1934 de verplichting voor bedrijwen met een bepaald aantal werknemers om een bedrijfsgeneeskundige dienst te hebben, in de Arbeidsomstandighedenwet is deze verplichting voor bij algemene maatregel van bestuur aan te wijzen bedrijven of inrichtingen overgenomen, onder wijziging van de naam in bedrijfsgezondheidsdienst ${ }^{297}$. Nieuw daarentegen is, eveneens voor bij algemene maatregel van bestuur aan te wijzen bedrijven of inrichtingen, de verplichting een veiligheidsdienst te hebben. De regeling van deze beide diensten wijken niet veel van elkaar af. De taak is het respectievelijk bevorderen van de gezondheid van de werknemer, voor zover die een relatie heeft met zijn arbeid en arbeidsmilieu en van de veiligheid en de hygiëne. De diensten moeten samenwerken met, adviseren en bijstand verlenen aan zowel de werkgever als de ondernemingsraad, de arbocommissie en de werknemers. De bedrijfsarts en de veiligheidskundige die de leiding heeft van de betreffende dienst moet rechtstreeks toegang hebben tot de directie, terwijl de deskundigen, die werkzaam zijn in de onderscheiden diensten hun taak onafhankelijk van de werkgever en met behoud van hun zelfstandig oordeel op het gebied van hun deskundigheid moeten kunnen uitoefe$\operatorname{nen}^{208}$.

Teneinde te bevorderen dat deze beide diensten mede recht kunnen doen aan de doelstelling "welzijn", kunnen zij geintegreerd worden in een zogenaamde arbodienst ${ }^{290}$. Deze dienst is er gekomen op aandrang van de Tweede Kamer $^{300}$; de bewindsman zelf was minder gelukkig met een dergelijke regeling, daar de arbodiensten vooral een toekomstperspectief waren, temeer, omdat twee van de drie componenten van een dorgelijke dienst, namelijk veiligheid en welzijn, nog van de grond zouden moeten komen ${ }^{301}$.

De Arbeidsomstandighedenwet voorziet tevens in de mogelijkheid dat de werkgever aan zijn verplichting om een gezondheids-, veiligheids- of arbodienst in stand te houden kan voldoen, door zich aan te sluiten bij een zogenaamde gezamenlijke dienst ${ }^{302}$. Deze mogelijkheid is vooral de moeite waard voor kleinere, minder draagkrachtige ondernemingen ${ }^{303}$.

\subsubsection{Arbo-instituut}

Tot slot bepaalt de Arbeidsomstandighedenwet, dat bepaalde bedrijven of inrichtingen aangesloten moeten zijn bij een zogenaamd arbo-instituut ${ }^{304}$, dat tot taak heeft voorlichting en informatie te verschaffen en onderzoek te verrichten op het gebied van de veiligheid, de gezondheid en het welzijn in verband met de $\operatorname{arbeid}^{305}$. Voorgeschreven is, dat werkgevers en werknemers in een dergelijk instituut paritair vertegenwoordigd dienen te zijn ${ }^{\text {sioe }}$.

\subsubsection{Gefaseerde invoering}

De Arbeidsomstandighedenwet zou gefaseerd ingevoerd worden. De zogenaamde eerste fase trad op 1 januari 1983 in werking ${ }^{307}$ en op 1 juni 1985, terwijl de tweede fase met ingang van 1 januari 1988 van kracht werd ${ }^{308}$. Het ligt in de bedoeling de derde en laatste fase van invoering op 1 oktober 1990 te doen plaatsvinden $^{300}$.

\subsubsection{Deregulering}

Evenals het wetsvoorstel tot wijziging van de Arbeidswet 1919, waarbij nachtarbeid voor vrouwen in de industrie werd geregeld, zou de Arbeidsomstandighedenwet niet aan de dereguleringsoperatie ontkomen, hetgeen niet zo verwonderlijk is. De Arbeidsomstandighedenwet was al snel het voorbeeld, dat werd aangehaald van een wet, die een belemmerende rol zou vervullen bij het nastreven van het belangrijkste doel van het bedrijfsleven, het winstgevend produceren van goederen en diensten. Alleen de snelheid waarmee een en ander gebeurde kan enige verbazing wekken. Dit blijkt duidelijk uit het volgende citaat van Van Duijn $^{310}$ : 
"Gezien de werwachte verborgen beleidskosten van deze wet zou het goed zijn om te bezien

of hier al niet gedereguleerd zou kunnen worden al voor de regulering een feit is".

Nog voordat de eerste fase van de wet in werking zou treden vroeg de verantwoordelijke bewindsman al een advies $^{31}$ om zo snel mogelijk aan te geven

"waar de knelpunten of belemmeringen worden ervaren in de wet- en regelgeving, of in de uitwoering daarvan, met betrekking tot de arbeidsomstandigheden"

om op die manier

"te werken aan vereenvoudiging en opschorting van wet- en regelgeving met het oog op een structureel herstel van de werkgelegenheid".

Allereerst was daar de commissie-Van der Grinten, waarvan het rapport met het standpunt van het kabinet over de uitgebrachte adviezen op 27 juni 1983 aan de Tweede Kamer werd medegedeeld ${ }^{312}$, gewolgd door de commissie-Geelhoed. Het eindbericht van deze commissie werd op 7 maart 1984 aan het parlement bekend gemaakt ${ }^{\text {sis }}$.

De commissie-Van der Grinten formuleerde ${ }^{314}$ onder meer de aanbeveling, dat er én kader tot stand komt voor veiligheids- en gezondheidswetgeving in de arbeidsorganisatie en dat er een begin wordt gemaakt met het gebruik van globale normen op die terreinen. Voorts was de commissie de mening toegedaan, dat het bevorderen van het welzijn van de werknemers niet als zelfstandig bestanddeel dient te worden gezien, maar als een van veiligheid en gezondheid afgeleide en derhalve secundaire doelstelling. Wanneer het welzijn, zoals in de Arbeidsomstandighedenwet is gebeurd, nader is omschreven, leidt dit, aldus deze commissie, tot grote verschillen van inzicht.

Het in de Arbeidsomstandighedenwet voorziene proces van beleidsafweging zal naar haar mening daardoor worden verstoord, terwijl geen matstaven aanwezig zijn voor de bevoegdheden van de ondernemingsraad en de arbeidsinspectie. Het bevorderen van het welzijn kan slechts een ondersteunende functie hebben voor het bereiken van doelstellingen op het gebied van velligheid en gezondheid. Zij stelde dan ook voor de betreffende bepaling in de Arbeidsomstandighedenwet te herformuleren. Ten aanzien van het arbeidsveiligheidsrapport luidde de aanbeveling van de commissie-Van der Grinten na te gaan waar de knelpunten zich bevinden en dat voorzichtigheid dient te worden betracht bij het introduceren van volgende fasen.

De commissie-Geelhoed, die de opdracht had de Arbeidsomstandighedenwet nader te toetsen aan ruimere maatstaven dan de commissie-Van der Grinten, namelijk doorzichtigheid en overzichtelijkheid van de normstelling, externe en interne beleidslasten, horizontale en verticale coördinatielasten en lasten voortvloeiende uit controlle, handhaving en rechtsbescherming, kwam tot onder meer de volgende bevindingen en voorstellen $^{316}$ :

- handhaving van de welzijnsdoelstelling als zelfstandige doelstelling onder concretisering en limitering van het aantal voorschriften, waarin het bereiken van deze doelstelling, hetzij met zoveel woorden, hetzij in geoperationaliseerde vorm is neergelegd;

- het schrappen van de verplichting tot het oprichten of zich aanshiten bij een arbodienst;

- de handhaving van de verplichting tot het opstellen van een arbeidsveiligheidsrapport ${ }^{310}$;

- het vervallen van de registratieplicht van bijna-ongevallen;

- het overleg op ondernemingsniveau moet in een meer globale en flexibele zin geherformuleerd worden;

- het laten vervallen van de verplichting tot het aanstellen van mentoren voor de begeleiding van jeugdigen;

- het laten vervallen van de instelling van de districtscommissies, en

- het niet verplicht stellen van het moeten aansluiten bij een arbo-instituut ${ }^{317}$.

Een en ander zou resulteren in een wijziging van de Arbeidsomstandighedenwet in $1987^{318}$, waarbij een deel van de voorstellen werd overgenomen. $Z$ o werd bijyoorbeeld de bepaling, waarin de algemene verplichtingen van de werkgever zijn neergelegd, onder meer ten aanzien van het welzijn ${ }^{318}$, geconcretiseerd en gelimiteerd, de verplichting tot registratie van bijna-ongevallen is geschrapt; de verplichting tot aansiuiting bij een arbodienst is komen te vervallen. De betreffende bepaling is dusdanig geformuleerd, dat er een beperking is aangebracht tot de welzijnstaken, in die zin, dat het gaat om taken in de adviserende en onder- 
steunende sfeer, welke als zodanig onderscheiden moeten worden van die taken die de werkgever al moet verrichten om tot naleving van de materieelrechtelijke welzijnswoorschriften te komen, die overigens eveneens geëxpliciteerd en beperkt zijn ${ }^{320}$. Daarnaast is bijvoorbeeld de taak van de Arboraad om desgewenst de ondernemingsraad bijstand en advies te geven komen te vervallen.

\subsubsection{Samenloop Wet op de ondernemingsraden en de Arbeidsomstandighedenwet}

In de zomer van 1988 is bij de Tweede Kamer een wetswoorstel aanhangig gemaakt, waarbij onder meer de samenloop van de Wet op de ondernemingsraden en de Arbeidsomstandighedenwet opgeheven wordt ${ }^{324}$. De bedoelde wetswijziging ${ }^{\text {a22 }}$ treedt met ingang van 1 april 1990 in werking. De samenloopproblemen betreffen vooral de rechten van leden van ondernemingsraden, de daarop van toepassing zijnde geschillenprocedures en het instemmingsrecht. In het wetsvoorstel wordt voorgesteld in de Arbeidsomstandighedenwet alleen die rechten van de ondernemingsraad dan wel arbocommissie te ( blijven) regelen, die uitsluitend uit die wet voortvloeien: het recht op informatie van bijvoorbeeld de hoofden van de bedrijfsgeneeskundige dienst en veiligheidsdienst en van de arbeidsinspectie; het recht de ambtenaren van de arbeidsinspectie te vergezellen bij bedrijfsbezoeken en een onderhoud met hen te hebben buiten aanwezigheid van derden. De rechten van de ondernemingsraad, die in de Wet op de ondernemingsraden zijn opgenomen, worden uit de Arbeidsomstandighedenwet geschrapt, terwijl woor de arbocommissie deze rechten van overeenkomstige toepassing worden verklaard. Beide wetten kennen verschillende geschillenprocedures. Die van de Arbeidsomstandighedenwet begint met het verzoek om wetstoepassing, welke kan leiden tot een aanwijzing van het districtshoofd van de arbeidsinspectie. De geschillenprocedure inzake rechten in de Wet op de ondernemingsraden begint met voorlegging aan de betrokken bedrijfscommissie, gevolgd door een bindend uitspraak van dit orgaam. Vervolgens lopen de geschillenprocedures parallel. In beide gevallen bestaat het vervolg uit een beroep op de minister, eventueel gevolgd door een beroep op de Afdeling rechtspraak van de Raad van State op grond van de Wet administratieve rechtspraak overheidsbeschikkingen. De procedure in de Arbeidsomstandighedenwet zal echter overeind blijven, terwijl de procedure van de Wet op de ondernemingsraden verwangen zal worden door een procedure bij de kantonrechter, voorafgegaan door een bemiddeling en advics van de bedrijfscommissie ${ }^{323}$. Er zullen dus twee geheel verschillende procedures ontstaan ${ }^{324}$.

\subsubsection{Slot}

De Arbeidsomstandighedenwet wordt terecht eén van de grootste sociale wetten in het naoorlogse tijdbestek genoemd. Gestoeld op de gedachte van medezeggenschap kan de wet, als zijn doelstellingen goed voor ogen worden gehouden, voor de komende decennia de weg banen naar een verdere humamisering van de arbeid, dit in een tijdsbestek waarin de arbeid te veel wordt gezien alls cen middel om via geproduceerde goederen met zoveel mogelijk vrije tijd de eigen welvaart te kunnen vergroten. Tot een nadere bezinning op de inhoud wan de arbeid en het gelluk, die deze aan de mens kan verschaffen, komt men halaas nog te weinig toe. Wij zweven in een tijdsbestek tussen de no-nonsense cultuur, individualisme en super-individualisme en wat men noemt "the new age", waarin de mens het eigen leven innerlijk wil verdiepen, uitstijgend boven het eigen-ik. Overgezet op de arbeidsverhoudingen kan de Arbeidsomstandighedenwet daar als sleutel fungeren. Uiteraard wil ik mij verre houden van zwevend idealisme, maar het leek mij dienstig om deze aspecten van de Arbeidsomstandighedenwet te belichten.

Bij de invoering heeft de Arbeidsomstandighedenwet een eerste crisis doorgemaakt. De introductie van het begrip welzijn in de Arbeidsomstandighedenwet leidde in het begin van de tachtiger jaren tot een soort angstbeeld met betrekking tot een mogelijke inmenging van de overheid door de arbeidsinspectie door middel van een aanwijzing. Maar deze angst is wel erg voorbarig. Zo kan de arbeidsinspectie een dergelijke aanwijzing terzake van het welzijn eerst geven, nadat door de betrokkenen een verzoek orn wetstoepassing is gedaan. Hierbij zal ongetwijfeld de praktische haalbaarheid van de aanwijzing in het betreffende speciale 
geval in die omstandigheden in aanmerking worden genomen. Bovendien voorziet de wet in een beroepsgang, welke tot gevolg heeft dat de uitwoering van de aanwijzing wordt opgeschort. Het belangrijkste is echter en dat wordt door Geers ${ }^{325}$ opgemerkt, dat de nadelen van opneming van het begrip in een aantal artikelen niet opwegen tegen de expliciete erkenning in de wet dat ook de arbeid wordt gezien als een integraal onderdeel van het maatschappelijk en individueel bestaan. Op die wijze zou vermeden kunnen worden, dat bij een afweging tussen humanisering van de arbeid en produktieviteitsontwikkeling de weegschaal niet altijd zonder meer doorsllaat naar het tweede ${ }^{328}$. In dat kader is toe te juichten, dat het begrip welzijn vrij ongeschonden uit de dereguleringstoets is gekomen

De basisbepaling voor samenwerking en overleg binnen de onderneming is de verplichting daartoe opgelegd aan de werkgever en de werknemers. De in de wet neergelegde formuleringen "moeten" en "samenwerken" komt wat geforceerd over, maar wordt in de daarop volgende, voornamelijk, procedure-bepalingen uitgewerkt, waardoor verdedigd kan worden, dat de samenwerking daardoor wat meer inhoud krijgt, zoals de regeling van de arbocommissie. Deze kan alleen worden ingesteld als er geen ondernemingsraad is, dat wil dus zeggen voor bedrijven met 35 of meer werknemers. Alle rechten, die de Arbeidsomstandighedenwet geeft aan de leden van een arbocommissie gelden ook voor de leden van de ondernemingsraad. De ondernemingsraad heeft de bevoegdheid om een commissie voor veiligheid, gezondheid en welzijn in te stellen. In dat geval gaan de bevoegdheden van de arbocommissie over op de ingestelde commissie van de ondernemingsraad. Geers $^{327}$ merkt op, dat de regeling te vrijblijvend is; aan de ondernemingsraad wordt overgelaten of er al dan niet een dergelijke commissie wordt ingesteld. De bewindsman heeft dan wel opgemerkt, dat hij de vrijheid van de ondernemingsraad niet wilde aantasten ${ }^{328}$, maar dit kan er toe leiden, dat in bedrijven die verplicht zijn tot het instellen van een ondernemingsraad het bedoelde geinstitutionaliseerde overleg over veiligheid, gezondheid en welzijn achterwege blijft.

De verwachtingen te dien aanzien van de wet waren en zijn hooggespannen. Voorall gezien het feit, dat de werknemer een toch niet onbelangrijke rol is toebedeeld. Ondanks het feit, dat dit toe te juichen is, is dit tevens de zwakke schakel. De rechten, die aan een werknemer zijn toebedeeld, zoals informatie, inspraak en zelfs instemming, lopen via een ondernemingsraad en/of een arbocommissie. Het uitgangspunt dat hieraan, evenals trouwens bij de Wet op de ondernemingsraden, ten grondslag ligt, is, dat de onderneming gezien dient te worden als een gezamenlijke belangengemeenschap. Maar deze gedachtengang blijkt voortdurend stuk te lopen op de praktijk, waarin de bestaande belangentegenstellingen en machtsverschillen (vaak nog te ) doorslaggevend zijn ${ }^{\text {sze }}$. Er rust daarom op de vakbeweging de taak om collectieve belangenbehartiging op landelijk niveau niet ten koste te doen gaan van het bedrijfsgebeuren op een lager niveau. De in de Arbeidsomstandighedenwet gegeven formele voorschriften ten aanzien van de medezeggenschap moeten omgezet worden in democratiseringsprocessen, die daadwerkelijk leven ${ }^{330}$. De werknemers, gesteund door de vakbeweging, moeten, waar dit maar enigszins mogelijk is, de grenzen, die de Arbeidsomstandighedenwet geeft, aftasten en verleggen, waarbij een belangrijke rol weggelegd is voor de arbeidsinspectie, die vaak in een soort scheidsrechterlijke functie daaraan kan bijdragen.

Directeur-generaal van de Arbeid De Roos heeft artikel 3 - algemene verplichtingen van de werkgever -, artikel 4 - beleidsvoering en jaarplan - en artikel 13 - de verplichting tot samenwerking -

"de kern van de structuur van de Arbowet"

genoemd $^{331}$. Opmerkelijk is dan echter well, dat juist deze bepalingen in de derde en laatste fase van de invoering van de wet vallen. Een mogelijk argument hiervoor, dat de betreffende bepalingen veel voorbereiding vergen, zodat zij eerst in de laatste fase ingevoerd kunnen worden, is niet echt overtuigend.

De regeling van het werkoverleg is vaag. Er ontbreekt een aanduiding omtrent de frequentie van het overleg, de faciliteiten en de bescherming tegen benadeling en ontslag en dat terwijl onderzoek heeft aangetoond, dat een van de knelpunten, waarmee het werkoverleg telkens te kampen, heeft het gebrek is aan continuiteit $^{332}$. Koopman is zelfs bevreesd, dat de Arbeidsomstandighedenwet er toe kan leiden, dat op grote schaal 
marginaal werkoverleg bevorderd zou kunnen worden, dus van beperkte strekking met een lage frequentie en een indirect karakter ${ }^{333}$. Bovendien is de verplichting tot het instellen van het werkoverleg niet rechtstreeks aan de werkgever opgelegd, hetgeen op zich zelf niet verwonderlijk is, maar dat kan wel tot problemen leiden.

Over de in de Arbeidsomstandighedenwet neergelegde regeling van het werkoverleg stelde de bewindsman het volgende ${ }^{334}$ :

"Men moet dit artikel zien als een eerste aanzet om in Nederland een wettelijke verplichting tot werkoverleg in te voeren. Daarbij kan, gezien de nieuwheid van het terrein, nog niet in bijzonderheden worden getreden. Wellicht is het mogelijk om, wanneer het SER-advies inzake het sociaal beleid in de onderneming is uitgebracht, de thans gegeven globale verplichting verder te detailleren en in te vullen, eventueel langs de weg van het geven van aanwijzingen door de Arbeidsinspectie"t.

Het bedoelde advies van de Sociaal-Economische Raad laat echter geen twijfel bestaan over het feit, dat men vindt dat dit soort zaken binnen de onderneming zelf geregeld behoort te worden ${ }^{335}$. Het heeft er dus alle schijn van, dat de wetgever hier te veel van het goede heeft willen doen.

Ik wil thans nog enige opmerkingen maken over het overleg op landelijk niveau. Geers ${ }^{336}$ vraagt zich af of het functioneren van de Arboraad niet leidt tot een zekere uitholling van de Sociaal-Economische Raad. Men zou kunnen stellen, dat de Arboraad een soort filterfunctie bekleedt waar een voordiscussie plaatsvindt, als voorpost voor een gerichte advies-aanvraag aan de Sociaal-Economische Raad. Maar dat brengt het risico met zich, dat de eerstgenoemde uitmaakt, dat er aan de laatstgenoemde een advies gevraagd wordt en wat de inhoud van een dergelijke aanvraag zal zijn. Voorts bestaat het risico van getrapt adviseren. Daarmee bedoel ik, dat de bewindsman in zijn advies-aanvraag aan de Sociaal-Economische Raad aangeeft over welke punten door dit adviesorgaan de Arboraad gehoord dient te worden, waarop dit advies dan integraal in het advies van de Sociaal-Economische Raad opgenomen kan worden. Deze problemen, alsook de vraag, wanneer een zaak voor advies wordt voorgelegd aan het ene dan wel het andere advies-orgaan zijn door middel van goede afspraken te voorkomen. Andere vraag blijft natuurlijk of het niet overzichtelijker en duidelijker zou zijn om de Arboraad tot een commissie van de Sociaal-Economische Raad te maken ${ }^{337}$. Uit de samenstelling en taak van de Arboraad blijkt, dat dit orgaan voor een tweeledig doel wordt gebruikt, namelijk als advies- en overlegorgaan waar ambtenaren lid van zijn, waardoor het gevaar van vermenging kan ontstaan, met als gevolg, dat de positie van de lid-ambtenaren in het gedrang kan komen. Het worden van een commissie van de Sociaal-Economische Raad levert voor wat betreft het materiële werk van de Arboraad geen probleem op. Alleen de overlegfunctie, die de Arboraad nu heeft, komt dan te vervallen, maar dat lijkt mij geen bezwaar, want daarvoor zijn talloze andere mogelijkheden te bedenken.

Tot slot wil ik nog iets opmerken over de dereguleringsoperatie in het kader van de Arbeidsomstandighedenwet. Deze heeft naar mijn mening slechts een mager resultaat opgeleverd en geeft ook eerder de indruk van een verplicht nummer, een geforceerde operatie. Eén en ander wil niet zeggen, dat het geen gevolgen heeft gehad.

Het was verstandiger geweest de Arbeidsomstandighedenwet eerst in de praktijk uit te proberen, om daarna de eventuele knelpunten op te lossen. Nu wordt de indruk gewekt, dat de dereguleringsoperatie is gebruikt, om, zoals Geers ${ }^{338}$ het stelt,

"onderdelen van de Arbowet te schrappen die het bedrijfsleven niet welgevallig zijn".

Deze opvatting wordt nog versterkt door het feit, dat een onderwerp als werkoverleg, waarvan hierboven vastgesteld is, dat de wetgever wellicht te veel van het goede heeft willen doen in het kader van de deregulering niet eens genoemd is. 


\section{Krittek op de arbeidsinspectie; van het Project Ontwikkeling Arbeidsinspectie naar Arbo'91}

\subsection{Kritiek op de arbeidsinspectie}

Tijdens de behandeling van de Arbeidsomstandighedenwet in het parlement is de onderbezetting van de arbeidsinspectic ruimschoots aan de orde gekomen. Veelal werd het standpunt gehuldigd, dat voor een goed functioneren van de arbeidsbeschermende wetgeving een kwantitatief en kwalitatief behoorlijk uitgeruste arbeidsinspectie een bellangrijke voorwaarde is ${ }^{339}$. Over het functioneren van de arbeidsinspectie bestonden al jaren twijfels. Twijfels over de onderbezetting, de kwaliteit van het geleverde werk en de houding, waarmee de dienst tegenover haar taak staat. De directeur-generaal van de Arbeid de Roos gaf zelf toe, dat de arbeidsinspectie kwalitatief en kwantitatief moest worden versterkt. Ook van de zijde van de vakbeweging werd gesteld, dat de dienst meer mankracht diende te krijgen. De verantwoordelijke bewindsman Albeda stelde een uitbreiding van de dienst met 200 nieuwe medewerkers in het vooruitzicht. Een uitbreiding, die bedoeld was om de bezoekfrequentie an in het bijzonder kleinere bedrijven op te voeren, om zo inhoud te kunnen geven aan het met de sociale partners te voeren overleg ${ }^{340}$; de uitbreiding van de dienst zou enkele jaren in beslag nemen. Een motie om deze termijn op ten hoogste vijf jaar te stellen werd echter verworpen $^{34 t}$.

Sinds de belangstelling voor de arbeidsomstandigheden in het midden van de jaren zeventig groeide, kwam. er ook kritiek los op het functioneren van de arbeidsinspectie. Aan de kritiek zou, zowel door het parlement, als door de betrokken bewindsman tijdens de behandeling van de Arbeidsomstandighedenwet naar verhouding weinig aandacht worden besteed. De kritiek richtte zich onder meer op de controle op de naleving van de wettelijke voorschriften en een te gering aantal onaangekondigde inspectïes in de bedrijven. Zo werd van de zijde van de vakbeweging onder meer het volgende naar voren gebracht ${ }^{342}$.

"De dienst treedt in de praktijk meer op als een welwillend adviseur van de werkgever dan als een politie-apparaat dat er in de eerste plaats is om de naleving van de arbeidsbeschermende wetten te controleren. Zo'n taak veronderstelt dat de Arbeidsinspectie zich aan de kant stelt van de groep die zij moet beschermen: de werknemers. In de praktijk gebeurt dat niet"

De Bruin ${ }^{343}$ zou nog verder gaan. Hij had het over

"het in de verdrukking komen van de primaire taak"

van de arbeidsinspectie, namelijk

"de inspektie en de controle".

Bloemarts ${ }^{344}$ schetst de kritiek, die in de kringen van de vakbeweging wordt geuit als volgt. De huidige personeelsbezetting is onwoldoende voor een adequate inspectie en controle op de naleving van de arbeidsbeschermende wetgeving. De uitvoering van deze taak van de arbeidsinspectie komt in de verdrukking door allerlei nieuwe werkzaamheden, waarmee zij wordt belast. Daarbij verwijst hij naar artikel 49 van de Wet op de ondernemingsraden en de subsidieregelingen arbeidsplaatsverbetering. Voorts is de communicatie tussen de arbeidsinspectie en de werknemers en hun vertegenwoordigers gebrekkig en wordt door haar wijze van optreden twijfel opgeroepen over haar effectiviteit van de controle. Hij noemt onder meer:

"- een onvoldoende allert optreden bij klachten van werknemers;

- en de wel eens bestaande neiging het accent van controle op en afdwinging van naleving van de voorschriften te verleggen naar vormen van min of meer vrijblijvend advies, leidend tot een ongewenste vertrouwelijkheid tussen controleur en werkgever".

\subsection{Het Project Ontwikkeling Arbeidsinspectie}

Niet mis te verstaan waren de resultaten van een onderzoek door een extern Adviesbureau Mens en Organisatie, neergelegd in het rapport "De Arbeidsinspectie in ontwikkeling"345. Het onderzoek werd voorafgegaan door de activiteiten van een op 1 april 1975 ingestelde werkgroep $^{348}$, die tot taak had de daarvoor 
benodigde organisatorische voorwaarden te creëren voor een experiment "Heroriëntering Arbeidsinspectie", waarna het experiment in het tiende district van de arbeidsinspectie van start zou kunnen gaan. De bedoeling was om na te gaan, op welke wijze de arbeidsinspectie meer systematisch aandacht zou kunnen besteden aan het sociaal beleid in de onderneming ${ }^{347}$. De werkgroep bracht een rapport uit, waarin zij stelde een vooronderzoek noodzakelijk te achten, alvorens tot een definitieve experimenteeropzet te kunnen komen. Voorts zou een adviesbureau de nodige ondersteuning moeten verlenen en zou evaluatie van het experiment moeten plaatswinden door een wetenschappelijk instituut.

Dit rapport leidde tot een andere opzet dan het voorgestelde experiment in cén district. Een verbreding werd noodzakelijk geacht. De vraag over de wijze waarop de arbeidsinspectie op de huidige en toekomstige taken zou moeten inspelen, diende te worden geplaatst binnen het totaal functioneren van de dienst ( de wijze van werken, de bemanning, de reorganisatie en dergelijke ). Beperking tot eén experimenteerdistrict werd ongewenst geacht, omdat de gehele arbeidsinspectie, dus ook de centrale dienst, bij de vraag naar de gewenste heroriëntatie zou moeten worden betrokken ${ }^{348}$. Daarmee hangt samen de beklemtoning van het project als proces van verandering en de wenselijkheid een zo groot mogelijke participatie van de medewerkers en andere betrokkenen. Bij dit punt speelden verschillende argumenten een rol zoals de ervaringen van een aantal betrokkenen, opgedaan bij andere organisatie-projecten, de nadruk van de dienstcommissie en de districtshoofdenvergadering op het feit, dat medewerking van alle ambtenaren verkregen zou moeten worden en zeker ook opvattingen over samenwerking, leiding geven en veranderen.

De beperking tot de sociale beleidsaspecten werd eveneens minder gewenst geacht, omdat het toch zou moeten gaan om de samenhang hiervan met de technische en medische beleidsaspecten als onderdelen van het algemeen beleid. De vervulling van de huidige en de gewenste toekomstige taken diende te worden geplaatst binnen het totale functioneren van het directoraat-generaal van de Arbeid; dit hield in aandacht voor de middelen, de methoden, de instrumenten, de bedrijfsbenadering, de medewerkers, de deskundigen en de organisatie ${ }^{34 \theta}$.

Deze voorbereiding op het vooronderzoek heeft op 7 april 1976 geleid tot een brief van de directeur-generaal van de Arbeid aan alle medewerkers, waarin de start van het Project Ontwikkeling Arbeidsinspectie werd aangekondigd.

Aan de brief was als bijlage de opzet van het vooronderzoek toegevoegd. De brief was tevens een afsluiting van de tot dan gevoerde discussies, waarmee het werk van de hierboven bedoelde werkgroep in feite ten einde was gekomen.

De achtergrond waartegen het onderzoek geplaatst moet worden is eigenlijk al geschetst in de inleiding van dit hoofdstuk. Voor de arbeidsinspectie brengen de aldaar geschetste ontwikkelingen de nodige consequenties met zich. De arbeidsinspectie heeft zich van oudsher gericht op de bescherming van werknemers tegen onveilige en ongezonde arbeid en de arbeidsomstandigheden. Door de snelle technologische en maatschappelijke ontwikkelingen is de taak van de arbeidsinspectie aanmerkelijk verzwaard. In de bedrijven is een groeiende aandacht ontstaan voor de sociale aspecten van het bedrijfsgebeuren: democratisering, werkoverleg, werkstructurering en de mogelijkheden op het terrein van de ergonomie. De overheid ziet voor zich zelf in deze een taak; door middel van wetgeving wordt geprobeerd de humanisering van de arbeid en arbeidsomstandigheden te stimuleren. Voor de arbeidsinspectie heeft een en ander gevolgen voor haar werkwijze en taakuitvoering. Dit heeft al eerder geleid tot een eerste onderzoek door het bureau Bosboom en Hegener aan het einde van de jaren zestig, maar met de resultaten daarvan is niet veel gebeurd. Een nadere bezinning op het huidige' en toekomstige functioneren van de arbeidsinspectie opende de weg voor een nieuw onderzoek. In de opdrachtformulering aan het ingeschakelde externe adviesbureau werd het doel van het $\mathrm{nu}$ in te stellen vooronderzoek als volgt geformuleerd $\mathrm{d}^{350}$

"... in overleg met de betrokkenen zal worden nagegaan hoe het project vorm kan krijgen; hierbij zal moeten worden uitgegaan van de huidige situatic en van de mogelijkheden die deze biedt voor het toekomstige functioneren van de dienst". 
Aan de volgende activiteiten moest aandacht worden besteed: kennisneming en verkenning van meningen en inzichten betreffende het project, inventarisatie van het huidige functioneren en van de wensen en mogelijkheden met betrekking tot het toekomstig functioneren wan de arbeidsinspectie en het uitwerken van een voorstel voor opzet en uitvoering van het project. Het vooronderzoek werd in mei 1976 gestart en werd afgerond in april 1977. In het bewuste eindrapport wordt een beschrijving gegeven van de organisatie van de arbeidsinspectie ten aanzien van de structuur, het management, de doelstellingen, de instrumenten, de beschikbare middelen en het personeel- en organisatiebeleid. De bevindingen liegen er niet om $^{351}$. Ten aanzien van bijvoorbeeld de taakomschrijving van de arbeidsinspectie wordt geconstateerd, dat daardoor aan de ambtenaar een zeer ruime taakopdracht wordt verleend ${ }^{352}$. Bij de uitvoering van deze opdracht kan de betrokken ambtenaar voor een deel steunen op een aantal wettelijke bevoegdheden, waarin de zogenaamde legitimiteit voor zijn optreden is gelegen. Opvallend was, dat nogal wat (buitendienst)ambtenaren bij hun optreden in arbeidsorganisaties een grote terughoudendheid betrachten, wanneer zij zich niet geruggesteund voelen door in de "wettelijke basis" gegronde duidelijk hanteerbare instrumenten. Het ontbreken van dergelijke duidelijke instrumenten leidt vaak tot een gevoel van onzekerheid bij de betrokken ambtenaar. Die uit zich in de vraag of de bewoegdheid tot optreden niet beperkt is tot uitsluitend die wetten en besluiten, waarin duidelijk sprake is van een concrete norm en waarin de gedetailleerde regelgeving gekoppeld is aan mogelijke saneties.

"Anders gezegd, er is spanning te konstateren tussen de ruime taakbeschrijwing dan wel de opsomming van taken enerzijds en de wijze waarop die taken door de ambtenaar worden uitgevoerd anderzijds".

Deze gesignaleerde onzekerheid is echter niet alleen hiervan het gevolg. Een tweetal andere ontwikkelingen zijn hier zeker debet aan. Intern zijn er beleidsontwikkelingen, die nader vorm geven aan de overheidsvisie op humanisering van de arbeid, terwijl er extern de zich wijzigende opvattingen zijn over arbeid en arbeidsomstandigheden, die resulteren in een ander verwachtingspatroon ten aanzien van het optreden van de arbeidsinspectie en die nogal eens leiden tot kritiek op deze dienst. Daarnaast komen de (buitendienst)ambtenaren in aanraking met een grote verscheidenheid aan arbeidsorganisaties, zowel naar aard als naar omvang. Het eerste punt leidt ertoe, dat de ambtenaar de "taal" van vele bedrijfstakken moet kunnen spreken en zeker moet kunnen verstaan. Hij moet ook inzicht hebben in de problemen, die kenmerkend zijn voor de diverse typen en soorten bedrijven. Het tweede punt betekent, dat de (buitendienst)ambtenaar zich geconfronteerd ziet met een zeer uiteenllopende mate van deskundigheid. Immers hoe groter de organisatie, hoe meer kans op aanwezigheid van specialisten op deelterreinen.

Het adviesbureau acht voor de werkwijze van de arbeidsinspectie onder meer het volgende kenmerkend: - de benadering op bedrijfstakniveau is sterk gericht op individuele personen - directeuren, bedrijfsleiders, personeelschefs en individuele werknemers - en veel minder op groepen en overlegorganen, zoals de ondernemingsraden;

- de contacten met de arbeidsorganisaties komen voor een belangrijk deel tot stand op initiatief van de arbeidsorganisaties zelf, doordat een groot deel van de voorgeschreven procedures - bijvoorbeeld Hinderwetprocedures, ontheffingen van het verbod van werktijdverkorting en overwerkvergunningen - verloopt via de arbeidsinspectie; de afhandeling hiervan legt een groot beslag op de beschikbare capaciteit van deze dienst, hetgeen ten koste gaat van het aantal bedrijfscontroles op initiatief van de arbeidsinspectie zelf;

- door een vrij grote afstand tussen de diverse personeelsgroepen van de arbeidsinspectie en tussen de districten en de centrale dienst is er weinig sprake van; dat de uitvoering van de diverse deeltaken leidt tot een geïntegreerde totaalaanpak van de problematiek;

- de instelling van de ambtenaren van de arbeidsinspectie is sterk normatief, dat wil zeggen, dat zij zich in hun optreden gesteund voelen en willen voelen door een wettelijk instrumentarium, waarin een gedetailleerde normering is opgenomen.

Tot slot een citaat:

"De Arbeidsinspectie heeft zich door ...... tot een dienst ontwikkeld die zich kenmerkt door een uitstekende technische know-how, die ook naar onze mening door de technologische 
ontwikkeling op dit moment eerder versterking dan verzwakking behoeft; maar tevens een dienst die de ontwikkelingen op sociaal-wetenschappelijk gebied en andere terreinen van het sociaal beleid dan het veiligheidsaspekt, onvoldoende heeft gevolgd, Doordat op technisch gebied genoeg te doen valt, dat gebied gemakkelijk grijpbaar is en minder politick-gevoelig, is de nadruk in de na-oorlogse jaren komen te liggen op uitbreiding van de technische know-how. Dit heeft overigens wel geleid tot een situatie, waarin tekort wordt gedaan aan doelstelling en taken van de Arbeidsinspectie, zoals deze in lengte van jaren werden beleefd, namelijk het leveren van een adequate bijdrage van overheidswege aan een aanvaardbare werksituatie, zowel technisch, als medisch, als sociaal gezien".

In het rapport werden zowel de organisatiestructuur, het informatieproces, het personeelsbeleid, de personeelsbezetting, als de werkwijze voor verbetering vatbaar gevonden. Vervolgens werd een uitwerking gegeven voor een op te zetten projectorganisatie, bestaande uit vijf werkgroepen en een coördinerende projectgroep.

Als eerste stap werd een projectgroep ingesteld, die tot taak kreeg de opzet van de projectorganisatie uit te werken; er werd een projectplan opgesteld, waarin doel en aanpak van het project, de structuur en de inhoud van de projectorganisatie, alsmede de besluitvormingsprocedures werden aangegeven. Het doel van het project werd als volgt omschreven:

"Het doelmatig functionéren van DG-Arbeid als geheel met dien verstande dat recht wordt

gedaan aan zowel de doelstellingen van het externe als het interne sociale beleid ${ }^{\text {1353 }}$.

Deze formulering riep een tweetal vragen op: gaat de dienst nu zelf doelstellingen en taken vaststellen; gaat de dienst aan de leiband lopen van de sociale partners, gezien het feit, dat deze bij de besluitvorming zijn betrokken? Beide vragen werden in het projectplan ontkennend beantwoord; de doelstellingen en taken zijn bij wet of besluit vastgelegd. De bedoeling is niet dat op eigen houtje doelstellingen en taken toegevoegd, dan wel geschrapt gaan worden, maar om ordening te brengen, die kan leiden tot het stellen van prioriteiten aan de inzet van mensen en middelen. Ook is het niet de bedoeling om aan de leiband van de sociale partners te lopen; de arbeidsinspectie - de overheid dus - heeft een eigen verantwoordelijkheid. Wel hebben alle betrokken partijen elkaar nodig om gezamenlijk de maatschappij te dienen, ieder vanuit zijn eigen verantwoordelijkheid. Gezien de taaktoebedeling aan de Arboraad in de Arbeidsomstandighedenwet en de wijze, waarop het vergunningenbeleid arbeids- en rusttijden tot stand is gekomen, dient bij het antwoord op de tweede vraag naar mijn mening wel een vraagteken worden geplaatst.

Bij de aanpak van het project werd gekozen voor een methode van ontwikkeling en participatie, omdat deze begrippen pasten binnen het cultuurpatroon van het directoraat-generaal van de Arbeid en aansloten op de ervaringen van de medewerkers, opgedaan in de bedrijven, begrippen ook die een belangrijk onderdeel vormden van de visie, die werd gedragen door de leiding van dit directoraat-generaal en tenslotte ook begrippen die centraal stonden in de benadering van de externe adviseurs ${ }^{354}$.

In het kader van het project zijn vijf werkgroepen aan de slag gegaan. Bij de samenstelling van deze werkgroepen is gezocht naar ervaring en kennis op het betreffende gebied; de bijeengebrachte ervaring en kennis moest een waarborg zijn voor het ontstaan van zinvolle voorstellen. Een andere waarborg voor dit laatste werd gezocht in het feit, dat de werkgroepen deze voorstellen zouden moeten ontwikkelen in samenspraak met de districten en afdelingen. Dit laatste hield in, dat de participatie zich niet beperkte tot de besluitvorming, maar eveneens in de "voorstelfase" aan de orde was. Op deze wijze werden de voorstellen niet ontwikkeld vanuit de studeerkamer, maar vanuit de kennis en beleving van de dagelijkse realiteit, in gesprekken met districten en afdelingen. Welke werkgroepen betrof het nu?

De werkgroep "doelstellingen en taken", die door inventarisatie en beschrijving voorstellen moet ontwikkelen betreffende:

- de doelstellingen; datgene wat de organisatie moest bereiken ( de verdeling in districten );

- de vertaling van de doelstellingen in concrete taken. 
Nu zijn doelstellingen en taken geen statisch gegeven, maar iets dat door de maatschappelijke ontwikkelingen wordt beinvloed; zij moeten in de tijd worden aangepast en veranderd. Het gaat om het aangeven van een ramwerk, van waaruit de organisatie opereert, het aangeven van een vertrekpunt voor activiteiten die hiervan zijn afgeleid, zoals de inrichting van de organisatie, de benodigde mankracht en de werkwijze. Het ging dus om:

- het verkrijgen en verschaffen van inzicht in de huidige en toekomstige doelstellingen en taken;

- het verkrijgen en verschaffen van inzicht in de beschikbare en te hanteren methoden en instrumenten;

- het aangeven van de onderlinge samenhang tussen doelstellingen, taken en werkwijzen.

Met andere woorden: de taak van deze werkgroep was om duidelijkheid, zowel in- als extern, te verschaffen over de koers, die de arbeidsinspectie vaart en in de toekomst zal moeten gaan varen.

De werkgroep "werkwijze" kreeg tot taak de huidige werkwijzen te inventariseren, te beoordelen en verbeteringswoorstellen te formuleren. Bij de bestaande activiteiten en de daarbij behorende werkwijzen dienden de gehanteerde middelen, methoden, instrumenten en noodzakelijke tijdsbesteding betrokken te worden. Vervolgens moesten de werkwiijzen geëvalueerd worden op effectiviteit - het bereiken van een doel - en efficiëncy - het verkrijgen van een optimaal resultaat met beperkte mankracht, middelen en tijd.

De werkgroep "werkterrein" diende een kwantitatieve en kwalitatieve beschrijving te geven van het werkterrein van het directoraat-generaal van de Arbeid. De taken van deze werkgroep kwamen neer op:

- het verkrijgen en verschaffen van inzicht in aard en omvang van de problemen in de arbeidsorganisaties;

- het verkrijgen van aansluiting tussen de structuur van het directoraat-generaal van de Arbeid en de struc-

tuur van het werkterrein;

- het doen van voorstellen voor een ordening van het werkterrein, die een beschrijving mogelijk maakt naar voor het directoraat-generaal van de Arbeid relevante gezichtspunten, die voortvloeien uit de wettelijke doelstellingen en taken;

- het geven van een kwalitatieve en kwantiatieve beschrijving volgens deze ordening, die zowel inzichtelijk, beschikbaar als overdraagbaar moet zijn.

Met andere woorden: deze werkgroep had tot taak het in kaart brengen van de voor het directoraat-generaal van de Arbeid van belang zijnde probleemgebieden.

De werkgroep "personeel en organisatie" had tot taak met voorstellen te komen tot aanpak van de knelpunten op respectievelijk het terrein van het personeelsbelleid, van de organisatorische en bestuurlijke vormgeving, van het financieel beleid en de huisvesting, waarbij prioriteit gegeven diende te worden aan het oplossen wan de knelpunten in de management- en overlegstructuur.

De laatste werkgroep "informatievoorziening" had tot taak:

- het in kaart brengen van de bestaande informatievoorziening;

- het verschaffen van inzicht in de tijdsbesteding aan de diverse taken, bedrijven en instellingen door de diverse ambtenaren;

- het beschikbaar maken van deze informatie voor het management, de buitendienst- en binnendienstmedewerkers.

De eindprodukten van de werkgroepen moesten vanzelfsprekend beantwoorden aan de taakopdrachten, maar de voorstellen dienden tevens te voldoen aan enkele algemene eisen; zo dienden zij:

- een verwijzing te bevatten naar het bestaande beleid op het betrokken taakveld en aan te geven wat de ratio is voor verbeteringsvoorstellen;

- een raming te bevatten van de benodigde middelen gelet op de mankracht, materieel, huisvesting en financièn;

- een tijdsplanning aan te houden ten aanzien van de uitvoering van de te nemen maatregelen; 
- aan te geven, op welke wijze de bestaande organisatie de taak van de werkgroep kan overnemen, zodat bij het einde van het project de taken blijvend in de dienst zijn geinntegreerd ${ }^{355}$; ook hiervoor dienen in de meest ruime zin de middelen te worden aangegeven;

- aan te geven, op welke wijze de voorstellen na verloop van tijd zullen worden geëvalueerd, zodat ook op dit punt de dynamiek wordt ingebouwd ${ }^{358}$.

Het projectplan zelf was eind 1979 tot stand gekomen, terwijl de besluitvorming daarover in de loop van 1980 werd afgerond. De hierboven bedoelde werkgroepen werden al in juni 1979 ingestell. In 1980 en 1981 waren de eerste ontwerp-voorstellen van de werkgroepen gereed, die vervolgens in de loop van 1981 werden aangepast en uitgebreid.

In 1982 is het overzicht van de doelstellingen gereedgekomen, dat wil zeggen de beschrijvingen van de gewenste situaties vanuit het perspectief van het directoraat-generaal van de Arbeid. Bij de opstelling van dit overzicht is gebruik gemaakt van de zogenaamde specificatie-methode, dat wil zeggen het uitsplitsen van de hoofddoelstelling in een aantal meer concrete subdoelstellingen. Om het geheel praktisch bruikbaar te maken zijn subdoelstellingen geformuleerd, die aangrijpingspunten vormen voor het te voeren beleid ${ }^{357}$. In het eindrapport is een methodiek ontwikkeld waarmee voor de afzonderlijke doelstellingen kan worden nagegaan, welke beleidsstrategie, instrumenten en taken moeten worden gehanteerd, en in hoeverre dit weer leidt tot vernieuwing of afstoting van taken. Met het gereed komen en aanvaarden van het eindrapport werd de taak van deze werkgroep overgenomen door de staande organisatie ${ }^{358}$.

In 1983 is een voorstel ontwikkeld voor een geautomatiseerd systeem, waarin basisgegevens zijn opgenomen over de arbeidsorganisaties en de daarin werkzame personen. In dit systeem zal de informatie via terminals opvraagbaar zijn in de districten; het ligt in de bedoeling deze basisgegevens te koppelen aan gegevens uit andere informatiebronnen, zoals ongevallen- en verzuimciffers, gegevens over het werken in ploegendienst, gegevens over het gebruik van toxische stoffen. Tevens zal in de loop van de tijd het activiteitendagrapport aan deze basisgegevens worden gekoppeld, waardoor inzicht zal worden verkregen over de tijds- en capaciteitsinzicht van de dienst ${ }^{358}$.

In 1983 is een model ontwikkeld, aan de hand waarvan per afzonderlijk taakgebied min of meer uniforme, maar ook systematische en planmatige wijzen van werken worden verbijzonderd. In het model zijn een aantal basiseisen geformuleerd, waaraan elke werkwijze moet voldoen ${ }^{300}$. Op basis wan thet model zijn een drietal varianten ontwikkeld, namelijk: een algemene werkwijze $\mathrm{e}^{361}$, een specialistische werkwijze ${ }^{362}$ en een projectmatige werkwijze ${ }^{383}$. Met deze werkwijze-varianten wordt het mogelijk de aanwezige deskundigheid op een efficiënte wijze in te zetten voor die problemen, waarvoor die deskundigheid is vereist ${ }^{364}$.

Vanaf 1982 zijn voorstellen gedaan over de nieuwe structuur van de centrale dienst en de districten. In 1984 zouden de discussies over de hoofdstructuur van het directoraat-generaal van de Arbeid en de inrichting van de centrale dienst afgerond worden, waarna met de invoering werd begonnen. In het najaar van 1984 zijn in dit kader directieleden benoemd, die vervolgens tot taak hebben gekregen om de invoering binnen hun directie te realiseren. Hierbij is gekozen voor een invoering "top-down" om aan de invoering snel en doelmatig gestalte te geven. Een belangrijke verandering is het besluit de organisatie niet langer naar disciplines, maar naar produkten in te richten, waarbij wordt aangesloten op de Arbeidsomstandighedenwet. De directie van het directoraat-generaal van de Arbeid bestaat nu behalve uit een een directeur-generaal van de arbeid uit nog vier directeuren, namelijk veiligheid, gezondheid, sociaal arbeidsbeleid en algemeen en intern beleid ${ }^{385}$. 
De activiteiten van de nieuwe directie veiligheid zijn gericht op het verkrijgen en verschaffen van inzicht, waar het gaat om de veiligheid in of ten behoeve van de arbeidsorganisaties, alsmede de factoren die hierop van invloed zijn. Daartoe is deze directie opgesplitst in een aantal aandachtsgebieden, namelijk:

- algemene veiligheid;

- bouwveiligheid;

- chemische veiligheid;

electrotechuische veiligheid;

- mechanische veiligheid;

nucleaire veiligheid.

De opbouw van de directie veiligheid ziet er schematisch als volgt uit:

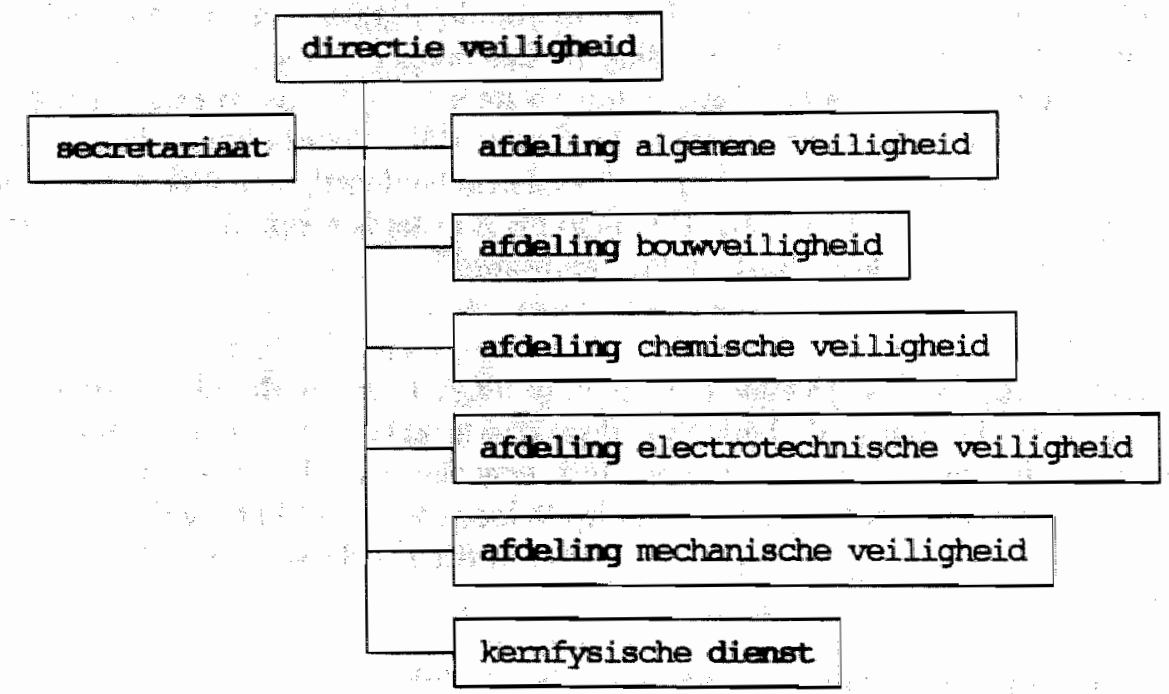

De nieuwe directie gezondheid ${ }^{360}$ is gevormd door het samenvoegen van diverse technisch georiënteerde afdelingen en de medische dienst. De belangrijkste aandachtsgebieden zijn:

- toxische stoffen;

- fysische factoren;

- biologische factoren;

- psycho-sociale en perceptief-mentale factoren;

- ioniserende straling;

- organisatie en kwaliteit van de bedrijfsgezondheidszorg.

De samenstelling van de afdelingen binnen deze directie is zodanig, dat de belastende factor vanuit één-afdeling kan worden uitgevoerd, waardoor een integraal beleid ontwikkeld kan worden. De directie gezondheid is opgesplitst in vijf afdelingen, namelijk toxische stoffen, fysische factoren, stralingshygiëne, organisatie bedrijfsgezondheidszorg en arbeidsgezondheidskunde. De doelstelling van de afdeling toxische stoffen is "het bevorderen van zodanige arbeidsomstandigheden in de bedrijven en op de werkplek dat de gezondheid van de werkende mens bij het beroepsmatig omgaan met toxische stoffen en materialen zo optimaal mogelijk wordt beschermd".

De afdeling fysische factoren ontleent zijn taak uit de doelstelling van de fysische arbeidshygiëne: het vanuit de centrale overheid bevorderen van zodanige fysische omstandigheden bij het verrichten van arbeid, dat 448 
werknemers noch acuut, noch op lange termijn gezondheidsschade oplopen. De afdeling stralingshygiêne heeft als doelstelling het bevorderen van de totstandkoming en uitvoering van een beleid, dat beoogt de werkende mens en/of zijn nageslacht te beschermen tegen de nadelige invloed op de gezondheid van ioniserende en niet-ioniserende straling in de arbeidssituatie. De afdeling organisatie bedrijfsgezondheidszorg heeft drie hoofddoelstellingen: het bevorderen van de zorg naar - in beginsel - alle werkenden in ons land, het formuleren en coördineren van het wettelijk toezicht op de zorgkwaliteit en het bevorderen van een infrastructuur van bedrijfsgezondheidsdiensten, passend binnen het geheel van voorzieningen in de gezondheidszorg. Tot slot de afdeling arbeidsgezondheidskunde, die als uitgangspunt van haar activiteiten heeft de gezondheidseffectenkant van schadelijke factoren in de arbeid; activiteiten, die afgestend zijn op het voorkomen van arbeidsgebonden aandoeningen.

De opbouw van de directie gezondheid ziet er schematisch als volgt uit:

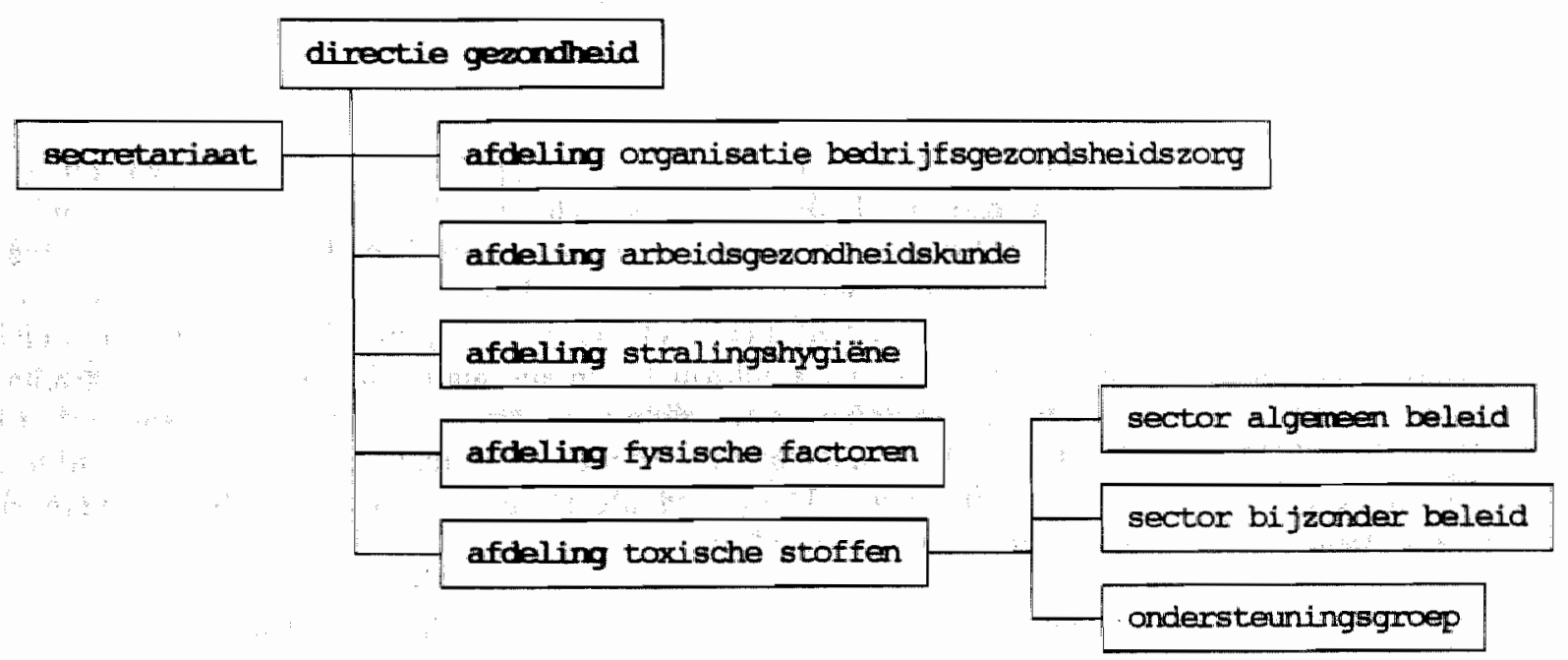

De activiteiten van de directie sociaal arbeidsbeleid zijn gericht op het optimaal doen functioneren van de werkende mens in arbeidsorganisaties, tegen de achtergrond van het proces ter bevordering van menswaardige arbeid. Het gaat om zaken als: organisatie van de arbeid, individuele taak en functie-inhoud, ergonomie, medezeggenschap voor zover het betreft de arbeidsomstandigheden, personeelsbeleid, deskundigheidsbevordering in verband met de arbeids- en rusttijden ${ }^{367}$. De directie bestaat uit een secretariaat en drie afdelingen, namelijk de afdeling organisatiebeleid in verband met de arbeid, de afdeling personeelsbeleid in arbeidsorganisaties en de afdeling werktijdregelingen. De afdeling organisatiebeleid heeft als doelstelling het bevorderen van een doelstreffend organisatiebeleid in arbeidsorganisaties, gericht op het optimaal functioneren van de werkende mens, zowel individueel als in groepsverband. De taken die daaruit voortvloeien liggen vooral op het gebied van arbeids- en organisatiekunde en ergonomie. De afdeling heeft als doelstelling het ontwikkelen van het overheidsbeleid met betrekking tot aspecten van het personeelsbeleid in ondernemingen. De afdeling werktijdregelingen houdt zich bezig met het beleid ten aanzien van arbeids- en rusttijden en het verbod van werktijdverkorting. 
De opbouw wan de directie sociaal arbeidsbeleid ziet er schematisch als volgt uit:

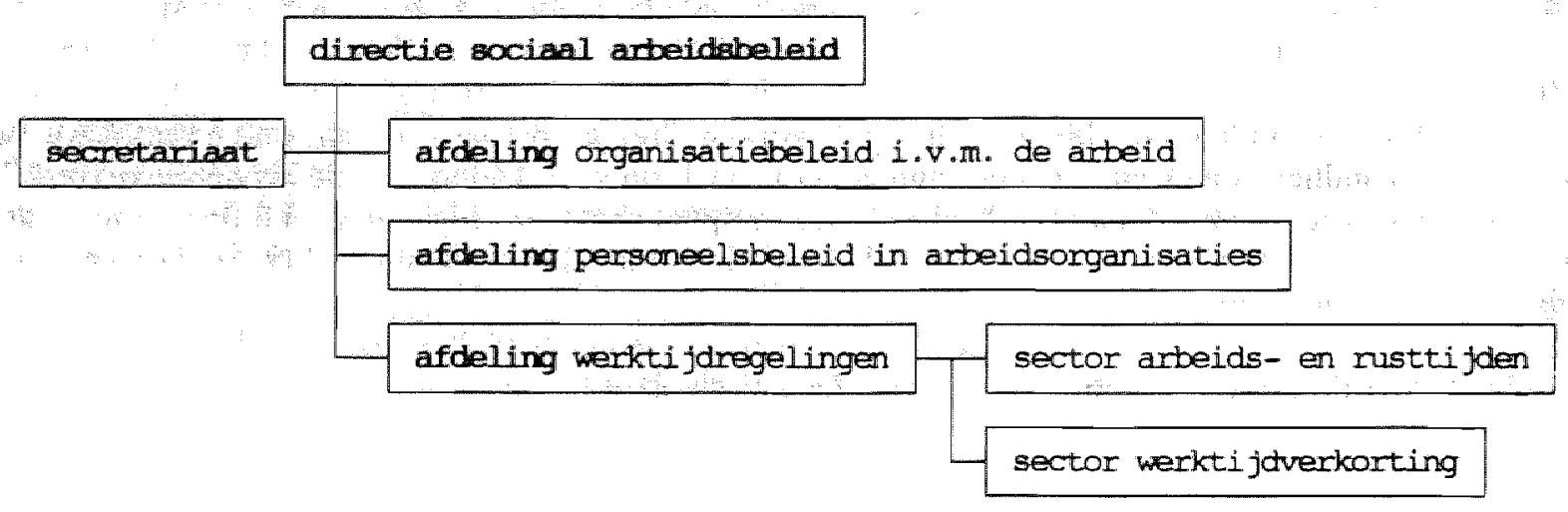

De nieuwe directie algemeen en intern beleid richt zijn activiteiten op de zorg voor de ontwikkeling en uitvoering van het algemeen beleid, dat extern beleidsoverleg, voorlichting, arbeidsplaatsverbetering en bedrijfstak-aangelegenheden omvat. Verder draagt deze directie zorg voor de juridisch-bestuurlijke en wetgevende aspecten van het beleid van het directoraat-generaal van de Arbeid. De activiteiten van deze directie hebben vervolgens betrekking op de zorg voor: de ontwikkeling, uitwoering en evaluatie van het interne beleid ten aanzien van personeel, organisatie en opleidingen; informatie en automatisering; planning, programmering en financien. Een en ander binnen de van departementszijde aangegeven kaders en uitgevaardigde richtlijnen. Deze directie bestaat uit vijf afdelingen, namelijk: de afdeling personeel, organisatie en opleidingen; de afdeling planning, programmering en financien; de afdeling informatievoorziening; de afdeling wetgeving en juridische zaken en de afdeling algemeen arbeidszaken.

De opbouw van de directie algemeen en intern beleid ziet er schematisch als volgt uit: 
directie algemeen en intern beleid

afdeling personeel, onganisatie en opleidingen

sector personeelsbeleid en witwoering sector organisatiebeleid

sector opleidingen

sector personeelsinfomatie en budgetadministratie

afdeling planning, programering en financiën

sector plaming, programmering en rapportage
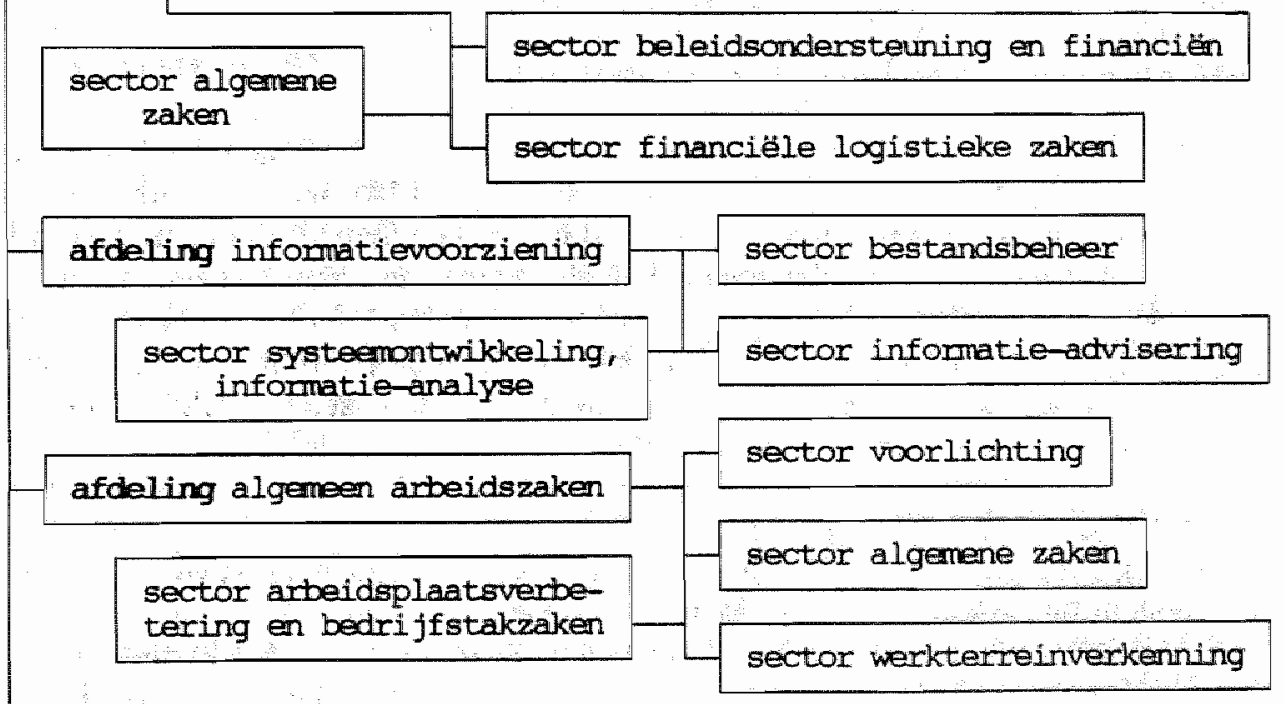

afdeling wetgeving en juridische zaken sector gezondheid

sector sociaal arbeidsbeleid

sector veiligheid en gevaarlijke werktuigen 
In 1986 zijn beslissingen genomen omtrent de organisatie van de districten, die wat betreft de structuur overeenkomt met de directie-opbouw van het directoraat-generaal, de geografische herindeling ${ }^{368}$ hiervan waarover in de volgende paragraaf meer - en taken en structuren van de districtsadministratie. Voorts is verder gewerkt aan de werkwijze van de arbeidsinspectie op het gebied van bedrijfsbenadering, van interne werkprocessen en van informatievoorziening. Eén en ander gebeurde door de staande organisatie, die vanaf 1982 de taken van de projectorganisatie over heeft genomen, waardoor de projectorganisatievorm zou veranderen en op termijn op zou houden te bestaan.

Het hele Project Ontwikkeling Arbeidsinspectie zou in de pas moeten lopen met de in fasen in te voeren Arbeidsomstandighedenwet. Tijdens de parlementaire behandeling van deze wet schetste de bewindsman althans voor wat betreft de werkwijze en de interne organisatie een aantal grondtrekken, waarmee hij tevens aangaf wat er aan ontbrak, namelijk het stimuleren van samenwerking tussen werkgever en werknemer op het niveau van de arbeidsorganisatie; het intensiveren van de contacten met werkgevers en werknemers en hun vertegenwoordigers in de overlegorganen van de onderneming; verdieping en verbreding van specifieke deskundigheid binnen de dienst; verbeterde samenwerkingsvormen binnen en tussen disciplines, die binnen de dienst werkzaam zijn; uitbouw van de integratie tussen de beleidsvoorbereiding en de beleidsuitvoering; afstemming van de centrale en decentrale organisatie op de problematiek van het werkterrein. Over de werving, selectie, opleiding en vorming onderstreepte de bewindsman de opmerking van Kamerleden ${ }^{369}$, dat miet alleen gelet moest worden op de objectieve technische kundigheid, maar vooral ook op gemotiveerdheid om als overheidsdienaar te werken aan arbeidsbescherming en arbeidsontplooiing ${ }^{370}$.

In een terugblik en evaluatie stellen Bor, De Roos en Van Veen een aantal zaken na zeven jaar projectervaring vast. Zo stellen zij onder meer, dat de tot dan ( 1985 ) bereikte resultaten tot stand zijn gekomen via veel inspanning van een groot aantal mensen gedurende een lange tijd, in een langdurig en arbeidsintensief proces. Daarna geven zij hun mening over zaken als organisatie-, management- en overlegstructuur; doelstellingen en taken; werkwijze en werkterrein en een aantal managementinstrumenten, zoals planning, programmering en informatie. Zij menen, dat het project een belangrijke bijdrage heeft geleverd aan het tot stand brengen van een directoraat-generaal van de Arbeid, dat zijn maatschappelijke functie op een effectieve wijze kan vervullen ${ }^{371}$. Maar Bor stelt in december 1985 het volgende ${ }^{372}$ :

"Door diverse oorzaken is het hele project sterk in de ontwikkeling van voorstellen blijven steken en heeft te weinig/vrij laat geleid (eerst nu!) tot het aanbrengen van concrete verbeteringen in de structuur en de werkwijze van onze dienst. In gewoon Nederlands te veel denken en praten, te weinig doen en realiseren".

Hij geeft ook aan, dat achteraf met betrekking tot de opzet en uitvoering van het project wel een aantal concrete verbeteringen te formuleren zijn, zoals het bij de ontwikkeling van voorstellen minder naar absolute consensus streven, maar meer ruimte geven voor alternatieve voorstellen; het bij het ontwikkelen van de voorstellen zich meer richten op het werkterrein, de arbeidsorganisatie en de verbetering van het participatie- en besluitvormingsproces, daar na verloop van tijd de betrokkenheid van de medewerkers omsloeg in een soort matheid. Zijn constatering, dat het project het nodige op gang heeft gebracht, maar dat nog veel is blijven liggen en aangepakt moet worden, kan ik alleen maar beamen, maar het rendement van de reorganisatie-activiteiten is veel te gering. De Algemene Rekenkamer achtte ${ }^{373}$, gemeten aan de doelstellingen van het project enerzijds en de inzet van mensen en middelen ${ }^{374}$ anderzijds de resultaten van het langdurige organisatieontwikkelingsproject ontoereikend. In een reactie van de directeur-generaal van de Arbeid aan zijn ambtenaren naar aanleiding van de publikaties in diverse dagbladen ${ }^{375}$ over een uitgelekte versie van een concept-rapport van de Algemene Rekenkamer, werd deze stelling onderschreven ${ }^{378}$.

Ruim tien jaar na de start van het project blijken de feitelijke gevolgen voornamelijk beperkt te zijn tot organisatorische veranderingen en dan nog voornamelijk bij de centrale dienst, en voorbereiding van veranderingen in de districten. In de uitvoerende fase stagneerde het project, waardoor nog geen concrete veranderingen in de werkwijze en prioriteitsstelling zichtbaar werden. Het project is langzaam doodgebloed. De naam 
wordt niet meer genoemd, maar dat hoeft ook niet, want een nieuw project heeft zich al aangediend, nameijjk Arbo'91.

\subsection{Arbo'91}

In dit Arbo'91 worden de werkwijze en de organisatie van de arbeidsinspectie (opnieuw) onder de loep genomen. Het hoofddoel van deze operatie is een marktgerichte opstelling en een doelgerichte en efficiënte inzet van de beschikbare middelen en instrumenten.

Problemen op het gebied van de veiligheid, gezondheid en welzijn hebben in arbeidsorganisaties in de verschillende bedrijfstakken en bedrijfsklassen een eigen verschijningsvorm en karakter; niet overal spelen dezelfde problemen en niet overal zijn de problemen even zwaar. Op bedrijfsklassenniveau kan vaak een goed inzicht worden verkregen van de aldaar aan de orde zijnde problemen en kunnen de ontwikkelingen, die relevant zijn voor de arbeidsomstandigheden in kaart worden gebracht. Daarbij komt de mate waarin de bedrijfstakorganisaties daar zelf al op inspelen en het optreden van de overheid in beeld. Een globale inventarisatie heeft er toe geleid, dat een viertal bedrijfstakken nader wordt onderzocht. Hiervoor wordt een marktanalyse opgesteld, die besproken wordt met werkgevers- en werknemersorganisaties. Daarna wordt een strategische benadering geformuleerd, dat wil zeggen, dat wordt aangegeven, welke instrumenten van overheidsbeleid en welke middelen landelijk en per district zullen worden ingezet in de komende tijd en wat daarmee bereikt zou moeten worden. De diverse in de betreffende bedrijfstak betrokken partijen zullen daarbij ingeschakeld worden, overeenkomstig $\epsilon e n$ van de belangrijkste doelstellingen van de Arbeidsomstandighedenwet en van het overheidsbeleid, namelijk dat de verantwoordelijke personen en instellingen zoveel mogelijk worden aangezet tot zelfwerkzaamheid. Met deze aanpak is in 1987 gestart in de volgende bedrijfstakken: zeehavens $^{377}$, bouw, klein-metalal en hout- en meubelindustrie. Inmiddels zijn de marktverkenningen en zijn de marktstrategiëen van de zeehavens en de bouw gereed en is het overleg met werknemers en werkgevers gestart. De martverkenningen van de twee overige bedrijfstakken zijn eveneens gereed en zijn de marktstrategiëen in voorbereiding; hetzelfde geldt trouwens voor de bedrijfstak bagger. Van de bedrijfstakken wegvervoer en rubber zijn marktverkenningen in voorbereiding, terwijl deze voor de intramurale gezondheidszorg en de land- en tuinbouw nog moeten starten ${ }^{378}$.

Naast deze meer bedrijfstakgerichte aanpak vraagt een nieuwe benadering van de markt om aangepaste methoden van werken en instrumenten om het gewenste doel te bereiken. Niet alleen op bedrijfstakniveau zijn er belangrijke onderlinge verschillen te ontdekken, ook in de wijze waarop bedrijven hun interne organisatie hebben gegeven vallen grote verschillen waar te nemen, zoals bijvoorbeeld de mate van deskundigheid op het gebied van de arbeidsomstandigheden, de aanwezigheid van vormen van medezeggenschap en het voeren van een arbeidsomstandighedenbeleid. Verschillen, die enerzijds te maken hebben met de bedrijfsgrootte en anderzijds met de aan- of afwezigheid van motivatie en aandacht voor goede arbeidsomstandigheden. Een zich rekenschap geven van dergelijke verschillende situaties kan van de zijde van de arbeidsinspectie leiden tot een doeltreffende beïnvloeding en doelmatige inzet van mensen en middelen. Nieuwe benaderingen in deze zijn: de zogenaamde netwerkbenadering, bijwoorbeeld overleg met en voorlichting aan de bedrijfstakorganisaties, en de zogenaamde auditinterventie, een benadering waarbij naar de kwaliteit van de organisatie en het functioneren wordt gekeken ${ }^{370}$. Een ander, niet nieuw, maar wel belangrijk instrument is het handhavingsbeleid, en dan met name waar het gaat om de ontwikkeling en inwoering van cen landelijk handhavingsbeleid, waarin samen met het Openbaar Ministerie naar een integratie is gezocht van de bevordering van de zelfwerkzaamheid van de bedrijven, het bevorderen van structurele aandacht voor de arbeidsomstandigheden en een adequate aanpak van overtredingen en zij, die hen begaan.

De in ons land gekozen wijze van het benaderen van de problematiek van de arbeidsomstandigheden komt overigens overeen met de conclusies en aanbevelingen, die zijn gedaan in een studïe over de arbeidsomstandigheden in de Europese Gemeenschap ${ }^{380}$, zij het in Europees verband. Eén van de conclusies luidt ${ }^{381}$ : 
"... This endorses the point already made, namely that analysis of working conditions and endeavours to improve them should deal with complex rather than with particular aspects. As an consequence, this principe would favour sector analysis on a European level - especially where the situation is critical".

In veel gevallen wordt activiteit van de arbeidsinspectie ingegeven door signalen van buiten, zoals bijvoorbeeld meldingen van ongevallen, klachten, verzoeken om vergunningen of ontheffingen, beoordelingen, advisering of voorlichting. In veel gevallen wordt echter de hulp ingeroepen van de arbeidsinspectie, terwijl dit niet echt nodig is. Het gevolg daarvan is wel, dat de aandacht van deze dienst, en misschien meer dan nodig is, uitgaat naar bedrijven met een eigen deskundigheid en relatief geringe problemen op het terrein wan de arbeidsomstandigheden. De arbeidsinspectie zal in dit soort gevallen steeds meer of terug verwijzen naar de eigen deskundigheid of doorverwijzen naar andere instanties. Niet ieder signaal van buitenaf zal meer leiden tot een bedrijfsbezoek of een onderzoek door de arbeidsinspectie. Op deze wijze komen, zowel tijd, als middelen vrij, die kunnen worden ingezet daar waar de arbeidsinspectie actief haar aandacht aan moet besteden. In toenemende mate zullen dat de kleinere bedrijven zijn en bedrijven, waar een eigen deskundigheid ontbreekt. Maar zij niet alleen; ook de bedrijven waar de wil om aan de arbeidsomstandigheden te werken ontbreekt $^{302}$, zullen meer aandacht krijgen en hard(er) worden aangepakt.

Een andere belangrijke verandering in de benaderingswijze van bedrijven wordt de inspectie, waarbij elke inspecteur zoveel als redelijkerwijs mogelijk en wenselijk is, aspecten van veiligheid, gezondheid en welzijn of sociaal arbeidsbeleid betrekt ${ }^{333}$, waardoor cen samenhangende aanpak wordt bereikt. Eén van de aandachtspunten wordt het arbeidsomstandighedenbeleid in de te inspecteren arbeidsorganisaties. Op deze wijze wordt voorkomen, dat los van elkaar verschillende ambtenaren met een verschillende taak of disciplime in het zelfde bedrijf aan het werk zijn. Ten einde dit te kunnen verwezenlijken dienen de inspecterende districtsambtenaren, de zogenaamde buitendienst-ambtenaren, van de arbeidsinspectie daartoe breed geschoold of gekwalificeerd te zijn. Voor een aantal functies in de districten zal daaraan een specialisatie gekoppeld worden, waarbij een zodanige verdeling plaats zal vinden, dat een district in zijn geheel over de noodzakelijke kennis beschikt terzake van het gehele arbeidsomstandighedenbeleid. De huidige functiebenamingen komen te vervallen. Daarvoor in de plaats komt éen functiebenaming: de inspecteur van de arbeid ${ }^{384}$. Er wordt hierbij echter wel een onderscheid gemaakt naar taak. Allereerst de inspecteur van de arbeid, van wie het werkterrein ligt in minder complexe arbeidssituaties voor wat betreft de technische problematiek dan de organisatie. Vervolgens de inspecteur van de arbeid ten behoeve van de meer complexe arbeidssituaties, waaronder complexe ongevallen, ontheffingsaanvragen en dergelijke. Daarnaast de inspecteur van de arbeid met een specialisme. Daarbij wordt gedacht aan de volgende disciplines: proces-; transport- en machineveiligheid, arbeidshygiëne, chemie, geluid en trillingen, klimaat en lucht, straling, personeel en organisatie, en arbeidskunde en werktijden. Tot slot inspecteurs van de arbeid met een zeer specifieke deskundigheid en een bredere taakstelling. Het betreft: veiligheidskunde, arbeidsgezondheidskunde en bedrijfskunde. Het ligt in de bedoeling, dat zij inspecties van de arbeidsinspectie die in grote(re) bedrijven plaatsvinden, leiden ${ }^{385}$. De invoeringsdatum van deze functies van inspecteurs van de arbeid is 1 januari $1990^{389}$.

Het vorenstaande geeft aan, dat er in het kader van Arbo'91 veel gebeurt en nog veel te gebeuren staat ${ }^{387}$. In een reactie op het rapport van de Algemene Rekenkamer terzake van het Project Ontwikkeling Arbeidsinspectie, stelde de bewindsman ${ }^{38 s}$, dat om en nabij de peillatum van de Algemene Rekenkamer - begin 1988 - het project Arbo"91 was doorgevoerd. Zijn voorkeur zou er naar uitgegaan zijn om het onderzoek wan de Algemene Rekenkamer een aantal jaren uit te stellen, zodat de resultaten van deze andere, sterk actiegerichte aanpak, wat meer zichtbaar zouden zijn geweest. Maar in dat opzicht moet de Federatie van Nederlandse Vakverenigingen in de brief aan de Vaste Kamercommissie van Sociale Zaken en Werkgelegenheid naar aanleiding van het rapport van de Algemene Rekenkamer gelijk gegeven worden ${ }^{389}$ "De intenties zijn er om tot verandering te komen, maar dat het rapport van de Algemene Rekenkamer gedateerd is, omdat 
die intenties inmiddels geraliseerd zijn, zoals de bewindsman in zijn reactie stelt, is naar mijn mening een wat al te optimistische conclusie.

Mogelijk kan dit project er dan toe leiden, dat het volgende tot het verleden zal behoren. Niet alleen het Project Ontwikkeling Arbeidsinspectie, maar ook de Arbeidsomstandighedenwet levert een bron voor een veranderende taakopvatting bij de arbeidsinspectie. Ten aanzien van de Arbeidsomstandighedenwet kunnen als voorbeelden genoemd worden de informatieplicht ten aanzien van de werknemersvertegenwoordiging, het recht van de leden van de werknemersvertegenwoordiging on de arbeidsinspectie te vergezellen bij bezoeken aan de onderneming en om vertrouwelijk met de betrokken ambtenaren van gedachten te wisselen, de mogelijkheid dat een vakvereniging, zij het onder bepaalde voorwaarden een verzoek om wetstoepassing kan doen en de plicht om onderzoekrapporten openbaar te maken. Dat van de zijde van de arbeidsinspectie beide zaken serieus genomen werden blijkt onder meer uit de bezoeken ${ }^{300}$, in de jaren 1983 en 1984 aan ondernemingen van 100 of meer werknemers, waar een ondernemingsraad functioneert. Het doel van deze gesprekken was het verhelderen van taak en posicie van de werkgever, ondernemingsraad en deskundige diensten in relatie tot arbeidsinspectie en het maken van afspraken over procedures voor de uitvoering van de wettelijke bepalingen voor zover de ondernemingsraad daarbij taken of bevoegdheden heeft. In totaal zijn er in de genoemde jaren met ongeveer 1650 ondernemingsraden gesprekken gevoerd ${ }^{391}$. Over de resultaten hiervan was de arbeidsinspectie tevreden, althans zo lijkt het ${ }^{392}$. Uit een later gehouden onderzoek blijkt echter, dat tweederde deel van de ondervraagde arbeidsinspecteurs teleurgesteld is over de gesprekken. In dat kader werden termen gebruikt als "matheid", "mosterd na de maaltijd", "magere inbreng van de ondernemingsraad" en "geringe belangstelling"

\section{Veranderingen in de wettelike regeling van de organisatie van de arbeidsinspectie}

In 1974 achtte de toenmalige bewindsman Boersma de tijd rijp om de wettelijke regeling ter zake van de arbeidsinspectie te herzien. Op 30 mei van dat jaar werd een wetsvoorstel daartoe bij de voorzitter van de Tweede Kamer ingediend ${ }^{394}$. Voorgesteld werd de artikelen 77 en 78 van de Arbeidswet 1919 te vervangen door de artikelen $76 \mathrm{a}, 77$ en 78 . Het nieuwe artikel 76a bepaalt in het eerste lid, dat er een arbeidsinspectie is, terwijl het daaropvolgende artikellid regelt, dat er aan het hoofd van de dienst van de arbeidsinspectie een directeur-generaal van de Arbeid staat. Voorts vermeldt hetzelfde artikellid, dat het land ten behoeve van de dienst van de arbeidsinspectie door de minister van Sociale Zaken in districten wordt verdeeld en dat aan het hoofd van ieder district een districtshoofd fungeert. Tot sllot schrijft dit tweede lid van artikel 76 a van de Arbeidswet 1919 voor, dat de minister van Sociale Zaken regels vaststelt omtrent de wijze, waarop de ambtenaren van de arbeidsinspectie de hun bij of krachtens de wet opgedragen taken, die zij onder de bevelen van de bewindsman uitoefenen, vervullen. Het laatste lid van dit artikel schrijft voor, dat een verslag van de werkzaamheden van de arbeidsinspectie aan de Staten-Generaal overgelegd wordt. Het nieuwe artikel 77 van de Arbeidswet schrijft voor, dat de door de minister daartoe aangewezen ambtenaren van de arbeidsinspectie in het door hem aangewezen ambtsgebied belast zijn met de handhaving van en de medewerking aan de uitvoering van het bij of krachtens de Arbeidswet 1919 bepaalde.

De verdeling van het rijk in districten was op grond van het oude artikel 77, tweede lid, van de Arbeidswet 1919 voorbehouden aan de Kroon. Ook hier wordt in de nieuwe wettelijke regeling gekozen voor de vorm van een ministerieel besluit.

Het essentiële verschil tussen de oude en de nieuwe wettelijke regeling is, dat nu een ieder die in dienst treedt bij de arbeidsinspectie ambtenaar van deze dienst is, en dat slechts zij die daartoe aangewezen zijn, belast zijn met de handhaving van en de medewerking aan de uitvoering van een wet en daarmee tevens opsporingsbevoegdheid hebben.

Met name omtrent het door de bewindsman gebezigde begrip "regeling van de organisatie van de Arbeidsinspectie" vroeg men zich in de Tweede Kamer af ${ }^{305}$, of dit tevens de wijze omvat, waarop vanuit de bedrijven informatie aan de arbeidinspectie kan worden doorgegeven. Daarbij werd gedacht aan de risico's, die 
daaraan voor de werknemers verbonden kunnen zijn, zeker wanneer het bedrijven betreft waar geen ondernemingsraad functioneert. De bewindsman antwoordde daar ontkennend op, daar de Arbeidswet 1919 een eigen regeling kent en de wet de nodige waarborgen geeft met betrekking tot de geheimhouding ${ }^{396}$. Met andere woorden: in deze zijn de risico's, voor werknemers werkzaam in ondernemingen waar geen ondernemingsraad functioneert ten opzichte van ondernemingen waar dit wel het gevall is, niet groter.

Deze nieuwe wettelijke regeling van de arbeidsinspectie zou overigens zonder problemen in het parlement behandeld worden ${ }^{397}$.

Daar in artikel 32 , eerste lid, van de Arbeidsomstandighedenwet gesproken wordt over de ambtenaren van de arbeidsinspectie aangewezen krachtens artikel 77 van de Arbeidswet 1919, waarbij dus wordt uitgegaan van het nieuwe artikel 77 , moesten de betreffende arbeidswettelijke bepalingen gelijktijdig met de eerste fase van de Arbeidsomstandighedenwet in werking treden, derhalve op 1 januari 1983. Echter, voor dat dit kon gebeuren moesten eerst het Organisatiebesluit Arbeidsinspectie, het Besluit tot verdeling van het Rijk in districten en het Besluit bevattende instructie voor de ambtenaren van de Arbeidsinspectie, alle algemene maatregelen van bestuur worden ingetrokken en worden vervangen door ministeriële regelingen.

De regelingen met betrekking tot de verdeling van het rijk in districten en de werkwijze van de ambtenaren van de arbeidsinspectie zijn copieen van hun voorgangers ${ }^{300}$.

Recent is de verdeling van het rijk in districten gewijzigd ${ }^{399}$. Het tot dan bestaande aantal van tien districten van de arbeidsinspectie is teruggebracht tot $\mathrm{acht}^{400}$. Als redenen voor de wijziging van de indeling in districten worden in de toelichting een viertal redenen gegeven, namelijk:

1. de invoering van de Arbeidsomstandighedenwet heeft een uitbreiding tot gevolg van het takenpakket van de arbeidsinspectie. Hiervoor is vereist, dat in ieder district een minimale deskundigheid aanwezig is. In de oude districten zijn er een aantal, die te klein van omvang zijn om een dergelijk basispakket aan deskundigheid in huis te hebben,

2. de indeling in tien districten geeft een onevenwichtigheid te zien in zwaarte tussen de districten;

3. vermindering van het aantal districten vergroot het doeltreffend en doelmatig functioneren van de arbeidsinspectie, en

4. de grenzen van de districten in de bestaande indeling geven op een aantal plaatsen geen aansluiting te zien op die van de rechterlijke indeling.

Voor de nieuwe indeling gelden de volgende uitgangspunten en criteria:

a. Doelmatigheid en efficiency heeft geleid naar een indeling van de districten van de arbeidsinspectie, waardoor deze vergelijkbaar zijn voor wat betreft de omvang en het werkgebied, waarbij als norm geldt de aantallen te inspecteren arbeidsorganisaties en de daarin aanwezige personele bezetting, namelijk $>10$ werknemers. Daarnaast dient in een district een minimale personeelsbezetting aanwezig te zijn, teneinde over die deskundigheid te beschikken om op de diverse terreinen de problematiek terzake van de arbeidsomstandigheden in arbeidsorganisaties aan te kunnen pakken;

b. Uit het oogpunt van herkenbaarheid, efficiency en doelmatigheid is er naar gestreefd de districtsgrenzen te laten samenvallen met de grenzen van de rechterlijke indeling ${ }^{401}$, om zo een zo goed mogelijke afstemming te krijgen tussen de uitvoering van toezichthoudende en opsporende taken door de arbeidsinspectie en de vervolgingstaken door het Openbaar Ministerie. Dit bevordert de eenheid van optreden van de overheid ten opzichte van de arbeidsorganisaties en derhalve een zo gelijk mogelijke rechtsbehandeling ${ }^{402}$.

Tenslotte zijn de herindelingsvoorstellen, blijkens de toelichting, getoetst aan de Wet gemeenschappelijke regelingen ${ }^{403}$. In het kader van deze wet ${ }^{404}$ strekt de door de provincies tot stand gebrachte indeling in samenwerkingsgebieden tot richtlijn voor onder meer de afbakening van de rayonindeling van gedeconcentreerde rijksdiensten, zoals de arbeidsinspectie, voor zover deze betrekking hebben op belangen die de gemeenten in het bijzonder raken ${ }^{405}$. Hierbij werd uiteraard in de eerste plaats gedacht aan de toepasselijkheid van de Arbeidsomstandighedenwet en de Arbeidswet 1919 op onder meer gemeentelijke instellingen en diensten. In het totaal van de arbeidsorganisaties, dat door deze wetten bestreken wordt, vormen deze 
evenwel een kleine minderheid. Niettemin wordt vastgesteld, dat bij de verdere invoering van de Arbeidsomstandighedenwet - in een later stadium de nieuwe Arbeidswet - het belang van de genaeentelijke diensten of instellingen in het totaal van bedoelde arbeidsorganisaties zal toenemen. Vervolgens speelt een rol het raakvlak tussen de arbeidsinspectie en de gemeenten voor wat betreft het gemeentelijke takenpakket op het terrein van de milieuwetgeving, met name waar het gaat om de Hinderwet Desalniettemin wordt aan de relatie tussen de arbeidsinspectie en het Openbaar Ministerie een zwaarder gewicht toegekend, dan aan de relatie tussen arbeidsinspectie en de gemeenten.

Wat betreft de ministeriele regeling betreffende de organisatie van de arbeidsinspectie ${ }^{400}$, zal het geen verbazing wekken, dat degenen die voorheen tot de ambtenaren van de arbeidsinspectie gerekend werden, thans degenen zijn, die in het door de minister aan te wijzen ambtsgebied, belast zijn met de handhaving van hetgeen bij of krachtens in de relevante wetgeving is bepaald en met de medewerking aan de uitvoering hiervan. Dit zijn ${ }^{407}$
a. de directeur-generaal van de Arbeid;
b. hoofdinspecteur van de arbeid, ( adjunct-)inspecteur van de arbeid, (adjunct-)inspectrice van de arbeid, technisch ambtenaar bij de arbeidsinspectie, controleur van de arbeid of opzichteres van de arbeid;
c. medisch-adviseur of geneeskundige bij de arbeidsinspectie;
d. elektrotechnisch-adviseur of elektrotechnisch-ingenieur bij de arbeidsinspectie;
e. scheikundig-adviseur of scheikundig-ingenieur bij de arbeidsinspectie;
T. landbouwkundige bij de arbeidsinspectic.

Deze groep van ambtenaren zou tegelijkertijd uitgebreid worden met de kernfysisch-adviseur en de kernfysisch-inspecteur bij de arbeidsinspectie, wier ambtsgebied het gehele rijk beslaat ${ }^{403}$. Zij staan de directeurgeneraal van de Arbeid bij in de vervulling van diens taak en voeren daartoe de door hem gegeven opdrachten wit voor de behandeling van zaken, die de veiligheid van nucleaire installaties, ioniserende stralen uitzendende toestellen en het aanwenden van radioactieve stoffen betreffen ${ }^{409}$. Daarnaast is de kernfysisch-adviseur bij de arbeidsinspectie naast het districtshoofd van de arbeidsinspectie belast met het toezicht op de handhaving van en de medewerking aan de uitvoering van wettelijke voorschriften alsmede de opsporing van overtredingen, voor zover dit betreft de behandeling van zaken, die verband houden met nucleaire veiligheid van inrichtingen, waarin kernenergie kan worden vrijgemaakt, splijtstoffen kunnen worden vervaardigd, bewerkt of verwerkt dan wel splijtstoffen worden opgeslagen, daaronder begrepen de stralingshygiëne in de inrichtingen ${ }^{410}$. De kernfysisch-adviseur wordt daarin bijgestaan door de kernfysisch-inspecteurs en door eén of meer technische ambtenaren bij de arbeidsinspectie ${ }^{411}$. De kernfysisch-adviseur regelt zijn werkzaamheden in overeenstemming met de deswege door de directeur-generaal van de Arbeid gegeven voorschriften en brengt jaarlijks aan hem verslag uit over zijn werkzaamheden, ingericht overeenkomstig diens aanwijzingen. Voorts dient de kernfysisch-adviseur de minister desgevraagd wan advies en kan hij de bewindsman en de directeur-generaal van de Arbeid voorstellen doen. Bij inzending van een voorstel aan de bewindsman zendt hij gelijktijdig een afschrift aan de directeur-generaal ${ }^{112}$.

De positie, die de kernfysisch-adviseur inneemt in de organisatie van de arbeidsinspectie, is te vergelijken met die van de medisch-adviseur, de elektrotechnisch-adviseur en de landbouwkundige bij de arbeidsinspectie.

Het ambtsgebied van de hierboven onder $b$ bedoelde ambtenaren omvat een of meer van de districten van de arbeidsinspectie, zoals bij hun benoeming is bepaald ${ }^{413}$. Dit impliceert, dat aan de handhavings-en opsporingsbevoegdheden van deze ambtenaren van de arbeidsinspectie territoriale beperkingen zijn gesteld. Deze territoriale beperkingen blijken in de praktijk nogal eens problemen op te leveren. Wanneer bijwoorbeeld een overtreding plaatsvindt in een ander district dan, waar de werkgever kantoor houdt of waar een getuige zich bevindt, dient het opmaken van een proces-verbaal door de verbalisant gedeeltelijk overgedragen te worden aan een ambtenaar uit het andere betrokken district. Dit houdt verband met het bepaalde in arti- 
kel 146, eerste lid, van het Wetboek van Strafvordering, waarin is bepaald, dat de bevoegdheid van opsporingsambtenaren - in casu de ambtenaren van de arbeidsinspectie - is beperkt tot het grondgebied, waarvoor zij zijn aangesteld. Wanneer een opsporingsambtenaar derhaive buiten zijn ambtsgebied strafbare feiten opspoort en bij ontdekking daarwan een proces-verbaal opmaakt, thandelt hij onbevoegd en kan het proces-verbaal als zodanig niet als wettig bewijsmiddel dienen ${ }^{414}$. Het overdragen van de opsporing aan een andere ambtenaar is zeer onpraktisch, aangezien bedoelde ambtenaar niet op de hoogte is van de details, die tot het opmaken van het proces-verbaal hebben geleid. Ten einde dit bezwaar van de territoriale beperking op te heffen is het betreffende artikel in het Organisatiebesluit Arbeidsinspectie gewijzigd ${ }^{415}$, zij het dat dit niet geldt voor hoofdinspecteur van de arbeid. De bedoelde ambtenaren, niet zijnde hoofdinspecteur van de arbeid, treden eerst buiten het district, waarin hun een standplaats is aangewezen, in opdracht of met toestemming van de hoofdinspecteur van de arbeid in dat district. Indien zij buiten dat district optreden zijn zij onderworpen aan het gezag van de hoofdinspecteur van de arbeid in het district waar zij optreden ${ }^{416}$. Toch geeft deze nieuwe regeling aanleiding tot verwarring, juist door het gebruiken van de term hoofdinspecteur. In artikel 10 van het Organisatiebesluit is vermeld, clat aan het hoofd van een district staat een door de minister aan te wijzen hoofdinspecteur van de arbeid. In dat zelfde artikel wordi gesproken van het districtshoofd, met andere woorden: de hoofdinspecteur van de arbeid is het districtshoofd. Heden ten dage zal dat niet meer opgaan. Onder het districtshoofd zijn thans een aantal hoofdinspecteurs werkzaam. Het kan toch niet de bedoeling zijn, dat deze hoofdinspecteurs opdracht geven of toestemming verlenen, dat bijvoorbeeld een controleur van de arbeid buiten zijn aangewezen district opereert, en dan valt onder gezag van de hoofdinspecteur van de arbeid in dat andere district. Bedoeld is ongetwijfeld het districtshoofd van de arbeidsinspectie ${ }^{417}$.

Eén en ander leidt er toe, dat vastgesteld kan worden, dat er in de regeling van de organisatie van de arbeidsinspectie, zoals die thans voorligt, een aantal onvolkomenheden dan wel onduidelijkheden voorkomen. Bovendien is het besluit op oude leest geschoeid en zijn er bij de arbeidsinspectie niet alleen functies gekomen, die niet in het besluit als zodanig genoemd worden, zodat de status van deze ambtenaren voor wat betreft de handhavings- en opsporingsbevoegdheden ontbreekt, maar zijn functies - denk aan de medisch, electrotechnisch en scheikundig adviseur, elektrotechnisch en scheikundig ingenieur en de landbouwkundige bij de arbeidsinspectie - opgeheven als gevolg van de reorganisatie van het directoraat-generaal van de Arbeid, zodat terzake omtrent handhavings- en opsporingsbevoegdheden onduidelijkheid bestaat ${ }^{418}$.

\section{Over de ministerięle verantwoordelijkheid en de bevoegdheden van het districtshoofd en de directeur-ge- neraall van de Arbeld}

In de inleiding van hoofdstuk 5 is reeds opgemerkt, dat de arbeidsinspectie een gedeconcentreerde rijksdienst is, waarbij de minister de top vormt van de organisatiestructuur. Onder hem functioneren de directeur-generaal van de Arbeid en de districtshoofden van de arbeidsinspectie, die elk hun eigen verantwoordelijkheid hebben met betrekking tot de door hen wit te voeren taak. Met andere woorden: de betrokken ambtenaar is en kan alleen verantwoordelijk zijn voor zijn eigen doen en laten, die beiden worden bepaald door de bevoegdheden, die het betreffende ambt met zich brengt. Hiervan kan afgeleid worden, dat de betrokken bewindsman niet verantwoordelijk is voor een door het districtshoofd - om ons daartoe te beperken - gegeven (rechts)beslissing, die gebaseerd is op een door de wet gegeven bevoegdheid, zoals bijwoorbeeld het geven van een voorschrift, een aanwijzing of een oordeel, alsof hij deze beslissing zelf genomen zou hebben. Het gaat hier om een andere soort verantwoordelijkheid dan de ministeriële verantwoordelijkheid. Wanneer de bewindsman in het parlement over een dergelijke beslissing van het districtshoofd wordt aangesproken, dan is hij wel verantwoordelijk voor het daaraan ten grondslag liggende beleid. Daarnaast strekt de ministeriële verantwoordelijkheid zich eveneens uit over de door hem achteraf genomen maatregelen om zo eventuele onjuiste beslissingen van het districtshoofd in de toekomst te vermijden.

Een volgende vraag, die van belang is, is, of de (politiek) verantwoordelijke bewindsman de (rechts) beslis- 
singen van de districtshoofden mag beinvloeden. Kortom, maar dan meer algemeen gesteld: mag hij aan ambtenaren, die op basis van een wettelijke regeling een eigen beslissingsbevoegdheid hebben, alleen algemene aanwijzingen geven of mag hij ook concrete aanwijzingen geven voor een bepaald geval?

Hierover wordt in de literatuur verschillend gedacht. Zo stelde Oud ${ }^{418}$ daaromtrent het volgende:

De minister heeft niet alleen het recht algemene instructies voor de dienst uit te vaardigen, doch ook om een bepaalde ambtenaar voor een bepaald geval de te nemen beslissing voor te schrijven".

Hierin wordt hij gesteund door Wesseling en Hermsen ${ }^{420}$. Van der Pot ${ }^{421}$ daarentegen meende, dat de bewindsman niet de bevoegdheid heeft om de ambtenaar voor te schrijven hoe hij van zijn bevoegdheid gebruik moet maken.

"Hebben zulke ambtenaren bij de wet een eigen beslissingsbevoegdheid voor bepaalde gevallen gekregen, zoals het districtshoofd van de arbeidsinspectie, dan mag de minister hun zelfs niet voorschrijven hoe zij daarvan gebruik hebben te maken".

Als tegenhanger geeft de wet, zo vervolgde hij, aan de belanghebbende het recht om beroep in te stellen op de minister. Scholtens ${ }^{422}$ is ter zake van de arbeidsinspectie een zelfde mening toegedaan; een minister zal nooit mogen bevelen, dat een voorschrift van een bepaalde inhoud wordt uitgevaardigd, omdat hij dan feitelijk als beroepsinstantie zal zijn verdwenen. Maar, zo vervolgt hij

"als het gezag, dat ten slotte voor de wetsuitvoering in haar geheel verantwoordelijk is, zal

hij het recht moeten hebben om te gelasten, dat een inspecteur gebruik maakt van den weg, waarlangs z.i. alleen een goede wetsuitwoering is te verkrijgen, ook als die weg uit het geven van een voorschrift zou bestaan".

Hij voegt daaraan toe, dat voor de vraag waartoe de werkgever dan feitelijk verplicht zal zijn, afhangt van hetzij het districtshoofd, als de (rechts)beslissing zonder beroep is of wordt nageleefd, hetzij de minister, in geval van beroep.

Donner ${ }^{423}$ nam aanvankelijk een genuanceerder standpunt in.

"Vaak kent de wet de minister de bevoegdheid toe om aan zulke instanties (gedeconcentreerde rijksdiensten: JwD) "aanwijzingen" of bevelen te geven, doch niet altijd. Ook wanneer dat niet het geval is, zijn zulke aanwijzingen ( die dikwijls in de vorm gegoten zullen zijn, dat de minister de betreffende instantie "witnodigt" of "in overweging" geeft om iets te doen of na te laten) niet per se uitgesloten. Vooral wanneer de bevoegde een ambtenaar is die hierrarchisch aan de minister ondergeschikt is, zijin zij niet ondenkbaar".

Niet veel later geeft hij opnieuw blijk van een zelfde genuanceerd beeld, waarbij deels aangesloten wordt bij de opvatting van Oud ${ }^{424}$. Hij stelt, dat, voor zover dit niet uitdrukkelijk is bepaald; men uit de regeling zelf zal moeten opmaken of deze bevoegdheden opdraagt, die in zelfstandigheid worden uitgeoefend.

"Wanneer de wet echter aan de ambtenaar der politie of aan anderen bevoegdheden tot controle, tot opsporing of tot het geven van aanwijzingen geeft, dan geschiedt dit om de betrokkenen tegenover de burger te rechtvaardigen, allerminst om hen aan de bevelen van hun meerderen te onttrekken. Tussen die twee uiitersten ligt een scala van mogelijkheden". Weer iets later ${ }^{425}$ laat hij zich echter iets vager uit over deze zaak ${ }^{426}$.

Stroink meent een aantal, naar mijn mening redelijke, argumenten naar voren te kunnen brengen, die tot de conclusie leiden dat het de voorkeur verdient er van uit te gaan, dat, althans in verreweg de meeste gevallen, de minister geen concrete aanwijzingsbevoegdheid heeft.

Allereerst geeft hij aan, dat het aannemen van een concrete aanwijzingsbevoegdheid van de minister met zich brengt, dat het onderscheid tussen attributie en delegatie enerzijds en mandaat anderzijds vervaagt. Attributie of delegatie hebben geen zin meer, wanneer de bewindsman toch in ieder concreet geval de inhoud van de beslissing kan bepalen; volstaan zou kunnen worden met mandatering. Tegenargument zou kunnen zijn, dat bij attributie of delegatie er toch twee verantwoordelijkheden blijven bestaan, namelijk, die van de bewindsman voor zijn aanwijzing en die van de ambtenaar, werkzaam in een gedeconcentreerde rijksdienst, 
voor zijn beslissing. Terecht merkt Stroink ${ }^{427}$ op, dat het vervagingsprobleem daarmee niet opgeheven wordt. Er noet ook een duidelijk onderscheid gemaakt worden in deze verantwoordelijkheden. De minister is voor zijn doen en laten primair verantwoording schuldig aan het parlement; de betreffende ambtemaar is voor zijn doen en laten verantwoording schuldig aan de minister. Wanneer de minister nu cen concrete aanwijzingsbevoegdheid zou hebben, zijn deze beide verantwoordelijkheden nauwelijks meer van elkaar te onderscheiden ${ }^{428}$.

Vervolgens voert Stroink aan, dat een concrete aanwijzingsbevoegdheid vanuit het oogpunt wan de (politieke) ministeriele verantwoordelijkheid nawwelijks zin heeft.

In de concrete titoefening van de bevoegdheden door de betreffende ambtenaar spelen politieke overwegingen niet of nauwelijks een rol. De burger heeft bovendien in het algemeen via hetzij administratief beroep; hetzij administratieve rechtspraak de mogelijkheid tegen de beslissingen op te komen. Mochten zich bij de witoefening van de bevoegdheden door de betreffende ambtenaar toch politieke kwesties voordoen als gevolg van veranderende omstandigheden of inzichten, dan kan de minister daarop inspelen door middel van algemeen verbindende voorschriften, indien daartoe de bevoegdheid bestaat, dan wel door het geven van richtlijnen aan de betreffende ambtenaar ${ }^{429}$. Op deze wijze manifesteert zich dan de ministeriële verantwoordelijkheid.

In het geval van de districtshoofden van de arbeidsinspectie heeft de betrokken bewindsman, daar, waar de wet hen bevoegdheden verleent, naar mijn mening geen concrete aanwijzingsbevoegdheid. In die gevallen waar de wet eveneens bevoegdheden toekent aan de directeur-generaal van de Arbeid geldt hetzelfde. Een mooi voorbeeld van het ingrijpen in het kader van de ministeriële verantwoordelijkheid is het publiceren van de richtlijnen inzake het verbod van kinderarbeld, als gevolg van het feit, dat bij het verlenen van ontheffing door de districtshoofden problemen waren gerezen en er misverstanden bestonden omtrent het te voeren beleid.

Over de relatie tussen het districtshoofd en de directeur-generaal van de Arbeid als hoofd van de dienst van de arbeidsinspectie merkt Scholtens ${ }^{4}{ }^{430}$, dat zijns inziens de taak van de directeur-generaal tegenover het districtshoofd meer gedacht is als een overleggende en een stimulerende dan als een rechtstreeks bevelende, althans wat de materièle wetsuitvoering betreft. Ik denk echter, dat deze relatie afhankelijk is van de persoon die tot directeur-generaal van de Arbeid benoemd is en de wijze waarop die zijn taak opvat. De directeur-generaal van de Arbeid heeft in het Organisatiebesluit Arbeidsinspectie bevoegheden toebedeeld gekregen die wel degelijk meer inhouden dan overleggen en stimuleren. Zo heeft het districtshoofd er voor te zorgen, dat zijn opdrachten om bepaalde bedrijwen te bezoeken en tot het uitoefenen van toezicht op de naleving van bepaalde wettelijke voorschriften worden uitgevoerd ${ }^{431}$. Dit wil naar mijn mening echter nog niet zeggen, dat het hier om een concrete aanwijzingsbevoegdheid gaat hoe in een concreet geval het districtshoofd zijn wettelijk toegekende bevoegdheden dient te hanteren; die bevoegdheden zijn aan hem door de wetgever geattribueerd en van die bevoegdheden kan alleen hij in een concrete situatie gebruik maken.

\section{Tripartisering. Een discussie over een nieuw bestuursmodel voor het directoraat-generaal van de Arbeid}

Tijdens de behandeling van het wetsvoorstel, waarbij de Arbeidsomstandighedenwet in het kader van de deregulering ${ }^{432}$ gewijzigd werd, is aan de hand van artikel 45 van die wet, dat handelt over de districtscommissie, gediscussieerd over bestuurlijke veranderingen op het terrein van het directoraat-generaal van de Arbeid.

Overeenkomstig het voorstel van de commissie-Geelhoed ${ }^{433}$ en het advies van de Arboraad ${ }^{434}$ stemde het kabinet in beginsel in met het laten vervallen van artikel 45 . Deze instemming gold echter slechts in beginsel, omdat de uiteindelijke beslissing te dienaangaande afhankelijk werd gesteld van de resultaten van de lopende discussie over ( functionele) decentralisatie binnen het ministerie van Sociale Zaken en Werkgelegenheid $^{435}$. Bij deze discussie speelt, aldus de toenmalige staatssecretaris De Graaf, een rol welke 
mogelijke consequenties de tripartisering van de arbeidsvoorziening met zich kan brengen ${ }^{436}$. Tijdens de mondelinge beraadslaging "in de Tweede Kamer nodigde het Kamerlid De Leeuw ${ }^{437}$ de bewindsman uit om enkele gedachten te ontwikkelen over een mogelijke herijking van de bevoegdheden tussen de centrale overheid, lagere overheden en het bedrijfsleven, onder andere op het terrein van de arbeidsomstandigheden en de arbeidsinspectie. Hij nam daarbij vast een voorschot en gaf enkele, zijns inziens, belangrijke beleidslijnen in overweging. In de eerste plaats wees hij op de mogelijkheid van de zogenaamde functionele decentralisatie in de zin van het toekennen van grotere verantwoordelijkheid aan werkgevers en werknemers op bedrijfstakniveau, overigens naast een verantwoordelijkheid van de overheid op dit terrein. In de tweede plaats noemde hij de mogellijkheid van regionalisatie, de zogenaamde territoriale decentralisatie, waarbij grotere verantwoordelijkheid aan de regio's, waarbinnen de arbeidsinspectie werkzaam is, worden toebedeeld. In de derde en laatste plaats dacht hij aan de zogenaamde tripartisering van het arbeidsomstandighedenbeleid,

"of andere vormen van verder gaande verzelfstandiging, gekoppeld aan een grotere en directere inbreng en verantwoordelijkheidsbeleving van sociale partners, niet alleen op centraal niveau, ook in bedrijven en bedrijfstakken".

Het verzoek van het Kamerlid De Leeuw aan de bewindsman om enige gedachten te ontwikkelen werd echter niet gehonoreerd. De staatssecretaris vond ${ }^{436}$, dat allereerst maar eens ervaring met de tripartisering van de arbeidsvoorziening moest worden opgedaan. Zijn afhoudende standpunt blijkt uit de woorden:

"nog eens goed bekeken, overwogen en beoordeeld worden".

Zonder overigens een "harde toezegging" te doen, wilde hij wel proberen rond 1990 de Tweede Kamer een notitie over dit vraagstuk te doen toekomen ${ }^{439}$.

Tijdens de behandeling van de begroting van het ministerie van Sociale Zaken en Werkgelegenheid voor het dienstjaar 1989 zou het Tweede Kamerlid en partijgenoot van De Leeuw, Terpstra ${ }^{40}$ terugkomen op de tripartisering; dit was voor het gehele beleid in het kader van de arbeidsomstandigheden, naar zijn mening, een goede zaak ${ }^{44}$.

"Overheid, werkgevers en werknemers worden dan samen verantwoordelijk voor de arbeidsomstandigheden, voor het ziekteverzuim - met name de bestrijding daarvan - en voor de mogelijkheden tot integratie van gehandicapten in de onderneming. Dit sluit naar ons idee geheel aan bij de overdracht van de sociale zekerheid en de Arbeidsvoorzieningswet". Maar de bewindsman bleef bij zijn eerder ingenomen standpunt ${ }^{442}$.

Niet alleen in het parlement, maar ook daarbuiten vormt de bestuurlijke herziening van de structuur van het directoraat-generaal van de Arbeid onderwerp van discussie. In een discussienota "Toekomst in Banen" van het Christelijk Nationaal Vakverbond ${ }^{443}$ spreekt deze werknemersorganisatie zich uit voor privatisering van dit onderdeel van het ministerie van Sociale Zaken en Werkgelegenheid. Uitzondering wordt gemaakt voor de opsporingstaken van de arbeidsinspectie, omdat deze politionele taak aan de overheid toebehoort. Op korte termijn dient bestudeerd te worden of en hoe tripartisering vorm en inhoud kan krijgen. Al snel wordt dat standpunt aanzienlijk afgezwakt, zoals blijkt uit het volgende ${ }^{444}$ :

"Het CNV spreekt zich uit voor onderzoek naar de mogelijkheid van tripartisering van het

Directoraat-Generaal van de Arbeid van het Ministerie van Sociale Zaken en Werkgelegenheid.

Dit Directoraat-Generaal houdt zich onder meer bezig met veiligheid, gezondheid en welzijn op de werkplek.

Speciale aandacht in dit onderzoek verdienen de opsporingstaken van de arbeidsinspectie".

Uit het vorenstaande blijkt naar mijn mening, dat aan de problematiek rond een bestuurlijke herziening van het directoraat-generaal van de Arbeid vele haken en ogen zitten, maar dat het alleszins de moeite waard is om daar enige beschouwingen aan te wijden. 
Een discussie over de bestuurlijke structuur van het ministerie van Sociale Zaken en Werkgelegenheid is niet nieuw. De vormen van bestuurlijke reorganisatie hadden vooral betrekking op het instellen van nieuwe dienstonderdelen en de omvorming; samenvoeging en opsplitsing van bestaande dienstonderdelen. Een voorbeeld daarvan is de loontechnische dienst, die eerst bij het directoraat-generaal van de Arbeid was ondergebracht, maar later weer werd afgesplitst en werd ondergebracht bij het directoraat-generaal voor Algemene Beleidsaangelegenheden. Een ander voorbeeld is de afsplitsing van het directoraat-generaal Volksgezondheid en de verzelfstandiging van het directoraat-generaal Milieu en de milieuinspectie, die uiteindelijk in het ministerie van Volksgezondheid, Ruimtelijke Ordening en Milieu zijn plaats zou vinden ${ }^{445}$.

In het begin van de jaren tachtig concentreerde de discussie over mogelijke bestuurlijke veranderingen zich vooral rond mogelijke vormen van decentrallisatie ${ }^{46}$. Op 30 september 1982 werd de Tweede Kamer door het toenmalige kabinet-Van Agt een decentralisatieplan ter kennisneming voorgelegd ${ }^{447}$. Bijna een jaar later, op 13 september 1983, werd het definitieve Decentralisatieplan de Tweede Kamer aangeboden ${ }^{449}$. Hierin werd een duidelijke voorkeur uitgesproken voor de zogenaamde territoriale decentralisatie, waarbij overdracht plaatsvindt van bevoegdheden van het rijk nai $r$ lagere bestuursorganen ${ }^{449}$. De discussie binnen het ministerie van Sociale Zaken en Werkgelegenheid leidde uiteindelijk tot een mengvorm van functionele en territoriale decentralisatie of wel tot tripartisering op landelijk of regionaal niveau. In het kader van de advisering van de Sociaal-Economische Raad over een nieuwe Arbeidsvoorzieningswet werd in een interimadvies van 9 mei $1984^{450}$ gesteld, dat

"thans de tijd is gekomen de meer institutionele betrokkenheid van sociale partners mede

vorm te geven door de opzet van een tripartite bestuur van de arbeidsvoorziening, zowel

op centraal als op regionall niveau".

In het eindadvies van 25 oktober $1985^{451}$ werd een bestuurlijk model bepleit van functionele decentralisatie langs territoriale grenzen, of wel integratie van de sociale partners in het bestuur van de arbeidsvoorziening in combinatie met een regionale bestuursvorm voor de gewestelijke arbeidsbureaus.

Bij de eerderbedoelde departementale discussie was echter eveneens een zogenaamde "strategische kernbeslissing" aan de orde geweest, die behelst, dat er op de terreinen arbeidsomstandigheden, arbeidsvoorziening en sociale zekerheid gestreefd zou moeten worden naar een gezamenlijke, functioneel gedecentraliseerde bestuursvorm met een territoriale geleding onder een tripartiete beheer. Het in 1985 over een dergelijk model gevoerd overleg met vertegenwoordigers van werkgevers- en van werknemersorganisaties maakte echter duidelijk, dat voor dit idee weinig steun te vinden zou zijn; in tegendeel, voorrang diende verleend te worden aan de bestuurlijke vernieuwing op het terrein van de arbeidsvoorziening,

"zij het in dier voege dat een meer geỉntegreerde benadering van de bestuurlijke vernieu-

wing in een latere fase niet wordt belemmerd ${ }^{\mathrm{H} 652}$.

Tot nu toe is slechts cen keer door vertegenwoordigers van werkgeverszijde, namelijk Crijns en Van Ho$\mathrm{ve}^{453}$, een pleidooi voor een dergelijk geintegreerd model, een "gedifferentieerd meer-trajecten-stelsel", zoals zij dat noemen, gevoerd. Hiermee wordt op landelijk, bedrijfstak- en ondernemingsniveau een samenhang aangebracht tussen de terreinen sociale zekerheid, arbeidsvoorwaarden, arbeidsomstandigheden en arbeidsbemiddeling.

In het kader van de heroverwegingsoperatie, die betrekking had op de gedeconcentreerde rijksdiensten, was tén van de varianten, die voor het directoraat-generaal van de Arbeid werd bezien de functionele en/of territoriale decentralisatie. Ten aanzien van de eerste vorm van decentralisatie werd van de zijde van dit directoraat-generaal aangevoerd, dat toch moeilijk initiatieven ondernomen konden worden op een traject, waarop de koers met betrekking tot de arbeidsvoorziening nog moest worden uitgezet. De tweede vorm van decentralisatie, waarbij overdracht van taken en bevoegdheden aan provincies en gemeenten dienden te worden bewerkstelligd, gaf problemen in verband met het feit, dat in het kader van het arbeidsomstandighedenrecht landelijk gezien een zo uniform mogelijk beleid diende te worden gevoerd en er bovendien meer raakvlakken waren met de bedrijfstakken dan met regio's. 
Alvorens in te gaan op een mogelijke andere vorm van de bestuurlijke structuur van het directoraat-generaal van de Arbeid, eerst nog het volgende.

Het arbeidsomstandighedenbeleid, zoals dat door het directoraat-generaal van de Arbeid wordt voorbereid en uitgevoerd, vindt voor een belangrijk deel zijn weerslag in wetgeving, al dan niet in formele zin, na advisering door het bedrijfsleven en onafhankelijke deskundigen; denk daarbij aan de Arboraad en de Sociaal-Economische Raad. Van groot belang voor de beleidsbepaling is de formulering van een landelijk gezien zo uniform mogelijk beleid, om zo ongelijke behandeling van bedrijven en daarmee de mogelijke oneerlijke concurrentie te vermijden. Hoewel op landelijk niveau de algemene beleidsbepaling plaatsvindt, is de regelgeving dusdanig, dat in de sfeer van de algemene beleidsuitvoering door de arbeidsinspectie een op concrete gevallen toegespitste inhoudelijke invulling van dit beleid kan plaatsvinden.

Bovendien moet niet uit het oog verloren worden, dat, naast de reeds bestaande internationale normen in deze, de totstandkoming van de interne markt, de invloed van de Europese Gemeenschap op het nationale beleid nog zal toenemen. Dit heeft de consequentie, dat de hoofdlijnen van het te voeren beleid op het niveau van een centraal bestuursorgaan zal moeten plaatsvinden.

Waar het de voorbereiding van het beleid betreft, bestaan er tussen het directoraat-generaal van de Arbeid bestuurlijke raakvlakken met talloze andere instanties.

Binnen het ministerie van Sociale Zaken en Werkgelegenheid gaat het ter zake van de arbeidsvoorziening om fricties die bestaan op de arbeidsmarkt; voor wat de sociale zekerheid betreft om zaken als de Wet arbeid gehandicapte werknemers, het bestrijden van de oorzaken die ten grondslag liggen aan ziekteverzuim en arbeidsongeschiktheid - het zogenaamde volumebeleid -, de bedrijfsgezondheidszorg en de sociale werkvoorziening en op het terrein van de algemene beleidsaangelegenheden spelen onderwerpen als werktijdverkorting, het onderzoekbeleid, de behandeling van internationale aangelegenheden, het sociaal beleid in de onderneming en de toepassing van de Wet op de ondernemingsraden.

Buiten het eigen ministerie liggen er relaties met andere departementen, zoals het ministerie van Volkshuisvesting, Milieu en Ruimtelijke Ordening als het gaat om milieuhygiëne, bestrijdingsmiddelen en kernenergie; het ministerie van Welzijn, Volksgezondheid en Cultuur, waar het aspecten van volksgezondheid betreft, waaronder bijvoorbeeld de bedrijfsgeneeskundige zorg; het ministerie van Binnenlandse Zaken terzake van de openbare veiligheid, bijvoorbeeld bij werkstakingen en regelingen voor het overheidspersoneel; het ministerie van Verkeer en Waterstaat, in verband met vervoersaangelegenheden; het ministerie van Economische Zaken, waar het betreft de economische situatie van bedrijven - denk daarbij aan werktijdverkorting - en acties ter bevordering van integrale kwaliteitszorg in de bedrijven; het ministerie van Landbouw en Visserij met betrekking tot de bestrijdingsmiddelen en het ministerie van Onderwijs en Wetenschappen in het kader van de programmering van het onderzoek (T.N.O.). Tot slot zijn er raakvlakken met het ministerie van Justitie en wel het Openbaar Ministerie over aangelegenheden als het handhavingsbeleid.

Daarnaast zijn er raakvlakken naar werkgevers- en naar werknemersorganisaties, al dan niet in het kader van de geïnstitutionaliseerde advisering.

In de districten van de arbeidsinspectie zijn er raakvlakken naar de provincie ter zake van aangelegenheden op het terrein van bijvoorbeeld de milieuhygiëne, en de gemeenten terzake van bijvoorbeeld de Hinderwet.

Het vorenstaande maakt naar mijn mening duidelijk, dat voor het arbeidsomstandighedenbeleid coördinatie met andere beleidsterreinen dringend noodzakelijk is. Bij een verandering van de bestuurlijke structuur op het terrein van het arbeidsomstandighedenbeleid, zal derhalve eveneens nagegaan moeten worden of en in hoeverre de bestaande bestuurlijke relaties opnieuw te rangschikken zijn en eventueel vervangen kunnen worden door andere en wat het daadwerkelijke profijt zal zijn van een dergelijke enorme operatie. Als men daarbij in ogenschouw neemt, dat er inhoudelijk nog zoveel veranderd moet worden aan de arbeidsomstandigheden en wat voor consequenties de Europese markt na 1992 met zich brengt, dan vraag ik mij ernstig af of met de beperkte mogelijkheden, die er liggen, alle energie hierop in de nabije toekomst geworpen moet worden. Een bestuurlijke krachtmeting tussen de verschillende departementen brengt ons inhoudelijk niet 
veel verder. Bovendien zie ik niet goed, hoe de inspectie en de beleidsvorming zich op verschillende, geheel anders gestructureerde wiveaus, zullen voltrekken.

Als we nu terugkeren naar de voorzetten, die van de zijde van de Kamerleden De Leeuw en Terpstra omtrent de tripartisering van het arbeidsomstandighedenbeleid zijn gedaan; dan blijkt daarop vanuit het parlement al enige kritiek geleverd te zijn. Mevrouw Rempt Halmmans de Jong ${ }^{454}$ verwijt De Leeuw met zoveel woorden, dat hij zich klaarblijkelijk onvoldoende gerealiseerd heeft, dat daar, waar hij verwijst naar de arbeidsinspectie, hier sprake is van een controlerend orgaan.

"Meent hij dat een controlerend lichaam tripartiet moet worden beheerd? Is dat niet uitsluitend een taak van de overheid? Ik ken geen controleorgaan dat door de overheid is ingesteld en dat tripartiet wordt beheerd",

aldus mevrouw Rempt $-\mathrm{Halmmans}$ de Jong ${ }^{455}$. Zij wordt daarin bijgevallen door het Kamerlid Leijnse ${ }^{456}$, die opmerkt ${ }^{A 57}$, dat

"tripartisering langzamerhand een modewoord begint te worden in de kringen van het CDA".

De opvatting van Geelhoed over de tripartiseringsgedachte in het algemeen laat aan duidelijkheid niet te wensen over ${ }^{458}$. Hij noemt het een volkomen doodlopende en gedateerde oplossing, een "neocorporatistische tendens" die ontleend is aan de jaren vijftig.

"Maar de jaren vijftig laten zich niet klakkeloos overzetten naar de jaren negentig",

aldus Geelhoed. De economie was toen nog gesloten, de technologische ontwikkeling verliep traag en bovendien:

"We waren een horige samenleving, zeer gezagstrouw, verzuild, trouw aan de voorlieden, maar ook heel homogeen. Over de basisuitgangspunten was iedereen het wel eens en daardoor kon dat neocorporatistische model werken. Maar nu gaat dat niet meer. Alle mooie tripartite ideologie ten spijt, moet je vaststellen dat daar vanaf het begin van de jaren zestig bijzonder weinig uitgekomen is. Al jaren sluiten we sociale akkoorden, maar het enige wat je ziet is dat de partijen steeds meer gevangenen van elkaar worden".

Bij de voorzetten omtrent de tripartisering van het arbeidsomstandighedenbeleid is verwezen naar een dergelijke operatie op het terrein van het arbeidsvoorzieningsbeleid, maar deze is nog niet afgerond en daar is dan ook geen enkele ervaring mee opgedaan. In dat opzicht is de opmerking van staatssecretaris De Graaf, dat, voordat er ook maar over tripartisering van het arbeidsomstandighedenbeleid gedacht kan worden, allereerst de ervaringen hiermee op het arbeidswoorzieningsbeleid moeten worden afgewacht, terecht. En dan hebben we het nog niet over de verschillen tussen het terrein van de arbeidsvoorziening en de arbeidsomstandigheden. Bij de eerstgenoemde ligt namelijk de nadruk op dienstverlening, terwijl bij de laatstgenoemde gaat om een tak van de overheidsdienst met een tweeledige functie, namelijk toezicht op de naleving van de wetgeving en de medewering aan de uitwoering ervan en het opsporen van strafbare feiten.

Bovendien heeft het arbeidsomstandighedenbeleid raakvlakken met bijna alle beleidsterreinen van de overige departementen. Als er al problemen rijzen omtrent de ministeriële verantwoordelijkheid ter zake van het arbeidsvoorzieningsbeleid, hoe moet dat dan op een complex terrein als de arbeidsomstandigheden. Hiervoor heb ik reeds gepleit voor het overhevelen van de adviestaak van de Arboraad naar een commissie van de Sociaal-Economische Raad, wat tot gevolg zal hebben, dat de overlegfunctie van de Arboraad komt te vervallen; waarvoor andere mogelijkheden te bedenken zijn. Daarbij zou aangesloten kunnen worden bij de aanzet, die in het project Arbo'91 wordt gegeven, namelijk een bedrijfstakgewijze aanpak, waarbij de diverse betrokken partijen, zoals werkgevers- en werknemersorganisaties (zullen) worden betrokken, en aan het tot stand gekomen Bouwconvenant. Het betreft dan een variant op artikel 45 van de Arbeidsomstandighedenwet, waarin de districtscommissies zijn geregeld en aan de hand waarvan de discussie over tripartisering werd aangewakkerd Ik doel op een vorm van functionele decentralisatie op bedrijfstakniveau in de vorm van tri- 
partite samengestelde bedrijfstakraden, een in andere landen van de Europese Gemeenschap geen onbekend verschijnsel. Zo bestaan in België negen "Comite's Professionels de Securité, d'Hygiène et d'Embelissement des Liewx de Travail ${ }^{459}$. Denemarken kent twaalf van dergelijke raden ${ }^{460}$. Vergelijkbare organen bestaan in Ierland en het Vereningd Koninkrijk. Deze organen hebben steeds een adviserende bevoegdheid bij de uitvoering en de bevordering van de toepassing van het arbeidsomstandighedenrecht in de betreffende bedrijfistak $^{481}$.

\section{De Wet op de ondernemingsraden}

Bij de Wet op de ondernemingsraden van 1971 had de arbeidsinspectie een taak gekregen met betrekking tot het functioneren van de ondernemingsraden; een taak die gelegen was in de wenselijkheid van de centrale overheid om meer inzicht te krijgen in het reilen en zeilen van de ondernemingsraden. Bij de herziening van de Wet op de ondernemingsraden in $1979^{462}$ zou de tekst van het betreffende artikel aangepast worden. Er is toen bepaald, dat de arbeidsinspectie niet langer uitsluitend inlichtingen over het functioneren van de ondernemingsraad kan vragen aan de ondernemer, maar eveneens aan de ondernemingsraad zeif. Tijdens de parlementaire behandeling van de wijzigingswet werd vanuit de Tweede Kamer bezwaar gemaakt tegen het handhaven van de bepaling, dat de arbeidsinspectie inlichtingen kan vagen aan de ondernemer ${ }^{483}$. Het

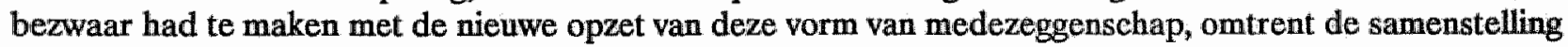
van de ondernemingsraad - de ondernemer is niet langer lid en voorzitter - en de introductie van de zogenaamde overlegvergadering ten behoeve van de ondernemingsraad ( nieuwe stijl) en de ondernemer ${ }^{404}$. Het werd namelijk onjuist geacht, dat de ondernemer inlichtingen verstrekt aan de arbeidsinspectie over het functioneren van de ondernemingsraad. Als de arbeidsinspectie deze informatie verzamelt bij personen, als de ondernemer, die niet zelf in de ondernemingsraad zitting hebben, dan zou dat $60 \mathrm{k}$ moeten gebeuren bij andere gesprekspartners van de ondernemingsraad. Daarbij werd verwezen naar de vakbeweging en naar de mogelijkheid van een enquête onder het personeel. Alleen de ondernemingsraad zou aan de arbeidsinspectie en trouwens ook aan de bedrijfscommissie kunnen rapporteren over het eigen fumctioneren. Rapportage door de ondernemer zou alleen betrekking kunnen hebben op het functioneren van de ondernemingsraden in het kader van de overlegregeling. De bewindsman deelde deze opvatting niet ${ }^{465}$.

"Bovendien zullen vele voor de Arbeidsinspectie interessante gegevens, zoals bijvoorbeeld die met betrekking tot de samenstelling van het personeel, het beste door de ondernemer verstrekt kunnen worden".

De taak die de arbeidsinspectie toebedeeld had gekregen in het kader van de ondernemingsraden, valt wellicht te verklaren uit het feit, dat de arbeidsinspectie contacten onderhield met die ondernemingsraad, bijvoorbeeld in het kader van de vergunningverlening op grond van de Arbeidswet 1919. Dat deze taak voor de dienst behouden bleef, valt te verklaren uit het feit, dat de contacten tussen arbeidsinspectie en ondernemingsraad verbeterd werden en dat de ondernemingsraad meer betrokken werd en wordt bij de arbeidswetgeving; denk daarbij aan de nachtarbeid voor vrouwen in de industrie en de Arbeidsomstandighedenwet.

\section{De Wet arbeid gehandicapte werknemers}

De Wet plaatsing minder-valide arbeidskrachten heeft niet het effect gehad dat ervan werd verwacht. Als eén van de oorzaken kan onder meer aangegeven worden de inadequate definitie van het begrip minder-valide en het als gevolg daarvan ontbreken van de mogelijkheden om de naleving van deze wet te bevorderen of af te dwingen. De Raad voor de Arbeidsmarkt adviseerde in $1975^{466}$ om deze wet in te trekken en te doen vervangen door een wet met een andere strekking. Daarbij werd gewezen op het belang van een betere coördinatie van beleid en van de uitvoering van de maatregellen ten behoeve van gehandicapten. In het advies van 21 november $1980^{467}$ stemde de Sociaal-Economische Raad in met de achtergrond van de kabinetsvoornemens, dat het dringend gewenst was om maatregelen te treffen om de groei vam het aantal arbeidson- 
geschikten terug te dringen en mogelijk het bestaande aantal te werminderen. De Sociaal-Economische Raad had bij dit advies zijn oordeel over de woorgenomen reïntegratiemaatregelen opgeschort totdat kennis genomen kon worden van de inhoud van de herziene Wet plaatsing minder-valide arbeidskrachten. Tevens deelde de Raad mee, dat deze reintegratiemaatregelen geplaatst zouden worden in een advies over vermijdbaar verzuim en arbeidsongeschiktheid. Nadat in december 1980 door de betrokken bewindswrouwe mevrouw Dales een voorontwerp van Wet arbeid gehandicapte werknemers de Raad was toegezonden, vroeg zij vervolgens in januari 1982 advies over maatregelen tot het tegengaan van ziekteverzuim, waarbij tevens gevraagd werd om de inzichten kenbaar te maken ontrent het genoemd ontwerp-wetsvoorstel. Een maand later, in februari van dat jaar, bracht de Sociaal-Economische Raad het advies inzake vermijdbaar verzuim bij ziekte en arbeidsongeschiktheid ${ }^{468}$ uit, waarin aangetoond werd dat een geïntegreerde aampak noodzakelijk is.

Deze geintegreerde beleidsaanpak beweegt zilch rond een aantal kernpunten van het reïntegratiebeleid van gehandicapten, waronder het reduceren van buiten de gehandicapte zelf gelegen feitelijke en vermeende belemmeringen ${ }^{469}$. Een feitelijke belemmering is het tekort aan arbeidsplaatsen voor gehandicapten, enerzijds door een algemene structureel tekort aan arbeidsplaatsen in Nederland en anderzijds doordat veel arbeidsplaatsen niet geschikt zijn voor gehandicapten ${ }^{470}$. In de op 16 mei 1986 tot stand gekomen Wet arbeid gehandicapte werknemers ${ }^{471}$ wordt de eerste oorzaak ondervangen door de in deze wet opgenomen quotumregeling, waarvan het percentage ligt tussen 3 en $7 \%{ }^{472}$. De tweede oorzaak is ondervangen door de bepaling, die het aanpassen van de arbeidsplaats in alle opzichten dwingend voorschrijft ${ }^{473}$ "Naast deze wet biedt ook de Arbeidsomstandighedenwet, wanneer die in zijn geheel in werking zal zijn getreden, mogelijkheden ter zake. De reikwijdte van de bepaling in de Wet arbeid gehandicapte werknemers ontloopt de inhoud van artikel 3 van de Arbeidsomstandighedenwet weinig, maar deze specifieke bepaling kan gezien worden als een aanscherping, een precisering van datgene, wat al uit de Arbeidsomstandighedenwet voortvloeit. Zo kan het districtshoofd van de arbeidsinspectie in het kader van de Wet arbeid gehandicapte werknemers een eis stellen, terwijl dat in het kader van artikel 3 van de Arbeidsomstandighedenwet is beperkt tot de bevoegdheild tot het geven van een aanwijzing. In de praktijk zal zoveel mogelijk eerst worden bezien, of er aanleiding is voor het geven van een aanwijzing op basis van de Arbeidsomstandighedenwet. Afhankelijk van de omstandigheden zal in plaats daarvan echter ook gebruik gemaakt kunnen worden van de in Wet arbeid gehandicapte werknemers neergelegde bevoegdheid tot het stellen van een eis ${ }^{474}$. Tot nu toe kan door het districtshoofd alleen nog maar gebruik gemaakt worden van de mogelijkheid tot het stellen van een eis, daar de bewuste bepaling van de Arbeidsomstandighedenwet nog niet in werking is getreder..

De vermeende bolemmeringen zijn voornamelijk gebaseerd op de gedachte, dat gehandicapten een verminderde arbeidsprestatie leveren, derhalve niet produktief zijn en door veelvuldig verzuim extra geld zouden kosten. Aan de Wet arbeid gehandicapte werknemers ligt de gedachte ten grondslag, dat het overgrote deel van de gehandicapten in staat is om op volwaardige wijze, evenals niet-gehandicapte werknemers, aan het arbeidsproces deel te nemen. Dil kan teruggevonden worden in het in de wet neergelegde beginsel van gelijke beloning bij gelijkwaardige arbeidsprestatie en dezelfde arbeidsduur als een niet-gehandicapte werknemer $^{475}$ :

\section{De Wet chemische afvalstoffen en de Afvalstofienwet}

Op 14 april 1971 deed de toenmalige staatssecretaris van Sociale Zaken en Volksgezondheîd de Tweede Kamer een voorontwerp van een Wet inzake de bodemverontreiniging toekomen ${ }^{478}$. Dit heeft er uiteindelijk toe gelleid, dat het voorontwerp gesplitst werd in een aparte wettelijke regeling voor de afvalverwijdering en een wett ter bescherming van de bodem tegen verontreiniging. In verband met de hoge urgentie van het probleem werd ten aanzien van de chemische afvalstoffen; waaronder in dit verband ook de afgewerkte olie wordt verstaan ${ }^{477}$, in 1976 een afzonderlijke wet in het Staatsblad gepubliceerd, de Wet chemische afvalstoffen ${ }^{478}$.

Deze wet zou gevolgd worden door complementaire wetgeving, de Afvalstoffenwet ${ }^{479}$. Wordt in de Wet 
chemische afvalstoffen een centrale rol aan de rijksoverheid met betrekking tot de uitvoering van de wet toegewezen, in de laatstgenoemde wet wordt vooral een belangrijke taak toebedeeld aan de provinciale overheden, die samen met de besturen van de op hun grondgebied gelegen gemeenten gestalte moeten geven aan een doeltreffend beleid inzake een verantwoorde verwijdering van afvalstoffen.

Het verschil tussen de beide wetten komt tot uiting in de van elkaar afwijkende vergunningstelsels, waarvan dat woor chemisch afval een aanvullend en dat van de Afvalstoffenwet meer een integraal karakter draagt, doordat het de regeling mogelijk maakt van allerlei aspecten van milieubelasting en van doelmatigheidselementen in éen vergunning. Maar de uitgangspunten van beide wetten zijn hetzelfde; zij moeten worden gezien als belangrijke bouwstenen van thet milieuhygiënisch beleid, aldus de verantwoordelijke bewindsman ${ }^{480}$.

Wat is nu de rol van de arbeidsinspectie terzake van het milieubeleid? Vergunningverlener in het kader van de Afvalstoffenwet zijn gedeputeerde staten van de provincie, waarin de inrichting geheel of in hoofdzaak is of zal zijn gelegen. Gedeputeerde staten dienen burgemeester en wethouders van de gemeente waarin de bedoelde inrichting gelegen is of zal zijn, alsook het betrokken districtshoofd van de arbeidsinspectie in de gelegenheid te stellen hen van advies te dienen omtrent de vergunningaanvraag en voorts, indien het verlenen van de gevraagde vergunning wordt overwogen, over het ontwerp hiervan ${ }^{401}$. De taak van de arbeidsinspectie bij de uitvoering van de Afvalstoffenwet is, evenals bij de Wet inzake de luchtverontreiniging, én van adviseur, niet meer en niet minder.

In het dagelijkse werk komt de milieu-inspectie in contact met mensen van de arbeidsinspectie. Als het gebruik van giftige grondstoffen bijwoorbeeld wordt tegengegaan, kan dat een gunstige invloed hebben op de totalle hoeveelheid milieugevaarlijke afvalstoffen; tegelijkertijd kunnen de arbeidsomstandigheden van de betrokken werknemers verbeterd worden. De belangen van de beide inspectiediensten lopen synchroom, zodat onderling overleg gewenst is. Kesselaar van de milieu-inspectie zegt het als volgt ${ }^{4 \mathrm{~B}}$ :

"Met name in het veld - bij de dagelijkse werkzaamheden - kunnen we de samenwerking met de arbeidsinspectie uitbreiden. Zo nu en dan gebeurt dat ook al. Bij het verplicht stellen van een veiligheidsrapport bijvoorbeeld; sluit het werk van de arbeidsinspectie nauw aan bij de inspanningen van de milieu-inspectie; wij juichen een dergelijk rapport vanuit milieuoogpunt zeer toe".

Maar men is wel beducht voor een institutionalisering van deze samenwerking, omdat het gevaar bestaat van

"een zekere mate van over-regeling".

Met een sobere taaktoebedeling van de arbeidsinspectie is het dus mogelijk, dat er een verantwoorde coördinatie tot stand komt tussen het milieubeleid en het beleid op het terrein van de arbeidsbescherming.

\section{De Binmenschepenwet}

Andere vaarsystemen, met name de semi- en de volcontinuvaart, andere vaar- en vervoerstechnieken, zoals het containervervoer, de duwvaart en het toenemende gebruik van zeeschipbakken ${ }^{463}$ hebben het beeld van de Nederlandse binnenvaart ingrijpend gewijzigd. Grote tankschepen zijn niet meer weg te denken uit het verkeer op de Nederlandse wateren, evenals als trouwens de grote vervoerseenheden in de reeds genoemde duwvaart. De drukte op de belangrijkste vaarwegen is eveneens toegenomen. Maar niet alleen het beroepsmatige vervoer is in omvang toegenomen, ook het aantal pleziervaartuigen vertoont de laatste jaren een sterke stijging. Met betrekking tot de visserij geldt, dat een aantal schepen, dat gebruikt worden voor het vissen op de binnenwateren niet voorzien is van een certificaat van deugdelijkheid ingevolge de Schepenwet $^{484}$, omdat zij niet buitengaats komen. Bovendien heeft de sportvisserij op de binnenwateren een grote omvang bereikt en is de verwachting, dat deze nog zal toenemen. De ontwikkeling in de binnenvaart en de toenemende vervoersstroom dwingen ertoe, naar de mening van de toenmallige bewindslieden van de ministeries van Verkeer en Waterstaat en van Sociale Zaken, de leemten, die ontstaan zijn in de bestaande wetgeving ten aanzien van de veiligheid van de vaart op de binnenwateren, op te vullen, om zo ongelukken te voorkomen. De verkeersdrukte op de voornaamste vaarwegen vraagt om waarborgen ter zake van de veiligheid 
van de schepen en de bekwaamheid van de bemanning; dit wordt nog verstrekt door het toenemende vervoer per binnenschip van gevaarlijke stoffen. Bij of krachtens verschillende wetten worden voorschriften gegeven met betrekking tot de veiligheid in de binnenvaart. De belangrijkste daarvan zijn: de Wet Openbare Vervoermiddelen $^{485}$, de Verenwet ${ }^{486}$, de Veiligheidswet 1934 en de Wet Gevaarlijke Stoffen ${ }^{487}$. Voor de Rijnvaart gelden de Reglementen betreffende het onderzoek van schepen op de Rijn en betreffende het verlenen van Rijnschipperspatenten ${ }^{486}$. Het probleem ten aanzien van deze wetgeving is, dat zij een beperkt karakter draagt, aangezien zij slechts of voor bepaalde schepen of voor bepaalde wateren geldt of slechts een specifiek veiligheidsaspect betreft ${ }^{40}$. Ten einde tot een voor de gehele binnenvaart geldende veiligheidsregeling te komen, waarbij eisen worden gesteld aan de romp, de inrichting, de werktuigen en de uitrusting van de schepen en aan de bekwaamheid van de kapitein, is een algemene wettelijke regeling, namelijk de Binnenschepenwet $t^{400}$, tot stand gebracht.

De Veiligheidswet 1934 en het daarop gebaseerde Veiligheidsbesluit binnenvaart bevatten een regeling mett betrekking tot de veiligheid van de arbeid bij het vervoer te water anders dan met zeeschepen. Deze hangen weer naww samen met de regelen ter bevordering van de veiligheid van het schip zelf. Zo beinvloeden de sociale voorschriften met betrekking tot de bemanningsverblijven de bouw van het schip. De veiligheid van de arbeidsplaats aan boord, de deugdelijkheid van de toegangsmiddelen, zoals trappen, ladders, loopplanken, loopbruggen en dergelijke, van luiken, scheerbalken, sleephaken, kettingen en andere uitrustingsstukken raken ook de inrichtings- en uitrustingsvoorschriften voor de veilige vaart met het schip. In de toelichting op het ontwerp-Binnenschepenwet wordt de wenselijkheid kenbaar gemaakt om deze regelingen met betrekking tot binnenschepen en die verwant zijn aan de regeling van de Binnenschepenwet over te brengen naar het op deze wet te baseren Binnenschepenbesluit. Ten aanzien van de regeling in het Veiligheidsbesluit Binnenvaart met betrekking tot het laden en lossen wordt geen overbrenging beoogd, zodat hiervoor het genoemde besluit blifft bestaan ${ }^{491}$. Hetzelfde geldt overigens ook ten aanzien van schepen van lagere overheden.

Gezien het vorenstaande is het niet verwonderlijk, dat de arbeidsinspectie een van de overheidsinstanties ${ }^{482}$ is, die belast is met het onderzoek van en het toezicht op de schepen, alsmede met het opsporen van overtredingen $^{403}$. Maar in de Binnenschepenwet is tevens een regeling opgenomen, die overeenkomt met het bepaalde in artikel 12 van de Veiligheidswet 1934 , waarop het Veiligheidsbesluit binnenvaart is gebaseerd, op grond waarvan het districtshoofd van de arbeidsinspectie voorschriften kan geven ter naleving van hetgeen ten aanzien van de veiligheid van de arbeid aan boord is bepaald ${ }^{484}$. Ten aanzien van de regeling van de veiligheid, de gezondheid en het welzijn aan boord van schepen kan opgemerkt worden, dat de regeling in de Binnenschepenwet wel erg mager afsteekt tegenover die welke was neergelegd in de Veiligheidswet 1934/ Arbeidsomstandighedenwet. Voor de werknemers geldt, dat zij in het kader van de Binnenschepenwet bijvoorbeeld geen beroep kunnen doen op het recht van werkonderbreking.

\section{De Dlergeneesmiddelenwet}

Sterk veranderende omstandigheden in de veehouderij nopen tot aanpassing en uitbreiding van de veterinaire wetgeving. Schaalvergroting en intensieve produktiemethoden vereisen een blijwende veterinaire verzorging van de veestapel in plaats van incidentele behandeling van het zieke dier. Het accent van de diergeneeskundige verzorging koint steeds meer te liggen bij de preventieve gezondheidszorg; bedrijfshygiëne, huisvesting en diervoeder krijgen meer aandacht. De verouderde veterinaire wetgeving dient derhalve te worden bijgesteld en uitgebreid. Een element van deze wetgeving is de Diergeneesmiddelenwet ${ }^{485}$. Het belang van deze wet is niet alleen gelegen in de garanties die de wet aan de dierenarts en een de houder van dieren biedt inzake de deugdelijkheid van de beschikbare geneesmiddelen; de aan het gebruik van diergeneesmiddelen klevende gevaren voor mens en dier kumnen worden geëlimineerd. De nieuwe wet berust op twee pijlers, namelijk een registratieregeling en een kanalisatieregeling. De eerstgenoemde regeling beoogt door een registratieplicht te bewerkstelligen, dat de kwaliteit en de samenstelling van ieder diergeneesmiddel aan een zorg- 
vildig onderzoek wordt onderworpen, alvorens te worden toegelaten tot de Nederlandse markt. De laatstgenoemde regeling moet voorkomen, dat de onder dat regiem vallende diergeneesmiddelen in verkeerde handen kunnen vallen om onoordeelkundig gebruik van geneesmiddelen te voorkomen. Deze regeling bepaalt namelijk langs welke kanalen een diergeneesmiddel zijn weg zal vinden van de fabrikant naar het dier, waarbij tussenkomst van de dierenarts een absolute voorwaarde is ${ }^{466}$.

Het zal duidelijk zijn, dat de Diergeneesmiddelenwet niet gericht is op de bescherming van de veiligheid en de gezondheid van werknemers die bij hun arbeid met diergeneesmiddelen omgaan of bij de bereiding daarvan betrokken zijn, maar op de bewaking van de kwaliteit van diergeneesmiddelen, de bescherming van de gezondheid van mens en dier en op de bescherming van het milieu. Bescherming van de werknemers dient plaats te vinden in een andersoortige wetgeving. Niettemin kunnen de bij een aanvraag tot registratie van een diergeneesmiddel overgelegde gegevens en bescheiden, mede van bellang zijn om inzicht te verkrijgen in de eventuele risico's voor de veiligheid en de gezondheid van de werknemers, die op de én of andere manier bij hun arbeid met diergeneesmiddelen omgaan, aldus de beide verantwoordelijke bewindslieden van Landbouw en Visserij, en Welzijn, Volksgezondheid en Cultuur. In verband hiermee is in de wet ten behoeve van de bewindsman van Sociale Zaken en Werkgelegenheid het recht opgenomen op informatie over de aanvraag en de daarbij overgelegde gegevens en bescheiden, die voor de beoordeling van de bedoelde arbeidsrisico's van belang zijn. Daartoe is bepaald ${ }^{407}$, dat de minister van Sociale zaken en Werkgelegenheid van diens ambtgenoot van Landbouw en Visserij een exemplaar van zowel de aanvraag tot registratie en de daarbij overgelegde gegevens, als van de ministeriële registratiebeschikking zal ontvangen. Een zelfde recht op informatie is opgenomen met betrekking tot de door de minister van Landbouw en Visserij te verlenen vergunningen voor het bereiden, verpakken, etiketteren of afleveren van diergeneesmiddelen en gemedicineerde voeders ${ }^{498}$. Op die manier krijgt de arbeidsinspectie wetenschap over de bedrijven, waarin en de voorwaarden, waaronder werkzaamheden met de diergeneesmiddelen worden verricht, hetgeen een doeltreffender toezicht op de arbeidsomstandigheden in die bedrijven mogelijk maakt.

Daarnaast kunnen in het kader van de uitvoering van de Diergeneesmiddelenwet algemeen maatregelen van bestuur worden vastgesteld aangaande onderwerpen, waarover ook in het kader van de arbeidsbeschermende wetgeving regels zijn of kunnen worden gegeven, zoals bijvoorbeeld aan de inrichting en het gebruik van lokaliteiten waar diergeneesmiddelen of mengvoeders worden bereid, verwerkt of verpakt, en aan de technische uitrusting in dergelijke lokaliteiten ${ }^{499}$. Ten einde te voorkomen dat de bij de uitvoering van de wet te stellen regels, vanwege de raakpunten met de bedoelde onderwerpen in de arbeidsbeschermende wetgeving, met die wetgeving in strijd zouden komen, is in de wet vastgelegd, dat bij de voordracht van bepaalde algemene maatregelen van bestuur vooraf overleg gevoerd dient te worden met de minister van Sociale Zaken en Werkgelegenheid ${ }^{500}$ en die op zijn beurt weer zijn arbeidsinspectie raadpleegt.

\section{De Wet milieugevaarlijke stoffen}

De huidige westerse samenleving wordt gekenmerkt door een intensief gebruik van door de mens vervaardigde stoffen. Sinds de Tweede Wereldoorlog is het gebruik hiervan sterk toegenomen en is de chemische industrie spectaculair gegroeid. De geproduceerde hoeveelheid chemicaliën was in 1963 in vergelijking tot 10 jaren daarvoor verdubbeld; in 1978 was deze hoeveelheid nog eens 10 maal zo groot. Maar niet allieen de geproduceerde hoeveelheden nemen toe, ook het aantal stoffen groeit. Geschat wordt, dat ongeveer 60000 stoffen in regelmatige produktie zijn. Een groot deel van deze verbindingen wordt industrieel toegepast, maar tal van produkten vinden ook direct hun weg naar de consument, zoals bijvoorbeeld produkten op het gebied van was- en schoonmaakmiddelen, verven, kleefstoffen, hobby- en bouwmaterialen, bestrijdingsmiddelen, cosmetica, voedseladditieven en geneesmiddelen.

De groei van de chemische industrie is gepaard gegaan met een sterke toename van de kennis omtrent het ontwikkelen van stoffen en omtrent produktie- en analysetechnieken. De kennis van toxische eigenschappen van stoffen en de daaruit voortvloeiende risico's voor mens en milieu heeft hiermee echter geen gelijke tred gehouden. Op dit punt is de aandacht vooral gericht geweest op de meest direct waarneembare schadelijke 
effecten. Steeds duidelijker is geworden, dat de sterk toegenomen produktie en verspreiding van chemische stoffen leidt tot problemen die niet direct werwacht waren. Het risico, dat stoffen opleveren, is niet afhankelijk van de eigenschappen van een stof, maar ook aan de mate van blootstelling aan die stof en de kans daarop en dus in veel gevallen van de hoeveelheid van de stof die in gebruik is.

Het vorenstaande maakt duidelijk, dat het wit het oogpunt van bescherming van mens en millieu nodig is, dat er aan stoffen, naast onderzoek met betrekking tot "positieve" chemische eigenschappen en toepassingsmogelijkheden, ook onderzoek wordt verricht naar hun mogelijk schadelijke effecten. Hoewel kennis over die mogelijk schadelijke effecten achtergebleven is bij de meer technische kennis, is er wel een sterke ontwikkeling geweest in de onderzoeksmethoden naar die schadelijke effecten. Hierdoor kunnen gegevens verkregen worden die het mogelijk maken om een inzicht te krijgen in de risico's die stoffen voor mens en milieu opleverener

In tal van wetten wordt in enige vorm een (gedeeltelijke) regelling gegeven van de bescherming van mens en milieu tegen de mogelijke gevaren van chemische stoffen. Regelingen die gericht zijn op stoffen of produkten züjn de Bestrijdingsmiddelenwet 1962, de Wet op de geneesmiddelenvoorziening ${ }^{502}$ en enige besluiten op grond van de Warenwet ${ }^{503}$. Deze wetgeving heeft slechts betrekking op chemische stoffen, al dan niet in preparaten-vorm, die gebruikt worden voor een beperkt aantal toepassingen. $\mathrm{Zij}$ hebben daarbij gemeen, dat ze bewust in contact gebracht worden met de mens (geneesmiddelen, voedseladditiewen, cosmetica ) of het milieu (bestrijdingsmiddelen), onder doorgaans goedbekende omstandigheden. Deze wetgeving is vooral gericht op de risico's die stoffen vanaf het moment van hun toepassing opleveren. Er zijn enkele wetten die nog nadrukkelijker betrekking hebben op bepaalde fasen in het leven van een stof: De Veiligheidswet 1934, inmiddels vervangen door de Arbeidsomstandighedenwet, op het gebruik van stoffen in de arbeidssituatie, de Wet gevaarlijke stoffen; op het vervoer van gevaarlijke stoffen, en de Wet chemische afvalstoffen op stoffen in het afvalstadium. De Veiligheidswet 1934 en de Arbeidsomstandighedenwet geven regels met het oog op het voorkomen en bestrijden van ongevallen en gevaren voor de gezondheid en de hygiëne bij de arbeid in ondernemingen, waaronder ook voorschriften vallen voor het werken met bepaalde stoffen en voor de maximaal aanvaardbare concentraties van schadelijke stoffen. Het doel van de Wet gevaarlijke stoffen is om in het belang van de openbare veiligheid, de volksgezondheid en ter bescherming van personen werkzaam in ondernemingen, het vervoer, de verpakking, de aflevering, de nederlegging en het zich ontdoen van gevaarlijke stoffen te regelen. De Wet chemische afvalstoffen geeft ter bescherming van het milieu een regeling voor de doelmatige verwijdering van chemische afvalstoffen en afgewerkte olie. Daartoe kent de wet een stelsel van verboden, meldingen en vergunningen terzake van de verwijdering van die afvalstoffen. Daarnaast zijn er een aantal wetten die zijn bedoeld om lozingen van (milieugevaarlijke) stoffen in één bepaald milieucompartiment tegen te gaan. Op grond van deze emissie-beperkende wetten worden met name voorschriften gegeven, dic zijn gericht op de milieukwaliteit in bepaalde regionale situaties, en op de emissie vanuit een inrichting of werk op een bepaalde plaats. De uitwoering van deze wetten, bijvoorbeeld de Wet inzake de luchtverontreiniging, de Wet verontreiniging oppervlaktewatere ${ }^{504}$, de Wet verontreiniging zeewater $^{505}$ en de Wot bodembescherming ${ }^{506}$ vindt dan ook grotendeels gedecentraliseerd plaats. Overigens kennen deze wetten voorschriften met een meer algemene strekking. Tot slot de Hinderwet en de Kernenergiewet. Op grond van de Hinderwet kunnen ter voorkoming van gevaar, schade of hinder aan in het Hinderbesluit aangewezen inrichtingen eisen worden gesteld bij de vergunningverlening onder andere met betrekking tot de produktie, opslag en vervoer van chemische stoffen binnen een inrichting. Deze wet is echter beperkt, namelijk alleen gericht op hetgeen in inrichtingen plaats vindt en voor zover dat buiten die inrichting tot effecten kan leiden. Ook deze wet wordt gedecentraliseerd uitgevoerd. De Kernenergiewet geeft een bijzondere regeling met betrekking tot de eigenschappen van stoffen, door onder meer te yoorzien in de bescherming van mens en milieu tegen de gevaren van radioactieve stoffen ${ }^{507}$.

De hiervoor gememoreerde wetgeving bestrijkt velerlei terreinen, zonder dat gesproken kan worden van een samenhangend systeem van wetten, dat de gevaren voor mens en milieu die chemische stoffen veroorzaken, 
dekt. Geen van deze wetten biedt voldoende grondslag voor een samenhangend beleid gericht op het tegengaan van de ongecontroleerde blootstelling van mens en milleu aan chemische stoffen in het algemeen, en alle tezamen zijn ze dat evenmin. Om die reden is er behoefte aan een nieuwe wet, die het mogelijk maakt inzicht te krijgen in de gevaren van stoffen voor mens en milieu, en wel voordat deze stoffen een aanzienlijke verspreiding hebben gekregen, en die het mogelijk maakt de gevaren integraal aan te pakken. Een dergelijke breed opgezette wet, de Wet milieugevaarlijke stoffen ${ }^{\text {sos }}$, heeft onvermijdelijk raakvlakken met de hiervoor genoemde wetgeving ${ }^{1509}$.

In de Wet milieugevaarlijke stoffen wordt een samenhangend systeem van onderzoek en informatieverschaffing geschapen voor wat betreft stoffen die aangemeld moeten worden. Dit systeem - kennisgeving met basism dossier, aanvullende meldingen, stapsgewijs toenemend nader onderzoek, met de mogelijkheid van nader onderzoek op elk moment bij gebleken noodzaak daarto $\mathrm{e}^{510}$ - is gecompleteerd door het moment van kennisgeving gekoppeld aan het tijdstip van produktie, en door introductie van een algemene zorgplicht met betrekking tot informatieverschaffing en risicobeperkende maatregelen voor beroepsmatige handelingen met chemische stoffen. Hiermee is de basis gelegd voor een preventief overheidsbeleid ten aanzien van nieuwe. stoffen ${ }^{511}$. Daarnaast beoogt de wet het op de markt brengen en het gebruik van bepaalde gevaarlijke stoffen en preparaten te beperken ${ }^{512}$.

De Wet milieugevaarlijke stoffen heeft betrekking op alle chemische stoffen en preparaten, ongeacht de doeleinden waarvoor zij worden vervaardigd en gebruikt en op alle fasen van hun levensloop, dat wil zeggen vanaf de vervaardiging tot en met de verwijdering of vernietiging in de afvalfase. Er wordt beoogd een basis te geven voor een bescherming tegen alle schadelijke effecten, die voor mens en milieu van die stoffen en preparaten kunnen uitgaan; er is geen beperking aangebracht naar milieucompartiment waarin die gevaren kunnen optreden noch naar de hoedanigheid van de te beschermen mens ${ }^{5 / 3}$. De wet is niet alleen een onmisbaar instrument genoemd ter bescherming van de belangen waarvan de bewindsman van Volkshuisvesting, Ruimtelijke Ordening en Milieubeheer primair verantwoordelijk is, maar ook een instrument ter bescherming van de veiligheid en gezondheid van werknemers en consumenten. Dit betreft met name hoofdstuk 2 (kennisgeving), hoofdstuk 3 (onderzoek) en paragraaf 2 van hoofdstuk 4 (verpakking, aanduiding en aanbeveling ). De bewindslieden van Welzijn, Volksgezondheid en Cultuur en van Sociale Zaken en Werkgelegenheid zijn betrokken bij de uitvoering van de bedoelde hoofdstukken; daartoe zijn organisatorische voorzieningen getroffen, zoals de toezending van gegevens en de verdeling van taken bij de beoordeling en de regelgeving ${ }^{514}$.

De bescherming van mens en milieu ziet daarbij in elk geval ook op de mens in de arbeidssituatie. Om die reden is aan de minister van Sociale Zaken en Werkgelegenheid een bijzondere medebetrokkenheid toegekend. Die komt tot uitdrukking in de toezending in alle gevallen van een exemplaar van het kennïsgevingsdossier $^{515}$ en van naderhand ingediende gegevens ${ }^{516}$, in medebetrokkenheid bij de opdrachten tot nader onderzoek op grond van hoofdstuk 2 paragraaf $3^{517}$, van het ontwerp, en in medebetrokkenheid bij de voordracht van de algemene maatregel van bestuur die op onderzoek, kennisgeving, indeling, verpakking, etikettering en registratie betrekking hebben ${ }^{518}$. De bedoelde bewindsman wordt ook betrokken bij opdrachten tot onderzoek van bestaande stoffen $^{519}$.

Buiten de sfeer van verpakking en etikettering geeft de Wet milieugevaarlijke stoffen geen regulerende maatregelen ter bescherming van de mens tegen de gevaren van stoffen in de arbeidssituatie, aangezien de arbeidsveiligheidswetgeving daarin voorziet ${ }^{520}$.

Bij het tot standbrengen van nieuwe wetgeving rijst steeds de vraag hoe de nieuwe wet moet worden ingepast in het bestaande stelsel van wetgeving. De vraag wordt moeilijker te beantwoorden naarmate de nieuwe wet een breder terrein bestrijkt en daardoor met meerdere wetten raakpunten heeft. De Wet milieugevaarlijke stoffen heeft door de brede strekking talrijke grensgebieden met andere wetten. Besloten is om op enkele terreinen een geldend wettelijk stelsel op te heffen en in deze nieuwe wet op te nemen. Zo zijn de Wet ge- 
vaarlijke stoffen ${ }^{521}$ en de Wet chemische afvalstoffen ${ }^{522}$ gewijzigd. Voor de overige wetgeving is hier on wee redenen van afgezien. In de eerste plaats vertonen de bestaande wetten grote verschillen in doelstellingen en werkingssfeer. Zo beogen de Bestrijdingsmiddelen 1962 en de Wet op de geneesmiddelenvoorziening niet alleen respectievelijk het milieu en de mens tegen de gevaren van de erdoor bestreken produkten, maar tevens de deugdelijkheid te waarborgen van die produkten woor het doel waarvoor zij worden gemaakt. Het oogmerk van wetten als deze is belangrijk ruimer dan de doelstelling wan de nieuwe wet. Andere wetten daarentegen hebben een belangrijk engere doelstelling. Zo beoogt de Wet verontreiniging oppervlaktewateren alleen bestrijding van de waterverontreiniging en de Arbeidsomstandighedenwet alleen de bescherming van de arbeidende mens. Samenvoeging van al deze verschillende stelsels zou, ingeval men de onderscheidene stelsels ongewijzigd zou opnemen, leiden tot een vergaarbak van intrinsiek verschillende regelingen, waarmee de beoogde duidelijkheid niet gediend is. In de tweede plaats beogen de onderscheiden wetten, waarmee de Wet milieugevaarlijke stoffen raakulakken heeft, ieder voor zich de samenhang op een bepaald beleidsternein te verzekeren, bijvoorbeeld een samenhangend afvalstoffen-, bestrijdingsmiddelen-, luchtverontreinigings-en arbeidsveiligheidsbeleid. Het uit deze wetten lichten van die onderdelen die op stoffen of preparaten betrekking hebben zou die wetten min of meer verminkt achterlaten, het risico van desintegratie van het beleid op de desbetreffende beleidsterreinen met zich brengen en bovendien in de plaats van de dan opgeloste afstemmingsproblemen nieuwe afstemmingsproblemen in het roepen.

De Wet-milieugevaarlijke stoffen heeft dan ook een aanvullend karakter. Ten dele is dit in de wet zelf neergelegd, waarin ten aanzien wan een aantal wetten een afbakening tot stand is gebracht, die op verschillende wijze aan de voorrang van die wetten gestalte geeft ${ }^{\text {bas }}$. Het aanvullende karakter van de Wet milieugevaarlijke stoffen komt tevens naar voren als het gaat om het treffen van beperkende maatregelen; leiden de gegevens tot het oordeel vain overheidszijde dat beperkende maatregelen noodzakelijk zijn, dan komt verwolgens de vraag aan de orde op welke wettelijke grondslag die matregelen kunnen en moeten worden gebaseerd. Veroorzaakt een stof slechts in én milieucompartiment problemen, dan kan het met her oog op integratie met andere maatregelen doelmatig zijn, de betrokken maatregelen op grond van de wet voor dat milieucompartiment te treffen. De Wet milieugevaarlijke stoffen is dan wel toegepast om een inzicht te verkrijgen in de gevaren die een stof veroorzaakt, maar niet als grondslag voor de beperkende maatregeler ${ }^{524}$.

Het stelsel van maatregelen waarin hoofdstuk 4 van de wet voorziet, is in beginsel dekkend, dat wil zeggen ter bescherming van mens en milieu kunnen in beginsel alle noodzakelijke maatregelen met betrekking tot alle stoffen en preparaten in elke fase van de levensloop worden getroffen. Ook hierbij geldt evenwel, dat eerst wordi bezien in hoeverre de reeds bestaande wetgeving daarin kan voorzien ${ }^{525}$.

Op grond van artikel 47 , eerste lid, van de Wet milieugevaarlijke stoffen wijst de eerstwerantwoordelijke minister van Volkshuisvesting, Ruimtelijke Ordening en Milieubeheer in overeenstemming met bij algemene maatregel van bestutr angewezen ministers ambtenaren aan die belast zijn met het toezicht op de naleving van het bij of krachtens deze wet bepaalde. Eén van dic ministers is de bewindsman van Sociale Zaken en Werkgelegenheid ${ }^{\text {ta }}$. In de nota van toelichting op het bedoeld besluit stat vermeld, dat met het toezicht op de naleving wan de hoofdstukken 2 en 3 van de wet, met name voor zover deze betrekking hebben op het vervaardigen van stoffen en preparaten, mede belast worden de ambtenaren van de arbeidsinspectie, die toezien op de bescherming van de arbeidsplaats; dit vanwege de directe samenhang tussen de (onderzoek) gegevens met betrekking tot de te produceren stoffen en de arbeidsomstandigheden. Hetzelfde geldt voor de eerste paragraaf van hoofdstuk 4 van de wet, voor zover de op grond daarvan uit te vaardigen maatregelen samenhang vertonen met de doelstelling van de wetgeving inzake de arbeidsomstandigheden, en voor de weede paragraaf van dit hoofdstuk over de verpakking, etikettering en aanbeveling. Met het toezicht op de naleving van de wet door de krijgsmacht zijn eveneens de ambtenaren van de arbeidsinspectie belast, daar waar samenhang bestaat met de arbeidsomstandigheden ${ }^{627}$.

Op overtreding van het bij of krachtens de Wet milieugevaarlijke stoffen gestelde is het stelsel van strafsancties en maatregelen van de Wet op de economische delicten van toepassing verklaard ${ }^{528}$ vanwege het feit, dat het overgrote deel van de wet zich richt op handelingen die in het kader van economische activiteiten 
worden verricht ${ }^{529}$.

\section{Het Buitengewoon Besluit Arbeidsverhoudingen 1945}

\subsection{Het ontslagverbod}

Ten aanzien van de bemoeienissen van de arbeidsinspectie met het ontslagverbod kan het volgende worden opgemerkt. Na een snelle stijging van het aantal ontslagvergunningaanvragen in de jaren 1974 en 1975 , zou dit aantal in 1976 al weer dalen, namelijk van 69.338 naar 59.145, om het jaar daarop overigens weer enigszins te stijgen. In het volgende jaar 1978 zou een nagenoeg gelijk aantal ontslagvergunningaanwragen ingediend worden. Het aantal nadere onderzoeken van de zijde van de arbeidsinspectie zou echter van 340 in 1977 oplopen tot 702 in $1978^{530}$. Vanaf 1979 zou dergelijke informatie niet meer in het jaarverslag worden vermeld.

Op 8 december 1986 is aan de Tweede Kamer een wetsvoorstel voorgelegd, waarin onder meer artikel 6, vierde lid, van het Buitengewoon Besluit Arbeidswerhoudingen 1945 wordt gewijzigd ter zake van de rol van de arbeidsinspectie in ontslagzaken ${ }^{531}$. Volgens de oorspronkelijke regeling, moet de directeur van het gewestelijk arbeidsbureau, alvorens een beslissing te nemen omtrent het al dan niet verlenen van toestemming tot het beëindigen van een arbeidsverhouding in overleg treden met de arbeidsinspectie, die terzake vertegenwoordigers van de in aanmerking komende organisaties van werkgevers en van werknemers hoort. In de praktijk vindt het overleg met de arbeidinspectie en het horen van de werkgewers- en werknemersorganisaties in de meeste gevallen in de bijeenkomsten van de zogenaamde "kleine ontslagcommissie" plaats. Daarnaast wordt een deel van de aanvragen voor een ontslagvergunning door de directeur van het gewestelijk arbeidsbureau via de arbeidsinspectie voorgelegd aan de zogenaamde vertrouwensinstanties, waarin de werkgeversen werknemersorganisaties zijn vertegenwoordigd. Bij de besluitvorming van de directeur van het gewestelijk arbeidsbureau bestaat vooral behoefte aan een bijdrage van de arbeidsinspectie in geval uit de verzamelde informatie blijkt, dat nadere informatie nodig is over de arbeidsomstandigheden. Doelmatigheidsoverwegingen maken het gewenst, dat de directeur van het gewestelijke arbeidsbureau uitsluitend in overleg treedt met de arbeidsinspectie in bovengeschetste situaties ${ }^{532}$. De arbeidsinspectie zal voorts haar contacten met de vertrouwensinstanties beëindigen, terwijl het in de rede ligt, dat de directeur van het gewestelijk arbeidsbureau voortaan rechtstreeks contact onderhoudt met deze instanties. De beoogde beperking brengt voor de arbeidsinspectie een aanzienlijke vermindering van de werklast met zich, daar de taak van deze dienst alle aspecten van alle ontslagvergunningsaanvragen omvat. De verwachting is, dat de nieuwe opzet nog slechts circa $0,5 \%$ van de buitendienstcapaciteit van de arbeidsinspectie zall vragen; een capaciteit die thans 5 a $6 \%$ bedraagt ${ }^{533}$. Het voorstel ontmoette in de Tweede Kamer geen tegenstand. De taakstelling van de arbeidsinspectie wordt in een nieuw vierde lid, van artikel 6 aldus geformuleerd:

"Alvorens een beslissing te nemen ingevolge het eerste lid, hoort de Directeur van het Gewestelijk Arbeidsbureau ter zake vertegenwoordigers van de in aanmerking komende organisaties van werkgevers en van werknemers en treedt hij, indien aannemelijk is dat de voorgenomen beëindiging van de arbeidsverhouding verband houdt met de arbeidsomstandigheden, in overleg met het districtshoofd van de Arbeidsinspectie; deze stelt zonodig cen onderzoek in".

In de Eerste Kamer daarentegen werden nogal wat vragen opgeworpen over de nieuwe rol van de arbeidsinspectie bij ontslagzaken. Zo werd de bewindsman tijdens de schriftelijke behandeling gevraagd of hij kon aangeven, wanneer naar zijn oordeel de arbeidsinspectie betrokken, dan wel ingeschakeld wordt bij een voorgenomen beëindiging van de arbeidsverhouding. Anders geformuleerd: wanneer houdt voorgenomen beëindiging van de arbeidsverhouding verband met de arbeidsomstandigheden? Als voorbeeld werd gedacht aan een scheepswerf - nieuwbouw en reparatie - of een onderneming met een afdeling, die een onderdeel sluit, omdat niet aan de gestelde of te stellen milieuvoorwaarden voldaan wordt. Is voor ontslag van de werknemer 
in de ene afdeling wel en in de andere afdeling niet een onderzoek door de arbeidsinspectie noodzakelijk $^{534}$ ? De bewindsman bevestigde inderdaad dat laatste, maar ontweek de overige vragen ${ }^{535}$. Hij verwees naar een richtlijn aan de directeuren van de gewestelijke arbeidsbureaus, waarin uiltvoerig zal worden ingegaan op de taak en de mogelijkheden van de arbeidsinspectie, zodat duidelijkheid ontstaat omtrent het al dan niet inschakelen van de arbeidsinspectie. Wel zei hij, dat door middel van wekelijkse toezending aan de arbeidsinspectie van informatie over werkgevers, die een ontslagvergunning hebben aangevraagd, de arbeidsinspectie ook zelf kan bepalen of een nader onderzoek gewenst is. Op deze wijze wordt, aldus de bewindsman, gewaarborgd, dat de arbeidsinspectíe op de hoogte blift van belangwekkende marktontwikkelingen. Tijdens de mondelinge behandeling in de Eerste Kamer werd de duidelijkheid, die volgens de bewindsman ontstaiat omtrent het al dan niet inschakelen van de arbeidsinspectie, in twijfel getrokken.

Maar wat gebeurt er nu als er verschil van inzicht bestaat tussen de directeur van het $\mathrm{GAB}$ en de vertegenwoordiger van werkgevers en/of werknemers? Wat is de procedure als een individuele werknemer van oordeel is dat de arbeidsinspectie behoort op te treden en het GAB dat niet nodig acht? Welke prioriteiten krigen de activiteiten ten behoeve van ontslagprocedures nog bij de arbeidsinspectie? Want - dat weet de minister ook - ook bij deze dienst is sprake van een tekort aan personeel en een te grote werkdruk".

Kortom, aldus het bewuste Kamerlid ${ }^{\text {s3e }}$, allemaal vragen waarover geen duidelijkheid bestaat en hij vervolgt:

Je kunt dan toch niet spreken van zorgvuldige wetgeving? Dat tast toch de rechtszekerheid aan? In zo'n situatie is de zwakste, de werknemer, degene die het gelag betaalt, die aan het kortste eind trekt".

Zijns inziens verdwijnt het beoogde evenwicht, toch én van de uitgangspunten van het Buitengewoon Besluit Arbeidsverhoudingen 1945 , volledig ${ }^{537}$. In zijn antwoord ${ }^{538}$ deelde de bewindsman zijn voornemen mee een circulaire te versturen, waarin aandacht wordt besteed aan de wijze van samenwerking tussen het gewestelijk arbeidsbureau en de arbeidsinspectie en de wijze waarop de arbeidsinspectie geïnformeerd zal worden over de ontslagvoornemens op de regionale arbeidsmarkt. Het is, aldus de bewindsman, het overwegen waard hierin een regeling te treffen voor het geval dat er, als de arbeidsinspectie ingeschakeld moet worden, verschil van mening zou ontstaan. Het bewuste Kamerlid is benieuwd naar de door de bewindsman toegezegde regeling. De wetswijziging wordt vervolgens aangenomen en op 22 december 1988 in het Staatsblad gepubliceerd $^{539}$ om op 1 januari van het daarop volgende jaar in werking te treden. De door de bewindsman bedoelde circulaire is inmiddels uitgegaan ${ }^{640}$. Omtrent de werkafspraken staat hierin vermeld, dat de arbeidsinspectie in verschillende stadia van de ontslagprocedure kan worden betrokken; bij de indiening van een ontslagvergunningaanvraag, wanneer onderkend wordt dat arbeidsomstandigheden bij het ontslag een belangrijke rol spelen; indien tijdens het toepassen van hoor- en wederhoor, gegevens naar voren komen die de inbreng van de arbeidsinspectie wenselijk maken; op verzoek wan én of beide vertegenwoordigers uit de ontslagcommissie, indien zij nadere gegevens van de arbeidsinspectie wenselijk achten. In geval de ontslag-

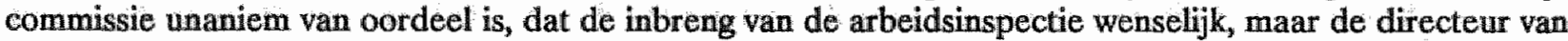
het gewestelijk arbeidsbureau het hiermee niet eens, dient voorlegging plaats te vinden aan de directeurgeneraal voor de Arbeidsvoorziening. Dit laatste geldt tevens, wanneer de directeur van het gewestelijk arbeidsbureau meent, dat de ontsllagreden geen verband houdt met de arbeidsomstandigheden, terwijl de arbeidsinspectie een andere mening is toegedaan. De adviesaanvraag van de directeur van het gewestelijk arbeidsbureau aan de arbeidsinspectie dient schriftelijk te gebeuren, waarbij de reeds aanwezige stukken op het gewestelijk arbeidsbureau in cople worden meegezonden. Een bedrijfsbezoek van de zijde van de arbeìdsinspectie kan noodzakelijk zijn; de beide diensten van Sociale Zaken en Werkgelegenheid zullen dan met elkaar in overleg treden om te bezien op welke wijze het bedrijfsbezoek gestalte zal krijgen en door wie dit bezoek zal worden afgelegd, een keuze die bepaald wordt door de individuele omstandigheden van het geval. De arbeidsinspectie dient binnen veertien dagen te adviseren. Dit zijn de hoofdlijnen van de circulaire van de bewindsman.

Men kan zich afvragen of dit nu de bedoeling was van het kritische Eerste Kamerlid. 
Is met deze wetswijziging de rol van de arbeidsinspectie in ontslagzaken teruggebracht, in het op 14 maart 1989 in de Tweede Kamer ingediende wetswoorstel waarbij de invoering wan de Arbeidswoorzieningswet ${ }^{541}$ wordt geregeld ${ }^{542}$, wordt het vierde lid van artikel 6 van het Buitengewoon Besluit Arbeidsverhoudingen 1945 zo gewijzigd, dat, alvorens een beslissing inzake het verlenen van toestemming om de arbeidsverhouding te beëindigen, degene, die de beslissing zal nemen, vertegenwoordigers van de in aanmerking komende orga* nisaties van werkgevers en werknemers hoort. De arbeidsinspectie heeft, ook al is aannemelijk, dat dle beeindiging van de arbeidsverhouding verband houdt met arbeidsomstandigheden, bij het verlenen van een ontslagvergunning geen (wettelijke) taak meer; overigens, zonder dat daaromtrent ook maar enig woord in de toelichting aan wordt gewijd.

\subsection{Het verbod van werktijdverkorting}

De voortdurende problemen rond de bedrijvigheid in vele bedrijven hebben er toe geleid, dat toepassing van de richtlijnen verbod van werktijdverkorting verder werden versoepeld. De versoepeling had echter betrekking op de totale toegestane duur van de werktijdverkorting. Bedroeg het gemiddelde aantal weken verkort werken per bedrijf, waarvoor vergunning werd verleend, in 1971 nog circa 8 weken, zowel in 1975 als in 1976 heeft dit circa 12 weken bedragen. Daaruit blijkt tevens, dat de bedoelde versoepeling in hel algemeen niet heeft geleid tot een bedenkelijk langere periode dan voorheen. Dit beleid beoogde vele bedrijven te steunen bij hun streven zoveel mogelijk arbeidsplaatsen te behouden; op die wijze zijn in een aantal gevallen voortijdige ontslagen voorkomen. Maar ook het soepele ontheffingenbeleid kan echter voor een structurele overcapaciteit geen oplossing bieden. De verbondenheid met de Werkloosheidswet enerzijds en de relatie van de richtlijnen ten opzichte van artikel $1638 \mathrm{~d}$ van het Burgerlijk Wetboek staan een overvloedig verlenen van ontheffingen in de weg ${ }^{543}$. Overigens zou het aantal verleende uren werktijdverkorting in 1976 , in vergelijking met 1975 , al snel dalen van 31.371 .030 tot 14.109.828; een daling die zich overigens zou doorzetten tot en met $1979^{544}$. In 1980 zou het beroep op het mogelijkheid van werktijdwerkorting weer sterk toenemen, als gevolg van een doorzettende economische stagnatie, en wel van 1.219.352 in 1979 naar 4.532.795. De verzoeken om ontheffingen konden echter voor een groot deel niet gehonoreerd worden, vanwege het feit, dat de voorwaarde van de maximale termijn van herstel van de bedrijvigheid, die werd aangehouden op 6 maanden, overschreden werd ${ }^{155}$. De stijging in het toegestane aantal werktijdverkortingen zou voordturen tot en met 1982, daarna zou een gestage daling intreden tot 512.976 in $1986^{548}$.

De werkgelegenheidsproblematiek als witvloeisel van de economische recessie bracht met zich, dat van regeringszijde werd nagegaan, in hoeverre werktijdverkorting ook in andere gevallen dan duidelijke tijdelijke problemen kan worden toegepast ${ }^{647}$. In 1975 verklaarde de toenmalige minister Boersma, dat met name gedacht werd aan herstructureringsprocessen en een noodzakelijke afbouw van bepaalde economische activitei$\operatorname{ten}^{548}$. Dienovereenkomstig werd in februari 1976 een regeling inzake verruimde werktijdwerkorting afgekondigd.

Bij de "normale" werktijdverkorting, dus voor een beperkte periode, werd $80 \%$ van het loon over de niet-gewerkte uren uit de wachtgeld- en/of werkloosheidsfondsen uitgekeerd. De verruiming hield in, dat naast deze bestaande regeling van overheidszijde een financiële tegemoetkoming werd gegeven aan het bedrijf, dat voor de maatregel in aanmerking kwam. Het ging om bedrijven, die in tijdelijke moeilijkheden verkeerden en die ingevolge de richtlijnen al vooor werktijdverkorting in aanmerking kwamen. Het verzoek om toepassing van de verruimde werktijdverkorting werd mede beoordeeld in het licht van de al bestaande regelingen voor steunverlening aam individuele bedrijven. De financiële tegemoetkoming bedroeg $25 \%$ van de loonkosten over de niet-gewerkte uren, dus naast de $80 \%$-uitkeringen van de bedrijfsverenigingen ${ }^{54 \%}$. De $5 \%$ "extra" diende als tegemoetkoming voor de algemene kosten. Bij overschrijding van een bepaald minimumbedrag moest een deel van de overheidsbijdrage terugbetaald worden ${ }^{550}$. In een brief aan de Tweede Kamer werd de regeling bestempeld als een sociale maatregel die diende om arbeidsplaatsen te behouden ${ }^{551}$.

Gezien de aard van de regeling is het duidelijk, dat de aanvragende bedrijven aan strengere eisen dienden 
te voldoen dan in het geval van de "normale" werktijdverkorting ${ }^{552}$. De opmerkelijke verschillen met de richtlijnen werktijdverkorting lagen in de aantoonbare liquiditeitsproblemen, de dreiging van collectief ontslag en de openlijke verruiming van het begrip "tijdelijkheid", dat toch al rekbaar was gebleken. De reden voor de verruiming was gelegen in het feit, dat in toenemende mate was gebleken, dat het instrument van werktijdverkorting voor een zo beperkte periode de effecten van de lange duur van de recessie en van de sterke terugval in de afzet in vele bedrijfstakken op onvoldoende wijze kon worden opgevangen ${ }^{553}$.

Niet alleen de voorwaarden, maar ook de te volgen procedure was strenger. Zowel het ministerie van Financiên als van Economische Zaken werden bij de behandeling van de aanvragen betrokken. Laatstgenoemde stelde een afzonderlijk onderzoek in naar de liquiditeitspositie en levensvatbaarheid van de betrokken onderneming. Doorgaans vormde de verruimde werktijdverkorting een additionele maatregel als onderdeel van maatregelen, die onder andere door het Bureau Bijzondere Bedrijfsproblemen van Economische Zaken waren verkregen. De aanvragen kwamen onder meer via de arbeidsinspectie ${ }^{554}$ bij het directoraat-generaal van de Arbeid binnen, waarna de aanvraag in eerste instantie werd behandeld door de werkgelegenheidscommissie ${ }^{555}$. Vervolgens vond behandeling plaats in de zogenaamde BBA-commissie, waarna - na goedkeuring - de uitvoering in handen werd gegeven van het directoraat-generaal voor de Arbeidsvoorziening, dat de financiën van deze regeling beheerde ${ }^{556}$.

Ook artikel 8 van het Buitengewoon Besluit Arbeidsverhoudingen 1945 zou onderwerp vormen van de dereguleringsactiviteiten. De commissie-Van der Grinten stelt in de inleiding van haar rapport ${ }^{557}$, dat voor nader onderzoek naar de dereguleringsmogelijkheden in elk geval een aantal beleidsterreinen in aanmerking komt, waaronder het functioneren van de arbeidsmarkt en de inkomensvorming. Dit zou resulteren in het rapport Deregulering inkomensvorming en arbeidsmarkt. In dit rapport ${ }^{558}$ wordt allereerst aandacht besteed aan het belang van het bewuste artikel voor zowel de werkgever, als de werknemer(s) met betrekking tot het voortbestaan van de arbeidsorganisatie en de daarvan deel uitmakende arbeidsplaatsen door respectievelijk een verlichting van de loonkosten en een inkomensgarantie en bestendiging van de arbeidsverhouding gedurende de periode van verminderde bedrijvigheid. Bovendien kan het instrument van werktijdverkorting een, zij het beperkte, aanvullende rol spelen bij de overheidsbemoeienis in het kader van het steun- en sectorbeleid. Veelal maakt sanering deel uit van de uitvoering van dat beleid, dat gericht is op het economisch gezond maken van bedrijven en sectoren. Voor het (structureel) handhaven van een bedrijf of sector kan werktijdverkorting op korte termijn een bijdrage betekenen in het overlevingsplan. Gesteld kan worden, zo vervolgt het rapport, dat de inkomensgarantie gecombineerd met de ontheffingsmogelijkheid in de praktijk bevredigend functioneert. Van fundamentele kritiek van werkgevers- en/of werknemersorganisaties is tot op heden niet of nauwelijks gebleken. Met betrekking tot de uitvoering van het werktijdverkortingsinstrument was er geen aanleiding verder te willen dan zoveel mogelijk bekorting van de procedure door verkorting van besluitvormingslijnen, waarbij de beslissing op een verzoek tot ontheffing van het verbod aan een termijn gebonden zou worden.

In het rapport Deregulering inkomensvorming en arbeïdsmarkt wordt gesteld, dat het verbod van werktijdverkorting van algemene strekking is en betrekking heeft op zowel een tijdelijke, als een permanente verkorting van de arbeidsduur. De permanente werktijdwerkorting - arbeidstijdverkorting - was steeds vrijwel uitsluitend gefinancierd via inlevering van de prijscompensatie; het verbod kwam zodoende niet aan de orde. In 1983 zou daar echter verandering in komen $^{559}$. Het ligt, aldus het rapport in de rede, dat indien de verkorting van de normale arbeidsduur met verlaging van het nominale loon wordt overeengekomen, de overheid hieraan in beginsel alle medewerking verleent door middel van een technisch eenvoudige vrijstelling op grond van het derde lid van artikel 8 van het Buitengewoon Besluit Arbeidsverhoudingen 1945, waarbij onder ogen moest worden gezien de vraag of elke verkorting van de normale arbeidsduur in combinatie met vermindering van loon, zonder meer moet worden geaccepteerd. Indien de verkorting bij collectieve arbeidsovereenkomst is geregeld zouden ter zake geen nadere voorwaarden behoeven te worden gesteld. Ten aanzien van ondernemingen waarop geen collectieve arbeidsovereenkomst van toepassing is, zou met het oog op de zwakke onderhandelingspositie van individuele werknemers gedacht kunnen worden aan een beperking 
tot 36 uur voor volwassenen en tot 32 uur voor jeugdigen, waarbij de loonsverlaging niet verder zou mogen gaan dan in evenredigheid met de verkorting van de arbeidsduur, aldus het rapport.

Deze laatstbedoelde gedachtengang sloot geheel aan bij de door de bewindsman zelf bij eerder gelegenheden naar voren gebrachte ideeën ${ }^{560}$. Bij besluit van 12 juni $1985^{561}$ is door de minister van Sociale Zaken en Werkgelegenheid de bewuste vrijstelling uitgevaardigd met als argument de in het verbod van werktijdverkorting gelegen belemmeringen voor arbeidstijdverkorting ( permanente werktijdverkorting ) weg te nemen $^{582}$. De doelstelling van het besluit is niet anders dan op korte termijn een situatie scheppen, dat het proces vain arbeidstijdverkorting strekkende tot behoud, dan wel creatie van werkgelegenheid geen onnodige belemmeringen ondervindt. De toelichting geeft tevens aan, dat het besluit geen betrekking heeft op situaties, waarin sprake is van een tijdelijke vermindering van de bedrijvigheid in een onderneming die, om welke reden dan ook, noopt tot een tijdelijke verkorting van de werktijd. De bestaande uitvoering van het derde lid van artikel 8 van het Buitengewoon Besluit Arbeidsverhoudingen 1945 ingevolge de richtlijnen werktijdverkorting zal hiernaast gewoon doorgang vinden. Arnold ${ }^{5}$ heeft zich afgevraagd, of de eerderbedoelde richtlijnen niet met zich brengen of een vrijstelling om structurele werktijdverkorting mogelijk te maken wel mag worden uitgevaardigd. In een reactie daarop ${ }^{5 e 4}$ ben ik uitgegaan van een andere vraagstelling, namelijk: In hoeverre vormt het in het eerste lid van artikel 8 van het Buitengewoon Besluit Arbeidsverhoudingen neergelegde verbod van werktijdverkorting een belemmering voor de bij de sociale partners levende ideeën over permanente werktijdverkorting of wel arbeidstijdverkorting? Aan de hand van de strekking van het verbod van werktijdverkorting en de tekst van de betreffende verbodsbepaling, ben ik tot de conclusie gekomen, dat bij overeenkomst het aantal door de werknemers te werken uren per week op minder dan 48 gesteld kan worden en dat de werkgever dan slechts hoeft te betalen over het (overeengekomen) aantal uren, dat door de werknemer gewerkt wordt; het verbod levert dan mijns inziens geen belemmeringen op voor de bij de sociale partners levende ideeën aangaande arbeidstijdverkorting. De door de minister uitgevaardigde vrijstelling mist daardoor naar mijn mening elke rechtsgrond.

In dat zelfde jaar 1985 zou een advies-aanvraag aan de Sociaal-Economische Raad gericht worden ${ }^{565}$ over het kabinetsvoornemen om de in artikel 8 , derde lid, van het Buitengewoon Besluit Arbeidsverhoudingen 1945 toegekende bevoegdheden aam de minister van Sociale Zaken en Werkgelegenheid tot het verlenen van ontheffingen over te dragen aan de besturen van de bedrijfsverenigingen, respectievelijk de Sociale Verzekeringsraad. Veel van de argumenten, die in het Rapport Deregulering inkomensvorming en arbeidsmarkt omtrent het belang van het artikel waren gegeven, komen in de adviesaanvraag terug. Bovendien wijst de adviesaanvraag nog op een arbeidsmarktpolitiek element; het voorkomen van ontslagen via het instrument werktijdverkorting heeft tot gevolg, dat de arbeidsmarkt niet extra belast wordt, hoewel én en ander wel dient te geschieden binnen het kader van de richtlijnen werktijdverkorting. Als argument voor de overdracht wordt gegeven, dat de betrokken instanties de meest aangewezen instanties zijn. Bij de keuze hebben twee zaken een rol gespeeld, aldus de adviesaanvrage, namelijk het feit dat deze instanties reeds bij de toepassing van het instrument werktijdverkorting zijn betrokken en dat via deze instanties alle voor werktijdverkorting in aanmerking komende sectoren van het bedrijfsleven bestreken worden. Het overdragen van de ontheffing verlenende bevoegdheid lijkt zijn basis te vinden in de dereguleringsoperatie, malar uit het advies ${ }^{568}$ van $^{3}$ de Sociaal-Economische Raad blijkt, dat het voornemen niet alleen binnen dat kader geplaatst dient te worden, maar dat ook andere, overwegingen een rol spelen. Daarmee kan alleen maar gedoeld zijn op de $2 \%$ operatie, één van de andere pijlers van het kabinetsbeleid. Hiermee kan dit overdrachtsvoorstel derhalve op dezelfde lijn geplaatst worden als de wijziging van de rol van de arbeidsinspectie bij ontslagzaken, die gemotiveerd werd met doelmatigheidsoverwegingen, maar, die, gezien het aangevoerde argument van de voor deze taak benodigde capaciteit van de dienst, ook alleen is ingegeven door de $2 \%$-operatie.

De Sociaal-Economische Raad zou echter adviseren, dat op zichzelf genomen de wenselijkheid en de noodzaak van een overheveling van de ontheffing verlenende bevoegdheid naar de bedrijfsverenigingen en de Sociale Verzekeringsraad onvoldoende is komen vast te staan en dat aan een dergelijke overheveling uiteenlo- 
pende bezwaren en negatieve effecten zijn verbonden, zoals de waarborg van het brengen van zoveel mogelijk uniformiteit in het ontheffingenbeleid, daar de kans aanwezig is dat "ruime" fondsen een soepeler beleid zullen voeren dan "krappe" fondsen, waardoor de mogelijkheid bestaat dat bedrijven hun normale bedrijfsrisico afwentelen op de fondsen waardoor concurrentievervalsing kan ontstaan. Verder speelt de afwijkende rechtsgang bij de beroepsmogelijkheden tegen een genomen beslissing, namelijk de Afdeling rechtspraak van de Raad van State ten aanzien van een geweigerde ontheffing en de Raad en Centrale Raad van Beroep op grond van de Werkloosheidswet. Deze bezwaren en negatieve effecten zouden slechts ten dele met aanvullende wetgeving kunnen worden weggenomen. De Raad komt tot de slotconclusie, dat het, zeker gelet op het feit dat de huidige praktijk bevredigend functioneert en er geen sprake is van fundamentele kritiek, geen aanbeveling verdient om de uitvoering van het verbod van werktijdverkorting over te dragen aan de bedrijfsverenigingen respectievelijk de Sociale Verzekeringsraad. Een dergelijke slotconclusie lag, gezien de inhoud en de strekking van de adviesaanvrage zo voor de hand, dat men zich af kan vragen waarom er eigenlijk advies werd gevraagd.

Maar én en ander wil nog niet zeggen, dat niet opnieuw een poging zal worden ondernomen om de bedoelde bevoegdheid over te dragen; argumenten als bijvoorbeeld doelmatigheidd en deregulering zullen wel weer opduiken, maar de werkelijke reden zal well opnieuw de of én of andere soort $2 \%$-operatie zijn.

15. Werkzaamheden in verband met andere wetten waarvan de handhaving en de medewerking aan de uitvoering geheel of gedeeltelijk aan de arbeidsinspectie is opgedragen

\subsection{De Rujtijdenwet 1936}

Op 1 april 1978 is het nieuwe, op de Rijtijdenwet 1936 gebaseerde Rijtijdenbesluit $^{587}$ ter vervanging van $^{5}$ het besluit van $1971^{168}$ in werking getreden. Overigens heeft de Sociaal-Economische Raad in dezelfde periode een advies ${ }^{509}$ uitgebracht over een wijziging van de Rijtijdenwet 1936 . Geadviseerd is onder meer de fictieve bepaling, die de werkgever steeds in eerste aanleg strafrechtelijk verantwoordelijk stelt te vervangen door een bepaling, die de chauffeur onder omstandigheden een eigen strafrechtelijke aansprakelijkheid geeft. Bovendien wordt geadviseerd om de Rijtijdenwet 1936 onder de werking van de Wet op de economische dellicten te brengen.

De naleving van de arbeids- en rusttijden, zoals deze zijn neergelegd in het Rijtijdenbesluit, staan in de volle publieke belangstelling. Vanaf 1985 heeft de arbeidsinspectie, die de naleving van de desbetreffende wettelijke voorschriften met betrekking tot het zogenaamde eigen vervoer controleert, terwijl de rijksverkeersinspectie het beroepsvervoer controleert, een planmatige opzet van controles, zoals neergelegd in het rapport Controle Rijtijdenwet $1936^{570}$. In dat jaar is de in het rapport vastgelegde werkwijze van speerpuntacties geëffectueerd. In genoemd jaar waren de speerpuntacties gericht op de branches vis en bloemen en planten, waarbij 78 bedrijven werden gecontrolleerd en 35 processen-verbaal werden opgemaakt. De indruk was, dat bij intensief gebruik van de vervoersmiddelen, bijvoorbeeld bij internationaal vervoer, de bepalingen voor rij- en rusttijden onvoldoende werden gerespecteerd ${ }^{571}$. In de daaropvolgende jaren werden er steeds meer branches door middel van speerpuntacties onder de loep genomen; in 1986 werden 315 bedrijven gecontroleerd, in 1987 326. Er werden bij die gelegenheden respectievelijk 66 en 46 processen-verbaal opgemaakt, terwijl in 1987 tevens 24 schriftelijke waarschuwingen werden gegeven. De geconstateerde overtredingen betroffen voor vervoer op het buitenland voor het merendeel te korte rusttijden en te lang achter het stuur zitten en voor het binnenlandse vervoer werden voornamelijk overtredingen van de diensttijd geconstateerd. Voorts werden veel onvolkomenheden geconstateerd bij het bewaren en het invullen van de tachograafschij-
ven $^{672}$.

Van werkgeverszijde wordt bij monde van Vallenduuk ${ }^{573}$ op de vraag, waarom de rijtijdenwetgeving niet wordt nageleefd, geantwoord, dat de normen niet op de praktijk van het internationale vervoer geënt zijn, 
de chauffeur zelf niet aansprakelijk is en de wetgeving te vergelijken is met een volstrekt ontoegankelijk oerwoud. Dat zijn drie oorzaken. De oplossing, die hij aandraagt, is vrij simpel. Als nu eerst deze drie oorzaken worden weggenomen en het blijkt onnaleefbaar, dan mag pas naar andere oorzaken gekeken worden, zoals te weinig controle, te lage sancties en onereus ondernemersgedrag. Hij vervolgt met de stelling, dat de in economisch en sociaal opricht best geleide Nederlandse wegvervoerbedrijven er niet in zullen sllagen om internationaal vervoer te verrichten zonder daarbij in aanraking te komen met de kantonrechter in het kader van de rijtijdenwetgeving. Dit zegt:

"meer over de aanvaardbaarheid van de regeling, dan over het gedrag van deze en in feite

alle Nederlandse wegvervoerders".

Vallenduuk verwijst in dat verband naar het zogenoemde OHanlon-onderzoek ${ }^{574}$, waaruit blijkt, dat de mate van naleving niet noemswaardig van land tot land verschilt. Maar vaststat voor Vallenduuk, dat de regelgeving ondeugdelijk is. Dat de rijtijdenwetgeving een zeer complexe wetgeving is (geworden), zal door niemand ontkend worden, maar de benadering van Vallenduuk is wel erg eenzijdig. Bovendien gaat hij wel erg snel en gemakkelijk voorbij aan bijvoorbeeld de onderzoeksactiviteiten van de commissie voor ontwikkelingsproblematiek van bedrijven van de Sociaal Economische Raad ten aanzien van het sociaal beleid in het beroepsgoederenvervoer over de weg ${ }^{575}$. Daar wordt geconstateerd, dat het sociaal beleid in het beroepsgoederenvervoer over de weg nog weinig tot ontwikkeling is gekomen ${ }^{576}$.

Genoemd auteur wekt in een ander artikel ${ }^{577}$, waarin het jaarverslag van de rijkswerkeersinspectie afdeling controle wordt besproken, de suggestie, dat in het kader van het toezicht op de Rijtijdenwet 1936 het eigen vervoer, dat onder de competentie van de arbeidsinspectie valt ten opzichte van het beroepsgoederenvervoer, dat tot het werkterrein van de rijksverkeersinspectie behoort, een voorkeursbehandeling geniet en dat de arbeidsinspectie haar plicht zou verzuimen; er zou sprake zijn van "schijncontroles". In een reactie wijst de directeur-generaal van de Arbeid De Roos ${ }^{578}$ erop, dat bij een juiste interpretatic van statistische gegevens rekening gehouden dient te worden met een (groot) aantal variabelen. Hij brengt vervolgens een onderscheid aan tussen de omvang, de kwaliteit en de resullaten van de controles in de beide sectoren.

Ten aanzien van de omvang van de controles geeft hij aan, dat door de rijksverkeersinspectie in dat bewuste jaar 48.418 staandehoudingen op de weg werden verricht, waarvan 39.678 in het beroepsgoederenvervoer en 8.730 in het eigen vervoer. Door de beide toezichthoudende instanties werden in dat zelfde jaar gezamenlijk 885 bedrijfscontroles verricht, waarvan $627(70 \%)$ door de rijksverkeersinspectie en $258(30 \%)$ door de arbeidsinspectie. De directeur-generaal van de Arbeid trekt hieruit de conclusie, dat verhoudingsgewijs door de arbeidsinspectie een grotere controleinspanning is verricht, terwijl de verhouding $70 \%: 30 \%$ bij de bedrijfscontroles een redelijke weerspiegeling geeft van de marktverhoudingen voor wat betreft het vervoerde tonnage. Over de resultaten van de controles merkt hij onder meer op, dat in het algemeen in het eigen vervoer in vergelijking met het beroepsgoederenvervoer minder processen-verbaal worden opgemaakt ${ }^{570}$. Daarvoor, zo vervolgt de directeur-generaal van de Arbeid, zijn een aantal verklaringen te geven. De eerste betreft de marktontwikkeling; de relatieve overcapaciteit in het beroepsgoederenvervoer heeft een druk op de vrachtprijzen tot gevolg en leidt tot scherpe concurrentie. In het beroepsvervoer, waar het vervoer het hoofdprodukt is, speelt een lage ritprijs uit concurrentieoverwegingen een grotere rol dan bij het eigen vervoer, waarbij het vervoer, als bijprodukt, slechts een deel van de produktieprijs uitmaakt. In het eigen vervoer speelt het element van concurrentie well een rol, maar beperkter in omvang. De er een verband bestaat tussen concurrentie en het overtreden van de rijtijdenregelgeving wordt bevestigd door het totstandkomen van het Convenant Wegvervoer ${ }^{580}$, waarin de relatie een belangrijk element vormt in het kader van het concurrentievoorwaardenstelsel. De tweede verklaring betreft de samenstelling van de populatie; bij het eigen vervoer is het aandeel grensoverschrijdend vervoer, dat gevoelig is voor overtredingen van de rijtijdenregelgeving, aanzienlijk lager. Bij de gelijkmatige spreiding van de bedrijfscontroles, hetgeen overigens door Vallenduuk wordt bepleit, betekent dit een lager totaal-yerbaliseringspercentage voor het eigen vervoer. De derde verklaring kan gelegen zijn in het feit, dat de bedrijfscultuur in het beroepsgoederenvervoer in veel gevallen anders is, dan die in het eigen vervoer. Een rol daarbij speelt de lagere organisatiegraad van de werknemers 
in de eerstbedoelde bedriffstak en het veelvuldiger aanwezig zijn van een medezeggenschapsorgaan in de laatstbedoelde bedrijfstak.

De directeur-generaal van de Arbeid stelt vervolgens, dat de situatie in het wegvervoer op het gebied van de rij- en rusttijden in het bijzonder en de arbeidsomstandigheden in het algemeen een punt van zorg is voor het ministerie van Sociale Zaken en Werkgelegenheid en ook de volle aandacht heeft. $\mathrm{H}_{\mathrm{j} j}$ verwijst in dit verband naar de marktverkenning wegvervoer die door de arbeidsinspectie wordt verricht.

Uit het vorenstaande mag, meen ik, worden afgeleid, dat Vallenduuk wel zeer sterk naar voren treedt als exponent van de veelal grote bedrijven in het beroepsgoederenverwoer ${ }^{\text {sit }}$, vertegenwoordigd in het KNVTO; een beroepsorganisatie waarbij door sommige aldaar werkzame personen soms wel gebruik gemaakt wordt van twijfelachtige methoden, zoals blijkt uit de slotalinea van de eerderbedoelde reactie van de directeur-generaal van de Arbeid:

Tot slot verzoek ik u n.a.v. een mij onder ogen gekomen schrijven van 14 juli jl. van de heer A. Reijnders ${ }^{582}$ aan de Inspecteur-Generaal voor het Vervoer, kritiek op het optreden van de AI niet bij het Ministerie van Verkeer \& Waterstaat, doch bij het DirectoraatGeneraal van de Arbeid neer te leggen",

omdat dit de meeste mogelijkheden geeft tot een constructieve dialoog. Wellicht, dat hier een heel andere zaak speelt. Op dit moment zijn er ongeveer 60.000 bedrijven met eigen vervoer en ongeveer 8.000 in het beroepsgoederenvervoer. De bedrüfscontroles in de eigen vervoersector worden gedaan door de arbeidsinspectie, die in het beroepsgoederenvervoer door de rijksverkeersinspectie. Mocht nu door het tegen elkaar uitspelen van de beide controlerende instanties, waar het gezien het vorenstaande wel heel erg op lijkt, het gehele controle-terrein aan én van beide worden toebedeeld, waarbij de bewuste beroepsgoederenvervoerders een voorkeur hebben voor de rijksverkeersinspectie, dan betekent dit, dat deze dient niet 8.000 maar 68.000 bedrijven te controleren heeft, waardoor de bezoekfrequentie snel zou afnemen, waardoor de beroepsgoederenvervoerders minder gecontroleerd zouden worden. Dit kan alleen worden tegengegaan door de rijksverkeersinspecties dienovereenkomstig uit te breiden, maar dat lijkt mij in deze tijd slechts een illusie.

\subsection{De Hinderwet}

Het milieubeleid en de wetgeving op dat terrein hebben sinds de jaren zestig een snelle ontwikkeling doorgemaakt.

"De wetgeving inzake de milieuhygiëne heeft een vaak zo genoemde sectorale opbouw. Dat wil zeggen, dat de verschillende wetten zich richten op de onderscheiden aspecten van de zorg voor de milieuhygiëne als het voorkomen of beperken van de verontreiniging van water, lucht en bodem, van geluidhinder en van gevaar, schade en hinder door ioniserende stralen. Naar mate het programma van sectorale wetten zijn voltooiing nadert, doet zich de noodzaak gevoelen van een wettelijke regeling met betrekking tot een aantal algemene onderwerpen op het terrein van de milieuhygiëne. Hiermee wordt beoogd de eenheid van wetgeving inzake de milieuhygiëne te bevorderen en de onderlinge samenhang te versterken".

Zie hier de grondslag voor de Wet algemene bepalingen milieuhygiêne ${ }^{593}$. Als onderwerpen die zich voor de regeling in deze wet lenen, komen in aanmerking die de sectorale wetten gemeenschappelijk hebben. Het bijeenbrengen van een groot aantal bepalingen over gemeenschappelijke onderwerpen in een wet biedt als voordelen, dat deze voortaan op éen plaats te vinden zijn en dat de wijzigingen daarvan gelijktijdig gelden en van gelijke inhoud zijn. Daarnaast zullen voor opneming in de Wet algemene bepallingen milieuhygiëne die onderwerpen in aanmerking komen, die niet in de sectorale wetten kunnen worden opgenomen, omdat zij de grenzen van de afzonderlijke wetten overschrijden ${ }^{584}$. Als eerste onderwerpen zijn in de wet opgenomen algemene regelen van inspraak-en beroepsmogelijkheden bij de totstandkoming van beschikkingen en een regeling inzake de coördinatie bij de voorbereiding en behandeling van vergunningaanvragen. De doelstellingen van deze regelingen zijn als volgt: ten eerste hebben zij ten doel meer eenheid te brengen in de 
nu veelal ongelijksoortige en ongelijktijdig verlopende procedures voor inspraak en beroep bij het totstandkomen van beschikkingen op het gebied van de milieuhygiëne. Daarnaast beoogt de wet de inspraakmogelijkheden te verbeteren. Als derde doelstelling geldt het verbeteren van de doelmatigheid van het beshitvormingsproces ten aanzien van beschikkingen, met name gericht op het verkorten van de duur er van. Voorts wordt met de coördinatiersgeling tevens beoogd het bevorderen van de samenhang, zowel procedureel als inhoudelijk, van de beschikkingen die op hetzelfde project betrekking hebben. De regelingen, die in de wet zijn opgenomen, zijn van toepassing op onder meer de Hinderwet, de Kernenergiewet, de Wet inzake de luchtverontreiniging, de Wet chemische afvalstoffen en de Afvalstoffenwet ${ }^{585}$. Voor zover de regelingen van de Wet algemene bepalingen milieuhygiëne van toepassing zijn verklaard, konden bepalingen met betrekking tot inspraak en beroep uit die wetten vervallen ${ }^{589}$. De wijzigingen die hiervoor nodig waren, zijn aangebracht bij de Wet houdende invoering van de Wet algemene bepalingen milieuhygiene ${ }^{587}$.

Ter zake van de Hinderwet werden in het kader van deze invoeringswet een aantal wijzigingen aangebracht voor wat betreft de rol van de arbeidsinspectie ${ }^{589}$. Allereerst werden de in de Hinderwet aan de districtshoofden van de arbeidsinspectie toegekende bevoegdheden expliciet beperkt tot de veiligheid en gezondheid wan de werknemers ${ }^{589}$. Vervolgens stelt het gemeentebestuur onder meer het districtshoofd in de gelegenheid advies uit te brengen omtrent het verzoek om vergunning en omtrent de ontwerp-beschikking, voor zover daarbij belangen betrokken kunnen zajn die tot het terrein van zijn werkzaamheden, in casu derhalve de veiligheid en de gezondheid van werknemers, behoren. Voorts is het districtshoofd bevoegd te allen tijde uit eigen beweging het gemeentebestuur van advies te dienen ${ }^{590}$. Ten aanzien van het provinciaal bestuur is een daarmee overeenkomstige verplichting opgelegd ten aanzien van de rol van het districtshoofd van de arbeidsinspectie $^{591}$. De meest ingrijpende verandering is echter, dat de koppeling van de Veiligheidswet 1934 en de Hinderwet wordt losgelaten. Hierdoor hoeft bij een aanvraag om een Hinderwetvergunning niet langer gewacht te worden op de zogenaamde 35bis-verklaring voordat de vergunningaanvraag bekend gemaakt kan worden.

Het aantal ontvangen Hinderwetvergunningaanvragen tot oprichting dan wel uitbreiding van inrichtingen was in 1975 teruggelopen tot 13693, maar zou in de daarop volgende jaren toenemen tot 18849 . In 1978 en 1979 zou het aantal vergunningaanvragen zich min of meer stabiliseren om vervolgens weer te stijgen in 1980. Ook nu weer kenmerkt het aantal vergunningaanvragen door sterke schommelingen, maar na 1980 is er sprake van daling om uiteindelijk in 1986 te resulteren in een aantal van $12903^{\text {592. }}$. Het aantal gevallen, waarin schriftelijk advies werd gegeven aan gemeentebesturen schommelde sterk, bijvoorbeeld 271 in 1976,155 in 1979 en 626 in $1986^{593}$. Verder stond de arbeidsinspectie de gemeenten bij ten aanzien van de aan de Hinderwetvergunning op te leggen voorwaarden, werden er wijzigingen in de voorwarden, die aan de ontwerpvergunning waren verbonden, voorgesteld en waren er evenals in de vorige periodlen klachten over het niet of onvoldoende verstrekken van gegevens aan belanghebbenden.

\subsection{De Wet inzake de luchtverontreiniging}

Na 1975, het jaar waarin de meeste aanvragen in het kader van de Wet inzake de luchtverontreiniging, namelijk 110, om advies door de arbeidsinspectie waren ontvangen, zou het aantal ontvangen advies-aanvragen teruglopen. Er was met betrekking tot het aantal afgegeven adviezen om voorschriften aan een vergunning te verbinden een sterk wisselend beeld te zien. Zo werden er in 1976 99, in 1977105 en in 197874 adviesaanvragen ontvangen. In 1981 waren dit er 63,198348 en in $198549^{594}$. Bedroegen de aangegeven adviezen met voorstellen om voorschriften aan de vergunning te verbinden in 19779 , in 1978 daalde dit aantal 5 en werden in 1985 in het geheel geen adviezen gegeven. Hoewel in de jaren $1983 \mathrm{t} / \mathrm{m} 1985$ respectievelijk 35,53 en 38 ontwerp-vergunningen voor advies werden ontvangen, bedroeg aantal afgegeven adviezen terzake respectievelijk 1,27 en $0^{505}$. 
Reeds in de hoofdstukken $10 \mathrm{en} 11$ was geconstateerd, dat de Huisarbeidswet 1933 tot een dode letter was geworden. Overigens is wel aardig te vermelden, dat in 1979 door de burgemeester van de gemeente van inwoning nog 46 loonboekjes in het kader van het Huisarbeidsbesluit 1936 werden verstrekt ${ }^{506}$, en dat de gemeente Aalten bij brief van 19 december 1988 de directewr-generaal van de Arbeid verzoekt om een vijftal loonboekjes toe te zenden ${ }^{697}$.

In 1982 werd de regering in een motie-Beckers uitgenodigd te onderzoeken, welke aanpassingen in bestaande regelingen, waaronder de Huisarbeidswet 1933 getroffen dienen te worden om te bereiken dat thuiswekers juridisch en fiscaal als reguliere werknemers worden behandeld ${ }^{588}$. In november 1984 maakte de toenmalige bewindsvrouwe Kappeyne van de Coppello aan de Tweede Kamer haar standpunt bekend ten aanzien van tot deze motie ${ }^{599}$. Met betrekking tot de Huisarbeidswet 1933 sloot de staatssecretaris aan bij de desbetreffende conclusile van het rapport "Deregulering Inkomensvorming en Arbeidsmarkt", dat er alle aanleiding zou zijn om de afschaffing van deze wet na te streven, aangezien de wet maar zeer ten dele wordt uitgevoerd en ten dele is achterhaald ${ }^{600}$; een toch wat wonderlijke eufemistische formulering voor een wet, waarvan wordt gezegd dat deze een dode letter is geworden. Om echter te voorkomen dat ten gevolge van volledige opheffing van de Huisarbeidswet 1933 de arbeidsinspectie niet meer kan intervenièren bij evidente mistanden in thuiswerksituaties, wilde de bewindsvrouwe eerst, dat nagegaan werd in hoeverre een gedeeltelijke incorperatie van deze wet in de Arbeidsomstandighedenwet nogelijk is. Zij dacht aan een op de Arbeidsomstandighedenwet gebaseerd uitvoeringsbesluit "huisarbeid", waarin bepalingen zijn opgenomen met betrekking tot bijzondere gevaren voor de veiligheid en de gezondheid van de thuiswerker, alsmede verbodsbepalingen om bepaalde werkzaamheden thuis te laten verrichten en verplichtingen voor de opdrachtgever tot het geven van instructies en het verstrekken van veilig gereedschap. Tevens kondigde zij aan, dat de regering condities wilde scheppen om de arbeidsmarktpositie van de thwiswerkers te verbeteren door onder meer een meer systematische overheidsvoorlichting over de al bestaande rechten en het subsidiëren van een thuiswerksteunpunt. Een dergelijk thuiswerksteunpunt, dat op initiatief van de Vrouwenbond van de Federatie van Nederlandse Vakverenigingen tot stand is gekomen te Hengelo ging offcieel op 11 november 1985 van start. Tevens zijn in de afgelopen jaren diverse rapporten over het verschijnsel huisarbeid verschenen, zoals: Het verschijnsel thuiswerk en Telework ${ }^{601}$, naast een aantal omtrent de zogenaamde flexibele arbeidsrelatie, waar thuiswerk er een van is ${ }^{602}$, alle op instigatie van het ministerie van Sociale Zaken en Werkgelegenheid. Het laatste rapport met betrekking tot de arbeidsomstandigheden van thuiswerksters dateert van januari 1989 en betreft een inventariserend onderzoek, verricht door de arbeidsinspectie in samenwerking met het thuiswerksteunpunt te Hengelo ${ }^{803}$. Dit rapport is door de staatssecretaris van Sociale Zaken en Werkgelegenheid bij brief van 31 januari 1989 de voorzitter van de Tweede Kamer aangeboden ${ }^{804}$. In deze brief schrijft de bewindsman, dat de Arbeidsomstandighedenwet slechts in principe van toepassing op huisarbeid, namelijk in die gevallen waarin arbeid wordt verricht krachtens arbeidsovereenkomst dan wel anderszins onder gezag arbeid wordt verricht. Ten einde de reikwijdte van de wet ook over de thuiswerksters te doen uitstrekken, meldt de bewindman, dat een wijziging van de Arbeidsomstandighedenwet wordt voorbereid. Tevens zal er over de wijze, waarop een en ander ingevuld moet worden, informeel overleg plaatsvinden met werkgevers- en werknemersorganisaties in die economische sectoren waar het verschijnsel tot op heden bet meeste voorkomt; schoen- en andere lederwarenindustrie, metaalproduktenindustrie, de elektrotechnische industrie en de rubber- en kunststofindustrie.

\subsection{Overige}

Het toezicht op de naleving van de bepalingen van de overige wetten, waaronder bijvoorbeeld de Phosphorluciferwet: 1901, de Wet wekelijkse rustdag toonkunstenaars en de Winkelsluitingswet 1952 leverde geen of geen noemenswaardige problemen op. 


\section{Bijzondere opdrachten}

Ook in deze periode is de arbeidsinspectie belast geweest met wat in eerdere perioden bijzondere opdrachten genoemd is.

\subsection{Vrijstelling militaire dienst/koninklijke onderscheidingen}

Ook nu worden op verzoek van de minister van Defensie door de arbeidsinspectie aanvragen om vrijstelling van militaire dienstplicht wegens onmisbaarheid van de dienstplichtige in het bedrijt, waarin deze werkzaam is, beoordeeld. Een dergelijke advies wordt gevraagd, wanneer de reeds beschikbare gegevens en adviezen onvoldoende inzicht geven voor een beslissing voor de aanvraag. Zo werden in 1976460 van dergelijke aanvragen ontvangen, terwijl in 1978 dit aantal 416 bedroeg $^{605}$. In 1981 bedroeg het aantal adviesaanvragen nog $210^{800}$. In het jaarverslag van genoemd jaar wordt voor het eerst tevens melding gemaakt van een andere, al langer bestaande activiteit van de arbeidsinspectie, namelijk het ten behoeve van de minister van Sociale Zaken en Werkgelegenheid uitbrengen van adviezen inzake het verlenen van koninklijke onderscheidingen aan personen in industriële en ambachtelijke bedrijven; in 1981 bedroeg het aantal adviezen 106. In de daaropvolgende jaarverslagen worden de gegevens van deze beide activiteiten samengevat in eén tabel, waardoor nadere informatie per activiteit niet meer gegeven kan worden.

\subsection{Civiele verdediging}

Evenals in de voorgaande periode hield de arbeidsinspectie zich bezig met het in het kader van de civiele verdediging evalueren van de risico's, die verbonden zijn aan de aanwezigheid van gevaarlijke stoffen in de bedrijven en met het ontwerpen van maatregelen ter beveiliging tegen mogelijke gevaren voor personeel en bevolking. Hoewel in een aantal gevallen grote potentiële gevarenbronnen aanwezig zijn, is, dank zij de ingevoerde veiligheidswoorzieningen en -maatregelen, de kans op de realisering van een calamiteit door gevaarlijke stoffen zeer klein. Deze voor vredesomstandigheden ontworpen voorzieningen zullen echter in het algemeen onvoldoende bestand zijn tegen oorlogsgeweld, waardoor een sterk werhoogde kans op het optreden van calamiteiten met gevaarlijke stoffen rekening moet worden gehouden. De meest effectieve benadering voor het verlagen van de oorlogsrisico's met gevaarlijke stoffen is het reeds in vredestijd elimineren van grote potentiële gevarenbronnen, waar dit technisch mogelijk en economisch haalbaar is. Aan de hiertoe ten dienste staande mogelijkheden wordt van de zijde van het directoraat-generaal van de Arbeid woortdurend veel aandacht besteed.

De totale bedreiging door gevaarlijke stoffen wordt, behalve door de gevaarseigenschappen van de stoffen, bepaald door het aantal plaatsen waar deze stoffen zich bevinden en door de omvang, waarin en de omstandigheden, waaronder deze stoffen voorkomen. Voor het verkrijgen van inzicht ten aanzien van de plaatsen als hiervoor bedoeld werd een inventarisatie van grote opslaglokaties uitgevoerd, zodat in het begin van deze periode een globaal overzicht bestond.

Door het directoraat-generaal wordt deelgenomen aan het werk van diverse commissies en instanties, die rampenregelingen voorbereiden. Ook wordt regelmatig deelgenomen aan het voorbereiden en uitvoeren van rampenoefeningen, meer speciaal voor wat betreft de problematiek van de gevaarlijke stoffen en de industriele risico's. Een belangrijk instrument, dat is ontwikkeld ten behoeve van de verbeterde beheersing van de risico's met gevaarlijke stoffen, is het arbeidsveiligheidsrapport. Deze regeling is in eerste instantie opgezet in verband met de risico's onder vredesomstandigheden, maar zal tevens van groot belang zijn in het kader van de civiele verdedigingsvoorbereiding. Hierna is overigens gestopt met de hiervoor bedoelde inventarisatie, omdat dit rapport, naast de beschrijving van de inrichting, een evaluatie bevat van de gevaren, verbonden aan de opslag-en produktieinstallaties bij het bedrijf, waarin zich belangrijke hoeveelheden gevaarlijke stoffen bevinden, alsmede een beschrijving van de regelingen, die zijn getroffen in geval van een calamiteit. Met inachtneming van de geheimhoudingsbepalingen voor wat betreft de zaken en bedrijfsgeheimen staat de in- 
formatie uit de veiligheidsrapporten ter beschikking van de civiele verdediging ${ }^{607}$.

\subsection{Het Nederlands Instituut voor Arbeidsomstandigheden}

In 1975 is de Stichting van Communicatie met betrekking tot gegevens voor onderzoek inzake Ziekteverzuim opgericht door de ministeries van Sociale Zaken en van Binnenlandse Zaken, de Sociale Verzekeringsraad en de Federatie van Bedrijfsverenigingen. Het bestuur van deze stichting werd gevormd door vertegenwoordigers van deze instanties. In 1979 is de directeur-generaal van de Arbeid De Roos voorzitter geworden van dit bestuur ${ }^{608}$ "In dat zelfde jaar heeft de werkgroep "Taakconceptie Veiligheidsinstituut" aan de bewindsman van Sociale Zaken haar eindrapport aangeboden. Deze werkgroep bestond wit vertegenwoordigers van het ministerie van Sociale Zaken, de Federatie van Bedriffswerenigingen, de Sociale Verzekeringsraad, het Arbeidsongeschiktheidsfonds, het Veiligheidsinstituut en de Nederlandse Vereniging van Veiligheidstechnici, en stond onder voorzitterschap van de directeur-generaal van de Arbeid. In het eindrapport werd een aantal suggesties gedaan voor de taken, de bestuursamenstelling en de funanciering van het Veiligheidsinstituut en werd het werk van het Veiligheidsinstituut in het bredere kader van alle instellingen en instanties, die zich met de privé- en bedrijfsveiligheid bezig houden, geplaatst. Een apart onderdeel in het eindrapport vormden de mogelijkheden tot samenwerking en mogelijke integratie van de Stichting van Communicatie met betrekking tot gegevens voor onderzoek inzake Ziekteverzuim met het Veiligheidsinstituut, juist vanwege de verwantschap tussen beide instellingen:

- de Stichting Coördinatie van Communicatie met betrekking tot gegevens voor onderzoek inzake Ziekteverzuim houdt zich bezig met de wisselwerking tussen de gezondheid van de mens en de mate, waarin hij deelneemt aan het arbeidsproces;

- het Veiligheidsinstituut verricht onderzoek met betrekking tot de veiligheid en gezondheid in het werk en met betrekking tot de goede sfeer bij de arbeid.

De activiteiten van het Veiligheidsinstitunt liggen, aldus de werkgroep, in het verlengde van de genoemde stichting, zodat, waar mogelijk, binnen het kader van de afzonderlijke doelstellingen coördinatie van activiteiten moet worden nagestreefd ${ }^{800}$.

In mei 1987 besloten de besturen van de beide stichtingen te fuseren tot de Stichting het Nederlands Institwut voor Arbeidsomstandigheden ${ }^{810}$, dat op 1 september van dat jaar werd geëeffectueerd ${ }^{\text {B11. }}$. Maar deze nieuwe stichting zou eerst in het daarop volgende jaar, op 9 maart, echt van start gaan ${ }^{812}$.

\subsection{De Subsidieregelingen arbeidsplantsverbeteringen}

Nadat in de eerste helft van 1975 het voorbereidende werk was verricht, kwam in mei van dat jaar een subsidieregeling arbeidsplaatsverbetering tot stand. De regeling, die als experiment bedoeld was, richtte zich op de verbetering van de individuele arbeidsplaats, waarbij zowel materiële als immateriële factoren van belang waren. Het onderzoek hieromtrent werd verricht door de arbeidsinspectie en het gewestelijk arbeidsbureau, terwijl de eindbeoordeling gebeurde door een zogenaamde centrale commissie, waarin, behalve ambtenaren van het ministerie van Sociale Zaken, tevens zitting hadden ambtenaren van het ministerie van Economische Zaken en van Financiền. De sluitingsdatum was gesteld op 1 oktober 1975; op dat moment waren er 986 aanvragen ontvangen, hetgeen aanzienlijk meer was, dan men aanvankelijk verwachtte. Het merendeel van de aanvragen bleek betrekking te hebben op verbeteringen op materieel gebied, waarbij afzuiginstallaties, klimaatverbetering en lawaaibestrijding het meest opvielen. Daarnaast werden relatief veel aanvragen ontvangen die betrekking hadden op ergonomische verbeteringen. Verbeteringen op immaterieel gebied, zoals werkoverleg en werkstructurering vormden slechts een klein deel van het totaal.

De behandeling van de aanvragen vereiste, gezien de omvang en complexiteit van de voorgestelde projecten, langdurige en diepgaande studie. Ook het aan de behandeling van de subsidie-aanvragen verbonden werk voor de districten van de arbeidsinspectie was veelal tijdrovend en inspannend; er was uitgebreid onderzoek nodig, waarvoor de benodigde gegevens in het bedrijf vaak niet snel beschikbaar waren. Ook administratief 
betekende étn en ander een omvangrijke taak. Bij de behandeling in de districten speelden in vrijwel alle districten de aangewezen districtscoördinatoren een belangrijke rol. Deze zorgden voor het coördineren van de aan de regeling verbonden werkzaamheden, intern alsook extern, bijvoorbeeld in de contacten met de gewestelijke arbeidsbureaus. Zij fungeerden ook veelal, namens het districtshoofd, als voorzitter van de ingestelde begeleidingscommissies, waarin voorts vertegenwoordigers van het gewestelijke arbeidsbureau, van werkgevers- en werkmemersorganisaties zitting hebben. Deze commissie ziet toe op een juiste uitvoering van de gesubsidieerde projecten en rapporteert over de voortgang ${ }^{\text {eis }}$.

In juni 1976 werd bekend gemaakt, dat de experimentelle regeling gecontinueerd zou wordien; dit geschiedde in het kader van de nota inzake de Selectieve Groei. In deze nota werd aangekondigd, dat van 1977 tot en met 1980 opnieuw middelen beschikbaar zullen komen voor de subsidiëring van arbeidsplaatsverbetering. Een belangrijke rol bij de voorbereiding van de nieuwe subsidieregeling speelde de zogenaamde Centrale Begeleidingscommissie, waarin werkgevers- en werknemersorganisaties zijn vertegenwoordigd en die op 5 april 1976 werd geinstalleerd; de taak van deze commissie was de bewindsman van Sociale Zaken te adviseren omtrent het beleid ten aanzien van de arbeidsplaatsverbetering ${ }^{814}$.

In de loop van de jaren werden er duizenden subsidieaanvragen ingediend op basis van dit nieuwe instrument. $\mathrm{Na} 1981$ zijn de subsidiemogelijkheden, als uitvloeisel van de noodzaak tot bezuiniging op de overheidsuitgaven, belangrijk ingekrompen. Oorspronkelijk droegen de subsidieregelingen arbeidsplaatsverbetering een overwegend "algemeen" karakter. Daarnaast kwamen er regelingen tot stand op de realisering van verbetering in een bepaalde sector of bedrijfstak, zoals bijwoorbeeld de landbouw, de binnenvaart, de rubberindustrie. Ook regelingen die gericht waren op éen enkele soort verbetering zagen het daglicht, zoals de subsidieregeling functieverbetering. Tot slot kwamen er subsidieregelingen, die gericht waren op het ontwikkelen van nieuwe verbeteringen, zoals ten aanzien van metaalprodukten en scheeps- en industrieel onderhoud ${ }^{615}$. In een beoordeling van dit instrument stelt $\operatorname{Vos}^{618}$, dat de animo voor arbeidsplaatsverbetering in het bedrijfsleven nog ruimschoots aanwezig is. Bezien vanuit de Nederlandse industriepolitiek past een op ontwikkeling en innovatie gerichte arbeidsplaatsverbetering binnen de huidige koers, die gekenmerkt wordt door een terughoudende opstelling ten opzichte van steunverlening aan bedrijven, gecombineerd met een bevordering van "speerpuntindustrieën" en van de toepassing van nieuwe technologische ontwikkelingen. Als aanzet is dit te vergelijken met de koersverandering in West-Duitsland, waar vanaf het begin van de jaren tachtig het concept van een sociaal georiënteerd technologiebeleid als uitgangspunt voor de humaniseringsactiviteiten is gekozen. De Nederlandse ontwikkelingen op het terrein van arbeidplaatsverbeteringen van de laatste jaren gaan een zelfde kant op. Alleen de schaal, waarop dit gebeurt, vindt Vos zeer bescheiden. Poll en Lou$\operatorname{man}^{647}$ zijn wellicht nog positiever. Zij stellen, dat de nationale economie gebaat zou kunnen zijn met meer aandacht voor de arbeidsplaatsverbetering. Wanneer kwaliteit van de arbeid meer als uitgangspunt wordt gekozen voor beleid en besluitvorming, kan dit leiden tot een hogere produktiviteit, kwaliteit en flexibiliteit van produktieprocessen en dienstverlening. Bovendien, zo vervolgen zij, levert arbeidsplaatsverbetering uitbreiding van kennis, ergonomische produkten en de daarmee gepaard gaande werkgelegenheid en exportmogelijkheden. Voor werknemers leidt arbeidsplaatsverbetering tot vermindering van de belasting, die meestal ook na het werk nog te merken is en tot een verhoging van de kans op een volledig arbeidsleven.

De Algemene Rekenkamer is in haar al eerder aangehaalde rapport beduidend minder positief. Met het oog op de twijfel omtrent de effectiviteit van de regelingen van de functie of arbeidsplaats, werd afgevraagd of subsidiëring van arbeidsplaatsen door het directoraat-generaal van de Arbeid nog wel op zijn plaats was. Wellicht, omdat

"meting binnen de bedrijven van de kwaliteit van de arbeidsomstandigheden voor en na het aanbrengen van de voorzieningen, dan wel het treffen van de maatregelen, nooit had plaatsgevonden".

Het begrip "meting" is van doorslaggevende betekenis voor de stellingmame van de Algemene Rekenkamer. Een evaluatieonderzoek naar de algemene subsidieregeling 1977 bracht aan het licht, dat het functioneren van de werknemers in zoverre gunstig beïnvloed was, dat zij de aangebrachte voorzieningen positief hadden ervaren $^{618}$. De Algemene Rekenkamer verwijst in haar rapport naar een bijdrage van Vos in het Tijdschrift 
voor Arbeidswraagstukken, maar gaat daarbij wel erg selectief te werk, namelijk door alleen op te nemen, dat effecten op ziekteverzuim en kwalitatieve discrepanties op de arbeidsmarkt zich per project konden voordoen, maar over het gehele bedrijfsleven bezien moodzakelijkerwijs beperkt zijn. Selectief want, nadat Vos allereerst had opgemerkt, dat uit evaluatieonderzoeken blijkt, dat men over de directe effecten van de uitgevoerde projecten overwegend positief was, vervolgt hij met de opmerking dat deze, door de Algemene Rekenkamer gememoreerde constatering voor de hand ligt, wanneer in aanmerking wordt genomen, dat tegenover een veelheil aan verbeterde arbeidsomstandigheden c.q. - plaatsen in vrijwel alle onder de werkingssfeer van de regeling vallende ondernemingen slechts een beperkt subsidiëringsbudget stond. Per slot van rekening kon met de in de periode 1977 tot en met 1981 beschikbare gelden hooguit gemiddeld $1 \%$ van de jaarlijkse bedrijfsinwesteringen in machines en outillage worden beïnloed. Maar Vos wijst nog op een ander probleem, namelijk het conjuncturele van de regelingen, met andere woorden: de jaarlijks terugkerende onzekerheid over de continuiteit en de inhoud van de regeling. Vandaar ook dat hij melding maakt van voorstellen om de looptijd van de regeling(en) te verlengen en de financiële middelen een structureel karakter te geven en te verruimen ${ }^{210}$. Vreemder is echter het gegeven, dat de bewindsman het met de Algemene Rekenkamer eens is en de meer dan evenredige daling van de begroting ten aanzien van de subsidies toegeschreven kan worden aan de gewenste heroverweging van het subsidieinstrument. Of de bewindsman leest de evaluatierapporten niet of hij maakt van de nood een deugd door een gewone bezuiniging - op een subsidiepot is bezuinigen nu eenmaal eenvoudiger en wellicht gewenster dan het bezuinigen op andere zaken - als een heroverweging voor te doen.

\subsection{De Interdepartementale werkgroep selectieprocedure}

Begin 1979 startte de interdepartementale werkgroep selectieprocedures, waarin vertegenwoordigers van de ministeries van Sociale Zaken, van Binnenlandse Zaken en van Justitie zitting hadden, met de opdracht de aanbevelingen van de commissie selectieprocedure, beter bekend als de commissie-Hessel naar haar voorzitter, die zijn neergelegd in het rapport "Een sollicitant is ook een mens ${ }^{\text {m820 }}$, te evalueren. Zowel het voorzitterschap, als het secreatriaat berustten bij het directoraat-generaal van de Arbeid. In januari 1980 werd de bewindsman van Sociale Zaken een interimrapport aangeboden, waarin op voorhand de voorkeur werd uitgesproken voor een opzet waarbij in een wettelijke regeling de basis wordt gelegd voor een regeling met betrekking tot werving en selectie. Na het uitbrengen van dit interimrapport is, met instemming van de betrokken bewindslieden, deze opzet nader uitgewerkt. Ten aanzien van een aantal belangrijke onderdelen van selectieprocedures - het psychologisch en het geneeskundig onderzoek - werden subgroepen ingesteld, die eind 1980 hun bevindingen gerapporteerd hebben en die daarna wan hun taak werden ontheven. Een andere subgroep hield zich bezig met de wettelijke vormgeving ${ }^{\text {e21 }}$. Bij de uitwerking hebben de volgende zaken een rö gespeeld:

- de regeling zal moeten gelden voor zowel de overheid als de particuliere sector;

- de regeling zal betrekking moeten hebben op zowel de grondbeginselen bij werving en selectie, waarbij aangesloten kan worden bij de door de commissie-Hessel geformuleerde rechten van een sollicitant, als de belangrijkste, meer concrete aspecten en onderdelen van de procedure van werving en selectie;

- de regeling moet voldoende ruimte laten voor het specifieke van concrete situaties en voor bijzondere eisen, die kunnen voortvloeien uit de aard van de arbeidsorganisatie, daar het verloop van de procedure van werving en selectie immers sterk wordt bepaald door de aard en het niveau van de functie en door de aard en de omvang van de arbeidsorganisatie.

In april 1982 heeft de interdepartementale werkgroep selectieprocedures haar eindrapport aan de toenmalige staatssecretaris van Sociale Zaken en Werkgelegenheid mevrouw d'Ancona aangeboden, waarin de voorkeur wordt uitgesproken voor een wettelijke regeling terzake van werving en selectie ${ }^{622}$. In juni van dat jaar werd het rapport de Tweede Kamer aangeboden. Kort daarna kondigde de toenmalige staatssecretaris Van Zeijl aan, dat hij, alvorens over de aanbevelingen van de werkgroep een besluit te nemen; met de opstellers van het rapport en met de Stichting van de. Arbeid oriënterende gesprekken zou voeren. De reden van het 
gesprek met de Stichting van de Arbeid was gelegen in het feit, dat dit overlegorgaan op verzoek van de toenmalige bewindsman Albeda bij brief van 4 augustus 1980 , zich aan het beraden was over de mogelijkheden om - in afwachting van een wettelijke regeling - de totstandkoming van vrijwillige afspraken tussen de sociale partmers te bevorderen ${ }^{623}$. In juli 1982 waren de zogenaamde aanbevelingen wan de Stichting van de Arbeid met betrekking tot de regelingen inzake werving en selectie tot stand gekomen ${ }^{\text {t24 }}$. In september 1982 vonden de vorenbedoelde gesprekken plaats. Naar aanleiding hiervan informeerde staatssecretaris mevrouw Kappeyne van de Coppello bij brief van 3 aprill 1983 over haar yoornemen omtrent werving en selectie. $\mathrm{Zij}$ kondigde aan de Stichting van de Arbeid met klem te zullen vragen te bevorderen, dat de aanbevelingen over werving en selectie zouden leiden tot regelingen terzake in het bedrijfsleven. Voorlopig zou dan worden afgezien van een advies-aanvrage aan de Sociaal-Economische Raad. Tevens maakte de bewindsvrouwe kenbaar, dat haar voornemen was, dat na 2 of 3 jaar geëvalueerd zou worden, in hoeverre de Stichtingsaanbevelingen een beduidend en waarneembaar effect op het sociaal beleid zouden hebben. Op grond van dit evaluatie-onderzoek zal dan worden bezien, of het al dan niet gewenst was om alsnog een wettelijke regeling voor te stellen ${ }^{625}$. Door de Dienst Collectieve Arbeidsvoorwaarden werd in juli 1984 een onderzoek gepubliceerd naar de vraag, of en in hoeverre bepalingen van collectieve arbeidsovereenkomsten aansluiten bij de aanbevelingen van de Stichting van de Arbeid van 21 juli 1982. Geconcludeerd werd, dat in vrijwel alle collectieve arbeidsovereenkomsten, die deel uitmaakten van het onderzoek een of meer bepalingen zijn opgenomen inzake werving en selectie. Met name wordt daarbij aandacht geschonken aan het aangaan van een schriftelijke arbeidsovereenkomst, een moment in de fase die direct volgt op de feitelijke selectie, en aan de interne vacaturevervulling, wat betrekking heeft op al in dienst zijndle werknemers. Bepalingen omtrent psychologische en medische keuringen komen eveneens in een aantal collectieve arbeidsovereenkomsten voor. De overige door de Stichting van de Arbeid onderscheiden fasen in de wervings-en selectieprocedu$\mathrm{re}^{620}$, die verder alleen betrekking hebben op sollicitanten, zijn vrijwel niet (profit-sector) of heel summier (non-profit-sector) in collectieve arbeidsovereenkomsten geregeld. Het zwaartepunt van de in de onderzochte collectieve arbeidsovereenkomsten aangetroffen bepalingen inzake werving en selctie ligt derhalve bij de werknemer; terwijl bescherming van de sollicitant in de betreffende bepalingen niet direct op de voorgrond staat. Alleen in de collectieve arbeidsovereenkomst voor het ziekenhuiswezen sluiten de bepalingen inzake werving en selectie grotendeels, aan bij de aanbevelingen over werving en selectie van de Stichting van de Arbeid. Al met al een tamelijk bedroevend resultaat. Eind 1984 zouden resultaten van een onderzoek, dat verricht was door de arbeidsinspectie, naar de huidige wervings- en selectiepraktijk in een aantal onderzoekingen en instellingen, bekend gemaakt worden ${ }^{627}$. Hieruit blijkt, dat een belangrijk deel van de respondenten niet of slechts oppervlakkig op de hoogte is van de aanbevelingen van de Stichting wan de Arbeid. Van de 40 respondenten, die onder een collectieve arbeidsovereenkomst vallen, is de helf volledig onbekend met het bestaan hiervan, terwijl 8 respondenten $(20 \%)$ niet inhoudelijk op de hoogte zijn. Wel wordt geconstateerd, dat in de collectieve arbeidsovereenkomsten uit de non-profit-sector, met name in de gezondheidssector, relatief de meeste bepalingen terug te vinden zijn, die in materiele zin overeenkomen met de Stichtingsaanbevelingen. Bijna de helft van de hiervoor bedoelde 40 respondenten is op de hoogte van de bepalin. gen in hun collectieve arbeidsovereenkomsten, die betrekking hebben op het aanstellen van nieuw personeel. Deze bepalingen betreffen in de regel: de meldingsplicht bij het gewestelijk arbeidsbureau, de (voorrangs) positie van interne sollicitanten, psychologische en medische keuringen. Bepalingen ter bescherming van de positie van de externe sollicitant worden nawwelijks aangetroffen ${ }^{828}$. Het resultaat van dit onderzoek maakt, dat het beeld niet veel rooskleuriger wordt. Het wachten is nu op stappen, die er toe leiden dat de sollicitant echt beschermd gaat worden.

\section{Tot besluit}

\subsection{Inleiding}

Aan het einde gekomen van een lange weg waarin de ontwikkeling van de arbeidsinspectie in een verande- 
rende wetgeving is beschreven, will ik dit hoofdstuk afsluiten met een tweetal beschouwingen. De eerste beschouwing betreft de in het inleidende hoofdstuk gestelde vragen omtrent de taken die aan de arbeidsinspectie waren toebedeeld en waarom zij gedurende haar bestaan zich met andere (beleids-)terreinen heeft beziggehouden. De tweede beschouwing betreft de kritiek op de arbeidsinspectie.

\subsection{De an de arbeidsinspectie toebedeelde taken}

In het verlengde van de discussie omtrent de vraag door wie er nu gecontroleerd moest worden, lag de vraag of, als dit een afzonderlijk inspectie-orgaan zou zijn, door dit orgaan nog eén of meer andere taken vervuld dienden te worden. Daarbij werd gedacht aan onder meer een adviserende en voorlichtende taak. In deze paragraaf zal worden nagegaan welke taken aan de arbeidsinspectie waren toebedeeld, en waarom zijj zich met andere beleidsterreinen heeft beziggehouden, dan die waarvoor zij was ingesteld.

In de Arbeidswet 1889 was voor de betreffende ambtenaren van de arbeidsinspectie een tweeledige taakstelling neergelegd. Op grond van artikel 12 van de Arbeidswet 1889 waren deze ambtenaren belast met het "toezicht op de vitwoering" van de wet, alsmede, ingevolge artikell 18 van de Arbeidswet 1889, met het opsporen van overtredingen hiervan. De Veiligheidswet van 1895 en de Caissonwet 1905 kenden een zelfde tweeledige taakstellingez, zij het dat "toezicht op de vitwoering" plaats had gemaakt voor "toezicht op de naleving $^{\text {"230 }}$, beide overigens geen gelukkige formulering van de toezichthoudende taak van de arbeidsinspectie. Aangezien de Phosphorluciferwet 1901 slechts verbodsbepalingen bevat, is de taakstelling beperkt tot het opsporen van overtredingen ${ }^{631}$.

De in de genoemde wetten neergelegde taakstelling kan worden opgesplitst in twee elementen, namelijk toezicht en opsporing.

De Arbeidswet 1889 bevatte bepalingen tot het tegengaan van overmatige en gevaarlijke arbeid van jeugdige personen en van vrouwen, terwijl in de Veiligheidswet van 1895 bepalingen waren neergelegd teneinde het verblijven in fabrieken en werkplaatsen te beveiligen. De Caissonwet 1905 was eveneens gericht op de veiligheid van de arbeiders; de betreffende wet bevatte bepalingen terzake van de beveiliging bij het uitvoeren van bouwwerken onder grotere dan de atmosferische luchtdruk. Terzake van de Phosphorluciferwet 1901 geldt voor wat betreft de opsporingsbevoegdheid van de ambtenaren van de arbeidsinspectie een beperking tot dat onderdeel, dat betrekking heeft op de verwaardiging van witte fosforlucifers. Hieruit kan de conclusie worden getrokken, dat op basis van de strekking van deze wetten de aldaar voor de arbeidsinspectie neergelegde taak hoofdzakelijk gericht was op de arbeidersbescherming in enge zin, dat wil zeggen het beschermen van de arbeider, niet alleen tegen gevaren die uit het verrichten van arbeid voortvloeiden, maar tevens tegen overmatige werktijden.

Na een herhaling van de in de Arbeidswet 1889 zelf neergelegde taak, met een verbreding naar de daarop gebaseerde algemene maatregelen van bestuur en ministeriële regelingen, werd, via de wettelijke opdracht, dat de werkkring en de bewoegdheden van de betreffende ambtenaren bij algemene maatregel van bestuur geregeld diende te worden, "het toezicht op de uitvoering" in dat besluit nader uitgewerkt. Deze nadere uitwerking kan men aanduiden met de term "feitelijke taakstelling". In deze feitelijke taakstelling, die wit een aantal elementen ${ }^{622}$ bestaat, zoals bijvoorbeeld het bevorderen van uniformiteit in de toepassing van de gegeven voorschriften, het verstrekken van inlichtingen en het geven van adviezen, springt éen element in het oog. Het betreft het verstrekken van inlichtingen en het doen van voorstellen aan hen die arbeid doen verrichten, om zo de bezwaren, die anders uit de toepassing van de wettelijke voorschriften voor de nijverheid zouden voortvloeien, weg te nemen. Met name dit omzichtig geformuleerde element van de feitelijke taakstelling maakt duidelijk, dat op het terrein van de sociale wetgeving behoedzaam te werk gegaan diende te worden, en dat de industrieel gevrijwaard moest worden van ( al ) te nadelige gevolgen van deze wetgeving. 
In artikel 9 van de Veiligheidswet van 1895 was een zelfde opdracht als in artikel 12 van de Arbeidswet 1889 omtrent de werkkring en bevoegdheden van de betreffende ambtenaren neergelegd. De gekozen systematiek leidde ertoe, dat nu een op deze beide artikelen gebaseerde algemene maatregel van bestuur moest worden uitgevaardigd. In deze algemeene maatregel van bestuur werd opnieuw, maar no de in deze beide wetten zelf neergelegde wettelijke taakstelling herhaald en eveneens opnieuw verbreed naar de op deze wetten gebaseerde algemene maatregelen van bestuur en ministeriële regelingen. Vervolgens was "het toezicht op de naleving" onderscheidenlijk "toezicht op de uitvoering" opnieuw nader uitgewerkt in een feitelijke taakstelling $^{633}$, die echter de omzichtige van de vorige mist. Daarbij zal ongetwijfeld een rol gespeeld hebben het toegenomen besef, mede als gevolg van de activiteiten van de arbeidsinspectie, dat de arbeiders in de fabrieken en werkplaatsen grote risico's liepen en dat de bescherming hiertegen (te) veel te wensen overliet. Maar zeker ook de ervaringen die men inmiddels had opgedaan met de betreffende ambtenaren van de arbeidsinspectie zullen daar miet vreemd aan zijn geweest. De Vries ${ }^{634}$ gaat wel heel ver door te stellen, dat de inspecteurs door hun kalm optreden en door hun raadgevingen gaandeweg min of meer populair werden. Maar duidelijk was wel geworden, dat de betreffende ambtenaren van de arbeidsinspectie de ondernemers welwillend tegemoet traden en niet, om de woorden van Kerdijk ${ }^{\mathrm{Bas}}$ aan te halen,

"met de vijandige gestrengheid van den slechts bevelenden ambtenaar"

jegens hen optrad.

Hiervoor is al geconstateerd, dat de in de betreffende onder de arbeidsinspectie regarderende wetgeving de wettelijke taakstelling gericht was op arbeidersbescherming in enge zin. Bij de uitwerking van het "toezicht houden op" in de betreffende algemene maatregel van bestuur was echter steeds een ruimere feitelijke taakstelling van de arbeidsinspectie neergelegd, waardoor in vele gevallen niet alleen buiten de oevers werd getreden van wat $\mathrm{k}$ genoemd heb arbeidersbescherming in enge zin, maar geheel andere beleidsgebieden werden betreden dan het terrein van de arbeidersbescherming. Hieraan ligt mijns inziens ten grondslag de redenen, die een rol hebben gespeeld bij het ontstaan van de arbeidsinspectie, waaronder het van regeringswege beschikken over een orgaan, dat haar op de hoogte kon houden omtrent de bestaande toestanden op nijverheidsgebied en dat haar kon adviseren omtrent de toepassing en verbetering wan de wettelijke bepalingen betreffende de factor arbeid. Op deze wijze was het mogelijk om de feitelijke taken binnen een wettelijke opdracht gestalte te geven, maar evengoed leidde deze feitelijke taakstelling weer tot nieuwe wettelijke taakstellingen.

Dit was het eerst het geval bij de Ongevallenwet 1901. Terzake van deze wet had de arbeidsinspectie een aantal wettelijke taken gekregen. Allereerst het verschaffen van informatie aan de Rijksverzekeringsbank over een bepaalde onderneming, die bekend was bij de arbeidsinspectie. Vervolgens het wegnemen van misstanden in het belang van, zowel de Rijksverzekeringsbank als de betrokken werkgever. Tot slot het adviseren en voorlichten van de werkgever op het gebied van de veiligheid, voor zover de betreffende inrichting niet onder de werkingssfeer van de Veiligheidswet van 1895 viel. Maar daarnaast werd de arbeidsinspectie tevens belast met het geven van adviezen over de indeling van de onderneming in een gevarenklasse, de toekenning van een gevarencijfer, de aard van de inrichting of de toekenning van de schadeloosstelling. Niet alleen leidde de feitelijke taakstelling tot een nieuwe wettelijke taakstelling, maar deed een nieuw element haar intrede: er werd een beroep gedaan op de kennis, die bij de arbeidsinspectie over bedrijven en inrichtingen aanwezig was.

De reorganisatie van de arbeidsinspectie in 1909 leidde tot een gewijzigde, maar beter geformuleerde wettelijke taakstelling. De ambtenaren van de arbeidsinspectie, waren; behalve met de taak hun bij andere wetten opgedragen, nu belast met de handhaving van en de medewerking aan de uitvoering van de Arbeidswet 1889. De overige onder de arbeidsinspectie regarderende wetten zouden vanaf nu verwijzen naar deze basisbepaling in de arbeidswetgeving. De thans geformuleerde wettelijke taakstelling omvatte meer dan het houden van toezicht op de naleving, namelijk nog andere verrichtingen, die voor de uitvoering van de wet noodzakelijk waren. Overigens geldt deze formulering heden ten dage nog. Naast deze toezichthoudende taak waren 
de ambtenaren van de arbeidsinspectie belast met het opsporen van overtredingen van de bedoelde wetten. Dus ook hier geldt een wettelijke taakstelling, die opgesplitst kan worden in twee elementen, namelijk toezicht en opsporing.

Het toezichthoudende element, de handhaving van en de medewerking aan de uitwoering van de wetgeving; werd nader uitgewerkt in de navolgende feitelijke taakstelling, waarin overigens de in de wet neergelegde taak wederom herhaald werd:

a. het bezoeken van plaatsen, dic aan het toezicht zijn onderworpen;

b. het bevorderen van uniformiteit in de toepassing van de gegeven voorschriften;

c. het bevorderen van overeenstemming tussen de eisen van de wetgeving en de belangen van alle bij de arbeid betrokken personen;

d. het op verzoek adviseren van de vergunningverlenende instanties (de burgemeesters en de commissarissen van de Koningin $)^{630}$

e. het desgevraagd adviseren van en het desgevraagd mondeling of schriftelijk verschaffen van inlichtingen aan de verantwoordelijke bewindsman;

f. het de bewindsman doen van voorstellen;

g. het zich op de hoogte houden van de arbeidstoestanden en de gebeurtenissen, die van belang zijn, voor de kennis van de arbeidsverhoudingen;

h. het instellen van onderzoeken en verzamelen van gegevens die voor de arbeidsinspectie van belang zijn. Deze feitelijke taakstelling van de arbeidsinspectie, die overigens heden ten dage nog geldt, is, in vergelijking met de eerdere feitelijke taakstelling aanmerkelijk verruimd door de toevoeging van twee nieuwe elementen, namelijk de onderdelen $\mathrm{g}$ en $\mathrm{h}$. Opmerkelijk is vooral de onder g genoemde taak van de arbeidsinspectie: het zich op de hoogte houden van de arbeidstoestanden en de gebeurtenissen, die van belang zijn voor de kennis van de arbeidsverhoudingen. Ongetwijfeld speelde daarbij het volgende een niet onbelangrijke rol: Sinds 1906 ontstaat de moderne vakbeweging, die streefde naar verbetering van de arbeidsvoorwaarden, waaronder een verhoging van het loon en een verkorting van de arbeidstijd. Eveneens in het begin van deze eeuw ontwikkelen zich de werkgeversorganisaties. Dat betekent dat er een verschuiving plaatsvindt van een individueel naar een collectief optreden. Dit laatste vindt zijn weerslag in de afsluiting van collectieve arbeidsovereenkomsten; waarvan de erkenning in de rechtsorde plaatsvindt in artikel $1637 \mathrm{n}$ van de op 1 februari 1909 in werking getreden Wet op de arbeidsovereenkomst. Het begrip arbeidsverhouding betekent meer dan alleen het geheel van collectieve betrekkingen terzake van de arbeid als produktiefactor tussen werkgevers en arbeiders. Het kan zich ook richten op de rechtsbetrekking tussen twee personen, waarbij de een arbeid doet verrichten en een ander die arbeid verricht. Tot slot kan het ook een beperkte betekenis hebben, namelijk als synoniem voor de arbeidsovereenkomst of de dienstbetrekking.

Overigens passen de beide bedoelde onderdelen $g$ en $h$ wel in de redenen die aan het ontstaan van de arbeidsinspectie ten grondslag lagen, namelijk het beschikken over een overheidsorganisatie, die kan fungeren als informatiebron terzake van de factor arbeid.

Na de reorganisatie kwamen een wijziging van de Arbeidswet 1889 - de Arbeidswet 1911 - en de Steenhouwerswet 1911 tot stand. De laatstgenoemde wet beoogde de gevaren terzake van de gevreesde steenhouwersziekte tegen te gaan. In beide gevallen betreft het wetgeving in het kader van de arbeidersbescherming in enge zin. Maar tot de Eerste Wereldoorlog en ook tijdens deze oorlog werden door de arbeidsinspectie vele activiteiten verricht die niet tot haar eigenlijke werkterrein, dat wil zeggen arbeidersbescherming in enge zin, behoorden. De basis van deze activiteiten ligt eveneens in het gegeven, dat de arbeidsinspectie over kennis beschikte van het bedrijfsleven. Maar dat niet alleen; de arbeidsinspectie was in staat niet bekende, maar noodzakelijke informatie op korte termijn te verkrijgen. Het antwoord op de vraag, waarom de arbeidsinspectic daarvoor ingeschakeld werd, is naar mijn mening eenvoudig: zij was de enige overheidsorganisatie, die zich met deze activiteiten kon bezighouden, omdat zij over het daarvoor vereiste apparaat beschikte.

Met de totstandkoming van de Arbeidswet 1919 verandert het beeld. Hoewel deze wet, blijkens de conside- 
rans, de arbeidsduur in het algemeen beperkte en gevaarlijke arbeid van jeugdige personen en van vrouwen wilde tegengaan, reikte de wet echter verder dan de arbeidersbescherming in enge zin van de voorgaande wetten. Het karakter van deze wet bestond niet alleen meer uit het bestrijden vain misstanden, maar gaf in feite een regeling van de factor arbeid ${ }^{637}$. Hieruit kan worden afgeleid, dat de feitelijke taakstelling van de arbeidsinspectie nu voor een deel zijn weerslag vindt in de uitvoering van de wettelijke taakstelling, namelijk het op grond van de Arbeidswet 1919 te voeren vergunningenbeleid.

In de periode tot de Tweede Wereldoorlog zou de feitelijke taakstelling leiden tot nieuwe wettelijke taakstellingen. Als eerste moet genoemd worden de Huisarbeidswet 1933, waarbij voor het eerst het beginsel werd verlaten van onthouding van overheidsbemoeienis op het terrein van de loonvorming door het vaststellen van een minimumloonregeling. De handhaving van, de medewerking aan de uitwoering van deze wet alsmede het opsporen van overtredingen was opgedragen aan de arbeidsinspectie. Hiermee deed de arbeidsinspectie officieel haar intrede op het terrein van de loonvorming. Ten tweede wil ik wijzen op de taak van de arbeidsinspectie in het kader van de Wet algemeen verbindend en onverbindend verklaren van bepalingen van collectieve arbeidsovereenkomsten, namelijk het op verzoek van de verantwoordelijke bewindsman instellen van onderzoeken naar de naleving van verbindend verklaarde bepalingen van collectieve arbeidsovereenkomsten. In de jaren ' 30 was overigens de toenemende bemoeienis van de overheid op sociaal-economisch terrein zuiver incidenteel en werd het volledig gedicteerd door de loop der gebeurtenissen. Dit blijkt onder meer uit de Wet houdende tijdelijke maatregelen betreffende de mechanisatie in de sigarenindustrie, de Wet tot regeling van het verrichten van arbeid door vreemdelingen, de Wet inzake verdeling van de beschikbare arbeid 1937 en de Bedrijfsvergunningenwet 1938. Ten aanzien van de bemoeienis van de arbeidsinspectie met deze wetten gold steeds het argument, dat deze overheidsdienst reeds contact had met het bedrijfsleven en over een grote hoeveelheid kennis beschikte over alles wat zich daar voordeed. Opvallend bij de laatstgenoemde wetten is echter, dat de arbeidsinspectie miet meer als enige overheidsdienst genoemd wordt. De positie van de arbeidsinspectie veranderde, was zij tot dan toe de enige, die zich op dit terrein bewoog, de toenemende bemoeienis van de overheid op sociaal-economisch terrein leidde tot uitbreiding van haar taken; er kwamen andere departementen, waaronder Economische Zaken.

De activiteiten van de arbeidsinspectie gedurende de Tweede Wereldoorlog bestonden, naast de taak haar opgelegd bij de al bestaande wetten, uit werkzaamheden die betrekking hadden op maatregelen die door of namens de bezetter waren uitgevaardigd, zoals bijvoorbeeld de verboden tot het stilleggen van ondernemingen, tot verkorting van de werktijd, tot het ontslaan van werknemers, en tot het verlagen van de lonen. Ook hier zou gesteld kunnen worden, dat de aan de arbeidisnsepctie toebedeelde feitelijke taakstelling ten grondslag lag aan deze wettelijke taakstellingop het terrein van de arbeidsverhoudingen.

Noch de wettelijke, noch de feitelijke taakstelling van de arbeidsinspectie zou na de Tweede Wereldoorlog veranderen. De reeds bestaande bemoeienis van de arbeidsinspectie op het gebied van de arbeidsverhoudingen, werd na de oorlog allereerst voortgezet via het Buitengewoon Besluit Arbeidswerhoudingen 1945, op grond waarvan de arbeidsinspectie bemoeienis had met het ontslagverbod, het verbod van werktijdverkorting en de loon- en arbeidsvoorwaarden, en uitgebreid via de Wet plaatsing minder-valide arbeidskrachten, daar waar de arbeidsinspectie belast was met het toezicht terzake van de loonbetaling van de minder-valide arbeider.

Op het terrein van de arbeidersbeschermende wetgeving, het oorspronkelijke werkterrein van de arbeidsinspectie, zouden er, afgezien van de Arbeidswet 1919, aanvankelijk weinig veranderingen optreden. Met de Veiligheidswet 1934 breidde de wetgever de reikwijdte ten opzichte van haar voorgangster aanmerkelijk uit, maar bescherming van de arbeider tegen gevaren die uit het verrichten van arbeid voortwloeiden stond voorop. Maar de veranderingen kondigden zich op dit terrein al aan: preventie als basis voor regelgeving. Ik doel hiermee op het op vrijwillige basis instellen van een bedrijfsgeneeskundige dienst, die uiteindelijk in 1959 zou leiden tot een wijziging van de genoemde wet. Van belang is wat de toenmalige bewindsman destijds 
stelde: "beveiliging bij de arbeid" in de considerans van de wet moest ruim worden opgevat en zeker niet beperkt blijven tot de veiligheid in engere zin. De argumentatie voor het opnemen van de bedrijfsgeneeskundige zorg in de Veiligheidswet 1934 en het daarmee onder de hoede brengen van de arbeidsinspectie, rustte op het feit, dat deze zorg zich afspeelde binnen de bedrijfsgemeenschap en de arbeidsinspectie belast was met het toezicht op de veiligheid bij de arbeid in het algemeen en bij het verblijven in fabrieken of werkplaatsen in het bijzonder. Een ander standpunt zou, aldus de bewindsman, leiden tot miskenning van de oorsprong en de ontwikkeling van de bedrijfshygiëne.

De hiervoor bedoelde verandering werd eveneens aangekondigd door de Röntgenstralenwet, die echter nooit in werking is getreden. De beschermende werking van deze wet beoogde zich niet meer alleen uit te strekken tot degene, die gevaar liep bij het verrichten van bepaalde arbeid en zich van dat gevaar bewust was, althans zou moeten zijn, maar tevens tot ieder ander, die zonder zich bewust te zijn van enig gevaar, in de omgeving verbleef, waarin die arbeid werd verricht.

Deze gedachtengang zou na de Tweede Wereldoorlog worden doorgetrokken met de totstandkoming van de Sillicosewet en de Wet op de gevaarlijke werktuigen, beide stammend uit het begin van de jaren '50. De eerste wet was gericht op het voorkomen en bestrijden van silicose en andere stoflongziekten. Aan de tweede wet lag ten grondslag om in het belang van de veiligheid bepalingen vast te stellen ten aanzien van de vervaardiging van en handel in gevaarlijke werktuigen en beveiligingsmiddelen, alsmede over de keuring hiervan. Deze beide op preventie gerichte wetten reikten verder dan arbeidersbescherming; er was sprake van een bescherming van de arbeid in de ruimste zin.

In dezelfde tijd deed zich nog een nieuwe ontwikkeling woor. Naast de uitbouw van het instituut van de bedrijfsgeneeskundige dienst, de aanstelling van veiligheidsinspecteurs en de instelling van veiligheidscommissies veranderden de opvattingen over de arbeider en zijn arbeid. Als onderdeel van een goed bedrijfsbeheer ontstond belangstelling voor het bedrijfsmaatschappelijk werk en het sociaal welzijn in de onderneming, geënt op het beginsel, dat er zelfs bij een goede wettelijke regeling van de arbeidersbescherming altijd factoren zijn, waardoor bepaalde personen - soms ernstige - schade oplopen. In het verlengde hiervan lag besloten, dat personeelsbelangen oftewel de sociale belangen een onderdeel vormden van het belang van de onderneming als zodanig. Werkgever en arbeiders zouden in de onderneming harmonieus moeten samenwerken: de grondgedachte die aan de Wet op de ondernemingsraden van 1950 ten grondslag lag. De arbeidsinspectie anticipeerde hierop, hetzij op basis van haar zeer ruime feiteliike taakstelling, hetzij op basis van haar wettelijke taakstelling, zoals bijvoorbeeld terzake van de uitvoering van de Arbeidswet 1919. Overigens mag niet onvermeld blijven, dat de arbeidsinspectie vanaf 1971 in het kader van de Wet op de ondernemingsraden de bevoegdheid krijgt om inlichtingen te verkrijgen over de werkzaamheden en het functioneren van de ondernemingsraad, waarvoor het overigens niet onbekende argument werd gebezigd, dat de arbeidsinspectie uit hoofde van haar taak regelmatig in de ondernemingen komt. Deze zich in de jaren ' 50 voordoende ontwikkelingen vormen de basis van de Arbeidsomstandighedenwet.

Na de Tweede Wereldoorlog blijft er sprake van een zich verder uitbreidende overheidsbemoeienis op sociaal-economisch terrein. Dit leidt tot een toename van het aantal bijzondere overheidsdiensten, zoals bijvoorbeelld de loontechnische dienst ${ }^{638}$, de algemene inspectiedienst ${ }^{639}$ en de economische controledienst ${ }^{840}$. Dit betekende de bemoeienis van de arbeidsinspectie op een aantal terreinen met betrekking tot de arbeidsverhoudingen verminderde of verdween. De Wet tot regeling van het verrichten van arbeid door vreemdelingen zou allereerst vervangen worden door de Wet arbeidsvergunning vreemdelingen, welke op haar beurt weer vervangen werd door de Wet arbeid buitenlandse werknemers. Had de arbeidsinspectie bemoeienis met de eerste wet, met de beide laatstgenoemde wetten had niet zij, maar de loontechnische dienst bemoeienis. Hetzelfde geldt ten aanzien van de lonen en andere arbeidsvoorwaarden. Ten aanzien van de Bedrijfsvergunningenwet is het beeld niet anders. De wet van 1938 zou vervangen worden door de Bedrijfsvergunningenwet 1954, welke onder de economische controledienst regardeert.

De geschetste ontwikkelingen vormden een voorbode van een nieuw soort wetgeving, die niet alleen meer 
werd gericht op de persoon, die arbeid verricht, maar ook op de bescherming van anderen, die aan dezelfde gevaren zijn bloot gesteld of kunnen worden blootgesteld, met andere woorden: een integrale benadering van de mens als consument, als persoon die arbeid verricht, en zijn omgeving. Ik doel hiermee op wetgeving, die met de Bestrijdingsmiddelenwet 1962 een aanvang neemt. De kern van deze wet is het verbod om bestrijdingsmiddelen in de handel te brengen en toe te passen, indien dit middel niet tevoren door een bevoegde instantie op zijn deugdelijkheid is beproefd en indien het aan waarborgen ontbreekt, dat redelijkerwijze bij zijn toepassing ontoelaatbare gevolgen ontstaan, zowel op het terrein van de volksgezondheid, het milieu als op het terrein van de arbeidsbescherming. Een dergelijke integrale wet heeft tot gevolg, dat én of meerdere bijzondere overheidsdiensten met het toezicht en de uitvoering belast worden. De arbeidsinspectie dient zich bezig te houden met de op haar terrein liggende taak van het opsporen van overtredingen van specifieke veiligheidsvoorschriften aangaande de opslag en de toepassing van bestrijdingsmiddelen. De Bestrijdingsmiddelenwet 1962 zou al snel gevolgd worden door de Kernenergiewet, de Wet Gevaarlijke. Stoffen en de Wet inzake de luchtverontreiniging. Deze ingeslagen weg wordt voortgezet via de Wet chemische afvalstoffen, de Afvalstoffenwet, de Diergeneesmiddelenwet en de Wet millieugevaarlijke stoffen. Afhankelijk van de wet is de arbeidsinspectie belast met de uitvoering, met het opsporen van overtredingen of fungeert de arbeidsinspectie als adviseur van de vergunningverlenende instantie. De wettelijke taakstelling is dus gebaseerd op de relatie tussen het interne milieu, wat het tot het werkterrein van de arbeidsinspectie behoort, en het externe milieu; een taakstelling, die haar niet vreemd is, gezien de koppeling die was gelegd tussen de Veiligheidswet van 1895 en later de Veiligheidswet 1934 en de Hinderwet.

Een vergelijkbare situatie doet zich voor terzake van de Wet arbeid gehandicapte werknemers. Hier is sprake van een integrale beleidsbenadering van één speciale groep van werknemers. Ook hier is de wettelijke taak van de arbeidsinspectie beperkt tot het terrein van de arbeidsomstandigheden.

Hiervoor is de Arbeidsomstandighedenwet al genoemd. Met deze benaming komt tot uitdrukking, dat deze wet regelingen beoogt te geven voor al die factoren die in het arbeidsmilieu en met betrekking tot de werkende mens een rol spelen ${ }^{641}$. De wet bevat bepalingen omtrent de arbeidsomstandigheden in het algemeen en de veiligheid, de gezondheid en het welzijn in verband met de arbeid in het bijzonder, zulks ter bevordering van menswaardige arbeid; er is dus sprake van een integrale benadering omtrent de problematiek rond de arbeidsomstandigheden. Dit leidt in het kader van Arbo'91 tot een taakstelling van de arbeidsinspectie, die als volgt luidt ${ }^{\text {b42 }}$ :

"het vanuit de overheid beïnvloeden van de kwaliteit van de arbeidsomstandigheden in arbeidsorganisaties".

Dit betekent, dat niet alleen de wettelijke, maar ook de feitelijke taakstelling zich beperkt tot ến terrein, namelijk de arbeidsomstandigheden, maar dan wel in een veel ruimer perspectief gezien. Tijdens de gefaseerde invoering van de Arbeidsomstandighedenwet werden als reactie op de (inter)nationale economische crisis de zogenaamde grote operaties gestart, waaronder de zogenaamde $-2 \%$-operatie, waarbij door middel van het afstoten van taken enerzijds moest worden voldaan aan de gestelde capaciteitsreductie van $8 \%$, terwijl anderzijds ruimte moest worden gecreëerd voor nieuw beleid. In het kader van deze zogenaamde herallocatie van taken werden voorstellen uitgewerkt tot afstoting van taken van de arbeidsinspectie in het kader van het Buitengewoon Besluit Arbeidsverhoudingen 1945 - de ontslagprocedure en het verbod van werktijdverkorting -; taken waarvan men vond, dat zij niet tot het terrein van de arbeidsinspectie, de arbeidsomstandigheden, behoorden.

Bij een terugblik zien we dus, dat de wettelijke taakstelling van de arbeidsinspectie zich aanvankelijk beperkte tot arbeidersbescherming in enge zin. Tevens zien we, dat de nadere uitwerking van de wettelijke taakstelling, de feitelijke taakstelling, ruimer was. De feitelijke taken van de arbeidsinspectie konden binnen een wettelijke opdracht gestalte krijgen, maar evengoed leidde deze feitelijke taakstelling weer tot nieuwe wettelijke taakstellingen. Door een verruiming van de feitelijke taakstelling bij de reorganisatie van 1909, kon de arbeidsinspectie zich bezighouden met hetgeen zich onder meer afspeelde op het terrein van de arbeidsverhou- 
dingen. Een belangrijke argument hiervoor was allereerst, dat de arbeidsinspectie de enige overheidsdienst was, die zich met dergelijke activiteiten kon bezighouden, omdat het daarwoor vereiste apparaat aanwexig was. Vervolgens speelde het argument, dat bij de arbeidsinspectie kennis aanwezig was van het bedrijfsleven. Naast een uitbreiding van de al bestaande wettelijke taken op het terrein van de arbeidersbescherming, welke successievelijk verandert van arbeidersbescherming in enge zin naar arbeidsbescherming, leidde de feitelijke taakstelling met name in de jaren 30 tot nieuwe wettelijke taken juist op het terrein van de arbeidsverhoudingen, zoals bijvoorbeeld de Wet tot regeling van het verrichten van arbeid door vreemdelingen. Bij de toen tot stand gebrachte wetgeving en de rol, die de arbeidsinspectie daarbij toebedeeld kreeg, speelde opnieuw het argument, dat de arbeidsinspectie beschikte over kennis van het bedrijfsleven en reeds contacten onderhield met dat bedrijfsleven. Deze ontwikkeling terzake van het terrein van de arbeidswerhoudingen zette zich voort tijdens de Tweede Wereldoorlog en daarna. Maar wel veranderde positie van de arbeidsinspectie al gedurende diezelfde jaren 30 als gevolg van een uitbreiding van de overheid met nieuwe diensten en nieuwe taken. Na de oorlog zou dit nog versterkt worden, waardoor diverse wettelijke taken op het terrein van de arbeidsverhoudingen na de oorlog (uiteindelijk) zouden komen te vervallen. Voortschrijdende ontwikkelingen op het terrein van de arbeidsomstandigheden zouden ertoe leiden, dat de feitelijke en wettelijke taakstelling steeds meer integreren en zullen integreren en wel tot het terrein van de arbeidsomstandigheden, Overigens is het dan wel hoog tijd om de zeer ruim geformuleerde feitelijke taakstelling, zoals deze is neergelegd in het Organisatiebesluit Arbeidsinspectie, aan te passen.

\subsection{Naar analeiding van de kritiek op de arbeidsinspectie}

De arbeidsinspectie maakt rond de viering van haar honderdjarig bestaan een woelige tijd door. Tot in het begin van de jaren zeventig kon zij betrekkelijk ongestoord haar taak uitoefenen, hoewel toen al enige spanningen woorkwamen tussen de uitvoering in de praktijk en de snelle technische en maatschappelijke ontwikkelingen. Sinds het midden van de jaren zeventig leidde een toenemende belangstelling onder meer van werkgevers- en van werknemerszijde tot kritiek op het functioneren van de arbeidsinspectie. De reactie hierop van de zijde van de arbeidsinspectie werd, aldus Geers $^{643}$, gekenmerkt door het ontkennen van de kritiek, afweer en het aanbrengen van cosmetica. Hij verwijst daarbij naar een in 1976 uitgebrachte brochure, waarin alleen maar een positief beeld van de arbeidsinspectie werd geschetst en met geen woord werd ingegaan op de kritiek $^{644}$. Vier jaar later schetste een toenmalig districtshoofd van de arbeidsinspectie naar aanleiding van het negentigjarig bestaan van de dienst een overwegend rooskleurig beeld en werd de kritiek afgedaan met het verwijt, dat de critici slecht geinformeerd waren ${ }^{645}$. Met het in 1977 verschenen rapport "Arbeidsinspectie in Ontwikkeling" kregen de critici echter een behoorlijke steun in de rug. Dit rapport vormt de basis voor het Project Ontwikkeling Arbeidsinspectie. Kon Geers ${ }^{\circledR 48}$ nog schrijven, dat de kritiek op de arbeidsinspectie minder lijkt te zijn, de werkelijkheid is inmiddels anders. Door de Algemene Rekenkamer, en daarin gevolgd vanuit vakbondskringen, wordt niet mis te verstane kritiek geleverd, onder meer ten aanzien van de resultaten van het vorenbedoelde project, gezien de inzet van mensen en middelen en de doelstellingen daarvoor. Hierop werd van de zijde van de arbeidsinspectie afwerend gereageerd door te verwijzen naar het project Arbo'91.

De kritiek, die op de arbeidsinspectie geleverd is en wordt, is heel begrijpelijk en vaak niet ten onrechte. Toch wil ik op een aantal feitelijkheden wijzen, waarop de arbeidsinspectie niet of nauwelijks invloed heeft en die wellicht tot een meer genuanceerd beeld kunnen leiden.

In de eerste plaats wil ik wijzen op de dualistische taakstelling van de dienst, zowel in de nationale regelgeving, als in de terzake relevante verdragen van de Internationale Arbeidsorganisatie. De arbeidsinspectie heeft een tweeledige taka, namelijk het houden van toezicht en het opsporen van overtredingen. De in de betreffende wetgeving gekozen formulering

"het handhaven van en de medewerking aan de uitvoering van .....", duidt enerzijds op het administratieve toezicht en anderzijds op het repressieve toezicht. De eerste vorm van 
toezicht is naww verbonden aan de uitwoering van de betreffende wetgeving en is vooral gericht op preventie, dat wil zeggen het bevorderen van gedrag dat in overeenstemming is met de doeleinden, die aan de wettelijke voorschriften ten grondslag liggen door middel van voorlichting, advisering en het geven wan aanwijzingen. De tweede vorm van toezicht is niet zozeer gericht op preventie als wel op het aan het licht brengen van eventuele overtredingen.

Deze dualistische taakstelling leidt tot verschillende verwachtingspatronen bij de direct betrokkenen, de werkgevers en de werknemers. Geers wijst erop ${ }^{647}$, dat de werknemersorganisaties in deze ook niet geheel vrij uitgaan, door enerzijds te pleiten voor een weinig "ambtenaarachtig" optreden en het achterwege laten van regelzifterij en anderzijds te vragen om een uitputtend gebruik maken van de in de wet gegeven bevoegdheden en instrumenten in het kader van het toezicht en de opsporing.

In de tweede plaats is de personele bezetting van de arbeidsinspectie een knelpunt: Wanneer men van een overheidsorganisatie - volkomen terecht - verlangt, dat deze op een adequate wijze de haar opgelegde, en overigens in aantal toenemende, taken vervult, dient men deze organisatie ook de middelen ter beschikking stellen om dit te doen. Eén van deze middelen is de al genoemde personele bezetting; het aantal zogenaamde buitendienst-ambtenaren, dat de inspectiebezoeken moet afleggen en dat de contacten met de betrokkenen in de bedrijven en instellingen moet onderhouden, is volstrekt onvoldoende. Zeker als men dit aantal afzet tegen het aantal overige ambtenaren van de arbeidsinspectie; de verhouding is dan 1 op 2. Er kan derhalve gesproken worden van een zekere scheefgroei, maar dat wil niet zeggen, dat ik wil pleiten om het aantall laatstbedoelde ambtenaren drastisch te verminderen. Het werkterrein van de arbeidsinspectie is zo complex geworden, dat centralisatie van bepaalde kennis bij het directoraat-generaal van de Arbeid vrijwell onvermijdelijk is. Hetzelfde geldt voor ondersteunende of administratieve ambtenaren, die zorg hebben te dragen woor een adequate verwerking en registratie van gegevens.

In de derde plaats moet gewezen worden op aangelegenheden, die samenhangen met de werkzaamheden van de arbeidsinspectie als opsporingsinstantie, namelijk het vervolgings- en straftoemetingsbeleid. Het vervolgings- en seponeringsbeleid, dat door het Openbaar Ministerie wordt gehanteerd, is vaak voor de betrokken ambtenaren onbegrijpelijk en werkt dan demotiverend. Daarnaast is het straftoemetingsbeleid evenmin een stimulans. Als thet al tot straffen kwam, waren deze laag en stonden deze in geen verhouding tot het voordeel dat bij het plegen van de overtredingen van de voorschriften werd behaald. Inmiddels is de strafmaat van bijvoorbeeld de Arbeidswet 1919 opgetrokken van ten hoogste fl.100,-- naar ten hoogste fl.5000,-per overtreding, hoewel de mogelijkheid van hechtenis beperkt is gebleven tot ten hoogste én maand. In de Arbeidsomstandighedenwet is echter gebroken met het aloude eigen sanctioneringsstelsel; overtredingen worden aangemerkt als economisch delict, waardoor niet alleen hogere straffen, maar ook verschillende straffen of maatregelen kunnen worden opgelegd. Een mooi voorbeeld hiervan is een uitspraak van de rechtbank te 's-Gravenhage in 1989 in het geval van een aannemingsbedrijf te Leiderdorp. Tegen dlit bedrijf waren al eerder processen-verbaal opgemaakt, eisen gesteld en zelfs het bevel tot stillegging van werk gehanteerd. Nu was opnieuw een proces-verbaal tegen het bedrijf opgemaakt. De rechtbank veroordeelde het bedrijf tot een boete van fl.8000,-- en een voorwaardelijke bedrijfssluiting van drie maanden met een proeftijd van twee jaar. En dit had effect, nu werden wel de nodige maatregelen genomen, werden alle uitvoerders nader geinstrueerd en werd contact opgenomen met zowel de arbeidsinspectie, als de met Aboma ${ }^{648}$.

In de vierde en laatste plaats moet men beducht zijn voor een overschatting van de mogelijkheden, die de arbeidsinspectie heeft op het punt van controle en handhaving. Het is een illusie om te verwachten dat de arbeidsinspectie alles weet en alle denkbare misstanden kan corrigeren. En dan nog, als stringente controle al zou leiden tot het nalleving van alle wettelijke voorschriften, dan is dit nog geen garantie, dat er veilig en gezond wordt gewerkt. 
1. Met name bij de werknemersorganisaties en dan vooral bij de Industriebond NVV groeit de belangstelling voor de gevaren die de gezondheid en de veiligheid van de werknemers bedreigen. Dit blijkt uit de algemene beleidsprogramma's inzake de humanisering van de arbeid: Beleidsprogramma veiligheid en gezondheid, Amsterdam 1977, Sociaal beleid en humanisering, Amsterdam 1977, Zie H.M. de Burlett, t.a.p., blz. 15; A.J.C.M. Geers, t.a.p., blz. 245 .

2. In dat verband mag verwezen worden naar L. Reijnders e.a., Veilig op je werk, Amsterdam 1976, blz. 101, die melding maakt wan de vasthoudendheid van de vakbond om in de collectieve arbeidsovereenkomst bepalingen op te nemen op het gebied van de arbeidsomstandigheden bij Shell-Pernis in 1975.

3. Loonbureau, Veiligheid, gezondheid, hygiëne en milieu; bepalingen terzake voorkomend in de collectieve arbeidsovereenkomsten voor bedrijfstakken, 's-Gravenhage 1977.

4. In de metaal-CAO werd onder meer aambevolen onder meer aandacht te schenken aan de volgende punten: de veiligheidsopleiding, de verdeling van de verantwoordelijkheid voor de veilligheid tussen leiding, werknemers en gespecialiseerde functionarissen, de taak van de ondernemingsraad en het overnemen van die taak door een commissie, het betrekken van de overige werknemers bij het veiligheidsbeleid en het opstellen van een veiligheidsprogramma. Daarnaast waren er in andere bedrijfstak-cao's bepalingen opgenomen inzake onder meer een geneeskundig onderzoek, arbeid door jeugdigen, rook- en alcoholverbod, schaftgelegenheden en slaapdiensten.

5. A.J.C.M. Geers, t.a.p., blz. $101-102$.

6. DCA, Arbeidsomstandigheden in cao's, 's-Gravenhage ( februari ) 1987.

7. Zie DCA, Arbeidsomstandigheden in cao's, blz. 19.

8. DCA, Arbeidsomstandigheden in cao's, blz. $16-17$.

9. P. Wouters, Mislukte voorzet, ja; verloren wedstrijd nee, een onderzoek naar CAO-bepalingen op het terrein van de kwaliteit wan de arbeid, Industriebond. FNV (oktober) 1987; zie ook K. Korevaar/F. Soeterbroek, Arbeidsomstandigheden en CAO-beleid, in T.v.A. $1989 \mathrm{blz} .62 \mathrm{t} / \mathrm{m} 70$.

10. Wet van 8 november 1980 , Stb. 664 .

11. Dit zou de voorstanders van een terugtreden van de wetgever in deze vooralsnog toch te denken moeten geven. Verwezen mag worden naar W.J.P.M. Fase, Collectief arbeidsrecht na vijftig jaar, in Vijftig jaar sociaal recht in Leiden, Deventer 1986, blz. 25 , die een dergelijk terugtreden van de overheid bijvoorbeeld ten aanzien van de arbeidswetgeving in enge zin en de medezeggenschapswetgeving bepleit; zie ook A.J.C.M. Geers, t.a.p., blz. 266.

12. Het bezigen van de term "aanzet" is bewust, omdat hier naar mijn mening gesproken moet worden van een variant die in de wetgeving voorkomt. Bedoeld wordt het in artikel 1 van het op de Arbeidswet 1919 gebaseerde Arbeidsbesluit 1920, waarin onder meer is geregeld, dat een vrouw geen arbeid mag verrichten bestaande uit het tillen, trekken, duwen, dragen of op andere wijze verplaatsen van een last, indien deze arbeid 
kennelijk of naar het oordeel van het districtshoofd van de arbeidsinspectie of voor haar een te grote krachtsinspanning vereist of om enige andere reden een gevaar voor haar gezondheid oplevert.

13. Het betreft hier de collectieve arbeidsovereenkomsten voor schilder-, stukadoor-, afbouw- en terrazzobedrijven. Het bouw- en natuursteenbedrijf zal in 1991 volgen. Zie L. Burdorf/J. Klaver/P. Swuste, Asbest: handig, onverwoestbaar en dodelijk, in Intermediair $1989 / 32$ blz. 43.

14. In dit kader kan worden verwezen naar de brief van het FNV aan de Vaste Kamercommissie voor Sociale zaken en Werkgelegenheid van 28 september 1989 over de arbeidsinspectie en haar functioneren, waarin het volgende vermeld wordt:

"Een ander voorbeeld betreft het asbestbeleid. Na vele aandringen verkondigt de staatssecretaris De Graaf begin dit jaar een verbod op het gebruik van asbest te willen invoeren. Hoewel de Arboraad met het principe al heeft ingestemd en op de desbetreffende adviesaanvrage wacht, is de centrale dienst nog niet eens in staat een datum te noemen waarbinnen deze adviesaanvrage te verwachten valt".

L. Burdorf/J. Klaver/P. Swuste, in Intermediair 1989/32 blz. 43, schrijven het volgende. In 1978 werd een verbod op alle soorten asbest als de meest wenselijke oplossing gezien. Een belangrijk obstakel, de beschikbaarheid van veilige en volwaardige vervangingsmiddelen, blijkt overwonnen te zijn. Ook de werkgevers zijn inmiddels overtuigd van de gezondheidsrisico's, en hun aanvankelijke weerstand tegen een algeheel verbod is afgenomen. Met andere woorden: de bij de collectieve arbeidsovereenkomsten betrokken partijen zijn het eens, maar de wetgever laat op zich wachten.

15. Hoe effectief een dergelijk convenant is, moet nog blijken. Zie L. Burdorf/J. Klaver/P. Swuste, in Intermediair $1989 / 32$ blz. 43 .

16. Het convenant is tot stand gekomen in een tripartite werkgroep onder leiding van de directeur-generaal van de Arbeid De Roos; de werkgroep wist overigens in de korte periode van twee en een halve maand het convenant gestalte te geven, aldus minister Nijpels in zijn toespraak bij de ondertekening van het convenant. Overigens zullen de bepalingen van het convenant nader uitgewerkt worden en in hun toepassing worden gëvalueerd door eveneens een tripartite werkgroep, waarvan de directeur-generaal van de Arbeid eveneens het voorzitterschap op zich neemt, terwijl de directie Coördinatie Bouwbeleid van het ministerie van Volkshuisvesting, Ruimtelijke Ordening en Milieubeheer het secretariaat zal voeren.

17. Deze bewindsman is coördinerend "bouwminister".

18. Zie het gezamenlijke persbericht van de beide bewindslieden, het Algemeen Verbond Bouwbedrijf, Bouw- en Houtbond FNV, Hout-en Bouwbond CNV, Stichting Federatie Aannemers in de Afbouw-en Nevenbedrijven van de Bouwnijverheid van 16 augustus 1989, no. 168 ( ministerie van Volkshuisvesting, Ruimtelijke Ordening en Milieubeheer ).

19. Zie SER, Advies inzake sociaal beleid in de onderneming 1981/04. Zie voor het regeringsstandpunt terzake Tweede Kamer, zitting 1984 - 1985, 18711.1; zie voorts Tweede Kamer, zitting 1984 - 1985, 18711.2 ( verslag van een mondeling overleg).

20. Zie SER, Advies inzake het klachtrecht van individuele werknemers 1981/14.

21. Tweede Kamer, zitting 1974 - 1975, 13100.2 ( hfdst. XV begroting Sociale Zaken ) blz. 8 t/m 12 en blz. 18. 
22. Tweede Kamer, zitting 1974 - 1975, 13318.2 blz. 72 .

23. Tweede Kamer, zitting $1974-1975,13318.2$ (Nota inzake de Werkgelegenheid 1975), blz. $71-72$.

24. Tweede Kamer, zitting 1975 - 1976, 13955.2 (Nota inzake de Selectieve Groei (Ecomomische Structuurnota)) blz. 193 - 194 .

25. Wet van 5 juli 1979 , Stb. 448

26. Tweede Kamer, zitting 1976-1977, 14100.2 (Hfdst. XV begroting Sociale Zaken ) blz. 12.

27. Tweede Kamer, zitting 1977 -1978, 14800.2 ( hfdst. XV begroting Sociale Zaken) blz. 54 - 55; Tweede Kamer, zitting $1978-1979,15300.2$ ( hfdst. XV begroting Sociale Zaken) blz. 71.

28. Tweede kamer, zitting 1978 - 1979, 15650.2 (Volumebeleid ) blz. 25.

29. Tweede Kamer, zitting 1978-1979, 15650.2 (Volumebeleid) blz. $24-25$.

30. Tweede kamer, zitting $1979-1980,15800.2$ ( hfdst. XV begroting Sociale Zaken ) blz. 80.

31. Zie ook A.J.C.M. Geers, t.a.p., blz. 325; H.G. de Gier, Voor alle zekerheid. Sociaal beleid in maatschappelijk-cultureel perspectief, 's-Gravenhage 1987, blz. 114 - 115.

32. Tweede Kamer, zitting 1981 - 1982, 17100.2 (hfdst. XV begroting Sociale Zaken en Werkgelegenheid) blz, 27 .

33. Tweede Kamer, zatting 1982 - 1983, 17600.2 (hfdst. XV begroting Sociale Zaken en Werkgelegenheid) ble. 76 .

34. Zie Tweede Kamer, zitting 1984 - 1985, 18315.3 ( Samenhang grote operaties) blz. 3.

35. Tweede Kamer, zitting $1983-1984,18315.2$ ( Samenhang grote operaties) blz. 7 .

36. Deze operatie is ontstaan in januari 1981 onder het eerste kabinet-Van Agt. De vraagstelling daarbij was: Hoe zouden we de overheidsbemoeienis op diverse beleidsterreinen opzetten indien we, met de uiterst beperkte financiële ruimte in het achterhoofd, opnieuw vanuit een nul-positie zouden starten, los van historisch gegroeide verhoudingen, afspraken, wetten, regelingen en verwachtingen? Deze benadering werd zowel voor de korte als de middellange termijn bepaald door de taakstelling in de financiële sfeer: het aangeven van wegen waarlangs de noodzakelijke beperking van de groei van de uitgaven kon worden bewerkstelligd (Tweede Kamer, zitting 1983 - 1984, 16625.66 (Samenvattend Eindrapport Heroverweging Derde Ronde) blz. 4).

37. Zie Tweede Kamer, zitting 1985-1986, 16625.78 ( Samenvattend Eindrapport 4de ronde) blz. $28-29$.

38. Jaarverslag Directoraat-Generaal van de Arbeid over 1985, blz. 13.

39. Jaarverslag Directoraat-Generaal van de Arbeid over 1983, blz. 14. 
40. Zie Tweede Kamer, zitting 1982 - 1983, 17555.51. (Kabinetsformatie 1982 ) en Tweede Kamer, zitting 1981 - 1982, 16625.39 (Heroverweging collectieve uitgaven. Deelrapport 31 Regulering en deregulering Rapport van de Heroverwegingswerkgroep "Wettelijke voorschriften in verband met de economische ontwikkeling").

41. Tweede Kamer, zitting 1984 - 1985, 18315.3 (Samenhang grote operaties ) blz. 13.

42. Dit betreft overtredingen, die geen betrekking hebben op administratieve voorschriften zoals het hebben van een arbeidslijst. Het aantal overtredingen te dienaangaande bedroeg 429; zie Jaarverslag Arbeidsinspectie 1977, "s-Gravenhage 1979, blz. 22.

43. Jaarverslag Aurbeidsinspectie 1978, 's-Gravenhage 1979, blz. 39.

44. Zie Jaarverslag Arbeidsinspectie 1981, 's-Gravenhage 1982, blz. 45 - 46.

45. Op het gebied van de uitschakeling van de overcapaciteit, de capaciteitsbeheersing en de vaststelling van minimum-broodprijzen. Zie Jaarverslag Arbeidsinspectie 1982, 's-Gravenhage 1983, blz. 120.

46. Rapport Arbeidsomstandigheden in de Broodbakkerij, 's-Gravenhage 1982, blz. $285-286$ en blz. $296 \mathrm{t} / \mathrm{m}$ 304.

47. Besluit van 19 augustus 1961 , Stb. 264 .

48. Zie artikel 93, tweede lid, onder $\mathrm{j}$, van de Wet op de Bedrijfsorganisatie.

49. Zie A.L. Melai, Tuchtrechtspraak arbeidstijden broodbakkerij, (oktober) 1985; archief directoraat-generaall van de Arbeid.

50. Bij de Wet van 23 juni 1976, Stb. 367.

51. Tweede Kamer, zitting 1975 - 1976, 13.247.34; zie Hand. Tweede Kamer, ziting 1975 - 1976, blz. 3504.

52. Jaarverslag Arbeidsinspectie 1977, 's-Gravenhage 1979, blz, 17 - 18.

53. Tweede Kamer, zitting 1985 - 1986, 19.348.

54. Zie Hand. Tweede Kamer, zitting $1987-1988$, blz. 4759 .

55. Deze opmerking is afkomstig van de VVD-fractie; Hand. Tweede Kamer, zitting 1987 - 1988, blz. 4317. Het standpunt van de regering in deze is neergelegd in de beleidswoornemens Winkelsluitingswet 1976; zie Tweede Kamer, zitting $1987-1988,20035$.

56. Het standpunt van de CDA-fractie; zie Hand. Tweede Kamer, zitting 1987 - 1988, blz. 4338.

57. Dit blijkt wel uit de discussie en de onrust onder het winkelpersoneel, die ontstond na het in maart 1990 moeizaam tot bereikte compromis tussen het bedrijfsleven en de consumentenorganisaties dat de winkels op doordeweekse dagen een half uur en op zaterdag éen uur langer open mogen zijn. Op 12 juli 1990 stemde de ministerraad in met het voorstel van de minister van Economische Zaken tot wijziging van de Winkelsluitingswet 1976. De belangrijkste wijziging betreft de verschuiving van het uiterste sluitingstijdstip van win- 
kels van 18.00 uur naar 18.30 uur van maandag tot en met vrijdag en van 17.00 uur naar 18.00 uur op zaterdag. Zie Stcrt. 1990 134. Zie ook onder meer Trouw, D'66 probeert nog een half uur langer te winkelen, 9 maart 1990; De Volkskrant, Bonden verdeeld over voorstel wijziging winkelsluitingstijd, 9 maart 1990; De Volkskrant, Winkelpersoneel gaat actievoeren tegen latere sluitingstijd, 6 april 1990.

58. Zie PB 14 februari 1976, no. L. 39/40. Zie bijlage II van het SER, Advies arbeidsbescherming vrouwelijke werknemers 1980/2, blz, $23 \mathrm{t} / \mathrm{m} 26$ en bijlage B van het advies van de Emancipatiecommissie aangaande Arbeidsbeschermende maatregelen, juli 1979 , blz. $47 \mathrm{t} / \mathrm{m} 50$.

59. Zie artikel 5, tweede lid, onder a en c, van de zgn. tweede richtlijn.

60. Zie artikel 5, tweede lid, onder c, eerste zinsnede, van de zgn. tweede richtlijn.

61. Brief van 21 juni 1978. no. 82569. Zie SER-advies 1980/2 bijlage I, blz. $19 \mathrm{t} / \mathrm{m} 22$ en Emancipatiecommissie, Advies arbeidsbeschermende maatregelen, bijlage A, blz. $43 \mathrm{t} / \mathrm{m} 46$.

62. Zie het advies van de Emancipatiecommissie, blz. 22.

63. Zie het advies van de Emancipatiecommissie, blz. 28.

64. Zie hierover N. Kukler, Nachtarbeid door vrouwen in de industrie, in De Veiligheid 1984 blz. 497. Zie ook Tweede Kamer, zitting 1982 - 1983, 17032.5 ( memorie van antwoord) bijlage II ( evaluatierapport van de experimenten met nachtarbeid door vrouwen in de industrie ) en Tweede Kamer, zitting 1983 - 1984, 17032.7 ( brief met als bijlage twee evaluatieverslagen experimenten ).

65. Zie SER-advies 1980/2, blz. 11. Verwezen wordt naar SER, Advies over de verbetering van de arbeidsmarktpositie van vrouwen 1979/17.

66. Zie SER-advies 1980/2, blz. 12 - 13.

67. Zie SER-advies 1980/2, blz. 17 en advies Emancipatiecommissie, blz. 30.

68. Zie Nachtarbeid een duistere zaak, oktober 1979, blz. 19.

69. J. Siersema/T. Hak, "Even slecht is ook gelijk". Nachtarbeid in de industrie: nu ook voor vrouwen?, in Intermediair $1980 / 11 \mathrm{blz} .35 \mathrm{t} / \mathrm{m} 41$. Zie ook J. Siersema, Vrouwenarbeid - nachtwerk? Over arbeidsbescherming en emancipatie, Amsterdam 1981.

70. B.S. Frenkel, in TVVS 1980 blz. 60.

71. Tweede Kamer, zitting 1981, 17038.1 en 2.

72. Zie voor een samenvatting van het wetsvoorstel I.P. Asscher-Vonk, Nachtarbeid voor vrouwen, in S.M.A. $1981 \mathrm{blz} .772 \mathrm{t} / \mathrm{m} 782$.

73. In de Arbeidswet 1919 werd een nieuw artikel 28a ingevoegd.

74. Tweede Kamer, zitting 1981, 17032.3 (memorie van toelichting) blz. 10. 
75. Tweede Kamer, zitting 1981 - 1982, 17032.4 (voorlopig verslag) blz. 1.

76. Tweede Kamer, zitting 1981 - 1982, 17032.4 (voorlopig verslag) blz: 2 - 3. De D'66-fractie wordt hierin gesteund door de CPN-fractie, die tegen het wetsvoorstel is ( we Tweede Kamer, zitting 1981 - 1982, 17032.4 (voorlopig verslag) blz. 3 ) alsook de PPR-fractie ( zie Tweede kamer, zitting 1981 - 1982, 17032.4 (voorlopig verslag ) blz 4 ).

77. Hand. Tweede Kamer, zitting 1984 - 1985, blz. $5279-5280$.

78. Hand. Tweede Kamer, ziting $1984-1985$, blz. $5250-5251$.

79. Deze argumenten speelden bij het tot stand komen van de Arbeidswet 1889 en de Arbeidswet 1919 ; zie I.P. Asscher-Vonk, in S.M.A. 1981 blz. 774 t/m 776.

80. Hand. Tweede Kamer, zitting 1984 - 1985, blz. 5282.

81. Tussen het eindverslag en het verschijnen van de nota naar aanleiding ervan verstreek meer dan eén jaar. Dit als gevolg van de activiteiten van de commissie-Geelhoed, die in het kader van de deregulering bet wetsvoorstel aan een nader onderzoek onderwierp. Het rendement van dit nader onderzoek was een zogenaamde horizonbepaling, waardoor de tijdsduur van het stelsel in het wetsvoorstel zou worden beperkt tot drie jaar ( zie Tweede Kamer, zitting 1983 - 1984, 17931.9 ( eindbericht van de commilssie-Geelhoed ) blz. $317 \mathrm{t} / \mathrm{m}$ 322; Tweede Kamer, zitting 1983 - 1984, 17032.8 ( nota naar aanleiding van het eindverslag ).

82. Wet van 5 maart 1986 , Stb. 147.

83. Ministerie van Sociale Zaken en Werkgelegenheid, Vrouwen en nachtarbeid. Onderzoek naar nachtarbeid door vrouwen in de industrie ( hierna Onderzoek nachtarbeid ), 's-Gravenhage 1988, blz. 1.

84. Onderzoek nachtarbeid, blz. 48 - 49 .

85. Onderzoek nachtarbeid, blz, $51-52$.

86. Onderzoek nachtarbeid, blz. 53 .

87. Zie Tweede Kamer, zitting 1981, 17032.3 ( memorie van toelichting) blz. 10.

88. Zie artikel 11, eerste lid, van het Werktijdenbesluit voor kantoren 1937.

89. Tweede Kamer, zitting 1987 - 1988, 20689.3 (memorie van toelichting ) blz. 4.

90. Tweede Kamer, zitting 1987 - 1988, 20689.1 en 2.

91. Wet van 11 april 1989 , Stb. 95 .

92. Zie bijvoorbeeld Hand. Tweede Kamer, zitting $1988-1989$, blz. $5252-5253$.

93. Bij brief van 26 juni 1972, weergegeven in SER; Interimadvies inzake een Jongerenstatuut, 1974/9 Bijlage I. 
94. SER-advies $1974 / 9$, blz $3-4$.

95. SER-advies $1974 / 9$, blz. 4 en blz. 8

96. Tweede Kamer, zitting $1974-1975,13547.1$ en 2.

97. Van de zijde van de KVP-, ARP-en CHU-fractie; Tweede Kamer, zitting 1975 - 1976, 13547.3 (voorlopig verslag) blz. 1.

98. Van de zjde van de PvdA-fractie; Tweede Kamer, zitting 1975 - 1976, 13547.4 (voorlopig verslag) blz. 1 - 2. Ook de VVD-fractie maakte opmerkingen in deze richting; Tweede Kamer, zitting 1975-1976, 13547.4 (voorlopig verslag) blz. $2-3$.

99. Toweede Kamer, zitting 1976 - 1977, 13547.5 (memorie van antwoord) blz. 1.

100. SER, Vervolgadvies inzake een Jongerenstatuut 1976/1.

101. Hij verwees daarbij naar de aangekondigde Stagenota en de beschouwing die zijn ambtgenoot van Onderwijs en Wetenschappen Van Kemenade had gewijd aan het verschijnsel stage en de positie van de stagiair (Hand. Tweede Kamer, zitting $1975-1976$, blz. 3952). De zogenaamde Stagenota zou worden ingediend op 26 april 1977; zie Tweede Kamer, zitting 1976-1977, 14450.1 en 2 (Stages. Discussienota van de ministers van Onderwijs en Wetenschappen en van Sociale Zaken )

102. In plaats van te verwijzen naar de opvattingen van zijn ambtgenoot van Onderwijs en Wetenschappen, aldus de PvdA-fractie ( Tweede Kamer, zitting 1976 - 1977, 13547.8 ( eindverslag ) blz. 1 ).

103. Tweede Kamer, zitting 1976 - 1977, 13547.9 ( nota naar aanleiding van het eindverslag ), blz. 1.

104. Wet van 18 mei 1977, Stb. 360.

105. Om precies te zijn op 1 februari 1981; zie K.b. van 29 december 1980, Stb. 778.

106. SER, Interimadvies inzake een Jongerenstatuut 1974/9, blz. 7 - 8 .

107. Zie onder meer A. Kappelhof/J. van Drongelen, Het verbod van kinderarbeid, in S.M.A. 1986 blz. 226.

108. Zie H. Hoeksema/J. van Drongelen, "Als dit niet strafbaar is, kan de arbeidsinspectie beter ophouden met zjjn werk tegen de kinderarbeid", in SR 1988 blz. $255 \mathrm{t} / \mathrm{m} 258$.

109. Stcrt. 1984138.

110. Zie voor een uitgebreidere behandeling van deze richtlijnen A. Kappelhof/J. van Drongelen, in S.M.A. 1986 blz. $230 \mathrm{t} / \mathrm{m} 232$.

111. SER-advies $1976 / 1$, blz, 3 - 4.

112. De SER stelde, dat de activiteiten van de ondernemer op het gebied van voorlichting en begeleiding in een actief sociaal ondernemingsbeleid geïtegreerd diende te zjjn; zie SER-advies 1976/1, blz. 3 . 
113. Tweede Kamer, zitting $1977-1978,14828.1$ en 2.

114. Gewezen mag worden op de op 10 december 1974 bij de SER ingediende adviesaanvraag inzake het sociaal beleid in de onderneming.

115. Tweede Kamer, zitting 1976 - 1977, 14497.1 en 2.

116. Tweede Kamer, zitting 1977 - 1978, 14828.3 ( memorie van toelichting ) blz. 5.

117. Zie Tweede Kamer, zitting 1979 - 1980, 14497.10 ( tweede nota van wijzigingen ).

118. Zie H. Dekkers/R. Verstegen/M. van Tits/J. van de Ven, De positie van jeugdigen in het arbeidsproces. Het Jongerenstatuut nader beschouwd, 's-Gravenhage 1987 ( hierna Rapport jeugdigen ).

119. In 1984 was ruim $29 \%$ van alle werklozen jonger dan 23 jaar. Binnen de groep van jongeren onder 23 jaar was ongeveer $30 \%$ op zoek naar een baan. Van de ouderen ( $>23$ jaar ) was dit percentage $17 \%$. Het aantal jeugdigen ( $<18$ jaar ) dat geen volledig, noch partieel onderwijs volgt, kan geschat worden op ongeveer 55.000. Het aantal geregistreerde werkloze jeugdigen kan volgens het ministerie van Sociale Zaken en Werkgelegenheid vastgesteld worden op 26.400 , dat is $3,8 \%$ van het total aantal 15-, 16- en 17-jarigen op 1 januari 1985 ). Zie Rapport jeugdigen, blz. 2.

120. Rapport positie jeugdigen, biz. 116 t/m 119.

121. Brief van 17 maart 1988 , nr. DGA/SAB/87/19529.

122. De SER heeft te dienaangaande nog geen advies uitgebracht.

123. Zie Rapport positie jeugdigen, blz. 120.

124. Zie FNV, Wat we willen met de APO, februari 1978. Zie ook M. Davidse/W. van Voorden/J. Boersma/J.A. van Kranendonk, APO's..... wat zijn dat eigenlijk?, SMO 's-Gravenhage 1978/8; H.L. Bakels, t.a.p., 8 e druk 1987, blz. $200-201$.

1.25. C. van Veen (voorzitter van het VNO ) liet weten, dat de remedie, die de werkgevers voor ogen hadden ten einde de werkloosheid te bestrijden bestond uit het verlagen van de lonen en bet verhogen van de rendementen en daarmee basta; zie L. de Wolf, Werkgevers willen flexibele werktijden (de machteloosheïd van de vakbeweging), in Intermediair van 23 september $1983 / 38$ blz. 15. Deze laatste geeft bovendien een aantal aardige reacties van ondernemers uit verschillende bedrijfstakken op het verschijnsel "werkweekverkorting".

126. RCO, De arbeidsduur (verslag van de Commissie Arbeidsduur RCO aan het Centraal Beraad Arbeidsvoorwaarden )( hierna RCO, De arbeidsduur), (oktober) 1980; zie ook RCO, Discussienota arbeidsduur, op weg naar individualisering van de arbeidstijd ( hierna RCO, Discussienota arbeidsduur), "s-Gravenhage (december) 1980.

127. RCO, De arbeidsduur, blz. 6; RCO, Discussienota arbeidsduur, biz. 44 - 45 .

128. RCO, De arbeidsduur, blz. 36 - 37; RCO, Discussienota arbeidsduur, blz. $44-45$. 
129. RCO, De arbeidsduur, blz. 36 ; RCO, Discussienota arbeidsduur, blz. 44 .

130. RCO, De arbeidsduur, blz. 36 - 37; RCO, Discussienota arbeidsduur, blz. 44 - 45 .

131. Stichting van de Arbeid, Centrale aanbevelingen inzake aspecten van een werkgelegenheidsbeleid, 'sGravenhage 24 november 1982 (weergegeven in Dienst Collectieve Arbeidsvoorwaarden, Ontwikkelingen in CAO's sinds de centrale aanbevelingen van de Stichting van de Arbeid, 's-Gravenhage 1983, bijlage 1a).

132. Zie L. de Wolff, in Intermediair 1983/38 blz. 15 en blz. 17; W.J.P.M. Fase, Arbeidsduurverkorting, in S.M.A. 1983 blz. 343. Onder nexibele werktijden kan worden verstaan: die regelingen, die de mogelijkheid bieden om, afhankelijk van de eisen, die de bedrijfsvoering stelt, korter dan wel langer te werken dan de overeengekomen arbeidstijd per dag en per week, en op ander tijdstippen dan nu gebruikelijk is, echter met behoud van de overeengekomen arbeidsduur. Deze omschrijving is afkomstig uit de adviesaanvrage aan de Stichting van de Arbeid van 27 juli 1984, DGA/HASB/ 1984/9804, inzake de Arbeidswet 1919 en nieuwe arbeidstijdpatronen.

133. Deze brief werd tevens aan de Tweede Kamer gezonden; zie Tweede Kamer, zitting 1978 - 1979, 15394.11.

134. Zie voor een begripsbepaling J. van Drongelen, in S.M.A. 1983 blz. 78 - 79.

135. Zie voor een overzicht van de arbeidswettelijke normen $H$. Hoeksema/J. van Drongelen, De arbeidsen rusttijden van de arbeiders van 18 jaar of ouder op grond van de Arbeidswet 1919 in vogelvlucht, in S.M.A. 1987 blz. 163 t/m 169; B.S. FrenkeV/A.T.J.M. Jacobs, t.a.p., blz. 27 t/m 35.

136. Hand. Tweede Kamer, zitting 1978 - 1979, blz. 4396. Zie ook Tweede Kamer, zitting 1978 - 1979, 15394.22.

137. Hand. Tweede Kamer, zitting 1978 - 1979, blz. 4397.

138. Brief van 7 februari 1980, Hoofdafdeling Wetgevingsbeleid, no. 90.875 .

139. De feitelijke werktijd, 8 uren per dag en 40 uren per week, verschilde sterk van de arbeidswettelijk toegestane uren, bijwoorbeeld in fabrieken of werkplaatsen $81 / 2$ uur per dag en 48 uren per week. Er kon dus op weekbasis 8 uren overgewerkt worden, zonder dat daartoe een overwerkvergunning vereist was.

140. Voor het werken in ( semi-)continudiensten was een bijzondere regeling opgenomen, waarbij voor de vaststelling van het aantal dagen, waarop arbeid werd verricht, een dienst die zich over 2 opeenvolgende dagen uitstrekte, gerekend diende te worden als én dag.

141. Zie SER, Advies beperking overwerk 1982/16, blz. 11.

142. SER-advies $1982 / 16$, blz. 15 .

143. Bestaande uit de werkgeversleden, alsmede de Kroon-leden Van den Beld, Van Doorn, De Galan, Van der Grinten, Halberstadt, Kuipers, Meulenberg, Meys, Vermeijden, Van Wijk en Wolfson. Zie SER-advies 1982/16, blz. 15 t/m 20. 
144. Deze opmerking is in het kader van het wetsvoorstel niet relevant. De systematiek van de Arbeidswet 1919 staat niet ter discussie. Het wetswoorstel beoogt de wettelijk toegestane arbeidsduur terug te brengen, vooruitlopende op een algehele herziening van de wet.

145. Daarbij speelde een rol een onderzoek van de RCO naar de consequenties van het wetsvoorstel voor de bestaande werktijdregelingen; waarbij een aantal ( praktische) gevolgen naar voren kwam, onder meer ten aanzien van de ploegendienst-roosters. Zie RCO, Rapport Enige gegevens en conclusies op basis van het onderzoek naar de mogelijke consequenties voor het bedrijtsleven van het wetsontwerp tot wijziging van de Arbeidswet 1919 ( 5-dagen wetje), februari 1981.

146. Of herverdeling van arbeid een oneigenlijk element is in het kader van de Arbeidswet 1919, is, gezien de ontstaansgeschiedemis van de wet, nog maar de vraag. Een ander punt is, dat dit in de toelichting op het wetsvoorstel wel sterk benadrukt wordt, maar of het terecht is, is een tweede. De toegestane wekelijkse wettelijke arbeidsduur wordt teruggebracht in overeenstemming met de geldende praktijk, hetgeen in overeenstemming is met de considerans van de wet. Trouwens iedere limitering van de arbeidsduur leidt tot een herverdeling van arbeid. Daarnaast doet de meerderheid van de Raad voorkomen alsof het voorstel absoluut is, terwijl voorzien is in een ontheffings- en vrijstellingsmogelijkheid, zodat eventuele ongewenste gevolgen opgevangen kunnen worden.

147. Bestaande uit de werknemersleden en het Kroonlid Franssen. Ten aanzien van de twee onderhavige standpunten onthield het Kroonlid De Pous zich van een oordeel.

148. Zie SER-advies $1982 / 16$, blz. $21 \mathrm{t} / \mathrm{m} 23$.

149. Brief van 8 april 1983, no. 134932, HASB; zie ook de Notitie werkgelegenheidsbeleid ( januari) 1983, blz.. 16.

150. Brief van 27 juli 1984, DGA/HASB/84/9804.

151. De bewindsvrouwe gaf aan, dat deze advies-aanvraag vooruitliep op een integrale herziening van de Arbeidswet 1919, waarover de Stichting van de Arbeid bij een bij de brief van 3 september 1984, DGA/ HASB/ $84 / 9235$, gevoegde discussienota "inzake een nieuwe wettelijke werk- een rusttijdenregeling" advies werd gevraagd. Het advies inzake een nieuwe wettelijke werk- en rusttijdenregeling is in augustus 1987 uitgebracht.

152. Zie Loontechnische Dienst, Arbeidsduurverkorting in de periode november 1982 tot en met april 1985, 's-Gravenhage ( april ) 1986, blz. 19. Zie ook Loontechnische Dienst, De concrete invulling van de arbeidstijdverkorting, 's-Gravenhage ( december) 1986.

153. De in deze advies-aanvraag geschetste ( bijzondere ) problemen met betrekking tot de arbeid verricht door jeugdige arbeiders en de hiervoor bij of krachtens het Jongerenstatuut geldende arbeids- en rusttijden blijven hier buiten beschouwing.

154. M.H. van Eijk/H.J.P. Derks, Nieuwe arbeidstijdpatronen en hun effecten op veiligheid, gezondheid en welzijn. Een literatuuronderzoek Uitgevoerd in opdracht van het Directoraat-Generaal van de Arbeid door het IVA ( hierna Onderzoek nieuwe arbeidstijdpatronen ), Voorburg (januari ) 1987.

155. Ook wel "compressed worktime", "prestijd", "gecomprimeerde werktijd" of "compacte werktijd" genoemd. De samengedrukte werktijd kan worden onderverdeeld in de samengedrukte werkdag, waarbij de (middag) pauze verkort wordt van bijvoorbeeld eén uur tot een half uur, en de samengedrukte werkweek, wat neer- 
komt op een combinatie van een langere werkdag en een kortere werkweek; bijvoorbeeld een vierdaagse werkweek, waarbij echter het gemiddeld aantal overeengekomen arbeidsuren per week in beginsel gellik blijft. Zie. Onderzoek nieuwe arbeidstijdpatronen, blz. $27 \mathrm{t} / \mathrm{m} 32 \mathrm{en} \mathrm{blz.} 68$ - 69. Een voorbeeld van een samengedrukte werkweek kwam voor bij het bedrijf KMWE-precisie, waar de werktijd, in overleg met de vakorganisaties, voor een deel van het produktie-personeel was teruggebracht tot 3 werkdagen van 10,75 uur, waardoor een zogenaand twee-ploegenstelsel mogelijk werd. De gemiddelde werktijd per week werd daarbij teruggebracht tot 35,8 uur. Van de zijde van de arbeidsinspectie werd bezwaar gemaakt tegen deze lange werkdagen en werd een maximale arbeidsdag van ten hoogste 9,5 uur toegestaan, hetgeen echter wel tot gevolg had, dat de bedrijfstijd teruggebracht werd van 64,5 uur tot 57 uren per week. Zie ook A.J.C.M. Geers/G.J.J. Heerma van Voss, Flexibilisering van werktijden en de buigzame zorg voor menswaardige arbeidsomstandigheden, in SR 1988 blz. 216 , die overigens ook terecht op het volgende bezwaar, dat aan deze oorspronkelijke werktijdregeling kleeft, wijzen. De werknemers konden mamelijk geen verlof opnemen en alleen Goor met collega's te ruilen was een aaneengesloten vakantie mogelijk, hetgeen in strijd geacht kan zijn met de hoofdregel die ten aanzien van de minimum val antie in artikel $1638 \mathrm{bb}$ van het $\mathrm{BW}$ is neergelegd.

156. Onderzoek nieuwe arbeidstijdpatronen, blz. $33 \mathrm{t} / \mathrm{m} 40$ en blz. $69-70$.

157. Keuze werktijden kunnen worden onderverdeeld in glijdende, zwevende en variabele werktijden. Een glijdende werktijdregeling is een werktijdregeling met eventueel per dag wisselende begintijden van de arbeid, mar met een constant aantal arbeidsuren per dag en per week. Bij een zwevende werktijdregeling kiest de arbeider individueel of groepsgewijs zijn arbeidstijden die voor een bepaalde periode, bijvoorbeeld een week of een maand, zullen gelden. Bij gespreide werktijden worden de begin-, pauze- en eindtijden voor verscheidene arbeiders gelijktijdig bepaald. Zie onderzoek nieuwe arbeidstijdpatronen, blz, $60 \mathrm{t} / \mathrm{m} 64$ en blz. 73 - 74 .

158. Bij flexibele arbeidstijden kunnen vastliggende en veranderende elementen worden onderscheiden. Vastliggende elementen zijn onder meer het aantal te werken uren per dag of per week, de pauzetijden en bijvoorbeeld de ploegwisseling. Veranderende elementen kunnen onder meer betrekking hebben op de inzetbaarheid van de arbeider en het verplicht verrichten van overwerk. Geconstateerd wordt, dat de vastliggende elementen steeds meer onder druk komen te staan, door een nieuw vastliggend element, namelijk de (gemiddelde ) jaarlijkse arbeidsduur; zie Onderzoek nieuwe arbeidstijdpatronen, blz. $41 \mathrm{t} / \mathrm{m} 59 \mathrm{en}$ blz. $70 \mathrm{t} / \mathrm{m}$ 73.

159. Ten einde verwarring te voorkomen zal de term nieuwe arbeidstijdpatronen in het vervolg gebruikt worden.

160. Zie voor deze normen RCO, Discussienota arbeidsduur, blz, 15 - 16 en het rapport: Deregulering inkomensworming en arbeidsmarkt (DIA), Tweede Kamer, zitting 1983 - 1984, 17931.24 blz. 27. Overigens geven de door de bewindsvrouwe gegeven normen niet aan hoelang er maximaal per week gewerkt mag worden. Daaraan veranderen de vier-wekelijkse norm en de jaarnorm niets, daar deze uitgaan van een wekelijks gemiddelde.

161. Advies van 10 mei 1985, nr. S.A. 50.074/E/VI/Bu; zie Tweede Kamer, zitting 1986 - 1987, 19993.2 (bijlage blz. $31 \mathrm{t} / \mathrm{m} 37$.

162. Daarmede beoogde men de groeiende maatschappelijke ontwikkeling naar meer verantwoordelijkheid van sociale partners voor het vaststellen van arbeidstijdpatronen te benadrukken.

163. Tweede Kamer, zitting $1986-1987,19993.1$ en 2. 
164. Voor de overige categorieên van arbeid gelden dezelfde uitgangspunten, voor zover dit vereist is. Zie H. Hoeksema/J. van Drongelen, in S.M.A. $1987 \mathrm{blz.} 163 \mathrm{t} / \mathrm{m} 169$.

165. Dit criterium is te vinden in artikel 28, eerste lid, van de Arbeidswet 1919 en dient ter toetsing van een verzoek om onder meer overwerk te mogen verrichten.

166. Dit experiment wordt nog steeds voortgezet. Zie hierover L. de Bie, De mini-shift, in PW $1984 / 7 \mathrm{blz}$. $9 \mathrm{v} / \mathrm{m} \mathrm{12}$, die de mini-shift, als hier gevolgd, omschrijft met een letterlijke vertaling, namelijk een "kleine ploeg", hetgeen staat voor het werken met groepen, die in plaats van de volledige werktijd slechts 5 uur per dag aanwezig zijn. Een neutralere omschrijving kan als volgt gegeven worden: een regeling waarbij gewerkt wordt in 2- of 3-ploegen van bijvoorbeeld 5 of 6 uren per dag, zonder dat er sprake is van een ploegwisseling. Er zijn vaste ploegen, die bestaan uit een specifieke groep werknemers, zoals bijvoorbeeld een ochtendploeg met jeugdige werknemers en een avondploeg met ( gehuwde) vrouwen.

167. Zie Tweede Kamer, zitting 1987 - 1988, 19993.3. De bijgestelde nota zou op 12 februari 1988 bekend gemaakt worden ( zie Tweede Kamer, zitting 1987 - 1988, 19993.4)

168. Lid van de CDA-fractie.

169. Tweede Kamer, zitting 1987 - 1988, 19993.6 (verslag van een mondeling overleg ).

170. Lid van de VVD-fractie.

171. Lid van de PrdA-fractie.

172. Zie Tweede Kamer, zitting 1987 - 1988, 19993.5

173. Brief van 3 september 1984, DGA/HASB/84/9253. Tegelijkertijd is de bedoelde discussienota voor advies aan de Emancipatieraad voorgelegd.

174. Stichting van de Arbeid, Advies inzake een nieuwe wettelijke arbeids- en rusttijdenregeling, 's-Gravenhage 1987 (hierna Advies nieuwe Arbeidswet). Dit advies is samengevat door H. Hoeksema/J. van Drongelen, Het advies van de Stichting van de Arbeid inzake een nieuwe wettelijke werk- en rusttijdenregeling, in S.M.A. 1988 blz. $18 \mathrm{t} / \mathrm{m}$ 31. Zie ook A.J.C.M. Geers/G.J.J. Heerma van Voss, in SR 1988 blz. $216 \mathrm{t} / \mathrm{m} 221$. De Emancipatieraad verwerkte zijn reactie in het Advies flexibilisering van arbeidsrelaties, 's-Gravenhage 1987, II/35/87.

175. Discussienota, blz. 5 .

176. In de discussienota, blz. 3, wordt hieronder verstaan "naast de traditionele weg voor veiligheid en gezondheid, het bevorderen van de optimale ontplooiing van de mens in zijn arbeid door het creëren van nieuwe organisatie- en werkvormen die naast de technische en economische eisen die de bedrijfsvoering stelt, tevens tegemoet komen aan de psychische en socialle behoeften van de arbeidende mens".

177. Dit is te ongenuanceerd; zie H.Hoeksema/J. van Drongelen, Over de werkingssfeer en toepasselijkheid van de Arbeidswet 1919, in S.M.A. $1987 \mathrm{blz} .105 \cdot \mathrm{t} / \mathrm{m} 111$. 
178. Zie H. Hoeksema/J. van Drongelen, in S.M.A. $1987 \mathrm{blz}$. 110 - 111. Opgemerkt dient te worden, dat deze in de Arbeidswet 1919 neergelegde mogelijkheid om bepaalde personen op grond van hun inkomen of functie geheel of gedeeltelijk uit te zonderen van de toepasselijkheid van de wet, wel erg zwaar benadrukt wordt door dit als een praktisch bezwaar op te voeren.

179. Advies nieuwe Arbeidswet, blz. $4 \mathrm{t} / \mathrm{m} 6$.

180. Zie in dit verband ook het SER-advies $1982 / 16$, blz. 16.

181. Wat hiermee wordt bedoeld, wordt in het advies echter niet duidelijk gemaakt.

182. Discussienota, blz: 9 en blz. 15.

183. Advies nieuwe Arbeidswet, blz. 6 .

184. Discussienota, blz. 17.

185. Advies nieuwe Arbeidswet, blz. 9 - 10.

186. Zie Advies nieuwe Arbeidsdwet, blz. 11 - 12.

187. Zie artikel 27 , eerste lid, onder $c$, van de Wet op de ondernemingsraden.

188. Advies nieuwe Arbeidswet, blz. 10 - 11.

189. Dan wel algemeen verbindend verklaarde bepalingen van collectieve arbeidsovereenkomsten.

190. Zie H. Hoeksema/J. van Drongelen, in S.M.A. 1988 blz. $23 \mathrm{t} / \mathrm{m} 30$.

191. Zie A.T.J.M. Jacobs, Het recht op collectief onderhandelen in rechtsvergelijkend en Europees perspectief, Alphen a/d Rijn/Brussel 1986, blz. 299. Zie ook M.M. Olbers, Arbeidsvoorwaardenregeling bij wet of cao, in Schetsen voor Bakels, Deventer 1987, blz. 195.

192. Zie ook A.J.C.M. Geers/G.J.J. Heerma van Voss, in SR 1988 blz. 217.

193. Resp. de artikelen 28 en 27 van de Wet op de ondernemingsraden.

194. Zie A.T.J.M. Jacobs, t.a.p., blz. 307.

195. Zie CCOZ, Het werkt anders, Voorburg 1986

196. Brief van 10 maart 1989, DGA/SAB/89/04246. De SER brengt naar alle waarschijnlijkheid eind 1990 het advies uit. Inmiddels hebben reeds advies uitgebracht: Emancipatieraad, Advies herziening Arbeidswet, 's-Gravenhage ( december 1989 ); Raad voor het Jeugdbeleid, Jong geleerd oud gedaan? Een advies over de positie van kinderen en jeugdigen in de nieuwe Arbeidstijdenwet, Rijswijk ( januari ) 1990; Centrale Commissie voor Georganiseerd Overleg in Ambtenarenzaken, Advies inzake de Herziening Arbeidswet van 26 maart 1990, no. GO/90.091/CC Z.1162/907. 
197. Zie over de Arbeidstijdenwet onder meer N. Kukler, Arbeidstijdenwet opent weg naar nieuwe werktijdpatronen, in Gids voor personeelsbeleid $1989 / 6 \mathrm{blz} .22 \mathrm{t} / \mathrm{m} 27 ; \mathrm{N}$. Kukler, Advies-aanvrage SER over vervanging van Arbeidswet 1919: nieuwe rechten voor werknemers, in ORinformatie april $1989 \mathrm{blz} .4 \mathrm{t} / \mathrm{m} 6 \mathrm{en}$ blz. 11, K. Terwan, Nieuwe Arbeidstijdenwet en kinderarbeid, in S.M.A. $1990 \mathrm{blz} .200 \mathrm{t} / \mathrm{m} 208$; K. Wentholt, Emancipatiebeleid dringt niet door in de nieuwe Arbeidstijdenwet, in S.M.A. 1990 blz: $444 \mathrm{t} / \mathrm{m} 455$.

198. Besluit van 12 januari 1976, Stb، 97.

199. Besluit van 4 januari 1977 , Stb. 52 .

200. Besluiten van 21 januari 1982, Stb. 58 en Stb. 59 ( resp. t.a.v. fabrieken of werkplaatsen en de zgn. restgroepen ).

201. De zgn. EG-kaderrichtlijn van 27 november 1980, Pb EG 1980 L 327.

202. Richtlijn van 22 juli 1982, Pb. EG 1982 L 247.

203. Richtlijn van 19 september 1983, Pb EG 1983 L 263

204. Besluit van 18 februari 1988 , Stb. 100 .

205. Resp. Besluiten van 22 november 1988, Stb. 560 en Besluit van 1 april 1977, Stb. 269.

Zie onder meer: J.V.H. Notemans/Y. Kant/L.P.H. Vermeer, Asbest in het garagebedrijf. Verbod toepassing asbest in remvoering belemmerd door EG-regels, in M.v.A. 1989 blz. $391 \mathrm{t} / \mathrm{m} 395$.

206. Besluit van 30 augustus 1989 , Stb. 416.

207. Zie SER, Advies inzake vernieuwing van de wetgeving betreffende de gezondheid en de veiligheid bij de arbeid, 1976/18 bijlage I.

208. Zie vorige nt.

209. Hand. Tweede Kamer, 1979 - 1980, blz. 5388.

210. Hand. Tweede Kamer, zitting $1979-1980$, blz. 4657.

211. Hand. Tweede Kamer, zitting 1979 - 1980, blz. 4673.

212. Hand. Eerste Kamer, zitting 1980 - 1981, blz. 76.

213. Wet van 8 november 1980 , Stb. 664 .

214. Tweede Kamer, zitting 1976 - 1977, 14497.3 (memorie van toelichting) blz. 31.

215. Zie de artikelen 11 en 17 van de Arbeidsomstandighedenwet.

216. Tweede Kamer, zitting 1976 - 1977, 14497.3 ( memorie van toelichting ) blz. 34 .

217. Zie de artikelen 3 en 4 van de Arbeidsomstandighedenwet. 


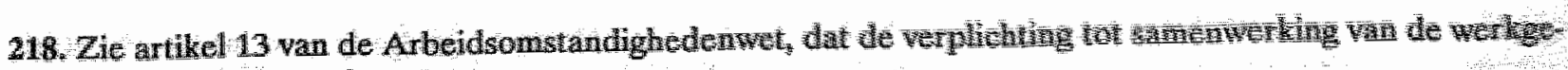
ver en de werkeners bevat.

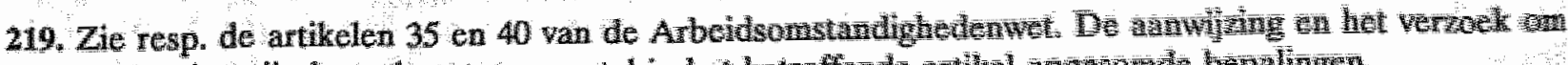

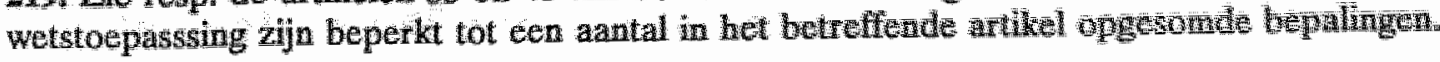

220. Zie de artikelen $43 \mathrm{t} / \mathrm{m} 45$ van de Arbeidsonstandighedenwet.

221. Zie de artikelen $17 \mathrm{l} / \mathrm{m} 20$ van de Arbeidsomstandighedenwe.

222. Tweede Kamer, zitting $1976-1977,144973$ ( menore van wellching) blz. 39.

223. Zie artikel 3 van de Arbeidsomstandighedenwet.

224. Zie artikel 3, eerste lid, onder e en g, van de Arbeidsomstandighedenwet. Zie Tweede Kaner, Rat $1976-1977,14497.3$ (memorie van toeliching) blz. $53-54$

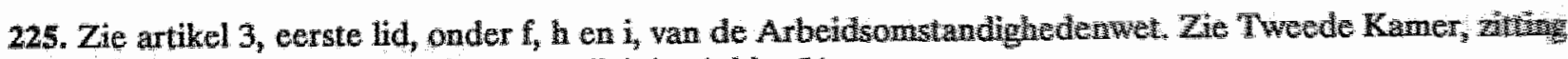
$1976-1977,14497.3$ ( memorie van toelichting) blz. 54.

226. De leden van de CDA-fractie voegen of in het kader van de bij de SER in behandeling zinde advesaanvraag d.d. 10 december 1974 omtrent het te voeren social beleid binaen de onderneming, dit advesergaan zijn mening zon kunen geven over de introductie van het begrip welzhn in he onderhavige wetswowstel, dan wel dat het uitbreagen van het advies terzake van het sociale beleid enige mate versneld zon kuzaes worden, zodat het nog tijdens de behandeling van het wetsvoorstel in de beschonwing zou kunnen werdes betrokken ( zie Tweede Kaner, zitting 1977-1978, 14497.4 ( woorlopig verdigg) blz.7).

227. Zie Tweede Kamer, zitting $1977-1978,14497.4$ ( voorlopig verslag) ble. 8, FNV en Radd van Besture in Arbeidszaken, brieven van resp. 8 en 19 september 1977 , aan de leden van de vaste commissie voor Sontile Zaken van de Tweede Kamer mel commentaar op wetsqoonstel 14497.

228. Zie Tweede Kamer, zitting 1977 - 1978, 14497.4 ( voorlopig verslag ) blz. 12.

229. Tweede Kamer, zitting 1978 - 1979, 14497.5 (memorie van antwoord) blz. 7 .

230. Tweede Kamer, zitting 1978 - 1979, 14497.5 ( memorie van antwoord) blz. 9 - 10 .

231. De oorspronkellijke artikelen van het wetsontwerp, namelijk 3 en 4 werden samengevoegd tot een nieuw artikel 3 en werd onderdeel i toegevoegd.

232. Met name de VVD-fractie; zie Tweede Kamer, zitting 1978 - 1979, 14497.9 ( eindverslag ) blz. 5.

233. Dit geldt trouwens voor het gehele artikel 3 van de Arbeidsomstandighedenwet.

234. Zie artikel 3, eerste lid, onder a $t / \mathrm{m} c$, van de Arbeidsomstandighedenwet.

235. Tweede Kamer, zitting 1976 - 1977, 14497.3 ( memorie van toelichting ) blz. 40.

236. Tweede Kamer, zitting 1976 - 1977, 14497.3 ( memorie van toelichting ) blz. 34 . 
237. Of een andere door de verantwoordelijke minister aangewezen ambtenaar; zie artikel 36, eerste lid, van de Arbeidsomstandighedenwet. Beiden kunnen een onder hun gezag werkzame ambtenaar machtigen tot het stellen van eisen; zie artikel 36 , tweede lid, van de Arbeidsomstandighedenwet.

238. Bedoeld zijn de artikelen 2 en 24 van de Arbeidsomstandighedenwet.

239. Zie bijvoorbeeld artikel 218 van het Veiligheidsbesluit voor fabrieken of werkplaatsen 1938 en artikel 55 van het Electrotechnisch Veiligheidsbesluit 1938.

240. Zie de artikelen $7,9,11,12$ en 28 van de Veiligheidswet 1934 .

241. Zie artikel 36, zesde lid, van de Arbeidsomstandighedenwet.

242. Zie artikel 36 , zevende lid, van de Arbeidsomstandighedenwet.

243. Zie artikel 36, achtste lid, van de Arbeidsomstandighedenwet.

244. Zie artikel 35 van de Arbeidsomstandighedenwet. Zie hierover J.A. Knegt, "De aanwijzing": fictie of bruikbaar gereedschap, in M.v.A. 1988 blz. $326-327$.

245. Zie Tweede Kamer, zitting 1976 - 1977, 14497.3 ( memorie van toelichting ) blz. 47 .

246. Aldus de PvdA-fractieleden; zie Tweede Kamer, zitting 1977 - 1978, 14497.4 (voorlopig verslag ) blz. $14-15$.

247. Tweede Kamer, zitting $1978-1979,14497.5$ (memorie van antwoord ) blz. 23 .

248. Zie artikel 35, zesde en zevende lid, van de Arbeidsomstandighedenwet.

249. Zie artikel 40 van de Arbeidsomstandighedenwet. Zie A.J.C.M. Geers, Verzoek om wetstoepassing, in Risikobulletin 1981/12 blz. 2 en 11.

250. Zie artikel 37 van de Arbeidsomstandighedenwet.

251. Zie Hfdst. 10 par. 4 (Een bijzondere bevoegdheid van het districtshoofd van de arbeidsinspectie in het kader van de Arbeidswet 1919 en de Veiligheidswet 1934 ).

252. Directoraat-Generaal van de Arbeid Jaarverslag 1988, (z.p. ), blz. 43.

253. Zie artikel 37 van de Arbeidsomstandighedenwet.

254. A.J.C.M. Geers, Intsrumenten Arbowet worden nog weinig gebruikt, in ORinformatie februari $1986 \mathrm{blz}$. 40.

255. Zie A.J.C.M. Geers, in ORinformatief februari $1986 \mathrm{blz} .40$.

256. Zie ook artikel 86, eerste lid, van de Arbeidswet 1919. De tekst van deze geheimhoudingsbepalingen is opnieuw vastgesteld bij de Wet van 1 december 1988 , Stb. 572 . 
"Ieder heeft het recht verzoeken schriftelijk bij het bevoegd gezag in te dienen".

258. Jaarverslag Arbeidsinspectie over 1980, over 1981, over 1982, over 1983, resp. blz. 202, blz. 231, blz. 183, blz. 175; Jaarverslag Directoraat-Generaal van de Arbeid over 1985, blz. 138.

259. Directoraat-Generaal van de Arbeid Jaarverslag 1988, blz. 44.

260. Zie ook A.J.C.M. Geers, in ORinformatie december 1986 blz. 11 - 12.

261. Artikelen 6 en 7 van de Arbeidsomstandighedenwet.

262. Artikel 9 van de Arbeidsomstandighedenwet.

263. Resp. de artikelen 4 en 10 van de Arbeidsomstandighedenwet.

264. Artikel 5 van de Arbeidsomstandighedenwet.

265. Zie hierover J.H.B.M. Willems, De melding van beroepsziekten, Voorburg ( maart) 1987.

266. Dit laatste is een gevolg van het door de Tweede Kamer aannemen van een amendement van het CDA; zie Tweede Kamer, zitting 1979 - 1980, 14497.53 en Hand. Tweede Kamer, zitting 1979 - 1980, blz. 4913.

267. Tweede Kamer, zitting 1976 - 1977, 14497.3 (memorie van antwoord) blz. 42.

268. Tweede Kamer, zitting 1978-1979, 14497.5 (memorie van antwoord) blz. 34 - 35. Overigens kan de minister van Sociale Zaken en Werkgelegenheid nadere regels uitvaardigen; zie artikel. 4, zesde lid, van de Arbeidsomstandighedenwet.

269. Tweede Kamer, zitting 1977 - 1978,14497.4 (voorlopig verslag ) blz. 24.

270. Tweede Kamer, zitting 1978 - 1979, 14497.5 ( memorie van antwoord) blz. 35.

271. Bij de Wet van 23 november 1977, Stb. 689.

272. Tweede Kamer, zitting 1975 - 1976, 13914.3 ( memorie van toelichting ) blz. 6.

273. Zie artikel 20v van de Veiligheidswet 1934 en artikel 5, eerste lid, van de Arbeidsomstandighedenwet.

274. Zie artikel 5, zesde lid, van de Arbeidsomstandighedenwet.

275. Zie artikel 20x van de Veiligheidswet 1934 en artikel 5, negende lid, van de Arbeidsomstandighedenwet.

276. Een dergelijke aanwijzing geschiedt, hetzij bij algemene maatregel van bestuur, hetzij door de directeurgeneraal van de Arbeid; zie artikel 5, eerste en tweede lid, van de Arbeidsomstandighedenwet.

277. Tweede Kamer, zitting 1975 - 1976, 13914.3 (memorie van toelichting) blz. 5

278. Tweede Kamer, zitting 1978 - 1979, 14497.5 ( memorie van antwoord) blz. 36. 
279. Zie artikel 12 van de Arbeidsomstandighedenwet.

280. Zie bijvoorbeeld artikel 7, zesde lid, van de Veiligheidswet 1934.

281. Tweede Kamer, zitting 1976 - 1977, 14497.3 (memorie van toelichting) blz. 42.

282. Tweede Kamer, zitting 1977 - 1978, 14497.4 ( voorlopig verslag) blz. 18.

283. Tweede Kamer, zitting 1978 - 1979, 14497.5 ( memorie van antwoord) blz. 27.

284. Zie artikel 40 van de Arbeidsomstandighedenwet.

285. Zie hierover onder meer A.J.C.M. Geers/J.K.M. Gevers, Arbeidsomstandighedenrecht, Deventer 1979, blz. 150 t/m 155; J.K.M. Gevers, Werkweigeren of doorwerken, in Risicobulletin 1980/4 blz. 9 - 10.

286. Zie artikel 13 van de Arbeidsomstandighedenwet.

287. Zie artikel 14 ( oud) van de Arbeidsomstandighedenwet; thans artikel 15 van die wet. Zie par. 3.2.14. ( samenloop Wet op de ondernemingsraden en de Arbeidsomstandighedenwet).

288. Aangezien artikel 27 , vijfde lid, van de Wet op de ondernemingsraden van overeenkomstige toepassing is verklaard, geldt deze bevoegdheid van de arbocommissie niet, wanneer de betreffende materie al in een collectieve arbeidsovereenkomst is geregeld.

289. Zoals onder meer de verplichting van de werkgever, de deskundigen in het bedrijf of de inrichting en de ambtenaren van de arbeidsinspectie om hen de nodige inlichtingen te verschaffen; de mogelijkheid om ambtenaren van de arbeidsinspectie tijdens hun bezoek aan het bedrijf of de inrichting te vergezellen en zich buiten tegenwoordigheid van anderen met hen te onderhouden en zonodig deskundigen van buiten het bedrijf of de inrichting uit te nodigen, zij het, dat voor de kosten die daarmee samenhangen, toestemming van de werkgever nodig is.

290. Overeenkomstig de regeling die geldt voor leden van de ondernemingsraad; zie artikel 14 , dertiende lid, van de Arbeidsomstandighedenwet en artikel 21 van de Wet op de ondernemingsraden.

291. Zie artikel 16 van de Arbeidsomstandighedenwet.

292. Zie de artikelen 43 en 44 van de Arbeidsomstandighedenwet.

293. Zie artikel 43, vierde en vijfde lid, van de Arbeidsomstandighedenwet.

294. Voorheen beter bekend als de MAC-commissie. De afkorting staat voor Maximaal Aanvaardbare Concentratie en dan van gevaarlijke stoffen. Zie Stcrt. 1988185 blz. 15.

295. Als voorloper van de Arboraad werd door de betreffende bewindsman in april 1980 de zogenaamde Voorlopige Arbeidsraad geïstalleerd, om mee te denken over het uitvoeringsbeleid van de Arbeidsomstandighedenwet.

296. Zie artikel 45 van de Arbeidsomstandighedenwet. 
297. Zie artikel 18 van de Arbeidsomstandighedenwet.

298. Nadere regels over taak en werkwijze worden bij algemene maatregel van bestuur vastgesteld.

299. Zie artikel 17 van de Arbeidsomstandighedenwet.

300. Door het aannemen van het amendement (zie Tweede Kamer, zitting 1979-1980, 14497.163) van Bakker en Toussaint ( resp. CDA en PvdA ); zie Hand. Tweede Kamer, zitting 1979 - 1980, blz. 4914.

301. Hand. Tweede Kamer, zitting 1979 - 1980, blz. 4681 - 4682; zie ook blz. 1362.

302. Zie artikel 20 van de Arbeidsomstandighedenwet.

303. Nadere regels worden gesteld over het beheer en de rechtsvorm van een gezamenlijke dienst, alsook over de manier, waarop de werknemers van de aangesloten bedrijven of inrichtingen in het beheer en bestuur ervan moeten zijn vertegenwoordigd.

304. Zie artikel 21 van de Arbeidsomstandighedenwet.

305. Ook over het beheer van een arbo-instituut worden madere regels gesteld.

306. Zie AJ.C.M. Geers, "Zulks ter bevordering van menswaardige arbeid" De nieuwe Arbeidsomstandighedenwet, in Intermediair 1981/9 blz. $1 \mathrm{t} / \mathrm{m} 9$ en blz. 27; A.J.C.M. Geers/ J.K.M. Gevers, De veiligheid en gezondheid van de werknemers en het ontwerp Arbeidsomstandighedenwet, in S.M.A. 1978 blz. $159 \mathrm{t} / \mathrm{m} 172$.

307. Zie Besluit van 15 november 1982, Stb. 673.

308. Resp. besluit van 28 maart 1985, Stb. 212 , Wet van 9 januari 1985, Stb. 129, en besluit van 21 december 1987, Stb. 605.

309. Zie A.J.C.M. Geers, De nieuwe mogelijkheden per 1 oktober. Laatste fase Arbo-wet in werking, in ORinformatie mei $1990 \mathrm{blz}, 6 \mathrm{t} / \mathrm{m} 8$.

De inwerkingtredingsdatum van 1 oktober is gerealiseerd; zie besluit van 12 september 1990, Stb. 488. Tegelijkertijd trad in werking het Veiligheidsbesluit restgroepen (Besluit van 20 september 1990, Stb. 491), zij het gefaseerd ( zie besluit van 20 september 1990, Stb. 492 ). Het genoemde veiligheidsbesluit bevat voorschriften woor die categorieën bedrijven of inrichtingen waarop geen van de al uitgevaardigde veiligheidsbesluiten, zoals bijvoorbeeld het Veiligheidsbesluit voor fabrieken of werkplaatsen, het Landbouwveiligheidsbesluit, het Veiligheidsbesluit Binnenvaart en het Veiligheidsbesluit Stuwadoorsarbeid, van toepassing is. Bij restgroepen dient bijvoorbeeld gedacht te worden aan degenen, die arbeid verrichten in kantoren, winkels, pakhuizen, zieken- en bejaardenhuizen.

310. J.J. van Duijn, Macro-economische gevolgen van deregulering, in Beleid en Maatschappij 1982 blz. 218.

311. Aan de VAR bij brief van 7 oktober 1982, no. 240.221 AAZ.

312. Tweede Kamer, zitting 1982 - 1983, 17931.5.

313. Tweede Kamer, zitting 1983 - 1984, 17931.9. 
314. Tweede Kamer, zitting 1982 - 1983, 17391.5 blz. 3 en 30.

315. Tweede Kamer, zitting $1983-1984,17391.9$ blz. $165 \mathrm{t} / \mathrm{m} 171$.

316. Echter met de toevoeging, dat het verspreidingsgebied van dit rapport met het oog op mogelijke activiteiten van terreurgroepen sterk beperkt diende te worden.

317. Zie voor de standpuntbepaling van het kabinet aangaande de voorstellen van de commissie-Geelhoed: Tweede Kamer, zitting 1984 - 1985, 17931.45; zie ook Tweede Kamer, zitting 1986 - 1987, 19824.3 (memorie van toelichting ) bijlage 1 .

318. Wet van 26 november 1987 , Stb. 535 .

319. Zie over dit begrip onder meer O. Smit, Hoe het begrip "welzijn" meer handen en voeten krijgt. Om "welzijn" te kunnen meten hoeft niet het wiel opnieuw uitgevonden te worden, in ORinformatie mei $1990 \mathrm{blz}$. $16 \mathrm{t} / \mathrm{m} 19$.

320. Zie. Tweede Kamer, zitting $1986-1987,19824.3$ (memorie van toelichting) blz. 8.

321. Dit probleem was al reeds gesignaleerd in het VAR-advies inzake de eerste fase van invoering van de Arbeidsomstandighedenwet, Zoetermeer 1982/2, blz. $11 \mathrm{t} / \mathrm{m} 21$. Over de oplossing van het probleem verschilde men echter van mening. De werkgeversvertegenwoordigers drongen aan op wetswijziging. Naar aanleiding van dit advies is door de verantwoordelijke bewindsman toegezegd om de SER om advies hierover te vragen. Dit is gebeurd op 10 augustus 1984 . Op 23 mei 1986 werd het bedoelde advies uitgebracht; zie SER, Advies samenloop Wet or en Arbowet, "s-Gravenhage 1986/6. Zie I. de Meester/H. van de Kamp, Het spanningsveld tussen Arbowet en WOR, in S.M.A. 1982 blz. 726 t/m 735; A.J.C.M. Geers, t.a.p., blz. 190 t/m 196.

322. Wet van 1 februari 1990 , Stb. 91.

323. Zie P.F. van der Heijden, Nieuwe geschillenregeling in de WOR, in ORinformatie januari 1990 blz. 22 23.

324. Tweede Kamer, zitting 1987 - 1988, 20583.3 (memorie van toelichting) blz. $3 \mathrm{t} / \mathrm{m}$ 6. Zie ook A.J.C.M. Geers, t.a.p., blz. 190 - 191; A.J.C.M. Geers, Opheffing samenloop bepalingen WOR en Arbowet, in ORinformatie januari $1990 \mathrm{blz} .24 \mathrm{t} / \mathrm{m} \mathrm{27}$. Van belang is om te vermelden, dat artikel 14 ( oud) van de Arbeidsomstandighedenwet bij deze wetswijziging is gewijzigd en vernummerd tot artikel 15.

325. A. Geers, in Intermediair $1981 / 9$ blz. 3.

326. Zie ook de rede van het Tweede Kamerlid Hartmeijer; Hand. Tweede Kamer, zitting 1979 - 1980 , blz. 4663 .

327. A.J.C.M. Geers, in Intermediair 1981/9 blz. 7; zie ook A.J.C.M. Geers/J.K.M. Gevers, in S.M.A. 1978 blz. 162; H.G. de Gier, "Making work more human?", in Beleid en Maatschappij 1980 blz. 103.

328. Tweede Kamer, zitting 1976 - 1977, 14497.3 (memorie van toelichting ) blz. 62.

329. Zie ook W.H.J. Reynaerts, Wet en bedrijfsdemocratie, in Beleid en Maatschappij 1977 blz. 212. 
330. W.H.J. Reynaerts, in Beleid en Maatschappij 1977 blz. 214.

331. A.J. de Roos, De Arbeidsomstandighedenwet, in S.M.A. 1982 biz. 308.

332. Zie P.L. Koopman, De Arbeidsomstandighedenwet: een nieuwe impuls voor werkoverleg?, in Intermediair 1981/37 blz. 53 .

333. P. L. Koopman, in Intermediair $1981 / 37$ blz. 55 .

334. Tweede Kamer, zitting 1979 - 1980, 14497.11 ( nota naar aanleiding van het eindverslag ) blz. 39.

335. SER-Advies 1981/4.

336. A.J.C.M. Geers, in Intermediair $1981 / 9 \mathrm{blz} .9$.

337. Op grond van artikel 43 van de Wet op de Bedrijfsorganisatie.

338. A.J.C.M. Geers, t.a.p, blz. 110.

339. Zie Tweede Kamer, zitting 1977 - 1978, 14497.4 (voorlopig verslag ) blz. 14 t/m 17.

340. Zie Tweede Kamer, zitting 1978 - 1979, 14497.5 ( memorie van antwoord) blz. 22.

341. Tweede Kamer, zitting 1979 - 1980, 14497.176. Zie Tweede Kamer, zitting 1979 - 1980, blz. 4916.

342. Industriebond FNV (landelijke adviescommissie veiligheid en gezondheid), Diskussiebrochure. Een ontwerp-beleidsprogram voor veiligheid en gezondheid, aprill 1977, blz. 5 .

343. A. de Bruin, Humanisering van de arbeid door de vakbeweging sterker naar voren gebracht, in De Veiligheid $1977 \mathrm{blz}$. $266 \mathrm{t} / \mathrm{m} 269$. Betrokkene is secretaris van de FNV.

344. J. Bloemarts, Op weg naar een drie-partijen-model voor het sociaal beleid in de onderneming, in S.M.A. 1978 blz. 597 - 598.

345. Adviesbureau Mens en Organisatie, De Arbeidsinspectie in ontwikkeling. Hoofdpunten wit een vooronderzoek, Amsterdam 1977 ( hierna Mens en Organisatie, POA).

346. De werkgroep bestond uit medewerkers van het tiende district, van het directoraat-generaal van de Arbeid en enkele departementale stafmedewerkers.

347. De keuze voor een experiment lag in het feit, dat een experimentenaanpak destijds in sociaal-wetenschappelijke kring vrij populair was, aldus H.Th. Bor/AJ. de Roos/G. van de Veen, Project ontwikkeling arbeidsinspectie: ervaringen met een organisatieontwikkelingsproject bij het directoraat-generaal van de Arbeid, in Organisatieverandering in de Rijksdienst. Praktijk en perspectieven, "s-Gravenhage 1985, blz. 297 ( hierna H.Th. Bor e.a., POA ). Zij verwijzen daarbij naar de in die tijd ontstane experimentenreeks onder auspiciën van de SER-COB, gericht op de bevordering van de medezeggenschap en het project "Arbeidsbureau Nieuwe Stijl", waarvan de start ook via een experiment heeft plaatsgevonden. 
348. Er was klaarblijkelijk een vrees, dat de experimenteerresultaten te vrijblijvend benaderd zouden worden. De verbreding zou bewerkstelligen, dat de gehele dienst erbij betrokken werd; zie $\mathbb{H}$.Th. Bor e.a, POA, blz. 288.

349. Zie H.Th. Bor e.a., POA, blz, 297 - 298; Mens en Orgamisatie, POA, blz. 1.

350. Mens en Organisatie, POA, blz. 2.

351. Deze zijn samengevat in Mens en Organisatie, De Arbeidsinspectie in ontwikkeling. Hoofdpunten uit een vooronderzoek, Amsterdam (juli) 1977. Zie ook Jaarverslag Arbeidsinspectie 1977, Voorburg 1979, blz. $3 \mathrm{t} / \mathrm{m} 9$.

352. Zie de artikel 11 en 12 van het Organisatiebesluit Arbeidsinspectie.

353. In de toelichting op dit doell werd in het projectplan opgemerkt:

"Het bereiken van humane levens- en werkomstandigheden is niet alleen een doelstelling van het externe beleid maar evenzeer van het interne beleid. Vanzelfsprekend is een goed intern sociaal beleid hiervoor een vereiste maar tevens een waarde op zich die zal moeten worden gerealiseerd".

Het bevorderen van de doelmatigheid speelt een belangrijke rol. Doelmatigheid moet echter hier niet uitgelegd worden als een begrip met een sterk efficiency-karakter. Het begrip moet hier ruim gehanteerd worden en wel zó, dat een doelmatige organisatie hanteerbare doelstellingen heeft, beschikt over een apparaat om die doelstellingen te verwezenlijken en kennis heeft van de mate, waarin en de wijze waarop de doelstellingen worden bereikt. Zie H.Th. Bor e.a., POA, blz. 302.

354. In het projectplan werd op de volgende manier geprobeerd de bedoeling aan te geven:

"Voor de gemaakte keuze gellen de volgende argumenten:

- doel van het project is het beter functioneren van de organisatie; het is dan van belang dat iedereen in de organisatie vanaf het begin betrokken is bij het proces dat op deze verbetering is gericht. Het betrekken van de medewerkers van de dienst bij het opstellen van werkgroepvoorstellen en de besluitvorming over en de invoering van deze voorstellen, is noodzakelijk om tot blijvende verbetering te komen;

- de dienst wordt echter ook in haar werk in de bedrijven enz. in toenemende mate geconfronteerd met participatieve processen. het is dan ook van het grootste belang dat de Arbeidsinspectie met de oplossing van haar eigen problemen met deze participatieve aanpak de nodige ervaring opdoet".

Deze participatieve aanpak wil echter niet zeggen, dat de meerderheid beslist over wat er gaat gebeuren, hetgeen het geval is bij een democratiseringsaanpak. Wel wordt het beleid niet vastgesteld, voordat de betrokken hun inbreng hebben kunnen leveren en hun oordeel bekend is bij degenen die de besluiten nemen. Zie H.Th. Bor e.a., POA, blz. 304.

355. Voor de werkgroepen gold, dat zij ophielden te bestaan, wanneer de bestaande organisatie in staat was de taken over te nemen zowel organisatorisch als procedureel.

356. Zie H.Th. Bor e.a., POA, blz. $307 \mathrm{t} / \mathrm{m} 310$.

357. De hoofddoelstelling luidde: "Beroepsarbeid moet menswaardig zijn". Een subdoelstelling van de eerste orde is bijwoorbeeld: 
De arbeid moet zodanig zijn, dat de grootst mogelijke veiligheid voor de mens bij zijn beroepsarbeid wordt verkregen".

Een subdoelstelling van de tweede orde is bijvoorbeeld:

"Er moeten zodanige organisatorische maatregelen getroffen zijn met betrekking tot de vei-

ligheid van de mens bij zijn beroepsarbeid, dat voor deze de grootst mogelijke veiligheid wordt verkregen".

Zie Projectwerkgroep doelstellingen en taken, Deelrapport 1 ( augustus ) 1982 .

358. Projectwerkgroep doelstellingen en taken; Eindrapport ( 1984); zie H.Th. Bor, POA, blz. $318 \mathrm{t/m} 322$.

359. Projectwerkgroep werkterrein, Deelrapport 1 ( juni ) 1983; H.Th. Bor e.a., POA, blz, 326.

360. Deze basiseisen zijn:

1. het bevorderen van een zo groot mogelijke toegankelijkheid van de arbeidsinspectie;

2. het opbouwen van een relatiepatroon met de arbeidsorganisaties, gericht op bevordering van zelfwerkzaamheid van en samenwerking tussen werkgever en werknemer;

3. het werken vanuit een samenhangende benadering van het werkterrein waarbij inbreng van alle nodige invalshoeken ( veiligheid, gezondheid en welzijn ) gewarborgd is;

4. het waar mogelijk en zinvol werken met gestandaardiseerde procedures en onderzoekmethodieken;

5. het evenwichtig benaderen van het werkterrein gebaseerd op een prioriteitenstelling, die uitgaat van een adequaat inzicht in het totale werkterrein;

6. het inbouwen van een systematische evaluatie van effecten van het handelen;

7. het hanteren van een besturingssysteem waar de voor een goede taakuitoefening noodzakelijke planning, beleidsontwikkeling, ütvoeringswoorbereiding, voortgangscontrole, rapportage, kwaliteitsbewaking en menskrachtplanning deel van uitmaken, en

8. het inbouwen van voldoende ruimte voor eigen initiatief voor de individuele medewerkers van de dienst. Zie Projectwerkgroep werkwijze, Naar een nieuwe werkwijze van de Arbeidsinspectie en de Inspectie van de havenarbeid, ( april ) 1983; H.Th. Bor e.a., POA, blz. $324-325$.

361. Hierbij gaat het om problemen van algemene aard, waarbij de ambtenaar van de arbeidsinspectie het probleem als incident aanpakt en zo mogelijk oplost, een en ander naar bevind van zaken. Mocht een bredere vervolgaanpak nodig zijn, die meer gericht is op de beinvloeding van het bedrijfsbeleid, dan kan hij zo nodig anderen inschakelen. Voor een dergelijke situatie is wel een permanente samenwerkings-en overlegstructuur nodig.

362. Hierbij gaat het om bepaalde specifieke onderwerpen, die kunnen worden aangepakt en afgehandeld wolgens van tevoren afgesproken procedures.

363. Hierbij wordt het probleem bekeken en de aanpak georganiseerd door een uit meerdere deskundigheden ad hoc samengestelde werkgroep ( projectteam ).

364. Projectwerkgroep werkwijze, Naar een nieuwe werkwijze ( april ) 1983; H.Th. Bor e.a., POA, blz. 325 326.

365. De structurering van de directie en de afdelingen binnen de directies sociaal arbeidsbeleid en gezondheid is in 1986 afgerond. Voor de beide andere directies gold, dat het proces op dat moment in een eindstadium was. Zie Jaarverslag Directoraat-Generaal van de Arbeid over 1986, 's-Gravenhage 1987, blz. 12. 
366. Zie J. Willems, DGA kent een nieuwe Directie Gezondheid Integrale aanpak per beleidsitem, in M.v.A. $1988 \mathrm{blz} .75 \mathrm{t} / \mathrm{m} 83$.

367. Zie W. Smid, Directie Sociaal Arbeidsbeleid nader belicht. DG Arbeid in ontwikkeling, in M.v.A. 1988 blz, 470 t/m 474.

368. Zie paragraaf 5.

369. Van de PvdA-fractie; zie Tweede Kamer, zitting 1978 - 1979, 14497.9 ( eindversiag ) blz. 8.

370. Tweede Kamer, zitting 1979 - 1980, 14497.11 ( nota naar aanleiding van het eindverslag ) blz. $6-7$.

371. H.Th. Bor e.a., POA, blz. 327.

372. H.Th. Bor in zijn toespraak als POA-coördinator ter gelegenheid van de opheffing van de Projectgroep POA en de POA-werkgroepen, Breda 18 december 1985.

373. Tweede Kamer, zitting 1988 - 1989, 21283.2 ( Rapport Arbeidsinspectie) blz. 40.

374. De Algemene Rekenkamer heeft van de uitgaven in verband met dit organisatie-ontwikkelingsproject een globale optelling gemaakt. In de periode 1981 - 1986 bedroegen de directe uitgaven voor het project circa ff. 5 miljoen. Op het begrotingsartikel voor organisatiekosten was daarnaast over de periode $1981-1986$ een bedrag van circa fl. 4 miljoen geboekt. De geinvesteerde arbeidstijd (voor actieve deelname aan werken projectgroepen en participatie in de besluitvorming ) werd van de zijde van het directoraat-generaal van de Arbeid geraamd op bijna 100 mensjaren over de gehele periode ( salariskosten tenminste fl. 7 miljoen ); zie Tweede Kamer, zitting 1988 - 1989, 21283.2 ( Rapport Arbeidsinspectie) blz. 35.

375. Zie bijvoorbeeld de Volkskrant van 19 augustus 1989 "Arbeidsinspectie functioneert rommelig en slecht".

376. Brief van 23 augustus 1989.

377. Zie hierover: J. Klaver, Havens als proefterrein. Nieuwe aanpak Arbeidsinspectie, in Risikobulletin 1988/ 4 blz. $9-10$.

378. Zie DGA Post oktober 1989 ( special over de voortgang Arbo'91).

379. Dit zou het "arbosysteem" of de "arbobenadering" genoemd kunnen worden.

380. European Foundation, Working Conditions in the Community - Situations and Trends - (Summary), ( november) 1989.

381. European Foundation, Working Conditions in the Community - Situations and Trends - (Summary), ( november) 1989, P. 8.

382. Deze worden omschreven als de "knoeiers en niet-willers".

383. Dit wordt aangegeven met de term "vgw-brede inspectie". 
384. Zie Werkgroep Arbo'91 betreffende functies in de buitendienst van de Arbeidsinspectie, Rapport Toekomstschets Arbeidisnspectie II: Inspecteur van de Arbeid. Voorstel voor functies in de buitendienst van de Arbeidsinspectie en een ontwikkelingsmodel voor de kwalitatieve personele bezetting, (november) 1988 ( hierna Werkgroep Arbo'91, Rapport Inspecteur van de Arbeid), blz. 8.

385. Werkgroep Arbo'91, Rapport Inspecteurs van de Arbeid, blz. 11 t/m 19; Formatierapport (mei) 1989.

386. DGA Post oktober 1989 (special voortgang Arbo'91). Het tempo van de invoering van de nieuwe functies is afhankelijk van de in de districten van de arbeidsinspectie aanwezige kwaliteit en van de loopbaanmogelijkheden. Voor de ontwikkeling wordt door de werkgroep rekening gehouden met een periode van 5 tot 10 jaar; zie Werkgroep Arbo'91, Rapport Inspecteur van de Arbeid, blz. 9.

387. Jaarverslag Directoraat-Generaal van de Arbeid over 1987, 's-Gravenhage 1988, blz. 3 t/m 5.

388. Tweede Kamer, zitting 1988-1989, 21283.2 ( Rapport Arbeidsinspectie ) blz. 47.

389. Brief van 28 september 1989.

390. De zogenaamde "relatie-opbouw-gesprekken".

391. Dat is ongeveer $70 \%$ van het geplande aantal.

392. In ieder geval de staatssecretaris; zie Voortgangsnotitie betreffende de Arbeidsomstandighedenwet over de periode 1984 tot medio 1985 , 's-Gravenhage 1985 , blz. 4.

393. ITS-onderzoek 1988, blz. 32; zie A.J.C.M. Geers, t.a.p, blz. 243.

394. Tweede Kamer, zitting 1973 - 1974, 12939.1.

395. De PudA-fractie; zie Tweede Kamer, zitting 1974 - 1975, 12939.4 ( voorlopig verslag ) blz. 2.

396. Zie de artikelen 79,80 en 86 van de Arbeidswet 1919.

397. Op 15 mei 1975 werd het wetsvoorstel zonder stemming door de Tweede Kamer aangenomen en op 24 juni door de Eerste Kamer, zonder beraadslaging en zonder stemming, om vervolgens op 25 juni van dat jaar tot wet te worden verheven ( Stb. 403 ).

398. Zie resp. de regelingen van 6 december 1982, no. 246912, Directoraat-Generaal van de Arbeid, Hoofdafdeling Wetgevingsbeleid, Stcrt. 247, en no. 246913, Directoraat-Generaal van de Arbeid, Hoofdafdeling Wetgevingsbeleid, Stcrt. 247. Bij deze laatste regeling werd tevens het op het oude artikel 78 van de Arbeidswet 1919 gebaseerde besluit van 1 september 1931, no. 2078, Afd. Arbeid, bevattende de instructie van de administratieve ambtenaren bij de arbeidsinspectie, ingetrokken.

399. Bij regeling van 12 juli 1988, nr. 88/1850/POO Directoraat-Generaal van de Arbeid, Stcrt. 149 (in werking getreden op 1 september 1988 ). De eerdere regeling werd tegelijkertijd ingetrokken.

400. Ten behoeve van de dienst van de arbeidsinspectie wordt het rijk ingedeeld in acht districten, waarvan omvatten: 
"- het 1ste de provincie Limburg; het gedeelte der provincie Noord-Brabant, dat behoort tot het rechtsgebied van de kantongerechten Eindhoven, Helmond en Boxmeer;

- het 2 de de provincie Zeeland en het gedeelte van de provincie Noord-Brabant, dat niet behoort tot het 1 ste district;

- het 3de het gedeelte der provincie Zuid-Holland, dat behoort tot het rechtsgebied van de kantongerechten Rotterdam, Schiedam, Brielle, Sommelsdijk en het arrondissement Dordrecht;

- het 4de de provincie Utrecht, het gedeelte der provincie Noord-Holland dat behoort tot het rechtsgebied van het kantongerecht Hilversum en het niet tot het $8 \mathrm{e}$ district behorende gedeelte van de provincie Gelderland en Flevoland;

- het 5de het gedeelte der provincie Zuid-Holland, dat niet behoort to het 3 de district;

- het 6de het gedeelte der provincie Noord-Holland, dat niet behoort tot het 4 de district, het gedeelte van de Waddenzee gelegen ten westen van de scheidslijn getrokken door het midden van het Eierlandse Gat en het meest westelijke punt van de gemeente Wonseradeel, alsmede het in dit besluit niet territoriaal ingedeelde watergebied;

- het 7de de provinciën Groningen, Friesland, en Drenthe, alsmede het gedeelte van de Waddenzee dat niet behoort tot het 6 de district; - het 8ste de provincie Overijssel, de gemeenten Noordoostpolder en Urk van de provincie Flevoland en het gedeelte der provincie Gelderland dat behoort tot het rechtsgebied van de kantongerechten Apeldoorm, Zutphen, Groenlo, Terborg, Arnhem en Zwolle, met uitzondering van de gemeenten Oldebroek en Hattem".

Samengevat bestaan de belangrijkste wijzigingen uit een samenvoeging van het vijfde en zesde district tot éfn district en het samenvoegen van het vierde, zevende en achtste district tot twee districten.

401. Het betreft de grenzen van de 62 in Nederland werkzame kantongerechten. Liever nog had men, blijkens de toelichting, aangesloten bij de grenzen van de 5 in ons land aanwezige arrondissementen, maar op grond van efficiency en doelmatigheid is van een indeling in 5 districten van de arbeidsinspectie afgezien.

402. Opmerkelijk is, dat in de toelichting met geen woord wordt gerept over de heroverwegingsoperatie ten aanzien van de gedecontreerde rijksdiensten. Wellicht dat een goed verstaander aan de termen "doelmatig" en "efficiency" al voldoende heeft. In een ontwerp-nota van de afdeling Algemen Arbeidszaken van het directoraat-generaal van de Arbeid, getiteld Verandering bestuurlijke structuur DGA. Mogelijkheden en varianten (april) 1989 ( hierna: Ontwerp-nota Verandering structuur), blz. 6, wordt in dit kader expliciet verwezen naar deze heroverwegingsoperatie.

403. Wet van 20 december 1984, Stb. 667

404. Zie resp. de artikelen 7 en 2 van de Wet gemeenschappelijke regelingen.

405. Afwijking van bedoelde indeling is mogelijk indien de aard van het belang of de schaal waarop dat behartigd moet worden, afwijking bijzonder aangewezen maakt, aldus de toelichting.

406. Besluit van 3 augustus 1982, no. 241238, Directoraat-Generaal van de Arbeid, Hoofdafdeling wetgevingsbeleid, Stcrt. 154.

407. Zie artikel 1 , onder a $t / m$ d, f en $g$, van het Organisatiebesluit Arbeidsinspectie.

408. Zie resp. artikel 1, onder e, en 2, van het Organisatiebesluit Arbeidsinspectie. 
409. Zie artikel 9 van het Organisatiebesluit Arbeidsinspectie.

410. Zie de artikelen $16 j^{\circ} 11$ van het Organisatiebesluit Arbeidsinspectie.

411. Zie artikel 16 van het Organisatiebesluit Arbeidsinspectie.

412. Zie artikel 17 van het Organisatiebesluit Arbeidsinspectie.

413. Zie artikel 2 van het Organisatiebesiuit Arbeidsinspectie.

414. HR 30 oktober 1962, NJ 196329.

415. Bij regeling van 14 juli 1987, Directoraat-Generaal van de Arbeid, ASfd. Wetgeving en Juridische Zaken, no. 87/0309. Stcrt. 140.

416. Zie het nieuwe artikel 2, eerste en tweede lid, yan het Organisatiebesluit Arbeidsinspectie. Artikel 12 van het beslluit is dienovereenkomstig aangepast.

417. In artikel 10 van het Organsiatiebesluit Arbeidsinspectie wordt in de nieuwe versie gesproken van een inspecteur van de arbeid die het districtshoofd wanneer nodig vervangt, maar hier zal bedoeld zijn de hoofdinspecteur.

418. Opgemerkt dient te worden, dat een wijziging van het Organisatiebeslluit Arbeidsinspectie voorhanden is, en vooralsnog eind 1989, begin 1990 gereed zal zijn. Het betreft echter een aanpassing aan de nieuwe functie van inspecteur van de arbeid; zie DGA Post oktober 1989 ( special voortgang Arbo'91).

419. P.J. Oud, Het consitutionele recht van het Koninkrijk der Nederlandem deel II, Zwolle 2e druk 1970, blz. 430 .

420.J.H. Wesseling/A.B. Hermsen, De Kleuteronderwijswet; met aantekeningen, Alphen a/d Rijn (losbladig); zie F.A.M. Stroink, Deconcentratrie, 's-Gravenhage 1978, blz. 149.

421. C.W. van der Pot, Handboek van het Nederlandse staatsrecht, Zwolle Se druk 1953, blz. 282 - 283.

422. A.L. Scholtens, in Staatsrechtelijke opstellen, blz. 165.

423. A.M. Donner, Handboek van het Nederlandse staatsrecht, Zwolle 9e druk 1972, blz. 337.

424. A.M. Donner, Algemeen deel, in Nederlands bestuursrecht, Alphen a/d Rijn 4e herziene druk 1974, blz. 111.

425. A.M. Donner, t.a.p., Zwolle 10e druk 1977, blz. 307.

426. Zie ook F.A.M. Stroink, t.a.p., blz. $147 \mathrm{t} / \mathrm{m} 151$.

427. F.A.M. Stroink, t.a.p., blz. 154 - 155.

428. F.A.M. Stroink, t.a.p., blz. 155, verwijst hierbij naar Ch.J. Enschede, Handelingen NJV deel II 1968 blz. $76 \mathrm{t} / \mathrm{m}$ 79; J.H.A. Logeman, Over de theorie van een stellig staatsrecht, Leiden 1948, blz. 108. 
429. Zie ook L. Bleumer-Van der Klein/F. Hent, Theorie en praktijk van de beleidsvorming door de arbeidsinspectie, in AAe 1978 blz. 380.

430. A.L. Scholtens, in Staatsrechtelijke opstellen, blz. 164 - 165.

431. Zie artikel 13 van het Organisatiebesluit Arbeidsinspectie.

432. Zie par. 3 ( de Veiligheidswet 1934 en de Arbeidsomstandighedenwet ).

433. Zie par. 3 ( de Veiligheidswet 1934 en de Arbeidsomstandighedenwet ).

434. Arboraad, Advies inzake de tweede en volgende fasen van invoering van de Arbeidsomstandighedenwet, Zoetermeer 18 april 1985, blz. 42.

435. Tweede Kamer, zitting 1986 - 1987, 19824.3 ( memorie van toelichting ) blz. 9.

436. Tweede Kamer, zitting 1986 - 1987, 19824.5 (memorie van antwoord) blz. 12. Zie ook Tweede Kamer, zitting 1986 - 1987, 19915.1 ( Hoofdlijnen Arbeidsvoorzieningswet ); Tweede Kamer, zitting 1987 - 1988, 20659.2 (Arbeidsvoorzieningswet). Zie hierover onder meer: M.M. Sanderse, Naar een betere arbeidsvoorziening, in SR $1989 \mathrm{blz}, 96 \mathrm{t} / \mathrm{m} \mathrm{105;} \mathrm{M.} \mathrm{van} \mathrm{der} \mathrm{Woude,} \mathrm{De} \mathrm{ontwikkeling} \mathrm{der} \mathrm{particuliere} \mathrm{arbeidsvoorziening}$ in een afkalvende rechtsbescherming, in SR $105 \mathrm{t} / \mathrm{m} 108$; WJ. Wolfs, Overheid en sociale partners in publiekrechtelijke organisatie. Arbeidsvoorzieningswet, in Privatisering 1988/9 blz. 24 t/m 26; H. Horsman, De nieuwe Arbeidswoorzieningswet: de geboorte van een effectief arbeidsvoorzieningsbeleid?, Rotterdam 1987; H. Naber, Enkele juridische aspecten van arbeidsvoorziening nieuwe stijl, in S.M.A. $1987 \mathrm{blz} .633 \mathrm{t} / \mathrm{m} \mathrm{641}$; A.M. Proos, Tripartiete overleg binnen het te voeren arbeidsvoorzieningenbeleid. Ingrijpende veranderingen bij arbeidsbureaus?, in De Gids 1986/1 blz. 13 t/m 16.

437. Lid van de CDA-fractie; zie Hand. Tweede Kamer, zitting 1986 - 1987, blz. 4457 - 4458.

438. Zie Hand. Tweede Kamer, zitting 1986 - 1987, blz, 4502 en blz. 4510.

439. Hand. Tweede Kamer, zitting 1986 - 1987, blz. 4511.

440. Lid van de CDA-fractie.

441. Zie Hand. Tweede Kamer, zitting 1988 - 1989, blz. 2714.

442. Hand. Tweede Kamer, zitting 1988 - 1989, bli. 2781 - 2782.

443. CNV, Discussienota "Toekomst in Banen", Sociaal-politiek program van het CNV voor de periode 1990 1994, Utrecht 1988, blz. 30.

444. CNV, "Toekomst in Banen". Sociaal-Politiek Program van het CNV voor de periode $1990-1994$, Utrecht ( juli ) 1989, blz. 41.

445. Afdeling algemene arbeidszaken van het directoraat-generaal van de Arbeid, Ontwerp-nota Verandering bestuurlijke structuur Directoraat-Generaal van de Arbeid (hierna Ontwerp-nota bestuurlijke verandering), (april) 1989, blz. 5. 
446. Zie Tweede Kamer, zitting 1980 - 1981, 16492.1 en 2 (aanbiedingsbrief en de Nota decentralisatie van rijkstaken )

447. Zie Tweede Kamer, zitting 1982 - 1983, 16492.6 (aanbiedingsbrief en het Decentralisatieplan ). Dit plan, dat nog slechts voorlopige voornemens bevatte, werd voor advies voorgelegd aan de provincies, de Raad voor het binnenalands bestuur, de Raad voor de gemeente financiën en de Vereniging van Nederlandse gemeenten.

448. Tweede Kamer, zitting 1982 - 1983, 16492.7 en 8 (aanbiedingsbrief en het Decentralisatieplan).

449. Zie Tweede Kamer, zitting 1982 - 1983, 16492.8 (Decentralisatieplan ) blz. 7.

450. SER, Advies rol sociale partners in het arbeidsvoorzieningsbeleid, 1984/10, blz. 29.

451. SER, Advies inzake de nieuwe Arbeidsvoorzieningswet, 1985/19, blz. 8.

452. Ontwerp-nota bestuurlijke verandering, blz. 6.

453. J.H.J. Crijns/F.S wan Hove, Op weg naar herijking van sociale-economische besturing. Een verbreed en verdiept decentralisatiemodel voor de jaren negentig, in Vakbeweging in verandering. Dilemma's en uitdagingen, Deventer 1986, blz. $37 \mathrm{t} / \mathrm{m} \mathrm{50.} \mathrm{Zij}$ stellen daarbij wel, dat zij éen en ander strikt op persoonlijke titel schrijven.

454. Lid van de VVD-fractie.

455. Hand. Tweede Kamer, zitting 1986 - 1987, blz. 4458.

456. Lid van de PvdA-fractie.

457. Hand. Tweede Kamer, zitting 1986 - 1987, blz. 4458.

458. Zie P. Koedijk, Prof. mr. L.A. Geellhoed: "Nieuwe ideeën voor een herinrichting van onze samenleving ontbreken", in VN 21 januari 1989 blz. 4.

459. Namelijk voor de bouwnijverheid, de diamantbewerking, de glas-, hout-, keramische en metaalbedrijven, de grafische en chemische industrie, alsmede voor de land-, tuin-en bosbouw.

460. Voor de ijzer- en metaalindustrie, de bouw, de grafische industrie, transport en groothandel, industrie algemeen, de publieke sector, detailhandel, dienstverlening, voedings-, dranken- en tabaksindustrie, land-, tuin-en bosbouw, welzijn en gezondheidszorg, alsmede onderwijs.

461. Zie J.K.M. Gevers, Health and Safety Protection in Industry: Participation and Information of Employees and Workers, Luxembourg 1987 ( EUR 11314).

462. Wet van 5 juli 1979 , Stb. 448 .

463. Dit bezwaar werd gemaakt door de PvdA-fractie; zie Tweede Kamer, zitting 1976 - 1977, 130954.5 (voorlopig verslag) blz. 72 . 
464. Zie resp. de artikelen 7 en 23 van de Wet op de ondernemingsraden.

465. Tweede Kamer, zitting 1976 - 1977, 13954.6 ( memorie van antwoord) blz. 50.

466. Raad voor de Arbeidsmarkt, Advies inzake de opneming van gehandicapten in het arbeidsproces, $1975 / 9$, blz, $22-23$.

467. SER, Advies Beperking groei uitgaven sociale zekerheid, 1980/19, blz. 16.

468. SER, Advies inzake vermijdbaar verzuim bij ziekte en arbeidsongeschiktheid, 1982/1.

469. Daarnaast betreft de geïntegreerde beleidsaanpak het wegnemen van bij de gehandicapte zelf gelegen. belemmeringen, die kunnen voortvloeien uit de aard en de ernst van de handicap zelf, alsook de gecoördineerde en geïntensiveerde toepassing van de reeds bestaande en door de Wet arbeid gehandicapte werknemers aangevulde en verbeterde maatregelen en instrumenten, waaronder een verbeterde samenwerking tussen de verschillende ( uitvoerings-)organen. Zie Tweede Kamer, zitting 1981 - 1982, 17.384.3 (memorie van toelichting ) blz. $6-7$.

470. Zie Tweede Kamer, zitting 1981 - 1982, 17384.3 (memorie van toelichting) blz. 5 t/m 7.

471. De wet is met ingang van 1 juli 1986 (zie Besluit van 16 juni 1986 , Stb. 346 ) in werking getreden, met uitzondering van de artikelen $3 \mathrm{t} / \mathrm{m} 5$ (quotumverplichting), welke op 1 januari 1989 in werking zijn getreden. Zie G.J.M. de Leijzer, De WAGW in de praktijk, in M.v.A. 1989 blz. $165 \mathrm{t} / \mathrm{m} 160$.

472. Zie artikel 3 van de Wet arbeid gehandicapte werknemers.

473. Zie artikel 6 van de Wet arbeid gehandicapte werknemers.

474. Tweede Kamer, zitting 1981 - 1982, 17.384.3 ( memorie van toelichting ) blz. 22.

475. Loondispensatie is in uitzonderingsgevallen mogelijk.

476. Tweede Kamer, zitting 1970 - 1971, $11268.1 \mathrm{t} / \mathrm{m} 3$.

477. Tweede Kamer, zitting 1973 - 1974, 12662.3 (memorie van toelichting) blz. 8 - 9.

478. Wet van 11 februari 1976 , Stb. 214.

479. Wet van 23 juni 1977 , Stb. 455.

480. Tweede Kamer, zitting 1974 - 1975, 13364.3 ( memorie wan toelichting) blz. 30.

481. Zie artikel 38 van de Afvalstoffenwet.

482. Zie C. de Last, Milieuproblematiek vraagt aandacht van SZW, in Sozavox 1989/5 blz. 4.

483. De zgn. lashbakken, bacatbakken en seabee's.

484. Wet van 1 juli 1909, Stb. 219. 
485. Wet van 23 april 1880, Stb. 67.

486. Wet van 5 juli 1921 , Stb. 838 .

487. Andere wetten die genoemd kunnen worden, zijm onder meer: de Stuwadoorswet, de Wet op de gevaarlijke werktuigen, de Stoomwet en de Kernenergiewet.

488. Deze Reglementen zijn gebaseerd op de zgn. Akte van Manmheim ( Trb. 1955161 ); zie resp. Stb 1976 476 en 303 .

489. Zie Tweede Kamer, zitting 1975 - 1976, 13978.3 ( memorie van toelichting ) blz. 17 t/m 19.

490. Wet van 30 september 1981 , Stb. 678 .

491. Zie Tweede kamer, zitting 1975 - 1976, 13978.3 ( memorie van toelichting ) blz. $24-25$.

492. De andere overheidsinstantie is de scheepvaartinspectie; zie artikel 28 van de Binnenschepenwet.

493. Zie artikel 48 van de Binnenschepenwet. De overige opsporingsinstanties zijn: de bij of krachtens artikel 141 van het Wetboek van Strafvordering aangewezen ambtenaren en de ambtenaren van de scheepvaartinspectie.

494. Zie de artikelen $13 \mathrm{t} / \mathrm{m} 15$ van de Binnenschepenwet, waarvan de tekst is aangepast na de totstandkoming van de Arbeidsomstandighedenwet.

495. Wet van 27 juni 1985 , Stb. 410.

496. Zie Tweede Kamer, zitting 1982 - 1983, 17764.3 (memorie van toelichting ) blz. 2 - 3.

497. Zie de artikelen 3, vierde lid, en 8 , tweede lid, van de Diergeneesmiddelenwet.

498. Zie artikel 26 , tweede lid, van de Diergeneesmiddelenwet.

499. Zie artikel 23 van de Diergeneesmiddelenwet.

500. Zie artikel 50 van de Diergeneesmiddelenwet. De bepaalde algemene maatregelen van bestuur zijn die als bedoeld in de artikelen $23,38,42$ en 43 van de genoemde wet.

501. Tweede Kamer, zitting 1980 - 1981, 16800.3 (memorie van toelichting) blz. 5 - 6 .

502. Wet van 28 juli 1958 , Stb. 403.

503. Wet van 28 december 1935 , Stb. 793 .

504. Wet van 13 november 1969, Stb. 536.

505. Wet van 5 juni 1975 , Stb. 352.

506. Wet van 3 juli 1986, Stb. 374 . 
507. Zie Tweede Kamer, zutting $1980-1981$, 16800.3 (memorie van toelichting) blz. $8 \mathrm{t} / \mathrm{m} 10$.

508. Wet van 5 december 1985, Stb. 639. Deze wet is en wordt gefaseerd ingevoerd. Zie de Besluiten van 9 januari 1986, Stb. 10, van 11 december 1986, Stb. 623, van 15 maart 1988, Stb. 98, en wan 1 juli 1988 , Stb. 314.

509. Zie Tweede Kamer, zitting 1980 - 1981, 16800.3 (memorie van toelichting) blz. $10-11$.

510. Dit ter uitvoering van de richtlijn van de Raad van de Europese Gemeenschappen van 18 september 1979, houdende de zesde wijziging van de Richtlijn 67/548/EEG, inzake de indeling, de verpakking en het kenmerken van gevaarlijke stoffen, Pb. EG L.259/10; zie Tweede Kamer, zitting 1980 - 1981, 16800.3 (memorie van toelichting ) blz. 12 .

511. Tweede Kamer, zitting 1980 - 1981, 16800.3 ( memorie van toelichting ) blz. 44.

512. Dit ter uitvoering van de richtlijn van de Raad van de Europese Gemeenschappen van 27 juli 1976 inzake de beperking van het op de markt brengen en het gebruik van bepaalde gevaarlijke stoffen en preparaten, Pb. EG L. 262/201; zie Tweede Kamer, zitting 1980 - 1981, 16800.3 ( memorie van toelichting ) blz. 12.

513. Tweede Kamer, zitting 1983 - 1984, 16800.9 ( memorie van antwoord ) blz. 6.

514. Eerste Kamer, zitting 1984 - 1985, 16800.163b (memorie van antwoord) blz. 3.

515. Zie artikel 6, tweede lid, van de Wet milieugevaarlijke stoffen.

516. Zie de artikelen 13, derde lid, 14, tweede en negende lid en 15, tweede lid, van de Wet milieugevaarlijke stoffen.

517. Zie artikel 16 , eerste lid, van de Wet milieugevaarlijke stoffen.

518. Zie het Kennisgevingsbesluit Wet milieugevaarlijke stoffen van 18 november 1986, Stb. 592, en het Beslluit verpakking en aanduiding milieugevaarlijke stoffen van 15 maart 1988, Stb. 98.

519. Zie de artikelen 20 , derde lid, 21 , eerste lid, en 23 , eerste lid, van de Wet milieugevaarlijke stoffen. Zie Tweede Kamer, zitting 1983 - 1984, 16800.9 ( memorie van antwoord) blz. 15.

520. Tweede Kamer, zitting 1980 - 1981, 16800.3 ( memorie van toelichting) blz. 20.

521. Zie artikel 68 van de Wet milieugevaarlijke stoffen. In dit artikel is onder meer artikel 7 van de Wet gevaarlijke stoffen ingetrokken. Dit artikel 68 is in werking getreden op 1 september 1988; zie het Besluit van 15 maart 1988, Stb. 98.

522. Zie artikel 69 van de Wet milieugevaarlijke stoffen.

523. Zie artikel 71 van de Wet milieugevaarlijke stoffen.De wet is niet van toepassing op stoffen of preparaten voor zover daaromtrent regelen zijn gesteld in de Wet op de geneesmiddelenvoorziening, de Bestrijdingsmiddelen 1962, de Diergeneesmiddelenwet, de Kernenergiewet, de Wet gevaarlijke stoffen, daar waar het het vervoeren, ten vervoer aanbieden, laden en lossen, neerleggen tijdens het vervoer, in Nederland invoeren en uitvoeren betreft, de Wet verontreiniging oppervlaktewateren, daar waar het het vaststellen van grens- 
waarden betreft, en de Wet verontreiniging zeewater; beide laatste wetten woor zover het verbod geldt om zich te ontdoen van stoffen en preparaten. Zie ook Tweede Kamer, zitting 1983 - 1984, 16800.9 ( memorie van antwoord ) blz. $7-8$.

524. Tweede Kamer, zitting 1983 - 1984, 16800.12 ( nota naar aanleiding van het eindverslag ) blz. 25.

525. Tweede Kamer, zitting $1983-1984,16800.9$ (memorie van antwoord) blz. 7 .

526. Besluit van 11 februari 1986 , Stb. 35 .

527. Zie ook beschikking wan 9 juni 1986, Stert. 114 .

528. Zie artikel 66 van de Wet milieugevaarlijke stoffen.

529. Tweede Kamer, zitting 1980 - 1981, 16800.3 (memorie van toelichting) blz. 79 .

530. Jaarverslag Arbeidsinspectie 1976, 1977 en 1978, resp. Voorburg 1978, 1979 en 1979, resp. blz. 92, blz. 67 en blz. 126.

531. Tweede Kamer, zitting 1986-1987, 19810.1.

532. Interne richtlijnen van het directoraat-generaal voor de Arbeidsvoorziening zullen voorzien in werkafspraken hieromtrent. Daarbij zal tevens de instructie worden uitgevaardigd, dat de directeur verzoeken van een of beide vertegenwoordigers van de werkgevers - en werknemersorganisaties tot verzameling van gegevens, zal honoreren; zie Tweede Kamer, zitting 1986 - 1987, 19810.3 (memorie van toelichting ) blz. 3.

533. Tweede Kamer, zilting 1986 - 1987, 19810.3 (memorie van toelichting) blz. 3 - 4.

534. Deze vragen zijn afkomstig van de PvdA-fractie; zie Eerste Kamer, zitting 19810.252a (voorlopig verslag) blz. 2 .

535. Eerste Kamer, zitting $1988-1989,19810.252$ b ( memorie van antwoord) blz. 3 .

536. Dit is het Eerste Kamerlid Pit van de PvdA-fractie.

537. Hand. Eerste Kamer, zitting 1988 - 1989, blz. 282.

538. Hand. Eerste Kamer, zitting 1988 - 1989, blz. 287 -288.

539. $\mathrm{Stb}, 573$

540. Brief van 22 december 1988, ARBVO-Jura-B, no. 8823840.

541. Zie Tweede Kamer, zitting 1987 - 1988, 20569.1 - 2.

542. Tweede Kamer, zitting 1988 - 1989, 21063.1 - 2 .

543. Jaarverslag Arbeidsinspectie 1976, blz. 22 - 23. Zie voor de relatie tussen de onderscheiden wetsartikelen: J. van Drongelen, t.a.p., blz. 52 t/m 60 . 
544. Jaarverslag Arbeidsinspectie 1979, Voorburg 1980, blz. 45 .

545. Jaarverslag Arbeidsinspectie over 1980, Voorburg 1981, blz. 64. Juist vanwege het toenemende beroep op de mogelijkheid van werktijdverkorting kon in dat verslagjaar geen cijfermatige informatie worden gegeven.

546. Jaarverslag Arbeidsinspectie 1979, 1981, 1982, 1983, resp. Voorburg 1980, 1982, 1983 en 1984, resp. blz. 45, 54, 126 en 118. Jaarverslag Directoraat-Generaal van de Arbeid over 1986, Voorburg 1987. Het jaarverslag Directoraat-Generaal van de Arbeid over 1987, Voorburg 1988, bevat hierover geen informatie meer.

547. Zie Interim-nota inzake bestrijding van de werkloosheid ( september) 1974, blz. 21.

548. Nota inzake de werkgelegenheid ( februari ) 1975, blz. 61.

549. Vandaar dat ook wel werd gesproken van de $105 \%$-regeling.

550. Deze terugbetaling diende binnen 3 jaar na het boekjaar, waarin de verruimde werktijdverkorting was toegepast, plaats te vinden. Zij werd afhankelijk gesteld van de in die periode behaalde fiscale winsten van het bedrijf; zie persbericht van 18 februari 1976.

551. Tweede Kamer, zitting 1975 - 1976, 13686.1, blz. 4 .

552. De overigens niet gepubliceerde richtlijnen luidden: de aanvragende bedrijven dienen aantoonbaar in financiële moeilijkheden te verkeren en het op eigen kracht niet te kunnen bolwerken; dreigend collectief ontslag; het nauwelijks aanwezig zijn van herplaatsingsmogelijkheden voor de betrokken werknemers; de aanwezigheid van uitzicht op verbetering na de overbruggingsperiode; het eerder toegepast hebben van werktijdverkorting met een minimum van zes weken; de werktijdverkorting mocht ten hoogste $50 \%$ van de normale werktijd betreffen en tot slot een maximale duur van negen maanden hebben. De overheidsbijdrage gold alleen voor die werknemers, die in dienst van het bedrijf bleven.

553. Tweede Kamer, zitting 1975 - 1976, 13686.1.

554. Alsook via Inspectie van de Havenarbeid en het directoraat-generaal van Algemene Beleidsaangelegenheden.

555. Hierin waren zowel het ministerie van Financièn als van Economische Zaken en van Sociale Zaken vertegenwoordigd.

556. Zie J. van Drongelen, t.a.p., blz, $46 \mathrm{t} / \mathrm{m} 48$.

557. Tweede Kamer, zitting 1982 - 1983, 17931.5 blz. 11.

558. Tweede Kamer, zitting 1983 - 1984, 17931.24, blz. 14 - 15.

559. In de sigarenindustrie was een collectieve arbeidsovereenkomst afgesloten met arbeidstijdverkorting met vermindering van het nominale loon.

560. Zie de Notitie Werkgelegenheidsbeleid van 28 jannari 1983, blz. 16; zie ook Werkgellegenheidsnota, Tweede Kamer, zitting 1983 - 1984, 18102.2, blz. 40. 
561. Besluit wan 12 juni 1985, no.85/1073 DG ABA/WBTA, Stcrt. 118.

562. Zie M.G. Rood/E.P.de Jong ( red. ), Zakboek arbeidsrecht, Deventer ( losbladig ), B.II - 11.3.3. voor een uitgebreidere behandeling van de vrijstelling.

563. J.G.M. Arnold, in S.M.A. 1986 blz. 325 - 326.

564. J, van Drongelen, in S.M.A. 1986 blz. $661 \mathrm{t} / \mathrm{m} 664$.

565. Bij brief van 14 juni 1985, no. Arb/HASB/85/4490.

566. SER, Advies van 17 december 1985 inzake artikel 8 BBA 1945, brief no. W.5449 Mdu/SM.

567. Besluit van 21 september 1977 , Stb. 547.

568. Besluit van 22 januari 1971, Stb. 25.

569. SER, Advies inzake enige wijzigingen van de Rijtijdenwet 1936, 's-Gravenhage 12 augustus 1977.

570. Directoraat-Generaal van de Arbeid, Rapport Controle Rijtijjdenwet 1936, Voorburg ( april ) 1985; zie ook Directoraat-Generaal van de Arbeid, Controle Rijtijdenwet 1936, Voorburg ( april ) 1987.

571. Jaarverslag Directoraat-Generaal van de Arbeid over 1985 , blz. 93 - 94.

572. Jaarverslag Directoraat-Generaal van de Arbeid over 1986 en over 1987, resp. blz. 82 en blz. 23.

573. Zie J.B. Vallenduuk, Waarom de Rijtijdenwet niet wordt nageleefd, in Nederlands Transport $1988 / 8$.

574. F. van Ouwerkerk/W. van der Hoeven/J.F. O'Hanlon, Arbeidsomstandigheden van internationale vrachtwagenchauffeurs, Voorburg ( maart) 1987 ( Directoraat-Generaal van de Arbeid S32).

575. COB/SER, Sociaal beleid in het beroepsgoederenvervoer over de weg. Onderzoekrapport. Onderzoek naar mogelijkheden voor versterking van het sociaal beleid in samenhang met het economisch beleid in wegvervoerbedrijven (hierna COB/SER, Sociaal beleid beroepsgoederenvervoer),'s-Gravenhage 1984.

576. Zie COB/SER, Sociaal beleid beroepsgoederenvervoer, blz. XV.

577. J.B. Vallenduuk, Goede feitelijke informatie, conclusies twijfelachtig...., in Nederlands Transport 1989/ 13-14, blz $8 \mathrm{t} / \mathrm{m} 10$.

578. Brief van 9 november 1989, DGA/SAB/89/15980, aan de algemeen voorzitter van de KNVTO, welke organisatie verantwoordelijk is voor het bewuste tijdschrift.

579. Rijksverkeersinspectie, Jaarverslag 1988, blz. 15.

580. Dit Convenant is tot stand gekomen op 30 september 1985 en is trouwens medeondertekend door de vertegenwoordiger van het KNVTO.

581. Hij is dan ook werkzaam bij het KNVTO. 
582. Algemeen secretaris van het KNVTO.

583. Wet van 13 juni 1979 , Stb. 442 .

584. Zoals de instelling van de Centrale Raad voor de millieuhygiène en de milieu-effectrapportage, resp. Wet van 1 oktober 1980, Stb. 757, en van 29 augustus 1985 , Stb. 494

585. Zie artikel 6 , tweede lid, van de Wet algemene bepalingen milieuhygiëne.

586. Tweede Kamer, zitting 1976 - 1977, 14311.3 ( memorie van toelichting ) blz. 2 - 3 .

587. Wet van 13 juni 1979 , Stb. 443 .

588. Zie de artikelen $\Pi$ en $X$ van de Wet invoering van de Wet algemene bepalingen milieuhygiëne.

589. Zie artikel 1 , derde lid, van de Hinderwet.

590. Zie artikel 8 , leden 2 en 3 , van de Hinderwet.

591. Zie artikel 21, tweede lid, van de Hinderwet.

592. Jaarverslag Arbeidsinspectie over 1976, over 1977, over 1978, over 1979, over 1982, en over 1984, resp. blz. 89 , blz. 64, blz. 122, blz. 171, blz. 189 en blz. 137. Jaarverslag Directoraat-Generaal van de Arbeid over 1986, blz. 138.

593. Jaarverslag Arbeidsinspectie over 1976 en over 1979, resp. blz. 89 en blz. 171. Jaarverslag DirectoraatGeneraal van de Arbeid over 1986, blz. 138.

594. Jaarverslag Arbeidsinspectie over 1976, over 1978, over 1981 en over 1983, resp. blz. 89, blz. 122 , blz. 230 en blz. 177. Jaarverslag Directoraat-Generaal van de Arbeid over 1985, blz. 154.

595. Jaarverslag Arbeidsinspectie over 1978, blz. 122; Jaarverslag Directoraat-Generaal van de Arbeid over 1985 , blz. 154.

596. Jaarverslag Arbeidsinspectie over 1979, blz. 180. In de beide daaropvolgende jaarverslagen werden dergelijke Joonboekjes door de burgemeesters klaarblijkelijk niet meer verstrekt. In bet Jaarverslag Arbeidsinspectie over 1982 ontbreekt de bewuste tabel volledig.

597. Brief van 19 december 1988, archief directoraat-generaal van de Arbeid.

598. Tweede Kamer, zitting 1981 - 1982, 17100.29 ( hfdst. XV begroting Sociale Zaken en Werkgelegenbeid ).

599. Tweede Kamer, zitting 1984 - 1985, 18600.34 ( Hfdst. XV begroting Sociale Zaken en Werkgelegenheid ).

600. Tweede Kamer, zitting 1983 - 1984, 17931.24 (Deregulering van Overheidsregelingen ) blz 26. 
601. Het verschijnsel thuiswerk. Een methodologisch vooronderzoek, 's-Gravenhage (oktober) 1984; Telework. Een overzichtsstudie naar recente trends en toekomstperspectieven, 's-Gravenhage (december) 1986.

602. Zie Flexibele arbeidsrelaties. Rapportage van de eerste fase van de werkzaamheden van de Werkgroep Flexibele Arbeidsrelatie, 's-Gravenhage (juli) 1986; Flexibele inzet van arbeidskrachten, 's-Gravenhage (november) 1987.

603. Arbeidsomstandigheden van thuiswerksters. Een inventariserend onderzoek naar de arbeidsomstandigheden van thuiswerksters, 's-Gravenhage ( januari ) 1989.

604. Tweede Kamer, zitting 1988 - 1989, 20800.51 (hfdst. XV begroting Sociale Zaken en Werkgelegenheid).

605. Zie Jaarverslag Arbeidsinspectie over 1976 en 1978, resp. blz. 92 en 125

606. Jaarverslag Arbeidsinspectie over 1981, blz. 120.

607. Zie Jaarverslag Arbeidsinspectie over 1976, over 1977 en over 1978, resp. blz. 90 - 91, blz. $65 \mathrm{t} / \mathrm{m} 67$ en blz. $123 \mathrm{t} / \mathrm{m}$ 125. Vanaf het Jaarverslag Arbeidsinspectie over 1979 wordt geen melding meer gemaakt van de activiteiten in het kader van de civiele verdediging.

608. Jaarverslag Arbeidsinspectie over 1979, blz. 115.

609. Persbericht van 7 februari 1979, no. 79/12; zie ook Tweede Kamer, zitting 1979 - 1980, 15800.2 ( hfdst. XV begroting Sociale Zaken ) blz. 84 .

610. Zie Stcrt. $1987136 \mathrm{blz} .3$.

611. Als bestuursleden van het NIA zijn benoemd vertegenwoordigers van de directoraten-generaal van de Arbeid en voor Sociale Zekerheid van het ministerie van Sociale zaken en Werkgelegenheid, een vertegenwoordiger van het ministerie van Binnenlandse Zaken, vertegenwoordigers van de centrale werkgevers- en werknemersorganisaties. Tot algemeen directeur is benoemd J.T. Allegro, met als diens plaatsvervanger B.G.M. Ris. Zie M.V.A. 1987 blz. 573.

612. Zie Stcrt. 198849 blz. 2 - 3.

613. Jaarverslag Arbeidsinspectie over 1974 - 1975 en over 1976, resp. blz. 84 - 85 en blz. 81 t/m 83 .

614. Jaarverslag Arbeidsinspectie over 1976, blz. 82 - 83.

615. Zie C.J. Vos, Tien jaar arbeidsplaatsverbetering, in T.v.A. 1986 blz. $78 \mathrm{t} / \mathrm{m}$ 88; K.J. Poll/J.A.M. Louman, Kosten en baten van arbeidsplaatsverbetering, in T.v.A. 1985 blz. $25 \mathrm{t} / \mathrm{m} \mathrm{31;} \mathrm{B.} \mathrm{Tappèl/N.} \mathrm{Terra,} \mathrm{Het} \mathrm{werkt}$ anders: een overzicht van maatregelen tegen veel voorkomende problemen met de kwaliteit van arbeidsplaatsen in de industrie, Voorburg 1986 (Directoraat-Generaal van de Arbeid S18), en Het werkt anders: elf deelrapporten, Voorburg 1986 ( Directoraat-Generaal van de Arbeid S18-1 t/m S18-11).

616. C.J. Vos, in T.v.A. 1986 blz. 87.

617. K.J. Poll/J.A.M. Louman, in T.v.A. 1985 blz. 31. 
618. Eindrapport, Evaluatie subsidieregeling arbeidsplaatsverbetering 1977, 's-Gravenhage (augustus) 1980.

619. C.J. Vos, in T.v.A. 1986 blz. $85-86$.

620. Eindrapport Commissie Selectieprocedures, Een sollicitant is ook een mens, 's-Grawenhage (november) 1977 ( Verslagen en rapporten 1977/5).

621. Jaarverslag Arbeidsinspectie over 1980, over 1981 en over 1982, resp. blz. 121, blz. 115 - 116 en blz.

622. Eindrapport werkgroep selectieprocedures, 's-Gravenhage ( mei ) 1982.

623. Jaarverslag Arbeidsinspectie over 1981 en over 1982, resp. blz. 115 en blz. 16.

624. Weergegeven in DCA, Werving en selectie in cao's, 's-Gravenhage (juli ) 1984, blz. 51 t/m 67.

625. Zie DCA, Werving en selectie in cao's, blz. $12 \mathrm{t} / \mathrm{m} 16$.

626. De bedoelde fasen zijn: het ontstaan van een vacature, de bekendmaking van de vacature en van de selectiemiddelen, de sollicitatie, de eerste selectie, het sollicitatiegesprek, nader onderzoek, de eindselectie en de beslissing en de klachtprocedure.

627. Directoraat-Generaal van de Arbeid, Werving en selektie in 51 Nederlandse arbeidsorganisaties, 's-Gravenhage ( december) 1984.

628. Directoraat-Generaal van de Arbeid, Werving en selektie in 51 Nederlandse arbeidsorganisaties, blz. 7.

629. Zie de artikelen 9 en 21 van de Veiligheidswet van 1895 en de artikelen 3 en 11 van de Caissonwet 1905.

630. Zie artikel 9 van de Veiligheidswet van 1895 en artikel 3 van de Caissonwet 1905.

631. Zie artikel 6 van de Phosphorluciferwet 1901.

632. Deze feitelijke taakstelling was als volgt uitgewerkt:

a. het bezoeken van plaatsen waar arbeid wordt of pleegt te worden verricht;

b. het bevorderen van uniformiteit in de toepassing van de gegeven voorschriften;

c. het bevorderen van overeenstemming tussen de eisen van de wetgeving en de belangen van alle bij de arbeid betrokken personen;

d. het in het bijzonder letten op de gevaren die bepaalde soorten van arbeid voor de gezondheid en het leven van jeugdige personen en van vrouwen opleverden;

e. het verschaffen van inlichtingen en het doen van voorstellen aan hen die arbeid doen verrichten, om zo de bezwaren, die anders uit de toepassing van de wettelijke voorschriften voor de nijverheid zouden voortvloeien, weg te nemen;

f. het op verzoek adviseren van de vergunning verlenende instanties ( de burgemeesters en de commissarissen van de Koning );

g. het verstrekken van inlichtingen en het adviseren van de verantwoordelijke bewindsman aangaande alle onderwerpen van wetgeving betreffende de arbeid, en

h. het de bewindsman doen van voorstellen terzake van wetgeving, die noodzakelijk of gewenst geacht werd. Zie ook hfdst. 3 par. 2 ( in den beginne waren er slechts drie). 
633. Deze feitelijke taakstelling was als volgt uitgewerkt:

a. het bezoeken van plaatsen die aan het toezicht waren onderworpen;

b. het bevorderen van uniformiteit in de toepassing van de gegeven voorschriften;

c. het bevorderen van overeenstemming tussen de eisen van de wetgeving en de belangen van alle bij de arbeid betrokken personen;

d. het in het kader van de Arbeidswet 1889 op verzoek adviseren van de vergunning verlenende instanties (de burgemeesters en de commissarissen van de Koning);

e. het verstrekken wan inlichtingen en het adviseren van de verantwoordelijke bewindsman, en

f. het de bewindsman doen van voorstellen.

Zie ook hfdst. 3 par. 6 (uitbreiding van de arbeidsinspectie).

634. C.W. de Vries, in Soc. Jaarboek woor Nederland jrg. 1920 (deel II 1922) blz. 21 nt. 2.

635. A. Kerdijk, in S.W. 1896 blz. 242.

636. Dit element van de feitelijke taakstelling is vervallen bij de Arbeidswet 1911, waarbij de arbeidsinspectie als vergunning verlenende instantie werd aangewezen.

637. Dit blijkt onder meer uit het feit, dat aan de op grond van deze wet verleende overwerkvergunningen loonvoorwaarden - de hoogte van de vergoeding van het overwerk - werden verbonden, dat werkgevers werden gedwongen om vooraf met arbeidersvakverenigingen overleg te plegen over de verzoeken om vergunning, dat de werkgever zich bij een bepaalde werkgeversorganisatie moest aansluiten of zich diende te onderwerpen aan de door deze organisatie gestelde regels, dat overwerkvergunningen werden verleend met als argument buitenlandse concurrentie, en dat overwerkvergunningen werden verleend in een crisisperiode om de weeklonen van de arbeiders niet beneden een bepaald minimum te laten dalen.

638. Beschilkking van 28 januari 1950, Stcrt. 22.

639. Koninklijk besluit van 19 januari 1954, Stcrt. 16 .

640. Beschikking van 7 juni 1949, Stcrt. 108.

641. Tweede Kamer, zitting 1976 - 1977, 14497.3 ( memorie van toelichting) blz. 37.

642. Arbo'91 in kort bestek (Werkplan Arbo'91 ), ( mei ) 1989, blz. 7.

643. A.J.C.M. Geers, t.a.p., blz. 242 .

644. Arbeidsinspectie, mens en werk; de Arbeidsinspectie is er goed voor, 's-Gravenhage 1976.

645. J.J. van Dodeweerd, De Arbeidsinspectie bestaat 90 jaar, in S.M.A. 1980 blz. 378 t/m 385; Zie de reactie van A.J.C.M. Geers, Enkele kanttekeningen bij de 90 -jarige Arbeidsinspektie, in S.M.A. 1980 blz. $737 \mathrm{t} / \mathrm{m}$ 741 met naschrift van J.J. van Dodeweerd op blz. $741-742$.

646. A.J.C.M. Geers, t.a.p., blz. 243.

647. A.J.C.M. Geers, t.a.p., blz. 244.

648. Zie DGA Post oktober 1989, blz. 10. 


\section{Inleiding}

In het inleidende hoofdstuk is reeds opgemerkt, dat de systematiek waarbij de chronologische behandeling van het onderwerp de voornaamste leidraad vormt een nadeel in zich bergt. Zoals eveneens reeds opgemerkt en inmiddels gebleken is, worden in de verschillende hoofdstukken bepaalde begrippen gehanteerd, zonder dat daar inhoudelijk aandacht aan besteed kon worden, omdat het gevaar van versnippering en daarmee onduidelijkheid en verwarring aanwezig is. In dit hoofdstuk wordt daarom afzonderlijk in paragraaf 1 aan drie in het kader van het arbeidsomstandighedenrecht veelvuldig gehanteerde begrippen "onderneming", "bedrijf" en "inrichting" een beschouwing gewijd worden. Ook is naar strafrechtelijke elementen verwezen, zonder dat aan de strafrechtelijke aansprakelijkheid in het kader van het genoemde rechtsgebied nader ingegaan is. Dit gebeurt ook in dit hoofdstuk en well in paragraaf 2 In het inleidende hoofdstuk is tevens opgemerkt, dat in het hoofdstuk, dat handelt over de ontstaansgeschiedenis van de arbeidsinspectie in de negentiende eeuw, aandacht is besteed aan controle-middelen en bevoegdheden die aan de ambtenaren van het controlerende orgaan en dit alleen in dit hoofdstuk plaatsvindt, ondat acceptatie van deze aangelegenheden er toe heeft geleid, dat aan het principe hiervan niet meer getornd werd. Anders is het ten aanzien van bijvoorbeeld een later gegeven bevoegdheid, zoals het bevel tot stillegging van werk, dat in de chronologische behandeling zonder problemen kon worden behandeld, omdat het gevaar van versnippering en verwarring niet aanwezig was. Hetzelfde geldt ten aanzien van een onderwerp als de (sub) delegatie. In paragraaf 4 van dit hoofdstuk wordt echter een tweetal bevoegdheden nader beschouwd, namelijk de verplichting tot het verschaffen van inlichtingen en het recht om plaatsen te betreden, omdat dit twee ontegenzeggelijk zeer essentiële bevoegdheden zijn. Aan deze twee bevoegdheden is de aan de betreffende ambtenaren opgelegde verplichting tot geheimhouding onlosmakelijk verbonden, zodat in de laatste paragraf van dit hoofdstuk daaraan aandacht wordt besteed. Wel moet opgemerkt worden, dat de aandacht terzake van de genoemde onderwerpen voornamelijk uitgaat naar hetgeen geldt ten aanzien van de basiswetten van het arbeidsomstandighedenrecht, namelijk de Arbeidswet 1919, de Veiligheidswet 1934 en de Arbeidsomstandighedenwet.

\section{De begrippen "onderneming", "bedrijf" en "inrichting"}

\subsection{De begrippen "onderneming" en "bedrijf"}

\subsubsection{Inleiding}

Zowel de Arbeidswet 1889, als de Veiligheidswet bezigen de begrippen onderneming en bedriff zonder dat de wetgever aangaf wat nu onder die begrippen moest worden verstaan. Wel maakte de toenmalige bewindsman kenbaar, dat hij meende, dat het begrip "onderneming" ruimer was en verschillende bedrijven kon omvatten ${ }^{2}$. Met de invoering van de Ongevallenwet $1901 \mathrm{zou}$ in deze wat verwarrende situatie verandering worden gebracht. Ten einde in overeenstemming te blijven met de in de laatstgenoemde wet gehanteerde terminologie, zou in de Arbeidswet 1911 het begrip bedrijf, waar het in die wet voorkwam in de zin van onderneming, door deze laatste term vervangen worden ${ }^{3}$.

Een essentieel kenmerk van het begrip onderneming in de Ongevallenwet 1901 was het maken van winst, althans het beogen daarvan. Op 19 januari 1904 besliste de Centrale Raad van Beroep ${ }^{4}$ namelijk, dat ten aanzien van

"werkzaamheden" verricht in dienst van publiekrechtelijke lichamen niet de eis (wordt) ge- 
steld, dat zij geschieden in een onderneming, zodat dientengevolge de omstandigheid of het

publiekrechtelijke lichaam al dan niet winst of voordeel beoogt met die werkzaamheden

geen invloed uitoefent

op 21 december $1915^{5}$ werd dit eerder ingenomen standpunt nog eens bevestigd door dit rechtscollege door de beslissing, dat het Sint Aloysius College te Sittard geen werkzaamheden in een onderneming uitoefende, omdat

bij de exploitatie geen winst wordt gemaakt noch beoogd".

Dit uitgangspunt zou zijn weerslag vinden ten aanzien van de Arbeidswet 1911. In het standaard-arrest van 15 juni 1914 karakteriseerde de $\mathrm{HR}^{\text {t }}$ het begrip onderneming als volgt:

"waar de Arbeidswet 1911 het uit de Ongevallenwet 1901 overgenomen woord "onderneming" bezigt, moet daaraan de betekenis worden toegekend, die aan het woord in het dage-

lijkse leven wordt geschonken: namelijk in het bijzonder in betrekking tot handel en nijver-

heid "een zaak, die men opzet of drijft om geldelijke voordelen te behalen;".

Ook hier onderscheidt het winstelement een onderneming van een andere werkeenheid ${ }^{7}$.

Zowel in de Arbeidswet 1919, als de Veiligheidswet 1934 zouden de begrippen onderneming en bedrijf opnieuw gebruikt worden ${ }^{8}$. De toenmalige bewindsman Aalberse verklaarde ${ }^{\theta}$ tijdens de parlementaire behandeling van de eerstgenoemde wet, onder verwijzing naar het reeds aangehaalde arrest van de $H R$, dat van een onderneming geen sprake is,

"wanneer niet voorzit het begrip van geldelijk voordeel".

Overigens wordt door de HR de vraag of dit oogmerk aanwezig is van feitelijke aard geacht ${ }^{10}$.

\subsubsection{Levenbach versus De Gaay Fortman}

De Gaay Fortman maakt in zijn op 12 juni 1936 verdedigde proefschrift over de onderneming in het arbeidsrecht $^{11}$ ernstig bezwaar tegen de door de HR gegeven uitleg van het begrip onderneming en in aansluiting daarop op het door minister Aalberse tijdens de parlementaire behandeling van de Arbeidswet 1919 hieromtrent gestelde ${ }^{12}$.

Eén en ander is het gevolg van het door de auteur zelf gehanteerde begrip onderneming. Allereerst maakt hij een onderscheid tussen een onderneming in economisch-organisatorische zin ( naar buiten ) en in technisch-organisatorische zin (naar binnen). Vervolgens behandelt hij de technisch-organisatorische eenheid, waarin arbeid wordt verricht. Dit arbeidsgeheel noemt hij de onderneming. Op deze wijze vermijdt hij derhalve het gebruik van de term bedrijf, zij het tot zijn leedwezen, daar dit begrip het wezen van de moderne onderneming beter vertolkt dan de term onderneming zelf ${ }^{3}$, omdat zoals uit het citaat blijkt, dat het "een voortdurend bedrijvig zijn", een "zonder ophouden werken" aanduidt ${ }^{14}$.

"Wanneer men het woord bedrijf gebruikt, denkt men aan een voortdurend bedrijvig zijn, een voortdurend ingespannen bezig zijn, een zonder ophouden werken aan een bepald doel. Het woord bedrijf heeft een technische klank. Men ziet, als men het woord hoort, de fabrieksgebouwen als het ware voor zich met de draaiende machines en de rustelloos werkende arbeiders ..... Wat daarentegen het woord onderneming betreft ..... het roept bij ons herinneringen op aan de handelsman, die wint, omdat hij waagt, maar om dezelfde reden ook vaak verliest. Door het onzekere, dat eraan verbonden is, mist het het voortdurende, het onafgebrokene van het begrip bedrijf. Het heeft meer een economische klank".

Ten aanzien van het door hem hanteren van het begrip onderneming schrijft De Gaay Fortman ${ }^{15}$ echter wel, dat hij zo een naar zijn mening verkeerd wetenschappelijk spraakgebruik moet volgen. Zijn enige argument hiervoor is, dat een meerderheid van de schrijvers met de term bedrijf een samenstel bedoelt van ondernemingen, die een soortgelijk produkt voortbrengen, met andere woorden: bedrijf in het kader van de bedrijfsorganisatie.

"En aangezien nu de wetgever met de Bedrijfsradenwet ${ }^{10}$ voor het eerst duidelijk eveneens 
aan bedrijf deze betekenis heeft gegeven en in verdere arbeidswetten, indien bedrijf daarin al eens in de zin van onderneming voorkomt, dit toch zelden het geval is, menen wij ons bij deze ontwikkeling te moeten aansluiten en te moeten spreken van onderneming;".

In een bespreking van het proefschrift vit Levenbach ${ }^{77}$ bezwaren tegen het door De Gaay Fortman gekozen begrip ondememing. Hij had van bedrijf of van bedrijfshuishouding moeten spreken, aldus Levenbach. Zijn keuze miskent de resulaten van de economische wetenschap en met name van de bedrijfshuishoudkunde. Levenbach ontkent niet, dat in de economische wetenschap het begrip bedrijf nu eens een afzonderlijke bedrijfshuishouding en dan weer voor de gehele bedrijfstak wordt gebruikt. Dit had De Gaay Fortman echter niet moeten verleiden tot het aanwenden van het begrip onderneming onder verwerping van het begrip bedrijf, maar tot een nadere analyse van de verschillende betekenissen van dit laatste begrip. In de bedrijfshuishoudkunde is, aldus Levenbach, het begrip bedrijf nauwkeurig geanalyseerd en wordt daarbij een onderscheid gemaakt tussen:

a. bedrijf als technisch-organisatorische eenheid, die op de uitvoering van een bijzonder deel van de maatschappelijke voortbrenging gericht is en die dus bepaalde goederen vervaardigt of bepaalde diensten levert. Deze eenheid noemt De Gaay Fortman onderneming, terwijl Levenbach stelt, dat dit als "(afzonderlijk) bedrijf" betiteld had moeten worden;

b. bedrijf als groep van gelijksoortige bedrijfshuishoudingen oftewel de bedrijfstak, en

c. bedrijf als economische bedrijvigheid of het bedrijfsleven als zodanig.

Daarnaast geeft de bedrijfshuishoudkunde, zo vervolgt Levenbach, als definitie van ondermeming: een vermogensrechtelijke zelfstandige eenheid, die om winst te maken, dat wil zeggen om een van een bepaald produktieproces of serie produktieprocessen afhankelijk wisselend inkomen, in het maatschappelijk verkeer optreedt.

De consequentie van de keuze van De Gaay Fortman is, aldus Levenbach, dat er talrijke bedrijven zijn, die niet om winst te behalen zijn opgezet en dus geen ondernemingen zijn, maar wel organisatorische arbeidseenheden, bedrijfshuishoudingen, vormen, waarop de meeste van de door De Gaay Fortman gegeven beschouwingen van toepassing zijn ${ }^{18}$. Het verwijt dat De Gaay Fortman de HR ingevolge het arrest van 15 juni 1914 maakt, dat hierbij geen rekenschap is gegeven van het wezen van het organisme, waarin de meeste arbeiders het grootste deel van hun leven doorbrengen, vindt Levenbach ${ }^{19}$ niet terecht. Hij meent, dat de HR de terminologie zuiver heeft gesteld door in zijn interpretatie van het begrip onderneming het element: "om winst" op te nemen. Want ondanks het feit, dat de begrippen bedrijf en onderneming, zoals zij bijvoorbeeld in de Arbeidswet 1889 en in de Arbeidswet 1911 zijn gehanteerd tot verwarring aanleiding kunnen geven, staat eén ding vast: met deze wetten beoogde de wetgever de beschermende hand uit te steken naar jeagdige personen en vrouwen in kapitalistische fabrieken en werkplaatsen: en niet overal.

Hoewel De Gaay Fortman wel een onderneming in economisch-organisatorische zin en in technisch-organisatorische zin onderscheidt, geeft hij zelf toe, dat deze nooit van elkaar afgescheiden kunnen worden ${ }^{20}$ vanwege het feit, dat ook de technisch-organisatorische eenheid steeds in het maatschappelijk verkeer optreedt. Alleen wanneer dit laatste gebeurt om winst te behalen, zo stelt Levenbach,

"wordt het bedrijf in een onderneming uitgeoefend":

anders niet. De normen van de arbeidersbeschermende wetgeving zijn primair gesteld ten behoeve van arbeiders, die werken in bedrijven, die kapitalistisch, dat wil zeggen als ondernemingen om winst, worden geëxploiteerd. En pas bij uitbreiding werden daar andere bedrijven - bedrijven die uitsluitend in het algemeen belang werkzaam zijn, overheidsbedrijven, liefdadig ingestelde bedrijven en dergelijke - mee gelijkgesteld, zodat ook daar deze beschermende normen gingen gelden, maar niet over de hele linie. Juist door het begripsgebruik van de HR kunnen hier, aldus Levenbach, onderscheidingen worden gemaakt, die bij het woordgebruik van De Gaay Fortman onmogelijk zijn ${ }^{21}$. 
Tot sllot merkt Levenbach ${ }^{22}$ op, dat het onderscheid tussen de begrippen onderneming en bedriff niet alleen in het verleden grote betekenis heeft gehad, maar ook voor de toekomst van belang zou blijven. Zeker kan toegegeven worden, dat het huidige arbeidsrecht niet alleen maar normen bevat, die ten doel hebben om de arbeider te beschermen tegen de (over)macht van de werkgever. Veel problemen in het arbeidsbestel, die vroeger uitsluitend gerelateerd werden aan de verhouding van de om-winstwerkende kapitalist en de loonarbeider, worden nu als organisatorische problemen van een bedrijfshuishouding gezien, die zich evengoed voordoen in een niet om winst gedreven bedrijf. Dit mag er dan weer niet toe leiden, dat het hele onderscheid tussen de beide begrippen moet worden weggevaagd. Allerlei verhoudingen blijven woorlopig nog enigszins anders liggen in een bedrijf, dat om winstbejag is opgezet, dan in een instelling van algemeen nut. Het arbeidsrecht zal daar rekening mee moeten houden. De regels, die niet alleen voor ondernemingen, maar voor alle bedrijven moeten gelden, moeten via uitbreiding van de toepasselijkheid van die regels gestalte krijgen, zonder dat het begrip onderneming verwatert. De Gaay Fortman ${ }^{23}$ had zelf al het volgende opgemerkt:

"Het gevaar is groot, dat het recht, wanneer het zich gaat bemoeien met instellingen op sociaal of economisch terrein en daar reeds bestaande begrippen een juridische inhoud gaat geven, die begrippen losmaakt van de bodem, waarin zij wortelen, en tot onwezenlijke begrippen maakt".

Aan dit gevaar zijn, zo stelt Levenbach, zowel rechtspraak als wetgeving, die naast het begrip bedrijf in de betekenis van bedrijfstak ook het begrip bedrijf als bedrijfshuishouding kennen, maar dit laatste niet met het begrip onderneming identificeren, ontsnapt, wat De Gaay Fortman met zijn woordgebruik echter niet gelukt is.

\subsubsection{Een nieuw begrip "onderneming"}

In het verlengde van hetgeen Levenbach heeft gesteld, zouden in het arbeidsrecht andere aspecten van de onderneming dan alleen het winst beogende element gestalte krijgen; namelijk het zijn van een werkgemeenschap waarin personen en zakelijke produktiemiddelen tot éen geheel onder leiding voor een (bepaald) produktiedoel samen zijn gebracht ${ }^{24}$. In dat kader is betoogd, dat bij de regeling van de rechtsverhoudingen in een dergelijke werkgemeenschap het winstaspect, dat in de arbeidersbeschermende wetgeving tot dusverre aan een onderneming was toebedeeld, niet een zo belangrijke rol mag spelen, om zo nieuwere denkbeelden over de arbeidsverhoudingen en de gezagsverhouding binnen die werkgemeenschap te grondvesten ${ }^{26}$; denkbeelden over medezeggenschap van werknemers.

Deze nieuwere denkbeelden zouden hun neerslag vinden in onder meer de Wet op de ondernemingsraden van 4 mei 1950. In deze wet zou aan het begrip onderneming een andere inhoud worden gegeven dan in de Arbeidswet 1919 en in navolging daarvan de Veiligheidswet 1934. In het betreffende wetsvoorstel ${ }^{26}$ was opgenomen, dat onder onderneming diende te worden verstaan, zowel een onderneming, gedreven met het oogmerk om winst te behalen, als een onderneming, gedreven zonder een zodanig oogmerk ${ }^{27}$. De toelichting ${ }^{28}$ leert, dat met de nadere precisering van het begrip onderneming beoogd was aan te geven, dat onder ondernemingen in het onderhavige wetsvoorstel niet worden verstaan de natuurlijke of rechtspersonen die een functie in het bedrijfsleven vervullen, maar de technisch-organisatorische eenheden, bijvoorbeeld de fabriek of de handelszaak, die, of het ambachtsbedrijf, dat door hen bij het vervullen van die functie wordt geèxploiteerd $^{2 \theta}$. Het voorlopig verslag ${ }^{30}$ maakt duidelijk, dat men van diverse zijden de mening was toegedaan, dat de opgenomen definitie de in de toelichting weergegeven bedoeling in het geheel niet dekt. Met een juridisch-economisch begrip kan nooit een technisch-organisatorische eenheid worden omschreven. Het is dan ook niet duidelijk, zo wordt vervolgd, of een onderneming, die drie fabrieken exploiteert, één dan wel drie ondernemingsraden zou moeten instellen. Men vroeg zich dan ook af of het niet de voorkeur zou verdienen in de definitie te stellen, dat onder een onderneming mede wordt verstaan een gedeelte van een onderneming, dat een technisch-organisatorische eenheid vormt (1). 
Uiteindelijk zou de parlementaire behandeling van het betreffende wetsvoorstel ertoe leiden, dat de Wet op de ondernemingsraden van 4 mei 1950 geen afzonderlijke definitie bevatte van het begrip onderneming. Wel zou bepaald worden, dat onder onderneming mede diende te worden verstaan een bedrijf waarmee niet beoogd werd winst te behalen ${ }^{31}$. Via deze gelijkstellingsmogelijkheid werd derhalve kenbaar gemaakt, dat het begrip in het kader van deze wet ruim opgevat diende te worden.

In de nieuwe Wet van de ondernemingsraden van 28 januari 1971 wordt het begrip onderneming omschreven als $^{32}$ :

"elk in de maatschappij als zelfstandige eenheid optredend organisatorisch verband waarin

krachtens arbeidsovereenkomst arbeid wordt verricht".

Met deze nieuwe begripsomschrijving wordt, aldus toelichting ${ }^{33}$, beoogd materieel geen wijziging te brengen in de bestaande situatie. Het bedoelde samenwerkingswerkingsverband van mensen wordt, ongeacht de werkzaamheden die er worden verricht en ongeacht het doel waarvoor het in het leven is geroepen, als onderneming in de zin van de wet beschouwd. Functie en winstoogmerk zijn dus, blijkens de toelichting, niet relevant voor het wettelijk ondernemingsbegrip; bepalend is wel of het samenwerkingsverband in de maatschappij als zelfstandige eenheid optreedt. De doelstelling van deze wet is, dat ondernemingsraden zoveel mogelijk aan de voet worden ingesteld ${ }^{34}$; het grondkarakter van de wet is gericht op een overleg op een zo laag mogelijk niveau in de vorm van ondernemingsrade ${ }^{35}$.

\subsubsection{Van Dodeweerd versus Van $Z_{w a m}$}

Vrij recent is er opnieuw een discussie over het begrip onderneming gevoerd. Deze discussie werd ingeluid door Van Dodeweerd ${ }^{38}$, die voor zijn stellingname uitgaat van hetgeen De Gaay Fortman in 1936 heeft betoogd. Ook Van Dodeweerd onderscheidt een onderneming in economisch-organisatorische zin en in technisch-organisatorische zin. Ook hij stelt, dat het ineengestrengeld zijn van de onderneming in economisch-organisatorische zin en van de onderneming in technisch-organisatorische zin wel de oorzaak moet zijn van het feit, dat de toenmalige bewindsman tijdens de parlementaire behandeling van de Arbeidswet 1919, onder verwijzing naar het arrest van de HR van 15 juni 1914, verklaarde dat van een onderneming geen sprake is, wanneer niet voorzit het begrip van geldelijk voordeel. Deze laatste eigenschap noemde hij kenmerkend voor de onderneming in technisch-organisatorische zin, waarvoor de Arbeidswet 1919 regels geeft ${ }^{37}$. Hij vervolgt met de stelling, dat het streven naar geldelijk voordeel voor de onderneming in technisch-organisatorische zin niet aanvaard kan worden, daar haar doel alleen gericht is op het voortbrengen van goederen of het verrichten diensten. De onderneming in economisch-organisatorische zin daarentegen tracht geldelijk voordeel te behalen door goederen of diensten tegen betaling aan derden ter beschikking te stellen. Dit heeft dan ook tot gevolg, dat vrijwel iedere wet op het terrein van de arbeidersbescherming het begrip onderneming per definitie uitbreidt, zodat uiteindelijk toch weer uitgekomen wordt bij de technisch-organisatorische eenheid. Hij vervolgt met de stelling, dat zich in Nederland als vast begrip heeft ontwikkeld, dat met de onderneming in het arbeidsrecht bedoeld wordt elke technisch-organisatorische eenheid, die zelfstandig optreedt en als zodanig in het rechtsleven een eigen rol speelt. In een reactie hierop merkt Van Zwam op ${ }^{38}$, dat de wetshistorische interpretatie van het begrip onderneming in de Arbeidswet 1919 en de Veiligheidswet 1934 niet verandert doordat nieuwe betekenissen van het begrip onderneming opduiken. Uitbreiding van het begrip op een dusdanige wijze, dat de wettelijke bepalingen van toepassing worden op organisaties die voorheen niet onder de wet vielen, kan alleen door een formele wetswijziging. Van Zwam verwijst ter illustratie voor de interpretatie van het arbeidswettelijke begrip onderneming naar een aantal rechterlijke uitspraken. Naast het al behandelde arrest van de HR van 15 juni 1914 noemt hij de arresten van de HR van 15 januari $1940^{38}$ en 14 juni $1955^{40}$. In het eerstgenoemde arrest constateert de HR allereerst, dat "zoowel uit de bewoordingen als uit de geschiedenis van art. derde lid aanhef en onder b van meergenoemde wet blijkt, dat onder de daar genoemde inrichtingen of takken van dienst van publiekrechtelijke lichamen niet vallen dezulke, welke een onderneming zijn in 
den zin wan het eerste lid van dit artikel", waartoe vereist is, dat zij is opgezet of gedreven om geldelijke voordelen te behalen. De gemeentelijke gasen waterbedrijwen te Maastricht zijn, zo vervolgt de $\mathrm{HR}$, niet opgezet of worden niet gedreven om geldelijke voordelen te behalen, doch om een taak van de gemeente naar behoren te vervullen, en zijn dus geen ondernemingen in de zin van het eerste lid van deze wet, maar vallen onder de gelijkstelling inrichtingen of takken van dienst van de gemeente als bedoeld in het derde lid van genoemd artikel. In het laatstgenoemde arrest aangaande het al dan toepasselijk zijn van de Arbeidswet 1919 op de Nederlandsche Heide Maatschappil, stelt de HR, dat

"de Ned. Heide Mij niet is een onderneming in den zin van art. lid 1 dier Wet, nui zij, ..., niet het maken van winst beoogt;

dat echter volgens lid 3 van dat artikel met ondernemingen o.a. worden gelijkgesteld inrichtingen of takken van dienst, onder beheer van rechtspersoonlijkheid bezittende verenigingen, voorozver aldaar werkzaamheden plegen voor te komen als in een fabriek of werkplaats;

dat deze bepaling medebrengt, dat zulke inrichtingen of takken van dienst voor een deel hunner werkzaamheden als onderneming in de zin der Arbeidswet 1919 moeten worden beschouwd, ook al zouden zij voor een ander deel zulks niet zijn;".

Daarnaast bestrijdt Van Zwam, dat er zich in de literatuur een vast begrip onderneming heeft ontwikkeld. Hij doet daarbij een beroep op Van Schilfgaarde ${ }^{41}$ die juist de pluriformiteit van dit begrip benadrukt:

"Hoe in deze omschrijving de term onderneming precies moet worden begrepen behoeft hier niet te worden uiteengezet. Een grote verscheidenheid van definities wordt in de literatuur aangeboden. De kans dat het mogelijk is een voor alle gevallen bruikbare omschrijving op te stellen moet niet hoog aan worden aangeslagen. Hier wordt als uitgangspunt genomen het als zodanig optredende organisatorisch verband. Van ondergegeschikte betekenis is dan of dit verband zelfstandig is of onzelfstandig, of het deelneemt aan het economisch verkeer dan wel het maatschappelijk verkeer; of het uitsluitend, niet uitsluitend of niet op winst gericht is; of het "in stand wordt gehouden", wordt "gedreven" of "toebehoort aan" een natuurlijke persoon dan wel een rechtspersoon".

\subsubsection{Het begrip "onderneming" in het kader van de Arbeidsomstandighedenwet}

De Arbeidsomstandighedenwet als opvolger van de Veiligheidswet 1934 bezigt zowel het begrip bedrijf als het begrip onderneming ${ }^{42}$. Dit laatste begrip wordt echter slechts gebruikt in relatie tot de ondernemingsraad en heeft dan vanzelfsprekend die betekenis welke nit de Wet op de ondernemingsraden voortvloeit of richt zich op het beleid van de werkgever en kan in dat verband betrekking hebben op een groter organisatorisch verband dan in het kader van de Wet op de ondernemingsraden is bedoeld ${ }^{43}$.

In tegenstelling tot de Arbeidswet 1919 en de Veiligheidswet 1934 die een eigen strafsanctie kennen ten aanzien van overtredingen ${ }^{44}$, leidt het niet-naleven van de bepalingen van de Arbeidsomstandighedenwet tot een economisch delict ${ }^{45}$. In dat kader is het mogelijk om op grond van de Wet op de economische delic$\operatorname{ten}^{46}$ bijkomende straffen en maatregelen op te leggen. In de betreffende bepalingen van deze wet wordt bet begrip onderneming gehanteerd ${ }^{47}$.

Volgens Van Dodeweerd ${ }^{48}$ moet bij de bepaling wat hierbij als onderneming moet worden gezien gedacht worden aan de laagst geformeerde technisch-organisatorische eenheid. Hij verwijst in dat verband naar het werk van Paardekoper ${ }^{49}$. Deze neemt echter een genuanceerder standpunt in ${ }^{50}$. Hij wijst er uitdrukkelijk $o p$, dat de interpretatie van het begrip onderneming in een bepaalde regeling aan de hand van de wijze waarop het elders wordt gehanteerd, sllechts betrekkelijke waarde heeft, omdat het in elk van die regelingen een eigen betekenis heeft, die aan het bijzondere doel van die regeling is angepast ${ }^{51}$. 


\subsubsection{Inleiding}

Zowel de Arbeidswet 1919, als de Veiligheidswet 1934 en de Arbeidsomstandighedenwet bezigen naast de begrippen onderneming en bedrijf de term invichting ${ }^{52}$, al dan niet los van het begrip bedrijf, zonder dat de wetgever kenbaar heeft gemaakt wat nu precies onder een inrichting dient te worden verstaan. Ten einde toch enig inzicht te krijgen omtrent de betekenis van het begrip inrichting wordt vaak een zijstap gemaakt naar een wet waarbij het begrip als zodanig centraal staat, namelijk de Hinderwet ${ }^{53}$.

\subsubsection{Het begrip "inrichting" in de Hinderwet}

Het doel van de Hinderwet is door middel van eea vergunningenstelsel te voorkomen dat inrichtingen, gevaar, schade of hinder voor de omgeving veroorzaken ${ }^{54}$. Ook hier heeft de wetgever niet aangegeven wat onder het begrip inrichting dient te worden verstaan. Wel wordt in de wet zelf aangegeven, dat onder het begrip inrichting mede wordt verstaan: een plaats, welke, zonder dat daar enig bouwwerk of getimmerde aanwezig is, wordt gebezigd als werk-, bewaar-, stort-, opslagplaats of iets dergelijks. Aangezien het begrip inrichting bij de Hinderwet centraal staat, maar nergens is aangegeven wat daaronder moet worden verstaan, is de betekenis die de rechtspraak in deze aan het begrip heeft gegeven van belang. Daarbij doen zich een aantal vragen voor:

1. wanneer is er sprake van een inrichting en wat kan of moet bijvoorbeeld in verband met het stellen van woorschriften nog tot de inrichting gerekend worden?

2. wat kan nog tot een inrichting behoren of, anders gezegd, mag een bedrijf voor de toepassing van de Hinderwet in meer inrichtingen verdeeld worden?

Ten aanzien van de eerste vraag kan opgemerkt worden, dat de Kroon aan het begrip inrichting een zeer ruime interpretatie geeft. Zo wordt onder meer in het Koninklijk besluit van 25 november $1959^{55}$ en in het Koninklijk besluit van 7 september $1961^{58}$ overwogen:

"gelet op de geest en de strekking van de wet, welke worden bepaald door het streven gevaar, schade en hinder van ernstige aard zoveel mogelijk te weren, moet aan het begrip "inrichting" een zo ruim mogelijke betekenis worden toegekend. Vrijwel elke door de mens ondernomen bedrijvigheid, welke binnen een zekere begrenzing pleegt te worden verricht en daarbuiten gevaar, schade of hinder van ernstige aard kan veroorzaken, levert voldoende grond op om te spreken van een inrichting in de zin van de Hinderwet".

Deze omschrijving is nagenoeg een standaardoverweging geworden in de jurisprudentie van de Kroon als het gaat om de beantwoording van de vraag of sprake is van een hinderwetplichtige inrichting. Zo werd het storten van hoogovenvliegas op een bouwterrein met het oog op de fundering van een bouwwerk beschouwd als een inrichting bestemd tot verwerking van afval; het ging hier om een eenmalige bedrijvigheid waarvan de gevolgen blijvend zijn ${ }^{57}$. Het opbrengen van rioolslib en het laten drogen ervan werd eveneens bestempeld tot een inrichting, bestemd tot verwerking van afval ${ }^{56}$.

pok een mobiele gelegenheid voor het bereiden van voedings- en genotsmiddelen, waaronder frituurartikelen is eveneens een inrichting, zij het dat in het kader van het Hinderbesluit ${ }^{50}$ er wel sprake moet zijn van een

vaste standplaats.
Daarnaast heeft de Kroon een duidelijk standpunt ingenomen ten aanzien van de uitzonderingsbepaling voor installaties die tijdelijk worden geplaatst bij wegenbouwprojecten. Met betrekking tot een asfaltmenginstallatie weigerden de burgemeester en wethouders op het verzoek van het districtshoofd van de arbeidsinspectie te Deventer tot sluiting over te gaan, omdat zij van mening waren, dat de installatie tijjelijk was geplaatst voor bepaalde wegenbouwprojecten. Het betrokken districtshoofd meende dat van tijdelijkheid niet meer kon worden gesproken nu de werkzaamheden aan de betreffende rijksweg circa 8 maanden in beslag zouden 
nemen. Hij meende, dat een termijn circa 6 maanden als grens van tijdelijkheid kon worden aangemerkt, ondanks het feit dat hij daarvoor noch in de wet, noch in de rechtspraak enige aanknopingspunten kon vinden. Hij zou evenwel door de Kroon in het gelijkgesteld worden, zodat een vergunning ingevolge de Hinderwet vereist was, op grond van de volgende overwegingen ${ }^{80}$ :

"dat immers gebleken is, dat genoemde installatie, gelegen aan de weg Zwolle-Almelo, niet slechts ter plaatse is opgesteld voor de aanleg van de weg Zwolle-Raalte, doch dat genoemde installatie mede wordt gebezigd ten behoeve van andere werken in een wijde ongeving; dat woorts bij de keuze van de plaats van opstelling der inrichting niet zozeer de plaats van het uit te voeren werk is geweest, doch meer de aanwezigheid in de onmiddellijke nabijheid der inrichting van geschikt vaarwater voor de aanvoer van grondstoffen".

Ook een asfaltbetoninstallatie werd door de Kroon als een inrichting in de zin van de Hinderwet aangemerkt, alhoewel ook in dit geval was aangevoerd, dat de installatie werd gebruikt ten behoeve van werkzaamheden aan een bepaalde weg en dat de installatie na beëindiging van deze werkzaamheden zou worden verplaatst.

Dat aan het begrip inrichting een zeer ruime interpretatie wordt gegeven, onderwond ook een exploitant van een varkensmesterif ${ }^{61}$. Deze ging in beroep tegen de door burgemeester en wethouders gedane kennisgeving van hun voornemen tot sluiting van de inrichting, daar hij meende dat voor het exploiteren van een varkensmesterij geen vergunning ingevolge de Hinderwet vereust is. Maar de Kroon ${ }^{62}$ besliste dat een varkensmesterij, bestaande uit een varkensstal en een mestvaalt wel voldeed aan de omschrijving van het betreffende begrip, daar voor het oprichten enzovoort van een inrichting bestemd tot bewaring van mest en meststoffen een vergunning vereist is ${ }^{63}$. De eis van vergunning geldt niet alleen voor de tot het bedrijf behorende mestvaalt, maar voor de gehele inrichting, dus ook voor dat deel waar de varkenshokken staan. De gedane kennisgeving was derhalve terecht en het beroep werd ongegrond verklaard. Vervolgens moet worden genoemd de zaak van een vennootschap die een mergelgroeve, alsmede een mergelzeef- en maalinstallatie exploiteerde. Voor een dergelijke installatie is een vergumning ingevolge de Hinderwet vereist ${ }^{64}$. In de beroepsprocedure werd door een omwonende aangevoerd, dat hinder van ernstige aard werd ondervonden van de genoemde mergelgroeve. In verband met deze bezwaren hadden burgemeester en wethouders bij het verlenen van de gevraagde vergunning hieraan voorschriften verbonden, die uitsluitend betrekking hadden op de bij de winning van mergel veroorzaakte hinder, er van uitgaande, dat de groeve tot de inrichting behoorde. De Kroon $^{\text {65 }}$ besliste evenwel, dat:

"hoewel een zeker verband bestaat tussen de winning van mergel en de inrichting waarvoor vergunning wordt gevraagd toch niet kan worden gezegd, dat de mergellgroeve zulk een essentieel onderdeel uitmaakt van de onderhavige installatie, dat zij hiermede een inrichting in de zin van de wet vormt".

Enkele jaren later zou de Kroon ${ }^{66}$ echter anders beslissen. Het ging om een inrichting tot het opslaan en mengen van zand, grind en cement waarvan hinder door lawaai werd ondervonden, namelijk bij het lossen van grind, het storten van grind in de elevatorbak en in de weegbak. Het lossen van grind en zand geschiedt, zodanig, dat het per schip aangevoerde materiaal door de schippers gelost wordt met behulp van op het schip opgestelde losgerei. Maken de schepen en losgerei geén deel uit van de inrichting, de opslag van zand en grind behoren wél tot de inrichting. De Kroon overwoog nu dat, aangezien de grondstoffen onmisbaar zijn voor de samenstelling van de betonmortel, voortdurend nieuw zand en grind moet worden aangevoerd, zodat dan ook het uit de schepen in de inrichting ontvangen van deze materialen als een wezenlijk onderdeel van de inrichting moet worden aangemerkt. In latere jurisprudentie ${ }^{87}$ zou ten aanzien van schepen en mobiele werktuigen beslist worden, dat zij in bepaalde gevallen wél tot de inrichting gerekend kunnen worden, namelijk wanneer zij ten tijde van hun deelneming aan het produktieproces als een essentieel onderdeel van de inrichting kunnen worden beschouwd en geacht worden hiermee én geheel te vormen.

De tweede vraag betreft de mogelijkheid of een bedrijf in meerdere inrichtingen mag worden verdeeld. De grootschaligheid van bepaalde industrieën, zoals bijwoorbeeld raffinaderijen en chemische bedrijven, en de 
verplichting een nauwkeurige beschrijving van de plaats van de inrichting bij de aanvraag te overleggen, alsmede een opgave van wat er in de inrichting wordt verricht, brengen voor de vergunningaanvrager een enorme hoeveelheid werk met zich, waarbij het risico aanwezig is, dat de stukken niet volledig zijn, zodat de vergunningsaanvraag niet-ontvankelijk dient te worden verklaard. Om deze redenen zal bij een gemeente de neiging bestaan om een bedrijf in kleinere en daardoor handzamere eenheden te splitsen, zeker wanneer het een bedrijf betreft, waar verschillende produkten in evenzovele gebouwen worden vervaardigd, of een bedrijf, dat naar zijn aard gemakkelijk in onderdelen is te splitsen. Is een dergelijke splitsing in het kader van de Hinderwet mogelijk? Maatgevend voor de Kroon ${ }^{68}$ is, of tussen de onderscheidene bedrijfsgedeelten

"een dusdanig onverbrekelijke samenhang bestaat, dat zij tezamen als éćn inrichting in de zin van de Hinderwet dienen te worden beschouwd".

Dit werd bijwoorbeeld het geval gevonden bij twee aan elkaar grenzende vuilstortplaatsen, met een deurenfabriek en deurenlakkerij en met een kalvermesterij en een mestvarkensbedrijf, maar niet met een kalvermesterij te Wildervank en een aan de overkant van het Stadskanaal gelegen gelijksoortig bedrijf van dezelfde exploitant. Ook twee bedrijven die juridisch toebehoren aan verschillende besloten vennootschappen kunnen toch aangemerkt worden als één inrichting, nu zij gevestigd zijn op een bedrijfsterrein dat één geheel vormt en deze bedrijven onderling zodanige organisatorische, technische en functionele bindingen hebben, dat zij geacht moeten worden één geheel te vormen ${ }^{69}$. Het in gevallen gevoerde betoog, dat het technisch en functioneel zeer goed mogelijk zou zijn één of meer bedrijfsonderdelen elders als een zelfstandige eenheid te vestigen, werd door de Kroon niet relevant gevonden. Bovendien, zo werd vervolgd, is het systeem van deelvergunningen niet in het belang van de omwonenden ${ }^{70}$,

"aangezien alsdan uitsluitend aandacht kan worden geschonken aan het gevaar, de schade of de hinder, voortvloeiende uit elk van de secties afzonderlijk, doch niet van het bedrijf in zijn totaliteit bezien".

Gezien het vorenstaande kan worden gesteld, dat in het kader van de Hinderwet het begrip inrichting een zeer ruime betekenis moet worden toegekend; een vestiging kan als én inrichting worden beschouwd, wanneer er gesproken kan worden van een geografische, organisatorische, technische én functionele eenheid. Een openbare weg, die door een vestiging loopt, is op zich geen belemmering voor de geografische eenheid; een woonwijk, een braakliggend stuk land of een ander bedrijf daarentegen kunnen een vestiging in meerdere inrichtingen verdelen ${ }^{71}$. Ten aanzien van de organisatorische en functionele aspecten is van belang of de verantwoordelijkheid voor de feitelijke bedrijfsvoering op een persoon kan worden teruggevoerd ${ }^{72}$.

Voor de vraag, of er sprake is van één of meerdere inrichtingen, zijn eigendomsverhoudingen niet relevant $\mathrm{t}^{73}$. Bovendien is het niet noodwakelijk, dat de bedrijvigheid in een inrichting plaats vindt in het kader van een onderneming ${ }^{74}$.

\subsubsection{Het begrip "inrichting" in het arbeidsomstandighedenrecht}

De werkingssfeer van zowel de Arbeidswet 1919, als de Veiligheidswet 1934 strekt zich uit tot alle arbeid, zijnde alle werkzaamheden in een onderneming ${ }^{75}$. Voor de vraag welk werktijdenbesluit of veiligheidlsbesluit in een bepaalde situatie van toepassing is, is de aard van de te verrichten werkzaamheden in de ruimte waarin zij verricht worden bepalend. Als voorbeeld moge dienen het begrip "fabriek of werkplaats". In artikel 2, eerste lid, onder a, van de Arbeidswet 1919 wordt de volgende omschrijving gegeven:

"alle open of besloten ruimten waar, anders dan uitsluitend ten behoeve van eene daar gevestigde huishouding, pleegt gewerkt te worden aan of ten behoeve van het vervaardigen, schikt of meer geschikt maken of aan of ten behoeve van het vermietigen van voorwerpen of stoffen, of waar voorwerpen of stoffen eene daartoe strekkende bewerking plegen te ondergaan, of waar handelswaren met het oog op den verkoop in het klein plegen te worden afgewogen, afgemeten of verpakt, anders dan in winkels voor den verkoop ter plaatse en 
op veilingen"

In artikel 3, eerste lid, van de Veiligheidswet 1934 vindt men een vergelijkbare omschrijving van dit begrip "fabriek of werkplaats". De overige in de opsomming van de desbetreffende in de beide wetten neergelegde definitiebepaling voorkomende werkeenheden kunnen niet alleen als een uitbreiding van het begrip worden genoemd, maar zijn soms een nadere aanduidling. Onder het begrip "fabriek of werkplaats" moet mede worden verstaan aanhorigheden, zoals gangen, trappen, portalen, kelders, zolders, berg- en opslagruimten, terreinen, laboratoria, privaten en schaftlokalen ${ }^{76}$. De aanhorigheden hebben

"ten doel iederen twijfel af te snijden omtrent de vraag, of de aanhoorigheden aan een fa-

briek of werkplaats vallen onder de bij of krachtens de Arbeidswet voor fabrieken of werkplaatsen gestelde yoorschriften" ${ }^{\text {"T7? }}$.

In de toelichting op de Veiligheidswet 1934, wordt opgemerkt, dat de praktijk een dergelijke regeling van de aanhorigheden heeft

"doen gevoelen, nu het volgens de bestaande wet eenigszins onzeker is, of haar bepalingen wel kunnen worden doorgevoerd in localiteiten, waar niet regelmatig wordt gewerkt, doch waar het in het belang van het personeel toch gewenscht, ja noodzakelijk is, dat voorzieningen kunnen worden getroffen, bijv, ten aanzien van verlichting en zindelijkheid".

Bij aanhorigheden gaat het derhalve om zaken die behoren tot of deel uitmaken van, in het gekozen geval, fabrieken of werkplaatsen. Er hoeft geen directe verbinding te bestaan tussen de aanhorigheid en bijvoorbeeld de fabriek of werkplaats.

Centraal in de gegeven definitiebepaling staat derhalve allereerst de ruimte, dat wil dus zeggen een ruimtelijke begrenzing waarbinnen bepaalde activiteiten plegen plaats te vinden. Het voor het begrip "fabriek of werkplaats" gekozen systeem geldt eveneens voor andere in de Arbeidswet 1919 onderscheiden categoriën van arbeid.

Nu is het mogelijk dat in een bepaalde ruimte verschillende werkzaamheden worden verricht: Daarvoor geeft artikel 7, eerste lid, van de Arbeidswet 1919 een regeling.

"Indien in eene ruimte zoodanige verschillende werkzaambeden worden verricht, dat die ruimte beschouwd moet worden als eene fabriek of werkplaats, een winkel, een kantoor, eene apotheek, een koffiehuis, een hôtell of eene verplegings- of verzorgingsinrichting en tevens als een ander dezer inrichtingen, gelden ten aanzien van die werkzaamheden de bepalingen van de verste strekking, behoudens in de gevallen bij algemene maatregel van bestuur genoemd".

In dit artikellid wordt het begrip "inrichting" gehanteerd en door verwijzing naar een ruimte die bijvoorbeeld als een fabriek of werkplaats kan worden aangemerkt, omvat het begrip "inrichting" hier dus zowel de ruimte waar bepaalde werkzaamheden plegen te worden verricht als de aanhorigheden zoals bijvoorbeeld de terreinen en is in het gekozen voorbeeld synoniem van het begrip "fabriek of werkplaats", maar kan evengoed een kantoor, een winkel en dergelijke zijn. Het heeft hier een ruimtelijke betekenis.

Ook in de Veiligheidswet 1934 wordt het begrip "inrichting" gebruikt. Zo bepaalt artikel 20c, eerste lid, van de Veiligheidswet 1934, dat het hoofd of de bestuurder van een onderneming, waartoe een inrichting behoort, vallende onder een bij algemene maatregel van bestuur hiertoe aangewezen categorie, verplicht is er voor te zorgen, dat aan die inrichting een bedrijfsgeneeskundige dienst verbonden is, die door de verantwoordelijke bewindsman ten behoeve van die inrichting is erkend. In de toelichting ${ }^{70}$ bij de Wet van 25 maart $1971^{\text {Ta }}$, waarbij de regeling van de bedrijfsgeneeskundige diensten in de Veiligheidswet 1934 gewijzigd is, staat omtrent het bezigen van de term "inrichting" in het betreffende artikel het volgende vermeld:

"Indien nu het begrip "fabriek of werkplaats" niet langer wordt gebezigd, zal daarvoor in de plaats dus een andere term, waaraan een ruimtelijke betekenis kan worden toegekend, moeten worden ingevoerd. Daartoe wordt blijkens het ontwerp het woord "inrichting" gekozen. Een inrichting als hier bedoeld, kan bijwoorbeeld zijn - onderscheiden naar feitelijk 
daarin uitgevoerde werkzaamheden - een fabriek, een werkplaats, een kantoor, een winkel, een depôt of een middel van vervoer van een onderneming".

Tevens wordt in de toelichting kenbaar gemaakt, dat wanneer tot een onderneming enige inrichtingen behoren, die geografisch in elkaars nabijheid zijn gelegen, het te ver zou gaan te verlangen, dat een bedrijfsgeneeskundige dienst zijn taak slechts ten aanzien van het personeel van eén inrichting doelmatig kan uitoefemen; het verdient integendeel aanbeveling het gezamenlijke personeel, werkzaan in de hier bedoelde inrichtingen, te doen verzorgen door een bedrijfsgeneeskundige dienst, wooropgesteld dat deze daartoe voldoende bemand en geoutilleerd is.

"Liggen echter de tot eenzelfde onderneming behorende inrichtingen vrij sterk geografisch verspreid, dan is het voor een goede functionering van de bedrijfsgeneeskundige zorg wenselijk die zorg te beperken tot het personeel van elke apart gesitueerde inrichting. In zodanig geval ware dus aan elke inrichting afzonderlijk een bedrijfsgeneeskundige dienst te verbinden",

aldus de toelichting. Een en ander leidt tot de conclusie, dat het begrip inrichting hier zeer ruim wordt opgevat $^{80}$. Maar de toenmalige bewindsman ${ }^{81}$ zag niet in, dat dit tot interpretatiemoeilijkheden zou leiden. Hij verwees in dat verband naar het begrip "inrichting" in de Hinderwet waar ook het begrip inrichting, zonder nadere definiëring, wordt gebezigd en dat in de praktijk niet tot grote moeilijkheden aanleiding heeft gegeven. Maar wel moet er op gewezen worden, dat het hier gaat om geografisch verspreide inrichtingen die tot éen onderneming behoren; dit in tegenstelling tot de Hinderwet waar het niet noodzakelijk is, dat de bedrijvigheid in een onderneming plaatsvindt.

Ten slotte wil ik wijzen op de Arbeidsomstandighedenwet, waar in diverse artikelen het begrip inrichting, overigens veelal in combinatie met het begrip bedrijf, wordt gebruikt. Naast deze begrippen besteedt deze wet ook aandacht aan werkverbanden buiten inrichtingen en bedrijven. Ik doel hiermee op artikel 1, vijfde lid, van die wet. De tweede volzin van dit artikellid begint met de woorden:

"Waar in deze wet de woorden "bedrijf" of "inrichting" worden gebruikt om een plaats aan te duiden.....".

Het gaat hier derhalve om een plaats, een ruimtelijke begrenzing in de lijn van het begrip inrichting in de Arbeidswet 1919 en in de Veiligheidswet 1934. In de tweede volzin wordt vervolgens aangegeven, dat deze plaats mede

"een andere plaats (omvat) waar werknemers arbeid verrichten".

Met andere woorden: plaatsen buiten het bedrijf of de inrichting, waar door werknemers arbeid moet worden verricht worden onder het begrip bedrijf of inrichting gebracht. Deze uitbreidende betekenis is, volgens de toelichting ${ }^{82}$, van belang voor een aantal wettelijke voorschriften zoals aangaande de melding en registratie van ongevallen en beroepsziekten, het voorkomen van gevaar voor andere personen dan werknemers, de werplichting tot samenwerking tussen werkgever en werknemers ${ }^{\text {ea }}$.

In de eerste volzin van artikel 1, vijfde lid, van de Arbeidsomstandighedenwet wordt bepaald, dat waar

"in deze wet de bevoegdheid wordt verleend tot aanwijzing van bedrijven of inrichtingen.

dan wel delen daarvan, hetzij per categorie, hetzij individueel, zulks mede omwat de be-

voegdheid tot aanwijzing van werkverbanden die niet aan een bedrijf of een inrichting ge-

bonden zijn".

Blijkens de toelichting ${ }^{84}$ zijn een aantal regelingen ( bijvoorbeeld die inzake het jaarplan en het jaarverslag $^{85}$ ) alleen van toepassing op bedrijven en inrichtingen die krachtens de wet worden aangewezen. Sommige werkverbanden zijn echter niet gebonden aan een bedrijf of inrichting, bijvoorbeeld een bouwwerk. Het eerste gedeelte van het vijfde lid van artikel 1 beoogt nu te voorkomen dat de aanduiding bedrijven of inrichtingen bij de uitvoering van de wet te weinig armslag zou geven om an te geven waar de betrokken bepalingen van toepassing zijn. Van deze in de eerste volzin van het vijfde lid van artikel 1 van de Arbeidsomstandighedenwet is gebruik gemaakt in het Besluit verplichtstelling van bedrijfsgezondheidsdiensten " ${ }^{B \otimes}$. In artike1 2, eerste lid, onder a, van dit besluit wordt bepaald, dat die categorieën van bedrijven of inrichtingen 
worden aangewezen waarin 500 of meer werknemers in dienst van de werkgever werkzaam zijn en waarin tevens witsluitend of in hoofdzalak arbeid in een fabriek of werkplaats dan wel stuwadoorsarbeid wordt verricht. Het tweede lid van dit artikel bepaalt nu, dat dit mede geldt voor in elkaars nabijheid gelegen bedrijven of inrichtingen van eenzelfde werkgever, die, zo zij te zamen als één bedrijf of éen inrichting werden aangemerkt, als zodanig onder deze categorie zouden vallen. Tot zo ver is er niets bijzonders aan de hand. De verplichtstelling is gekoppeld aan bedrijven of inrichtingen. Van de uitbreidingsmogelijkheid die gegeven is in artikel 1, vijfde lid, van de Arbeidsomstandighedenwet is echter wel gebruik gemaakt. Op grond van artikel 2, derde:lid, van her Besluit verplichtstelling van bedrijfsgezondheidsdiensten worden voor de toepassing van het eerste lid van dit artikel tevens aangewezen werkverbanden als bedoeld in artikel 10, eerste lid, van de Wet Sociale Werkvoorziening ${ }^{87}$.

\subsection{Conclusies}

Thans is het moment aangebroken om aan het bovenstaande enige conclusies te verbinden. Ten aanzien van bet begrip onderneming, zoals dat in diverse wettelijke regelingen wordt gebezigd, kan geen uniforme omschrijving worden gegeven. Een en ander vindt zijn oorzaak in het feit, dat de diverse wettelijke regelingen telkens een andere doelstelling hebben en de inhoud van het betreffende begrip wordt bepaald door het door de wetgever te beschermen belang. Om die reden heeft het begrip in het medezeggenschapsrecht een ruime betekenis, namelijk elk in de maatschappij als zelfstandige eenheid optredend organisatorisch verband, terwijl hetzelfde begrip in de arbeidersbeschermende wetgeving de betekenis heeft van een zaak die men opzet of drijft om winst te behalen. Aan deze laatste vaststelling moet echter onmiddellijk worden toegevoegd, dat de werkingssfeer van de betrokken wetgeving door de gegeven omschrijving van het begrip "onderneming" te beperkt zou zijn. Dientengevolge heeft de wetgever zijn toevlucht gezocht in een uitbreiding van deze begripsomschrijving door andere werkeenheden via de zogenaamde gelijkstellingen met een onderneming gelijk te stellen.

Ten aanzien van het begrip bedrijf geldt min of meer het zelfde. Dit begrip kan betrekking hebben op de bedrijfshuishouding die bepaalde goederen vervaardigt of bepaalde diensten levert, zodat het begrip de betekenis krijgt van een technisch-organisatorische eenheid. In deze betekenis wordt het onder meer gebezigd in de Arbeidsomstandighedenwet: Daarnaast kan het begrip bedrijf duiden op een groep van gelijksoortige bedrijfshuishoudingen met andere woorden aan de bedrijfstak - in deze betekenis wordt het begrip bedrijf onder meer gebezigd in artikel 28, zevende lid, van de Arbeidswet 1919 - alsmede op het bedrijfsleven als zodanig. Vastgesteld kan derhalve worden dat én en ander afhankelijk is van de contekst waarin dit begrip wordt gebruikt.

Aan het begrip inrichting zoals dat wordt gebezigd in de Arbeidswet 1919 dient een beperkte, maar ruimtelijke betekenis te worden toegekend. In de Veiligheidswet 1934 heeft het begrip een ruimere betekenis ten aanzien van de verplichting tot het hebben van een bedrijfsgeneeskundige dienst. In de Arbeidsomstandighedenwet heeft het begrip verschillende betekenissen afhankelijk van de context waarin het wordt gehanteerd.

Terugkomend op de visies van De Gaay Fortman en Levenbach op het begrip onderneming en bedrijf, kan ik de gedachtengang van de laatstgenoemde vanuit juridisch oogpunt volledig onderschrijven. Dit uitgangspunt heeft er toe geleid, dat het begrip onderneming, in eerste instantie in de Arbeidswet 1919, uitgebreid moest worden door middel van de zogenaamde gelijkstellingen met een onderneming om tegemoet te komen aan de eisen van de praktijk. Met name de gelijkstellingen leidden tot menig verschil van mening. In de Arbeidsomstandighedenwet is met dit stelsel gebroken; hier gaat het niet meer om de institutie waar bepaalde werkzaamheden worden verricht, maar om de arbeidsverhouding, de relatie waarin de werknemer tot zijn werkgever staat. 


\section{De regeling van de aansprakelijkheid in het arbeidsornstandighedenrecht}

\subsection{Arbeids- en rusttijden}

De ratio van de Arbeidswet 1919 is tweeledig, namelijk het beperken van de arbeidsduur in het algemeen en het tegengaan van gevaarlijke arbeid van jeugdige personen en vrouwen.

Als deze strekking van de wet in het oog wordt gehouden, dan is het niet verwonderlijk, dat de wetgever de strafrechtelijke aansprakelijkheid voor de naleving van de gegeven bepalingen niet gelegd heeft bij de arbeiders zelf, maar hoofdzakelijk op de schouders van het hoofd of de bestuurder van een onderneming dan wel op het opzichthoudend personeel, voor zover het door hem met de zorg van de naleving van die bepalingen is belast. Daarnaast bevat de Arbeidswet 1919 een bijzondere aansprakelijkheidsregeling ten aanzien van de arbeids- en rusttijden van arbeiders van in het buitenland gevestigde ondernemingen en ten aanzien vam kinderarbeid. Door het streven om ontduiking zoveel mogelijk tegen te gaan, is de formulering van de aansprakelijkheid voor het verrichten van de verboden arbeid in de Arbeidswet 1919 tamelijk gecompliceerd geworden.

\subsection{De voorgeschiedenis}

\subsubsection{De Kinderwet-Van Houten}

De Kinderwet-Van Houten verbood het in dienst nemen of het in dienst hebben van kinderen beneden de twaalf jaren ${ }^{88}$.

Bij overtreding van dit verbod waren

"de hoofden of de bestuurders der onderneming, in of bij welke het kind in dienst is bevon-

$\operatorname{den}^{\mathrm{n}}$

aansprakelijk $\mathrm{k}^{89}$. Als echter de indienstneming had plaatsgehad buiten weten van deze aansprakelijke hoofden of bestuurders en deze konden bewijzen, dat zij de overtreding, onmiddellijk na daarvan kennis te hebben genomen, hadden doen ophouden, dan werd degene aansprakelijk gesteld, die het kind in dienst had genomen ${ }^{80}$. De door de wetgever gekozen formulering leidde tot grote onzekerheid over het antwoord op de vragen of er sprake was van een overtreding van het verbod van kinderarbeid en zo ja, wie daarvoor in ellk afzonderlijk geval aansprakelijk was ${ }^{\text {}}$.

\subsubsection{De parlementaire enquête van 1886}

De parlementaire enquête-commissie van 1886 meende, dat de problemen bij de toepassing van de Kinderwet-Van Houten konden worden ondervangen door

"niet het in dienst nemen of het in dienst hebben, maar datgene waar het eigenlijk op aan-

komt, namelijk het laten arbeiden van een kind"

bij de wet strafbaar te stellen. De parlementaire enquête-commissie vond eeth bijzondere strafbaarstelling en de daarmee samenhangende bijzondere disculpatiegrond dan ook overbodig. Alles kwam neer op de omschrijving van het strafbare feit. De gekozen ruime uitdrukking: het laten arbeiden van een kind, maakte het, aldus de enquête-commissie, mogelijk, dat zowel hoofden als bestuurders van ondernemingen als hoofden van gezinnen of gestichten, voogden en verzorgers al naar gelang de omstandigheden aansprakelijk konden worden gesteld voor de overtreding van het verbod ${ }^{82}$.

\subsubsection{De Arbeidswet 1889}

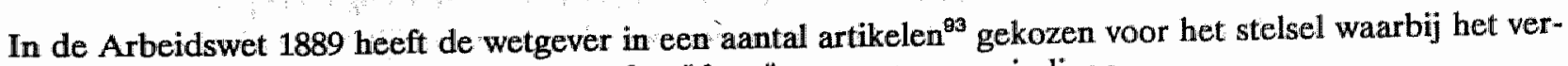
boden werd arbeid te "doen" verrichten of te "doen" aanvangen en eindigen. 
Overtreding van éen van deze artikelen werd strafbaar gesteld, maar zonder dat een nadere aanduiding van de dader werd gegeven ${ }^{24}$ ( de zogenaande "geobjectiveerde aansprakelijkheid"). Uit de parlementaire behandeling ${ }^{85}$ blijkt, dat in tegenstelling tot het woord "laten", dat ook het lijdelijk gedogen, het toelaten omvat, aan het woord "doen" een actieve betekenis moet worden toegekend, dat het een actief handelen veronderstelt, zodat overtredingen alleen maar willens en wetens kunnen worden gepleegd.

Deze uitleg werd aanvankelijk overgenomen in de jurisprudentie ${ }^{98}$. Maar al snel werd echter voor het "doen verrichten ${ }^{n}$ geen actieve handeling meer geëist. Strafbaar was nu, in de meeste gevallen het hoofd of de bestuurder van een onderneming; die de overtreding van de Arbeidswet 1889 willens en wetens liet gebeuren, met andere woorden hij die de overtreding bewust gedoogde ${ }^{87}$.

\subsubsection{De Arbeidswet 1911}

Het bovenstaande, in de Arbeidswet 1889 neergelegde stelsel werd, zij het iets anders geconstrueerd, in de Arbeidswet 1911 overgenomen en uitgebreid. Uitgangspunt van deze wet was, dat allerlei arbeid door de door de wet beschermde personen "niet mocht worden verricht" ${ }^{\text {ing }}$. Aansprakelijk was degene, die het verbod overtrad om arbeid in strijd met het bij of krachtens de Arbeidswet bepaalde "te doen verrichten ${ }^{\text {mile? }}$. Evenals in de Arbeidswet 1889 was er sprake van een geobjectiveerde aansprakelijkheid, zodat niet vereist was, dat het hoofd of de bestuurder van een onderneming ${ }^{100}$ die arbeid deed verrichten ${ }^{101}$.

In de jurisprudentie werd de lijn die bij de Arbeidswet 1889 was gevolgd met betrekking tot de strafbaarstelling, voortgezet; strafbaar was hij die overtreding van de Arbeidswet 1911 willens en wetens toeliet, zonder dat van een bepaalde opdracht daartoe sprake was ${ }^{102}$. Maar in de Arbeidswet 1911 werd de aansprakelijkheid uitgebreid. Het hoofd of de bestuurder van een onderneming was namelijk verplicht er voor te zorgen, dat geen arbeid werd verricht in strijd met het bij of krachtens deze wet bepaalde ${ }^{103}$. Daarnaast kwam in deze wet voor het eerst een bepaling voor, die onder meer deze zorgverplichting legde op het opzichthoudend personeel, voor zover het door het hoofd of de bestuurder van een onderneming daarmee was belast $^{104}$. De toenmalige minister was van mening ${ }^{105}$, dat een dergelijke bepaling aanzienlijk tot de naleving van de wet zou bijdragen. Immers het opzichthoudend personeel, dat door het hoofd of de bestuurder opgedragen is voor de naleving van de wettelijke bepalingen zorg te dragen, zal zich, als dit niet behoorlijk gebeurt, niet alleen tegenover het hoofd of de bestuurder, maar evengoed tegenover de rechter hebben te verantwoorden.

Deze ruime aansprakelijkheid eiste, aldus de minister ${ }^{100}$, op grond van de billijkheid als tegenwicht de bevoegdheid om zich in geval van een plaatsgevonden overtreding van schuld vrij te pleiten. Er laten zich gevallen denken, zo vervolgde hij, dat er niettegenstaande alle voorzorgen door het hoofd of de bestuurder en het opzichthoudend personeel genomen, toch arbeid wordt verricht die door de wet verboden is. In bepaalde gevallen kan deze aansprakelijkheid dus te ver gaan. Daarom werd in de wet een beperking aangebracht ${ }^{10 \%}$.

Bepaald werd, dat aan de zorgverplichting geacht werd te zijn voldaan, wanneer het hoofd of de bestuurder of het opzichthoudend personeel kon aantonen, dat door hem 1e de nodige bevelen waren gegeven, $2 \mathrm{e}$ de nodige middelen waren verschaft, en $3 e$ het redelijkerwijs te vorderen toezicht was gehouden om de naleving van de bepalingen te verzekeren, wartoe hij verplicht was zorg te dragen.

\subsection{De Arbeidswet 1919}

Het systeem van de Arbeidswet 1911 is overgenomen in de Arbeidswet 1919. Maar ook nu weer is de aansprakelijkheid uitgebreid.

Op grond van artikel 74, eerste lid, van de Arbeidswet 1919 is het verboden arbeid te doen verrichten in strijd met het bij of krachtens deze wet bepaalde. Door deze formulering worden arbeiders geen verplichtingen opgelegd, want, hoewel kinderen, jeugdige personen, vrouwelijke en mamnelijke arbeiders geen arbeid of slechts arbeid binnen bepaalde grenzen mogen verrichten, is niet het verrichten, maar alleen het doen ver- 
richten van arbeid verboden. In de Arbeidswet 1919 is dus opnieuw gekozen voor de geobjectiveerde aansprakelijkheid. Het verbod is dan ook van toepassing op een met gezag beklede bedrijfsleider die, noch als hoofd of bestuurder ${ }^{108}$, noch als opzichthoudend personeel belast is met de zorg voor de naleving van het bij of krachtens de wet bepaalde, aldus de rechtbank te Rotterdam in $1926^{100}$.

Evenals de Arbeidswet 1911 bevat de Arbeidswet 1919 bepalingen - respectievelijk artikel 74, tweede en vierde lid, en artikel 75 - waarbij een zorgverplichting met betrekking tot de naleving van het bij of krachtens de wet bepaalde, de gebruikmaking van een vergunning ${ }^{110}$, en de naleving van een voorschrift, voorwaarde of een eis, is opgelegd aan het hoofd of de bestuurder van een onderneming en het opzichthoudend personeel, voor zover het door hem daarmee is belast. Overtreding van deze zorgverplichting kan alleen door hen gebeuren en niet door de zo even bedoelde bedrijfsleider ${ }^{111}$. Maar als er sprake is van vervanging van het hoofd of de bestuurder van een onderneming ${ }^{112}$, is de vervanger aansprakelijk en is het hoofd of de bestuurder, die vervangen is, van de zorgverplichting ontheven ${ }^{113}$.

Overigens ontslaat de opdracht - onvoldoende is dus een eenvoudige aanwijzing - die het hoofd of de bestuurder aan het opzichthoudend personeel met betrekking tot de zorgverplichting toebedeelt, het hoofd of de bestuurder niet van zijn eigen aansprakelijkheid ${ }^{14}$.

\subsubsection{De Arbeidswet 1919 en de aansprakelijkheid ten aanzien van de arbeids- en rusttijden van arbeiders van in het buitenland gevestigde ondernemingen}

In de vorige paragraaf is de aansprakelijkheid aan de orde geweest ten aanzien van de naleving van de arbeids- en rusttijden van arbeiders, die in de in ons land gevestigde ondernemingen arbeid verrichten.

Maar hoe is de aansprakelijkheid geregeld ten aanzien van de naleving van de arbeids- en rusttijden van arbeiders van in het buitenland gevestigde ondernemingen, die in een onderneming en hier te lande werkzaamheden verrichten ${ }^{115}$ ? Het antwoord op deze vraag is te vinden in artikel 74, derde lid, van de Arbeidswet 1919. In dit artikellid wordt namelijk bepaald, dat de in artikel 74, tweede lid, van de wet bedoelde verplichting van het hoofd of de bestuurder niet geldt ten aanzien van personen, die geen deelnemen aan de bedrijfsarbeid, indien deze personen, hetzij zelf hoofd of bestuurder van een andere onderneming zijn, hetzij in dienst van het hoofd of de bestuunder van een andere, in Nederland gevestigde onderneming zijn. Deze thans in artikel 74, derde lid, van de Arbeidswet 1919 geformuleerde redactie is eerst in 1930 tot stand gebracht $^{116}$. Voordien gold de in het tweede lid van artikel 74 van de wet bedoelde verplichting van het hoofd of de bestuurder niet ten aanzien van personen, die geen deelnamen alan de bedrijfsarbeid, indien die personen, hetzij zelf hoofd of bestuurder van een andere onderneming waren, hetzij in dienst waren van zodanig hoofd of bestuurder. Deze bepaling kan, aldus de toelichting ${ }^{117}$, moeilijkheden opleveren wanneer personeel van in het buitenland gevestigde ondernemingen hier te lande arbeid in een andere onderneming verrichten. Als voorbeeld wordt daarbij gegeven een monteur van een in het buitenland gevestigde machinefabriek, die in ons land in één of andere fabriek een machine monteert. In een dergelijk geval zal bij niet-naleving van de bij of krachtens de Arbeidswet 1919 gegeven voorschriften ter zake van de arbeids-en rusttijden een vervolging hiervan tegen het hoofd of bestuurder van die in het buitenland gevestigde onderneming, aldus de bewindsman, praktisch wel achterwege moeten blijven. Hoewel hij dus formeel wel aansprakelijk blijft, beoogt de thans geldende nieuwe redactie van artikel 74, derde lid, van de Arbeidswet 1919 hierin een voorziening te treffen. De aansprakelijkheid van het hoofd of de bestuurder van cen onderneming ten aamzien van ander dan zijn eigen personeel, zoals deze geldt op grond van thet tweede lid van artikel 74 van de wet, wordt alleen opgeheven indien dat ander personeel in dienst is van een hier te lande gevestigde onderneming. In het tegengestelde geval rust op het hoofd of de bestuurder van de onderneming waarin gewerkt werd door personen, die in dienst zijn van een in het buitenland gevestigde onderneming, de in het tweede lid bedoelde verplichting ook met betrekking tot dat personeel ${ }^{11}$. 


\subsubsection{De Arbeldswet 1919 en een bijzondere aansprakelijkheid in verband met kinderarbeid}

Bij de wijziging in $1922^{19}$ is een uitbreiding van de aansprakelijkheid in artikel 74 , vijfde lid, van de Arbeidswet 1919 neergelegd, die verband houdt met kinderarbeid (eweneens in de vorm van een zorgverplichting ). Een ieder namelijk, die over een kind de ouderlijke macht of de voogdij uitoefent, alsmede ieder ander, die aan het hoofd staat van een gezin waarin dat kind wordt opgevoed, is na schriftelijke waarschuwing van het districtshoofd van de arbeidsinspectie verplicht te zorgen, dat dat kind geen arbeid, noch arbeid als hoofd of bestuurder van een onderneming ${ }^{\text {t20 }}$ verricht. De minister meende ${ }^{12 i}$, dat evenzeer als van ouders of voogden onder strafbedreiging wordt gevorderd, dat zij voor het verstrekken van onderwijs zorg dragen, van hen mag worden geëist, dat zij toezien, dat hur kind/kinderen of pupil/pupillen geen arbeid verricht/ verrichten, die tot zedelijk bederf kan leiden.

Wil intussen deze aansprakelijkheid terecht worden gevestigd, zo vervolgde hij, dan moet vaststaan, dat zij, die de ouderlijke macht of de voogdij uitoefenen, weten, dat hun kind of pupil verboden arbeid verricht. Zolang dit niet het geval is, kan redelijkerwijs van hen niet worden gevorderd, dat zij maatregelen treffen om een eventualiteit, waarvan wellicht nooit sprake is geweest, tegen te gaan. Vandaar, aldus de minister, dat hun aansprakelijkheid eerst ontstaat, wanneer zij vooraf door het districtshoofd van de arbeidsinspectie schriftelijk zijn gewaarschuwd.

In artikel 74, vijfde lid, van de Arbeidswet 1919 wordt, zij het kunstmatig geconstrueerd, "opzet" vereist, omdat de aansprakelijkheid van de aldaar bedoelde personen is gebaseerd op het feit, dat zij "weten", dat verboden kinderarbeid wordt verricht. Omdat overtreding van de bij de Arbeidswet 1919 strafbaar gestelde feiten overtredingen zijn ${ }^{122}$, is dit een afwijking van het Wetboek van Strafrecht, waarin opzet gewoonlijk slechts geëist wordt bij misdrijven.

\subsection{Veiligheid en gezondheid}

\subsubsection{De Velligheidswet 1934}

De regeling van de strafrechtelijke aansprakelijkheid in het kader van de veiligheidswetgeving is geheel gebouwd op het principe van de Arbeidswet. In de Veiligheidswet van 1895 ontbrak een aansprakelijkheidsregeling van de arbeider; aansprakelijk voor de naleving van de door de wet gegeven voorschriften was, door middlel van een zorgverplichting, het hoofd of de bestuurder ${ }^{123}$. Nu was de werkingssfeer van deze Veiligheidswet beperkt; deze beoogde alleen beveiliging van de arbeiders bij het verblijven in fabrieken en werkplaatsen. De Veiligheidswet 1934 daarentegen richt zich op de beveiliging bij de arbeid in het algemeen en bij het verblijwen van fabrieken of werkplaatsen in het bijzonder. Voor dit doel heeft de wetgever een reeks van beveiligingsmaatregelen voorgeschreven, waarvoor de naleving door middel van een zorgverplichting in de eerste plaats op het hoofd of de bestuurder van een onderneming is gelegd. Evenals de Arbeidswet 1919 kent de Veiligheidswet 1934 een aansprakelijkheidsregeling met betrekking tot het opzichthoudend personeel, voor zover het door het hoofd of de bestuurder met de zorg voor de naleving van die bepalingen is belast $^{124}$.

\subsubsection{De Veiligheidswet 1934 en een bijzondere aansprakelijkheid voor het hoofd of de bestuurder}

De Veiligheidswet 1934 bevat in artikel 19 een bijzondere aansprakelijkheidsregeling voor het hoofd of de bestuurder van ene onderneming ten aanzien van gevaarlijke, onbeveiligde werktuigen en toestellen. Hij is namelijk verplicht er voor te zorgen, dat in zijn onderneming bij algemene maatregel van bestuur aangewezen werktuigen, toestellen; vaten of gereedschappen niet worden vervaardigd, verkocht, verhuurd, afgeleverd of ten verkoop, ter verhuring of ter aflevering voorhanden gehouden, indien deze niet aan bij die algemene maatregell gestelde veiligheidsvoorschriften voldoen. Ter motivering van deze bepaling merkte de toenmalige bewindsman op ${ }^{126}$, dat ondanks het woortdurend inspecteren van fabrieken en werkplaatsen en het op an- 
dere wijze propageren van het gebruik van veilige werktuigen en toestellen, de arbeidsinspectie telkens stoot op het in gebruik nemen van dezelfde onbeveiligde machines, die zij op andere plaatsen had doen vervangen of verbeteren.

"De gebruikers, dikwijls weinig technisch ontwikkelde kleine ondernemers, laten zich die machines door den leverancier of een reizuger aanpraten, onbewust van de fouten, die er aan kleven, en van het verbod om ze te gelbruiken".

De bewindsman vervolgde met de opmerking, dat soms de bron opgespoord kon worden en het soms lukte om herhaling te voorkomen, vooral wanneer het een binnenlandse fabriek betrof, die de machine had gemaakt.

"Maar dikwijls blijven die pogingen onvruchtbaar en het is geen zeldzaamheid, dat uit den vreemde werktuigen voor verkoop hier te lande worden ingevoerd, waarvan in eigen land het gebruik verboden is of bijzondere beveiliging is voorgeschreven".

Als voorbeelden gaf hij vleesmolentjes, acetyleentoestellen en gecombineerde houtbewerkingsmachines. De bedoeling van deze bepaling is derhalve om een breidel aan te leggen tegen het veelvuldig gebruik van machines en toestellen, die voor de met de behandeling belaste personen groot gevaar voor ongevallen opleveren $^{126}$. Maar om de vrees voor willekeur zoveel mogelijk weg te nemen, zal de aanwijzing van die werktuigen, toestellen en dergelijke gebeuren bij algemene maatregel van bestuur, waarin veiligheidsvoorschriften worden opgenomen, waaraan zij moeten voldaan ${ }^{12 \pi}$. Overigens stelde de bewindsman, dat het bewuste artikel stellig ook toepassing kan vinden op ingevoerde machimes, want het verbiedt onder meer het verkopen, verinuren, afleveren en ten koop, ter verhuring of ter aflevering voorhanden houden van niet behoorlijk beveiligde machines, voor zover bij die algemene maatregel van bestuur aangewezen. Maar hij gaf toe, dat het niet rechtstreeks de invoer tegenhield, maar hij was er wel van overtuigd, dat het verbod de invoer zou beïnVloeden ${ }^{128}$.

\subsubsection{De Veiligheidswet 1934 en de aansprakelijkheid van de arbeider}

Kende de Veiligheidswet van 1895 geen aansprakelijkheidsregeling voor de arbeider, sinds de Veiligheidswet 1934 is de arbeider niet geheel straffeloos meer. Zo bepaalt bijvoorbeeld artikel 7 , zesde lid, van die wet $^{129}$, dat een arbeider, die arbeid verricht, waarop een voorschrift gegeven bij of krachtens de in het eerste lid bedoelde algemene maatregel van bestuur, of een eis, gesteld door het districtshoofd, als bedoeld in het eerste of derde lid, betrekking heeft, in de gevallen bij die algemene maatregel bepaald ${ }^{130}$, verplicht is dat voorschrift of die eis na te leven en de op grond van dat voorschrift of die eis aanwezige en voor hem bestemde beveiligingsmiddelen an te wenden. Deze aansprakelijkheidsregeling voor de arbeider is echter gelimiteerd; het is slechts van toepassing

"voor zoover hij redelijkerwijze kan worden geacht met dat voorschrift of dien eisch bekend te zijn $^{* 131}$.

In de toelichting ${ }^{132}$ wordt terzake in de eerste plaats opgemerkt, dat deze strafbaarstelling van de arbeider wordt ingevoerd voor de gevallen, waarin de werkgever al het mogelijke heeft gedaan om de wet na te leven, maar de arbeider nalatig blijft om van de aanwezige beveiligingsmiddelen gebruik te maken of andere in het bellang van veiligheid en gezondheid gestelde voorschriften na te leven, met als gevolg gevaar voor zich zelf of voor zijn mede-arbeiders. De toelichting vervolgt ${ }^{133}$ echter met de opmerking, dat het in die bepaalde gevallen waarin de arbeider aansprakelijk wordt gesteld, niet gaat

"om het overdragen van de aansprakelijkheid van het hoofd of de bestuurder, maar alleen hierom, dat naast het hoofd of de bestuurder eventueel ook de arbeider strafbaar zal zijn, indien hij bepaalde voorschriften of eischen niet naleeft. Voor de strafbaarheid is noodig, dat de arbeider redelijkerwijze kan geacht worden met het voorschrift of den eisch, waarvan overtreding plaats had, bekend te zijn"134. 


\subsection{Verniteuwing; de aansprakelijkheidsregeling in de Arbeídsonstandighedenwet}

In de Arbeidsomstandighedenwet is in vergelijking met haar voorgangster een aantal veranderingen aangebracht ter zake van de strafrechtelijke aansprakelijkheidsregeling, overigens met de handhaving van het gegeven, dat de werkgever degene is, die in de eerste plaats aansprakelijk is. De Veiligheidswet 1934 kende slechts een aansprakelijkheidsregeling voor natuurlijke personen, namelijk voor het hoofd of de bestuurder en/of het opzichthoudend personeel. Door het in de Arbeidsomstandighedenwet bezigen van de term werkgever en het aanmerken van overtredingen van deze wet als een economisch delict ${ }^{135}$, geldt nu een aansprakelijkheidsregeling voor zowel een natuurlijk persoon als een rechtspersoon. In artikel 6 van de Wet op de economische delicten wordt namelijk gesproken van

"hij, die een economisch delict begaat...".

Op grond van artikel 51 van het Wetboek van Strafrecht zijn strafrechtelijk aansprakelijk:

a. de rechtspersoon;

b. degene die opdracht heeft gegeven tot het plegen van een strafbaar feit;

c. degene die feitelijke leiding heeft gegeven aan de verboden gedraging, en

d. de rechtspersoon en één van deze natuurlijke personen tesamen.

Voor de toepassing van dit wetsartikel is de vraag van belang onder welke omstandigheden de natuurlijke persoon die feitelijke macht uitoefent ten aanzien van gedragingen van de rechtspersoon strafbaar is, indien door die rechtspersoon verboden gedraging worden verricht. Voor de beantwoording van deze vraag is allereerst het arrest van de HR van 23 februari $1954^{136}$ van belang. De betreffende zaak had betrekking op een in een eénmanszaak begane onregelmatigheid ten aanzien van uitvoerdocumenten en de uitvoer van ijzerdraad. De exportmanager tevens chef-inkoper van dit bedrijf had te dienaangaande een strafbaar feit gepleegd en de vraag was of deze economische fraude aan de eigenaar van de éenmanszaak kon worden toegerekend. De HR beantwoordde deze vraag in het betreffende arrest ontkennend:

"dat toch handelingen zoals dergelijk in strijd met de wet invullen van formulieren, doen toekomen van die formulieren aan den Dienst van In- en Uitvoer en uitvoeren van goederen, indien verdachte erover vermocht te beschikken, of die handelingen al dan niet plaats vonden, en deze behoorden tot de zodanige, welker plaatsvinden blijkens den loop van zaken door verdachte werd aanvaard of placht te worden aanvaard;".

Voor het beantwoorden van de gestelde vraag of de strafbare gedraging de eigenaar kan worden aangerekend, zijn dus twee elementen van belang, namelijk: is de verboden gedraging iets waarover de eigenaar kan beschikken, dat wil zeggen zijn gezag kan doen gelden, en geeft de gang van zaken in het bedrijf aanwijzingen, dat de eigenaar aanvaardt, dat de ondergeschikten de verboden gedraging plegen, dan wel dat hij deze placht te aanvaarden. Van een betrokkenheid van de eigenaar bij een concrete strafbare gedraging hoeft dus niet te blijken ${ }^{\mathbf{1 3 7}}$, voldoende is, wanneer er sprake is van enige vorm van actieve feitelijke betrokkenheid bij de bedrijfsvoering ${ }^{138}$. Maar in dit geval ging het om een eénmansbedrijf. De vraag rees of de in het arrest geformuleerde criteria ook zouden gelden in het geval er sprake zou zijn van een rechtspersoon. Mulder $^{139}$ beantwoordde deze vraag bevestigend, daarin gevolgd door Remmelink ${ }^{140}$ en Torringa $^{141}$. Op de vraag of een rechtspersoon "de visserij heeft uitgeoefend" in strijd met de wettelijke vangstbeperkingsvoorschriften, besliste de HR in het arrest van 1 juli $1981^{142}$, dat van een zodanig bewerkstelligen sprake is, indien de aan boord van het vissersvaartuig verrichte handelingen zijn aan te merken als gedragingen van de rechtspersoon.

"Dit zou het geval zijn, indien de verdachte er over vermocht te beschikken of die handelingen al dan niet zouden plaats vinden en deze behoorden tot de zodanige welker plaats vinden blijkens de feitelijke gang van zaken door de verdachte werd aanvaard of placht te worden aanvaard".

Deze overweging komt overeen met die uit het eerder al gememoreerde arrest uit 1954.

Ook in andere arresten in de eerste helft van de jaren tachtig werd voor het antwoord op de vraag naar het feitelijke leidinggeven genoegen genomen met het feit dat van enige actieve betrokkenheid bij de bedrijfsvoe- 
ring gebleken was ${ }^{143}$.Hierbij ging het echter steeds om betrekkelijk kleine, weinig gecompliceerde vennootschappen. In de beschikkingen van 19 november 1985 werd door de $\mathrm{HR}^{144}$ bij een meer gecompliceerde bankinstelling als Slavenburg de eis gesteld, dat de feitelijke leidinggever "op de hoogte was of had kunnen of behoren te $z_{i j n}$ "van de verboden gedragingen. In de vervolgbeschikkingen van 16 december $1986^{145}$ besliste de HR het volgende:

"5.1.1. Van feitelijk leidinggeven aan verboden gedragingen kan onder omstandigheden sprake zijn indien de desbetreffende functionaris - hoewel daartoe bevoegd en redelijkerwijs gehouden - maatregelen ter voorkoming van deze gedragingen achterwege laat en bewust de aanmerkelijke kans aanvaardt dat de verboden gedragingen zich zullen voordoen. In deze situatie wordt de zojuist bedoelde functionaris geacht opzettelijk de verboden gedragingen te bevorderen.

5.1.2. De bewuste aanvaarding van de aanmerkelijke kans als onder 5.1.1. bedoeld kan zich te dezen voordoen, indien hetgeen de verdachte bekend was omtrent het begaan van strafbare feiten door de bank rechtstreeks verband hield met de in de kennisgeving van verdere vervolging omschreven verboden gedragingen".

Welke omstandigheden dat overigens zullen zijn, zal door de rechter die over de feiten oordeelt, moeten worden uitgemaakt ${ }^{148}$.

In het arrest van de HR van 14 september $1987^{147}$ komt vrijwel dezelfde overweging voor. In de betreffende strafzaak ging het om de vervolging van een directeur van een rechtspersoon, die een vrachtgoederenverwoerbedrijf exploiteert. Een chauffeur had in het buitenland ritten uitgevoerd zonder echter de op grond van de Rijtijdenwet 1936 vereiste rust- en wachttijden in acht te nemen ${ }^{148}$. Overtreding van deze wettelijke normen worden aan de werkgever, de rechtspersoon, toegerekend ${ }^{149}$. De bedoelde directeur werd echter vervolgd, omdat hij de feitelijke leiding aan de verboden gedraging had gegeven. De rechtbank te Haarlem ${ }^{150}$ zou hem echter van het telastegelegde vrijspreken. Want wel was komen vast te staan, dat hij ervan op de hoogte was, dat de chauffeurs in dienst van de rechtspersoon regelmatig soortgelijke feiten als het thans het in de telastelegging omschreven hebben gepleegd zonder dat hij, als directeur van de rechtspersoon passende maatregelen heeft genomen, hoewel die wel in zijn macht lag. Maar:

"Niet is echter kunnen komen vast te staan dat de verdachte ook van de in de telastelegging

geconcretiseerde gedraging op de hoogte was",

aldus de rechtbank ${ }^{151}$. Het vonnis van de rechtbank wordt met letterlijk dezelfde overwegingen gecasseerd, zodat aangenomen mag worden, dat de in de HR-beschikkingen gekozen formulering een algemene gelding heeft $^{152}$. Maar duidelijk zal zijn, dat over de zogenaamde wetenschapseis niet alleen het laatste woord nog niet gesproken, maar ook het laatste vonnis nog niet is geveld.

Bij de aansprakelijkstelling van de werkgever is een tweedeling aangebracht. Naast de algemene zorgverplichtingen, zoals neergelegd in onder andere de artikelen 3 en 4 van de Arbeidsomstandighedenwet; die zijn bedoeld om het begrip welzijn te verduidelijken, onderscheidenlijk instructies bevatten over het te voeren ondernemingsbeleid ${ }^{153}$, bestaat een zorgverplichting voor de werkgever voor de meer traditionele veiligheidsen gezondheidsaspecten ${ }^{154}$. Wat de algemene zorgverplichting van de werkgever betreft, will ik nader aandacht besteden aan de in artikel 11 neergelegde verplichting, die geen betrekking heeft op de veiligheid van de werknemers maar van derden; een nieuw element in deze wetgeving. Volgens dit artikel is de werkgever, indien bij of in rechtstreeks verband met de arbeid die hij door zijn werknemers doet verrichten, in een bedrijf of inrichting of in de onmiddellijke omgeving daarvan enig gevaar kan ontstaan voor de veiligheid of de gezondheid yan andere personen dan die werknemers, doeltreffende maatregelen ter voorkoming van dat gevaar moet nemen. Reeds lange tijd werd het bij de uitvoering van de Veiligheidswet 1934 als een nadeel gevoeld, dat hiermee geen gevaren konden worden voorkomen of beperkt die andere personen kunnen bedreigen dan zij die "arbeid in een onderneming" verrichten, ook niet in die gevallen waarin die gevaren hun oorsprong vinden of rechtstreeks verband houden met de arbeid, aldus de bewindsman ${ }^{165}$. De gevaren kunnen zich voordoen ten aanzien van personen waarvoor de werkgever geen verantwoordelijkheid 
draagt $^{156}$, zoals bijwoorbeeld bezoekers wan een bedrijf of werknemers van andere bedrijven, die incidentele werkzaamheden moeten uitvoeren. Ten aanzien van deze laatstgenoemde personen geldt overigens niet, dat de werkgever wan deze werknemers van zijn aansprakelijkheid is ontheven. De verantwoordelijke minister licht dit toe met een voorbeeld. Indien de monteur van een fabriek of reparatiebedrijf in een ander bedrijf in een ander bedrijf een reparatie moet verrichten, zal zjjn werkgever aansprakelijk kunnen worden gehouden voor de intrinsieke veiligheid van bijvoorbeeld het elektrische handgereedschap waarvan de monteur zich bedient. Indien echter in de ruimte waar de herstelling moet gebeuren een specifiek gevaar - denk aan ontploffing bij vonkvorming - bestaat, dan ligt het volgens deze bepaling op de weg van de leiding van het bedrijf, waartoe deze ruimte behoort, om ter zake de nodige maatregelen te treffen. Maar daarnaast richt het artikel zich op gevaarsituaties in de onmiddellijke omgeving van het bedrijf, die een gevolg zijn van de bedrijfsarbeid. Voor het overgrote deel van deze gevaarssituaties bestaan al speciale wetten, zoals de Hinderwet en de Kernenergiewet. Maar er blijven leemten over. Opnieuw bedient de bewindsman zich van een voorbeeld. De in de bouw thans algemeen gebruikte elektrische hefwerktuigen vormen ook buiten de in de werktijd gelegen perioden - weekeinde, vakanties - een bron van gevaar, indien deze in zodanige toestand worden achtergelaten, dat onbevoegden zich daartoe toegang kunnen verschaffen en deze in werking kunnen brengen $^{157}$.

Vervolgens is ook de persoonlijke aansprakelijkheid uitgebreid ${ }^{158}$. In artikel 28 van de Arbeidsomstandighedenwet is namelijk de mogelijkheid geopend on bij algemene maatregel van besturur te bepalen, dat de nalevingsverplichting van de tot de werkgever gerichte voorschriften, krachtens artikel 24 van de wet vastgesteld $^{459}$, ook kan rusten op een ander dan die werkgever.

De wet, aldus de toenmalige bewindsman ${ }^{160}$, voorziet in een stelsel waarbij de normen zich uitsluitend richten tot degene die het meest in staat is het doel van de normen te verwezenlijken. Indien het gaat om woorschriften over een veilig gebruik van machines en andere werktuigen en in het algemeen om voorschriften inzake een veilige toestand van machines of van terreinen en opstallen ( bijwoorbeeld constructie, aard van het materiaal waaruit zij bestaan, de staat waarin zij verkeren ) zal het vaak voor de hand liggen om ook dan de werkgever aansprakelijk te houden. Toch verdient, zo vervolgt hij, het in bepaalde gevallen de voorkeur dat in plaats van de werkgever een derde tot naleving wordt verplicht: De gedachte achter dit artikel 28 is, dat door mensen buiten het bedrijf steeds meer machines, werktuigen en dergelijke worden vervaardigd of verhuurd, die voor gebruik bil de arbeid bestemd zijn, terwijl de werkgever dikwijls weinig of geen invloed heeft op de staat van de hem ter beschikking gestelde machines, werktuigen en dergelijke. Dan ligt het voor de hand om degene die die zaken ter beschikking aansprakelijk te stellen voor de toestand waarin die zaken verkeren ${ }^{101}$.

Op grond van artikel 28 van de Arbeidsomstandighedenwet kunnen aangewezen worden de eigenaar of beheerder dan wel degene die kan beslissen over het onderhoud van schepen, vaartuigen of andere vervoermiddelen, gebouwen, inrichtingen, installaties, terreinen of andere ruimten, gereedschappen, installaties, machines, werktuigen of andere hulpmiddelen bij de arbeid ${ }^{182}$.

De aansprakelijkheid voor het opzichthoudend personeel, zoals dat is neergelegd in artikel 29, eerste lid, van de Veiligheidswet 1934 komt in de Arbeidsomstandighedenwet niet meer voor. Een dergelijke bepaling kan worden gemist, omdat de verantwoordelijkheid van het hoofd of de bestuurder van de onderneming vervangen is door die van de werkgever, die in ondernemingen waarin sprake is van leidinggevend personeel praktisch steeds een rechtspersoon is en artikel 51 van het Wetboek van Strafrecht hiervoor een voorziening geeft $^{163}$. Daarvoor in de plaats is artikel 31 in de Arbeidsomstandighedenwet opgenomen, waarin is bepaald, dat als de werkgever werknemers, niet zijnde bestuurders, opdraagt toezichthoudende taken uit te oefenen op grond van de wet, hij ervoor heeft te zorgen dat aan die werknemers de bevoegdheden en middelen worden verleend die nodig zijn voor een goede uitoefening van die taken en dat slechts én werknemer met eenzelfde taak belast wordt ${ }^{184}$; deze voorwaarde is in overeenstemming met de uitspraak van het Ktg. te Middelburg van 4 februari $1953^{165}$, waarin beslist werd, dat slechts eén arbeider met dezelfde taak mag 
worden bellast. Bovendien moet de opdracht nauwkeurig de taken omschrijven en moet zij schriftelijk zijn vastgelegd, onder vermelding van de naam van de werknemer. Volgens de bewindsman is dit geen disculpatie-artikel, maar worden er rechtstreeks de modaliteiten geregeld waaronder cen werkgever de zorg voor de naleving aan personeelsleden mag opdragen ${ }^{* 6}$, overigens zal het gaan om gelijke taken als die, welke verbonden waren aan de mede-aansprakelijkheid van artikel 29, eerste lid, van de Veiligheidswet 1934, derhalve uitvoerende, begeleidende, initiërende en toezichthoudende taken. In een beleids- en uitvoeringsnota terzake van dit artikel wordt nog eens aangegeven wat het verschil tussen artikel 29 van de Veiligheidswet 1934 en artikel 31 van de Arbeidsomstandighedenwet. Op grond van artikel 29 van de Velligheidswet 1934 werd het opzichthoudend personeel (mede)aansprakelijk voor de naleving van de betreffende bepalingen; artikel 31 van de Arbeidsomstandighedenwet bevat daarentegen een regeling van organisatorische aard ${ }^{767}$. De Arboraad kan zich blijkens het advies van 3 april 1987 in deze uitleg vinden ${ }^{168}$. Vervolgens wordt in het advies gevraagd om duidelijk aan te geven het onderscheid tussen het ontstaan van strafrechtelijke aansprakelijkheid en de uit het opdragen van toezichthoudende taken als bedoeld in artikel 31 van de Arbeidsomstandighedenwet voortvloeiende overdracht van verantwoordelijkheid ${ }^{169}$. Zelf merkt de Arboraad in zijn advies, overigens terecht, op, dat een taakstelling nooit een overdracht van strafrechtelijke aansprakelijkheid kan inhouden. De destijds verantwoordelijke bewindsvrouwe had in de bedoelde nota echter wel opgemerkt, dat een taakopdracht wel een grond kan zijn voor een eventuele latere aansprakelijkheid ${ }^{170}$. Als de bewindswrouwe mevrouw Kappeyne van de Coppello hiermee beoogt heeft te zeggen, dat degene die de taak toebedeeld heeft gekregen bij de constatering van een overtreding op een later tijdstip, op grond hiervan aansprakelijk gesteld kan worden, dan lijkt mij dit juist. Wel moet er dan aan gedacht worden, dat hij op grond van artikel 51 van het Wetboek van Strafrecht ook een leidinggevende of opdrachtgevende rol moet hebben gespeeld terzake van de overtreding.

Over een taakopdracht op grond van artikel 31 van de Arbeidsomstandighedenwet heeft inmiddels de HR reeds uitspraak gedaan. In het arrest van 9 april $1985^{171}$ werd de opvatting, dat het door het hoofd of de bestuurder van een onderneming met de zorg voor de naleving van de artikelen 6 , derde lid, en 7 , vijfde lid, van de Veiligheidswet 1934 belaste opzichthoudend personeelslid, dat de in die bepalingen bedoelde verplichtingen verzaakt om ervoor te zorgen dat in die onderneming wordt voldaan aan het Veiligheidsbesluit voor fabrieken of werkplaatsen 1938 gelijk moet worden gesteld met degene die overeenkomstig artikel 51, tweede lid, onder $2^{\circ}$, van het Wetboek van Strafrecht "feitelijke leiding" geeft aan de verboden gedraging van een rechtspersoon die als werkgever niet voldoet aan de verplichting als bedoeld in artikel 26 , eerste lid, van de Arbeidsomstandighedenwet tot naleving van het Veiligheidsbesluit, door de HR verworpen. Het door het hoofd of de bestuurder wan een onderneming met de naleving daarvan belaste personeelslid dat niet voldoet aan de in de artikelen 6, derde lid, en 7, vijfde lid, van de Veiligheidswet 1934 vermelde verplichtingen al door het enkele niet voldoen aan die verplichtingen een overtreding begaat die in artikel 31 van de Arbeidsomstandighedenwet strafbaar zijn gesteld, terwijl, indien een rechtspersoon als werkgever niet voldoet aan. de in artikel 26, eerste lid, van de Arbeidsomstandighedenwet vermelde verplichting, een door het hoofd of de bestuurder van die rechtspersoon met de nakoming van deze verplichting belast opzichthoudend personeelslid slechts strafbaar is, indien hij "feitelijke leiding heeft gegeven" aan het handelen en/of nalaten dat de door de rechtspersoon als werkgever begane overtreding oplevert.

De verantwoordelijke staatssecretaris merkt in de hiervoor bedoelde nota op, dat een persoon met een taakopdracht deze taak op zijn beurt niet kan toewijzen aan een ander ${ }^{172}$. De Arboraad is het hier niet mee eens; artikel 31 van de Arbeidsomstandighedenwet zou zich naar haar mening niet verzetten tegen deze zogenaamde subdelegatie, als

"maar wordt voldaan aan de eisen die in dit artikel aan het opdragen van leidinggevende taken zijn gesteld. De strekking van het wit artikel 31 aangehaalde zinsnede is het voorkomen van onduidelijkheid over de vraag wie waarvoor zorg heeft te dragen".

En die onduidelijkheid kan ontstaan wanneer meer werknemers met een zelfde taak zijn belast of wanneer er sprake is van overlappingen van taken. Bij subdelegatie in de door de haar bedoelde zin zou er geen sprake zijn van de onduidelijkheid die het artikel beoogt te voorkomen, aldus de Arboraad ${ }^{173}$. Dit standpunt 
nu is onbegrijpelijk. Al bij de Veilighelidswet 1934 speelde het probleem van dit zogenaamde doordelegeren. Werd het daar al reeds op grond van de tekst van de wet afgewezen - artikel 29, eerste lid, van die wet beval de termen

"voor zoover het door hem (dat wil zeggen: het hoofd of de bestuurder, JvD) met de zorg

is .... belast"

- voor artikel 31 van de Arbeidsomstandighedenwet is thet niet anders, want daar wordt gesproken van de "werkgever" die "aan werknemers toezichthoudende taken opdraagt". Nog afgezien van de vraag of een werknemer die een taak opgedragen krijgt van de werkgever bij het doorgeven van een taak ook in staat is alle middelen en bevoegdheden over te dragen.

Bovendien is de Arboraad van mening ${ }^{174}$, dat hij voor zijn standpunt steun vindt in de beleidsnota, omdat daarin gesteld wordt, dat het mogelijk is een werknemer een taak op te dragen over een bepaald zorggebied en tevens een andere werknemer cen overeenkomstige taak te geven voor een tweede zorggebied, dat niet samenvalt met het eerste ${ }^{175}$. De Arboraad meent ten onrechte, dat in dit geval meerdere werknemers met een zelfde taak zijn belast, terwijl de beleidsnota in dit opzicht aan duidelijkheid niet te wensen overlaat.

"Het kan voorkomen dat twee (of meer) werknemers eenzelfde taak opgedragen krijgen, echter met een verschillend zorggebied: leidinggevende A krijgt dezelfde taakopdracht m.b.t. afdeling A als leidinggevende B m.b.t. afdeling B. Met name uit de nauwkeurige taakomschrijving kan blijken of niet eenzelfde taak is opgedragen aan twee personen. Een omschrijving van het zorggebied vormt daarbij een onlosmakelijk onderdeel van de taakomschrijving".

Het is te betreuren, dat dit soort misverstanden omtrent een dergelijke wetsbepaling bestaan. Tevens is jammer, dat door de activiteiten van de commissie-Geelhoed in het kader van de deregulering de taakopdrachtmogelijkheid beperkt is tot toezichthoudende taken en zo een onnodige uitholling van de inhoud van artikel 31 van de Arbeidsomstandighedenwet heeft bewerkstelligd.

Ook de aansprakelijkheid van de werknemer heeft een belangrijke verandering ondergaan. In de Arbeidsomstandighedenwet wordt de zorg voor een veilig en gezond arbeidsmilieu niet meer gezien als een plicht die vrijwel geheel en eenzijdig op de schouders van de werkgever rust. De werknemers krijgen voorlichting en onderricht en zij hebben mede een stem in het bepalen van het beleid op het gebied van de veiligheid, de gezondheid en het welzijn in verband met de arbeid. Tegenover de daarbij gekregen rechten en bevoegdheden past het in het uitgangspunt van de wet om de werknemer, meer dan in de Veiligheidswet 1934 het geval is; verplichtingen op te leggen met een daarmee corresponderende aansprakelijkheid,

"al is deze uiteraard van veel beperkter omvang dan die van de werkgever" "77e.

De algemeen geformuleerde verplichtingen van de werknemer zijn neergelegd in artikel 12 van de Arbeidsomstandighedenwet. Op grond van deze bepaling zijn de werknemers verplicht in verband met de arbeid de nodige voorzichtigheild en zorgvuldigheid in acht te nemen om zo gevaren te vermijden voor de veiligheid en de gezondheid van hen zelf of van anderen dan wel met het oog op hun welzijn. De in de tekst gebezigde woorden "of anderen" slaan niet alleen op de bescherming van de veiligheid en de gezondheid van de medewerknemers, maar zij kunnen in voorkomende gevallen ook de belangen van de zogenaamde niet-werknemers of werknemers van andere bedrijven, die met hen te maken krijgen, dienen ${ }^{177}$.

Vervolgens worden onder a tot en met e verplichtingen opgenomen die beschouwd kunnen worden alls een uitwerking van deze algemeen geformulleerde bepaling.

Naast deze algemene zorgverplichting blijven de concrete verplichtingen van de werknemer in de diverse veiligheidsbesluiten hun betekenis houden.

Hoe is de aansprakelijkheid geregeld ten aanzien van de naleving van de veiligheidswetgeving van arbeiders/ werknemers van in het buitenland gevestigde ondernemingen die in een onderneming en hier te lande werkzaamheden verrichten? Hiervoor kan hetzelfde voorbeeld gehanteerd worden, dat door de toenmalige bewiadsman in het kader wan de Arbeidswet 1919 werd aangehaald; een monteur van een in het buitenland 
gevestigde machinefabriek, die in ons land in eén of andere fabriek een machine monteert. Wanneer ik mij beperk tot de Arbeidsomstandighedenwet zal duidelijk zijn, dat de in het buitenland gevestigde werkgever aansprakelijk is voor de naleving van de voorschriften terzake van de veiligheid en de gezondheid van zajn werknemers. Maar een vervolging tegen deze werkgever van die in het buitenland gevestigde onderneming zal praktisch wel achterwege moeten blijven. De Arbeidsomstandighedenwet voorziet niet in een bijzondere regeling hiervoor. Dat betekent, dat wanneer men tot vervolging wegens het niet-naleven van de betreffende voorschriften zou willen overgaan, maar dan van de Nederlandse werkgever voor wie deze werkzaamheden worden verricht, een ingewikkeld bewijsrechtelijk probleem een barrière opwerpt. Aangetoond moet dan worden, aangezien deze Nederlandse werkgever geen arbeidsovereenkomst met deze werknemers heeft en er eveneens geen sprake van inlening ${ }^{178}$, dat er sprake is van een werkgever die een ander onder ziju gezag arbeid doet verrichten ${ }^{179}$. Ten einde de formele aansprakelijkheid van de buitenlandse werkgever om te zetten in een materiële aansprakelijkheid voor de Nederlandse werkgever zou het aan te raden zijn een bepaling in de Arbeidsomstandighedenwet op te nemen van de volgende strekking:

"De bij of krachtens deze op de werkgever rustende verplichtingen gelden eveneens ten aanzien van werknemers, die arbeid verrichten in zijn bedrijf of inrichting die aldaar gewoonlijk niet wordt verricht, en die in dienst zijn van een werkgever van een in het buitenland gevestigd bedrijf of gevestigde inrichting".

\subsection{Disculpatie}

\subsubsection{De Arbeidlswet 1919}

Voor het hoofd of de bestuurder van de onderneming of het opzichthoudend personeel, voor zover het door hem met de naleving van het bij of krachtens de Arbeidswet 1919 bepaalde is belast, was in artikel 76, eerste lid, van de wet een disculpatiegrond neergelegd, die gelijkluidend was aan die in de Arbeidswet $1911^{180}$. Ook hier moest aan de drie vereisten worden voldaan. Bij een wijziging van de Arbeidswet 1919 in 1922 werd deze disculpatiegrond echter enger gemaakt door de toevoeging van een vierde vereiste. Gebleken was, aldus de minister ${ }^{181}$, dat de bestaande redactie van het bewuste artikel te ruim was. De toevoeging maakt nu disculpatie slechts mogelijk als het hoofd of de bestuurder van een onderneming en het opzichthoudend personeel, voor zover daarmee belast, aantoont, dat door hen: 1e de nodige bevelen zijn gegeven, 2e de nodige maatregelen zijn getroffen ${ }^{182}$, 3e de nodige middelen zijn verschaft, en 4 e het redelijkerwijs te vorderen toezicht is gehouden om de naleving van de wettelijke bepalingen, waatover de zorgplicht zich uitstrekt, te verzekeren.

Over de vraag wat onder "de nodige bevelen" en "de nodige maatregelen" valt, heeft de HR zich in het arrest van 1 februari $1949^{183}$ uitgesproken. Het vonnis van de rechtbank ${ }^{194}$ komt er op neer, volgens de samenvatting van de HR, dat het hoofd of de bestuurder aan de hem in de Arbeidswet 1919 opgelegde verplichting tot naleving en zorg steeds en onder alle omstandigheden geacht moet worden te hebben voldaan, wanneer hij met het nemen van maatregelen zover is gegaan, dat nog verder strekkende maatregelen tot een werkstaking - en daarmee samenhangende erastige schade voor het bedrijf - zou hebben geleid. De stelling van de Advocaat-Generaal is, dat het hoofd of de bestuurder in een dreigende werkstaking nooit en onder geen omstandigheid reden mag zien om zich van verdere maatregelen te onthouden. De HR kiest een tussen deze beide uiterste standpunten gelegen positie. Overwogen wordt namelijk, dat ook maatregelen, waarvan een werkstaking - en daarmee samenhangende ermstige schade voor het bedrijf - is te duchten, niet onder alle omstandigheden zijn uitgesloten. Zo kan een werkstaking zo'n grote schade met zich zou brengen en het nalaten van verdere maatregelen de verplichting tot naleving van de wettelijke bepaling in vergelijking daarmee zo weinig ondermijnen, dat van deze maatregelen mag worden afgezien.

Een andere vraag is, wat de bedoeling van de in artikel 76, eerste lid, van de Arbeidswet 1919 neergelegde 
disculpatiegrond is. Uit de parlementaire behandeling ${ }^{185}$ blijkt, dat het uitdrukkelijk niet de bedoeling van de minister is geweest, om een uitspraak te doen over de mate van zorg die door het hoofd of de bestuurder of het opzichthoudend personeel moet worden aangewend. Het artikel handelt over de grenzen van de strafrechtelijke aansprakelijkheid. Noch het hoofd of de bestuurder, noch het opzichthoudend personeel, voor zover daarmee belast, kan strafrechtelijk aangesproken worden wegens het niet-naleven van de zorgverplichting als aan de hierboven genoemde vier vereisten is voldaan. Ook de HR heeft zich over de bedoeling van artikel 76, ecrste lid, van de Arbeidswet 1919 uitgelaten en wel in het arrest van 4 november $1929^{186}$. De bepaling beoogt, aldus de HR ook blijkens zijn geschiedenis, niet de in artikel 74 gegeven voorschriften te verzwakken, maar bedoelt aan te geven onder welke omstandigheden het hoofd of de bestuurder of opzichthoudend personeel van een onderneming redelijkerwijs geacht mag worden de bij artikel 74 opgelegde verplichtingen te zijn nagekomen, zodat zij voor de niet-naleving door anderen van de bepalingen, voor de naleving waarvan zij verplicht waren te zorgen, niet langer strafrechtelijk aansprakelijk zijn. Tevens besliste de HR dat aan alle vier in artikel 76, eerste lid, genoemde vereisten moet zijn voldaan en dat de toetsing hiervan een feitelijke is, die niet voor cassatie in aanmerking komt.

Bovendien besliste de HR in dit arrest, alsook in het arrest van 12 februari $1934^{187}$, dat de bewijslast, dat aan de vier vereisten is voldaan, berust bij het hoofd of de bestuurder of het opzichthoudend personeel van een onderneming. Daarmee gaf de HR te kennen, dat het genoemde artikel geen strafuitsluitingsgrond, waarover in de volgende paragraaf meer, bevat, omdat voor het leveren van het bewijs daarvan ook de vervolgingsinstantie - het Openbaar Ministerie - werkzaam moet zijn ${ }^{188}$.

Bij het arrest van 19 november $1934^{189}$ besliste de HR echter uitdrukkelijk dat dit artikel 76 , eerste lid, geen strafuitsluitingsgrond is. In het zich toen voordoende geval, waarin de in artikel 76 , eerste lid, genoemde vereisten door de verdachte waren aangetoond, diende geen ontslag van rechtsvervolging, maar vrijspraak te volgen. In het arrest van 16 mei $1938^{190}$ is door de HR dezelfde opvatting neergelegd.

Uit deze arresten kan worden geconcludeerd, dat het bij artikel 76, eerste lid, van de Arbeidswet 1919 gaat om het al dan niet plegen van een strafbaar feit en niet om een strafuitsluitingsgrond.

De laatste vraag die rijst is of artikel 76, eerste lid, een van artikel 51 van het Wetboek van Strafrecht afwijkende bepaling is. Ook over deze vraag heeft de HR zich moeten buigen. Beslist werd ${ }^{191}$, dat bij artikel 76 , eerste lid, een bijzondere, van artikel 51 van het Wetboek van Strafrecht afwijkende regeling is gegeven; toepassing van dit laatstgenoemde artikel is dus uitgesloten. Wil dus vrijspraak kunnen volgen, dan is dit alleen mogelijk als aan de vereisten van het in de Arbeidswet 1919 neergelegde artikel 76, eerste lid, is voldaan. Andere omstandigheden die aangevoerd kunnen worden om aan een veroordeling te ontkomen doen niet terzake.

\subsection{De Veilligheidswet 1934}

Op grond van artikel 29, eerste en tweede lid, van de Veiligheidswet 1934 kunnen het hoofd of de bestuurder alsook het opzichthoudend personeel van een onderneming op dezelfde gronden als genoemd in artikel 76 van de Arbeidswet 1919 disculperen. Ook hier geldt; dat door het verstrekken van een opdracht de aansprakelijkheid niet op anderen wordt afgewenteld. Zo bijvoorbeeld oordeelde de kantonrechter te Middelburg ${ }^{192}$ over het verweer van een chef van de montagebouw die aanvoerde dat niet hij, maar de hoofdmonteur die de leiding had over de montagewerkzaamheden, aansprakelijk moest worden gesteld, het volgende:

"Dit verweer gaat echter niet op, omdat ook verd. naar zijn eigen erkentenis door het hoofd of de bestuurders van genoemde onderneming met de zorg voor de naleving van bedoelde bepalingen was belast en van de hieruit voortvloeiende aansprakelijkheid niet wordt ontheven door het enkele feit dat daarnaast anderen, - in dit geval de aan de verd. ondergeschikte hoofdmonteur B. - met dezelfde zorg zijn belast".

Maar, omdat de verdachte in het onderhavige geval kon aantonen dat het door hem uitgeoefende toezicht 
in feitelijk opzicht doeltreffend was geweest, werd hij wrijgesproken.

\subsection{Strafuitsluitingsgronden}

\subsection{Inleiding}

De wetgever heeft in het Wetboek van Strafrecht en in bijzondere strafwetten, zoals die op het terrein van het arbeidsomstandighedenrecht, niet afzonderlijke strafbepalingen opgenomen. Hij omschrijlt ook situaties, waarin overtredingen van die strafbepalingen niet in een veroordeling kunnen resulteren, omdat er zich bijzondere omstandigheden hebben voorgedaan, die het telastegelegde strafbare feit rechtvaardigen dan wel dat het de dader niet verweten kan worden en hem geen schuld treft; de zogenaamde strafuitsluitingsgronden. Strafuitsluitingsgronden kunnen derhalve onder meer onderverdeeld worden worden in de zogenaamde rechtvaardigingsgronden en schulduitsluitingsgronden. Nu spelen er op het terrein van het arbeidsomstandighedenrecht slechts twee strafuitsluitingsgronden, namelijk de alleen in de Arbeidswet 1919 neergelegde rechtvaardigingsgrond overmacht en de niet in enige wettelijke regeling gegeven, maar door de jurisprudentie aanvaarde, schulduitsluitingsgrond afwezigheid van alle schull.

\subsubsection{De rechtvaardigingsgrond overmacht in de Arbeidswet 1919}

\subsubsection{Het ontstaan en de strekking van de rechtvaardigingsgrond overmacht}

De wetgever was van mening, dat de disculpatiegrond in artikel 76 van de Arbeidswet 1919 niet voldoende was. Om die reden is in artikel 83, vierde lid, van de Arbeidswet 1919 een afzonderlijke strafuitshuitingsgrond te vinden en wel de rechtvaardigingsgrond "overmacht".

Artikel 83, vierde lid, van de Arbeidswet 1919 bestaat uit twee delen. In het eerste gedeelte is bepaald, dat het op grond van artikel 83, eerste lid, strafbaar gestelde feit niet strafbaar is als het feit onder de ge-geven omstandigheden als gerechtvaardigd is te beschouwen en het onverwijld door of namens het hoofd of de bestuurder van een onderneming wordt medegedeeld aan het districtshoofd van de arbeidsinspectie. Dit gedeelte is het oude zesde lid van genoemd artikel, dat bij de Wet van 25 april $1951^{193}$ is vernummerd tot het zevende lid en bij de Wet van 11 februari $1988^{194}$ opnieuw is vernummerd tot vierde lid. In het tweede gedeelte van artikel 83, vierde lid, van de Arbeidswet 1919, wordt aangegeven, dat als omstandigheden waaronder het feit als gerechtvaardigd is te beschouwen uitsluitend aangemerkt kunnen worden zich plotseling voordoende ongevallen dan wel de onmiddellijke dreiging daarvan, alsmede andere onvoorzienbare noodgevallen van niet-periodiek karakter, waardoor de normale gang van zaken in de onderneming wordt verstoord. Dit gedeelte is ingevoegd bij de Wet van 25 maart $1971^{195}$.

Het dus toen nog zesde lid van artikel 83 is bij nota van wijzigingen ${ }^{100}$ in het ontwerp-Arbeidswet ${ }^{107}$ ingevoegd. De reden waarom dit gebeurde werd door de toenmalige minister als volgt aangegeven ${ }^{188}$ :

"In elke onderneming kunnen zich gevallen voordoen, waarin naleving van de ontworpen wet in strijd zou zijn met het algemeen belang of met belangen, die zoo groot zijn, dat het belang der wetsnalleving daar verre bij ten achter staat. Rampen, verkeersstoornissen, plotseling zich voordoende ongevallen, die onmiddellijk afgifte of bereiding van genees- of verbandmiddelen eischen, het nemen van maatregelen tot afwending van gevaren b.v. van instorting van huizen, kunnen noodzakelijk maken, dat langer of op andere tijden wordt gewerkt dan de wet toelaat. Tijd om de noodige vergunning tot afwijking van de wet te verkrijgen is in den regel dan niet beschikbaar; ook kan afgeweken moeten worden van een wetsbepaling, waarvan de wet geen vrijstelling kent.

Het zou in hooge mate onbillijk, zo zelfs in strijd met het algemeen belang zijn, wetso-ver- 
treding onder zulke omstandigheden strafbaar te stellen. Tot op zekere hoogte komt artikel 40 van het Wetboek van Strafrecht hieraan tegemoet. Verschillende gevallen zijn echter denkbaar, welke niet zijn terug te brengen tot het begrip "overmacht". Met het oog hierop is het nieuwe 6 de lid van artikel 83 opgemomen. Een eenigszins ruime omlijning van de gevallen, waarin overtreding niet strafbaar behoort te zijn, kan hier niet gemist worden. Tot misbruik zal dit niet leiden, wanneer - zoals in het 6 de lid van artikel 83 geschiedt - aan het bedrijfshoofd alleen dan de kans op straffeloosheid wordt gegeven, wanneer hij onverwijld aan het districtshoofd der arbeidsinspectie mededeeling doet van de overtreding. Elk geval zal op zich zelf moeten worden onderzocht. Is de overtreding naar het oordeel van het districtshoofd en van den rechter onder de gegeven omstandigheden niet gerechtvaardigd, dan zal bestraffing niet uitblijven."

In een latere fase van de parlementaire behandeling van het wetsvoorstel ${ }^{190}$ wees de bewindsman er op, dat in het oog gehouden moest worden, dat het artikellid een rechtvaardigingsgrond geeft voor soortgelijke gevallen als in artikel 40 van het Wetboek wan Strafrecht bedoeld zijn. Opneming ervan werd alleen wenselijk geacht, zo vervolgde hij, omdat verschillende gevallen, die naar analogie van artikel 40 van het Wetboek van Strafrecht een rechtvaardigingsgrond behoren op te leveren, volgens de jurisprudentie van de HR niet onder het begrip "overmacht" van het laatstgenoemde artikel zijn te brengen.

Ten aanzien van de strekking van het toen nog zesde lid van artikel 83 van de Arbeidswet 1919 besliste de HR in het arrest van 9 oktober $1922^{200}$ dat

"de kennelijke strekking van deze zeer ruim opgestelde bepaling is om den dader vrij uit te laten gaan, indien de omstandigheden, waaronder het feit is gepleegd, van zodanige aard

zijn, dat datardoor naar' 's rechters oordeel de wetsovertreding wordt verontschuldigd".

Opmerkelijk is, dat in het bewuste artikellid "s rechters oordeel" niet vermeld wordt, dat daarin niet van "verontschuldigd" maar van "gerechtvaardigd" sprake is en dat niet de daad, maar het feit niet-strafbaar verklaard is, aldus Vrij ${ }^{201}$. Bovendien besliste de HR dat, aangezien de wet hieromtrent geen nadere aanduiding bevat,

"het oordeel over ieder geval geheel is overgelaten aan den rechter, die over de feiten beslist".

In het arrest van 17 november 1930 202, waarbij de Advocaat-Generaal Van Lier concludeerde,

"dat in cassatie niet onderzocht kan worden, of omstandigheden als in dezen zijn vastge-

steld, terecht aanleiding hebben gegeven om de overtreding gerechtvaardigd te achten",

overwoog de HR, dat

"de vraag of onder de gegeven omstandigheden de overtreding in den zin van art. 83 lid 6

voornoemd als gerechtvaardigd was te beschouwen, niet aan de orde kon komen",

om zich vervolgens in een beoordeling over de toepassing van het artikellid te geven.

Daarentegen is in het arrest van 2 januari $1933^{203}$ de in het arrest van 1922 gehanteerde formulering nog eens woordelijk herhaald. Dit, terwijl de HR zich in het arrest van 27 juni $1938^{204}$ opnieuw begaf in een beoordeling van de toepassing van artikel 83, zesde lid, van de Arbeidswet 1919.

Het antwoord op de vraag of deze arresten nu met elkaar in strijd zijn of niet, kan eenvoudig luiden; nee, alle betreffende arresten zitten op dezelfde lijn. Bij de toepassing van een artikel waarin een strafuitsluitingsgrond is neergelegd, zoals artikel 83 , zesde lid, van de Arbeidswet 1919, is aan de rechter een tweeledige taak toegewezen. In de eerste plaats moet hij de feiten vaststellen, om in de tweede plaats een wettelijke bepaling op deze feiten toe te passen. Het oordeel over de feiten als zodanig is van feitelijke aard, zodat cassatie niet mogelijk is. In het geval van artikel 83 , zesde lid, kan de rechter bij de toetsing van deze feiten aan deze wettelijke bepaling het recht schenden. De mogelijkheid dat dit zal gebeuren is geringer naarmate de wet termen gebruikt waarbij aan het oordeel van de rechter een grote vrijheid wordt gelaten, zoals in het geval van het onderhavige artikel, gezien de formulering 
"indien het ( strafbaar gestelde feit) onder de gegeven omstandigheden als gerechtvarardigd is te beschouwen".

Als nu de arresten van 1922 en 1933 en die van 1930 en 1938 hieraan worden getoetst, dan blijkt, dat bij de beide eerstgenoemde de rechtstrijd handelt over de feiten of omstandigheden als bedoeld in artikel 83 , zesde lid, terwijl bij de twee laatstgenoemde arresten de toepassing van dit artikellid op deze feiten of omstandigheden aan de orde is, aldus Pompe ${ }^{205}$. Alleen in het laatstbedoelde geval bestaat de cassatiemogelijkheird.

De vraag of een strafbaar feit onder de gegeven omstandigheden gerechtvaardigd is; maakt dat de rechter belangen moet afwegen, namelijk het door de norm beschermde belang en het door de overtreding beschermde belang. Nu worden in de arresten van 1930 en 1938 door de HR voorwaarden genoemd waaraan de werking van de feiten of omstandigheden gebonden zou zijn. Met andere woorden: vór de belangenafweging bestaan voorwaarden waaraan voldaan moet zijn, will een belangenafweging nog plaats kunnen vinden. In een dergelijke situatie, wanneer dus niet aan de bedoelde voorwaarden is voldaan, dan is het feit in geen geval gerechtvaardigd te noemen. De voorwaarden zijn door de HR ontleend aan de geschiedenis van ( de totstandkoming van ) artikel 83, zesde lid, van de Arbeidswet 1919. Volgens het arrest van 17 november 1930 is de bepaling alleen geschreven

"voor gevallen, waarin onmiddellijk moet worden gehandeld ...., wanneer de tijd om de

noodige vergunning tot afwijking van de wet te verkrijgen in den regell ontbreekt".

Maar ook voor de gevallen van een wetsbepaling, waarvan de wet geen vrijstelling kent, moet, aldus de HR in hetzelfde arrest, onmiddellijk worden gehandeld. De voorwaarde dat onmiddellijk moet worden gehandeld, houdt dus voor de toepassing van artikel 83 , zesde lid, in, dat niet enige tijd tevoren bekend was, dat afwijking van de arbeidswettelijke bepalingen noodzakelijk was en evenmin, dat, nadat deze noodzakelijkheid was gebleken, uitstel van het strafbaar handelen mogelijk was.

In het arrest van 27 juni 1938 stelt de HR als voorwaarde, dat, indien met de overtreding het algemeen belang of een gewichtig bijzonder belang wordt gediend, de dader zich niet door een vrijstelling van het verbod tegen de gevolgen van de wetsovertreding heeft kunnen dekken, hetzij doordat de tijd of gelegenheid tot het verkrijgen ervan ontbrak, hetzij zich een geval voordeed waarvoor de wet een zodanige vrijstelling niet kent. In dit arrest heeft de HR de eis van de noodzaak van het onmiddellijk handelen laten vallen in geval de wet de mogelijkheid tot vrijstelling niet kent, en in het geval dat de vergunningsmogelijkheid bestaat, is de noodzaak tot het onmiddellijk handelen minder klemmend gemaakt, maar is de noodzakelijkheid van het onmiddellijk handelen als zodanig bevestigd ${ }^{200}$.

Het tweede deel van de rechtvaardigingsgrond verlangt, dat het feit

"onverwijld door of namens het hoofd of de bestuurder der onderneming wordt medege-

deeld aan het districtshoofd".

Blijkens het arrest van 17 november 1930 dient het begrip "onverwijld" volgens de HR vitgelegd te worden als "tijdens of na het plegen van het feit". De bedoeling van dit deel van de rechtvaardigingsgrond is te voorkomen, dat een arbeidswettelijke bepaling wordt overtreden en wordt afgewacht of de arbeidsinspectie de overtreding ontdekt om dan nog eens, na wie weet hoe lang, te proberen om de overtreding van de bepaling te rechtvaardigen.

De overtreder mag het oordeel over de gerechtvaardigheid van de overtreding niet in eigen hand nemen, met een goede kans, dat de overtreding niet wordt geconstateerd, waardoor zijn oordeel niet ter discussie wordt gesteld; door de verplichting de overtreding onverwijld mede te delen, wordt het oordeel over het al dan niet gerechtvaardigd zijn ervan in handen van anderen - in eerste instantie de arbeidsinspectie en vervolgens de rechter - gelegd met de mogelijkheid, dat de overtreding niet gerechtvaardigd wordt geacht ${ }^{207}$. Als aan dit deel van het zesde lid van artikel 83 deze bedoeling moet worden toegekend, dan zou deze, aldus $V_{r i j}{ }^{208}$, in gevallen waarin de omstandigheden niet zo onmiddellijk voordat men moet handelen waren opgekomen, of men had nog gelegenheid vórdat men handelde om de op handen zijnde overtreding aan te melden, zeker evengoed vervuld worden door dit vooraf te melden als door het onmiddellijk handelen na 
het begaan van de overtreding mede te delen. Het zinsverband van de betreffende bepaling sluit zijns inziens niet uit, dat het begrip "onverwijld" een tijdstip kort vóor het plegen van de overtreding omvat; zodra te voorzien is, dat deze overtreding niet te vermijden is. Dit standpunt van Vrij is al eerder door de Advocaat-Generaal Van Lier in diens conclusie bij het arrest van 17 november 1930 ingenomen. Hij meende, dat de wet alleen "onverwijlde" kennisgeving aan het districtshoofd vordert, zodat deze zowel kort vóór als korte tijd na het gebeuren kan geschieden.

Nadat het zesde lid van artikel 83 van de Arbeidswet 1919 in 1951 werd vernummerd tot het zevende lid, is de betreffende bepaling in 1971 aangevuld, in die zin, dat de omstandigheden, waaronder het feit uitsluitend als gerechtvaardigd is te beschouwen, in de wet zijn aangegeven. Deze aanvulling houdt, aldus de memorie van toelichting van de wijzigingswet ${ }^{209}$, verband met het commentaar van de commissie van deskundigen wan de Internationale Arbeidsorganisatie, die toezicht uitoefent op de naleving van de arbeidsverdragen van deze organisatie. Deze commissie was van mening, dat artikel 83, nu zevende lid, van de Arbeidswet 1919, wat betreft de formulering van "overmacht" niet overeenstemde met de in de verdragen 89 en $90^{210}$ neergelegde overmachtclausules ${ }^{211}$. Hoewel deze overmachtclausules niet gelijkluidend zijn geredigeerd, kunnen zij inhoudelijk als volgt worden samengevat: een omstandigheid kan als gerechtvaardigd worden beschouwd, als zij niet te voorzien was, geen periodiek karakter draagt en een inbreuk vormt op de normale bedrijfsarbeid, met andere woorden hieraan niet binnen het raam van de normale dagarbeid tegemoet kan worden gekomen. De commissie vond, dat het bewuste artikel in de Arbeidswet 1919 een ruimere strekking heeft, omdat het in straffeloosheid woorziet ingeval een overtreding van de wet "onder de gegeven omstandigheden als gerechtvaardigd is te beschouwen". Bij de aanvulling van artikel 83, zevende lid, van de Arbeidswet 1919 is zoveel mogelijk bij de in de beide arbeidsverdragen gebruikte terminologie aangesloten. Als omstandigheden ter rechtvaardiging van de overtreding kunnen na de wetswijziging uitsluitend aangemerkt worden: zich plotseling voordoende ongevallen, dan wel de onmiddellijke dreiging daarvan, alsmede andere onvoorzienbare noodgevallen van niet-periodiek karakter, waardoor de normale gang van zaken in de onderneming wordt verstoord.

Deze aanvulling heeft mijns inziens geen gevolgen voor wat betreft de arresten van de HR van 17 november 1930 en 27 juni 1938, omdat deze arresten betrekking hebben op voorwaarden die aan de orde zijn, voordat een belangenafweging plaatsvindt, terwijl de aanvulling van artikel 83, zevende lid, van de Arbeidswet 1919 eerst een rol speelt bij die belangenafweging zelf.

Bij de Wet van 11 februari $1988^{212}$, in verband met de indeling van strafbare feiten in geildboetecategorieën, heeft opnieuw een vernummering plaatsgevonden. Het zevende lid van artikel 83 van de Arbeidswet 1919 is hierbij vernummerd tot vierde lid, zonder dat overigens materieel iets gewijzigd is.

\subsubsection{De relatie tussen de bijzondere overmachtbepaling van artikel 83, vierde lid, van de Arbeidswet 1919 en de algemene overmachtbepaling van artikel 40 en het Wetboek van Strafrecht}

Een belangrijke vraag is die naar de relatie tussen artikel 83, vierde lid, van de Arbeidswet 1919 en artikel 40 van het Wetboek van Strafrecht.

Het argument voor het opnemen van toen nog het zesde lid van artikel 83 van de Arbeidswet 1919 was, dat er verschillende omstandigheden zujn, die een rechtvaardigingsgrond behoren op te leveren, maar die door de jurisprudentie van de HR niet onder het begrip "overmacht" van artikel 40 van het Wetboek van Strafrecht te vatten zijn. In het arrest van 15 oktober $1923^{213}$ heeft de HR het begrip "overmacht" van laatstgenoemd artikell uitgebreid door daaronder ook "noodtoestand"214 te brengen. Pompe ${ }^{215}$ meent, dat de wetsgeschiedenis van artikel 83, zesde lid, van de Arbeidswet 1919 niet met vrucht aangevoerd kan worden tegen deze ruime uitleg van artikel 40 van het Wetboek van Strafrecht, omdat de wetsgeschiedenis uitgaat van een enge uitleg van het laatstgenoemde artikel. Hij stelt dan ook, dat de enige betekenis van het zesde lid van artikel 83 van de Arbeidswet 1919 ten opzichte van artikel 40 van het Wetboek van Strafrecht gelegen 
is in de eis, dat de afwijking van een arbeidswettelijke norm gepaard moet gaan met een onverwijlde mededeling daarvan aan het districtshoofd. Op grond hiervan is artikel 83, zesde lid, vala de Arbeidswet 1919 een bijzondere bepaling die voorgaat boven de algemene bepaling van artikel 40 van het Wetboek van Strafrecht, die bestemd is voor het gehele Nederlandse recht ${ }^{216}$. Vrij ${ }^{217}$ vindt deze redenering van Pompe onbegrijpelijk, omdat hij niet alleen in strijd is met de wetsgeschiedenis van artikel 83, zesde lid, van de Arbeidswet 1919, maar ook systematisch onjuist is. Hij doet daarvoor een beroep op het arrest van 27 februari $1939^{21 e}$ waarin de HR stelt, dat

"nu aldus de wet een speciale en volledige voorziening geeft voor gevallen, waar bijzondere omstandigheden ene overtreding rechtvaardigen",

maar het bevoegd gezag - in casu de arbeidsinspectie -

"de omstandigheden niet van dien aard heeft bevonden, dat deze tot vrijstelling behoorden te leiden",

voor een beroep op artikel 83, zesde lid, van de Arbeidswet 1919 geen plaats meer was, "doch evenmin voor een beroep op overmacht, gegrond eveneens op dezelfde omstandigheden".

Opmerkelijk is, dat Nolte ${ }^{219}$ aan hetzelfde arrest ontleent, dat artikel 83, zesde lid, van de Arbeidswet 1919 een bijzondere bepaling is, die prevaleert boven de algemene bepaling, neergelegd in artikel 40 van het Wetboek van Strafrecht.

Naar mijn mening is de uitleg die Vrij aan het arrest van 27 februari 1939 geeft niet juist. De HR heeft in het bewuste arrest aangegeven, dat artikel 83, zesde lid, van de Arbeidswet 1919 een bijzondere bepaling is - "een speciale en volledige voorziening" - en dat wanneer een beroep op deze bijzondere bepaling geen effect heeft niet nog eens een beroep gedaan kan worden op de algemene bepaling die is neergelegd in artikel 40 van het Wetboek van Strafrecht.

Vrij ${ }^{220}$ wijst er verder op, dat het enige verschil tussen de beide rechtvaardigingsgronden is, dat het ene wel en het andere geen bestuurselement - het onverwijld mededelen aan het districtshoofd - bevat. Hij is dan ook van mening, dat blijkens de toelichting de wetgever vóór alles de werking van artikel 40 van het Wetboek van Strafrecht wil, en dat artikel 83, zesde lid, van de Arbeidswet 1919 slechts opgenomen is voor die gevallen die niet onder de werking van het eerstgenoemde artikel vallen ${ }^{221}$. Als artikel 83 , zesde lid, van de Arbeidswet 1919, zo vervolgt hij, artikel 40 van het Wetboek van Strafrecht opzij zou zetten, dan zou de bepaling die bestemd is om de werking van de andere bepaling uit te breiden, deze werking nota bene inperken: alle overmacht, waarvan geen onverwijlde mededeling was gedaan, zou strafbaar worden.

Vrij mag dit dan wonderlijk noemen, maar het is naar mijn mening niet onlogisch om aan een specialle regeling extra voorwaarden toe te voegen ten opzichte van de algemene, bestaande regeling. De toelichting maakt. uiteindelijk duidelijk wat de wetgever met het bestuurselement beoogt: het bedrijfshoofd wordt alleen dan kans op straffeloosheid gegeven, als hij die onverwijlde mededeling doet, dit om misbruik te voorkomen. Het bestuurselement is dan ook door de wetgever tot een essentieel onderdeel van de rechtvaardigingsgrond bestempeld en bevestigt alleen maar de uitleg dat het bewuste arbeidswettelijke artikellid een speciale bepaling is ten opzichte van de algemene bepaling van artikel 40 van het Wetboek van Strafrecht.

Overigens brengt de aanvulling in 1971 in artikel 83 van de Arbeidswet 1919 en de wijziging in 1988 aangebracht hierin verder geen verandering.

\subsubsection{De verhouding tussen disculpatie en overmacht}

Als het hoofd of de bestuurder van een onderneming, ondanks al zijn inspanningen, de arbeiders niet zover heeft weten te krijgen dat deze de bij of krachtens de Arbeidswet 1919 gegeven bepalingen naleven, dan wordt hierin voorzien door artikel 76, eerste lid, van de Arbeidswet 1919 . Hier ligt het zwaartepunt op oorzaken die binnen de onderneming ontstaan. Bij artikel 83, vierde lid, van de Arbeidswet 1919 liggen de oorzaken van het niet-naleven van de wettelijke verplichtingen buiten de onderneming ${ }^{222}$. 


\subsubsection{Afwezigheid van alle schuld}

Naast de in de Arbeidswet 1919 en de Veiligheidswet 1934 neergelegde disculpatiemogelijkheid en de alleen in de eerstgenoemde wet neergelegde rechtvaardigingsgrond overmacht kan op het terrein van het arbeidsomstandighedenrecht het sinds 1916 in de jurisprudentie erkende beginsel "afwezigheid van alle schuld" een rol spelen. In dat bewuste jaar besliste de $\mathrm{HR}$ in het water en melk-arrest ${ }^{223}$, dat indien bij een overtreding bleek van "afwezigheid van alle schuld" ( a.v.a.s., zoals Vrij het afkortte ${ }^{224}$ ) de dader niet strafbaar was. Met het begrip "schuld" wordt in dit verband bedoeld alle schuld in de zin van verwijtbaarheid. In het geval van "avas" dient de rechter de dader van alle rechtsvervolging te ontslaan ${ }^{225}$.

In het geval van "avas" kan het oordeel van de arbeidsinspectie een rol spelen. Zo aanvaardde de rechtbank te Maastricht ${ }^{226}$ het beroep op "avas", omdat de arbeidsinspectie geen duidelijke aanwijzingen had gegeven omtrent de maatregelen die de verdachte moest treffen. Er kan in dat geval van de verdachte niet worden geëist, dat hij, terwijl ovrheidsinstanties geen oplossing wisten, bij de aanvang van het werk adequate veiligheidsmaatregelen had getroffen. De rechtbank te Assen ${ }^{227}$ meende in een ander geval, dat de controlebezoeken van de arbeidsinspectie in dit geval weliswaar niet disculperend, maar wel aansprakelijkheidsvermin. derend konden werken.

\subsection{Samenvatting}

\subsubsection{Aansprakelijkheidsregeling}

De regeling van de strafrechtelijke aansprakelijkheid voor de naleving van de arbeids- en rusttijdenbepalingen, neergelegd in de Arbeidswet 1919 richt zich niet tot de arbeiders maar hoofdzakelijk tot het hoofd of de bestuurder van een onderneming dan wel op het opzichthoudend personeel. De strafrechtelijke aansprakelijkheid kan worden opgesplitst in:

1. een geobjectiveerde aansprakelijkheid, waarbij een ieder die bij of krachtens deze wet verboden arbeid "doet verrichten" strafbaar is,

2. een zorgverplichting

a. van het hoofd of de bestuurder of het opzichthoudend personeel,

b. van ouders en voogden met betrekking tot het verbod van kinderarbeid.

De Arbeidswet 1919 kent voorts een bijzondere aansprakelijkheidsregeling voor arbeiders van in het buitenland gevestigde ondernemingen die in ons land werkzaamheden komen verrichten.

De strafrechtelijke aansprakelijkheid in het kader van de veiligheidswetgeving is gebouwd op het principe van de Arbeidswet. De strafrechtelijke aansprakelijkheid is gestoeld op een zorgverplichting van het hoofd of de bestuurder van een onderneming of het opzichthoudend personeel. Deze zorgverplichting betreft niet alleen de naleving van voorschriften betreffende de veiligheid en de gezondheid, maar eveneens het vervaardigen, het verkopen, het verhuren, het afleveren of ten verkoop, ter verhuring of ter aflevering voorhanden houden van gevaarlijke werktuigen, toestellen en dergelijke. In tegenstelling tot de Arbeidswet 1919 waar de arbeider nauwelijks strafrechtelijk aansprakelijk is, is de arbeider in het kader van de Veiligheidswet 1934 niet straffeloos meer, wanneer de werkgever alles heeft gedaan om de wet na te leven, maar de arbeider nalatig blijft om de aanwezige beveiligingsmiddelen te gebruiken of andere in het belang van de veiligheid en de gezondheid gestelde voorschriften dan wel een door het districtshoofd van de arbeidsinspectie gestelde eis na te leven. Wel geldt voor de aansprakelijkheid van de betrokken arbeider de beperking dat hij redelijkerwijs met dat voorschrift of die eis bekend is.

In de Arbeidsomstandighedenwet zijn er in vergelijking met de Veiligheidswet 1934 een aantal veranderingen aangebracht ter zake van de aansprakelijkheidsregeling. Allereerst is het door de overtredingen van de wet aan te merken als een economische delict nu mogelijk niet alleen de natuurlijke persoon, maar ook de 
rechtspersoon als zodanig dan wel degene, die feitelijke leiding aan of opdracht tot de verboden gedraging heeft gegeven, aan te spreken. Doordat er duidelijkere verbanden in de aansprakelijkheidsregeling zijn gelegd naar de rechtspersoon, kunmen overtredingen vervolgd worden zonder dat er direct een feitelijke dader aan te wijzen is.

De aansprakelijkheidsregeling voor zover deze zich richt tot de werkgever is gebaseerd op een zorgverplichting, waarbij een tweedeling gemaakt kan worden, namelijk ten aanzien van de meer traditionele veiligheidsen gezondheidsaspecten en ten aanzien van algemene verplichtingen bijvoorbeeld woor wat betreft het te voeren beleid. Daarnaast is de persoonlijke aansprakelijkheid uitgebreid. Op grond van artikel 28 van de Arbeidsomstandighedenwet kan bij algemene maatregel van bestuur worden bepaald, dat de de werkgever opgelegde zorgverplichting tot naleving van de op artikel 24 van de wet gebaseerd voorschriften ook kan rusten op een ander dan die werkgever.

De aansprakelijkheidsregeling van het opzichthoudend personeel komt in de Arbeidsomstandighedenwet niet meer voor. Daarvoor in de plaats is de regeling terzake van de taakopdracht in artikel 31 van die wet gekomen. Een regeling die enerzijds van organisatorische aard is, maar anderzijds tevens een aansprakelijkheidsregeling kan betekenen, wanneer de betrokkene feitelijke leiding aan dan wel opdracht tot de verboden gedraging heeft gegeven.

Ook de aansprakelijkheidsregeling van de werknemer heeft een wijziging ondergaan. Naast de concrete verplichtingen van de werknemer in de diverse veiligheidsbesluiten is in artikel 12 van de Arbeidsomstandigheden voor de werknemer een algemene zorgverplichting opgenomen terzake van de veiligheid, de gezondheid van hemzelf of van anderen, dat wil zeggen collega's, niet-werknemers en werknemers van andere bedrijven die met hem te maken krijgen, dan wel met oog op hun welzijn. Terzake van de aansprakelijkheidsregeling ten aanzien van de naleving van de veiligheidswetgeving van arbeiders/werknemers, die in een onderneming hier te lande werkzaam zijn, maar die in dienst van van in het buitenland gevestigde ondernemingen, schiet de aansprakelijkheidsregeling duidelijk te kort.

\subsubsection{Disculpatie}

De strafrechtelijke aansprakelijkheid in zowel de Arbeidswet 1919 als in de Veiligheidswet 1934 wordt beperkt door een zogenaamde disculpatiemogelijkheid. Op grond van deze regeling wordt geacht aan de zorgverplichting van de bedoelde personen te zijn voldaan wanneer aangetoond wordt, dat door hen aan de vier in de wet genoemde vereisten is voldaan. Deze disculpatiegrond is geen strafuitsluitingsgrond; het gaat om de vraag of al dan niet een strafbaar feit is gepleegd, zodat bij honorering van een beroep hierop leidt tot vrijspraak. Een dergelijke disculpatiemogelijkheid komt in de Arbeidsomstandighedenwet niet meer voor.

\subsubsection{Strafuitsluitingsgronden}

Van de drie wetten kent alleen de Arbeidswet 1919 een bijzondere overmachtsregelling. Deze bestaat uit twee delen, namelijk

- het niet strafbaar zijn van een feit, als het onder de gegeven omstandigheden is te rechtvaardigen, en

- het onverwijld mededelen van het strafbare feit aan thet districtshoofd van de arbeidsinspectie.

Voor de normen waarvan door middel van een vergunning kan worden afgeweken, moet de noodzaak aanwezig zijn om onmiddellijk te handelen als de tijd en de gelegenheid ontbreken om een dergelijke vergunning aan te vragen. Van de normen waarvan geen afwijking mogelijk is geldt een dergelijke voorwaarde niet. De betekenis en de draagkracht van de feiten en omstandigheden zijn van feitelijke aard. Het onverwijld mededelen kan zowel kort vór alls een korte tijd na het plegen van het strafbare feit plaatsvinden. Dit onverwijld mededelen vormt een essentieel onderdeel van de rechtvaardigingsgrond overmacht.

Tot slot is voor het arbeidsomstandighedenrecht nog het door de jurisprudentie erkende beginsel "afwezigheid van alle schuld" van belang. Het oordeel van de arbeidsinspectie kan in dat kader een bevrijdende om- 
standigheid vormen.

\section{Bewoegdheden in het kader van het toezicht en de opsporing}

\subsection{Inleiding}

De daartoe door de minister van Sociale Zaken en Werkgelegenheid aangewezen ambtenaren van de arbeidsinspectie zijn in het bijzonder belast met het toezicht op onder meer de naleving van de Arbeidswet 1919, de Veiligheidswet 1934 en de Arbeidsomstandighedenwet. Deze toezichthoudende taak wordt omschreven door middel van de termen:

"... belast met de handhaving van en de medewerking aan de uitvoering van ...."228.

Deze taakstelling is gericht op, zowel het administratieve, als het repressieve toezicht. De in het kader van het toezicht door de wetgever gegeven bewoegdheden kunnen worden uitgeoefend en worden ook vaak gebruikt, zonder dat er sprake is van enig vermoeden van het plegen van een strafbaar feit. Wanneer blikt, dat het administratieve toezicht onvoldoende is, en aanvaardbare grenzen worden overschreden, volgt het repressieve toezicht, dat gericht is op het aan het licht brengen van eventuele overtredingen. Dit toezicht kan overgaan in een strafrechtelijke handhaving door middel van opsporing van strafbare feiten ${ }^{229}$.

Voor wat betreft het opsporen van strafbare feiten staan de bedoelde ambtenaren van de arbeidsinspectie gelijk met de ambtenaren van de rijks-en gemeentepolitie en met de overige bij artikel 141 van het Wetboek van Strafvordering aangewezen personeel, met andere woorden: met de algemene opsporingsambtena$\operatorname{ren}^{230}$.

De nauwe verwevenheid in deze wetten tussen opsporing en toezicht maakt, dat de taak van hen die bijvoorbeeld in de Arbeidswet 1919 en de Veiligheidswet 1934 met de opsporing zijn belast, in ruime zin moeten worden opgevat en tevens thet repressief toezicht omvat. Dat betekent, dat dit repressief toezicht ook de medewerking aan de uitwoering betreft. In de gevallen, dat bij de controle op de naleving ook een taak voor de algemene opsporingsambtenaren is weggelegd, worden ook aan hen een aantal bevoegdheden verleend. In de Arbeidsomstandighedenwet is wel een scheiding gemaakt tussen opsporende en toezichthoudende taken. De taak van de algemene opsporingsambtenaren is, via artikel 17 van de Wet op de economische delicten, beperkt tot opsporing (in enge zin). De minister van Justitie stelt zich op het standpunt, dat alle bevoegdheden van deze laatstgenoemde wet opsporingsbevoegdheden zijn, die alleen bij het bestaan van een redelijke vermoeden van een gepleegd strafbaar feit kunnen worden gebruikt ${ }^{23 t}$.

Dit onderscheid tussen opsporing en toezicht komt echter niet in de Arbeidswet 1919, noch in de Veiligheidswet 1934 voor. Zo worden in deze wetten niet alleen aan de toezichthoudende ambtenaren, maar ook aan de opsporingsambtenaren bevoegdheden toegekend, waarvoor het niet noodzakelijk is dat er een redelijk vermoeden van het plegen van een strafbaar feit bestaat, zoals de bevoegdheid tot het vorderen van inlichtingen. Aan de opsporingsambtenaren komt onder meer de bevoegdheid tot het betreden van plaatsen toe. Daaruit volgt, dat de toezichthoudende ambtenaren met name deze bevoegdheid aan hun opsporingsbevoegdheid moeten ontlenen. Maar dat betekent; dat het voor hen niet kán gaan om een opsporingsbevoegdheid; zij zouden hun toezichthoudende bevoegdheden, waaraan een betreden van plaatsen in het algemeen vooraf moet gaan, anders niet kunnen uitoefenen ${ }^{232}$.

In de beide volgende paragrafen zullen de beide genoemde bevoegdheden, mamelijk het vorderen van inlichtingen en het betreden van plaatsen nader beschouwd worden.

\subsection{De plicht tot spreken en het recht om te awijgen}

\subsection{Inleiding}

Artikel 79, eerste lid, van de Arbeidswet 1919, artikel 23, eerste lid, van de Veiligheidswet 1934 en artikel 
33, eerste lid, van de Arbeidsomstandighedenwet leggen aan bepalde categorieën van personen de verplichting op om de met het toezicht op de naleving daarvan belaste ambtenaren de verlangde inlichtingen te verschaffen over zaken en feiten die de naleving van deze wetten betreffen ${ }^{23}$. Voor wat betreft de Arbeidswet 1919 en de Veiligheidswet 1934 richt deze verplichting zich tot het hoofd of de bestuurder van de onderneming en de daarin werkzame personen, terwijl in de Arbeidsomstandighedenwet deze verplichting geldt voor de werkgever en de werknemers alsmede de in de artikelen 27 en 28 van die wet bedoelde natuurlijke of rechtspersonen. Geen van deze bepaling is echter gelijkluidend. Zo spreekt artikel 33, eerste lid, van de Arbeidsomstandighedenwet niet alleen over de verlangde inlichtingen maar ook over gegevens. Zowel artikel 23, eerste lid, van de Veiligheidswet 1934 als het zo juist genoemde artikel van de Arbeidsomstandighedenwet schrijft in tegenstelling tot artikel 79 van de Arbeidswet 1919 voor, dat de desverlangde informatie binnen een door deze ambtenaren gestelde termijn schriftelijk moet worden verstrekt. Wellicht dat het verschil te verklaren valt uit het feit, dat de Arbeidswet 1919 talloze schriftelijke controlemiddelen - arbeidskaart, arbeidslijst, arbeidsregister, rooster ${ }^{234}$ - kent, die onverwijld ter inzage moeten worden gegeven aan de bedoelde ambtenaren.

De strekking van deze artikelleden is, dat het de controlerende ambtenaar mogelijk en gemakkelijk gemaakt wordt om na te gaan of de bij of krachtens de genoemde wetten gegeven voorschriften behoorlijk worden nageleefd en om die reden dus ook of er overtredingen plaatsvinden ${ }^{235}$. Niet-naleving ervan levert een strafbaar feit op, dat gekwalificeerd is als een overtreding ${ }^{230}$.

In het kader van het Wetboek van Strafvordering ${ }^{237}$ wordt op grond van artikel 27, eerste lid, - voordat een vervolging is aangevangen - als verdachte onder meer aangemerkt, degene te wiens aanzien uit feiten of omstandigheden een redelijk vermoeden van schuld aan enig strafbaar feit voortvloeit, terwijl op grond van artikel 29 , eerste lid, van dat zelfde wetboek een verdachte niet tot antwoorden verplicht is. Ingevolge het tweede lid van het laatstgenoemde artikel moet hiervan, voordat het verhoor aanvangt, mededeling gedaan worden. De vraag rijst hoe de wettelijke verplichting tot het verschaffen van inlichtingen zich verhoudt tot het bepaalde in het Wetboek van Strafvordering.

\subsubsection{De verplichting tot het verschaffen van inlichtingen}

Deze vraag is voor het eerst ter sprake gekomen in 1929. Toen veroordeelde de kantonrechter te Rotter$\mathrm{dam}^{238}$ het hoofd of de bestuurder van een onderneming, waar onder meer pepermunt werd vervaardigd, tot een boete van fl. 40,-- vanwege het weigeren van de op grond van artikel 79, eerste lid, van de Arbeidswet 1919 verlangde inlichtingen. Het beroep van de verdachte op het in artikel 29 , eerste lid, van het Wetboek van Strafvordering geregelde zwijgrecht werd verworpen met de overweging,

"dat een algemeen voorschrift niet kan derogeren aan een speciaal voorschrift zoals het on-

derhavige artikel 79 der Arbeidswet".

In hoger beroep werd, met bevestiging van de uitspraak, deze overweging door de rechtbank te Rotter$\operatorname{dam}^{239}$ verworpen. Het beroep op het zwijgrecht, zoals neergelegd in artikel 29 , eerste lid, van het Wetboek van Strafvordering, faalde echter, aldus de rechtbank,

"omdat dit artikel slechts bepaalt dat een verdachte niet tot antwoorden verplicht is, terwijl

artikel 79 der Arbeidswet het hoofd of de bestuurder van eene onderneming de verplichting

oplegt inlichtingen te geven omtrent zaken en feiten de naleving van deze wet betreffende".

Artikel 29 van het Wetboek van Strafvordering is, volgens de rechtbank, "een gansch andere regeling" dan artikel 79 van de Arbeidswet $1919^{240}$.

De beslissing van de kantonrechter en de daarbij gegeven motivering is naar mijn mening onjuist. Het bepaalde in artikel 79, eerste lid, van de Arbeidswet 1919 geldt algemeen en is ook algemeen gesteld in zoverre, dat het betrekking heeft op het horen van verdachten en van getuigen/deskundigen zonder daarbij een 
onderscheid te maken. Deze arbeidswettelijke bepaling is in zoverre bijzonder, dat de verplichting tot het verschaffen van inlichtingen alleen betrekking heeft op het horen van personen omtrent zaken en feiten die met de naleving van de Arbeidswet 1919 samenhangen. Artikel 29, eerste lid, van het Wetboek van Strafvordering is eveneens algemeen geldend in zowerre, dat het op alle verhoren van verdachten betrekking heeft. Het adagium

"Lex specialis derogat legi generali"

is naar mijn mening door de kantonrechter ten onrechte toegepast. De kantonrechter heeft onvoldoende onderkend, dat het hier gaat om twee artikelen die ieder hun eigen gebied bestrijken en dus naast elkaar staan, maar elkaar voor een deel kunnen overlappen, namelijk in die gevallen, waar iemand de wettelijke plicht heeft om inlichtingen te verschaffen als verdachte wordt gehoord. Ook het argument van de rechtbank, dat er sprake is van "een gansch andere regeling" schiet tekort, omdat voorbijgegaan wordt aan het feit, dat in het onderhavige geval de verdachte, die niet tot antwoorden verplicht is en het hoofd of de bestuurder van een onderneming; die verplicht is de verlangde inlichtingen te verschaffen én en dezelfde persoon is ${ }^{241}$.

In 1931 zou de verhouding tussen de beide artikelen opnieuw aan de orde komen. De rechtbank te Haarlem $^{242}$ oordeelde, dat het criterium over de vraag welke van de beide artikelen van toepassing is, afhangt van de omstandigheden of de ambtenaar van de arbeidsinspectie

"'tis opgetreden als controleerend ambtenaar, dan wel als opsporend ambtenaar".

Het door de verdachte gedane beroep op het in artikel 29 , eerste lid, van het Wetboek van Strafvordering neergelegde zwijgrecht werd door de rechtbank niet gehonoreerd, omdat vast was komen te staan, dat de bedoelde ambtenaar louter als controlerend ambtenaar optrad. Voorts overwoog de rechtbank, dat ook indien een ambtenaar van de arbeidsinspectie op grond van een redelijk vermoeden van schuld aan een strafbaar feit gerechtigd zou zijn, het hoofd van de onderneming als verdachte te horen, die ambtenaar daartoe niet behoeft over te gaan en ook dan artikel 79 van de Arbeidswet 1919 mag toepassen. De exceptionele verplichting als in dat artikel omschreven blijft dan op het hoofd of de bestuurder van de onderneming rusten, aangezien de geldigheid en mogelijkheid van toepassing van dat artikel niet in geval vam redelijk vermoeden van schuld wordt uitgesloten. De HR dacht daar, blijkens het arrest van 22 juni $1931^{243}$, anders over. Het beroep van de verdachte op artikel 29, eerste lid; van het Wetboek van Strafvordering werd gehonoreerd, met het argument, dat het bewuste artikel ten opzichte van artikel 79 van de Arbeidswet 1919 een zogenaamde "lex posterior" is. De motivering van de rechtbank, dat het stellen van vragen in het kader van artikel 79 van de Arbeidswet 1919 of artikel 29 van het Wetboek van Strafvordering geheel afhankelijk is van de keuze - willekeur - van de ambtenaar, werd door de HR, overigens terecht, als onaannemelijk verworpen.

De door de HR gegeven motivering omtrent de verhouding tussen de beide wetsartikelen is wellicht ingegeven door het beoogde resultaat, aldus $\mathrm{Melai}^{244}$. Wel constateert hij, dat voor het overige niets uit het arrest kan worden geconcludeerd. Een terechte conclusie; immers na de inwerkingtreding van het Wetboek van Strafvordering zijn een aantal bijzondere strafwetten op het terrein van het arbeidsomstandighedenrecht uitgevaardigd, waarin een met artikel 79 van de Arbeidswet 1919 overeenkomende bepaling is opgenomen, zoals bijwoorbeeld de Veiligheidswet 1934 en de Arbeidsomstandighedenwet. Een consequent vasthouden aan dit arrest zou ertoe leiden, dat bij de toepasselijkheid van deze latere wetten aan de verdachte het in artikel 29 , eerste lid, van het Wetboek van Strafvordering toegekende zwijgrecht ontzegd zou zijn, hetgeen onacceptabel is. Uitgangspunt ten aanzien van de verplichting tot het verschaffen van inlichtingen als bedoeld in artikel 79 van de Arbeidswet 1919 dient namelijk te zijn, dat deze informatieplicht geen voorschrift van strafvordering is ${ }^{245}$. De informatieplicht is geboren uit de noodzaak om de naleving van bijwoorbeeld de Arbeidswet 1919 te controleren. Het in artikel 29, eerste lid, van het Wetboek van Strafvordering neergelegde zwijgrecht voor een verdachte vloeit voort uit het in ons strafrecht geldende rechtsbeginsel, dat niemand verplicht is (actief) aan zijn eigen veroordeling mee te werken ${ }^{240}$. De wetgever heeft "elke pressie in inquisitorialen

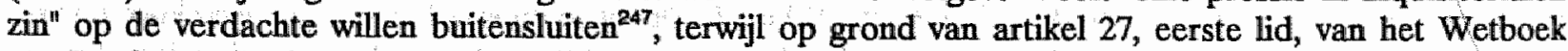
van Strafvordering vóor dat de vervolging is aangevangen als verdachte wordt aangemerkt degene te wiens 
aanzien uit feiten of omstandigheden een redelijk vermoeden van schuld aan enig strafbaar feit voorvloeit. Op het moment, dat degene, die op grond van artikel 79, eerste lid, van de Arbeidswet 1919 verplicht is om inlichtingen te verschaffen, op grond van artikel 27 , eerste lid, van het Wetboek van Strafvordering als verdachte is aan te merken, zall zijn verplichting om te antwoorden geëindigd zijn. Overigens zal het voor een ambtenaar, die in het kader van zijn taakuitwoering inlichtingen inwint, niet steeds eenvoudig zijn het juiste moment te bepalen, waarim hij aan degene aan wie hij de vragen stelt, op grond van artikel 29 , tweede lid, van het Wetboek van Strafvordering zal hebben mee te delen, dat deze, als verdachte, niet tot antwoorden verplicht is.

Het zij nogmaals gezegd: uitgangspunt is en blijft, dat degene die in het kader van het arbeidsomstandighedenrecht om inlichtingen gevraagd wordt, verplicht is deze te verstrekken ${ }^{243}$. De plicht tot antwoorden is zowel in de Arbeidswet 1919, als in de Veiligheidswet 1934 en de Arbeidsomstandighedenwet ongeclausuleerd opgenomen. De betreffende ambtenaar heeft een aan die wetten ontleend recht op informatie; hij zall, wanneer hij omtrent zaken en feiten, die de naleving van deze wetten betreffen, inlichtingen vraagt, op de in die wetten neergellegde antwoordplicht moeten wijzen. Weigert degene, die verplicht is inlichtingen te verschaffen, dit laatste, dan wordt hij verdacht van het plegen van een strafbaar feit, namelijk van het niet-verstrekken van de gevraagde informatie. Op het moment, dat hij daaromtrent wordit verhoord, treden de regels van het Wetboek van Strafvordering in werking en moet de nu verdachte gewezen worden op zijn zwijgrecht. Het onderwerp van onderzoek van de betreffende ambtenaar is dan het strafbare feit van het niet-antwoorden. In dit geval schuift dit strafbare feit van het niet-antwoorden als het ware vór de overtredingen van bijvoorbeeld de Arbeidswet 1919 waar de activiteiten van de (opsporings-)ambtenaar zich in eerste instantie op richtte ${ }^{249}$.

Maar ook kan het verloop van de controle zodanig zijn, onder meer doordat de antwoorden van degene die een informatieplicht heeft opgelegd gekregen, onbevredigend zijn, dat een verdenking ontstaat. Wanneer dat het geval is, is het moment aangebroken om degene die gecontroleerde wordt als verdachte aan te merken en ook als zodanig te behandelen ${ }^{250}$. Dat betekent, dat, als bij de controlle tegen degene die krachtens de wet een verplichting heeft tot het verstrekken van inlichtingen, een verdenking rijst, aan deze de mededeling, dat hij niet tot antwoorden verplicht is, moet worden gedaan.

\subsubsection{Juiste inlichtingen verschaffen of niet?}

De HR besliste in het arrest 22 juni 1931 tevens, dat er geen sprake is van een overtreding van artikel 79 van de Arbeidswet 1919 wanneer een pertinent door de betreffende ambtenaar gestelde vraag in de ene of in de andere zin wordt beantwoord, terwijl later blijkt, dat het antwoord niet naar waarheid is gegeven. Toepasselijkheid van het bewuste arbeidswettelijke artikel is echter niet uitgesloten in gevallen, waarin op het verzoek om inlichtingen met niet ter zake doende mededelingen of met kennelijke uittvluchten wordt geantwoord.

De HR gebruikt hiervoor een aantal argumenten, namelijk dat het niet uitdrukkelijk in de Arbeidswet 1919 staat; dat juiste inlichtingen moeten worden verstrekt; dat anders ook het niet opzettelijk verstrekken van onjuiste inlichtingen onder het artikel zou vallen; dat anders, in overeenstemming met verschillende andere wetten, het opzettelijke verstrekken van onjuiste inlichtingen als misdrijf - dus geen overtreding - zou worden aangemerkt, en dat anders de wetgever zou hebben na te gaan of hoofden of bestuurders ook voordat zij als verdachte zijn te beschouwen wel op straffe van het zich schuldig maken aan een misdrijf zouden moeten worden verplicht zichzelf te bezwaren. Met Pompe ${ }^{25 !}$ kan gesteld worden, dat het wel een behoorlijk aantal argumenten zijn, maar dat zij geenszins overtuigend zijn. Artikel 79, eerste lid, van de Arbeidswet 1919 verplicht het boofd of de bestuurder aan de bevoegde ambtenaren de verlangde inlichtingen te geven omtrent zaken en feiten, die de naleving van deze wet betreffen. Het ligt dus voor de hand, dat wel steeds juiste inlichtingen verlangd worden ${ }^{252}$. Degene die onjuiste inlichtingen verschaft, kan niet geacht worden de verlangde inlichtingen te geven. De tekst van het betreffende artikel brengt het derhalve al met zich mee. Als 
het standpunt van de HR juist zou zijn, dan was voldoende geweest om in het betreffende artikel alleen een verplichting tot het geven van antwoord op te nemen ${ }^{253}$. Het bewuste artikel geeft niet afzonderlijk aan, dat juiste inlichtingen moeten worden verschaft, maar dat is ook niet nodig. Toegegeven zij, dat ook niet opzettelijk onjuist verstrekte inlichtingen onder het artikel vallen. Wanneer echter noch van opzet, noch van onachtzaamheid sprake is, zal, en dat is toch de leer van de HR zelf, de dader niet strafbaar zijn. Dat het opzettelijk verstrekken van onjuiste informatie als een misdrijf zou worden aangemerkt, baseert de HR op "verschillende andere wetten", zonder er echter $\epsilon$ en te noemen ${ }^{254}$. Omtrent het door de HR gesignaleerde probleem terzake van het zichzelf bezwaren, kan worden opgemerkt, dat er inderdaad conflicten kunnen ontstaan, als men enerzijds verplicht wordt om de gevraagde inlichtingen te verschaffen, terwijl men anderzijds het gevaar loopt, ook v6or men als verdachte wordt beschouwd, zichzelf te bezwaren. De HR vindt hiervoor wel een buitengewoon eenvoudige, maar allerminst fraaie oplossing; de betrokken persoon kan zich uit een dergelijke situatie redden, niet door te zwijgen, maar blijkbaar alleen door te liegen. Pompe vraagt zich af, of de betrokkene, wanneer zich een dergelijk conflict voordoet wel steeds strafbaar is. Wordt hij als verdachte beschouwd dan geldt artikel 29, eerste lid, van het Wetboek van Strafvordering. Maar zou hij er zich voordien niet op kunnen beroepen, dat de wet er blijkbaar afkerig van is, iemand te dwingen voor zichzelf bezwarende verklaringen af te leggen. Hij verwijst daarbij naar de artikelen 137 , en 189 , tweede lid, van het Wetboek van Strafrecht en 219 van het Wetboek van Strafvordering. Met behulp van een analoge toepassing kan dit beginsel ook in de door de HR bedoelde gevallen kunnen worden toegepast.

\section{Het betreden van plaatsen}

\subsubsection{Inleiding}

In paragraaf 4.1. is al duidelijk gemaakt, dat tussen de Arbeidswet 1919 en de Veiligheidswet 1934 enerzijds en de Arbeidsomstandighedenwet anderzijds een belangrijk verschil bestaat. De laatstgenoemde wet maakt in tegenstelling tot de beide eerdergenoemde wetten een onderscheid tussen opsporing en toezicht. Dit onderscheid heeft, zoals zal blijken, gevolgen met betrekking tot de regeling terzake van het betreden van plaatsen door de bedoelde aangewezen ambtenaren van de arbeidsinspectie.

\subsubsection{Arbeidswet 1919 en Veiligheidswet 1934}

Zowel de bedoelde ambtenaren van de arbeidsinspectie als de ambtenaren van rijks- en gemeentepolitie en de overige bij artikel 141 van het Wetboek van Strafvordering aangewezen personen hebben toegang tot alle plaatsen, waar arbeid wordt verricht of pleegt te worden verricht of ten aanzien waarvan redelijkerwijze vermoed kan worden, dat aldaar arbeid wordt verricht. Deze algemene regel geldt zowel voor de Arbeidswet 1919, als de Veiligheidswet $1934^{255}$. De laatstgenoemde wet bepaalt echter nog, dat de bedoelde ambtenaren eveneens toegang hebben tot alle fabrieken of werkplaatsen ${ }^{256}$, tot de inrichtingen in een onderneming van land-, tuin- of bosbouw, veehouderij of veenderij ${ }^{25}$, alsmede tot alle tot een onderneming behorende plaatsen waar werktuigen, toestellen, vaten of gereedschappen ${ }^{258}$ aanwezig zijn of ten aanzien waarvan redelijkerwijze vermoed kan worden, dat aldaar zodanige voorwerpen aanwezig zijn. Dit onderscheid voor wat betreft de toegang tot plaatsen, kan verklaard worden uit het verschil terzake de toepasselijkheid van beide
wetten.

\subsubsection{Beperking voor ambtenaren, niet zijnde ambtenaren van de arbeidsinspectie}

Geldt deze bevoegdheid voor alle hiervoor bedoelde ambtenaren, in de Arbeidswet 1919 wordt een beperking aangebracht met betrekking tot de minister van Sociale Zaken en Werkgelegenheid aangewezen verplegings- en verzorgingsinrichtingen en gestichten. Deze beperkende bepaling werd door de toenmalige bewindsman in de toelichting ${ }^{250}$ verdedigd met de opmerking, dat ook al behoren deze inrichtingen naar zijn 
mening onder de wet te vallen, aan de andere kant zoveel mogelijk gewaarborgd dient te worden, dat het daar uit te oefenen toezicht met de nodige takt zal geschieden. Tot op heden zijn alleen aangewezen de inrichtingen tot het verplegen van zieken ${ }^{200}$. Hiertoe hebben, behoudens uit anderen hoofde aan anderen toekomende bevoegdheid, alleen toegang de door die minister aangewezen ambtenaren; dit zijn de ambtenaren van de arbeidsinspectie ${ }^{261}$. Overigens kan het verschil in deze tussen de Arbeidswet 1919 en de Veiligheidswet 1934 worden verklaard uit het feit, dat de laatstgenoemde wet niet van toepassing is op de bedoelde soort inrichtingen.

\subsubsection{Bijzondere voorschriften voor ambtenaren, niet zijnde ambtenaren van de arbeidsinspectie}

Zowel de Arbeidswet 1919 als de Veiligheidswet 1934 kennen een bepaling waarin de bewoegdheid tot het betreden van plaatsen aan ambtenaren, niet zijnde ambtenaren van de arbeidsinspectie, aan nadere voor-schriften is gebonden.

In artikel 85, tweede lid, van de Arbeidswet 1919 is bepaald, dat voor zover de toegang uit andere hoofde niet vrijstaat, de ambtenaren van rijks- en gemeentepolitie, die geen hulpofficier van justitie zijn, voor het betreden van de bedoelde plaatsen een bijzondere schriftelijke last nodig hebben van de burgemeester of van de kantonrechter. Aan deze ambtenaren van rijks- en gemeentepolitie kan, ook nu weer voor zover hun de toegang niet uit andere hoofde vrijstaat, een algemene schriftelijke last worden verstrekt, die echter voor een periode van ten hoogste drie maanden van kracht is ${ }^{202}$. Waar het ambtenaren van de rijkspolitie betreft, wordt deze last door de kantonrechter verleend onder goedkeuring van de procureur-generaal, fungerend directeur van politie. Aan die van de gemeentepolitie gebeurt dat door de burgemeester onder goedkeuring van de commissaris van de Koningin.

Artikel 33, tweede lid, van de Veiligheidswet 1934 bevat een bepaling, die van gelijke strekking is als die van de Arbeidswet 1919; materieel wijkt deze bepaling echter nogal af. Voor zover uit andere hoofde de toegang niet vrijstaat, hebben de ambtenaren van de marechaussee, die geen hulpofficier van justitie zijn, de bos- en veldwachter en andere ambtenaren van rijks- en gemeentepolitie, beneden de rang van inspecteur van de rijksveldwacht en van commissaris van politie, voor het betreden van de bedoelde plaatsen een bijzondere schriftelijke last nodig van de burgemeester of van de kantonrechter. Ook hier is de mogelijkheid geopend om, voor zover de toegang niet uit andere hoofde vrijstaat, een algemene schriftelijke last te verstrekken ${ }^{263}$. Aan de ambtenaren van de marechaussee en van de rijkspolitie wordt de last ook hier verstrekt door de kantonrechter, ook nu onder goedkeuring van de procureur-generaal, fungerend directeur van politie: Aan die van de gemeentepolitie door de burgemeester onder goedkeuring van de commissaris van de Koningin. De afwijkingen betreffen derhalve niet alleen de genoemde ambtenaren, maar ook de duur van het van kracht zijn van de algemene schriftelijke last.

\subsubsection{Hulp van de sterke arm}

Zowel artikel 85 van de Arbeidswet 1919 als artikel 33 van de Veiligheidswet 1934 bevatten een bepaling, dat wanneer de toegang wordt geweigerd of belemmerd, of op aanmelding tot toelating niet wordt geantwoord, de toegang verschaft kan worden desnoods met inroeping van de sterke arm. Aanvankelijk kende zowel de Arbeidswet 1889, als de Veiligheidswet slechts de bepaling dat bij weigering van de toegang de hulp van de sterke arm kon worden ingeroepen ${ }^{264}$. De uitbreiding van deze bepaling werd noodzakelijk geacht door de ervaring uit de praktijk ${ }^{265}$.

\subsubsection{Het betreden van een woning}

Hoewel zowel de Arbeidswet 1919, als de Veiligheidswet 1934 een bepaling bevatten omtrent het betreden 
van een woning, zijn ook deze niet gelijkluidend.

Artikel 85 , vierde lid, van de Arbeidswet 1919 bepaalt, dat plaatsen, waar arbeid wordt verricht of pleegt te worden verricht of ten aanzien waarvan redelijkerwijze kan worden vermoed, dat aldaar arbeid wordt verricht, die tevens woningen of alleen door een woning toegankelijk zijn, door de betreffende ambtenaren niet tegen de wil van de bewoner binnengetreden kan worden. Dit is eerst mogelijk op vertoon van een schriftelijke bijzondere last van de burgemeester of van de kantonrechter. Van dit binnentreden wordt door de betreffende ambtenaren een proces-verbaal opgemaakt en binnen twee mal 24 uren aan degene, in wiens woning is binnengetreden, in afschrift medegedeeld.

Artikel 33, vierde lid, van de Veiligheidswet 1934 bepaalt, dat de plaatsen waartoe de betreffende ambtenaren toegang hebben, die tevens woningen zijn of alleen door een woning toegankelijk zijn tegen de wil van de bewoner niet betreden worden. Dit is echter wel mogelijk wanneer zij vergezeld zijn van de kantonrechter, van een commissaris van politie of van de burgemeester van de gemeente of in het bezit zijn van een schriftelijke bijzondere last van de burgemeester of van de kantonrechter. Ook van dit binnentreden wordt door de betreffende ambtenaren een proces-verbaal opgemaakt en binnen twee maal 24 uren aan degene; in wiens woning is binnengetreden, in afschrift medegedeeld. Maar het artikellid bepaalt tevens, dat daarin van het tijdstip van het binnentreden en van de redenen, die daartoe geleid hebben, melding wordt gemaakt.

De afwijkingen betreffen derhalve niet alleen de personen die de betreffende ambtenaren bij het betreden van een woning moeten vergezellen, maar ook de inhoud van het in afschrift mede te delen proces-verbaal van binnentreden.

De Grondwet vereist voor het betreden van woningen een wettelijke regeling. Artikel 153 van de uit 1848 stammende Grondwet bepaalde het volgende:

"Niemand mag een woning eens ingezetenen diens ondanks binnentreden, dan op last eener magt, door de wet bevoegd verklaard dien last te geven, en volgens de vormen in de wet bepaald".

De wijziging van de Grondwet in 1887 bracht in het wezen van deze bepaling geen verandering. Wel werd de benaderingswijze veranderd. In nu artikel 158 van de Grondwet werd het "huisrecht" ofwel de onschendbaarheid van de woning positief geformuleerd; het binnentreden van een woning was slechts onder bepaalde voorwaarden toegestaan ${ }^{26 \theta}$. Deze bepaling zou ongewijzigd blijven tot de wijziging van de Grondwet in 1983. In artikel 12, eerste lid, van de nieuwe Grondwet wordt voorgeschreven, dat de wet of een gedelegeerde regeling bepaalt in welke gevallen en door wie, tegen de wil van de bewoner, in een woning kan worden binnengetreden. Het tweede lid van dit artikel stelt enige vormvereisten aan een dergelijke binnentre$\operatorname{ding}^{267}$.

\subsection{De Arbeidsomstandighedenwet}

\subsubsection{Het betreden van plaatsen in het kader van het toezicht}

Al eerder is gememoreerd, dat in de Arbeidsomstandighedenwet een onderscheid is gemaakt tussen opsporing en toezicht. De door de minister van Sociale Zaken en Werkgelegenheid aangewezen ambtenaren van de arbeidsinspectie zijn op grond van artikel 32 , derde lid, van deze wet bevoegd alle bedrijven, inrichtingen en andere plaatsen te betreden, én en ander voor zover dit noodzakelijk is voor de juiste vervulling van hun toezichthoudende taak. De uitoefening van de bevoegdheid is derhalve afhankelijk gesteld van de taakvervulling, waardoor er zowel tussen het doel, namelijk het toezicht, en het middel, de gegeven bevoegdheid, een relatie, bestaat ${ }^{238}$. Overigens wordt in de toelichting door de toenmalige bewindsman ${ }^{268}$ in dit verband ten onrechte gesteld, dat deze bevoegdheid wordt toegekend in het kader van hun opsporingstaak. 
Op deze betredingsbevoegdheid is én uitzondering gemaakt; woningen mogen in het kader van de toezichthoudende taak niet worden betreden, althans naar men mag aannemen, tegen de wil van de bewoner. De door de bewindsman gegeven toelichting op dit artikel is summier en bevat geen verklaring waarom de bedoelde ambtenaren van de arbeidsinspectie in het kader van het toezicht deze bevoegdheid niet hebben gekregen.

\subsection{De toezichthoudende taak en het betreden van woningen}

Hiervoor is al geschreven, dat toezichthoudende taken kunnen worden uitgeoefend en vaak ook worden gehanteerd, zonder dat er sprake is van een redelijk vermoeden van het plegen van een strafbaar feit. Een dergelijke verdenking vormt de basis, de rechtvaardiging van de opsporingsbevoegdheden, waaronder, zij het onder voorwaarden, het betreden van woningen; een dergelijke rechtvaardiging ontbreekt ten aanzien van het toezicht. Dat impliceert, dat waar de wetgever de toezichthoudende ambtenaren een dergelijke bevoegdheid wil toekennen, hij daarvoor een rechtvaardiging zal hebben te geven. De toenmalige bewindsman van Justitie heeft voor een dergelijke rechtvaardiging een aantal uitgangspunten gegeven ${ }^{270}$. Deze zijn:

"1. Van geval tot geval moet worden nagegaan of behoefte bestaat aan speciale toezichthoudende bevoegdheden en of niet met de algemeen geldende opsporingsbevoegdheden kan worden volstaan.

2. De toezichthoudende bevoegdheden moeten steeds zo beperkt als mogelijk is worden geformuleerd. Wanneer b.v. volstaan kan worden met de bevoegdheid tot het binnentreden van bedrijfsterreinen en -gebouwen, moet niet de bevoegdheid worden verleend alle plaatsen te betreden. In het bijzonder op het gebied van het binnentreden van woningen is de grootste terughoudendheid geboden.

3. Ook in die gevallen waarin bepaalde toezichthoudende bevoegdheden op zichzelf gewenst zijn om de naleving van een bepaalde wet te kunnen verzekeren, dient het maatschappelijk belang dat met de betrokken wettelijke regeling wordt nageleefd te worden afgewogen tegen de ingreep in de privacy van de burgers die het gevolg zou zijn van uitoefening van toezichthoudende bevoegdheden".

De meeste strafrechtelijke bepalingen, ook die van de Arbeidsomstandighedenwet, zullen niet worden nageleefd alleen op grond van het feit, dat ze van kracht zijn. Toezicht en opsporing zullen die naleving moeten kunnen afdwingen. Hoe meer waarde wordt gehecht aan de naleving van die voorschriften, des te meer zal directe handhaving door het uit te oefenen toezicht worden nagestreefd. Suyver schrijft daarover het volgen$\mathrm{de}^{2 \pi}:$ :

"De creatie van controlebevoegdheden houdt vanzelfsprekend verband met de door de bijzondere wet te beschermen belangen; naarmate die door de wetgever als gewichtiger worden beschouwd, pleegt hun aantal of omvang toe te nemen".

Bij het toekemnen van een controlerende bevoegdheid gaat het, aldus Melai ${ }^{272}$, om wetten,

"die een kwetsbaar maatschappelijk, hygiënisch, medisch of ander algemeen belang bescher-

men dan wel beogen de algemene veiligheid van personen te bevorderem".

Hoewel hij daarbij verwijst naar artikel 85 van de Arbeidswet 1919, gaat dit evenzeer op voor artikel 33 van de Arbeidsomstandighedenwet.

De overwegingen die aan het toekennen van toezichthoudende bevoegdheden ten grondslag kunnen liggen, kunnen worden geillustreerd aan de hand van het verschijnsel huisarbeid. Naar mijn mening is alleszins te verdedigen, dat de wetgever bij de totstandkoming van deze wet zich onvoldoende rekenschap heeft gegeven van de problematiek rond de huisarbeid. Dit terwijl toch artikel 2 van de Huisarbeidswet 1933 uitdrukkelijk bepaalt, dat deze wet

"geenerlei wijziging in de toepasselijkheid van de Arbeidswet 1919 en de Veiligheidswet

1934 op huisarbeid"

brengt, en in artikel 56 van de Arbeidsomstandighedenwet is bepaald, dat in het eerdergenoemde artikel in 


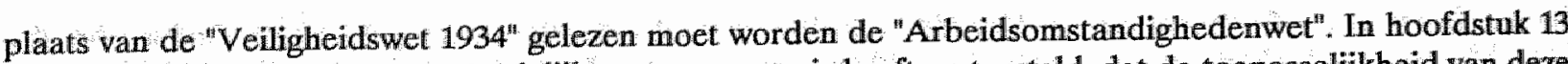
is al opgemerkt, dat de verantwoordelijke staatssecretaris heeft vastgesteld, dat de toepasselijkheid van deze wet op hüsarbeid maar beperkt is. Tijdens de mondelinge behandeling van de wet waarbij de Arbeidsomstandighedenwet met betrekking tot de deregulering werd gewijzigd, was door het Tweede Kamerlid Leijn$s^{273}$ de arbeidsbescherming van de thuiswerker naar voren gebracht ${ }^{274}$; hij vroeg de bewindsman prioriteit te willen geven aan de totstandkoming van een algemene maatregel van bestuur op grond van de artikelen 24 en 27 van die wet, waarbij dit terzake van de buisarbeid zou worden geregeld ${ }^{275}$. De bewindsman reageerde met de opmerking ${ }^{278}$, dat met een dergelijke maatregel niet kon worden volstaan. Er is nog een wijziging van de bepaling in de wet zelf vereist, waarin het ambtenaren van de arbeidsinspectie niet is toegestaan om woningen te betreden.

Deze bepaling zal moeten worden gewijzigd, zodat kan worden toegezien op de naleving

van de opgestelde voorschriften",

aldus de bewindsman, die daar overigens wel aan toevoegt, dat de nodige zorgvuldigheid in acht genomen moet worden gezien het feit, dat in artikel 12 van de Grondwet terzake het nodige voorschrijft. Er mag vanuit worden gegaan, dat de bewindsman hier het in de Arbeidsomstandighedenwet gemaakte onderscheid tussen toezicht en opsporing onderkent. Mevrouw Rempt-Halmmans de Jong ${ }^{277}$ daarentegen doet dit klaarblijkelijk niet, gezien het volgende:

"Want het niet kunnen binnentreden van huizen waar betaalde arbeid wordt verricht, geeft

grote problemen bij diverse wetten".

Ook in het kader van de Arbeidsomstandighedenwet kunnen woningen worden betreden, maar alleen in het kader van de opsporing, dus waar sprake is van een redelijk vermoeden van een strafbaar feit.

Voor de mogelijkheid tot het moeten kunnen binnentreden van woningen door ambtenaren van de arbeidsinspectie in het kader van het toezicht zijn goede gronden aan te voeren. Een voorwaarde voor handhaving door opsporing is, dat een mogelijke niet-naleving ter kennis komt van de opsporingsambtenaren. Is dit niet mogelijk, dan kan een opsporingsonderzoek niet gestart worden. Deze kennis kan verworven worden door eigen waarneming, door aangifte door derden of door een klacht, al dan niet anoniem. Eigen waarneming als basis voor een opsporingsonderzoek levert geen problemen op als het strafbare feit begaan wordt op plaatsen, waar het zichtbaar zijn van de niet-naleving voor de opsporingsambtenaren mogelijk is. Strafbare feiten die binnenshuis worden begaan, kunnen, behoudens aangifte of een klacht, niet ter kennis van de opsporingsambtenaren komen en dus ook niet worden opgespoord. Overtreding van de eventuele huisarbeidbesluit, gebaseerd op de Arbeidsomstandighedenwet, zal door de betrokken thuiswerker die bij die niet naleving in bepaalde opzichten een belang heeft of meent te hebben, zeker niet ter kennis van de opsporingsambtemaren worden gebracht. Met andere woorden: wanneer de niet-naleving van strafbare feiten voor de opsporingsambtenaren zelf niet zichtbaar is en de aangiftebereidheid alsook de mogelijkheid om gebruiken te kunnen maken van het "klachtrecht" zal ontbreken, zijn bevoegdheden in het kader van het toezicht gewenst. Aangevoerd kan worden dat de uitgevaardigde voorschriften in deze bij gebreke van toezichthoudende aandacht van overheidszijde nauwelijks enig effect zullen kunnen resulteren. Daarbij moet dan wel, juist vanwege de beschermen van de privacy van de betrokken burger(s), aangegeven worden wanneer een woning in het kader van het toezicht mag worden betreden; niet volstaan kan worden met een verwijzing naar de door de bevoegde ambtenaren van de arbeidsinspectie te vervullen taak. Gedacht kan worden aan de beperking, dat er een redelijk vermoeden dient te bestaan, dat er in de betrokken woning huisarbeid wordt verricht Daarnaast kan de bevoegdheid tot het betreden van woningen beperkt worden tot door de verantwoordelijke bewindsman nader aangewezen ambtenaren van de arbeidsinspectie, bijvoorbeeld het districtshoofd. Verwezen kan vervolgens worden naar de eerder door de minister van Justitie gehanteerde uitgangspun$\operatorname{ten}^{278}$. 
Voor zover de bedoelde ambtenaren van de arbeidsinspectie activiteiten verrichten in de hoedanigheid van opsporingsambtenaren, hebben zij op grond van artikel 20, eerste lid, van de Wet op de economische delicten te allen tijde toegang tot alle plaatsen, waarvan naar hun redelijk oordeel de betreding voor de vervulling van hun taak nodig is. Uitgezonderd zijn echter de vergaderzaal van de Staten-Generaal, van de staten van een provincie of van de raad van een gemeente, gedurende de vergadering, lokalen voor de godsdienst bestemd, gedurende de godsdienstuitoefening en lokalen waarin terechtzittingen worden gehouden, gedurende de terechtzittingen ${ }^{279}$. Zo nodig kunnen zij zich de toegang verschaffen met behulp van de sterke arm.

Het tweede lid van genoemd artikel bepaalt, dat zij een woning niet tegen de wil van de bewoner betreden dan ter opsporing van een economisch delict, en zij vergezeld worden door een commissaris van politie of door de burgemeester van de gemeente. Tevens kunnen zij een woning betreden tegen de wil van de bewoner, wanneer zij in het bezit zijn van een algemene of bijzondere schriftelijke last van de procureur-generaal bij het gerechtshof of van de officier van justitie, dan wel wanneer zij voorzien zijn van een bijzondere schriftelijke last van een van zijn hulpofficieren.

Ook van dit binnentreden dient binnen twee maal 24 uren een proces-verbaal opgemaakt te worden, waarin het tijdstip van binnentreden alsmede het beoogde doel wordt vermeld. De bedoelde ambtenaren hebben de bevoegdheid bepaalde personen aan te wijzen om then te vergezellen, maar ook daarvan moet in het prom ces-verbaal van binnentreden melding worden gemaakt, aldus het derde lid van artikel 20 van de Wet op de economische delicten.

Bij een vergelijking van deze bepaling met die van de Arbeidswet 1919 en de Veiligheidswet 1934 valt opnieuw te constateren, dat er afwijkingen zijn, zowel ten aanzien van de personen die de betreffende ambtenaren bij het betreden van de woning moeten of kunnen vergezellen, als ten aanzien van het op te maken proces-verbaal van binnentreding.

\subsubsection{De gehanteerde begrippen}

\subsubsection{1. "Toegang hebben tot", "binnentreden" en "betreden"}

De wetgever hanteert bij de toekenning van de bevoegdheden in het kader van zowel de opsporingstaak als de toezichthoudende taak verschillende begrippen. In artikel 85, eerste lid, van de Arbeidswet 1919, artikel 33, eerste lid, van de Veiligheidswet 1934 wordt gesproken van het "toegang hebben tot" plaatsen. In artikel 85, vierde lid, van de Arbeidswet 1919 en artikel 33, vierde lid, van de Veiligheidswet 1934 wordt het begrip "binnentreden" gebezigd. In artikel 32 van de Arbeidsomstandighedenwet wordlt gesproken van het "betreden" van plaatsen door de aangewezen ambtenaren van de arbeidsinspectie in het kader van het toezicht.

Hoewel deze begrippen taalkundig niet altijd onderling verwisselbaar zijn, omschrijven zij juridisch dezelfde handeling. Het begrip "toegang hebben tot" betekent taalkundig, dat men vrij is om naar binnen te gaan, terwijl "betreden" betekent: de voet zetten op bijwoorbeeld een terrein, en het "binnentreden" verwijst naar het de voet zetten in bijvoorbeeld een huis ${ }^{280}$.

\subsubsection{Het begrip "woning"}

Het begrip "woping" wordt nergens in de wetgeving geprecisieerd. In eerste instantie heeft men zich laten leiden door de idee, dat de Grondwet het recht op huisvrede en niet zozeer het eigendomsrecht beoogt te waarborgen. De huurder van een woning heeft in deze opvatting ook een recht op huisvrede ook al is hij geen eigenaar van de woning. Het gaat bij het waarborgen van die huisvrede derhalve niet zozeer om de ( juridische status van de ) persoon van de bewoner, maar om de woning

"als het territoir waar de bewoner met zijn gezin zijn gebied heeft, waar hij eigen baas is, 
derhalve om de besloten sfeer, de intimiteit van de woning", aldus de advocaat-generaal 's Jacob in zijn conclusie bij HR 7 februari $1956^{281}$. Hij is overigens wel van mening en wordt daarin gesteund door Melai ${ }^{232}$, dat de inbreuk op de huisvrede ook aanwezig kan zijn in een woning, die tijdelijk onbewoond is of waarvan de bewoner tijdelijk afwezig is.

Buys $^{283}$ omschreef een woning al als volgt:

"Woning is de plaats waar de mensch feitelijk zijn privaat huiselijk leven leidt en die hij daarom aan zijn persoon verbindt door ze van de buitenwereld af te sluiten".

De criteria die hij voor een woning onderscheidt zijn dus: het gebruik dat van die plaats gemaakt wordt in overeenstemming met zijn bestemming en het feit, dat deze afgesloten kan worden. Verkouteren ${ }^{284}$ vereiste voor de beschouwen van een plaats als een woning, dat uiterlijk moet blijken, dat de persoon in kwestie op de betreffende plaats zijn huiselijk leven leid, er eet en slaapt, zijn vrouw en kinderen heeft. Bakhoven ${ }^{285}$ sluit zich hilerbij aan, maar geeft tevens een uitbreiding aan het begrip gezien het feit, dat hüj een woning beschouwt

"de van de buitenwereld afgescheiden plaats waar iemand - eventueel met zijn gezin - zijn privaat huiselijk leven leidt of pleegt te leiden, alsmede alle ter beschikking en ten gebruike van den bewoner staande besloten ruimten, welke binnenshuis gemeenschap hebben met die plaats, zonder dat daarvoor andermans gebied behoeft te worden betreden".

Volgens Bakhoven behoren derhalve andere vertrekken, ruimten of lokalen, die een bouwkundig geheel vormen met een woning, onder het begrip "woning" te worden gebracht. Een standpunt dat steun vindt in de jurisprudentie; een werkplaats, die gelegen is binnen en deel uitmaakt van een tot woning bestemd perceel, geniet evengoed als andere perceelsgedeelten, die niet als woonvertrek plegen te worden gebezigd, zoals bijvoorbeeld een kelder en gangen, de bescherming waarmee de onschendbaarheid van de woning omgeven word ${ }^{286}$,

Het begrip "woning" dient ruim geinterpreteerd te worden. Zo zijn als woning aangemerkt: tenten, woonwagens, woonboten, herbergen die aan een woning verbonden zijn, keten en woonvertrekken ${ }^{287}$.De kamer van een kamerbewoner is een woning; onder omstandigheden geldt ook een hotelkamer als een woning. Het karakter van woning gaat niet verloren bij tijdelijke afwezigheid van de beworier bijvoorbeeld in verband met vakantie of verblijf in een ziekenhuis ${ }^{28}$. Maar trappen en portalen van een flatgebouw of een etagewoning die toegang geven tot een woning of lokaliteiten van andere aard, worden daarentegen niet geacht deel van de woning uit te maken ${ }^{28 \theta}$.

\subsection{Samenvatting en conclusies}

Zowel de Arbeidswet 1919 als de Veiligheidswet 1934 en de Arbeidsomstandighedenwet kennen een voor bepaalde personen neergelegde verplichting tot informatieverschaffing aan de met het toezicht op de naleving belaste ambtenaren over zaken en feiten die de naleving van die wetten betreft. Geen van deze bepalingen is gelijklluidend. Hoewel daar wel een verklaring voor te geven is, is het jammer, dat hier niet, zoals de in de volgende paragraaf te bespreken geheimhoudingsverplichting, tot harmonisatie van de arbeidsomstandighedenwetgeving besloten is. Er zou daarbij aangesloten kunnen worden bij de in artikel 33, eerste lid, van de Arbeidsomstandighedenwet neergelegde verplichting.

De wettelijke verplichting tot het verschaffen van informatie is ongeclausuleerd opgenomen. Bij deze verplichting is het onderscheid tussen de toezichthoudende en de opsporende taak van met betrekking de ambtenaren van de arbeidsinspectie van belang. Degene die weigert deze gevraagde informatie te verschaffen aan de betreffende ambtenaar in het kader van diens toezichthoudende taak is strafbaar. Eerst wanneer tegen de betrokkene de verdenking is gerezen van het plegen van een strafbaar feit, moet hem mededeling gedaan worden van het feit; dat hij op grond van artikel 29 van het Wetboek van Strafvordering niet verplicht is om te antwoorden. Als er een conflict ontstaat tussen het moeten verschaffen van informatie en het zichzelf bezwaren, vórdat men als verdachte wordt aangemerkt, is het twijfelachtig of een zwijgen leidt tot een veroordeling. 
Overigens staat voorop, dat de verlangde informatie omtrent zaken en feiten die de naleving van deze wetten betreffende naar waarheid moet worden verstrekt. Wanneer de betrokkene echter zonder opzet of door onachtzaamheid onjuiste informatie verschaft, ligt het niet in de rede dat hij snel veroordeeld zal worden.

\section{De geheilmhoudingsverplichting}

\subsection{Inleiding}

De bevoegdheid van de betreffende ambtenaren om plaatsen te betreden in het kader van de uitoefening van hun taak heeft er toe geleid dat dezelfde ambtenaren een geheimhoudingsverplichting is opgelegd. Als motivering van een dergelijke verplichting gaf de toenmalige bewindsman van Justitie Ruys van Beerenbroek het volgende ${ }^{280}$ :

"Waar de nijverheids-ondernemers in het algemeen belang moeten dulden het binnentreden van ambtenaren in hunnen fabrieken enz, hebben zij recht daarvan geen grotere bezwaren te ondervinden dan strikt noodzakelijk is, in elk geval niet duurzaam daardoor schade te lijden".

Cort van der Linden schreef eens ${ }^{201}$, dat de verplichting tot geheimhouding $z 6$ van zelf spreekt, dat hij het niet nodig vond daar nader op in te gaan. Op zich valt op deze uilspraak niet veel af te dingen, maar wat wel van belang is om na te gaan, hoever de reikwijdte van deze verplichting strekt.

\subsection{De geheimhoudingsverplichting in de Arbeidswet 1889 en de Veiligheidswet}

In artikel 20 van de Arbeidswet 1889 en in navolging daarvan artikel 23 van de Veiligheidswet was bepaald, dat de bedoelde ambtenaren verplicht waren tot geheimhouding van hetgeen hun in plaatsen waar arbeid wordt verricht of pleegt te worden verricht over het daar uitgeoefende bedrijf bekend is geworden. Deze geheimhoudingsverplichting gold echter alleen voor zover dit niet in strijd was met de bepalingen van de betreffende of een andere wet. Al met een al een zeer ruime geheimhoudingsverplichting, die verklaard werd met een verwijzing maar de bereidheid van de ondernemers om de betreffende ambtenaren zonder bezwaar toegang tot de bedoelde plaatsen te geven ${ }^{202}$.

Opzettelijke schending van deze geheimhoudingsverplichting werd bestraft met een gevangenisstraf van ten hoogste zes maanden of een geldboete van maximaal fl.600,- en kon leiden tot ontzetting van het "recht om ambten" te bekleden. Degene aan wiens schuld een dergelijke schending te wijten was, kon gestraft worden met een gevangenisstraf van ten hoogste drie maanden of een geldboete van maximal fl.300,--. Tot sllot bepaalde de betreffende artikelen dat het hier een zogenaamd klachtdelicht betrof, dat wil zeggen dat geen vervolging plaatsvond dan na een klacht van het hoofd of de bestuurder van het betreffende bedrijf:

\subsection{Uitbreiding van de geheimhoudingsverplichting in de Arbeidswet 1911}

Een bij de inspecteur van de arbeid van het toen zesde district ingekomen klacht met betrekking tot het te laat verrichten van arbeid in een hoedenatelier was aanleiding de betreffende inrichting te Hilversum aan een inspectie te onderwerpen. De ondervraging van de werkzame meisjes leidde niet tot enig resultaat; allen beweerden, nooit later dan tot 20.00 uur voor het bedrijf te werken en hoewel de opzichter van de arbeid aan de waarheid van de verklaringen twijfelde, kon er geen overtreding geconstateerd worden. Na ongeveer vier maanden werd de klacht herhaald, vermoedelijk door dezelfde persoon. Er werd nu wel bijverteld, dat de eerder ondervraagde meisjes nu niet op het betreffende atelier werkten en nu geneigd waren, de waarheid te vertellen. Bij de tweede inspectie bleek, dat twee meisjes, om 08.00 uur met de werkzaamheden begonnen en gedurende drie maanden tot 22.00 uur of 23.00 uur en soms tot 02.00 uur doorwerkten; zij bovendien geen vol uur rust hadden genoten tussen 11.00 uur en 15.00 uur en per dag langer dan 11 uren arbeid verrichtten. Bij de eerder inspectie hadden zij dit niet durven te vertellen, omdat zij door de bedrijfsleider 
onder meer met ontslag waren bedreigd. $Z_{i j}$ voegden er nog aan toe, dat na de eerste inspectie, de activiteiten voor het bedrijf na 20.00 uur in de huiskamer werden voortgezet. Het proces-verbaal van het getuigenverhoor werd opgemaakt, waarin 450 overtredingen van de Arbeidswet 1889 werden vermeld. Bij de terechtzitting was de bedrijfsleider als getuige opgeroepen. De verdachte werden slechts 60 overtredingen ten laste gelegd.

Voordat de zaak echter ter terechtzitting werd behandeld, waren de betrokken meisjes verzocht op het politiebureau te verschijnen, waar hun nadrukkelijk werd gevraagd de naam van de anonieme klager te noemen; zij weigerden echter deze naam te noemen of ontkenden de naam van de betrokkene te kennen. Ter terechtzitting werd hun opnieuw gevraagd de klager te noemen en de kantonrechter drong herhaaldelijk bij de betrokken ambtenaar van de arbeidsinspectie aan op de beantwoording van dezelfde vraag. Maar deze laatste kende de naam van de klager niet ${ }^{263}$. In het betreffende jaarverslag van de arbeidsinspectie ${ }^{284}$ wordt opgemerkt, dat het

"echter wel geen betoog (behoeft), dat het voor de handhaving van de Arbeidswet de meest bedenkelijke gevolgen zou hebben, indien de ambtenaren door de Rechterlijke macht konden gedwongen worden, de namen te noemen van hen, die hen omtrent eenig feit hebben ingelicht. Zulk een vraag aan de arbeiders is intusschen niet minder bedenkelijk".

Tijdens de begrotingsbehandeling voor het dienstjaar 1910 gaf de toenmalige bewindsman van Landbouw, Nijwerheid en Handel Talma reeds uitdrukkelijk de wens te kennen in de wet een waarborg te scheppen, dat de namen van hen die aangifte doen van overtredingen van het bij of krachtens de Arbeidswet 1889 desgewenst geheim blijven, zodat hun medewerking aan de handhaving van de wet hun geen persoonlijk nadeel zal kunnen berokkenen ${ }^{295}$. Ter staving hiervan verwees de bewindsman naar het voorgaande.

De betreffende bepaling in de Arbeidswet 1889 werd in de Arbeidswet 1911 dienovereenkomstig aangepast. De opsporingsambtenaren waren nu, behalve jegens hun superieuren, verplicht tot geheimhouding van de namen van de personen die aangifte hebben gedaan van een overtreding van het bij of krachtens die wet bepaalde. Alleen uitdrukkelijk toestemming van de betrokkene zelf kan deze geheimhoudingsverplichting opheffen. Overtreding van deze verplichting is strafbaar gesteld; ook hier betreft het een zogenaamd klachtdelict. Deze nieuwe geheimhoudingsverplichting maakte het mogelijk ook voor de rechter het stilzwijgen over de persoon die aangifte heeft gedaan te bewaren, dit in verband met het in de artikelen 66, 100 en 163 (oud) van het Wetboek van Strafvordering ${ }^{296}$ bepaalde, aldus de bewindsman ${ }^{297}$.

Eên en ander brengt met zich, dat de geheimhoudingsverplichting, zoals deze in de Arbeidswet 1911 was neergelegd in twee elementen gesplitst kan worden, namelijk een geheimhouding voor de betrokken ambtenaren terzake van

- hetgeen in plaatsen, waar arbeid wordt verricht of pleegt te worden verricht, over het daar uitgeoefend wordend bedrijf bekend is geworden, en

- de namen van personen die aangifte hebben gedaan van een arbeidswettelijke overtreding.

Opgemerkt moet echter worden, dat in de Veiligheidswet een dergelijke uitbreiding van de geheimhoudingsverplichting niet zou worden opgenomen.

\subsection{De geheimhoudingsverplichting in de Arbeidswet 1919 en de Veiligheidswet 1934}

In artikel 86 van de Arbeidswet 1919 zou een geheimhoudingsverplichting worden opgenomen die overeenkwam met de regeling in haar voorgangster. De namen van personen die aangifte hadden gedaan van een arbeidswettelijke overtreding mochten nu echter alleen bekend gemaakt worden, wanneer zij "schriftelijk", dit in tegenstelling tot de eerdere regeling waar al gesproken werd van "uitdrukkelijk", hadden verklaard tegen de mededeling daarvan geen bezwaar te hebben.

De Veiligheidswet 1934 zou een hiermee overeenkomende regeling bevatten ${ }^{208}$, dat wil zeggen dat eerst ruim 20 jaar na de Arbeidswet 1911 de geheimhoudingsverplichting van de beide wetten gelijkgeschakeld zou worden; zij zouden dit vervolgens verder ook blijven. 
De bedoelde zeer ruim geformuleerde geheimhoudingsverplichting zou enkele tientallen jaren ongewijzigd blijven. Eerst in 1967 zou er een wijziging van de betreffende wetsartikelen plaatsvinden ${ }^{299}$. Maar deze wijziging betrof niet de materiële inhoud van de geheimhoudingsverplichting, maar de bestraffing van het schenden ervan. Door een wijziging van artikel 272 , eerste lid, van het Wetboek van Strafrecht, waarbij hij

"die enig geheim, waarvan hij weet of redelijkerwijs moet vermoeden, dat hij uit hoofde van ambt, beroep of wettelijk voorschrift, dan wel van vroeger ambt of beroep verplicht is het te bewaren, opzettelijk schendt",

gestraft wordt met gevangenisstraf van ten hoogste eén jaar of een geldboete van maximaal fl. 6000 ,--, werden onder meer de desbetreffende artikelleden in de artikelen 86 van de Arbeidswet 1919 en 34 van de Veiligheidswet 1934 omtrent de bestraffing van de schending van de geheimhouding geschrapt.

\subsection{Beperking van de geheimhoudingsverplichting}

In verband met het in de Veiligheidswet 1934 opnemen van de regeling van het veiligheidsrapport in de zeventiger jaren, werd door de toenmalige bewindsman van Sociale Zaken Boersma voorgesteld de geheimhoudingsverplichting terzake uit te breiden.

"De ambtenaren die uit hoofde van deze wet in kennis worden gesteld van de bedoelde vei-

ligheidsrapporten, zijn verplicht tot geheimhouding van al hetgeen hun uit die rapporten of de wijzigingen daarvan omtrent het betrokken bedrijf bekend is geworden, voor zover deze geheimhouding niet in strijd is met de bepalingen van deze of van een andere wet", aldus het voorgestelde nieuwe derde lid van artikel 34 van de Veiligheidswet $1934^{300}$. Deze uitbreiding was klaarblijkelijk niet dusdanig, dat de bewindsman meende daaraan in de toelichting enige woorden te moeten besteden $^{301}$. Vanuit de Tweede Kamer werd echter gevraagd ${ }^{302}$ in hoeverre deze uitbreiding van artikel 34 in het beleid van het kabinet met betrekking tot de openbaarheid paste ${ }^{303}$. Daarnaast werd er vanuit de Tweede Kamer nog als belangrijkste punt van kritiek op de bestaande wetgeving de geheimhouding genoemd ${ }^{304}$, die met het wijzigingswoorstel niet werd weggenonen ${ }^{305}$. De bewindsman antwoordde ${ }^{303}$, dat de geheimhoudingsverplichting in toenemende mate een punt van kritiek was vanwege de ruime en globalle bewoordingen waarin deze geheimhoudingsplicht was geformuleerd. Hij verwees daarbij naar de begrotingsbehandeling van het ministerie van Justitie voor het dienstjaar 1974 waar toen hierover vragen werden gesteld $^{307}$. In het als gevolg hiervan gehouden (ambtelijk) overleg tussen de beide departementen was naar voren gekomen, dat de formulering van de geheimhoudingsbepalingen herziening behoefde. Vandaar dat in de adviesaanvraag aan de Sociaal-Economische Raad van 19 juni 1975 een vraagstelling op dit punt was opgenomen $^{308}$. Het bedoelde adviesorgaan kon zich vinden in een geheimhoudingsverplichting voor de ambtenaren van de arbeidsinspectie die in overeenstemming was met het betreffende Verdrag van de Internationale Arbeidsorganisatie ${ }^{300}$, aldus de minister ${ }^{310}$. Hij vervolgde met de opmerking dat een vernieuwing van de wetgeving - de Arbeidsomstandighedenwet - nog enige tijd zou duren. Daar juist in een aangelegenheid als het veiligheidsrapport de geheimhouding een belangrijke rol speelt, besloot hij de nieuwe formulering met voorrang tot stand te brengen en een voorstel daartoe bij nota van wijziging op te nemen ${ }^{31 !}$. De bedoelde geheimhoudingsverplichting voor de betreffende ambtenaren werd als volgt geredigeerd:

"De in artikel 32 bedoelde ambtenaren zijn verplicht tot geheimhouding van alle zaken en

bedrijfsgeheimen, waarvan zij in hun hoedanigheid kenmisnemen voor zover deze geheim-

houding niet in strijd is met de bepalingen van deze of een andere wet".

De geheimhoudlingsbepalingen van de andere wetten waaronder de Arbeidswet 1919 werden tegelijkertijd dienovereenkomstig aangepast; zodat er terzake van de algemene regeling inzake de geheimhouding uniformiteit in wetgeving zou ontstaan.

Ten aanzien van het wijzigingsvoorstel van de Veiligheidswet 1934 vermeldde de bewindsman in zijn toelichting het volgende. De oorspronkelijke bewoordingen van de geheimhoudingsplicht waren zo algemeen gesteld, dat strikt formeel gezien aan de betrokken ambtenaar ruimte geboden werd om zich tegenover elk ver- 
zoek om inlichtingen - ongeacht de inhoud van het werzoek - afwijzend op te stellen. Dit laatste was dan wel geen gangbare praktijk, maar er deden en doen zich toch problemen voor met betrekking tot de toepassing van dit artikel. De minister wees in dit verband op het feit, dat werknemers, aan wie in een bedrijf een ongeval is overkomen, meer dan voorheen een civiele procedure tot schadevergoeding op grond van artikel 1403 wan het Burgerlijk Wetboek tegen de werkgever aanhangig maken. In dergelijke gevallen kan een door de arbeidsinspectie gedaan onderzoek onder omstandigheden een belangrijke rol spelen; het ligt dan ook voor de hand, dat de benadeelde partij aan deze dienst een verzoek richt om een afschrift van het desbetreffende onderzoeksrapport te mogen ontvangen. Dergelijke verzoeken worden, aldus de bewindsman, in de praktijk niet categorisch afgewezen met een beroep op de geheimhoudingsplicht; zij worden vrijwel altijd ingewilligd. Maar in de geschetste situatie verstrekt het districtshoofd van de arbeidsinspectie echter informatie, die binnen de omschrijving van het bewuste artikel 34 van de wet valt. Hetzelfde probleem doet zich voor, indien aan de arbeidsinspectie om andere redenen dan de zojuist genoemde, inlichtingen worden gevraagd. In ieder individueel geval zal de betrokken ambtenaar zelf kunnen en ook moeten beslissen hoe hij zich tegenover een dergelijke verzoek om inlichtingen moet opstellen. Voor richtlijnen of instructies op dit punt biedt het betrokken wetsartikel geen ruimte, aldus minister Boersma.

$\mathrm{Nu}$ allerwege wordt aangedrongen op meer openheid van de zijde van de overheid, zo vervolgde hij, kan verwacht worden, dat aan de ambtenaren van de arbeidsinspectie in toenemende mate inlichtingen zullen worden gevraagd met betrekking tot zaken waarvan zij ambtshalve kennis dragen en waarvan geheimhouding geenszins noodzakelijk moet worden geacht. Vandaar ook dat hij in de eerderbedoelde adviesaanvraag aan de Sociaal-Economische Raad de geheimhoudingsplicht aan de orde had gesteld. In overeenstemming met het advies van de Sociaal-Economische Raad wordt in het ontwerp-Arbeidsomstandighedenwet de plicht tot geheimhouding beperkt tot zaken- en bedrijfsgeheimen ${ }^{312}$. De bewindsman verwees hierbij naar het op de arbeidsinspectie betrekking hebbende Verdrag no. 81 van de Internationale Arbeidsorganisatie.

$\mathrm{Na}$ het inwerkingtreden van de bedoelde wetswijziging ${ }^{3+3}$ luidde de bedoelde geheimhoudingsverplichting als volgt:

"De ..... bedoelde ambtenaren zijn verplicht tot geheimhouding van alle zaken- en bedrijfsgeheimen, waarvan zij in hun hoedanigheid kennisnemen voor zover deze geheimhouding niet in strijd is met de bepalingen van deze of een andere wet".

Bij zakengeheimen gaat het bijvoorbeeld om financieel-economische geheimen, dus geheimen die de financieel-economische positie van de bedrijven betreffen, de commerciële geheimen, die over de zakenrelaties gaan en over het doen van offertes en geheimen over prijscalculaties. Bij bedrijfsgeheimen kan gedacht worden aan technische uitvindingen waarvan de onderneming door eigen onderzoek of op grond van licenties kennis heeft verkregen. De bewindsman stelde, dat daarmee een vrij enge begrenzing is gegeven aan datgene wat uitgesproken onder de geheimhoudingsplicht van de betrokken ambtenaar valt ${ }^{314}$.

\subsection{De geheimhoudingsverplichting in de Arbeidsomstandighedenwet}

De regeling van de geheimhouding in het ontwerp-Arbeidsomstandighedenwet komt overeen met die in de Veiligheidswet 1934, De bedoelde ambtenaren waren op grond van het voorgestelde artikel 32 verplicht tot geheimhouding van zaken- en bedrijfsgeheimen, voor zover deze geheimhouding niet in strijd was met de bepallingen van deze of een andere wet; van de namen van personen die aangifte doen van een overtreding van de bij of krachtens deze wet gegeven voorschriften. Voorts werd voorgesteld een geheimhoudingsverplichting terzake van zaken- en bedrijfsgeheimen op te nemen voor aangegeven ambtenaren, anderen dan die van de arbeidsinspectie ${ }^{315}$, en de ondernemingsraad en de terzake bevoegde commissie op te nemen in het kader van het veiligheidsrapport ${ }^{316}$. In de toelichting op dit betreffende artikel wordt verwezen naar de regeling terzake in de Veiligheidswet ${ }^{317}$, maar dit was voor de Tweede Kamer niet voldoende; er bleven een aantal vragen over. Zo werd gevraagd ${ }^{318}$ of het begrip zaken- en bedrijfsgeheimen ruim of eng geïnterpreteerd diende te worden. Voorts werd gevraagd of het enkel openbaren van een de gezondheid bedreigende stof het schenden van een zaken- en/of bedrijfsgeheim is. De minister verwees in zijn antwoord ${ }^{319}$ naar 
de eerdere parlementaire behandeling van de wijziging van onder meer de Veiligheidswet 1934 en hetgeen daar was opgemerkt over het genoemde begrip. Hij merkte daarbij op dat het ging om een enge begrenzing van de geheimhoudingsplicht van de ambtenaren. Het enkel openbaren van een de gezondheid bedreigende stof betekent niet zonder meer een inbreuk op deze geheimhoudingsplicht. Hiervan is eerst sprake, aldus de bewindsman, indien door de bekendmaking een technische vinding openbaar gemaakt zou worden. Een aanduiding van een stof, die niet verder gaat dan nodig is om het gevaar voor de gezondheid te signaleren, viel zijns inziens niet snel onder het specifiek naar buiten brengen van een bedrijfsgeheim. Op de uitgesproken veronderstelling, dat de geheimhoudingsplicht toch in elk geval niet zou mogen gellen tegenover de rechter in een civiel- of strafrechtelijk geding ${ }^{320}$, antwoordde de minister ${ }^{321}$, dat dit in geval van een dagvaarding van een ambtenaar als getuige een juiste veronderstelling is. Dit antwoord doet wat vreemd aan; want is de opgelegde geheimhoudingsplicht niet, zoals hiervoor al vermeld is, een verschoningsrecht van deze ambtenaar? In een latere fase van de parlementaire behandeling zou de bewindsman dit zelf ook inzien. Hij maakte duidelijk $k^{322}$, dat bedoeld was te zeggen, dat een ambtenaar van de arbeidsinspectie als getuige in een proces mededelingen kan doen omtrent het gebruik van een voor de gezondheid gevaarlijke stof voor zover hij daarmee niet een bedrijfsgeheim bekendmaakt. Tevens maakte de bewindsman kenbaar, dat het begrip bedrijfsgeheim eng uitgelegd dient te worden. Het gaat hier om gegevens welke van belang zijn in de concurrentiestrijd en waarvoor de "bedrijfsspionage" zich interesseert. Op dit punt geldt de geheimhoudingsplicht - in de vorm van een verschoningsrecht - ook tegenover de rechter. Wel is het zo, dat uiteindelijk de rechter degene is, die de reikwijdte van dit verschoningsrecht bepaalt.

Bij nota van wijzigingen ${ }^{323}$ zou onder meer het artikel waarin de geheimhoudingsverplichting is opgenomen gewijzigd worden. Twee wijzigingen springen daarbij in het oog.

Allereerst de wijziging waarbij niet alleen meer de namen van personen die aangifte hebben gedaan van een overtreding geheim dient te blijven, maar nu ook de namen van personen die een klacht hebben ingediend. Deze wijziging had dus eerst plaats in 1979 en niet in 1967 , zoals Geers stelt ${ }^{324}$. Uit deze wijziging, die overigens door de betrokken bewindsman niet werd toegelicht ${ }^{325}$, kan een afgeleid recht van klagen worden gedistilleerd ${ }^{328}$; een dergelijke geheimhoudingsverplichting betekent een belangrijke bescherming voor de werknemers ${ }^{327}$. Het recht van klagen van de één wordt dus afgeleid van de verplichting om de naam van de klager geheim te houden van een ander. De Grondwet kent daarentegen wel een algemeen petitierecht; artikel 5 bepaalt, dat een ieder het recht heeft verzoeken schriftelijk bij het bevoegd gezag in te dienen. Een klacht als bedoeld in artikel 34, tweede lid, van de Arbeidsomstandighedenwet kan gezien worden als een specifiek verzoek. Een andere vraag is, of in dit geval de arbeidsinspectie verplicht is de klacht te behandelen en/of te beantwoorden. Met name deze verplichting is van groot belang voor de individuele werknemer ${ }^{328}$. Aanvankelijk beoogde het grondwettelijke petitierecht niets anders dan een vrijwaren van strafrechtelijke vervolging van de verzoeker. In de praktijk is daar echter een verplichting aan toegevoegd, namelijk dat de petitie bekeken én behandeld moet worden. Van Maarseveen schrijft hierover het volgen$\mathrm{de}^{328}$ :

"Weliswaar gaan de juridische verplichtingen niet zover dat ook antwoord moet worden gegeven op een binnengekomen petitie, maar het politieke en ambtelijke praktijk om met name klachtpetities eerst te beantwoorden met een bericht van ontvangst en daarna zo mogelijk ook met een inhoudelijk antwoord. Dat gebeurt niet met alle petities, maar alle petities worden wel volgens een bepaalde procedure, die van orgaan tot orgaan kan verschillen, beantwoord".

Hij vervolgt met de stelling, dat het ongelezen terzijde leggen ongrondwettig is en in strijd is met beginselen van behoorlijk bestuur en behoorlijke politiek, omdat het een onzorgvildig handelen is ten opzichte van degene die een petitie indient. Centraal bij Van Maarseveen staat derhalve de behandelingsplicht ${ }^{330}$, maar geldt ook een beantwoordingsplicht? Een beantwoordingsplicht moet volgens Geers ${ }^{331}$ eveneens worden aangenomen, omdat het onbeantwoord laten evengoed in strijd is met de beginselen van behoorlijk bestuur. Hij beroept zich daarbij op de parlementaire geschiedenis van het bewuste grondwettelijke artikel. Hoewel 
een wettelijke antwoordplicht werd afgewezen, vermeldde de toelichting ${ }^{332}$ wel:

"..... dat zich reeds in belangrijke mate de bestuurspraktijk heeft gevormid dat verzoeken van burgers worden beantwoord: deze bestuurspraktijk zou zich aldus kunnen ontwikkelen, dat ook de behandeling en beantwoording van verzoekschriften beheerst wordt door de algemene beginselen van behoorlijk bestuur"

De toenmalige minister van Binnenlandse Zaken meende, dat beantwoording vanzelfsprekend is ${ }^{333}$.

Daarom ben ik het met de Raad van State eens dat het vanzelf spreekt dat men een verzoekschrift, dat ook maar de schijn van redelijkheid heeft, beantwoordt, maar dat het ook mogelijk moet zijn om niet of niet langer te antwoorden".

Welke wegen staan de klager nu open, wanneer hij niet tevreden is met het gegeven antwoord of wanneer een beantwoording achterwege blijft? De toenmalige minister van Sociale Zaken verdedigde de regeling van het verzoek om wetstoepassing met argument, dat de meerwaarde van een dergelijke verzoek in vergelijking met het individuele klachtrecht gelegen is in een beroepsprocedure. Met andere woorden: de bewindsman zegt met zoveel woorden, dat op een klacht geen beroepsmogelijkheid openstaat. Maar dit is niet geheel juist, zoals Geers $^{334}$ terecht opmerkt. Iedereen heeft het recht om brieven te schrijven aan wie dan ook; dit is een feitelijke mogelijkheid. Het grondwettelijke petitierecht voegt iets aan deze feitelijke mogelijkheden toe. $\mathrm{Er}$ is wat genoemd wordt een subjectief publiekrecht gecreëerd, waardoor er bepaalde rechtsgevolgen optreden. Zo mag niemand in de uitoefening van zijn recht worden belemmerd; dit kan een onrechtmatige daad opleveren. Een zodanig optreden kan bij de burgerlijk, administratieve en zelfs de strafrechter worden aangevochten. Overheidsorganen zoals bijwoorbeeld de arbeidsinspectie zijn in rechte gehouden petities in ontvangst te nemen en in behandeling te nemen. Wanneer een orgaan schriftelijk laat weten een petitie niet in ontvangst te nemen, kan het in een aantal gevallen via de administratieve rechter daartoe gedwongen worden. Hoofden van ministeries aan wie opzet of grove schuld terzake van daadwerkelijk schending van het petitierecht kan worden verweten zijn strafrechtelijk aansprakelijk op grond van het Wetboek van Strafrecht $^{395}$. Daarnaast bestaat de mogelijkheid, om, wanneer van de zijde van bijvoorbeeld de arbeidsinspectie niet adequaat wordt gereageerd op klachten ten aanzien van overtreding van veiligheidswoorschriften, het Openbaar Ministerie te verzoeken om aan de arbeidsinspectie een bevel tot een opsporingsonderzoek te geven $^{336}$

Het bovenstaande betreft echter alleen schriftelijk gedane klachten. Wat nu als het mondelinge klachten betreft? Ook deze zullen, woor zover zij de schijn van redelijkheid hebben, serieus in behandeling moeten worden genomen en wanneer gegevens van de klager bekend zijn, zal deze van het resultaat op de hoogte moeten worden gebracht. In grote lijnen zal hetzelfde gelden, maar dan als afgeleide van het grondwettelijke petitierecht en wanneer het anonieme klachten betreft zal de taakstelling van een overheidsorgaan als de arbeidsinspectie een belangrijke rol spelen, namelijk het toezicht op de onder haar regarderende wetgeving en de opsporing van overtredingen daarvan. De anonieme klacht kan dan gezien worden als een informatiebron waarop een optreden van de arbeidsinspectie gerechtvaardigd geacht kan worden te zijn.

De tweede wijziging betreft de uitbreiding van de kring van personen voor wie een geheimhoudingsplicht geldt. Op grond van een nieuw vierde lid van het nu tot artikel 31 vernummerde artikel geldt eveneens een geheimhoudingsplicht terzake van zaken- en bedrijfsgeheimen voor leden van een commissie voor veiligheid, gezondheid en welzijn al dan niet van de ondernemingsraad; ook hier geldt, evenals voor de ambtenaren van de arbeidsinspectie, voor zover deze geheimhouding niet in strijd is met de bepalingen van deze wet of een andere wet. De bewindsman stelde, dat er tussen de arbeidsinspectie en de bedoelde commissie geen geheimhoudingsschot diende te zijn. Terzake van de uitzondering "voor zover deze geheimhouding niet in strijd is met de bepalingen van deze of een andere wet" wees hij op de volgende samenhangen:

"Artikel 31 ( thans: 34, JvD) legt aan de ambtenaren van de Arbeidsinspectie geheimhouding op ten aanzien van zaken- en bedrijfsgeheimen, "voor zover deze geheimhouding niet in strijd is met de bepalingen van deze of een andere wet". Deze uitzondering geeft o.a. voorrang aan de informatieplicht, vervat in artikel 12, zevende lid ( thans: 14 , tiende lid, 
JvD ). Dezelfde clausule aan het slot van het nieuwe vierde lid van artikel 31 (thans: 34 ,

JvD ) geeft voorrang o.a. aan de verplichting tot het geven van inlichtingen aan de ambtenaren van de arbeidsinspectie, welke ingevolge artikel 30 ( thans: 33, JD ) rust op de leden van de commissie als werknemers".

Met andere woorden: de geheimhoudingsbepalingen zijn zo geformuleerd, dat daarvan afwijkende voorschriften al dan niet vastgelegd in de Arbeidsomstandighedenwet zelf, hiervoor in de plaats treden. Dit laatste is van belang voor de informatieplicht die de ambtenaren van de arbeidsinspectie is opgelegd jegens de werknemers(-vertegenwoordiging) ${ }^{337}$, althans voor zover het de Arbeidsomstandighedenwet zelf betreft.

Een ander punt is, dat de ambtenaren van de arbeidsinspectie terzake van de geheimhouding te maken hebben met de Wet openbaarheid van bestuur ${ }^{339}$ en de Algemeen Rijksambtenarenreglement ${ }^{338}$.

De Wet openbaarheid van bestuur legt geen verplichting tot het verschaffen van informatie op aan de individuele ambtenaar; een dergelijke verplichting is opgelegd aan overheidsorganen, na een verzoek daartoe, de zogenaamde "passieve informatieplicht" ${ }^{\text {340 }}$. Een dergelijk verzoek kan worden gedaan door een individuele burger, maar ook bijwoorbeeld door eem werkgever(sorganisatie) of een werknemersorganisatie of een persorgaan. De verantwoordelijkheid voor het verschaffen van informatie berust in het gevall van de arbeidsinspectie bij de minister van Sociale Zaken en Werkgelegenheid. In de praktijk komt het erop neer, dat de bevoegdheid om te beslissen op een verzoek om informatie is voorbehouden aan de districtshoofden onderscheidenlijk de (plaatsvervangend) directeur-generaal van de Arbeid en in laatste instantie de secretaris-generaal van het departement ${ }^{341}$.

Van belang is wel, dat de Wet openbaarheid van bestuur onder "informatie" gegevens verstaat, die zijn neergelegd in schriftelijke stukken en in ander materiaal zoals foto's, films, ponskaarten- en banden en ellektromagnetische banden en kaarten $^{342}$. Uitgangspunt van deze wet is, dat verzoeken om informatie ingewilligd dienen te worden, tenzij daartegen bezwaar bestaat op grond van de in artikel 4 van de wet gegeven weigeringsgronden. Als één van de weigeringsgronden noemt het genoemde artikel bedrijfs- en fabrikagegegevens die vertrouwelijk aan de overheid zijn medegedeeld. Dit is een zogenaamde absolute weigeringsgrond ${ }^{343}$. Andere weigeringsgronden waarbij een belangenafweging plaats dient te vinden hebben betrekking op de opsporing en vervolging van strafbare feiten en op de inspectie, controlle en toezicht door of vanwege overheidsorganen $^{344}$.

Volgens artikel 59, eerste lid, van het Rijksambtenarenreglement zijn ambtenaren verplicht tot geheimhouding van hetgeen hun in hun ambt ter kennis is gekomen, voor zover die verplichting "uit de aard der zaak" volgt. De betekenis van deze geheimhoudingsbepaling is beperkt door de geheimhoudingsbepalingen in de arbeids- en veilgiehidswetgeving en het bij of krachiens de Wet opnebaarheid van bestuur bepaalde. Dit heeft tot gevolg, dat de in het eerste lid van het genoemde artikel bedoelde geheimhoudingsplicht nog slechts betrekking heeft op informatie, die niet is neergelegd in shcriftelijke stukken en die geen gegevens bevat die vallen onder de categorie zaken- en bedrijfsgeheimen. Het tweede lid van genoemd artikel bepaalt, dat de geheimhoudingsplicht niet geldt ten opzichte van de hiëarchisch hogere; deze kan de geheimhoudingsplicht gedeeltelijk opheffen, ook ten opzichte van derden.

\subsection{Opnieuw een wijziging van de geheimhoudingsbepalingen}

In 1987 werd een wetsvoorstel ingediend ${ }^{345}$ waarbij de geheimhoudingsbepalingen van onder meer de Arbeidswet 1919, de Veiligheidswet 1934 en de Arbeidsomstandighedenwet gewijzigd werden. Directe aanleiding voor het wijzigingsvoorstel vormde het feit, dat de geldende geheimhoudingsbepaling in de Veiligheidswet 1934 en in de Arbeidsomstandighedenwet het niet toeliet om bij algemene maatregel van bestuur te bepalen, dat de arbeidsinspectie gegevens, die zaken-en bedrijfsgeheimen bevatten aan met name genoemde personen of commissies toezendt of kan toezenden. Bij de voorbereiding van de algemene maatregel van bestuur ter bescherming van werknemers bij het uitvoeren van recombinant-DNA-bewerkingen, het zogenaamde Recombinamt-DNA-besluit deed zich dit probleem concreet voor ${ }^{346}$. Het ligt in de bedoeling, dat de 
arbeidsinspectie bij de uitvoering van dit besluit door ter zake deskundigen wordt geadviseerd. De deskundigheid op dit gebied is thans nog gebundeld in de Commissie ad hoc recombinant-DNA-werkzaamhe$\operatorname{den}^{347}$, die zal worden wervangen door een nieuwe recombinant-DNA-commissie met een gelijksoortige taakstelling ${ }^{348}$. Noch de geheimhoudingsbepaling in de Veiligheidswet 1934, noch die in de Arbeidsomstandighedenwet laat toe, dat de arbeidsinspectie vertrouwelijke gegevens met betrekking tot een recombinantDNA-bewerking aan de commissie toezendt. Om toezending aan de commissie mogelijk te maken en haar leden een geheimhoudingsplicht op te leggen moesten de betreffende geheimhoudingsbepalingen gewijzigd worden, aldus de toenmalige minister van Sociale Zaken en Werkgelegenheid De Graaf ${ }^{49}$. Hij stelde voor een algemene geheimhoudingsplicht op te nemen voor een ieder die betrokken is bij de uitvoering van bedoelde wet(ten) en die daarbij de beschikking krijgt over gegevens, waarvan hij het vertrouwelijke karakter kent of redelijkerwijs moet vermoeden en voor wie niet reeds uit andere hoofde van ambt, beroep of wettelijk voorschrift ter zake van die gegevens een geheimhoudingsverplichting geldt. De geheimhoudingsverplichting geldt niet voor zover enig wettelijk voorschrift hem bekendmaking verplicht of uit zijn taak bij de uitvoering van de bedoelde wet(ten) de noodzaak tot bekendmaking voortvloeit.De bewindsman stelde tevens voor de bijzondere geheimhoudingsbepaling omtrent de namen van personen die een klacht hebben ingediend onderscheidenlijk aangifte hebben gedaan van een overtreding te laten vervallen, omdat deze verplichting ook in artikel 59 van het Rijksambtenarenreglement besloten ligt. Geers ${ }^{350}$ verzet zich daartegen. Hij stelt, dat niet goed valt in te zien, waarom in het geval waar het kennelijk de bedoeling is dat de bescherming van de bron van de klachten gegarandeerd blijft, deze intentie niet blijvend geformuleerd kan worden in de Arbeidsomstandighedenwet. Bovendien, zo vervolgt hij, zou de opheffing van de voorgeschreven geheimhouding, waarbij volledig wordt teruggevallen op artikel 59 van het Rijksambtenarenregelement, ook kunnen plaatsvinden na mondelinge toestemming, terwijl de Arbeidsomstandighedenwet schriftelijke toestemming van de betrokkene vereist. Hij stelt dan ook voor de "oude" regeling te handhaven.

Ook vanuit de Tweede Kamer werden dergelijke geluiden naar voren gebracht ${ }^{351}$. De bewindsman erken$\mathrm{de}^{\mathbf{3 5 2}}$, dat wanner de geheimhouding van de bron van klachten en aangiften niet verzekerd is, het risico bestaat, dat de arbeidsinspectie van een belangrijke informatiestroom wordt afgesneden, wat haar functioneren als toezichthoudend orgaan niet ten goede komt. Hij hield echter vol, dat deze vertrouwelijkheid ook in de door hem voorgestelde opzet verzekerd is. Artikel 59 van het Rijksambtenarenreglement rept weliswaar niet met zoveel woorden over geheimhouding van namen van onder meer klagers, maar de plicht tot geheimhouding daarvan ligt wel in het artikel besloten.

Het door de bewindsman volharden in zijn standpunt bracht de Tweede Kamerleden De Leeuw en Leijnse er toe een amendement in te dienen van de volgende strekking. De bedoelde ambtenaren zijn, behoudens tegenover hen aan wier gezag zij uit kracht van hun ambt zijn onderworpen, verplicht tot geheimhouding van de namen van personen door wie een klacht is ingediend of aangifte is gedaan van een overtreding van het bij of krachtens de wet bepaalde, behoudens wanneer deze personen hun schriftelijk hebben verklaard tegen de mededeling van hun namen geen bezwaar te hebben ${ }^{353}$. Dit amendement werd met algemene stemmen aangenomen ${ }^{354}$. Geers kan derhalve tevreden zijn; de "oude" regeling wordt niet alleen gehandhaafd, maar ook uitgebreid. Het geheimhouden van de namen van klagers was alleen geregeld in de Arbeidsomstandighedenwet; nu geldt het ook voor onder meer de Veiligheidswet 1934 en de Arbeidswet 1919.

\subsection{Samenvatting}

Na de laatste wijziging van de geheimhoudingsbepalingen in onder meer de Arbeidswet 1919 , de Veiligheidswet 1934 en de Arbeidsomstandighedenwet geldt een geheimhoudingsverplichting die in twee elementen gesplitst kan worden.

Allereerst wat genoemd kan worden de geobjectiveerde geheimhouidingsverplichting. Een ieder die betrokken is bij de uitvoering van de bedoelde wetten en daarbij de beschikking krijgt over gegevens, waarvan hij het vertrouwelijke karakter kent of redelijkerwijs moet vermoeden en voor wie niet reeds uit hoofde van ambt, beroep of wettelijk voorschrift ter zake van die gegevens een geheimhoudingsverplichting geldt, is verplicht 


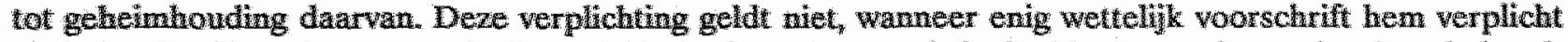

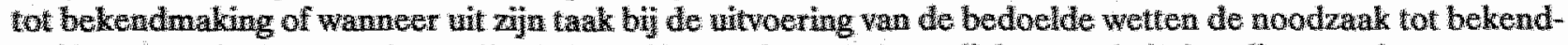

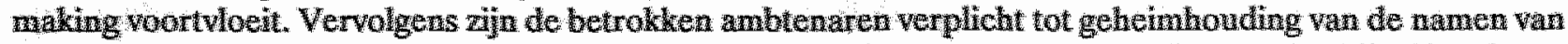
personen door wie een kacht is ingediend of angifte is gedaan van cen overtreding van het bij of krachtesn

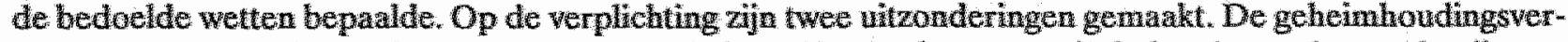

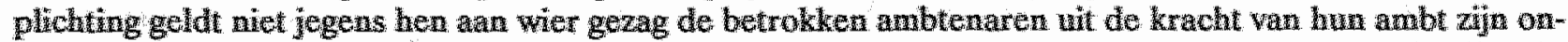

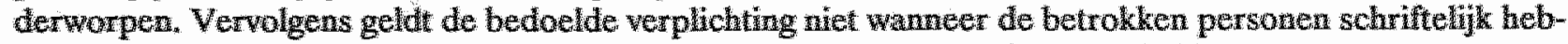
ben verklaard, dat zu tegen de bekendmaking van hun namen geen bewaar hebben.

De laatste wizziging lerzake wan de onderhavige wetten aakt in ieder geval dat op cen onderling samenhan-

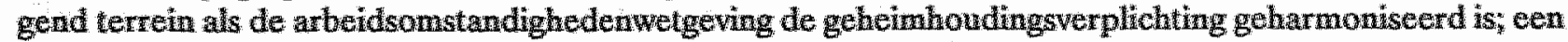
zata dite tot tevedenheid stemt. 
1. Zie bijvoorbeeld de artikelen 1 en 11 van de Arbeidswet 1889 en de artikelen 1 en 10 van de Veiligheidswet."

2. Eerste Kamer, zitting 1888 - 1889,60a ( Eindverslag bevattende de memorie van antwoord ) blz. 3.

3. Zie Tweede Kamer, zitting $1909-1910,257.3$ (memorie van toeliehting) blz. 8. Zie ook T. Koopmans, De begrippen werkman, arbeilder en werknemer, Alphen a/d Rijn 1962, blz. 16; J. van Drongelen, Nogmaals fabriek of werkplaats: Arbeidswet 1919, Veiligheidswet 1934, Arbeidsomstandighedenwet, in S.M.A. 1989 blz. 486. Dit artikel is een reactie op een bijdrage van H.J. van Zwam, Fabriek of werkplaats: Arbeidswet 1919, Veiligheidswet 1934, Arbeidsomstandighedenwet, in S.M.A. 1988 blz. 389, die ten onrechte opmerkte, dat het begrip "onderneming" in de Arbeidswet afkomstig was uit de Ongevallenwet 1901.

4. CRvB 15 januari 1904; zie H.L. van Duyl/A. Heringa, Litteratuur en rechtspraak betreffende de Ongevallenwet 1901 en Beroepswet, Haarlem 1905, blz. 53 no. 18. Zie ook M.G. Levenbach, Het juridische begrip "onderneming", in S.M. 1949 blz. 175.

5. CRvB 21 december 1915; zie M.G. Levenbach, in S.M. 1949 blz. 175 nt. 1.

6. HR 15 juni 1914, NJ 1914 blz. 1005 - W. 9666, daarmee bevestigend Rb. Zwolle 2 april 1914 , NJ 1914 blz. 486, waarin dezelfde overwegingen vermeld worden.

7. Zie M.G. Levembach, in S.M. 1949 blz. 175 - 176.

8. Zie bijwoorbeeld de artikelen 1, eerste lid, aanhef, en 28, vijfde en zevende lid, van de Arbeidswet 1919 en de artikelen 1 en 2 van de Veiligheidswet 1934.

9. Hand. Tweede Kamer, zitting 1918 - 1919, blz. 2880; zie W.F. de Gaay Fortman, De onderneming in het arbeidsrecht, Amsterdam 1936, blz. 40 en G.W. Caron, De Arbeidswet 1919, Deventer 1921, blz. 3.

10. Zie HR 15 januari 1940, NJ 1940 388; HR 15 juni 1955, NJ 1956 14. Zie T. Koopmans, t.a.p., blz. 304.

11. Zie nt. 8 .

12. W.F. de Gaay Fortman, t.a.p. bla. $40 \mathrm{t} / \mathrm{m} 45$. Zie ook zijn derde stelling:

"De rechtspraak van de Hoge Raad inzake de betekenis van het begrip onderneming in de zin van de Arbeidswet 1919 miskent het wezen van de onderneming in het arbeidsrecht".

13. W.F. de Gaay Fortman, t.a.p., blz. 34 .

14. C.P.M. Romme, De onderneming als gemeenschap in het recht, Amsterdam 1946, blz. 16, daarentegen acht de term "onderneming" geschikter, omdat dit meer "het accent van menselijk doen" heeft. Zie ook T. Koopmans, t.a.p., blz. 306.

15. W.F. de Gaay Fortman, t.a.p., blz. 34.

16. Wet van 7 aprill 1933 , Stb. 160. 
17. M.G. Levenbach, Het afzonderlijk bedrijf in het arbeidsrecht, in R.B.A. XXII blz.34.

18. Zo had De Gaay Fortman kunnen voorkomen een door hem opgemerkte maar niet opgeloste moeilijkheid omtrent de private huishouding, waarvan hij zelf zegt, dat zij onder zijn begrip onderneming valt, maar er natuurlijk geen is; zie W.F. Gaay Fortman, t.a.p., blz. 43 - 44 nt. 2.

19. M.G. Levenbach, in R.B.A. XXII blz. 34 .

20. W.F. de Gaay Fortman, t.a.p., blz. 49.

21. Hij wordt hierin gesteund door T. Koopmans, t.a.p., blz. 306. Deze stelt bovendien, dat voor de vraag of het uitgangspunt in de arbeidsbeschermende wetgeving gewijzigd dient te worden, niet relevant is, dat de geldende regeling op een theoretisch juiste basis steunt, maar of het resultaat al dan niet bevredigend is en dat dit laatste het geval zou zijn, zo vervolgt hij, is door De Gaay Fortman niet beweerd.

22. M.G. Levenbach, in R.B.A. XXII blz. 34.

23. W.F. de Gaay Fortman, t.a.p., blz. 49.

24. Zie M.G. Levenbach, in S.M. 1949 blz. 177. Zie ook bijwoorbeeld W.F. de Gaay Fortman, t.a.p., blz. 95 96; F.J.H.M. van der Ven, De arbeidsverhouding in de onderneming, en Het gemeenschapskarakter der onderneming, in Arbeidsrechtelijke en sociaal-politieke opstellen, Bussum 1945, resp. blz. $127 \mathrm{t} / \mathrm{m} 155 \mathrm{en}$ blz. $156 \mathrm{t} / \mathrm{m}$ 169; C.P.M. Romme, De onderneming als gemeenschap van het recht, Amsterdam 1946; J.Ph.M. van Campen, Onderneming en rechtsvorm, Utrecht 1945.

25. M.G. Levenbach, in S.M. 1949 blz. 177.

26. Tweede Kamer, zitting 1947 - 1948, 884.2.

27. Zie artikel 1, onder a, van het wetsvoorstel.

28. Tweede Kamer, zitting 1947 - 1948, 884.3 (memorie van toelichting) blz. 9.

29. Zie hierover M.G. Levenbach, in S.M. 1949 blz. $178-179$.

30. Tweede Kamer, zitting 1947 - 1948, 884.4 ( voorlopig verslag ) blz. 4.

31. Zie artikel 1, derde lid, van de Wet op de ondernemingsraden.

32. Zie artikel 1, eerste lid, onder c, van de Wet op de ondernemingsraden.

33. Tweede Kamer, zitting 1969 - 1970, 335.3 (memorie van toelichting ).

34. Zie de beschikking van de minister van Sociale Zaken van 5 februari 1973, no. 3678; zie B.Geersing/P.F. van der Heijden, Rechtspraak medezeggenschap 1971 - 1981, Alphen a/d Rijn 1982, blz. 11 t/m 14.

35. Zie de beschikking van de minister van Sociale Zaken van 4 juli 1976, no. 21336; zie B. Geersing/P.F. van de Heijden, t.a.p., blz. $14 \mathrm{t} / \mathrm{m} 18$. 
36. J.J. van Dodeweerd, Strafrechtelijke aansprakelijkheid in het kader van de Veiligheidswet 1934 in scholen en het begrip "onderneming" in het arbeidsrecht, in De Veiligheid 1983 blz. 95 - 96.

37. Hij verwijst in dit verband naar de considerans van de Arbeidswet 1919 in samenhang met artikel 1, eerste lid, aanhef.

38. H.J. van Zwam, Het hoofd of de bestuurder der onderneming, in De Veiligheid 1983, blz. $253 \mathrm{t} / \mathrm{m} 257$ en blz. $313 \mathrm{t} / \mathrm{m} 317$.

39. HR 15 januari 1940 , NJ 1940388.

40. HR 15 juni 1955 , NJ 195614 .

41. P. van Schilfgaarde, Rechtspersonen (algemeen deel ), Deventer 1979, blz. 4.

42. Zie bijvoorbeeld artikelen 1, vijfde lid, en 14, eerste lid, ( oud ) van de Arbeidsomstandighedenwet. Het laatste artikel is bij de Wet van 1 februari 1990, Stb. 91, gewijzigd en vernummerd tot artikel 15. Zie hfdst. 12 par. 3.2.14 (samenloop Wet op de ondernemingsraden en de Arbeidsomstandighedenwet ).

43. Zie bijwoorbeeld resp. de artikelen 14, eerste lid ( oud ), en 4, eerste lid, van de Arbeidsomstandighedenwet. Zie ook H.J. van Zwam, in De Veiligheid 1983 blz.. 255 . Zie nt. 42.

44. Zie resp. de artikelen 83 van de Arbeidswet 1919 en 31 van de Veiligheidswet 1934.

45. Zie artikel 57 van de Arbeidsomstandighedenwet.

46. Wet van 22 juni 1950 , Stb. K. 258.

47. Zie de artikelen 7, onder c ( stillegging van de onderneming), en 8 , onder a (onderbewindstelling van de onderneming ), van de Wet op de economische delicten.

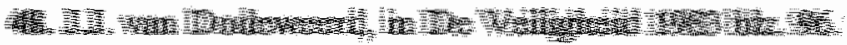

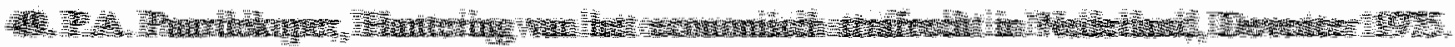

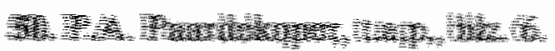

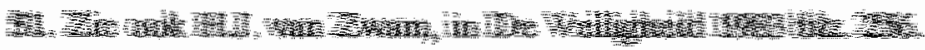

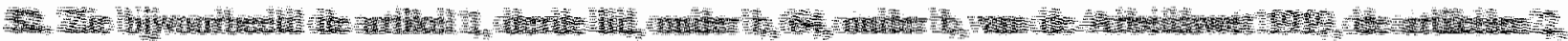

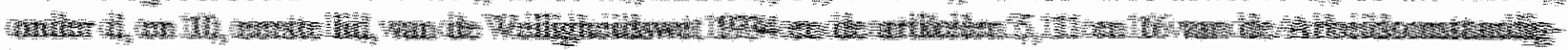

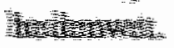

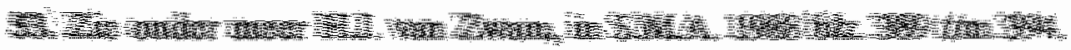

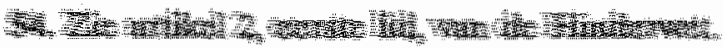




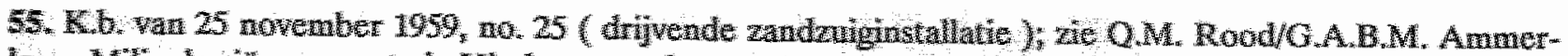

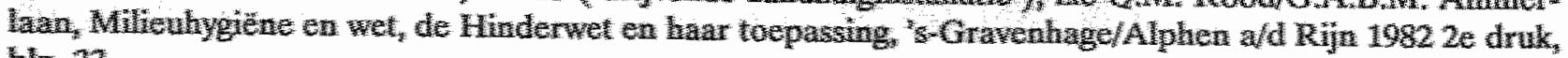

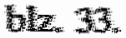

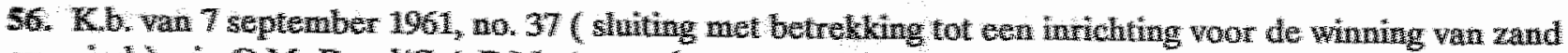

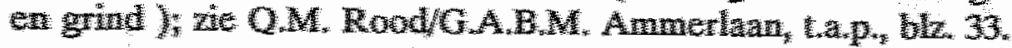

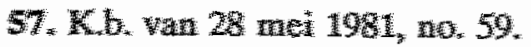

518.

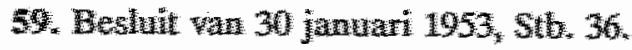

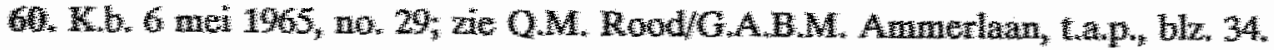

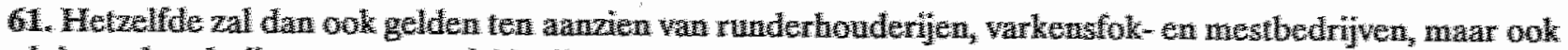

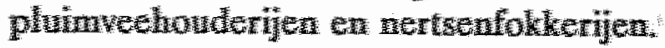

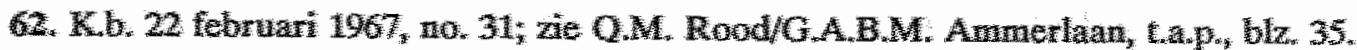

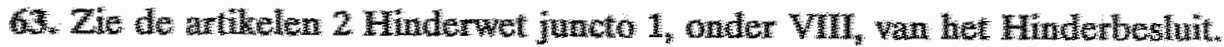

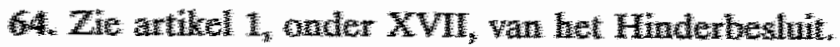

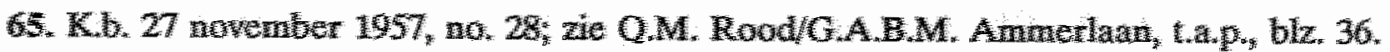

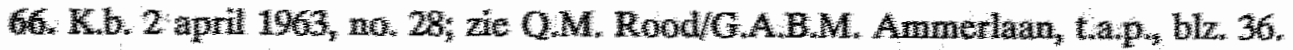

67. K. 9. a

68. Zie Bouwrecht 1976 ble. 748 .

69. K.b. 28 januari 1978, no. 34, ze ook K.b. 7 maart 1979, no.91. Zie Q.M. Rood/G.A.B.M. Ammertan, t.a.p. ble, 38 .

70. Ze O.M. Rood/G.A.B.M. Ammerlaan, ta.p., blz. $37-38$.

71. Kb."s van resp. 17 mei 1978,9 december 1978 en 6 september 1978 , zie H.J. van Zwam, in S.M.A. 1988 bi2. $390-391$.

72. Nota van toelichting by het Beslait van 28 september 1987, Stb. 473 .

73. Zie nota van toelichting bij Beslut van 28 september 1987, Stb. 473 .

74. Zue HR 8 aprin 1975, NJ 1975284.

75. Het begrip "onderneming" moet in dit geval rumer gezien worden, dat "een zaak die men opzet om winst te behalen". 
De beilde wetten kennen namelijk een uitbreiding van de werkingssfeer door middel van de zogenaamde gelijkstellingen met een onderneming. Zie onder meer H. Hoeksema/J. van Drongelen, in S.M.A. 1987 blz. 105 $-106$.

76. Zie artikel 2, eerste lid, van de Arbeidswet 1919 en artikel 3, tweede lid, van de Veiligheidswet 1934.

77. Tweede Kamer, zitting $1927-1928,255.3$ (memorie van toelichting wijzigingswet Stb. 1930261 ).

78. Tweede Kamer, zitting $1968-1969$, 10070.5 (memorie van toelichting ) blz. 13 - 14 .

79. Wet van 25 maart 1971 , Stb. 225.

80. Zie ook "Tweede Kamer, zitting 1968 - 1969, 10070.9 ( voorlopig verslag ) blz. 3.

81. Tweede Kamer, zitting 1969 - 1970, 10070.10 ( memorie van antwoord) blz. 8 .

82. Tweede Kamer, zitting 1976 - 1977, 14497.3 (memorie van toelichting ) blz. 50.

83. Resp. de artikellen 9, tweede en derde lid, 11 en 13 van de van de Arbeidsomstandighedenwet.

84. Tweede Kamer, zitting 1976 - 1977, 14497.3 ( memorie van toelichting ) blz. 50 .

85. Resp. de artikellen 4 en 10 van de Arbeidsomstandighedenwet.

86. Besluit van 13 november 1974, Stb. 740; laatstelijk gewijzigd bij Besluit van 18 mei 1982, Stb. 408.

87. Wet van 23 november 1967, Stb. 687. In het bewuste artikel 10, eerste lid, van deze wet wordt eveneens het begrip "werkverband" gebruikt: het gemeentebestuur dient éen of meer organisatorische eenheden, die in hoofdzaak gericht zijn op het doen verrichten van de aangewezen werkobjecten, als werkverband aan te wijzen. Zie ook artikel 13 van deze wet.

88. Artikel 1 van de Wet van 19 september 1874 , Stb. 130 .

89. Artikel 3, eerste lid, van de Wet van 19 september 1874 , Stb. 130.

90. Artikel 3, tweede lid, van de Wet van 19 september 1874 , Stb. 130.

91. Zie voor een jurisprudentieoverzicht: Verslag van de parlementaire enquête-commissie. Bijlagen Tweede Kamer, zitting $1886-1887,105.5$ blz. 79 t/m 81; J. van Waning, t.a.p., blz. 16 t/m 32; A. Postma, t.a.p., blz. $87 \mathrm{t} / \mathrm{m} 93$ en blz. $131-132$.

92. Verslag van de parlementaire enquête-commissie. Bijlagen Tweede Kamer, zitting 1886 - 1887, $105.5 \mathrm{blz}$. $81 \mathrm{t} / \mathrm{m} 83$

93. Artikelen $3 \mathrm{t} / \mathrm{m} 9$ van de Arbeidswet 1889.

94. Artikel 17 van de Wet van 5 mei 1889 , Stb. 48 . 
95. Zie Bijlagen Tweede Kamer, zitting $1888-1889,53.5$ (memorie van antwoord) blz. 6 en Hand. Tweede Kamer, zitting $1888-1889$, blz, $1100 \mathrm{t} / \mathrm{m}$ 1120. Zie ook H. Goeman Borgesius, t.a.p., blz. $41 \mathrm{t} / \mathrm{m} 43 ; \mathrm{J}$. Oppenheim, t.a.p., blz. $54-55$.

96. Zie bijvoorbeeld HR 20 maart 1899, W.7258 ( een veroordelend vonnis werd gecasseerd, omdat uit het vonnis niet bleek van enige last door of namens de requiranten gegeven, met de strekking om de wettelijke rusttijd te beperken ).

97. Zie HR 17 februari 1902, W.7727; HR 24 mei 1904, W.8070; HR 14 januari 1907, W.8487.

98. Zie bijvoorbeeld de artikelen 4, 6 en 9, van de Arbeidswet 1911.

99. Artikel 14, eerste lid, van de Arbeidswet 1911.

100. Onder de uitdrukking "hoofd of bestuurder van een onderneming" is slechts te verstaan hij, die in de onderneming het hoogste gezag uitoefent en niemand boven zich heeft, hetgeen echter niet uitsluit, dat deze éen of meer personene, bekleed met gelijk gezag, naast zich heeft, aldus de HR in het arrest van 23 december 1912, W.9432.

101. HR 15 december 1913, NJ 1914, blz. 337 - W.9598.

102. Zie HR 11 januari 1915, NJ 1915, blz. 512 - W.9777.

103. Artikel 14, tweede lid, van de Arbeidswet 1911.

104. Artikel 15, eerste lid, van de Arbeidswet 1911. Deze constructie is overgenomen van artikel 3 van het Mujnreglement 1906, Stb. 248 (gebaseerd op artikel 9 van de Wet van 27 april 1904, Stb. 73, houdende nadere bepalingen betreffende de mijnontginning tot wijziging van de Wet van 21 april 1810, Bull. des Lois, no. 285).

105. Tweede Kamer, zitting 1910 - 1911, 39.1 (memorie van antwoord ) blz. 23.

106. Tweede Kamer, zitting 1909 - 1910, 257.3 (memorie van toelichting ) blz. 5. Zie Tweede Kamer, zitting 1909 - 1910, 257.7 ( voorlopig verslag ) blz. 11 en Tweede Kamer, zitting 1910 - 1911, 39.1 ( memorie van antwoord ) blz. 23.

107. Artikel 16 van de Arbeidswet 1911. Ook deze formulering komt overeen met die van artikel 3 van het Mijnreglement 1906.

108. Zie voor de omschrijving van "hoofd of bestuurder" nt. 96. Indien een persoon, in dienst van een publiekrechtelijk lichaam, voor dat lichaam arbeid verricht, wordt ingevolge artikel 95, eerste lid, van de Arbeidswet 1919 als hoofd of bestuurder aangemerkt het hoofd of de bestuurder van de inrichting, waar die werkzaamheden worden verricht, of - indien zij buiten enige inrichting platshebben - het hoofd of de bestuurder van de tak van dienst, waarvoor zij worden verricht.

109. Rb. Rotterdam 20 mei 1926 , NJ 1926 , blz. 1176 .

110. Zie artikel 74, vierde lid, van de Arbeidswet 1919, waarin verwezen wordt naar de artikelen 30 , eerste lid, en 52, negende lid, van de wet. 
111. Rb. Rotterdam 11 oktober 1927 , NJ 1929 blz. 63 ( de onderhavige zaak was toegespitst op het hoofd of de bestuurder van een onderneming, maar geldt naar onze me-ning evengoed voor het opzichthoudend personeel op wie de zorgverplichting is gelegd ).

112. $\mathrm{Bij}$ verwanging wegens ziekte; artikel 91, eerste lid, onder $\mathrm{c}_{\text {, wan }}$ de Arbeidswet 1919.

113. Zie HR 1 juni 1931, NJ 1932 blz. 1155.

114. Zie Rb. Amsterdam 14 mei 1929, W.12008 en HR 20 april 1969, NJ 197046.

115. Zie ook J. van Drongelen, De naleving van de arbeids- en rusttijden van arbeiders van in het buitenland gevestigde ondernemingen, in SR $1986 \mathrm{blz} .129$ - 130.

116. Wet van 14 junil 1930 , Stb. 261 .

117. Tweede Kamer, zitting $1927-1928,255.3$ (memorie van toelichting wijzigingswet 1930, Stb. 261 ) blz. 8.

118. Tweede Kamer, zitting 1927 - 1928, 255.3 ( memorie van toelichting wijzigingswet 1930, Stb. 261 ) blz. 8-9.

119. Wet van 20 mei 1922 , Stb. 364 .

120. Arbeid door het hoofd of bestuurder van een onderneming valt op grond van artikel 1 , eerste lid, onder c, buiten de werkingssfeer van de Arbeidswet 1919.

121. Tweede Kamer, zitting 1921 - 1922, 458.3 ( memorie van toelichting) blz. 3.

122. Artikel 87 van de Arbeidswet 1919. Hierop bestaat slechts eén witzondering. Een ieder die zulks aangaat is verplicht zich te gedragen overeenkomstig een door of namens het districtshoofd van de arbeidsinspectie gegeven bevel tot stillegging van werk en de daarmee samenhangende getroffen maatregelen of gegeven aanwijzingen. Niet-naleving hiervan is een misdrijf ( zie de artikelen $82 \mathrm{bis} t / \mathrm{m}$ 82quinquies en 87 ).

123. Zie bijvoorbeeld de artikelen 6,7 en 8 van de Veilligheidswet. Zie voor de omschrijving van het begrip "hoofd of bestuurder" nt. 96. In artikel 30, eerste lid, van de Veiligheidswet 1934 is bepaald, dat ten aanzien van een onderneming onder beheer van een publiekrechtelijk lichaam als hoofd of bestuurder wordt aangemerkt hij, die door het publiekrechtelijk lichaam aan het hoofd van die onderneming is gesteld.

124. Zie artikel 29 van de Veiligheidswet 1934.

125. Tweede Kamer, zitting 1931 - 1932, 217.3 (memorie van toelichting) blz. $3-4$.

126. Zie Tweede Kamer, zitting 1931 - 1932, 217.3 (memorie van toelichting) blz. 15 .

127. De bedoelde algemene maatregel van bestuur is het Veiligheidsbesluit gevaarlijke werktuigen, Stb. 1940 842.

128. Zie Tweede Kamer, zitting 1933 - 1934, 71.1 ( verslag ) blz. 17. 
129. Zie ook de artikelen 9, zesde lid, 11, vijfde lid, 12, vijfde lid, 16, vijfde lid, en 20s, vijfde lid, van de Veiligheidswet 1934.

130. Zie artikel 217 van het Veiligheidsbesluit voor fabrieken of werkplaatsen 1938 , Stb. 872 .

131. Een dergelijke limitering ontbreekt in artikel 20q, zesde lid, van de Veiligheidswet 1934.

132. Tweede Kamer, zitting 1931 - 1932, 217.3 ( memorie van toelichting ) blz. 6.

133. Tweede Kamer, zitting 1931 - 1932, 217.3 ( memorie van toelichting ) blz. 11.

134. Deze aansprakelijkheidsregeling was echter niet nieuw; zij was reeds ingevoerd in de Stuwadoorswet bij Wet van 27 juli 1931, Stb. 331.

135. Zie artikel 57 van de Arbeidsomstandighedenwet.

136. HR 23 februari 1954, NJ 1954378 ( het zgn IJzerdraad-arrest). Zie over dit arrest onder meer A. Mulder, Schets van het economisch strafrecht, Zwolle $4 \mathrm{e}$ druk 1983, blz. 58 en blz. $66 \mathrm{t} / \mathrm{m} 69$.

137. Zie A. Mulder, Feitelijke leiding geven aan de verboden gedraging, indien het strafbaar feit door een rechtspersoon is begaan, in TVVS $1988 \mathrm{blz} .215$.

138. Zie A.C. 't Hart, nt. HR 7 februari 1984, NJ 1984 527; H. de Doelder/A.C. 't Hart, De strafbaarheidl van natuurlijke personen voor feiten begaan door een rechtspersoon, in DD 1983 blz. 45 - 46.

139. A. Mulder, t.a.p., Zwolle 3e druk 1974, blz. 78 .

140. J. Remmelink, in T.J. Noyon/G.E. Langemeijer, Het Wetboek van Strafrecht, Arnhem 7e druk (losbladig), artikel 51 aant. 6 (blz. 389-390).

141. R.A. Torringa, De rechtspersoon als dader; strafbaar leidinggeven aan rechtspersonen, Arnhem (z.j.), blz. $30-31$.

142. HR 1 juli 1981, NJ 198280.

143. Zie HR 16 juni 1981, NJ 1981 586; HR 2 maart 1982, NJ 1982 446; HR 22 maart 1983, NJ 1983 502; HR 7 februari 1984, NJ 1984527.

144. HR 19 november 1985, NJ 1986125 en 126.

145. HR 16 december 1986, NJ 1987321.

146. Wel moet men zich realiseren, dat het in deze zgn. Slavenburg-beschikkingen ging om de vraag of het Hof te Amsterdam met zijn oordeel was gebleven binnen de grenzen van situaties waarin nog sprake kan zijn van bedoeld feitelijke leidinggeven. Zie A. Mulder, in TVVS 1988 blz. 218.

147. HR 14 september 1987, NJ 198845.

148. Zie artikel 17 , tweede lid, van het Rijtijdenbesluit. 
149. Zie artikel 3, eerste lid, van de Rijtijdenwet 1936, dat luidt als volgt:

"Indien cen persoon, die in een dienstbetrekking als bemaaningslid werkzaam is, in strijd handelt met het bij of krachtens een algemene maatregel van bestuur, als bedoeld in artikel 1 , bepaalde, wordt zijn werkgever geacht het feit te hebben gepleegd".

150. Rb. Haarlem 15 mei 1986.

151. Wel moet echter opgemerkt worden, dat het vonnis van de rechtbank gewezen werd nà de HR-beschikking van 19 november 1985, maar vór de vervolg-beschikkingen van 16 december 1986.

152. Zie A. Mulder, in TVVS blz. $218-219$.

153. Deze zorgverplichtingen zijn dan ook slechts indirect, via de zogenaamde aanwijzing, strafrechtelijk gesanctioneerd (zie de artikelen 35 en 57 van de Arbeidsomstandighedenwet ).

154. Zie onder meer artikel 24 van de Arbeidsomstandighedenwet.

155. Tweede Kamer, zitting $1976-1977,14497.3$ ( memorie van toelichting ) blz. 57 - 58.

156. Zie artikel 1 van de Arbeidsomstandighedenwet.

157. Deze bepaling is wel rechtstreeks strafrechtelijk gesanctioneerd; zie artikel 57 van de Arbeidsomstandighedenwet.

158. Dit in vergelijking tot artikel 19 van de Veiligheidswet 1934. Eén en ander houdt onder meer verband met het feit, dat de Stuwadoorswet voor wat de veiligheids- en gezondheidsaspecten in de Arbeidsomstandighedenwet opgaat ( zie artikel 49 van de Arbeidsomstandighedenwet waarin is bepaald, dat voor de toepassing van deze wet het Veiligheidsbesluit Stuwadoorswet ( Stb. 1950 K. 519 ) geacht wordt te zijn vastgesteld krachtens deze wet ). Zie Tweede Kamer, zitting 1976 - 1977, 14497.3 (memorie van toelichting) blz. 76.

159. In dit artikel worden niet limitatief een groot aantal onderwerpen opgesomd waarover bij algemene maatregel van bestuur nadere regels kunnen worden gesteld ter verzekering van de veiligheid, ter bescherming van de gezondheid en ter bevordering van het welzijn van de werknemers in verband met de arbeid.

160. Tweede Kamer, zitting 1978 - 1979, 14497.5 (memorie van antwoord) blz. 72.

161. Zie A.J.C.M. Geers, Veilig en wel. De Arbeidsomstandighedenwet: een nieuwe taak voor de OR, Alphen a/d Rijn 1981 ( hierna: Veilig en wel ), blz. 110.

162. Overigens wordt in artikel 28 van de Arbeidsomstandighedenwet uitdrukkelijk bepaald, dat de eigen werkgever civielrechtelijk aansprakelijk blijft. Dit wil zeggen, dat als een werknemer op grond van een hem overkomen bedrijfsongeval door een hulpmiddel van een ander schadevergoeding wil hebben, hij zich niet moet wenden tot de wèl strafrechtelijk aansprakelijke derde maar tot zijn eigen werkgever. Zie Tweede Kamer, zitting 1979 - 1980, 14497.11 ( nota naar aanleiding van het eindverslag) blz. 42; A.J.C.M. Geers, Veilig en wel, blz. 110.

163. Tweede Kamer, zitting 1976 - 1977, 14497.3 ( memorie van toelichting ) blz. 78. 
164. Zie over dit artikel van de Arbeidsomstandighedenwet: J.J. van Dodeweerd, De Arboraad in de fout. De problemen rond art. 31 Arbowet, in M.v.A. 1988 blz. $198-199 ;$ H.J. van Zwam, Spreiding van verantwoordelijkheden. De taakopdracht van art. 31 Arbowet, in M.v.A. 1988 blz. $262 \mathrm{t} / \mathrm{m} 265$.

165. Ktg. Middelburg, 4 februari 1953, Beslissing 1953 blz. 400 .

166. Tweede Kamer, zitting 1978 - 1979, 14497.5 ( memorie van antwoord) blz. 74.

167. Arboraad, Advies inzake artikel 31 van de Arbeidsomstandighedenwet (opdragen toezichthoudende taken aan leidinggewenden ), Zoetermeer 3 april 1987, R-1244/vZ/NK ( hierna; Advies artikel 31) Bijlage II, blz. 3 .

168. Arboraad, Advies artikel 31, blz. 2.

169. Arboraad, Advies artikel 31, blz. 3 .

170. Arboraad, Advies artikel 31, Bijlage II blz. 4.

171. HR 9 april 1985, NJ 1985 859. Zie over dit arrest J.J. van Dodeweerd, Mede-aansprakelijkheid en feitelijk leiding geven, in M.v.A. 1987 blz. 238 - 239.

172. Arboraad, Advies artikel 31, Bijlage II blz. 6.

173. Arboraad, Advies artikel 31, blz. 5 .

174. Arboraad, Advies artikel 31, blz. 6 .

175. Arboraad, Advies artikel 31, Bijlage II blz. 10.

176. Tweede Kamer, zitting 1976 - 1977, 14497.3 (memorie van toelichting ) blz. 42 .

177. Tweede Kamer, zitting 1976 - 1977, 14497.3 (memorie van toelichting) blz. 58. Zie ook A.J.C.M. Geers, Veilig en wel, blz, 49.

178. Zie artikel 1 , eerste lid, onder a, van de Arbeidsomstandighedenwet.

179. Zie artikel 1, tweede, onder a, van de Arbeidsomstandighedenwet:

180. Zie artikel 16 van de Arbeidswet 1911.

181. Tweede Kamer, zitting 1921 - 1922, 458.3 (memorie van toelichting) blz. 16. Dit terwijl de minister tijdens de behandeling van de Arbeidswet 1919 nog stelde, dat gelijksoortige bepalingen in de Arbeidswet 1919, de Steenhouwerswet (Wet van 7 oktober 1911, Stb. 315; inmiddels ingetrokken) en de Stuwadoorswet (Wet van 16 oktober 1914, Stb. 486), blijkens de ervaring, niet hebben geleid tot ongewenste gevolgen (Tweede Kamer, zitting 1918 - 1919, 408.5 (memorie van antwoord) blz. 42.

182. Dit is het nieuwe, toegevoegde element. 
183. HR 1 februari 1949, NJ 1949552 . Zie over dit arrest W. Pompe Over de verantwoordelijkheid van werkgever en werknemer iv.m. werkstaking, in N.J.B. 1949 blz. 643 - 644.

184. Rb. Almelo 20 april 1948.

185. Zie Eerste Kamer, zilting 1910 - 1911, 39.3 (memorie van toelichting ) blz. 15.

186. HR 4 november 1929, NJ 1929 blz. 1662 - W.12051. Zie ook HR 12 februari 1934, NJ 1934 blz. 1155 W. 12767 .

187. HR 12 februari 1934 , NJ 1934 blx. 1155 - W.12767.

188. Zie W. Pompe nt. HR 16 mei 1938, NJ 19381019.

189. HR 19 november 1934 , NJ 1935 blz. 349 - W.12855.

190. HR 16 mei 1938, NJ 19381019.

191. Zie bijvoorbeeld HR 24 juni 1921, NJ 1921 blz. 1063 - W.10806 en HR 24 januari 1927, NJ 1927 blz. $247-$ W.11640.

192. Ktg. Middelburg 11 februari 1953, NJ 1953296.

193. Wet van 25 april 1951, Stb. 135.

194. Wet van 11 februari 1988 , Stb. 77 .

195. Wet van 25 maart 1971, Stb. 224 .

196. Tweede Kamer, zitting 1918 - 1919, no. 408.6.

197. Tweede Kamer, zitting 1918 - 1919, no. 408.2.

198. Tweede Kamer, zitting 1918 - 1919, 408.5 ( memorie van antwoord ) blz. 43. Zie ook Hand. Tweede Kamer, zitting $1918-1919$ II, blz. 2829 en 2877.

199. Eerste kamer, zitting 1918 - 1919, 408.5 (eindverslag bevattende de memorie van antwoord ) blz. 18 . Zie ook Eerste Kamer, zitting 1918 - 1919, 408.202 ( voorlopig verslag) blz. 15 en Hand. Eerste kamer, zitting $1918-1919 \mathrm{I}, \mathrm{blz}$. 77, 78, 82, 95 en 113 .

200. HR 9 oktober 1922, NJ 1923 blz. 3 - W.10957.

201. Zie M.P. Vrij, Overmacht bij de naleving van strafrechtsnormen met bestuurselementen in het arbeidsrecht, in Publiekrechtelijke opstellen, Zwolle 1950, blz. 313.

202. HR 17 november 1930 , NJ 1931 blz. 162 - W.12240 (met nt. M.P. Vrij ).

203. HR 2 Januari 1933, NJ 1933 blz. 402 - W.12582. 
204. HR 17 juni 1938, NJ 1938997 (met nt. W. Pompe).

205. Zie W. Pompe, nt. HR 27 juni 1938, NJ 1938997.

206. Zie M.P. Vrij, t.a.p., blz. 315 - 316 en nt. HR 17 november 1930, W.12240; W. Pompe, nt. HR 27 juni 1938, NJ 1938 997, die beide over de gekozen basis van de voorwaarden weinig te spreken zijjn.

207. M.P. Vrij in nt. HR 17 november 1930, W.12240.

208. M.P. Vrij in nt. HR 17 november 1930, W.12240.

209. Tweede Kamer, zitting 1968 - 1969, 10070.3 (memorie van toelichting ) blz. $6-7$.

210. Resp. Night Work ( Women ) en Night Work of Young Persons (Industry), beide uit 1948.

211. Resp. artikel 4, onder a, luidend ( voor zover van belang ):

"in case of force majeure, when in any undertaking there occurs an interruption of work which it was impossible to foresee, and which is not of a recurring character",

en artikel 4, tweede lid, luidend ( voor zover van belang ):

"in case of emergencies which could not have been controlled or foreseen, which are not of a periodicall character, and which interfere with the normal working of the industrial undertaking".

Zie Internationale Labour Conventions and Recommendations 1919 - 1981, Genève, resp. blz. 707 en 753.

212. Wet van 11 februari 1988 , Stb. 77 .

213. HR 15 oktober 1923, NJ 1923 blz. 1239 - W.11113.

214. "Noodtoestand" als rechtvaardigingsgrond kan zich voordoen bij een conflict zowel tussen twee rechtsbelangen als tussen twee rechtsplichten of tussen een rechtsbelang en een rechtsplicht. Het gaat erom, dat het zwaarstwegende belang of de zwaarsttellende plicht is behartigd. Van "overmacht" was daarvoor slechts sprake bij een ogenblikkelijke psychische drang die op de pleger van het strafbare feit een zodanige druk uitoefende, dat hij daaraan geen weerstand kon bieden (zie HR 16 juni 1913, NJ 1913 blz. 1080 ).

215. W. Pompe in nt. HR 27 juni 1938, NJ 1938997.

216. W. Pompe wordt daarin gevolgd door H.J.A. Nolte, Het strafrecht in de afzonderlijke wetten, Utrecht/Nijmegen 1949 , blz. 171.

217. M.P. Vrij, t.a.p., blz. 319.

218. HR 27 februari 1939, NJ 1939864 (De procedure vond zijn oorzaak in het feit, dat een overwerkvergunning op grond van artikel 28 van de Arbeidswet 1919 was geweigerd wegens het niet voldoen aan de aldaar gestelde voorwaarden ).

219. H.J.A. Nolte, t.a.p., blz. 171; zie nt. 25.

220. M.P. Vrij, t.a.p., blz. 318 . 
221. Hij verwijst daarbij onder meer naar Rb. Rotterdam 19 januari 1932, NJ 1932540.

222. Zie M.P. Vrij, t.a.p., blz. 329 - 330.

223. HR 14 februari 1916, NJ 1961 blz. 681.

224. Zie J.M, van Bemmellen, Ons strafrecht 1 algemeen deel - het materiële strafrecht, Groningen Se druk 1975 , blz. 113.

225. Zie HR 25 februari 1929, NJ 1929 blz. 1500.

226. Rb. Maastricht 4 november $1969, \mathrm{NJ} 1971166$.

227. Rb. Assen 8 december 1972, NJ 1973466.

228. Zie artikel 77 van de Arbeidswet 1919, artikel 21, eerste lid, van de Veilligheidswet 1934 en artikel 32 , eerste lid, van de Arbeidsomstandighedenwet.

229. Zie G.P.A. Aler, De politiebevoegdheid bij opsporing en controle, Zwolle 1982, blz. 54.

230. Zie artikel 84, eerste lid, van de Arbeidswet 1919, artikel 32, eerste lid, van de Veiligheidswet 1934 en artikel 17 van de Wet op de economische delicten (zie artikel 57 van de Arbeidsomstandighedenwet ).

231. Zie G.P.A. Aler, t.a.p., blz. 77. Zie ook Tweede Kamer, zitting 1973 - 1974, 12723.5 ( memorie van antwoord Machtigingswet 1974 ) blz. 20.

232. Zie G.P.A. Aler, t.a.p., blz. 101 t/m 103.

233. Voor de Arbeidswet 1919 en de Veiligheidswet 1934 komt de bevoegdheid tot het vorderen van inlichtingen dus eveneens toe aan de algemene opsporingsambtenaren. De bevoegdheid in de Arbeidsomstandighedenwet is beperkt tot de ambtenaren van de arbeidsinspectie of anderen door de minister van Sociale $\mathrm{Za}$ ken en Werkgelegenheid aangewezen personen, die belast zijn met het toezicht.

234. Zie de artikel 67 en 68 van de Arbeidswet 1919.

235. Zie P.W. Bakhoven, Recht om te zwijgen en plicht om te antwoorden, in N.J.B. 1931 blz. 276. Zie ook Th.W, van Veen, Van plicht tot spreken en recht tot zwijgen: Art. 29 Sv. bevat een uitzondering, in DD 1979 blz. $691-692$.

236. Zie artikel 83, eerste, $j^{\circ}$ artikel 87 van de Arbeidswet 1919; artikel 31, eerste lid, jo artikel 35 van de Veiligheidswet 1934; artikel 57 van de Arbeidsomstandighedenwet.

237. Vastgesteld bij Wet van 15 januari 1921, Stb. 14; in werking getreden op 1 januari 1926 (zie Besluit van 4 december 1925 , Stb. 465 ).

238. Ktg. Rotterdam 7 mei 1929, W.12502.

239. Rb. Rotterdam 8 oktober 1929, NJ 1931 blz. 185 W.12080. 
240. Tegen deze uitspraak is geen cassatieberoep ingesteld. Zie hierover L.Ch. Besier, Recht om te zwijgen en plicht om te antwoorden, in N.J.B. 1931 blz. $242 \mathrm{t} / \mathrm{m} 244$.

241. Zie ook A.L. Melai, Wetboek van Strafvordering, Arnhem (losbladig), artikel 29 onder 13.

242. Rb. Haarlem 19 mäart 1931.

243. HR 22 juni 1931, NJ 1931 blz. 1602 nt W. Pompe; W.12547.

244. A.L. Melai, t.a.p., artikel 29 onder 13.

245. W.P. Bakhoven, in N.J.B. 1931 blz. 277; Th.W. van Veen, in DD 1979 blz. 691.

246. Zie Th.W. van Veen, in DD 1979 blz. 688, die overigens daarop volgende strelkt, dat een analyse van het Nederlandse procesrecht niet een beginsel tot niet meewerken met uitzonderingen oplewert, maar een beginsel van wel meewerken, maar met zekere restricties. Zie ook HR 27 juni 1927, NJ 1927 blz. 926 ; Rb. Dordrecht 27 november 1931, NJ 1933 blz. 1080.

247. Zie conclusie A-G Van Lier bij HR 22 juni 1931, NJ 1931 blz. 1603.

248. Zie Th.W. van Veen, in DD 1979 blz. 692; J.W. Fokkens, Onrechtmatig verkregen bewijsmateriaal (2), in Advocatenblad $1981 \mathrm{blz} .4$.

249. Zie Th.W. van Veen, in DD $1979 \mathrm{blz} .692 \mathrm{t} / \mathrm{m} 693$.

250. Zie G.E. Mulder, nt. HR 2 oktober 1979, NJ 1980 243. Zie ook J.W. Fokkens, in Advocatenblad 1981 blz. 4 .

251. W. Pompe, nt. HR 22 juni 1931, NJ 1931 blz. 1607 - 1608.

252. Zie ook A-G Van Lier in zijn conclusie bij HR 22 juni 1931, NJ 1931 blz. 1604.

253. W. Pompe verwijst in dat verband naar de regeling van de plicht om te getuigen tijdens het gerechtelijk voorzonderzoek, zoals deze is neergelegd in de artikelen 217 e.v. van het Wetboek van Strafvordering.

254. Zie W. Pompe, nt. HR 22 juni 1931, NJ 1931 blz. 1607 - 1608, die verwijst naar de Invaliditeitswet.

255. Zie de artikelen 85, eerste lid, aanhef, van de Arbeidswet 1919 en 33, eerste lid, van de Veiligheidswet 1934.

256. Zie voor de definitie artikel 3 van de Veiligheidswet 1934 .

257. Zie artikel 10, eerste lid, van de Veiligheidswet 1934.

258. Verwezen wordt naar artikel 19 van de Veiligheidswet 1934.

259. Tweede Kamer, zitting 1918 - 1919, 408.3 (memorie van toelichting ) blz. 46. 
260. Zie de beschikking van de minister van Arbeid, Handel en Nijverheid van 23 oktober 1928, no. 2597, Afd. Arbeid, Stcrt. 208; laatstelijk gewijzigd bij beschikking van 9 nowember 1951, no. 1687, Afd. Arbeidersbescherming.

261. Zie nt. 6.

262. Eér. en ander behoudens tussentijdse intrekking.

263. Deze algemene last kan te allen tijde worden ingetrokken door degene die hem heeft verstrekt.

264. Zie artikel 19, derde lid, van de Arbeidswet 1889 en artikel 22, derde lid, van de Veiligheidswet.

265. Zie Tweede Kamer, zitting 1931 - 1932, 217.3 ( memorie van toelichting ) blz. 19.

266. Het bewuste artikel luidde:

"Het binnentreden in eene woning tegen den wil van den bewoner is alleen geoorloofd in de gevallen bij de wet bepaald, krachtens eenen bijzonderen of algemeenen last van eene magt door de wet aangewezen.

De wet regelt de vormen, waaraan de uitoefening van deze bevoegdheid gebonden is". Zie A.L. Melai, t.a.p., artt. 120 - 123 onder 3.

267. Zie over de ontwikkeling van deze grondwettelijke regeling H. Verkouteren, Artikel 153 Grondwet, Amsterdam 1880, bzl. $1 \mathrm{t} / \mathrm{m}$ 28; C.L. van Harinxma thoe Slooten, Het binnentreden van woningen, Leiden 1891, blz. 5 t/m 12; J.T. Buys, De Grondwet, toelichting en kritiek deel II, Arnhem 1887, blz. 392 t/m 395. Zie voorts A.Q.C. Tak, Het huisrecht, Hoenderloo 1973, dat van grote invloed is geweest op de totstandkoming van het bedoelde thans geldende artikel 12 van de Grondwet, aldus P.W.C. Akkermans, De Grondwet Een artikelsgewijs commentaar, Zwolle 1987, blz. 257 nt. 3. Zie voor een behandeling van artikel 12 van de Grondwet eveneens P.W.C. Akkermans, t.a.p, blz. $256 \mathrm{t} / \mathrm{m} 272$.

268. Zie ook Tweede Kamer, zitting 1976 - 1977, 14497.3 (memorie van toelichting ) blz. 79 , waar de bewindsman het volgende stelt:

"Ik ben dan ook van mening, dat de bevoegdheid tot het binnentreden van bedrijven en andere ruimten waar arbeid wordt verricht in verband met deze taak moet worden bezien...".

269. Zie Tweede Kamer, zitting 1976 - 1977, 14497.3 (memorie van toelichting) blz. 78.

270. Tweede Kamer, zitting 1973 - 1974, 13100.20 ( Hfdst. VI begroting Justitie ) blz. 4; zie ook G.P.A. Aler, t.a.p., blz. $109-110$.

271. J.J.H. Suyver, Vergelijkend onderzoek naar enige dwangmiddel tijdens de opsporing, Preadvies voor de Vereniging voor de vergelijkende studie van het recht van België en Nederland, 's-Gravenhage 1979, blz. 31. Zie ook G.P.A. Aler, t.a.p., blz. 110 - 111.

272. A.L. Melai, t.a.p., artikel 29 onder 8.

273. Lid van de PrdA-fractie.

274. Hand. Tweede Kamer, zitting 1986 - 1987, blz. 4453. 
275. Zie ook Tweede Kamer, zitting 1986 - 1987, 19824.7 (eindverslag ) blz. 5; Tweede Kamer, zitting 1986 1987, 19824.8 ( nota naar aanleiding van het eindverslag) blz. 6 .

276. Hand. Tweede Kamer, zitting 1986 1987, blz. 4500.

277. Lid van de VVD-fractie.

278. Zie G.P.A. Aler, t.a.p., blz. 109 t/m 117.

279. Zie artikel 123 van het Wetboek van Strafvordering.

280. Zie ook A.L. Melai, t.a.p., artikel 29 onder 4.

281. HR 7 februari 1956, NJ 1956147.

282. A.L. Melai, t.a.p., artikel 29 onder 5.

283. J.T. Buys, t.a.p., blz. 396.

284. H. Verkouteren, t.a.p., blz. 98.

285. W.P. Bakhoven, Bevoegdheden tot in beslagneming en huiszoeking, in TvS 1939 blz. 295.

286. Aldus HR 14 december 1914, Nj 1915 blz. 368. Het betreft de beschermen van de onschendbaarheid van de woning in thet kader van artikel 138 van het Wetboek van Strafrecht.

287. Zie A.L. Melai, t.a.p., artikel 29 onder 5.

288. HR 4 januari 1972, NJ 1972121.

289. Zie HR 16 december 1907, W.8633. Zie P.W.C. Akkermans, t.a.p., blz, 264 nt. 38.

290. Bijlagen Tweede Kamer, zitting 1888 - 1889, no. 53.3 (memorie van toelichting ) blz. 5.

291. P.W.J.H. Cort van der Linden, De rechtskennis van den ingenieur, tiende deel: arbeidswetgeving, Amsterdam ( z.j. ), blz. 88.

292. Zie Bijlagen Tweede Kamer, zitting 1888 - 1889, 53.3 (memorie van toelichting ) blz. 5 .

293. Zie Centraal Verslag der Arbeidsinspectie over 1907 - 1908, blz, 121 - 122.

294. Centraal Jaarverslag der Arbeidsinspectie over 1907 - 1908, blz. 122.

295. Hand. Tweede Kamer, zitting 1909 - 1910, blz. 812.

296. De bedoelde artikelen bevatten een verschoningsrecht ter zake van het geven van een getuigenenis, indien de betrokkenen uit hoofde van beroep of ambt tot geheimhouding verplicht zijn.

297. Zie Bijlagen Tweede Kamer, zitting 1909 - 1910, 257.3 (memorie van toelichting) blz. 23. 
298. Zie Bijlagen Tweede Kamer, zitting $1931-1932,217.3$ ( memorie van toelichting) blz. 19.

299. Wet van 30 juni 1967 , Stb. 377 .

300. Tweede Kamer, zitting 1976 - 1977, 13914.2.

301. Tweede Kamer, zitting 1976 - 1977. 13914.3 ( memorie van toelichting ).

302. Door de PvdA-fractie.

303. Tweede Kamer, zitting 1976 - 1977, 13914.4 ( voorlopig verslag ) blz. 3.

304. Door de C.P.N.-fractie.

305. Tweede Kamer, zitting 1976 - 1977, 13914.4 (voorlopig verslag) blz. 5 .

306. Tweede Kamer, zitting 1976 - 1977, 13914.5 ( memorie van antwoord ) blz. 7.

307. Zie Hand. Tweede Kamer, zitting 1973 - 1974, blz. 702. De vragen werden gesteld door het Tweede Kamerlid Wolff van de C.P.N..

308. SER-Advies 1976/18, Bijlage I blz. 7.

309. Verdrag 81 ; zie hfdst: 15 .

310. Zie SER-Advies 1976/18, blz.. 16.

311. Tweede Kamer, zitting 1976 - 1977, 13914.6.

312. Deze formulering komt overeen met artikel 20 van de Wet op de ondernemingsraden.

313. Wet van 23 november 1977 , Stb. 689; in werking getreden op 1 februari 1982 ( zie K.b. van 30 december 1981, Stb. 826 ).

314. Hand. Tweede Kamer, zitting 1977 - 1978, blz. 397.

315. Namelijk:

- de regionale inspecteur van de volksgezondheid, belast met het toezicht op het milieu, in wiens ambtsgebied het bedrijf, de inrichting of het deel ervan waarop het veiligheidsrapport betrekking heeft, gelegen is; - het hoofd van het district van de dienst van het stoomwezen, in wiens ambtsgebied het bedrijf, de inrichting of het deel daarvan, waarop het rapport betrekking heeft gelegen is;

- de districtsinspecteur voor het brandweerwezen, in wiens ambtsgebied het bedrijf, de inrichting of het deel daarvan waarop het rapport betrekking heeft is gelegen, onderscheidenlijk, indien die inrichting niet in het ambtsgebied van een distrcitsinspectie voor het brandweerwezen is gelegen de hoofdinspecteur voor het brandweerwezen.

316. Zie artikel 6, zesde lid, van het ontwerp-Arbeidsomstandighedenwet; Tweede Kamer, zitting 1976 - 1977, 14497.2. In het betreffende artikellid, werd voorgesteld, dat het districtshoofd hen een afschrift van het veiligheidsrapport of van een wijziging daarvan zou toezenden. 
317. Zie Tweede Kamer, zitting 1976 - 1977, 14497.3 (memorie van toelichting) blz. 79.

318. Door de leden van de PvdA-fractie; zie Tweede Kamer, zitting 1977 - 1978, 14497.4 (voorlopig verslag) blz. 54 .

319. Tweede Kamer, zitting 1978 - 1979, 14497.5 (memoric van antwoord) blz. 75 .

320. Evenals naar voren gebracht door de leden van de PvdA-fractie; zie Tweede Kaner, zitting 1977 - 1978 , 14497.4 (voorlopig verslag) blz. 54.

321. Tweede Kamer, zitting 1978 - 1979, 14497.5 ( memorie van antwoord ) blz. 75.

322. Tweede Kamer, zitting 1979 - 1980, 14497.11 ( nota naar aanleiding van het eindverslag ) blz. 43.

323. Tweede Kamer, zitting 1978 - 1979, 14497.6.

324. A.J.C.M. Geers, t.a.p, blz. 240.

325. De bewindsman stelde in zijn antwoord, dat de strikte geheimhoudingsplicht in het tweede lid van artikel 31 (thans: 34, JvD) ongewijzigd is overgenomen uit artikel 34 van de Veiligheidswet 1934. Hij heeft zich klaarblijkelijk niet gerealiseerd, dat in dat bewuste artikellid alleen wordt gesproken van de namen van personen die aangifte hebben gedaan van een overtreding.

326. In Hfdst. 12 is in dat verband al gewezen op het in artikel 5 van de Grondwet neergelegde petitierecht.

327. A.J.C.M. Geers, t.a.p., blz. 240 , vraagt zich af of het in de praktijk wel altijd mogelijk is om de namen van de klagers geheim te houden, zeker daar waar het kleinere ondernemingen betreft.

328. Dit, omdat hem niet het recht toekomt om een verzoek om wetstoepassing aan de arbeidsinspectie te richten; zie hfdst. 12 par. 3.2.5. (instrumenten ter beschikking van de arbeidsinspectie ).

329. H.Th.J.F. van Maarseveen, Petitierecht, in Grondrechten. commentaar op hoofdlstuk 1. van de herziene Grondwet, Nijmegen 1982, blz. $140-141$.

330. Zie ook M.C.B. Burkens, Beperking van grondrechten, Deventer 1971, blz. 92 nt. 2.

331. A.J.C.M. Geers, t.a.p., blz. 281.

332. Tweede Kamer, zitting $1975-1976,13872.3$ ( memorie van toelichting) blz. 28 .

333. Hand. Tweede Kamer, zitting 1976 - 1977, blz. 456.

334. A.J.C.M. Geers, t.a.p., blz. 282.

335. Zie de artikelen 355, onder 3 en 4, en 356 van het Wetboek van Strafrecht. Zie H.Th.J.F. van Maarseveen, in Grondrechten. commentaar op hoofdstuk 1 van de herziene Grondwet, blz. 144 - 145.

336. Zie A.J.C.M. Geers, t.a.p., blz. 282. 
337. Zie artikel 14, tiende lid, (oud) van de Arbeidsomstandighedenwet. Zie nt 42.

338. Wet van 9 november 1978 , Stb. 581 .

339. Besluit van 12 junil 1931 , Stb. 248.

340. Daarnaast bestaat de zogenaamde "actieve informatie", dat wil zeggen informatie die de overheid uit eigen beweging dient te verstrekken. Zie artikel 2 van de Wet openbaarheid van bestuur.

341. Via voorheen de Stafafdeling Externe Betrekkingen en thans de Centrale directie voorlichting, bibliotheek en documentatie.

342. Zie artikel 1, tweede en derde lid, van de Wet openbaarheid van bestuur $j^{2}$ artikel 1 van het Besluit openbaarheid van bestuur ( Stb. 1979590 ).

343. Zie artikel 4, onder c, van de Wet openbaarheid van bestuur.

344. Zie resp. artikel 4, onder $f$ en onder g, van de Wet openbaarheid van bestuur.

345. Zie Tweede Kamer, zitting $1986-1987,19934.1$ en 2.

346. De bedoelde besluiten heten inmiddels Besluit genetische modificatie Arbeidsomstandighedenwet en Besluit genetische modificatie Veiligheidswet 1934; de ontwerp-besluiten zijn inmiddels voorgepubliceerd in Stcrt. 1989 no. $116 \mathrm{blz} .12 \mathrm{t} / \mathrm{m} 15$.

347. Zie Stert: 1979 no. 120.

348. Zie Tweede Kamer, zitting 1983 - 1984, 18422.1 en 2.

349. Tweede Kamer, zitting 1986 - 1987, 19934.3 (memorie van toelichting ) blz. 1 - 2.

350. A.J.C.M. Geers, t.a.p., biz. $240-241$.

351. Van de zijde van de CDA- en de PvdA-fractie; zie Tweede Kamer, zitting 1986 - 1987, 19934.4 (voorlopig verslag) blz. $1-2$.

352. Tweedle Kamer, zitting 1987 - 1988, 19934.5 (memorie van antwoord) blz. 3 - 4.

353. De Kamerleden zijn resp. lid van de CDA- en van de PvdA-fractie; Tweede Kamer, zitting 1987 - 1988, 19934.9.

354. Hand. Tweede Kamer, zitting $1988-1989$, blz. 12. 


\section{DE ARBEIDSINSPECTIE EN DE REGELINGEN VAN DE INTERNATIONALE AR- BEIDSORGANISATIE}

\section{Inleiding}

In het inlleidende hoofdstuk is reeds gewezen op de voor het rechtsgebied arbeidsomstandighedenrecht steeds meer in belang toenemende rechtsbron, die gevormd wordt door internationale verdragen en diverse andere internationale regelingen en aanbevelingen van onder meer van de Raad van Europa, de Europese Gemeenschappen en de Internationale Arbeidsorganisatie. Een aantal van deze internationale regelingen bevatten bepalingen omtrent een controlerend orgaan. Zo vermeldt artikel 20 van het Europees Sociaal Handvest, dat

"iedere overeenkomst sluitende partij dient te beschikken over een aan haar nationale om-

standigheden aangepast stelsel van arbeidsinspectie".

In het kader van de door de Europese Gemeenschap uitgevaardigde richtlijnen kan gewezen worden op de richtlijn ${ }^{\prime}$ betreffende de standaardprocedures voor de controle op de toepassing van Verordening no $3820 /$ 85 tot harmonisatie van bepaalde voorschriften van sociale aard voor het wegvervoer en Verordening no. $3821 / 85$ betreffende het controleapparaat in het wegvervoer. Overigens heeft deze laatste Verordening betrekking op het geinstalleerd zijn en gebruik maken van de zogenaamde tachograaf. De bedoelde richtlijn heeft betrekking op het controlebeleid, dat door de toezichthoudende instanties dient te worden gevoerd, en niet op de inrichting van de controlerende instanties, waaronder de arbeidsinspectie zelf?

De Internationale Arbeidsorganisatie is echter de enige internationale organisatie, die gedurende haar bestaan expliciete regelingen heeft uitgevaardigd ten aanzien van de inrichting en de bevoegdheden van een dergelijke inspectiedienst. Aanvankelijk was dit de aanbeveling betreffende de algemene beginselen voor de inrichting en de bevoegdheden van de arbeidsinspectie 1923: na de Tweede Wereldoorlog vervangen door een tweetal verdragen, mamelijk het Verdrag betreffende de arbeidsinspectie in industrie en handel en het Verdrag betreffende de arbeidsinspectie in de landbouw en de bij deze verdragen behorende aanbevelingen. In dit hoofdstuk wordt nagegaan in hoeverre ons land voldeed aan de eerstgenoemde aanbeveling en in hoeverre voldaan wordt aan de beide verdragen en de daarbij behorende aanbevelingen.

2. De Aanbeveling betreffende de algemene beginselen voor de inrichting en de bevoegdheden van de arbeidsinspectie $1923^{3}$

\subsection{Hoofddoelstelling}

Ten aanzien van de algemene beginselen voor de inrichting en de bevoegdheden van de arbeidsinspectie is in 1923 een aanbeveling in het kader van de Internationale Arbeidsorganisatie aangenomen.

Als hoofddoelstelling van de inspectie werd aangegeven:

"het verzekeren van de wetten tot bescherming der arbeiders in de uitoefening van hun be-

roep ( arbeidsduur en rusttijden, nachtarbeid, verbod om zekere personen gevaarlijken of ongezonden of te zwaren arbeid te doen verrichten, hygiëne en veiligheid, enz.. )".

Desalniettemin bood de aanbeveling de mogelijkheid tot het verrichten van nevenfuncties voor zover cén en ander de controle vereenvoudigde dan wel voortvloeide uit

"de ondervinding, die hun eigenlijk ambt hun verschaft". 


\subsection{Bevoegdheden}

De aanbeveling bevatte voorschriften met betrekking tot de aard van de functies en bevoegdheden van de inspectie. Zo moesten de inspecteurs het recht hebben om op elk uur van de dag of de nacht die plaatsen te bezoeken en te inspecteren, waarvan zij redelijkerwijs wermoeden, dat aldaar personen werkzaam waren, die onder de wettelijke bescherming vielen en overdag alle plaatsen binnen te gaan waarvan zij redelijkerwijs konden veronderstellen, dat daar inrichtingen aanwezig waren, die aan hun toezicht onderworpen waren, alsmede in de toebehoren daarvan ${ }^{5}$. Ten aanzien van deze voorgeschreven bevoegdheid mag verwezen worden naar het feit, dat zowel de Arbeidswet 1919 als de Veiligheidswet 1934 in respectievelijk de artikelen 85, eerste lid, en 33, eerste lid, bepalingen bevatten, dat de bedoelde ambtenaren

"toegang hebben tot alle plaatsen waar arbeid verricht wordt of pleegt verricht te worden of ten aanzien waarvan redelijkerwijs vermoed kan worden dat aldaar arbeid verricht wordt .....".

Deze aan de bedoelde ambtenaren toekomende bevoegdheid tot het betreden van plaatsen kan te allen tijde, dus zowel overdag als 's nachts plaatsvinden. Daarnaast moesten deze ambtenaren het recht hebben om zonder getuigen het personeel, verbonden aan de inrichting, te ondervragen; inlichtingen te verkrijgen van een ieder, waarvan een getuigenis nodig mocht blijken, en inzage te hebben in alle wettelijke voorgeschreven controlemiddelen. De eerstgenoemde bevoegdheid, het horen van personeel zonder dat daar getuigen bij aanwezig zijn, is noch in de Arbeidswet 1919, noch in de Veiligheidswet 1934 opgenomen, maar werd in de praktijk wel gebezigd, om zo ongewenste druk op de betrokkene te vermijden. Dit hangt ten nauwste samen met de aan de ambtenaren toegekende bevoegdheid om inlichtingen te verkrijgen, hetgeen expliciet in de beide wetten is geregeld. Het hoofd of de bestuurder van de onderneming, alsmede de daarin werkzame personen zijn verplicht hen de verlangde inlichtingen te verschaffen omtrent zaken en feiten, die de naleving van deze wetten betreffen. En daarbij gaat het om het verschaffen van de juiste inlichtingen. Druk van buitenaf op een persoon, dat niet de juiste of zelfs valse informatie wordt verleend moet dan ook vermeden worden? Als tegenhanger moest hen, volgens de aanbeveling, geheimhouding worden opgelegd ter zake van fabrieksgeheimen en exploitatie-methoden, waarvan zij in de uitoefening van hun ambt kennis nemen. In zowel de Arbeidswet 1919, als de Veiligheidswet 1934 was de bedoelde ambtenaren een geheimhoudingsplicht opgelegd, maar deze geheimhoudingsplicht was aanzienlijk ruimer, dan die welke de aanbeveling voorschrijft. Dit kon er toe leiden, dat de arbeiders aan wie een ongeval was overkomen, verstoken bleven van informatie, die uit het onderzoek van de arbeidsinspectie kon blijken, waardoor betrokkenen benadeeld werden. Maar gewezen moet worden op het feit, dat een arbeider voor zijn aanspraak op een uitkering in het kader van de Ongevallenwet 1921 van de Rijksverzekeringsbank in ruil daarvoor zijn aanspraken in het kader van het civiele recht, uitzonderingen daargelaten, diende te laten vervallen. De schadevergoeding die hem uitgekeerd werd, was dan wel verzekerd, maar bij zeer ernstige ongevallen bedroeg deze slechts een deel van de totale schade $^{\mathbb{E}}$. Dat kan echter nooit de bedoeling van de aanbeveling zijn geweest. Bij een beperkte geheimhoudingsverplichting kon de betrokken informatie alsnog worden gebruikt voor civiele procedures. Vervolgens moesten de inspecteurs in gevallen, waarin er aanleiding bestond om onmiddellijk maatregelen te treffen ten einde de installaties en de inrichting van lokaliteiten of toestellen in overeenstemming met de wettelijke voorschriften te brengen, maatregelen kunnen gelasten, dat binnen een bepaalde tijd "een juiste en nauwkeurige uitvoering" van deze voorschriften betreffende de veiligheid en de hygiëne van de arbeiders werd verzekerd. Deze verplichting van de aanbeveling vindt haar vertaling in de mogelijkheid die zowel de Arbeidswet 1919, als de Veiligheidswet 1934 aan ambtenaren van de arbeidsinspectie bieden om eisen te kunnen stellen? De bevoegde autoriteiten zouden op de hoogte moeten gebracht van alle ongevallen en éen van de eerste plichten van de inspecteurs behoorde te zijn, dat zij daarnaar een onderzoek instelden en dan met name naar die ongevallen die "van ernstigen aard" waren en die welke zich dikwijls voordeden, om zodoende maatregelen te bestuderen om herhaling te voorkomen. Voor deze verplichting mag verwezen worden naar artikel 26 van de Veiligheidswet 1934, waarin de bevoegdheid tot het te allen tijde (doen) instellen van een onderzoek naar aanleiding van een ongeval is geregeld. Bovendien moet het hoofd of de bestuurder bij dit bedoel- 
de ongevalsonderzoek de hulp (doen) verlenen, die door de betrokken ambtenaren redelijkerwijs wordt verlangd om de oorzaak en de toedracht van dat ongeval vast te stellen. Overigens diende een ongeval gemeld te worden aan de Rijksverzekeringsbank in het kader van de Ongevallenwet 1921, die vervolgens op haar beurt op grond van artikel 25, eerste lid, van de Veiligheidswet 1934 de uitslag van een door haar ingesteld onderzoek zo snel mogelijk had mede te delen aan het districtshoofd van de arbeidsinspectie, die zonodig zelf nog een onderzoek kon (doen) instellen.

De inspecteurs zouden de hoofden van de ondernemingen moeten inlichten en adviseren met betrekking tot de beste typen van inrichting met het oog op de veiligheid en hygiëne. Voor deze verplichting zij verwezen naar de koppeling die is gelegd tussen de Hinderwet en de Veiligheidswet 1934 door middel van de zogenaamde bis-artikelen.Het preventieve toezicht dat in dit kader ontstond, werd aangevuld met overleg met hoofden van ondernemingen, architecten en anderen, die plannen hadden tot oprichting van een fabriek of werkplaats. Daarbij werd gebruik gemaakt van de goede samenwerking met bouw- en woningtoezicht in verschillende gemeenten, waardoor bouwplannen ter kennis van de arbeidsinspectie werden gebracht en gebouwen, die men als fabriek of werkplaats wilde inrichten tijdig konden worden gekeurd, waardoor op eventuele tekortkomingen kon worden gewezen ${ }^{10}$. Daarnaast zouden zij de samenwerking tussen de hoofden van de ondernemingen en degenen die daarin werkzaam waren, moeten stimuleren,

"om den persoonlijken zin voor voorzichtigheid op te wekken, veiligheidsmaatregelen aan

te bevelen en de beschermingsmiddelen te vervolmaken".

Ongetwijfeld heeft de arbeidsinspectie gepoogd deze samenwerking te stimuleren. Gezien de toch beperkte omvang van de dienst kon echter meer verwacht worden van de inmiddels vrijwillig opgerichte veiligheidscommissies, waarvan de wettelijke regeling in de Veiligheidswet 1934 werd vastgelegd. Dat dergelijke commissies tot stand konden komen was, naar mijn mening, eerder een gevolg van de toenemende betekenis van de arbeidersorganisaties, dan van de activiteiten van de arbeidsinspectie.

Tot slot zouden de inspecteurs betrokken moeten zijn bij de verbetering en vervolmaking van de maatregelen in het belang van de hygiëne en de veiligheid. Dit zou kunnen door,

"hetzij door voortdurende studie van de techniek der inwendige inrichting van werkplaatsen,

hetzij door bijzondere onderzoekingen betreffende de vraagstukken der hygiëne en veilig-

heid, hetzij op eenige andere wijze".

Terzake van deze verplichting kan gewezen worden op de taak van zowel de directeur-generaal van de Arbeid, als het districtshoofd van de arbeidsinspectie om aan de betrokken bewindsman advies uit te brengen en voorstellen te doen, hetzij uit eigen beweging, hetzij op verzoek. Bovendien diende het districtshoofd onderzoeken ( te doen ) verrichten en gegevens ( te doen ) verzamelen die voor de arbeidsinspectie van belang kunnen zijn.

\subsection{De samenstelling van het personeel}

Voor landen, die in inspectie-districten zijn verdeeld, sprak de aanbeveling de wenselijkheid uit om, ten einde in de verschillende districten een uniforme toepassing te verkrijgen van de wetgeving en van de werkzaamheden van de inspectie het meeste resultaat te behalen, de districts-inspecteurs onder het algemene toezicht te plaatsen van een

"inspecteur met buitengewone hoedanigheden en een langdurige ondervinding" ${ }^{11}$.

Deze verplichting vraagt om een centralisatie/concentratie van de arbeidsinspectie, die in ons land met de benoeming van een directeur-generaal van de Arbeid plaatsgevonden heeft.

Van belang was voorts de bepaling, dat de inspectie onder onmiddellijk en uitsluitend gezag moest worden gesteld van de "centrale landsoverheid", met andere woorden: een overheidsdienst, hetgeen in ons land ook het geval is. Hij zou in geen enkel opzicht onder toezicht moeten staan of afhankelijk moeten zijn van de plaatselijke overheden. Met het overhevelen van de vergunningsmogelijkheden op grond van de Arbeidswet van de commissarissen van de Koningin en de burgemeesters naar de arbeidsinspectie werd zijn afhankelijke positie voor wat dit deel betreft, beëindigd ${ }^{12}$. Terzake van ongevalsmeldingen bleef, zoals uit het voren- 
staande reeds blijkt, de afhankelijkheid van anderen onverkort bestaan.

Daarnaast zou de staat

"deskundigen met kennis en ondervinding op medisch, technisch, elektrotechnisch en ander gebied"

in dienst moeten hebben, die zich bezig dienden te houden met de moeilijke wetenschappelijke en technische vraagstukken, die zich voordoen bij de moderne industrie wat betreft het gebruik van gevaarlijke stoffen, het verwijderen van stof en het afvoeren van schadelijke gassen, het gebruik van electrische stroom en dergelijke. Ik meen hier te kunnen volstaan met een verwijzing naar de diverse "specialiteiten" die" in de loop van het bestaan aan de arbeidsinspectie zijn toegevoegd ${ }^{13}$.

De aanbeveling bevatte ook een regeling met betrekking tot de gelijke behandeling van mannen en vrouwen. De inspectiedienst moest namelijk uit zowel mannen, als vrouwen bestaan. Als het duidelijk is, dat voor bepaalde aangelegenheden en voor bepaalde werkzaamheden de inspectie beter aan mannen opgedragen kon worden en voor andere aan vrouwen, dan verzette de aanbeveling zich daar niet tegen. Maar wel moesten de vrouwelijke inspecteurs in het algemeen dezelfde bevoegdheden en functies bezitten en hetzelfde gezag uitoefenen als de inspecteurs ${ }^{14}$ en moesten zij dezelfde rechten hebben om tot hogere posten te worden benoemd.

\subsection{Waarborging onafhankelijkheid}

Voor het personeel van de inspectie bevatte de aanbeveling een aantal voorzieningen, waardoor het onafhankelijk was van "veranderingen in de regering". Om hen bovendien onafhankelijk te maken van beinvloeding van buitenaf, moesten zij een

"goede positie hebben en een behoorlijke bezoldiging genieten".

Ten einde hun onafhankelijkheid eveneens te bevorderen moest niet worden toegestaan, dat zij enig belang hadden bij de ondermemingen, waarover zij toezicht uitoefenden.

De onafhankelijkheid van de betrokken ambtenaren werd gewaarborgd door het hebben van een ambtenarenstatus. Op grond van het Organisatiebesluit konden de betrokken ambtenaren zonder toestemming van de verantwoordelijke bewindsman middellijk, noch onmiddellijk deelnemen aan bedrijven of ondernemingen, onder bepalingen van enige wet vallende, waarvan de handhaving of de medewerking aan de uitvoering ervan aan hen is opgedragen. Zij mochten ook niet zonder toestemming een ander ambt of "bediening" bekleden en werkzaamheden ten behoeve van derden verrichten ${ }^{15}$.

\subsection{Werkwilgze}

De aanbeveling maakte kenbaar, dat, aangezien tussen de bezoeken van de inspecteurs aan een onderneming noodzakelijkerwijze enige tijdruimte zal verlopen, het van groot belang was, dat hoofden van de ondernemingen of hun vertegenwoordigers (strafrechtelijk) aansprakelijk gesteld werden voor de naleving van de wettelijke voorschriften. Dit beginsel was niet van toepassing in de bijzondere gevallen, waarin de wet een voorafgaande waarschuwing voorschrijft, voordat de inspecteurs tot uitvoering van bepaalde maatregelen over konden gaan.

Voorts werd in de aanbeveling de noodzaak uitgesproken, dat de inspecteurs in het algemeen de ondernemingen zouden bezoeken zonder voorafgaande waarschuwing aan de werkgever.

Uitgaande van het gegeven, dat er grote verschillen bestaan tussen de verschillende ondernemingen omtrent de 'omvang, de belangrijkheid en de moeilijkheden die zich kunnen voordoen vanwege het feit, dat zij soms verspreid zijn over het platteland, werd in de aanbeveling de wenselijkheid uitgesproken, dat ten minste éen maal per jaar elke onderneming voor een algemene inspectie werd bezocht. Dit los van de bijzondere bezoeken naar aanleiding van klachten of andere redenen. Belangrijke ondernemingen, ondernemingen waarin de inrichting niet voldoende is met het oog op de veiligheid en de gezondheid van de arbeiders, en ondernemingen waarin voor de gezondheid schadelijke of gevaarlijke arbeid wordt verricht, zouden veel meer bezocht 
moeten worden. Bovendien zou een onderneming waar ernstige onregelmatigheden waren ontdekt, na korte tijd opnieuw bezocht moeten worden, om na te gaan of hierin verbetering was gebracht.

Het is maar goed, dat de aanbeveling geen verplichting kende om een bedrijf eenmaal per jaar te bezoeken, want daar kon in de verste verte niet aan voldaan worden. Zonder twijfel lag de oorzaak in het feit, dat het werkterrein zich alsmaar uitbreidde en de uitbreiding van de dienst daar niet navenant aan was.

\subsection{Klachtrecht en samenwerking tussen werkgevers en arbeiders}

Noodzakelijk was, aldus de aanbeveling, om het aan de arbeiders of hun vertegenwoordigers gemakkelijk te maken om de inspecteurs van iedere inbreuk op een wettelijke voorschrift in de onderneming, waarin zij werkzaam zijn, in kennis te stellen. Een dergelijke klacht diende ertoe te leiden, dat de inspecteur direct een onderzoek instelde. De klacht diende absoluut vertrouwelijk behandeld te worden; de inspecteur mocht de werkgever of diens vertegenwoordiger geen enkele aanwijzing geven, dat zijn bezoek het gevolg was van een klacht.

Een expliciet klachtrecht kenden de Arbeidswet 1919 en de Veiligheidswet 1934 niet en kon hoogstens afgeleid worden van het grondwettelijke petitierecht. Well werd in de praktijk gehandeld overeenkomstig de in de aanbeveling neergelegde regeling ${ }^{16}$.

Omtrent het verzekeren van de samenwerking tussen werkgevers en arbeiders en hun onderscheiden organisaties met het doel om de omstandigheden met betrekking tot de veiligheid en gezondheid van de arbeiders te verbeteren, schreef de aanbeveling voor, dat het wenselijk was, dat de inspectie hen van tijd tot tijd raadpleegde over de beste maatregelen die daartoe genomen zouden kunnen worden. In dit verband mag verwezen worden naar de Hooge Raad van Arbeid, die bestond uit werkgeversleden en een gelijk aantal arbeidersleden, deskundigen op sociaal-economisch gebied en een aantal ambtenaren die ambtshalve lid waren ${ }^{17}$, en die de betrokken bewindsman van advies diende terzake van het in de aanbeveling bedoelde gebied.

\subsection{Verslagen}

Tot slot gaf de aanbeveling een regeling omtrent het vaststellen van verslagen over de resultaten en werkzaamheid van de inspectie en omtrent de inhoud hiervan.

Uit het historische overzicht blijkt herhaaldelijk hoe gedetailleerd en minitieus verslag gedaan werd over de resultaten en werkzaamheden van de arbeidsinspectie ${ }^{18}$.

\subsection{Slotbeschouwing}

Deze uitvoerige aanbeveling bevatte de algemene beginselen voor de inrichting en de bevoegdheden van de arbeidsinspectie. De bijzondere vormen, waarin deze beginselen tot toepassing moesten worden gebracht, werden geheel overgelaten aan het oordeel van het land zelf. Bij de formulering van de beginselen was men te rade gegaan bij ervaringen, die al sinds een geruime tijd in de praktijk waren opgedaan. Ik meen, dat gezien het vorenstaande de woorden van Molenaar ${ }^{10}$, dat de arbeidsinspectie in ons land in alle opzichten aan de desiderata van deze aanbeveling voldeed, toch een te rooskleurig beeld geven.

\section{Het Verdrag betreffende de arbeidsinspectie in industrie en handel ${ }^{20}$}

Op de van 19 juni tot 11 juli 1947 te Genève gehouden Internationale Arbeidsconferentie werd het Verdrag betreffende de arbeidsinspectie in industrie en handel aangenomen. De uit 1923 stammende aanbeveling was in de loop der jaren door de ontwikkelingen achterhaald. Er werd behoefte gevoeld aan een regeling bij verdrag. Op de agenda van de in 1940 te houden Arbeidsconferentie kwam het onderwerp al voor. De bedoeling was om het verdrag in een enkele discussie te aanvaarden, nadat de materie door een in mei - juni 1939 gehouden technische conferentie was voorbereid. Door de oorlog kon hieraan echter geen uitvoering worden 
gegeven. Na de oorlog werd de draad weer opgepakt ${ }^{21}$. Tevens werd tijdens deze arbeidsconferentie een aanbeveling met betrekking tot de arbeidsinspectie aangenomen ${ }^{22}$.

Het verdrag regelt de taak en de bevoegdheden van de arbeidsinspectie, en bestaat uit vier delen: het eerste deel heeft betrekking op de arbeidsinspectie in industriële ondernemingen ${ }^{23}$, het tweede deel op de arbeidsinspectie in de handel $1^{24}$, terwijl de beide laatste delen bepalingen van algemene aard bevatten ${ }^{25}$

\subsection{De verplichting tot het hebben van een arbeidsinspectie}

Op grond van de artikelen 1 en 22 van het verdrag moet elke lid-staat van de Internationale Arbeidsorganisatie, die het verdrag heeft bekrachtigd, een arbeidsinspectie hebben onderscheidenlijk voor industriële inrichtingen en voor handelsinrichtingen. Dit verdrag is door ons land bekrachtigd en in werking getreden op 15 september $1952^{20}$.

\subsection{De taak van de arbeidsinspectie}

De taak van de arbeidsinspectie is geregeld in artikel 3, eerste lid, van het verdrag en is opgebouwd uit drie elementen:

1. het verzekeren van de naleving van de wettelijke bepalingen betreffende de arbeidswoorwaarden en de bescherming van werknemers bij de uitoefening van hun werkzaamheden, zoals bepalingen betreffende de arbeidsduur, de lonen, de veiligheid, de gezondheid en het welzijn, de tewerkstelling van kinderen en jeugdige personen en andere aanverwante aangelegenheden, voorzover de inspecteurs van de arbeid er mee belast zijn de naleving van deze bepalingen te verzekeren;

2. het geven vant technische inlichlingen en adviezen aan de werkgevers en de werknemers over de meest doeltreffende middelen om de wettelijke bepalingen na te leven;

3. het onder de aandacht brengen van de bevoegde autoriteit van de gebruiken en misbruiken die niet met name onder de bestaande wettelijke bepalingen vallen ${ }^{27}$.

Naast deze primaire taak van de arbeidsinspectie, die gerelateerd is aan de naleving van wettelijke bepalingen, kunnen ook andere, op de preventie gerichte taken aan deze dienst opgedragen worden. Daarbij kan gedlacht worden aan het aan de arbeidsinspectie ter toetsing voorleggen van plannen betreffende nieuwe inrichtingen, nieuwe installaties of nieuwe produktieprocessen, zodat nagegaan kan worden of deze plannen de toepassing van de wettelijke bepalingen inzake de veiligheid en de gezondheid van werknemers zouden bemoeilijken dan wel onmogelijk zoudlen maken. Even zeer kan gedacht worden aan (voorlichtings-)activiteiten ter voorkoming van bedrijfsongevallen en beroepsziekten ${ }^{28}$.

Andere functies of taken kunnen aan de arbeidsinspectie worden opgedragen, maar op grond van het tweede lid, van artikel 3 van het verdrag zullen deze de inspecteurs van de arbeid bij de uitoefening van hun voornaamste taak niet mogen hinderen, noch op enigerlei wijze afbreuk mogen doen aan het gezag of de onafhankelijkheid, die voor de inspecteurs bij hun relatie met werkgevers en werknemers noodzakelijk zijn ${ }^{2 \theta}$.

Artikel 3, ecrste lid, onder a en b, en het tweede lid, vormt een combinatie van een aantal aan de lid-staten voorgelegde vragen voor de totstandkoming van het verdrag. Deze luidden als volgt:

"(a). Do you consider that it should be specified that the object of labour inspection, for the purposes of the proposed international regulations, is to secure the enforcement at legally binding provisons relating to the conditions at work and the protection of the workers while engaged in their work, and where necessary, to supply technical information and advice to the employers and workers concerning the most effective means of complying with such provisions?

(b). If you do not consider the above definition of the object of labour inspection satisfacto- 
ry, what other definiton would you propose?

(c). Do you consider it desirable to infest in the text of the international regulations a purely illustrative list of subjects appropriately covered by the term "conditions of work and protection of the workers while engaged in their work"?

(d). If so, do you consider that the following subjects should be included in such an illustrative list:

(I) hours of work and rest?

(II) weekly rest days, public holidays and other holidays?

(III) night work?

(IV) prohibition of the employment of certain persons on dangerous, unhealthy or physically unsuitable work?

(V) protection of women and juvenile workers?

(VI) health and safety?

(VII) protection of wages?

(VIII) regulation of wages?

(IX) workers' rights in case of dismissal?

(e). Do you propose that any other subjects should be included in such an illustrative list? If so, which?".

Het owergrote deel van de antwoorden van de lid-staten stemde in met de taakstelling van de arbeidsinspectie, die zich beperkt tot het verzekeren van de naleving van wettelijke bepalingen met betrekking tot arbeidsvoorwaarden en de bescherming van de werknemers bij de uitoefening van hun werkzaamheden. Anders ligt het met het geven van technische inlichtingen en adviezen door de inspecteurs. Dat dit toch in het verdrag is opgenomen vindt zijn oorzaak in het feit, dat een dergelijke adviserende taak als middel beschouwd dient te worden om de voonaamste taak - het verzekeren van de naleving van de wettelijke voorschriften - te kunmen bewerkstelligen. Een nadere invulling van de termen " arbeidsvoorwaarden en de bescherming van werknemers bij de uitoefening van hun werkzaamheden" door middel van een illustratieve lijst werd slechts door een gering aantal lid-staten afgewezen ${ }^{30}$.

Ons land kon zich vinden in de aanvankelijk voorgestelde taakstelling van de arbeidsinspectie. Wel werd de volgende suggestie gedaan:

"The definition given could be adopted subject to the addition of the following: "in so far as national legislation expressively entrusts supervision of the application of the legal provisions concerned to the labour inspectorate". This would make ratification of the Convention possible by a country like the Netherlands, for example, where supervisions of the payment of fixed wages as well as the enforcement of required notice periods in case of dismissal is not entrusted to the labour inspectorate ${ }^{\mathrm{m3t} \text {, }}$

een suggestie, die in de verdragstekst zijn weerslag heeft gevonden.

\subsubsection{Wettelijke bepalingen betreffende de arbeidswoorwaarden en de bescherming van werknemers}

De in artikel 3, eerste lid, van het verdrag gehanteerde formulering laat de individuele lid-staten vrij een keuze te maken voor wat betreft de wettelijke bepalingen met betrekking tot de arbeidsomstandigheden die onder het bereik van de arbeidsinspectie vallen. Zoals al eerder is geconstateerd, is wetgeving over het algemeen niet de enige mogelijkheid om de arbeidsomstandigheden te regelen; vaak spelen collectieve arbeidsovereenkomsten een aanvullende rol. Om die reden bepaalt artikel 27 van het verdrag dan ook, dat de gebezigde term "wettelijke bepalingen" behalve wetgeving, ook scheidsrechtelijke beslissingen en collectieve arbeidsovereenkomsten, die wetskracht hebben, omvat en ten aanzien waarvan het handhaven van de naleving aan de arbeidsinspectie is opgedragen ${ }^{32}$.

De taak van de arbeidsinspectie zoals die in de Arbeidswet 1919, de Veiligheidswet 1934 en de Arbeidsom- 
standighedenwet is neergelegd, is tweeledig, namelijk het houden van toezicht en het opsporen van overtredingen. De voor het toezicht gekozen terminologie luidt:

"... het handhaven van en de medewerking aan de uitvoering van ..."."

Deze formulering duidt op enerzijds het administratieve toezicht en anderzijds op repressief toezicht. Het administratief toezicht is nauw verweven met de uityoering en is vooral gericht op preventie, dat wil zeggen het bevorderen van gedrag dat in overeenstemming is met de gegeven wettelijke voorschriften en de doeleinden die aan die voorschriften ten grondslag liggen. Preventie gebeurt door middel van voorlichting, advisering en het geven van aanwijzingen ${ }^{33}$. Eerst wanneer uit dit administratieve toezicht duidelijk blijkt, dat aanvaardbare grenzen worden overschreden komt het repressieve toezicht aan de orde. Dit laatste onderscheidt zich van administratief toezicht, doordat het niet gericht is op preventie, maar op het aan het licht brengen van eventuele overtedingen van de gegeven voorschriften. Dit repressief toezicht kan overgaan in de opsporing van strafbare feiten, de strafrechtelijke reactie ${ }^{34}$.

Ter zake van het door de arbeidsinspectie gevoerde beleid in het kader van de Arbeidsomstandighedenwet gelden, in overeenstemming met het vorenstaande, de volgende hoofdlijnen ${ }^{35}$. Er wordt uitgegaan van een tweetal werkwijzen, namelijk de standaardwerkwijze en de werkwijze bij ernstige overtredingen. De wijze van optreden van de zijde van de arbeidsinspectie kan in drie fasen gebeuren. In de eerste fase wordt bij het constateren van discrepantie met de gegeven wettellijke voorschriften ${ }^{36}$ geprobeerd door middel van overleg en" voorlichting, tot verbetering van de situatie te komen. Dit wordt aangeduid als het bevorderen van de zelfwerkzaamheid. Eventueel gemaakte afspraken zijn niet vrijblijvend en worden schriftelijk vastgelegd. Als de eerste fase geen of onvoldoende resultaat heeft gehad, wordt in de tweede fase gebruik gemaakt van de aan de arbeidsinspectie gegeven instrumenten, zoals de eis, de aanwijzing, maar ook kan een waarschuwing gegeven worden. Als ook deze tweede fase geen positieve gevolgen heeft, wordt er overgegaan tot het opmaken van een proces-verbaal. Bij ernstige overtredingen van de wettelijke voorschriften, bij herhaling of bij onwil kunnen deze fasen elkaar versneld opvolgen of kunnen er fasen worden overgeslagen.

\subsubsection{Inlichtingen en adviezen aan werkgevers en werknemers}

De activiteiten, die door de arbeidsinspectie ondernomen worden in het kader van het verzekeren van de naleving van wettelijke bepalingen, zullen weinig effect sorteren zolang werkgevers en werknemers zich niet volledig bewust zijn van hun wederzijdse rechten en plichten; dit geldt zeker, wanneer zij niet overtuigd zijn van het nut van de op hen van toepassing zijnde wettelijke bepalingen. Vandaar dat tot de taak van de arbeidsinspectie gerekend wordt het geven van technische inlichtingen en adviezen aan werkgevers en werknemers over de meest doeltreffende middelen om de wettelijke bepalingen na te leven. Deze taak beoogt een zo effectief mogelijke uityoering van de wetgeving en andere voorschriften te waarborgen. In dit opzicht zullen het verzekeren van de naleving van en het geven van inlichtingen en adviezen over de wettelijke bepalingen elkaar niet alleen aanvullen, maar zijn zij onlosmakelijk met elkaar verbonden ${ }^{37}$.

Over dit onderdeel merkt het comité van deskundigen het volgende $\mathrm{op}^{38}$ :

"It is generally accepted that a succesful advisery function will achieve more than mere reliance upon enforcement and nowadays labour inspectors are no longer looked upon merely as policemen responsible for imposing fines on persons infringing labour laws. This development is welcome, particulary as it emphasis the importance of prevention. But a correct balance must be struck between the two approaches to obtain the greatest degree of success of the inspectorates' work. It is essential that, whilst concentrating on their advisery role, inspectors do not lose sight at the importance of enforcement".

Over (technische) voorlichting en advisering aan werkgevers en werknemers kan het volgende worden opgemerkt. Hierwoor is al gememoreerd, dat in een concrete situatie, wanneer er discrepantie wordt geconstateerd met de gegeven wettelijke voorschriften door middel van overleg, voorlichting en advisering wordt geprobeerd tot verbetering van de situatie te komen. Daarbij kan onder meer gebruik worden gemaakt van de 
zogenaamde publikatiebladen; deze sluiten aan bij de bestaande regelgeving en geven aan op welke wijze, althans naar het oordeel van de arbeidsinspectie aan de wettelijke voorschriften kan worden voldaan ${ }^{39}$. Het betreft hier in feite een vorm van pseudo-wetgeving ${ }^{40}$, een door de arbeidsinspectie gepubliceerde interpretatie van de wetgeving, dat wil zeggen dat een op andere wijze voldoen aan de wettelijke voorschriften dus mogelijk blijft. Daarnaast bestaan er de zogenaamde concept-publikatiebladen ${ }^{41}$; deze lopen vooruit op de publikatiebladen zolang, de wetgeving binnen het kader waarin het blad wordt gehanteerd nog niet is uitgewerkt, dan wel de bewindsman wetgeving ( op korte termijn) heeft toegezegd, maar deze nog niet van kracht is. Daarnaast wordt een concept-publikatieblad ook gebruikt als mogelijkheid om, wanneer regelgeving wel bestaat, commentaar te leveren op de (nadere) invulling hiervan. Dit laatste geldt eveneens voor de concept-voorlichtingsbladen ${ }^{42}$. Verder worden er ook voorlichtingsbladen uitgegeven ${ }^{43}$, waarbij overigens geen directe relatie met de bestaande wetgeving aanwezig behoeft te zijn, maar waardoor geprobeerd wordt bepaalde ontwikkelingen te stimuleren. Naast de folders en brochures die worden uitgegeven, worden tot slot ook films en video's ${ }^{44}$ ter beschikking gesteld ${ }^{45}$.

In het kader van Arbo'91 is gesteld, dat de taak van de arbeidsinspectie is:

"het vanuit de overheid beinvloeden van de kwaliteit van de arbeidsomstandigheden in arbeidsorganisaties".

Daarbij worden twee uitgangspunten gehanteerd, namelijk:

1. de zorg voor de arbeidsomstandigheden is primair de verantwoordelijkheid en taak van werkgevers en werknemers;

2. de overheid schept wettelijke kaders, stimuleert en handhaaft.

In het kader van het tweede uitgangspunt wordt verwezen naar het hiervoor al gememoreerde handhavingsbeleid, dat betrekking heeft op de Arbeidsomstandighedenwet. Voorts wordt gesteld, dat de gecombineerde taak van stimulering en handhaving ook in het bewuste Verdrag no. 81 over de arbeidsinspectie is vastgelegd, namelijk:

:to supply technical information and advice to employers and workers concerning the most effective means of complying the legal provision;

. to enforce the law".

Deze passage zou het uitgangspunt onderstrepen, dat werkgevers en werknemers in eerste instantie zelf verantwoordelijk zijn voor goede arbeidsomstandigheden en de overheid de kaders vaststelt waaraan minimaal voldaan moet worden ${ }^{48}$. De taak van de arbeidsinspectie is volgens het verdrag het verzekeren van de naleving van de wettelijke voorschriften onder meer betreffende de bescherming van werknemers bij de uitoefening van hun werkzaamheden. Daarnaast moet de arbeidsinspectie technische inlichtingen en advieżen aan de betrokkenen verstrekken over de meest doeltreffende middelen om die wettelijke bepalingen na te leven. Deze beide verdragselementen zijn verwerkt in de hiervoor al gegeven taakstelling in onze nationale wetgeving, namelijk: het handhaven van en het meewerken aan de uitvoering van bepaalde wetten, en het opsporen van overtredingen van bij die wetten strafbaar gestelde feiten.

Dat werkgevers en werknemers primair verantwoordelijk zijn voor goede arbeidsomstandigheden valt noch uit het verdrag, noch uit onze eigen wetgeving af te leiden. Overigens valt uit beide gegeven taken ook de voorgestane veel ruimere taak af te leiden. Klaarblijkelijk bestaat er verschil van opvatting over de taak van de arbeidsinspectie, namelijk die welke door de wetgever is gesteld, en die welke in het kader van Arbo'91 wordt gebezigd.

\subsubsection{Het onder de aandacht brengen van tekortkomingen van de wettelijke bepalingen}

Deze aan de arbeidsinspectie opgelegde taak kan worden omschreven als de zogenaamde "oog- en oorfunctie". Deze taak, waarvan het belang wordt benadrukt door het comité van deskundigen ${ }^{47}$, is een belangrijke factor in de ontwikkelingen op sociaal terrein ${ }^{48}$.

"It is properly understood and properly carried out, it should promote the introduction of 
new protective measures. Thanks to their direct knowledge of the working environment, labour inspectors are ideally situated to alert the authorities to the need for new regulations that are better suited to the needs of workers".

De arbeidsinspectie heeft onder meer als taak opgedragen gekregen om de betrokken bewindsman zowel mondeling, als schriftelijk inlichtingen te verschaffen, hetzij op verzoek, hetzij uit eigen beweging en kan de bewindsman voorstellen doen. Verder moet het districtshoofd zich op de hoogte houden van de arbeidstoestanden in zijn district en van de gebeurtenissen die van belang zijn voor de kennis van de arbeidsverhoudingen, stelt hij onderzoeken in en verzamelt hij gegevens die voor de arbeidsinspectie van belang kunnen $z^{i j} n^{49}$. Op deze wijze kunnen tekortkomingen bijvoorbeeld van wettelijke voorschriften onder de aandacht van de verantwoordelijke bewindsman worden gebracht. Dit kan de zogenaamde "oog- en oorfunctie" van de arbeidsinspectie worden genoemd.

In het kader van de heroverwegingsoperatie, het onderdeel dat gericht was op het intern functioneren van de overheild, werd in het betreffende eindrapport gesteld, dat de "oog- en oorfunctie" van een dienst als bijvoorbeeld de arbeidsinspectie kritisch bezien moest worden in relatie tot andere communicatiemiddelen ${ }^{50}$. In een eerdere versie van dit eindrapport ${ }^{51}$ werd de "oog- en oorfunctie" in de huidige tijd nog discutabel genoemd. Het commité van deskundigen hecht in tegenstelling tot de samenstellers van het eindrapport in het kader van de heroverwegingsoperatie grote waarde aan juist deze "oog- en oorfunctie" van de arbeidsinspectie. Dat is op zich niet zo verwonderlijk. Hoe wil men anders kennis opdoen van en over de arbeidsomstandigheden van werknemers dan door de situaties, waarin in de praktijk gewerkt wordt, te aanschouwen en te onderzocken.

\subsubsection{Preventieve taken}

Voorkomen is beter dan genezen, luidt het spreekwoord; daarmee wordt aangegeven van hoe groot belang dit is in verband met de taken van de arbeidsinspectie. Daarbij spelen voornamelijk twee elementen een rol, namelijk het in kennis stellen van bedrijfsongevallen en beroepsziekten en het deelnemen van de arbeidsinspectie aan onderzoeken.

\subsubsection{Bedrijfsongevallen en beroepsziekten}

Op grond van artikel 14 van het verdrag moet de arbeidsinspectie in kennis worden gesteld van de bedrijfsongevallen en de gevallen van beroepsziekten, in de gevallen en op de wijze voorgeschreven bij nationale wetgeving. De doelstelling van deze verdragsbepaling wordt door het comite van deskundigen in eerste instantic als volgt aangegeven ${ }^{52}$ :

"The purpose of this provision is to enable labour inspectors to carry out surveys on industrial accidents and cases of occupational disease and to have the proper steps taken to prevent their occurence".

Later zou deze doelstelling aangevuld worden. Het in kennis stellen van de arbeidsinspectie van bedrijfsongevallen en beroepsziekten wordt niet als doel op zich meer gezien, maar als hulpmiddel om ongevallen te voorkomen ${ }^{\text {t3: }}$ :

"Its purpose is to enable the labour inspectors to conduct investigations in the undertaking to establish the causes of work accidents and occupational diseases and to have steps taken to avoid their reoccurrence. Although accidents in undertakings may not necessarily cause actual injury, they can provide extremely useful information on the state of the buildings, plant and equipment".

Over het in kennis worden gesteld van bedrijfsongevallen en beroepsziekten kan het volgende opgemerkt worden. Aanvankelijk liepen deze meldingen via derden. Ongevallen werden door de Rijkswerzekeringsbank 
gemeld in het kader van de ongevallenwetgeving. Daarna was de arbeidsinspectie ter zake van de melding van ongevallen en beroepsziekten afhankelijk van de bedrijfsverenigingen ${ }^{64}$. Al eerder is geschreven, dat Willems $^{55}$ stelt, dat het in ons land gebezigde systeem slecht functioneerde. Met de komst van de Arbeidsomstandighedenwet is op het terrein van de melding van ongevallen en beroepsziekten een verandering aangebracht. In artikel 9 van deze wet is een regeling opgenomen ten aanzien van de melding en registratie van ongevallen en beroepsziekten. In dit artikel wordt de werkgever de verplichting opgelegd om aan werknemers overkomen ongevallen ${ }^{58}$, die een ernstig lichamelijk letsel ${ }^{57}$ of de dood tot gevolg hebben gehad, dan wel wanneer een gebeurtenis heeft plaatsgevonden in zijn bedrijf of inrichting waarbij grote materiele schade $^{58}$ en tevens gevaar voor de veiligheid en de gezondheid van de werknemers heeft bestaan, aan het districtshoofd van de arbeidsinspectie te melden. Een zelfde verplichting geldt ter zake van het bestaan of redelijkerwijze vermoeden van een beroepsziekte ${ }^{59}$. Het doel van de in artikel 14 gegeven verdragsverplichting is de arbeidsinspectie de gelegenheid te geven een onderzoek in te stellen om zo herhaling te voorkomen. De arbeidsinspectie-ambtenaren hebben op grond van artikel 32, vierde lid, van de Arbeidsomstandighedenwet de bevoegdheid te allen tijde een onderzoek ter zake van een ongeval in te stellen. De beperking die in de meldingsverplichting van artikell 9 van de Arbeidsomstandighedenwet is neergelegd, zou wellicht op zich niet geheel in overstemming kunnen zijn met hetgeen de verdragsverplichting voorschrijft, omdat daar geen beperking aan de zwaarte van het ongeval wordt aangebracht, maar dat wordt anderzijds opgevangen door de meldingsverplichting die aan de bedrijfsverenigingen is opgelegd. Dat systeem moet dan wel sluitend zijn en Willems heeft daar terecht grote twijfels over. Voorts wil ik nog opmerken, dat van de arbeidsinspectie ook niet verlangd worden, dat ter zake van iedere ongevalsmelding ook daadwerkelijk een onderzoek wordt ingesteld: Ik kan me voorstellen, dat; wanneer in een bedrijf in een redlelijk korte periode regelmatig kleine, onbeduidende ongevallen gebeuren, dat reden kan zijn voor de arbeidsinspectie om aan dat bedrijf een bezoek te brengen.

\subsubsection{Nieuwe inrichtingen, nieuwe installaties of nieuwe produktieprocessen}

Voorschriften met betrekking tot voorafgaand toezicht voor nieuwe inrichtingen, nieuwe installaties en nieuwe produktieprocessen zijn neergelegd in de aanbeveling betreffende de arbeidsinspectie. Aldaar wordt enerzijds vereist, dat de arbeidsinspectie vooraf gewaarschuwd wordt over het voornemen een industriële of handelsinrichting te openen, terwijl anderzijds vereist wordt, dat plannen betreffende nieuwe inrichtingen, nieuwe installaties en nieuwe produktieprocessen worden voorgelegd aan de arbeidsinspectie, ten einde haar mening te vernemen omtrent de vraag of die plannen de toepassing van wetgeving inzake de gezondheid en de veiligheid van de werknemers zouden bemoeilijken of onmogelijk zouden maken en, of zij van zodanige aard zijn, dat zij waarschijnlijk een gevaar voor de gezondheid en de veiligheid van de werknemers opleveren en zonodig de door de arbeidsinspectie verlangde veranderingen van die plannen in acht genomen moeten worden.

Over deze taakstelling van de arbeidsinspectie wordt door het comité van deskundigen het volgende gezegd $^{\text {aO }}$ :

"The Committee wishes to draw special attention to the importance of prior knowledge and control. Several factors make this increasingly important. The speed of technical change continues to increase: new chemicals are brought into being and radioactive materialls find wider use. Machinery and chemicals created in one country are used in another country, often with a lack of technical information accompanying their transfer. Workplaces are used for a variety of changing operations and the processes and materials used are rapidly changing. However vigilant the inspectors, they will need assistance from other agencies whose specialised functions (e.g. control of environment planning) or knowledge (e.g. research and development institutes) are essential to supplement the inspectors' knowledge".

De op preventie gerichte taken van de arbeidsinspectie in het kader van de veiligheid en de gezondheid, on- 
der meer met betrekking tot nieuwe inrichtingen, nieuwe installaties of nieuwe produktieprocessen zijn neergelegd in de Hinderwet. Aanvankelijk was er een nawwe relatie tussen de Hinderwet en de veiligheidswetgeving door middel van de zogenaamde "bis"-artikelen. Dat betekende, dat alvorens een Hinderwetvergunning kon worden verstrekt door het districtshoofd van de arbeidsinspectie een zogenaamde negatieve 35bis-verklaring moest zijn afgegeven, hetgeen erop neerkomt, dat er een toetsing plaatsvond aan de op grond van de veiligheidswetgeving gegeven voorschriften. Deze toetsende functie in het kader van de op grond van de Hinderwet af te geven vergunningen is met de wijziging van deze wet in 1979 komen te vervallen $^{84}$. De provinciale, onderscheidenlijk gemeentelijke autoriteiten stellen het districtshoofd in de gelegenheid advies uit te brengen omtrent het verzoek om vergunning en de ontwerp-beschikking voor zover daarbij belangen betrokken kunnen zijn die de veiligheid en gezondheid van de werknemers betreffen. Voorts kan hij uit eigen beweging advies uitbrengen. Dit ter kennis komen van dergelijke informatie, vindt echter alleen plaats wanneer de betreffende inrichting Hinderwetplichtig is. Bovendien is de arbeidsinspectie ter zake afhankelijk van derden. Omtrent nieuwe produktieprocessen kan opgemerkt worden, dat die niet aan de arbeidsinspectie voorgelegd worden, zodoende kunnen van die zijde geen wijzigingen in de betreffende plannen worden aangebracht, waardoor de veiligheid en de gezondheid van de werknemers zo min mogelijk gevaar lopen.

\subsection{Andere taken}

Op grond van artikel 3, tweede lid, van het verdrag kunnen aan de inspecteurs van de arbeid andere dan de in het eerste lid van dat artikel bedoelde taken worden opgedragen, zollang dit maar geen afbreuk doet aan hun voornaamste taak - het verzekeren van de naleving van wettelijke bepalingen -, noch hun gezag en onpartijdigheid geweld aan gedaan wordt.

Als andere taken die aan de arbeidsinspectie opgedragen zouden kunnen worden, kunnen genoemd worden: het beslechten van arbeidsgeschillen, deelname aan collectieve onderhandelingen, activiteiten op het terrein van de economie en ander bijkomende administratieve taken, zoals bijvoorbeeld het verzekeren van de nalleving van de wettelijke bepalingen inzake collectieve arbeidsovereenkomsten.

Ter zake van het aan de arbeidsinspectie opdragen van andere taken, merkt het comite van deskundigen het volgende op ${ }^{62}$ :

"The number of additional tasks entrusted to the inspection service is liable, in many cases, to reduce the effectiveness of its principal duties. There is an risk that, with so many responsibilities, labour inspectors may devote more time to subsidiary economic or other duties at the expense of those that should constitute the essential part of their work, namely the enforcement of laws and regulations relating to occupational safety and health and conditions of work. The situation in some countries has reached a point where governements and workers and employersorganisations may have to consider how to tackle the problem of labour inspectors overburdened with subsidiary duties. There are two main solutions. One would be to increase the staff of the inspection services; this raises the more general problem of the means of action available to the inspection service. The alternative would be to relieve labour inspectors of some of their subsidiary duties.

As far as countries that have ratified Convention No. $81 \ldots .$. are concerned, the Committee has already made comments in many cases where it has felt that various subsidiary duties of the inspection services might distract them from their principal job. In several instances, steps have been taken or envisaged by governements to remedy the situation".

In verband met het opdragen van andere taken aan de arbeidsinspectie mag allereerst gewezen op de subsidieregelingen arbeidsplaatsverbetering, waarvan de behandeling van de betreffende aanvragen nogal wat beslag leggen op de arbeidsinspectie. Vervolgens kan de taak van de arbeidsinspectie in het kader van het Buitengewoon Besluit Arbeidswerhoudingen 1945 geneomd worden. Zowel artikel 6, waar de bemoeienis van de arbeidsinspectie al teruggedrongen is tot het terrein van de arbeidsomstandigheden - en deze bemoeienis 
in de toekomst wellicht zal verdwijnen -, als artikel 8 zijn bepalingen die veel beslag op de dienst legden/ leggen in economisch slechte tijden, waarbij de bescherming van de werknemers tegen het verlies van de arbeidsplaats eigenlijk het kernpunt is waar het om draait.

Ten aanzien van het bemiddelen in arbeidsgeschillen merkt de hiervoor bedoelde aanbeveling op, dat inspecteurs niet als bemiddelaar of scheidsrechter mogen optreden in arbeidsgeschillen. Vanaf het moment van aanvaarding van deze aanbeveling was en blijft dit een controversieel punt, aldus het comite van deskundigen $^{63}$ :

"Some consider that inspection functions as such are incompatible with conciliation and arbitration functions, as there may be confusion between the role of inspectors as conciliators, seeking a solution acceptable to both parties, and their role as quaranters of the due enforcement of the law, a role which is incompatible with any idea of compromise. This view is supported by certain pratical considerations: the extra work generated by the settlement of disputes may be such an to leave the inspectors little or no time for their principal supervisory function. The opposite view is that the labour inspector, by virtue of his first-hand knowledge of the working environment, is ideally suited to the function of conciliation".

Het comité van deskundigen geeft toe, dat het betrekken van de arbeidsinspectie in arbeidsgeschillen zijn nut in een groot aantal gevallen heeft bewezen, maar voegt daar het volgende aan toe ${ }^{64}$ :

"The fact remains, however, that in numerous countries the inspectors are unable to fulfill their fundamental function of enforcing labour laws and regulations because of the lime they devote to their conciliation duties, which is often considerable. This part of the wider problems of the overburdening of labour inspectors with additional tasks ...... As already pointed out it is important that a labour inspectors' role as conciliator when endeavouring to resolve a dispute should not induce him to compromise regarding the enforcement of law".

Op grond van de aanbeveling mogen de ambtenaren van de arbeidsinspectie dus niet als bemiddelaar of scheidsrechter in arbeidsgeschillen optreden. Op grond van artikel 6 van het Organisatiebesluit Arbeidsinspectie onthouden de ambtenaren van de arbeidsinspectie zich van

"alle inmenging in geschillen tussen werkgevers en arbeiders, voor zover zij hiertoe niet

door de Minister van Sociale Zaken en Werkgelegenheid gemachtigd zijn".

In eerste instantie lijkt er dus geen probleem te zijn. Maar toch: wat is een arbeidsgeschil? Dit is in feite niets anders dan een geschil, dat wil zeggen een onenigheid, tussen de werkgever en de werknemers over arbeidswoorwaarden, zoals loon, maar ook over arbeidsomstandigheden, zoals de arbeids- en rusttijden. Het kan dus ook een verschil van mening tussen beiden zijn over de naleving van een of meer in het kader van de arbeidsomstandighedenwetgeving gegeven voorschriften. Deze benadering brengt met zich, dat de arbeidsw inspectie op grond van "haar" wetgeving optreedt als bemiddellaar. Ik doel hiermee op het instrument dat de arbeidsinspectie kan gebruiken, namelijk de aanwijzing, die soms alleen gegeven kan worden na een verzoek om wetstoepassing, en dit verzoek kan alleen gedaan als tussen de betrokkenen een verschill van mening. Met andere woorden: de wetgever maakt derhalve dat de arbeidsinspectie als bemiddelaar of scheidsrechter in een arbeidsgeschil optreedt, en dit is toch niet rijmen met de regeling in de aanbeveling en het organisatiebesluit. Hetzelfde geldt ten aanzien van bijvoorbeeld artikel 10a van de Arbeidswet $1919^{05}$.

\subsection{De organisatie van de arbeidsinspectie}

\subsubsection{Overheidsorgaan}

Op grond van artikel 4 van het verdrag moet de arbeidsinspectie onder toezicht en controle staan van een centrale autoriteit, voor zover dit met de administratieve praktijk van een lid-staat te verenigen is ${ }^{60}$. Het 
comite van deskundigen geeft de bedoeling van het artikel als volgt weer ${ }^{87}$ :

"It is however clear that the Convention, in providing for labour inspection to be placed under the supervision and control of an central authority, held it essential that the inspectorate should be able to act according to uniform principles and procedures applicable to the whole country and all the undertakings and individuals subject to its supervision.

This uniformity implies dependence by the inspectorate on an single central authority, or at least close co-operation between the different supervisory authorities if the inspectorates are attached to different government departments".

Het oorspronkelijke voorstel sprak van

"the direct and exclusive control of a central authority"

De aan de lid-staten voorgelegde vraag luidde:

"(a). Do you consider that the international regulations should lay down that each inspection service should be placed under the direct and exclusive control of a central authority

(it being understood that in a federal country the term "central authority" may be interpreted as meaning either the federal authority or the authority of any of the federal units)? (b). Do you consider that the international regulations should allow for exceptions to this general principle?

(c). If so, what exceptions would you propose?".

Niet alle lid-staten waren echter bereid deze formulering te accepteren ${ }^{69}$,

"unless it permitted the continuation of national or local arrangements, generally for the de-

legation of certain inspection duties, which have been found useful in practice ${ }^{170}$.

Het standpunt, dat door ons land werd ingenomen, laat aan duidelijkheid niets te wensen over ${ }^{71}$. Zonder enig woorbehoud werd werd geaccepteerd, dat in ons land de arbeidsinspectie

"should be placed under the direct and exclusive control of a central authority".

Dat door ons land aan deze verdragsverplichting wordt voldaan leidt geen twijfel; de arbeidsinspectie is in ons land een overheidsorgaan.

\subsubsection{Samenwerking}

Artikel 5 van het verdrag schrijft voor, dat de bevoegde autoriteit passende maatregelen moet treffen ter bevordering van:

a. een daadwerkelijke samenwerking tussen de diensten van de arbeidsinspectie enerzijds en andere veiligheidsdiensten en openbare en particuliere instellingen, die gelijksoortige werkzaamheden verrichten, anderzijjds; en

b. samenwerking tussen de ambtenaren van de arbeidsinspectie en de werkgevers en de werknemers of hun organisaties.

Voor het geval, dat gekozen is voor een (arbeids)inspectie-systeem, dat is samengesteld uit een aantal verschillende organen, is het, volgens het comite van deskundigen ${ }^{72}$, noodzakelijk, dat deze verschillende organen nauw contact met elkaar houden.

"This collaboration is all the more desirable when there is no technical unit in which the missions carried out by the different services can be co-ordinated".

Het comité van deskundigen benadrukt, dat ${ }^{73}$

"as certain recent catastrophes have shown (Bhopal in India ( 1984 ), Three Miles Island in the United States ( 1979 ), Seveso in Italy ( 1976 ), it is important for the inspection services to work in close collaboration with the bodies responsible for the environment".

Voldoet ons land aan de in artikel 4 neergelegde verdragsverplichting, anders is het echter met betrekking 
tot de verplichting die in het daarop volgende artikel op deze centrale autoriteit is gelegd, dat er een daadwerkelijke samenwerking moet bestaan tussen de arbeidsinspectie en andere veiligheidsdiensten en openbare en particuliere instellingen, die gelijksoortige werkzaamheden verrichten. De verdragsverplichting spreekt uitdrukkelijk van daadwerkelijke samenwerking tussen de verschillende betrokken instanties. Dat betekent, dat bepalingen als artikel 8 van het Besluit risico's zware ongevallen ${ }^{74}$, waarin is voorgeschreven, dat ingeval met betrekking tot een zelfde inrichting een rapport inzake de externe veiligheid en een of meer arbeidsveiligheidsrapporten moeten worden ingediend, de onderscheidenen overheidsorganen bij wie de betrokken rapporten moeten worden ingediend, hun activiteiten met betrekking tot het stand komen van die rapporten zoveel mogelijk op elkaar moeten afstemmen, niet voldoende zijn; hetzelfde geldt ten aanzien van de diverse commissies waar verschillende overheidsdiensten zitting hebben. Aan de bedoelde daadwerkelijke samenwerking schort het nogal eens. De Algemene Rekenkamer geeft daarvan in haar rapport over de arbeidsinspectie een aantal voorbeelden. Zo werd geconstateerd, dat samenwerking verbeterd zou kunnen worden tussen de arbeidsinspectie die het lawaai op de arbeidsplaats poogt te bestrijden en de milieudiensten van lagere overheden die zich onder meer bezighouden met de problematiek van het verkeerslawaai ${ }^{75}$. Hetzelfde wordt gesteld ten aanzien van het op de Wet gevaarlijke werktuigen gebaseerde Liftenbesluit I. De afstemming van de activiteiten van de arbeidsinspectie op die van de particuliere organisatie, het Lifteninstituut; dat als enige bevoegd is tot keuring en afgifte van certificaten ${ }^{76}$, zou eveneens kunnen worden verbeterd, vooral op het terrein van administratieve aangelegenheden ${ }^{77}$. Ook blijken er terzake van het door jongeren verrichten van arbeid met betrekking tot de zogenaamde "snuffelstages" en "leerlingplaatsen" en de daarbij gelden arbeids- en rusttijden tussen de arbeidsinspectie en de onderwijsinspectie terzake van de controlegrenzen geen duidelijke afspraken te zijn. Wel wordt bij toevallige constatering van overtreding van de Leerplichtwet 1969 in arbeidssituaties (wederzijds) signalerend naar elkaar opgetreden ${ }^{78}$.

Al met al een niet al te rooskleurig beeld dat door de Algemene Rekenkamer omtrent de daadwerkelijke samenwerking tussen de arbeidsinspectie en de genoemde (overheids)instanties wordt geschetst. Er is echter overigens geen aanleiding om te veronderstellen, dat deze daadwerkelijke samenwerking tussen de arbeidsinspectie en andere (overheids)instanties, zoals bijvoorbeeld de rijksverkeersinspectie en de algemene inspectiedienst, wel bestaat. Ook hier is wel sprake van een institutionalisering van overleg, zoals bijvoorbeeld tussen het directoraat-generaal van de Arbeid en het directoraat-generaal voor Verkeer, maar hiervoor is al geconstateerd, dat dit nog geen daadwerkelijke samenwerking garandeert. Veelal zal daadwerkelijke samenwerking afhangen van persoonlijke contacten tussen de ambtenaren van de verschillende overheidsinstanties onderling.

Wat zeker niet onvermeld mag blijven is de relatie tussen de arbeidsinspectie als opsporingsinstantie en het Openbaar Ministerie, waar de dienst in deze hoedanigheid onder regardeert. Het Openbaar Ministerie is bijvoorbeeld niet verplicht om de arbeidsinspectie te informeren over de afhandeling van de door haar ambtenaren opgemaakte processen-verbaal. Bovendien is het vervolgings- en seponeringsbeleid, dat door het Openbaar Ministerie wordt gevoerd, vaak een bron van onbegrip. In één district geeft het vervolgtraject van de in 1986 opgemaakte processen-verbaal het volgende beeld te zien. Van de 51 opgemaakte processen-verbaal hebben er 13 tot een veroordelend vonnis geleid en 25 tot een schikking. Er waren 7 processen-verbaal geseponeerd en nog eens 6 waren in 1989, dus 3 jaar later nog niet door het Openbaar Ministerie afgehandeld $^{7 \ominus}$. Ook het op de hoogte gesteld worden van rechterlijke uitspraken en het krijgen van afschriften hiervan, verloopt niet vlekkeloos. Ook hier geldt, dat persoonlijke contacten en initiatieven van groot belang zijn.

Voor wat betreft de samenwerking van de ambtenaren van de arbeidsinspectie en de werkgevers en de werknemers of hun organisaties moet allereerst worden gewezen op het geïnstitutionaliseerde kader - SociaalEconomische Raad, Stichting van de Arbeid en Arboraad -, waar de betrokken werkgevers- en werknemersorganisaties, al dan niet met onafhankelijken of vertegenwoordigers van de overheid, participeren in advisering over nieuwe regelgeving en de uitvoering daarvan dan wel waarin overleg plaatsvindt omtrent daarmee verband houdende aangelegenheden.

Maar daarnaast vindt ook anderzins overleg plaats tussen de arbeidsinspectie en werkgevers- en werknemers- 
organisaties. Een voorbeeld is de samenwerking in het kader van het door de arbeidsinspectie verlenen van ontheffingen van het in artikel 8, eerste lid, van het Buitengewoon Besluit Arbeidsverhoudingen 1945 neergelegde verbod van werktijdverkorting, waarbij paritair samengestelde vertrouwensinstanties van werkgeversen werknemerswertegenwoordigers worden ingeschakeld. Voorts kan bijvoorbeeld worden gewezen op de samenwerking tussen de Landelijke Commissie voor het slagersbedriff en het overleg met het Georganiseerde Overleg in het bakkersbedriff op het terrein van de arbeids- en rusttijden. In het kader van Arbo'91 wordt gewerkt via een bedrijfstakgewijze aanpak waarbij diverse betrokken partijen, waaronder werkgevers- en werknemersorganisaties, ingeschakeld ( zullen) worden, hetgeen in het verlengde hiervan ligt. Een andere vorm van samenwerking is neergelegd in de Arbeidsomstandighedenwet. Gewezen kan worden op de informatieplicht van ambtenaren van de arbeidsinspectie ten aanzien van de werknemersvertegenwoordiging, het recht van leden van de werknemersvertegenwoordiging om de bedoelde ambtenaren bij bezoeken aan de onderneming te vergezellen en om vertrouwelijk met hen van gedachten te wissellen, met andere woorden de samenwerking tussen de arbeidsinspectie en de ondernemingsraad. Maar ook dit is in feite niet nieuw; na het totstandkomen van de Wet op de ondernemingsraden werd bij het onderzoek naar aanleiding van de vergunningaanvragen zeer vaak het oordeel van de ondernemingsraden betrokken, in navolging van haar voorgangsters, de fabriekskernen waar regelmatig overleg werd gepleegd ten einde het verrichten van overwerk in goede banen te leiden.

\subsection{Personele aangelegenheden betreffende de arbeidsinspectie}

\subsubsection{Status}

Op grond artikel 6 van het verdrag moet het personeel van de arbeidsinspectie uit ambtenaren bestaan, van wie de rechtspositie en arbeidsvoorwaarden zodanig zijn, dat zij van de bestendigheid van hun betrekking verzekerd zijn en onafhankelijk zijn van elke verandering van regering en elke onbehoorlijke beïnvloeding van buiten.

Dit artikel vond zijn grondslag in een aantal aan de lid-staten voorgelegde vragen, die als volgt luidden:

"1. Do you consider that is should be laid down in the international regulations that the labour inspectors should be given all the requisite quarantees for preserving their independence and impartiality as against any external influences.

2. If so, do you consider that is should be further specified that such quarantees should be provided -

a. preferably, by giving labour inspectors the benefit of civil services regulations; or

b. in countries where labour inspectors do not enjoy the benefit of civil service regulations, by laying down that an inspector, after establisment in the service, may not be dismissed except on one of certain grounds?

3. If your answer to question 2 is in the affirmative, do you consider that the grounds for dismissal might be specified as follows:

a. Age limit?

b. Expiry of contract of engagement?

c. Duly proved incompetence?

d. Grave derelliction of duty?

e. Conduct incompatible with the inspectors' duties?

f. Invalidity?

g. Suppression of post in consequence of reorganisation of the service?

or

h. Reduction in the number of posts?

Please state, in particular, if any, of these grounds you would propose to delete and what 
grounds, if any, you would propose to add ${ }^{20}$.

Voor de uitoefening van de aan de arbeidsinspectie opgedragen taken werd voor het personeel het hebben van de status van ambtenaar het meest geëigende middel geacht ten einde hun onpartijdigheid en onafhankelijkheid te waarborgen ${ }^{81}$. Maar andere mogelijkheden, waarbij de onafhankelijkheid van het personeel van de arbeidsinspectie gewaarborgd is, werden eveneens acceptabel gevonden. Of dit het geval is, is volgens het comité van deskundigen ${ }^{82}$

"to be found in the inspector's unquestioned ability to point out, without fear of open or covert reprisal, that the methods followed in a given undertaking are contrary to the law and must therefore be changed".

Met betrekking tot de onafhankelijkheid van de inspecteurs wordt bovendien nog het volgende opgemerkt ${ }^{\text {ss }}$.

"This is an essential principle on which the efficiency of inspection systems rests. Inspectors cannot act in full independence in their service if their career prospects depends on political considerations".

Het personeel dat werkzaam is bij de arbeidsinspectie bestaat voor het overgrote deel uit ambtenaren. Deze status geldt zeker ten aanzien wan die ambtenaren die door de minister van Sociale Zaken en Werkgelegenheid zijn aangewezen en in die hoedanigheid belast zijn met de handhaving van het bij of krachtens diverse wetten bepaalde en de medewerking aan de uitvoering ervan en die als gevolg daarvan tevens belast zijn met de opsporing van strafbare feiten ${ }^{84}$. De ambtelijke status zou een waarborg moeten zijn om hun onpartijdigheid en onafhankelijkheid te waarborgen ${ }^{85}$.

\subsubsection{Arbeidswoorwaarden}

In het algemeen zijn de arbeidswoorwaarden voor het personeel van de arbeidsinspectie dezelfde als voor andere ambtenaren ${ }^{8 \theta}$. Het comité van deskundigen behandelt een aantal aspecten op het terrein van de arbeidsvoorwaarden die van bijzonder belang geacht worden te zijn, ten einde de onafhankelijkheid van de arbeidsinspectie zoveel mogelijk te waarborgen ${ }^{87}$ :

1. aanstelling(-speriode),

2. beloning en

3. carrière-vooruitzichten.

\subsubsection{Aanstelling(-speriode)}

Over het algemeen heeft het personeel van de arbeidsinspectie, na een proeftijd, een vaste aanstelling. Het comite van deskundigen merkt daarover het volgende op ${ }^{88}$ :

"Accordingly, it should be possible to dismiss them only for a serious professionall misconduct, which should be defined in as precise terms as possible in order to avoid arbitrary interpretations. Moreover, it is important that a decision to dismiss an inspector, like any other decision to apply a sanction with important consequences, should be taken, or at least confirmed, by an organ offering the necessary guarantees of independence or autonomy with respect to the hierarchical authority and in accordance with a procedure guaranteeing the right of defence and appeal".

Bij een eerdere gelegenheid had het comité van deskundigen ${ }^{89}$ al vastgesteld, dat zij niet ontslagen konden worden:

"...unless guilty of serious dereliction of duty defined in the regulations, or in certain circumstances and in accordance with procedures safeguarding the rights of defence".

Terzake van de aanstelling(-speriode) geldt hetgeen woor ambtenaren in het algemeen geldt. De aanstelling 
gebeurt in vaste of tijdelijke dienst, terwijl aan de aanstelling in vaste dienst een aanstelling in tijdelijke dienst yoorafgaat ${ }^{\circ}$.

\subsubsection{Beloning en carriêre-vooruitzichten}

Is de bestendigheid van de aanstelling een eerste vereiste om de onafhankelijkheid van het personeel van de arbeidsinspectie te garanderen, de effectiviteit van de dienst verlangt daarenboven een beloningsniveau en carrière-vooruitzichten, die dusdanig zijn, dat allereerst hoog gekwalificeerd personeel aangetrokken kan worden en vervolgens, hen dient te beschermen tegen elke onbehoorlijke beînvloeing van buiten ${ }^{91}$. Het comite van deskundigen stelt op dit punt het wolgende

"Labour inspectors' promotion and their careers in the inspectorate should be based on objective criteria. Finally in view of the pressures to which they may be exposed, it is particulary important that they should receive a reasonable balance, in order to ensure their independence".

Om die reden is het dan ook wenselijk ${ }^{93}$,

"... that the classification of labour inspectors in the grade structure should correctly reflect the importance of their tasks and their responsabilities ..... Moreover, since the base salary often represents only one element of remuneration, it is important that labour inspectors should also enjoy the bonuses and allowances paid to other officials".

Goede carrière-vooruitzichten vindt het comite van deskundigen een niet te onderschatten factor om tot de stabiliteit en de kwaliteit van het personeel van de arbeidsinspectie bij te dragen ${ }^{94}$.

De arbeidsvoorwaarden wan de ambtenaren bij de arbeidsinspectie verschillen niet van die van andere ambtenaren in rijksdienst.

De personeelsbezetting van het directoraat-generaal van de Arbeid ${ }^{95}$ naar sallarisopbouw per 31 december 1988 was als volgt ${ }^{96}$;

\begin{tabular}{|c|c|c|c|c|}
\hline $\begin{array}{c}\text { salarisschalen } \\
\text { B.B.R.A. }\end{array}$ & mannen & vrouwen & $\begin{array}{c}\text { absoluut } \\
\text { totaal }\end{array}$ & $\begin{array}{c}\text { procentueel } \\
\text { totaal }\end{array}$ \\
\hline $1-5$ & 37 & 100 & 137 & 13,7 \\
$5-11$ & 557 & 100 & 657 & 65,5 \\
11 en hoger & 184 & 25 & 209 & 20,5 \\
\hline totaal & 778 & 225 & 1003 & 100 \\
\hline
\end{tabular}

B.B.R.A. = Bezoldigingsbesluit Burgerlijke Rijksambtenaren ${ }^{97}$ 
De salarisschalen van de districtsambtenaren van de arbeidsinspectie ${ }^{98}$ waren als volgt:

\begin{tabular}{|l|c|}
\hline functie-benaming & $\begin{array}{c}\text { salarisschaal } \\
\text { B.B.R.A. }\end{array}$ \\
\hline controleur van de arbeid & 8 \\
\hline technisch ambtenaar bij de arbeidsinspectie & 10 \\
\hline de inspectrice van de arbeid & 10 \\
\hline de hoofdinspecteur van de arbeid veiligheid & 15 \\
\hline de hoofdinspecteur van de arbeid gezondheid * & 15 \\
\hline de hoofdinspecteur van de arbeid sociaal arbeidsbeleid & 14 \\
\hline het districtshoofd van de arbeidsinspectie & 17 \\
\hline
\end{tabular}

* tevens geneeskundige bij de arbeidsinspectie

$\mathrm{Bij}$ de nieuwe generieke functie-benaming inspecteur van de arbeid ziet de opbouw van de salarisschalen voor deze categorie van ambtenaren er als volgt uit:

\begin{tabular}{|l|c|}
\hline functie-benaming & $\begin{array}{c}\text { salarisgchaal } \\
\text { B.B.R.A. }\end{array}$ \\
\hline inspecteurs van de arbeid (minder complexe arbeidssituaties) & 9 \\
\hline inspecteur van de arbeid (complexe arbeidssituaties) & 10 \\
\hline inspecteur van de arbeid met specialisme & 11 \\
\hline inspecteur van de arbeid met specialisme veiligheidskunde & 13 \\
\hline inspecteur van de arbeid met specialisme arbeidsgezondheidskunde * & 14 \\
\hline inspecteur van de arbeid met specialisme bedrijfskunde & 13 \\
\hline het districtshoofd van de arbeidsinspectie & 16 \\
\hline
\end{tabular}

* tevens geneeskundige bij de arbeidsinspectie

Een vergelijking met enkele functies in buitendiensten van andere overheidsinstanties leert het volgende. In de salarisschaal 8 van het Bezoldigingsbesluit Burgerlijke Rijksambtenaren wallen medewerkers wegvervoer van de rijksverkeersinspectie, de controleur diergeneesmiddelen van de algenene inspectiedienst, de controleur gevaarlijke stoffen en de keuringsambtenaar specialist bijzondere weegwerktuigen. Over de aard van de werkzaamheden van deze ambtenaren in vergelijking met die van de inspecteur van de arbeid kan onder meer het volgende worden opgemerkt. Er bestaat een duidelijke opdracht; er is eén soort van werkzaamheid. Er zijn minder consequenties verbonden naar aangrenzende arbeids-en organisatieterreinen. Er is minder differentiatie in bedrijfstakken. Voorts is er duidelijker regelgeving aanwezig, zodat de interpretatiemogelijk- 
heden geringer zijn.

Vergelijkt men de functie van inspecteur van de arbeid met die van een consulent beleidsoverdracht of beleidsterrein bij de rijksconsulentschappen bij het directoraat-generaal voor Sociale Zekerheid, die is ingedeeld in salarisschaal 10 wan het Burgerlijk Bezoldigingsbesluit Rijksambtenaren, dan heeft eerstgenoemde miet alleen te maken met overheidsinstanties als gemeenten, maar ook met vrije, zelfstandig gevestigde bedrijven. Beide categorieën van ambtenaren hebbem well te maken met een veelheid aan regelgeving, terwijl de inspecteur van de arbeid vaak geconfronteerd wordt met het ontbreken van concrete normen, waardoor meer wordt overgelaten aan eigen interpretatie in een concrete situatie en aan de zogenaamde redelijkerwijs-beoordeling.

Met betrekking tot het personeelsbeleid kan het volgende worden opgemerkt.

In 1986 is een werkgroep gestart met het doel een globaal loopbaanbeleid voor het directoraat-generaal van de Arbeid te ontwikkelen. In het daarop volgende jaar is deze werkgroep met woorstellen gekomen. Parallel aan de discussie hierover zijn er binnen het departement voorstellen ontwikkeld over een systeem voor "management-developement" en mobiliteitsbevordering. Het doel van "management-developement" is het verbeteren van de kwaliteit van het management, waarvan mobiliteitsbevordering ến van de instrumenten is.

De voorstellen die voor het gehele ministerie van Sociale Zaken en Werkgelegenheid in eerste instantie zijn ontwikkeld betroffen de ambtenaren met een functie op het niveau van de salarisschalen 15 tot en met 18 . In 1989 is hetzelfde gebeurd ten aanzien van de salarisschalen 10 tot en met 14 . Bovendien is door de centrale dienstcommissie aandacht gevraagd voor de ontwikkelingsmogelijkheden van het personeel in de lagere salarisschalen ( schaal 1 tot en met 9 ) en is tevens gevraagd om te bezien hoe daar actief vorm aan gegeven kan worden.

Voorstellen voor het directoraat-generaal van de Arbeid zijn neergellegd in een nota ${ }^{9:}$.

Voor de uitwerking van het loopbaanbeleid zijn diverse commissies ingesteld ${ }^{100}$.

In het verlengde van het loopbaanbeleid zijn functionerings- en beoordelingsgesprekken geïntroduceerd.

Vanaf medio 1987 is door het ministerie van Binnenlandse Zaken geld beschikbaar gesteld om bepaalde deskundigen die vrijwel niet op de arbeidsmarkt te vinden zijn "te kopen dan wel te behouden". Deze maatregel betekende voor het directoraat-generaal van de Arbeid, dat er in 1987 voor automatiseringspersoneel en financieel-economische specialisten f1.30.000,-- en voor de technische ambtenaren f1.90.000,-- beschikbaar kwam; in het daarop wolgende jaar was dit in totaal fl.110.000,-- ${ }^{101}$.

Naar mijn mening kan eerst met het nieuwe personeelsbeleid voor de buitendienst-ambtenaren, die werkzaam zijn in de districten wan de arbeidsinspectie, waarvoor in 1986 de eerste aanzet is gegeven en waaraan in het begin van 1990 uitvoering is gegeven, en de daarbij behorende salarisschalen en de carriere-vooruitzichten die daaruit voort kunnen vloeien, gezegd worden, dat voldaan wordt aan hetgeen terzake in artikel 6 van het verdrag is neergelegd.

\subsubsection{Werving}

Artikel 7 van het verdrag bepaalt met betrekking tot de werving, dat, behoudens voorwaarden voor het in dienst nemen van personen in openbare dienst, die door de nationale wetgeving worden gesteld, de inspecteurs uitsluitend op grond wan hun geschiktheid voor de taak, die zij op zich moeten nemen, aangenomen zullen mogen worden. De wijze waarop die geschiktheid wordt vastgesteld, wordt door de bevoegde autoriteit bepaald. Deze bepalingen zijn gebaseerd op het uitgangspunt, dat de effectiviteit van de arbeidsinspectie voor eèn belangrijk deel afhangt van de kwaliteit van het personeel ${ }^{102}$.

De werving van het personeel van de arbeidsinspectie geschiedt op basis van geschiktheid voor de te vervullen taak: De nieuwe opzet voor de buitendienst betekent overigens ook dat aan de hand van de nieuwe func- 
tie personen aangetrokken zullen worden op grond van hun geschiktheid voor de taak die zij moeten vervullen. Overigens moet wel worden opgemerkt, dat het voorgestelde ten aanzien van de functies van inspecteurs van de arbeid bedoeld is als een soort startsituatie en tevens bedoeld is voor de komende vijf jaar als een te bereiken doelstelling van operationalisering. Feitelijk ontstaat namelijk een soort interim-formatie omdat rekening gehouden dient te worden met het "zittende" personeel en dergelijke.

\subsubsection{Opleiding}

Met betrekking tot de opleiding schrijft artikel 7 , derde lid, van het verdrag voor, dat de inspecteurs van de arbeid voor de uitoefening van hun functie een behoorlijke opleiding moeten ontvangen. Het comité van deskundigen benadrukt het belang van "het opleiden"103.

"The growing complexity of the tasks of inspection services due to technical change makes the systematic training of inspectors indispensable, as never before ..... Whatever the value at the training given to inspectors on their entry into service, it is advisable that it should be periodically supplemented, not only in order to refresh their knowledge but also to keep them abreast with new technologies".

Met betrekking tot hetgeen verdragsmatig is gesteld ten aanzien van de opleiding van de inspecteurs van de arbeid kan het volgende opgemerkt worden. In 1988 werd aan opleidingen een bedrag van 1,6 miljoen gulden uitgegeven ${ }^{104}$. Het betrof functiegerichte opleidingen die zijn gericht op het toerusten en toegerust houden van de betrokken ambtenaren voor hun huidige functie dan wel vaststaande toekomstige functie. Als uitgangspunt gold, dat de betrokkenen voor hun functie geschikt waren, dat wil zeggen voldeden aan de aanstellingseis, maar nog moesten worden toegerust voor hun taakvervulling. Binnen de categorie "functiegerichte opleidingen " kan onderscheid worden gemaakt tussen opleidingsactiviteiten als gevolg van nieuwe of veranderde wetgeving en uitvoeringsbeleid, dan wel opleidingen in het kader van de organisatieveranderingen ${ }^{105}$. Opleidingen, bij- en omscholing in het kader van de organisatieveranderingen vormden in 1988 de meerderheid van de opleidingsinspanning. Daarnaast waren er automatiseringsopleidingen en financieel-economische opleidingen ${ }^{106}$.

\subsection{Middelen ter beschikking van de arbeidsinspectie}

De voornaamste middelen waarmee de activiteiten van de arbeidsinspectie uitgevoerd worden, zijn in de eerste plaats de toezichthoudende ambtenaren en in de tweede plaats het materieel, dat hen ter beschikking wordt gesteld. Dit zijn volgens het comite van deskundigen ${ }^{107}$ de factoren die niet alleen regelmatige inspecties mogelijk maken, maar ook bewerkstelligen, dat de bescherming van de werknemers verwezenlijkt kan worden.

\subsubsection{Omvang van de arbeidsinspectie}

Op grond van artikel 10 van verdrag moet het aantal inspecteurs van de arbeid voldoende zijn om een doeltreffende uitoefening van de taken van de dienst van de arbeidsinspectie te verzekeren; bij de vaststelling van dat aantal moet behoorlijk rekening gehouden worden met:

a. de belangrijkheid van de taken, die de inspecteurs te vervullen hebben, in het bijzonder met:

$1^{\circ}$ het aantal, de aard, de omvang en de ligging van de werkplaatsen, die aan het toezicht van de inspectie onderworpen zijn;

$2^{\circ}$ het aantal en de verscheidenheïd van de groepen werknemers, die in de werkplaatsen werkzaam zijn; $3^{\circ}$ het aantal en de ingewikkeldheid van de wettelijke maatregelen, waarvan de naleving verzekerd moet worden;

b. de materiële uitvoeringsmiddelen, die ter beschikking van de inspecteurs worden gesteld; 
c. de praktische voorwaarden, waaronder de inspectiebezoeken gebracht zullen moeten worden, ten einde doeltreffend te zijn.

Aan de basis van dit artikel ligt een aan de lid-staten voor de totstandkoming van het verdrag voorgelegde vraag, die luidde als volgt:

"Do you consider that, with a view to permitting the inspection services to perform their work efficiently, the international regulations should lay down that the number of inspectors shall be determined with due regard for -

(a) the importance of the duties to be performed, and in particular -

(i) the number, nature, size and situation of the establishments and workplaces liable to inspection?

(ii) the number and variety of the workers employed in such establishments and workpla ces? and

(iii) the extent of the tasks entrusted to the inspection service, from the point of view of the number and the complexity of the legal provisions which it has to enforce?

(b) the extent of the material means placed at the disposal of the inspectors (telephone, means of transport, clerical assistance, office accommodations, etc. )?

(c) the pratical conditions under which visits of inspection must be carried out in order to be effective ( visits to be of reasonable duration - choice of the most appropriate mo ments for visits - necessity of carrying out visits unexpectedly, etc. )?"

Uit de binnengekomen antwoorden kan worden afgeleid, dat de grote meerderheid van de lid-staten de voorgestelde criteria onderschreef ${ }^{\text {tos }}$.

De verdragsverplichting, dat het aantal inspecteurs voldoende moet zijn om een doeltreffende uitoefening van de taken van de dienst van de arbeidsinspectie te verzekeren geeft aanleiding tot het maken van de volgende opmerkingen.

De omvang van de arbeidsinspectie is tijdens de parlementaire behandeling van de Arbeidsomstandighedenwet onderwerp van discussie geweest. De toenmalige regering heeft bij die gelegenheid de indruk gewekt, dat de in werking treding van die wet gepaard diende te gaan met een niet onbelangrijke uitbreiding van het uitvoerende apparaat van de arbeidsinspectie ${ }^{109}$. Deze uitbreiding met ongeveer 200 ambtenaren werd door de toenmalige bewindsman van Sociale Zaken Albeda om een aantal redenen noodzakelijk geacht ${ }^{110}$.

"Ten eerste zal de intensivering van de contacten tussen de werknemers in de arbeidsorganisatie en de Arbeidsinspectie de nodige mankracht vragen. Ten tweede zullen er als gevolg van de Arbeidsomstandighedenwet nieuwe terreinen worden betreden welke kwalitatieve en kwantitatieve personeelsuitbreiding moodzakelijk zullen maken. Ten derde zal het landelijk te voeren overleg in de Arbeidsraad (thans Arboraad, JvD ) de nodige mankracht vergen".

De noodzaak tot uitbreiding van de arbeidsinspectie werd door het parlement onderschreven ${ }^{114}$. De vraag werd zelfs gesteld of deze uitbreiding wel voldoende was voor een adequate uitvoering van bestaande taken van de arbeidsinspeetie ${ }^{112}$. Trouwens ook het Christelijk Nationaal Vakverbond had gepleit voor een drastische uitbreiding van de arbeidsinspectie ${ }^{113}$. De bewindsman ${ }^{114}$ achtte een drastische verhoging van de uitbreiding alleen al in verband met de opname-capaciteit van de organisatie, althans op korte termijn, niet realiseerbaar.

In 1985 werden ten behoeve van de invoering van de eerste fase van de Arbeidsomstandighedenwet bij de overheid 30 formatieplaatsen beschikbaar gesteld ${ }^{115}$. Ook bij andere gelegenheden, zoals bij de behandeling van de voorstellen op het terrein van lawaai en van toxische stoffen werden toezeggingen gedaan. Vanaf 1977 zijn er bij het directoraat-generaal van de Arbeid 126 formatieplaatsen bijgekomen, terwijl er 205 plaatsen extra waren gevraagd. Over de jaren 1983 - 1989 heeft het directoraat-generaal van de Arbeid in totaal 193 formatieplaatsen in kader van de inleveroperaties moeten inleveren, waarvan 87,5 door de ar- 
beidsinspectie; daarentegen leverde de toewijzing ingevolge de doorgevoerde arbeidsduurverkorting ongeveer 7,5 formatieplaats $\mathrm{p}^{116}$. Deze tegen elkaar inwerkende ontwikkelingen leidde tot ingewikkelde berekeningen en een niet gering aantal (interne) nota's. De uitkomst van dit alles was, dat de personeelsbezetting van het directoraat-generaal van de Arbeid van eind 1982 tot eind 1986 nagenoeg gelijk bleef; eerst daarna valt enige groei te constateren. Het aandeel van het aantal personeelsleden in de districten van de arbeidsinspectie op het totale personeelsbestand van het directoraat-generaal van de Arbeid zou echter, zij het licht, dalen. De omvang van het personeelsbestand in de districten, opgesplitst in staf en administratie en de zogenaamde buitendienst, bedroeg in 1983 respectievelijk 200 en 275 personen (respectievelijk $26 \%$ en $36 \%$ van het totale personeelsbestand van het directoraat-generaal van de Arbeid ) en in 1988 respectievelijk 202 en 278 personen (respectievelijk $25 \%$ en $34 \%$ van het totale personeelsbestand van het directoraat-generaal van de Arbeid). Wordt de verdeling van het personeel bezien, dan kunnen in de omvang van het aantal buitendienst-ambtenaren per district verschillen waargenomen worden. In één district verminderde de omvang van $64 \%$ naar $50 \%$, terwijl in een ander district het aantal buitendienst-ambtenaren onverminderd op $56 \%$ bleef ${ }^{17}$.

Hieronder worden de ontwikkelingen in de omvang van het personeelsbestand voor de jaren 1983 tot en met 1988 weergegeven ${ }^{118}$.

\begin{tabular}{|l|r|r|r|r|r|r|}
\hline \multicolumn{7}{|c|}{ Onvang personeelsbestand arbeidsinspectie } \\
\hline & 1983 & 1984 & 1985 & 1986 & 1987 & 1988 \\
\hline Centraal & 292 & 284 & 291 & 323 & 315 & 339 \\
& 388 & 388 & 398 & 428 & 408 & 418 \\
\hline Districten & 475 & 468 & 448 & 450 & 477 & 480 \\
& 628 & 628 & 618 & 588 & 608 & 598 \\
\hline totaal & 767 & 725 & 739 & 773 & 792 & 819 \\
totaal 100\% & & & & & & \\
\hline
\end{tabular}

\begin{tabular}{|l|c|r|r|r|r|c|}
\hline \multicolumn{7}{|c|}{ Omvang persaneelsbestand birmen de districten } \\
\hline & 1983 & 1984 & 1985 & 1986 & 1987 & 1988 \\
\hline $\begin{array}{l}\text { staf en } \\
\text { administratie }\end{array}$ & 200 & 198 & 191 & 192 & 200 & 202 \\
\hline buitendienst & 275 & 270 & 257 & 258 & 277 & 278 \\
\hline
\end{tabular}

De Algemene Rekenkamer ${ }^{19}$ trok hieruit de wel haast onvermijdelijke conclusie, dat op deze wijze niet tegemoet gekomen werd aan het regeringsvoornemen tot versterking van het uitvoerende apparaat van de arbeidsinspectie. De daarbij bedoelde verhoogde aandacht voor kleinere ondernemingen heeft moeten wijken voor ( voorlichtende ) activiteiten in het kader van de Arbeidsomstandighedenwet, die in de eerste fase was gericht op groteŗe ondernemingen. Men moet zich hierbij echter wel realiseren, dat het hier nog alleen maar een verwijzing betreft naar de Arbeidsomstandighedenwet en dus niet naar al die andere wetten, zoals bijvoorbeeld de Arbeidswet 1919, de Veiligheidswet 1934 en hun talloze uitvoeringsbesluiten, de Rijtijdenwet 1936, de Wet arbeid gehandicapte werknemers, de Hinderwet, de Wet inzake de luchtverontreiniging, de Wet chemische afvalstoffen, de Binnenschepenwet, het Buitengewoon Besluit Arbeidsverhoudingen 1945 en andere taken. Uit het voorafgaande hoofdstuk waarin een aantal juridische problemen, en dan nog beperkt 
tot de drie basiswetten, afzonderlijk beschouwd zijn, blijkt al dat het gaat om ingewikkelde en complexe wetgeving. De Industriebond van toen nog het Nederlands Verbond van Vakverenigingen en het Christelijk Nationaal Vakverbond drongen aan op versterking van de personeelsbezetting van de arbeidsinspectie. Het vorenstaande moet naar mijn mening leiden tot de conclusie, dat de omvang van de arbeidsinspectie niet voldoende geacht kan worden om een doeltreffende uitoefening van de taken die aan deze dienst zujn opgedragen, te waarborgen.

Het comite van deskundigen ${ }^{120}$ uitte zijn grote bezorgdheid over de imkrimpingen van het personeelsbestand van de arbeidsinspectie(s) en zelf's over de vermindering van het aantal arbeidsinspecties. Bezuinigingen op het terrein van de overheidsuitgaven in de ontwikkelde ("rijke(re)") landen hadden geleid tot overeenkomstige bezuinigingen voor wat betreft de arbeidsinspectie(s). Het comite van deskundigen vroeg zich $\mathrm{af}^{121}$, of, waar algemene bezuinigingen op het terrein van de overheidsuitgaven werden toegepast, dit onvermijdelijk moest leiden tot bezuinigingen bij de arbeidsinspectie(s). Het sprak de hoop uit, dat alle betrokken partijen diepgaand en blijvend alle belangen tegen elkaar bleven afwegen, gezien zowel de economische en sociale waarde van een dergelijk instituut als de maatschappelijke kosten die het gevolg zijn van het verminderen van de effectiviteit ervan.

Door het comite van deskundigen werd daarop het volgende opgemerkt ${ }^{122}$ :

"However, the Committee is also aware that a situation may occur where although a labour inspection establishment may have reached a reasonably adequate size in the general opinion, it may not continue to keep pace with the growth of economic activity or employment and their technological complexity. Therefore, problems of resource management for inspection also arise ..... In this connection instances have been noted with interest where management and labour have taken the initiative - in close co-operation with, and under the supervision and guidance of, labour inspection services - to train and organise personnel at the level of the undertaking to perform tasks which foreshadow, extend or enhance the work of official inspectors".

Daar wordt dan wel de volgende kanttekening bij geplaatst ${ }^{123}$ "

"The influence of those directly concerned upon increasing safety performance in the plant and upon achieving the actual betterment of the workplace is undeniable. It can produce very valuable results in a very large number of workplace, and we would not want to diminish its importance in any way. However, we have to point out that it is also an aspect of human nature that those that live every day with a certain physical danger facing them may, with time, become less aware of its existence or of its seriousness, or "home blind" .... This is one reason why, in some cases, a labour inspection coming from the outside is necessary to recognise the occupational hazard and point it out".

De houding van het comite van deskundigen terzake van de inkrimping van het personeelsbestand van de arbeidsinspectie en zelfs over de vermindering van het aantal arbeidsinspecties bestond wit het slechts de hoop uitspreken, dat alle betrokken partijen zich bewust zullen zijn van zowel de economische en sociale waarde van een dergelijk instituut als de maatschappelijke kosten die het gevolg zijn van het verminderen van de effectiviteit ervan. Het lijkt meer een standpuntbepaling op grond van politieke keuzes; landen, waaronder ons land, die bezuinigingen doorvoeren waardoor de effectiviteit van de uitoefening van de taken van de arbeidsinspectie vermindert, handelen in strijd met de in artikel 10 neergelegde verdragsverplichting.

\subsubsection{Personeels-samenstelling}

Met betrekking tot de personeels-samenstelling wordt in artikel 8 van het verdrag bepaald, dat zowel mannen als vrouwen benoemd kumnen worden tot het personeel van de arbeidsinspectie; indien nodig, zullen aan de inspecteurs, onderscheidenlijk inspectrices, bijzondere taken opgedragen kunnen worden. 
Omtrent deze verdragsverplichting kan het volgende opgemerkt worden.

Zowel mannen als vrouwen kunnen tot het personeel van de arbeidsinspectie benoemd worden. Zo heeft de arbeidsinspectie zajn eerste vrouwelijke districtshoofd mevrouw Maat-Koolen ${ }^{\text {tin }}$ gehad, kende de arbeidsinspectie ook mannelijke inspectrices van de arbeid, en waren drie van de acht functies van hoofdinspecteur in de districten vervuld door vrouwen ${ }^{125}$.

De personeels-samenstelling is als volgt ${ }^{126}$ :

\begin{tabular}{|l|c|c|c|c|}
\hline \multicolumn{2}{|l|}{ Verhouding mamen en vrouman } \\
\hline & jaar & marmen & vrowmen & totaal \\
\hline Centralle Dienst & 1986 & 243 & 76 & 319 \\
& 1987 & 239 & 76 & 315 \\
& 1988 & 247 & 92 & 339 \\
\hline Arteidsinspectie/Inspec- & 1986 & 391 & 92 & 483 \\
tie van de Havenarbeid & 1987 & 384 & 93 & 477 \\
& 1988 & 383 & 97 & 480 \\
\hline
\end{tabular}

Een ander aspect van de samenstelling van het personeel van de arbeidsinspectie heeft zijn weerslag gevonden in het daarop volgende verdragsartikel. In artikel 9 wordt namelijk elke lid-staat de verplichting opgelegd om te verzekeren, dat behoorlijk bevoegde deskundigen en technici waaronder begrepen specialisten op het gebied van de geneeskunde, werktuig- en bouwkunde, elektrotechniek en scheikunde, worden opgenomen in de arbeidsinspectie. Dit ter verzekering van de toepassing van de wettelijke bepalingen betreffende de gezondheid en de veiligheid van de werknemers bij de uitoefening van hun werkzaamheden en ter onderzoek van de uitwerking van toegepaste procédees, gebruikte materialen en arbeidsmethoden op de gezondheid en de veiligheid van de werknemers.

Aan de basis van dit artikel ligt de volgende aan de lid-staten bij de totstandkoming van het verdrag voorgelegde vraag:

"Do you consider that the international regulations should require the association in the work of inspection, for the purposes of enforcing the provisions concerning health and safety, and according to the methods deemed most desirable or appropriate by the national authorities, of duly qualified technical experts and specialists in -
(a) medicine?
(b) engineering?
(c) electricty? and
(d) chemistry?"

Een grote meerderheid van de lid-staten beantwoordde deze vraag bevestigend. Nieuw Zeeland, Zwitserland en Uruguay stelden respectievelijk voor aan de bedoelde opsomming toe te voegen: mijnbouw, fysica, arbeidsrecht en politieke economie en weg en waterbouwkunde ${ }^{127}$ "

Het comité van deskundigen benadrukt ${ }^{128}$

"the importance of the optimal management of technical specialisations required for, and available to, labour inspection services as a key factor in determining their effectiveness. It is not only a question of numbers and professional specifications: it is also a question of being able to cope with the realities of industry at an given place and time and even more of whether staff are utilised in the manner which in given circumstances is most likely to 
result in effective protection and advice".

Daaraan wordt het volgende toegevoegd ${ }^{129_{*}}$ :

To the extent that certain highly expertise is scarce, decisions may have to be made regarding the level of expertise at which routine inspections are to be made, while the more skilled professionals may have to be pooled centrally or regionally, at least in inspectorates having competence for a large spectrum of industrial activities. Where certain industrial sectors are entrusted to special inspectorates, the case is different: e.g., mine and transport technical inspectors can obviously only be recruited from among expert technicians qualified in their respective fields. Even in their general inspectorates, certain countries with a complex industrial structure tend to organise and train individual inspectors so as to enrich specialised knowledge of the problems of particular industries of processes".

Ten aanzien van deze verdragsverplichting meen ik te kunnen volstaan met te stellen, dat hieraan voldaan.

\subsubsection{Stoffelijke middelen}

Op grond van artikel 11, eerste lid, van het verdrag moet de bevoegde autoriteit de nodige maatregellen nemen om aan de "nspecteurs van de arbeid ter beschikking te stellen:

a. plaatselijke kantoren, doelmatig ingericht overeenkomstig de eisen van de dienst en toegankelijkheid woor alle belanghebbenden;

b. vervoersfaciliteiten, nodig voor de uitoefening van hun functie waar zich geen behoorlijke openbare vervoermiddelen bevinden.

Het daarop volgende artikellid verplicht de bevoegde autoriteit de nodige maatregelen te nemen om aan de inspecteurs van de arbeid alle reiskosten en bijkomende uitgaven die nodig zijn voor de uitoefening van hun taak te vergoeden.

\subsubsection{Kantoren, uitrusting en documentatie}

Met betrekking tot deze aangelegenheden maakt het comité van deskundigen de volgende opmerkingen ${ }^{130}$. Aangezien de arbeidsinspectie voortdurend contact onderhoudt met het "publiek" is het

"important for their local offices to be introduced in such a way as to facilitate public access and also to create a pleasant atmosphere, which can contribute to the establishment of good relations between the public and the inspection staff".

Een volgende stap om het vertrouwen van werkgevers en werknemers, die een bezoek aan de arbeidsinspectie brengen,

"is for each inspector to have a private office; furthermore, communication facilities ( telephone, secretariat ) are needed for messages to be left for the inspector when he is out of his office on inspection visits".

Daarnaast moeten de gebouwen van de arbeidsinspectie ruimten bevattem woor bibliotheken, laboratoria, faciliteiten voor tentoonstellingen en lezingen, waarbij het comite van deskundigen benadrukt, dat "the provision of these facilities is more than a matter of routine importance. Indeed, inspection services need more than the usual office facilities equipment and secretariat support. In order to plan, carry out and follow up their work, these services need an effective systeem of registration and records of undertakings as an information tool; .... In addition, the inspectorate needs adequate equipment (which has to be stored and maintained, and requires personel trained for its use ) for the necessary sample-taking, measurements and so on in undertakings. More sophisticated analytical work requires regional or central labo- 
ratories, either attached to the inspectorate or available to it at universities, public hygiene institutes and the like ........

Een andersoortig probleem betreft het voor de arbeidsinspectie beschikbaar zijn van gebouwen en voorzieningen

"to prepare, stock and dispense, in clear, comprehensible form, information to employers and workers, not only on how to comply with the law, but also on how to prevent occupational accidents and diseases, on recommended codes and practice, and the like".

Het comité van deskundigen

"believes, however that great attention should be paid, or continue to be paid, to every opportunity available to boost the effectiveness of labour inspectorates through appropriate information to employers and workers on appropriate technical practices, as well as on their duties and responsibilities".

In het gebouw van het directoraat-generaal van de Arbeid zijn een (volwaardige ) bïbliotheek en een laboratorium gehuisvest. Het bedoelde gebouw voldoet echter niet meer; het is te klein om het te huisvesten personeel onder te brengen en dit ondanks het feit, dat een deel van het personeel al is ondergebracht in een ander overheidsgebouw. Wel zal tegen het einde van 1990 een nieuw departementsgebouw in gebruik worden genomen, waar de diverse departementsonderdelen, waaronder het directoraat-generaal van de Arbeid met uitzondering van het laboratorium, waarvoor een andere locatie wordt gezocht, in ondergebracht zullen worden. Het is echter de vraag of het ruimtegebrek, dat min of meer kenmerkend is voor de huidige situatie in het nieuwe gebouw tot het verleden zal behoren. Overigens is dit niet alleen een probleem, dat zich bij het directoraat-generaal van de Arbeid voordoet; in een aantal districten is de situatie niet veel beter.

In de districtskantoren van de arbeidsinspectie zijn geen laboratoria aanwezig. Wel beschikt men over bijvoorbeeld meetapparatuur en dergelijke; zonodig worden de ambtenaren van de betreffende afdelingen van het directoraat-generaal van de Arbeid ingeschakeld.

Afhankelijk van de beschikbare ruimte is er de mogelijkheid aanwezig om tentoonstellingen te houden of lezingen te geven.

Omtrent de administratie in twee onderzochte districten merkt de Algemene Rekenkamer ${ }^{131}$ op, dat er in totaal ongeveer 15 bestanden werden aangetroffen. Soms bleken ambtenaren te beschikken over eigen bedrijfsbestanden. Enkele ambtenaren hadden thuis op door hen persoonlijk aangeschafte personal computers gegevens over bezochte bedrijven vastgelegd. Voor het archiveren van gegevens over de bedrijven maakte men in het ene district gebruik van stamkaarten, in het andere van bedrijvendossiers. In tén van de andere districten van de arbeidsinspectie werd geëxperimenteerd met een aansluiting op het landelijk register van bedrijfsvestigingen. In eén van de districten werd vastgesteld, dat een gescheiden bestaan van gegevensbestanden voor inspectie conform de Arbeidsomstandighedenwet en voor de Arbeidswet 1919 kan leiden tot onvoldoende coördinatie in het externe optreden van de buitendienstambtenaren. Het bleek voorgekomen te zijn, dat verschillende ambtenaren gelijktijdig maar onalhankelijk van elkaar eenzelfde bedrijf inspecteerden. De meeste van de aangetroffen gegevensbestanden gingen terug op wettelijke bepalingen. Voor een doelmatige en doelgerichte organisatie van de arbeidsinspectie zijn echter, aldus de Algemene Rekenkamer, echter ook gegevens nodig over ( potentiële ) risico's in de bedrijven. Dergelijke gegevens waren incidenteel in de administraties aanwezig. Zij maakten doorgaans deel uit van de ervaringskennis van de ambtenaren $^{132}$.

Geconstateerd, kan worden, dat de situatie ten aanzien van de kantoren, de uitrusting ervan en de documentatie van de arbeidsinspectie op gespannen voet staat met de verdragsverplichting terzake.

\subsubsection{Vervoersfaciliteiten}

Met betrekking tot de vervoersfaciliteiten merkt het comité van deskundigen het volgende op ${ }^{133}$ : 
"Readily available means of transport, allowing inspection visits to be effected without waste of time, can ensure maximum efficiency from the viewpoint of the duration, frequency and timeless of such visits. A particular effort should be made in this connection ${ }^{\text {t11. }}$

Ten aanzien van dit punt zou ik willen volstaan met te stellen, dat dit onderdeel geen probleem oplevert.

\subsubsection{Inspectiebezoeken}

Op grond van artikel 16 van het verdrag moeten de inrichtingen zo vaak en zo zorgvuldig worden geïnspecteerd als nodig is om een daadwerkelijke naleving van de betreffende wettelijke bepalingen te verzekeren.

Het oorspronkelijk artikel schreef voor ${ }^{134}$, dat inspectiebezoeken ten minste één maal per jaar dienden plaats te vinden in gevaarlijke en ongezonde werkplaatsen en zo vaak als nodig om een daadwerkelijke naleving van de wettelijke bepalingen in andere werkplaatsen te bewerkstelligen. Bij de totstandkoming van het verdrag werd het echter ongewenst geacht om de frequentie van de inspectiebezoeken aan een bepaalde tijdsperiode te binden ${ }^{135}$.

Voor wat betreft de inspectiebezoeken wijst het comité van deskundigen op het belang ${ }^{136}$

"that the management of labour inspection services ensures that inspectors spend most of their time ( say three of four days a week) actually doing field work (i.e. visiting enterprises), rather than sedentary office work (discussing cases, answering calls, reporting or collecting information, maintaining correspondence, or involved in administrative red tape )".

Tijdens de parlementaire behandeling van de Arbeidsomstandighedenwet werd door de toenmalige bewinds$\operatorname{man}^{137}$ de constatering van de Industriebond van toen nog het Nederlands Verbond van Vakverenigingen, dat een doorsneebedrijf eens in de 3, 4 maanden door de arbeidsinspectie werd bezocht, te optimistisch genoemd; organisaties met meer dan 20 werknemers worden eens per half jaar, organisaties met 5 tot 20 werknemers eens per anderhalf à twee jaar en kleine organisaties gemiddeld eens per zes à zeven jaar bezocht.

De Algemene Rekenkamer ${ }^{138}$ constateerde dat per district geen systematische gegevens beschikbaar waren over afgelegde bedrijfsbezoeken naar risico-klasse en grootte-klasse. De Algemene Rekenkamer geeft daarbij de volgende twee tabellen ${ }^{139}$ :

\begin{tabular}{|l|r|r|r|}
\hline \multicolumn{3}{|l|}{ Werkterrein Arbeidsinspectie } \\
\hline & 1983 & 1984 & 1985 \\
\hline aantal vestigingen & 604685 & 607008 & 608409 \\
waarvan: & & & \\
$1 \mathrm{t} / \mathrm{m} 9$ werknemers & 547500 & 547500 & 547500 \\
$10 \mathrm{t} / \mathrm{m} 99$ werknemers & 57572 & 53686 & 55186 \\
$100 \mathrm{t} / \mathrm{m} 999$ werknemers & 5373 & 5588 & 5501 \\
1000 of meer werknemers & 240 & 234 & 222 \\
\hline
\end{tabular}

Bij deze tabel wordt als bron gegeven: ramingen van het directoraat-generaal van de Arbeid ${ }^{140}$. 


\begin{tabular}{|l|r|r|r|}
\hline \multicolumn{4}{|c|}{ Amtal bedri ffabezoeken Adbeidsinspectie } \\
\hline & 1983 & 1984 & 1985 \\
\hline bij vestigingen & 79617 & 80373 & 75670 \\
van: & & & \\
$1 \mathrm{t} / \mathrm{m} 9$ werknemers & 27813 & 28192 & 26603 \\
$10 \mathrm{t} / \mathrm{m} 99$ werknemers & 32393 & 33625 & 31242 \\
$100 \mathrm{t} / \mathrm{m} 999$ werknemers & 15779 & 15239 & 14251 \\
1000 of meer werknemers & 3632 & 3677 & 3574 \\
\hline
\end{tabular}

Bij deze tabel wordt als bron gegeven: interne overzichten van het directoraat-generaal van de Arbeid $^{141}$

Uit deze informatie leidde de Algemene Rekenkamer af, dat op een totaal van ongeveer 600000 ondernemingen en instellingen de omvang van de buitendienst van de arbeidsinspectie van circa 260 personen betekent één ambtenaar op 2300 bedrijven. Er van uitgaande, dat het maximale aantal bedrijfsbezoeken per amblenaar op ongeveer 300 per jaar moeten gesteld, kwam de Algemene Rekenkamer tot de slotsom, dat er een theoretische inspectiekans bestaat van ongeveer énmaal per zeven à acht jaar.

Voor een vergelijking tussen drie districten werden op verzoek van de Algemene Rekenkamer enige uitdraaien gemaakt van beschikbare gegevens over de bezoekfrequentie naar grootte van het bedrijf. Hieruit traden per bedrijfssector en naar grootteklasse grote verschillen in bezoekfrequentie tussen deze districten te voorschijn. Op basis van de verstrekte gegevens constateerde de Algemene Rekenkamer, dat er in de drie districten bedrijven bestonden in de bouw, handel, horeca, reparatie, transport, kantorensector en dienstverlening, die weinig of nooit bezocht werden ${ }^{142}$.

Terzake van een specifiek onderwerp, namelijk stralingsbescherming ligt het anders. In elk district van de arbeidsinspectie is ten minste een ambtenaar met stralingsbescherming als hoofdtaak belast, hetgeen neerkomt op één inspecteur op 150 bedrijven ${ }^{143}$.

Het vorenstaande leidde tot schriftelijke vragen vanuit de Tweede Kamer $^{144}$ aan de verantwoordelijke bewindsman, waaronder de volgende:

"Hebt u bij het debat over het ontwerp Arbowet deze Kamer medegedeeld, dat de bezoek-

frequentie van de arbeidsinspectie aan kleine bedrijven op eenmaal per zes à zeven jaar lag, terwijl deze in werkelijkheid beduidend lager lag en ligt"?

Daarop antwoordt de bewindsman wel erg ontwijkend. Allereerst wordt medegedeeld, dat niet exact te reconstrueren is waarop de toendertijd gegeven cijfers zijn gebaseerd, maar vermoed wordt dat gedoeld werd op de bezoekfrequentie in de sector fabrieken of werkplaatsen, daar verwezen werd naar een uitspraak van de Industriebond van het Nederlands Verbond van Vakverenigingen. Vervolgens wordt medegedeeld, dat het hier een berekening van de statistische bezoekkans betreft en dat dit nog niets zegt over de effectiviteit van het opereren van de arbeidsinspectie, maar dat werd ook niet gevraagd.

De volgende schriftelijk gestelde vraag had betrekking op hoe vaak de arbeidsinspectie gemiddeld genomen, de grotere bedrijven en de kleinere bedrijven bezoekt. In het antwoord werd herhaald, dat een statistische bezoekkans van geringe betekenis is, omdat het gemiddelden zijn voor zeer heterogene bedrijfsgroepen, waarvan sommige zeer vaak, en andere bijna nooit worden bezocht.

Vervolgens werd gevraagd, hoe bij een dergelijke frequentie sprake kan zijn van een doeltreffende controle op de naleving van veiligheids- en andere normen in de werksituatie. In het antwoord werd gesteld, dat twee zaken in aanmerking genomen moesten worden. In de eerste plaats vindt er een weging plaats in het inspectiebeleid. Niet alle bedrijfsklassen zijn namelijk even risicovol, waar het de arbeidsomstandigheden betreft. 
In een nota van het directoraat-generaal van de Arbeid, getiteld: Typologie van objectorganisaties ${ }^{1.45}$ en dat uit 1987 dateert, worden de bedrijfsklassen ingedeeld in vier groepen naar zwaarte van de arbeidsomstandighedenproblematiek. Hieruit blijkt de groep met bedrijfsklassen met de grootste problemen op dit terrein ongeveer $13 \%$ van alle bedrijven te omvatten. De arbeidsinspectie besteedt ongeveer $50 \%$ van haar bezoeken aan deze bedrijven. Ook de kleinere bedrijven worden in deze "risico-groep" frequent bezocht. Rekening houdend met de risico"s in de verschillende bedrijfstakken kan worden gesteld, dat in die bedrijven, waar het nodig is, de arbeidsinspectie zelf frequenter komt dan de toenmalige minister van Sociale Zaken destijds meldde. Hieruit volgt, dat er ook bedrijfsklassen zijn waar de bezoekfrequentie lager ligt. Maar dit is te verantwoorden op grond van de gemaakte prioriteiten-afweging. Dit antwoord ontlokt bij mij het volgende. Dat de arbeidsinspectie prioriteiten moet stellen, alleen al gezien de personele capaciteit, is juist. Maar waarom was de Algemene Rekenkamer van dit antwoord klaarblijkelijk niet op de hoogte, gezien het feit, dat haar rapport hiervan geen melding maakt? En hoewel in het antwoord percentages worden gegeven, wordt niet aangegewen hoe hoog dan wel precies deze bezoekfrequentic is.

In de tweede plats wordt in het antwoord opgemerkt, dat de vraag suggereert, dat de arbeidsinspectie naleving van de gegeven normen alleen kan bereiken door middel van controle op de werkplek. De bewindsman wees er echter uitdrukkelijk op, dat bij het werk van de arbeidsinspectie, geheel naar de geest van de Arbeidsomstandighedenwet, voorop staat, dat de werkgevers en werknemers primair zelf verantwoordelijk zijn voor de arbeidsomstandigheden in hun bedrijf. Een belangrijk deel van het beleid is gericht op het bevorderen van deze eigen verantwoordelijkheid. Nog los van het feit, dat het voor mij nog maar de vraag is, of de gestelde vraag dit suggereert, en het feit, dat werkgevers en werknemers zelf verantwoordelijk zijn voor de arbeidsomstandigheden in hun bedrijf en de arbeidsinspectie die probeert te stimuleren, blijft toch onverkort van kracht, dat de arbeidsinspectie in het leven geroepen is en verantwoordelijk is voor een doeltreffende controle op de naleving van de wettelijke normen. Bovendien schrijft Verdrag no. 81 deze taak voor.

Het vorenstaande overziend kan naar mijn mening worden geconstateerd, dat de personele bezetting van de arbeidsinspectie te gering is om aan de in artikel 16 gegeven verdragsverplichting te voldoen. Zeker als men daarbij het oorspronkelijke artikel in de beschouwing betrekt, namelijk inspectie é́nmaal per jaar van gevaarlijke en ongezonde werkplaatsen en zo vaak als nodig om een daadwerkelijk naleving van de wettelijke bepalingen in andere werkplaatsen te bewerkstelligen.

\subsection{Bevoegdheden}

Ten einde de inspecteurs de mogelijkheden te verschaffen om de hun opgedragen taak uit te kunnen oefenen voorziet het verdrag in het aan hun verschaffen van een aantal bevoegdheden. Deze zijn:

1. in het kader van de toezichthoudende taak:

- de bevoegdheid om in elke aan toezicht onderworpen inrichting binnen te treden;

- de bevoegdheid om inspecties te kunnen uitvoeren;

2. de bevoegdheid om te bevelen dat de nodige maatregelen moeten worden getroffen om de tijdens de in spectie geconstateerde gebreken te (doen) verhelpen.

\subsubsection{Toexichthoudende bevoegdheden}

Op grond van artikel 12 van het verdrag moeten de inspecteurs van de arbeid, voorzien van behoorlijke legitimatiebewijzen, de bevoegdheid hebben:

a. om vrijelijk, zonder voorafgaande kennisgeving op elk uur van de dag en de nacht in elke aan toezicht onderworpen inrichting binnen te treden;

b. om overdag alle localiteiten te betreden, waarvan zij een redelijke grond hebben te veronderstellen, dat deze aan toezicht onderworpen zijn;

c. om over te gaan tot alle onderzoeken, controles en enquêtes, die zij nodig mochten oordelen om er zich 
van te verzekeren, dat de wettelijke bepalingen daadwerkelijk in acht genomen worden en in het bijzonder $1{ }^{\circ} \mathrm{om}$ alleen of in tegenwoordigheid van getuigen de werkgever of het personeel van de onderneming te ondervragen over alle aangelegenheden betreffende de toepassing van de wettelijke bepalingen;

$2^{\circ}$ om overlegging te vragen van alle boeken, registers en documenten, waarvan het aanhouden bij de wetgeving is voorgeschreven ten einde na te gaan of die in overeenstemming met de wettelijke bepalingen zijn en om afschriften daarvan of uittreksels daaruit te maken;

$3^{\circ}$ om het aanplakken van mededelingen te eisen, waarvan het aanbrengen bij wettelijke bepalingen vereist is;

$4^{\circ}$ om monsters van materialen en stoffen, die gebruikt of behandeld worden, te nemen en mede te nemen ten einde die te analyseren, mits de werkgever of diens vertegenwoordiger gewaarschuwd is, dat materialen of stoffen daartoe (mee)genomen zijn.

Het zelfde artikel bepaalt vervolgens, dat de inspecteur van de arbeid de werkgever of diens vertegenwoordiger van zijn aanwezigheid in kennis moet stellen; tenzij hij van oordeel is, dat een dergelijke kennisgeving de uitoefening van zijn taak zou kunnen schaden.

Terzake van de in artikel 12 van het verdrag neergelegde verplichting, dat de ambtenaren van de arbeidsinspectie in het bezit dienen te zijn van behoorlijke legitimatiebewijzen dient gewezen te worden op hetgeen in artikel 3 van het Organisatiebesluit Arbeidsinspectie is bepaald, namelijk dat de door de minister van Sociale Zaken en Werkgelegenheid aangewezen ambtenaren, als bedoeld in artikel 1 van dat besluit, bij de uitoefening van hun ambt steeds voorzien zijn van een hun door hem afgegeven legitimatiekaart.

Daar waar het verdrag de ambtenaren van de arbeidsinspectie de bevoegdheid voorschrijft omtrent het betreden van plaatsen, meen ik te kunnen volstaan met een verwijzing naar het betreffende paragraaf-onderdeel in het vorige hoofdstuk ${ }^{146}$.

De bevoegdheid van de ambtenaren van de arbeidsinspectie om, hetzij alleen, hetzij in tegenwoordigheid van getuigen, de werkgever of het personeel te ondervragen over alle aangelegenheden die de toepassing van wettelijke bepalingen betreffen, kent het arbeidsomstandighedenrecht formeel niet. Dit wil overigens niet zeggen, dat het bedoelde ondervragen niet conform dit voorschrift zou gebeuren. In het verlengde hiervan moet worden gewezen op de verplichting tot het verschaffen van informatie door bepaalde personen aan de bevoegde ambtenaren omtrent zaken en feiten die de naleving van de wet betreffen. Ook hier meen ik te kunnen volstaan met een verwijzing naar het paragraaf-onderdeel in het worige hoofdstuk, dat handelt over de plicht tot spreken en het recht om te zwijgen. Wel moet er op gewezen worden, dat leden van een commissie voor veiligheid, gezondheid en welzijn of van de ondernemingsraad het recht hebben zich buiten tegenwoordigheid van anderen met de ambtenaren van de arbeidsinspectie te onderhouden. De werkgever komt uiteraard het zelfde recht toe. Bovendien kan het initiatief voor een vertrouwelijk gesprek van de betrokken ambtenaren zelf uitgaan ${ }^{147}$.

In het arbeidsomstandighedenrecht is op de werkgever de verplichting gelegd, dat de bevoegde ambtenaren op aanvrage de door de wetgeving voorgeschreven controlemiddelen ter inzage dienen te krijgen. Zo schrijft de Arbeidswet 1919 voor, dat het hoofd of de bestuurder verplicht is er voor te zorgen, dat de arbeidskaarten onverwijld ter inzage worden verstrekt aan de met het toezicht belaste ambtenaren ${ }^{148}$. Dezelfde verplichting geldt tem aanzien van het arbeidsregister ${ }^{148}$. Het hoofd of de bestuurder is verplicht in een inrichting op een voor in die inrichting werkzame arbeiders vrij toegankelijke plaats een gedagtekende en door hem ondertekende arbeidslijst op te hangen en opgehangen te houden en wel zodanig dat daarvan gemakkelijk kennis kan worden genomen ${ }^{150}$.

Conform hetgeen in het verdrag wordt voorgeschreven kent de Arbeidswet 1919 een bepaling, waarin het hoofd of de bestuurder van een onderneming verplicht is om te voldoen aan een eis van het districtshoofd van de arbeidsinspectie om op een door hem aangegeven plaats op te hangen en opgehangen te houden de door of namens het districtshoofd schriftelijk, gedagtekend en ondertekend, verstrekte mededelingen, die betrekking hebben op de naleving van enige wet waarvan het toezicht op de naleving aan de arbeidsinspectie is opgedragen ${ }^{151}$. 
Tot slot zijn de ambtenaren van de arbeidsinspectie bevoegd, overeenkomstig de verdragsverplichting, alle onderzoekingen en handelingen te verrichten, én en ander voor zover dit noodzakelijk is voor de juiste vervulling van hun taak. Bovendien moet hen alle hulp worden gegeven, voor zover dit redelijkerwijs verlangd kan worden. De bedoelde onderzokkingen en handelingen omvatten met name:

a. het verrichten van beproevingen en metingen;

b. het maken van tekeningen en fotografische opnamen;

c. het nemen van monsters van stoffen en voorwerpen;

d. het voor nader onderzoek medenemen van voorwerpen of gedeelten daarvan.

Wanneer van de twee laatstbedoelde bevoegdheden gebruik wordt gemaakt, moet de betrokken ambtenaar daarvan desgevraagd een deugdelijk bewijsstuk van de door hem verrichte handeling verstrekken ${ }^{152}$.

De verplichting, dat de ambtenaar van de arbeidsinspectie de werkgever of diens vertegenwoordiger van zijn aanwezigheid in kennis moet stellen, kent onze wetgeving niet. Ook dit wil niet zeggen, dat dit niet gebeurt. Daarnaast moet gewezen op het in de Arbeidsomstandighedenwet neergelegde recht van de leden van een commissie voor veiligheid, gezondheid en welzijn of van een ondernemingsraad om ambtenaren van de arbeidsinspectie tijdens hun bezoek aan het bedrijf of de inrichting te vergezellen, tenzij deze laatsten te kennen geven dat daartegen vanwege een goede uitoefening van hun taak bezwaren bestaan ${ }^{153}$. Van dit recht kan alleen gebruik gemaakt worden wanmeer de leden van de bedoelde commissie of de ondernemingsraad van de aanwezigheid van de betreffende ambtenaren op de hoogte zijn gesteld. Bij dit "vergezelrecht" kan gedacht worden aan een inspectie in het kader van de controle op de naleving of naar aanleiding van een ongeval, een verzoek om wetstoepassing of een aanvraag om ontheffing. Owerigens kunnen de bezwaren die de ambtenaar zou kunnen maken tegen dit "vergezellen" in verband met zijn taakuitoefening liggen op het terrein van persoonsgebonden zaken, zoals het horen van getuigen of bij een ongevalsonderzoek. Het recht is evenmin van toepassing wanneer de ambtenaar het bedrijf of die inrichting bezoekt voor een onderhoud of bespreking met de werkgever, al dan niet op diens verzoek. Wel verzoekt de betrokken ambtenaar van de arbeidsinspectie daarbij altijd of de werkgever melding wil maken van een dergelijk gesprek bij de bedoelde commissie- of ondernemingsraadleden. Overigens gaat in het omgekeerde geval een dergelijk verzoek uit naar de laatstbedoelden. Wil men over en weer bij een gesprek met én van hen aanwezig zijn, dam moeten de werkgever en de werknemers dit onderling afspreken ${ }^{154}$.

Terzake van de toezichthoudende bevoegdheden kan gezegd worden, dat ons land voldoet aan de terzake geldende verdragsverplichting.

\subsubsection{Corrigerende bevoegdheden}

"An inspection service lacking the necessary powers to enjoin undertakings to take the measures called for to remedy defects observed during an inspection visit would not be very effective",

aldus het comité van deskundigen ${ }^{155}$.Vandaar dat artikel 13 van het verdrag aan de inspecteurs van de arbeid de bevoegdheid toekent om maatregelen te nemen om gebreken, die geconstateerd zijn in een installatie, een inrichting of bij de arbeidsmethoden, ten aanzien waarvan zij een redelijke grond hebben om te veronderstellen, dat die een bedreiging voor de gezondheid en de veiligheid van de werknemers vormen, te verhelpen. Daartoe hebben zij het recht om te (doen) gellasten ${ }^{158}$, dat:

a. bianen een vastgestelde termijn de veranderingen aan de installatie worden aangebracht, die noodzakelijk zijn om de strikte toepassing van de wettelijke bepalingen betreffende de gezondheid en de veiligheid van de werknemers te verzekeren;

b. in gevallen van dreigend gevaar voor de gezondheid en de veiligheid van de werknemers onmiddellijk van kracht wordende maatregelen genomen worden.

Met betrekking tot deze laatste bevoegdheid merkt het comite van deskundigheden het volgende op ${ }^{157}$; "It should be noted that the inspector must be empowered to order the taking of measures 
with immediate executory force whether or not a legal provision has been infringed".

De districtshoofden van de arbeidsinspectie hebben de bevoegdheid om eisen te stellen terzake van de toepassing van de wettelijke bepalingen betreffende de veiligheid en gezondheid van werknemers. De werkgever is verplicht hieraan te voldoen; de werknemers slechts in geval dit bij de eis is bepaald. Deze verplichting geldt niet zolang er tegen de eis een bezwaarschrift kan worden ingediend en zolang omtrent een zodanig bezwaarschrift niet is beslist ${ }^{158}$. Deze schorsende werking kan, echter indien in verband met gevaar voor de veiligheid of de gezondheid de naleving van de eis geen uitstel kan lijden, niet van toepassing worden verklaard. Voor wat betreft het bevel tot stillegging van werk wil ik volstaan met een verwijzing naar de desbetreffende paragraaf in hoofdstuk $10^{169}$.

\subsection{Verplichtingen}

Als tegenhanger wan de bevoegdheden die aan de inspecteurs worden toegekend, zijn ook een aantal verplichtingen opgelegd.

\subsubsection{Geen direct of indirect belang in ondernemingen onder hun toezicht geplaatst}

Ten einde hun onpartijdigheid en onafhankelijkheid te waarborgen ${ }^{160}$, schrijft artikel 15 van het verdrag voor dat zij generlei direct of indirect belang mogen hebben in de onder hun toezicht geplaatste ondernemingen.

Ten aanzien van deze verdragsverplichting kan gewezen op het feit, dat de door de verantwoordelijke bewindsman aangewezen ambtenaren zonder zijn toestemming noch "middellijk noch onmiddellijk" deel mogen nemen aan bedrijven en ondernemingen die onder de bepalingen vallen van enige wet waarvan het toezicht: aan hen is opgedragen ${ }^{181}$.

\subsubsection{Geheimhoudingsverplichting}

Bovendien hebben zij een geheimhoudingsplicht opgelegd gekregen met betrekking tot de fabricage- of handelsgeheimen of produktiewijzen waarvan zij tijdens de uitoefening van hun functie kemnis hebben genomen $^{162}$, étn en ander hetzij strafrechtelijk, hetzij passend disciplinair gesanctioneerd. Tot slot hebben zij de verplichting opgelegd gekregen de bron wan een klacht, waarbij een gebrek aan een installatie of een inbreuk op de wettelijke bepalingen aan hen ter kennis is gebracht als strikt vertrouwelijk te beschouwen. De inspecteurs moeten tevens jegens de werkgever of diens vertegenwoordiger verzwijgen dat een inspectiebezoek een gevolg is van een klacht. Een uitzondering is mogelijk, wanneer een wettelijke regeling de bekendmaking van de naam van de klager met diens uitdrukkelijke toestemming geschiedt.

Voor wat betreft de geheimhoudingsverplichting zij verwezen naar de laatste paragraaf van het worige hoofdstuk $^{103}$.

\subsection{Verslagen en rapportages}

Wanneer er sprake is van een centrale inspectie-autoriteit moeten op grond van artikel 19 van het verdrag door de inspecteurs van de arbeid of de plaatselijke inspectiebureaus - al naar het geval zich voordoet - periodieke verslagen van algemene aard over de resultaten van hun werkzaambeden hieraan worden voorgelegd. Daarbij geldt dat dit ten minste éen maal per jaar dient te gebeuren.

Op grond van artikell 11, tweede lid, van het Organisatiebesluit Arbeidsinspectie brengt het districtshoofd van de arbeidsinspectie jaarlijks aan de directeur-generaal van de Arbeid vóor een door deze te bepalen da- 
tum een verslag wit ower zijn werkzaamheden en over die van de onder zijn bevelen werkzame ambtenaren. Dit verslag dient te ingericht overeenkomstig de aanwijzingen van de directeur-generaal van de Arbeid. In artikel 17 van hetzelfde besluit geldt een zelfde verplichting woor de medisch-adviseur, de elektrotechnischadviseur, de kernfysisch adviseur en de landbouwkundige bij de arbeidsinspectie. Maar wel dient opgemerkt te worden, dat deze functies bij de nieuwe organisatieopbouw van het directoraat-generaal van de Arbeid zijn opgeheven ${ }^{164}$.

De centrale inspectie-autoriteit dient op grond van het daarop volgende verdragsartikel een algemeen jaarverslag over de werkzaambeden van de onder haar toezicht geplaatste inspectiediensten te doen verschijnen. Die verslagen zullen binnen een redelijke termijn - in elk geval binnen 12 maanden - na afloop van het jaar, waarop zij betrekking hebben, moeten worden witgegeven ${ }^{165}$.

Artikel 76a, derde lid, van de Arbeidswet 1919 schrijft voor, dat jaarlijks een verslag van de werkzaamheden van de arbeidsinspectie aan de Staten-Generaal moet worden overgelegd. Opvallend is, dat in dit wettelijke voorschrift niet wordt aangegeven wie dit verslag moet samenstellen, noch wie daarvoor verantwoordelijk is. Omtrent de samenstelling van het verslag biedt het Organisatiebesluit echter uitkomst. Op grond van artikel 8 van dit besluit is éen van de taken van de directeur-generaal van de Arbeid: het jaarlijks aan de verantwoordelijke bewindsman vó́r een door deze te bepalen datum uitbrengen van een verslag over de werkzaamheden van de arbeidsinspectie. Tegelijkertijd dient hij de jaarlijks door de districtshoofden en de medisch-adviseur, de elektrotechnisch adviseur, de kernfysisch adviseur en de landbouwknndige bij de arbeidsinspectie uit te brengen verslagen over te leggen. Verder is de directeur-generaal belast met de zorg voor de samenstelling van verdere verslagen, waarvan de openbaarmaking door de verantwoordelijke bewindsman of door hem zelf gewenst wordt geacht en onderwerpt deze aan het oordeel van de bedoelde minister.

De praktijk geeft discrepantie met deze wettelijke regeling te zien; het is al eerder opgemerkt, waarbij verwezen is naar de organisatorische veranderingen bij het directoraat-generaal van de Arbeid.

Tot het jaarverslag over 1987 bracht de directeur-generaal van de Arbeid een verslag van de werkzaamheden uit aan de betrokken bewindsman. Dat blijkt uit het voorwoord bij ieder jaarverslag, waarin tevens verwezen werd naar de wettelijke voorschriften. In de jaarverslagen over 1987 en 1988 ontbreken dergelijke verwijzingen. Uit het voorwoord van de directeur-generaal van de Arbeid blijkt, dat het respectievelijk gaat om een "bescheiden maar markante selectie uit het vele wat wij doen",

en een

"selectie uit het werk dat wij in 1988 deden",

aldus de directeur-generaal van de Arbeid De Roos. De beide jaarverslagen, die zowel de arbeidsinspectie, de inspectie van de havenarbeid als de dienst voor het stoomwezen omvatten, beslaan met inbegrip van grafieken en tabellen sllechts respectievelijk 35 en 48 bladzijden.

Vastgesteld kan worden, dat de bedoelde jaarverslagen niet aan de nationale voorschriften voldoen, doch ook niet aan de verdragsverplichting.

Ingevolge artikel 21 van het verdrag zullen de jaarverslagen de volgende en andere ter zake dienende aangelegenheden hebben te bevatten:

a. de wetten en reglementen tot de bevoegdheid van de arbeidsinspectie behorende;

b. personeel van de arbeidsinspectie;

c. statistieken van de inrichtingen onderworpen aan inspectie, en het aantal van de daar werkzame werkne mers;

d. statistieken van inspectiebezoeken;

e. statistieken van begane overtredingen en van opgelegde straffen;

f. statistieken van arbeidsongevallen;

g. statistieken van beroepsriekten.

Welke andere ter zake doende aangelegenheden worden bedoeld, blijkt uit aanbeveling 81 , zij het dat daarbij de beperking "voor zover mogelijk" is toegevoegd. Zo wordt genoemd onder de noemer bijzonderheden om - 
trent de diensten van de arbeidsinspectie: het totaal aantal inspecteurs, tevens onderverdeeld naar verschillende categorieën, het aantal inspectrices en bijzonderheden omtrent de geografische spreiding van de diensten der inspectie.

Ten aanzien van de aan inspectie onderworpen inrichtingen en de daarin werkzame personen dient een uitsplitsing plaats te vinden naar: mannen, vrouwen, jeugdigen en kinderen. Ook worden met betrekking tot de statistieken van inspectiebezoeken en arbeidsongevallen en beroepsziekten nadere gegevens verzocht. Wat betreft de inhoudelijke aspecten richten we ons voornamelijk op de beide hiervoor bedoelde jaarverslagen, omdat het hierbij gaat om jaarverslagen nieuwe stijl, waarbij, aldus de directeur-generaal van de Arbeid De Roos aangesloten wordt bij de nieuwe werkwijze van de arbeidsinspectie. Maar met deze jaarverslagen nieuwe stijl is het, waar het de inhoudelijke aspecten betreft, verdragsmatig ook niet in orde. De beide jaarverslagen bevatten geen overzicht van de wetten die tot de bevoegdheid van de arbeidsinspectie behoren. Hetzelfde geldt ten aanzien van het personeel van de arbeidsinspectie; deze informatie is echter wel weer te vinden in de sociale jaarverslagen. Het jaarverslag over 1988 bevat in tegenstelling tot het eerdere jaarverslag een tabel waarin een overzicht wordt gegeven van het aantal vestigingen, verdeeld naar grootteklasse, in het geautomatiseerde CRS-bestand ${ }^{168}$. De beide jaarverslagen bevatten een tabel waarin het aantal afgelegde bezoeken per bedrijfsgroottegroep door de buitendienst-ambtenaren van de arbeidsinspectie als percentage van het totaal aantal bedrijfsbezoeken, waarbij toegevoegd wordt, dat het totaal antal bedrijfsbezoeken de afgelopen jaren gemiddeld 80.000 per jaar bedroeg ${ }^{167}$. In de jaarverslagen tot 1986 vindt men echter een tabel waarin het feitelijke aantal bedrijfsbezoeken door de buitendienst-ambtenaren weergegeven $^{168}$. De beide jaarverslagen bevatten geen statistieken van begane overtredingen en van de opgelegde straffen. De beide jaarverslagen geven slechts aan hoeveel processen-verbaal zijn opgemaakt; hoeveel daarvan terzijde zijn gelegd; hoeveel er vervolgd zijn; hoeveel schikkingen er zijn getroffen; hoeveel veroordelende en niet-veroordelende vonnissen in eerste instantie zijn gewezen ${ }^{160}$. In het jaarverslag over 1988 wordt in een andere tabel aangegeven in welke bedrijfstak de processen-verbaal zijn opgemaakt ${ }^{170}$. De eerdere jaarverslagen bevatten veel meer statistische gegevens omtrent de begane overtredingen en de processen-verbaal $^{171}$. Wel bevat het jaarverslag over 1988 een aantal tabellen waarin informatie wordt gegeven over de toegepaste instrumenten inzake de Arbeidsomstandighedenwet en het atntal vestigingen per bedrijfsklasse ${ }^{172}$. De beide jaarverslagen geven de zogenaamde kerncijfers bedrijfsongevallen ${ }^{173}$. Het jaarverslag over 1988 geeft nog informatie over het aantal door bedrijfsongevallen getroffen personen per bedrijfstak ${ }^{174}$. Statistieken over beroepsziekten ontbreken in de beide jaarverslagen ${ }^{175}$.

Toen bij de totstandkoming van de Arbeidswet 1889 de toenmalige inspecteurs werden verplicht om jaarlijks een beredeneerd verslag te doen van hun ambtsbezigheden, was dit met de bedoeling dat deze verslagen de bouwstoffen zouden leveren voor de latere uitbreiding van de sociale wetgeving. In dat opzicht kan de toenmalige inspecteurs niets verweten worden. De verslagen waren zeer minitieus en bevatten een schat aan informatie. Dat kan helaas niet gezegd worden van de jaarverslagen nieuwe stijl; het zijn geen verslagen van de werkzaamheden en de informatie, waaronder de statistische gegevens, is zeer beperkt ${ }^{178}$ "In ieder geval voldoen de jaarverslagen nieuwe stijl op een aantal punten niet aan hetgeen verdragsmatig terzake is voorgeschreven.

Terzake van hetgeen aanbeveling 81 nog voorschrijft het volgende. Noch de beide jaarverslagen noch de sociale jaarverslagen geven nadere informatie over het totaal aantal inspecteurs, onderverdeeld naar verschillende categorieën, het aantal inspectrices en bijzondere omtrent de geografische spreiding van de diensten van de arbeidsinspectie. Uitsplitsing van de in de aan inspectie onderworpen inrichtingen werkzame personen naar geslacht en leeftijdscategorie - jeugdige of kind - ontbreekt eveneens. Dus ook hier valt de toetsing van de jaarverslagen negatief uit.

\subsection{Strafrechtelijke sanctionering}

Artikel 17 van het verdrag schrijft voor, dat personen, die de wettelijke bepalingen, waarvan de naleving on- 
derworpen is aan het toezicht van de inspecteurs wan de arbeid, niet nakomen of veronachtzamen, aan onmiddellijke wettelijke vervolging, zonder voorafgaande waarschuwing, bloot gesteld dienen te zijn. Uitzonderingen kunnen bij wettelijke regelingen worden bepaald woor die gevallen, waarin wooraf een waarschuwing zal moeten wordlen gegeven om in de toestand verbetering te brengen of preventieve maatregelen te nemen. Wel wordt aangegeven, dat het aan de vrije beslissing van de inspecteurs van de arbeid overgelaten dient te worden om waarschuwingen of raadgevingen in plaats van het instellen van vervolgingen (of het aanbevelen daarvan) te geven.

Het niet-nakomen of veronachtzamen van de wettelijke woorschriften waarvan het toezicht op de naleving is opgedragen aan de arbeidsinspectie kan leiden tot onmiddellijke strafrechtelijke vervolging. De betrokken ambtenaren van de arbeidsinspectie kunnen onmiddellijk een proces-verbaal opmaken, maar de beslissing of vervolging ook daadwerkelijk plaatsvindt ligt in handen van het Openbaar Ministerie. Hier blijken persoonlijke contacten en initiatieven niet onbelangrijk te zijn. Veel zaken worden afgedaan door middel van schikkingen; daarnaast wordt nogal eens gebruik gemaakt van de zogenaamde seponeringsbevoegdheid. Beide een bron van onvrede bij de buitendienst-ambtenaren van de arbeidsinspectie. Een bijkomend gevolg is, dat er niet snel overgegaan wordt tot het opmaken van processen-verbaal.

Ook in geval van een eis tot naleving, waarvan de niet-naleving een zelfstandig strafbaar feit oplevert, levert niet-naleving van de bepaling, waarop de eis is gebaseerd, eveneens zonder meer een strafbaar feit op. Als voorbeeld moge dienen de Arbeidsomstandighedenwet. Artikel 26, eerste lid, van die wet bepaalt, dat de werkgewer en de werknemers verplicht zijn tot naleving van de voorschriften of verboden welke bij of kraclhtens het betreffende hoofdstuk $V$ van de wet bij algemene maatregel van bestuur zijn vastgesteld. In artikel $216 a$ van het Veiligheidsbesluit voor fabrieken of werkplaatsen $1938^{177}$ wordt bepaald, dat de werkgever verplicht is tot naleving van de voorschriften en verboden welke krachtens de hoofdstukken II en IV van dit besluit zijn vastgesteld ${ }^{178}$. Op grond van artikel 57 van de Arbeidsomstandighedenwet levert niet-naleving van de in artikel 26, eerste lid, van dit neergelegde verplichting een strafbaar feit, een economisch delict, op. In artikel 36 van de Arbeidsomstandighedenwet is de bevoegdheid van het districtshoofd van de arbeidsinspectie neergelegd omtrent het stellen van een eis onder meer betreffende de wijze waarop de voorschriften krachtens artikel 24 van de wet moeten worden nageleefd. Dit artikel 24 vormt de basis voor het bedoelde veiligheidsbesluit. Artikel 36, vijfde lid, van de Arbeidsomstandighedenwet bepaalt, dat de werkgever verplicht aan een eis te voldoen. Op grond van artikel 57 van de Arbeidsomstandighedenwet levert het niet-naleven van deze verplichting door de werkgever eveneens een strafbaar feit, opnjeuw een economisch delict $o p^{179}$. De wettelijke voorschriften waarbij het districtshoofd van de arbeidsinspectie op grond van artikel 35 van de Arbeidsomstandighedenwet een aanwijzing kan geven, werden door de toenmalige bewindsman dusdanig gewaardeerd, dat direct strafrechtelijke sanctionering ongewenst is: Vandaar dat alleen het niet-naleven van de aanwijzing een strafbaar feit oplevert ${ }^{180}$.

Het daarop volgende artikel schrijft niet alleen voor, dat bij de nationale wetgeving doeltreffende straffen moeten worden voorgeschreven op overtreding van de wettelijke voorschriften, waarvan de naleving is onderworpen aan het toezicht van de inspecteurs, maar tevens voor obstructie tegen de inspecteurs in de uitoefening van hun functie(s). Strafbepalingen die overigens ook daadwerkelijk moeten worden toegepast:

De straffen die op de niet-naleving van de wettelijke voorschriften gesteld verschillen. De Arbeidswet 1919 kent een eigen strafsanctie. Aanvankelijk stond op de niet-naleving van de in deze wet gegeven voorschriften een hechtenis van ten hoogste én maand of een geldboete van maximaal honderd gulden. Recidive binnen twee jaar na een onherroepelijk veroordelend vonnis leverde een straf op van ten hoogste twee maanden. hechtenis of een geldboete van maximal tweehonderd gulden. Bij een tweede of volgende herhaling volgde nog slechts hechtenis ${ }^{181}$. Bij de wet van 11 februari $1988^{182}$ werd deze strafmaat gewijzigd. Overtreding wordt nu nog gestraft met een hechtenis van ten hoogste éen maand of een geldboete van de tweede categorie. Dit laatste is een verwijzing naar de Wet vermogenssancties ${ }^{183}$, waarbij een systeem, van geldboete-categorieën werd ingevoerd. De tweede categorie wil zeggen, dat een geldboete van vijfduizend gulden kan 
worden opgelegd. De recidive-bepalingen zijn vervallen. De strafbare feiten zijn gekwalificeerd als overtredingen. Daarop geldt eén uitzondering: het niet-nalleven van een bevel tot stillegging van werk en de daarbij gegeven aanwijzingen leveren een misdrijf op, met als strafsanctie: gevangenisstraf van ten hoogste zes maanden en een geldboete van de derde categorie, hetgeen overeenkomt met tienduidend gulden ${ }^{184}$. Voor de bedoelde wetswijziging was de hoogte van de geldboete beperkt tot maximaal tweeduizend gulden ${ }^{185}$.

De Arbeidsomstandighedenwet kent een andere soort van strafsanctie. Niet-naleving van de betreffende wettelijke voorschriften levert een economisch delict $\mathrm{op}^{188}{ }^{18}$, gekwalificeerd als overtreding ${ }^{187}$, met als strafsanctie een hechtenis van ten hoogste zes maanden en een geldboete van de derde categorie. Opmerkelijk is, dat in tegenstelling tot de Veiligheidswet 1934 en de Arbeidswet 1919 het bevel tot stillegging van werk eveneens gekwalificeerd is als overtreding in plaats van misdrijf; mijns inziens kan deze "degradatie" in strafmaat gezien worden als een niet doeltreffende straf. De strafmaat staat in dit geval niet in verhouding met de aard van de gepleegde overtreding, namelijk het niet-naleven van een bevel, dat gegeven wordt in de situatie waarin sprake is van een ernstig gevaar voor personen ${ }^{189}$. Deze situatie wordt gelijkgesteld voor wat betreft de strafsanctie met het niet-naleven van het schriftelijk vastleggen van de wijze van samenwerking tussen meerdere werkgevers, de voorzieningen die daarbij getroffen zullen worden en de wijze waarop het toezicht op die voorzieningen zal worden uitgeoefend ${ }^{\text {tag }}$.

Terzake van de obstructie tegen de inspecteurs in de uitoefening van hun functie(s) kan het volgende opgemerkt worden.

Indien hen de toegang tot de plaatsen waar arbeid wordt verricht of pleegt te worden verricht of ten aanzien waarvan redelijkerwijze vermoed kan worden, dat aldaar arbeid wordt verricht, wordt geweigerd of belemmerd of hun op aanmelding tot toelating niet wordt geantwoord, kunnen zij zich die verschaffen met behulp van de sterke $\operatorname{arm}^{100}$. Hij die zich met geweld of bedreiging met geweld verzet tegen een ambtenaar

"werkzaam in de rechtmatige uitoefening van zijn bediening, of tegen personen die hem

daarbij krachtens wettelijke verplichting of op zijn verzoek bijstand verlenen",

maakt zich schuldig aan wederspanningheid, dat als misdrijf is gekwalificeerd, en dat gestraft kan worden met gevangenisstraf van ten hoogste éen jaar of een geldboete van de derde categorie ${ }^{101}$. De eis, dat de ambtenaar werkzaam dient te zijn, brengt niet alleen met zich, dat hij al een bepaalde handeling in dat verband dient te verrichten ${ }^{182}$, maar ook dat niet als verzet kan worden aangemerkt ( bedreiging met) geweld, wanneer die handeling al is gestaakt; dat kan, naar gelang de situatie die zich voordoet, mishandeling of bedreiging zijn, maar geen wederspannigheid. Aan een bevel van een ambtenaar hoeft geen gehoor gegeven te worden, maar verzet levert wederspannigheid op.

De toetsing van de verdragsbepalingen omtrent strafrechtelijke sanctionering levert, behoudens een kleine kritische kanttekening nauwelijks problemen op.

\subsection{Slotbeschouwing}

Toetsing van het Verdrag betreffende de arbeidsinspectie in industrie en handel laat zien, dat er nogal eens een discrepantie tussen de verdragsverplichtingen en de situatie in ons land terzake van de arbeidsinspectie bestaat. Een knelpunt is ongetwijfeld het onderdeel, dat de middelen, die ter beschikking van de arbeidsinspectie staan, regelt, en zeker daar waar het de menskracht van de arbeidsinspectie betreft. Daardoor is het aantal bedrijfsbezoeken, die door de betreffende ambtenaren van de arbeidsinspectie worden uitgevoerd, te gering; daarover kan geen twijfel bestaan. Efficiency-maatregelen kunnen dit, denk ik, maar zeer ten dele opvangen. Ook een gegeven is, dat de arbeidsinspectie niet onbeperkt uitgebreid kan worden. Er zal naar andere wegen gezocht moeten worden, en éen daarvan ligt in de taken die de arbeidsinspectie toebedeeld zijn of zullen worden. Ik zal daar nog nader in het slothoofdstuk ingaan.

Een tweede knelpunt betreft de jaarverslagen en rapportages. Toegegeven moet worden, dat het verdrag op dit punt wel erg gedetailleerd is. Men kan zich afvragen of een dergelijke krachtsinspanning nog wel verant- 
woord is. Ik denk het wel, In de eerste plaats is het een verantwoording van hetgeen de arbeidsinspectie als zodanig heeft gedaan in het kader van de uitoefening van de aan haar toevertrouwde taken. In de tweede plaats kan door middel van dergelijke verslagen en rapportages op knelpunten gewezen worden, die bijvoorbeeld kunnen bestaan tussen wet en praktijk en derhalve als bron van beleid, al dan niet neergelegd in wetgeving, kunnen fungeren. In de derde plaats kan het jaarverslag dienen als een informatiebron voor allen, die willen weten hoe het in ons land er yoor staat op het terrein van de arbeidsomstandigheden/het arbeidsomstandighedenrecht.

\section{Het Verdrag betreffende de arbeidsinspectie in de llandbouw ${ }^{193}$}

Op 4 juni 1969 werd tijdens de te Geneve gehouden Internationale Arbeidsconferentie werd het Verdrag betreffende de arbeidsinspectie in de landbouw aangenomen en werd tevens een daarbij behorende aanbeveling alanvaard ${ }^{164}$.

\subsection{De verplichting tot het hebben van een arbeidsinspectie in de landbouw}

Op grond van artikel 3 van het verdrag moet iedere lid-staat van de Internationale Arbeidsorganisatie die het verdrag heeft bekrachtigd een arbeidsinspectie voor de landbouw bezitten. Het verdrag is bekrachtigd en op 29 juni 1974 voor ons land in werking getreden ${ }^{195}$.

\subsection{Een afzonderlijke arbeidsinspectie in de landbouw?}

Het nu te behandelen verdrag schrijft in artikel 7 voor, dat de arbeidsinspectie in de landbouw onder toezicht en controle van een centraal orgaan dient te staan, woor zover dit met de administratieve praktijk van een lid-staat te verenigen is ${ }^{108}$.

Het verdrag geeft in hetzelfde artikel vier mogelijkheden ter zake van het beginsel dat er controle en toezicht uitgeoefend dient te worden door een centraal orgaan, namelijk door:

1. én dienst voor de arbeidsinspectie, bewoegd voor alle sectoren van het economische leven;

2. eén dienst voor de arbeidsinspectie, waarbij in een interne functionele specialisatie wordt voorzien door middel van een passende opleiding, voor inspecteurs die hun functie in de landbouwsector moeten uitoefenen;

3. Een dienst voor de arbeidsinspectie, waarbij in een interne institutionele specialisatie wordt voorzien door de instelling van een op dat gebied competente dienst, waarvan de ambtenaren hun functie in de landbouw zouden uitoefenen;

4. een gespecialiseerde arbeidsinspectie in de landbouw, onder supervisie van een centraal orgaan, waaraan dezelfde uitsluitende bevoegdheid is toegekend ten aanzien van de arbeidsinspectie in andere sectoren van het economische leven, zoals de industrie, het vervoer en de handel.

"The application of Convention No. 129 does thus not necessarily imply the establishment

of special inspection services for agriculture",

aldus het comite van deskundigen ${ }^{197}$. Voor ons land is dat dan ook niet gebeurd. In ieder district van de arbeidsinspectie zijn ambtenaren aanwezig, die de landbouw tot het werkterrein hebben. Met de reorganisatie van de het directoraat-generaal van de Arbeid is de functie van landbouwkundige bij de arbeidsinspectie komen te vervallen. Het comite van deskundigen ${ }^{188}$ heeft al gewezen op het tekort aan personeel en de redenen waarom met betrekking tot de arbeidsinspectie in de landbouw ${ }^{189}$ en is daarover met de Nederlandse regering in discussie. Hiermee wordt impliciet aangegeven, dat men twijfels heeft over het feit of ons land voldoet aan de verdragsverplichtingen terzake. 
Dit verdrag betreffende de arbeidsinspectie in de landbouw kont voor wat betreft de structuur overeen met het hiervoor behandelde verdrag terzake van de arbeidsinspectie in industrie en handel. Well houden de artikelen 4 en 5 rekening met de bijzondere verhoudingen in de agrarische sector: het toepassingsgebied van het verdrag is beperkt tot werkmemers, die geen gezinslid zijn van het hoofd wan de ondernemilng en leerlingen, die feitelijk in de landbouw werkzaam zijn. De mogelijkheid bestaat evenwel dat een lid-staat, die het verdrag bekrachtigt, ook éen of meer in artikel 5 genoemde andere groepen agrarische werkers onder het toezicht van de arbeidsinspectie doet vallen.

Het verdrag wijkt op een aantal punten af van Verdrag no. 81. Het betreft de facultatieve bepalingen vervat in het tweede lid van de artikelen 6,8 en 12 met betrekking tot respectievelijk de taak, de rechtspositie van de ambtenaren en de samenwerking met andere diensten of openbare of erkende instellingen die soortgelijke werkzaamheden verrichten. De toenmalige bewindsman maakte duidelijk dat van deze facultatieve bepalingen geen gebruik zal worden gemaakt ${ }^{200}$.

In artikel 16 wordt voorzien dat bij een inspectiebezoek de inspecteur niet alleen de werkgever of diens vertegenwoordiger, maar ook de werknemers of hun vertegenwoordigers in kennis moet stellen van zijn aanwezigheid, tenzij hij meent, dat een dergelijke kennisgeving de doeltreffendheid van de controle zou kunnen schaden $^{201}$. Ook dienen de vertegenwoordigers van de werknemers op grond van artikel 18 van het verdrag in kennis te worden gesteld van de geconstateerde tekortkomingen en de eventueel door de arbeidsinspectie voorgeschreven veiligheidsmaatregelen die getroffen moeten worden.

Nieuw ten opzichte van het verdrag betreffende de arbeidsinspectie in de industrie en handel is het bepaalde in artikel 17 waarin aan de arbeidsinspectie in de landbouw een preventieve taak is toebedeeld met betrekking tot nieuwe installaties, stoffen en produktiemethoden. Daarbij moet wel aangetekend worden, dat aambeveling no. 81 betreffende de arbeidsinspectie al een dergelijke bepaling bevat. 
1. Richtlijn van 23 november 1988 , Pb. L. $325 / 55$.

2. Opgemerkt dient te worden, dat het controlebeleid niet voldoet aan de formele noch aan de materiële vereisten van de richtlijn. Aanvulling van regelgeving is derhalve noodzakelijk. De voorschriften richten zich tot de opsporingsdiensten van de overheid en kunnen niet als een algemeen naar buiten werkende regeling worden beschouwd; het betreft regelingen met een zuiver intern karakter. Bewindslieden kunnen krachtens een hun van oudsher toekomende bevoegdheid algemene regels stellen om de interne organisatie van de rijksdienst te regelen. Het verplichtende karakter van deze regels worden geacht te berusten op de plicht van de ambtenaren (en andere medewerkers) om algemen aanwijzingen van het bevoegd gezag betreffende het interne functioneren van de dienst te gehoorzamen; zie Commissie Wetgevingsvraagstukken, Eindrapport Orde in de regelgeving, "s-Gravenhage $1985, \mathrm{blz}, 16.17$. Aan de bedoelde EG-richtlijn kan mijns inziens voldaan worden door het door de betrokken bewindslieden opstellen van richtlijnen, die bekendgemaakt worden in de Stert.. Daardoor verliezen de richtlijnen hun niet-dwingende karakter; de bewindslieden verplichten zich jegens een ieder overeenkomstig deze richtlijnen te handelen. Bovendien brengt publikatie met zich, dat minder snel tot wijziging zal worden overgegaan, dan wanneer er sprake is van een (niet-gepubliceerde) interne instructie, met andere woorden: de bewindslieden verplichten zichzelf ook.

3. Aanbeveling 1923, no. 20. Zie Tweede Kamer, zitting 1924 - 1925, 223.2 ( nota nopens de aanbeveling betreffende de algemeene beginselen voor de inrichting en de bevoegdheden van de Arbeidsinspectie ). De tekst van de aanbeveling is bij deze nota als bijlage bijgevoegd.

4. Wisselend naar gelang de opvattingen, gebruiken of zeden van de verschillende landen konden aan de inspecteurs nevenfuncties worden opgedragen. Daarbij golden de volgende voorwaarden:

a. dat zij in niets de uitoefening van de hoofdtaak van de inspecteurs mochten schaden;

b. dat zij zoveel mogelijk door de aard van de werkzaamheden zelf verband hielden met het oorspronkelijke doel van de inspectie, namelijk de bescherming van de gezondheid en de veiligheid van de arbeiders; c. dat zij in geen enkel opzicht het gezag of de onpartijdigheid konden schaden, die de inspecteurs tegenover werkgevers en arbeiders in acht dienden te nemen.

5. Overigens werd tevens voorgeschreven, dat de inspecteurs alvorens te vertrekken, waar mogelijk, de ondernemer of diens plaatsvervanger op de hoogte moesten brengen van het bezoek.

6. Zie Hfdst. 14 par. 4.3 ( het betreden van plaatsen ).

7. Zie Hfdst. 14 par. 4.2 ( de plicht om te spreken en het recht om te zwijgen ). Zie ook Hfdst. 8 par. 11 ( uitvoering van de Arbeidswet 1919), waar een voorbeeld van de bedoelde ongewenste druk op degene van wie bepaalde inlichtingen worden gevraagd, is gegeven.

8. Zie A.J.C.M. Geers, t.a.p., blz. 58 - 59; B. Clausing, Aansprakelijkheid van werkgever en derden, in het bijzonder tegen de ongevalsgetroffenen in de Ongevallenwet en in het ontwerp WAO, in S.M.A. 1964 blz. $407-408$.

9. Zie de artikelen 10 van de Arbeidswet $1919 j^{\circ} 67 \mathrm{~h}$ van het Arbeidsbesluit 1920 en 7 van de Veiligheidswet 1934. 
10. Zie Hfdst. 9 par. 4 (werkzaamheden in verband met wetten waarvan de handhaving en de medewerking aan de uitvoering geheel of gedeeltelijk aan de arbeidsinspectie was opgedragen ).

11. Indien de industrie van een land zo belangrijk is, dat de benoeming van meer dan eén hoofdinspecteur vereist is, zouden deze van tijd tot tijd bijeen moeten komen, om de vragen die zich hebben voorgedaan in hun inspectiegebied omtrent de toepassing van de wet en de verbetering van de arbeidsvoorwaarden te bespreken; zie par. 9 van de aanbeveling.

12. Zie Hfdst. 6 par. 2 (de Arbeidswet 1911 ).

13. Zie Hfdst. 8 par. 6 (de uitwerking van de regeling van de arbeidsinspectie).

14. Voorwaarde was, dat zij de "noodlige oefening en ondervinding" bezaten; zie par. 12 van de aanbeveling.

15. Zile artikel 6 van het Organisatiebesluit ( Stb. 1920720 ).

16. Zie Hfdst. 14 par. 5.6 ( de geheimhoudingsverplichting in de Arbeidsomstandighedenwet).

17. Zie Hfdst. 8 par. 2 (de Hooge Raad van Arbeid).

18. Zie bijvoorbeeld Hfdst. 9 par. 14 (de Steenhouwerswet 1921 ) en par. 15 ( de Veiligheïdswet).

19. A.N. Molenaar, De naleving van arbeidsconventies, 's-Gravenhage 1938, blz. 18 - 19.

20. Verdrag no. 81; zie Trb. 1951140 en de Wet van 9 september 1949, Stb. J. 424.

21. Nadat door het Internationale Arbeidsbureau eerst nog nadere inlichtingen aan de regeringen waren gevraagd.

22. Aanbeveling no. 81. Zie Tweede Kamer, zitting 1948 - 1949, 1352.1 (brief met nota die betrekking heeft op twee door de ILO aangenomen aanbevelingen betreffende de arbeidsinspectie ). De tekst van de aanbeveling is als bijlage bij de nota gevoegd.

23. Zie de artikelen $3 \mathrm{t} / \mathrm{m} 21$ van het verdrag.

24. Artikel 24 van het verdrag verklaart de artikelen $3 \mathrm{t} / \mathrm{m} .21$ van overeenkomstige toepassing ten aanzien van de arbeidsinspectie voor handelsinrichtingen.

25. Zie Tweede kamer, zitting 1948 - 1949, 1195.3 (memorie van toelichting van de Wet van 9 september 1949, Stb. J.424, houdende voorbehoud der bevoegdheid tot toetreding tot het verdrag) blz. 1.

26. Zie Trb. 1951140.

27. De zgn. "oog- en oorfunctie" van de arbeidsinspectie.

28. Zie bijv. de artikelen $2 \mathrm{t} / \mathrm{m} 7$ van aanbeveling no. 81 , betreffende de arbeidsinspectie; zie Tweede kamer, zitting 1948 - 1949, 1352.1 ( brief van de minister van Sociale Zaken bij een nota met betrekking tot twee door de LAO aangenomen aanbevelingen betreffende de arbeidsinspectie ). 
29. ILO, Labour Inspection, general Survey by the Committee of Experts on the Application of Conventions and Recommendations, International Labour Conference, 71st Session, Geneva 1985 ( hierna ILO, Labour Inspection ), p. 25.

30. Zie ILO, The Organisation of Labour Inspection in Industrial and Commercial Undertakings, Report IV, International Labour Conference, 30th Session, Geneva 1947 ( hierna ILO, The Organisation of Labour Inspection ), p. 17 ut/incl 24 en p. 125 - 126.

31. Zie ILO, The Organisation of Labour Inspection, p. 21 - 22.

32. Zie ILO, Labour Inspection, p. 27.

33. In dit verband mag verwezen worden naar de rede van de directeur-generaal van de Arbeid van 30 mei 1986 ter gelegenheid van het 75 -jubileum van de Vereniging van controleurs, waarin hij stelt, dat een inspecteur van de arbeid niet kan volstaan met signaleren en onderzoeken van problemen, maar dat deze aangepakt moeten worden en dat daarbij gebruik gemaakt kan worden van instrumenten en methoden, zoals: "overleggen, voorlichten, adviseren, ........".

34. Zie ook G.P.A. Aler, t.a.p., blz. 134 - 135.

35. Brief van 2 maart 1989, DGA/AIB/WJZ/8904150, aan de Landelijke vergadering van economische officieren van justitie met als bijlage een ontwerp Hoofdlijnen van de uitvoering van het handhavingsbeleid Arbowet ( hierna Ontwerp-handhavingsbeleid ). Medio 1990 verscheen een folder van het directoraat-generaal van de Arbeid onder de titel: Arbeidsinspectie en handhaving. Deze folder gaat, anders dan de titel suggereert alleen over de handhaving van de Arbeidsomstandighedenwet

36. In het Ontwerp-handhavingsbeleid wordt gesproken van "het constateren van overtredingen". Ik geef als gevolg van het onderscheid tussen toezicht en opsporing, echter de voorkeur aan de gekozen formulering.

37. Zie ILO, Labour Inspection, p. 33.

38. ILO, Labour Inspection, p. 35.

39. Voorbeelden zijn:

- Bouw en inrichting van bedrijfsruimten, 7e druk 1983 ( P30);

- Veilig werken met bestrijdingsmiddelen in de land- en tuinbouw, 4e druk 1972 ( P42);

- Aanwijzingen tot het voorkomen van koolmonoxidevergiftiging, 1963 ( P67).

40. J. van der Hoeven, Pseudo-wetgeving, Zwolle 2e druk 1967, heeft deze term geïntroduceerd. Het betreft hier een vorm van regelgeving door een bestuursorgaan zonder dat het regelstellende orgaan op dit punt wetgevende bevoegdheid bezit; de betrokken partijen gedragen zich echter op dezelfde wijze alsof dit laatste wel het geval is. Zie J. van der Hoeven, t.a.p., blz. 4 - 5; zie ook L. Bleumer - Van der Klein/F. Hent, in AAe $1978 \mathrm{blz} .380 \mathrm{t} / \mathrm{m} 382$.

41. Voorbeelden zijn:

- Arbeidsveiligheidsrapport: Leidraad voor het samenstellen, 3e druk 1982 ( CP3 );

- Arbowet artikel 10: Jaarverslag, 1987 ( CP9);

- Laboratoria: Bouw en inrichting, 1988 (CP16-1). 
42. Voorbeelden zijn:

- De melding van beroepsziekten, vermoede beroepsziekten en "gevaar voor de gezondheid", welke in hoofdzaak door arbeid of arbeidsomstandigheden zijn veroorzaakt: Handleiding voor artsen, 1988 (CV7);

- Fysieke belasting, 1988 (CV9).

43. Voorbeelden zijn:

- Checklist procesinstallaties. Aandachtspunten voor een veilig ontwerp, 2e druk 1986 ( V11 );

- Werktijden: wet en wens, arbeidstijd, bedrijfstijd, vrije tijd, 1989 ( V17 ).

44. Voorbeelden zijn:

- Experimenten met chloor (Nederlandse en Engelse versie), verfilming van experimenten die werden gehouden om antwoord te krijgen op vragen over de gevolgen van een ongeval met chloor;

- Ik leef nog ( Nederlandse versie), Gevaren in de landbouw. Aandacht voor veiligheidsmaatregelen. Gesprekken met personen die ervaringen hebben met ongevallen;

- Veilig werken in besloten ruimten ( Nederlandse, Arabische, Turkse en Marokkaanse versie ).

45. Zie voor een volledig overzicht: DG Arbeid, Publikaties arbeidsinspectie lijst 1, Voorburg ( juli ) 1989.

46. Arbo'91 in kort bestek (Werkplan Arbo'91), ( mei ) 1989, blz. 7.

47. ILO, Report of the Committee of Experts on the Application of Conventions and Recommendations, Report III ( Part 4 (a)), International Labour Conference, 61st. Session, Geneva 1976 ( hierna Report of the Committee of Experts 1976 ), p. 107.

48. ILO, Labour Inspection, p. 36.

49. Zie bijvoorbeeld Hfdst. 8 par. 6 ( de uitwerking van de regeling van de arbeidsinspectie ).

50. Zie Tweede Kamer, zitting 1985 - 1986, 16625.78 ( Heroverwegingen. Samenvattend Eindrapport 4de ronde ) blz. 4 en 32 .

51. Eindrapport van de werkgroep "Heroverweging gedeconcentreerde Rijksdiensten", ( januari ) 1985.

52. ILO, Report of the Committee of Experts on the Application of Conventions and Recommendations, Report III ( Part IV ), International Labour Conference, 30th Session, Geneva 1966 ( hierna Report of the Committee of Experts 1966 ), p. 211.

53. ILO, Labour Inspection, p. 40.

54. Zie Hfdst. 12 par. 12 ( werkzaamheden in verband met andere wetten waarvan de handhaving en de medewerking aan de uitvoering geheel of gedeeltelijk aan de arbeidsinspectie was opgedragen ).

55. J.H.B.M. Willems, t.a.p., blz. 10 - $\mathbb{1 1}$; zie vorige nt..

56. Onder "ongeval" moet ingevolge artikel 2, eerste lid, van het Besluit van 22 september 1987, Stcrt. 197, worden verstaan:

"een aan een werknemer in verband met het verrichten van arbeid overkomen ongewilde, plotselinge gebeurtenis, die schade aan de gezondheid of de dood tot vrijwel onmiddellijk 
gevolg heeft gehad en ertoe heeft geleid, dat de werknemer tussen de werktijd de arbeid heeft gestaakt en niet meer heeft hervat, dan wel met de arbeid geen aanvang heeft gemaakt".

57. Onder "ernstig lichamelijk" moet ingevolge artikel 2, tweede lid, van het Besluit van 22 september 1987 , Stcrt. 197, worden verstaan:

"schade aan de gezondheid, die binnen 24 uur na het tijdstip van de gebeurtenis leidt tot opname in een ziekenhuis ter observatie of behandeling, dan wel naar redelijk oordeel blijvend zal zijn".

58. Onder "grote materiële schade" moet ingevolge artikel 3 van het Besluit van 22 september 1987, Stcrt. 197 , worden verstaan:

"schade aan gebouwen, materieel, grondstoffen of produkten, die een rechtstreeks gevolg van een ongewenste gebeurtenis is, ten bedrage van ten minste $f 100000$. "

59. Onder "beroepsziekte" wordt ingevolge artikel 4 van het besluit van 22 september 1987, Stcrt. 197, verstaan:

"een ziekte of aandoening, die in hoofdzaak het gevolg is van arbeid of arbeidsomstandigheden".

60. ILO, Labour Inspection, p. 49.

61. Zie Hfdst. 13 par. 12 ( Hinderwet).

62. ILO. Labour Inspection, p. 55 - 56.

63. ILO, Labour Inspection, p. 50.

64. ILO, Labour Inspection, p. 52 .

65. Ingevoegd bij de Wet van 12 april 1989, Stb. 95. Dit artikel luidt:

"1. Het hoofd of de bestuurder is, voor zover zulks redelijkerwijs van hem geverdg kan worden, na een verzoek daartoe, verplicht de arbeids- en rusttijden van een zwangere arbeider zodanig in te richten, dat tegemoet gekomen wordt aan haar specifieke omstandigheden. Deze verplichting geldt eerst twee weken nadat het verzoek is gedaan.

"2. Het districtshoofd kan, op verzoek van het hoofd of de bestuurder of de zwangere arbeider, een uitsrpaak doen betreffende de naleving van het in het eerste lid, eerste volzin bepaalde. De werkgever is verplicht aan de uitspraak te voldoen".

De beide laatste artikelleden zijn procedurevoorschriften.

66. In het geval van een federale staat duidt de term "centrale autoriteit", hetzij de federale autoriteit, hetzij een centrale autoriteit van een samenstellende eenheid aan; zie artikel 4 , tweede lid, van het verdrag.

67. Report of the Committee of Experts 1966, p. 219.

68. Zie MO, The Organisation of Labour Inspection, p. $24-25$. 
69. Zie ILO, The Organisation of Labour Inspection, p. 25 ut/i 35. Als voorbeeld moge dienen de reactie van het Verenigd Koninkrijk op de vragen neergelegd in nt. 68.

"(a). No. A requirement that all labour inspection provided for under nationall laws should be under the exclusive control of a centrall authority would imply undue interference with the discretion of national Governments. Some requirements for the protection of workers are so closely allied to the general law relating e.g.s to the safe construction of buildings and to public health that their enforcement may well be entrusted to local government authorities responsible for enforeing the general law; and in the case of many classes of workplace, which are in any ewent inspected by inspectors of local authorities, these inspectors may well be entrusted concurrently with the enforcement of a wider range of requirements. National Governments should not therefore be prevented from ratifying the proposed Convention(s) by reason of the fact that their law and administrative structure are based upon a system of local governement. The Convention(s) may well, however, require that the central authority or its inspectors should have power to intervene in case of default on the part of a local authority.

(b) and (c). No other exceptions are suggested".

Zie ILO, The Organisation of Labour Inspection, p. 21.

70. ILO, The Organisation of Labour Inspection, p. 160.

71. MO, The Organisation of Labour Inspection, p. 32.

72. ILO, Labour Inspection, p. 63.

73. ILO, Labour Inspection, p. 68.

74. Besluit van 15 september 1988 , Stb. 432.

75. Tweede Kamer, zitting 1988 - 1989, 21283.2 ( Rapport Arbeidsinspectie) blz. 54.

76. Volgens vastgestelde regels en modelcertificaten.

77. Tweede Kamer, zitting 1988 - 1989, 21283.2 ( Rapport Arbeidsinspectie) blz. 58.

78. Tweede Kamer, zitting 1988 - 1989, 21283.2 (Rapport Arbeidsinspectie).

79. Zie het antwoord van staatssecretaris De Graaf van Socialle Zaken en Werkgelegenheid op vragen gesteld door het Tweede Kamerlid Leijnse ( lid van de PvdA-fractie) naar aanleiding van een uitgelekte versie van het rapport van de Algemene Rekenkamer over de arbeidsinspectie, in de Volkskrant van 19 augustus 1989; zie Aanh. Hand. Tweede Kamer, zitting 1988 - 1989, 878.

80. Zie ILO, The Organisation of Labour Inspection, p. 35 - 36.

81. Zie ILO, The Organisation of Laour Inspection, p. 36 ut/i 43 and p. 130 - 131. Zie ook ILO, Labour Inspection, p. 70 .

82. ILO, Report of the Committee of Experts on the Application of Conventions and Recommendations, Report III ( Part IV), International Labour Conference, 40th Session, Geneval 1957 ( hierna Report of the 
Committee of Experts 1957), p. 160, Report of the Committee of Experts 1966, p. 222. Zie ook ILO, Labour Inspection, p. 70 .

83. ILO, Labour Inspection, p. 69 .

84. Zie artikel 1 van het Organisatiebeshit Arbeidsinspectie, dat gebaseerd is op artikel 77 van de Arbeidswet 1919.

85. Zie voorts par." 3.7 . (verplichtingen).

86. Report of the Committee of Experts 1966, p. 222; HO, Labour Inspection, p. 71.

87. ILO, Labour Inspection, p. 71.

88. ILO, Labour Inspection, p. 71.

89. Report of the Committee of Experts 1966, $\mathrm{p}_{\mathrm{i}}$ 223, waarbij overigens verwezen wordt naar de opsomming, die in de vragenlijst aan de lid-staten is voorgelegd en in het ontwerp-verdrag voorkomt.

90. Zie artikel 5 van het Algemeen Rijksambtenarenreglement (Besluit van 12 juni 1931, Stb. 248 ).

91. ILO, Labour Inspection, p. 71.

92. Report of the Committee of Experts 1966, p. 223. Zie ook artikel 14 van de Aanbeveling inzake de arbeidsinspectie van 1923 , no. 20 .

93. ILO, Labour Inspection, p. 72 .

94. ILO, Labour Inspection, p. 72.

95. Het betreft hier een overzicht van, zowel de Centrale Dienst, als de arbeidsinspectie, de inspectie van de havenarbeid en de dienst voor het stoomwezen; een verdere uitsplitsing is in het Sociaal Jaarverslag van het Directoraat-Generaal van de Arbeid over 1988 ( hierna Sociaal Jaarverslag 1988) niet gemaakt.

96. Sociaal Jaarverslag 1988, blz. 17.

97. Besluit van 1 november $1983, \mathrm{Stb} .571$.

98. Alleen deze salarisschalen van deze toezichthoudende en opsporende ambtenaren van de arbeidsinspectie worden gegeven, omdat deze functies in artikel 1 van het Organisatiebesluit Arbeidsinspectie voorkomen en nog bestaan. Zie Hfdst. 12 par. 5 (Veranderingen in de wettelijke regeling van de organisatie van de arbeidsinspectie ). De salarisschalen van de bedrijfsorganisatorisch medewerker en de sociaal coördinator, die beide eveneens niet in het bedoelde artikel van het organisatiebesluit voorkomen en om die reden niet in het overzicht worden opgenomen, zijn beide 11 van het B.B.R.A..

99. Directoraat-Generaal van de Arbeid, Nota MD/loopbaanbeleid, Voorburg ( meil ) 1989. 
100. Namelijk de Centrale MD-commissie, bestaande uit de secretaris-generaal (voorzitter) en de directeuren-generaal, en de MD-commissie van het directoraat-generaal van de Arbeid; bestaande nit de directeurgeneraal van de Arbeid ( voorzitter), het districtshoofd van de arbeidsinspectie ( derde district), de directeur algemeen en intern beleid, de directeur veiligheid, het hoofd van de afdeling perosneel, organisatie en opleidingen, de MD-adviseur ( mevrouw Bouwens) en de tijdelijke project-directeur ( E.H. Siccama ).

101. Zie Directoraat-Generaal van de Arbeid, Sociaal Jaarverslag 1986, 1987 en 1988, resp. blz. 16 - 17, blz. $23 \mathrm{t} / \mathrm{m} 25$ en blz. $28 \mathrm{t} / \mathrm{m} 30$.

Voorwaarden zijn:

- er moet sprake zijn van moeilijk te krijgen personeel, dat zeer aantrekkelijk is op de externe arbeidsmarkt; - voor eigen ambtenaren geldt, dat zij op het einde van hun salarisschaal moeten zitten en geen directe promotie-mogelijkheden hebben;

- het gaat om bindingspremies, die binden voor een bepaalde periode; de bedragen zijn minimaal fl.5.000,-en maximaal f1.10.000,-- in 1987 en maximaal fl.15.000,-- in 1988.

102. ILO, Labour Inspection, p. 74.

103. ILO, Labour Inspection, p. $76-77$.

104. Sociaal jaarverslag over 1988, blz. 21. Wel dient opgemerkt te worden, dat het hier opleidingen betreft aangaande de totale personeelsbezetting van het directoraat-generaal van de Arbeid ( zie ook nt 94 ). Overigens vormt deze 1,6 miljoen gulden $2,2 \%$ van de totale loonsom van dit directoraat-generaal.

105. Zie Hfdst. 12 par 4. ( kritiek op de arbeidsinspectie; van het Project Ontwikkeling Arbeidsinspectie naar Arbo ${ }^{3} 91$ ).

106. Sociaal Jaarverslag over 1988 blz. 20 en blz. 22.

107. ILO, Labour Inspection, p. 105. Report of the Committee of Experts 1966, p. 245.

108. Zie ILO, The Organisation of Labour Inspection, p. 85 - 86 and 88 ut/i 92 .

109. Zie Tweede Kamer, zitting 1978 - 1979, 14497.5 (memorie van antwoord) blx. 22; Tweede Kamer, zitting 1979 - 1980, 14497.11 ( nota naar aanleiding van het eindverslag) blz. $5 \mathrm{t} / \mathrm{m} 7$. Zie ook Tweede Kamer, zitting $1978-1979,14497.9$ ( eindverslag ) blz. 8.

110. Tweede Kamer, zitting 1978 - 1979, 14497.5 ( memorie van antwoord ) blz. 22.

111. Tweede Kamer, zitting 1979 - 1980, 14497.9 ( eindverslag ) blz. 8.

112. Met name door de leden van de S.G.P.- en de P.P.R.-fractie; zie Tweede Kamer, zitting 1979 - 1980, 14497.9 ( eindverslag ) blz. 8.

113. C.N.V., Brief van 30 mei 1979 aan de Vaste Commissie van de Tweede Kamer, betreffende het: Gewijzigd ontwerp Arbeidsomstandighedenwet.

114. Tweede Kamer, zitting 1979 - 1980, 14497.11 ( nota naar aanleiding van het eindverslag ) blz. 7.

115. Tweede Kamer, zitting 1985 - 1986, 19200.14 ( Hfdst. XV Sociale Zaken en Werkgelegenheid ) blz. 6. 
116. Tweede Kamer, zitting $1988-1989,21283.2$ ( Rapport Arbeidsinspectie) blz, 23, Aanh. Hand. Tweede Kamer, zitting 1988 - 1989, 878 ( zie ook nt. 76 ).

117. Zie Tweede Kamer, zitting 1988 - 1989, 21283.2 ( Rapport Arbeidsinspectie) blz.23.

118. Zie Tweede Kamer, zitting 1988 - 1989, 21283.2 (Rapport Arbeidsinspectie) ). Zie ook Jaarverslag Arbeidsinspectie over 1983, ble. 52 - 53, Jaarverslag Arbeidsinspectie en Inspectie van de Havenarbeid over 1984, blz. 37 - 38; Jaarverslag Directoraat-Generaal van de Arbeid over 1985 en over 1986, resp. blz. 32 33 en blz. $27-28$.

119. Tweede Kamer, zitting 1988 - 1989, 21283.2 ( Rapport Arbeidsinspectie) blz. 23.

120. ILO, Labour Inspection, p. 108.

121. ILO, Labour Inspection, p. 110 .

122. ILO, Labour Inspection, p. 111.

123. ILO, Labour Inspection, p. 111. Verwezen wordt naar: ILO, Report of the Tripartite Mission on Labour Inspection in Norway, Geneva 1979.

124. Districtshoofd van het zesde district (oud) te Haarlem; inmiddels plaatsvervangend secretaris-generaal van Sociale Zaken en Werkgelegenheid.

125. Zie Ministerie van Sociale Zaken en Werkgelegenheid, Sociaal Jaarverslag 1988, blz. 25.

126. Directoraat-Generaal van de Arbeid, Sociaal Jaarverslag 1986, 1987 en 1988, resp. blz. 18, blz. 11 en blz. 18.

127. Zie ILO, The Organisation of Labour Inspection, p. $25 \mathrm{ut} / \mathrm{i} 35$.

128. ILO, The Organisation of Labour Inspection, p. 32, p. 34 and p. 35 .

129. ILO, Labour Inspection, p. 114.

130. ILO, Labour Inspection, p. 116 ut/i 118.

131. Tweede Kamer, zitting 1988 - 1989, 21283.2 ( Rapport Arbeidsinspectie ), blz. 25 - 26.

132. Zie voor een oordeel van de Algemene Rekenkamer over de in de twee bedoelde districten aanwezige gegevensbestanden, aan de hand van de systematiek, de inrichting en de actualiteit van de gegevens: Tweede Kamer, zitting 1988 - 1989, 21283.2 (Rapport Arbeidsinspectie ) blz, 26 ( schema 4 Kwaliteit gegevensbestanden ).

133. Report of the Committee of Experts 1966, p. 248.

134. ILO, The Organisation of Labour Inspection, p. 188. 
135. ILO, Record of Proceedings, International Labour Conference, 30 th Session, Geneva 1948 ( hierna Records of Proceedings 1948 ), p. 505. Zie ook ILO, Labour Inspection, p. 120.

136. ILO, Labour Inspection, p. 123.

137. Tweede Kamer, zitting $1978-1979,144975$ ( memorie van antwoord ) blz. 22.

138. Tweede Kamer, zitting 1988 - 1989, 21283.2 (Rapport Arbeidsinspectie) blz. 23.

139. Tweede Kamer, zitting 1988 - 1989, 21283.2 ( Rapport Arbeidsinspectie) blz. 24.

140. In de betreffende jaarverslagen wordt informatie verstrekt over het aantal vestigingen in het geautomatiseerdle CRS-bestand: het aantal geregistreerde vestigingen betreft over $1983 \mathrm{t} / \mathrm{m} 1985$ resp. 381761,419613 en 44486. Zie Jaarverslag Arbeidsinspectie over 1983, blz. 137; Jaarverslag Arbeidsinspectie en Inspectie van de Havenarbeid over 1984, blz. 99; Jaarverslag Directoraat-Generaal van de Arbeid over 1985, blz. 107. Overigens is het aantal vestigingen in 1986 en 1988, resp. 450.045 en 520.220. Zle Jaarverslag Directoraat-Generaal van de Arbeid over 1986, blz. 92; Directoraat-Generaal van de Arbeid Jaarverslag 1988, blz. 41. Het Jaarverslag Directoraat-Generaal van de Arbeid over 1987 bevat hierover geen informatie.

141. Ook hier geven de betreffende jaarverslagen een ander beeld waar het bezoeken van vestigingen van bedrijven betreft, namelijk resp. 76968, 78974 en 72669. Zie Jaarverslag Directoraat-Generaal van de Arbeid over 1985, blz. 109 .

142. Tweede Kamer, zitting 1988 - 1989, 21283.2 ( Rapport Arbeidsinspectie) blz. 24.

143. Zie Tweede Kamer, zitting 1988 - 1989, 21283.2 (Rapport Arbeidsinspectie) blz. 64.

144. Aanh. Hand. Tweede Kamer, zitting $1988-1989,878$.

145. Directoraat-generaal van de Arbeid, Typologie van objectorganisaties, ( februari ) 1987.

146. Hfdst. 13 par. 4.3. ( het betreden van plaatsen).

147. Zie A.J.C.M. Geers, t.a.p., blz. 187.

148. Zie artikel 67, eerste lid, tweede volzin, van de Arbeidswet 1919.

149. Zie artikel 69, onder $b, j^{\circ}$ artikel 68 , eerste lid, onder $b$, van de Arbeidswet 1919.

150. Zie artikel 68, eerste lid, onder a, van de Arbeidswet 1919.

151. Zie artikel 69, onder e, van de Arbeidswet 1919.

152. Zie de artikelen 32, derde lid, en 33, tweede lid, van de Arbeidsomstandighedenwet. Zie ook artikel 79, tweede en derde lid, van de Arbeidswet 1919.

153. Zie artikel 14, tiende, onder $\mathrm{d}$, van de Arbeidsomstandighedenwet. 
154. Directoraat-Generaal van de Arbeid, Hoofdafdeling voor Sociaal bedrijfsbeleid, Het uitvoeringsbeleid met betrekking tot het vergezelrecht, Voorburg ( juli ) 1985, blz. 3; zie ook A.J.C.M. Geers, t.a.p., blz. 186.

155. ILO, Labour Inspection, p. 89.

156. Behoudens het recht op beroep, hetzij door middel van het zgn. administratieve beroep, hetzij door middel van de zgn. administratieve rechtspraak.

157. ILO, Labour Inspection, p. 90.

158. Zie artikel 36 van de Arbeidsomstandighedenwet.

159. Hfdst. 10 par. 4 ( een bijzondere bevoegdheid van het districtshoofd van de arbeidsinspectie in het kader van de Asbeidswet 1919 en de Veiligheidswet 1934 ). Deze bevoegdheid komt ook voor in de Arbeidsomstandighedenwet: zie Hfdst. 12 par 3 (de Veiligheidswet 1934 en de Arbeidsomstandighedenwet).

160. Zie ILO, Labour Inspection, p. 96.

161. Zie artikel 81 van de Arbeidswet $1919 j^{\circ}$ artikel 4 van het Organisatiebesluit.

162. Deze geheimhoudingsplicht geldt tevens voor het geval zij de dienst verlaten hebben.

163. Hfdst. 13 par. 5 ( de geheimhoudingsverplichting ).

164. Zie hfdst. 12 par. 5 ( veranderingen in de wettelijke regeling van de organisatie van de arbeidsinspectie).

165. Deze jaarverslagen moeten weer binnen 3 maanden na verschijning de directeur-generaal van de ILO worden toegezonden.

166. Zie Directoraat-Generaal van de Arbeid Jaarverslag 1988, blz. 41 (tabel 1). Dergelijke informatie was in de jaarverslagen tot 1987 telkens opgenomen; zie bijvoorbeeld Jaarverslag Arbeidsinspectie over 1983, blz. 137 (tabel 4a); Jaarverslag Arbeidsinspectie en Inspectie van de Havenarbeid over 1984, blz. 99 (tabel 4a); Jaarverslag Directoraat-Generaal van de Arbeid over 1985, over 1986, resp. blz. 106 (tabel 5a) en blz. 92 (tabel 5.1.1a).

167. Jaarverslag Directoraat-Generaal van de Arbeid over 1987, blz. 26 (tabel 1 ); Directoraat-Generaal van de Arbeid Jaarverslag 1988, blz. 41 ( tabel 2 ).

168. Zie Jaarverslag Arbeidsinspectie over 1983, blz. 137 ( tabel 4c ); Jaarverslag Arbeidsinspectie en Inspectie van de Havenarbeid over 1984, blz. 99 ( tabel 4c); Jaarverslag Directoraat-Generaal van de Arbeid over 1985, over 1986, resp. bliz. 106 ( tabel 5c) en blz. 92 (tabel 5.1c).

169. Jaarverslag Directoraat-Generaal van de Arbeid over 1987, blz. 29 ( tabel 5 ); Directoraat-Generaal van de Arbeid Jaarverslag 1988, blz. 44 ( tabel 9 ).

170. Directoraat-Generaal van de Arbeid Jaarverslag 1988, blz. 41 ( tabel 3 ). 
171. Zie bijwoorbeeld Jaarverslag Arbeidsinspectie en Inspectie van de Havenarbeild over 1984, blz. 107 - 108 (tabel 9 en 9.4 ), blz. 123 (tabel 26 ), blz 126 (tabel 30 ), blz. 127 ( tabel 32 ), blz. 134 ( tabel 39), blz. 135 ( tabel 40 ).

172. Directoraat-Generaal van de Arbeid Jaarverslag 1988, blz $41 \mathrm{tm} 43$ (tabell $3 \mathrm{t} / \mathrm{m} 5$ ).

173. Jaarverslag Directoraat-Generaal van de Arbeid over 1987, blz. $31 \mathrm{t} / \mathrm{m} 33$ (tabel 7 ); Directoraat-Generaal van de Arbeid Jaarverslag 1988, blz. $44 \mathrm{t} / \mathrm{m} 46$ (tabel 10). De infomatie, die in deze tabellen is verwerkt, is ontleend aan gegevens van het Centraal Bureau voor de Statistiek.

174. Directoraat-Generaal van de Arbeid Jaarverslag 1988, blz. 46 (tabel 11 ).

175. Trouwens ook in de eerdere jaarverslagen.

176. E. Vanvugt, Wat duinwater van de patroon, in De Volkskrant van 24 februari 1990 , schrijft, dat het jaarverslag van de arbeidsinspectie oogt als een "glossy full-color tijdschrift".

177. Dit veiligheidsbesluit wordt op grond van artikel 47, onder a, van de Arbeidsomstandighedenwet te zijn vastgesteld krachtens die wet.

178. Zie voor de werknemersverplichting ter zake artikel 217 van het Veiligheidsbesluit voor fabrieken of werkplaatsen 1938 .

179. Zie in dit veband ook HR 19 september 1988, NJ 1989145.

180. Zie Hfdst 12 par. 3 ( de Veiligheidswet 1934 en de Arbeidsomstandighedenwet).

181. Zie artikel 83 (oud) van de Arbeidswet 1919.

182. Wet van 11 februari 1988 , Stb. 77.

183. Wet van 31 maart 1983, Stb. 153.

184. Zie de artikelen 83, derde lid, jo 82quinquies van de Arbeidswet 1919.

185. Zie artikel 83, zesde lid, (oud) van de Arbeidswet 1919.

186. Zie artikel 57 van de Arbeidsomstandighedenwet.

187. Zie de artikelen 2 , vierde lid, $j^{\circ} 1$, onder $4^{\circ}$, van de Wet op de economische delicten.

188. Zie artikel 37 van de Arbeidsomstandighedenwet.

189. Zie de artikelen $57 \mathrm{j}^{\circ} 30$, tweede lid, van de Arbeidsomstandighedenwet.

190. Dit voorbeell is ontleend aan artikel 85 van de Arbeidswet 1919.

191. Zie artikel 180 van het W.v.Sr.. 
192. Zie Hof Arnhem 19 juli 1905, W.8312, waarin het achtervolgen van een stroper door een ambtenaar als een geval van handelend optreden werd bestempeld. De achtervolging is een handeling en zij richt zich direct tegen degene die achtervolgd wordt.

193. Verdrag no. 129. Zie Trb. 197074.

194. Aanbeveling no. 133 .

195. Zie Trb. 1973137 .

196. In geval van een federale staat kan de uitdrukking "centraal orgaan" een orgaan aanduiden op federaal niveau dan wel op het niveau van een deelgebied van een federatie; zie artikel 7, tweede lid, van het verdrag.

197. ILO, Labour Inspection, p. 58 .

198. ILO, Labour Inspection, p. 108.

199. Zie nt. 108 .

200. Tweede Kamer, zitting 1972 - 1973, 12346.1 (brief met toelichtende nota ).

201. Zie artikel 12, tweede lid, van Verdrag no. 81. 


\section{SLOTBESCHOUWING EN SAMENVATTING}

\section{Inleiding}

Deze studie bevat de resultaten van een onderzoek naar naar de ontwikkeling van de arbeidsinspectie in een veranderende wetgeving. Dit afsluitende hoofdstuk bevat een slotbeschouwing waarin antwoord wordt gegeven op de nog resterende vraag in hoeverre kennis uit het verleden kan worden benut in het kader van toekomstige ontwikkelingen bij de arbeidsinspectie en haar beleidsterreinen. Daarbij komen onder meer de ontwikkeling van het rechtsgebied arbeidsomstandighedenrecht en de nadruk die daarbij ligt op de strafrechtelijke sanctionering aan de orde. In het kader van de handhaving van de onder de arbeidsinspectie regarderende wetgeving doe ik de suggestie om selectiever met de strafrechtelijke sanctionering om te gaan. Tot slot wordt dit hoofdstuk afgesloten met een samenvatting.

\section{Slotbeschouwing}

Hoe kan nu de kennis uit het verleden worden benut in het kader van toekomstige ontwikkelingen bij de arbeidsinspectie en haar beleidsterreinen?

Er blijkt een zekere spanning te bestaan tussen de redenen, die aan het instellen van de arbeidsinspectie als afzonderlijk orgaan ten grondslag lagen en de praktische uitwerking ervan. Zo was de arbeidsinspectie niet alleen een toezichthoudende en opsporende instantie terzake van de uitgevaardiggde arbeidersbeschermende wetgeving, maar diende de dienst tevens te fungeren als informatiebron terzake van de factor arbeid, terwijl grote terughoudendheid bestond ten aanzien van het aanstellen van voldoende ambtenaren. Vervolgens wordt de geschiedenis van de arbeidsinspectie en van haar werkterrein gekenmerkt door spanning tussen de wettelijke en de feitelijke taakstelling. Deze ruimere feitelijke taakstelling gecombineerd met het feit, dat de arbeidsinspectie lange tijd de enige overheidsinstantie is geweest, die zich op sociaal-economisch terrein bewoog, leidde tot een zich steeds maar uitbreidend werkterrein, dat boven haar oorspronkelijke wettelijke werkterrein, de arbeidersbescherming, uitsteeg. Inmiddels is de feitelijke taakstelling van de arbeidsinspectie beperkt door de zich na de Tweede Wereldoorlog verder uitbreidende overheidsbemoeienis op sociaal-economisch terrein, met een toename van bijzondere overheidsdiensten op dit terrein. De activiteiten van de arbeidsinspectie zijn daardoor teruggebracht naar haar oorspronkelijke wettelijke taakstelling, de arbeidersbescherming. Maar ook de ontwikkelingen op dit gebied stonden niet stil; de bescherming van de arbeider tegen gevaren, die uit het verrichten van arbeid voortvloeiden, ontwikkelde zich tot het arbeidsomstandighedenrecht, waarin al die factoren, die in het arbeidsmilieu en met betrekking tot de werkende mens een rol spelen. Maar, hoewel haar feitelijke en wettelijke taakstelling integreren, de arbeidsinspectie wordt geconfronteerd met een aantal feitelijkheden waar zij niet of nauwelijks invloed op kan uitoefenen, doch die van betekenis zijn voor de wijze waarop zij de haar opgedragen taken vervuld of kan vervullen, zoals de dualistische taakstelling en de onvoldoende personele bezetting.

Uit honderd jaar arbeidsinspectie kan mijns inziens worden afgeleid, dat de destijds door de drie inspecteurs van de arbeid ingeslagen weg, waarbij de nadruk lag op signaleren, informeren en voorlichten, een belangrijk stempel heeft gedrukt op de werkzaamheden van de arbeidsinspectie. Het informeren en voorlichten resulteerde in een coöperatieve instelling van de dienst, een bereidheid om mee te denken over het aanbrengen van veranderingen en verbeteringen op het terrein van de arbeidsomstandigheden. Het enige nadeel aan dit soort activiteiten voor de arbeidsinspectie verbonden is, dat het resultaat heel vaak niet direct zichtbaar is en dat dit bovendien van geval tot geval kan verschillen. Al deze activiteiten brachten tevens met zich, dat de arbeidsinspectie zonder enige twijfel de drijvende kracht is geweest en nog is achter menige regeling op 
sociaal terrein en op het terrein van het arbeidsomstandighedenrecht. Met name waar het dit laatste betreft, gaat het wooral om aanpassingen en veranderingen en het witvaardigen van geheel nieuwe, strafrechtelijke wetgeving. Het is dan ook niet vreemd, dat het vooral de arbeidsinspectie is, die belast is met de controle op de naleving hierwan. Het is dit aspect van de taak van de arbeidsinspectie, het controleren en handhaven, waar de kritiek op de arbeidsinspectie zich op richt'. Dat laatste is niet verwonderlijk, omdat van controle en handhaving een direct effect wordt verwacht.

Uit de ontwikkeling van het arbeidsomstandighedearecht kan worden afgeleid, dat de wetgever de in dat kader uitgevaardigde normen met een zeker automatisme in de strafrechtelijke sfeer heeft getrokken. Wellicht is dit het gevolg van het feit, dat de arbeidsinspectie veelal aan de basis van de regeling staat en zij niet alleen haar bestaan, maar ook haar wettelijke taakstelling ontleent aan een bijzondere strafwet, de Arbeidswet 1889. Men zou dus kunnen spreken van een soort "strafrecht-cultuur". Door op de uitgevaardigde normen een strafsanctie te stellen wekt de wetgever toch op zijn minst de verwachting, dat de overheid in staat is de handhaafbaarheild hiervan af te dwingen; de praktijk leert echter dat het anders is. Met andere woorden: door ongenuanceerd te kiezen voor strafrechtelijke normering worden bij werknemers, bij werkgevers en bij de wetgever zelf bepaalde verwachtingen gewekt ten aanzien van het functioneren van de arbeidsinspectie in deze, die niet waar gemaakt kunnen worden. De praktische mogelijkheden voor deze overheidsdienst waren en zijn beperkt, mede als gevolg van de onderbezetting op het personele vlak; op dit terrein is de arbeidsinspectie gedurende haar honderd- jarige bestaan overigens altijd al stiefmoederlijk bedeeld geweest. Om de handhaafbaarheid wel te bewerkstelligen dan wel tot een acceptabel niveau te brengen, zou de arbeidsinspectie zeer aanzienlijk uitgebreid moeten worden. Of deze uitbreiding ook daadwerkelijk gerealiseerd wordt en ook de mate waarin deze uitbreiding gestalte krijgt, is een politieke beslissing, waarbij de beschikbaarheid van de vereiste financiële middelen ongetwijfeld een belangrijke rol speelt.

Rond de eeuwviering van de arbeidsinspectie staat het terugdringen van het ziekteverzuim en de arbeidsongeschiktheid weer centraal. De minister van Sociale Zaken en Werkgelegenheid De Vries stelde ${ }^{2}$, dat het beeld zich aftekent, dat ten minste $30 \%$ van het totaal, geheel of gedeeltelijk arbeidsgeschikten een gevolg is van het arbeidsverleden; zeker als men daarbij de arbeidsomstandigheden in brede zin beziet. Hij raamde de kosten die aan het ziekteverzuim en de arbeidsongeschiktheid verbonden zijn op zo'n 30 miljard gulden per jaar. Hij achtte de beperking van de omvang van de arbeidsongeschiktheid een belangrijk onderwerp, ook voor de arbeidsinspectie. Maar dan zal deze zelfde bewindsman er voor moeten zorgen, dat deze overheidsdienst wel over voldoende middelen beschikt om daadwerkelijk een rol van betekenis te kunnen spelen bij het terugdringen van de arbeidsongeschiktheid. Dat betekent dan ook, dat ik hoop, dat de politieke besluitworming daaromtrent niet beheerst wordt door de uitdrukking

"penny wise and pound foolish":

Mijns inziens kan niet alleen worden volstaan met een zeer aanzienlijke uitbreiding van het personeelsbestand van de arbeidsinspectie. Gezien de te hoge verwachtingen die men van de arbeidsinspectie heeft, zou de wetgever bij zichzelf te rade moeten gaan of en in hoeverre strafrechtelijke normering bijdraagt in de effectiviteit van de handhaving van de norm. Met andere woorden: ligt het voor de hand om altijd maar voor een strafrechtelijke norm te kiezen?

Een blik in het Burgerlijk Wetboek leert, dat de arbeidsomstandigheden in een onderneming niet alleen genormeerd worden door het strafrecht, maar ook, zij het pover, door het civiele recht. In het inleidende hoofdstuk zijn in het kader van de Wet op de arbeidsovereenkomst een aantal voorschriften genoemd. Tevens is verwezen naar een aantal algemene verplichtingen, die een werkgever en een arbeider jegens elkaar hebben. Deze algemene verplichtingen zijn onder meer neergelegd in de artikelen $1638 \mathrm{z}$ en $1639 \mathrm{~d}$ van het Burgerlijk Wetboek. Deze bepalingen schrijven voor, dat de werkgever onderscheidlenlijk de arbeider in het algemeen verplicht zijn al datgene te doen en na te laten, wat een goed werkgever onderscheidenlijk arbeider behoort te doen en na te laten. In het strafrechtelijk gesanctioneerde arbeidsomstandighedenrecht komen vele voorschriften voor die een uitvloeisel van deze algemene verplichtingen kunnen worden beschouwd. Ik 
noem een aantal woorbeelden vit de Arbeidswet 1919. In het kader wain deze wet moet het hoofd of de bestuurder zorgen, dat aan een vrouwelijke arbeider, die een borstkind heeft en hem hiervan in kennis heeft gesteld, behoorlijk gelegenheid wordt gegeven om haar kind te zogen ${ }^{3}$. De naleving van deze zorgverplichting is strafrechtelijk gesanctioneerd. Uit de jaarverslagen van de arbeidsinspectie blijkt, dat terzake van een overtreding van deze verplichting nog nooit een proces-verbaal opgemaakt. Wel is deze verplichting in civiele procedures, overigens ook eerst 60 jaar na totstandkoming, opgevoerd in het kader van het zijn van een goed werkgever in de zin van artikel 1638z van het Burgerlijk Wetboek ${ }^{4}$, Daarnaast kent de Arbeidswet 1919 een verplichting voor de werkgever om de arbeids- en rustijden van een zwangere arbeidster zodanig in te richten, dat tegemoet gekomen wordt aan haar specifieke omstandigheden, én en ander voor zover dit redelijkerwijs van hem gevergd kan worden ${ }^{5}$. De wetgever geeft zowel het hoofd of de bestuurder de mogelijkheid om aan het districtshoofd van de arbeidsinspectie een uitspraak te vragen omtrent de naleving van deze verplichting; aan deze uitspraak moet gevolg worden gegeven. Vergelijkbare verplichtende bepalingen voor het hoofd of de bestuurder kent de Arbeidswet 1919 ten aanzien van arbeid in verband met onderwijs door jeugdige personen ${ }^{*}$.

Niet alleen de Arbeidswet 1919, maar ook de Arbeidsomstandighedenwet kent voorbeelden van dergelijke verplichtingen, zoals bijvoorbeeld artikel 3 , waarin de werkgever de algemene zorg voor veiligheid, gezondheid en welzijn in verband met de arbeid opgelegd is, artikel 4 terzake van de beleidsvoering, de artikelen 6 en 7 over voorlichting en onderricht en artikel 12, dat de algemene verplichtingen voor de werknemer bevat.

Bedoelde verplichtingen zijn mijns inziens voorbeelden van een normering waarin de mogelijkheden van de arbeidsinspectie op het terrein van de handhaving van de norm, en daarmee de effectiviteit van de strafrechtelijke normering worden overschat. De arbeidsinspectie kan terzake van deze verplichtingen doorgaans twee wegen bewandelen. Allereerst kan worden gekozen voor het "meedenken", daar waar de opgelegde verplichtingen problemen opleveren. Dit "meedenken" en het zoeken naar een oplossing is eerst effectief wanneer er voor de beide partijen een aanvaarbaar compromis gevonden wordt. Wanneer dit niet mogelijk blijkt te zijn, rest er voor de arbeidsinspectie, daar waar het hoofd of de bestuurder onwillig en halstarrig is, niets anders dan het opmaken van een proces-verbaal. Niet alleen leert de praktijk, dat de weg van een strafrechtelijke procedure, als die al gevolgd wordt, zeer lang is, maar daarmee is het met de norm beoogde effect niet bereikt. Het hoofd of de bestuurder krijgt eventueel een boete opgelegd, maar de betrokken werkneemster is nog steeds niet in staat om haar kind te zogen, of de zwangere werkneemster moet nog steeds, tegen haar zin 's nachts of in ploegen werken.

Een andere vraag is, waarom de in de Arbeidsomstandighedenwet neergelegde verplichting tot samenwerking tussen de werkgever en de werknemers in het behartigen van de zorg voor de veilligheid, de gezondheid en het welzijn binnen het bedrijf of de inrichting, strafrechtelijk gesanctioneerd is, zij het in de vorm van een indirecte strafrechtelijke sanctionering. Immers via een verzoek om wetstoepassing kan het districtshoofd van de arbeidsinspectie voor deze gevallen een aanwijzing geven, die strekt tot naleving van deze verplichting. Bij deze constructie, die veel weg heeft van een soort geschillenbeslechting, lijkt eveneens sprake te zijn van een overschatting van de mogelijkheden van de arbeidsinspectie. Wanneer de samenwerking tussen de betrokkenen op dit terrein beperkt is, of volledig zoek is, dan is het maar zeer de vraag, of de gekozen vorm van overheidsinterventie daar verandering in kan brengen. Het samenwerken tussen werkgever en werknemers kan van overheidszijde nu eemmaal niet worden afgedwongen.

Daarnaast blijkt het in de Arbeidsomstandighedenwet gekozen systeem van strafrechtelijke sanctionering met betrekking tot het jaarverslag niet aan te sluiten op andere soorten van wetgeving. Zo staat in het rechtspersonenrecht op het niet-uitbrengen van een jaarverslag en van de jaarrekening, een civielrechtelijke sanctie. Ook in de Wet op de ondernemingsraden is de ondernemer een aantal verplichtingen opgelegd omtrent bijvoorbeeld het verstrekken van inlichtingen, van de jaarrekening en vervangende gegevens en het sociaal jaarverslag ${ }^{7}$, die civielrechtelijk zijn gesanctioneerd:

In een bedrijf of inrichting moet ingevolge de Arbeidsomstandighedenwet een arbocommissie worden inge- 
steld, wanneer dat bedrijf of die inrichting daartoe is aangewezen. Een dergelijke verplichting tot het hebben van een arbocommissie geldt echter niet, indien het aangewezen bedrijf of de aangewezen richting behoort tot een onderneming waarvoor een ondernemingsraad is ingesteld ${ }^{\mathbb{B}}$. En wat blijkt: in tegenstelling tot de arbocommissie is de verplichting tot instelling van een ondernemingsraad, zoals neergelegd in de Wet op de ondernemingsraden, bij niet-naleving alleen met een civiele actie te realiseren.

Gezien het vorenstaande zou ik willen pleiten voor een diepgaande doorlichting van de bestaande regelgeving op het terrein van het arbeidsomstandighedenrecht, waarbij vooral de nadruk zal moeten liggen op de vraag, of een op te leggen of opgelegde verplichting al dan niet strafrechtelijk gesanctioneerd dient te worden. Het is dus geen pleidooi om de tot stand gebrachte regelgeving af te schaffen, noch om iedere strafsanctie, die op een norm gelegd is te schrappen, maar een pleidool om het wapen van de strafsanctie selectiever te hanteren. Cornelissens ${ }^{\theta}$ denkt in dezelfde geest. Ook hij bepleit een selectiever gebruik van de strafsanctie. Wel wil hij zich beperken tot het terrein van de Arbeidsomstandighedenwet en tot die bepalingen, die "interrelationele" betrekkingen van individuen betreffen, zoals bijwoorbeeld het onderhouden van contacten tussen de werknemers onderling of op de toewijzing van taken aan de werknemer overeenkomstig zijn vakmanschap, waarbij het algemeen belang als zodanig minder naar voren treedt en waarbij de ernst van de overtreding, strafrechtelijk gezien, minder aanneembaar zal zijn te maken.

Wellicht dat de in de Arbeidsomstandighedenwet bestaande constructie waarbij sprake is van een indirecte strafrechtelijke sanctionering via de aanwijzingsmogelijkheid van de arbeidsinspectie een eerste stap is op de weg naar het selectief gebruiken van de strafrechtelijke sanctionering.

Bij een selectiever gebruik van het strafrecht kan de rol van de overheid op het terrein van het arbeidsomstandighedenrecht op onderdelen veranderen. Hoewel onder meer Rood ${ }^{10}$ heeft gesteld, dat met de de Arbeidsomstandighedenwet de overheid een terugtredende rol toebedeeld is, kan ik daarvoor geen bewijzen vinden. Wel is in de Arbeidsomstandighedenwet meer ruimte gecreëerd voor participatie van betrokkenen dan onder de Veiligheidswet 1934 en de Arbeidswet 1919.

Daar waar de wetgever inderdaad de strafrechtelijke sanctionering selectiever zou gaan hanteren em daardoor voor een deel van de betreffende wetgeving voor civielrechtelijke sanctionering zou kiezen, opent hij voor zichzelf de mogelijkheid om de civielrechtelijke variaties, die in de Wet op de arbeidsovereenkomst voorkomen, te hanteren. Zeer zorgvuldig zal men de aard van de regelgeving moeten beoordelen, om zo na te gaan in hoeverre van de aldaar gegeven mogelijkheden gebruik kan worden gemaakt. De wetgever heeft dan een aantal opties, die voor het bepalen van de keuze van belang zijn. De eerste optie betreft landelijke geldende normen. Deze normen vindt de wetgever dusdanig belangrijk en zwaarwegend, dat een afwijking niet toegestaan kan worden, maar waarvan de wetgever meent, dat het hanteren van de strafrecht niet leidt tot de gewenste effectiviteit terzake van de handhaving van overheidswege van deze norm. In dit geval zou de wetgever kunnen kiezen woor de variant van dwingend recht. Afwijking van deze norm is derhalve niet mogelijk, maar de handhaving wordt in dit geval overgelaten aan de betrokken partijen zelf. Bij de volgende opties wordt de mogelijkheid van decentralisatie van verantwoordelijkheden geopend; de nadruk ligt, all naar gelang van het karakter van de gegeven normen, op bedrijfstak- of ondernemingsniveau.

Dar waar het het bedrijfstakniveau betreft, heeft de wetgever de variant van het zogenaamde driekwartdwingend recht tot zijn beschikking. Deze variant houdt in, dat van de gegeven norm bij collectieve arbeidsovereenkomst of verordening kan worden afgeweken. Bij de derde en de vierde optie ligt de nadruk op ondernemingsniveau. Hier heeft de wetgever de keuze tussen semi-dwingend en aanvullend recht. Van semidwingendrechtelijke normen kan uitsluitend bij schriftelijke arbeidsovereenkomst of arbeidsreglement afgeweken; terzake van aanvullend recht is afwijking altijd toegestaan. Indien de werkgever van de mogelijkheid van bijvoorbeeld het arbeidsreglement gebruik wil maken om aan de afwijking van de gegeven norm gestalte

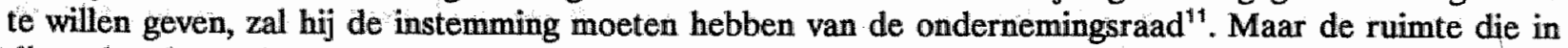
dit verband aan de ondernemingsraad gegeven wordt, is afhankelijk van de ruimte die de partijen bij een collectieve arbeidsovereenkomst of verordening bieden. Bij een inhoudelijke regeling van de geboden afwij- 
kingsmogelijkheid in een collectieve arbeidsovereenkomst of een arbeidswoorwaardenregeling uitgevaardigd door een publiekrechtelijk orgaan is de instemming van de ondernemingsraad niet vereist ${ }^{12}$. Verreweg de meeste opties impliceren, dat afwijkingen van de door de wetgever gegeven normen via de collectieve arbeidsovereenkomst of geregeld moeten of geregeld kunnen worden. Hierdoor wordt bewerkstelligd dat werkgevers(organisaties) en werknemersorganisaties in het kader van hun belangenbehartigende taak over de betreffende onderwerpen met elkaar onderhandelen en afspraken maken ${ }^{13}$. Opnieuw komt de handhaving te berusten bij de betrokkenen zelf.

Ook de Wet op de ondernemingsraden geeft aan, dat er mogelijkheden zijn voor de collectieve arbeidsovereenkomst. Sinds 1979 kan de verplichting tot het instellen van een ondernemingsraad ook worden opgenomen in de collectieve arbeidsovereenkomst. Alle wettelijke bepalingen terzake van de ondernemingsraad zijn dan op de ondernemer van toepassing als hij een ondernemingsraad instelt, omdat de collectieve arbeidsovereenkomst hem hiertoe verplicht ${ }^{14}$. Een vergelijkbare verplichting via een collectieve arbeidsovereenkomst zou ook terzake van de bedrijfsgezondheidsdienst en de veiligheidsdienst in de Arbeidsomstandighedenwet opgenomen kunnen worden. De verplichting geldt thans voor een bedrijf of inrichting, dat tot een bij algemene maatregel van bestuur aangewezen categorie behoort, of dat door de directeur-generaal van de Arbeid is aangewezen.

Bij het beëindigen van deze studie wil ik voor een hiervoor bedoelde wijze van doorlichten van de betrokken regelgeving de aandacht vragen. In de inleiding van hoofdstuk 12 werd aangegeven, dat de rol van de collectieve arbeidsovereenkomst op het terrein van het arbeidsomstandighedenrecht veeleer trendvolgend dan trendsettend is, met het gevolg, dat de dit rechtsinstituut op dit terrein beperkt is. Wellicht, dat de hiervoor gedane suggestie een keer ten goede met zich brengt. Op deze manier kan dan tevens worden bewerkstelligd, dat beter aangesloten wordt op de filosofie, die aan de Arbeidsomstandighedenwet ten grondslag ligt, namelijk de gedachte van de zelfwerkzaamheid van de betrokkenen; een zelfde gedachtengang geldt ter zake van een nieuwe arbeidswet. De voorstellen, die in de hoofdlijnennota, die aan de Sociaal-Economische Raad voor advies zijn voorgelegd, beogen namelijk

"meer ruimte te bieden voor een eigen invulling van de sociale partners".

Het is zeker, dat in de Arbeidsomstandighedenwet en de voorstellen van de nieuwe arbeidswet een ruimere plaats toegekend aan de betrokkenheid van de sociale partners op de verschillende niveau's. Toch bekruipt mij het gevoel, dat deze betrokkenheid grotendeels betrekking heeft op meedenken over de vraag, in hoeverre men zich kan vinden in nieuwe wetgeving en in de uitvoering daarvan. Het lijkt mij een zinvolle gedachte, dat deze toch beperkte betrokkenheid voor een deel van het arbeidsomstandighedenrecht wordt omgezet in directe betrokkenheid. Dit kan door het overdragen van verantwoordelijkheid. Hierdoor komt niet alleen de praktische invulling op, hetzij bedrijfstak-, hetzij bedrijfs- of ondermingsniveau. Ook de handhaving van dit deel van het arbeidsomstandighedenrecht rust meer in handen van de betrokkenen zelf. Op het belang hiervan is in de rechtssociologische literatuur al herhaaldelijk gewezen ${ }^{15}$. De overheid kan dan via de, daartoe voldoende uitgeruste arbeidsinspectie aan het resterende, strafrechtelijk gesanctioneerde deel van het arbeidsomstandighedenrecht, meer aandacht besteden en de handhaving ervan daadwerkelijk afdwingen, althans op een acceptabel niveau brengen.

\section{Samenvatting}

In hoofdstuk 1 wordt allereerst vastgesteld, dat de geschiedenis van de arbeidsinspectie onlosmakelijk verbonden is met die van het arbeidsomstandighedenrecht. Hierna wordt het rechtsgebied arbeidsomstandighedenrecht kort beschreven, onderverdeeld in nationale en internationale rechtsbronnen. Een beschrijving van de ontwikkeling van de arbeidsinspectie en haar werkterrein leert, dat zij zich niet alleen met het arbeidsomstandighedenrecht heeft bezig gehouden en bezig houdt, maar op vele andere terreinen bezig is (geweest). Voorts bevat dit hoofdstuk een beschrijving van de gevolgde werkwijze en geeft het een opbouw van de stu- 
die.

Hoofdstuk 2 geeft een beeld van de lange weg, die in de negentiende eeuw moest worden afgelegd alvorens ons land een arbeidsinspectie rijk was. De roep om overheidsbemoeing op het terrein van de arbeidsomstandigheden, en toezicht daarop, vindt zijn basis in de industrialisatie en het verschijnsel van de kinderarbeid. Voor het eerst gebeurde dit officieel in het provinciale verslag van de provincie Overijssel voor het jaar 1835. Dit resulteerde in correspondentie over en weer tussen de toenmalige bewindsman van het ministerie van Binnenlandse Zaken en de toenmalige gouverneur van de provincie. Deze laatste stelde een verbod van kinderarbeid voor, waarbij het toezicht diende te worden opgedragen aan de plaatselijke besturen. In 1841 zou een eerste ministerièle enquête worden ingesteld naar de arbeidsomstandigheden van met name kinderen, waarbij de wens om van overheidswege terzake regelen te stellen naar voren werd gebracht. De aangeschreven gouverneurs konden zich met deze wens verenigen, over de inhoud van de regeling verschilden zij van mening. Wel was duidelijk, dat zij ook voorzieningen wilden omtrent het toezicht op de naleving van een dergelijke regeling, waarbij de nadruk lag op het plaatselijke niveau. Eerst De Vries-Robbé pleitte in zijn uit 1860 daterende rapport voor de instelling van aparte inspecteurs, aan wie bepaalde bevoegdheden, zoals het kunnen betreden van fabrieken en het kunnen aanbevelen van veranderingen omtrent de hygiëne en de veiligheid, toegemeten dienden te worden. Dit rapport zou de stichtingsbrief van de arbeidsinspectie genoemd kunnen worden. Het leidde in hetzelfde jaar nog tot een nieuwe ministeriële enquête, met overigens hetzelfde resultaat als haar voorgangster, maar de maatschappelijke druk werd groter. Deze zou uiteindelijk resulteren in het initiatief-ontwerp van het Tweede Kamerlid Van Houten. Ondanks alle aandrang tijdens de parlementaire behandeling ervan vindt men in de Kinderwet-van Houten niets terug over het toezicht op de naleving van het daarin neergelegde verbod van kinderarbeid. Hoewel het wetje de basis vormt van het arbeidsomstandighedenrecht, had het praktisch weinig betekenis, niet alleen vanwege het feit, dat een afzonderlijk toezichthoudend orgaan met voldoende bevoegdheden ontbrak, maar ook vanwege de onduidelijkheden omtrent de reikwijdte van thet verbod. Al snel werden pogingen ondernomen niet alleen om de gesignaleerde gebreken op te heffen, maar ook om de reikwijdte van de overheidsbescherming te verbreden. Een voorontwerp-Van Lynden van Sandenburgh werd voor commentaar naar diverse nijverheidsorganisaties gezonden; hoewell de antwoorden vrij instemmend waren, werd het vraagpunt, of er afzonderlijke inspecteurs moeten komen, niet eenduidig beantwoord. De daarop volgende bewindsman Modderman diende in 1882 een wetsvoorstel in bij de Tweede Kamer, waarin zowel in de bedoelde uitbreiding werd voorzien, als in de instelling van afzonderlijke inspecteurs. Het voorstel werd in het parlement zeer ongunstig ontvangen. Zijn opvolger Du Tour van Bellinchave zou dit wetsvoorstel intrekken en vervolgens met een nieuw voorstel komen, waarin met name de regeling omtrent de afzonderlijke inspecteurs was weggelaten. Ook nu werd ditmaal aan hem het verwijt gericht, dat er onvoldoende feitelijke gegevens waren ingebracht, zodat de noodzaak van ingrijpen door de wetgever niet was aangetoond. Als reactie hierop werd in de jaren 1886 en 1887 een parlementaire enquête gehouden naar de werking van het Kinderwetje van Van Houten en de toestanden in fabrieken en werkplaatsen. Het door de enquête-commissie uitgebrachte verslag bracht zoveel misstanden aan het licht, dat verder ingrijpen van overheidswege niet kon worden uitgesteld. Een tweede ontwerp van Du Tour van Bellinchave, dat nog in 1887 werd ingediend en verder ging dan het eerste, werd niet meer afgedaan. Zijn opwolger Ruys van Beerenbroek diende een ontwerp in, dat de Arbeidswet 1889 is geworden. In deze wet is het toezicht op de naleving, alsmede de opsporing van overtredingen aan aparte functionarissen opgedragen, inspecteurs genaamd, van wie het aantal in de wet zelf was vastgelegd uit angst voor ambtenarij, die de vrije ondernemingsgeest zou kunnen dwarsbomen. Hoewel in het verslag van de parlementaire enquête-commissie eveneens gepleit was voor het instellen van afzonderlijke inspecteurs en Ruys van Beerenbroek zelf lid geweest was van deze enquête-commissie, was de regeling van het toezicht in de wet gekomen door initiatieven vanuit de Tweede Kamer en niet op voorstel van de bewindsman. De wet bevatte tevens een regeling van de bevoegdheden van deze inspecteurs en een aantal controlemiddelen, dat het toezicht diende te vereenvoudigen.

Het hoofdstuk beslüt met een afzonderlijke paragraaf waarin de vraag wordt beantwoord naar de redenen 
waarom een afzonderlijke arbeidsinspectie was ingesteld.

De hoofdstukken 3 tot en met 5 bestrijken de periode vanaf het ontstaan van de arbeidsinspectie tot de Eerste Wereldoorlog.

Behalve het verbod van kinderarbeid bevatte de Arbeidswet 1889 beschermende bepalingen ten aanzien van jeugdigen en vrouwen, althans voor zover zij arbeid verrichten in fabrieken of werkplaatsen. Naast een verbod van nacht- en zondagsarbeid en een beperking van de arbeidsduur, zouden voor hen bepaalde soorten van arbeid op grond van gevaren voor de gezondheid of het leven bij algemene maatregel van bestuur verboden worden, of slechts onder zekere voorwaarden kunnen worden toegestaan. Op 1 maart 1890 konden de, bij de wet ingestelde, drie inspecteurs van de arbeid met hun werkzaamheden in even zovele districten, "arbeidsinspectiën" genaamd, aanvangen. De taak van de inspecteurs van de arbeid bestond uit het toezicht op de uitvoering van de wet en het opsporen van overtredingen. In de nadere uitwerking van het toezicht op de uitvoering van de wet werd deze wettelijke verplichting herhaald, maar tevens werden daaraan toegevoegd de naar aanleiding van de wet uitgevaardigde algemeene maatregelen van bestuur en ministeriële regelingen; daartoe hadden zij de plaatsen, waar arbeid werd of pleegde te worden verricht, te bezoeken. Teneinde de uniformiteit in de toepassing van de wettelijke voorschriften te bewerkstelligen dienden de inspecteurs met elkaar in overleg te treden. Vervolgens dienden zij zoveel mogelijk overeenstemming te bevorderen tussen de door de wetgever gestelde eisen en de belangen van alle bij de arbeid betrokken personen. Tevens moesten zij de werkgevers inlichtingen verstrekken en voorstellen doen, die ertoe konden leiden, dat bezwaren die anders uit de toepassing van de wettelijke voorschriften voor de nijverheid zouden kunnen voortvloeien, zouden worden weggenomen. Ook hadden de inspecteurs tot taak in het bijzonder acht te slaan op de gevaren, die bepaalde soorten van arbeid opleverden voor de gezondheid of het leven van jeugdige personen en van vrouwen. Tot slot moesten zij de bewindsman desgevraagd van bericht en advies dienen en voorstellen doen, die zij nodig of wenselijk achten. Desgevraagd dienden zij de vergunning verlenende instanties op provinciaal en gemeentelijk niveau te adviseren. Tot slot moesten zij jaarlijks een beredeneerd verslag van hun werkzaamheden opstellen en dit de bewindsman toezenden. De ruime taakstelling leidde ertoe, dat de inspecteurs zich, naast het toezicht op de uitvoering van de Arbeidswet 1889, bezig hielden met het opnemen van de toestanden in de fabrieken en werkplaatsen, het verzamelen van gegevens en het adviseren over de hygiëne en beveiliging tegen ongevallen, het instellen van onderzoeken naar de sociale instellingen in het belang van de arbeiders en tot slot met de voltooïng van de nijverheidstatistiek. Het opsporen van overtredingen rekenden de inspecteurs niet in eerste instantie tot hun taak. Het is niet verwonderlijk, dat, gezien de werkzaamheden die door hen verricht moesten worden, de inspecteurs zelf al snel om uitbreiding vroegern met adjunct-inspecteurs.

Mede als gevolg van de door de inspecteurs ontwikkelde activiteiten, zou in 1895 de Veiligheidswet tot stand komen. Deze wet bevatte bepalingen tot beveiliging bij het verblijven in fabrieken of werkplaatsen. Het toezicht op de uitvoering van deze wet en het opsporen van overtredingen was toebedeeld aan de inspecteurs, die tevens de bevoegdheden kregen om aanwijzingen en voorschriften te geven, die moesten worden nageleefd. Met het uitvaardigen van deze wet werd de principiële beperking van de beschermende hand van de wetgever tot kinderen, jeugdigen en vrouwen losgelaten. Tegelijkertijd zou de Arbeidswet 1889 worden gewijzigd, waardoor het wettelijk aantal te benoemen inspecteurs kwam te vervallen, zodat de weg naar uitbreiding openstond. Het aantal inspecteurs werd in 1896 van drie naar zes uitgebreid en er werd aan een ieder een adjunct-inspecteur toegevoegd, éen en ander onder gelijktijdige uitbreiding van het aantal "arbeidsinspectiën".

De Veiligheidswet, die zich, in tegenstelling tot de Arbeidswet 1889, niet richtte tot de werkende personen, maar tot de inrichtingen, waarin gewerkt werd, leidde tot een relatie met de Hinderwet. Door het in de eerstgenoemde wet opnemen van de zogenaamde "bis"-artikelen werd voorkomen, dat de op grond van de laatstgenoemde wet te verlenen vergunningen of daaraan te verbinden voorwaarden in strijd zouden komen met de krachtens de Veiligheidswet gegeven voorschriften. Door deze relatie werden de inspecteurs, zij het in beperkte mate, betrokken bij de Hinderwet. De verbreding van het werkterrein leidde opnieuw tot uitbrei- 
ding van de arbeidsinspectie in 1899 met twee adjunct-inspecteurs. In datzelfde jaar werd een in 1898 gestarte proef met een adjunct-inspectrice geformaliseerd. Haar werkterrein richtte zich op de vrouwenarbeid. Voorts werd een korps van "bureel-ambtenaren", ter vervanging van de in tijdelijke dienst genomen ambtenaren, in het leven geroepen om de steeds toenemende administratieve werkzaamheden te verrichten. Een jaar later werd onder een evenredige vermeerdering van de districten het aantal inspecteurs van zes op negen gebracht en werd de functie van opzichter toegevoegd, deze technische ambtenaren dienden zich "met het meer eenwoudige werk" op het terrein van de inspectie-arbeid bezig te houden. Drie jaar later werd de dienst opnieuw uitgebreid, niet alleen met de functie van opzichteres, die zich in het bijzonder diende in te laten met het bezoeken wan de fabrieken en werkplaatsen waar meisjes en vrouwen werkten, maar ook met wat "specialiteiten" werden genoemd, namelijk de medisch-adviseur en de electrotechnicus (1903). Het werkterrein van de eerstbedoelde had betrekking op die wettelijke voorschriften op het terrein van de arbeidersbescherming, die in het belang van de gezondheid van de bij de arbeid betrokken personen waren uitgevaardigd, terwijl dit voor de laatstbedoelde gold ten aanzien van elektrische toestellen en geleidingen. Hoewel deze beide ambtenaren het gehele Rijk tot hun werkterrein hadden, en direct onder de verantwoordelijke bewindsman vielen, kon de medicus zijn werkzaamheden volledig zelfstandig verrichten, terwijl de electrotechnicus onder de bevoegde inspecteur viel, aan wie hij was toegevoegd.

Het resultaat van de door de inspecteurs verrichte onderzoeksactiviteiten mondde onder meer uit in de Phosphorluciferwet 1901, terwijl de beperkte strekking van de geldende regelgeving op het terrein van de veiligheid op initiatief van de inspecteurs leidde tot de Caissonwet 1905; het toezicht op beide wetten was opgedragen aan de inspecteurs, evenals de opsporing van overtredingen. Daarnaast hebben de inspecteurs hun medewerking verleend aan de totstandkoming van de Ongevallenwet 1901. Niet onvermeld mag blijven de door de inspecteurs uitgebrachte adviezen inzake de wettelijke beperking van de arbeidsduur voor alle volwassen arbeiders.

De bedoelde adviezen waren regelmatig inhoudelijk tegenstrijdig met elkaar, hetgeen alleen door centralisatie kon worden tegengegaan. Zowel in het parlement, als daarbuiten was al herhaaldelijk aangedrongen op een meer centrale leiding van de zich steeds uitbreidende arbeidsinspectie. Een eerste aanzet om tot een reorganisatie te komen, is te vinden in het ontwerp-Kuyper (1904). Dit 444 artikelen omvattende wetsvoorstel, houdende bepalingen ter bescherming van de arbeid, riep in het parlement vragen op, onder meer over de relatie tussen de arbeidsinspectie en het departement. Het wetsvoorstel is echter nooit verder gekomen dan het voorlopig verslag. Maar de kiem van de reorganisatie was gelegd. Enkele jaren later werd in het parlement de benoeming van een hoofdinspecteur gewenst geacht, vooral om uniformiteit in de inspectiewerkzaamheden en verslaglegging te bevorderen. Maar van regeringszijde was men nog niet overtuigd van de noodzaak van reorganisatie. Dit denkbeeld veranderde met de komst van minister Talma (1908). Het voornaamste gebrek zijns inziens van de bestaande organisatie was het gemis van een hoofd van de arbeidsinspectie. Nog voor het parlement op reces ging, werd een daartoe voorgestelde begrotingspost goedgekeurd en kon H.A. van IJsselstein met ingang van 1 oktober van dat jaar benoemd worden tot "inspecteur van de arbeid onder den persoonlijken titel van directeur-generaal van den arbeid". Daarna werd de reorganisatie van de dienst voorbereid, hetgeen gesanctioneerd diende te worden door wijziging van alle wetten waarvan de handhaving aan de inspecteurs was toevertrouwd of bij de uitvoering, waarvan zij betrokken waren; deze wetswijzigingen waren een jaar later een feit. Bij de wettelijke regeling werd de basisregeling neergelegd in de Arbeidswet 1889. Onder de directeur-generaal van de Arbeid werd een centrale dienst gevormd, waartoe behoorden de medisch-adviseur, de electrotechnisch ingenieur en de inspecteurs in algemene dienst, die bij die centrale dienst te werk zouden worden gesteld. Elke "arbeidsinspectie", voortaan district genoemd, werd geleid door een districtshoofd van de arbeidsinspectie. Onder hem werden werkzaam gesteld: de (adjunct-) inspecteurs, de (adjunct-)inspectrices, opzichters en controleurs, waarmee een nieuw ambt zijn intrede had gedaan bij de arbeidsinspectie. De taak van de directeur-generaal van de Arbeid was het leiding geven aan en het toezicht uitoefenen op de dienst van de arbeidsinspectie. Voorts kon hij de bewindsman uit eigen beweging of op verzoek van advies dienen en voorstellen doen, en mondeling of schriftelijk de gevraagde inlichtingen verschaffen. Ten opzichte van de districtshoofden bestond de taak van de directeur-generaal van de 
Arbeid wit het leiding geven aan de inspectie-arbeid en dan met name ten aanzien wan de uniformiteil van de uitvoering van de desbetreffende wetten, zoals door middel van overwerkvergunningen en opvattingen omtrent beveilligingen; hij had eveneens tot taak de in de districten verzamelde gegevens ontrent de arbeídstoestanden te verwerken, bepaalde onderzoekingen te laten verrichten of bepaalde gegevens te laten verzamelen door door de bewindsman te benoemen personen, het samenstellen van een algemeen - centraal jaarverslag en verslagen over bijzondere onderwerpen, die zonodig gepubliceerd konden worden en het overleg voeren met vertegenwoordigers van werkgevers- en arbeidersorganisaties. De zelfstandigheid van de districtshoofden werd overigens niet aangetast; zij behielden het recht te corresponderen met de bewindsman en hem voorstellen te doen, alsook de hun in de verschillende wetten gedelegeerde bevoegdheden. Wel werd hun taakstelling uitgebreid; zij dienden zich nu ook op de hoogte te houden van de arbeidstoestanden in hun district en van gebeurtenissen, die van belang waren voor de kennis van de arbeidsverhoudingen.

Nog geen twee jaar na de reorganisatie van de arbeidsinspectie werd de dienst uitgebreid met een geneeskundige (1911) en een scheikundig-ingenieur (1913). De eerste niet alleen varwege het feit, dat de taak van medisch-advisenr toenam, maar ook omdat te verwachten was, dat het medische element bij de arbeidswetgeving zich nog sterk zou ontwikkelen. De tweede vond haar grondslag in de bemoeienis van de arbeidsinspectie met de waterverontreiniging van strokarton- en aardappelmeelfabrieken; deze kreeg de beschikking over een eigen laboratorium, waardoor de mogelijkheid werd geopend onderzoekingen te verrichten, die voor de dienst van belang waren.

Een belangrijke toename van de werkzaamheden van de arbeidsinspectie vloeide voort uit de Arbeidswet 1911, waarin het medebewind van provinciale en gemeentelijke organen terzake van het verlenen van overwerkvergunningen werd beëindigd en waarbij deze bevoegdheid aan de districtshoofden van de arbeidsinspectie werd gedelegeerd. De gevreesde steenhouwersziekte had herhaaldelijk de aandacht van de arbeidsinspectie gehad en de bedreiging van de gezondheid van de arbeiders werd zo ernstig werden gevonden, dat de Steenhouwerswet 1911 tot stand kwam; deze zou echter geen grote verandering in de taak wan de arbeidsinspectie brengen. Wel zou tijdens de parlementaire behandeling van deze wet naar aanleiding van de aan het districtshoofd van de arbeidsinspectie toegekende bevoegdheden de problematiek van de zogenaamde (sub)delegatie en de grondwettelijke aspecten daarvan uitgebreid aan de orde komen.

In deze periode zouden er verschillende voorstellen gedaan worden, zowel in, als buiten het parlement om andere organen dan de arbeidsinspectie op het terrein van de arbeidsbeschermende wetgeving in te schakelen. Daarbij werd gedacht aan: "Commissiën uit werkliedenvereenigingen", de Raden van de Arbeid, de bakkersraden, bedrijvenraden en de Kamers van Arbeid.

Hoofdstuk 6 beslaat de periode van de Eerste Wereldoorlog. De mobilisatie van het leger als gevolg van de dreigende oorlogssituatie, maakte dat vele arbeiders onder de wapenen werden geroepen. Hierdoor werd niet alleen de arbeidsmarkt ontwricht, maar het gehele economische leven. Bovendien stagneerde de export, wat weer leidde tot grote werkloosheid. Deze omstandigheden maakten een verder gaande overheidsbemoeienis dan tot dusver gebruikelijk was, noodzakelijk. Dit alles bleef ook voor de arbeidsinspectie niet zonder gevolgen; haar normale werkzaamheden stagneerden. De dienst, die over vele en velerlei gegevens over de Nederlandse industrie beschikte, kreeg van regeringszijde nieuwe taken toebedeeld. Een, van haar eerste activiteiten lag, zij het slechts van korte duur, op het terrein van de arbeidsbemiddeling. Langduriger en veel omvattender waren haar werkzaamheden voor het Koninklijk Nationaal Steuncomitt, dat beoogde de nood te voorkomen en te leningen. Vervolgens hield de arbeidsinspectie zich onder meer bezig met verlofaanvragen voor dienstplichtigen, het verstrekken van certificaten vam oorsprong, de tewerkstelling van geïterneerde (Belgische) militairen, de industriële kolen- en de turfdistributie en met de samenstelling van zogenaamde Economische Nota's, waarin een overzicht werd gegeven van de economische situatie in ons land.

Op de valreep zou in deze periode nog het aantal districten van de arbeidsinspectie uitgebreid worden van negen naar tien, niet alleen om een bestaand district te ontlasten, maar tevens om belangrijke en in belang toenemende industriegebieden - Rotterdam en omgeving, Zeeuws-Vlaanderen en de westelijke helft van Noord-Brabant - tot hun recht te doen komen. 
De hoofdstukken 7 en 8 bestrijken de periode van het interbellum. De arbeidsinspectie werd na het einde van de Eerste Wereldoorlog aanvankelijk nog geconfronteerd met de naweeën van de activiteiten, die zij gedurende de oorlogsjaren had verricht. In de periode tot de wereldcrisis zijn twee zaken van groot belang. Allereerst de instelling van de Hooge Raad van Arbeid, een adviesorgaan waardoor een geïnstitutionaliseerd overleg ontstond tussen het georganiseerde bedrijfsleven enerzijds en de overheid anderzijds. Voor de arbeidsinspectie was de belangrijkste gebeurtenis de totstandkoming van de Arbeidswet 1919. Bij deze wet is sprake van een omkering van de "bewijslast". Voortaan behoefde niet meer te worden aangetoond, dat lange werktijden schadelijk waren en dat ingrijpen van overheidszijde geen schade toebracht aan het economische leven, maar nu moest aangetoond worden, dat economische of andere motieven een langer werken door de arbeiders noodzakelijk maakten. Niet economische, maar ethisch-sociale motieven vormden de grondslag van deze wettelijke regeling. Hilerdoor werd de wet meer dan alleen een regeling van de arbeids- en rusttijden, zij was een regeling van de arbeid, zoals blijkt uit de interpellatie van Drion. Onder druk van de internationale concurrentie zou de wet in 1922 alweer gewijzigd worden. De aanvankelijk 8-urige werkdag en 45-urige werkweek werden ingeruild voor de 8,5-urige werkdag en 48-urige werkweek. Tevens werd de mogelijkheid geopend om via het collectief overleg van de wettelijk voorgeschreven arbeidsduur af te wijken, zij het, dat dit gekoppeld werd aan cen door de betreffende bewindsman te verlenen vergunning. Tevens werd de zogenaamde machtigingsprocedure ingevoerd voor langdurige overwerkvergunningen.

De centrale dienst van de arbeidsinspectie zou in deze periode uitgebreid worden met een elektrotechnischadviseur en -ingenieur, een landbouwkundige bij de arbeidsinspectie en voorts werd de rang van scheikundig adviseur ingesteld en werd aan hem een scheikundige ingenieur toegevoegd. Tevens werd het aantal districten van de arbeidsinspectie uitgebreid tot $11(1922)$; een uitbreiding die door de bezuinigingsoperatie na de krach van 1929 weer werd teruggedraaid (1932).

Hierwit blijkt, dat de economische werelderisis niet aan de arbeidsinspectie voorbij is gegaan. Er moest capaciteit worden ingeleverd, terwijl de activiteiten van de arbeidsinspectie zich uitbreiden en verder zouden uitbreiden. Niet alleen door de totstandkoming van nieuwe uitvoeringsmaatregelen in het kader van de Arbeidswet 1919, maar evengoed door nieuwe regelgeving, zoals de herziening van de Veiligheidswet, de Huisarbeidswet 1933 en de Rijtijdenwet 1936. Aanpassing of ordening zijn begrippen, die in een economische crisissituatie naar voren komen. In de periode van de wereldcrisis werd steeds meer ordeningswetgeving uitgevaardigd, waarbij de arbeidsinspectie betrokken werd, zoals de Wet houdende tijdelijke maatregelen betreffende de mechanisatie in de sigarenindustrie, de Wet tot regeling van het verrichten van arbeid door vreemdelingen, de Wet inzake de verdeling van de beschikbare arbeid 1937, de Wet op het algemeen verbindend en onverbindend verklaren van bepalingen van collectieve arbeidsovereenkomsten en de Bedrijfsvergunningenwet 1938.

Ter zake van de werkloosheidsbestrijding trad herhaaldelijk de Arbeidswet 1919 in het voetlicht. Een van de mogelijkheden om de werkloosheid in te dammen en de beschikbare arbeid beter te verdelen was het voeren van een restrictief beleid ten aanzien van het verlenen van overwerkvergunningen. Een andere mogelijkheid was om via de Arbeidswet 1919 de invoering van de 40-urige werkweek door te voeren; dit laatste is nooit gebeurd.

Hoofdstuk 9 beschrijft de periode van de Tweede Wereldoorlog. Het normale inspectiewerk van de arbeidsinspectie kwam aanvankelijk als gevolg van de problemen, waarmee het bedrijfsleven werd geconfronteerd, nagenoeg stil te liggen. De werkzaamheden van de arbeidsinspectie hadden in deze periode in hoofdzaak betrekking op de uitwoering van wetgeving, die door of namens de Duitse bezetter was uitgevaardigd; een bezetter, die in feite alleen geinteresseerd was in de bijdrage van de Nederlandse samenleving aan de inspanningen van zijn oorlogsmachine. Als eerste kunnen genoemd worden de maatregelen met betrekking tot het beperken van werk, dat wil zeggen voorschriften betreffende het stilleggen van ondernemingen, de invoering van werktijdverkorting en het ontslaan van werknemers. Bij de uitvoering van deze voorschriften maakte de directeur-generaal van de Arbeid gebruilk van de door hem ingestelde zogenaamde vertrouwensinstanties, paritair samengestelde instanties van werkgevers en van arbeïders. Na een reorganisatie van de arbeidsbe- 
middeling en de instelling van een Rijksarbeidsbureau en gewestelijke arbeidsbureaus werden de bemoeienissen van de arbeidsinspectie met de ontslagzaken langzaam maar zeker beeindigd. Haar activiteiten terzake. van het verbod van werktijdverkorting bleven echter; door het invoeren van de zogenaamde "nul-uren"-vergunning zag de arbeidsinspectie toch nog kans arbeiders aan de directe greep van de bezetter voor de arbeidsinzet te onttrekken. Ten tweede kan gewezen op de maatregelen omtrent lonen, salarissen en andere arbeidsvoorwaarden. De arbeidsinspectie fungeerde hier als onderzoeks-en adviesinstantie voor het ingestelde college van Rijksbemiddelaars. Tevens fungeerde de dienst als opsporingsinstantie. In 1942 werd de rol van het college van Rijksbemiddelaars overgedragen aan de gemachtigde van de arbeid. Hoewel de arbeidsinspectie officieel geen bemoeienis had met de uitwoering van de bewuste verordening, werden voor de gemachtigde van de arbeid overeenkomstige werkzaamheden verricht als voor het college van Rijksbemiddelaars.

Daarnaast had de arbeidsinspectie bemoeienis met het Bedrijfsvergunningenbesluit 1941 en het Kartelbesluit en met de distributie van diverse goederen, zoals zeep, rantsoenen, schoenen en dergelijke.

De vertrouwenspositie, die de arbeidsinspectie had verkregen en dit in het bijzonder de directeur-generaal van de Arbeid Hacke, maakte dat zij zeer nauw betrokken raakte bij de plannen voior herstel van ons land, nadat het juk van de Duitse bezetter zou zijn afgeworpen, en in het bijzonder bij de oprichting van de Stichting van de Arbeid, als ontmoetingspunt van overheid en sociale partners.

De naar London uitgeweken Nederlandse regering stelde vanaf midden 1944 een aantal maatregelen vast om een chaos op social-economisch gebied na de bevrijding te voorkomen. De belangrijkste algemene regeling was het Buitengewoon Besluit Arbeidsverhoudingen, dat naast de regeling van de arbeidswoorwaarden tevens een ontslagverbod bevatte; dit laatste behoudens toestemming wan de directeur van het gewestelijk arbeidsbureau. In een Ontwerp Souverein Noodbesluit van de illegale commissie- Meurs, alsook in de Noodregeling Arbeidszaken waren vele bevoegdheden toegekend aan de directeur-generaal van de Arbeid, waarvan in het Buitengewoon besluit Arbeidsverhoudingen niets is terug te vinden. De toenmalige directeur-generaal van de Arbeid gaf verbitterd over de gang van zaken uiting in een pamflet van eind mei 1945.

Terugkijkend kan gesteld worden, dat de arbeidsinspectie niet alleen het vertrouwen had van de vertegenwoordigers van werkgevers- en arbeidersorganisaties, maar dat zij bij de uitvoering van de haar door de bezetter opgelegde taken al wat mogelijk was heeft gedaan om de greep van die bezetter op het Nederlandse arbeidspotentieel voor haar oorlogsmachine zoveel mogelijk te bemoeilijken.

In hoofdstuk 10 is de periode van de wederopbouw van 1945 tot 1962 beschreven. Gedurende de oorlogsjaren was gewerkt aan een na-oorlogs Nederland, waarin samenwerking de basis zou vormen voor het herstelbeleid. Deze samenwerkingsgedachte werd neergelegd in wetgeving en overlegstructuren, zoals de Wet op de Bedrijfsorganisatie, waarbij de Sociaal-Economische Raad werd ingesteld en de Wet op de ondernemingsraden. In het verlengde van de voor-oorlogse situatie werden op het terrein van de uitvoering van de Arbeidswet 1919 aanvankelijk de fabriekskernen en later de ondernemingsraden steeds meer betrokken. Soms was er samenwerking en overleg tussen de overheid en de vertegenwoordigers van werkgevers- en werknemersorganisaties in een bepaalde bedrijfstak, zoals in het bakkersbedrijf, en soms ging dit zelfs verder, zoals in het slagersbedrijf.

De uitvoering van de Arbeidswet 1919 vergde veel tijd van de arbeidsinspectie. Daarbij kan gedacht worden aan het verlenen van overwerkvergunningen en de problematiek rond de invoering van de vijf-daagse werkweek, die in 1962 gerealiseerd zou worden.

In deze periode werd niet alleen het aantal op de Arbeidswet 1919 gebaseerde werktijdenbesluiten uitgebreid, maar werd door een wetswijziging tevens de regeling van de arbeids- en rusttijden in de landbouw tot stand gebracht; het bijzondere van deze regeling is, dat, in tegenstelling tot de tot dan gevolgde systematiek, het uitvaardigen van een werktijdenbesluit achterwege blijft, wanneer en voor zover een verordening in het kader van de Wet op de Bedrijfsorganisatie geldt, waarin de betreffende materie is geregeld. Deze verordeningen gelden vanaf het begin van de zestiger jaren.

Ook in het kader van de Veiligheidswet 1934 zouden in deze periode een aantal veiligheidsbesluiten uitge- 
vaardigd worden. Maar dat niet alleen. Tevens werd in de wet cen regeling opgenomen van de bedrijfsgeneeskundige diensten. Van belang was, dat, ondanks de raakvlakken die er bestaan met de algemene gezondheidszorg, onderkend werd, dat bedrijfsgeneeskunde en arbeidersbescherming naww met elkaar verbonden zijn. Om die reden werd de bedrijfsgeneeskundige dienst ook in de Veiligheidswet 1934 geregeld en werd het toezicht daarop opgedragen aan de arbeidsinspectie.

Zowel de Arbeidswet 1919, als de Velligheidswet 1934 zouden in deze periode nog een belangrijke wijziging ondergaan. Het districtshoofd van de arbeidsinspectie kreegeen bijzondere bevoegdheid toegekend, namelijk het bevel tot stillegging van werk. Dit bevel kan uitgevaardigd worden, wanneer er sprake is van ernstig gevaar woor personen, dan wel wanneer er sprake is van het in ernstige mate overtreden van de arbeids- en rusttijden en de daarbij behorende administratieve bepalingen.

In deze periode werden de Silicosewet en de Wet op de gevaarlijke werktuigen uitgevaardigd. De eerste wet beoogde het gevaar woor silicose en andere stoflongziekten als gevolg van het inademen van stof te bestrijden.

De tweede wet bevatte voorschriften in het belang van de veiligheid en de gezondheid waaraan gevaarlijke werktuigen en beveiligingsmiddelen moesten voldoen of met betrekking daartoe in acht genomen moesten worden. Met deze wetgeving wordt de arbeidersbescherming uitgebreid tot een bescherming van de arbeid in de ruimste zin des woords en kan gesproken worden van volksbescherming.

Bij de uitwoering van het Buitengewoon Besluit Arbeidsverhoudingen 1945 was de arbeidsinspectie op verschillende manieren betrokken. Naast de controlerende taak, waarbij de controle op lonen en andere arbeidswoorwaarden een omvangrijke taak was, had de arbeidsinspectie een adviserende taak. Allereerst ter zake van het verlenen van ontslagvergunningen. Deze werden verleend door de directeur van het gewestelijk arbeidsbureau, na overleg met de arbeidsinspectie, die ter zake vertegenwoordigers van werkgevers- en werknemersorganisaties hoorde. Met deze compromis-achtige constructie was een einde gekomen aan de strijd tussen de directeur-generaal van de Arbeid en de directeur van het Rijksarbeidsbureau over de vraag wie de ontslagvergunningen mocht verlenen. Voorts diende de arbeidsinspectie de betreffende bewindsman van advies omtrent de wachtgeldregelingen ( deze speelden evenwel geen rol na het in 1952 volledig inwerkingtreden van de Werkloosheidswet) en tot slot werd het College van Rijksbemiddelaars geadviseerd ter zake van lonen en andere arbeidswoorwaarden. Dit laatste orgaan werd tevens geadviseerd over het verlenen van ontheffingen van het verbod van werktijdverkorting. Al snel zou de arbeidsinspectie echter zelf gemachtigd worden dergelijke ontheffingen te verlenen (1948).

Naast de overige wetten, waarvan de handhaving en de medewerking aan de uitvoering geheel of gedeeltelijk aan de arbeidsinspectie was opgedragen, zoals de Rijtijdenwet 1936, de Phosphorluciferwet 1901, de Caissonwet 1905, de Ongevallenwet 1921, de Hinderwet en de ordeningswetgeving, die nog stamde uit de vooroorlogse periode, zou de arbeidsinspectie belast worden met de uitvoering en het toezicht op de Wet wekelijkse rustdag toonkunstenaars en de Wet plaatsing minder-valide arbeidskrachten. Van deze laatste wet zouden echter nauwelijks impulsen uitgaan tot het in dienst nemen van minder-valide arbeidskrachten.

In deze periode kondigde zich het bedrijfsmaatschappelijk werk aan, dat door de arbeidsinspectie met belangstelling werd gevolgd. Het betrof een activiteit, die gebaseerd was op het principe, dat een goed personeelsbeleid een onderdeel vormde van de arbeidersbescherming, die op haar beurt als een onderdeel werd beschouwd wan goed bedrijfsbeheer. In 1950 werd voor dit onderdeel voor het eerst door de arbeidsinspectie officieel de term sociaal welzijn gehanteerd. Daarbij gaat het om de invloeden, die het moderne arbeidsproces had op de mens en de bedrijfsgemeenschap. De arbeidsinspectie werd betrokken bij sociaal-psychologische onderzoekingen en sociaal-psychologische aspecten van de arbeid, zoals bijvoorbeeld de ploegenarbeid, de arbeid die buitenshuis verricht werd door gehuwde vrouwen en de arbeid verricht door jeugdige personen.

Hoofdstuk 11 bestrijkt de periode van 1962 tot 1975 . Ondanks de turbulente jaren zestig, waarin in onze samenleving heel veel in beweging kwam - geëist werd inspraak, democratisering en medebeslissingsrecht, uitmondend in bijwoorbeeld een nieuwe Wet op de ondernemingsraden -, kan ten aanzien van de arbeidsinspec- 
tie en haar werkterrein worden gesteld, dat er zich in deze periode een situatie voordeed, die het best aangeduid kan worden als stilte voor de storm.

In dit tijdvak werden een aantal beslissingen genomen met betrekking tot de organisatie van de arbeidsinspectie. Met ingang van 1962 werd de departementale afdeling Arbeid(-ersbescherming) samengevoegd met de arbeidsinspectie tot een directie van de Arbeid, sinds 1964 het directoraat-generaal van de Arbeid. Onder dit directoraat-generaal van de Arbeid ressorteren naast de arbeidsinspectie, de inspectie van de havenarbeid en de dienst voor het stoomwezen.

In deze periode werd de arbeidsinspectie uitgebreid met een kernfysische dienst met aan het hoofd een kernfysisch adviseur (1968), een functie die overigens toen nog niet in het Organisatiebesluit Arbeidsinspectie werd opgenomen. In dat zelfde jaar werd door het adviesbureau Bosboom en Hegener een rapport uitgebracht over een onderzoek naar de organisatie van het directoraat-generaal van de Arbeid. Met dit onderzoek stond voor ogen de arbeidsinspectie optimaal te laten inspelen op de zich voortdurende wijzigende maatschappelijke en industriële omstandigheden. In het rapport werden een aantal voorstellen gedaan omtrent de inrichting van de leiding van het directoraat-generaall van de Arbeid; eén van deze voorstellen, namelijk het instellen van de functie van plaatsvervangend directeur-generaal werd ook gerealiseerd. Voor de districten van de arbeidsinspectie werd onder meer voorgesteld in de organisatiestructuur de technische en de sociaal-economische functie meer expliciet te maken. Dit resulteerde in de functie van bedrijfsorganisatorisch medewerker; een functie, die eveneens niet in het Organisatiebesluit werd opgenomen.

Wat betreft de Arbeidswet 1919 stond de arbeidsinspectie opnieuw voor de opgave in te spelen op de economische situatie. Als voorbeelden zijn genoemd de hantering van het vergunningenbeleid ten aanzien van overwerk en de arbeids- en rusttijdenproblematiek in de broodbakkerijsector ten einde concurrentievervalsing tegen te gaan. Bovendien werd in deze periode via overleg tussen de overheid en de betrokken sociale partners een voor alle betrokkenen aanvaardbare wettelijke arbeids- en rusttijdenregeling tot stand gebracht. In deze periode werd tevens, als gevolg van bij sommige arbeiders levende behoefte, geëxperimenteerd met het verrichten van zogenaamde permanente nachtarbeid in ploegendiensten. Voorts wordt geëxperimenteerd met zogenaamde variabele werktijden. Tot slot is deze periode van belang in verband met het tot stand brengen van het zogenaamde Jongerenstatuut, met als doel een integratie van werkende jongeren in het onderwijs met als einddoel een leerplicht tot 18 jaar. Veranderende maatschappelijke opvaltingen en economische omstandigheden zouden deze doelstellingen al snel doen sneuvelen.

In deze periode werd in het kader van de uitvoering van de Veiligheidswet 1934 onder andere aandacht besteed aan de bouwsector en aan de opslag en verwerking van gevaarlijke stoffen. Ook dringt in toenemende mate het besef door, dat voor de werkzaamheden van de arbeidsinspectie, niet alleen het zogenaamde "binnenmilieu" van groot belang is, maar ook het "buitenmilieu". Met het oog hierop werden tal van wetten uitgevaardigd, zoals de Bestrijdingsmiddelenwet 1962, de Kernenergiewet, de Wet Gevaliarlije Stoffen en de Wet inzake de luchtverontreiniging, waarbij de arbeidsinspectie een toezichthoudende, dan wel adviserende kreeg toebedeeld.

De activiteiten van de arbeidsinspectie in het kader van het Buitengewoon Besluit Arbeidsverhoudingen 1945 zouden een aanmerkelijke verandering ondergaan. Als gevolg van organisatorische veranderingen van het ministerie van Sociale Zaken en Volksgezondheid werd de bemoeienis van de arbeidsinspectie beperkt tot het verlenen van de ontslagvergunningen, het behandelen van aanvragen van ontheffingen van het verbod van werktijdverkorting en het toezicht houden op de naleving van andere arbeidswoorwaarden dan de lonen, neergelegd in bindende regelingen en collectieve arbeidsovereenkomsten.

Naast de overige wetten waarvan de handhaving van en de medewerking aan de uitvoering geheel of gedeeltelijk aan de arbeidsinspectie was opgedragen, zoals bijwoorbeeld de Steenhouwerswet 1921, de Huisarbeidswet 1933, de Rijtijdenwet 1936 en de Hinderwet, zou de arbeidsinspectie belast worden met het toezicht op de Wet op het werken onder overdruk, die diende ter vervanging van de Caissonwet 1905, en kreeg zij de wettelijke mogelijkheid om gegevens te verzamelen omtrent het functioneren van de ondernemingsraden.

Hoofdstuk 12 geeft een beeld van de periode 1975 tot 1990, waarin naast een toenemende belangstelling voor 
de arbeidsomstandigheden, ook kritiek op de arbeidsinspectie wordt gelewerd. Vanaf circa 1975 valt een veranderende rol van de overheid ter zake van de problematiek van het arbeidsomstandighedenrecht waar te nemen en wordt gewezen op het belang van immateriele arbeidsomstandigheden en het verbeteren van de arbeidsplaatsen. Alhoewel men het belang van de humanisering van de arbeid bleef onderkennen, treedt vanaf 1977 een verandering op in die zin, dat de overheid zich terzake meer terughoudend diende op te stellen. In het kader van het te voeren bezuinigingsbeleid speelde onder meer het zogenaamde volumebeleid, waarbij onder andere de humanisering van de arbeid als beleidsinstrument werd gehanteerd in de strijd tegen ziekteverzuim, arbeidsongeschiktheid en de moeilijk vervulbare vacatures, ondanks de grote werkloosheid. Denk daarbij aan de totstandkoming van de Wet arbeid gehandicapte werknemers en de subisidieregelingen arbeidsplaatsverbetering. Het beleid van het eerste en tweede kabinet-Lubbers kenmerkt zich door het terugdringen van het financieringstekort van de overheid en een versterking van de marktsector, hetgeen uitmondt in de zogenaamde grote operaties.

Voor wat betreft de Arbeidswet 1919 kenmerkt deze periode zich door drie grote zaken, namelijk het opheffen van het in de wet neergelegde onderscheid tussen mannen en vrouwen, het via het zogenaamde vijf-dagen-wetje en de nota vergunningenbeleid arbeids- en rusttijden, inspelend op de problematiek rond de arbeidstijdverkorting en de flexibilisering van de bedrijfsvoering, en de voorstellen om tot een nieuwe Arbeidswet te komen.

De wetgeving op het terrein van de veiligheid en gezondheid van de werknemers wordt in dit tijdvak stelselmatig uitgebreid. De belangrijkste gebeurtenis op dit terrein is echter de totstandkoming van de Arbeidsomstandighedenwet, ter vervanging van de Veiligheidswet 1934, de Silicosewet en de Wet op het werken onder overdruk. De belangrijkste verschillen ten opzichte van het verleden hebben betrekking op de reikwijdte van de wet, het expliciet opnemen van het element welzijn, de medezeggenschap van de werknemer en het overleg op micro-, meso- en macroniveau, het idee van samenwerking tussen de werkgever en de werknemers teneinde de arbeidsomstandigheden te bevorderen, de uitbreiding op het terrein van de deskundige diensten. De wet wordt gefaseerd ingevoerd, de laatste fase is gepland op 1 oktober 1990. Nog vo6r de inwerkingtreding van de eerste fase vond een confrontatie plaats als gevolg van $\epsilon e n$ van de hiervoor bedoelde grote operaties, namelijk de deregulering, die resulteerde in een wijzigingswet.

Niet alleen de belangstelling voor de arbeidsomstandighedenproblematiek neemt in deze periode toe, maar ook de kritiek op de arbeidsinspectie. Uit het onderzoek, ingesteld door een extern adviesbureau Mens en Organisatie, uitmondend in het rapport "De Arbeidsinspectie in ontwikkeling", blijkt, dat de organisatiestructuur, het informatieproces, het personeelsbeleid, de personeelsbezetting en de werkwijze voor verbetering vatbaar zijn. Via het Projectontwikkeling Arbeidsinspectie (1976) werd geprobeerd de bedoelde verbeteringen en een zo een doelmatig functionerende overheidsorganisatie op dit gebied tot stand te brengen. Eerst in 1984 zouden de hoofdstructuur van het directoraat-generaal van de Arbeid vastgesteld worden. Naast de directeur-generaal van de Arbeid bestaat de directie uit vier directeuren, namelijk veiligheid, gezondheid, sociaal arbeidsbeleid en algemeen en intern beleid. Twee jaar later zijn beslissingen genomen omtrent de structuur van de districten, die overeenkomt met de directie-opbouw van het directoraat-generaal van de Arbeid, de geografische herindeling, dat wil zeggen het terugbrengen van het aantal districten tot acht, en de taken en structuren van de districtsadministratie. Het rendement van de hele reorganisatie werd door velen te laag gevonden. Een nieuw project diende zich evenwel al weer aan, namelijk Arbo '91, waarin opnieuw de werkwijze en de organisatie van de arbeidsinspectie onder de loep genomen wordt. Hoofddoel van deze reorganisatie-operatie is een marktgerichte opstelling en een doelgerichte en efficiente inzet van de beschikbare middelen en instrumenten, onder meer door een meer bedrijfstakgewijze benadering.

Naast activiteiten op onder meer het terrein van de Rijtijdenwet 1936, een eventuele vervanging van de Huisarbeidswet 1933, het Buitengewoon Besluit Arbeidsverhoudingen 1945, alwaar de rol van de arbeidsinspectie in ontslagzaken werd teruggedrongen tot het zijn van adviesinstantie, daar waar het ontslag relatie heeft met de arbeidsomstandigheden, en de Hinderwet, wordt het werkterrein van de arbeidsinspectie uitgebreid met de al genoemde Wet arbeid gehandicapte werkmemers, en de Wet chemische afvalstoffen en de Afvalstoffenwet, de Binnenschepenwet en de Diergeneesmiddelenwet. 
Deze periode kenmerkt zich allereerst door een toenemende kritiek op de arbeidsinspectie en twee reorganisatieplannen, te weten het Project Ontwikkeling Arbeidsinspectie en Arbo'91. Vervolgens wordt éen van haar basiswetten, namelijk de Veiligheidswet 1934, vervangen door de Arbeidsomstandighedenwet; een wet die een groot aantal vernieuwingen met zich brengt voor het werk van de arbeidsinspectie. Daarnaast wordt haar andere basiswet, de Arbeidswet 1919, veelvuldig en ingrijpend gewijzigd en worden belangrijke stappen gezet om te komen tot een vervanging en algehele vernieuwing van deze wet in de geest van de Arbeidsomstandighedenwet. Ook is een vervanging van de Huisarbeidswet 1933 aan de orde, is haar taak terzake van het Buitengewoon Besluit Arbeidsverhoudingen 1945 onderwerp van discussie, wordt het werkterrein aanzienlijk uitgebreid, en wordt de arbeidsinspectie geconfronteerd met de deregulering, heroverweging, flexibilisering en bezuinigingen.

Dit hoofdstuk besluit met een paragraaf waarin nog eens terugblikkend de aan de arbeidsinspectie toebedeelde taken aan de orde komen en waarin naar aanleiding van de kritiek op de arbeidsinspectie enige kanttekeningen worden geplaatst die wellicht tot nuancering kunnen leiden

In hoofdstuk 13 worden een aantal juridische aangelegenheden op het terrein van het arbeidsomstandighedenrecht, maar dan beperkt tot de drie basiswetten, de Arbeidswet 1919, de Veiligheidswet 1934 en de Arbeidsomstandighedenwet, afzonderlijk beschouwd. Het betreft de veelvuldiggehanteerde begrippen "onderneming", "bedrijf" en "inrichting"; de strafrechtelijke aansprakelijkheid; een tweetal bevoegdheden, die de ambtenaren van de arbeidsinspectie hebben ter zake van de door hen uit te voeren taken, namelijk de verplichting tot het verschaffen van inlichtingen en het recht om plaatsen, waaronder woningen, te betreden, en tot slot de tegenhanger van deze beide bevoegdheden, namelijk de geheimhoudingsverplichting.

In hoofdstuk 14 wordt de regeling, de organisatie, de taken en dergelijke van de arbeidsinspectie in ons land getoetst aan terzake uitgevaardigde regelingen van de Internationale Arbeidsorganisatie. Het betreft de aanbeveling betreffende de algemene beginselen voor de inrichting en de bevoegdheden van de arbeidsinspectie 1923, het Verdrag betreffende de arbeidsinspectie in industrie en handel en het Verdrag betreffende de arbeidsinspectie in de landbouw. Terzake van de genoemde aanbeveling en het eerstgenoemde verdrag bevat het hoofdstuk van het betreffende onderdeel een slotbeschouwing.

In hoofdstuk 15 wordt in de slotbeschouwing gepleit voor een uitbreiding van de arbeidsinspectie alsmede voor een selectiever hanteren van het strafrecht op het terrein van het arbeidsomstandighedenrecht. 


\section{noten}

1. Overigens is dit niet de enige bron van kritiek; zo wordt bijwoorbeeld door de Algemene Rekenkamer kritiek geleverd op de ongestructureerde werkwijze van de dienst.

2. B. de Vries, Rede op 28 februari 1990 ter gelegenheid van het 100 -jarig bestaan van de arbeidsinspectie, Stcrt, 199043 , blz 2 .

3. Zie artikel 11, tweede lid, van de Arbeidswet 1919.

4. Zie T. Kappelhof/J. van Drongelen, in S.M.A. 1984 blz. $167 \mathrm{t} / \mathrm{m} \mathrm{173;} \mathrm{W.C.} \mathrm{Monster/M.P.} \mathrm{Timmers} \mathrm{-} \mathrm{de}$ Vin, t.a.p., blz. $148 \mathrm{t} / \mathrm{m} 153$.

5. Zie artikel 10a van de Arbeïdswet 1919.

6. Zie de artikelen 9b, vierde lid, en 9d van de Arbeidswet 1919.

7. Zie de artikelen $31,31 \mathrm{a}$ en $31 \mathrm{~b}$ van de Wet op de ondernemingsraden.

8. Zie artikel 14, eerste lid jo tweede en derde lid, (oud) van de Arbeidsomstandighedenwet. Bij de Wet van 1 februari 1990, Stb. 91 (in werking getreden op 1 april 1990), is dit artikel gewijzigd en vernummerd tot artikell 15.

9. J.A.M. Cornelissens, Arbowet en sociaal recht, in T.v.A. 1990 blz. $46 \mathrm{t} / \mathrm{m} 51$.

10. M.G. Rood, nt. AR 9 september 1985, AB 1986332 - blz. 977

11. Het instemmingsrecht geldt niet alleen voor het arbeidsreglement, als bedoeld in artikel $1637 \mathrm{j}$ van het B.W., maar ook voor bijwoorbeeld een regeling van een werktijd- of een vakantieregeling, op het gebied van veilligheid, gezondheid en welzijn in verband met de arbeid, van het werkoverleg, en met betrekking tot de positie van jongeren in de onderneming, zie artikel 27 , eerste lid, van de Wet op de ondernemingsraden.

12. Zie artikel 27 , derde lid, van de Wet op de ondernemingsraden.

13. Zie W.I.P.M. Fase, C.A.O.-recht, blz. 23, die deze ruime omschrijving gebruikt voor de c.a.o..

14. Zie artikel 49a (oud) van de Wet op de ondernemingsraden. Sinds de wijzigingswet van 1 februari 1990 , Stb. 91 , is dit geregeld in artikel 5a van genoende wet.

15. Zie onder meer A.A.G. Peters, Recht als project, in AAe 1979 blz. 881 t/m 893. 


\section{SUMMARY}

This book contains an investigation into the development of our Labour Inspectorate in a changing legislation. 1st March 1990, the centennial anniversary of our Labour Inspectorate, was chosen as the concluding date.

Chapter 1 starts out with the conclusion that the history of our Labour Inspectorate is indissolubly connected with our working conditions legal system, followed by a short description of the area of law concerning our working conditions legal system, subdivided into national and international sources of law. A description of the development of the Labour Inspectorate and its field of activity shows that it has engaged and still engages not only in the working conditions legal system, but in many other areas as well. Furthermore this chapter contains a description of the method applied and the structure of the paper.

Chapter 2 describes the long road that had to be covered in the 19th century before our country had a Labour Inspectorate. The call for governmental involvement in the field of working conditions and its inspection originates from industrialisation and the phenomenon of child labour. This started off officially in the provincial report for the province of Overijssel for the year 1835. This resulted in a correspondence to and fro between the then Minister of the Interior and the then Governor of the province. The latter proposed a ban on child labour, to be inspected by the local authorities. In 1841 a first ministerial enquiry into the working conditions of children in particular was to be carried out and the wish for governmental instruction in the matter emphasized. The addressed provincial governors were in agreement about this wish, but disagreed about the contents of the instruction. It was clear however that they too advocated facilities for inspection of the observance of such instruction, preferably on a local level. In his report dating $1860 \mathrm{De}$ Vries-Robbe was first to argue in favour of the installation of special inspectors who were to be given specific competences, such as free entrance to factories and the ability to recommend changes in hygienics and safety. This report might be called the Labour Inspectorate's charter of foundation. The same year it lead to another ministerial enquiry, which by the way underwent the same fate as its predecessor, although the social pressure increased. Eventually this was to result in Lower Chamber member Van Houten's bill. In spite of all the pressure exerted during its parliamentary procedure Van Houten's Children's Act reflects no elements of inspection of the ban on child labour included in the Act. Although the Act laid the foundation of our working conditions legal system, it had little practical meaning, firstly because it lacked a separate supervisory body, secondly because some degree of uncertainty about the actual range of the ban. Soon attempts were made both to remove observed shortcomings and to widen the scope of government: protection. A bill Van Lynden van Sandenburgh was sent to various industrial organizations for comment; although the reactions were were fairly approving, the point in question if separate inspectors were to be appointed was not answered unequivocally. In 1882 subsequent cabinet Minister Modderman presented a bill to the Lower House, which contained the intended extension as well as the institution of special inspectors. This bill was received very unfavourably in Parliament. Modderman's successor Du Tour van Bellinchave was to withdraw it and present a new one which in particular left out the special inspectors stipulation. Here again the general reproach was the absence of sufficient factual data, so that the need for governmental intervention was not proved necessary. As a reaction in 1886 and 1887 a parliamentary enquiry into the effects of Van Houten's Childrens' Act and the working conditions in factories and workshops was held. The report of the enquiry committee revealed so many social abuses that additional governmental intervention could not be delayed. A second bill Du Tour van Bellinchave, presented still in 1887 and more extensive than its original version, was not dealt with any more. His successor Ruys van Beerenbroek presented a bill that was to become 1889 Labour Act. In this Act inspection of observance and detection 
of violations are assigned to special officials, to be called inspectors, whose number was fixed in the Act itself to prevent officialdom thwarting free enterprise. Although the parliamentary enquiry committee's report had also pleaded in favour of the installation of special inspectors and although Ruys van Beerenbroek himself had been a member of this enquiry committee, the element of control of inspection in the Act was the Lower Chamber's initiative, not the minister's. Furthermore the Act controlled the competences of these inspectors and a number of measures simplifying inspection.

A concluding paragraph answers the question why a separate labour inspectorate was installed.

Chapters 3 to 5 inclusive cover the period from the origin of the Labour Inspectorate to the Great War ( the first World War).

In addition to the ban on child labour, the 1889 Labour Act contained protective measures regarding juveniles and women, so far as they work in factories or workshops. In addition to a ban on night- and Sundaylabour and a restriction of working hours, an administrative measure would exclude them from specific categories of labour endangering health of life or only allow them under specified conditions. March 1 st 1890 three authorized labour inspectors commenced their activities in as many districts, so-called "labour inspectorates". Their tasks consisted of the inspection of the implementation of the Act and the detection of violations. This liability was repeated in the further elaboration of the inspection of the Act's implementation, but administrative and ministerial measures originating from the Act were added; for this reason they had to visit actual or former workstations. In order to realize uniformity in the implementation of legal regulations inspectors had to confer on a regular basis. Furthermore they had to promote as much conformity as possible between legal demands and the interests of all work-related people. In addition they had to inform employers and make suggestions that might remove certain objections that could originate from the observance of industrial rule. More in particular the inspectors had to pay strict attention to specific categories of labour endangering life and health of juveniles and women. Finally, if requested, they had to inform and advise their minister and make any proposal they deemed necessary or advisable. If requested they had to advise licence-granting authorities on a provincial and municipal level. Finally they had to compose an annual, reasoned report of their activities and send it to their minister. These extensive terms of reference lead to a setting of task in which the inspectors, in addition to the inspection of the implementation of the 1889 Labour Act, engaged in recording working conditions in factories and workshops, collecting data and advising on hygienics and protective measures against accidents, investigating social institutions for the sake of the workers and finally completing industrial statistics. Inspectors did not consider investigation of violations among their prime tasks. Considering the amount of their work it is not surprising that the inspectors themselves soon requested extra personnel in the form of assistant inspectors. Partly as a result of inspectors' initiatives, in 1895 the Safety Act came into effect. This Act contained measures to safeguard those present in factories and workshops. Inspection of the implementation of this act and detection of violations was attributed to the inspectors, who in addition were qualified to give instructions and regulations that had to be observed. The enactment of this law discontinued the principal restriction of legislative protection of children, juveniles and women. At the same time the 1889 Labour Act was to be amended, as a result of which the legal number of appointed inspectors was cancelled, clearing the road for extensions. In 1896 the number of inspectors was extended from three to six, each of which accompagnied by an assistant inspector, the number of "labour inspectorates" being extended simultaneously. The Safety Act, which contrary to the 1889 Labour Act concentrated on working institutions instead of workers, was related to the Nuisance Act. So-called "bis"-sections in the Safety Act prevented licenses issued in accordance with the Nuisance Act or corresponding conditions to conflict with regulations based on the Safety Act. As a result of this relation the inspectors, albeit in a restricted sense, were involved in the Nuisance Act. In 1889 widening the sphere of activity yet again caused expansion of the Labour Inspectorate by two assistant inspectors. That same year an experi-ment with an assistant lady-inspector started in 1898, was formalised. In her work area she concentrated on women's labour. In addition a body of civil servants was called into being as a replacement for temporarily appointed civil servants; they had to accomplish the 
ever increasing amount of administrative chores. The next year, in tandem with a pro-portional increase of districts, the number of inspectors was increased from six to nine and the position of overseer added; these technical civil servants had to concern themselves with "simpler forms" of labour inspection. Three years later the branch was extended again with the position of lady-overseer who more particularly had to visit factories and workshops where girls and women were employed. A further extension were the so-called "specialties", notably the medical advisor and the electro-technician (1903). The former's sphere of activity related to legal regulations con-cerning workers' safety, i.e. regulations issued for the sake of labour related people's health; the latter concerned himself with electrical apparatus and conduction. Although these two civil servants had the whole State for their work area, and answered directly to the minister, the physician could do his job in a totally independent manner, while the electro-technician had to answer to his proper inspector.

The result of the investigation activities instigated by the inspectors lead a.o. to the 1901 Phosphorous Match Act, while the restricted scope of current regulations concerning safety, by initiative of the inspectors; led to the 1905 Caisson Act. Mention should be made of inspectoral advices referring to legal restrictions on working hours for all adult workers.

These advices frequently were contradictory in content, which could only be counteracted by centralization. Both in and out of Parliament a more centralized management of a continuously increasing Labour Inspectorate had been insisted upon. The initial impetus for reorganization can be found in the Kuyper Bill (1904). Consisting of 444 articles, this bill; containing labour protecting regulations, raised questions in Parliament as the relation between Labour Inspectorate and Parliament. THis bill however never passes the stage of preliminary report, but the seed of reorganization had been planted. Some years later in Parliament the appointment of a chief inspector was considered desirable, particularly to promote uniformity of inspectory activities and reporting. Government circles however were not yet convinced of the necessity of reorganization. This idea changed on the installation of Minister Talma (1908). In his view the principal flaw in the current organization was the lack of a managing director of the Labour Inspectorate. Even before Parliament went into recess, a proposed budget item was approved of and starting October 1st of the same year H.A. van IJsselstein was appointed "labour inspector bearing the personal title of Director General of Labour". Subsequently reorganization of the branch was prepared, which had to be sanctioned by altering all laws whose enforcement was entrusted to inspectors or whose execution they were involved in; these alterations came into effect a year later. The basic arrangement of its legal implementation had been stipulated in the 1889 Labour Act. Under supervision of the Director General of Labour a central branch was founded, consisting of a medical advisor, an electro-technical engineer and the public inspectors, who were to work in the central branch. Each "labour inspectorate', henceforth called "district", was supervised by a district manager of the labour inspectorate. The latter official supervised the (assistant-)inspectors, the (assistant-)lady-inspectors, overseers and controllers, so that a new function had been created in the field of labour inspection. The Director General of Labour was to supervise and inspect the labour inspectorate as a whole. Furthermore, of his own accord or on request, he was qualified to advise his minister and make propositions, and give any requested information, orally or in writing. As far as district managers were concerned the Director General's responsibility was the supervision of inspection work, notably in regard to uniformity of enforcement of the laws in question, e.g. by means of overtime permits and notions on security; in addition he had to handle data on labour conditions collected in the districts, to have specific investigations conducted of specific data collected on personnel to be appointed by the minister, to compose a general - centralized - annual report and reports on specific subjects to be published if need be, and finally to consult with representatives of employers' and workers' organizations. 'The district managers" independence was not infringed upon though; they maintained their right to be in correspondence with their minister and make propositions; in addition they retained any competences delegated from related laws. Their specification of duties was extended though; they had to keep themselves well informed about working conditions in their districts and keep abreast of events relevant to their knowledge of working conditions. Within two years after the reorganization of the Labour Inspectorate the branch was extended with a physician (1911) and a chemical engineer (1913), the former not only because of the fact that the medical 
advisor's task expanded, but because it was to be expected that the medical element in labour legislation was to expand vigorously. The latter's institution originated from the Labour Inspectorate's involvement in water pollution caused by strawboard and potato flour factories; he acquired his own laboratory and was thus given the opportunity to conduct explorations vital to the branch.

A major increase of the Labour Inspectorate's activities originated from the 1911 Labour Act, when the coadministration of provincial and municipal bodies relating to the rendering of overtime permits was cancelled, because this authority was delegated to district managers of the Labour Inspectorate. The much feared stone masons' disease had repeatedly come to the Inspectorate's attention and the threat to the workers' health was taken so seriously that in 1911 the Stone Masons' Act was effected, which didn't bring about major changes in the inspectorate's field of activity though. In parliamentary discussions of this bill, notably in relation to competences assigned to the Inspectorate's district manager, the problem of so-called (sub)delegation and its constitutional implications came up in extenso.

In that period of time several propositions were made, both in and out of Parliament, to involve bodies other than the Labour Inspectorate in the field of labour protective legislation, such as "committees of workers" unions; , the boards of labour, boards of bakers, works councils and labour chambers.

Chapter 6 covers the period of the Great War. Mobilization of the army resulting from the war threat, conscripted many workers. Both labour market and the entire economy were disrupted. Furthermore exports stagnated, which in return led to high unemployment. These circumstances necessitated more government intervention than usual hitherto and affected the Labour Inspectorate as well: its standard activities stagnated. The branch, having control of many and manifold data relating to Dutch industries, was assigned new tasks by the government. One of its first activities was, albeit of short duration, in the field of labour mediation. More protracted and much more comprehensive were its activities in the Royal National Relief Committee, which aimed at prevention and alleviation of poverty. In addition the Labour Inspectorate was involved in furlough applications for conscripts, the rendering of certificates of origin, employment of interned (Belgian) military personnel, industrial coal and peat distribution and the composition of so-called "economic notes" giving a survey of our country"s economic position.

Eventually in this period of time the number of Labour Inspectorate's districts was extended from nine to ten, both to take weight off an existing district and to do justice to major, even vital industrial areas: Rotterdam and its surrounding area, Zealand Flanders and the western half of North Brabant.

Chapters 7 and 8 cover the interbellum. Initially after the Great War the Labour Inspectorate was still confronted with the after-effects of activities carried out during the war-years. In the period leading up to the worldcrisis two items are of major importance. Firstly the institution of the High Labour Council, an advisory body bringing about institutionalized consultations of organized trade and industry on the one hand, and the government on the other hand. Secondly, for the Labour Inspectorate the realization of the 1919 Labour Act was the most important event. This act specifies a reversal of the "burden of proof". From now on there was no need to prove that long working hours were damaging and that government intervention was not damaging to economic life; on the contrary proof was necessary that economic and other motives necessitated longer working hours. Not economic, but ethical-social motives were the cornerstone of this legal arrangement. Thus the act went beyond a mere regulation of working and rest hours; it became a labour charter, as the Drion interpellation shows. Due to international competition the act was to be altered again in 1922. The original eight hour working day and 45 hour working week were exchanged for the 8.5 hour working day and the 48 hour working week. In addition an opportunity was created, by way of collective consultation, to deviate from legally prescribed working hours, although restricted by a licence issued by the minister concerned. Furthermore an enabling procedure for longterm overwork-licences was introduced.

In this period the central branch of the Labour Inspectorate was to be extended by an electro-technical advisor and -engineer and an agronomist; at that the position of chemical advisor was created to be 
seconded by a chemical engineer. The number of Labour Inspectorate districts was extended to 11 (1922); an extension to be cancelled again as a result of economy measures after the 1929 crash.

This goes to show that the economic worldcrisis did not pass over the labour inspectorate. Capacity had to be given up in a period that the Inspectorate's activities expanded and were to expand further due to both the realization of new implementing measures within the framework of the 1919 Labour. Act and the new instructions, e.g. the revision of the Safety Act, the 1933 Home Industry Act and the 1936 Driving Hours Act. Adaptation or arrangement are ideas emerging in an economic crisis. During the worldcrisis more and more arrangement legislation was enacted involving the labour inspectorate, a.o. the Act containing temporary measures to mechanize the cigar industry, the Foreign Workers Act, the 1937 Act dividing available labour, the Act declaring collective labour contracts binding and not binding and the 1938 industrial licence Act. In the fight against unemployment the Labour Act 1919 repeatedly came to the fore. One possible measure to contain unemployment and to better divide available labour was a restrictive policy towards the issuing of overwork licences. Another possibility was the introduction of the 40 howr working week via the $1919 \mathrm{La}-$ bour Act; the latter possibility was never effected.

Chapter 9 describes the period of the second World War. At first standard inspectory activities by the Labour Inspectorate practically stopped due to the problems presented to trade and industry. In this period the Inspectorate's activities principally related to the implementation of legislation enacted by or on account of the German occupier; the latter was in fact solely interested in the Dutch society's contribution to his warmachine. First to be mentioned are measures restricting work, more specifically regulations to close down companies, the introduction of short-time working and the dismissal of employers. By the execution of these measures the Director Generaal of Labour utilized so-called confidential bodies, i.e. committees consisting of equal representations of employers and their workers. After a reorganization of labour mediation and the introduction of an Employment Exchange and district job centres the Inspectorate's involvement in dismissals was ended, slowly but surely. Its activities relating to the ban on short-time working were not ended; by the introduction of so-called "zero-hours" licence the Inspectorate still had an opportunity to withdraw workers from the occupier's system of forced labour. Furthermore one might emphasize the meaures concerning wages, salaries and other labour conditions. Here the Inspectorate functioned as investigatory and advisory body for the appointed Board of Arbitration. In addition the branch played the role of investigation service. In 1942 the Board of Arbitration's task was transferred to the authorized labour representative. Although officially the Labour Inspectorate was not involved in the execution of the measure in hand, it carried out similar activities for the authorized labour representative as for the Board of Arbitration.

In addition the Inspectorate was involved in the 1941 Business Licence Resolution, the Trust Resolution and the distribution of various goods, e.g. soap, rations, shoes and the like.

The position of confidence acquired by the Labour Inspectorate, more particularly by Director General Hac$\mathrm{ke}$, caused the branch to become intricately involved in plans for national reconstruction after the German occupier's yoke would have been thrown off, notably in the foundation of the Trade Union Foundation, a meeting point for the government and its social partners.

The Dutch government, meanwhile fled to London, halfway 1944 , decreed a number of measures to prevent social-economic chaos after the liberation. The major public measure was the Extraordinary Resollution La bour Conditions which, apart from the arrangement of labour conditions, contained a ban on dismissal, barring approval of the district job centre's managing director. In a preliminary Emergency Resolution by the illegal Meurs committee, and in the Emergency Measure Labour Affairs, many competences had been assigned to the Director General of Labour, nothing of which can be found back in the Extraordinary Resolution Labour Conditions. The then Director General of Labour bitterly criticized the affair in a pamphlet dating the end of May 1945.

In retrospect it may be said that the Inspectorate had got the confidence of representatives of employers' and workers' organization, and in addition, in the execution of tasks assigned by the German occupiers, had done its utmost to impede the occupier's influence on the Dutch workers" potential for the warmachine as 
much as possible.

Chapter 10 describes the period of reconstruction from 1945 till 1962. In the war-years hard work had been done on postwar Netherlands where cooperation was be the cornerstone for the reconstruction programme. This cooperative idea was laid down in legislation and consultative structures, e.g. the Industrial Organization Act in which the Social Economic Council was founded, and the Works Councils Act. As a continuation of prewar situations, initially factory councils ( later on: works councils) were more and more involved in the implementation of the 1919 Labour Act. Sometimes co-operation and consultation took place between the authorities and representatives of employers' and workers organization in one specific branch of industry, e.g. bakers, and sometimes this even went further, as with butchers.

The implementation of the 1919 Labour Act was highly time consuming for the Inspectorate, taking into account the allowance of overwork licences and the issue of the introduction of the five-day working week, to be realized in 1962 .

In this period both the number of working hours resolutions based on the 1919 Labour Act was increased, and the regulation of working and rest hours in agriculture was realized by means of an amendment, the special element in this amendment being that, contrary to systems adhered until now, the promulgation of a working hours resolution does not take place, if and in so far a bye-law within the framework of the industrial organization Act settling the matter in hand, takes effect. These resolutions have taken effect since the early sixties.

In addition, within the 1934 Safety Act, in this period a number of safety resolutions would be issued, complemented by a system regulating industrial medicine. Here the major point was that, in spite of the common ground with the system of public health, it was understood that industrial medicine and workers" protection are cllosely connected. Thus industrial medicine was incorporated in the 1934 Safety Act, and its inspection was assigned to the Labour Inspectorate.

Both the 1919 Labour Act and the 1934 Safety Act were to undergo another major amendment in this period. Labour Inspectorate's district managers were given a particular competence, notably the order to stop work. This order can be issued in case of derious danger for personnel, or in case of serious violation of working and rest hours and related administrative regulations.

In this period the Silicosis Act and the Perilous Instruments Act were issued. The former act was intended to combat the danger of silicosis and other brown lung diseases resulting from dust inhalation.

The second act contained regulations in the interest of safety and health perilous tools and protective devices had to comply with or rules that had to be regarded. By means of this type of legislation the workers' protection is extended to labour protection in de widest possible sense and can be spoken of national protection. The Labour Inspectorate was involved in the implementation of the Extraordinary Resolution Labour Conditions in several ways. In addition to the controlling aspect, an extensive task being the control of wages and further working conditions, the Inspectorate played an advisory role, principally concerning dismissal procedures. Permission for dismissal was granted by managing directors of district job centres, after consultations with the inspectorate, which consulted with representatives of employers' and workers' organizations on the case in hand. As a result of this compromiselike construction the controversy between the Director General of Labour and the Director of the National Employment Office as to which organization was authorized to grant dismissal permits, was put an end to. Furthermore the Labour Inspectorate was obliged to advise the minister concerned about half-pay regulations ( these regulations however became redundant when in 1952 the Unemployment Act was fully enacted) and finally the branch advised the national Board of Arbitration on wages and further working conditions. The latter body was also advised on issuing exemptions from the ban on reduction of working hours. Soon the Inspectorate itself was authorized to issue these exemptions (1948).

Apart from other laws, the enforcement and cooperation in execution of which had been wholly or partially assigned to the Labour Inspectorate, e.g. the 1936 Driving Hours Act, the 1901 Phosphorous Match Act, the 1905 Caisson Act, the Nuisance Act and arrangement legislation dating from the prewar period, the In- 
spectorate was charged with the execution and inspection of the Musicians' Rest Day Act and the Handicapped Workers Act. The latter Act however hardly stimulated the employment of handicapped working workers.

In this period industrial welfare work emerged, a phenomenon closely watched by the Inspectorate. This activity was based on the principle that good personnel management was part of workers' safety; which in itself was considered part of good business management. In 1950 the Inspectorate for the first time officially referred to industrial welfare as social welfare. This relates to the influence of the modern employment on man and business community. The Inspectorate was involved in social-psychologicall explorations and social-psychological aspects of labour, notably shift work, work outside the home by married women and work by juveniles..

Chapter 11 covers the period 1962 - 1975. In spite of the turbulent sixties with their social demands (participation, democratization and right of consultation, for instance resulting in a new Works Council Act), it can be said of the Labour Inspectorate and its field of activity that in this period a situation occurred which can best be defined as the lull before the storm.

In this period a number of decisions was taken relating to the Inspectorate's organization. As from 1962 the departmental section Labour and Workers' Safety and the Labour Inspectorate were united into a Labour Directorate, which was called the Directorate General of Labour from 1964 onwards. Apart from the Labour Inspectorate, the Harbour Inspectorate and the Steam Engineering Section came under this Directorate General of Labour.

In this period the Directorate Generaal of Labour was extended by a nuclear physical section supervised by a nuclear physical advisor (1968), a function by then not yet included in the Organizational Resolution Labour Inspectorate. In the same year Bosboom and Hegener consultancy published a report about an investigation of the organization of the Directorate General of Labour. The objective of this investigation was to have the Labour Inspectorate operate to an optimal effect in permanently changing social and industrial circumstances. In the report a number of suggestions was made concerning the the management of the Directorate General of Labour; one of these suggestions, notably the introduction of the function of a substitute Director General; was effected. As for the Directorate's districts il was suggested a.o. to make the technical and social-economic function in the organizational structure more explicit. This suggestion resulted in the function of a business-organizational staff member; a function which was not included in the Organizational Resolution either.

As far as the 1919 Labour Act was concerned, the Labour Inspectorate again was confronted with the necessity to anticipate the economic situation. Examples are the procedure of licences for overwork and the problems of working and rest hours in the bakers' branch in order to counteract distortion of competition. Furthermore in this period, as a result of consultations between the authorities and the social partners concerned, a legal working and rest hours regulation was realized which was acceptable to all parties concerned. In addition in this period, resulting from a crying need among some workers, there were experiments with so-called permanent nightwork in shifts. In addition there are experiments with so-called variable working hours. Finally in this period the so-called Statute for the Young is realized, aiming at integrating working youngsters into education, the final aim being compulsory education until the age of 18 . Changing social conventions and economic circumstances would soon put an end to these objectives.

Within the framework of the implementation of the 1934 Safety Act this period a.o. paid attention to the building branch and the storage and processing of dangerous materials. Furthermore there is an increasing consciousness that, as far as the labour inspectorate's activities are concerned, both the so-called "inner" and the "outer" environment are of major significance. As a result of this view a number of laws were enacted, e.g. the 1962 Pesticide Act, the Nuclear Energy Act, the Act Dangerous Materials and the Air Pollution Act, acts in which the labour inspectorate was assigned inspective casu quo advisory tasks.

The Inspectorate's activities within the framework of the Extraordinary Resolution Working Conditions 1945 were to undergo a considerable alteration. As a result of organizational changes within the Ministry of Social 
Affairs and Public Health, the inspectorate"s involvement was restricted to the issuing of dismissal permits, processing requests for exemptions from the ban on reduction of working hours and the inspection of the observance of working conditions other than wages, laid down in binding regulations and collective labour contracts.

Apart from other laws, the enforcement and cooperation in execution of which had been wholly or partially assigned to the Labour Inspectorate, e.g. the 1921 Stone Masons Act, the 1933 Home Labour Act, the 1936 Driving Hours Act and the Nuisance Act, the Labour Inspectorate was charged with the inspection of the Overpressure Act, substitute for the 1905 Caisson Act; at that the Inspectorate got legal authority to collect data on the function of works councils.

Chapter 12 presents a picture of the period from 1975 till March 1st 1990, with both an increasing interest in working conditions and criticism of the Labour Inspectorate. From circa 1975 onwards the authorities' part in the problems of the legal system of working conditions is changing and the attention is focused on the importance of immaterial working conditions and the improvement of jobs. Although the significance of labour humanization was still recognized, from 1977 changes occur in the sense that the authorities should act in a more detached manner. Within the framwork of the policy of retrenchment, the so-called capacity policy became an important factor, in which a.o. the humanization of labour was employed as a policy instrument against absenteeism, incapacity for work and vacancies that were hard to fill, in spite of high unemployment. In this respect remember the realization of the Handicapped Workers Act and subsidies arrangement for job improvement. The policy of the first and second Lubbers cabinet is characterized by driving back the government's financing deficit and strengthening of the market sector, resulting in so-called great operations.

As far as the 1919 Labour Act is concerned this period is characterized by three major issues, notably the discontinuance of the legallized distinction between men and women, the anticipation of the problems of working hours reduction and the flexibilization of management by means of the so-called five day Act and the memorandum licence policy for working and rest hours, and finally proposals for a new Labour Act. Legislation in the field of workers' safety and health is systematically extended in this period. The most important event in this field however is the enactment of the Working Environment Act, as a substitute for the 1934 Safety Act, the Silicosis Act and the Overpressure Act. Major differences as compared to the past refer to the scope of the law, notbably the explicit inclusion of the welfare element, workers' participation and consultations on micro-, meso- and macrolevel, the idea of cooperation between employer and employees in order to improve working conditions and extensions in the field of expert branches. The Act will be introduced in stages, the last of which has been planned on 1st October 1990. Even before the realization of the first stage a confrontation occurred as a result of the abovementioned great operation, notably deregulation, resulting in an amendment.

In this period there is increase of both interest in the problems of working conditions and criticism of the Labour Inspectorate. An investigation by Mens and Organisatie extern consultancy resulting in a report called "The Labour Inspectorate in Development", shows that the organizational structure, the informational process, personnel policy, number of personinel and the method of working can be improved. Via Project Development Labour Inspectorate (1976) attempts were made to realize these improvements and a government organization functioning as efficiently as possible. For a start in 1984 the main structure if the Directorate General of Labour was determined. Apart from the Director General of Labour, the directory board consists of four managing directors, notably safety, health, social labour policy and general and intern policy. Two years later decisions were made concerning the structure of the districts, which is similar to the directory structure of the Directorate General of Labour, the geographical redivision, i.e. the reduction of the number of districts to eight, and the tasks and structures of district administration. By many the efficiency of the whole organization was considered too low. A new project came to the fore however, notably Arbo ' 91 , in which the mode of operation and the Inspectorate's organization were scrutinized once more. The principal aim of this reorganizational operation is a market approach and purposeful and efficient application of avai- 
lable means and instruments, a.o. by means of an approach per branch of industry.

Apart from activities a.o. in the field of the 1936 Driving Hours Act, a possible substitution of the 1933 Home Labour Act, the 1945 Extraordinary Resolution Labour Conditions, where the labour inspectorate's role in dismissals was reduced to an advisory one in questions where dismissal is related to working conditions, and the Nuisance Act, the Inspectorate's sphere of activities is extended to the above mentioned Handicapped Workers' Act, the Chemical Waste Act and the Waste Matter Act, the Inland Navigation Act and the Animal Medicines Act.

This period is foremost characterized by an increasing criticism of the labour inspectorate and by two reorganization schemes, notably the Project Development Labour Inspection and Arbo '91. Subsequently one of its basic laws, the 1934 Safety Act, is replaced by the Working Conditions Act, which carries a great number of renovations in the inspectorate's activities. Furthermore its second basic law, the 1919 Labour Act, is often changed considerably and major steps are taken to replace and fully renovate this law in the vein of the Working Environment Act. In addition a replacement of the 1933 Home Industry Act issidered, the Inspectorate's activities in relation to the 1945 Extraordinary Resolution Working Conditions is subject of discussion, its sphere of activities is extended considerably, and the branch is confronted with deregulation, reconsideration, flexibilization and retrenchment.

This chapter is concluded with a retrospective paragraph in which, once again, the tasks assigned to the Labour Inspectorate come up for discussion, and in which, as a result of criticism of the labour inspectorate, some remarks are made that might lead to differentiation.

In chapter 13 a number of juridical issues in the legal field of working conditons, albeit restricted to three basic laws, the 1919 Labour Act, the 1934 Safety Act and the Working Environment Act, is considered separately. This part refers to often used ideas as "company", "firm" and "institution", penal liability; two competences assigned to Labour Inspectorate's officials concerning their individual tasks, notably the obligation to give information and their right to enter sites, a.o. homes, and finally the counterpart of these two competences: the obligation of secrecy.

In chapter 14 arrangement, organisation, tasks etc. of the Labour Inspectorate in our country are examined for compatibility against comparable arrangements in the International Labour Organization. This part refers to Recommendations concerning general principles for arrangement and competences of the Labour Inspectorate 1923, the Treaty on Labour Inspection in Trade and Industry, and the Treaty on Labour Inspection in Agriculture. In relation to the said Recommendation and the former treaty the chapter contains final conclusions.

In chapter 15 the concluding observations argue in favour of an extension of the Labour Inspectorate and a more selective application of penal law in the legal system of working conditions. 


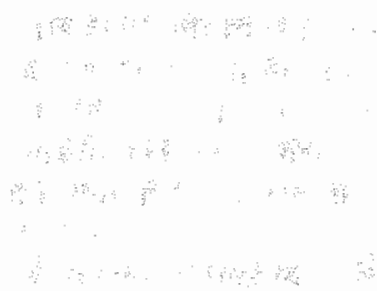

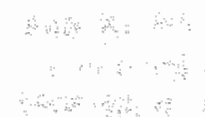




\section{LITERATUUR}

Aalberse, P.J.M. - Een onbekende enquette naar de arbeidstoestanden in Nederland, gehouden in het jaar 1841, in K.S.W. 1918 blz. $241 \mathrm{t} / \mathrm{m} 243$, blz. $253 \mathrm{t} / \mathrm{m} \mathrm{257,} \mathrm{blz.} 261 \mathrm{t} / \mathrm{m} \mathrm{263}$, blz. $283 \mathrm{t} / \mathrm{m} 286$, blz. $293 \mathrm{t} / \mathrm{m} 296$ en blz. $313 \mathrm{t} / \mathrm{m} 315$; Leiden ( z.j. )

Ackersdijck, J. - Over het werken van kinderen in fabrycken, in de Algemeene Konst- en Letterbode 1839 I blz. $82 \mathrm{t} / \mathrm{m} 85$

Adviesbureau Mens en Organisatie - De Arbeidsinspectie in ontwikkeling. Hoofdpunten uit een vooronderzoek, Amsterdam ( juli ) 1977

Akkermans, P.W.C. - De Grondwet. Een artikelsgewijs commentaar, Zwolle 1987

Aler, G.P.A. - De politiebevoegdheid bij opsporing en controle, Zwolle 1982

Albeda, W. - De crisis van de werkgelegenheid en de verzorgingsstaat. Analyse en perspectief, Kampen 1984

Ammerlaan, G.A.B.M. - Milieuhygiëne en wet, de Hinderwet en haar toepassing, "s-Gravenhage/Alphen a/d Rijn 2e druk 1982; zie Rood, Q.M.

Arbeid, Directie van de

- Adresboek van de Werkliedenorganisaties in Nederland, 's-Gravenhage 1910 ( uitgave no. 1)

- Verslag omtrent een onderzoek naar het levender polderjongens (met 1 kaart, 's-Gravenhage 1911 ( uitgave no. 3 )

- Onderzoek naar den fabrieksarbeid van gehuwde vrouwen in Nederland (met 1 kaart), 's-Gravenhage 1911 ( uitgave no. 4 )

- Gedwongen winkelnering in de Noordbrabantsche schoenenindustrie (met 1 kaart), "s-Gravenhage 1911 ( uitgave no. 6)

- Onderzoekingen naar de toestanden in de Nederlandsche huisindustrie, Deel I Voedings- en genotmiddelen, 's-Gravenhage 1911 ( uitgave no. 7a )

- Onderzoekingen naar de toestanden in de Nederlandsche huisindustrie, Deel II Diamantbewerking. -Drukkersbedrijf. - Chemische industrie. -Hout- en stroobewerking. -Metaalbewerking. $-\mathrm{Pa}$ pierbewerking. -Schoenmakers, 's-Gravenhage 1912 ( uitgave no. $7 \mathrm{~b}$ )

- Gedwongen winkelnering in de venen, 's-Gravenhage 1913 ( uitgave no. 12 )

- Onderzoekingen naar de toestanden in de Nederlandsche huisindustrie, Deell III Textielindustrie -Kleeding en Reiniging, "s-Gravenhage 1914 (uitgave no. $7 \mathrm{c}$ )

- Onderzoek naar de in Nederland bestaande fondsen tot ondersteuning van arbeiders bij ziekte, 's-Gravenhage 1912 ( uitgave no. 8)

- De bestrijding van het gevaar voor loodvergiftiging in de Nederlandsche diamantindustrie, 'sGravenhage 1912 ( uitgave no. 9)

- De Fabrieken en Werkplaatsen vallende onder de veiligheidswet ( samengesteld uit het Centrale kaartregister der Arbeidsinspectie in 1912), 's-Gravenhage 1913 ( uitgave no. 11)

- De looinijverheid in Nederland, 's-Gravenhage 1913 ( uitgave no. 13)

- Gedwongen winkelnering in de tabaksnijverheid en eenige andere bedrijfstakken, 's-Gravenhage 1914 ( uitgave no. 16 )

- De handvlasserij in Friesland, 's-Gravenhage 1915 ( uitgave no. 18)

- De arbeid van vrouwen en meisjes in het winkelbedrijf benevens eenige mededeellingen omtrent dit laatste, 's-Gravenhage ( uitgave no. 19)

- Onderzoekingen naar het oudbakken worden van brood en de middelen om dit te voorkomen, Deel I Het versch houden van brood, 's-Gravenhage 1917 ( uitgave no. 21a )

- Onderzoekingen naar het oudbakken worden van brood en de middelen om dit te voorkomen, Deel II Het oudbakken worden van brood ( een Physiologisch-Chemische Studie ), 's- 
Gravenhage 1917 ( uitgave no. 21b)

- Arbeidersbudgets gedurende de crisis, "s-Gravenhage 1917 ( uitgave no. 22)

- Gedwongen winkelnering in onderscheidenen bedrijfstakken in verschillende deelen des lands

(overzicht van het geheele onderzoek), 's-Gravenhage 1917 ( uitgave no. 23)

- Arbeidsvoorwaarden van het personeel op handelskantoren, 's-Gravenhage 1919 (uitgave no. 24)

- Adresboek van de Werklieden- en Ambtenarenorganisaties in Nederland in 1920, 's-Gravenhage 1920 (uitgave no. 25)

- De crisisinvloed op het bedrijfsleven. Resultaten van een onderzoek naar de bedrijvigheid op 1 October 1931 in de fabricks- en scheepsbouwnijverheid, het mijnwezen, de koopwaardij en in het havenbedrijf, ingesteld met medewerking van de Arbeidsinspectie, van de Inspectie van de Havenarbeid, het Mijntoezicht en de Scheepvaartinspectie, 's-Gravenhage ( $\mathrm{z}_{\mathrm{j}} \mathrm{j}$. )

Arbeild, Directoraat-generaal van de

- Jaarverslag over $1983 \mathrm{t} / \mathrm{m} 1988$, Voorburg/s-Gravenhage $1984 \mathrm{t} / \mathrm{m} 1989$

- Werving en selectie in 51 Nederlandse arbeidsorganisaties, 's-Gravenhage (december) 1984

- Rapport Controle Rijtijdenwet 1936, Voorburg (april ) 1985

- Socilaal Jaarverslag 1986 t/m 1988, Voorburg 1987 t/m 1989

- Typologie van objectorganisaties, Voorburg ( februari ) 1987

- Controle Rijtijdenwet 1936, Voorburg (april ) 1987

- Arbeidsomstandigheden van thuiswerkers. Een inventariserend onderzoek naar de arbeidsomstandigheden van thuiswerkers, 's-Gravenhage ( januari ) 1989

- Nota MD/loopbaanbeleid, Voorburg ( mei ) 1989

- Publikaties arbeidsinspectie, Voorburg (juli ) 1989

- DGA Post oktober 1989 ( special voortgang Arbo'91)

- Arbeidsinspectie en handhaving, 1990

Arbeid, Directoraat-general van de/afdeling Algemene Arbeidszaken - Ontwerp-nota Verandering bestuurlijke structuur Directoraat-Generaal van de Arbeid

Arbeid, Hooge Raad van

- Voorlopig Advies over vraagpunten betreffende bedrijfsorganisatie, no. 222, 's-Gravenhage 1921

- Advies betreffende het voorontwerp van wet tot wijziging van de Arbeidswet 1919, no. 546, 'sGravenhage 1921

- Advies inzake de reorganisatie, no. 69, 's-Gravenhage 1925

- Advies over een voorontwerp regelende de verbindendverklaring van collectie arbeidsovereenkomsten, 's-Gravenhage 1926

- Advies betreffende voorontwerp tot wijziging van de Arbeidswet 1919, no. 122, 's-Gravenhage 1927

- Advies betreffende: voorontwerp van een nieuwe Veiligheidswet, no. 105, 's-Gravenhage 1929

- Rapport inzake wettelijke verkorting van den arbeidsduur ter beperking van de crisiswerkloosheid, no. 15, 's-Gravenhage 1933

- Onderzoek naar de "blijvende werkloosheid" en haar bestrijding, "s-Gravenhage 1938

Arbeid, Inspecteurs van den

- Verslagen over 1890; over 1891; over 1895 - 1896; over 1897 - 1898; over 1898 - 1899; over 1899 - 1900; over 1903 - $1904 \mathrm{IV} / \mathrm{V}$

- Nota betreffende aanstelling van hulppersoneel, 's-Gravenhage 1893

Arbeiderspartij, Sociaal-Democratische - Arbeidersleven in Nederland. Resultaten der enquête, ingesteld door het NVV in het najaar vam 1907 naar de wenschelijkheid en mogelijkheid van beperking van den arbeidsduur voor volwassenen tot 10 uren per etmaal en afschaffing, respectievelijk beperking Arbeidsinspectie

van nacht- en kinderarbeid, (z.p.) 1908; zie Vakverenigingen, Nederlands Verbond van

- Centraal Jaarverslag over 1907 t/m 1982, Voorburg/ss-Gravenhage 1909 t/m 1983

- Arbeid op de Tweesprong, Opstellen uitgegeven ter gelegenheid van het vijfenzeventigiarig bestaan 
van de arbeidsinspectie, "s-Gravenhage 1965

- Verslag van de kleine enquête inzake de Wet op de ondernemingsraden, (november) 1972

- Wet op de ondernemingsraden. Verslag van de enquête naar de toepassing van de Wet op de ondernemingsraden on 1973, (december) 1974

- Mens en werk; de Arbeidsinspectie is er goed voor, 's-Gravenhage 1976 Arbeidsorganisatie, Internationale

- De invloed van internationale arbeidsverdragen en -aanbevelingen van de Internationale Arbeidsorganisatie, Deventer 1979

Arbeidsraad, Voorlopige - Advies inzake de eerste fase van invoering van de Arbeidsomstandighedenwet, Zoetermeer 1982/2

Arbo91, Werkgroep - Rapport Toekomstschets Arbeidsinspectie II: Inspecteur van de Arbeid. Voortsel voor functies in de buitendienst van de Arbeidsinspectie en een ontwikkelingsmodel voor de kwalitatieve Arboraad personeelsbezetting, ( november) 1988

- Advies inzake de tweede en volgende fasen van invoering van de Arbeidsomstandighedenwet, Zoetermeer 18 april 1985

- Advies inzake artikel 31 van de Arbeidsomstandighedenwet ( opdragen toezichthoudende taken aan leidinggevenden ), Zoetermeer 3 april 1987

Arnold, J.G.M. - Artikel 8 Buitengewoon Besluit Arbeidsverhoudingen 1945, in S.M.A. 1986 blz. $325 \mathrm{t} / \mathrm{m} 329$

Assendelft de Coningh, A.D. van - De wet op den vrouwen-en kinderarbeid, in De Economist $1889 \mathrm{blz} .280$ $\mathrm{t} / \mathrm{m} 295$ en blz. $353 \mathrm{t} / \mathrm{m} 361$

Asscher-Vonk, I.J. - Nachtarbeid voor vrouwen, in S.M.A. $1981 \mathrm{blz} .772 \mathrm{t} / \mathrm{m} 782$

Bakels, H.L.

- Het Europees Sociaal Handvest, in NJB $1959 \mathrm{blz} 85 \mathrm{t} / \mathrm{m} 91$

- Macht en onmacht in het privaatrecht, Deventer/Antwerpen 1965

- Schets van het Nederlands arbeidsrecht, Deventer 6e druk 1982; 7e druk 1986; 8e druk 1987; zie Opheikens, $\mathrm{L}$.

Bakhoven, P.W.

- Recht om te zwijgen en plicht om te antwoorden, in N.J.B. 1931 blz. $217 \mathrm{t} / \mathrm{m} 227$

- Bevoegdheden tot inbeslagneming en huiszoeking, in TWS $1939 \mathrm{blz} .268 \mathrm{t} / \mathrm{m} 317$

Bakker, J.H.M. - Het "Jordaan-oproer" - verzet tegen de steunverlaging in juli 1934, in TVSG 1978 blz. 35 $\mathrm{t} / \mathrm{m}$ 69; zie Nijhof, E.

Bakker, P. - in Elseviers Weekblad van 7 november 1953

Barents, R. - Grondlijnen van Europees recht, Alphen a/d Rijn/Brussel 1989; zie Brinkhorst, L.I.

Bavel, A.J. van - Werktijdverkorting en Arbeidswet 1919, in S.M.A. 1961 blz. 19 t/m 21

Becker, F. - De economische politiek van de jaren dertig, in Tijdschrift voor politieke economie $1978 \mathrm{blz}$.

$115 \mathrm{t} / \mathrm{m} \mathrm{127}$; zie Oenen, G.J. van

Beekenkamp, C. - Bedrijfsorganisatie van antirevolutionair standpunt beschouwd, Kampen 1932

Beishuizen, J. - De magere jaren, Nederland in de crisistijd 1929 - 1939, Leiden 2e druk 1967; zie Werkman, E.

Bemmelen, J.M. van - Ons strafrecht 1 algemeen deel - het materiële strafrecht, Groningen 5e druk 1975

Berg, J.Th.J. van den - Crisis in de Nederlandse politiek, Alphen a/d Rijn 1974; zie Molleman, H.A.A.

Besier, L.Ch.

- Het Nederlandsche strafproces. deel I, Haarlem 1925; zie Blok, A.J.

- Recht om te zwijgen en plicht om te antwoorden, in N.J.B. 1931 blz. $242 \mathrm{t} / \mathrm{m} 244$

Bie, L. de - De mini-shift, in PW 1984/4 blz. $9 \mathrm{t} / \mathrm{m} 12$

Bier, L. - Aansprakelijkheid voor bedrijfsongevallen en beroepsziekten, Deventer 1988

Bisschop Boele, E.H. - Sociale wetgeving, in Practische Sociologie, Groningen/s-Gravenhage/Batavia 1931; 
zie Jasephus Jitta, A.C.

Bleiswijk, M, van - EG-nieuwe stijl moet ook leiden tot verbetering van arbeidsomstandigheden, in M.v.A. 1988 blz. 539 t/m 542; zie Doorneveld-Luuring, $H$. van

Bles, A.E. - De Wet op de arbeidsovereenkomst. deel III, 's-Gravenhage 1908

Bleumer-Van der Klein, L. Theorie en praktijk van de bebeleidsvorming door de arbeidsinspectie, in AAe $1978 \mathrm{blz} .377 \mathrm{t} / \mathrm{m} 387$; zie Hent, F.

Bloemarts, J. - Op weg naar een drie-partijen-model voor het sociaal beleid in de onderneming, in S.M.A. $1978 \mathrm{blz}, 597 \mathrm{t} / \mathrm{m} 603$

Blok, A.J.-Het Nederlandsche strafproces. deel I, Haarlem 1925; zie Besier, L.Ch.

Blom, D. van - Mijnwezen, in Nederlands bestuursrecht, Alphen a/d Rijn 2e druk 1934, blz. 699 t/m 717

Boekman, E, - De eerste periodle der Nederlandsche arbeidswetgeving, in De Socialistische Gids 1919 blz. $580 \mathrm{t} / \mathrm{m} 587, \mathrm{blz}, 732 \mathrm{t} / \mathrm{m} 746 \mathrm{en}$ blz. $855 \mathrm{t} / \mathrm{m} 866$

Boersma, J. - APO's .... wat zijn dat eigenlijk?, SMO 's-Gravenhage 1978/8; zie Davidse, M./Kranendonk, Bölger, $B$. J.A. van/Noorden, W. van

- De werkgeversorganisatie in Nederland, in De Economist 1927 blz. 216 t/m 231

- Organisatorische verhoudingen tusschen werkgevers en arbeiders, Haarlem 1929

- De actie inzake de 40-urige werkweek, in De Economist $1932 \mathrm{blz} .864 \mathrm{t} / \mathrm{m} 869$

Bor, H.Th. - Project ontwikkeling arbeidsinspectie: ervaringen met een organisatieontwikkelingsproject bij het directoraat-generaal van de Arbeid, in Organisatieverandering in de Rijksdienst. Praktijk en perspectief, 's-Gravenhage 1985, blz. $292 \mathrm{t} / \mathrm{m} \mathrm{328;} \mathrm{zie} \mathrm{Roos,} \mathrm{A.J.} \mathrm{de/Veen,} \mathrm{G.} \mathrm{van} \mathrm{de}$

Bos, D. - De Bakkerswet, in Vragen des Tijds $1913 \mathrm{blz} .335 \mathrm{t} / \mathrm{m} 368$

Bosch, G. - Kinderarbeid, in De Economist 1877 I blz. $200 \mathrm{t} / \mathrm{m} 210$

Bosch Kemper, J. de

- Geschiedkundig onderzoek naar de armoede in ons vaderland, hare oorzaken en de middelen die tot hare vermindering zouden kunnen worden aangewend, Haarlem 1851

- Het Wetboek van Strafvordering I, Amsterdam 1838

Bousardt, M.C.H. - Onder Vrouwelijke Hoede. Vrouwen bij de Arbeidsinspectie, 's-Gravenhage 1990

Brinkhorst, LJJ. - Grondlijnen van Europees recht, Alphen a/d Rijn/Brussel 1989; zie Barents, R.

Broerse jr., C. - De Steenhouwerswet. Het Steenhouwersbesluit, Zutphen 1916

Brugmans, I.J.

- De arbeidende klasse in Nederland in de 19e eeuw ( $1813-1870)$, Utrecht/Antwerpen $8 \mathrm{e}$ druk ( $\mathrm{z.j.}$ )

- Honderd jaren Nederlandse nijverheid 1830 - 1930, in Welvaart en Historie. Tien studiën, 'sGravenhage 1970 , blz $118 \mathrm{t} / \mathrm{m} 139$

- Paardenkracht en mensenmacht. Sociaal-economische geschiedenis van Nederland 1795 - 1940, 's-Gravenhage 1976

Bruin, A. de - Humanisering van de arbeid door de vakbeweging sterker naar voren gebracht, in De Veiligheid $1977 \mathrm{blz} .267 \mathrm{t} / \mathrm{m} 269$

Bruinsma, Q.W.

- De geneeskundige wetgeving in Nederland en de ontwerpen tot herziening, in De Gids $1886 \mathrm{blz}$. $75 \mathrm{t} / \mathrm{m} 110$

- De Gezondheidswet, in Vragen des Tijds $1900 \mathrm{I}$ blz. $207 \mathrm{t} / \mathrm{m} 250$

Burdorf, L. - Asbest: handig, onverwoestbaar en dodelijk, in Intermediair 1989/32 blz. 37 t/m 43; zie Kllaver, J./Swuste, P.

Burger, H. - De medewerking der geneeskundigen aan het staatstoezicht op den arbeid, in Nederlandsch Tijdschrift voor Geneeskunde 1909 II ( overdruk )

Burkens, M.C.B. - Beperking van grondrechten, Deventer 1971

Burlet, H. de - Gezondheid en veiligheid op de werkplek, Leiden 1978 
Buys, J.T. - De Grondwet, toelichting en kritiek deel I, Arnhem 1887

Buyteweg, A. - Inventaris archief van de afdeling Arbeid $\Pi$, later de afdeling Arbeidsverhoudingen 1942 1949, 's-Gravenhage 1982

Bymholt, B.

- Kinderarbeid voor 1874 (een historische schets ), in De Socialistische Gids $1926 \mathrm{blz} .251 \mathrm{t} / \mathrm{m} \mathrm{267,}$ blz. $448 \mathrm{t} / \mathrm{m} 457$ en blz. $726 \mathrm{t} / \mathrm{m} 779$

- Geschiedenis der arbeidersbeweging in Nederland ( 1894 ) deel 1, Amsterdam 1975

C.J.D. - Overtreding der Arbeidswet, in Sociaal Weekblad 1898 blz. 299

Camijn, AJ.W. - Een eeuw vol bedrijvigheid. De industrialisatie van Nederland. 1814 - 1914, Utrecht/ Antwerpen 1987

Camminga, J.J. - Iets over de taak van de Controleurs van den Arbeid, in Gedenkboek 1909 - september 1934, Groningen/'s-Gravenhage/Batavia 1934, blz. 59

Campen, J.Ph.M. van - Onderneming en rechtsvorm, Utrecht 1945

Caron, G.W.

- De Arbeidswet 1919, Deventer 1921

- Regeling der verhoudingen tusschen werkgever en werknemer, Wassenaar 1941

Catz, E.W. - Quasi-zondagen, in De Gids 1967 blz. 112 - 113

Christe, D. - Arbeidsovereenkomst, Deventer ( losbladig, WABW )

Cillekens, C. - Krisis in Maastricht, werk en werkloosheid in de jaren dertig, Maastricht ( z.j. ); zie Roebroeks, W.

Clausing, B - Aansprakelijkheid van werkgever en derden, in het bijzonder tegen de ongevalsgetroffenen in de Ongevallenwet en in het ontwerp WAO, in S.M.A. $1964 \mathrm{blz} .406 \mathrm{t} / \mathrm{m} \mathrm{421...}$

Commissie, gemengde - De Wet op den kinderarbeid, voorstellen tot hare verbetering, Amsterdam 1880 Commissie bestaande uit afgevaardigden van de Vereeniging van Delfsche ingenieurs, de Maatschappij tot bevordering der bouwkunst, het Genootschap "Architectuur et Amicitia", de vakafdeeling voor bouw- en waterbouwkunde van het Koninklijk Instituut voor ingenieurs en de Sociaal-technísche Vereeniging van demokratische ingenieurs en architecten - Rapport Steenhouwersarbeid en steenhouwersziekte, Rotterdam 1910 Commissie-Ausums - Rapport wettelijke regeling van de bedrijfsgezondheidszorg, ( z.p. )( april) 1955

Commissie Bedrijfsgeneeskunde - Rapport ( z.p. )( juli ) 1951

Commissie-Fetter - Rapport Commissie bedrijfsgeneeskunde, ( juli ) 1951

Commissie-Hacke

- Eerste advies inzake werkloosheidsbestrijding, ( september ) 1933

- Tweede advies inzake werkloosheidsbestrijding, ( januari ) 1934

Commissie Jeugd in de Bedrijven

- Interimrapport "Personeelsbeleid voor jeugdigen. Wensen en feiten", 's-Gravenhage 1957

- Personeelsbeleid voor jeugdigen en Persoonsontwikkeling, "s-Gravenhage 1957

- Persoonsworming bedrijfsjeugd, 's-Gravenhage 1964

Commissie Ontwikkeling Bedrijven - Sociaal beleid in het beroepsgoederenverwoer over de weg. Onderzoekrapport. Onderzoek naar de mogelijkheden voor versterking van het sociaal beleid in samenhang met het economisch beleid in wegvervoerbedrijven, 's-Gravenhage 1984

Commissie Selectieprocedures - Eindrapport. Een sollicitant is ook een mens, "s-Gravenhage (november) 1977

Commissie-Verdam - Herziening van het ondernemingsrecht. Rapport van de Commissie ingesteld bij beschikking van de Minister van Justitie van 8 april 1960, 's-Gravenhage 1965

Commissie-Welter - Rapport van de Staatscommissie voor de verlaging van de rijksuitgaven, 's-Gravenhage 1932

Commissie Wetgevingsvraagstukken - Eindrapport Orde in de regelgeving, 's-Gravenhage 1985 
Cöordinatie van Communicatie met betrekking tot gegevens voor Onderzoek naar Ziekteverzüm, Stichting - Het werkt anders, Voorburg 1986

Cornelissens, J.A.M.

- Van individualistische naar institutionele vorming van arbeidsvoorwaarten, Deventer ( $\mathrm{z} . \mathrm{j}$. )

Coronel, S.Sr.

- Arbowet en social recht, in T.v.A. $1990 \mathrm{blz} .46 \mathrm{t} / \mathrm{m} 51$

- Middelburg voorheen en thans, Middelburg 1859

- De gezondheidsleer toegepast op de fabrieksnijverheid. Een handboek voor industriëlen, geneesen staathuishoudkundigen, Haarlem 1861

- De toestand der kinderen in onze fabrieken en het gewigt eener regeling van hunnen arbeid, in Tijdschr. Mij. van Nijverheid $1863 \mathrm{blz} .244 \mathrm{t} / \mathrm{m} 263$

- De Leidsche wolfabrieken en haar invloed op de gezondheid der arbeiders, in Ned. Tijdschr. voor Geneeskunde 1864 blz, $225 \mathrm{t} / \mathrm{m} 258$

- De diamantwerkers te Amsterdam. Eene hygiènische studie, in Ned. Tijdschr. voor Geneeskunde $1864 \mathrm{blz}, 633 \mathrm{t} / \mathrm{m} 650$

- De arbeid van kinderen tegenover de wetgeving, in De Economist $1873 \mathrm{blz} .488 \mathrm{t} / \mathrm{m} 504$ en blz. $615 \mathrm{t} / \mathrm{m} 655$

- In hoever is uitbreiding van de Wet op den kinderarbeid wenschelijk en uitvoerbaar?, in De Economist 1877 I blz. 384 t/m 390

- Kinderarbeid, Culemborg 1879

- Het geneeskundig staatstoezicht in Nederland, in Vragen des Tijds 1879 I blz. $339 \mathrm{t} / \mathrm{m} 372$

- Geschiedkundig overzicht van het vraagstuk van den kinderarbeid in Nederland, in De Tijdspiegel $1888 \mathrm{II} \mathrm{blz.} 29 \mathrm{t} / \mathrm{m} 58$

Cort van der Linden, P.W.J.H. - De rechtskennis van den ingenieur, tiende deel: arbeidswetgeving, Amster$\operatorname{dam}(\mathrm{zj}$.

Cremer, JJ. - Fabriekskinderen. Een smeekbede doch niet om geld, Arnhem 1863

Crijns, J.H.J. - Op weg naar herijking van social-economische besturing. Een verbreed en verdiept decentralisatiemodel voor de jaren negentig, in Vakbeweging in verandering. Dilemma's en uitdagingen, Deventer 1986, blz. $37 \mathrm{t} / \mathrm{m}$ 50; zie Hove, F.S. van

Davidse, M. - APO's ..... wat zijn dat eigenlijk?, SMO 's-Gravenhage 1978/8; zie Boersma, J./Kranendonk, J.A. van/Voorden, W. van

Dekkers, H. - De positie van jeugdigen in het arbeidsproces. Het Jongerenstatuut nader beschouwd, 's-Gravenhage 1987; zie Tits, M. van/Ven, J. van de/Verstegen, R.

Dercksen, W. - Vijfendertig jaar SER-adviezen deel I 1950,- 196, Deventer 1982; zie Fortuyn, P./Jaspers, T.

Derks, H.J,P. - Nieuwe arbeidstijdpatronen en hun effecten op veiligheid, gezondheid en welzijn. Een literatuuronderzoek Uitgevoerd in opdracht van het Directoraat-generaal van de Arbeid door het IVA, Voorburg (januari ) 1987; zie Eijk, M.H. van

Dienske, J.S. - Buitengewoon arbeidsrecht, Alphen a/d Rijn 5e druk 1965

Dienst Collectleve Arbeidsvoorwaarden

- Ontwikkelingen in CAO's sinds de centrale aanbevelingen van de Stichting van de Arbeid, 's-Gravenhage 1983

- Werving en selectie in cao's, 's-Gravenhage ( juli ) 1984

- Arbeidsomstandigheden in cao's, 's-Gravenhage ( februari) 1987

Diepen, A. - De Arbeidswet, toelichtingen en beschouwingen, voornamelijk met het oog op de Tilburgsche wolindustrie, Tilburg 1889

Diepenhorst, P.A. - De Nederlandsche arbeidswetgeving deel Y, Utrecht 1921

Dljkhuis, J.F.P. - De rechtsgrond van de medezeggenschap. Een onderzoek naar de gezagsverhoudingen in de onderneming, Leiden 1938 
Dijkman, J.H. - Herplaatsing van militairen, 萑 S.M. 1950 blz. $136 \mathrm{t} / \mathrm{m} 138$

Dillen, J.G. van - Van rijkdom en regenten. Handboek tot de Economische en Socialle Geschiedenis van Nederland tijdens de Republiek, 's-Gravenhage 1970

Dodeweerd, J.J. van

- Uitspraken Veiligheidswetgeving, Deventer 1979; zie Struik, J.

- De arbeidsinspectie bestaat 90 jaar, in S.M.A. 1980 blz. $378 \mathrm{t} / \mathrm{m} 385$ - in S.M.A. 1980 blz. 741 - 742 ( naschrift)

- Strafrechtelijke aansprakelijkheid in het kader van de veiligheidswet 1934 in schollen en het begrip "onderneming" in het arbeidsrecht, in De Veiligheid $1983 \mathrm{blz}$. .. $\mathrm{t} / \mathrm{m}$...

- De Arboraad in de fout. De problemen rond art. 31 Arbowet, in M.v.A. 1988 blz. 198 - 199

Doelder, H. de - De strafbaarheid van natuurlijke personen voor feiten begaan door een rechtspersoon, in DD $1983 \mathrm{blz} 41 \mathrm{t} / \mathrm{m}$ 49; zie Hart, A.C. 't

Donner, A.M.

- Handboek van het Nederlandse staatsrecht, Zwolle $9 \mathrm{e}$ druk 1972

- Algemeen deel, in Nederlands bestuursrecht, Alphen a/d Rijn 4e herziene druk 1974

Doorneveld-Luuring, H. van - EG-nieuwe stijl moet ook leiden tot verbetering van arbeidsomstandigheden, in M.v.A. $1988 \mathrm{blz} .539 \mathrm{t} / \mathrm{m}$ 542; zie Bleiswijk, M. van

Dorrestein, Th.H.J. - Hernieuwde belangstelling voor art. $1638 \mathrm{x}$, in N.J.B. $1972 \mathrm{blz} .1141 \mathrm{t} / \mathrm{m} 1151$

Drees, $\mathbf{W}$.

- Zestig jaar levenservaring, Amsterdam 1957

- Van mei tot mei, persoonlijke herinneringen aan bezetting en verzet, Assen 2e druk 1959

Drongelen, J. van

- Werktijdverkorting, Deventer 1983

- De verplichting tot het verrichten van overwerk, in S.M.A. $1983 \mathrm{blz} .78 \mathrm{t} / \mathrm{m} 83$

- Verdrag no. 103 van de Internationale Arbeidsorgansiatie en artikel 11 van de Arbeidswet 1919, in S.M.A. 1984 blz. $167 \mathrm{t} / \mathrm{m} \mathrm{173}$; zie Kappelhof, $\mathrm{T}$.

- De rol van de arbeidsinspectie in ontslagzaken, in Blinde vlekken in het sociaal recht, Deventer 1986, blz. $100 \mathrm{t} / \mathrm{m} 112$

- Het verbod van kinderarbeid, in S.M.A. 1986 blz. $223 \mathrm{t} / \mathrm{m}$ 234; zie Kappelhof, T.

- Variabele werktijdregeling. Van experiment naar een algemene vergunning, in S.M.A. 1986 blz. $297 \mathrm{t} / \mathrm{m} 306$

- Nogmaals artikel 8 van het Buitengewoon besluit Arbeidsverhoudingen 1945, in S.M.A. 1986 blz. $661 \mathrm{t} / \mathrm{m} 664$

- De naleving van de arbeids- en rusttijden van arbeiders van in het buitenland gevestigde ondernemingen, in SR 1986 blz. $29-130$

- Nevenarbeid of wel de grenzen ten aanzien van de wijze waarop de arbeider zijn vrije tijd naar eigen goeddunken kan indelen en besteden, in S.M.A. $1987 \mathrm{blz} .34 \mathrm{t} / \mathrm{m} 39$

- Over de werkingssfeer en de toepasselijkheid van de Arbeidswet 1919, in S.M.A. 1987 blz. $105 \mathrm{t} / \mathrm{m}$ 111; zie Hoeksema, $H$.

- De arbeids- en rusttijden van arbeiders van 18 jaar of ouder op grond van de Arbeidswet 1919 in vogelvlucht, in S.M.A. 1987 blz.163 t/m 169; zie Hoeksema, H.

- De Arbeidswet 1919 en het bevel tot stillegging van werk, in S.M.A. 1987 blz. $468 \mathrm{t} / \mathrm{m} 474$

- Het advies van de Stichting van de Arbeid inzake een nieuwe wettelijke werk-en rusttijdenregeling, in S.M.A. 1988 blz. $18 \mathrm{t} / \mathrm{m} 31$; zie Hoeksema, H.

- "Als dit niet strafbaar is, kan de Arbeidsinspectie beter ophouden met zijn werk tegen de kinderar-

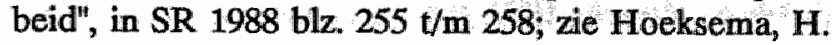

- Nogmaals fabriek of werkplaats: Arbeidswet 1919, Veiligheidswet 1934, Arbeidsomstandighedenwet, in S.M.A. 1989 blz. $486 \mathrm{t} / \mathrm{m} 493$

Duijn, J.J. van - Macro-economische gevolgen van deregulering, in Beleid en Maatschappij 1982 blz. 213 
t/m 219 en blx. 227

Duyl, H.L. - Literatuur en rechtspraak betreffende de Ongevallenwet 1910 en Beroepswet, Haarlem 1905; zie Heringa, A.

Elias, S. - Iets over steenhouwers en hun vak, Rotterdam 1909

Eijk, M.H, van - Nieuwe arbeidstijdpatronen en hun effecten op veiligheid, gezondheid en welzijn. Een literatuuronderzoek uitgevoerd in opdracht van het Directoraat-Generaal van de Arbeid door het IVA, Voorburg ( januari 1987); zie Derks, H.J.P.

Eillebrecht, A. - De sigarennijverheid in Culemborg, mensen en fabrieken, Culemborg ( $z_{\text {.j. }}$ ); zie Grimbergen, J/Schipper, P.

Emancipatiecommissie - Advies aangaande Arbeidsbeschermende maatregelen, ( juli ) 1979

Emancipatieraad

- Advies flexibilisering van arbeidsrelaties, 's-Gravenhage 1987

- Advies herziening Arbeidswet; 's-Gravenhage ( december) 1989

Engels, J.H.A.

- Het Centraal Verslag der arbeidsinspectie over 1925-I, in K.S.W. 1927 blz. 17 t/m 19

- Het Centraal Jaarverslag der arbeidsinspectie over 1926-I, in K.S.W. 1927 blz. 647 - 648; -II, in K.S.W. 1927 blz. $661-662$

Enschede, Ch.J. - Handelingen NJV deel II 1968 blz. 76 t/m 79

Erdbrink, R.J. - 30 jaren Rijksbemiddelaars I De periode tot 1942, in E.S.B. 1954 blz. 554 t/m 556; II De periode na 1945, in E.S.B. 1954 blz. $590 \mathrm{t} / \mathrm{m} 594$

F. - De organisatie van de Arbeidsinspectie in Nederland, in Sociaal Weekblad 1905 blz. $465 \mathrm{t} / \mathrm{m} 467$

Fase, W.J.P.M.

- Vijfendertig jaar loonbeleid in Nederland. Terugblik en perspectief, Alphen a/d Rijn 1980

- Publiekrechtelijke bedrijfsorganisatie en priwaatrechtelijke organisaties; geschiedenis van een onontwarbare knoop, in Gratia Commercii, Zwolle 1981, blz. $41 \mathrm{t} / \mathrm{m} 55$

- C.A.O.-recht, Alphen a/d Rijn 1982

- Arbeidsduurverkorting, in S.M.A. 1983 blz. 340 t/m 345

- Collectief arbeidsrecht na vijftig jaar, in Vijftig jaar sociaal recht in Leiden, Deventer 1986, blz. $19 \mathrm{t} / \mathrm{m} 45$

Fischer, E.J. - Fabriqueurs en fabrikanten. Twente, Borne en de kantoennijwerheid 1800 - 1930, Utrecht 1983 Fokkens, J.W. - Onrechtmatig verkregen bewijsmateriaal (2), in Advocatenblad $1981 \mathrm{blz} .1 \mathrm{t} / \mathrm{m} 6$ Fokker, E.

- De Ongevallenwet 1901 ( 2 dln ), Haarlem 1901/1903

- Hand, Nederlandsche Juristenvereeniging 1917, blz. 199 - 200

Folmer, Anth. - Arbeidsmarkt en Arbeidsbemiddeling; Voorkoming en bestrijding van werkloosheid;

Werkloosheidsvoorziening, in Het Departement van Arbeid, Handel en Nijverheid onder minister Aalberse 1918 - 1925, Alphen a/d Rijn 1926, blz. $165 \mathrm{t} / \mathrm{m} 235$

Fortuyn, P. - Vijfendertig jaar SER-adviezen deel I 1950,- 196, Deventer 1982; zie Dercksen, W./Jaspers, T. Foundation, European - zie Stichting tot verbetering van de levens- en arbeidsomstandgheden

Frenkel, B.S.

- in TVVS 1980 blz. 60

- Scholing en vakopleiding als sociaal recht, Tilburg 1986

- Nederlands bestuursrecht deel 6.1., Alphen a/d Rijn 1986; zie Jacobs, A.T.J.M.

Fruin, J.A. - De Nederlandsche Wetboeken, Utrecht 1879; 's-Gravenhage 2e druk 1888

Gaay Fortman, W.F. de

- De onderneming in het arbeidsrecht, Amsterdam 1936 
- Problemen van de Arbeid, in Nederlands economisch herstel, Amsterdam 1946, blz. 74 t/m 102 Galan, C. de - Arbeidsverhoudingen in Nederland, Utrecht/Antwerpen 4e druk 1983; zie Windmuller, J.P./Zweeden, A.F. van

Galbraith, J.K. - De krach van '29, Amsterdam 2e druk 1967

Geers, A.J.C.M.

- Schadeloosstelling van slachtoffers van bedrijfsongevallen en beroepsziekten, in N.J.B. 1977 blz. $951 \mathrm{t} / \mathrm{m}$ 959; zie Gevers, J.K.M.

- De veiligheid en gezondheid van de werknemers en het ontwerp Arbeidsomstandighedenwet, in S.M.A. 1978 blz. 159 t/m 172; zie Gevers, J.K.M.

- Arbeidsomstandighedenrecht, Deventer 1979; zie Gevers, J.K.M.

- Enkele kanttekeningen bij de 90-jarige Arbeidsinsepktie, in S.M.A. $1980 \mathrm{blz} .737 \mathrm{t} / \mathrm{m} 741$

- Veilig en wel. De Arbeidsomstandighedenwet: een nieuwe taak voor de OR, Alphen a/d Rijn 1981

- "Zulks ter bevordering van menswaardige arbeid" De nieuwe Arbeidsomstandighedenwet, in Intermediair $1981 / 9 \mathrm{blz}, 1 \mathrm{t} / \mathrm{m} 9 \mathrm{blz} .27$

- Verzoek om wetstoepassing, in Risikobulletin 1981/2 blz. 2 en 11

- Samenwerking in het kader van de Arbo-wet, in ORinformatie oktober $1985 \mathrm{blz} .16 \mathrm{t} / \mathrm{m} 18$

- Instrumenten Arbowet worden nog weinig gebruikt, in ORinformatie december $1986 \mathrm{blz.} 11$ - 12

- Flexibilisering van werktijden en de buigzame zorg voor menswaardige arbeidsomstandigheden, in SR $1988 \mathrm{blz} .216 \mathrm{t} / \mathrm{m} \mathrm{224}$; zie Heerma van Voss, G.J.J.

- Recht en humanisering van de arbeid, Deventer 1988

- Opheffing samenloop bepalingen WOR en Arbowet, in ORinformatie januari $1990 \mathrm{blz} .24 \mathrm{t} / \mathrm{m} 27$ Geersing, B. - Rechtspraak medezeggenschap 1971 - 1981, Alphen a/d Rijn 1982; zie Heijden, P.F. van der Georganiseerd Overleg in Ambtenarenzaken, Centrale Commissie voor het - Advies inzake de Herziening Arbeidswet, ( maart) 1990

Geudeker, Th.C.

- Arbeidsinspectie in de $17 \mathrm{e}$ eeuw, in Sociale Voorzorg $1924 \mathrm{I} \mathrm{blz.} 99 \mathrm{t} / \mathrm{m} 114$

- Arbeidswetgeving, in Maatschappelijke Encycolpaedie, Enschede 1930, blz. $351 \mathrm{t} / \mathrm{m} 355$

Gevers, J.K.M.

- Een kwart eeuw "Centrale Dienst", in Gedenkboek 1909 - september - 1934, blz. $69 \mathrm{t} / \mathrm{m} 109$

- Schadeloosstelling van slachtoffers van bedrijfsongevallen en beroepsziekten, in N.J.B. $1977 \mathrm{blz}$. $951 \mathrm{t} / \mathrm{m}$ 959; zie Geers, A.J.C.M.

- De veiligheid en gezondheid van de werknemers en het ontwerp Arbeidsomstandighedenwet, in S.M.A. $1978 \mathrm{blz} .159 \mathrm{t} / \mathrm{m}$ 172; zie Geers; A.J.C.M.

- Arbeidsomstandighedenrecht, Deventer 1979; zie Geers, A.J.C.M.

- Werkweigeren of doorwerken, in Risicobulletin 1980/4 blz. 9 - 10

- Health and Safety Protection in Industry: Participation and Information of Employers and Wokers, Luxembourg 1987

Giele, JI.

- De Eerste Internationale in Nederland - een onderzoek naar het ontstaan van de Nederlandse arbeidersbeweging van 1868 tot 1876 -, Nijmegen 1973

Gier, H.G. de

- Een kwaad leven - de arbeidsenquête van 1887, Nijmegen 1981 ( 3 delen )

- "Making work more human?", in Beleid en Maatschappij $1980 \mathrm{blz.} 101 \mathrm{t} / \mathrm{m} 107$

- Voor alle zekerheid. Sociaal beleid in maatschappelijk-cultureel perspectief, 's-Gravenhage 1987

- Geen wonderen verwachten van verbetering werksituatie allén. De relatie tussen arbeidsomstandigheden, ziekteverzuim en arbeidsongeschiktheid, ORinformatie meil $1990 \mathrm{blz} .42 \mathrm{t} / \mathrm{m} 45$

Gisolf, R.C.

- De goede werkgever, in Arbeid in kort geding, Deventer 1983, blz. $33 \mathrm{t} / \mathrm{m} 52$

- Ander werk, Arnhem 1985 
Goedhart, G.J. - De ontwikkeling der arbeidsbemiddeling in Nederland, Amsterdam 1929; zie Roeterink, A.

Goeman Borgesius, $\mathbf{H}$.

- De Arbeidswet - Wet van 5 mei 1889 ( Staatsblad no. 48 ), houdende bepalingen tot het tegengaan van overmatigen en gevaarlijken arbeid van jeugdige personen en van vrouwen - met inleiding en aanteekeningen, Sneek 1889

- De Arbeidswet en hare uitvoering, in De Economist $1889 \mathrm{blz} 659 \mathrm{t} / \mathrm{m} 678$

Goor, H. van - Pressiegroepen en sociale verandering, in Sociale Problemen deel 1, Utrecht/Antwerpen 1978, blz. $151 \mathrm{t} / \mathrm{m} 173$

Gorter, R.A.

- Sociaal-economische toetanden in Nederland, volgens officielle documenten wit het midden der vorige eeuw, in Sociale Voorzorg $1919 \mathrm{blz} .251 \mathrm{t} / \mathrm{m} \mathrm{274,} \mathrm{blz.} 505 \mathrm{t} / \mathrm{m} 523 \mathrm{en} \mathrm{blz.} 786 \mathrm{t} / \mathrm{m} \mathrm{811;}$ zie Vries, C.W. de

- Bijdrage tot de geschiedenis der Nederlandsche sociale wetgeving ( $1840-1874$ ), in De Economist 1919 blz. 299 t/m 335; zie Vries, C.W. de

- De eerste stap op het terrein der arbeidswetgeving in Nederland ( 1835 - 1840), in De Economist $1920 \mathrm{blz}, 257 \mathrm{t} / \mathrm{m} 290$

- Gegevens omtrent den kinderarbeid in Nederland volgens de enquêtes van 1841 en 1860, in Econ.Hist. Jaarboek 1922 ( overdruk ); zie Vries; C.W. de

Gribling, J.P. - P.J.M. Aalberse 1871 - 1948, Utrecht 1961

Grimbergen, J. - De sigarennijverheid in Culemborg, mensen en fabrieken, Culemborg ( z.j. ); zie Eillebrecht, A./Schipper, P.

Grinten, W.C.L. van der

- De algemeen verbindende ondernemersovereenkomst, in De Naamlooze Vennootschap 1939 blz. $193 \mathrm{t} / \mathrm{m} 197$ en blz. $238 \mathrm{t} / \mathrm{m} 241$

- Nieuw arbeidsrecht, Alphen a/d Rijn 4e druk 1942

- De goede werkgever en de goede arbeider, in Hedendaags arbeidsrecht, Alphe a/d Rijn 1966, blz. $134 \mathrm{t} / \mathrm{m} 145$

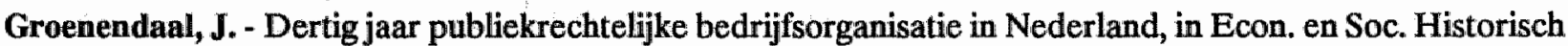
Jaarboek $1982 \mathrm{blz} .187 \mathrm{t} / \mathrm{m} 231$

Guide - Bezuiniging bij arbeid, in Tijdschrift der Nederlandsche Maatschappij voor Nijverheid en Handel 1922 blz. $47 \mathrm{t} / \mathrm{m} 49$

H.8. - Over kinderarbeid en Arbeidswet, in Sociaal Weekblad 1898 blz. $256-257$, blz. $264-265$ en blz. 272 t/m 274

Hacke, A.H.W. - Na vijf en twintig jaren Centrale Dienst, in Gedenkboek 1909 - september - 1934, Groningen/'s-Gravenhage/Batavia 1934, blz. $21 \mathrm{t} / \mathrm{m} 26$

Haersolte, W.F.A. van - De bescherming van de collectieve arbeidsovereenkomst door het recht, Amsterdam 1931

Hagoort, R. - De Christelijk-sociale beweging, Franeker 1955

Hak, T. - "Even slecht is ook gelijk". Nachtarbeid in de industrie: nu ook voor vrouwen?, in Intermediair $1980 / 11$ blz. $35 \mathrm{t} / \mathrm{m}$ 41; zie Siersema, J.

Haren, I.A.C. van - De ondernemingsraad. Een handleiding, Deventer 1979

Harixma thoe Sloten, C.L. van - Het binnentreden van woningen, Leiden 1891

Harmsen, G. - Voor de bevrijding van de arbeid. Beknopte geschiedenis van de Nederlandse vakbeweging, Nijmegen 1975; zie Reinalda, $B$.

Harrison, A. - A History of Factory Legislation, London 2d ed. 1911; zie Hutchins, B.L.

Hart, A.C. 't

- De strafbaarheid van natuurlijke personen voor feiten begaan door een rechtspersoon, in DD 1983 
blz. $41 \mathrm{t} / \mathrm{m} 49$; zie Doelder, H. de

- nt. HR 7 februari 1984, NJ 1984527

Havenman, B.W. - Doelmatige orgamisatie. Arbeidsinspectie of Rijksarbeidsbureau, in Je Maintiendrai van

12 oktober 1945

Heerma van Voss, G.J.J.- Flexibilisering van werktijden en de buigzame zorg voor menswaardige arbeidsomstandigheden in SR $1988 \mathrm{blz} 216$ t/m 224; zie Geers, A.J.C.M.

Heij, R. - Troelstra en het model van de nieuwe staat, Assen 1980; zie Hueting, E./Jong Edz., Fr. de

Heijden, P.F. van der

- Rechtspraak medezeggenschap 1971 - 1981, Alphen a/d Rijn 1982; zie Geersing, B.

- Nieuwe geschillenregeling in de WOR, in ORinformatie 12 januari $1990 \mathrm{blz} .22-23$

Heldt, B.H. - Algemeen Nederlandsch Werklieden Verbond 1871 - 1896, Leeuwarden 1896

Hen, P.E. de - Actieve en reactieve industriepolitiek in Nederland. De overheid en de ontwikkeling van de Nederlandse industrie in de jaren dertig en tussen 1945 en 1950, Amsterdam ( $2 . j$. )

Henri van der Putt, K.L. - Naar een betere verdeling van de beschikbare arbeid. Vrouwenarbeid. Mechanisatie, Eindhoven 1935

Hent, F. - Theorie en praktijk van de bebeleidsvorming door de arbeidsinspectie, in AAe $1978 \mathrm{blz} .377 \mathrm{t} / \mathrm{m}$ 387; zie Bleumer-Van der Klein, $\mathbf{L}$.

Heringa, A. - Literatuur en rechtspraak betreffende de Ongevallenwet 1910 en Beroepswet, Haarlem 1905; zie Duyl, H.L.

Hermsen. A.B. - De Kleuteronderwijswet met aantekeningen, Alphen a/d Rijn (losbladig); zie Wesseling, J.H.

Hes, B. - Het arbeidscontract, Groningen 1907

Heyermans, L. - Handleiding tot de kennis der beroepsziekten, Rotterdam 1908

Hijfte, B. van - Medezeggenschap en neo-corporatisme. Hoe de Wet op de ondernemingsraden van 1950 tot stand kwam, in Intermediair 1983/18 blz. $19 \mathrm{t} / \mathrm{m} \mathrm{29}$; zie Jong, J. de/Keman, H./Pater, K. de

Hoek, S. van der - Het bruine goud. Kroniek van de turfgravers in Nederland, Amsterdam 1985

Hoeksema, $\mathrm{H}$.

- Over de werkingssfeer en de toepasselijkheid van de Arbeidswet 1919, in S.M.A. 1987 blz. 105 t/m 111; zie Drongelen. J. van

- De arbeids- en rusttijden van arbeiders van 18 jaar of ouder op grond van de Arbeidswet 1919 in vogelvlucht, in S.M.A. 1987 blz.163 t/m 169; zie Drongelen, J. van

- Het advies van de Stichting van de Arbeid inzake een nieuwe wettelijke werk- en rusttijdenregeling, in S.M.A. $1988 \mathrm{blz} .18 \mathrm{t} / \mathrm{m} \mathrm{31;} \mathrm{zie} \mathrm{Drongelen,} \mathrm{J.} \mathrm{van}$

- "Als dit niet strafbaar is, kan de Arbeidsinspectie beter ophouden met zijn werk tegen de kinderar-

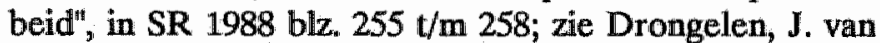

Hoeven, J. van der - Pseudo-wetgeving, Zwolle 2e druk 1967

Hoeven, W. van der - De Nederlandse sigarenmakers en tabakswerkersbond opgericht op 26 december 1887. Zijn geschiedenis, werken en streven, (z.p./z.j.)

Hoeven, W. van der - Arbeidsomstandigheden van internatioanle vrachtwagenschauffeurs, Voorburg (maart) 1987; zie Ouwerkerk, F. van/O'Hanlon, J.F.

Horsman, H. - De nieuwe Arbeidsvoorzieningswet: de geboorte van een effectief arbeidsvoorzieningsbeleid?, Rotterdam 1987

Houten, S. van

- De regstoestand der werklieden in Nederland. Ontwerp van wet met memorie van toelichting, $s^{\prime}$ Gravenhage 1870

- De staatsleer van Mr. J.R. Thorbecke, Groningen 1872

Hove, F.S. van - Op weg naar herijking van sociaal-economische besturing. Een verbreed en verdiept decentralisatiemodel voor de jaren negentig, in Vakbeweging in veranering. Dilemma"s en uildagingen, Deventer 1986, blz. $37 \mathrm{t} / \mathrm{m}$ 50; zie Crijns, J.H.J. 
Huart, F.J.A. - Grondwetsherziening 1917 en 1922, Arnhem 1922

Huet, P.A. - Beschouwingen over de toestanden in de industrie in Nederland in verband met het Verslag der Commissie van Enquête, Amsterdam 1887

Hueting, E. - Troelstra en het model van de nieuwe staat, Assen 1980; zie Jong Edz, Fr. de/Heij, R.

Futchins, B.L. - A History of Factory Legislation, London 2d ed. 1911; zie Harrison, A.

Huussen jr., A.H. - Coalitieverbod en stakingsvrijheid. Sociaal-rechtshistorische aspecten van de wet van 12 april 1872 ( Stb. 24), in Econ. en Soc. Hist Jaarboek 1982 blz. $96 \mathrm{t} / \mathrm{m} 113$

Usselstein, H.A. van

- dr. H.F. Kuyper, in Den Ingenieur 1910 blz. $964 \mathrm{t} / \mathrm{m} 966$

- Vijf en twintig jaren Arbeidsinspectie 1890 - 1915

- De Centrale Dienst der Arbeidsinspectie, in Gedenkboek 1909 - 1 september - 1934, Groningen/"sGravenhage/Batavia 1934 , blz. $7 \mathrm{t} / \mathrm{m} 14$

Jacobs, A. - Herinmeringen, Nijmegen 1978 ( reprint)

Jacobs, A.T.J.M.

- Het recht op collectief onderhandelen in rechtsvergelijkend en Europees perspectief, Alphen a/d Rijn/Brussel 1986

- Nederlands bestuursrecht deel 6.1., Alphen a/d Rijn 1986; zie Frenkel, B.S.

Jaspers, T. - Vijfendertig jaar SER-adviezen deel I 1950,- 196, Deventer 1982; zie Dercksen, W./Fortuyn, P.

Jeugdbeleid, Raad voor het - Jong geleerd oud gedaan? Een advies over de positie van kinderen en jeugdigen in de nieuwe Arbeidstijdenwet, Rijswijk ( januari) 1990

Jong, J. de - Medezeggenschap en neo-corporatisme. Hoe de Wet op de ondernemingsraden van 1950 tot stand kwam, in Intermediair $1983 / 18$ blz. $19 \mathrm{t} / \mathrm{m} \mathrm{29;}$ zie Hijfte, B. van/Keman, H./Pater, K.

de Jong Edz., Fr. de

- De enquêteurs geënquêteerd (Maastricht en de enquête naar arbeidstoestanden 1886/1887), in S.M.A. $1960 \mathrm{blz} .681 \mathrm{t} / \mathrm{m} 692$

- 'Troelstra en het model van de nieuwe staat, Assen 1980; zie Hueting, E./Heij, R.

Jonge, J.A. de - De industrialisatie in Nederland tussen 1850 en 1914, Nijmegen 1976 ( reprint)

Josephus Jitta, A.C.

- De practijk der Arbeidsgeschillenwet, "s-Gravenhage 1929

- Sociale wetgeving, in Practische Sociologie, Groningen/s-Gravenhage/Batavia 1931; zie Bisschop Boele, E.H.

Kamp, H, van de - Het spanningsveld tussen Arbowet en WOR, in S.M.A. 1982 blz, 726 t/m 735; zie Meester, I, de

Kamp, J.L.J. van de - Geschiedenis der pogingen tot wettelijke regeling van den landbouwarbeid, in R.B.A. XXIVe serie blz. $85 \mathrm{t} / \mathrm{m} 88$

Kamphuisen, P.W. - De collectieve en individuele arbeidsovereenkomst, Leiden 1956

Kant, Y. - Asbest in het garagebedrijf. Vebrod toepassing in remvoering belemmerd door EG-regels, in M.v.A. 1989 blz. 391 t/m 195; zie Notemans, J.V.H./Vermeer, L.P.H.

Kappelhof, $\mathbf{T}$.

- Verdrag no. 103 van de Internationale Arbeidsorgansiatie en artikel 11 van de Arbeidswet 1919, in S.M.A. 1984 blz. $167 \mathrm{t} / \mathrm{m}$ 173; zie Drongelen, J. van

- Het verbod van kinderarbeid, in S.M.A. $1986 \mathrm{blz} 223 \mathrm{t} / \mathrm{m} \mathrm{234;} \mathrm{zie} \mathrm{Drongelen,} \mathrm{J.} \mathrm{van}$

Kapteyn, PJ.G. - Inleiding tot het recht van de Europese Gemeenschappen, Deventer 4e druk 1987; zie Verloren van Themaat, $P$.

Katholiek Sociaal Weekblad 1902 - De Gezondheidswet, blz. 286 - 287 
Katholiek Sociaal Weekblad 1903 - Voorontwerp Arbeidswet 1903 ( overzicht der ontworpen bepalingen ook in vergelijking met de geldende Arbeidswet en Veiligheidswet ), blz. $177 \mathrm{t} / \mathrm{m} \mathrm{179,} \mathrm{blz.} 260 \mathrm{t} / \mathrm{m}$ 262

Katholiek Sociaal Weekblad 1904 - Studiên over de Arbeidswet, blz 225. blz. 232 - 233, blz 245 t/m 248 , blz. $256 \mathrm{t} / \mathrm{m} 258$, blz. $266 \mathrm{t} / \mathrm{m} 268$, blz. $292 \mathrm{t} / \mathrm{m} 295$, blz. $305-306$, blz. $328 \mathrm{t} / \mathrm{m} 331, \mathrm{blz} .339 \mathrm{t} / \mathrm{m} 341$, blz. $364-365$, blz. $375-376$, blz. $398 \mathrm{t} / \mathrm{m} 400$, blz. $423 \mathrm{t} / \mathrm{m} 425$, blz. $435-436$, blz. $508 \mathrm{t} / \mathrm{m} 510$, blz. $557 \mathrm{t} / \mathrm{m} 559$, blz. $604-605$, blz. $615 \mathrm{t} / \mathrm{m} 617$

Katholiek Sociaal Weekblad 1908 - Arbeidsduur I blz. $18 \mathrm{t} / \mathrm{m}$ 20; Arbeidsduur II, blz. 28 t/m 31; Arbeidsduur III, blz. $40 \mathrm{t} / \mathrm{m} \mathrm{43;}$ Arbeidsduur IV, blz. 53 - 54

Keesing, F.A.G. - De conjuncturele ontwikkeling van Nederland en de evolutie van de economische overheidspolitiek $1918-1939$, Nijmegen (reprint)

Keman, H. - Medezeggenschap en neo-corporatisme. Hoe de Wet op de ondernemingsraden van 1950 tot stand kwam, in Intermediair 1983/18 blz. $19 \mathrm{t} / \mathrm{m} \mathrm{29;} \mathrm{zie} \mathrm{Hijfte,} \mathrm{B.} \mathrm{van/Jong,} \mathrm{J.} \mathrm{de/Pater,} \mathrm{K.} \mathrm{de}$ Kerdijk, A.

- De Wet op den kinderarbeid, in Vragen des Tijds $1878 \mathrm{I} \mathrm{blz} 93 \mathrm{t} / \mathrm{m} 149$

- Een belangrijk rapport, in Vragen des Tijds $1880 \mathrm{II} \mathrm{blz.} 155 \mathrm{t} / \mathrm{m} 177$

- De werkzaamheden der gemeenten tot beteugeling van den kinderarbeid, in Vragen des Tijds 1882 I blz. $231 \mathrm{t} / \mathrm{m} 257$

- Het voorlopig verslag over het wetsontwerp op den kinderarbeid, in Vragen des Tijds 1883 II blz. $278 \mathrm{t} / \mathrm{m} 311$

- IJdele hoop, in Vragen des Tijds $1886 \mathrm{I} \mathrm{blz.} 139 \mathrm{t} / \mathrm{m} 158$

- Noodige medewerking, in Sociaal Weekblad 1896 blz. 241 - 242 en blz. $249-250$

- Vrouwelijke ambtenaren bij de Arbeidsinspectie, in Vragen des Tijds 1989 ( overdruk )

Kerkhoven, C.L.M. - De grondslagen der loontechniek, Alphen a/d Rijn 3e druk ( z.j. )

Kerkvliet Asz., Joh.

- Het Kinderwetje Van Houten, een gouden jubileum, in K.S.W. 1924 blz. $513 \mathrm{t} / \mathrm{m} \mathrm{518,} \mathrm{blz.} 529 \mathrm{t} / \mathrm{m}$ 532 , blz. $541 \mathrm{t} / \mathrm{m} 543$ en blz. $553 \mathrm{t} / \mathrm{m} 555$

- Van Vam Houten tot Ruys van Beerenbrouck Sr., in K.S.W. 1925 blz. 457 t/m 461

Klaver, J.

- Havens als proefterrein. Nieuwe aanpak Arbeidsinspectie, in Risikobulletin 1988/4 blz. 9 - 10

- Asbest: handig, onverwoestbaar en dodelijk, in Intermediair $1989 / 32$ blz. $37 \mathrm{t} / \mathrm{m} \mathrm{43}$; zie Burdorf, L./ Swuste, P.

Klein, P.W. - Depressie en beleid tijdens de jaren dertig, in Lof der Historie; opstellen over geschiedenis en maastchappij, Rotterdam 1973, blz. $287 \mathrm{t} / \mathrm{m} 335$

Kluiver, K - Middel tot wering van ambtenaren?, in Banket Bakkerij 21 februari 1940

Knegt, J.A. - "De aanwijzing": fictie of bruikbaar gereedschap, in M.v.A. 1988 blz. $326-327$

Koedijk, P. - Prof. mr. L.A. Geelhoed: "Nieuwe ideeën voor een herinrichting van onze samenleving ontbreken", in VN 21 januari 1989 blz. 4.

Koning, F. - Het systeem van het collectieve arbeidsvoorwaardenrecht, Deventer 1987

Koopman, P.L. - De Arbeidsomstandighedenwet: een nieuwe impuls voor werkoverleg?, in Intermediair 1981 $137 \mathrm{blz} .53 \mathrm{t} / \mathrm{m} 55$

Koopmans, $\mathbf{T}$.

- De begrippen werkman, arbeider en werknemer, Alphen a/d Rijn 1962

- Compendium van het staatsrecht, Deventer 1972

Korevaar, K. - Arbeidsomstandigheden en CAO-beleid, in T.v.A. $1989 \mathrm{blz} .62 \mathrm{t} / \mathrm{m} \mathrm{70;}$;ie Soeterbroek, F.

Kranenburg, R. - Decentralisatie van wetgeving en de arbeidsraden, in Vragen des Tijds $1917 \mathrm{l} \mathrm{blz.} 125 \mathrm{t} / \mathrm{m}$ 135

Kranenbrug, W.R.H. - De medische dienst bij de arbeidisnspectie, in Gedenkboek 1909 - 1 september - 1934, Groningen/s-Gravenhage/Batavia 1934, blz. 27 t/m 34 
Kranendonk, JA van - APO's wat zijn dat eigenlijk?, SMO 's-Gravenhage 1978/8; zie Boersma, J./Davidse, M./Voorden, W, van

Krelich, W. - Jordaners op de barricaden, Het oproer van 1934, Zutphen ( Z.j. )

Kreukels, L.H.M. - Mijnarbeid: volgzaamheid en strijdbaarheid. Geschiedenis van de arbeidsverhoudingen in de Nederlandse steenkolenmijnen 1900-1940, Assem/Maastricht 1986

Kroes, R. New Left, Nieuw Links, New Left. Verzet, beweging, verandering in Amerika, Nederland, Engeland Alphen a/d Rijn 1975.

Kuczynski, J. - Het ontstaian van de arbeidende klasse, Nijmegen $(z, j)$

Kuiper, D. - dr.ir. A.H.W. Hacke, in S.M.A. $1961 \mathrm{blz.} 615 \mathrm{t} / \mathrm{m} 617$

Kukler, N.

- Nachtarbeid door vrouwen in de industrie, in De Veiligheid $1984 \mathrm{blz}, 497 \mathrm{t} / \mathrm{m} 499$

- Arbeidstijdenwet opent weg naar nieuwe werktijdpatronen, in Gids voor personeelsbeleid 1989/6 blz. $22 \mathrm{t} / \mathrm{m} 27$

- Advies-aanvrage SER over vervanging van Arbeidswet 1919: nieuwe rechten voor werknemers, in ORinformatie april $1990 \mathrm{blz} .4 \mathrm{t} / \mathrm{m} 6 \mathrm{en} \mathrm{blz.} 11$

Lalleman, G.B. - Slavernij in Nederland, in De Economist $1855 \mathrm{blz} .33 \mathrm{t} / \mathrm{m} 43$

Last, C.C.A. - Arbeidsinspectie, in Sociale Voorzorg $1923 \mathrm{blz} .136 \mathrm{t} / \mathrm{m} .145$

Last, C. de - Milieuproblematiek vraagt aandacht van SZW, in Sozavox 1989/5

Leijzer, G.J.M. de - De WAGW in de praktijk, in M.v.A. 1988 blz. $155 \mathrm{t} / \mathrm{m} 160$

Levenbach, M.G.

- Overwerk, in R.B.A. XXe serie blz. $49 \mathrm{t} / \mathrm{m} 52$

- Het afzonderlijk bedrijf in het arbeidsrecht, R.B.A. XXIIe serie blz. $33 \mathrm{t} / \mathrm{m} 35$

- Nieuwe regelingen, in R.B.A. XXVle serie blz. $17 \mathrm{t} / \mathrm{m} 18$

- De ontslagregeling, in R.B.A. XXVIe serie blz. $33 \mathrm{t} / \mathrm{m} 37$

- De loonsverlagingsregeling, in R.B.A. XXVle serie blz. $49 \mathrm{t} / \mathrm{m} 53$

- Arbeid in een onderneming van landbouw, in R.B.A. XXVIe serie blz. $49 \mathrm{t} / \mathrm{m}$ 51, blz. 73 - 74 en blz. $77 \mathrm{t} / \mathrm{m} 79$

- Opmerkingen over de collectieve arbeidsovereenkomst, in R.M. 1933 blz. $273 \mathrm{t} / \mathrm{m} 326$

- Rechtsherstel en het Buitengewoon Besluit Arbeidsverhoudingen 1945, in N.J.B. $1946 \mathrm{blz} .357 \mathrm{t} / \mathrm{m}$ 362

- Waar staan we met het arbeidsrecht, in S.M. $1946 \mathrm{blz} .7 \mathrm{t} / \mathrm{m} 13$

- Kanttekeningen bij het BBA, in S.M. $1947 \mathrm{blz} .38 \mathrm{t} / \mathrm{m} 46$, blz. $83 \mathrm{t} / \mathrm{m} 91$, blz. $113 \mathrm{t} / \mathrm{m} 119$ en blz. $186 \mathrm{t} / \mathrm{m} 191$

- Het juridische begrip "onderneming", in S.M. 1949 blz. $175 \mathrm{t} / \mathrm{m} 180$

- Het herplaatsingsrecht van terugkerende militairen volgens artikel 5 van het Buitengewoon Besluit Arbeidsverhoudingen, in S.M. $1950 \mathrm{blz} .2 \mathrm{t} / \mathrm{m} 11 \mathrm{en} \mathrm{blz.} 62$

- Militaire dienst, beëindiging van de arbeidsverhouding en herplaatsingsrecht, in S.M. 1950 blz. 139 t/m 145

- Het honderdjarig Burgerlijk Wetboek en het arbeidsrecht, in Arbeidsrecht. Een bundel opstellen, Alphen a/d Rijn 1951, blz. $256 \mathrm{t} / \mathrm{m} 276$

- De Nederlandse loonpolitiek, Alphen a/d Rijn 1955

- Arbeid, in Nederlands bestuursrecht ( uitgave 1962) deel III, Alphen a/d Rijn 1964

- Historisch overzicht van de sociale verzekeringswetgeving, in Nederlands bestuursrecht (uitgave 1962 ) deel III, Alphen a/d Rijn 1964

Lijphart, A. - Kentering in de Nederlandse politiek, in Acta Politica 1968/1969 blz. 231 t/m 247

Logeman, J.H.A. - Over de theorie van een stellig staatsrecht, Leiden 1948

Loonbureau - Veiligheid, gezondheid, hygiëne en milieu; bepalingen terzake voorkomend in de collectieve arbeidsovereenkomsten, 's-Gravenhage 1977 
Loontechnische Dienst

- Arbeidsduurverkorting in de periode november 1982 tot en met april 1985, 's-Gravenhage (april) 1986

- De concrete invulling van de arbeidstijdverkorting, 's-Gravenhage (december) 1986

Louman, J.A.M. - Kosten en baten van arbeidsplaatsverbetering, in T.v.A. 1985 blz. 25 t/m 31; zie Poll, K.J. Luttenbergsch Chronolische Verzameling - Jaargang 1891

Maarseveen, H.Th.J.F. van - Petitierecht, in Grondrechten. commentaar op hoofdstuk 1 van de herzienen Grondwet, Nijmegen 1982, blz, $140 \mathrm{t} / \mathrm{m} 150$

Maenen, A.J.Fr. - Petrus Regout 1801 - 1873. Een bijdrage tot de sociaal-economische geschiedenis van Maastricht, Nijmegen 1959

Mannoury, J.

- De collectieve arbeidsovereenkomst, Alphen a/d Rijn 1961

- Honderd jaar na de Kinderwet van 1874. De politieke rehabilitatie van mr. S. van Houten, in Mast, W. v.d. S.M.A. 1974 blz. $353 \mathrm{t} / \mathrm{m} 369$

- De voorgeschiedenis van de reorganisatie der openbare arbeidsbemiddeling in Nederland, in E.S.B. 1942 blz. $338 \mathrm{t} / \mathrm{m} 340$

- De beteekenis der reorganisatie van de openbare arbeidsbemiddeling in Nederland, in E.S.B. 1942 blz. $349 \mathrm{t} / \mathrm{m} 351$

Maurits, A.J.R. - De 40-urige werkweek, in De Economist $1937 \mathrm{blz.} 478 \mathrm{t} / \mathrm{m} 486$

Meester, I. de - Het spanningsveld tussen Arbowet en WOR, in S.M.A. 1982 blz. 726 t/m 735; zie Kamp, H. van de

Meijers, E.M.

- De inspecteurs van den arbeid over den 10-urigen arbeidsdag, in Sociaal Weekblad 1908 blz. 57 $\mathrm{t} / \mathrm{m} 59$ en bly. $65 \mathrm{t} / \mathrm{m} 67$

- De arbeidsovereenkomst, Haarlem 3e druk 1924

Melai, A.L.

- Wetboek van Sträfvordering, Arnhem ( losbladig)

Mok, S.

- Tuchtrechtspraak arbeidstijden broodbakkerij, ( oktober) 1985

- Arbeidsrecht, Amsterdam 1936

- Het algemeen verbindend en onverbindend verklaren van bepalingen van collectieve arbeidsovereenkomsten, Haarlem 1939

Molengar, A.N.

- De naleving van arbeidsconventies, 's-GRavenhage 1938

- Arbeidsrecht I Algemeen deel, IIA Bijzonder deel Het geldende recht en IIB Bijzonder deel Het geldende recht, Zwolle 1953/1958

Molleman, H.A.A. - Crisis in de Nederlandse politiek, Alphen a/d Rijn 1974; zie Berg, J.Th.J. van den Monster, W.C.

- Het zoogrecht gespeend van een goede wettelijke regeling, in NJB $1987 \mathrm{blz}$. $931 \mathrm{t} / \mathrm{m}$ 935; zie Timmers-de Vin, M.P.

- Positierecht. Rechtspositie van zwangere en pas bevallen werkneemsters, Alphen a/d Rijn 1989; zie Timmers-de Vin, M.P.

Morren, H.J. Het Rijksarbeidsbureau, in E.S.B. $1940 \mathrm{blz} .670 \mathrm{t} / \mathrm{m} 672$

Mouton, J.Th.

- Wettelijke voorschriften betreffende gezondheid en veiligheid voor werklieden in fabrieken en werkplaatsen, Nijmegen 1886

- Op weg, in Vragen des Tijds 1889 II blz. $131 \mathrm{t} / \mathrm{m} 151$ 
- Congres voor nijverheidshygiëne en Reddingwezen 1890 deel I, Amsterdam 1891

Mulder, A.

- Schets van het economisch strafrecht, Zwolle 3e druk 1974; 4e druk 1983

- Feitelijke leiding geven aan de verboden gedraging, indien het strafbaar feit door een rechtspersoon is begaan, in TVVS 1988 blz. $213 \mathrm{t} / \mathrm{m} 219$

Mulder, J. - Het Nederlandsche veen, in Gedenkboek ter herinnering aan het vijftig-jarig bestaan der Arbeidsinspectie, Groningen/Batavia 1940, blz. $150 \mathrm{t} / \mathrm{m} 177$

Naber, H.

- Van preventief ontslagverbod terug naar repressief ontslagrecht, Deventer ( z.j. )

- Enkele juridische aspecten van arbeidsvoorziening nieuwe stijl, in S.M.A. 1987 blz. 633 t/m 641

Nachtarbeid - Vrouwen en nachtarbeid. Onderzoek naar nachtarbeid door vrouwen in de industrie, 's-Gravenhage 1988

Nagelkerke, A.G. - Arbeidsverhoudingen, theorie en praktijk deel 1, Leiden/Antwerpen 1982; zie Reynaerts, W.H.J.

Nijhof, E.

- Het "Jordaan-oproer" - verzet tegen de steunverlaging in juli 1934, in TwSG 1978 blz. 35 t/m 69; zie Bakker, J.H.M.

- "De geesel van onzen tijd" , een onderzoek naar werklozenbeleid en werkloosheidsbeleving in de jaren dertig te Utrecht, Leiden 1983; zie Schrage, P./Sturkenboom, M.

Nolte, H.J.A - Het strafrecht in de afzonderlijke wetten, Utrecht/Nijmegen 1949

Notemans, J.V.H. - Asbest in het garagebedrijf, Vebrod toepassing in remvoering belemmerd door EG-regels, in M.v.A. 1989 blz. 391 t/m 195; zie Kant, Y./Vermeer, L.P.H.

Oenen, G.J. van - De economische politiek van de jaren dertig, in Tijdschrift voor politieke economie 1978 blz. 115 t/m 127; zie Becker, F.

Olbers, M.M. - Arbeidsvoorwaardenregeling bij wet of cao, in Schetsen voor Bakels, Deventer 1987, blz. 185 t/m 198

Office, Internationaal Labour - The Organisation of Labour Inspection in Industrial and Commercial Undertakings, Geneva 1939

Ondernemingen, Verbond van Nederlandse - De ontstaansgeschiedenis van het Verbond van Nederlandse Ondernemingen in kort bestek, (juni) 1987

Oostrum, H. van - Arbeidsrechtelijke en strafrechtelijke aspecten van bedrijfsongevallen, in AAe $1974 \mathrm{blz}$. $131 \mathrm{t} / \mathrm{m} 144$

Opdorp, J.H. - Over kinderarbeid, in de Algemeene Konst- en Letterbode $1839 \mathrm{I} \mathrm{blz.} 114 \mathrm{t} / \mathrm{m} 116$

Opheikens, I. - Schets van het Nederlands arbeidsrecht, Deventer 6e druk 1982; 7e druk 1986; zie Bakels, H.L.

Oppenhelm, J. - De Wet van 5 Mei 1889 ( Staatsblad no. 48 ) tot het tegengaan van overmatigen en gevaarlijken arbeid van jeugdige personen en van vrouwen, Groningen 1889

Organisatlon, International Labour

- The Organisation of Labour Inspection in Industrial and Commercial Undertakings, Report IV, International Labour Conference, Thirtieth Session, Geneva 1947

- Report of the Committee of Experts on the Application of Conventions and Recommendations, Report III ( Part IV ), International Labour Conference, Fortieth Session, Geneva 1957

- Report of the Committee of Experts on the Application of Comnventions and Recommendations, Report III ( Part IV ), International Labour Conference, Fiftieth Session, Geneva 1966

- Report of the Committee of Experts on the Application of Conventions and Recommendations, Report III ( part 4 (a)), International Laboutr Conference, 61st Session, Geneva 1976

- Labour Inspection, general Survey by the Copmmittee of Experts on the Application of Conventi- 
Oud, P.J.

ons and Recommendations, International Labour Conference, 71st Session, Geneva 1985

- Het constitutionele recht van het Koninkrijk der nederlanden deel I, Zwolle 2e druk 1970

- Honderd jaren. Een eeuw van staatkundige vormgeving in Nederland ( 1840 - 1940), Assen 7e druk 1979

Ouwerkerk, F. van - Arbeidsomstandigheden van internatioanle vrachtwagenschauffeurs, Voorburg (maart) 1987; zie Hoeven, W, van der/O'Hanlon, J.F.

O'Hanlon, J.F. - Arbeidsomstandigheden van internatioanle vrachtwagenschauffeurs, Voorburg (maart) 1987; zie Hoeven, W. van der/Ouwerkerk, F. van

Paardekoper, P.A. - Hantering van het economisch strafrecht in Nederland, Deventer 1975

Pater, $\mathbf{K}$ de - Medezeggenschap en neo-corporatisme. Hoe de Wet op de ondernemingsraden van 1950 tot stand kwam, in Intermediair $1983 / 18 \mathrm{blz}, 19 \mathrm{t} / \mathrm{m} \mathrm{29}$, zile Hijfte, B. van/Jong, J. de/Keman, H.

Peters, A.A.G. - Recht als project, in AAe 1979 blz. $881 \mathrm{t} / \mathrm{m} 893$

Peype, T. van - De ontwikkeling van het loonvormingsrecht, Nijmegen 1985

Piepers, A.M. - Bijdrage tot de geschiedenis van het toezicht op het stoomwezen in Nederland, 's-Gravenhage 1914

Plate, A. - in Maatschappijbelangen $1939 \mathrm{blz} .115 \mathrm{t} / \mathrm{m} 118$

Ploeg, R. van der - Wij zijn allen werklieden. De opkomst van de moderne arbeidsmoraal in Nederland in de negentiende eeuw, Baarn 1986; zie Zinkstok, $R$

Poll, KJ. - Kosten en baten van arbeidsplaatsverbetering; in T.v.A. 1985 blz. $25 \mathrm{t} / \mathrm{m}$ 31; zie Louman, J.A.M. Pompe, W.

- nt. HR 16 mei 1938, NJ 19381019

- nt. HR 27 juni 1938, NJ 1938997

- Over de verantwoordelijkheid van werkgever en werknemer i.v.m. werkstaking, in N.J.B. 1949 blz. $641 \mathrm{t} / \mathrm{m} 646$

Posthumus, N.W.

- Uit de voorgeschiedenis van de wetgeving tegen den kinderarbeid, in Econ.-Hist. Jaarboek 1918

blz. $3 \mathrm{t} / \mathrm{m} 36$

- De geschiedenis van de Leidse lakenindustrie III, 's-Gravenhage 1939

- Kinderarbeid in de zeventiende eeuw in Delft, in Econ.-Hist. Jaarboek $1943 \mathrm{blz} .43 \mathrm{t} / \mathrm{m} 50$

- Bronnen tot de geschiedenis van de Leidse Textielnijverheid IV ( $1611-1650)(\mathrm{z} . \mathrm{p} . / \mathrm{zj}$. $)$, V ( 1651 $-1672)(\mathrm{z} . \mathrm{p} . / \mathrm{z.j}$.

Posthumus, P. - Harde guldens, harde tijden, beeld van het Jordaanoproer 1934, Amsterdam ( z.j.); zie Wetering, $H$. van de

Postma, A.

- Een onbekende enquête uit 1877, in Econ.-Soc. Hist. Jaarboek $1973 \mathrm{blz} .216 \mathrm{t} / \mathrm{m} 260$

- Een enquête uit 1883, in Econ. en Soc.-Hist. Jaarboek 1973 blz. $261 \mathrm{t} / \mathrm{m} 276$

- De mislukte pogingen tussen 1874 en 1889 tot verbetering en uitbreiding van de Kinderwet- van Houten, Deventer 1977

Pot, C.W. van der - Handboek van het Nederlandse staatsrecht, Zwolle 5 e druk 1953

Praeventieve Geneeskunde, Instituut voor - Rapport, Leiden 1948.

Proos, A.M. - Tripartiete overleg binnen het te voeren arbeidsvoorzieningenbeleid. Ingrijpende veranderingen bij arbeidsbureaus?, in De Gids $1986 / 1 \mathrm{blz}, 13 \mathrm{t} / \mathrm{m} 16$

Pyttersen, H. - Beknopte handleiding bij de Wet op de Kamers van Arbeid, Sneek 1897

Quint, A.W. - Twintig jaar Hooge Raad van Arbeid, in R.B.A. XXVe serie blz. $57 \mathrm{t} / \mathrm{m} 61,65 \mathrm{t} / \mathrm{m} 69 \mathrm{en} 81$ t/m 86 
Raad voor de Arbeidsmarkt - Advies inzake de opneming van gehandicapten in het arbeidsproces, $1975 / 9$ Raad van Centralle Ondernemingsorganisaties

- De arbeidsduur ( verslag van de Commissie arbeidsduur RCO aan het Centraal Beraad arbeidswoorwaarden), (oktober) 1980

- Discussienota arbeidsduur, op weg naar individualisering van de arbeidstijd, 's-Gravenhage ( december ) 1980

- Rapport Enige gegevens en conclusies op basis van het onderzoek naar de mogelijke consequenties voor het bedrijfsleven van het wetsontwerp tot wijziging van de Arbeidswet 1919 ( 5 -dagenwetje ), ( februari ) 1981

Raadgevend efficiency bureau Bosboom en Hegener NV - Rapport betreffende het onderzoek naar de organisatie van het Directoraat-Generaal van de Arbeid van het Departement van Sociale Zaken en Volksgezondheid, Amsterdam ( februari) 1968

Raalte, E, van - Troonredes - Openingsredes - Inhuldigingsredes 1814 - 1963, s-Gravenhage 1964

Raaymakers S.J., Chr. - Arbeidsduur voor volwassen mannen, Leiden 1908

Reinalda, B. - Voor de bevrijding van de arbeid. Beknopte geschiedenis van de Nederlandse vakbeweging, Nijmegen 1975; zie Harmsen, $G$.

Reijnders, L. e:a. - Veilig op je werk, Amsterdam 1976

Reljntjes, J.M. --Strafrechtelijk bewijs in wet en praktijk, Arnhem 1980

Remmelink, J. - in T.J. Noyon/G.E. Langemeijer, het Wetboek van Strafrecht, Arnhem 7de druk (losbladig) Reynaerts, W.H.J.

- Wet en bedrijfsdemocratie, in Beleid en Maatschappij $1977 \mathrm{blz} .208 \mathrm{t} / \mathrm{m} 215$

- Arbeidsverhoudingen, theorie en praktijk deel 1, Leiden/Antwerpen 1982; deel 2, Leiden/Antwerpen 1983; zie Nagelkerke, A.G.

Ringeling, J.H.A. - Rechtvaardig ontslag, Amsterdam ( z.j. )

Roebroeks, W. - Crisis in Maastricht, werk en werkloosheid in de jaren dertig, Maastricht ( z.j. ); zie Cillekens, $\mathrm{C}$.

Roeterink, A. - De ontwikkeling der arbeidsbemiddeling in Nederland, Amsterdam 1929; zie Goedhart, G.J.

Romein, A. - De lage landen bij de zee. Een geschiedenis van het Nederlandse volk, Amsterdam 1977; zie Romein, $\mathbf{J}$.

Romein, J. - De lage landen bij de zee. Een geschiedenis van het Nederlandse volk, Amsterdam 1977; zie Romein, A.

Romme, C.P.M. - De onderneming als gemeenschap wan het recht, Amsterdam 1946

Rood, M.G.

- Over de goede werkgever en de goede werknemer, in S.M.A. 1972 blz. $498 \mathrm{t} / \mathrm{m} 507$

- nt AR 9 september 1985, AB 1986332 - blz. 977

Rood, Q.M. - Milieuhygiëne en wet, de Hinderwet en haar toepassing, 's-Gravenhage/Alphen a/d Rijn $2 \mathrm{e}$ druk 1982; zie Ammerlaan; G.A.B.M.

Roos, A.J. de

- De Arbeidsomstandighedenwet, in S.M.A. $1982 \mathrm{blz} .305 \mathrm{t} / \mathrm{m} 316$

- Project ontwikkeling arbeidsinspectie: ervaringen met een organisatieontwikkelingsproject bij bet directoraat-generaal van de Arbeid, in Organisatieverandering in de Rijksdienst. Praktijk en perspectief, 's-Gravenhage 1985, blz. $292 \mathrm{t} / \mathrm{m}$ 328; zie Bor, H.Th./Veen, G. van de

- Rede ter gelegenheid van het 75-jubileum van de Vereniging van controleurs op 30 mei 1986

Roos, Th.A. de - Strafbaarstelling van economische delicten, Arnhem 1987

Rooy, P. de - Werklozenzorg en werkloosheidsbestrijding 1917 - 1940; Landelijk en Amsterdams beleid, Amsterdam 1979

Rossen, P. van - Historische achtegronden van de Dienst voor het Stoomwezen, in De Veiligheid 1982 blz. $11 \mathrm{t} / \mathrm{m} 14$

Rövenkamp, A.J.M. - Amsterdam in bewogen jaren, Herinneringen van een arbeidsbemiddelaar 1925 - 1956 , 
Amsterdam 1978

Rus, P.C. - Enige opmerkingen over het verbod om de werktijd op minder dan 48 uren per week te stellen artikel 8 van het B.B.A. 1945 -, in S.M. 1948 bll. 230 t/m 234

Rūter, A.J.C. - De spoorwegstakingen van 1903. Een spiegel der arbeidersbeweging in Nederland, Nijmegen 1972 (reprint)

Rutgers, J.C. - Bevoegdheden van een lagere wetgever Het College van Rijksbemiddelaars, in S.M. 1949 blz. $20 \mathrm{t} / \mathrm{m} 30$

Ruysch, W.P. - Hygiëne en Fabrieksarbeid, in Vragen des Tijds 1888 I blz. $141 \mathrm{t} / \mathrm{m} 168$

Sanderse, M.M. - Naar een betere arbeidsvoorziening, in SR $1989 \mathrm{blz} 96 \mathrm{t} / \mathrm{m} 105$

Sandick, J.C. - Het einde van de arbeidsovereenkomst bij millitaire dienst, in S.M. $1950 \mathrm{blz} .98 \mathrm{t} / \mathrm{m} 108$

Sassen, A. - Nadeelige vrijheid en noodzakelijke dwang, in Vragen des Tijds $1878 \mathrm{I}$ blz. $363 \mathrm{t} / \mathrm{m} 405$

Schaeffer, H.J. - November 1918. Journaal van een revolutie die niet doorging, Utrecht 1984

Schalk, J.C.J. van der - Art. 414 en 415 van den Code Pénal beschouwd in verband met de theorie van het loon, Leyden 1853

Schaper, B.W. - Oorsprong, achtergrond en historie van de I.A.O., in ILO 1919 - 1969. Vijftig jaar Internationale Arbeidsorganisatie, Alphen a/d Rijn 1969, blz $35 \mathrm{t} / \mathrm{m} 45$

Schilfgaarde, P. van - Rechtspersonen (algemeen deel), Deventer 1979

Schilstra, W.N. - Vrouwenarbeid in landbouw en industrie in Nederland in de tweede helft der negentiende eeuw, Nijmegen 1976 (reprint)

Schipper, J. - De banier opnieuw geheven, Hoorn 1956; zie Stapelkamp, A.

Schipper, P. - De sigarennijverheid in Culemborg, mensen en fabrieken, Culemborg ( z.j. ); zie Eillebrecht, A./Grimbergen, J.

Schlingemann, J.G.- Het voorkomen en beslechten van arbeidsgeschillen, 's-Gravenhage 1933

Schmidt, J.H. - Overgang van oorlogs- naar vredeseconomie, in Nederlands economisch herstel, Amsterdam/ Brussel 1946, blz. 9 t/m 26

Scholtens, A.L. - De uitvoering onzer Arbeidswetgeving, in Staatsrechtelijke opstellen, "s-Gravenhage 1927, blz. $142 \mathrm{t} / \mathrm{m} 175$

Schoolverbond, Nederlandsch - Rapport over het onderwijs der kinderen, die in of voor fabrieken arbeiden, Hand. en Verslagen van het Nederlandsch Schoolverbond 1872 no. 4

Schouten, M. - Voor de oorlog, herinneringen aan de jaren '30, Leiden 1982 ( 2 dln )

Schrage, P. - "De geesel van onzen tijd", een onderzoek naar werklozenbeleid en werkloosheidsbeleving in de jaren dertig te Utrecht, Leiden 1983; zie Nijhof, E./Sturkenboom, M.

Shirer, W.L. - 20th Century Journey. A Memoir of a Life and the Times, Volume II. The Nightmare Years, New York 1985 ( Export Edition )

Síersema, J.

- "Even slecht is ook gelijk". Nachtarbeid in de industrie: nu ook voor vrouwen?, in Intermediair 1980/11 blz. 35 t/m 41; zie Hak, T.

- Vrouwenarbeid - nachtwerk? Over arbeidsbescherming en emancipatie, Amsterdam 1981

Simons, D. - Beknopte handleiding tot het Wetboek van Strafvordering, Haarlem 2 e herbewerkte druk 1892

Slotenmaker LHzn, A. - De Ongevallenwet geschetst voor werkgevers en werklieden, Amsterdam 1902

Smid, W. - Directie Sociaal Arbeidsbeleid nader belicht. DG Arbeid in ontwikkeling, in M.v.A. 1988 blz. 470 $\mathrm{t} / \mathrm{m} 474$

Smissaert, H. - Economische Kroniek, in Onze Eeuw 1911 blz. 115 t/m 117

Smits, H. - De Nederlandsche Arbeidersbeweging in de negentiende eeuw, Rotterdam 1902

Sociaal-Economische Raad

- Advies over het ontwerp van een nieuwe Huisarbeidswet, 1958/3

- Advies over een eventuele wijziging van de broodbakkerijparagraaf van de Arbeidswet 1919, 1959/5

- Advies inzake uitbreiding bevoegdheden ondernemingsraden 1968/13 
- Advies inzake intrekking van de artikelen 6 en 8 BBA 1945, 1969/5

- Interimadvies inzake een Jongerenstatuut, 1974/9

- Advies inzake variabele werktijden 1975/1

- Vervolgadvies inzake een Jongerenstatuut 1976/1

- Advies inzake vernieuwing van de wetgeving betreffende de gezondheid en de veiligheid bij de arbeid $1976 / 18$

- Advies inzake enige wijzigingen van de Rijtijdenwet 1936, (augustus) 1977

- Advies over de verbetering van de arbeidsmarktpositie van vrouwen 1979/17

- Advies arbeidsbescherming vrouwelijke werknemers $1980 / 2$

- Advies inzake sociaal beleid in de onderneming 1981/04

- Advies Beperking groei nitgaven sociale zekerheid, 1980/19

- Advies inzake klachtrecht van individuele werknemers 1981/14

- Advies inzake vermijdbaar verzuim bij ziekte en arbeidsongeschiktheid 1982/01 (Bijlagen A, B, C, D en E )

- Advies beperking overwerk 1982/16

Advies rol sociale partmers in het arbeidsvoorzieningsbeleid 1984/10

- Advies inzake de nieuwe Arbeidsvoorzieningswet 1985/19

- Advies inzake artikel 8 BBA 1945, (december) 1985

- Advies samenloop Wet or en Arbowet 1986/6

Sociaal Maandblad Arbeid 1969 - speciaal nummer gewijd aan het 50-jarig bestaan van de I.A.O., Alphen a/d Rijn 1969

Soclaal Weekblad 1901 - De Gezondheidswet, blz. 157 - 158

Sociaal Weekblad 1904

- Beperking van den arbeidsduur van mannen, blz. $213 \mathrm{t} / \mathrm{m} 215$

- De vrouw en het ontwerp-Arbeidswet, blz. $385 \mathrm{t} / \mathrm{m} 388$

Sociale Geneeskunde, Algemene Nederlandse Vereniging voor (sectie voor Arbeids- en Bedrijfsgeneeskunde)

- Rapport betreffende de bedrijfsgeneeskunde in Nederland, ( z.p. ) 1947

Sociale Zaken en Werkgelegenheid, ministerie van

- Sociaal Jaarverslag 1988, 's-Gravenhage 1989

- Vrouwen en nachtarbeid. Onderzoek naar nachtarbeid door vrouwen in de industrie, 's-Gravenhage 1988

Soeterbroek, F. - Arbeidsomstandigheden en CAO-beleid, in T.v.A. $1989 \mathrm{blz.} 62 \mathrm{t} / \mathrm{m} \mathrm{70;}$ zie Korevaar, K. Sommerfeld, Th. - Der Gewerbearżt, Jena 1905

Spanjersberg, P.L. - Arbowet, ondernemingsraad en werkoverleg, in S.M.A. 1982 blz. 587 t/m 597

Stautsalmanak 1896, 's-Gravenhage 1895;

Stantscommissie inzake onvolwaardige arbeldskrachten - Verslag, "s-Gravenhage 1938

Staatsconmissle over de Werkloosheid - Algemeene Inleiding tot de Verslagen der Staatscommissie over de Werkloosheid betreffende Aard en Omvang der Werkloosheid in de verschillende bedrijfstakken, benevens omtrent de stand der middelen ter bestrijding der werkloosheid of ter lleniging harer gevolgen, 's-Gravenhage 1913; Eindverslag, "s-Gravenhage 1914

Statscommissie-Rochussen - Eindverslag 1894

Stapelkamp, A. - De banier opnieuw geheven, Hoorn 1956; zie Schipper, J.

Statistiek, Centrale Commissie voor de - Gedenkboek uitgegeven ter gelegenheid van het vijfentwintig jarig bestaan der Centrale Commissie voor de Statistiek 1892 - 1917, 's-Gravenhage 1917

Stichting van de Arbeid

- Advies inzake variabele werktijden, ( juli ) 1972

- Centrale aanbevelingen inzake aspecten van een werkgelegenheidsbeleid, 's-Gravenhage (november) 1982

- Advies inzake variabele werktijden, (april ) 1983 
- Stichting van de Arbeid 40 jaar, 's-Gravenhage 1985

- Advies inzake een nieuwe wettelijke werk-en rusttijdenregeling, (augustus ) 1987

- Vollumebeleid arbeidsongeschiktheidsregelingen, (oktober) 1989

Stichting tot verbetering van de levens- en arbeidsomstandigheden, Europese; zie Foundation, European

- Overzicht van de research van de Europese Stichting over ploegenarbeid 1977 - 1980, Dublin 1982

- New Forms of Work. Labour Law and Social Security Aspects in the European Community, Dublin 1987

- Legal and Contractual Limitation to Working-Time in the European Community Member States, Deventer 1988

- De melding van bedrijfsongevallen en beroepsziekten in de Europese Gemeenschap, Dublin 1989 Stikker, D.U.

- Working Conditions in the Community - Situations and Trends - ( Summary ), ) November ) 1989

- Het ontstaan van de Stichting van de Arbeid, in 10 jaar Stichting van de Arbeid, 's-Gravenhage (z.j.), blz. $15 \mathrm{t} / \mathrm{m} 34$

- Memoires, Herinneringen uit de lange jaren waarin ik betrokken was bij dè voortdurende wereldcrisis, Rotterdam/s-Gravenhage 1966

Stokman, S. - De Katholieke arbeidersbeweging in oorlogstijd, Utrecht/Brussel 1946

Stoomwezen, Dienst voor het - "Stoombedrijf en veiligheid", "s-Gravenhage 1955

Stroink, F.A.M. - Het leerstuk der deconcentratie, 's-Gravenhage 1978

Struik, J. - Uitspraken Veiligheidswetgeving, Deventer 1979; zie Dodeweerd, J.J.

Sturkenboom, M. - "De geesel van onzen tijd", een onderzoek naar werklozenbeleid en werkloosheidsbeleving in de jaren dertig te Utrecht, Leiden 1983; zie Nijhof, E./Schrage, P.

Suyver, J.J.H. - Vergelijkend onderzoek naar enige dwangmiddel tijdens de opsporing, Preadvies voor de Vereniging voor de vergelijkende studie van het recht van België en Nederland, '-Gravenhage 1979

Swuste, P. - Asbest: handig, onverwoestbaar en dodelijk, in Intermediair 1989/32 blz. 37 t/m 43; zie Burdorf, L./ Klaver, J.

Tak, A.Q.C. - Het huisrecht, Hoenderloo 1973

Tappèl, B.

- Het werkt anders: een overzicht van maatregelen tegen veel voorkomende problemen met de kwaliteit van arbeidsplaatsen in de industrie, Voorburg 1986; zie Terra, $\mathrm{N}$.

- Het werkt anders: 11 deelrapporten, Voorburg 1986; zie Terra, N.

Tempel, J. van den - De Nederlandse vakbeweging en haar toekomst, Rotterdam 1910

Terra, $\mathbf{N}$.

- Het werkt anders: een overzicht van maatregelen tegen veel voorkomende problemen met de kwaliteit van arbeidsplaatsen in de industrie, Voorburg 1986; zie Tappel, B.

- Het werkt anders: 11 deelrapporten, Voorburg 1986; zie Tappèl, B.

Thomas, M.W. - The early Factory Legislation, Leigh-on-Sea 1948.

Tijn, Th. van - Het sociale leven in Nederland, in Algemene geschiedenis der Nederlanden deel 13, Haarlem

(z.j.), blz. $77 \mathrm{t} / \mathrm{m} 100$

Timmers-de Vin, M.P.

- Het zoogrecht gespeend van een goede wettelijke regeling, in NJB $1987 \mathrm{blz} .931 \mathrm{t} / \mathrm{m}$ 935; zie Monster, W.C.

- Positierecht. Rechtspositie van zwangere en pas bevallen werkneemsters, Alphen a/d Rijn 1989; zie Monster, W.C.

Tinga, E. - Artikel 28, zevende en achtste lid van de Arbeidswet 1919, in Arbeid 1950 blz. 71 - 72

Tits, M. van - De positie van jeugdigen in het arbeidsproces. Het Jongerenstatuut nader beschouwd, 's-Gravenhage 1987; zie Dekkers, H/Ven. J. van de/Verstegen, $R$.

Torringa, T. - De rechtspersoon als dader; strafbaar leidinggeven aan rechtspersonen, Arnhem ( z.j. ) 
Treub, M.W.F. - Oorlogstij,, Haarlem/Amsterdam 1916

Troelstra, PJ. - Gedenkschriften IV (Storm), Amsterdam 1931

Tuyl, G.J. - Werkfonds 1934 , (2.p.) 1949

Ubachs, M. - Een eeuw modern kapitalisme. De Regouts/leed en strijd van maastrichts proletariaat, Nijmegen $(z . j)$

Ubink, P.A.G. - Tekstuitgaven van nieuwe regelingen ten aanzien van het arbeidsrecht, Alphen a/d Rijn 1943

Vakbeweging, Federatie Nederlandse - Wat willen we met de APO, ( februari ) 1978

Vakbeweging, Federatie Nederlandse/Industriebond - Diskussiebrochure. Een ontwerp-beleidsprogram voor veiligheid en gezondheid, (april) 1977

Vakverbond, Christelijk Nationaal

- Discussienota "Toekomst in banen", Sociaal-politiek program van het CNV voor de periode 1990 1994, Utrecht 1988

- "Toekomst in banen". Sociaal-politiek Program van het CNV voor de periode 1990 - 1994, Utrecht (juli ) 1989

Vakverenigingen, Nederlands Verbond van - Arbeidersleven in Nederland. Resultaten der enquête, ingesteld door het NVV in het najaar van 1907 naar de wenschelijkheid en mogelijkheid van beperking van den arbeidsduur voor volwassenen tot 10 uren per etmaal en afschaffing, respectievelijk beperking van nacht- en kinderarbeid, (zp. ) 1908; zie Arbeiderspartij, Sociaal-Democratische

Valentgoed, P.H. - Werktijdverkorting, in S.M.A. $1962 \mathrm{blz} .3 \mathrm{t} / \mathrm{m} 5$

Valkhoff, J. - Een ceuw rechtsontwikkeling. De vermaatschappelijking van het Nederlandse privaatrecht sinds de codificatie ( 1838 ), Amsterdam ze druk 1949

Vallenduuk, J.B.

- Waarom de Rijtijdenwet niet wordt nageleefd, in Nederlands Transport 1988/8

- Goede feitelijke informatie, conclusies twijfelachtig ...., in Nederlands Transport 1989/13-14

Veegens, D.G. - nt. HR 10 oktober 1946, NJ 1946337

Veegens, J.D. - Wettelijke maatregelen omtrent kinderarbeid en werklokalen, in Vragen des Tijds 1887 II blz. $55 \mathrm{t} / \mathrm{m} 94$

Veen, Th.W. van - Van plicht tot spreken en recht tot zwijgen: Art. 29 Sv. bevat een uitzondering, in DD $1979 \mathrm{blz} .687 \mathrm{t} / \mathrm{m} 693$

Veen, G. van de - Project ontwikkeling arbeidsinspectie: ervaringen met een organisatieontwikkelingsproject bij het directoraat-generaal van de Arbeid, in Organisatieverandering in de Rijksdienst. Praktijk en perspectief, 's-Gravenhage 1985, blz. $292 \mathrm{t} / \mathrm{m}$ 328; zie Bor, H.Th./Roos, A.J. de

Veerman, W. - Inventaris van het Archief van het Werkfonds 1934 en de Interdepartementale Commissie Werkloosheidszorg de Commissie Hacke ("H"), 's-Gravenhage 1970

Veldkamp, G.M.J. - Inleiding tot de sociale zekerheid en de toepassing ervan in Nederland en België deel I Karakter en geschiedenis, Deventer ( $2 . j$. )

Ven, F.J.H.M. van der

- Inleiding tot het arbeidsrecht, Tilburg 1941; Tilburg 2e druk 1946

- De arbeidsverhouding in de onderneming, in Arbeidsrechtelijke en sociaal-politieke opstellen, Bussum 1945, blz. $127 \mathrm{t} / \mathrm{m} 155$

- Het gemeenschapskarakter der onderneming, in Arbeidsrechtelijke en sociaal-politieke opstellen, Bussum 1945 blz. $156 \mathrm{t} / \mathrm{m} 169$

- Bedrijfsleven en democratie, Leiden 1955

Ven, J. van de - De positie van jeugdigen in het arbeidsproces. Het Jongerenstatuut nader beschouwd, 'sGravenhage 1987, zie Dekkers, H/Tits, M. van/Verstegen, R.

Vereeniging van democratische ingenieurs en architecten, Sociaal-technische - Brief van 20 maart 1909 met als bijlage: De reorganisatie van de Arbeidsinspectie 
Verkouteren, H. - Artikel 153 Grondwet, Amsterdam 1880

Verloren van Themaat, P. - Inleiding tot het recht van de Europese Gemeenschappen, Deventer 4e druk 1987; zie Kapteyn, P.J.G.

Vermeer, E. - Pieter Jelles Troelstra, Amsterdam 1960

Vermeer, L.P.H. - Asbest in het garagebedrijf. Verbod toepassing in remvoering belemmerd door EG-regels, in M.v.A. $1989 \mathrm{blz} .391 \mathrm{t} / \mathrm{m}$ 195; zie Kant, Y.Notemans, J.V.H.

Versluis, W.G. - Beknopte geschiedenis van de Katholieke arbeidersbeweging in Nederland, Utrecht/Nijmegen 1949

Verstegen, R. - De positie van jeugdigen in het arbeidsproces. Het Jongerenstatuut nader beschouwd, 's-Gravenhage 1987; zie Dekkers, H/Tits, M. van/Ven, J. van de

Veggeert, J.C.

- De kinderarbeid ( de geschiedenis van haar beperking door de kinderwet van mr. Samuel van

Houten ), Amsterdam 1951

- Kinderarbeid in Nederland 1500 - 1874 ( van berusting tot beperking), Assen 1964

- Kinderarbeid in de negentiende eeuw, Haarlem $2 e$ druk 1978

Vliegen, W.H. - Oorsprong, geschiedenis en hedendaagsche stand der socialistische beweging, Amsterdam 1931

Voorden, W. van - APO's ..... wat zijn dat eigenlijk?, SMO 's-Gravenhage 1978/8; zie Boersma, J./Davidse, M./Kranendonk, J.A. van

Vooys, Is.P. de - Arbeidsinspectie, in Vragen des Tijds 1901 ( overdruk)

Vos, C.J.

- Arbeidsbeleid en arbeidsverboudingen. Centralisering en fragmentering in het arbeidsbestel, Deventer 1982

- Tien jaar arbeidsplaatsverbetering, in T.V.A. $1986 \mathrm{blz} .78 \mathrm{t} / \mathrm{m} 88$

Vos, M.B.

- Arbeidsgeschillenwet 1923, Alphen a/d Rijn 1924

- Wijziging van artikel 1638w BW, in S.M.A. 1960 blz. 566 - 567

Vries, C.W. de

- Sociaal-economische toetanden in Nederland, volgens officiële docuementen uit het midden der vorige eeuw, in Sociale Voorzorg $1919 \mathrm{blz} .251 \mathrm{t} / \mathrm{m} \mathrm{274,} \mathrm{blz.} 505 \mathrm{t} / \mathrm{m} 523 \mathrm{en}$ blz. $786 \mathrm{t} / \mathrm{m} 811$; zie Gorter, R.A.

- Bijdrage tot de geschiedenis der Nederlandsche sociale wetgeving ( 1840 - 1874), in De Economist 1919 blz. 299 t/m 335; zie Gorter, R.A.

- Gegevens omtrent den kinderarbeid in Nederland volgens de enquêtes van 1841 en 1860, in Econ.Hist. Jaarboek 1922 ( overdruk ); zie Gorter, R.A.

- Van de Kinderwet-Van Houten tot de Arbeidswet 1889, in Soc. Jaarboek voor Nederland jrg. 1920 deel III Leiden 1922

- De systematiek van het arbeidsrecht, in Vijftig jaar Arbeidswet 1889 - 1939, Haarlem 1939, blz. $24 \mathrm{t} / \mathrm{m} 32$

- Early Labour Legislation deel I ( 1791 - 1848 ), Leiden 1949; zie Vries, J. de

Vries, J. de - Early Labour Legislation deel I ( 1791 - 1848), Leiden 1949; zie Vries, C.W. de

Vries, Joh. de - De Nederlandse economie tijdens de 20ste eeuw, Haarlem 1978

Vries Wzn, W. de - De totstandkoming van de Ongevallenwet 1901, Deventer ( $x . j$.

Vrij, M.P.

- nt. HR 17 november 1930, W.12240

- Overmacht bij de naleving van strafrechtsnormen met bestuurselementen in het arbeidsrecht, in Publiekrechtelijke opstellen, Zwolle 1950, blz. $309 \mathrm{t} / \mathrm{m} 353$

Vrouwenbeweging, Nederlandse - Nachtarbeid een duistere zaak, ( oktober ) 1979 
Waning, Jac. van - Wet op de kinderarbeid, Alphen a/d Rijn 1887

Weisglas, M. - Woord vooraf, in Nederlands economische herstel, Amsterdam/Brussel 1946, blz. 1 t/m 8

Welderen Rengers, WJ. van - Schets eener parlementaire geschiedenis deel I 1849 - 1891, "s-Gravenhage 4e druk 1950; deel II 1891 - 1901, 's-Gravenhage 4e bijgewerkte druk 1950; deel III 1901 - 1914, 'sGravenhage $4 \mathrm{e}$ bijgewerkte druk 1950

Wetsbesluiten tot stand gekomen tusschen 24 juni en 23 november 1945 met toelichting, 's-Gravenhage 1947 Werkgevers, Vereeniging van Nederlandsche - De organisatie van werkgevers deel V Nederland ( verslag uitgebracht door de commissie ter bestudeering van werkgeversvereenigingen ), 's-Gravenhage 1909

Werkgroep flexibele arbeldsrelaties

- Flexibele arbeidsrelaties. Rapportage van de eerste fase van de werkzaamheden van de Werkgroep flexibele arbeidsrelaties, "s-Gravenhage (juli) 1986

- Flexibele inzet van arbeidskrachten, 's-Gravenhage ( november) 1987

Werkgroep Herowerweging gedeconcentreerde rijksdiensten - Eindrapport, (januari ) 1985

Werkman, E: - De magere jaren, Nederland in de crisistijd 1929 - 1939, Leiden 2 e druk 1967; zie Beishuizen, J.

Wesseling, J.H. - De Kleuteronderwijswet met aantekeningen, Alphen a/d Rijn ( losbladig ); zie Hermsen, A.B.

Westhoff, J. - Arbeidersbescherming in engeren zin, in Het Departement van Arbeid, Handel en Nijverheid onder minister Aalberse 1918 - 1925, Alphen a/d Rijn 1926, blz. 1 t/m 60

Wetering, H. van de - Harde guldens, harde tijden, beeld van het Jordaanoproer 1934, Amsterdam ( $z . j$. ); zie Posthumus, $P$.

Wijnen, J.H. - De arbeid der kinderen in fabrieken, onder godsdienstig, zedelijk en stoffelijk oogpunt beschouwd (z.p.) 1873

Wilhelm, G.

- Dienst voor het Stoomwezen 125 jaar, in Noodzaak $1980 \mathrm{blz} .36 \mathrm{t} / \mathrm{m} 39$

- 125 jaar Stoomwezen, in Lastechniek $1980 \mathrm{blz} .210 \mathrm{t} / \mathrm{m} 213$

Willems, J.H.B.M.

- De melding van beroepsziekten. Een studie uitgevoerd in opdracht van het Directoraat-Generaal van de Arbeid door het Coroneel Laboratorium, Universiteit van Amsterdam, Voorburg ( maart) 1987

- DGA kent een nieuwe Directie Gezondheid. Integrale aanpak per beleidsitem, in M.v.A. 1988 blz. $75 \mathrm{t} / \mathrm{m} 83$

Withagen, T. - Hoe werkt de Engelse arbeidsinspectie?, in SR $1989 \mathrm{blz} .6 \mathrm{t} / \mathrm{m} 11$

Windmuller, J.P. - Arbeidsverhoudingen in Nederland, Utrecht/Antwerpen 4e druk 1983; zie Galan, C. de/ Zweeden, A.F. van

Winkel, N.C. - De taak van de arbeidsinspectie, in Gedenkboek ter herinnering aan het vijftigjarig bestaan der arbeidsinspectie, Groningen/Batavia 1940, blz. $7 \mathrm{t} / \mathrm{m} 36$.

Witt Hamer, M.J. de - De arbeidersvereenigingen, Leiden 1866

Wolf, L. de - Werkgevers willen flexibele werktijden ( de machteloosheid van de vakbeweging), in Intermediair $1983 / 38 \mathrm{blz} .15 \mathrm{t} / \mathrm{m} 21$

Wolfs, W.J. - Overheid en sociale partners in publiekrechtelijke organisatie. Arbeidswoorzieningswet, in Privatisering $1988 / 9 \mathrm{blz} .24 \mathrm{t} / \mathrm{m} 26$

Worthman, Ferd. - Geschichte des Coalitionsverbot und seiner Aufhebung in den Niederlanden, in Zeitschrift für die gesammte Staatswissenschaft 1876 S. 320 bis zum 351 und S. 583 bis zum 630

Woude, M. van der - De ontwikkeling der particuliere arbeidsvoorziening in een afkalvende rechtsbescherming, in $\mathrm{SR} 1989 \mathrm{blz} .105 \mathrm{t} / \mathrm{m} 108$

Wouten's, P. - Mislukte voorzet, ja; verloren wedstrijd, nee, cen onderzoek naar CAO-bepalingen op het terrein van de kwaliteit van de arbeid, Industriebond FNV ( otkober ) 1987 
Zaaijer Az., J. - De arbeidsenquête, in De Gids 1887 III blz. $36 \mathrm{t} / \mathrm{m} 71$

Zaalberg, C.J.P.

- Wettelijk minimumloon voor de huisindustrie, in Vragen des Tijds 1912 II (overdruk )

- Het K.N.S. en de werkloosheid, in T.N.V.W. $1917 \mathrm{blz} .643 \mathrm{t} / \mathrm{m} 645$

- Arbeidersbescherming; Berechting van overtredingen der Arbeidswetten; de Arbeidsinspectie en haar werk, in Sociaal Jaarboek voor Nederland, Leiden $1918 \mathbb{1}$, blz. $94 \mathrm{t} / \mathrm{m} 115$

- De 8-urendag in Nederland, in Sociale Voorzorg $1921 \mathrm{blz.} 598 \mathrm{t} / \mathrm{m} 607$

- Voordracht over zijn ervaringen bij de arbeidsinspectie, in Rotary Holland $1932 \mathrm{blz} .531 \mathrm{t} / \mathrm{m} 533$

- Vijf en twintig jaar Centrale Dienst, in Gedenkboek 1909 - september - 1934, Gronigen/"s-Gravenhage/Batavia 1934, blz. $15 \mathrm{t} / \mathrm{m} 20$

Zinkstok, $\mathbf{R}$ - Wij zijn allen werklieden. De opkomst van de moderne arbeidsmoraal in Nederland in de negentiende eeuw, Baarn 1986; zie Ploeg, R. van der

Zwam, H.J. van

- Veranderingen in het arbeidsomstandighedenrecht, Deventer 1983

- Het hoofd of de bestuurder der onderneming, in De Veiligheid blz. $253 \mathrm{t} / \mathrm{m} 257 \mathrm{en} \mathrm{blz.} 313 \mathrm{t} / \mathrm{m}$ 317

- Fabriek of werkplaats; Arbeidswet 1919, Veiligheidswet 1934, Arbeidsomstandighedenwet, in S.M.A. 1988 blz. 389 t/m 394

- Spreiding van verantwoordelijkheden. de Taakopdracht van art. 31 Arbowet, in M.v.A. 1988 blz. $262 \mathrm{t} / \mathrm{m} 265$

Zweeden, A.F. van - Arbeidsverhoudingen in Nederland, Utrecht/Antwerpen 4e druk 1983; zie Galan, C. de/ Windmuller, J.P. 
Rb. Rotterdam 15 mei 1875, W.3855

Rb. $s^{*}$-Gravenhage 18 oktober 1875, W.3904

Rb. Rotterdam 13 julli 1876, W.4230

Ktg. Vollenhove 6 september 1876, W.4048

Rb. Zwolle, 26 oktober 1876, W.4058

$\mathrm{Rb}$. Groningen 6 maart 1879 , W.4412

Rb. Rotterdam 15 maart 1879 , W.4347

HR 20 oktober 1879 , W.4444

Rb. Groningen 29 juni 1882, W.4810

HR 20 maart 1899, W.7258

HR 17 februari 1902, W.7727

CRvB 15 januari 1904

HR 24 mei 1904, W.8070

HR 6 juni 1904, W.8077

Hof Arnhem 19 juli 1905, W.8312

HR 14 januari 1907, W.8487

HR 16 december 1907, W.8633

HR 23 december 1912, W.9432

HR 15 december 1913, NJ 1914 blz. 337 - W.9598

Rb. Zwolle 2 april 1914, NJ 1914 blz. 486

HR 15 juni 1914, NJ 1914 blz. 1005 - W.9666

HR 11 januari 1915, NJ 1915 blz. 512 - W 9777

CRvB 21 december 1915

HR 14 februari 1916, NJ 1916 blz. 681

HR 24 juni 1921, NJ 1921 blz: 1063 - W.10806

HR 9 oktober 1922, NJ 1923 blz. 3 - W.10957

HR 15 oktober 1923, NJ 1923 blz. 1239 - W.11113

Rb. Amsterdam 3 juni 1924

HR 17 november 1924, W.11304

Ktg. Hoorn 13 mei 1925

Rb. Alkmaar 22 september 1925

HR 26 januari 1926 , NJ 1926 blz. 246 - W.11464

Rb. Rotterdam 20 mei 1926, NJ 1926 blz. 1176

HR 24 januari 1927 blz. 247 - W.11640

HR 27 juni 1927 , NI 1927 blz. 926

Rb. Rotterdam 11 oktober 1927 , NJ 1929 blz. 63

HR 25 februari 1929, NJ 1929 blz. 1500

Ktg. Rotterdam 7 mei 1929, W.12502

Rb. Rotterdam 8 oktober 1929, NJ 1931 blz. 185 - W.12080

Rb. Amsterdam 1929, W.12008

HR 4 november 1929, NJ 1929 blz. 1662 - W.12051

HR 17 november 1930, NJ 1931 blz. 162 - W.12240

Rb. Haarlem 19 maart 1931

HR 1 juni 1931, NJ 1932 blz. 1155 
HR 22 juni 1931, NJ 1931 blz. 1062

Rb. Dordrecht 27 november 1931, NJ 1933 blz. 1080

HR 19 januari 1932, NJ 1932540

HR 2 januari 1933 , NJ 1933 blz. 402 - W.12582

HR 12 februari 1934, NJ 1934 blz. 1155 - W.12767

HR 19 november 1934, NI 1935 blz. 349 - W.12855

HR 16 mei 1938 , NJ 19381019

HR 17 juni 1938, NJ 1938997

HR 15 januari 1940, NJ 1940388

HR 10 oktober 1946, NJ 1946337

Rb. Almelo 20 april 1948

HR 1 februari 1949, NJ 1949552

Ktg. Middelburg 11 februari 1953, NJ 1953296

HR 23 februari 1954, NJ 1954378

HR 15 juni 1955, NJ 195614

HR 7 februari 1956, NJ 1956147

K.b. 27 november 1957 , no. 28

K.b. 25 november 1959 , no. 25

K.b. 7 september 1961 , no. 37

K.b. 2 april 1963 , no. 28

K.b. 6 mei 1965 , no. 29

K.b. 22 februari 1967, no. 31

HR 20 april 1969, NJ 197046

Rb. Maastricht 4 november 1969, NJ 1971166

HR 4 januari 1972, NJ 1972121

Rb. Assen 8 december 1972, NJ 1973466

Minister van Sociale Zaken beschikking van 5 februari 1973, no. 3678

Minister van Sociale Zaken beschikking van 4 juli 1976, no. 21336

K.b. 28 januari 1978 , no. 34

K.b. 17 mei 1978

K.b. 7 september 1978

K.b. 9 december 1978 , no. 41

K.b. 7 maart 1979 , no. 91

HR 2 oktober 1979, NI 1980243

K.b. van 28 mei 1981 , no. 59

HR 16 juni 1981, NJ 1981586

K.b. 19 juni 1981, no. 49

HR 1 juli 1981, NJ 198280

HR 2 maart 1982, NJ 1982446

HR 22 maart 1983, NJ 1983502

HR 7 februari 1984, NJ 1984527

AR 9 september 1985, AB 1986332

HR 19 november 1985 , NJ 1986125 en 126

Rb. Haarlem 16 mei 1986

HR 16 december 1986, NJ 1987321

HR 14 september 1987 , NJ 198845

HR 19 september 1988, NJ 1989145 


\section{CURRICULUM VITAE}

Harry van Drongelen is geboren op 10 september 1952 te 's-Gravenhage. In 1972 behaalde hij het diploma Atheneum A aan het Stevin Lyceum te 's-Gravenhage. Vervolgens vervulde hij de militaire dienstplicht. In 1979 behaalde hij het doctoraal examen Nederlands recht en in 1981 het doctoraal examen vrije studierichting, beide aan de Rijksuniversiteit te Leiden. Vanaf mei 1979 is hij werkzaam bij de juridische afdeling van het directoraat-generaal van de Arbeid. 
bij mr.drs. J. van Drongelen, De ontwikkeling van de abeidsinspectie in een veranderende wetgeving

titelbiad

ns "written' toevegen permission

bla wo 20 regel van onder

wil" moet zijn: willea

blz 16 lie regel van onder

an verliep" toevoegen: hel

blz 20 12e regel van onder

n* "Kroon" toevoegen: diende te wordeo

biz 28 13e regel van boven

"wienig" moet zijn weinig

blz 31 13e regel van bovea

"jin" moet zijn: zijn

blz $712 e$ regel van onder

"ondezoek" moet $2 \mathrm{jjn}$ : onderzock

ble 72 24e regel van boveo

"besetrijden" moet zijn: bestrijden

blz 83 ise regel van boven

"eestgenoemde" moet zija: cerstgenoemde

bl2. 83 16e regel van boven

"om" moet zjp: op

blz 88 2le regel van onder

"gelijkonmige" moet ajja": gelijkwormige

blz 89 le regel van boven

"onderworpan" moet zijn: onderworpen

ble 9320 e regel van onder

"plasteland" moet zjja: platteland

blz 95 le regel van boven

"wij" moet zijn: $i j$

blz 9916 regel van bovea

"voor" moet zijn: van

blz 110 nt. 113

vers)ag" moet zijn: verslag

bb. 111 at. 126

113 (memorie van toelichting) blz 9 moet zijn: 11.4 (vootlopig verslag ) blz. 5

blz $12327 \mathrm{e}$ regel vas onder na "centrale" toevoegen: leiding

ble 125146 regel van onder "huees" moet zjja: kunoes

blz. 131 16e regel van onder "als" vervalt

bla 146 2le regel vas onder "door" moet zijn: daar

blz 149 11e regel van onder Teden-patroon" moet zijn: patroons

blz 162 \&en26e regel van boven "dienst" vervalt

bb. 16325 e regel van bovea Tunnes" moel zjj: konden

ble 170 lie regel van boven "voor" moet zijn: door

blz $17516 \mathrm{e}$ regel van boven "gebrek an" vervalt

bl2 18725 tegel van onder "conomiche" moet zija: cconomisehe

blz. 190

at 54 as "aangevoerd" vervalt af 54 toevoegen as "mijnarbeid" ( 8 e regel van onder)

blz 1912 regel van onder herstel moet zijn boold

ble 19610 e regel nan boven "dezelfde" moet zjo: bijzondere blz 199 2e regel van boven "rwam" moel zijn: ging

biz. $20312 \mathrm{e}$ regel van boven "periodde" moet ajja: periode

ble 20313 regel van boveo na "HR" toevoegen: namelijk die ven an "en" toevoegen die van

ble 2056 regel van boven "stelden' moet zijn: stellen

blz 2057 regel un boves "uit later tijden' vervalt

blz 207 6e regel ven onder "vruchen" moet zijn: vuchten

blz. 210 2e regel van boven mis en" vervalt

ble 210 i3e regel van onder "veraicingen" moet żjn: verkiczingen

ble 213 at. 12 "Schaeffer" moet zijn: Scheffer

ble. 217 nt. 69 "oprichters" moet zija: opzichters

ble 221 at 107

na "zelf" toevoegen: niet

blz 225 at. 220 "artikel 1932" moet zijn: winkels 1932

blz 233 20e regel van onder 'belangrijke' moet zijn: belangrijkste

blz 237 19e regel van onder "in dien zin" moet zjjn: is die zis

blz 242 lle regel van onder "de boofdregeling van bet ontwerp" moet aja: dit uitgangspunt

blz. 24324 e regel van onder "vreende" moel zjn: deze

blz 243 le regel van onder "veemde" moet zijn: butenlandse

blz 243 3e regel van onder na "opsporing" toevoegen: hiervan

ble 2449 regel van boven "dieast met" moet zija: Rijksdienst van

blz 24723 regel van bovea ns "onpartijdig' toevoegen: lichanen

blz. 248 6e regel van onder "vaarden" moel zijn: woorden

ble 248 le regel vas onder "worden" moel zijn: wendes

blz. 249 se regel vas boven ni "dar" toevoegen: cen

biz. 249 se regel van onder na "ns" toevoegen: cen

blz 250 se regel van onder "1939" moet dijn: 1934

blz 251 2e/23e regel van onder na "bin-nen" toevoegen: een

ble $25219 \mathrm{e}$ tegel van onder "het" vervalh

blz.253 12e regel van onder "overschreden perd" moet ajjn: voorischreed

blz 25310 regel van onder na "Verschuur" toevoegeñ: zoals biervoor al bleek

blz 25510 regel van boven "overkoerpelend" moek zjp: overkoepelend "ministeriezle" moet zjjas ministeriêle

blz. $2552 \mathrm{e}$ regel van onder ne "1933" toevoegen. gedaterde blz 257 re regel van onder bepalen' moet zijn: beperken

bliz 257 \&e regel van onder "asn" moet żja: bij

ble. 281 23e regel van bover "Op" moet zijo: as

blz 281 Le regel van ouder "enorm" moel ajja: enorme

bli. $28617 \mathrm{e}$ regel van onder "dezen" moet zija deze

blz 289 20e regel van onder "zelf. doen" moet zijn: zelfdoen

blz. 297 at. 63 wrd" woet dijn: werd

ble 303 3e regrel van boven verdrukken" encet zila: onderdrukken

blz 310 \&e regel van onder an "wettelijke" toevoegen: regeling

blz. $31114 \mathrm{c}$ regel van onder as "groot" loevoegen: belang

blz. 313 24e regel ven onder "arbeid" noet ajjn: artikel

blz. 315 ise regel van boven na "dergelijk" toevoegen: bevel

blz 320 16e regel vas onder "texticlindustrie en" moet zijn: de lexiel-. Voor "genotwidde" toevoegea: de

blz 323 15e regel van onder as "al" toevoegen: om

bl2. 32724 e regel van oader in de meeste" moet zijn: berbaaldelijk

blz 328 3e regel van boven "dat er" moet zija: van

blz $32928 \mathrm{e}$ regel van boven "in" moet zijn: vas

ble $33021 \mathrm{e} \mathrm{regel} \mathrm{van} \mathrm{onder}$ "thame" moet thitat tam

blz 332 lse regel var boven "op" moel zaju: moi

blz 33520 regel van boven "ni te gaan en" moet zija: nagegaan en ook hoe

blz. 335 17e regel van boven is "gerappeleerd" toevoegen: worden

blz 338 13e regel van onder van" moet zjn: voor

blz. 339 lle regel wa boven "waarin" moet zijn wharase

blz 339 loe regel van ooder "ciegen" moet zija: cigen

blz 34013 e regel ven onder bujdige" moet xijn bestande

bliz 341 19e regel van boven voor "op' toevoegen: andruk

blz 364 le regel van boven '1907 moet tijn: 1909

blz. 364 zoe regel van bovea "kregen" moet aja: kreeg

bli. 369 24e regel van onder "zestiger" moet zijn: jaren zestig

blz. 369 lle regel van onder "enerijds" moet zijax enerzijds

blz. 3819 e regel van onder "scheepvaarinspectie" moel zja scheep vartinspectie 
ble 382 te regel van onder "or' moer rijn: of

btz. $38812 \mathrm{e}$ regel ven onder "werd wijsgemaskt" moel zijn: wegmijs werd gemanht

ble 395 at 80 as "gen" tocvoegen: toe te staso

blz. 431 23e regel van boven "eis tok naleving" moet zijn: asnwijzing

blz 443 1le regel rean boved 'reorganisatie' moet zija: organisatie

ble 45325 regel vean ooder "martverkenaingen" moet zjjn: marktverkenningen

blz 475 2le regel ven onder "wordhures" moet zijn: voortduren

blz 475 \&e regel van onder rooort moel zijn: voor

blz. 480 ge regel van onder as "die" loevogen: welke

blz 481 19e regel van onder Temerit" moet zjn: wordt avoor "door" toevogea: gekenmeria

blz. 48113 regel van onder "asn" mose zijo: van

ble. $48212 \mathrm{e}$ regel van boven "tot" vervalt

blz 48725 regel van boved "selctie" moet zijn: selectie

biz 489 \&e regel van boven na "ormzichtige" toevoegen: formulering

blz 491 18e regel van onder "arbeidisnsepctie" moet zijn: arbeidsinspectie

blz 517 al 353 "waarde" moet zijn: voorwaarde

blz 531 at. 596 tweede zin: "in" moet zijn: uit werden" moet zijn: kan wordes afgeleid, dat na "verstrekt" toevoegea: werden

blz 5393 regel van onder as "ar." toevoegea: 1

blz 540 9e regel van bovea na "art" toevoegen: 1

biz. 54013 regel van boven voorozver" moel zjja: yoot zover

blz. 54912 e regel van onder "verrichten" moet zijn: verrichs

blz. 552 19e regel van boven "gedraging" moet bja: gedragingen blz. 552 ise regel vas onder "wanneer" moet ajn: dat

blz SS4 I8e regel ven onder an "beschitking" toevogea: stelt

blz 559 \&e regel van boven na "ivet" toevogen; alleen

biz 564 13e regel van boven "ortheidsinstanties" moet äja: overheidsinstanties

biz 574 12e regel won onder "gebruiken" moet zijn: gebruik

blz 578 19e regel van bovea as '1889' toevogen: bepaslde

blz 5807 regel van onder "angegeven" moet zija: angewezen

blz 582 le regel van onder "tiende" moet zijn: cerste

blz 583 17e regel van onder veilgiehidswetgeving" moet zijn: veiligheidswetgeving "opnebaarbeid" moet ajjn: openbaarbeid

ble 583 Le regel van onder "shcriftelijke" moet zjjn: schriftelijke

blz. 591 at 108 $96^{\circ}$ moet zijn: 100

blz 592 nt 111 "bas onze me-ning" vervalt

bly. 592 at. 123 $96^{\circ}$ moet zijn: 100

bli. 594 at 149 "bemaaningslid" moet zijn: bemanningalid

blz 606260 regel van onder "dat" moet zjijn: opda!

bl2 61310 e regel van onder na "iaak" toevoegen: niet

blz 615 20e regel van boven na "verlangd" toevoegen: kan

blz 6162 e regel van onder "geneomd" moet zijn: genoemd

blz 617 lle regel van onder aa "gedaan" toevoegea: worden

bl2 617 loe regel van onder $\mathrm{Na}$ "ing" toevoegen: bestaat

blz $6398 \mathrm{ge}$ regel van onder Bijzondere" moel zijn: bijzonderbeden

ble 644 at. 2 "algemen" moet zijn: algemene

ble 648 at 65 "uitspaak" moet zijn: uitspraak

blz. 651 nt. 104 94" moet zija: 95 ble. 62 nt. 113

(die ook at. 76) vervalt

biz. 657 7e regel ven boven

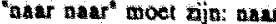

ble blz 65825 regel van onder "arbeidsgeschiktea" moet zija: arbeidsongeschikten

blz 600 6e regel vas onder woor "afgene-" toevoegen: worden

blz. 609 11e tegel van onder a "Tol' toevogen: bet adviserea terzake van

ble. 670 Le regel van boven "inspelead" moet zju: inspelen

blz 670 17e regel ran onder "cen 20 cen" moot tajn: $\cos 20$ 